

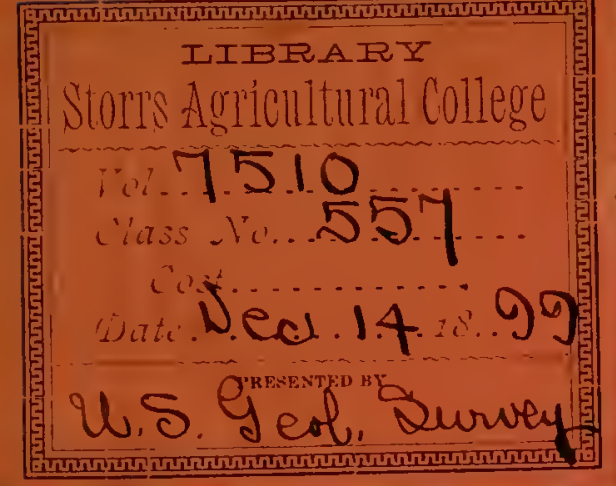



Digitized by the Internet Archive in 2009 with funding from .

Boston Library Consortium Member Libraries

http://www.archive.org/details/geologyofyellows00hagu 


DEPARTMENT OF THE INTERIOR

\title{
MONOGRAPHS
}

OF THE

\section{United States Geological Survey}

\author{
VOLUME XXXII \\ PART II
}

WA S II I N G T ON

GOVERNMENT PRINTING OFFICE 1899 

UNITED STATES GEOLOGICAL SURVEY CHARLLSS 1), WALCOTT, DRECTOR

\title{
GEOLOGY
}

\section{OF TIIF \\ YELLOWSTONE NATIONAL PARK}

\author{
PART II \\ DESCRIPTIYE GEOLOGY, PETROGRAPHY, AND PALEONTOLOGY
}

BY

ARNOLD HAGUE, J. P. IDDINGS, W. H. WEED

AxD

C. D. WALCOTT, G. H. GIRTY, T. W. STANTON, AND F. H. KNOWLTON

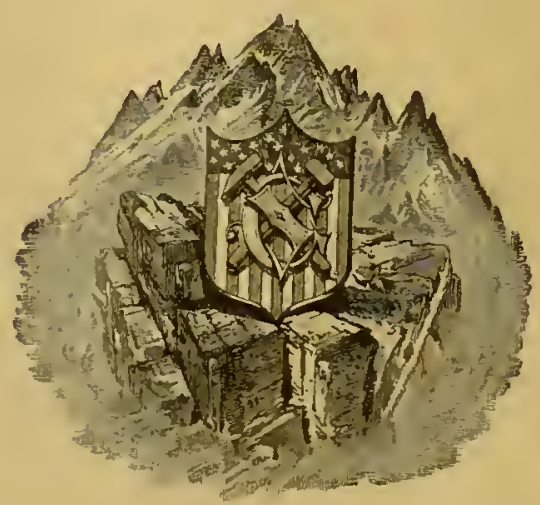

W A S I N GTON

GOVLRNMENT PRINTING OFFICE 1899 
7510 


\section{CONTENTS.}

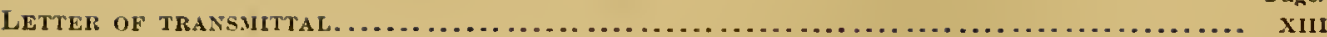

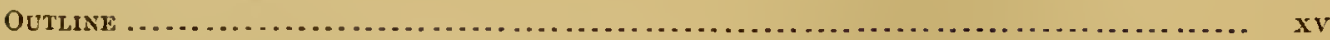

Chapter I.-Descriptive geology of the Gallatix Mountains, by J. P. lddings and W. II.

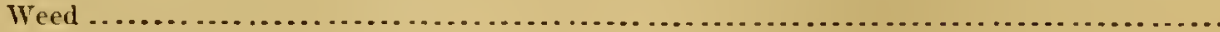

Iutroduction

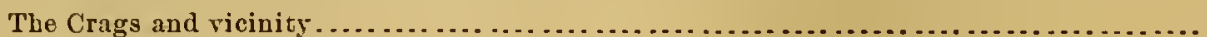

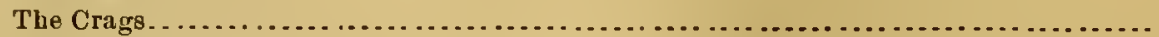

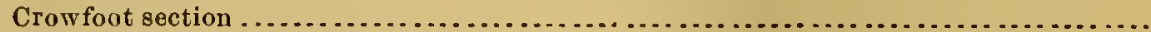

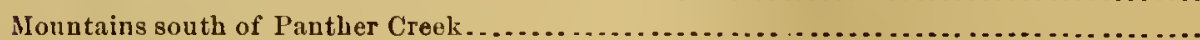

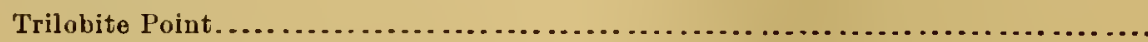

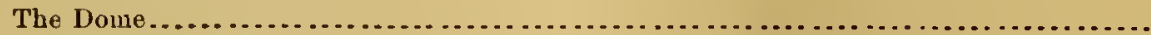

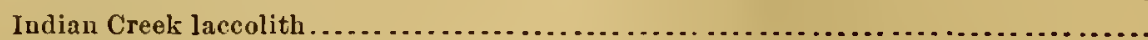

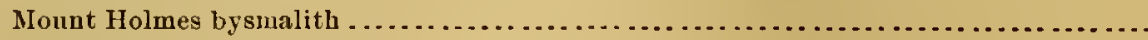

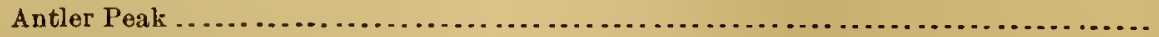

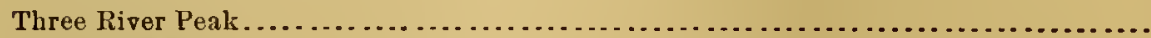

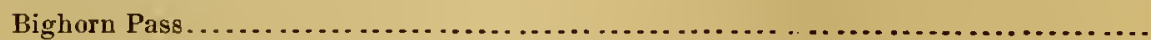

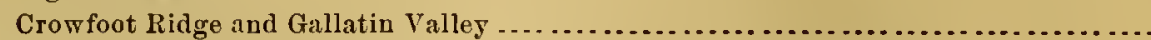

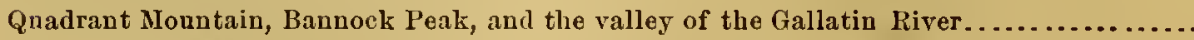

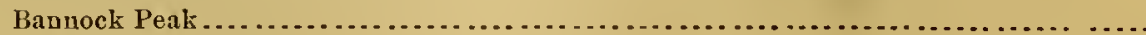

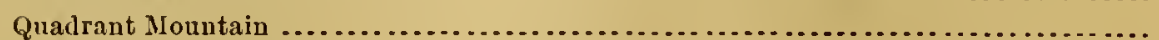

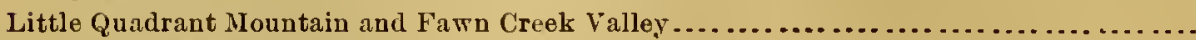

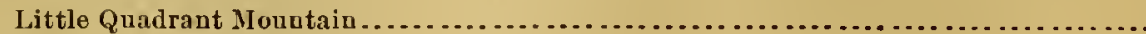

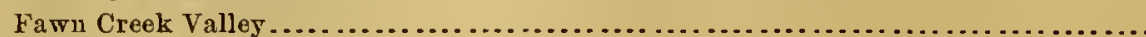

Region north of Gallatin River . . . . . . . . . . .

The Fan.

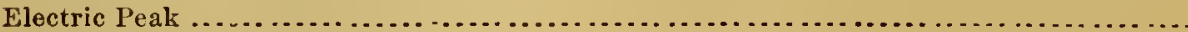

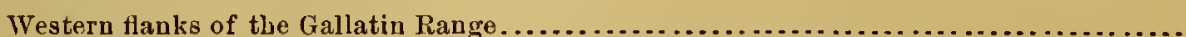

Eastern flank of the Madison Range ............................................

Ciapter II.-The intresive rocks of the Gallatin Mountains, Bunsex Peak, and Mount

EvERTS, by J. P. Iddings.

Indian Creek laccolith

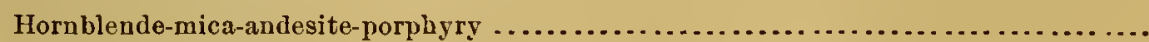

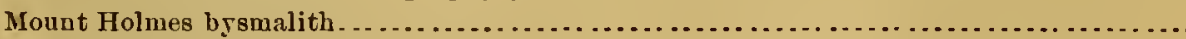

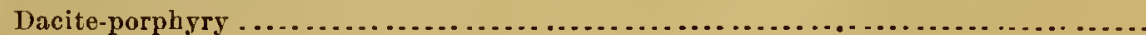

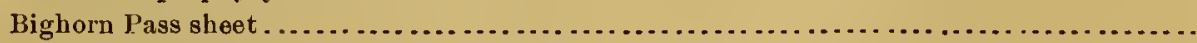

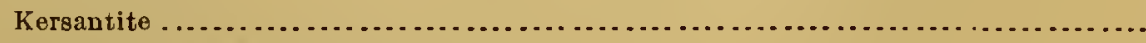

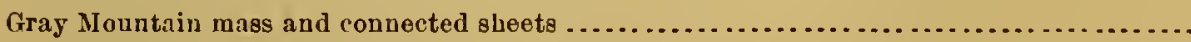

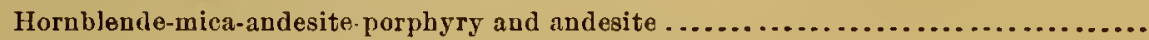

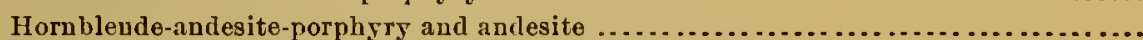

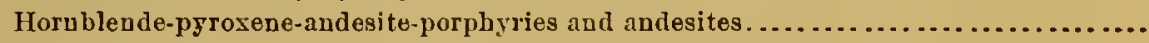

Chemical composition 
Chapter II-Continued. Page.

Differentiated sheet southeast of Electric Peak . . . . . . . . . . . . . . . . . . . . . 82

Gallatin River laccolith ............................................. 84

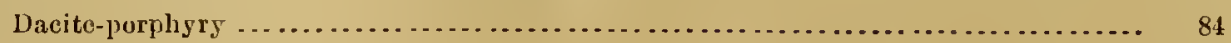

Intrusive sheets in Mount Everts ........................................ 85

The Bunsen Peak mass ................................................. 86

Dacite-porplyry ..................................................... 86

Chapter III.-The igneous rocks of Electic Peak and Sepulchre Mountain, by J. P.

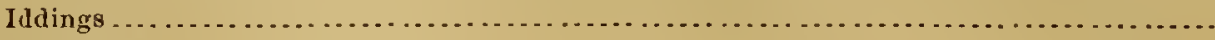

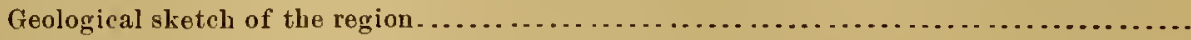

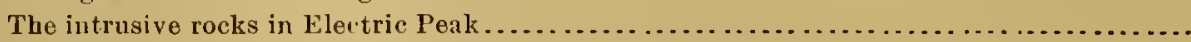

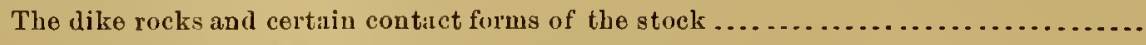

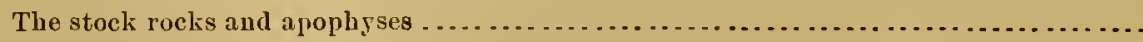

Varietios in which the dark-colored and light-colored minerals are nearly equal....

Varietics in which the light-colored minerals are in excess, but in which quartz is not excessive.

Varietics with an excess of light-colored minerals, in which quartz is abundant....

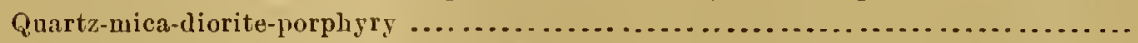

General consideration of the mineral and chemical composition of the intrusive rocks

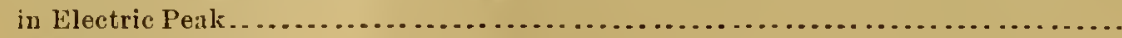

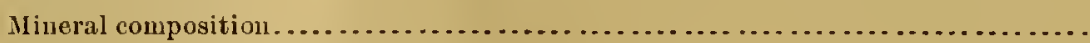

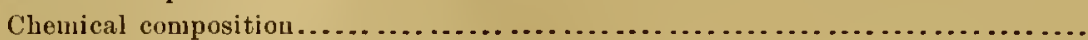

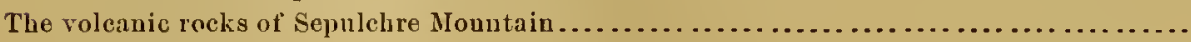

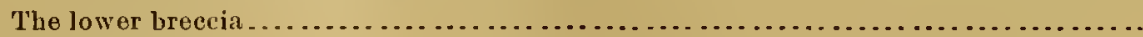

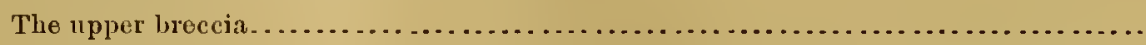

The dike rocks . . . . . . . . . . . . .

General consideration of the mineral and chemical composition of the ermptive rocks

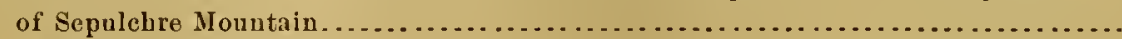

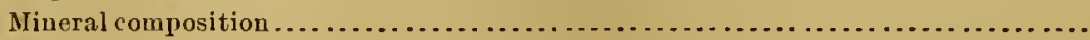

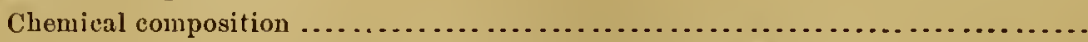

The extrusive igneous rocks west and south west of the Gallatin Mountains..............

Comparison of the rocks from Electric Peak and Sepulchre Mountain ..................

Correlation of the rocks on a chemical basis.

Chapter IV.-Descriptive geology of the northers had of the Teton Range, by J. P.

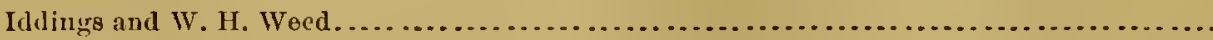

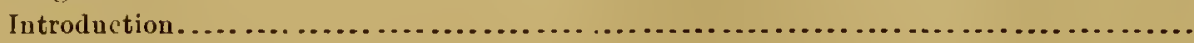

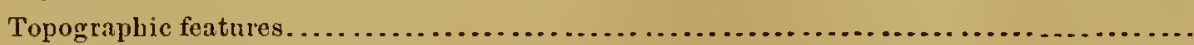

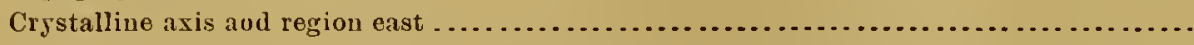

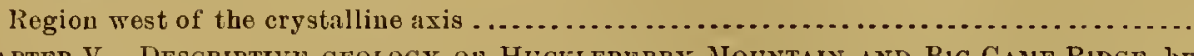

Chapter V.-Descriptive geology of Huchleberry Mountain and Big Game Ridge, by

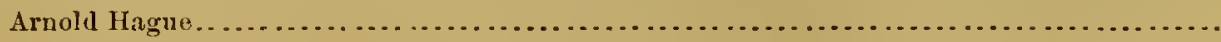

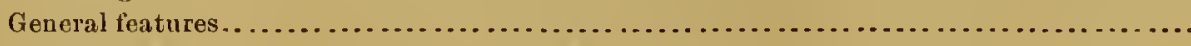

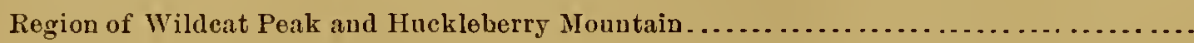

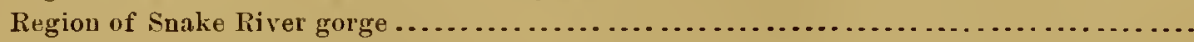

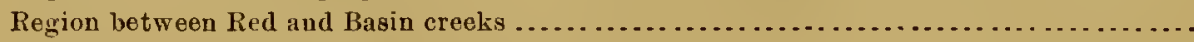

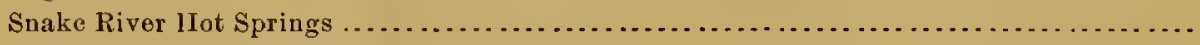

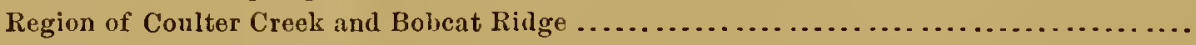

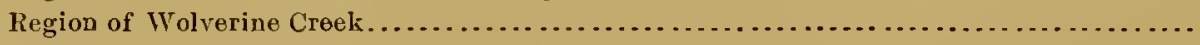

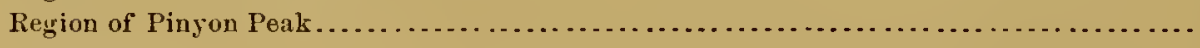

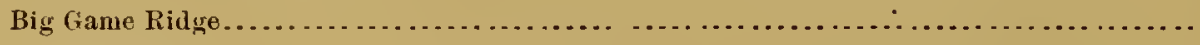

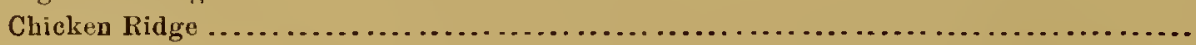

89

89

92

94

97

99 
Cuapter V-Continned. Page.

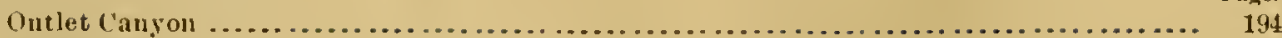

Clatnnel Ionntain...................................................... 196

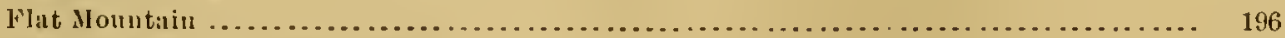

West Bise of 'Two Occan I'latean........................................ 197

Two droan l'liatean ................................................... 200

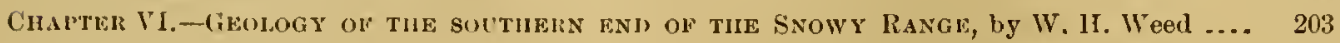

General description ..................................................... 203

'Topography ........................................................... 201

Serlimentary rocks ..................................................... 205

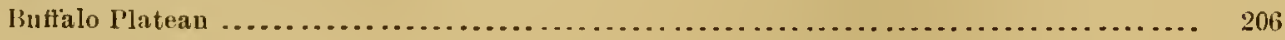

Lamar Vitley .......................................................... 207

Slough Creek ......................................................... 208

Sola Butte Creek ........................................................... 210

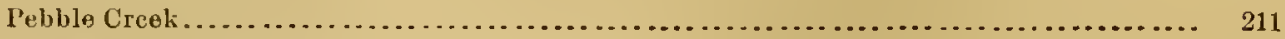

Soda Butte Valley ................................................. 212

Chapter vil.-The dissected volcano of Crandall Basin, Wyoming, by J. P. lddinga.. 215

Introlnction ......................................................... 215

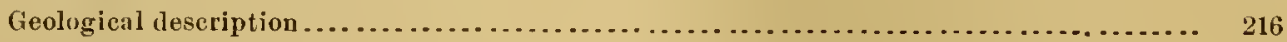

Genera] features....................................................... 216

Early acid breccia.................................................... 219

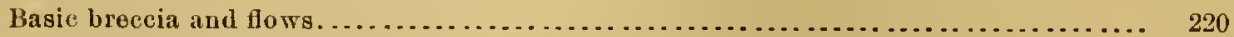

Distinctly bedded breceia....................................... 221

Chaotic breccia .................................................. 222

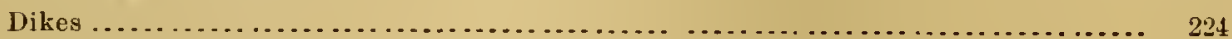

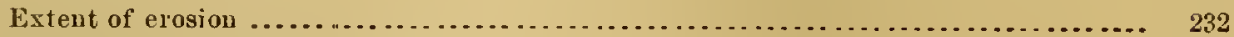

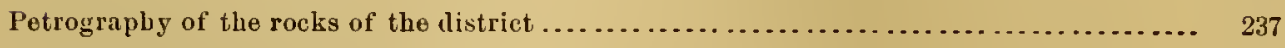

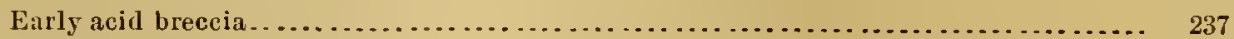

Basic breccia ancl lava flows. ............................................... 238

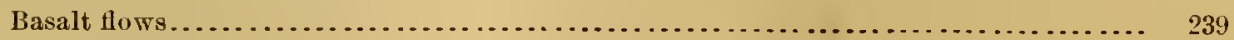

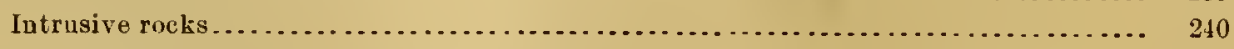

Ontlying dikes ................................................... 240

Granular core and intersecting dilies................................. 246

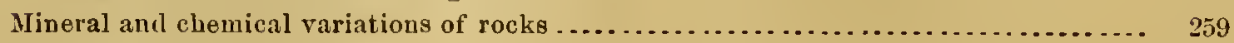

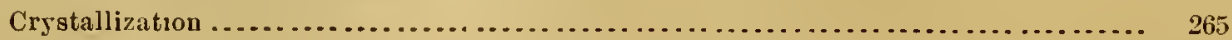

Derelopment of phenocrysts .......................................... 266

Chapter V'111.-Tie igneous rocks of the Absaroka Raxge and Two Ocean Plateau

and of outlying portions of tile Yellowstone National Park, by J. P. Iddings......

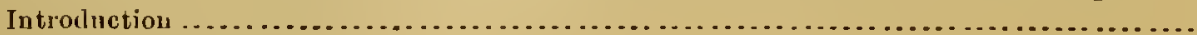

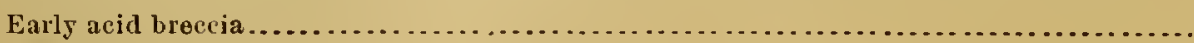

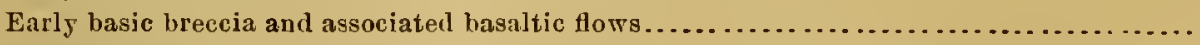

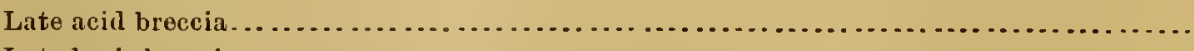

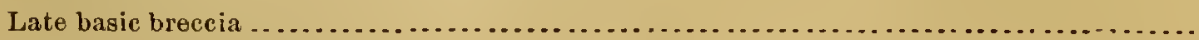

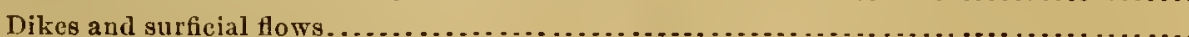

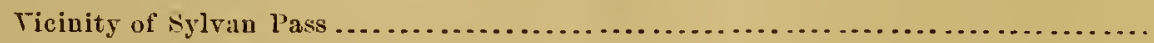

Dikes south aud southeast of Sylvan Pags .........

Jasire

'Irachytic rbyolite .......................................................... 321

Chapter IX.—Absarokite-siloshonite-Banakite series, by J. P. Iddings............... 326

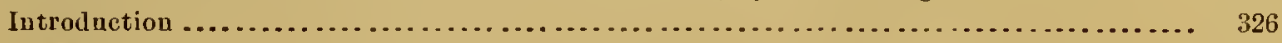

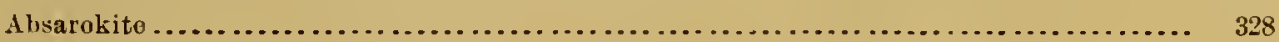


Chapter IX-Continued. Page

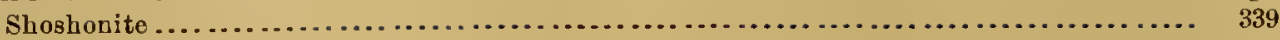

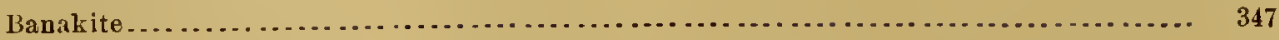

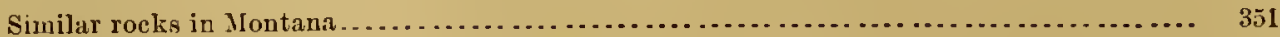

Chapter X.-The lihyolites, by J. P. Iddings ................................... 356

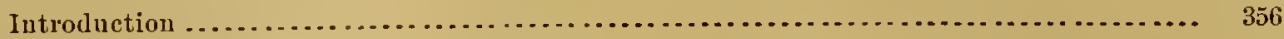

Megascopical characters. ................................................. 357

Vicinity of the Mammoth Hot Springs .................................. 357

Obsidian Cliff ...................................................... 359

Canyons of Gibbon River and Madison River ............................ 366

Madison Plateau north of the Lower Geyser Basin ............................ 367

Vieinity of the Lower Geyser Basin .................................. 369

Upper Goyser Basin ................................................... 372

Malison Platean sonth of the Geyser basins................................ 374

Bechler Canyon ........................................................ 375

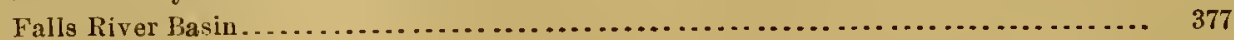

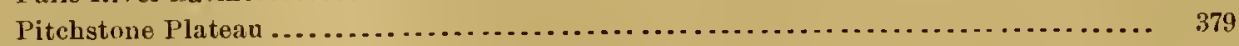

Red Monntains......................................................... 381

Vicinity of Yellowstone Lake ........................................ 382

Natural liridge ........................................................ 386

North and east of Yellowstone Lake .................................. 387

Vicinity of Yellowstone River ........................................... 388

Vicinity of the Grand Canyou of the Yellowstone............................ 389

Northeastern corner of Vellowstone Park................................... 391

Microscopical characters of the rhyolite ................................... 393

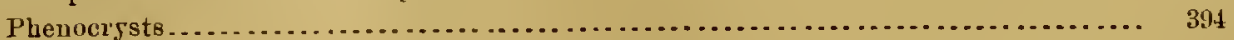

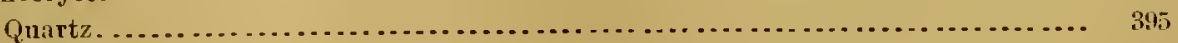

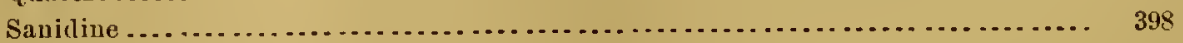

Plagioclase....................................................... 399

Prroxene ........................................................... 399

Magnetite and titaniferous iron oxide............................... 400

Zircop ........................................................... 401

Psendobrookite ........................................................ 401

Allanite and apatite.................................................... 402

Groundmass........................................................... 402

Glasses free or almost free from microlites............................. 403

Globnlitic glass ................................................... 406

Microlitic glass ..................................................... 408

Forms of growth of microscopic crystals ............................... 410

Lithophysic ......................................................... 416

Microgranular structure ................................................... 422

Relations of the various nicrostrnctures to one another in the rock mass.............. 423

Lamination and bancling ................................................ 424

Variations is composition among the rhyolites ................................ 427

Intermingled rhyolite and basalt ............................................ 430

Chapter XI.—Recent basalts, by J. P. Idilings ................................ 433

Ophitic basalt ......................................................... 436

Basalts related to those with ophitic structure............................... 437

Very fine-grained basailts with minute phenocryts............................. 439

Chapter XII.-Paleozonc fossill. ............................................ 440

Section I.-Cambrian fossils, by C. D. Walcott............................... 440

Section II.-Devonian and Carbouiferous fossils, by G. H. Girty ................... 479 


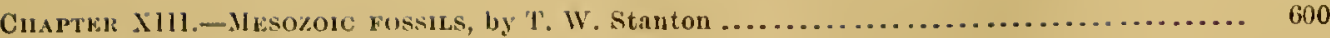

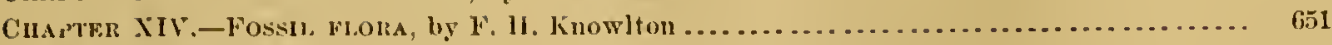

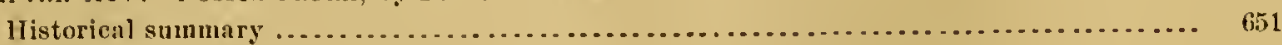

Finmeration and description of fossil plants from the laramio ................... 655

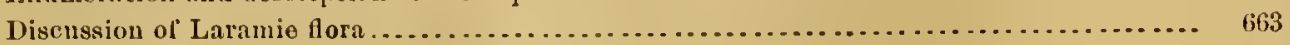

Enumeration and description of fossil planty from the Tertiary .................. 665

Plints, exclnsive of fossil wood ....................................... 665

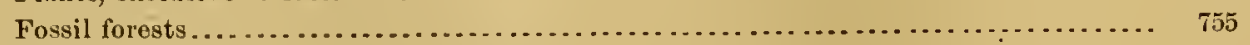

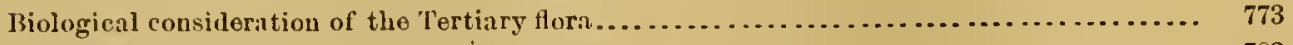

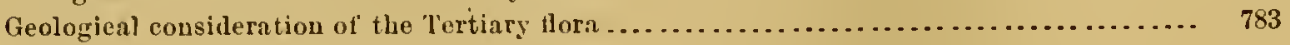

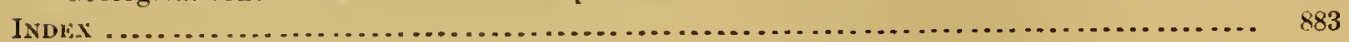





\section{ILLUSTRATIONS.}

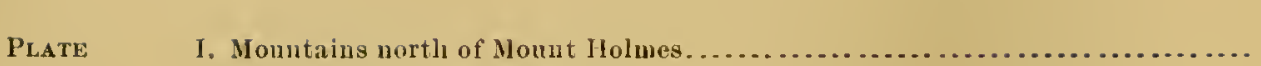

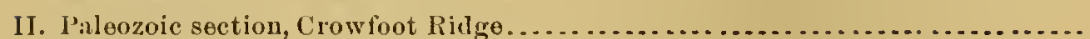

Page.

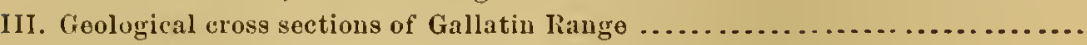

IV. Panoranic view of Gallatiu Range from Norris Geyser Basin ..............

V. Cross sections showing Hount Holmes bysmalith .....................

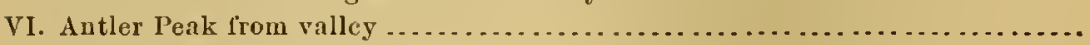

VII. Threo River leak from Gallatin Valley .............................

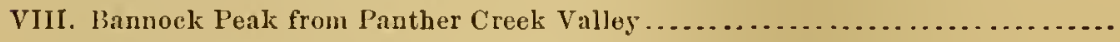

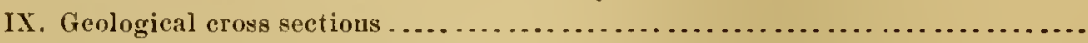

X. Geological map of Gallatin Range......................................

XI. Photomicrographs of andesite-porphyry and dacite-porphyry . . . . . . . . . . .

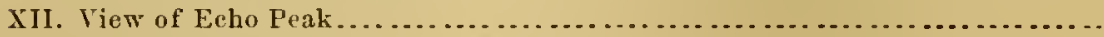

XIlI. Electric Peak from Sepnlchre Monntain ........ . . . . . . . . . . . . . . .

XIV. Head of East Gulch of Electric Peak ... . . . . . . . . . . . . . . . . . . . . . .

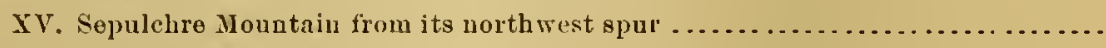

XVI. Geological map of Electric Peak and Sepulchre Mountan ................

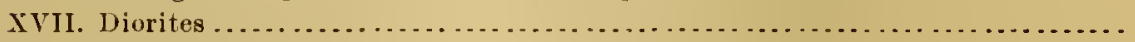

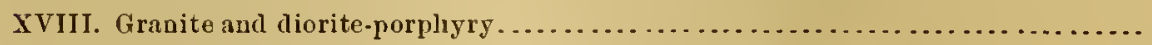

IIT. Photomicrographs of andesite-porphyrs and diorite

.

$\begin{array}{lll}\text { X.. Photomicrographs of diorite aud diorite-porphyry } \ldots \ldots \ldots \ldots \ldots \ldots \ldots \ldots \ldots \ldots & 104\end{array}$

XXII. Photomicrographs of pyroxene-andesitc and dacite..................... 130

XXIII. Naj of the northern end of the Teton Range ..................... 150

XXIV. Snake River Hot Springs .................................. 178

XxV. Outlet Canyon.............................................. 194

XXVI. Baronett Peak . ............................................ 204

XXVII. Geological map showing dissected rolcano of Cranclall Basin, Wyoming...... 216

XxviII. Intex Peak ................................................ 218

XXI.T. The Thunclerer aud Mount Norris .............................. 222

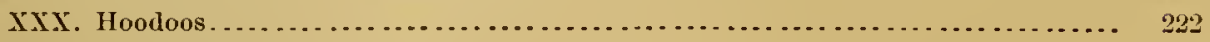

XXXI. Hurricane Ridge......................................... 226

XxxIl. Geological cross sections..................................... 232

XxxII. Photomicrographs of gabbro, diorite, ancl granitic aplite .............. 250

XxxIV. Photomicrographs of monzonite, diorite, and basalt ................ 250

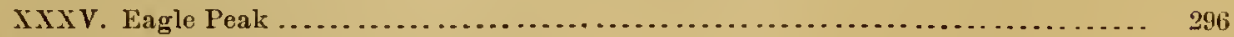

XXXVI. Photomicrograplis of absarokite.............................. 332

XXxVII. Photomicrographs of shoshonite and diorite-porphyry . . . . . . . . . . . 344

XXXVIII. Photomicrographs of banakite, quartz-banakite, aud andesite ........... 350

XXXIX. Obsidian Cliff columns ..................................... 360

XL. Top of columns............................................ 360

XLI. Lithophysa ................................................ 364 
Page.

XLII. Fissile lithoidal rbyolite, Ol,sidian Cliff ......................... 364

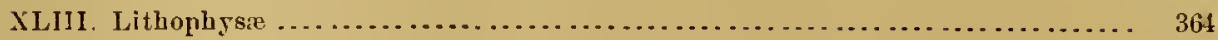

XLIV. Columnar rhyolite........................................ 364

XLV. Columuar Cliff, Madison Canyon ................................ 368

XLVI. Banded perlite............................................. 370

XLVII. Perlite with spherulites .................................. 370

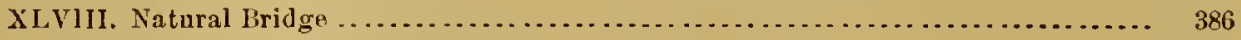

XLIX. Natural Bridge, vertical plates.............................. 386

L. Photomicrographs of rhyolitic glasses ............................ 406

L1. Jhotomierographs of rhyolitic glasses ........................... 406

LIl. Spherulites ............................................. 410

LIIl. Spherulites and feldspar needles ............................... 414

LIV. Photomicrographs of micrographic phenocrysts and spherulites ........... 414

LV. Photomicrographs of spherulitic structures ....................... 414

LVI. Photomicrographs of spherulitic structures and feldspar microlites ......... 422

LV1I. Diagrams of lithophsse ................................... 422

LVIII. Colımnar structure........................................ 436

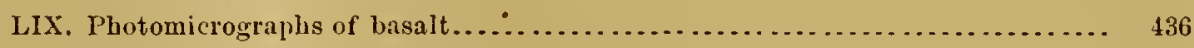

LX-LXV. Cambrian fossls........................................ 468-478

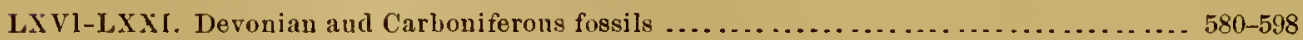

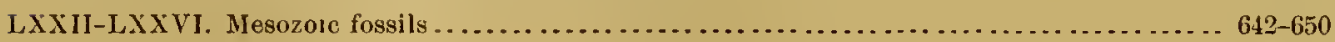

LXXVII-CXXI. Fossil flora ............................................ $794-882$

Fig. 1. Diagram showing variation in silica jercentages of rocks from Electrie Peak......... 117

2. Diagram showing molecular variation of the rocks at Electrie Peak ............... 119

3. Diagram showiug molecular variation of the rocks of Sepulchre Monutain ........... 136

4. Sections of sphcrulites with projecting prisms of orthoclase and a crescent-shaped lelt

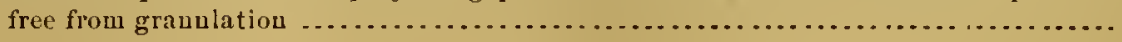




\title{
LETTER OF TRANSMITTAL.
}

\author{
Department of the Interior, \\ United States Geological Survey, \\ Washington, D. C., June 30, 1896.
}

Sir: I have the honor to transmit herervith the manuscript of Part II of a monograph on the Geology of the Yellowstone National Park. It embraces chapters on the descriptive geology of the mountains surrounding the Park Plateau, by myself and colleagues; elaborate investigations of the petrography of the crystalline rocks, by Prof. J. P. Iddings; reports upon the invertebrate paleontology of the Park and the Absaroka Range, by Messrs. C. D. Walcott, George H. Girty, and T. W. Stanton; and an exhaustive study of the fossil flora of the region, by Mr. F. H. Knowlton Very respectfully,

\section{Arnold Hagte, Geologist in Charge.}

Hon. Charles D. Walcott,

Director United States Geological Survey. 



\section{OUTLINLOE THIS VOLUML.}

CuApter 1. The Gallatin Mountains, extencling 18 miles within the bonndary of the lellowstone National l'ark, consist of sedinentary strata langing from the Cambrian, throngh the Silurian, Devonian, Carboniferous, and Inratrias, to the Laramio of the Cretaceous. Theso sedimentary rocks have becn upliftel by forces acting from the southwest. They dip northeast, and bave been folded to il slught cxtent transvorse to the strike. Subsequently they have been strongly faulted. The dislocation at the close of tho Laramie was accompanied bs intrusions of igneous magmas in several large laccolithic bodies and in numerous sheets, and in the vicinity of Jlectric Peak by dikes. Erosion has uncovered crystaltine schists at the southern and southwestern end of the range, and has laid bale exposures of all the sedimentary and igneons rocks. Finally, glaciation has modified the topography in a striking manner. The structural relations of the sedimentary and igneous rocks are illustrated by a number of geological sections.

CHAPTER II. This chapter treats almost exclusively of the intrusive rocks of the Gallatin Mountains. They are mainly tine-grained and aphanitic masses, in most occnrrences porphyritic and andesitic in character. The large bodies differ from one another somewhat in composition, and vary slightly in texture, iu different parts of the rock bodies. In one intrusive sheet there has been a pro. vounced differentiation by the settling of phenocrysts of augite.

Chapter III. Electric Peak and Sepulchre Mountain are described as parts of a Tertiary volcano which were faulted across the conduit, the amount of vertical displacement liaving been more than 5,000 feet. The deeper portions of the monntains, consisting of sedinentary strata intersected by dikes, sheets, and the stock or couduit of the volcano, have been bronght to the surface, as shown in the mass of Electric Peak. The ejected breccias and lava flows, together with the upper portion of the conduit, constitute Sepulchre Mountain. Lavas which are andesites in the latter mass are diorites and porplyries in the former. Rocks with like chemical composition are found to have differcnt mineral composition according as they are crystallized into phanerocrystalline diorites or into apha. uitic andesites.

Chapter IV. The northern end of the Teton Range extends bnt a short distance within the Yellow. stone National Park. It consists of a uncleus of crystalline schists and gneisees overlain by Paleozoic and Nesozoic strata flexed in an anticline with northward-dipping axis and fanlted to a slight extent. Birch Hills, a fer miles to the north, are an ontlier of the range. Upon greatly erodcd strata basic breccias were thrown ont, and after these had undergone fresh erosion vast flows of rhyolite covered the country and now form a part of the plateau of the Park, beneath which the vortheru extremity of the Teton Range is hidden.

CHAPTER V. The country described in this chapter embraces a mountainous area irregnlar in outline and of great diversity of form. It is sitnated in the sonthern part of the Park and the Yel. lowstone Park Forest Reservation. It cunsists of a number of ridges trending northwesterly and southeasterly, formed for the most part of llesozoic rocks. The older sedimentary rocks ire exposed, but the ridges are essentially made up of sandstones of Cretaceous age. The irregular outline of the mountains is due to the rhyolites of the Park Plateau that abut against the slopes of the upturned beds. The prinespal physical features of the region are Wildcat Peak and Huckleberry Mountain, Bobcat Ridge, Big Game Ridge, Chicken Ridge, Two Ocean Plateau, and the gorge of Snake River. West of Hnckleberry Mountain occur several exposnres of dacite surrounded by rhyolito. They are among the few outerops of dacite known in the Park, and are appirently older than the rbyolite. In the gorge of Snake liver the Madison limestones, Teton sandstones, and the Erlis limestones and 
shales are well shown. The Snake River hot springs are situated near the coutact of the rhyolite with the Carboniferous limestone, the lime of the travertine being derived from the Madison limestones. The incrustations around the springs resemble the travertine deposits found at the Mammoth Hot Springs. The characteristic and limited Wolverine flora, of Laramie age, occurs near the base of Pinyon Peak. The conglomerate of Pinyon Peak, a striking physical feature of the region, is described as overlying uncontormably the Laramie sandstones, and evidence is given showing that the conglomerate probably belongs to Eocene time, as it underlies the basic breccia of the Absaroka Range. The impressive gorge of Outlet Canyon cuts a deep passage completely through Chicken Ridge. The interesting feature of the canyon is that it at one time served as the discharge for the waters of Yellowstone Lake. This sheet of water, which now flows nortluard and drains to the Atlantic through Yellowstone Canyon, formerly discharged into Suake River and thence to the Pacific. Two Ocean Plateau shuts in the sedimentary ridges on the east. The platean, which rises 10,000 feet above sea level, forms a part of the Absaroka range and is made up of similar rolcanic breccias and silts.

Chapter VI. The extreme southern end of the Snowy liange forms the northeast corner of the Park. The crystalline core of the range forms a liroad, plateau-like summit, bordered by sedimentary rocks of Paleozoic age, which along the suuth slope dip gently away from it toward the Park. The highest peaks, together with extensive areas, are formed of andesitic breccias, but erosion has cut through them and exposer the mderlying linestones, showing that the rolcanic rocks rest npon a very uneven aull rugged surface. Detailed sections of the Paleozoic sedimentary rocks from the Flatheal formation to the Malison limestone are given, but the igueous rocks are described in other chapters.

Chapter VIl. The Hiocene volcano of Crandall Basin built itself upon a ridge of eroded Paleozoic rocks which dip toward the southwest from the crystalline schists of the Beartooth Range. Beneath the volcauo are zemnants of Eocene breccias and lava flows. The volcano consisted of basic andesitic breccias toppen by basalt flows and trarersecl by dikes that radiated from the stock or core which was the conduit beneath the crater. While bedded breccias characterize the outer portions of the rolcano, chaotic unberled breccias form the central portion. Comparison with modern active volcanoes indicates that the Craudall volcano rose to about 13,400 feet above its limestone floor. The phanerocrystalline rocks within the core are gabbros aul diorites, approaching monzonites in part, and are chemically like the basalts and andesites of the breccias, dikes, and flows, but differ from then in mineral composition. They also are parts of the volcano and are properly rolcanic rocks.

Chapter VIII. The Absaroka Range cousists largely of volcanic breccias, with subordinate amounts of massive flows or intrusive bodies. This chapter presents a petrographic treatment of those igneous rocks which lie within the limits of the Yellowstone Park, and their discussion is confined to an account of their field occurrence and distribution and a systematic description of their mineralogical characteristics and composition. The earliest accumulations occur at the northern eud of the range and are made up of early acid breccias found in disconnected remnants beneath early basic breccias. They consist mainly of hornblende-andesite and hornblende-mica-andesite. The early basic breccias are pyroxene-andesite, passing upward into the massive basalt flows. Upon the latter were thrown the late acid breccias, similar in composition and appearance to the early acid breccia. This passes upward into late basic loreccia, consisting of basic andesites with less basalt than is associated with the early basic breccia. The late basic breccia forms the southern portion of the range within the Yellowstone Park and also Two Ocean Plateau. At Sylvan Pass and in its vicinity it is traversed by dikes of andesite and a few of diorite. Remnants of surficial flows of uassive andesite form the summits of Mount Stevensou, Mount Doane, Colter Peak, ancl several prominent mountains south of Sylvan Pass. 
Cinaprex IX. ('ertain basiltic anel othre rocks associatel with the andexitiv brocrias and basalt flows lave a enusiloruhle content of urthoralsu in mieruscupie crygtals, and a comparatively

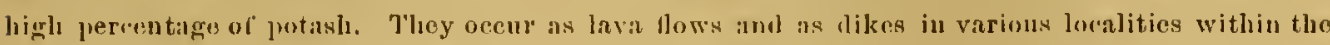

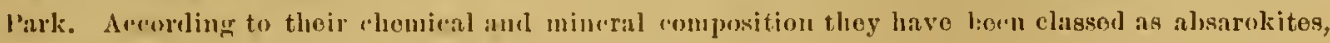
shoshonites, ind banakites.

Cuafrer $X$. Tho rlyolites of the l'ark aro amosi wholig extrusive lavas of cery uniform composition, but having a wile rangu of color, fexture, and moraseopic: luabit. 'The appearanco of the lis-

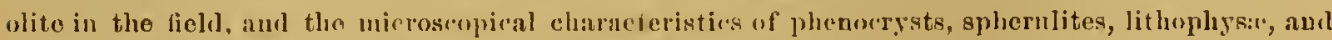

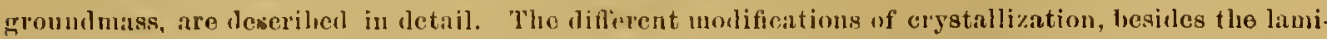
nation and formation of punice, are referable to heicrogeneity of the moltren magma, especially witl roference to tho amonut of vapor eontaind in it. liximples of intermingled basalt and rhyolite are clescribed, in which tho hasilt appears to lave heen iuclosed and partly muted by tho rhyolite.

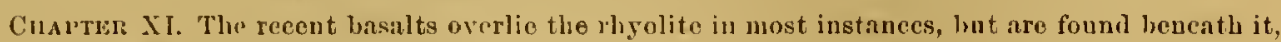
and also hetween ull'l and younger sheets of rligolite in sovera] lucalities. These lusalts are distin. gruisliea from those assuciater with the early and late basie breceias by loing opluitic and nonporpheritic for the jnogt part.

Cuaprer XII. This chapter describes tho Palenzoic fossils known to ocenr in the Yellomstone National Park and tho Alisaroka liange. It is alividel into two sections, the first treating of the CamIrian species anl the soeond of the lovonian and Carboniferms species. lioth Flatheal and Gallatiu formatims have yielded a small lut characteristic fann. From the Cambrian 21 species in all haro loen obtained, several of whiel are uew to science and descrilued here for the first time. No tossils of undonbted Silurian age bave hoen obtained, althongl the heds carry imperfeet and partially olutiterated organic forus. The Three Forks limestone has iunished a well-recoguized Devonian fauna. Frem the Madigon limestone a varied fanua las ben collected, but lolonging wholly to the Lower Carboniferons period.

Cuaptir XIII. The Mesozoic fossils obtained from the Yellowstone National l'ark wore found in the Gallatin Range near Electric Peak, Teton lange, in the neighloorloorl of Wildeat Peak and Huckleberry Mountain, and from the Cretaceous ridges in the southern end of the Park and Yellowstone Forest Reserve. The Mesozole strata have yiclded 78 species of invertelurates, of which oue is from beds supposed to be of Triassic age, 46 are Jurassic, and 31 arc Cretaccous. Tho fossils obtained were maiuly from the Ellis formation of thr. Jura aud the Coloralo of the Cretaccous. The Jurassic fossils form much tho largest and most prominent part of this colluction, and in number of species it eompares favorahly to the Jurassic of other parts of the liocky Monntaius.

Cusprer XIV. The Mesozoic fossil llora of the Yellowstone National Park is confined to the Laramie sandstones of the Cretaceous and is found on Mount Everts, near Mammoth Hot Springs, and at the hase of J'inyon Peak nour the heal of Wolverine Creck. "The ilora from this latter locality lias been designated the Wolverino Creek flora. The Tertiary tlora is very varjul aud possesses grut biological interest. It is a rich llora, and on comparing it with the living flora it breomes apparent that great climatic changes must have taken placo since the close of Miocene time to bave made these changes in plant life possihle. It is fonnd at numerous localities associaterl with the breceias and silts of the igneons rocks of the Alsaruka Range. It is foumel in the early aroid breceias, in tlie early hasic hreveias, in the late acid brecias, and in the hate basic brecias, where the muds and silts furuish a soil favorable for a vegetable growtl. The most interesting loeality as regards numbur of species and wode of occurrenee is the will-known Fossil Forest of Fpecimen Ridgro. The Terliary fossil flora embraces aloont 150 frrms that havo hecn distributed amonu 33 matural orders. This fossil Iora is illustrated lig forty-five plateg.

$$
\text { - MION XXXII, I'I II- II }
$$





\title{
GEOLOGY OF THE YELLOWSTONE NATIONAL PARK, PART II.
}

\author{
By ARNOLD HAGUE AND OTHERS. \\ CH A P T E R I. \\ DESCRIPTIVE GEOLOGY OF THE GALLATIN IIOUNTAINS. \\ By Joseph Paxson Iddings and Watter Harvey Weed.
}

\section{INTRODUCTION.}

The Gallatin MLountains form a range of peaks and ridges extending southward for 63 miles from the vicinity of Bozeman, on the line of the Northern Pacific Railroad, about latitude $45^{\circ} 40^{\prime}$. The range lies between the Yellowstone and Gallatin rivers and terminates in the neighborhood of Ilount Holmes, at about latitude $44^{\circ} 45^{\prime}$. The southernmost 18 miles of the range lies within the boundary of the Yellowstone National Park and forms that portion of it described in the present chapter. The northern portion falls within the region described in folios 1 and 24 of the Geologic Atlas of the United States. ${ }^{1}$

Within the Park boundary the peaks of the main chain reach altitudes of from 10,000 to 10,500 feet, and at Electric Peak 11,100 feet, and stretch from Electric Peak, which is situated directly on the northern boundary line, southward to Mount Holmes. The country has been deeply cut by erosion, and is drained by tributaries of the Yellowstone, Gallatin, and

1 Geologic Atlas U. S., folio 1, Livingston, Mont., 1893; and folio 24, Three Forks, Mont., 1896.

MON XXXII, PT II- 1 
Madison rivers, the watersheds between which meet one another in Three River Peak. The special description of the physiographic features of the region, however, including the glaciation, will be found in Part I of this report, where it is treated by Mr. Hagne. Without entering into a topographic description of the Gallatin Mountains, it will be in place here to call attention to the fact that the region in question, within the Park boundary, is a block of country delimited on the east and on the west by profound faults trending nearly north and sonth, the western fault line having a somewhat northeasterly trend. This block, about 7 miles wide, is bounded on the south by a capping of lavas, which borders it also to some extent on the east and on the west. The northern end of the block lies beyond the Park boundary, in the neighborhood of Cimnabar Mountain. The block is wider at the sonth, and narrows northward. It is a wedgeshaped mass cut diagonally across a synclinal trough, with one long and one very short limb. The latter appears for only a short distance at the northern end, in Cimnabar Momntain. Within the area of the Park the block has the structure of a monocline, dipping northeast across the longer diameter of the block. Minor faults and folds modify the structure somewhat and introduce local complications, which will be described in detail.

As a result of the dipping of the block to the northeast, the oldest formations are found at the southern and sonthwestern ends, and the youngest formations at the northern. The rocks are well exposed, the succession of the strata is clearly made out, and the form and character of the igneous material that has been forced through the sedimentary rocks are readily observed. The study of the igneons bodies and their relations to the geological structure of the block proves that the dynamic history of this particular area was complex, and extended over a long period after the deposition of the coal-bearing Laramie sandstones. In fact, a succession of dislocations must have followed one another through the greater part of the Tertiary period. This will appear from the description which follows.

Erosion has carved deeply the surface of this upturned, fractured, and distorted block, grooving it with valleys and gulches, the eastern system trending northeast and east and draining with the dip of the strata, the western system trending and draining northwest along the general line of the strike and being in all probability controlled by lines of fracture in this direction. The intervening elevations rise abruptly to sharp peaks 
and ridges, attaining altitudes of from 10,000 to 11,000 feet above sea level, with oceasional plateaus, 2,000 feet or more above the valley bottom.

The bold escarpment and barren upper portions of these mountains perinit their general structure to be made out with ease, even from a distance. Thus the general structure of the eastern face of the range may be seen from Bunsen Peak or Terrace Monntain. The open, park-like character of the valleys and lower slopes of the mountains, the abundance of grass and water, and the multitude of flowers that cover the whole country during the summer season render this one of the most picturesque and delightful of mountain regions, both for the geologist and for the artist.

\section{THE CRAGS AND VICINITY.}

A description of the geological features of the Gallatin Range naturally begins with an account of the region where the basal and lowest rocks of the series are exposed. These oecur in the southern and southwestern part of the range, and a description of the range from these peaks northward is, in general, also a description of successively later geological formations. The oldest rocks of the region are crystalline schists, which are mainly gneisses. These rocks form two prominent topographic features of the southeru end of the range. The first of these is the group of rugged peaks ealled The Crags, together with their less elevated spurs to the south, and their prolongation in the ridge trending northwest, parallel to Grayling Creek. Crowfoot Ridge constitutes the second prominent mass of crystalline schists, while the low rounded hills at the head of Grayling Creek are also formed of these rocks. A few inconspicuous outlying exposures of schist occur to the southwest, where erosion has removed the overlying sheet of rhyolitie lava.

THE CRAGS.

The rocky summits of The Crags and the ridges northwest are very rugged and difficult to traverse on account of the loose débris and thicktimbered slopes. But while the southern esearpment of Crowfoot Ridge is equally obstructed, its summit is comparatively open and level topped, showing little erosion since the removal of the sedimentary cover. 'The lower hills between Grayling and Maple creeks are rounded and smoothed, with every evidence of having been glaciated and considerably worn. Throughout this area of crystalline schists, coarse and fine grained gneisses 
alternate with one another, the coarser varieties being generally lightcolored mica-gneisses rich in feldspar and quartz. The finer-grained, dark-colored varieties are for the most part mica-gneisses richer in biotite. Mica-schists, sometimes highly gametiferous, occur in smaller quantities, and amphibolites are also found. The pronounced lamination or schistosity of the whole body of these rocks is quite uniform in its position, the layers standing at high angles or nearly vertical, with a general north-south trend. The microscopical study of these rocks shows them to be normal crystalline schists, laving the microstructure of highly metamorphosed rocks and exhibiting no traces of their previous character. Their study in the field was not thorough enough to throw any light on the question of their possible origin.

South and west of The Crags the crystalline schists are directly overlain by volcanic breccia and tuffs of andesites, whose subaerial accumulation is beyond question. Thiese rocks are generally dark colored, and occur in rugged outcrops and rough, angular talus blocks. In general, the easterly slopes are smooth, covered witl soil, and less steep than the western sides of the hills. The andesites are variegater in color and are chiefly hornblende-andesite, carrying some pyroxene and a little biotite. The occurrence of these subaerial breccias shows that at the time of their eruption the crystalline schists were exposed surface rocks which had undergone extensive erosion, by which they had acquired a pronounced mountainous topography.

On the west and south the schists pass under massive rhyolitic lava, which is part of the great plateau lavas farther south, and whose position with respect to the crystalline schists and andesitic breccias is such as to show that the rhyolitic lava flooded the lower levels of this gneissic region after the andesitic material had been accumulated and had been partly removed by erosion. That the rhyolite overlies the andesitic breccia is clearly shown in the walls of Maple Creek Canyon. The rhyolite also fills the valley bottom between two ridges of andesitic breccia in this vicinity, indicating the extent to which the andesite had been previously eroded.

There is marked contrast in the scenery and topography of the gneissic areas and of the country formed by the rhyolite, the former being essentially rugged and broken, while the latter is as yet comparatively little affected by erosion, the streams flowing in trenches and canyons cut 


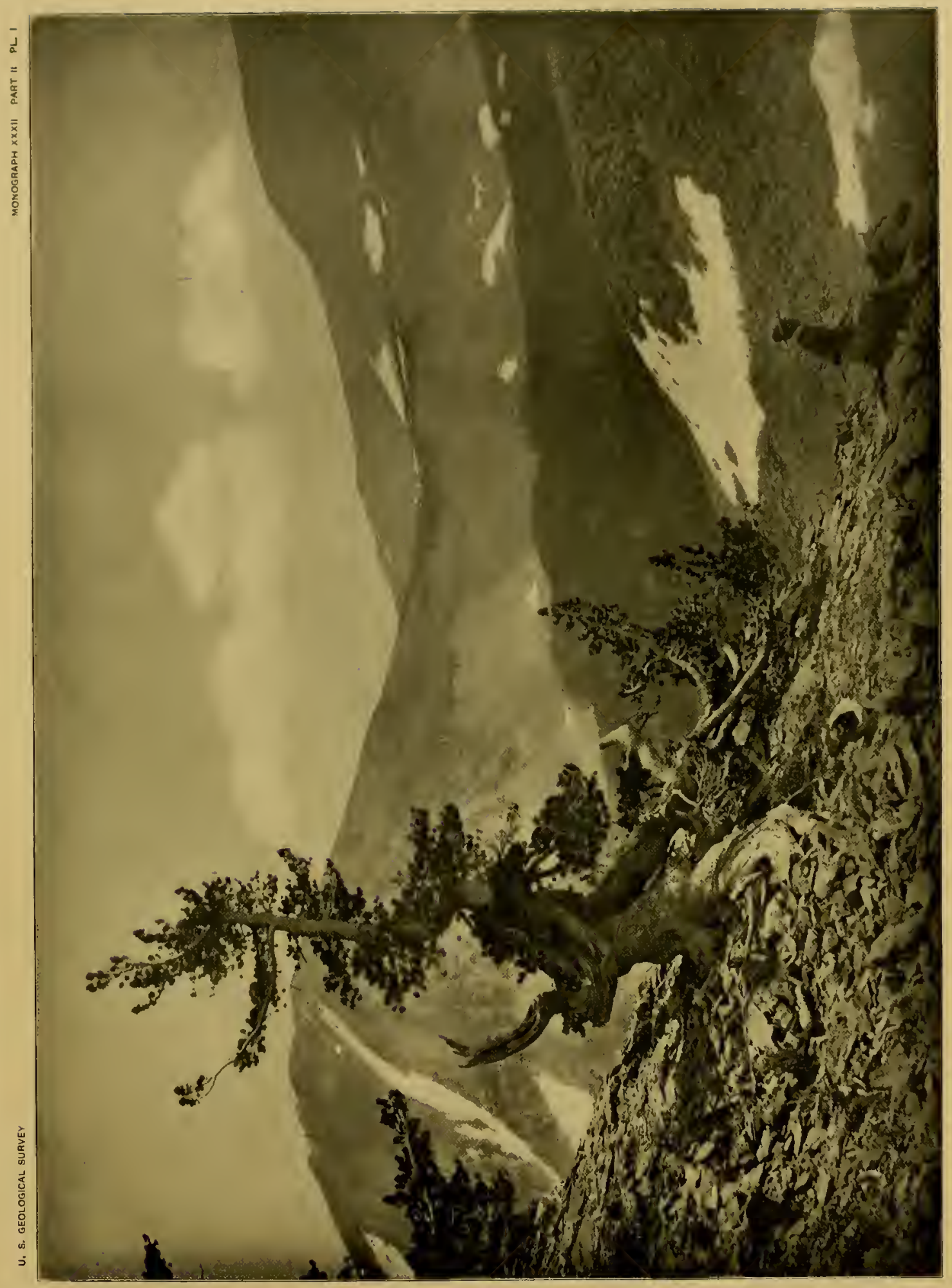



in the soft rock. Often the boundary between gneiss and rhyolite is defined by small drainage ways wom along the contact.

Along the western side of the gueissie area the rhyolitic lava rises to altitudes of 8,000 to 8,200 feet, while at the head of Maple Creek it rises to 8,700 feet, the level of the divide between this creek and Grayling Creek. From this it seems highly probable that the lava flooded the valley of Grayling Creek at the time of its eruption, and has since been removed by erosion. The absence of any remnant of rhyolite within this valley, as the map represents, is not based on a careful examination of the valley, but expresses our ignorance in respect to its occmrence there.

The marked contrast between the topographic character of the southem side of Crowfoot Ridge and that of the northem side is noteworthy. The sonthern slopes are alnost free from lateral spurs of any size and the ridge is approximately straight. On the north, spurs branch off at short intervals, increasing in size toward the west until they attain the proportions of mountain ridges. The three most prominent of these spurs trend nortl.

This contrast in topographic configuration is to be explained by the position of the former covering of sedimentary rocks, which were removed during the downcutting of the Grayling Creek Valley. This ereek, following the well-known habit of streams, formerly ent its chamnel westward along the strike of the northward-dipping sedimentary rocks, gradually deepening its channel mutil, reaching the underlying crystalline schists, it was compelled to contimue in the same course, deepening and widening the valley, whose straight northerly walls are due to the absence of lateral drainage chamels consequent upon the northward dip of the strata. The same configuration is seen in the upper valley of the Gallatin River and the valley of Fawn Creek, where the mountain gorges are cut in sedimentary rocks.

The topography of this ricinity is so closely dependent on the character and position of the strata immediately overlying the gneiss, and these strata have been tilted, curved, and faulted to such an extent, that it is advisable to postpone the description of this area until the less distributed rocks lying inmediately east of the main body of crystalline schists have been described.

The region just mentioned lies east of the main gneissic area, and is 
separated from it by a fanlt trending a little west of north. This fault crosses the southem end of Crowfoot Ridge, abont a mile west of the summit of Three River Peak, and passes sonthward along the west base of the mountains, between Indian and Maple creeks, disappearing beneath the more recent rhyolitic lavas. The eastem area embraces the most prominent peaks of the southern portion of the Gallatin Mountains, including Hount Holmes and the bare porpliyry peaks around the head of Indian Creek, besides Trilobite Point, The Dome, Antler Peak, and Three River Peak, peaks that are directly comnected with the mountains north of Panther Creek.

\section{CROWFOOT SECTION.}

Before taking up the description of these mountains, involving sedimentary rocks, it will be best to give an account of the stratigraphic series. A very carefully measured section was made of the Paleozoic strata exposed on a northerm lateral spur of Crowfoot Ridge. This high mountain ridge shows the entire sequence of the Paleozoic sediments of the region, from the crystalline schists to the top of the Carboniferous, exposed in an unbroken succession of apparently conformable beds dipping at an angle of $30^{\circ} \mathrm{N}$. The general form and profile of the ridge is shown in Pl. II, which gives a view of the ridge from the east. The illustration shows the bluffs formed by the harder beds of the series, rising above the slopes into which the shales and thinly berded strata have weathered down. Two lines of cliffs, formed by the mottled limestone, No. 14 of the section, and the Jefferson limestone, No. 19, are seen in the view. These horizons form characteristic cliffs thronghout the range, and are an important aid in reading the structure of the mountains. The section of the sedimentary rocks made at this place has served as a basis of comparison for all the other sections of the Paleozoic rocks made in the Gallatin Range. The beds are well exposed, the crest of the ridge being bare of soil or vegetation and the trend of the ridge being very nearly at right angles to the strike of the strata. 


\section{Crowfoot Ridlye section.}

33 Quadrant quartzite. Sundstono and quartzite, sacclaroicla] in texture, reddish near tho base, with dark-grily and very calcareons layers; passes at tols to a white sand-

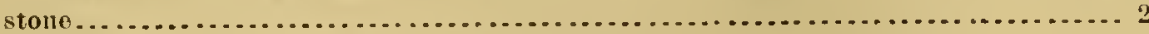

d. Limostone, light gray, brecciated and broken; in places iron stainerl.......... 100

c. Limestone, light gray, raried with lorown bands or finestripes and lines; contains chort, and is in places breceiated, the fragments being cemented by calcite.... 400

b. Linestone; crystalline, very light gray, weathering creamy white; contains white chert in bands aud nodn]es.................................. 30

a. Limestone, crystalline, dark brownish gray, intersected with calcite seams. Chert lands and nodnles are abundant............................. 125

Limestone, light gray and gray. Weathering gray; landed with lorown; banded appearance on weathered surface; finely crystalline. Fossils abnndant. ................ 380

1.. Limestone, crystalline, massive, light gray, with small brownish fossil fragments scatterorl throngh it. 'The upper 10 feet is a conglomerate of red, often cellular linestone. Fossils ................................................... 40

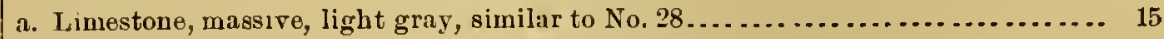

29 Limestone, light gray and brown, very finely crystalline or granular; well bedded, with layers 10 to 20 feet thick of brown or cream-colored limestone. Certain layers are banded with light.colored chert, weathering buff or brown; these layers carry corals and fossil shells.

28 Limestone, crystalline, light gray, generally massive, but iu places more thinly bedded, and striped with brown. The rock is often magnesian and impure. Fossils......... 200

27 Limestone, dark gray and buff, very argillaceons, thick and thinly bedded. Fossils from the upper portion and the lower portion of these berls are Lower Carboniferous.

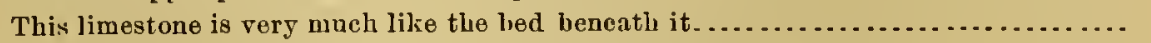

b. Limestone, more massively bedded than the underlying bed and coarser in crystallization; a quite pure limestone, full of fossil fragments ................ 15

26 a. Limestone, fissile and thinly bedded, impure and argillaceons. The fossils occur in lower and upper beds ........................................ 60

Limestone, coarsely crystallino, dark gray, somem hat variable; a little cherty; fossiliferous

24 Limestone, cherty; at base rery finely crystalline; occurs in massive layers and is pinkish gray. Higher up the beds are cherty, and the upper portion contains many crinoid stems and a few indistinct corals and shells. Weathers red, and is cracked and brecciated

23 Limestone, bnff and red, fissile, near base passing in to a more thickly bedded limestone. The rock is a deuse, compact, light limestone, argillaceous and siliceons .

22 Limestone, erystalline, dense, compact; the upper 20 feet is red and crackerl the berls beneath are massive, with toothed juuction surfaces. Rock is decidedly magnesian.. 50

21 Iimestone, in alternating beds of thin and fissile buff and massive gray limestones, the heds 15 to 20 feet thick, and the limestone much cracked This limestone is impure, argillaceous, and in some beds quite arenaceous

- ( b. Limestone, crystalline, dark gray, thick and thinly bedded, with fetid ollor, and containing gasteropod shells. The limestone is quite pure ............... 15

20 a. Limestone, crystalline, brown, crackled, with fetid odor. Slightly arenaceous; granular ............................................... 10 


\section{Crowfoot Ridge section-Continned.}

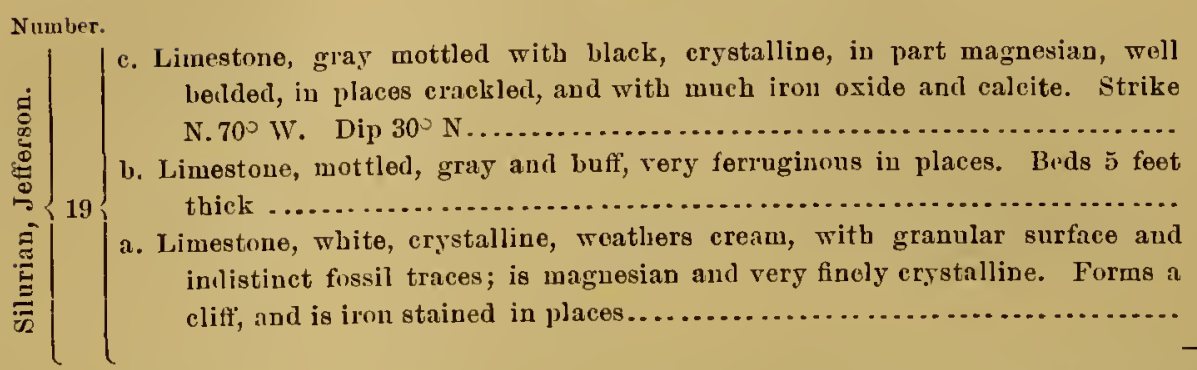

18 Limestone, conglomerate, nodular, and shaly layers near the hase, orerlain hy thick aud thin beds of densely crystalline limestoue alternating with thinuer, shaly aud fissile strata. Toward the npper part less shaly, denser, with brown layers and layers of

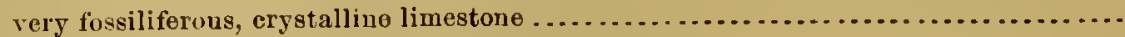

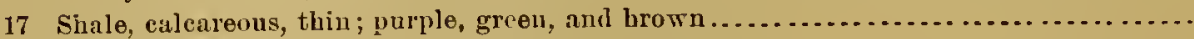

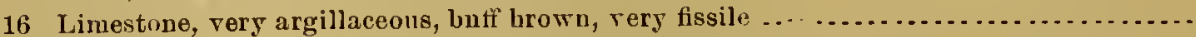

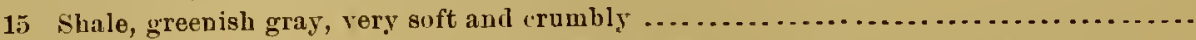

It Mottled limestone. The upper 2 feet is an arenaceous conglomerate, in which the fragments are rounded pehbles of shale and sandstoue; the matrix a slightly argillaceous sandstone. Strike N. $70^{\circ} \mathrm{W}$. Dip $27^{\circ} \mathrm{N}$. The mottled limestone is a pure, thickly bedded (20 fuet) rock, dark gray mottled with brown or black; crystalliue, with

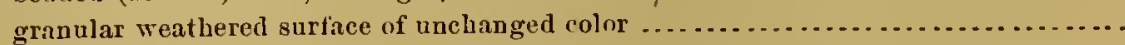

13 Limestone, variously moditied. The lower layers thickly and thinly bed ded, nueh of it coarsely crystalline, witl green grains of glauconite and great numbers of trilobite spines. Interbedded with this limestone are layers of dense, gray, fissile and thinly bedded limestone, with rellow bands, and limestone conglomerate. About the middle of the berls there are several thick beds of crystallive limestone containing green grains. This is overlain by a conglomerate. The matrix is pure limestone, the pebbles slightly argillaceous and resembling a nud deposit..........................

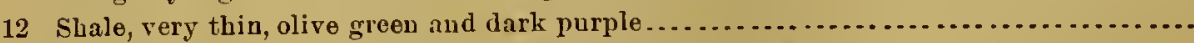

11 Limestone, pure and ferruginous. In general this limestone is red-brown, but contains masses of deuse, dark-colorsl limestone, which weather in balls with spherical shells. Balls 3 feet throngh

(Limestone couglowerate; brown-gray and gras pebbles in buff matrix. Fragments

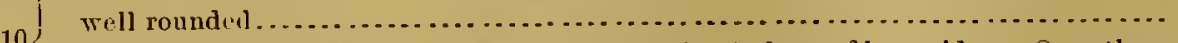

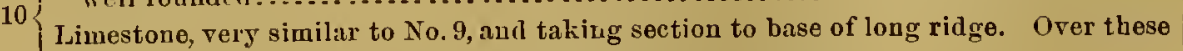

beds are layers of crystalline limestone, with green grains

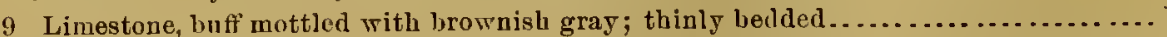

8 Limestone, massively bedded, quite pure; weathers with smooth surface; color, brown .

7 Limestoue, pure gray, with dense, lark-gray layers and streaks in a buff, grauular matrix. Rnus up to top of first point shown in Pl. II

6 Limestones, thinly bedded, light and dark gray in color, showing remains of shells and trilobites

5 Limestones, thinly bedded, with interberded micaceous shale, having fossil indications. Fossils collected from the upper part and from lowest beds ......................

4 Shale, micaceous, green and purplish

3 Sandstones, slightly indurated, red and green, with grains well rounded; quartzose....

2 Quartzite and sandstones, cross bedded, and containing well-rounded pebbles of gneiss.

1 Gneiss. 


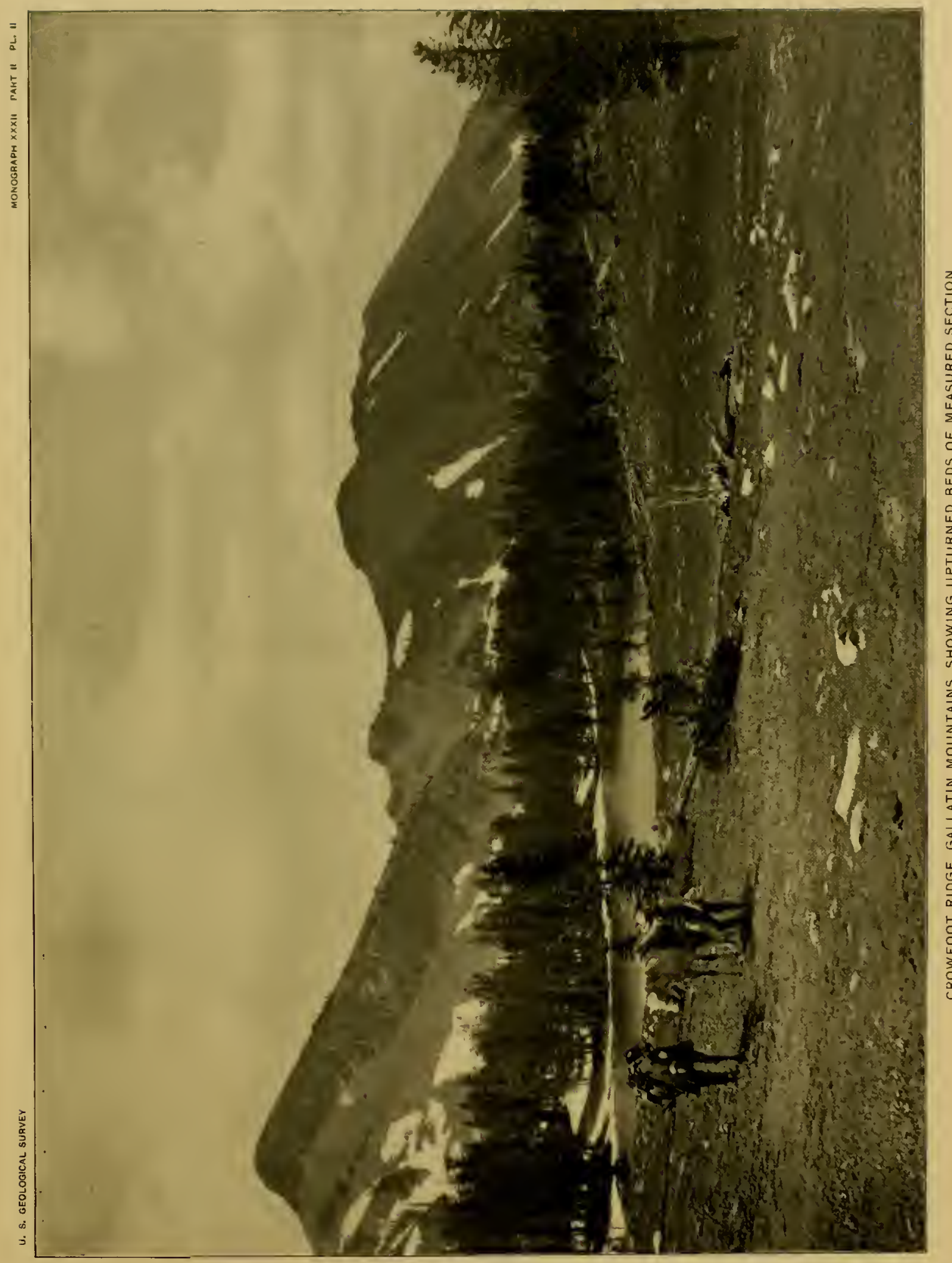





\section{MOUNTAINS SOUTII OF" PANTHEIR CREEK.}

The geological structure of the monntains east of the fanlt already mentioned as crossing Crowfoot Ridge is somewhat complicated by the presence of large bodies of igneons rock that have been forced between, and also across, the sedimentary strata. The exact position of these eruptive masses will appear from the description and map (PI. X). In general, the stratified rocks form a flat arch, the central portion of which is nearly horizontal, and beneath which the crystalline schists are exposed along the east base of the mountain escarpment for a distance of 4 miles. The strata immediately overlying these sehists at the northern end dip at a low angle, $5^{\circ}$, toward the northeast, and at the southern end they dip about $3^{\circ}$ toward the southwest. This is the simple structure of the eastern portion of the area along a line through Antler Peak, The Dome, Trilobite Peak, and the hills south of Winter Creek, which is shown in the geological cross section, Pl. III, fig. 1.

The igneous magma which was intruded into the shaly layers of the Flathead formation and was afterwards consolidated as the Indian Creek laccolith, was forced upward from some source at the north, uplifting the strata southward and wedging them apart, and being itself separated into two sheets by a thin, wedge-shaped layer of limestone. The sheets, which are nearly horizontal for a considerable distance, become thimmer southward and liave only a slight thickness where last exposed in this direction. In the ridge north of Indian Creek the sedimentary rocks overlying the intruded body arch over it from east to west in a pronounced manner, which is shown in cross section in Pl. III, fig. 2, and which will be deseribed later on.

Subsequent to the intrusion of this double sheet of igneous rock, there was another outbreak of molten magma of a slightly different character, which was forced upward directly through the rocks just described. The manner of its intrusion is shown by the nature of the contacts between the second eruptive mass and the surrounding rocks. This body forms a great mass, whose present exposure is 3 miles long and 2 miles wide, embracing the six white peaks surrounding the head of Indian Creek, of which Mount Holmes is the most conspicuous. With this preliminary sketch before us, it is possible to proceed to a more detailed description of the geology of this portion of the country. 
SOUTH END HILLS.

Commencing with the nost soutlern end of the eastern part of the ridge, where the sedimentary rocks begin to rise above the rhyolite plateau, we find limestone exposed on the crest of the low ridge $3 \frac{1}{2}$ miles south of Mount Holmes. The bedding is nearly horizontal, the dip being but $3^{\circ}$ to $5^{\circ} \mathrm{SW}$. throughout the greater part of the ridge. The character of the limestone varies from shaly and fissile to massive beds, the highest strata being mottled and banded, dark and light gray, and in places conglomeratic. The lithological characters are like those of the Cambrian formations about 300 to 600 feet above the base of the series as it exists in the section north of Crowfoot Ridge.

At the southwestern extremity of the southern end of this ridge there is a small exposure of coarse-grained gneiss, against which lies a bed of fine-grained gramular quartzite, about 50 feet thick, over which is light-gray limestone in apparent conformity. The highly inclined position of these beds, dipping $70^{\circ} \mathrm{NE}$., with strike N. $50^{\circ} \mathrm{W}$., and the nearly horizontal position of the limestone a short distance east, indicate a fault between these two sets of beds, which probably trends northwest and southeast, with hade to northeast, and with a downthow of not more than 500 feet. The extension of the fault could not be traced on account of the covering of lava.

The igneous rock intruded between the limestone and shales already mentioned is the thin edge of one of the sheets of the Indian Creek laceolith, and may be called andesite-porphyry. At the northern end of the ridge in question it is exposed in a cliff 100 feet high, which is about the thickness of the sheet in this place. Limestone is exposed beneath and also above it. The intrusive sheet can be traced for several miles sonthward, becoming thimer, until it is but 10 feet thick where last seen, before disappearing beneath the rhyolite of the platean. Above it, on the highest portion of the ridge, two small dikes of andesite-porphyry traverse the limestone across the axis of the ridge. A short distance to the southwest there is a narrow vertical dike of similar rock, about 3 feet wide, trending southwest and northeast. It rises slightly above the shaly surtace of the ground and exhibits two systems of inclined joints, forming rhombic horizontal columus. Near the sides of the dike a third, horizontal joint splits 
the rock into hexagonal columns, which are well defined near the outside of the dike, but disappear toward the center. The rock is dark colored and dense near the contact walls, becoming lighter colored and less dense toward the center, and containing irregular vesicular cavities, flattened parallel to the walls of the dike.

Direct connection between the formations of this ridge and those of the mountains north is obscured by the rhyolite lava which extends up Winter Creek and across the saddle of the divide to Maple Creek. A close correspondence, however, between the sections of limestones and the intrusive sheets is observed on both sides of Christmas Tree Park, and when the dip of the strata in each case and the altitudes at which similar horizons are exposed are taken into account, it appears that the rocks on both sides of the valley were continuous, with low southerly dip, before the valley was eroded and filled with rhyolite, or that a very slight fault has dropped the strata of the ridge just described a few hundred feet. In the diagram of cross sections, Pl. III, fig. 1 , the strata are drawn as though not faulted.

TRILOBITE POINT.

At the south and east base of the group of peaks directly connected with Mount Holmes, ineluding Trilobite Point and The Dome, crystalline schists are exposed at altitudes of from 8,000 to 8,500 feet, and in isolated localities at 8,700 feet. These outcrops form a low, rounded bench at the base of the mountains, the upper limit of the gneiss being highest at the south, and lowest in elevation north, in the bottom of Indian Creek. The isolated exposures near the head of Winter Creek are close to the margin of the great intrusive mass of Mount Holmes, and, though at about the same altitude as the other outcrops, show by the dip of the neighlboring stratified rocks that their position has been disturbed by the intrusion of this igneous mass. The limestones dip steeply in various directions, and the beds are largely concealed by drift, the outcrops being small and disconnected, so thit the precise stratigraphic structure was not apparent at this locality. The map represents the beds as continuous with those to be described in Trilobite Point, though they are in fact locally disturbed by the intrusion of the Holmes mass.

The character of the crystalline schists is like that of the area about The Crags-coarse-grained gneisses, mostly micaceous, with subordinate 
amount of schists and some ancient and metamorphosed intrusive bodies; the more detailed account of which is given in Part I of this monograph.

Aloug the eastern base of the mountains the gneiss forms prominent exposures, constituting the end of the long southeast spur' of 'Trilobite Point and forming bold escarpments on either side of the valley northeast of Mount Holmes, below the level of the glacially carved lake basins. The gneiss forms a bench extending along the eastern base of The Dome, the exposure having a height of 300 or 400 feet, and occurring across the valley of Indian Creek, where it is last seen to form a low, wooded hill on the northern side of the creek.

Immediately overlying the gneiss around three sides of Trilobite Point is the lower sheet of andesite-porphyry, a light-gray aphanitic rock with porphyritical erystals of feldspar, hornblende, and biotite. The sheet is between 200 and 300 feet thick and occupies the horizon of the Flathead shales, being overlain by 150 to 200 feet of Cambrian, Flathead limestone in nearly horizontal beds. Above the limestone is another sheet of andesite-porphyry, from 100 to 200 feet thick, which in turn is topped by the Upper Cambrian shale and trilobite-bearing limestone. The upper surface of the uppermost sheet of andesite-porphyry is quite irregularly defined, and the overlying limestone is traversed by small dikes and veins of igneous rock, that are in part offshoots from the lighter-colored igneous mass of Mount Holmes. The basal (lower) sheet of andesite-porphyry is thicker at the northern side and thinner at the southern side of the mountain.

At the saddle on the ridge connecting Trilobite Point with Mount Holmes, near the contact of the rocks just described with the igneous rock of the latter mountain, the beds of limestone and andesite-porphyry are turned up to an angle of about $45^{\circ}$, dipping eastward, away from the Holmes mass. The strata are greatly fractured and are penetrated by many small bodies of the Holmes rock.

THE DOME.

The Dome is a mountain summit northeast of Mount Holmes and connected with it by a low ridge. It is separated from Antler Peak and the northern portion of the range by the wide and deep valley of Indian Creek. The mountain is largely formed of andesite-porphyry, an extension of the Indian Creek laccolith, which rests upon crystalline schists and is capped by Cambrian limestones forming the summit of the peak. A thin belt of 
3 



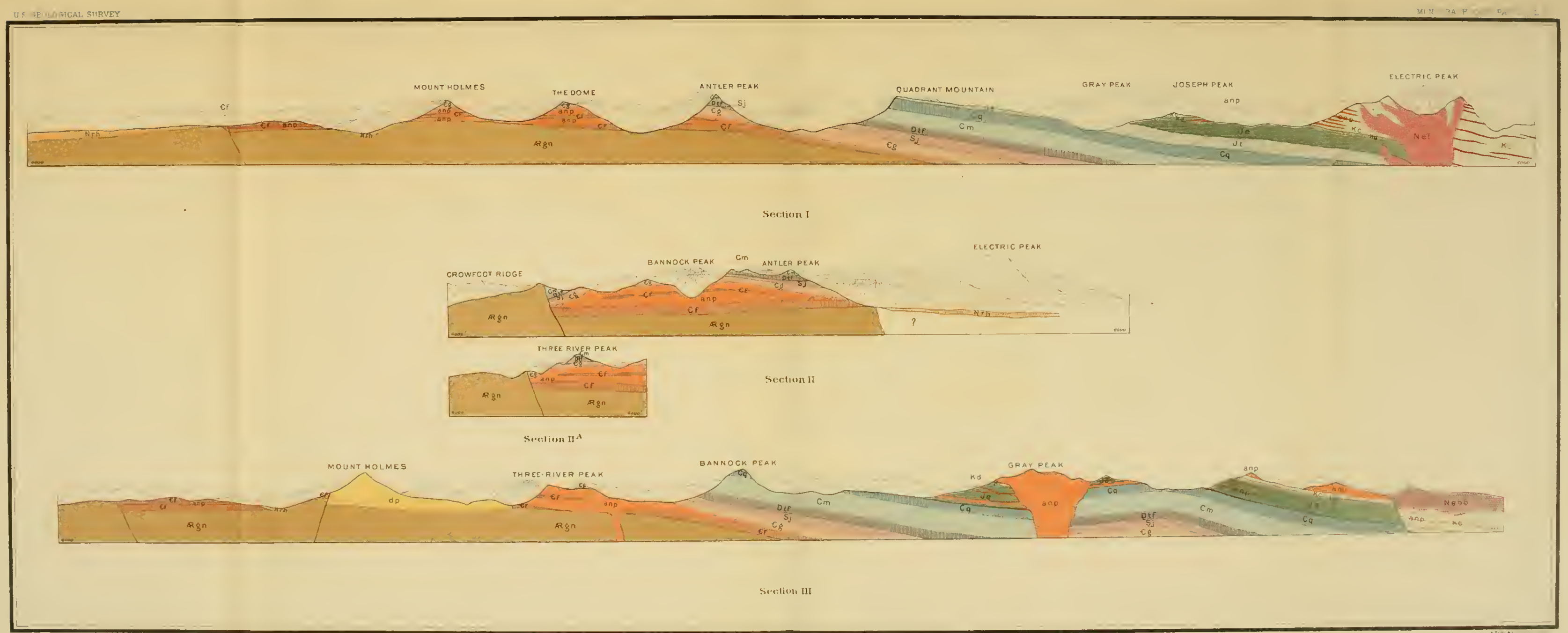

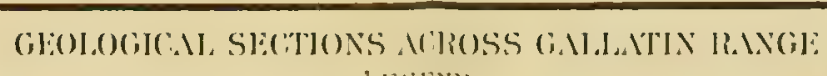

\begin{tabular}{|c|c|c|c|c|c|c|c|c|c|}
\hline & & & & & & & & & \\
\hline $\mathrm{Kd}$ & 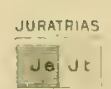 & $6 \mathrm{col} / \mathrm{cm}$ & 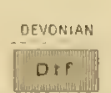 & {$\left[\begin{array}{c}\text { sinarin } \\
s_{j}\end{array}\right]$} & 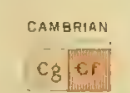 & 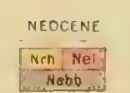 & 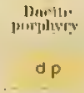 & 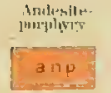 & 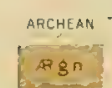 \\
\hline
\end{tabular}



these limestones is also included in the laceolithic mass separating the igneous rock into the two sheets, whose southward extension has already been noterl at Trilobite Point and the South End Hills.

On the southern side of the momtain the lower intruded sheet rests directly upon the crystalline sehists, and as we pass up the southern slope of the mountain, which is precipitous in places, we find a layer of limestone about 300 feet thick, which is not wholly continuous. Above it are several hundred feet of porphyry, and then a bluff wall of 200 feet of limestone that forms the surface of the table-topped portion of the mountain, upon which rises a cone of limestone 400 feet in height. The limestone has a slight dip sonthward, which brings the porphyry out at a higher altitude on the northern side of the peak. The eharacter of the limestone overlying the porphyry is the same as that of the limestone on the northern side of Indian Creek, which occurs in the same position, and which has been identified as Middle Cambrian. As these beds approach the eruptive mass forming the peak sonthwest of 'The Dome, they tum up abruptly to a steep angle, dipping away from it toward the northeast at $55^{\circ}$.

The steep northem face of The Dome, below the flat top, is almost wholly andesite-porphyry to within 300 feet of the bed of the creek; the lower part being limestone, forming steep walls that rise above a bench of gneiss. A thin belt of shale or limestone occurs about lialfway up the slope, inclosed in the porphyry. It does not appear to be contimous horizontally, though quite persistent. The eontact between the rocks just described and the intrusive mass to the west is sharply marked and nearly vertical, and will be deseribed in comnection with the oecurrenee of that roek body.

The limestone underlying the andesite-porphyry at the northern base of 'The Dome is in nearly horizontal beds, but at the eastern base of the mountain the gneiss rises up and ents it off. At a higher altitude the limestone is exposed with a steep westerly dip, evidently bent and faulted, with a throw of several hundred feet. At about this place the lower sheet of porphyry cuts down to the horizon of the gneiss.

\section{INDIAN CREEK LACCOLITH.}

North of the valley of Indian Creek the slopes rise steeply upward to the base of a wall or cliff that extends westward from the eastern face of the mountains to the head of Indian Creek Valley. The lower part of this 
great wall is formed of nearly horizontal beds of limestone (Flathead), upon which rests the great mass of intrusive andesite-porphyry whose southern extension has already been noted, and over which arches the distinctly bedded limestone that forms the eastern part and the summit of Antler Peak. This is the great intrusion termed by W. H. Holmes the "Indian Creek laccolite," whose mass forms the greater part of Antler Peak, the bold summit north of Indian Creek, and its extension westward to the slopes of Three River Peak. The structure and topography of this part of the ridge are clearly shown in the sketch by Mr. Holmes. ${ }^{2}$ In the middle of the ridge the overlying strata are absent, but at the western end of the ridge they recur, completing the westward-dipping limb of the arch, as shown in Pl. III, fig. 2.

This dome-shaped body of intrusive rock is a cross section of the donble sheet met with in the mountains soutl. In Antler Ridge it attains its maximum thickness, and appears as one massive body with a thin layer of shale or limestone inclosed near its middle, which is indicated in $\mathrm{Mr}$. Holmes's sketch. It is, however, not absolutely continuous. No doubt it is the thin edge of the limestone wedge that split the intrusive mass in two as it was forced southward.

An examination of the limestone underlying the laccolith shows that the prominent cliff, 75 to 100 feet high, is formed of the nodular limestones of the Flathead formation corresponding to the lower limestone belt of the Crowfoot section. These beds are more fully noted in the section of the sedimentary rocks of Antler Peak. Within the lowest micaceous shale beneath the laccolith there occurs a layer of white, lithoidal, igneons rock, 50 feet thick, and evidently a horizontal sheet, which is again exposed at about the same horizon 2 miles farther west. Petrographically it resembles the rock of Mount Holmes, of which it is probably an offshoot.

The contact between the lower massive limestone and the bottom of the laccolith is plainly exposed in places. The limestone exhibits little or no metanorphism, there being only a slight lightening of its color along the immediate contact. The crude columnar jointing of the massive limestone may have been the result of baking by the laccolithic mass, but it is not pronounced; however, it may easily be mistaken at a distance for the

'Twelfth Ann. Rept. U. S. Geol. and Geog. Surr. Terr. (for 1878), Part II, Washington, 1883.

Op. cit., P1. XIII, p. 24. 
well-known jointing of igneous rock. The limestone and shale inclosed within the body of the laccolith, also show ahmost no evidence of metamorphism other than a lightening of their color in immediate contact with the porphyry. The inelosed stratum of limestone is 20 to 40 feet thick, and lather persistent. It is nearly horizontal, or arches gradually with the enrve of the laccolith dome. Several masses of red and green shale, tilted at ligh angles, were seen in the igneous rock. These are probably blocks of the heavier sliale belt forming the upper part of the Flathead formation, and which is the horizon in which the laccolith appears to have been intruded. There are also small fragments of limestone and gneiss included in the porphyry, caught up in its passage through the lower rocks which were ruptured at the time of its intrusion.

The laccolith sheet thins ont eastward under Antler Peak, disappearing near the base of the eastern slope, where the upper and lower limestone strata meet and form the whole of the northeast spur of the mountain, dipping at the low angle of about $5^{\circ} \mathrm{NE}$. The apparently gradually increasing dip of the overlying limestones as they arch over the laccolith is found on investigation to be irregular, the dips varying along the cliffs forming the bare southern exposure, increasing from $5^{\circ}$ to $10^{\circ}$, and farther west to $20^{\circ}$, then becoming nearly horizontal just before reaching the depression on the ridge. There is, however, a northerly element of the dip which is not noticeable on the southern exposure. Where the dip changes noticeably, the limestone is shattered by innumerable small, vertical faults, close together; it thus behaved as a brittle, not as a plastic, mass at the time of the laccolithic intrusion. The overlying limestone embraces the upper part of the Cambrian formations, including the massive mottled limestone which is the base of the Gallatin limestones, together with the banen strata that represent the Sihurian and Devonian, and about 400 feet of the Carboniferous, which forms the summit of Antler Peak.

The laccolith is about 1,200 feet thick at the middle, where it forms a high point projecting into the valley of Indian Creek. Here the limestone capping has been removed by erosion, leaving the slope of the ridge to indicate about the slope of the old plane of contact. The triangular peak northwest of this point shows the overlying limestones dipping at $2^{\circ}$ to $3^{\circ}$ NW. and extending down the long divide to Bighom Pass, where they dip over the porphyry for a short distance at $10^{\circ}$ and also at $25^{\circ} \mathrm{NW}$., 
the generally low dip recurring again farther north. At Bighorn Pass the laccolith thins out and reaches its western limit.

In Three River Peak the porphyry is also overlain by limestone in nearly horizontal beds with slight westerly dip, the uppermost strata belonging to the Madison limestones of the Carboniferous.

Along the wesiern boundary of the laccolith, between Three River Peak and Bighom Pass at the head of Gallatin River Valley, the limestone strata dip W. $45^{\circ}$, becoming less inclined farther west, where they encounter a fanlt trending west of north, which brings them against gneiss and steeply tilted Cambrian beds. Unfortmately the strata bordering the laccolith on the north, along the bottom of Panther Creek Valley, are covered with loose material from the mountain slopes; hence the position of the rocks adjacent to the laceolith on the north was not discovered. In several places the porphyry has broken up through the overlying limestone.

Without entering too minutely into the petrographical character of the laccolith of andesite-porphyry, which will be described in detail in Chapter II, it may be well to mention some of its general characteristics. The andesite-porphyry is a light-gray to whitish aphanitic rock with many small phenocrysts of feldspar and fewer of biotite and hornblende. It forms massive outcrops intersected by joints in all directions, and the rock splits, upon weathering, into sherdy, angular fragments. In only one place was columnar jointing noted-on the sontheast spur of The Dome. In the central part of the laccolith the groundmass of the rock has a crystalline texture, though extremely fine grained. Near the margin the rock grows denser and darker colored. The same is true where the sheets become thinner toward the south. The extent of this mass in exposure is shown on the map, and its relation to the surrounding rocks is given in the cross sections.

\section{MOUNT HOLMES BYSMALITH.}

A great mass of igneous rock, 3 miles long and 2 miles wide, forms Hount Holmes and the ridge north to the summit of the peak west of The Dome, and extends across the head of Indian Creek and constitutes the chain of four peaks west of this creek and sonth of Three River Peak. This great body of igneous rock breaks up through the sedimentary strata as a 
core or plug. It is a type of intrinsion for which the name bysmalith has been proposed. ${ }^{1}$

A laccolith as defined by Gilbert ${ }^{2}$ is a body of igneous rock which has insinuated itself between two strata and opened for itself a chamber by lifting all the superior beds. A symmetrical dome-shaped body is the exceptional or ileal form, and, as Cross ${ }^{3}$ has pointed out, Gilbert's use of the term practically included all thick lenticular masses of intrusive igneous rock occurring at a certain geological horizon in a sedimentary complex. Cross includes under the term laccolith all masses in which the expansion of the body has taken place from a plane approximately parallel to the bedding, and says that numerous causes may affeet the regularity of the form. Of these the principal are: (1) Oblique position of the plane of expansion to bedding planes of the sediments; (2) lines of structural weakness in the strata; (3) presence of earlier intrusions; (4) lack of coherence and of pronounced bedding in strata invaded. These factors, we understand, simply modify the form of the laccolith, whose essential characters are those deseribed by Gilbert. They can not in any sense replace the latter.

A laccolith is distinguished from an intrusive sheet of igneons rock, which is an intrusion between strata accompanied by a certain amount of lifting of the superincumbent rock. The difference lies in the thickening of the igneous body into a more or less lenticular mass in the case of a laceolith, over which the strata arch; whereas the upper and lower surfaces of a sheet are almost parallel to each other. In sheets the lateral dimensions are very great as eompared with the depth or thickness; in laccoliths the difference between the thickness and the lateral dimensions is much less.

Cross has shown that a certain amount of vertical displacement may accompany the arching of the overlying strata, as in the laccolith of Mount Marcellina, ${ }^{4}$ without changing the general character of the intrusion. But where vertical displacement with faulting is one of the chief characteristies of the intrusion, a distinetion from normal laccolithic intrusion should be recognized. In the extreme this would result in the forcing upward of a

'Iddings, J. P., Bysmaliths: Jour. Geol., Vol. VI, 1898.

${ }^{2}$ Gilbert, G. K., Report on the Geology of the Henry Mountains, U. S. Geog. and Geol. Surv. Rocky Mountain region (J. W. Powell in charge), 1877, p. 160, Pl. V.

${ }^{3}$ Cross, Whitman, The laccolithic mountain groups of Colorado, Utah, and Arizona: Fourteenth Ann. Rept. U. S. Geol. Survey (for 1892-93), 1895, p. 236.

1 Loc. cit., p. 236.

MON XXXII, PT II-2 
more or less circular cone or cylinder of strata, having the form of a plug, which might be driven out at the surface of the earth or miglit terminate in a dome of strata resembling the dome over a laccolith. By this mode of intrusion the rertical dimension of the intruded mass becomes still greater as compared with the lateral dimensions, so that the shape is more that of a plug or core. Such an intruded plug of igneous rock may be termed a bysmalith $\left(\beta \dot{v} \sigma \mu \alpha=p l n g, \lambda_{2} \theta o s=\right.$ stone $)$. We have, then, transition from a flat, thin, intrusive sheet to a laccolith with lenticular form, and from this to a bysmalith with much greater depth and considerable vertical displacement.

Examples of bysmaliths are not common as yet. Russell ${ }^{1}$ has called attention to what he considers volcanic plugs in the region of the Black Hills of Dakota, and has suggested their recognition as types of intrusion different from normal laccoliths. A sharp discrimination of the two types may not always be possible, since they grade into each other, as in Mount Marcellina. In the intrusive bodies of Mount Holmes and the Indian Creek laccolith the contrast is sufficiently marked and the two types are well illustrated. Nearly two-thirds of the circumference of the Holmes mass is exposed as a nearly vertical plane of contact crossing almost horizontal strata. The western boundary is against gneiss and along a fault plane of considerable magnitude, which probably acted as the conduit through which the magma was forced. There is no means of knowing what may be the shape of the bottom of this bysmalith. It is possible that it may have risen through the fault fissure until it encountered the sedimentary strata resting upon the gneiss, with its inclosed laccolith. It may have spread laterally along shaly strata near the gneiss and beneath the laccolith; then its movement laterally may have been checked, for the pressure upward became sufficient to rupture the strata and laccolith and to force a mass of these rocks covering an area of orer 5 square miles up more than 2,000 feet-probably more thau twice that height.

The areal relation of the Hount Holmes bysmalith to the surrounding terranes is shown on the geological map, Pl. X. The vertical relations are shown in the profile sections of the Gallatin Mountains, Pl. III, fig. 3, and Pl. IX, fig. 4, and in Pl. V, figs. 1, 2, 3, which are profile sections through Echo Peak and Three River Peak, and through The Dome and the peak 


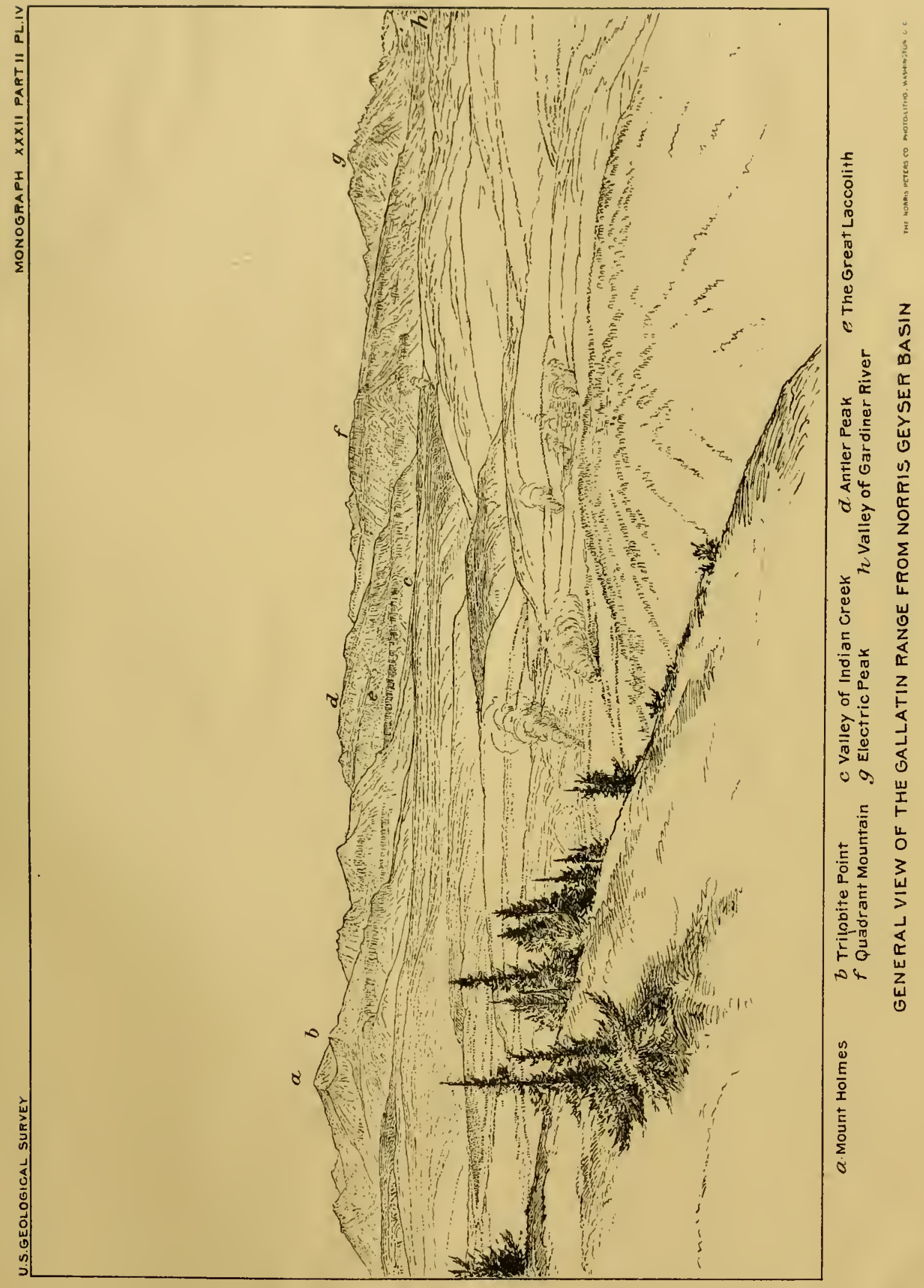



5 



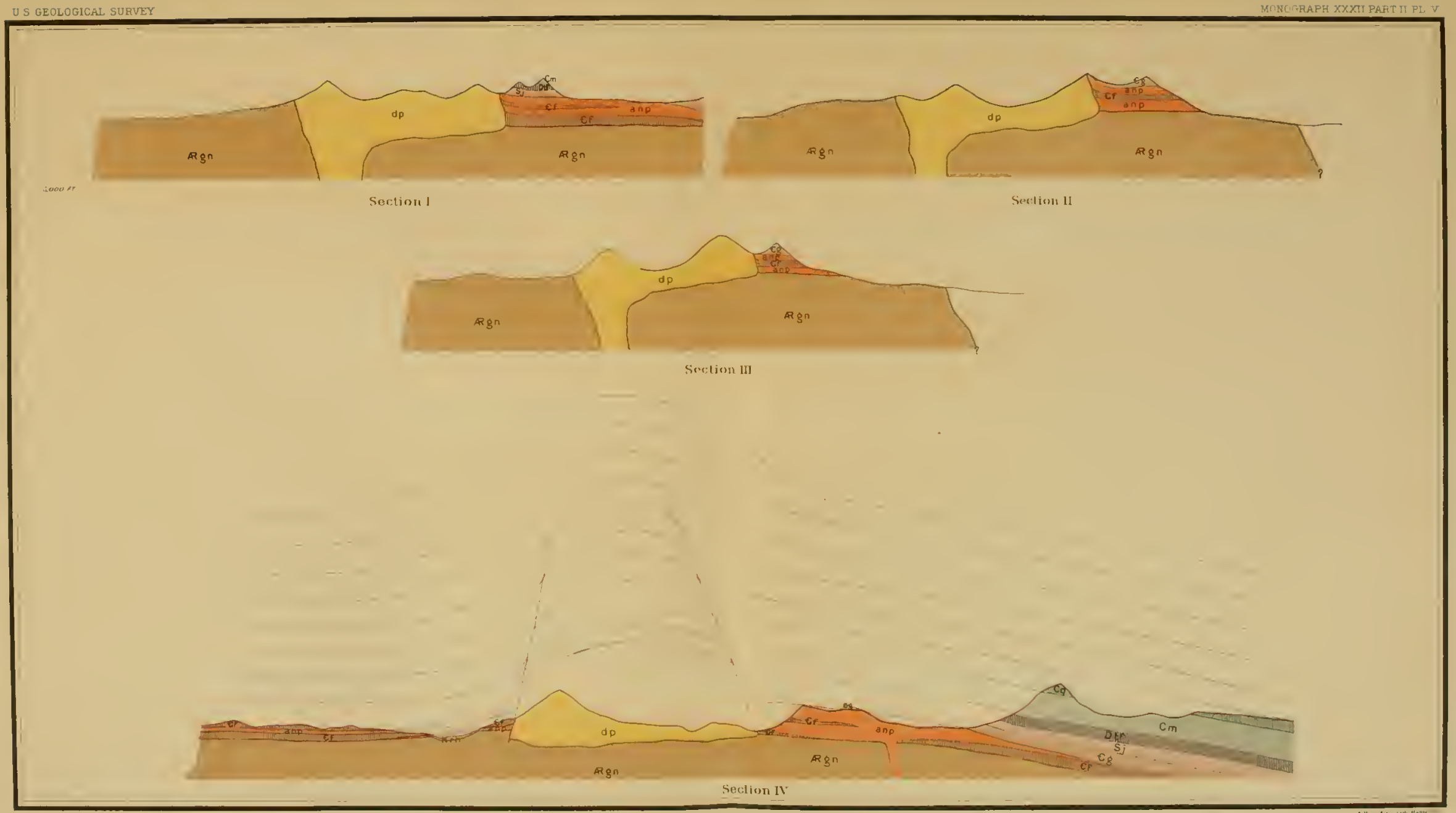

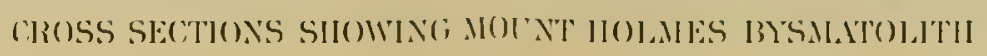

\begin{tabular}{|c|c|c|c|c|c|c|c|}
\hline CARBONIFEROUS & DEVONIAN & SILURIAN & CAMBRIAA & NEDCENE & $\begin{array}{l}\text { Dacite. } \\
\text { poryilyty. }\end{array}$ & $\begin{array}{l}\text { dindesite } \\
\text { porplogy }\end{array}$ & ARCHEAN \\
\hline $\mathrm{Cq} \mathrm{Cm}$ & $D \in P$. & $\mathrm{sj}$ & $\epsilon_{g} \in f$ & Nen & $d p$ & anp & ARn \\
\hline
\end{tabular}



sonthwest, and throngh Mount Hohnes and 'Trilobite Point. These cross the contact plane between the bysmalith and the stratal with the inclosed laceolith.

Owing to the crystalline character of the rock constituting the bysmalith, there is little doubt that it solirlified beneath a covering of strata. The erystals are larger than those forming the mass of the Indian Creek laccolith. A possible reconstruction of the position of the strata after the intrusion is given in PI. V, fig 4, in which all of the formations up to the top of the coal-bearing Laramie are represented-a total thickness of 9,000 feet.

The upper parts of the mountains into which this intrusion has been carved are barren and rocky above 9,000 feet, with comparatively smooth slopes covered with loose fragments of porphyry. The peaks are pointed in some cases and rounded in others, as may be seen from Pl. IV. The rock is very uniform in appearance throughout the entire extent of the mass. It is light gray to white, aphanitic to fine crystalline, with a slightly porphyritic structure in part. It shows small flakes of biotite and indistinct phenocrysts of feldspar. It is massive, with irregular joint cracks, and weathers into angular blocks and, slabs. Its megascopical characters are quite uniform throughout the greater part of the mass, which varies slightly in grain. But near the margin of the body the rock becomes denser and more aphanitic, showing a broad banding parallel to the walls of contact with the surrounding rocks. These walls are nearly vertical in the mountain west of The Dome, on the saddle east of Mount Holmes, and also on that of Echo Peak. In all cases examined, the neighboring limestones dip away at angles of $40^{\circ}$ to $55^{\circ}$, and the adjacent andesite-porphyry has been crushed and dislocated. It is reddened and in places is filled with veins and apophyses from the dacite-porphyry, which is clearly proved to be an intrusion subsequent to that of the Indian Creek laccolitl. Its western border in contact with the erystalline schists is obscured by débris, being located at the base of the mountains. These relations are shown in Pl. V.

The eruption appears to have taken place along the fault line that lies west of Three River Peak. There seems to be no break in the continuity of the bysmalith mass, and this fact indicates that it was intruded at one time. The vertical displacement of a mass of rock $2 \frac{1}{2}$ miles long and 2 miles wide, by what appears to have been a single act, is remarkable. The petrographical character of the rock is that of an intrusive, not a surficial, body; hence, 
we may assume that it did not reach the surface of the earth, but was covered by the sedimentary rocks it displaced. The same kind of porphyry occurs in two small bodies about 3 miles farther morth, along the Crowfoot fault line, west of Three River Peak. Here they have broken into Carboniferous limestone, which otherwise in this region is quite free from intrusions of igneous rock.

Still another small intrusion occurs along the northern border of the Indian Creek laccolith, but is confined to the upper horizon of the Cambriau rocks. It is a dark basic porphyry of an unusual character, with occasional phenocrysts of homblende, mica, and feldspar. It forms a small sheet, 50 to 75 feet thick, exposed on the divide south of Bighorn Pass and along the south base of Bannock Peak. It was not found in contact with the laccolith, and the relative times of their intrusion were not made out. There is no rock similax to it in the region explored, except a small sheet in Three River Peak, and nothing approaching it in composition occurs nearer than Electric Peak.

\section{ANTLER PEAK.}

The sedimentary rocks overlying the Indian Creek laccolitl, as already noted, form the summits of Antler and Three River peaks; stratigraphic sections were made at both these localities. Antler Peak is the prominent summit lying between The Dome and the flat-topped mass of Quadrant Mountain. (See Pl. VI.) The greater part of the mountain is formed of the intrusive mass of the Indian Creek laccolith, as just described. The sedimentary rocks are best exposed on the southern side of the mountain and at the eastem slopes, where the laccolithic rock passes beneath the limestones.

The gneiss is exposed on the low wooded hill at the southeast base of the peak, indicated on the map by the 8,000 -foot contour. This hill and the slopes back of it are covered heavily with drift, which usually conceals the gueiss and the overlying stratified rocks; there being no exposures except near the base of the great limestone ledge which forms such a prominent feature of the valley. The strata were examined where the ledge has been cut through by a small stream channel from the summit, the débris which elsewhere conceals the foot of the wall having here been washed away. The lowest strata exposed were thinly bedded limestones and rather heavy 
micaceous beds containing indistinct traces of fossils. The following section was made at this place:

\section{Indiun Creek section.}

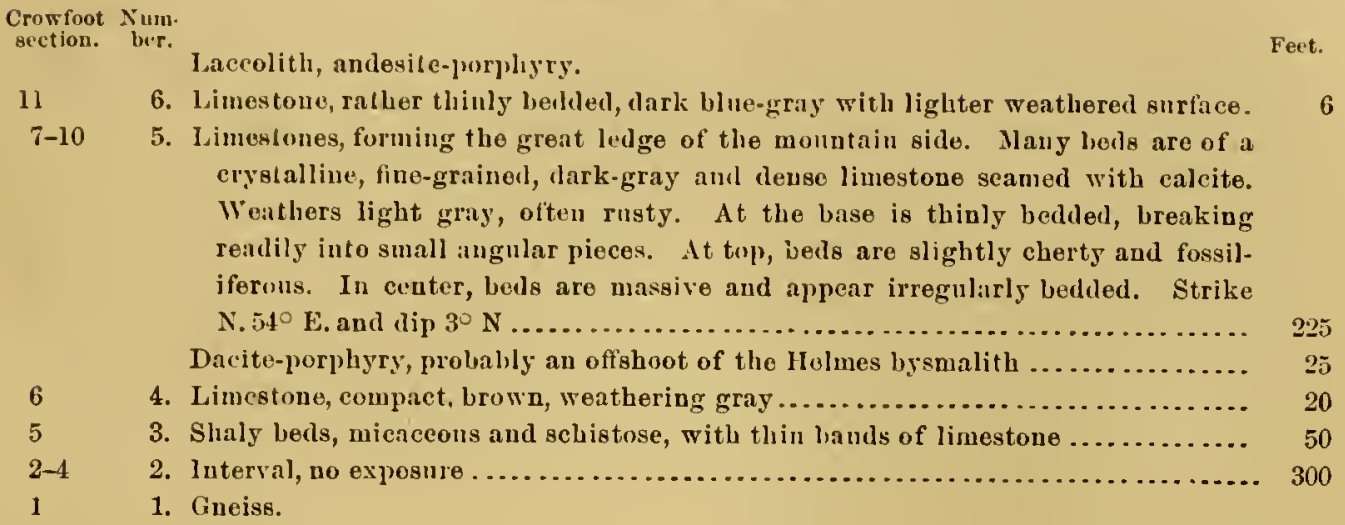

It will be seen from the above section that the andesite-porphyry of the laccolith immediately overlies the limestone No. 6 of this section, which corresponds to the Flathead limestones of the Crowfoot Ridge section. The laccolith has therefore been intruded in the upper shale belt of the Flathead formation, the shales being 150 feet thick in the Crowfoot section. The occurrence of the laccolithic intrusion is the same at the base of Three River Peak, where above the porphyry a part of the shales is found beneatl the limestones that form the lighest beds of the Flathead formation.

At Antler Peak the laccolith incloses parts of the Flathead limestones, as well as a thin belt of limestone and fragments of the underlying shale. Along the base of steeper slopes toward the northeast, the drift has covered all exposures; even the beds of the great limestone ledge are partially hidden. Over these beds we find a platform where the overlying shale and porphyry have been eroded, leaving the limestones underneath intact. That the bench is due to the erosion of the shale seems probable; easily yielding to disintegrating agencies, it has been carried away, undermining the porphyry, which has also been swept off by glacial action.

The lowest bed noted above the laccolith is a finely crystalline, lightdrab limestone, probably the upper beds of the Flathead limestone of the general section. The following succession of strata is exposed on the northeast spur of the mountain from the summit of the peak down to this bed: 


\section{Antler Peak section.}

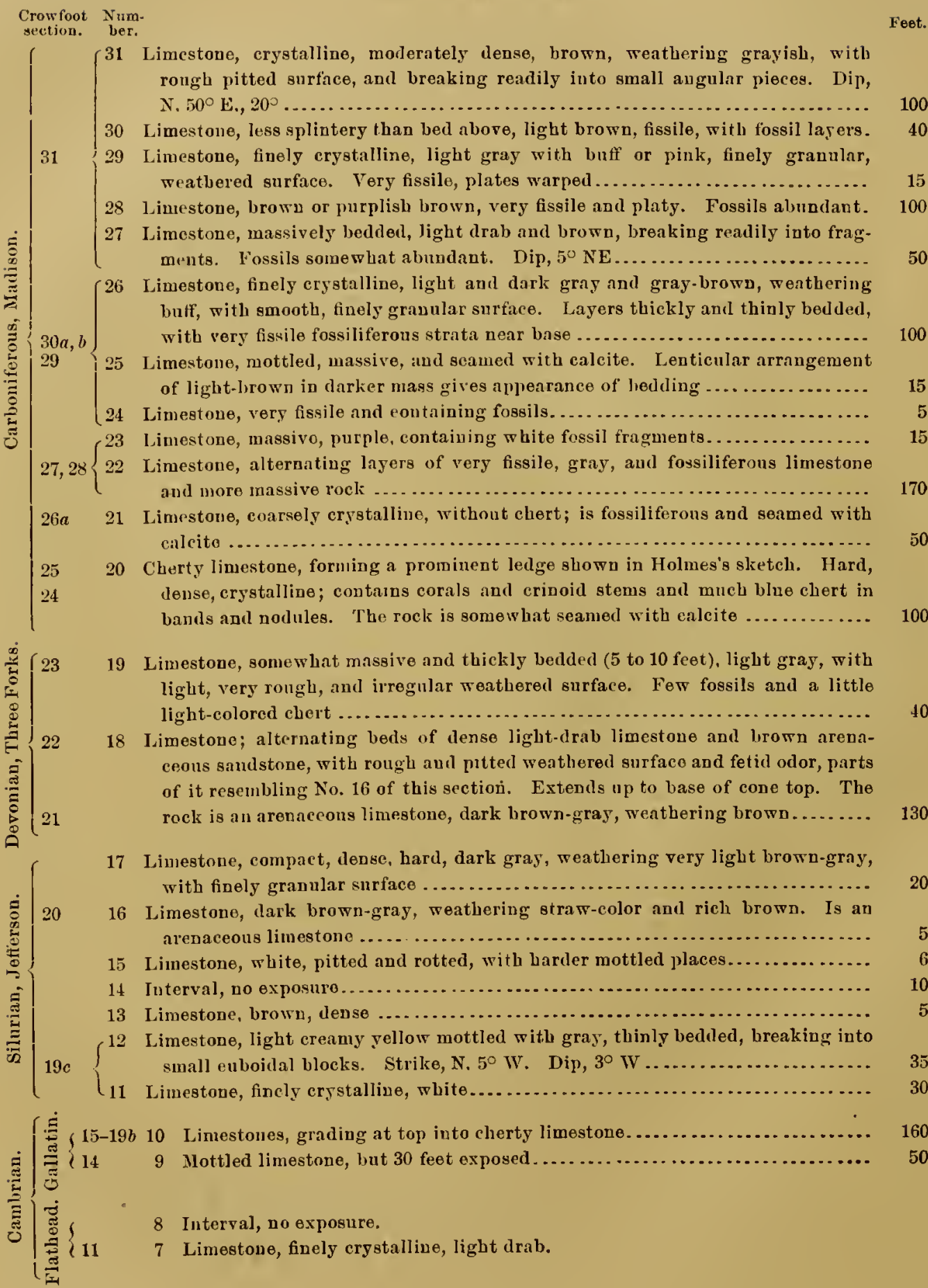




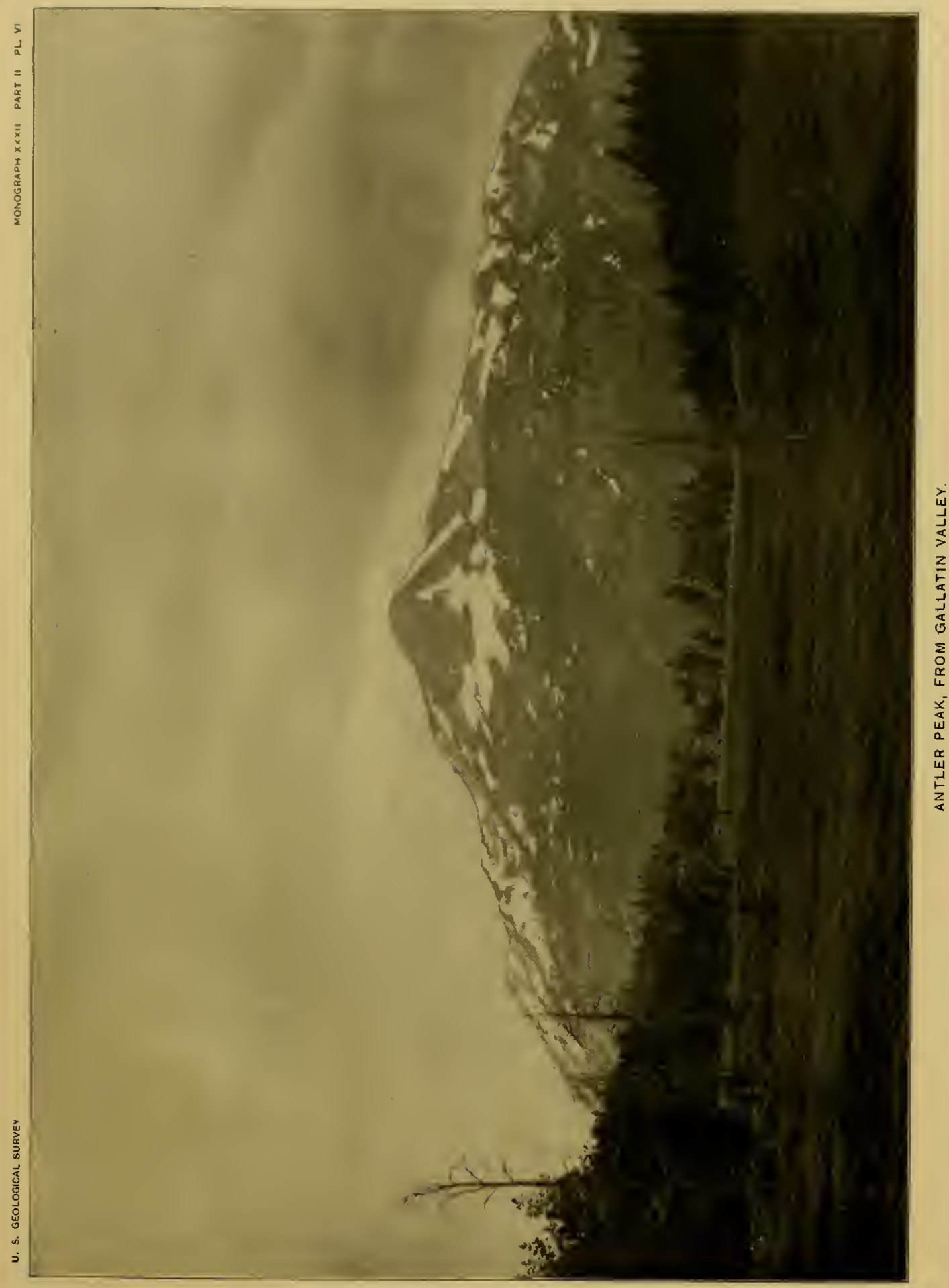



West of the eastern summit the edges of the lower beds outerop, and the Gallatin limestone is exposed in the saddle. On the northeast spur of the peak the Flathead limestones are exposed, the dip being $\mathrm{N} 30^{\circ} \mathrm{E} ., 10^{\circ}$.

THREE RIVER PEAK.

Three liver Peak is a sharp point whose position at the head of the Gallatin River and of branches of the Gardiner and Madison rivers makes the name appropriate. The slopes rise abruptly from the head of Indian Creek Valley on the east, while to the north an almost vertical wall rises above the deep blue waters of Gallatin Lake. The peak occurs on the western side of the Indian Creek laccolith, and the beds composing it, like those forming the summit of Antler Peak, consist of Paleozoic strata ranging from the Cambrian limestones to those of the Carboniferous. The sedimentary rocks are, however, penetrated by several sheets of intrusive rocks which are much decomposed, but represent phases of the Hount Holmes bysmalith. The following section shows the sequence of rocks exposed on the northern spurs of the peak from Indian Creek Pass to the summit:

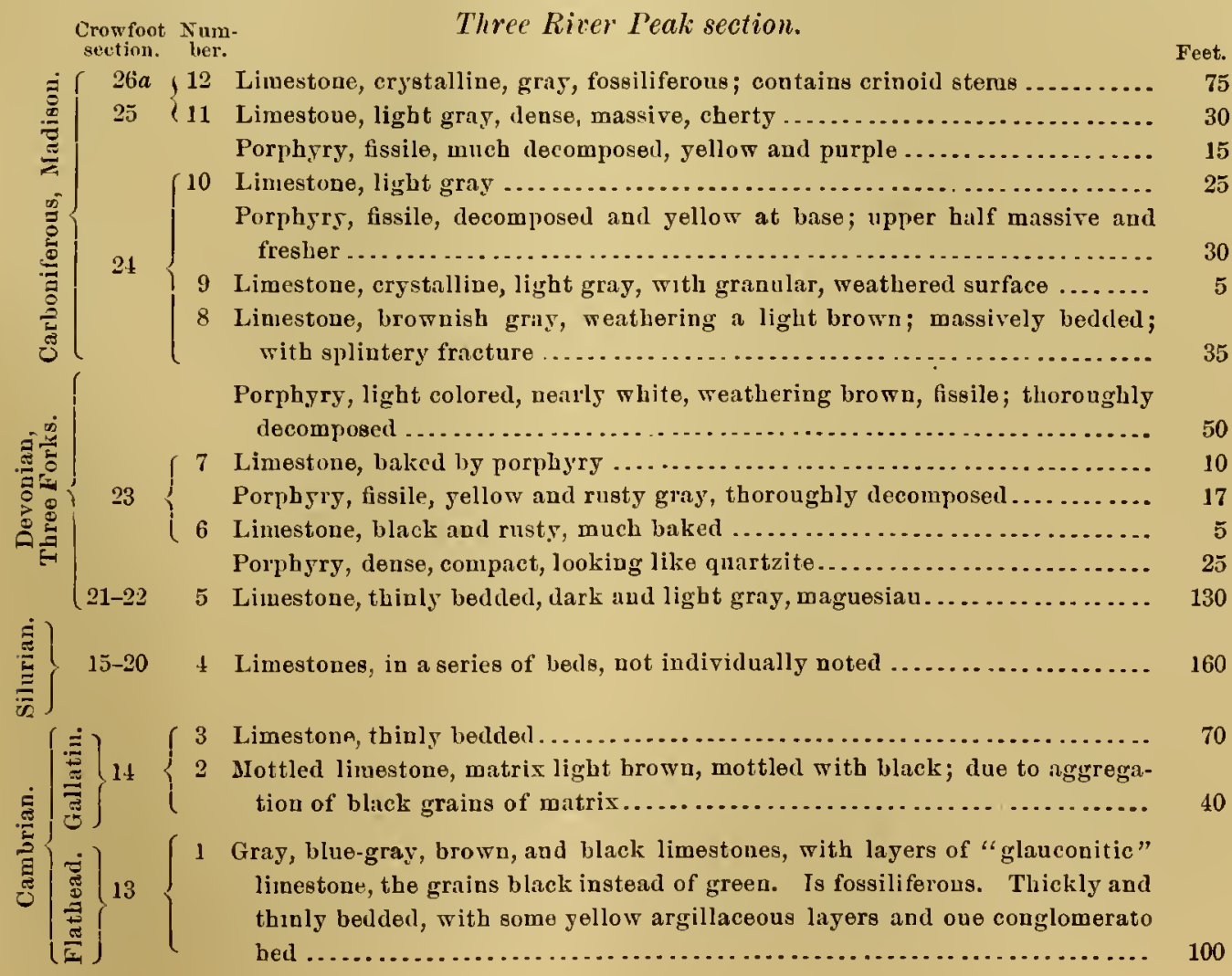


The shores of the Gallatin Lake, and the small hills adjoining, are formed of the laccolith rock, andesite-porphyry. The western boundary of this rock runs northward along a gully, west of the drainage from the lake, and through a small shallow pond to the saddle of Bighorn Pass. To the south the porphyry extends to the base of Three River Peak in the rear of the lake, and forms the saddle in the pass between Indian Creek and the valley of the Gallatin River; from here northward the exposure extends along the westem base of the ridge to Bighom Pass.

The position of the strata seen in the precipitons northern face of this peak is shown in Pl. VII. At the western base of this mountain they dip sharply over the edge of the laccolith, changing from nearly horizontal to $50^{\circ}$ or $70^{\circ} \mathrm{W}$., and gradually decreasing again westward. Into the axis of this abrupt bend a vertical offshoot from the andesite-porphyry has been intruded, showing that the limestones were ruptured at this place.

The limestone strata of Three River Peak are traversed by dikes of lithoidal igneons rock at various angles. One broad dike, 100 feet thick in places, cuts diagonally across the northern face, appearing on the eastern slope about halfway up to the summit. Another, about 10 feet thick, without phenocrysts, lies horizontally between the strata and might easily be mistaken for a compact sandstone. A narrower dike cuts nearly vertically through the western side of the momtain.

At the west base of the peak the gneiss is faulted against the limestones by the southern extension of the Gallatin fault. The position of the sedimentary beds which abut against the gneiss, as well as their fracturing, shows clear evidence of the presence of the fault. An intrusire body of igneons rock related to the Mount Holmes rock occurs at this locality.

On the saddle between Three River Peak and Echo Peak, near the contact of the Holmes bysmalith with the andesite-porphyry and limestone, the latter rocks are seen to have been turned up, so as to dip $40^{\circ}$ N., away from the bysmalith, and to be greatly shattered and dislocated, producing slickensides and a pulverizing of the rock along the fracture planes.

\section{BIGHORN PASS.}

Bighorn Pass is a low divide between the head waters of the Gallatin River and the drainage of Panther Creek, and affords an easy passage from the valleys west of the mountains across the range to the central region of 


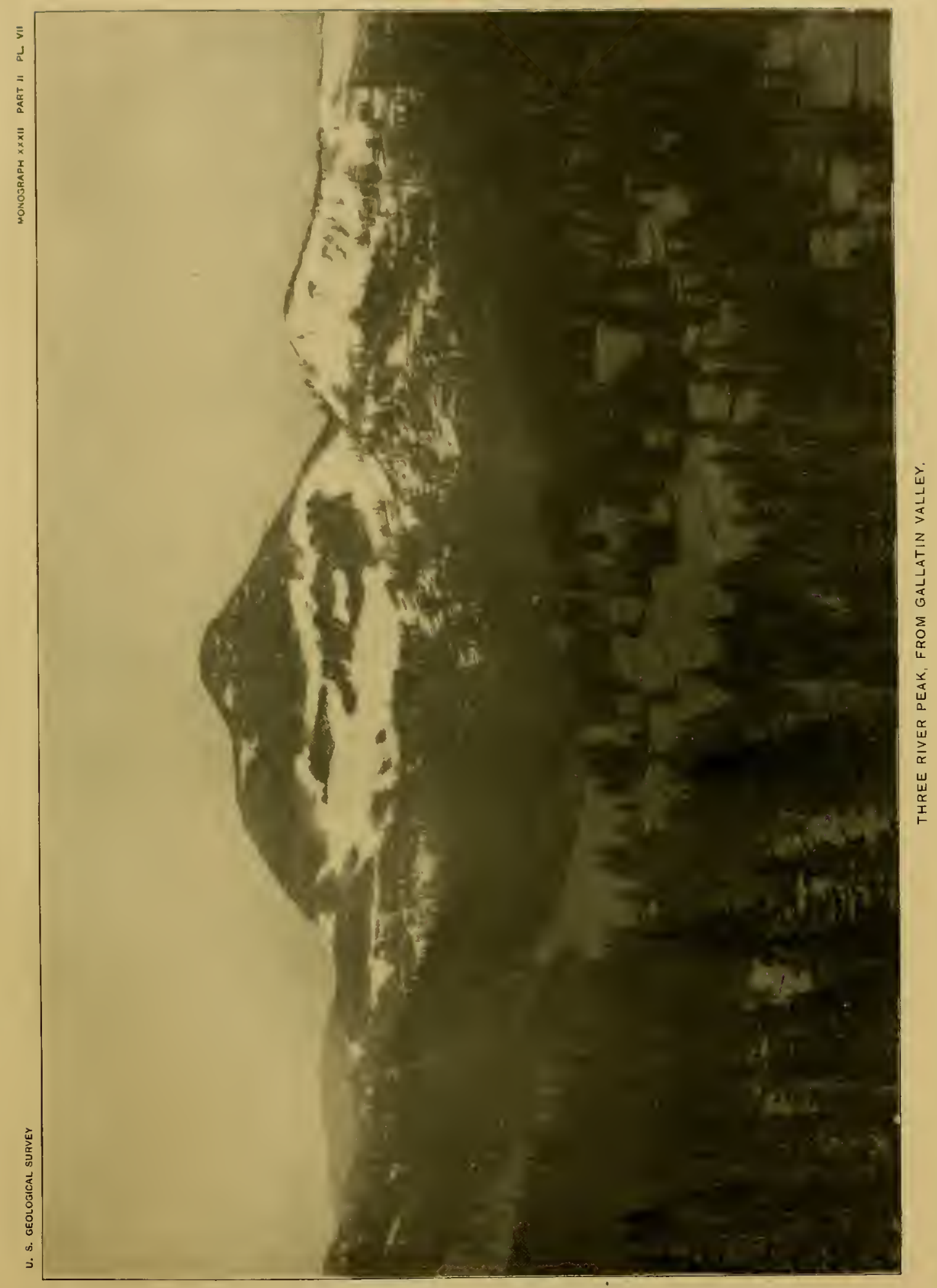



the Park. The pass is cut in the Paleozoic sedimentary rocks, which are slightly tilted by an intruder sleet of andesite-porphlyry that is the northern extension of the Indian Creek laccolith. A dark, lamprophyric rock occnis at the lowest point in the pass, where it is seen to form a sheet 50 feet thick intrusive in the Cambrian shales. The high ridge extending north from the head of Indian Creek to Bighorn Pass is formed of sedimentary beds that overlie the northrard extension of the Indian Creek laccolith. Above the andesite-porplyyry of the laccolith which forms the Indian Creek Pass the greon Flathead shales are exposed, overlain by the upper limestone series of the Flathead, which are here 100 feet thick and resemble quite closely the beds of this horizon as developed in Crowfoot Ridge. The summit of the ridge is formed of the Gallatin "mottled limestone," which dips to the northwest and makes a well-defined ledge, with a cliff face 30 feet high and a rounded but liummocky surface, the result of glacial planing. Near Bighorn Pass the beds are locally affected by an intrusion of the laccolith, and dip more steeply than the beds north of the pass, there being a difference of $5^{\circ}$ to $8^{\circ}$. Two sections of the Paleozoic rocks were measured in this vicinity; the first was made on the ridge running south, the second from Bighorn Pass to the summit of Bannock Peak. These sections show the following sequence of beds, arranged in descending order:

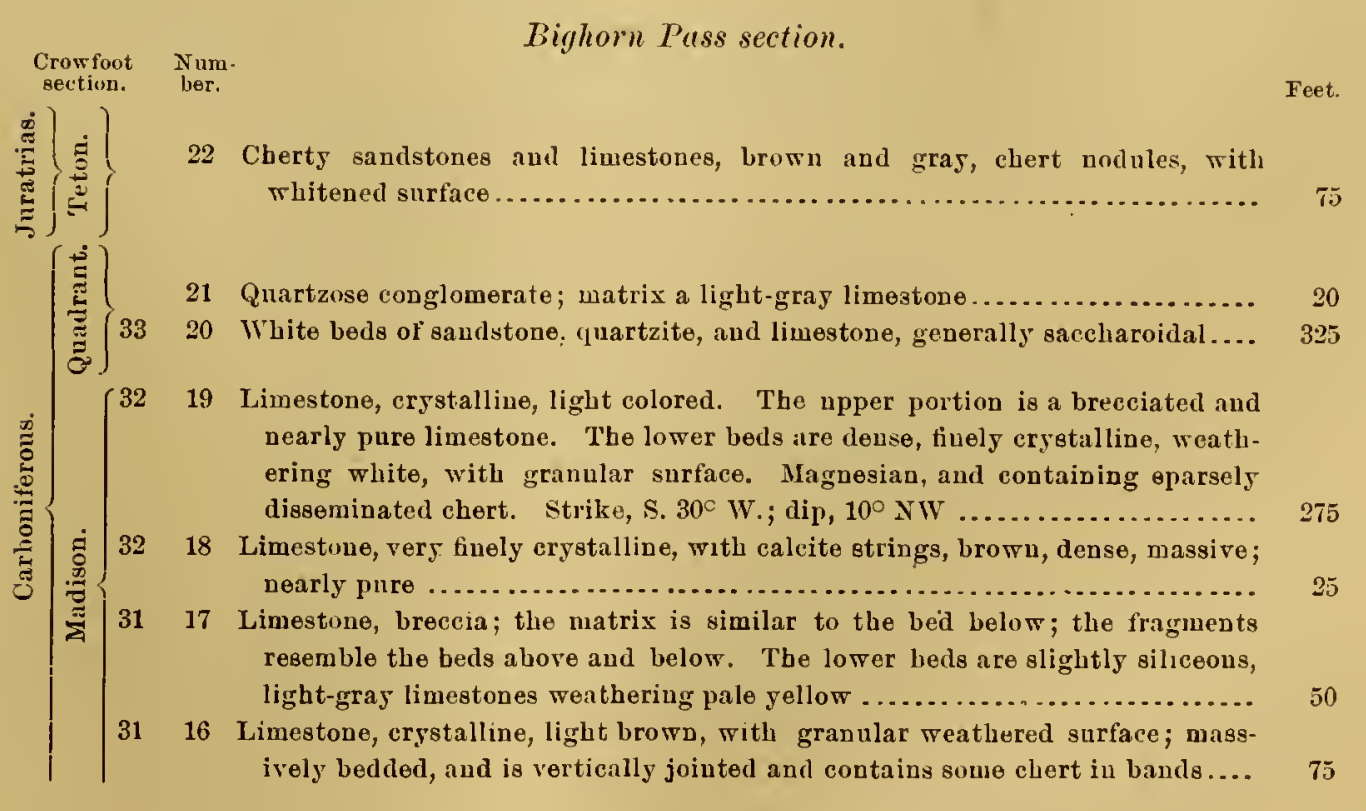




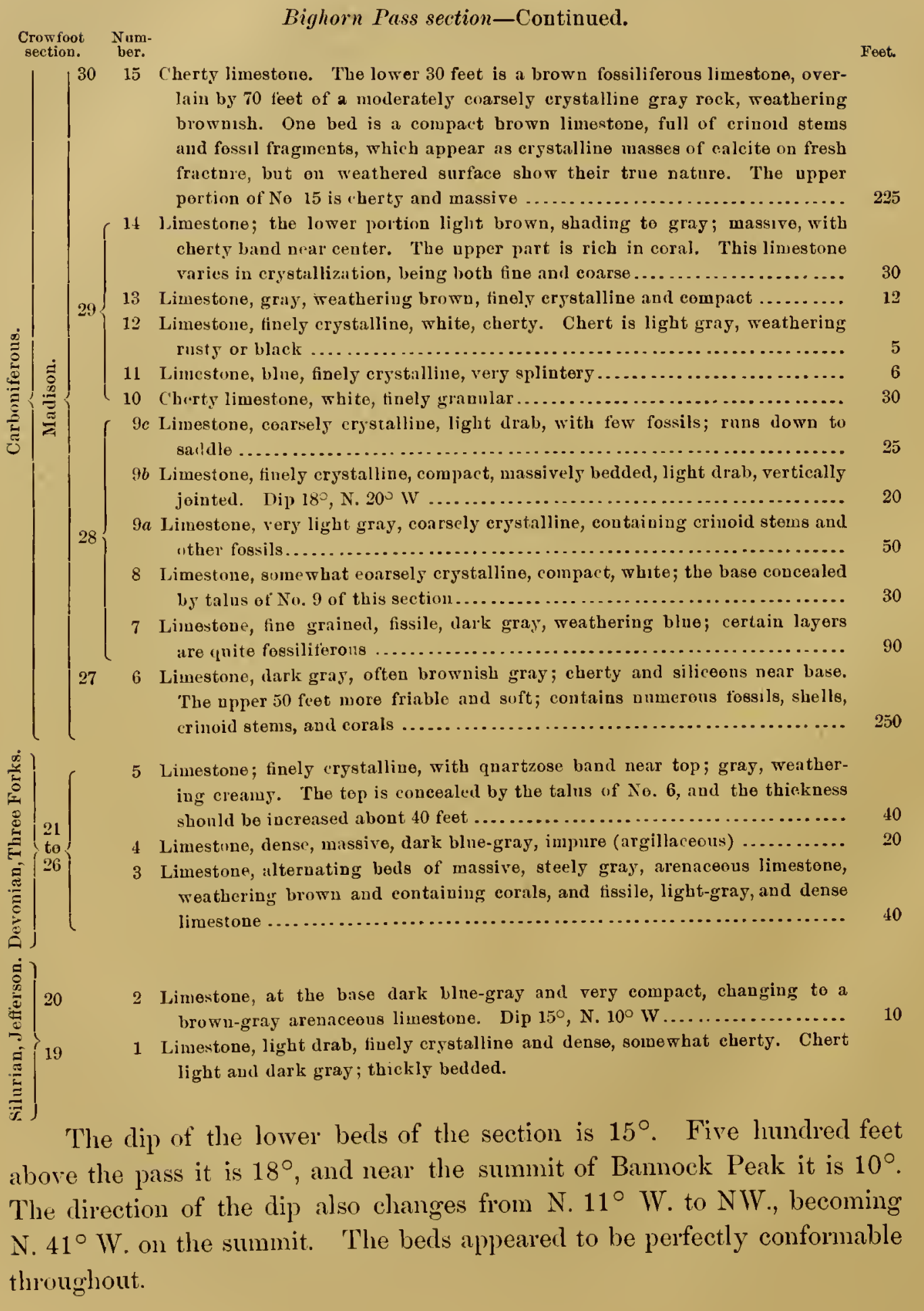


It will be observed that the thicknesses given in the foregoing section to the berls numbered 16 to 19 inclusive differ considerably from those of the Crowfoot Ridge section. The corrclation of the beds seems to be correct; the error can not be linge either in this or in the estimates of thicknesses, as the white Quidrant sandstones above and the arenaceous Jefterson limestones form a clieck on the work. This difference anounts to nearly 400 feet and is believed to occur in the upper beds of the Madison limestones.

West of Quadrant Mountain and Bannock Peak the range consists of a rugged region drained by the Gallatin River. 'This stream, which hearls in Gallatin Lake at the base of Three River Peak, flows through a valley that is one of the most beautiful parts of the park. Broad open meadows, diversified with clusters of pines and spruces, alteruate with small patches of forest that cover the broad ralley bottom. To the sonth the slopes rise steeply to the peaks of Crowfoot Riclge, while bold cliffs of white limestone wall in the valley upon the nortl. The river flows rapidly, in a succession of rapids and clear pebbly reaches, cutting the heavily bedded limestones that form the valley floor.

\section{CROWFOOT RIDGE AND GALLATIN VALLEY.}

On the west side of the ridge along which the chief stratigraphic section was studied a branch of Grayling Creek has cut a deep gulch, trending toward the northwest. This follows the outcrop of the Flathead shales, and has the gneiss and steeply dipping basal sandstone on the south side and the massive Paleozoic limestones on the north. Abont a mile down the gulch a fault crosses the country in a direction east of north, letting down the block of sedimentary rocks and crystalline schists on the west side of the fault, so that the strata dip at a more miform inclination of $15^{\circ}$ to $20^{\circ}$, and also $30^{\circ}$, NE. This throws the basal quartzite at least 800 feet lower down than the west end of the crest of Crowfoot Ridge, and brings the Quadrant quartzite back to the summit of the west spur of Crowfoot Ridge, from which it extends down its norther'n slope.

At the western base of the end of this mountain ridge the sedimentary rocks are lost sight of beneatl a deep accumulation of glacial drift, which obscures the contact between these rocks and the rhyolite lava that has buried them and the underlying crystalline schists, as already pointed ont. The north and south ends of the fault just noticed are lost beneath the same drift. 
East of the lighl ridge along which the sedinentary section was made, already referred to as Crowfoot Ridge, the strata are folded and fanlted in a pronounced, though not an extreme, manner. In the short spur between the two branches of the drainage east of the ridge there is a marked bend in the beds of limestone, which in the higher part of the spur dip steeply and can be traced continuously into the main body of the ridge, but at the lower end of the spur are nearly horizontal. There is thus a short fault line west of the spur, which runs out in the head of the guleh, and probably joins a longer fault which terminates somewhere near the junction of this drainage with the Gallatin River, as shown on the map There is also evidence of horizontal thrust in the telescoping of the limestone layers, which is seen on the east escarpment of the ridge.

The next spur east of the one called Section Ridge is a long low ridge, formed of nearly horizontal beds, with a slight syneline aeross its middle, the axis of the syncline being about northwest and southeast. At its southem end the beds turn up abruptly against the gneiss ridge, and the shaly horizons are eroded down, and do not rise in a high spur as erroneously drawn on the general map. There is a fold or bend in the strata as they eome from Section Ridge, the beds curving down toward the east so as to permit the strata in the low spur to lie at a low angle. This is probably accompanied by slight faulting, with nortl-south trend, situated near the bottom of the drainage. It was not observed, however, in the field.

Between this spur and the next large spur, abont a mile east, there is a broad fold in the strata. The beds that dip at a low angle of about $20^{\circ}$ to the north and northeast, arch over to an abrupt pitch with steep angle at the east side, near the south end of the east spur. This general areh is complicated by minor folds, not indieated on the map. The changes in dip and the differences in hardness of the shales and limestones show themselves in the topography, which is modified by glaciation. The easier degradation of the shaly layers leads to sink holes beneath stronger limestone layers. One has been made in the lowest micaceous shale, with the first massive limestone layers to the north. Farther east a small rock bound glacial lake occurs on the gneiss at its contact with basal quartzite. North and northeast of this lake the lowest belt of Cambrian limestone forms a bench and a long slope down to the drainage, which flows west of north. Here the general dip of the strata is $30^{\circ} \mathrm{NE}$. Near the lower end of the slope just mentioned are four small folds of the strata, with axes trending about 
N. $10^{\circ} \mathrm{W}$. The upper part of this drainage is located on the upper shale belt in the Canubrian, but leaves it lower down the slope. The upper stale belt may be traced across conntry by its influence on the topography, forming saddles where it crosses spurs which trend north, and giving rise to lateral drainage chamnels, feeding larger ones rumning north, or forming hasin-like depressions with sink holes, as already noted.

The head of the gulch cut in the shale belt just mentioned is not shown on the map, but it is quite strongly marked, being narrow and deep and trending north, and receiving the dhainage of the small pond sontheast of the larger lake noted above. The west wall of this gulch is formed of the lowest belt of Flathead limestone, with the lower micaceous shales of the Flathead formation to the west. At the spot where the drainage from the sinall pond falls in to the deep gulch, these strata are inverted, dipping $60^{\circ}$ or $70^{\circ} \mathrm{W}$.; strike, north and south. Hence the lower beds appear to overlie the upper ones. The gneiss is only a short distance west. The inverted beds ean be traced northward into vertical beds, and then into others dipping toward the northeast. To the south the inverted beds continue in the same position until they abut against the gneiss. It is evident that there has been some faulting and displacement of the basal formations for a short distance in the neighborhood of the unconformity just mentioned.

The portion of the high ridge east of the shale gulch and the ponds previously mentioned is in general a syncline with a flat anticlinal fold at its northern end, which is south of the saddle crossed by the fault to be described. The dip of the strata, which are very steep near the gneiss, changes from almost $45^{\circ} \mathrm{NE}$. to $15^{\circ}$ farther north, flattening to the syncline already mentioned. The axis of the synclinal fold is somewhat west of north, and the same fold may be observed to the southeast of this ridge. Southeast of the southern end of the ridge a drainage channel follows the line of the upper shale belt in a southeast direction. The sonthern side of this drainage is formed of the lowest massive belt of limestone, and south of this parallel gulches have been worn in the lower shale belts. These drain either through cuts across the belt of massive limestone or in sink holes beneath it. Here again the strata are inverted, with a dip of $50^{\circ}$ to $80^{\circ}$ SW., changing in places to vertical and also to steep dips to the northeast. Near where the gneiss ridge is faulted by the north-south fault, the basal beds of the sedimentary series are inverted, with dip of $20^{\circ}$ to $50^{\circ} \mathrm{SW}$., 
and form a narrow wedge between this fault and the gneiss. The Gallatin fault, which crosses the west base of 'Three River Peak, trends in a northnorthwest direction, crossing Crowfoot Ridge three-quarters of a mile west of Three River Peak, and crossing the ridge north of it at the saddle one mile north of the gneiss, thence following down the drainage, to die ont where it joins the short fault east of Section Ridge. The trend of the fault is nearly parallel with that of the Gallatin River, as will be seen on the map. The maximum displacement is about 2,000 feet.

The long, low, flat-topped ridge lying between this fault and Gallatin River consists of nearly horizontal beds of Carboniferous limestone capped by the white Quadrant quartzite or sandstone occurring at the top of the Carboniferons series. 'The dip of the beds is about $5^{\circ} \mathrm{NE}$. From this it is evident that there must be a fault or a fold between this ridge and the higher one east of Gallatin River. A fold exists west of Bighom Pass, but it was not followed down the valley. On both sides of the low ridge west of Gallatin River are bodies of intrusive igneons rock, related to the daciteporphyry of the Holmes bysmalith in composition and petrographical character. The rock is lithoidal and holds small mica phenocrysts; it is fissile near the contact with sedimentary rocks, and massive a few feet distant. It crosses the fault line and is found on its western side intruded in the axis of an anticlinal fold in Cambrian rocks. Its intrusion followed or accompanied the faulting. On the eastern side of the flat ridge it appears as an intrusive sheet, about 50 feet thick, forced between beds of Carboniferous limestone. This exceptional occurrence of igneous rock as an intrusive sheet in massive Carboniferons limestone is of limited extent and is in the immediate neighborhood of a fault, with which it is directly comected. Similar rock has been intruded into the west base of Three River Peak, and it may be assumed that the Holmes bysmalith was connected with the same line of faulting. The intrusion of this mass has been shown to have been subsequent to the upheaval that permitted the intrusion of the Indian Creek laccolith; hence it follows that the more steeply upturned position of the gneiss and Cambrian strata west of this fault was due to a later movement than the general uplifting of the body of the range. This steeper uplift was linited on the east by the fault last mentioned, and by that cutting across the northwest end of Crowfoot Ridge, which faults are probably contemporaneous and were accompanied by a slight faulting east of Section Ridge. 
QUADRANT MOUNAMN, BANXOCK PEAK, AND TIIE VALEET OF THE GALLATIN IEIVER.

In the less disturbed eastem portion of the Gallatin Range the Cambrian and Devonian strata pass northward with a low northeasterly dip, disappearing beneath the more massive beds of Carboniferons limestone along the base of the mountains north of Pauther Creek. The bold southern escarpments of Quadrant Mountain and Bamock Peak exhibit almost the entire section of Carboniferous strata, since they are topped near the summit of the former mountain by Juratrias beds. The nearly horizontal beds form massive cliffs that extend with gentle inclination along the eastern escarpment of this momtain, in lines parallel to the slope of its platean-like top, and that sink beneath the level of the valley as Fawn Creek is approached. They may be plainly made out in Mr. Holmes's panoramic sketch of the Gallatin Range, Pl. IV: Their character in Bamock Peak is seen in Pl. VIII. From here they extend westward along both sides and the bottom of the valley of the Gallatin River, forming the cliff along its northern side and dipping at a low angle toward the southeast, while on the south they form a high ridge and the mountainous spur of Crowfoot Ridge.

\section{BANNOCK PEAK.}

Bannock Peak is a sharp mountain summit north of the head of Panther Creek. Resting upon the more readily eroded beds of the Silurian and Devonian termanes, the massive Madison limestones form the main mass of the mountain and are capped by the resistant beds of the Quadrant quartzite, whose white ledges form a bold escarpment that encircles the peak.

On the northern side of the mountain a section was made of the strata exposed in the wall of the amphitheater cut between this peak and the broad plateau summit of Quadrant Mountain. This amphitheater, though apparently open, as shown on the map, is divided by a spur projecting southward from the extreme western end of Quadrant Mountain. This section was made from the bed of Panther Creek up the center of the amphitheater to the crest of the ridge dividing this from the amphitheater at the liead of Fawn Creek. The beds are exposed in a series of steps or benches, the lowest strata being the arenaceous Jefferson limestones, the underlying beds being covered by drift.

The beds $\operatorname{dip} \mathrm{N} .21^{\circ} \mathrm{W}$. at $8^{\circ}$, the determination being made on No. 4 of the section 


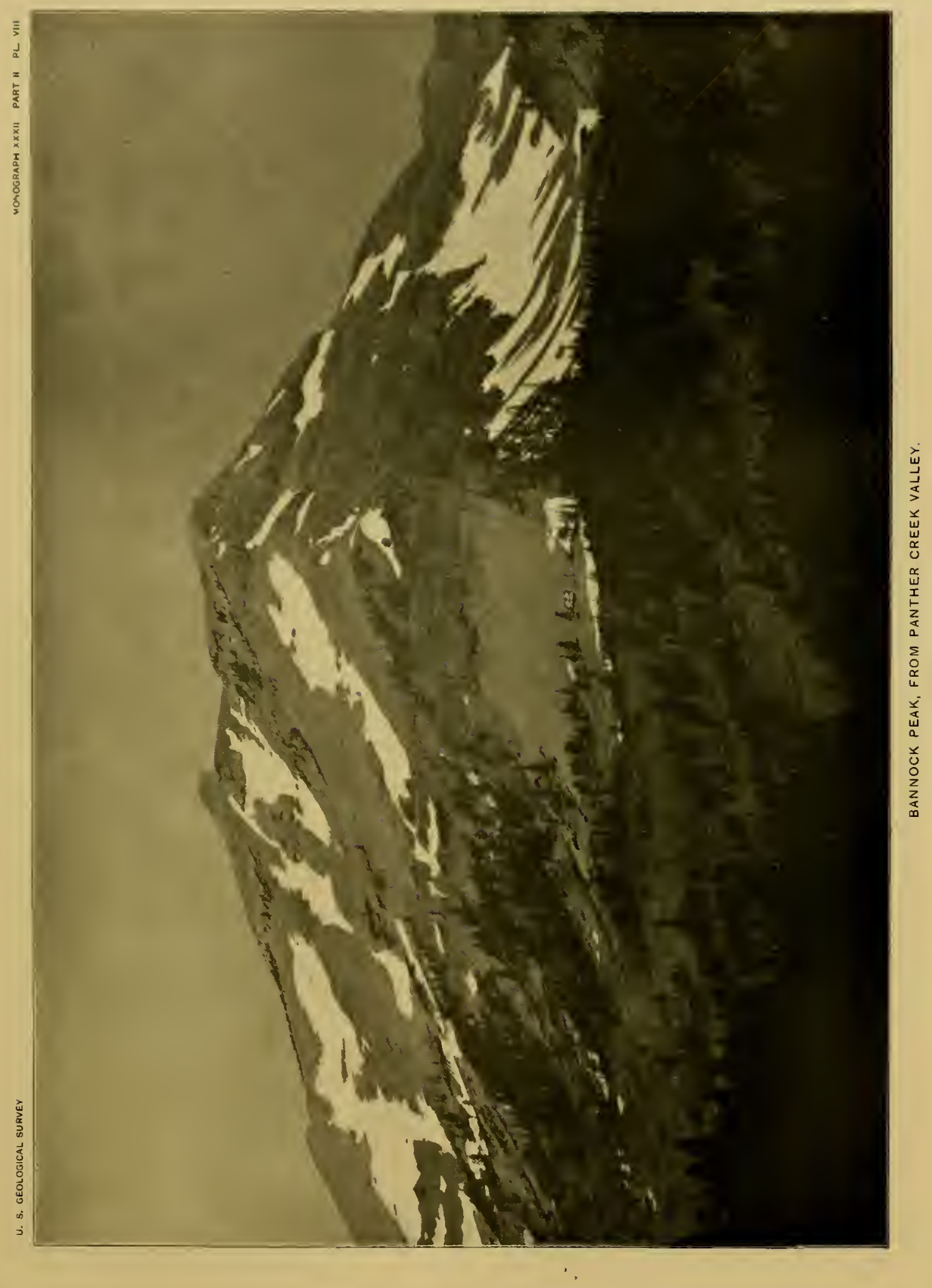





\section{QUADRANT MOUNTAIN.}

The broad summit of Quadrant Mountain is an open and grass-covered area, above which a bold pyramid formed of the red Teton sandstones rises quite abruptly. Snow fields corer the summit in early spring and remain through the summer, nourishing streams that flow in cascades over the walls of the Pocket. The upper slopes, which lie beneath the cliffs of white Quadrant sandstones, are dark with the lichen-covered débris from the overhanging walls, while the slopes beneath are thickly timbered. The summit of the mountain slopes northward with an angle of $3^{\circ}$ to $4^{\circ}$, conforming very nearly to the bed of the rocks. The flatness of the mountain top is clearly due to the resistant nature of the Teton limestones, as the overlying clays and sandstones are rapidly removed by erosion. This mountain block is of very simple stratigraphical structure. The beds are slightly flexed, without faulting, and are undisturbed by intrusives. The beds forming it are the Madison limestones, covered by the white Quadrant quartzites overlain by the cherty beds of the Teton formation. The strata forming the mountain are clearly a continuation of those of Antler Peak and Panther Creek Canyon; on the west the beds are seen to be connected witl those of Bannock Peak through the saddle of the amphitheater, while on the north the Quadrant quartzites form the floor of Fawn Creek Valley and pass under the slopes of Little Quadrant Mountain. Eastward the beds end in a cliff and steep slope along that north-south line which separates the sedimentaries of the range from the lavas of the platean. The general dip of the beds is a little west of north, about $8^{\circ}$, so that the slope of the summit corresponds approximately to the dip of the beds.

The summit of the mountain has been carefully examined. West of the Pocket the cherty Teton limestone covers the surface, which, when examined closely, is seen to be rough, gullied, and hummocked. The red hill on the summit of the mountain, southeast of the Pocket, is composed of the red Teton sandstones. This point is abcut 200 feet higher than the surrounding summit. On the east, sonth, west, and northwest these beds commence at the very foot of the hill; on the northeast the area extends about one-fifth of a mile farther. The general summit from the red point north is formed of the Teton cherty limestone and its associated lingula-bearing limestone, down to 9,200 feet, where the red beds again cover a portion of MON $\mathrm{xXXIl,} \mathrm{PT} \mathrm{Il-3}$ 
the mountain. Eastward the cherty beds have been removed from the bench, and the white beds of Quadrant quartzite are exposed.

On the summit of the 9,100-foot hill a small outcrop of the red and yellow sandstone (No. 38 of section below) is exposed. West of this hill is a deep cut, into which the small drainages of this part of the summit flow. The surface of the area covered by the red beds is generally smooth and grassy; the shales are exposed in cuts, but appear only as detritus on the summit.

On all sides of the mountain the white beds of Quadrant sandstone form an escarpment, often capped by the cherty limestone. This Teton cherty limestone varies greatly in character. Often it is a cherty sandstone with little if any calcareous material in it; again it is a true limestone; and these two extremes grade into each other. The chert seems to be formed of sand, for the transition between the sandstone and the chert is often very gradual. 'The color is a grayish brown.

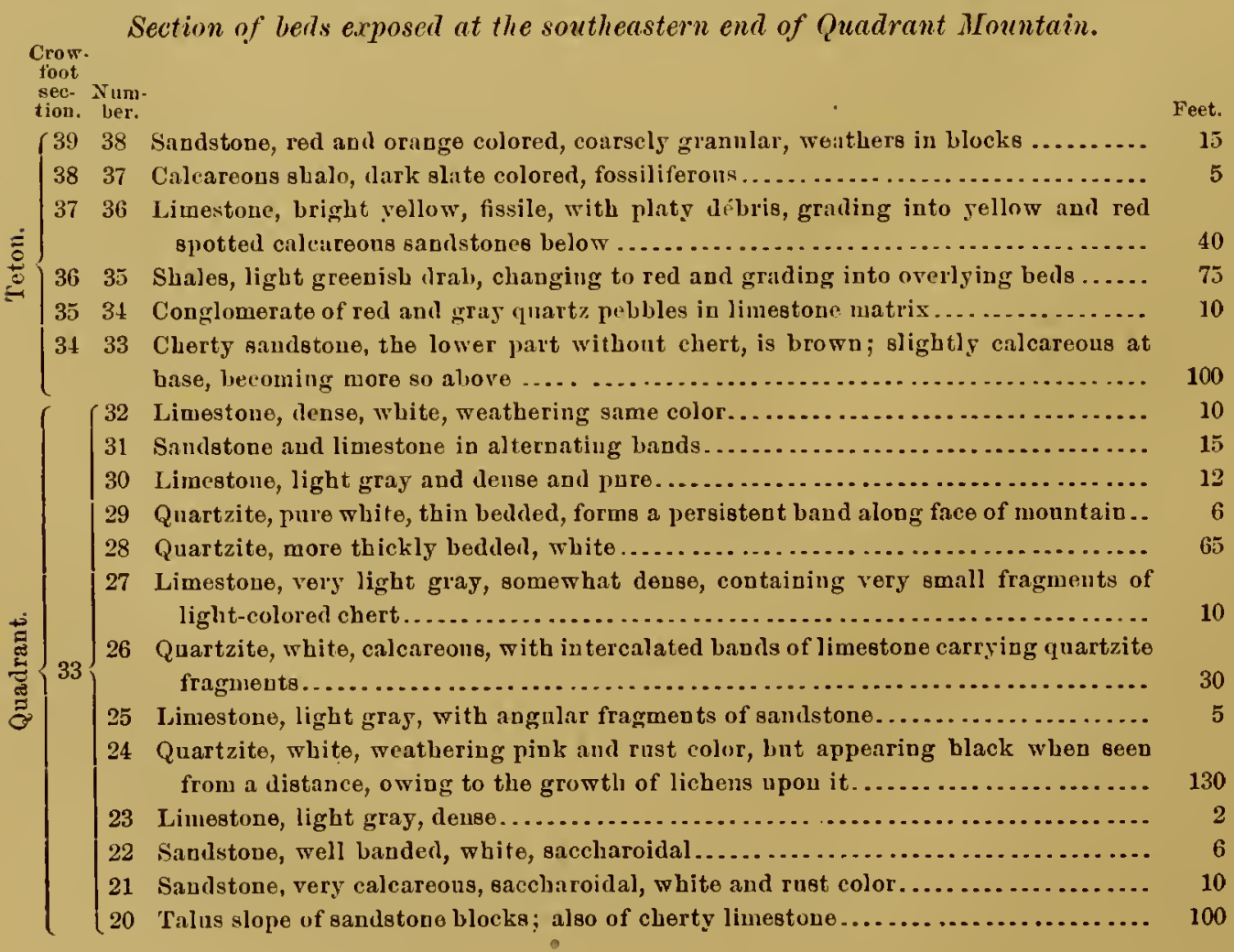


Section of beds exposed at the southeastern end of Quadrant Mountain-Continued.

Crow.

foot

Hec:- Num

tlon. ber.

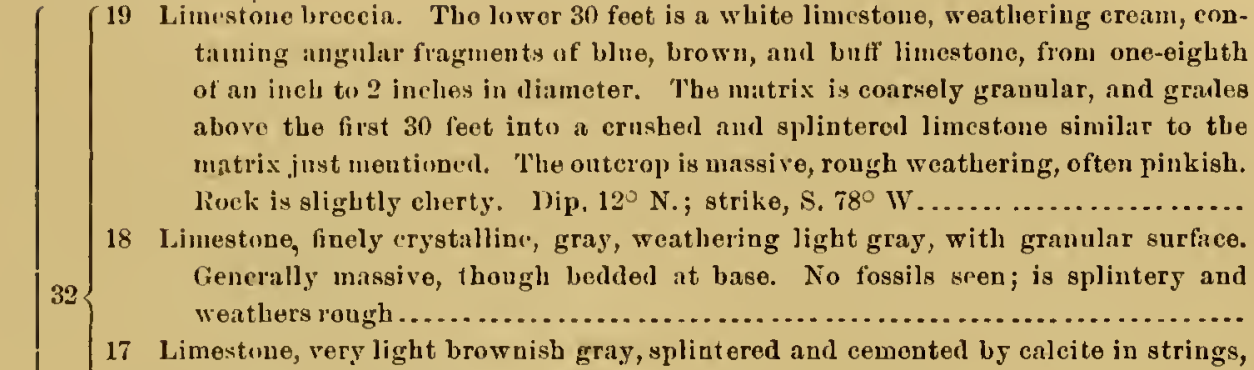
and by blue limestone

16 Limestone, brecciated at the baso; matrix gray, fraguents angular, browu and brownish gray; above this the limestone is massive and gray. Seamed with calcite and carries much of that mineral in pockets. It is somewhat cherty at the

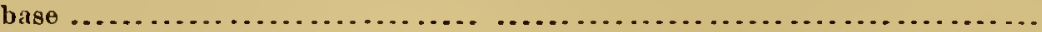

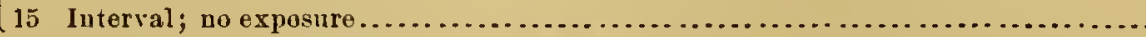

14 Limestone, finely crystalline and granular, brown, somewbat clerty .............

13 Limestone, very fine grained with sparsely disseminated chert, but varying to a very coarse-grained blue-gray rock. Color in goneral a light brown-gray. Weathers into irregnlar warped plates, due to jointing ....................

12 Limestone, coarsely crystalline, brownish gray, weathering gray with granular surface. Irregularly belded; fossiliferous; nuch broken ly vertical jointing...

11 Limestone, finely ersstalline, generally thiuly bedied, sometimes dark gray, but mostly brown, with granular weathered snrface, or a blue-gray more coarsely crystalline liuestone. Dip, $5 \circ \mathrm{N}$

$10 b$ Limestone, similar to No. 10a, but well banded. The fossiliferous layers weathering blue-gray; the noufossiliferous bands denser, granular, weatheriug light brown, and 1 to 3 inches thick . . . . . . . . . . . . . . . . . . . . . . . . . . . .

$10 a$ Limestone, in alternating lavers of liglt gray, finely crystalline and darker, coarsely

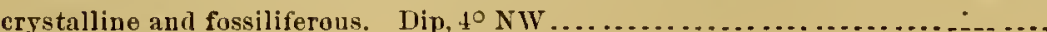

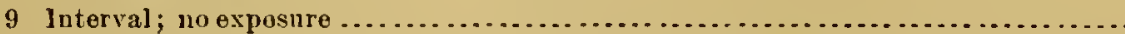

8 Limestone, finely graumlar, light brown, weathering same color; fissile, coutaius remains of fossils. Talus iudieates a greater tuickness than that given .......

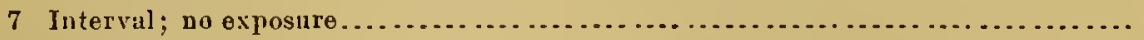

6 Limestoue, ligbt gray, finely crystalline, with gray and gramuar, glistening, weathered snrface.

5 Interval; no exposure

4 Limestove, coarsely crystalline, dark gray, weathering the same color; fossiliferous

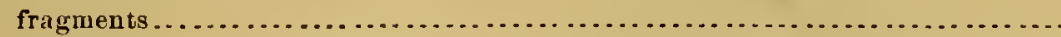

$29\{3$ Limestone, forming a well-marked and prominent ledge extendiug aronnel the mountain; massive, light drab, weathering dark gray and brown with glossy beaded crust. Contaius corals and other fossils ........................

2 Interval; no exposure..........................................

l Limestome, cherty, crjstalline but not grauular, compact, massively bedded. The upper part fossiliferous, containing crinoid stems, corals, anıl spirifers, Dip, about $5^{\circ} \mathrm{N}$ 


\section{LITTLE QUADRAN'T MOUNTAIN AND FAWN CREEK VALLEY. LITTLE QUADRANT MOUNTAIN.}

North of Quadrant Mountain is another flat-topped elevation, known as Little Quadrant Mountain, which is clearly defined from the adjacent mountains by the deeply incised ralleys of Fawn Creek and the headwaters of the Gardiner: The mountain is carved out of a block of Mesozoic strata, into which numerous sheets of andesite-porphyry, offshoots from the Gray Peak intrusion, have been injected. The resistant nature of these intruded sheets has produced the marked terracing which now forms so characteristic a feature of the southern slopes. The following section, made by Mr. George M. Wright, represents the beds exposed on the southern side of the mountain, the lowest strata being the brecciated limestone forming the top of the Madison limestone series, through which Fawn Creek has cut a small canyon at the forks of the stream:

\section{Section of beds exposed on south side of Little Quadrant Mountain.}

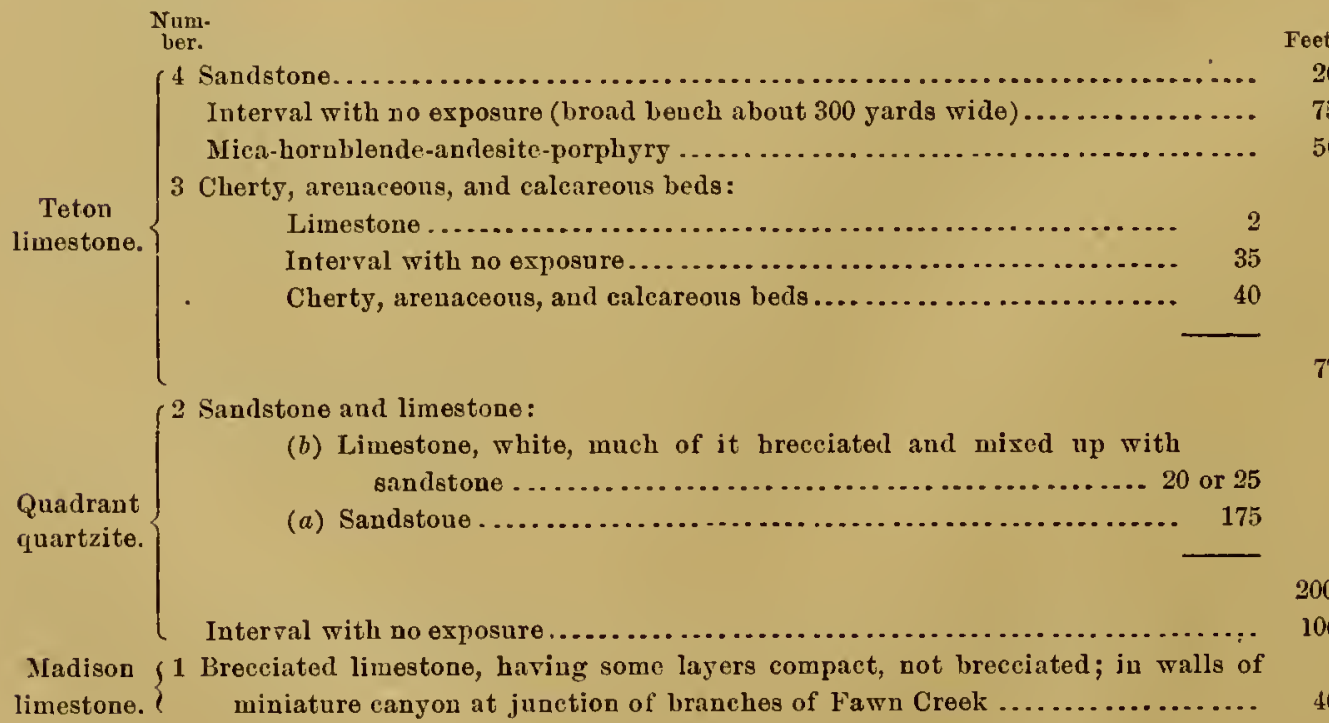

The total thickness of this section is not given, owing to the uncertainty of the exact thickness of two of the intervals above mentioned.

Above the beds of the section just noted there is a long steep slope, rising 300 feet or more to a prominent cliff formed of the Ellis sandstones. 
Another section, made by Mr. Wright, shows the sequence and thickness of the beds from this horizon to the summit of the momntain.

Section of beds exposed on south sidle of Little Quullont Mountuin.

Nour.

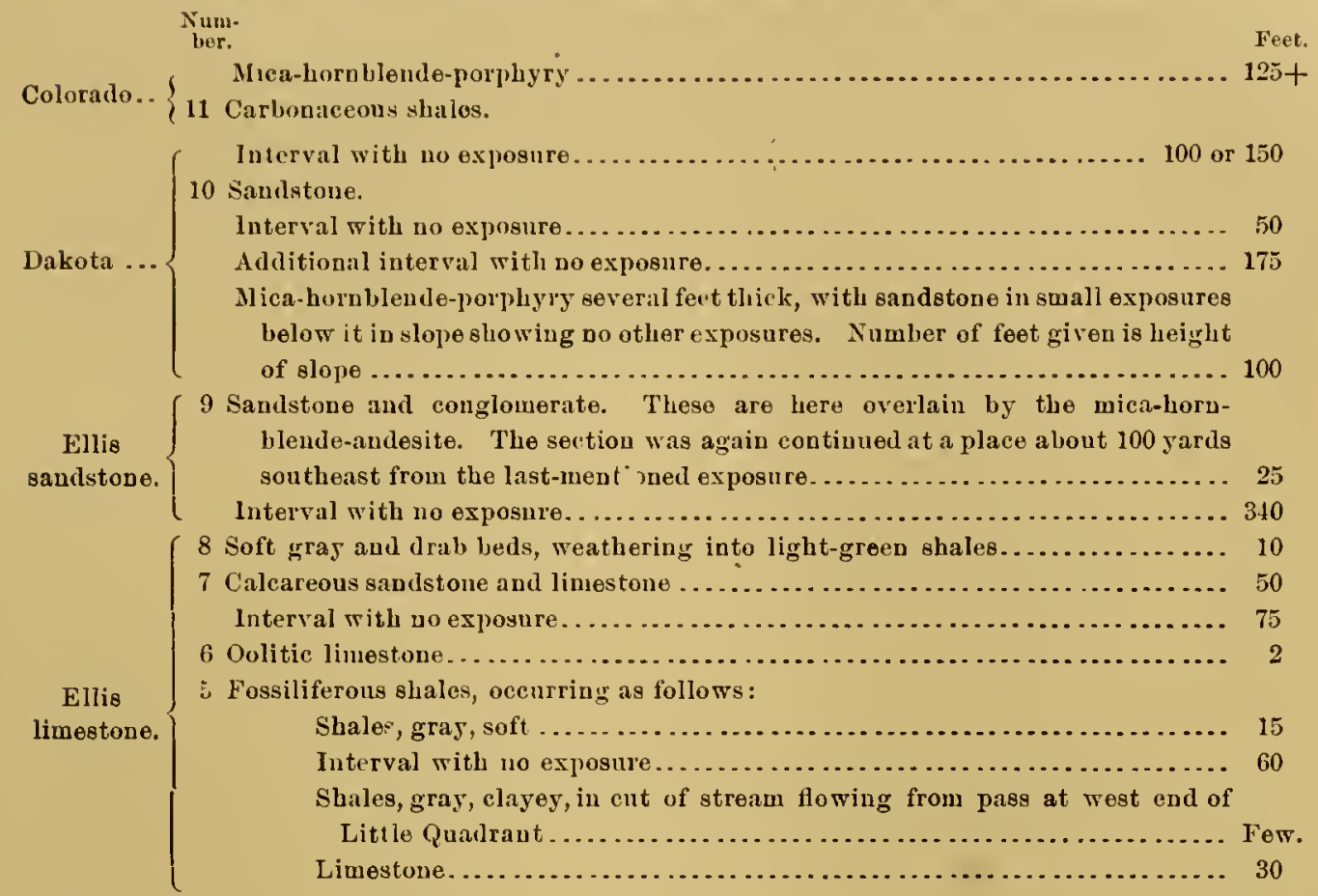

At the west end of Little Quadrant Mountain a branch of Fawn Creek has cut back to a low divide separating this monntain from Gray Peak. The lowest beds exposed by this stream are the Ellis limestones, which are exposed in the gulch 25 feet deep near the forks of the stream. The beds $\operatorname{dip}$ N. $25^{\circ} \mathrm{W}$. at $10^{\circ}$. The strata contain numerous fossils and are quite like the beds described later in the Fan Creek section. In the stream channel abore, there is an exposure of rery fissile calcareous sandstone in a ledge 5 feet thick, which is overlain by very arenaceons, granular, crossbedded, gray limestone, containing fossils which are mostly comminuted and broken. This exposure is 20 feet thick, and the bed is orerlain by a sandstone containing a few scattered pebbles. The strike is $\mathrm{S} .35^{\circ} \mathrm{W}$., and the dip is $10^{\circ} \mathrm{NW}$. Above this the stream flows over a small exposure of Dakota conglomerate, which is overlain by andesite-porphyry, forming a cliff 75 feet high, over which the stream flows in a succession of cascades This rock, which is an extension of the Gray Peak intrusion, is hornblendic, 
generally much decomposed, and shows no megascopic mica. This porphyry forms a bench north of the stream which extends back to the base of the cliffs where Dakota conglomerates occur. In the stream chamel a brownish-gray sandstone speckled with black, and belonging to the Dakota series, is overlain to the east by the andesite-porphyry, forming the two 9,000-foot hills shown on the map. These higher beds, forming the west end of Little Quadrant, are tilted up by the porphyry intrusion. The following section, made by Mr. Wright, shows the sequence and thickness of the beds exposed in ascending the creek, the beds being giren in descending order. The thicknesses are estimated and approximate, and are given in feet:

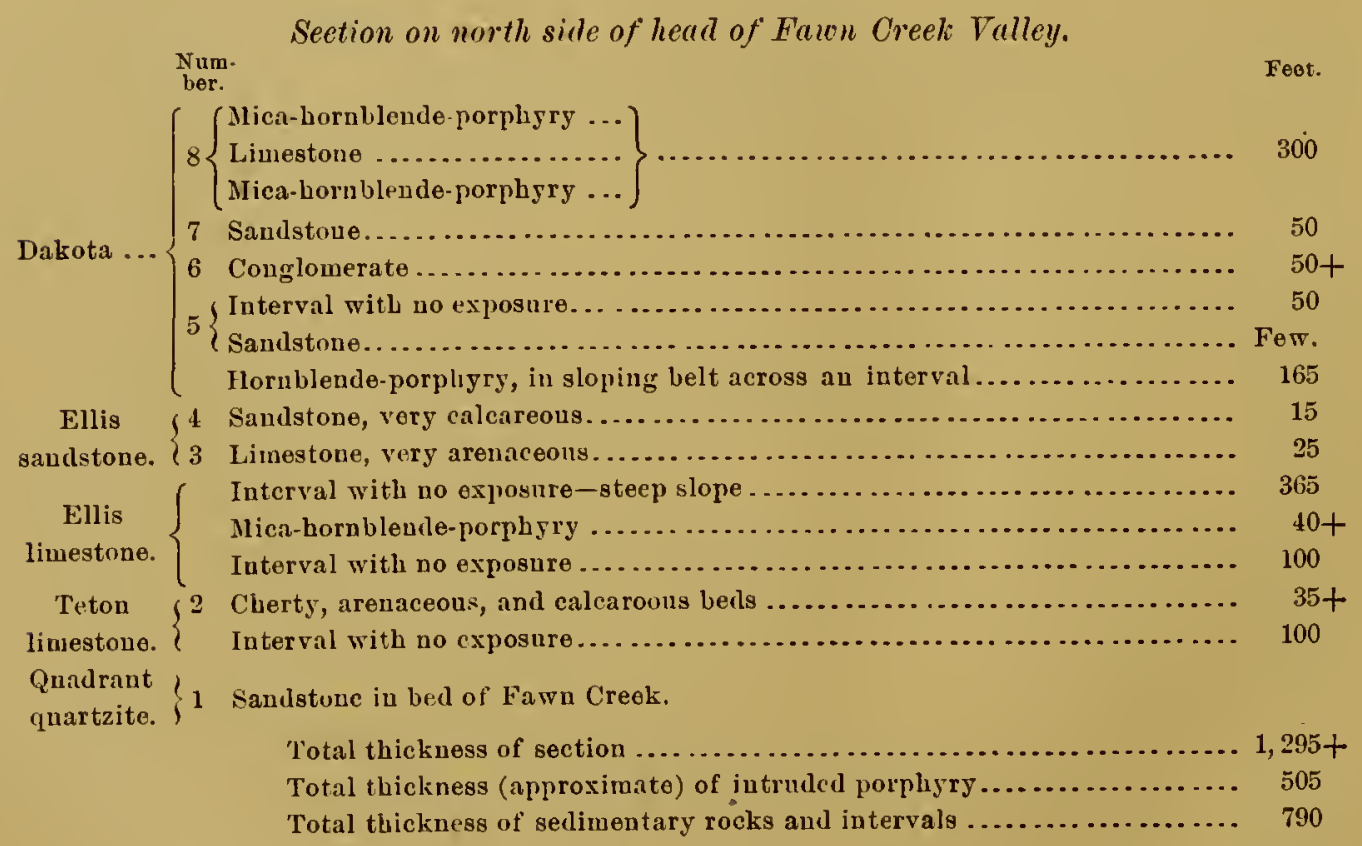

The slopes on the northern side of the west end of the mountain show a succession of beds very similar to that of the section just given. The measurement made of the series from the Dakota conglomerate to the summit of the ridge showed the 100 feet of conglomerate and sandstone, which was assigned to the Dakota, overlain by 45 feet of compact gray limestone considerably altered by intrusive sheets of porphyry, which occur both above and below the bed and also split it in half. The overlying sandstone, which forms the summit of the Dakota series, is a pure white, rather 
soft and fine-grained, massive bed, whose outerops often weather a lightbrown. The thickness is 50 feet, and it is overlain by carbonaceous shales which are quite arenaceons at the base and become more argillaceous above. These beds form the elifts extending eastward around the sides of the crescent-like amplitheater ent in the northwestern wall of the mountain. The blaek shales extend eastward along the crests of the eliff's of the crescent amplitheater for nearly a mile, when they break down and the sandstone forms the summit of the cliff. In the northwestern slopes of the mountain, sandstone is exposed in nearly all the lateral gullies and stream chamnels, the upper sandstone bed of the Dakota being especially prominent and forming a persistent ledge that extends around the north spur of the mountain and eonstitutes the wall of the amphitheater cut in its eastern faee. Beneath the cliffs which form the wall of the northwestern part of the mountain an andesite-porphyry sheet has furnished the material for a great morainal accumulation of angrular roeks, concealing all exposures and rendering travel difficult. The persistent nature of these andesiteporphyry sheets is shown by their oceurrence in so many localities at the same stratigraphic horizon. In the stream chamel north of Little Quadrant the sheet of andesite-porphyry oceurring between the Dakota limestone and the conglomerate is well exposed at 9,000 feet. In the vieinity of the lakes at the head of the valley the porphyry forms low rounded knolls, whose surfaces are scored and polished by glacial aetion. The lower slopes east of Little Quadrant have been earefully examined, but the morainal drift obseures all outerops.

\section{FAWN CREEK VALLEY.}

The valley of Fawn Creek shows good exposures of the Carboniferous roeks, overlain by the softer Mesozoie series. In a little gulch near the forking of the ereek, the Quadrant quartzite series is well exposed. On the south fork of the stream, just above this jumetion, a green magnesian bed, whose surface is red from the wash of the weathered outcrop, is also exposed. The overlying bed is a dark purplish-red rock spotted with green, highly ferruginous and argillaceous, being a very impure dolomite. This rock is overlain by an ontcrop of orecciated limestone, which is believed to represent the highest bed of the Madison limestone series. This breeciated eharaeter and the grannlar weathered surface of these 
limestones are persistent features of the upper beds of the Madison series in this vicinity. These beds are overlain by the white Quadrant quartzites, which are well exposed in the stream channel. In the bottom of the amphitheater at the head of Fawn Creek, a coarsely crystalline brown limestone is well exposed. The rock is fossiliferous, but the fauna presents no features different from those of the underlying limestones. The beds dip $10^{\circ} \mathrm{N}$. The amphitheater floor is heaped up in places with great piles of débris, but presents many smooth exposures of a dark, slaty limestone and of the coarsely crystalline rock just mentioned. In the latter there are numerous large sink holes or "swallow" holes, in which the waters flowing from the snow banks of the amphitheater walls pass underground, to reappear two miles down the valley as a large stream which forms the headwaters of Fawn Creek. The section of beds exposed in the amplitheater walls to the east has already been given in the account of Quadrant Mountain. Nowhere is the character of the Quadrant quartzite and of the immediately underlying Madison limestones better shown than it is in the walls south of Fawn Creek Valley. The sections which have already been given show the relative thickness of these beds and the development of the impure argillaceous dolomites whose red ledges form so prominent a feature of the rock outerops.

A comparison of the sections of the Quadrant quartzites made on the walls of Quadrant Mountain is given in the following table. A precise separation of the sandstones from the interbedded limestones is not always possible. Many of the sandstones are very calcareous, and in some cases would perhaps be classed as arenaceous limestones.

' Handbook of Physical Geology, A. J. Jukes-Brown, p. 87, London, 1884. 
REGION NORTII OF GALLATIN RIVER.

Comparison of sections of Quadrant formation.

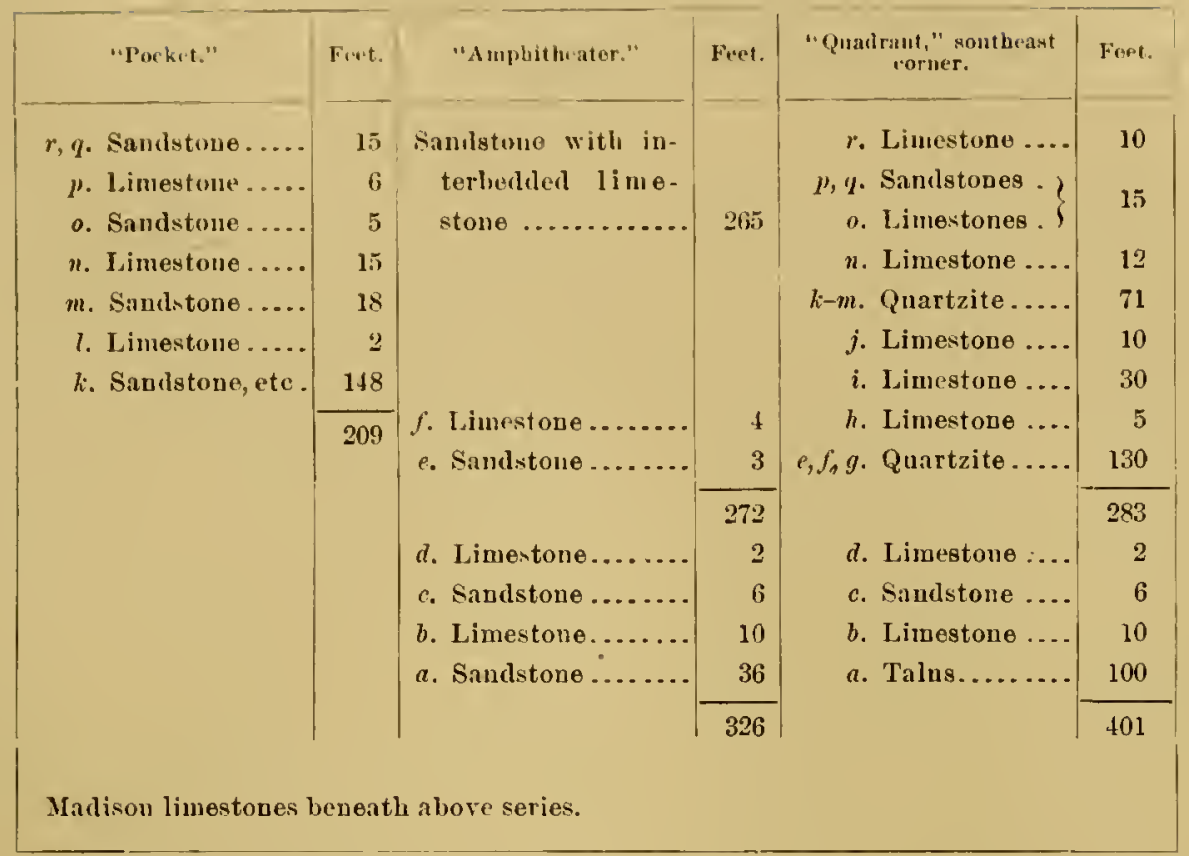

On the summit of the ridge west of Fawn Creek amphitheater, the Teton limestone is well exposed, the dip being $15^{\circ}$ and the direction N. $26^{\circ} \mathrm{W}$. These beds are undoubtedly tilted by their proximity to the Gray Peak bysmalith mass, although the tilting is not uniform, as the red sandstones forming the hill farther north have a dip of but $10^{\circ}$ in the direction N. $15^{\circ} \mathrm{W}$.

\section{REGION NORTH OF GALLATIN RIVER.}

As already pointed out, the escarpment wall on the north side of Gallatin River consists of massive Madison limestones topped by the white sandstone or quartzite of the Quadrant formation. These beds dip at an angle of about $10^{\circ} \mathrm{NE}$. throughout the greater part of the distance, having a more northerly dip in the vicinity of Bannock Peak, and at the western end of their exposure curving over from a northeasterly to a northresterly dip of $5^{\circ}$ to $10^{\circ}$, bending down toward the profound fanlt plane that bounds them on the west and brings them against subaerial breccias of andesite. Within the limits of this low anticlinal arch the sandstone is in places broken and polished with slickensides accompanying slight displacement 
of the rock. A well-marked bench occurs along the top of the steep slope or escarpment, its surface in places sloping with the dip of the strata. It is most pronounced when above the harder beds, especially where these are overlain by the more friable sandstone and soft shales of the Juratrias formations.

The bench is well developed on both sides of the drainage chamnel running west from Fawn Pass. Upon entering the terrane of the Juratrias formations, which are mainly fissile limestones and shales, passing downward into the sandstones of possible Triassic age, and passing upward into the friable sandstones underlying the Dakota conglomerate, we again encounter intruded sheets of igneous rock. These intrusive sheets are nearly conformable with the sedimentary strata, following the shale belts for long distances, and only occasionally breaking up across the strata to follow higher horizons. The first of these intrusive sheets met with above the Carboniferous limestones occurs in the base of the Juratrias shales below the Ellis shale beds, and forms a cliff rising above the bench west of Fawn Pass. The sheet of andesite-porphyry is possibly 200 feet thick at this place. It can be traced west and east from this exposure, contimuing at nearly the same horizon. The shale in contact with the porplyyry is more or less baked, and, like the igneous rock, resists erosion better than the altered shales, thus leading to the formation of bluffs or ledges.

Above this porphyry cliff the country slopes gradually and stretches eastward to Fawn Pass, rising abruptly to the triangular peak $1 \frac{1}{4}$ miles southwest of Gray Peak. This comparatively level country occupies the axis of a flat synclinal arch that dips to the northwest. The strata bend around from the gentle northeast dip through a northwesterly one to a southwest dip of $15^{\circ}$ to 2()$^{\circ}$, in which position they form the triangular peak just mentioned. It is evident, from a study of the regiom, that this southwesterly dip is due to the intrusion of a large body of igneous rock connected with the bysmalith of Gray Peak. The highest sedimentary rock in the triangular peak is Dakota conglomerate. It occurs again high up on the west spur of Gray Peak, where it dips toward the northeast. The ridge between these points traverses an anticlinal arch of Jurassic beds that bend over the igneous mass already mentioned. The shales include at least two thin sheets of igneous rock, each from 40 to 100 feet thick. One of these, in the mass of the triangular peak, thins out perceptibly toward the 
southwest. The corresponding intrusive sheets beneath the Dakota conglomerate in the southern slope of Gray Peak thin out toward the east, and near the end of the spur one of them breaks upward as a dike-like body across the Dakota conglomerate.

The porphyry forming the axis of this small areh extends south, constitutung the ridge of Fawn Pass. It extends east down the valley of Fawn Creek as an intrusive sheet near the base of the Juratrias shales, and extends sonth of lawn Pass as an intrusive sheet at the same horizon, and has been traced as a ledge along the ridge south and westward to the cliff first described north of Gallatin River. It becomes thinner as it is followed farther from the bysmalith, and it is evident that the intrusive sheets in this vicinity proceeded from the Gray Peak intrusive mass.

The sedimentary beds forming the mountain side south of Gray Peak dip into the mountain toward the north and northeast at a low angle and encounter the igneous rock of the bysmalith which forms the highest portion of the mountain mass from Gray Peak to Joseph Peak, and extends down the east slope to a level of 9,000 feet and down the west side to below this altitude. The igneous rock extends along the north face of the ridge west of Gray Peak. From it also proceel sheets of porphyry intruded between the Juratrias strata which are exposed along the soutl face of Little Quadrant Mountain and may be traced around the nortliern slopes.

On the northeru side of the mass the sedimentary beds dip.toward the southeast, into the igneous core Again, as at the southern side of this body, the highest horizon is that of the Dakota conglomerate which is found at the summit of Joseph Peak in contact with the intruded mass. As may be seen from the map and cross sections (Pls. IX and X), there is a quaquaversal arching of the strata, the center of which is located in the head of Fan Creek, northwest of Joseph Peak. From this point the berls dip south, southeast, east, northeast, north, and northwest. In the three valleys heading against the ridge surrounding this arch the beds dip to the east, northeast, and north at angles not far from $10^{\circ}$-in some cases reaching $25^{\circ}$.

At the west end of the ridge north of this part of Fan Creek, the beds arch over to the west and southwest with a dip of $20^{\circ}$, and pitch against the same fault plane noted north of Gallatin River which let down the volcanic breccia. Between the sedimentary strata, sheets of andesite- 
porphyry have been intruded exactly as on the sonthern and eastern sides of the bysmalith. The lowest one exposed, however, is beneath the Juratrias beds, immediately above the Carboniferous limestone. It appears around the head of Fan Creek, thimning out northward. Within the Ellis shales, beneath the Dakota conglomerate, there are five thin sheets of intrusive rock on the northern slope of Joseph Peak. Three of these have been recognized nortl of the saddle between Fan Creek and Gardiner River. They grow thinner and less noticeable to the northwest, and may be traced down the east slope of Joseph Peak, where, on account of the position of the beds, they form isolated patches. 'These sheets vary in thickness from 15 or 20 to 100 feet.

Above the Dakota conglomerate and sandstone, the slates and sandstones that alternate with one another through a thickness of nearly 3,000 feet, constituting the Coloralo and Montana formations, take part in the quaquaversal arching already described-that is, on the northern side. On the south they have been removed by erosion. In the ridge north of Fan Creek they dip to the northwest and north, curving over to a northeasterly dip in the ridge commecting this with Electric Peak, throughout which latter ridge they maintain a generally uniform dip to the northeast, continuing the same attitude beyond the boundary of the Yellowstone Park to the symclinal trough at Horr. In the ridge between the head branches of Gardiner River, these beds curve from an easterly dip near its west end to a northeasterly one farther down the ridge, and in Little Quadrant Mountain they also maintain a general northeasterly dip, as already noted.

The alternation of shales and sandstone layers seems to have been particularly favorable to the intrusion of sheets of igneous magmas. The fissile shale offered numerous planes of weakness and parting, while the sandstone layers tended to stiffen the strata and cause the splitting to follow more nearly constant horizons, for though there is some cross fracturing of the sedimentary beds, where the igneons rock may be seen crossing the strata to higher horizons, yet the persistency of the intrusive sheets is one of their marked features. This is observed both upon actual exposures over long distances and upon the comparison of genlogical sections made across the strata by several observers in numerous localities.

In the ridge north of Fan Creek the Colorado shales form the northern slope and steep spurs and a small portion of the western end. Directly 
above the Dakota conglomerate the shales are split by two thin sheets of andesite-porphyry, and also by a massive layer that appears as a small laccolith constituting the northwestern end of the ridge. The petrographical chlinacter of the sheets is not the same in all cases, but the distinctions are slight and will be discussed in Chapter II. In the ligh ridge between the head branches of Gardiner River, at least five different sheets of andesiteporphyry were observed, having the general dip of the shales and sandstones, with occasional ruptures across the berls. They were also found crossing the valley to the north and forming part of the ridge leading to Electrie Peak, as represented on the map. Their thicknesses are not constant, as may be seen in their exposures, but the actual variation is greatly exaggerated in appearance by the positions of the exposures, whether directly across the thickness or more or less parallel to the sheet. This impression is still further increased by the appearance produced by the more persistent talus slopes of the harder porphyry, which often obscure more easily removable areas of the softer shale. The same sheets occur in the shales in the upper part of Little Quadrant Mountain.

THE FAN.

Fan Creek drains the mountainous area whose various spurs converge to the west at the ribs of the Fan, from which resemblance the region derives its name. The encireling ridge which forms the divide between the waters of Fan Creek and those of the Gallatin and Gardiner drainages culminates in two prominent peaks, one of which, Gray Peak, has already been described. The other, lying to the north, is named Joseph Peak, and occupies a commanding position just west of Little Quadrant Mountain. The sonthern fork of Fan Creek is named Stellaria Creek. At the head of this stream the high ridge which is the southwestern extension of Gray Peak is formed of Mesozoic beds, having a strike of N. $20^{\circ}$ E. and a dip of $10^{\circ} \mathrm{W}$. The peak is formed of Dakota sandstone resting upon the Juratrias beds, and is cut by intrusive sheets of andesite-porphyry from the Gray Peak bysmalith, as already described on page 42 . 
The following section represents the beds exposed on the northern slopes of this ridge at a point just west of the 9,900-foot peak:

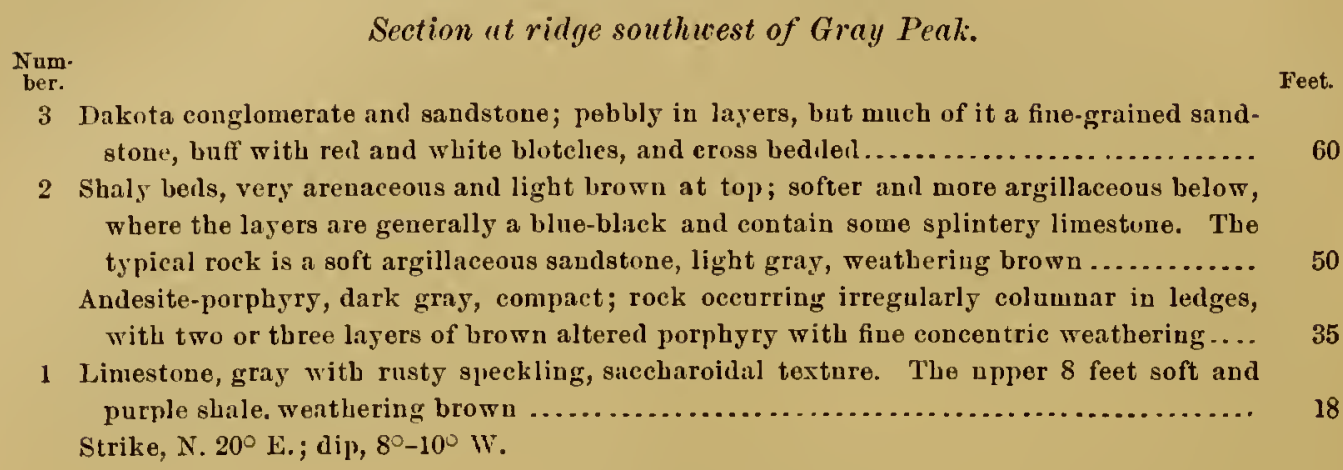

On the west side of this peak, 100 feet below the summit, the black shales are well exposed and form the crest of the ridge down to the saddle. West of the saddle they give place to the Dakota sandstone, which extends westward to the cliffs indicated upon the map. Farther west the ridge shows a succession of light-gray limestones overlying the red Teton sandstones. The latter beds form red slopes that extend westward to the andesite-porphyry lill shown upon the map.

The central ridge of the Fan, lying north of Stellaria Creek and west of Joseph Peak, is a loug flat-topped mass with grassy meadows and dense forests of pine. On the western end of this ridge exposures are scarce and must be sought for in the stream chamel. A short distance above the forks of Fan Creek, Stellaria Creek has cut a gorge through the intrusive sheet of andesite-porphyry. This rock is also exposed on the south slopes of the ridge to the north for a distance of $2 \frac{1}{2}$ miles above the mouth of Stellaria Creek. The rock is generally much decomposed, of a light-buff color, with numerous decomposed acicular hornblende and white plagioclase phenocrysts. The porphyry forms great heaps of tabular débris, often arranged in ridges running approximately east and west and separated from the solid rock by the hollows between the cliffs and these morainal ridges. These hollows are often without outlet, and sometimes hold small ponds. From the junction of the stream eastward the summit of the ridge shows no outcrops of sedimentary rocks, the covering of the porphlyry sheet just noticed having been removed by erosion and the summit being now heavily mantled with glacial drift, which seems to be at least 100 feet thick in the 
transverse drainage chanmel. 'This transverse drainage channel, which runs northward to join Fin Creek, forms the natural boundary line between the sedimentaries on the east and the andesite-porphyry on the west. The sedimentary rocks are light-gray limestones, having a strike of S. $20^{\circ} \mathrm{W}$., and a dip of $10^{\circ} \mathrm{W}$., which would carry the beds under the drift forming the summit of the ridge to the west. 'The higher slopes to the east show good exposures of the sedimentary rocks. A westem spur of Joseph Peak shows the following section of sedinentary rocks, the lowest bed exposed being part of the Quadrant quartzites.

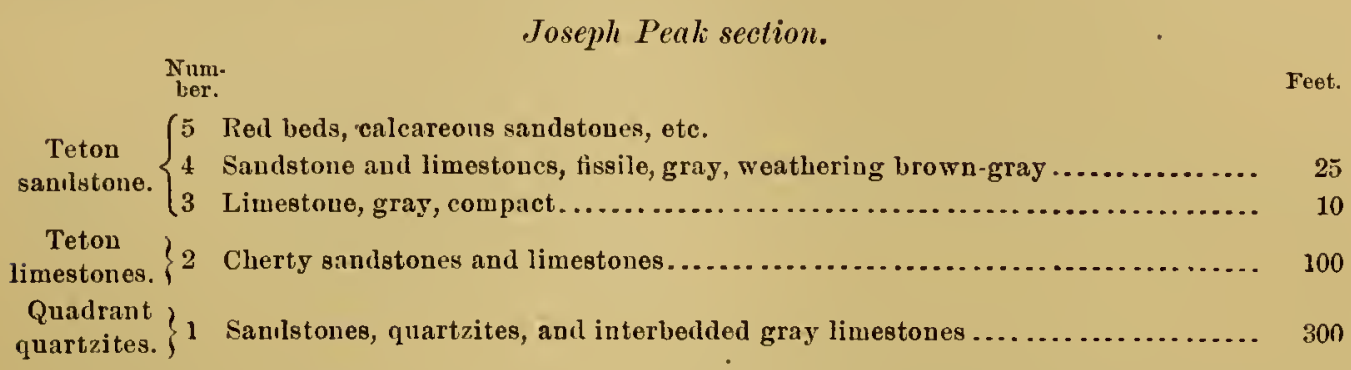

At the base of this spur the summit of the ridge is nearly flat and is largely strewn with chert weathered out of the Teton limestones. The beds here apparently dip SE. $10^{\circ}$, which takes them underneath Joseph Peak. The cherty beds of the Teton series are here quite well exposed. The chert occurs in both banded and nodular forms, and is so abundant that the remaining material, which is generally sandstone, forms but a minor feature. In seams and patches, however, the rock is free from chert, and is then mucin more calcareous and contains fragments of fossils. North of the spur from Joseph Peak the Teton limestone beds dip W. $8^{\circ}$, and strike S. $8^{\circ}$ E. Farther north the flat summit of the ridge is formed of a fine-grained andesite-porphyry, whose rust-colored exposures much resemble those of the sedimentary rocks. This rock forms the summit of a bold cliff to the north. This cliff, which is about 500 feet high, shows excellent exposures of the Quadrant quartzites resting upon Madison limestones, forming the channel of Fan Creek, and capped just beneath the andesiteporphyry by the cherty beds of the Teton series. This exposure shows a total thickness of 350 feet of Quadrant quartzite and 125 feet of the Teton limestone. The character of the cherty limestones varies from a dovecolored, nearly pure limestone to a granular brown sandstone which is not 
calcareous. The talus at the base of the cliffs, like that of the andesitic intrusive of Stellaria Creek, is arranged in morainal ridges, with a depression between these heapings and the base of the cliff. The valley of Fan Creek has been cut in the low anticline, exposing the Madison limestones overlain by the Quadrant quartzites, with the softer Mesozoic rocks forming ligher slopes to the north. In the small drainage cutting the slopes north of the creek the following section was measured:

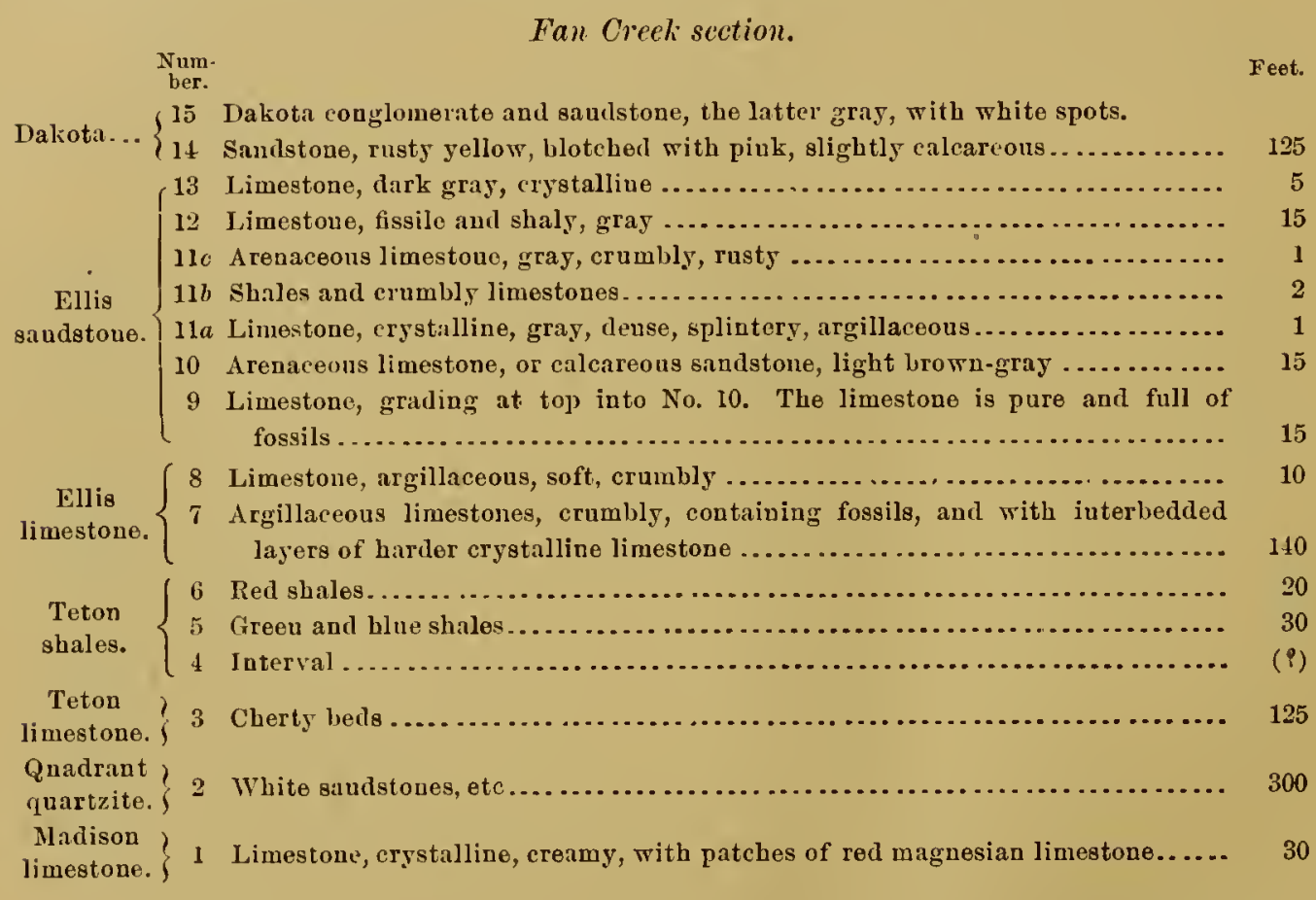

The summit of the ridge north of Fan Creek, already mentioned on page 43 , forms what might be termed the northern rib of the Fan and is capped by Dakota beds, whose persistent nature, combined with that of the intrusive sheets of andesite-porphyry, has left the ridge sharply defined. The Dakota conglomerate is but 20 feet thick and is overlain by buff-colored and pink sandstones similar to those mentioned in the section just given. At the head of Fan Creek a depression in the mountain ridge forms a pass to the headwaters of Gardiner River. The western slopes of this pass are thickly corered with soil and regetation, and no exposures are seen, but to the east the beds are well exposed where the streams from the snow banks of the ridge have washed the surface of the rocks bare of 
soil. The sidllle itself is formed of limestones broken thongh ly andesiteporphyy. 'The fellowing section shows the series of herls exposed from the pass to the summit of the pealk to the nortl:

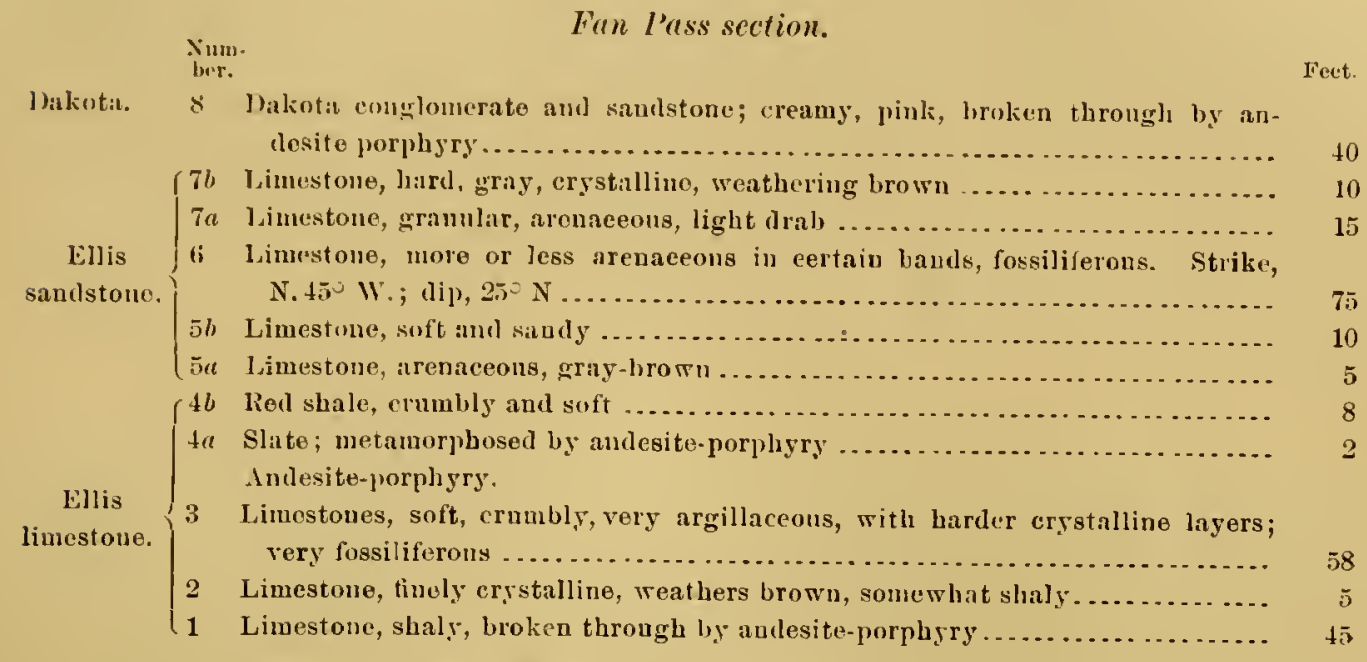

To the east of Fan Pass an extension of the anticlinal uplift noted to the west brings up the red sliales and sandstones from the upper portion of the Teton formation. From the summit of the mountain peak north of Fan Pass the ledge extends in a northwest direction until it neets the long southwestern spur of Electric Peak. The Dakota conglomerate forms the crest of the ridge as far as the second peak nortl of Fan Pass, and, as already noted, the same rock extends westward, forming the crest of the encircling ridge 'The summit of the second peak north of Fan Pass is formed of andesite-porphyry. This rests upon Dakota conglomerate and is overlain by cherty limestone, which is apparently part of the Dakota limestones, but is of different habit and carries light greenish-yellow chert. Between this point and the 10,100-foot peak to the northeast a succession of beds is exposed in which the shales are cut by intrusive slieets of andesite-porphyry. The Dakota limestone, somewhat metamorphosed, but showing the crystalline marks and the little gasteropod shells so characteristic of this horizon, is overlain by very splintery greenish-yellow shale, weathering brown. This in turn is capped by a baked sandstone about 20 feet thick, which is overlain by the upper quartzite belt of the Dakota series, the bed being here 30 feet thick. The carbonaceous shales of the Benton formation form the ridge from this point eastward to the slopes of MION XXXII, P'I II -4 
Electric Peak. The shales are cut by numerons intrusive sheets of andesite-porphyry and by a few dikes, one of which cuts the 10,100foot peak already noted. In the sandstone bed intercalated in the lower part of the Benton shales the little oyster, Ostren anomioides, occurs abundantly. The beds here have a dip of $10^{\circ} \mathrm{N}$., the strike being $\mathrm{N}$. $75^{\circ} \mathrm{F}$. The andesitic sheets noted on this ridge are continuons for long distances, their ledges being traceable along the slopes on either side of the ridge. In general, the andesitic sheets, being less easily eroded than the soft black shales, form the high points and mountainous summits of the ridge, while the saddles are cut in the softer rocks.

\section{ELECTRIC PEAK.}

Electric Peak is the highest and most imposing summit of the Gallatin Range. Its apex rises boldly above the adjacent mountains, and the long ridges which form its foundations dominate the country for many miles. The mountain is composed of sedimentary rocks of Cretaceons age, broken throngh and in part largely altered by igneons rocks. The sedimentary rocks only will be treated here, as these igneous rocks and their occurrence are of such interest that a special chapter is devoted to them.

The sedimentary rocks composing the mountain embrace the most recent strata of the sedimentary series to be found in the Gallatin Range, including a thickness of 4,300 feet of Cretaceous beds, whose uppermost portion is coal-bearing and belongs to the Laramie. Complete sections may be studied at two localities. One is the sontheastern spur of the peak, where the beds are sharply upturned against the Gallatin fault; the other is the long northern ridge of the peak which terminates in that mass of upturned and exposed strata known as Cinnabar Mountain. Althongh the latter locality lies just outside the limits of the Park, the section there exposed is typical for the region, and, combined with the sections already given of the Teton, Ellis, and Dakota formations, it forms a complete section of the Mesozoic strata of the range.

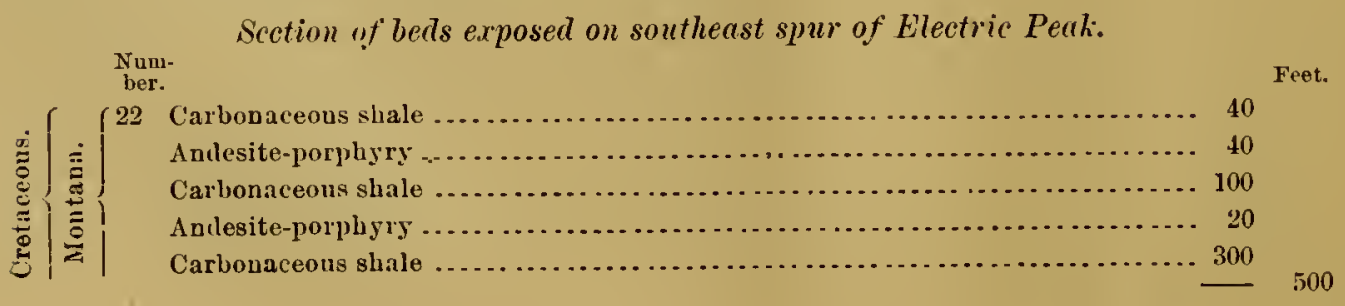


9 



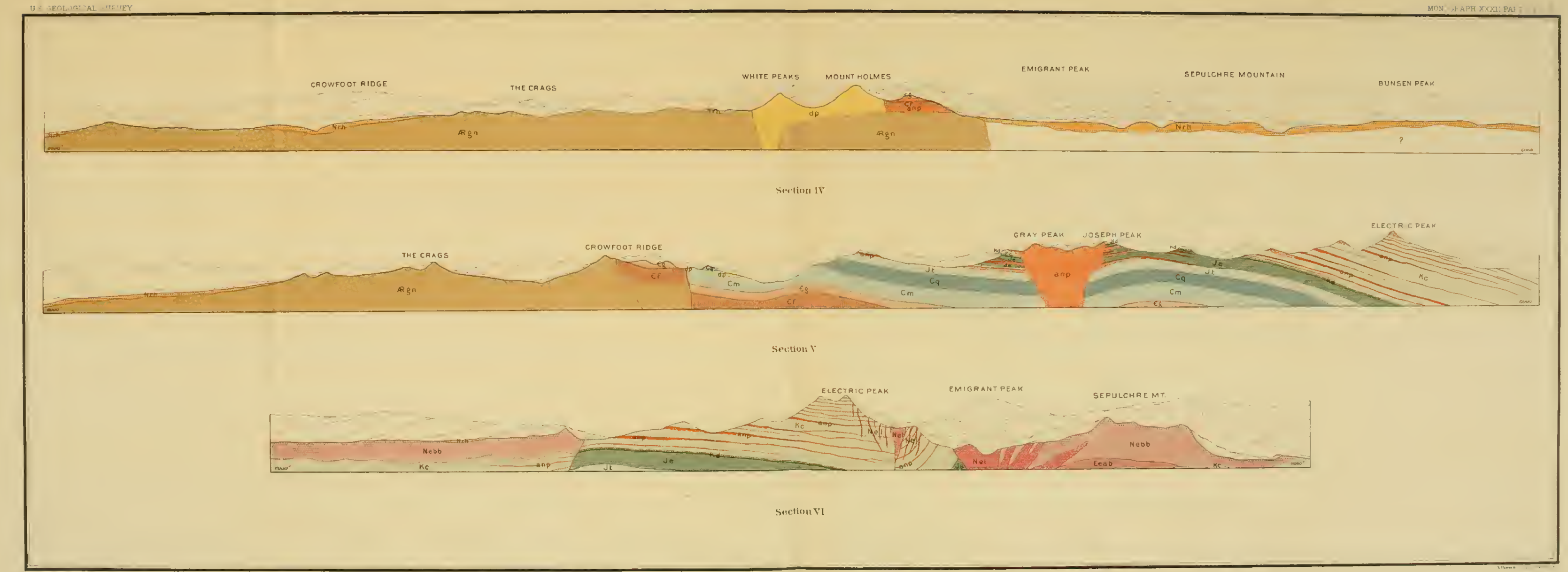

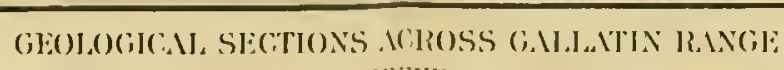

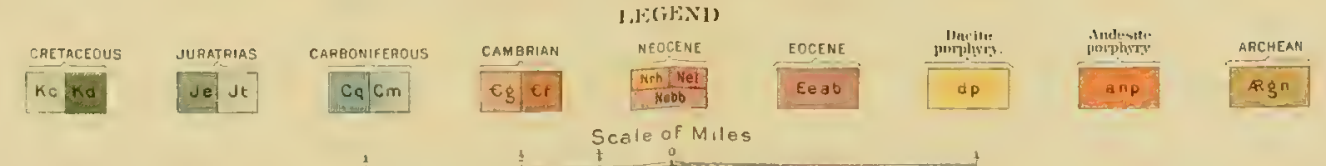



Scetion of beds exposed on southeast spur of Electric l'eak-Continued.

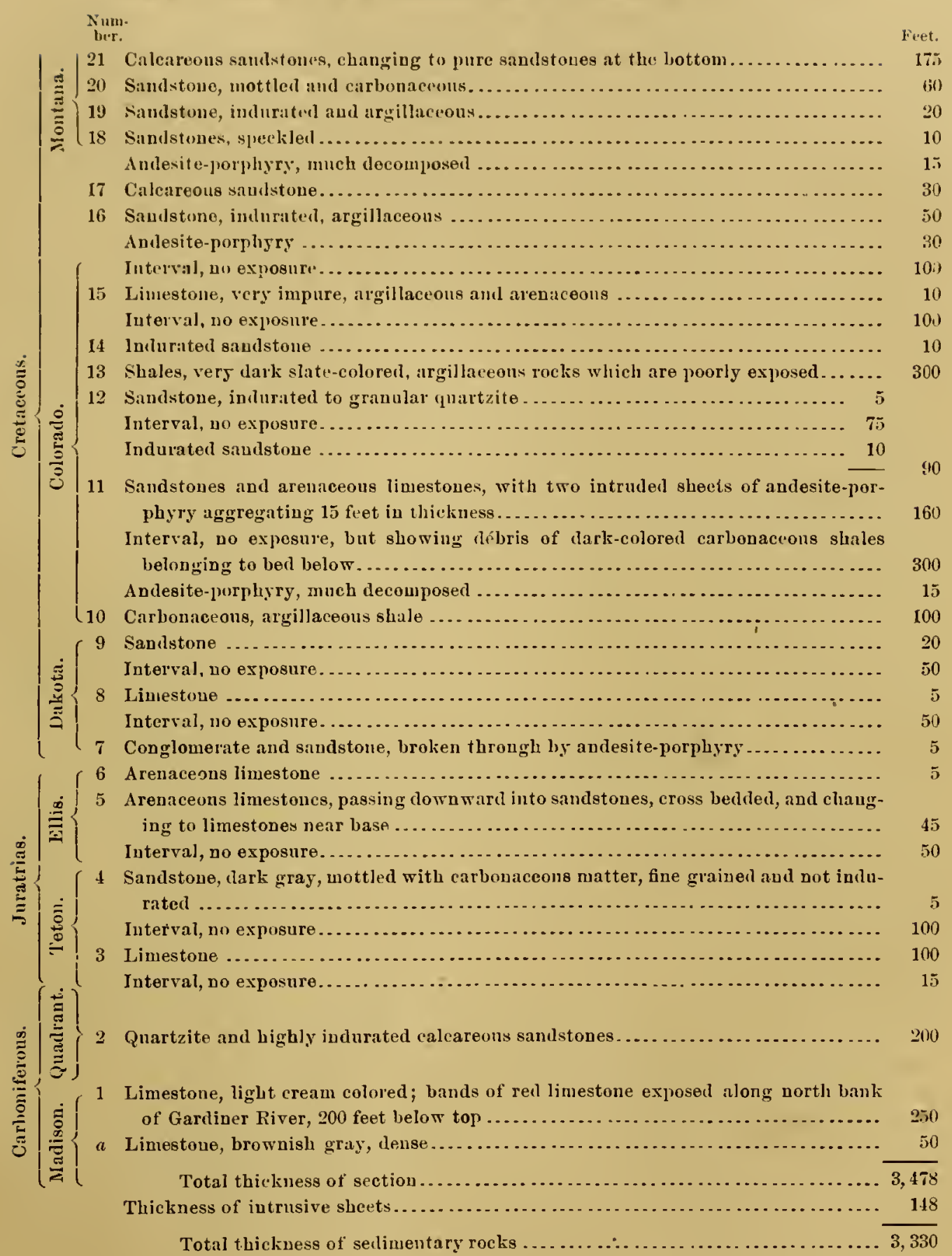


'The andesite-porphyries of this section occur as sheets intruded along the planes of bedding of the sedimentary rocks. With one exception intrusion is regular and does not break across the bedding planes of the shale. The dip and strike of the beds vary in passing' upward from Gardiner River to the summit of the peak. In many cases this cliange of dip is apparent in the exposure, but in most cases the outcrop is not sufficiently extensive to make the flexure apparent.

The long southwestern spur of Electric Peak, which has already been noted, shows sheet after sheet of andesite-porphyry cutting across the crest of the ridge and intruded in the dark shales of the Colorado formation, the beds dipping NE. about $10^{\circ}$. Three different bodies of andesiteporphyry have broken through one another in the high point southwest of the peak. One of these intrusions may be traced eastward along the southern slope of the mountain for some distance. The westem slope of the monntain shows the sedimentary and igneous layers in strong relief, and they may be distinguished at a distance. The inclination of these ledges is about $10^{\circ} \mathrm{N}$., corresponding to the greater dip, which is to the northeast. The sheets of igneous rock are seen to follow the bedding planes of the strata for considerable distance. Only one sheet was seen breaking up across the strata and proceeding along the higher horizon. The direction of this uprising is from south toward the north, and this occurrence, together with observations made on the eastern side of the mountain, showing a similar rise from the west to the east and a thinning out of the sheets in the same direction, indicates that these intrusive masses were injected from the southwest-that is, probably from the center occupied by the Gray Peak bysmalith. The intrusive sheets vary tiom a few feet to a hundred or more feet in thickness. The rocks differ slightly in petrographical character and.will be described more fully in Chapter II. The peak itself is formed of the soft shales and thinly bedded sandstones belonging to the Colorado and Montana formations. These rocks are penetrated by a number of intrusive dikes of andesite-porphyry, and the sedimentary series is much altered by the great intrusion of igneous rock forming the volcanic core east of the peak. On the summit of the peak the normal sandstones and shales are altered to slates and quartzites, the rocks being much shattered by joints and breaking readily into short, angular débris. The beds dip N. $10^{\circ}$ to $20^{\circ}$. 
The intrusive sheets extend, in diminishing numbers, northward in the north ridge of Electric l'eak. 'They resemble the sheets intruded in the Jumassic slates of Cimmabar. IIountain, though it is possible that the latter intrusive rocks were derived from other sourees nore directly comnected with the synelinal folding and faulting of Cimalbar Mountain.

The north ridge of Electric Peak terminates in the low knob called Cinnabar Momtain. This elevation is formed of upturned sedimentary beds, presenting a most excellent and complete section of the stratigraphic series from the Paleozoic to the summit of the Laramie, a section which is here given, as it is typieal for the Gallatin region. ${ }^{1}$

Section of the Mesozoic sedimcntary rocks exposed in Cinnabar Mountain and Electric Peak.

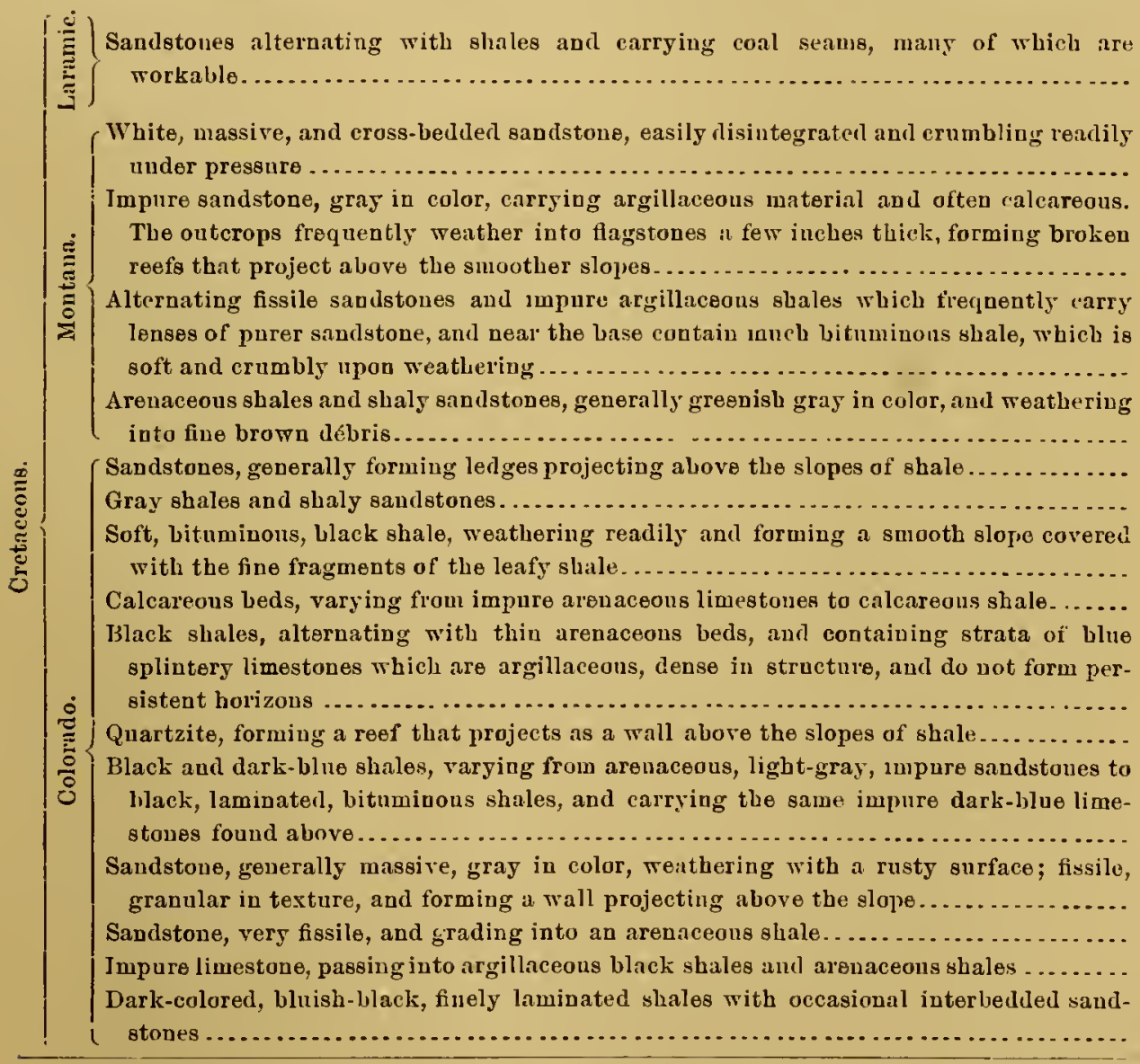

'See Cinnabar and Bozeman coal fields, by W. H. Weed: Bull. Geol. Suc. Am., Vol. 11, 1891, p. 359. 
Section of the .Mesozoic selimentary rocks exposed in Cinnabar .Yountain, etc.-Cont'd.

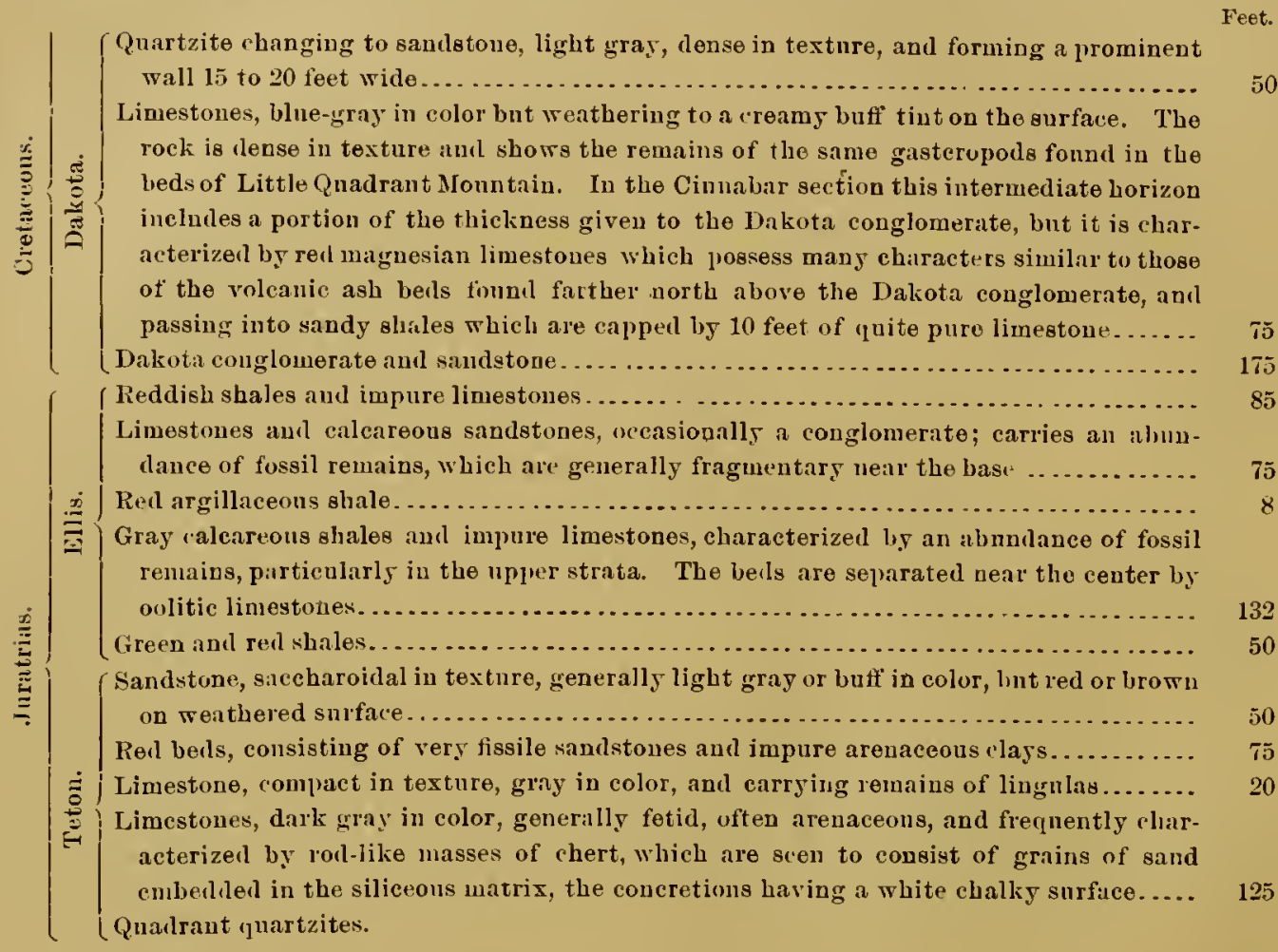

The western face of Electric Peak shows a number of sheets of igneous rock, varying from 5 to 50 feet in thickness; but no dikes, either vertical or inclined, were observed on this side of the mountain. The western summit consists of a sheet of andesite-porphyry several hundred feet thick. In the eastern spurs of the mountain numerous vertical and inclined dikes cut the upturned beds. Those on the southeastem spur trend to the southwest and northeast. They also traverse the eastern summit of Electric Peak. The southeastern spur of the mountain shows steeply upturned sedimentary beds, which at the base are overthrown and reversed. This spur probably consists of a synclinal fold which was accompanied by faulting, the eastern limb, forming the lower portion of the spur, having a nearly vertical position. The axis of the syncline lias a trend to the sonthwest and northeast. The overthrown beds at the southem extremity of this spur show Madison limestones, Quadrant quartzites, and the regular sequence of overlying Mesozoic strata. The beds strike north, and they dip from $50^{\circ}$ to $70^{\circ} \mathrm{E}$. The Gardiner River cuts across the 
end of this spur, the rocks being exposed in a small hill on the southwestern side of the streann, the channel having probably been deflecterl at this place by the alceumulation of glacial drift filling the old valley between Sepuldure Momtain and Little Quadrant. A detailed section of the beds exposed on the erest of this ridge has been given. The strike of the bets valries somewhat in ascending the spm, and the dip also chamges. The Dakota leelge, which crosses the ridge about 500 feet above the river, has a strike of $\mathrm{N} .32^{\circ} \mathrm{E}$., showing a considerable change in direction between the exposures here and those in the river bed. The axis of this synclinal fold and the fanlt plane are found high up on this sontheastern spur, where the Colorado slates have a vertical dip. The exact position of the fault plane can not be determined, and the extent of displacement is not known. That the intrusive sheets of igneous rock antedated the folding is clearly shown in the crushing and slight dynamic metamorphism observed here. Slickensides are found within the porphyry, and dragging planes are observable between the hard ernptive rock and the soft shales. A cone-in-cone structure of the latter rocks is also observed. On the other hand, the dikes of igneons rock which cut this spur of the mountain show no sign of disturbance attributable to the synclinal folding. They intersect sedimentary beds, and also the intercalated sheets of porphyry, at various angles. Where the shales and intrusive sheets are on edge, the dikes are often parallel to them and are easily confused with the intrusive sheets, which they closely resemble in petrographical character. These dikes are connected with a large body of igneous rock, mostly a diorite, which occupies a position on the line of fanlting and is situated in the deep gulch cut in the eastern summit of Electric Peak. The sedimentary beds in the neighborhood of this mass of igneous rock are extensively metamorphosed.

At the eastern base of Electric Peak a profound fault separates the mountain mass from the complex body of volcanic tuff-breccias and massive igneous rocks to the east. This fault is the northern continuation of the Gallatin fault, which has given rise to the abrupt escarpment faces on the east side of the Gallatin Range.

On account of the special importance of the relations existing between the igneous rocks of Electric Peak and those forming Sepulchre Mountain to the east of the fanlt, a detailed description of the geology of this locality is given in Chapter III, in which the petrology also will be fully discussed. 


\section{WESTERN FLANKS OF THE GALLATIN RANGE.}

In the northwestern portion of the Gallatin Range, within the Yellowstone Park, the western slopes of the mountains are abruptly terminated by a fault, bringing up the sedimentary beds against subaerial volcanic breccias that probably represent a remmant of the old Electric Peak and Sepulchre Mountain volcanic cone. The fanlt, where it crosses Fan Creek and along its course down Cimuabar Creek, shows a profound displacement. Its sonthem continuation has already been noted west of Gray Peak, but it hecomes of slight importance in the vicinity of Grayling Creek, west of the end of Crowfoot Ridge. The andesitic breccias which form the high mountain ridges west of this fault are continuous with the high range of the Gallatin which stretches northwar along the western side of the Yellowstone River to the vicinity of Bozeman. Within the park region the muderlying upturned and irregnlarly eroded sedimentary beds are not exposed. The position and dip of the strata forming the high ridge on the eastern side of the Gallatin River, just within the northwesteru corner of the park, show a monoclinal structure which would bring the Montana shales and sandstones beneath the andesite breccias and against the Fan Creek fault. It is clear that the horizon west of the fault was considerably higher than that to the east, for the latter is near the base of the Colorado shales and contains laccolithic sheets, which must have been intruded at considerable depths beneath the surface of the country, and were contemporaneous with those intruded in the upper part of the Colorado formation of Electric Peak, which is but 3 miles distant. Another fact that is apparent is that the sedimentary strata were upturned and eroded down to the Carboniferous saudstone, 7 miles to the west, before the rolcanic breccias were thrown out over the country.

The only other andesitic tuff-breccia in this vicinity occurs in isolated patches resting directly upon crystalline schists in the neighborhood of The Crags, 5 and 10 miles south of the breccia west of Gray Peak, and from 13 to 17 miles distant from the Electric Peak center of the eruption.

From these facts it would appear that the surface of the comntry at the time when the andesitic tuff-breccias were deposited consisted of crystalline schists in the south, of Carboniferous strata in the west, and of Cretaceons strata in the northeast. This indicates the uplifting of the 


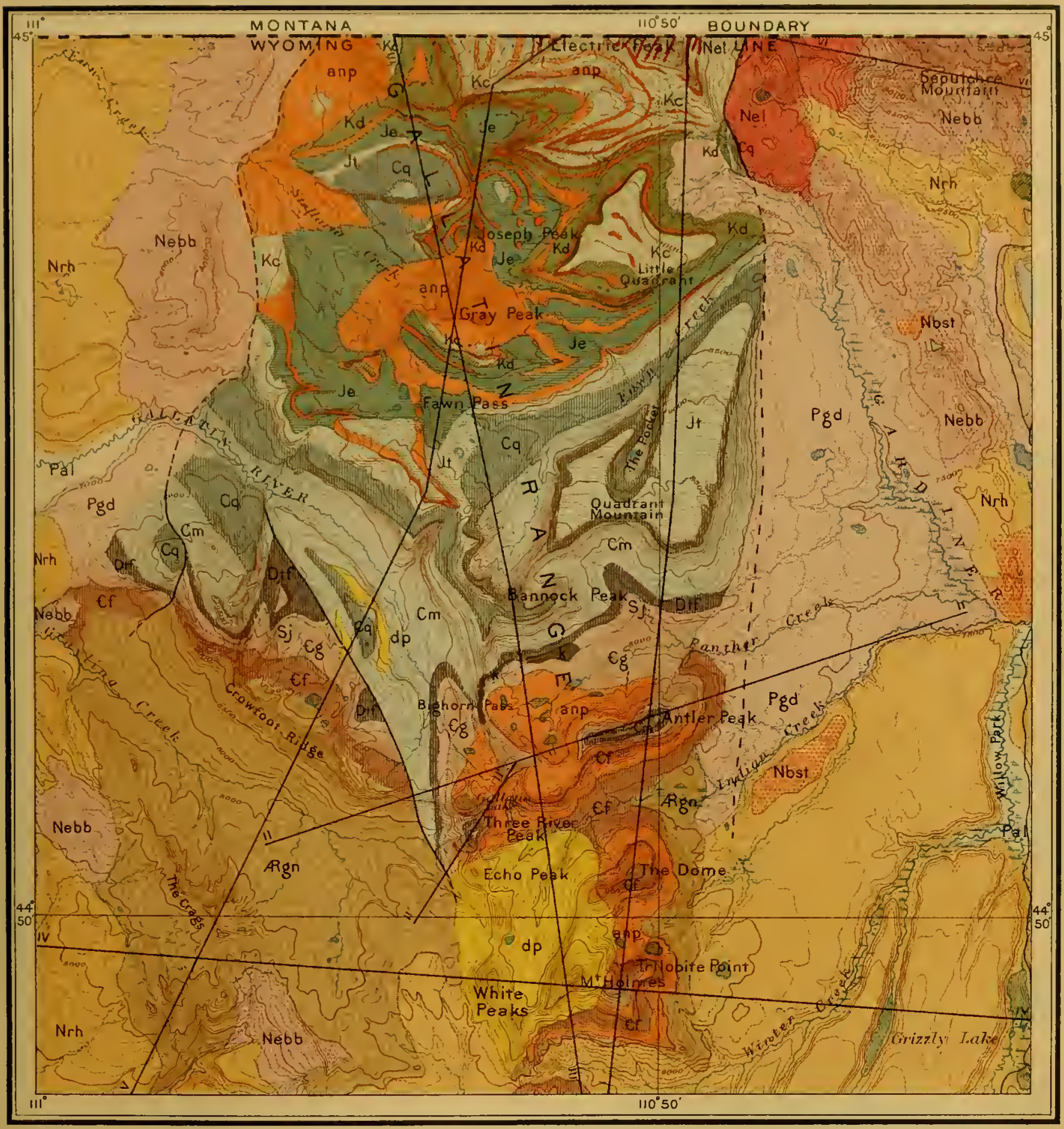

GEOLOGICAL MAP

$\mathrm{OF}$

GALLATIN RANGE, YELLOWSTONE NATIONAL PARI.

\section{LEGEND}
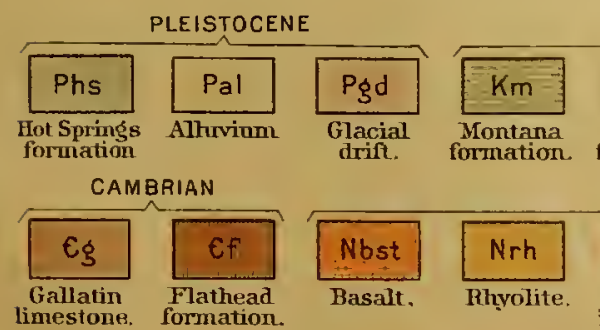

CRETACEOUS

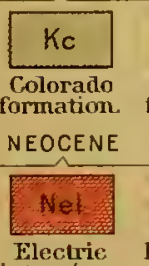

intrusives.

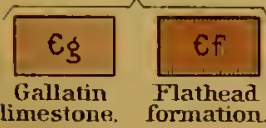

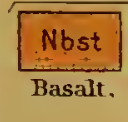
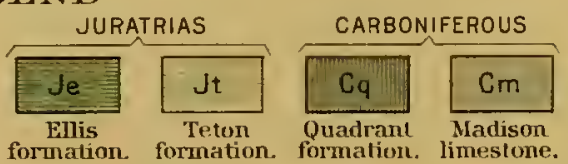

DEVONIAN SILURIAN

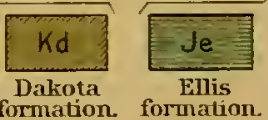

EOCENE
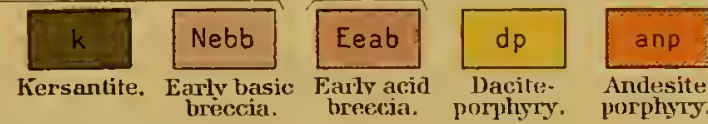

porphyry.

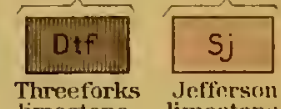

limestone. limestont.

ARCHEAN

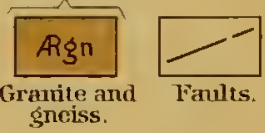
Scale 125000 

sedimentary strata and their tilting northward, followed by extensive erosion at the south prior to the extravasation of the andesitic breccia.

We have alrearly pointed out the connection between the intrusion of the Holmes bysmalitl and the fault traversing the eastern end of Crowfoot Ridge, noting their probable contemporaneity. The intrusion of the Ilohnes mass must have been followed by extensive erosion before the crystalline schists were exposed at the level they now occupy relative to the Holmes mass, after which erosion the andesitic breccias were thrown upon them. This separates the eruption of the Holmes bysmalith and that of the andesitic breccias by a very considerable length of time. No definite time relation has been male ont, however, between the two great intrusive bodies at the southern end of the Gallatin Range-Indian Creek laccolith and Holmes bysmalith - and the more complex intrusion of Gray Peak and the associated sheets of andesite-porphyry in the northern part of the range. Though separated by only a small distance, there is no structural feature which connects their intrusions in point of time, except the general fact that they are all much older than the eruptions that centered at Electric Peak.

\section{EASTERN FLANK OF TIIE MADISON RANGE.}

In the extreme northwestern corner of the Yellowstone Park there is a small area of mountainous country that is part of the eastern flank of the Madison Range. This area lies wholly within the Montana portion of the reservation. The Gallatin River has cut a narrow valley across this tract, exposing folded strata, in which the same sedimentary series seen in the Gallatin Range is developed, the lowest rocks belonging to the Cambrian and the highest being of Colorado Cretaceons age. These strata are flexed about a laccolitin of andesite-porphyry.

This mountain area is terminated on the south by the northern end of the rhyolite platean, whose lavas cover the southeastern flanks of the ligh mountain east of the Gallatin River and also occur in small isolated patches upon the mountain slopes to the north and west.

Topographically this little tract consists of parts of four distinct mountain masses. The largest lies east of the Gallatin and is embraced between that river and Fan Creek. This block and that north of it, and the flat topped mountain west of the Gallatin River, are all parts of the laceolithic uplift, which has been cut through by the river. The east bank 
of the Gallatin shows an excellent exposure of the contact between the andesite-porphyry and the Cambrian shales, the latter being altered by contact metamorphism for a few feet from the andesite-porphyry. The Caubrian shales are overlain by limestones in which there are intruded several sheets of andesite-porphyry, and are capped by cliffs of a heavily bedded white limestone of the Madison formation, with basic intrusions, near the summit of the mountain. The following partial section shows the series found immediately above the laceolith:

Scetion ertst of Gallatin River, beion Fun Creek.

Feet.

Mladison. Limeston's earying curals, thickly hedded, of a deuse texture, drab or dark-gray colored, and holding black rhert.

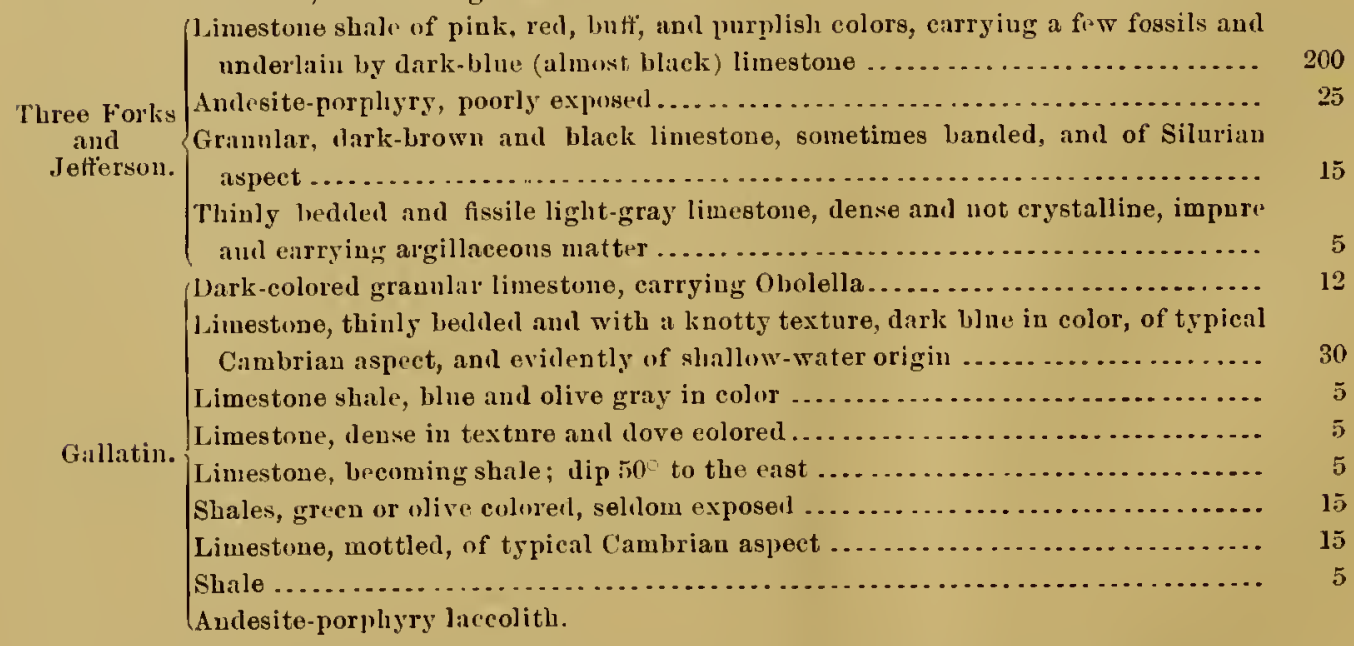

West of the Gallatin River the mountain slopes show andesite-porphyry extending up nearly to the summit of the flat-topped momitain, but the stratified rocks are seen both to the north and to the south, forming great curved plates, with dip away from the intrusion in every direction. A stream from the west has cut its valley in the dome, exposing the sedimentary rocks on the valley walls.

The mountain opposite the mouth of Fan Creek is composed entirely of Paleozoic strata, which are not affected by the laccolithic uplift, but dip to the east and northeast, away from the axis of the Madison Range. The lower slopes show Cambrian beds, which are overlain by the Silurian rocks, of which the most prominent strata are quartzitic in nature and form heary, massive beds that cap the summit of the mountain and extend east- 
ward down to the valley of the Gallatin kiver, the dip being about $20^{\circ}$. 'Tle summit of the mountain is Hat, and shows Carboniferons limestones dipping northeast at gentle angles. This mountain and the one north of it both show the characteristic flat-topped topography noticed in the lesser manginal peaks of the Madison Ramge.

'The andesite-porphryry of the laccolith is quite like those rocks in the Gallatin already deseribed, and its petrographic description is given in another chapter. A claracteristic feature of the exposures seen of this rock is the occurence of numerous included fragments of gneiss, schist, and lormblende-porphyry. The two patches of rliyolite which occur upon the slopes rest directly upon this andesite-porphyry, showing a thorough dissection of the laccolithic fold before the outpouring of the rhyolite flows. 


\section{H A P T E R I I. \\ THE INTRUSIVE ROCKS OF THE GALLATIN MOUNTAINS, BUNSEN PEAK, AND MOUNT EVERTS.}

By Josepil Paxion Iddings.

Having described the occurrence of the igneous rocks that lave been intruded within the sedimentary beds of the Gallatin Mountains, or have been thrown over their surface, so far ats their occurrence is related to the listory of the dynamic events that brought about the present structure and topography of the range, we may now describe their petrographical characters in relation to the mode of their occurrence, with special reference to the size of the various bodies of rock and their geological position.

From what has already been shown as to the relative age of the different intrusions, it will be proper to consider them in the following order: Indian Creek laccolith; Holmes bysmalith and comected ontliers; Bighorn Pass sheet; Gray Mountain intrusive and connected sheets; Electric Peak stock and dikes, together with the extrusive breccins and intrusive dikes of Sepulchre Mountain; and the breccias west and sonth of the Gallatin Range. In this connection may also be described the Bunsen Peak intrusive and the intrusive sheets in Mount Everts.

INDIAN CREEK IACCOLITH.

HORNBLENDE-MICA-ANDESITE-PORPHYRY.

The rock constituting this laccolith and its two sheet-like apophyses to the sonth is an intrusive mass, quite uniform in mineral composition throughout its whole extent. It exlibits a limited variability in texture and habit, ranging from those of a compact aphanitic or lithoidal lava to those of a minutely crystalline porphyry-like rock. Its predominant mineral constituents are lime-soda feldspar, hornblende, and biotite, with a small amount of magnetite and, in the coarser-grained forms, quartz. For this reason it may be called an andesite-porphyry with andesite facies. Its 
(chenical composition is given below. The portion of the rock analyzed wats the unaltered coarser-graned form $(55)^{1}$ occurring in the midhle of the laceolith on the north sicle of Indian Creek.

Analysis of hornblende-mica andesite-purphlyry.

\begin{tabular}{|c|c|}
\hline C'oustitue'ut. & Percent. \\
\hline 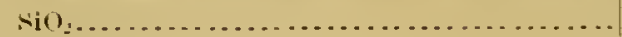 & 61.50 \\
\hline 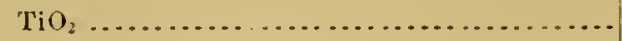 & Nonte. \\
\hline $\mathrm{Al}_{2} \mathrm{O}_{3} \ldots \ldots \ldots \ldots \ldots \ldots \ldots \ldots \ldots \ldots \ldots$ & 17.42 \\
\hline $\mathrm{Fe}_{2} \mathrm{O}_{3} \ldots \ldots \ldots \ldots \ldots \ldots \ldots \ldots \ldots \ldots$ & 4.66 \\
\hline 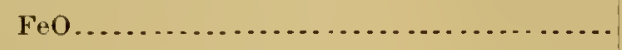 & 1.09 \\
\hline 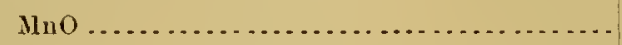 & 'Tract. \\
\hline $\operatorname{MgO} \ldots \ldots . . . . . .$. & 1.26 \\
\hline $\mathrm{CaO} \ldots . . . . .$. & 5. 33 \\
\hline 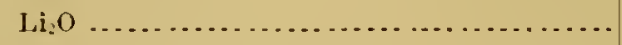 & .03 \\
\hline 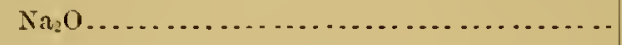 & 3.99 \\
\hline 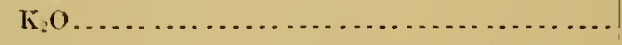 & 1.29 \\
\hline 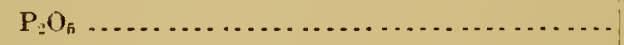 & .60 \\
\hline $\mathrm{SO}_{3} \ldots \ldots \ldots \ldots \ldots \ldots \ldots$ & .35 \\
\hline $\mathrm{H}_{2} \mathrm{O} \ldots \ldots \ldots \ldots \ldots \ldots \ldots \ldots \ldots \ldots \ldots \ldots \ldots \ldots$ & 2.44 \\
\hline Total $\ldots \ldots \ldots \ldots \ldots \ldots$ & 99.96 \\
\hline
\end{tabular}

The main body of the laccolith, where it is about 1,000 feet thick, is a light-gray rock crowded with small crystals of feldspar, mica, and hornblende, with a subordinate amount of groundmass, whose component grains are not discemible with the naked eye. The phenocrysts are 1 or $2 \mathrm{~mm}$. in diameter and smaller; occasional ones reach $3 \mathrm{~mm}$., The rock is ristinctly massive, cracking with irregular joints into angular or somewhat tabular fragnents, and exlubiting colummar jointing in only one locality, on the southeast slope of 'The Dome. Under the microscope the most crystalline portion of the laccolith (57), which proved to be the eastern-central part of the mass on the sonth side of Indian Creek, is seen to consist of the plienocrysts already named, cemented together by a holocrystalline aggregation of quartz and feldspar with scattered grains of biotite, homblende, and magnetite (Pl. XI, fig. 1). The areas of quartz inclose minute idiomorphic feldspar, in part, if not wholly, lime-soda feldspars, probably oligoclase. The quartz is allotriomorphic and has a micropoikilitic structure, the grains

1 Numerals in brackets usel in connection with the petrography in this monograph refer to the specimen numbers iu the Yellowstoue Park collection. 
ranging from 0.08 to $0.2 \mathrm{~mm}$. in diameter, the inclosed feldspars being about $0.04 \mathrm{~mm}$. long and $0.008 \mathrm{~mm}$. wide, and upward. Somewhat finer-grained forms were found in the central portions of the mass north of Indian Creek. In these there is a more marked difference between the gromndmass and phenocrysts. When seen under the microseope, the microstructure of the grounduass is more evenly granular, the grains averaging abont $0.04 \mathrm{~mm}$. in diameter in one case (56), and about $0.024 \mathrm{~mm}$. in another (55). This degree of erystallization corresponds to grade 20 of the table for the rocks of Electric Peak (Table XVII), for the first case, and to grades 11 and 9 of the same table for the last two respectively. The last is shown in Pl. XI, fig. 2.

The phenocrysts are not slarply outlined, and have numerous inclusions of irregular grains or streaks of quartz and feldspar. The feldspar phenocrysts are all lime-soda feldspar, in part labradorite, in part andesine. They are frequently shattered, with irregular cracks, and are penetrated by irregnlar streaks of quartz and feldspar, which are sometimes gramular. In places it looks as thongh the groundmass of the rock had penetrated cracks in the feldspars before it solidified. The feldspar individuals in one rock section are not all equally fissured, and not always in the same direction, so that the cracking appears to antedate the solidification of the rock. The biotites exhibit ver'y slight dislocation or bending in some cases, which may be referred to the same period. The biotite is dark brown, with moderate absorption and occasional twimning. 'The ontlines, often idiomorphic, are sometimes rery irregular, there being marginal inclosures of quartz and feldspar, and sometimes of magnetite, but not often. The homblende is green, with moderate pleochroism from strong green to light brown. The ontlines are quite irregular, and inclusions of the other minerals are frequent. There is sometimes a chloritic mineral present in small psendomorplss, which may possibly be altered pyroxene. In some instances it is decomposed hornblende. Magnetite is present in microscopic crystals, often idiomorphic; and apatite forms colorless microscopic crystals. Both homblende and biotite take part in the composition of the groundmass in the more crystalline varieties.

Somewhat finer-grmined microcrystalline structures are found in the rock, where it forms the thimmer sheets, 100 to 150 feet thick, beneath Trilobite Point $(72,73)$. Here the structure is confused, being partly micropoikilitic, partly microgranular. In the still finer-grained modifications the 


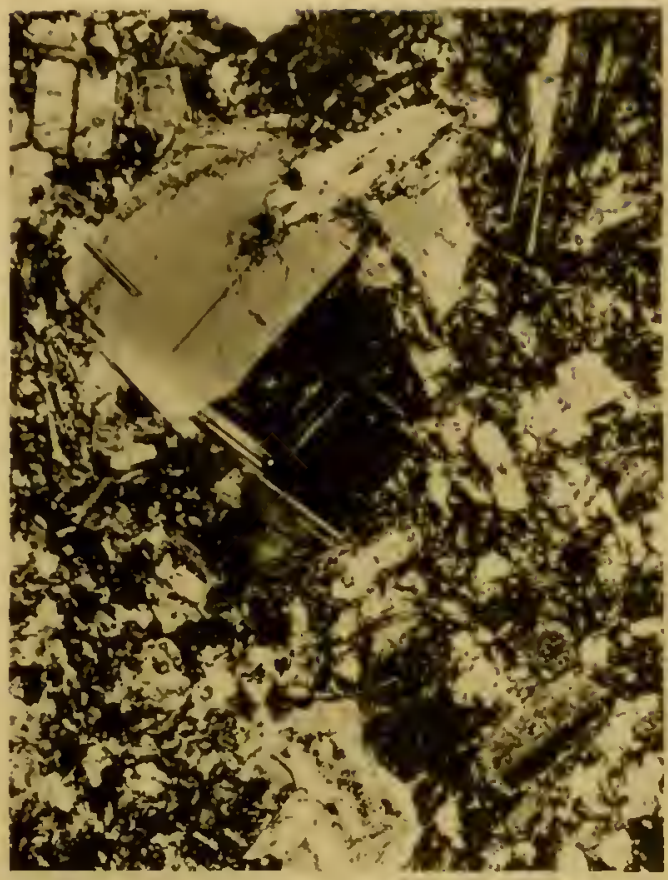

(A) $\times 29$

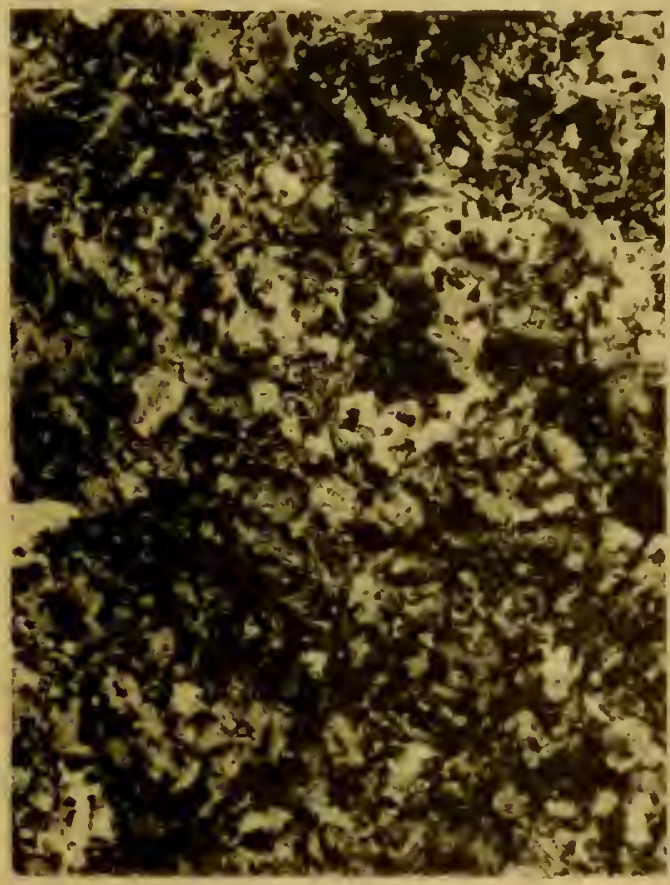

(C) $\times 28$

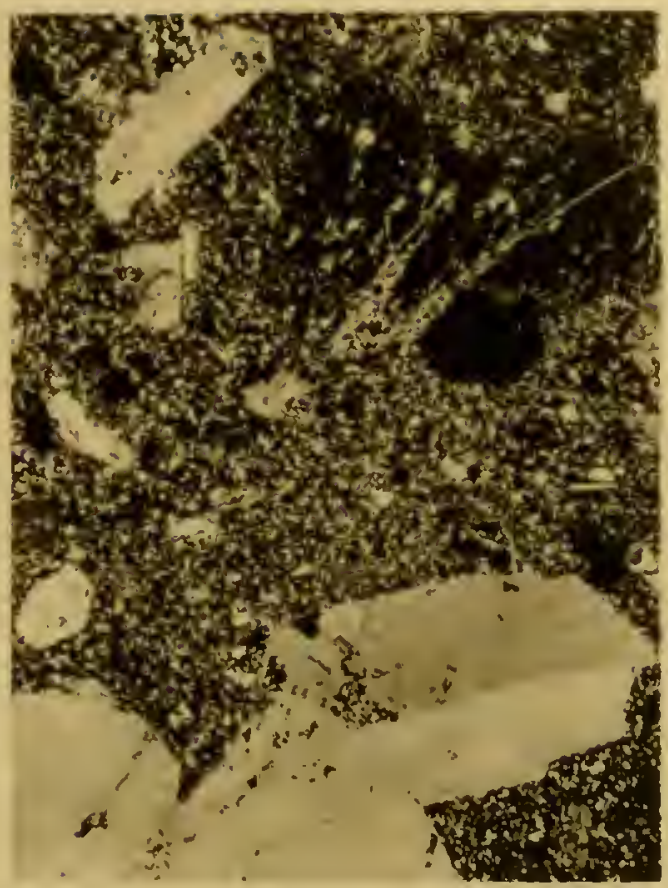

(B) $\times 3$

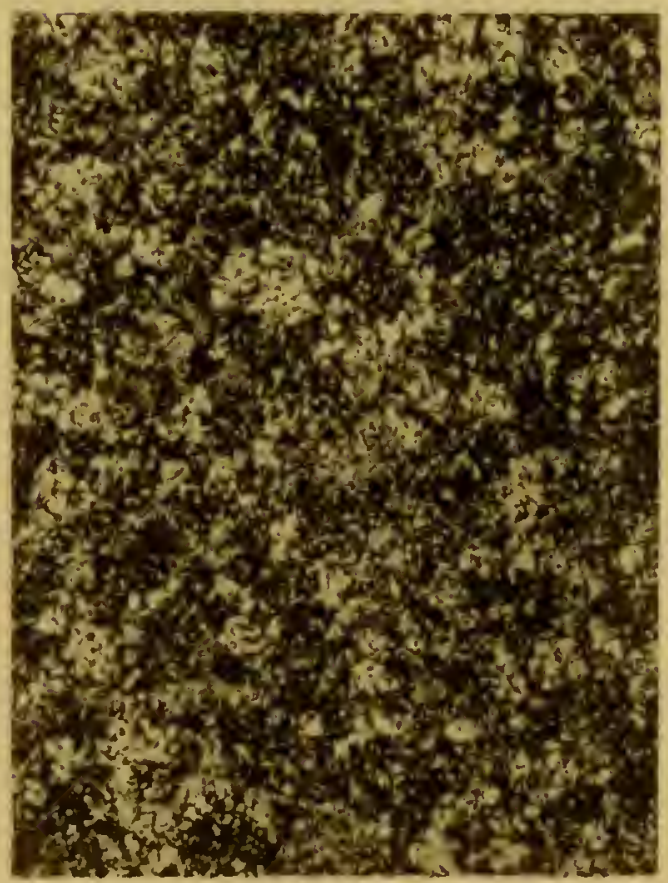

(D) $\times 45$ 

micropoikilitic quart\% patches grow less and less noticeable, and the feldspar microlites become mone pronomed, the microstucture being more like the characteristic felt-like or pilotaxitic structure of andesites. 'T'his transition oecols as the rock approarches the contact with inclosing rocks, and where the body thins ont. It alc(omplinies a darkening of the rock and an increasingly andesitic habit. 'The rock 20 feet from the bottom contact near the aast edge of the lacoolith north of Indian Creek is bluish gray, witl prominent feldspins that are decomposed (60). The homblendes are altered to chlorite and ralcite. Biotite is still fresh. The groundmass is holocrystalline and pilotaxitic. Near the bottom contact of the middle portion of the main laccolith body the rock grows darker and denser. At 6 feet from the contact it is darker gray than the main mass. The microstructure of the gromndmass is micropoikilitic, with the minute feldspars maintaining a fluidal arrangement (61). The rock 1 foot from contact is darker colored; its structure is still micropoikilitic, with more minute feldspars (62), while the rock directly in contact with the limestone is still darker and the microstrncture still finer grained and micropoikilitic (63). There is considerable calcite scattered in irregular microscopic aggregates througl the groundmass. The hornblendes are decomposed, and there is some secondary quartz. The micropoikilitic structure, lowerer, is not secondary, as seems to be the case in some porpliyries, ${ }^{1}$ since it varies in size of grain accorling to the distance from the contact plane, and is quite the same as that observed in perfectly fresh andesite-porphyries in other places. Similar modifications occur near the contact of the andesite-porphyry with the inclosed belt of linestone in the central part of the laccolith north of Indian Creek (66). The feldspar and biotite phenocrysts are fresh, while the hornblende is entirely decomposed.

Where the andesite-porpliyry is exposed in contact with the overlying limestone at the northwest base of Three River Peak, the same transition from coarser-grained to finer-grained gromulnass is observed $(68,69,70$, 71). The rock nearest the contact is very dark colored, dense, and distinctly porphyritic, and nnder the microscope is found to have the microstructure of a holocrystalline andesite-that is, the groundmass consists of microlites of feldspar and pyroxene, with scattered grains of magnetite, and

Williams, G. H., on the use of the terms poikilitic and micropoikilitic in petrography: Jour. Geol., Vol. I, No. 2, 1893, p. 179. Bascou, F., The structures, origin, and uouenclature of the acid volcanic rocks of South Hountain: Jour. Geol., Vol. I, No.8, 1893, p. 814. 
las an ill-defined micropoikilitic structure. Anong the phenocrysts are a few irregular individuals of quartz.

The closest approach to typical andesitic microstructure occurs in the dike cutting shales in the ridge south of Winter Creek, already described (p. 10). The transition from a groundmass of brown microcryptocrystalline matrix with distinct lath-shaped feldspar microlites and magnetite grains to one that is gray in thin section with larger feldspar laths and a slightly micropoikilitic structure can be observed in one rock section $1 \frac{1}{4}$ inches long (76). The finest-grain is at the contact with the inclosing rock. The dike is 3 feet wide and the central portion is slightly more crystalline. There is a pronounced fluidal arrangement of the feldspar microlites, more or less parallel to the sides of the dike. The homblende and biotite are both altered to chlorite, which also fills the centers of the feldspar phenocrysts, leaving a clear marginal zone. Magnietite occurs in phenocrysts and in minute crystals in the groundmass. Whatever ferromaghesian minerals may have been constituents in the groundmass have been chloritized, and there is no evidence that they were present in any considerable amount. In the rock from the horizontal sheet in this ridge of limestone the groundmass, which is coarser grained, contains abundant microlites of mica and altered homblendes, with minute magnetites. These minerals are also abundant as phenocrysts. Apatites and long, thin, doubly terminated crystals of zircon occur. Except for this slightly more ferromagnesian modification of the rock (74), the mineralogical composition of the laccolith is very uniform throughout the whole of its exposure, which covers a distance of 7 miles.

Segregations occur in places. They consist of comparatively coarsegrained crystallizations of green hornblende, with brownish tones, marked pleochroism, and orthopinacoidal twinning, besides lime-soda feldspar, in part labradorite, with magnetite, some biotite, and a little quartz and grains of calcite; the whole having a hypidiomorphic granular structure.

\section{MOUNT HOLMES BYSMLAITH.}

DACITE-PORPHYRY.

The rock constituting this great body, which embraces the mass of five mountain peaks, and is 3 miles long and 2 miles wide, is very unifor'm in general appearance through the whole extent of the borly. It is grayish white, with few small phenocrysts of feldspar and biotite, and has a fine- 
grained to aphanitic texture. It is not markedly porphyritic. The variations in texture occur near the margin of the body, where they bear a definite relation to the contact plane. They are accompanied by a slight change in the chemical composition. The uniformity in the character of the mass indicates that the whole body was one magma, erupted at one time. Its mineral composition is seen with the microscope to be quartz and alkali feldspar with biotite, corresponding to that of biotite-granite. Its chemical composition is shown by the following analyses, one of which represents the main mass of the rock; the other, which is more siliceous, is of rock from near the margin of the bysmalith, at Echo Peak.

Analyses of dacite-porphyry and rhyolite-felsite.

\begin{tabular}{|c|c|c|}
\hline Constituent. & $\begin{array}{l}\text { (7i) } \\
\text { Mount } \\
\text { Holmes. }\end{array}$ & $\begin{array}{c}(87) \\
\text { Eeho Peak. }\end{array}$ \\
\hline $\mathrm{SiO}_{2} \ldots \ldots \ldots \ldots \ldots \ldots \ldots \ldots \ldots \ldots$ & 69.54 & 74.51 \\
\hline $\mathrm{TiO}_{2} \ldots \ldots \ldots \ldots \ldots \ldots \ldots \ldots \ldots$ & None. & None. \\
\hline $\mathrm{Al}_{2} \mathrm{O}_{3} \ldots \ldots \ldots \ldots \ldots \ldots \ldots$ & 17.95 & 14.83 \\
\hline $\mathrm{F}_{2} \mathrm{O}_{3} \ldots \ldots \ldots \ldots \ldots \ldots \ldots \ldots \ldots \ldots$ & 2.50 & 1.09 \\
\hline $\mathrm{FeO} \ldots \ldots \ldots \ldots \ldots \ldots \ldots \ldots \ldots$ & .22 & Trace. \\
\hline МuO $\ldots \ldots \ldots \ldots \ldots \ldots \ldots \ldots \ldots$ & None. & Trace. \\
\hline $\operatorname{MgO} \ldots \ldots \ldots \ldots \ldots \ldots \ldots \ldots \ldots \ldots \ldots$ & .50 & .47 \\
\hline $\mathrm{CaO} \ldots \ldots \ldots \ldots \ldots \ldots \ldots \ldots \ldots \ldots \ldots$ & 1.80 & .81 \\
\hline $\mathrm{LiO}_{2} \ldots \ldots \ldots \ldots \ldots \ldots \ldots$ & Trace. & .02 \\
\hline $\mathrm{Na}_{2} \mathrm{O} \ldots \ldots \ldots \ldots \ldots \ldots \ldots \ldots \ldots$ & 4.30 & 4.38 \\
\hline $\mathbf{K}_{2} \mathrm{O} \ldots \ldots \ldots \ldots \ldots \ldots \ldots \ldots \ldots$ & 1.21 & 2.72 \\
\hline $\mathrm{P}_{2} \mathrm{O}_{5} \ldots \ldots \ldots \ldots \ldots \ldots \ldots \ldots \ldots \ldots$ & None. & Trace. \\
\hline $\mathrm{SO}_{3} \ldots \ldots \ldots \ldots \ldots \ldots \ldots \ldots \ldots \ldots$ & .37 & .24 \\
\hline $\mathrm{H}_{2} \mathrm{O} \ldots \ldots \ldots \ldots \ldots \ldots \ldots \ldots$ & 1.96 & .92 \\
\hline Total $\ldots \ldots \ldots \ldots \ldots \ldots \ldots$ & 100.35 & 99.99 \\
\hline
\end{tabular}

The chemical composition corresponds to that of a granite high in soda. The main mass has a chemical composition just on the border line between soda-rliyolite and dacite, while the marginal portion has the composition of soda-rhyolite. As already noted, its texture is not markedly porpliyritic, so that it stands between a distinct porphyry and a felsite. It is, consequently, difficult to give it a name that will not be open to criticism. We have called the main mass dacite-porpliyry.

In thin section the rock appears as a gray, very fine-grained mass with abundant minute specks of biotite. Under the microscope it is seen that MON XXXII, PT II- 5 
the microstructure and grain of the rock from the summit and south slope of Mount Hohmes $(77,78)$, and those of the rock from the White Peaks west of the head of Indian Creek $(80,81,82)$, are very uniform, and represent the coarsest-grained forms found. The highest part of the mass as it now exists, the summit of Mount Holmes, is nearly as coarsely crystallized as any part of the body examined.

The coarsest varieties consist of quartz in allotriomorphic individuals, inclosing nearly idiomorphic crystals of feldspar, with fewer of biotite and magnetite. The structure is thus micropoikilitic, or is almost exactly analogons in the relative proportions and sizes of the crystals to microphitic structure in ophitic basalt. The quartz extinguishes light between crossed nicols throughout small areas, in which are scattered more or less rectangular and lath-shaped feldspars. The quartzes are colorless and have few inclosures of liquid with moving bubbles and salt cubes. The feldspars are clourly and partly altered; hence the minerals are easily distinguished. The structure is shown in PI. XI, fig. 3. The feldspars are partly unstriated, in Carlsbad twins, with low extinction angles and low double refraction; these are probably orthoclase; others are partly striated, in polysynthetic twins, with low extinction angles, and are lime-soda feldspars, probably oligoclase. It appears as though the latter predominated. The few phenocrysts are striated lime-soda feldspars. Owing to the low percentage of calcium oxide in the rock, the feldspars must correspond to plagioclase rich in soda. In one instance the feldspar contains inclusions of what appears to be glass, but its exact nature is doubtful. Biotite occurs in six-sided plates and as irregular individuals, with brown color and strong absorption. They often contain minute magnetite grains. The biotite is sometimes in small aggregates with magnetite, which also occur's in scattered crystals. Apatite is present in long slender prisms, but is rare. In some cases it exhibits a distinct blue and brownish-purple pleochroism. Minute zircon prisms are present.

Among the secondary minerals is a little muscovite in radiating tufts. Chlorite, resulting from the alteration of biotite, is occasionally noticed. The decomposition of the feldspar produces a dust-like, indeterminable mineral, white by incident light and yellowish in transmitted light.

In the dacite-porphyry of Echo Peak there are occasional inclosures of what seems to be coarse-grained gneiss. The only specimen examined, however, shows a coarse-grained rock with somewhat gneissic structure, 
but composed of the same minerals as the dacite-porphyry: alkali feldspar, quartz, and biotite, with magnetite and zirem. The microscopical cliaracters of these minerals are like those of the minerals in the porphyry, and it is possible that these conuse-grained inclosures may be nothing but coarsely erystalline portions of the dacite magma. The gneissie structure may be the result of irregular clifferentiation, as in the case of the banded gabbro of Skye, ${ }^{1}$ described by Geikie and Teall.

The transition from the more coarsely crystalline central portion to the denser and finer-grained aphanitic marginal portion is shown in the changes in microstructure in specimens $(83,84,86,87,88)$ collected from Echo Peak and in the contact zone in the gulch between this and Three River Peak.

As the constitnent minerals become smaller the poikilitic quartz in two cases $(84,86)$ assumes more of an idiomorphie form, interrupted by small feldspar erystals lying at various angles. The quartz sections appear in nearly rhombic forms, the direction of extinction being diagonal to the rhombs. The crystals are more or less perfect hexagonal bipyramids, formed by $\pm R$. They sometimes lie in a finer-grained mixture of feldspar and quartz, which, however, does not amount to a groundmass, being in relatively small quantity. In other cases the finer-grained modifications of the rock are still micropoikilitic, and lave essentially the same structure as the coarser kinds. It would seem as though the idiomorphism of the quartzes occurred in cases where the feldspar was a little more abundant. The rock from which the second analysis (87) was made is minutely micropoikilitic. This aphanitic rariety is mottled witl small dark spots that prove to be chlorite, containing small scales and plates of muscovite, which also occurs scattered throngh the rock in small amount. No biotite is present. Magnetite occurs in small erystals. The clilorite and muscovite are seen in some cases to be alteration prodncts of biotite, so that in all the specimens examined it may be assumed to have had the same origin.

This more lithoidal or aphanitic form of the rock occurs in broad bands parallel to the plane of contact aronnd the margin of the bysmalitls. The banding is recognizable at a distance, and is shown in the photograph (Pl. XII) of the north side of Echo Peak. The banding stands at steep angles, which are more nearly vertical in lower exposures, suggesting a

1 Geikie, A., and Teall, J. J. H., On the banded structure of some Tertiary gabbros in the Isle of Skye: Quart. Jour. Geol. Soc., London, Vol. L, No. 200, 1894, pp. 645-660. 
dome-like shape to the bysmalith. The rock of the bands is massive, the banding being due to differences in the constituents or in the colors and texture, and not to parallel jointing. In the vicinity of Echo Peak, on its north side, the banding pitches downward at $30^{\circ}$ to $35^{\circ}$, passing under the tilted limestone. Very close to the contact with limestone the porphyry or felsite is dense and slaty (94), being split into thin plates parallel to the contact plane. These are traversed by numerous irregular joints, which break it into sherdy pieces at right angles to the contact plane. In places it carries quartz phenocrysts, and has the appearance of a quartz-porphyry.

The dense aphanitic variety is fine grained and without phenocrysts. It is holocrystalline, with the small quartzes idiomorphic and the feldspars less so, though many of the small feldspars are idionorphic, and the structure approaches panidiomorphic-granular. The average size of the quartzes is about $0.03 \mathrm{~mm}$.

A very similar modification of this rock forms an intrusive sheet or apophysis from the bysmalith in the limestone and shale beneath the Indian Creek laccolith on the north side of the valley of Indian Creek (95). It resembles the last-described variety in megascopical habit and platy parting and in microstructure, but the idiomorphism of the quartz is less pronounced. The thickness of the sheet is not known.

The marginal modification of the bysmalith is well shown in the mountain ridge west of The Dome and north of Mount Holmes. The same broad banding is present, the position of the bands being almost vertical in the southern exposure, where the contact is visible for hundreds of feet. The central, more crystalline form of the rock passes into a more plainly porphyritic zone, and this into an aphanitic zone, which is spotted near its contact with the surrounding rocks. The inclosing rocks are penetrated by narrow dikes of the aphanitic dacite-porphyry. The aphanitic modification (93) has very much the same microstructure as that near the contact north of Echo Peak, except for abundant small feldspars, which are larger than the constituents of the groundmass. They are only sparingly present in the case of the other locality. Parts of this contact zone are aphanitic, with irregularly stellate or dendritic spots (90). The microstructure is rather panidiomorphic, with distinct quartz crystals, and the dark-colored spots are biotite and muscovite and alteration products, now mostly iron oxide, probably derived from biotite. The mica, when unal- 


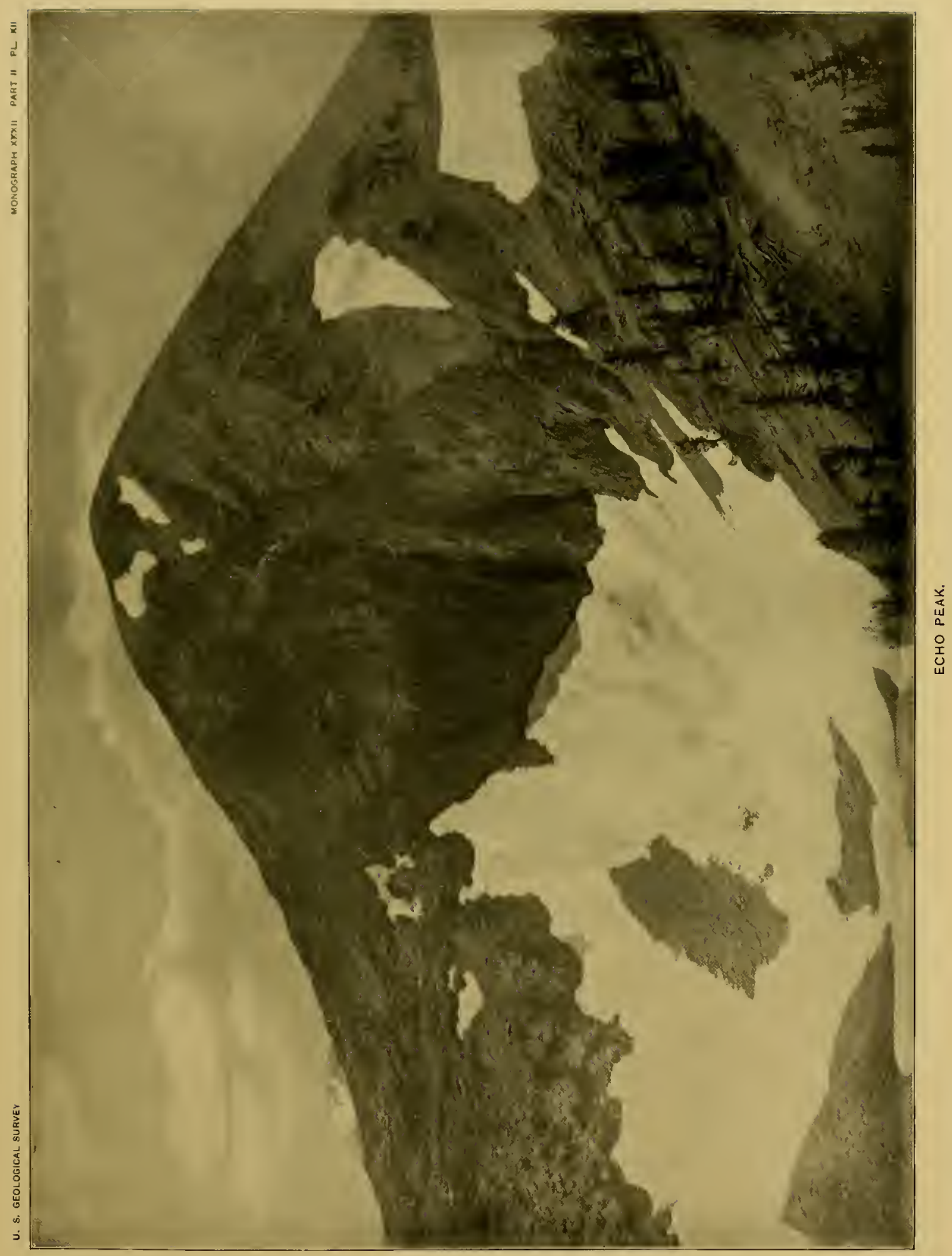



tered, extends through the gromudnass for some distance as single erystals, inclosing many ([uart\% crystals, in a poikilitic mamner.

'The same kind of contact zone exists east of Mount Holmes and west of 'Trilobite Point. The plane of contact is nearly vertical, and from the aphanitic marginal zone numerous offishoots penetrate the adjacent rocks. The dikes are white, aphanitic, and exhibit banding and flow structure. Specimens from the contact were studied and found to be very fine gramed, with micropoikilitic structure, the quartz individuals being about $0.15 \mathrm{~mm}$. in diameter, and having a skeleton-like form, the outline of each quartz being nearly idiomorphic, but not continuous, as shown in Pl. XI, fig. 4. The feldspar forms minute clonded grains and crystals. There are microscopic flikes of muscovite scattered through the rock, and some calcite. In the bysmalith rock immediately in contact with the andesite-porphyry of the laccolith the microscopic skeleton quartzes are scattered in a microcryptocrystalline groundmass. Calcite is abundant in irregular grains. The aphanitic rock penetrates the limestone in sheets that sometimes break into thin crumpled layers. This modification is microgranular, very fine grained, and not poikilitic, and consists of quartz and feldspar in allotriomorphic grains. 'The size of the grains varies slightly in alternate layers, producing the lamination. Minute flakes of unscovite are scattered through the rock and intersect one another at all angles. They are more abundant in some layers than in others.

Similar offshoots of microgramular rock occur on the north side of Panther Creek and near the ridge west of the head of Gallatin River. In these bodies, however, biotite is more abundant, and the micropoikilitic structure passes into micrographic structure as the feldspar inclostures assume a more uniform orientation $(96,97,98)$.

\section{BIGHORN PASS SHEET.}

\section{KERSANTITE.}

The small obscure body of dark-colored porphyry-like rock which is exposed in the vicinity of Bighorn Pass is characterized by phenocrysts of hormblende and mica, and rarely those of feldspar. In places the hornblendes are quite large; in other parts of the mass there are no phenocrysts (124). On the pass the sheet is from 50 to 75 feet thick. On the north sicle of Three River Peak there is a nearly horizontal intrusive sheet, 10 feet 
thick, of dense aphanitic gray and red rock (100), which might be mistaken at first glance for a fine-grained sandstone. It is at about the same horizon as the sheet at Bighorn Pass, and proves to be of similar rock. Its resemblance to this rock was not recognized in the field, and though associated with dikes of dacite-porphyry its relation to them was not noted.

Under the microscope the rock from Bighorn Pass is seen to consist of a holocrystalline groundmass of feldspar, mostly plagioclase, with quartz and some orthoclase, and larger crystals of augite, biotite, and occasional hornblende, with abundant magnetite, besides chlorite and calcite. It is not fresh, the augite and hornblende being partly decomposed. Its chemical composition is as follows:

Analysis of kersantite from Bighorn Pass.

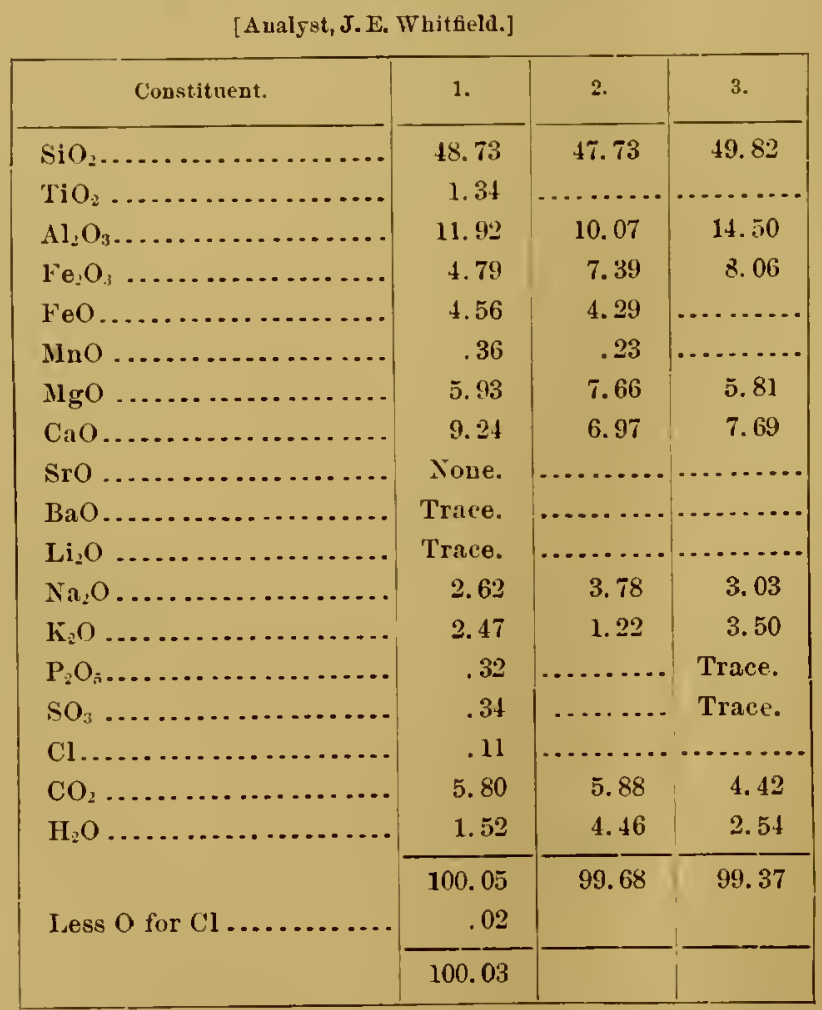

$1=$ Kersantite, Bighorn Pass.

$2=$ Minette, Eichelberg, Heillelberg. ${ }^{1}$

$3=$ Kersantite, between Falkenstein and Steiubach Miihle, Fichtelgebirge.2

1 From Roth's Tables of chemical aualyses, Beitrïge zur Petrographie der pluton ischen Gesteine, $4^{\circ}$, Berlin, 1873, xxvi.

${ }^{2}$ Ibid, 1884, xxiv. 
The high percentage of earbon dioxide, 5.80, corresponds to the abundance of calcite. 'The conparatively low alumina and relatively high alkalies are noteworthy. The pintash is eomparatively ligh for so basic a rock, and accounts for the presence of ahundant biotite. Magnesia is below the normal percentage for a rock with so little silica. It las entered into the composition of biotite, malacolite, and horublende. No orthorhombic pyroxene or olivine las been keveloped. A comparison of this rock with several others somewlat similar in chemical composition will be made later on.

'T'he microscopic feldspars are polysyntletic twins of lime-soda feldspar, with ligh extinction angles, corresponding to labradorite. They are nearly idiomorphic, rectangular to lath-shaped erystals, of pure substance, and when not obscured by calcite they apperr perfectly fresh and not at all crushed. It seems as though the calcite lad been derived from other somres-that is, from the pyroxene, or by infiltration from the inclosing limestone. The absence of strain or crushing is significant in connection with the proximity of this thin sheet to the massive laccolitl, and indicates that this lamprophyric rock is the more recent intrusion. In places the form of the feldspar is tabular. And sometimes the rectangular crystals are bounded by a margin of unstriated feldspar with allotriomorplic outline, and in some cases idiomolphic outline. This feldspar has a lower index of refraction than that of the inclosed feldspar, and is monotedly orthoclase. Its mode of occurrence is precisely the same as that of the orthoclase in the groundmass of the basaltic rocks, absarokite and shoslonite, described in Chapter IX. Grains of quartz constitute the last erystallization of the groundmass. It is probable, however, that some of the quartz is secondary, since it occurs in idionorphic crystals surrounded by calcite. There are many grains and crystals of magnetite and abundant minute hexagonal prisms of colorless apatite. Brown biotite is in part idiomorphic, in part allotriomorphic, with penetrations of plagioclase and inclusions of apatite and magnetite. The monoclinic pyroxene, with large angle of extinction and rather low donble refraction, is almost colorless in thin section, and is a diopside or malacolite. It is partly altered along cracks and around the margin, with the formation of calcite and chlorite. It is mostly idiomorphic, in comparatively large crystals, and does not occur in microlites in the groundmass. The crystals have the ordinary form and 
distinct prismatic cleavage. Inclusions of magnetite occur. The pyroxene appears to have been an earlier crystallization than the biotite. Hornblende, which is the most prominent constitnent in some forms of the rock, is hardly seen in the thin sections prepared. It occurs to only a small extent in microscopic erystals.

In the finer-grained modifications of the rock the porphyritical character of the pyroxene becomes more pronounced. The groundmass consists of allotriomorphic feldspars, with scattered lath-shaped crystals of plagioclase, apparently belonging to the more calcic varieties, together with magnetite or apatite; biotite is partly in microscopic individuals, partly in megascopic ones. There are also microscopic grains and crystals of calcite and patches of chlorite. In these varieties the pyroxene is wholly altered to chlorite or serpentine.

In a marginal modification of the rock, without phenocrysts, the crystallization of the groundmass is very fine grained, and the original structure is greatly obscured by secondary biotite in microscopic plates, which project into aggregates of quartz. This quartz exhibits peculiar interference phenomena, suggesting polysynthetic twinning.

The mineral composition of the rock, as well as the chemical, is unusual. They both correspond somewhat closely to certain kersantites and minettes, analyses of one of each of which are placed in columns by the side of the analysis of this rock for comparison. It is to be remarked that the minette, according to analysis, contains less potash than the kersantite. There is, in fact, nothing in the chemical composition to suggest the crystallization of orthoclase feldspar. But this is equally the case in the rock, leuciteabsarokite, from Ishawooa Canyon, whose analysis is given in Chapter IX, and in which the feldspathic constitnents are orthoclase and leucite. Several analogons magmas form dikes in the vicinity of the Crandall volcano (Chapter VII). They are somewhat richer in magnesia and potasl, and are characterized by olivine, biotite, and orthoclase feldspar. As in their cases, this unusual magma is known only in a small mass. Mineralogically it may be classed with kersantites, although it bears a certain resemblance to absarokite. 


\section{GRAY MOUNTAIN MASS AND CONNECITD SHEETS.}

The igneous mass of Gray Mountain and Joseph Peak, with the intrusive sheets directly connected with it, consists of andesite-porphyry and holocrystalline andesites, having a considerable range of composition. The greater portion is hornblende-mici-andesite-porphyry; a considerable part is hornblende-andesite-porplyyry, and a small part is hornblende-pyroxene, or pyroxene-andesite-porphyry, while some varieties might be classed as dacite. The numerous bodies examined exhibit a variation in the mineral composition, eren within some of the bodies of small size, especially with reference to the relative proportions of phenocrysts of hornblende and biotite. So that hormblende-mica-andesite-porphyries are in some places richer in mica than in others, or richer in lomblende. There is also a variation in the amount of dark-colored minerals present. Some are rich in ferromagnesian silicates; others poor in them. The latter are richer in feldspar and in groundmass, and are usually lighter colored. In general, it is found that in the varieties with comparatively few ferromagnesian silicates biotite is in excess of hornblende, but not always. In those richer in these minerals hornblende preponderates over biotite in most cases, but not in all. There is consequently a transition in varieties from those rich in hornblende with little or no biotite to those containing biotite with little or no hornblende. The last-named variety, however, does not constitute any considerable body. Only a very few carry quartz phenocrysts, but quartz is a microscopic constituent of the groundmass in all the more crystalline varieties, so that the classification of any of the rocks as dacite must rest upon a clemical basis.

HORNBLENDE-MICA-ANDESITE-PORPHYRY AND ANDESITE.

The main mass of the intrusion is hornblende-mica-andesite-porpliyry. It is a light-gray rock, with abundant small phenocrysts of feldspar, hornblende, and biotite, the groundmass being aphanitic. It is compact, with an even to hackly fracture, cracking into slabs and angular fragments. It resembles the Indian Creek laccolith very closely $(146,147,170)$.

The forty-five thin sections representing these hornblende-mica-andesiteporphyries resemble one another in so many respects that their microscopical characteristics may be described collectively. The constituent minerals being alike in nearly all cases, the difference between the various rock bodies lies in the crystallization of the groundmass. 
In only a few of the rocks are all of the minerals unaltered, or nearly fresh. In most cases the hornblende is completely decomposed, while biotite is generally maltered in most of them. The feldspars are unaltered in nearly all the rocks examined. The least altered rocks were found in the Gray Mountain mass $(146,147)$, in a heary sheet in the gulch on the southwest slope of Electric Peak (191), and in the sheet forming the western summit of Electric Peak (197). In these bodies the hornblende is almost entirely fresls.

The homblende is greenish brown with the usual pleochroism, between dark greenish brown and light brown. In some cases a zonal structure is exhibited, the zones being different shades of the same color. In other cases, notably in a segregation of lormblende, the color is chestnut brown to purplish brown, passing into greenish brown, and into green at the margin, the zonal arrangement of the color's not being parallel to crystallographic forms, but irregular. In some individuals the margin is reddish brown. These tones also occur in phenocrysts in the groundmass that incloses the segregations of hornblende. This particular rock is rich in hornblende and poor in biotite, and appears to be a less siliceous variety. In the more siliceons varieties of these rocks the hornblende has more of the greenish tone. The shape of its crystal is that common to these kinds of rocks-short, stont prisms, generally idiomorphic. Cleavage and twinning are also normal. The substance of the unaltered hornblende is quite pure, there being but few inclusions, usually magnetite. It occasionally surrounds biotite and angite (164) as nearly synchronous crystallizations, each being allotriomorphic with respect to the other. Sometimes there is a border of minute biotite plates surrounding the hornblende (146). Decomposition begins as chloritization around the margin of the hornblende and along cracks. When completely altered, there is a psendomorph consisting of chlorite with grains of iron oxide, and areas or cores of calcite, and sometimes muscovite in confused aggregations. The latter mineral appears to have been derived from the biotite in the rock, which is also decomposed in such cases (201). In an upturned sheet of andesite-porphyry in the southeast spur of Electric Peak the hornblende phenocrysts have been converted into nearly parallel aggregates of actinolite (222). In the rock on the south slope of Gray Mountain, where it appears to be somewlat coarser grained and more easily eroded (148), the hormblende, in part 
chloritized, is more or less wholly replaced by a zeolite, which from its optical behavior seems to be scolecite.

Biotite occurs in rather thick six-sided crystals, often idiomorph:c. The color is brown, with strong absorption. Inclusions are not frequent, being magnetite and apatite, rarely zircon. In some places lenticular layers of calcite have been deposited along cleavage planes in the biotite, distorting the lamellie. Decomposition results in the formation of chlorite and epidote, and sometimes of muscovite.

Feldspar phenocrysts are abmudant in most of the rocks, but not in all. In only a few cases are they unaltered; in general they are clouded with more or less secondary material. They are all plagioclase; the unaltered ones in the less siliceons rocks are in part labradorite. In other cases they appear to be andesine-oligoclase. Zonal structure is pronomeed. In some of the less altered feldspars minnte cracks, which are evidently the result of crushing, traverse the crystals in crudely parallel directions, and have led to the production of secondary minerals of several kinds. One is colorless, witl lower refraction than feldspar, but nearly the same donble refraction. It occurs in patches, with sharp-pointed edges. Another is colorless, witl higher refraction and stronger double refraction than feldspar. Its identity was not made ont. Other secondary minerals replacing feldspar are calcite, epidote, and a microcryptocrystalline aggregate which is indeterminable. In one instance (148) the same zeolite replaces feldspar which replaces hornblende.

Quartz occurs as phenocrysts in only a few cases $(147,198)$. It forms small rounded crystals, with occasional inclusions of other minerals. Magnetite in small grains may be reckoned with the phenocrysts. Apatite, and rarely zircon, also belong to the crystals first formed.

The groundmass of these hornblende-mica-andesite-porphyries is holocrystalline and exceedingly fine grained. No specimen of the central part of the Gray Mountain mass was collected, lience its coarsest erystallization is not known. Nothing was seen that indicated a coarser grain than exists in the Indian Creek laccolith. The specimens collected are from the marginal portion. Of these, the coarsest grained is microponklitic and finer grained than the coarsest-grained variety of the Indian Creek laccolith. This grades into modifications with less pronounced micropoikilitic structure $(146,147$, 148). The constituents of the groundmass are rectangular and lath-shaped 
feldspars with low extinction angles. Some exhibit no twinning. It is probable that oligoclase and orthoclase are both present. Irregularly shaped grains also occur. Quartz is present as poikilitic cement, or in minute grains when this structure is not developed. Magnetite crystals and some irregular shreds of bintite and green hornblende also take part in the groundmass. In this mass lie small crystals of feldspar and the ferromagnesian minerals, varying in size to the largest phenocrysts. In one specimen small quartz phenocrysts occur (147). The groundmass of the rock forming the western summit of Electric Peak is micropoikilitic, with more hornblende and biotite as constituents (197). The same structure is found in an altered sheet on the northeast spur of this mountain (214). Slightly finer-grained forms of this same structure occir in tivo other sheets in Electric Peak (201, 151). A lower grade of crystallization las smaller and less distinctly poikilitic graius, with clearly defined hath-shaped feldspars that sometimes exhibit a fluidal arrangement. A still lower grade consists of minute lath-shaped feldspars, with indistinct patches of poikilitic quartz, and spots that are microcryptocrystalline. There is sometimes pronounced flow structure. In thin sections the groundmass is gray, with minute feldspars, and magnetite grains, and occasional apatites. These modifications are but slightly different from andesites, and might be classed as such. They occur in varieties richer in biotite than in lornblende. A microstructure very similar to this, but less uniformly developed and still finer grained, is found in a crushed sheet in the southeast spur of Electric Peak (213). where the rock is considerably altered. In this case it is possible that the micropoikilitic structure is secondary. The lowest grade of crystallization allied to the micropoikilitic is one in which there is a brownish base, which is doubtfully holocrystalline. In this are feldspar microlites and irregular grains, in places approaching a poikilitic structure. It is probable that the rock is holocrvstalline. Its habit is thoroughly andesitic.

The microstructure of other modifications of these intrusive sheets is not very different from the micropoikilitic varieties, in that it consists of lathshaped feldspars and grains of feldspar and quartz of nearly the same size as in the other cases, but the poikilitic cementing quartz is wanting. These rocks are very fine grained, the average diameter of the grains being about $0.02 \mathrm{~mm}$., or smaller. In one instance the granular groundmass is filed with phenocrysts of feldspars and some micrographic intergrowth surrounding 
the smaller crystais (216). A granular microcrystalline to microcryptocrystalline structure occurs in some of the sheets.

Another class of microstructures is that in which the groundmass consists of grains and crudely idiomorphic erystals of feldspar and quartz, with abundant small crystals of quartz, nearly idiomorphic, in six-sided pyramids, generally inclosing several grains of feldspar. The strueture may grade into micropoikilitic. In the best-developed gronndmass of this kind, in andesite-porphyry from the ridge north of Fawn Pass (140), the quartz crystals are $0.3 \mathrm{~mm}$. in length and smaller. The rock is rich in biotite and poor in hornblende. In other cases the grain is smaller, and innumerable idiomorphic quartzes, 0.01 in dianeter, fill the groundmass. This structure is developed in the sheet of andesite-porphyry, rich in hornblende (191), which occurs in the gulch southwest of the summit of Electric Peak. In a few cases the lath-shaped feldspars preponderate over the granular minerals, giving the groundmass a holocrystalline pilotaxitic structure.

HORNBLENDE-ANDESITE-PORPHYRY AND ANDESITE.

Of the remaining intrusive sheets in this part of the Gallatin Mountains very mucli the greater number are hornblende-andesite-porphyries and holocrystalline andesites withont pyroxene and without biotite, except a trace in some instances. A very few bodies contain pyroxene, either with homblende or withont.

In contrast to the hornblende-nica-andesite-porphyries the hornblendeandesite-porphyries are less decomposed, the hornblende being only partly altered in most cases, and quite fresh in a number of instances. This is the more noteworthy since they appear to be older than the hornblende-mica rock in several instances, though not in all. The hornblende-andesiteporphyries and andesites are characterized by abundant small phenocrysts of homblende and fewer of feldspar. They vary in amount of phenocrysts and in the general color and habit of the rock. Some are scarcely distingnishable from the homblende-mica rocks into whoch they grade. 'The hornblende phenocrysts have the same habit and colors, brownish green, with reddish-brown tones in places, and upon alteration are replaced by chlorite or calcite, or both together, sometimes with grains of epidote or titanite. The feldspar phenocrysts are plagioclase, apparently andesinelabradorite, with zonal structure and twinning, as in the rocks just described. 
They are much less abundant and smaller in most of the present group, and are in part cracked and altered in the sane manner as in the hornblendemica rocks. In some instances the feldspar is perfectly fresh when the hornblende is entirely altered, and vice versa. The only other constituent that may be classed with the phenocrysts is maguetite, in small crystals, scattered throngh the rock, and inclosed in the hornblende. It is in some cases decomposed and replaced by aggregations of hydrous oxide of iron, lencoxene, and brightlly polarized scales of an undetermined mineral. The magnetite is plainly titaniferous, and chemical analysis shows 1.71 per cent of titanimm oxide in the rock analyzed. Pyrite is occasionally present.

The gromndmass, always holocrystalline, consists in most cases of a microcrystalline aggregation of grains that are indistinctly poikilitic, and of feldspar microlites, both lath-shaped and rectangular, together with magnetite and irregularly shaped hornblende or chlorite. In one case the micropoikilitic structure is more pronounced. In others the lath-shaped and rectangular feldspars preponderate. In two instances the groundmass is microcryptocrystalline, with scattered feldspar microlites and some indistinet micropoikilitic structure.

On the ridge ruming sonthwest from Electric Peak three distinct bodlies of intrusive rock intersect one another. The oldest is a somewhat altered hornblende-andesite-porphyry (185). This is traversed by a large sheet of hornblende-andesite-porpliyry, which is quite fresh, light gray colored, with abundant small phenocrysts of hornblende and feldspar. Through the rock are segregations, several inches in diameter, that differ greatly in texture and structure. Some appear as coarser-grained modifications of the main rock, others as varieties with larger hornblende. Some have a laminated or gneissoid structure. Occasionally small dark patches surround red gamets $(182,184,188,189)$. The main body of the rock, whose chemical composition is given in analysis 1, p. 81 , consists of a micropoikilitic groundmass, with abundant lath-shaped and rectangular feldspars, besides hornblende, a little chlorite, magnetite, and quartz, carrying phenocrysts of hornblende and cracked plagioclase. It is remarkable that by the side of greatly cracked crystals of plagioclase, with the cracks filled with the secondary mineral already described, the crystals of hornblende exhibit no cracking, often no cleavage, and no optical strain phenomena. The question arises whether or no the cracking of the feld- 
spar was produced by dynamic forces acting on the whole rock. The nearly parallel position of the cracks in all feldspars in one rock section indieates that it was due to such action. The total absence of eracking in the horublende and the rery fresh condition of this mineral are certainly remarkable (182). In one instance, where a large hornblende is adjacent to a feldspar, both are cracked in the same direction, but the hornblende exhibits no alteration along the cracks. The alteration within the feldspar appears to be confined entirely to its crystal, and to depend upon the feldspar substance, and not to be in the nature of an infiltration which might lave lodged within the cracks in the hornblende. At the margin of the rock body the color is dark and the phenocrysts are very small and in greater numbers (184). The groundmass is microcryptocrystalline, witl indistinct poikilitic patches. In other parts of the body the groundmass lias a microgranular structure with minute idiomorphic quartzes. This is in contact with one of the segregations (188), which consists of an aggregate of rectangular feldspars, for the most part in polysynthetic twins with low extinction angles, and of larger hornblendes, with a small amount of interstitial cement of feldspar and quartz grains. It contains long, slender needles of apatite, partially altered magnetite, and some chlorite in flakes, which suggest former biotite. The hornblende is precisely the same as that in the surrounding rock, and the segregation is plainly a local modification of the magma of the rock. One segregation consists wholly of brownish-green horublende. Another segregation consists of similar hornblende crystals crowded together, with rather large feldspars, and no finegrained cement. There is some quartz, calcite, and chlorite. The feldspars are more or less altered, while the hornblende is perfectly fresh. The banded segregations with gneissoid appearance consist of plagioclase and hornblende, with biotite in places, considerable magnetite and green spinel, besides chlorite as an alteration of biotite. There is little or no quartz. The banded structure is due to the arrangement of magnetite, spinel, and biotite in streaks or layers, and to the crystallization of part of the feldspar in small crystals and grains in layers. While the dark-colored minerals exhibit a pronounced parallel arrangement in places, the crystals of feldspar lie in all possible positions, and share in the banded character only by being in small grains or in large crystals. The hornblendes and some biotites are poikilitic, inclosing small rounded crystals of plagioclase. The 
end of a large hornblende is normally developed where it lies within the groundmass of the rock, but within the banded segregation it is poikilitic, and is traversed by a broad band of feldspar grains. In places where the banding of the magnetite and biotite is most pronounced and is in delicate lines, the feldspars are comparatively large and cross the lines of magnetite at all angles without modifying them. The lamination was earlier than the crystallization of the feldspars. It did not affect the orientation of the hornblende material. It must have preceded the crystallization of the lormblende. It affected the size of the feldspar crystals in part. The size of crystals clepends primarily upon the rate of cooling or upon the viscosity of the magma. Since the cooling must lave been the same for all parts of so small a mass, the most variable factor is likely to have been the viscosity, which depends not only on the temperature but on the chemical composition. Hence we may conclude that heterogeneity in the mass must have been the canse of the banding and abnormal microstructure in these small gneiss-like segregations.

\section{HORNBLENDE-PYROXENE-ANDESITE-PORPHYRIES AND ANDESITES.}

The hornblende-pyroxene-andesite-porphyries and andesites are few in number and are closely associated with the hornblende rocks. One forms a narrow sheet on the ridge north of the head of Fan Creek $(162,167)$. It is dense and andesitic in appearance, with homblende phenocrysts. The groundmass is holocrystalline and pilotaxitic, with abundant magnetite. Part of the rock has small phenocrysts of angite in addition to those of hornblende, besides numerous small augites, first recognized under the microscope. The groundmass is more coarsely crystallized.

Two other modifications occur, whose character is in doubt, owing to the complete decomposition of the ferromagnesian constituents. They were probably pyroxene rocks $(131,132,134,136)$. They are both fine grained, without phenocrysts. Their general mineral composition is similar to that of the rocks already described. Their microstructure is andesitic, approaching a microlitic and glassy structure. Some of the pseudomorphs have the shape of olivine, and it is possible that one of these rocks is an altered basalt or olivine-andesite. 
CHEMICAL COMPOSITION.

Of the rocks belonging to this intrusive mass and its ontlying sheets three have been analyzed chemically, and their malyses are given in the accompanying table. $N_{0} .1$ is from a sleet on the ridge sonthwest of the summit of klectric Peak (182), and is homblende-andesite-porphyry. No. 2 is the rock forming the thick sheet between Fan Creek and Cimabar Creek (164), and is hornblende-mica-andesite-porphyry. No. 3 is from the southern slope of Gray Mountain, and is part of the great intrusive mass (146); this also is hornblende-mica-andesite-porphyry.

Analyses of rocks from vicinity of Electric Peali, Fan Creel, and Gray Mountain.

[Analyst, J. E. Whittield.]

\begin{tabular}{|c|c|c|c|}
\hline Constituent. & 1. & a. & 3. \\
\hline $\mathrm{siO}=\ldots \ldots \ldots \ldots . . . . . . . . . .$. & 58.19 & 65.63 & 65.64 \\
\hline $\mathrm{TiO}_{3} \ldots \ldots \ldots \ldots \ldots \ldots$ & $1 . \pi 1$ & Trace. & None. \\
\hline $\mathrm{Al}_{2} \mathrm{O}_{3} \ldots \ldots \ldots \ldots \ldots \ldots$ & 36.70 & 17.00 & 17.29 \\
\hline $\mathrm{Fe}_{3} \mathrm{O}_{3} \ldots \ldots \ldots \ldots \ldots \ldots$ & 3.85 & 2.55 & 3.07 \\
\hline 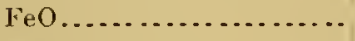 & 2.37 & 1. 19 & 1.29 \\
\hline $\ln \cap \ldots \ldots \ldots \ldots \ldots$ & .24 & …...... & Trace. \\
\hline $\lg \mathrm{l}_{\ldots} \ldots \ldots \ldots \ldots \ldots \ldots$ & 3.12 & $\stackrel{2.03}{2}$ & 1.78 \\
\hline 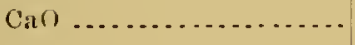 & 5.90 & 3.48 & 1.98 \\
\hline $\mathrm{Li}_{2} \mathrm{O} \ldots \ldots \ldots \ldots . . . . .$. & .01 & .04 & .04 \\
\hline $\mathrm{Na}, \mathrm{O} \ldots \ldots \ldots \ldots \ldots \ldots$ & 3.47 & 4.42 & 5.77 \\
\hline $\mathrm{K}_{2} \mathrm{O} \ldots \ldots \ldots \ldots \ldots \ldots$ & 1.59 & 1. 64 & 2.44 \\
\hline $\mathrm{P}_{2} \mathrm{O}_{3} \ldots \ldots \ldots \ldots \ldots \ldots \ldots$ & Trace. & .07 & .23 \\
\hline $\mathrm{SO}_{3} \ldots \ldots \ldots \ldots \ldots \ldots \ldots$ & .63 & Trace. & Trace. \\
\hline $\mathrm{CO}, \ldots \ldots \ldots \ldots \ldots$ & $\ldots \ldots \ldots$ & .27 & Trice. \\
\hline $\mathrm{H}_{.} \mathrm{O} \ldots \ldots \ldots \ldots \ldots \ldots$ & 2.44 & 2. 00 & 1.03 \\
\hline Total ......... & 100.52 & 100.32 & 100.73 \\
\hline
\end{tabular}

From these malyses it is seen that the hornblende-andesite-porphyry has 3 per cent less silica than the hornblende-mica rock of the Indian Creek laccolith with nearly the same alkalies, and that the former has more magnesia and considerable titanimm oxide. The hornblende-mica-andesiteporphyries of the Gray Iountain system which were analyzed have more silica than the Indian Creek laccolitl, and somewhat more alkalies and less lime. Chemically and mineralogically they are near dacites, and might be classed with them. Some of the rocks contain abundant idiomorphic quartz MON XXXII, PT $11-6$ 
in microscopic phenocrysts, and are undoubtedly dacite. No attempt has been made to distinguish on the map the different kinds of rocks forming the large mass and intrusive sheets just described.

\section{DIFFERENTIATED SHEET SOUTHEAST OF ELECTRIC PEAK.}

One intrusive sheet occurs in the upturned shales of the sontheastem spur of Electric Peak which deserves special mention. It is about 30 feet thick, and at present stands in a nearly rertical position, as do the inclosing shales. It is notable on account of its composition and the strongly contrasted character of the lower and upper parts of the sheet. The rock is massive and greenish near the eastern wall, which was originally the bottom surface; it is fissile and crumbles npon weathering, giving rise to a narrow gulch. Immediately in contact with the shale it is dense, with a purplish tinge. A layer of the sheet, 4 or 5 feet thick, near what was the bottom, is full of large porphyritical angites $(225,228)$. The remainder of the sheet does not contain them, except sporadically, and carries small feldspar phenocrysts. It is more massive, and weathers quite differently from the coarsely porphyritic part. From the abundance of large augite crystals in the bottom portion of the sheet it appears that these crystals must have settled to the lower part while the magma was quite liquid, a phenomenon not observed in any other rocks of this region, where the phenocrysts are uniformly disseminated through the rock. Such separations by gravity have been noted by Charles Darwin ${ }^{1}$ in the basalt lavas of the Galapagos Islands, and by Clarence King ${ }^{2}$ in the basalt flows of Hawaii. In each of these cases the rocks in which this phenomenon has been observed are basic, as is the intrusive sheet in question. A high degree of liquidity after the phenocrysts have been formed seems to be a necessary condition, and is one most likely to occur in basic rocks.

The chemical composition of the two parts of the sheet is shown by the following analyses. No. 1 is of the lower portion, crowded with large angite crystals, the layer being about one-sixth of the total depth of the sheet; No. 2 is of the more feldspathic portion; No. 3 is the average composition of the sheet, reckoning the parts analyzed in the proportion of 1 to 5 .

1 Volcauic Islands, London, 1851, p. 117.

${ }^{2}$ U. S. Geol. Expl. Fortieth Par, Vol. I, Systematic Geology, p. 715. 
Analyses of different parts of the shcet southeast of Eleetric l'eat.

\begin{tabular}{|c|c|c|c|}
\hline ('onstituent. & 1. & 2. & 3. \\
\hline $\mathrm{siO} . . . . . . .$. & 50.59 & 52.10 & 51.85 \\
\hline 'lio: .................... & .80 & .79 & $.7 !$ \\
\hline$\Delta I_{1} O_{3} \ldots \ldots \ldots \ldots \ldots \ldots$ & 11.53 & 16.34 & 15.54 \\
\hline $1 v_{3} O_{3} \ldots \ldots \ldots \ldots \ldots \ldots$ & $1.8: 3$ & 3.8 .1 & 3.50 \\
\hline leo & 7.64 & 6.82 & 6.95 \\
\hline 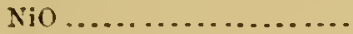 & .06 & $\ldots . . .$. & .01 \\
\hline $\operatorname{MnO} \ldots \ldots \ldots \ldots \ldots$ & .17 & 'Trace. & .03 \\
\hline $\lg 0 . . . . .$. & 11.27 & 4.33 & 5.49 \\
\hline $\mathrm{CaO} . . . . .$. & 8.79 & 4.73 & 5.40 \\
\hline BaO ......... & .10 & ...... & .01 \\
\hline SrO & .03 & ........ & Trace. \\
\hline $\mathrm{Na} O \ldots \ldots \ldots$ & 2.27 & 4.02 & 3.73 \\
\hline $\mathrm{K}_{2} \mathrm{O} \ldots \ldots \ldots$ & 2.33 & 4.20 & 3.89 \\
\hline $\mathrm{Li}_{2} \mathrm{O} \ldots \ldots \ldots$ & 'Trace. & .13 & .10 \\
\hline $\mathrm{P}_{2} \mathrm{O}_{3} \ldots \ldots \ldots \ldots$ & .48 & .68 & .64 \\
\hline 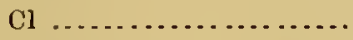 & Trince. & .24 & .20 \\
\hline $\mathrm{SO}_{3} \ldots \ldots \ldots \ldots \ldots \ldots$ & None. & .22 & .18 \\
\hline $\mathrm{H}_{2} \mathrm{O}$ below $110^{\circ} \ldots .$. & .21 & 1.74 & 1.78 \\
\hline $\mathrm{H}_{2} \mathrm{O}$ above $110^{\circ} \ldots \ldots$ & 1.76 & & \\
\hline Total........... & 99.86 & 100.18 & 100.09 \\
\hline \multirow[t]{2}{*}{ Less $O$ for $\mathrm{Cl} \ldots \ldots \ldots \ldots$} & -........ & .05 & .04 \\
\hline & & 100.13 & 100.05 \\
\hline
\end{tabular}

The chemical composition of the sheet is not like that of any of the igneous rocks of Electric Peak and Sepulchre Mountain, being lower in silica and proportionately ligher in alkalies. It approaches the composition of shoshonite (Chapter IX), and indicates that the magma is a more highly differentiated form of the general magma. The two parts of the sheet correspond in chemical composition more closely to absarokite and shoshonite (q. v.), and are the results of a differentiation in which the separation was according to mineral molecules, as it was actually the settling of pyroxene crystals. The ratio of the alkalies to one another in the two parts is nearly constant, indicating that they remained in combination.

The upper part of the rock, 10 feet from the top, consists of feldspar, most of which is plagioclase, and is striater. It is partly in tabular or equidimensional erystals, with allotriomorphic ontlines, partly in lath-shaped and rectangular crystals, more nearly idiomorphic and generally of smaller size. The extinction angles are low, often nearly zero, indicating oligoclase. 
Some of the feldspars exlihit no polysynthetic twinning and have low extinction angles, and are probably orthoclase. 'The substance of the feldspar is clonded by minnte secondary grains. There is also considerable colorless malacolite or diopside in small irregular crystals and in short stout prisms, besides partly altered nagnetite and abundant long needles of apatite; also abundant green and browu secondary mineral in irregular aggregations, which in places resembles microcryptocrystalline aggregates of chlorite or serpentine, and in other places appears to be microscopic erystals of brown mica. Biotite is also sparingly present in long shreds or crooked plates and in stout crystals. About 10 feet from the bottom of the sheet the lath-shaped feldspars are more abundant, long prismatic crystals of malacolite are numerous, and magnetite or ilmenite occurs in small grains and in greater mumbers. There are some porphyritical malacolites and feldspars, besides patches of brightly polarizing micro-fibrous material with larger needles of actinolite scattered throngh it.

The portion of the rock filled with large malacolite crystals consists of these large arystals, more or less idiomorphic in outline, in a subordinate amount of feldspar matrix, composed of lath-shaped feldspars, like those already described, besides small crystals of malacolite and iron oxide. There is much actimolite in thin needles, and in a greenish, microscopic felt, which is bright green or pleochroic in some places and colorless in others. Around the grains of magnetite the felt is colored brown. The large malacolites are to some extent altered to fiber's of actinolite that lie parallel to the prismatic axis of the pyroxene. It is a question whether the patches of actinolite felt may not be altered olivine. This seems probable from the shape of some of them, but no maltered olivine is observed in the thin sections of the rock.

\section{GALIATIY RIVER LACCOLITII.}

\section{DACITE-PORPHYRY.}

In comnection with the intrusive bodies in the Gallatin Mountains should be mentioned a laceolith-like mass situated on the Gallatin River just west of the border of the Yellowstone Park. It is within and neas the base of the Paleozoic strata. 'The rock is a dacite-porphyry with prominent phenocrysts of feldspar and abundant smaller ones of hornblende, besides small romuded crystals of yuartz. In thin sections the large teldspars are seen to 
be andesine-labmalorite with marked zonal structure, and with cracking and secondary inclusions similar to those in the andesite-porphyries of this region. The quartz erystals are sometimes idlomorphie pyramids, or are nearly spherical, or are irregularly slapeet. 'They contain bays and inclusions of groundmass and many liquid inclusions with cubes and gas bubbles; rhomboliedral clearage is occasionally developed. The homblende is green and more or less chloritized. A few crystals of biotite and of sphene were noticed. Magnetite oecurs in small individuals, and colorless apatite in comparatively large ones. Allanite is present in brown pleochroic crystals, with idiomorphic form and zonal structure. Strongly pleochroic epidote in irregular grains is sparingly present as a secondary mineral. The groundmass is fine grained, microgranular, with minute idiomorphic quartzes and abundant crystals of magnetite $(168,169)$.

\section{INTRUSIVE SHEETS IN MOUNT EVERTS.}

There are a number of intruded sheets of igneons rock within the Cretaceous strata of Mount Everts, the lowest being exposed near the base of the south side of the mountain, and the highest at the top of the west escarpment. The rocks as a group are dark greenish and brownish grays to slate color. They are dense and aphanitic to very fine grained, and for the most part are free from prominent phenocrysts. The rocks are altered holocrystalline andesites and andesite-porphyries.

The coarsest-grained form occurs in a sheet 20 to 30 feet thick at the base of the south face of the momutain (365). The rock is greatly fractured, with joints along which there has been sliding about parallel to the bedding of the inclosing sedimentary strata. It consists of nearly idiomorphic limesoda feldspars, with low extinction angles and low double refraction, abont $0.4 \mathrm{~mm}$. long, the marginal part being unstriated and clondy. $\mathrm{A}$ few are phenocrysts $2 \mathrm{~mm}$. long. There is considerable serpentine and a little palegreen augite not yet altered. Magnetite occurs in small crystals, and colorless apatite is abundant in minute thin prisms. Numerous shreds of red-brown biotite may be secondary. The rock is a pyroxene-andesiteporphyry.

In the west escarpment several thin sheets were observed by Mr. Wright. They are aphanitic and porphyritic $(356,357)$, with phenocrysts of feldspar and decomposed pyroxene. The feldspar is partly altered, and is probably labradorite. The groundmass is extremely fine grained and is 
composed of prisms of plagioclase, much serpentine or chlorite, and altered magnetite, which is now light yellow by incident light. There are suggestions of crystals of pyroxene, now altered. The structure is andesitic and the rocks are holocrystalline pyroxene-andesites. There is much calcite scattered through the rocks.

The intrusive sheet near the top of the northern part of the west escarpment, which can be distinguished even at a long distance from the inclosing sandstones, because of its dark color, is about 20 or 30 feet thick in places, but much thimer in others. It lies parallel to the bedding of the strata, except for short distances, where it breaks across the beds. In places it exhibits prismatic parting at right angles to the contact surfaces, and in other places the spheroidal sundering is well developed. The rock is dark and dense, with few phenocrysts of hornblende $(360,361,362)$. It contains segregations of hornblende. The same sheet of rock is exposed lower down the northwest spur of the mountain, near the line of the forty-fourth parallel of latitude $(363,359)$. It is a holocrystalline pyroxene-andesite, or pyroxene-andesite-porphyry, carrying a small amount of hornblende. 1ts habit is like that of similar andesites of Sepulchre Iominain, there being innumerable small phenocrysts of labradorite and prroxene in al groundmass of still smaller crystals of the same minerals, with magnetite and some micropoikilitic quartz. The rock is considerably decomposed in part, the pyroxenes having suffered most. Portions of it contain fresh angite and altered hypersthene. The hornblende is brown, with a border of magnetite and pyroxene. Near the contact planes of the sheet the groundmass of the rock is still finer grained.

These rocks are similar to the intruded sheets in the Cretaceous strata of Electric Peak, and it is possible that they may have been connected with them before the faulting of the region by the great north-south faults on both siles of Sepulchre Mountain.

\section{TIIE BUNSEN PEAK MASS.}

\section{DACITE-PORPHYRY.}

The Bunsen Peak mass is an intrusive body that broke through Cretaceous strata, which are exposed in contact with it on the Gardiner River near the mouth of Glen Creek, and which dip away from it northward at an angle of $10^{\circ}$. Erosion has removed the sedimentary covering, leaving an isolated, dome-like mountain, whose base has been surrounded on all sides by 
streans of rhyolitic and basaltic lavas. The rock is light gray and fine grained, with abundant small phenocrysts of feldspar and biotite. It is a mica-dacite-porphyry, whose chemical composition is as follows:

Analysis of Bunsen Peak mica-dacite-porphyry.

\begin{tabular}{|c|c|}
\hline Constituent. & (102) \\
\hline $\mathrm{siO}_{3} \ldots \ldots \ldots \ldots \ldots$ & 70.52 \\
\hline $\mathrm{TiO}_{2} \ldots \ldots \ldots \ldots$ & 'T'race. \\
\hline $\mathrm{Al}_{2} \mathbf{(}_{3} \ldots \ldots \ldots \ldots \ldots \ldots \ldots \ldots \ldots \ldots \ldots \ldots \ldots \ldots$ & 15.85 \\
\hline 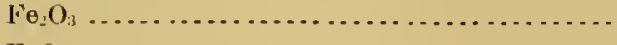 & 2. 28 \\
\hline 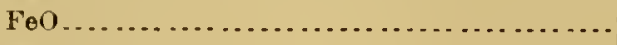 & .36 \\
\hline $\ln O \ldots . . . . . . .$. & .09 \\
\hline MgO......... & .09 \\
\hline $\mathrm{CaO} \ldots \ldots . .$. & 2.59 \\
\hline $\mathbf{L i} \mathbf{i}_{\mathrm{O}} \ldots \ldots \ldots$ & Trace. \\
\hline 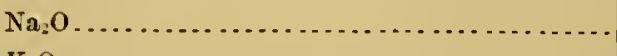 & 3.93 \\
\hline 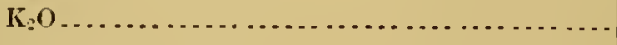 & 3.43 \\
\hline $\mathrm{P}_{2} \mathrm{O}_{6} \ldots \ldots \ldots \ldots$ & .17 \\
\hline 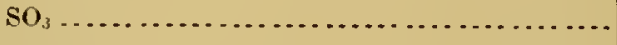 & .29 \\
\hline 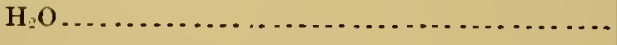 & .35 \\
\hline 'Total ....... & 99.95 \\
\hline
\end{tabular}

This analysis was made from the rock at the summit of Bunsen Peak. It is nearly the same as that of the rock from Mount Holnes (p. 65), being a little lower in alumina and higher in lime and potash.

The mineral composition and microstructure of the rock vary but slightly throughout the body. Under the microscope it is seen to consist of a holocrystalline groundmass of feldspar and quartz, with abundant flakes of biotite and a little magnetite. Small crystals of apatite and minute prisms of zircon are present. There are numerous phenocrysts of irregularly outlined biotite, idiomorphic feldspar, and a few corroded crystals of quartz. The feldspar phenocrysts are almost all polysynthetic twins of lime-soda feldspars, oligoclase-andesine, also twinned according to the Carlsbad law, and having marked zonal structure. A few appear to be labradorite. Some unstriated feldspars may be orthoclase. They have few inclusions, and exhibit very little decomposition in some parts of the rock. The cracking and secondary minerals characteristic of the feldspar phenocrysts in the intrusive rocks of the Gallatin Mountains also occur in parts of this rock. The biotite is brown, with strong absorption and few inclusions. It is for the most part unaltered. Quartz phenocrysts are much corroded and carry 
few inclusions. They are searce in most seetions of the rock, and are more numerous in the finest-grained portions at the northeastern extension of the mass. The groundmass in the coarsest-grained forms, which oceur about the middle of the northern and western sides of the mountain, is microerystalline, and consists of lath-shaped and reetangular feldspars and mieropoikilitic quartzes, about $0.05 \mathrm{~mm}$. in diameter and smaller, with some magnetite crystals and a few flakes of biotite. The microstructure is shown in Pl. XIX, fig. 1. The poikilitic quartzes are more pronounced in some parts of the rock than in others, and exhibit a tendeney toward idiomorphism $(105,106,108)$. The same structure occurs in smaller grain at the summit of the mountain, on its southeastern face, and at its northern base, where the rock is exposed in knolls near Gardiner River and elsewhere. Where the dacite-porphyry comes in contact with a large mass of sandstone, probably included within the igneons mass, the porphyry exhibits platy parting parallel to the pline of contact, which disappear's a short distance away. The microstructure of the roek near the contact is indistinetly mieropoikilitic, the quartz patches being very minute. In spots it is microcryptoerystalline. The finest-grained forms oecurring near the contact with sedimentary rocks on Gardiner River below the month of Glen Creek, and in the spur of the plateau west, are microgranular, with minute idiomorphie quartzes, averaging $0.01 \mathrm{~mm}$. in diameter.

A coarse-grained mass resembling granite occurs in the base of the eliff on the northern side of the mountain, and consists of quartz, feldspar, and biotite, with the grain of fairly coarse granite. It is a crystallization from the same magma as the dacite-porphyry, for the erystals of feldspar along its margin projeet into the porphyry groundmass with idlomorphie outline. It is not a broken fiagment of some foreign roek inclosed during the eruption of the porphyry. The mineral constituents are the same as those of the porphyry, both in kind and in general eharacter. The biotite has the same color and has similar inchisions of magnetite. The feldspars are orthoclase and oligoclase, with some crystals of andesine-labradorite. The quartz is allotriomorplie with respeet to all the other minerals, and contains gas inelusions, with a small amount of liquid. Magnetite, apatite, and zireon oeeur as in granite. This is clearly a coarse-graineid erystallization of the magma, due to some eause not known, and presents the true granite equivalent of the dacite-porpliyry. Similar coarse-grained masses nceur in the dacite-porphyry of the Holmes bysmalith, near Echo Peak. 


\title{
C H A P'T E R I I I.
}

\section{'IHE IGNEOUS ROCKS OF ELECTRIC PEAK AND SEPULCHRE MOUNTAIN.}

\author{
By Jusepir Paxson Iddings.
}

GEOLOGICAL SKETCH OF' 'THE REGION.

As already stated in Chapter II, the series of eruptions that broke through the synclinal fissure in what is now the eastern part of Electric Peak are so plainly related to the lavas that form the volcanic pile of Sepulchre Mountain and the foothills at its southwestern base, and the character of this relationship is of sich petrographical importance, that these rocks will be treated conjointly. ${ }^{1}$ It has been shown that the eruptions that accompanied the syuclinal folding and fissuring in the eastern part of Electric Peak were subsequent to the intrusion of the sheets of andesite-porphyry between the beds of shale and sandstone.

The general character and form of Electric Peak are exhibited in the accompanying map and illustrations. The Peak is the highest point in the Gallatin Mountains, being 11,100 feet in altitude, and is situated upon the northern boundary of the Yellowstone Park, the forty-fifth parallel of latitude passing just south of the summit. For this reason it is not well shown on either of the atlas sheets north or sonth of this parallel. The accompanying map (Pl. XVI) shows its relation to Sepulchre Mountain, as well as its geological structure, which has been explained on pages 50 to 55 , where the character of the sedimentary formations and their position and the nature of the intruded sheets of andesite-porphyry were described.

The sharply pointed peak has broad, steep slopes on the west and south, where streams have cut 3,000 feet below the summit of the mountain.

: Iddings, J. P., The cruptive rocks of Electric Peak nul Sepulchre Nonntain, Iellowstone National Park: Twelfth Aun. Rept. U. S. Geol. Surver, 1892, pp. 569-664. 
A narrow spur or ridge connects the peak with the momutains to the southwest, while a broad, high ridge on the north carries the gently dipping Cretaceous strata to the abrupt synclinal fold sonth of Cimmabar Mlountain. On the east and northeast of the smmmit deep gulches have been carved into the heart of the mass, reaching depths of 4,000 and 5,000 feet below its highest point. The valley of Reese Creek marks the line of faulting between Electric Peak and Sepulchre Mountain.

Only the eastem half of Electric Peak is involved in the consideration of the series of volcanic eruptions liere discussed, the central stock or conduit of eruption being located in the middle of the deep gulch east of the peak and in the rocky spmr north of the gulch, and the apophyses and dikes extending only short distances across the southeastern and northeastem spurs. The accompanying view of the eastern face of the momtain (Pl. XIII) shows the jagged northeastem spur on the right, with its steeply sloping base, and the deep east gulch in the middle, with light-colored morainal accumulations of rock fragments covering the bottom like a glacier. The long sontheastern spur is on the left, with its short, steep branch immediately sonth of the gulch. The barren slopes, partly covered with sliderock, are easily recognizer.

The sontheastern spur is formed of uptnmed beds east of the synclinal axis. The black shales which constitnte the greater part of the spur have been baked and indurated in the vicinity of the stock, so that they have withstood erosion sufficiently to form the pyramidal mass bounding the east gulch on the sonth. The main mass of Electric Peak and the greater portion of the northeast spur consist of less disturbed strata dipping toward the northeast. The strncture of the mountain is shown in the walls of the deep gulches draining east and northeast, as well as in the bare slopes on the sonth and west sides. The differences in the topography of the two halves of the mountain are dne to the influence of the vertically intruded rocks, which have metamorphosed the neighboring saudstones and shales, rendering them hard and resisting, and leading to the production of rungeed and pimacled ridges, witl precipitous walls hundreds of feet in height.

The east gulch forms an amplitheater at the base of the peak, which surmounts a precipice of nearly 1,500 feet. The walls of this amphitheater are shown in the panorama, Pl. XIV. The gulch crosses the synclinal axis and the stock of igneous rock, part of which is corered by débris. The cen- 
13 



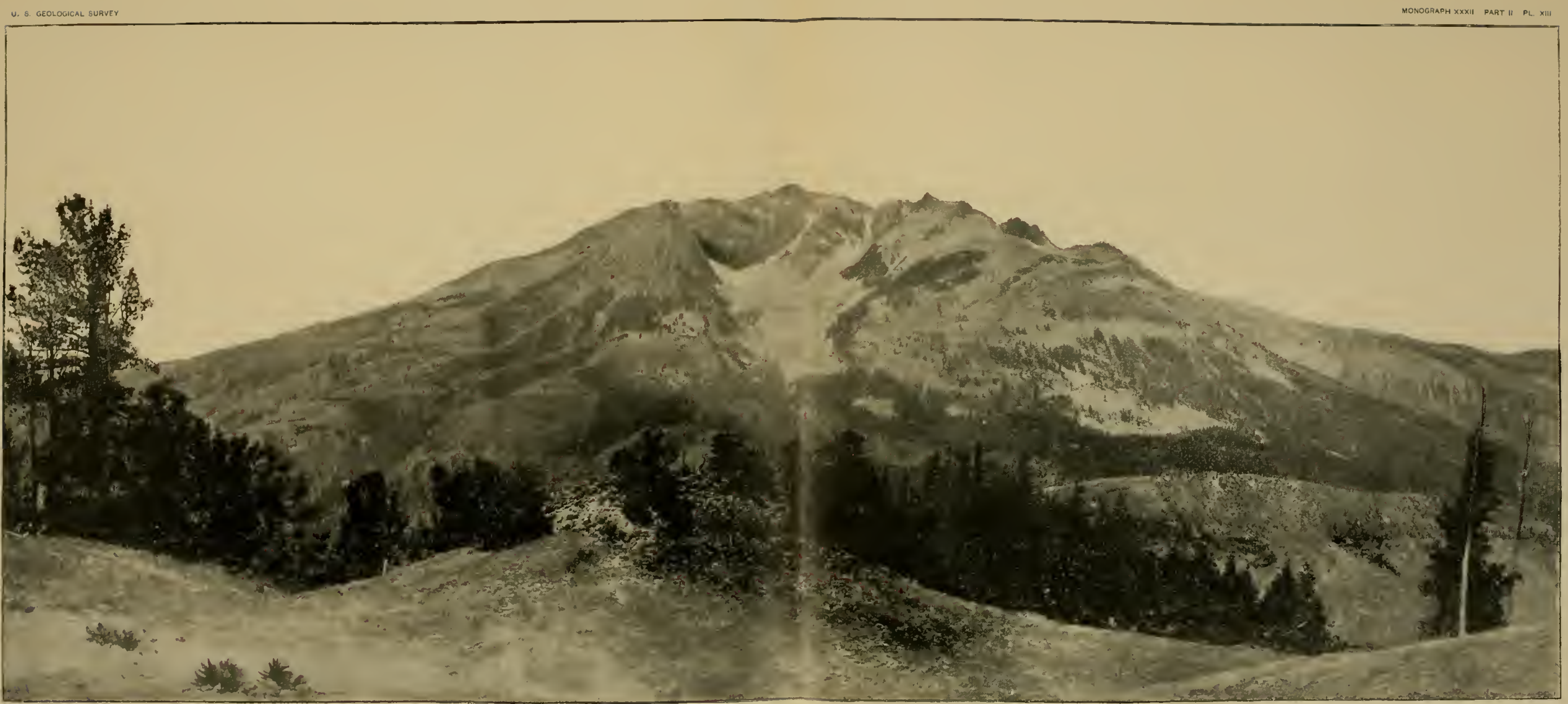



14 



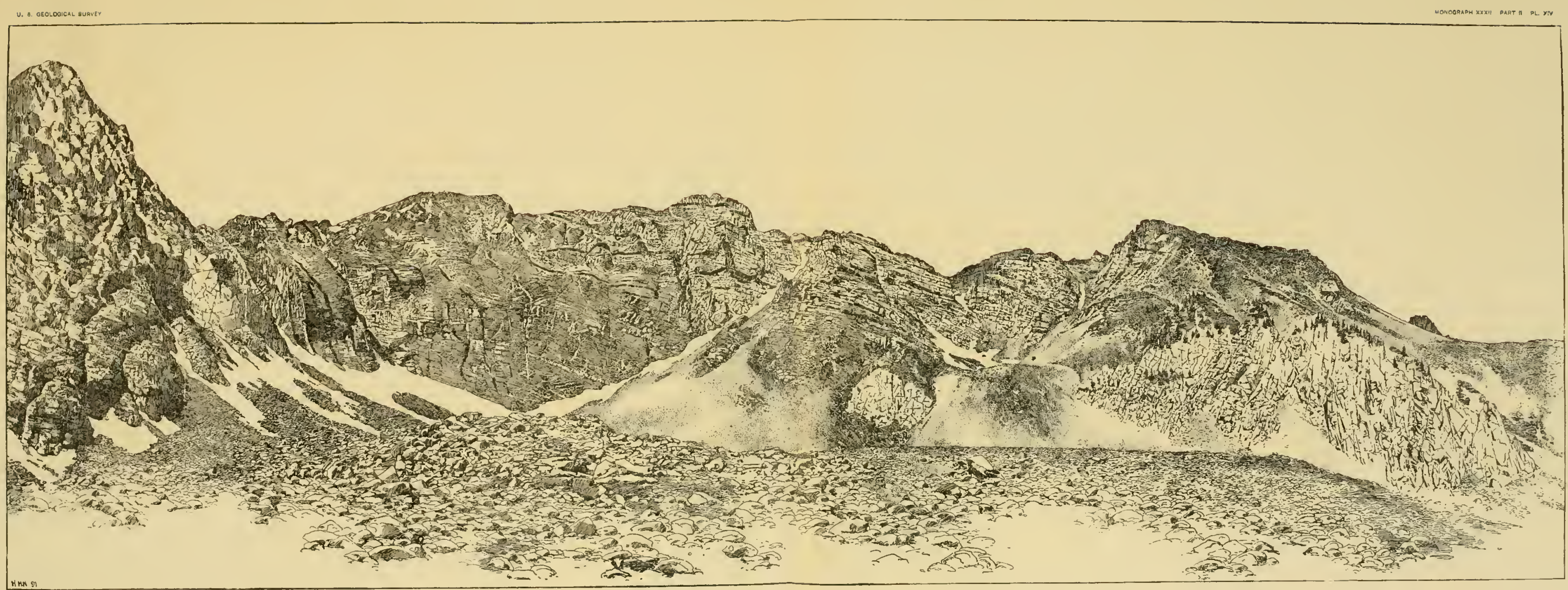



tral portion of the stock is located on the northeastern spur of the mountain, where it is surromederl hy samlstomes. It is well exposerl through a vertical distance of a thomsmol teet. A large apophysis extends up the crest of this spur, forming dark-colored pinnacles, shown on the right-hand side of the panomant. The southwestern end of the stock is exposed in the sontliem wall of the amphitheater (left sirle of the panorama). It is a high werge of arytalline rock, reaching to within a few hundred feet of the top of the clift. 'The crest of the southeastern spur, from an altitucle of 10,000 feet to the summit of the peak, is serrated by numerous narow gulches and rocky points, caused by the nnequal weathering of dikes and of upturned intrusive sheets. The nearly vertical dikes are frequent between the wedge of crystalline rock and the fanlt to the west. They become fewer toward the smmmit of the peak and do not oceur farther northwest. They extend across the sontheastern spur, appearing on its southern slope in walls rising above the black shales. They do not occur at the eastern base of the spur. Where dikes and upturned intrusive sheets are parallel it is difficult to distinguish them from one another. The sheets, however, usually exhibit signs of crushing and displacement. The dikes are more numerous and thicker nearer the area of metamorphism. They are not nore than a mile and a half long, and radiate from a center on the northeastern spur, which is about the location of the stock. They range through $45^{\circ}$ from south to southwest.

Sepulchre Mountain, east of the great fault, located near the line of Reese Creek, consists of andesitic tuff-breccia. With this mass of breccia, which also forms the low ridge south of the mountain, is associated a set of dikes and broad intrusive bodies that have broken np through the breccia. The breccia is 3,000 feet thick, and rests upon Cretaceous and older strata exposed along the northern and eastern bases of the momntain. It is well exposed in bold escarpments on the northern side of the mountain, the southern and southwestern sides being smooth, glaciated slopes with few ontcrops. 'The contrast between the northern and sonthern sides of the mountain is shown in $\mathrm{Pl}$. $\mathrm{XV}$, the view having been photographed from the northwestern spur, looking southeast.

The breccias are but crudely bedded; in places not bedded at all. With them are a few massive lava streams. The whole mass is distinctly volcanic. The dikes in the western part trend mostly in a north and northensterly direction, radiating from the ricinity of Caclse Lake. A few trend east. 
It is probable that, instead of the broad bodies of intrusive andesite and dacite represented on the map, there are a number of smaller bodies of similar rocks intersecting one another, but the data at hand are insufficient to enable their more accurate representation.

In the northwestern spur of the mountain the dikes are well marked, from 5 to 25 feet wide, and not perfectly straight. Some of the intrusive bodies carry inclosed masses and small fragments of black shale, and where the fault plane traverses the massive igneous rock the latter has been crushed into angular fragments, which are cemented together by particles of the same rock, producing a crushed breccia, somewhat resembling the tuffbreccia.

The rhyolite that occurs over the breccia in Glen Creek Valley is part of the great rhyolite sheet, and is of much nore recent date, following the faulting and erosion of the Electric Peak and Sepulchre Mountain masses.

'The accompanying map (Pl. XVI) shows in a simple manner the chief geological features of a limited area embracing the rocks to be described. The sedimentary terranes are colored according to the period in which they were formed, embracing the Carboniferous, Juratrias, and Cretaceons. The sheets of igneous rocks intruded between the strata are not drawn continuous, as they exist, owing to the fact that the data are insufficient. They are more mumerous than represented on the map, and are thinner. The same is true of the dikes.

Although the two mountains were at one time geologically connected and the eruptive rocks were in a sense a geological unit, it will be convenient and profitable to describe them separately at first, and afterwards to consider their correlation.

\section{THE INTRESIVE ROCKS IN ELECTRIC PEAK.}

The intrusive rocks in Electric Peak, west of the fanlt, necurring in the stock and its apophyses and in dikes, form a group of diorites and diorite- and andesite-porphyries of variable composition and structure. They grade into one another by transitions in composition and structure. The coarse-grained granular rocks-diorites-oceur almost wholly within the stock and its larger apophyses, while the finer-grained porphyritic rocks-porphyries-occur in the dikes and smaller apophyses, and in places along the margin of the stock, in contact with sedimentary rocks.

The greater part of the stock is diorite, which varies in structure and 
composition, in some places rapilly and quite irregularly. ILoreover, there are abundant evideneess of the successive eruption through the fissure or conduit of different molten magmas. The porphyries also differ from the main body of cliorite in the chinacter of their phenocrysts-that is, in those minerals which were present in the magnat when it came to rest. Most of the porphyries contain phenocrysts of homblende and hiotite, but none of pyroxene. ln some of the diorites there was an early crystallization of brown hornblende and of pyroxene, but none of biotite. In most of the diorites there is no evidence of any development of phenocrysts. They were magmas free from crystals at the time of their eruption.

In order to understand the relation of the various dikes to the stock rocks, let us consiler the possible course of events that would follow a synclinal fissuring of serlimentary strata when the dynamical action was repeated and when igneons magmas were forced up through the cracks. Evidently the first magma would penetrate all the small crevices connected with the larger fissures and fill them with its material, which would solidify rapidly as narrow dikes. The magma in the large fissure would remain molten much longer, consolidation setting in along the sides and in the narrow portions. A subsequent eruption would force out the molten portion and replace it by other material. It would fill any new crevices made at the time of its eruption. The number of such crevices would probably be smaller toward the end of the series of eruptions than at the beginning. Hence the number of dikes of the later magmas would be smaller. The magma that closed the conduit would in such a case be represented by few dikes. If the final action was a violent explosion, the reverse would be true. At Electric Peak the final eruption was comparatively weak, and is represented by a small body of quartz-diorite-porphyry within the stock and in six or eight narrow dikes trending sonthwest.

These rocks form a very complex group, so intimately connected geologically and exhibiting such gradual transitions in composition and structure from one extreme to another that there appears to be no simple method of describing them or of discussing their varions relationships. For convenience of petrographical deseription they will be treated in the following groups :

I. The greater number of dike rocks and some of the contact forms of the stock, probably older than the main body of the stock. 
II. The main body of the stock, most of its contact forms, and most of the rocks that have broken through it, with some apopliyses, probably contemporaneous with the main mass.

III. The quartz-mica-diorite-porphyry that broke through the stock and also produced some dikes.

1. THE DIKE ROCKS AND CERTAIN CONTACT FORMS OF THE STOCK.

Porphyries.-The porphyries forming most of the dikes, which are from 1 to 25 feet in width, have a generally miform labit. They are dense and aphanitic, filled with small phenocrysts of feldspar and ferromagnesian silicates, mostly homblende and biotite. They have a uniformly speckled appearance, with occasional spots of white feldspar or black ferromagnesian silicates. Variations in habit are due to differences in color, caused by the relative proportions of light and dark colored phenocrysts, and to the nature and amount of the groundmass. The color varies from dark greenish and purplish gray to light gray of different tints. The dike rocks are in some cases fresh and compact, in others decomposed and disintegrated.

In thin sections under the microscope the groundmass of all these dike rocks is found to be holocrystalline, and the phenocrysts are lime-soda feldspar and hornblende, generally with biotite, occasionally with pyroxene. The relative proportions of these minerals vary gradually among the rock bodies, so that the specimens collected may be arranged in the following subdivisions, according to the relative amounts of the ferromagnesian silicates :

TABLE I.-Winerul rariation of the andesite-porphyries of Electric Peak.

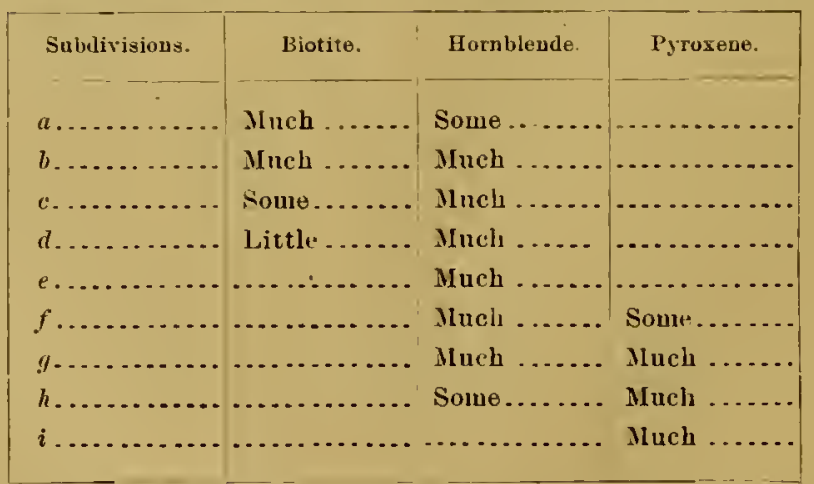

Besides the phenocrysts of biotite there are shreds of this mineral that belong to the period of erystallization of the groundmass. There is a 
graulual variation in the kinds of lime-soda feldspar accompanying that of the ferromiagnesian minerals. But transitions in the possible isomorphous series of homblendes or pyroxenes were not leteeted. 'T'he variation in mineral composition affects the microstructure of the gromudnass, an increase of quart\% being accompanied by an approach to a granular strueture.

Althomgl the coarseness of grain and at the same time the character of the microstructure vary to some extent with the size of the dike, and to a greater extent with the rate at which the mass cooled, for each of the mineralogical subdivisions indicated in the table, still, the conditions under which these various magmas cooled having been quite similar, the variations in the composition and nicrostrncture of the groundmasses of the subdivisions named bear a marked relation to the composition of the rock as a whole and to the rariations in the phenocrysts. This will appear from the following descriptions of the rocks belonging to the subdivisions in Table I:

(a) Gronudnass with micropoikilitic structure, the quartz grains in one case bejng 0.09 mm. to 0.43 $\mathrm{mm}$. in diameter, and containing latlı-shaped microlites of feldspar, gas cavities, and microscopic hornblendes and biotites. Auundant phenocrysts of lime-soda feldspar, 1 to $2 \mathrm{~mm}$. long, and smaller ones of horublende and biotite. The relative proportions of the latter minerals differ in different specimens. As the total amount of ferromagnesian minerals increases, the relative amonnt of hornblende increases. Small amounts of magnetite, apatite, and zircon oceur in all these rocks.

(b) The rocks of the second subdivision are nearly the same as those of the first.

(c) In the third division the micropoikilitic structure is not well marked and grades into one in which lath-shaped feldspar microlites are more prominent.

(d) and (e) Micropoikilitic structure is wanting. The grounduass is composed essentially of lathshaped microlites and grains of feldspar, approaching a fel: like or pilotaxitic structure. This change accompanies a diminution in the amount of quartz. In these five subdivisions pyroxent is entirely absent.

$(f)$ and $(g)$ These are similar to the last two subdivisions in microstructure and composition, lut pyroxene was originally present as phenocrysts and has heen uralitized. Biotite is only present in slireds in the groundmass and does not form phenocrysts.

(h) is represented by a coarser-grained rock, bnt slightly porphyritic. It consists of lath-shaped feldspars $0.4 \mathrm{~mm}$. to $0.7 \mathrm{~mm}$. long, between which is a very small amount of irregnlar grains of feldspar and quartz and ferromagnesian silicates, amplibole, and mica. There is much uralitized pyroxene, which formed the largest idiomorplic crystals.

(i) The rock of this division is like the last in microstructure, but is more porphyritic, with phenocrysts of plagioclase and pyroxene, the latter in part uralitized. Near the contact of this rock with metamorphosed sandstone the pyroxene is almost colorless, different from the varieties common in the pyroxene rocks of this region. It resembles the seconclary pyroxene which has resulted from the alteration of hornblende in other varieties of porphyry in this neighborhood.

The more quartzose porplyyries and the coarse-grained modifications eutting the stock will be described later. 'The microscopical characters of the minerals constituting the dike rocks are nearly the same throughout this series of rocks. 
'The feldspar' in all cases is lime-soda feldspar, with the usual polysynthetic twimning. In sections the forms of the feldspar crystals are latlshaped, rectangular, and tabular, the general habit being tabular parallel to the clinopinacoid. Zonal structure is pronounced. Their range appears to be from labradorite to oligoclase, the former prevailing in the more basic dike rocks, the latter in the more siliceons varieties rich in biotite. Primary inclusions of glass or of other minerals are scarce. Secondary inclusions are more numerous, and are gas cavities or needles of amphibole. The feldspars are more distinctly idlomorphic than the hornblendes, and are sometimes inclosed in hornblendes. More rarely homblende is inclosed in feldspar.

Primary hornblende phenocrysts are generally idiomorphic, but not always. In the prism zone the unit prism (110) and clinopinacoid (010) are well developed. Terminal planes are seldom observed. Twinning is common, parallel to the orthopinacoid (100). The color varies from brown to green, through reddish brown, greenish brown, and light brown, brownish green, and olive gray, sometimes with a reddish tint approaching violet gray. The olive gray and violet gray are common in many hornblendes of these dike rocks. The pleochroism is, then, olive gray $\| \mathfrak{c}$, olive brown $\| \mathfrak{b}$, light brown $\|$ a. The absorption is $\mathfrak{c}>\boldsymbol{b}>\boldsymbol{a r}$. The color is sometimes irregularly distributed in the crystal, the diuker shades being usnally in the center, but zonal structure is rare. In the less siliceous rocks of this series the hominlendes are somewhat darker colored, approaching chestnut brown. There are no characteristic inclusions. When associated with biotite the two minerals are so intergrown as to suggest synchronons crystallization. In some cases biotite is inclosed as a secondary mineral. The hormblende is in various stages of preservation, sometimes fresh, sometimes partially or completely altered. The usnal alteration products are chlorite and epidote, with calcite and quartz. Sometimes compact hornblende has been changed to fibrous, "reedy" amphibole.

Biotite forms six-sided plates, occasionally twinned parallel to the cleavage plane. It is dark reddlish brown with normal absorption. It is sometimes partially bleached, the light-colored spots containing bundles of rntile needles. It may be completely altered to chlorite and epidote, with calcite and quartz. Pyroxene was not found in an unaltered condition, and was only identified by its form. The iron oxide is probably magnetite, with 
15 



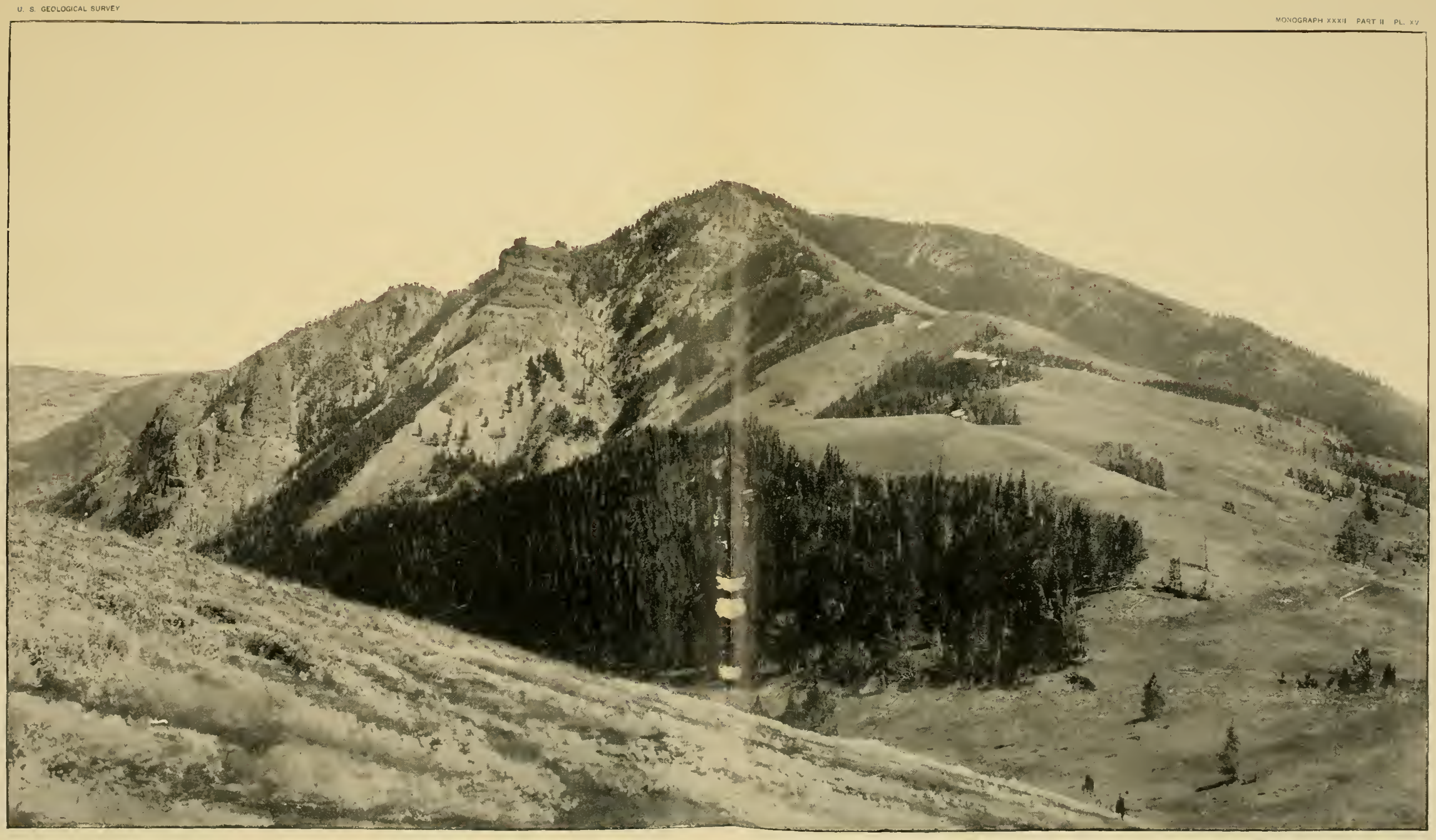



16 



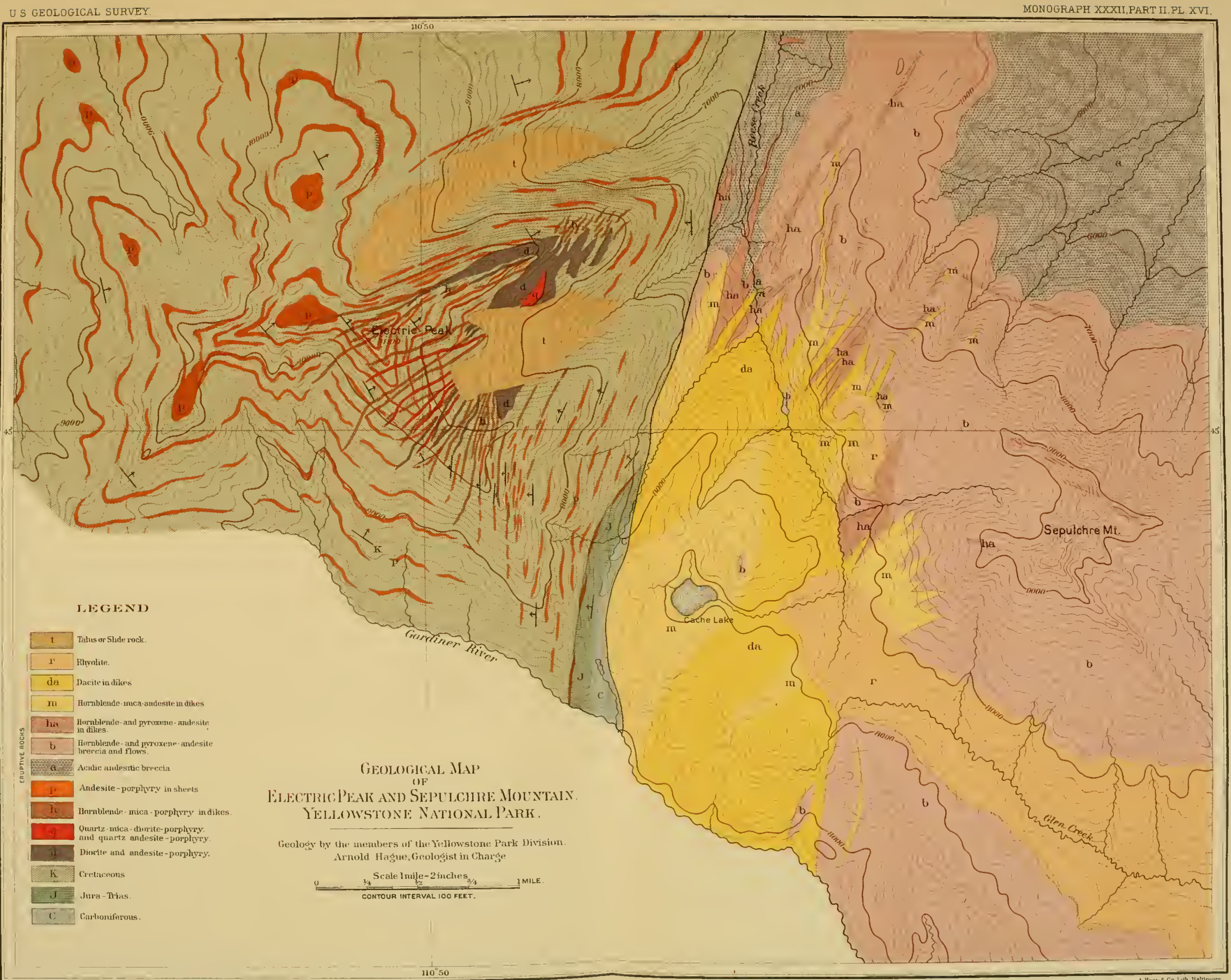



some titunim. Apatite is more abuntant in the more micaceous rocks. The same is true of zireon

Secondary lyroxene ocru's in porphyries within the metamorphosed sandstones, apparently derived from hornblende. 'The feldspar and biotite phenocrysts are quite fresh, and the general microstructure of the groundmass is normal for a hornblende-mica-andesite-porphyry. The augite substance is colorless and compact, with pyroxenic cleavage. It oceupies spaces with hornblende outlines in cross section, the plane of symmetry for both minerals being the same No pyroxene outlines were observed. Its refraction and double refraction are high, and the extinction angle is large. It sometimes forms irregular grains and minute aggregations not immediately comnecterl with a hornblende crystal. In some cases the homblende is not entirely changed to pyroxene. The process by which this alteration took place has not been made ont.

\section{THE STOCK ROCKS AND APOPHYSES.}

The diorite forming the body of the stock varies in the size of its erystals. Most of it is medium grained, consisting of clusters of feldspars, and others of ferromagnesian minerals, from $5 \mathrm{~mm}$. to $2 \mathrm{~mm}$. in diameter, and smaller. The coarsest is shown in fig. 1 of Pl. XVII, photographed natural size. The size of the component crystals is smaller than that of the elusters, and is from $1 \mathrm{~mm}$. to $2 \mathrm{~mm}$. A medium-grained form is shown in fig 2 of Pl. XVII. The grain sinks to fine grained and to microcrystalline. The rariation in grain is gradual in some parts of the mass and rapid in others. The finer-grained portions are darker colored. While a gradual transition from coarse to fine grained and from light to dark-colored rock can be traced in some places, the two extremes are in juxtaposition in others, with a sharp line of demarcation between, veins of the light-colored rock cutting the dark colored. In places also there are fragments of various modifications of the diorite inclosed in diorite, which appears to be a later intrusion.

The diorite also varies in mineral composition. For the most part the ferromagnesian and the nonferromagnesian minerals are in about equal proportions. In places the former preponderate. In other parts of the rock the other minerals are in excess. The minerals recognized megascopically are lime-soda feldspar, hornblende, and biotite. In places biotite is MON XXXII, PT II-7 
abundant. The lighter-colored varieties of the rock exhibit quartz. The finest-grained porphyritic forms show only feldspar and pyroxene phenocrysts, but most of the rock is evenly granular, with no porphyritic structure.

When exanined microscopically, the constituents are found to be hypersthene, augite, hornblende, biotite, lime-soda feldspar, orthoclase, quartz. These are not all in every modification of the rock. Their range of variation is indicated in Table II, in which $a$, $b$, etc., represent different mineralogical modifications of the rocks.

TabLe II.-Mineral variation of the diorites at Electric Peak.

\begin{tabular}{|c|c|c|c|c|c|c|c|}
\hline & Pyroxene. & Hornblencle. & Biotite. & Labradorite. & Oligoclase. & Orthoclase & Quartz. \\
\hline$a \ldots$ & Much ... & . . . . . & Little... & Much ... & Some ... & & Little. \\
\hline b... & Mucb... & Much ... & Some. & Much & Some & & Little. \\
\hline$c \ldots$ & Little... & Much... & Much. & Some ... & Somo ... & Little... & Some. \\
\hline$d \ldots$ & $\ldots \ldots \ldots \ldots$ & Much ... & Much .. & Some ... & Some ... & Little... & Much. \\
\hline e... & ... & Some ... & Much .. & Little... & Much ... & Little... & Much. \\
\hline$f \ldots$ & & LittIe.. & MIuch .. & $\ldots$. & Much ... & Little... & Much. \\
\hline$g .$. & & & Much .. & $\cdots$ & Much & Some ... & Much. \\
\hline
\end{tabular}

The diorite is traversed by reins or dikes of equally coarse-grained, lighter-colored diorite, sometimes approaching granite in composition. In one case the rock is fine-grained granite (fig. 1 of Pl. XVIII). In places there are narrow seams of feldspar and quartz, which grade into rock containing some biotite and hornblende, and finally into quartzose diorite. Such seams of feldspar and quartz appear to be the extremities of fissures or cracks in the early solidified magma, into which the fluid portion of subsequently intruded magma has been forced. They are of truly igneous origin, and consist of the most liquid portion of the magma, or that part which is the last to crystallize. Segregations rich in ferromagnesian minerals are abundant in some parts of the rock.

The marginal portions of the diorite core are different in different places. In some there are porphyry-like modifications, indicating the more rapid cooling of the margin of the mass. In other places the coarse-grained rock is directly in contact with the wall of the conduit, showing no indication of chilling. In the first case the surrounding rocks must have been cooler than the igneous magma. In the latter case they must have been 
equally hot, or nearly so, indicating the previous heating by earlier magnas. For convenience of description these rocks will be subdivided into the following groups:

II $a$. Varieties in which the dark-colored and the light-colored minerals are in nearly the same proportions.

IIb. Varieties in which the light-colored minerals are in excess and the amount of quartz is moderate.

Ilc. Like II $b$, but with much quartz.

The dark-colored uinerals include ferromagnesian minerals. The others are feldspar and quartz.

II . VARIETIES IN WIICH THE DARK-COLORED AND LIGHT-COLORED MINERALS ARE NEARLY EQUAL.

This group includes most of the stock rocks, and is the most basic. It embraces a series of varieties that grade into one another chemically, mineralogically, and structurally.

As regards the degree of crystallization, or the size of the grain of the rocks, they may be classed under 27 different grades, from fine to coarse. But no attempt has been made to establish a scale of uniform degrees. The arrangement is shown in Table VIII, Column II $a$. At the coarsestgrained end of the series are the diorites of the stock. Their structure is hypidiomorphic granular. Some of the mineral constituents have their proper erystallographic outline, but most of them are irregularly shaped.

The constituents are lime-soda feldspars, hornblende, augite, hypersthene, biotite, and quartz, with magnetite. The feldspars are more nearly idiomorphic than the other constituents. They are rectangular to lathshaped, with ontlines modified by the juxtaposition of other minerals. Quartz forms cementing grains, wholly allotriomorphic. Homblende, pyroxene, and biotite seldom exhibit crystal boundaries, and penetrate one another intricately. Magnetite is mostly found in the ferromagnesian silicates. Apatite is colorless and in crudely formed crystals. Zircon is rare.

The diorites of the seven highest grades of crystallization, Table VIIL, Column II $a$, have a structure similar to that just given, but vary in the relative abundance of the constituent minerals, as shown in Table V. In the coarsest form the feldspars are from $2.5 \mathrm{~mm}$. to $1 \mathrm{~mm}$. long, and the quartz grains $0.25 \mathrm{~mm}$. in diameter. The structure is shown in Pl. XIX, 
fig 2. In the seventh grade from the coarsest end the feldspars range from $1.25 \mathrm{~mm}$. to $0.5 \mathrm{~mm}$., and the quartzes are about $0.12 \mathrm{~mm}$.

As the grain becomes smaller, idiomorphic forms are more numerous, especially of hornblende and biotite. And these are more idiomorphic when quartz is more abundant, since they are always idiomorphic with respect to this mineral (Pl. XIX, fig. 3). A gradual change of this character can be followed to grade 26 of the table, where the average size of grain is $0.23 \mathrm{~mm}$. Here there is a slight tendency to porphyritic structure, which does not show megascopically. Porphyritic structure becomes noticeable in grade 24 (Pl. XIX, fig. 4), and still more so in grade 14. This has a groundmass composed of grains of feldspar and quartz with poorly defined outlines, besides microscopic pyroxenes and magnetites. The phenocrysts are lime-soda feldspar, hypersthene, angite, and some irregular patches of biotite. There is no hornblende. The finest-grained forms of these rocks, grades 17 to 13 , have similar structures, and might be called pyroxeneandesite-porphyry.

This group of rocks presents a continuons series from five-grained andesite-porphyry, with phenocrysts of hypersthene and plagioclase, to coarse-grained hornblende-mica-diorite with a variable percentage of pyroxene. In two instances the transition is represented by specimens collected within short distances of one another. Thus, Nos. 268 to 271, 279 , and 287 (Pl. XIX, fig. 3) were 1 foot apart in a continuous rock mass, and No. 266 is from the same mass. Nos. 277, 278, 281, 284, and 289 are from one rock mass exhibiting a gradual change of grain through a distance of 4 feet. No. 267 is from the same mass.

The microscopical characters of the constituent minerals are much the same throughout the series, but there are certain features that vary with the coarseness of grain of the rock.

The feldspars are mostly labradorite, and to a less extent andesine. The idiomorphic crystals and the zonal portion of the allotriomorphic ones increase in size as the grain of the rock becomes larger. Their twin lamellæ become broader, the number of inclusions of pyroxene and other ferromagnesian minerals and of magnetite diminish with increasing grain, and the abundance of minute dots and needle-like inclusions increases. The feldspars, forming inregular grains in the groundmass of the andesiteporphyries, crystallize as a border around the idiomorphic feldspars in the 


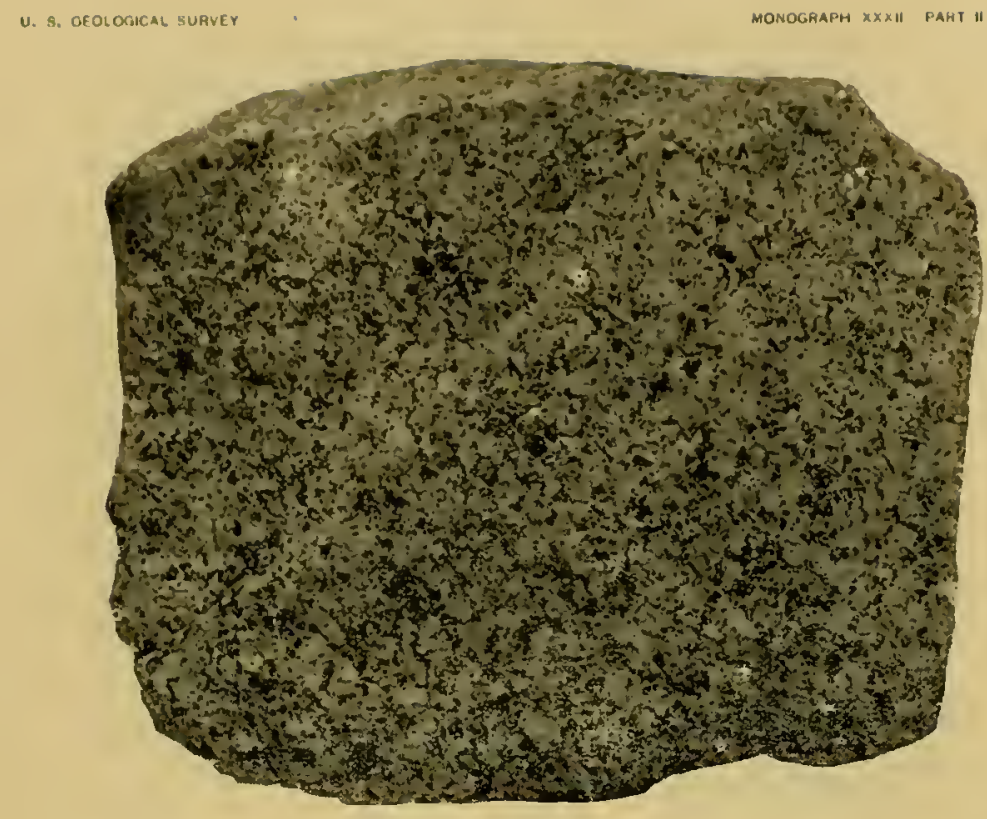

A.

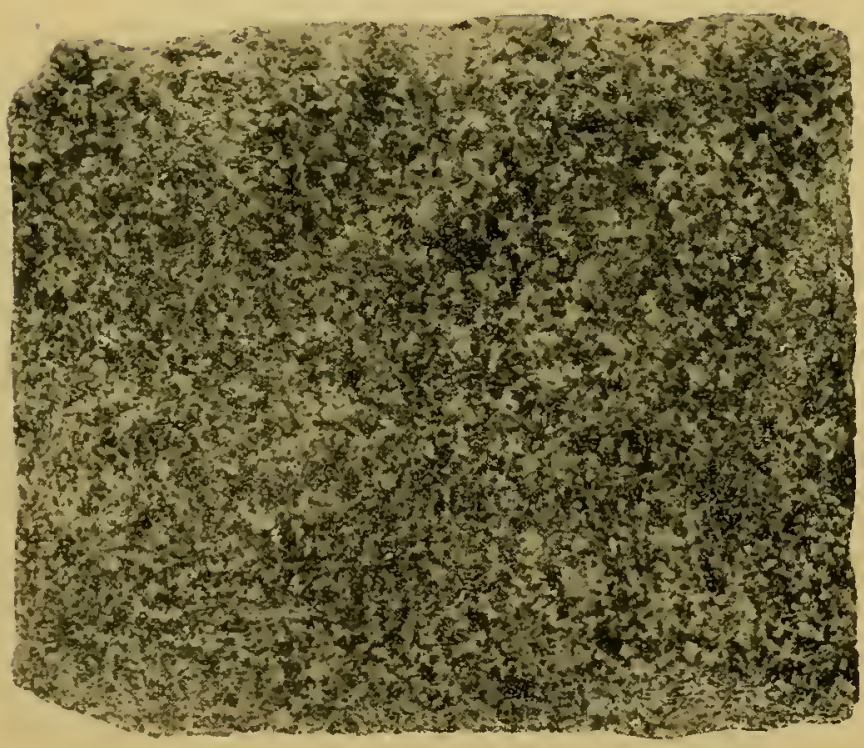

$B$.

DIORITES.

A. Coarse grain; $B$. Medium grain 



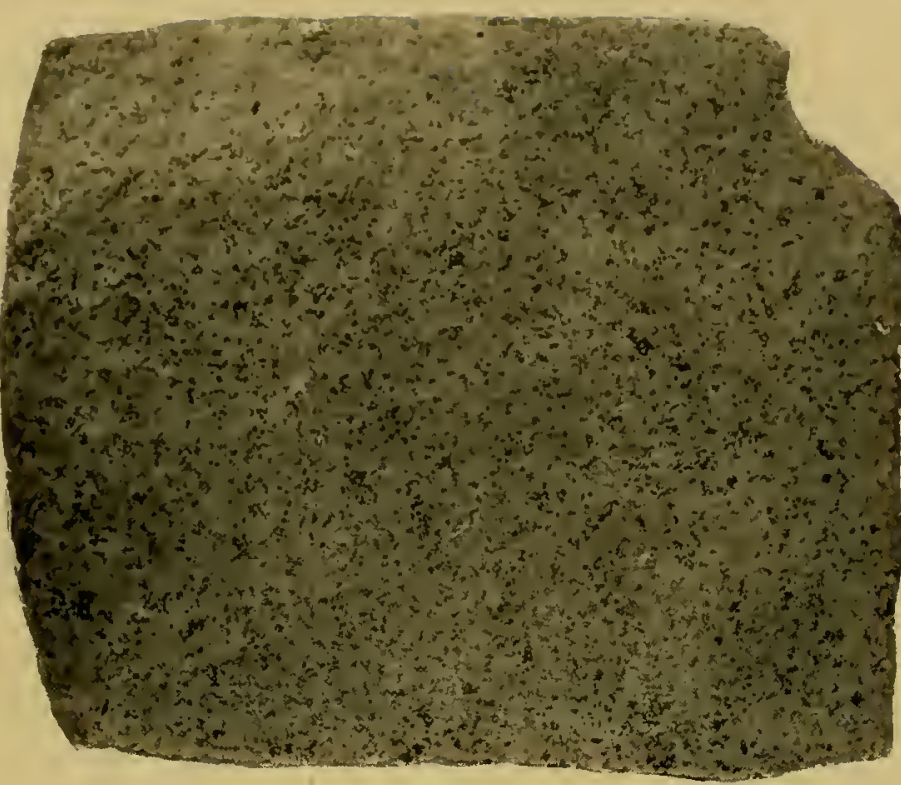

A. GRANITE

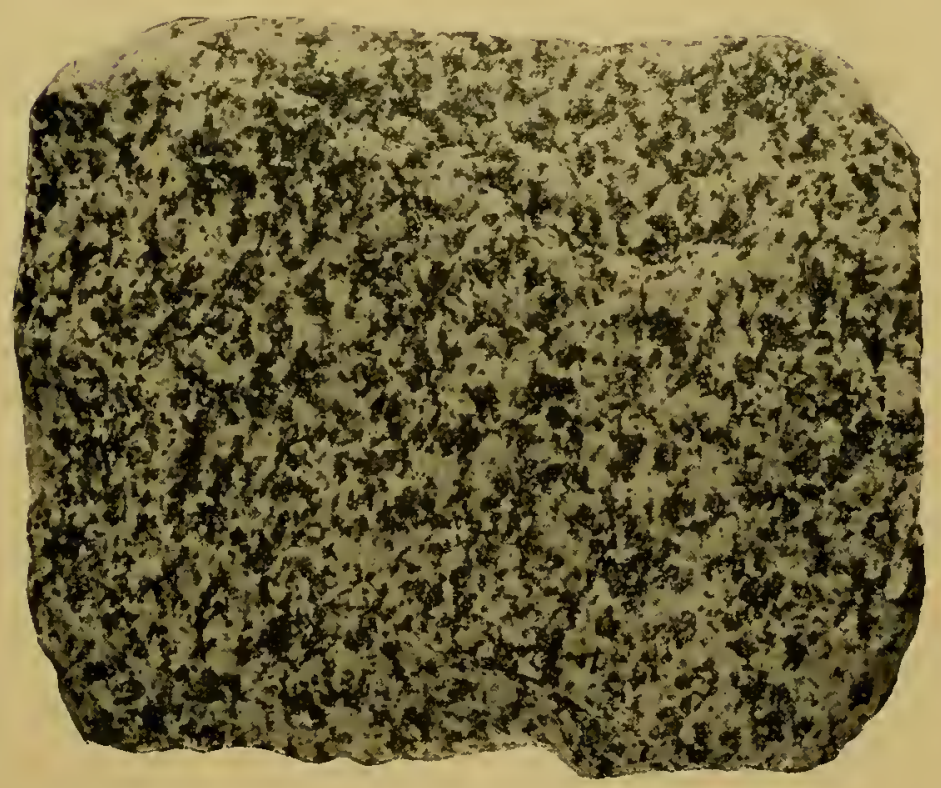

73, DIORITE-PORPHYRY 

coarser-graned varieties. The border is allotriomorphic and more alkaline than the center. Orthoclase is recognizable in the coarsest-graned rocks.

Quartz necurs in allotriomorphic crystals, nearly contemporaneous with the orthoclase, which is also allotriomorphic. 'T'le gas and fluid inclusions in the quartz increase in number and in size with the size of the quartzes aurl with the grain of the rock.

Hyperstlene and augite form idiomorphic and allotriomorphic individuals in the porpliyries. They are much more irregularly shaped in the coarsest-grained rocks, and are in larger individuals. When grown together, the hypersthene is always the older, being inclosed by the augite; rarely they mutually penetrate one another, as though their crystallization was synchronous.

Primary brownish-green hormblende occurs in a similar manner. It frequently surrounds the pyroxenes more or less completely, and is usually the younger growth. Occasionally it appears to be contemporaneous with augite. It is more abundant as the grain of the rock becomes coarser. Dark-brown horublende sometimes is present as an independent crystallization.

Biotite is mostly in allotriomorphic crystals. The ferromagnesian minerals occur isolated from one another to some extent, but are generally intergrown in the most intimate mamer. Though there is an apparent order in the time of their erystallization, beginning with hypersthene and augite and ending with biotite, still in most cases they have grown synchronously. 'This is specially true in the coarser-grained rocks.

Magnetite has two periods of crystallization in the porphyritic rocks, but only one in the uniformly granular ones, the size of the crystals increasing and their number diminishing. Apatite forms abundant minute idiomorphic crystals in the finer-grained rocks, and fewer, larger, poorly shaped individuals in the coarser-grained rocks. Zircon is more noticeable in the coarser rocks and is in larger crystals.

All of these variations of character plainly indicate that the physical conditions that brought about the variation in the texture of the rocks affected the crystallization of the earliest-forming minerals, and since these conditions were localized in the stock, it follows that portions of the igneous magma were completely liquid when they arrived in this part of the conduit.

The intergrowths of green hormblende witl pyroxene, which are the results of primary crystallization in these diorites, find their analogies in 
similar intergrowths of homblende and pyroxene in unaltered, often pumiceous, glassy lavas. They are to be distinguished from the formation of hornblende from pyroxene by secondary processes of metamorphism, which may also lead to the production of compact green hornblende. The transformation of both pyroxene and compact hornblende into fibrous amphibole has taken place in some of these rocks to a limited extent. They are in general very fresh and unaltered.

II b. VARIETIES IN WHICH THE LIGHT-COLORED MINERALS ARE IN EXOESS, BUT IN WHICH QUARTZ IS NOT EXCESSIVE.

These include the more feldspathic facies of the diorite, whether within the main body, on its margin, or as dikes or veins within the mass. There is considerable quartz and a range of ferromagnesian minerals that connect them with the preceding varieties. The finer-grained forms approach the dike rocks in microscopical characters, and are possibly connected with them geologically.

Hornblende, pyroxene, and biotite are similar to the same minerals in the main body of diorite, and exhibit the same relations to one another when in juxtaposition, but vary more widely in their relative proportions, as shown in Tables V and VI. The feldspars are somewhat more alkaline, and have a slightly different habit from those in the main diorite. The quartz plays a somewhat different rôle. Its crystals occasionally possess a crudely idiomorphic form, and because of their greater abundance the microstructure exhibits more of a granitic appearance than in the less siliceous diorites.

The coarsest-grained variety (313) consists of broad plagioclase feldspars from $1 \mathrm{~mm}$. to $2 \mathrm{~mm}$. long, with numerous sinall quartz grains located along the line of junction of the feldspars; hornblende and biotite occur in irregularly shaped anhedrons, the hornblende being in part phenocrystic. Magnetite and apatite are also present. When the grain of the rock becomes smaller the feldspars stand out more prominently in a fine-grained groundmass. The porphyritic texture is quite pronounced in specimen 308 from near contact with sedimentary rocks. Its grade of crystallization is 27. The large feldspars and homblendes are idiomorphic. The crystals composing the groundmass exhibit an approach to idiomorphism, especially the feldspars, and to some extent the quartzes. This structure is . shown in fig. 1, Pl. XX. 
II C. VARIETIES WITII AN EXCESS OF LIGIT-COLORED MINERALS, IN WIICH QUARTZ IS AIIUNDANT.

These include very quartzose and very feldspathic varieties of diorite, approaching granite in composition and structure (320 to $323,275 a$ and 286a). 'They are mostly coarse-graned dikes or veins cutting the diorite mass. 'They correspond to grades 37 and 40, Table VIII. In this group are also placed certain apophyses (314-319) from the stock that penetrate the sedimentary rocks.

These rocks are very similar to those of Group IIb, but contain more quartz, and the feldspars appear to be still more alkaline. Oligoclaseandesine is the predominant feldspar, but there is some labradorite and some orthoclase. Orthoclase is very abundant in one modification of the rock, which is in fact a fine-grained granite. It forms a large body on the northeast spur of Electric Peak, in the rugged mass of dark-colored diorite needles. Its crystallization is about grade 35, and its microstructure approaches panidiomorphic, as shown in Pl. XX, fig. 2. The other varieties are more properly quartz-mica-diorites. In the coarsest-grained forms the ferromagnesian minerals are biotite and horublende, with no pyroxene, and with biotite in excess of hornblende. The microstructure of one of the coarser-grained varieties (321), grade 37, is shown in Pl. XX, fig. 3, and that of the finest-grained one (314), grade 19, in Pl. XXI, fig. 1 . The latter is a pronounced porphyry.

II $c^{\prime}$. Certain narrow apophyses in the immediate vicinity of the stock are rich in quartz, but contain more calcic feldspar and a variable amount of pyroxene, besides biotite and hornblende. 'They appear to be quartzose facies of the pyroxene-diorite of the stock, and have not been found cutting the main body or forming dikes at any considerable distance from the stock. Their mineralogical composition is indicated in Table VII by the first six numbers (314 to 319 ). With increase of quartz the microstructure becomes more evenly granular.

\section{QUARTZ-MICA-DIORITE-PORPHYRY.}

The last magma erupted through the Electric Peak conduit formed quartz-mica-diorite-porphyry. It is a broad wedge-shaped mass cutting the main diorite, narrower toward the north, and sending ont dikes into the sedimentary strata to the southwest. The rock is light gray to white, with 
abundant small phenocrysts of feldspar, quartz, and biotite. Its habit is like that of the other porphyries, and is produced by the great number of small phenocrysts. The groundmass is hardly recognized megascopically, except in the finest-grained varieties. The coarsest varieties occur within the stock; the finest-grained ones in the narrow dikes cutting the sontheast spur of Electric Peak. Their grades of erystallization are shown in Table VIII, Column III.

The rock is intermediate between quartz-diorite-porphyry and graniteporphyry. It varies slightly in mineral composition and in chemical composition, and the extremes would be classed under these two kinds of rocks. Besides biotite there is a little hornblende in some cases, but it is almost entirely absent from most of the rock. The biotite is partly chloritized, and the feldspars are more or less altered.

In the finest-grained varieties the groundmass is microcrystalline, approaching microcryptocrystalline. The phenocrysts of feldspar, quartz, and biotite are sharply defined. The feldspar is mostly oligoclase, with possibly a little orthoclase. The quartzes are smaller than the feldspars. Most of them exhibit, in thin sections, straight-edged crystallographic outlines. Others are rounded more or less completely. Both forms occur together in the same rock section. In some cases the outlines are irregular becanse of bays or pockets of groundmass let into their sides. These occur in otherwise straight-edged and in rounded quartzes. They appear to be original inclusions rather than the results of corrosive action of the magma on idiomorphic crystals. There are bipyramidal inclusions of glass and others of gas and fluid. In coarser-grained groundmasses the ontlines of feldspar and quartz phenocrysts are not so sharply defined, but are jagged. Around some quartzes there is a narrow border of groundmass, part of which extingnishes light in mison with the quartz phenocryst, showing that the quartz in this part of the groundmass has one orientation parallel to that of the quartz phenocryst.

The corresponding rock within the stock is much coarser grained, with larger and more numerons phenocrysts, so crowded together as to leave but little groundmass. The feldspar phenocrysts are similar to those in the finergrained rocks, but those of quartz gradually lose their idiomorphic shape as the groundmass becomes coarser, and, extending out among the smaller crystals of feldspar, take on a very irregular outline (Pl. XX, fig. 4). There 

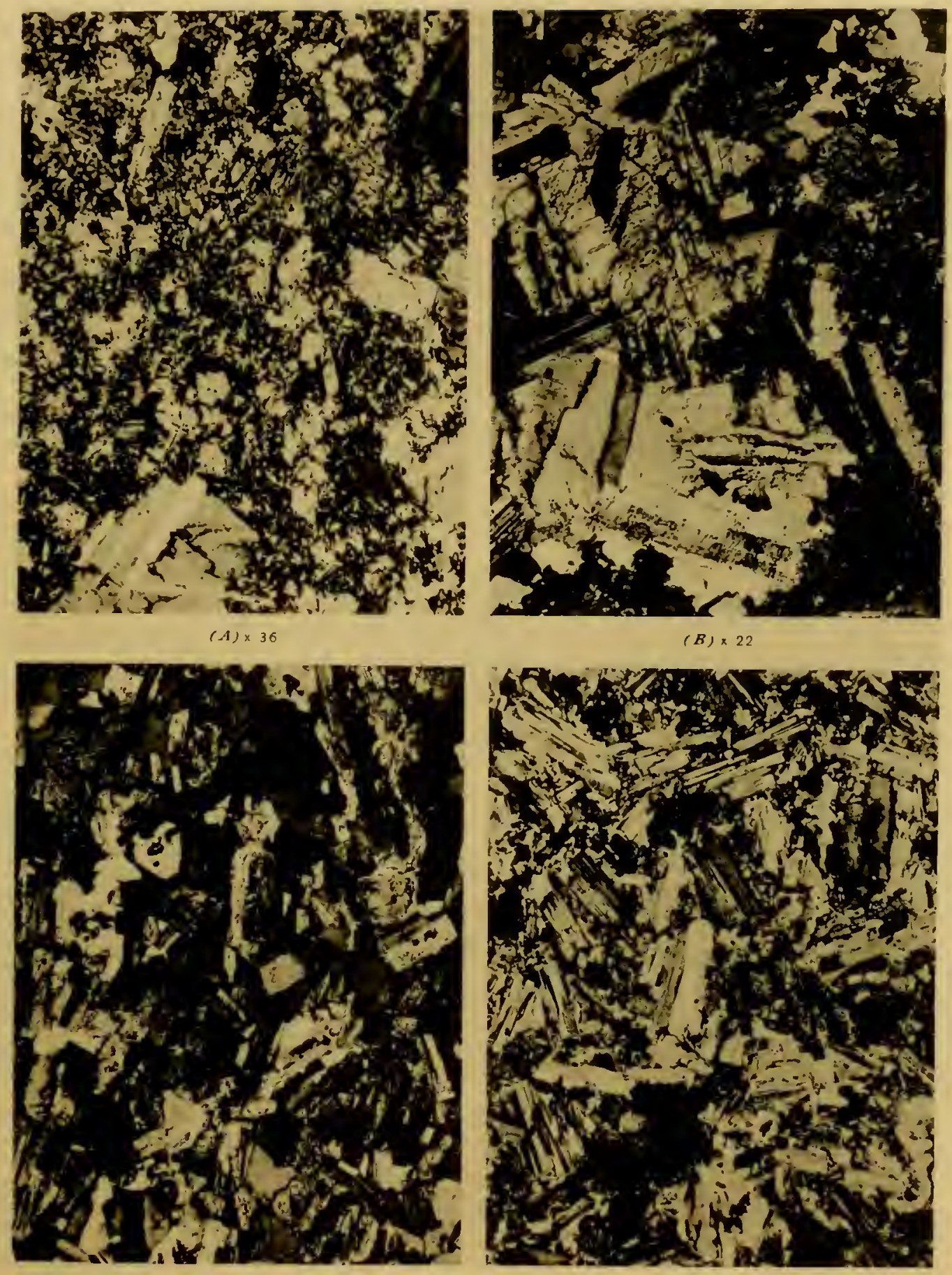

(C) $\times 28$

(D) $\times 29$ 


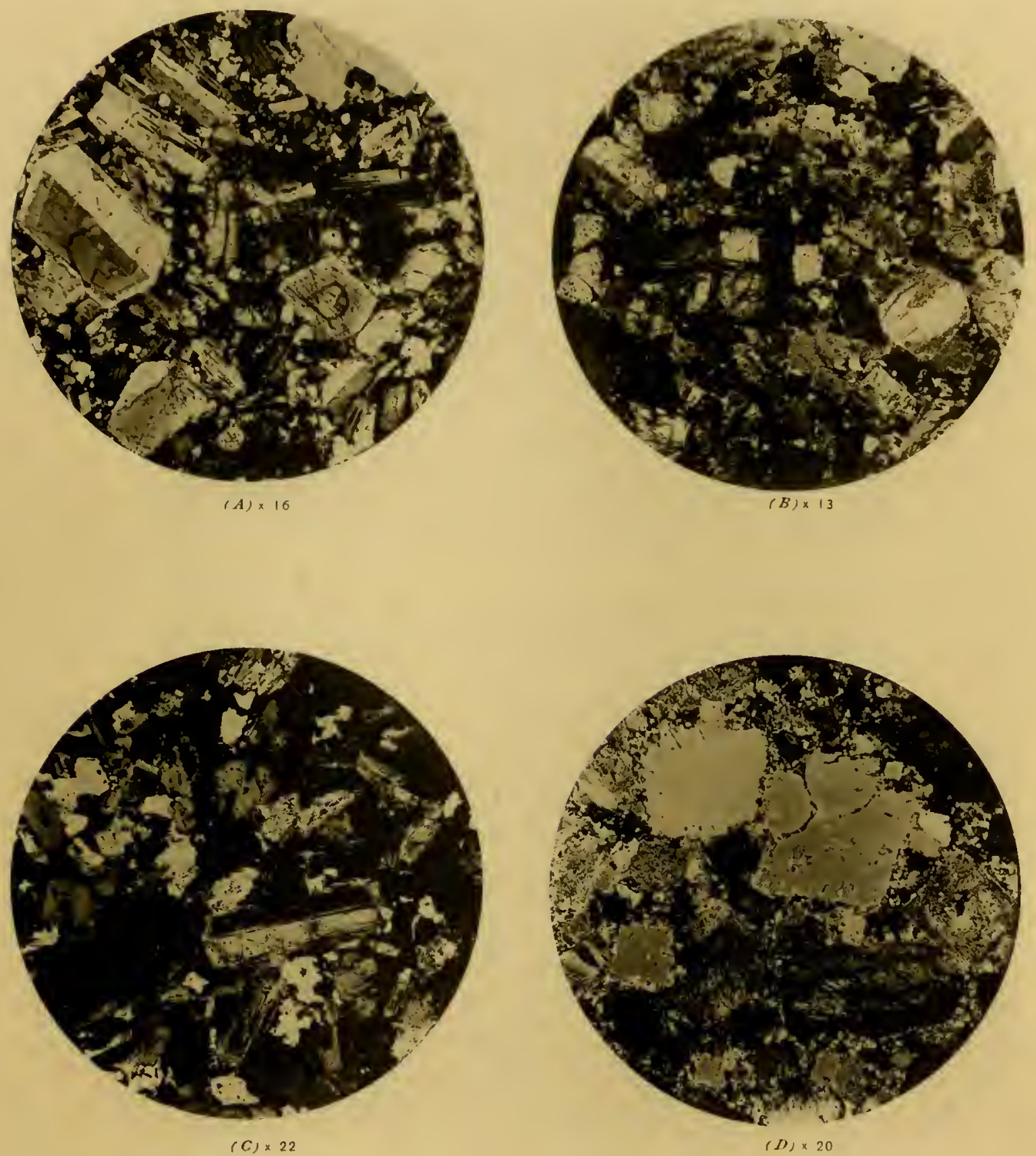



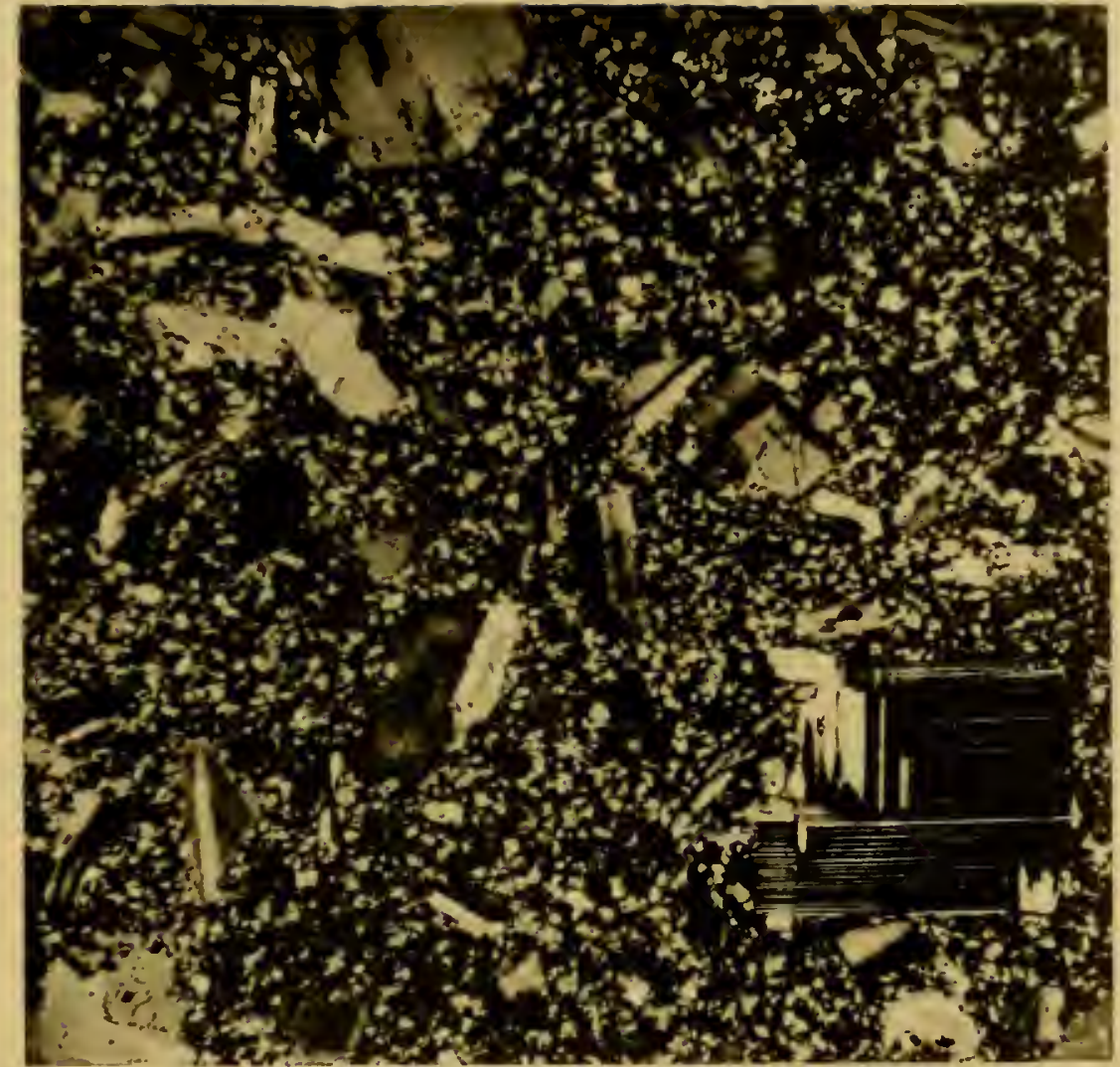

(A) $\times 35$

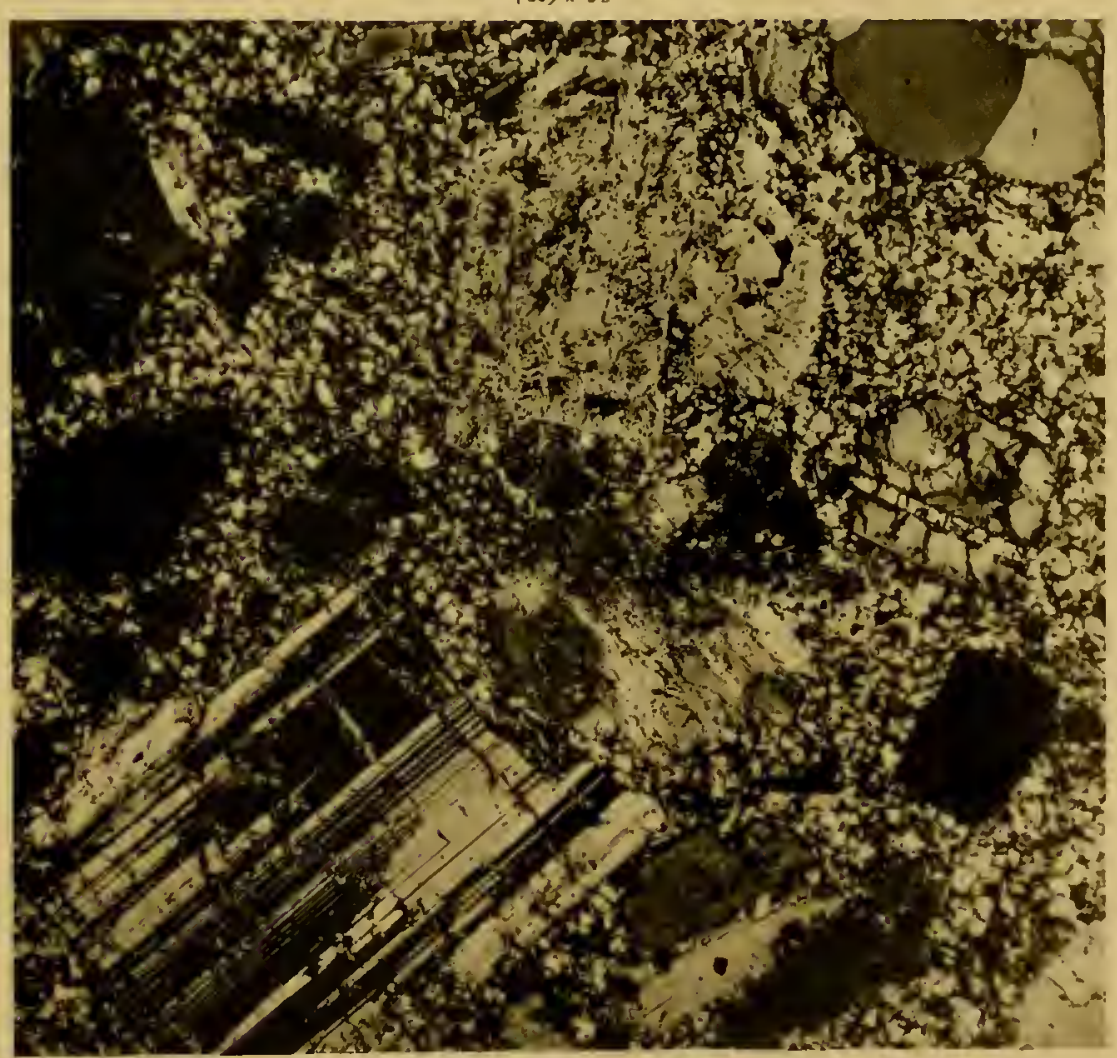

(B) $\times 33$

PHOTOMICROGRAPHS OF DIORITE-PORPHYRY AND DACITE 

is a gradual transition from the sharply idiomorphie quartz phenocrysts of the fine-grained porphyries to allotriomorplic erystals, such as oceur in granites and in the coarser-grained porplyyries. 'This shows that the porphyritical quartzes were the last phenocrysts to crystallize, and that their crystallization in the coarser-grained varieties continued into the period of erystallization of the gromdmass without evidence of interruption.

\section{GENERAL CONSIDERATION OF THE MINERAL AND CHEMICAL COMPOSITION OF THE INTRUSIVE ROCKS IN ELECTRIC PEAK.}

MINERAL COMPOSITION.

In order to convey an idea of the variations in mineral composition of the rocks just described, recourse has been had to tabular statements of the relative abmndance of the constituent minerals in the different groups of rocks. The tables serve not only to condense into very compact space many data, but place them in such form that they may be comprehended at a glance, while at the same time the formal arrangement of the data often conveys idens of transitional relationships not easily expressed otherwise. The same is true of data relative to degree of crystallization, which will be explained later on.

In the dike rocks constituting Gronp I, and in the dikes of Group III, the mineral variations most readily noted affect the phenocrysts, and more particularly those of the ferromagnesian minerals and quartz. Variations in the feldspars may be recognized, but with more diffieulty, and may be expressed in general terms by saying that those in the more basic rocks are richer in calcinm, while those in the more siliceons rocks are richer in sodium, and that the transition between the extremes appears to be gradual. The variations in the phenocrysts other than the feldspars are indicated in Table III, in which the first column contains symbols of mineralogical subdivisions to be used for correlation in subsequent tables. In this table no account is takell of the degree of crystallization. 
TABLE III.-Wineral variation in the dike rocks of Electric Peak.

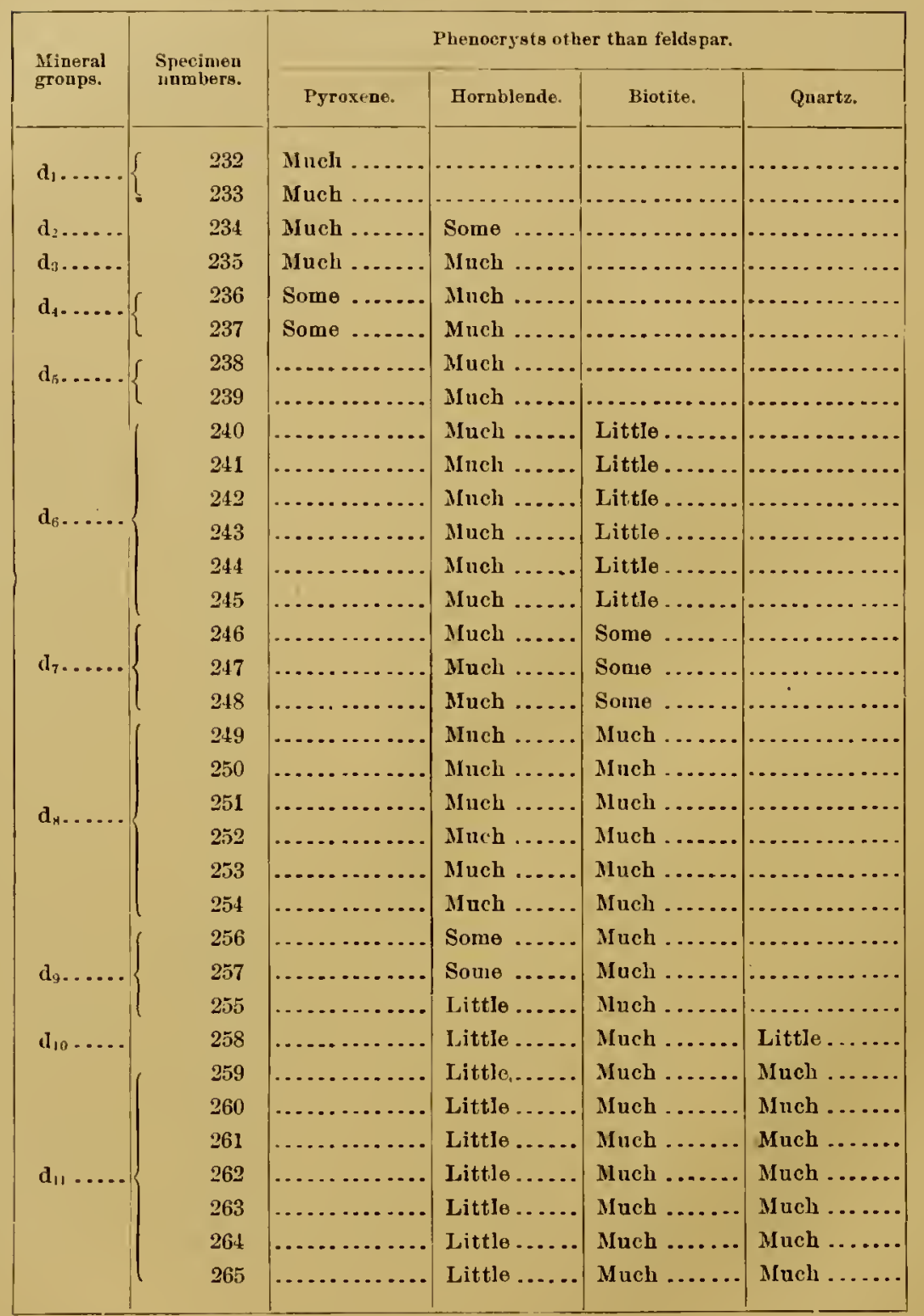

The transition indicated in the table is from acidic rocks with much porphyritical quartz and biotite and very little homblende, through intermediate rocks with much porphyritical biotite and homblende, to basic rocks with pyroxene and little or no porphyritical hornblende or biotite, but which, being more coarsely crystalline, contain some biotite as a product of the final consolidation of the groundmass, which is related in its occurrence 
to the biotite in the diorite. 'The gradual nature of the tramsition from one extreme to the other is apparent at a glance.

The impossibility of consilering certain rocks as definite types with which to compare other rocks in the region is also evident when it is observed that the mineralogical rariation takes place within certain limits in one rock body (Nos. 247, 250, 255, 256, and 257 are from the same dike), and that what appears to be a mineralogical modification of one particular rock body is the cliaracteristic combination of another, and its modification is something different. Field observation shows that in this locality the greater number of dikes are composed of rocks with variable percentages of porphyritical hornblende and biotite, and that the other varieties are less numerous. In another region other varieties predominate. The chemical variations which are indicated by the silica percentages range from $57.12 \mathrm{in}$ subdivision $d_{3}$ to 61.85 in $d_{7}$, and probably reach 69.00 in $d_{11}$. They indicate a correspondence between the mineralogical and chemical variations for this group of rocks.

TABLE IV.-Grades of crystallization of the dike rocks of Electric Peak.

\begin{tabular}{|c|c|c|c|c|c|c|c|c|c|c|c|}
\hline \multirow{2}{*}{$\begin{array}{c}\text { Grades } \\
\text { of cristal- } \\
\text { lization. }\end{array}$} & \multicolumn{11}{|c|}{ Miveralogical grouping indicated in Table III. } \\
\hline & $d_{1}$ & $d_{2}$ & $d_{3}$ & $d_{4}$ & $d_{\delta}$ & $d_{6}$ & $d_{7}$ & $d_{B}$ & $d_{9}$ & $a_{10}$ & $d_{11}$ \\
\hline $6 \ldots$ & $\ldots$ & & . . . . . & ......... & & 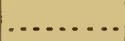 & & - & & & 259 \\
\hline $7 \ldots$ & ...... & ...... & ..... & $\ldots .$. & $\ldots$. & 240 & & $\ldots$ & $\ldots$ & $\ldots$ & 260,261 \\
\hline $8 \ldots$ & $\ldots .$. & & ...... & $\ldots .$. & 238 & $\ldots \ldots . .$. & & - & $\cdots$ & $\ldots \ldots$ & 262,263 \\
\hline 9 & $\ldots$ & $\ldots .$. & $\ldots . .$. & ..... & $\ldots .$. & 241,242 & . . . . . & . . . . & ...... & 258 & 264,265 \\
\hline $10 \ldots$ & $\ldots .$. & & ..... & $\ldots$. & $\ldots$. & 243 & 246 & … & - . . . . . . & $\ldots$. & $\ldots . .$. \\
\hline $11 \ldots$ & & & . . . . . & . . . . . & $\ldots .$. & 244,245 & ......... & ......... & 255,256 & $\ldots \ldots$ & ...... \\
\hline 12. & $\ldots .$. & & ..... & $\ldots \ldots$ & 239 & $\ldots$ & . . . . . . . & 249,250 & 257 & ... & $\ldots .$. \\
\hline $13 \ldots$ & $\ldots \ldots$ & & $\ldots$ & $\ldots \ldots$ & $\ldots \ldots$ & ......... & .......... & 251 & . . . . . . & ...... & $\ldots \ldots$ \\
\hline $14 .$. & & & ..... & ....... & $\ldots$ & & 247,248 & 252,253 & & . & \\
\hline $16 \ldots$ & & & 235 & $\ldots . . .$. & . . . . . & . . . . . . . & .......... & 254 & . . . . & & ..... \\
\hline $19 \ldots$ & 232 & $\ldots$ & ..... & 236,237 & & & & & & ..... & \\
\hline $20 \ldots$ & 233 & . . . . & ....... & $\ldots \ldots \ldots$ & $\ldots$ & $\ldots \ldots$ & $\ldots$ & ..... & ...... & ..... & $\ldots$. \\
\hline $25 \ldots$ & .... & 234 & $\ldots$ & & & & & & & & \\
\hline
\end{tabular}

Table IV expresses the range in degree of crystallization of the groundmass of these rocks, which are arranged in colnmns corresponding to the mineralogical grouping of Table III. It is to be remarked that the specimens were collected from different-sized dikes and from different parts of the dikes, so that the variations in grain can not be compared very closely 
with the mineral composition. But when the size of the dikes in each case is taken into consideration it becomes even more evident than from the table that the coarseness of grain bears a very considerable relation to the chemical composition of the rock. The variation in grain between the sides and center of a dike and between dikes of different widths, for rocks of nearly the same composition, is not so great as the variation between rocks of different composition where the size of the dikes in which they occur is somerwhat similar. Thus, specimen No. 233 is from the center of a 4 -foot dike, and No. 232 from the contact wall of the same; and specimen No. 247 is from the center of an 8-foot dike, and Nos. 257 and 250 are from the contact walls of the same; Nos. 264 and 265 are from 4 -foot dikes, and No. 263 is from a 2-foot dike. They all occur at nearly the same altitude, but it is possible that the pyroxene-bearing rock, No. 233, may have been intruded in rocks which were more heated at the time of its intrusion and so have acquired its degree of crystallization through slower cooling, but this is not so likely to have happened in the case of rock No. 234, which is in the same part of the mountain as No. 235, but is in a dike 10 feet wide and is very much coarser grained than No. 233. (See Table VIII.)

The groundmass of the rock with porphyritical quartz and biotite, No. 265 , is made up of mimute grains of quartz and feldspar, about $0.015 \mathrm{~mm}$. in diameter, while the groundmass of the pyroxene-bearing variety, No. 233, is made up of lath-shaped and irregularly shaped feldspar about $0.10 \mathrm{~mm}$. to $0.14 \mathrm{~mm}$. in length, and the groundmass of No. 234 is composed of lathshaped feldspars $0.5 \mathrm{~mm}$. to $0.7 \mathrm{~mm}$. in length.

The character of the groundmass changes from an even granular structure in the acidic rocks, through one made up of irregular grains and lath-shaped feldspars in the intermediate rocks, to an aggregation of lathshaped feldspars with almost no irregular grains in the basic varieties.

The tendency of basic rocks to crystallize more completely and with larger groundmass crystals than acidic rocks is constantly observed among the extrusive rocks, such as basalts, andesites, and rhyolites. The same law appears to obtain among the intrusive rocks. It is of course necessary to compare rocks that appear to have crystallized under very nearly the same physical conditions.

The rocks of Group II have been described in greater detail on account of their number and importance, and have been subdivided into three sub- 
groups, II $a$, II $h$, IIc. The tables presenting the results of this part of the work have a different form and are arranged separately for each subdivision. They are 'Tables V, VI, and VII.

TABLE V.-Wineralogieal variation among the diorites of Group IIa.

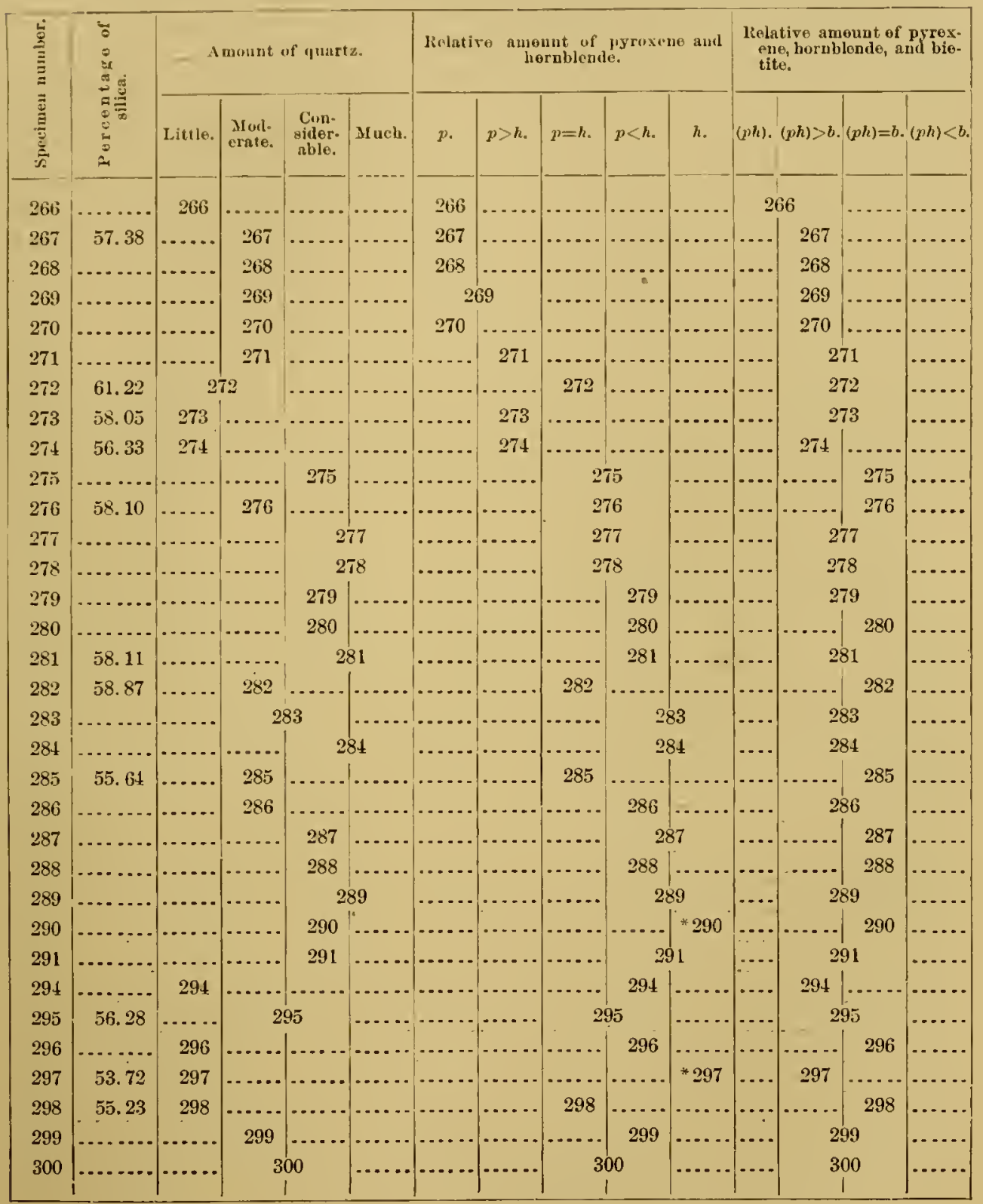

* The hernblende in theee rocks is in part eecondary ; pyrexene may have been present eriginally. 
TABLE VI._Mineralogical variation among the diorites of Group IIb.

\begin{tabular}{|c|c|c|c|c|c|c|c|c|c|c|c|c|c|c|}
\hline \multirow{2}{*}{ 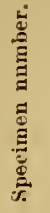 } & \multirow{2}{*}{ 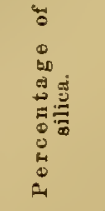 } & \multicolumn{4}{|c|}{ Amount of quartz. } & \multicolumn{5}{|c|}{$\begin{array}{c}\text { Relative amount of pyroxeoe and } \\
\text { hornblende. }\end{array}$} & \multicolumn{4}{|c|}{$\begin{array}{l}\text { Helative amount of pyrox- } \\
\text { ene, bornblende, and bio- } \\
\text { tite. }\end{array}$} \\
\hline & & Little. & $\begin{array}{l}\text { Mrorl- } \\
\text { erate. }\end{array}$ & $\begin{array}{l}\text { Con. } \\
\text { silter- } \\
\text { ahle. }\end{array}$ & Mueh. & $p$. & $p>h$. & $p=h$. & $p<h$ & $h$. & $(p h)$, & $(p h)>b$. & $p h)=b$. & $(p h)<b$ \\
\hline 301 & & & & 301 & & & & & & 301 & & 301 & & \\
\hline 302 & $\ldots$. & & & 302 & & & & & ...... & 302 & & 30 & & \\
\hline 303 & 65.60 & & - $\ldots$. & 303 & $\cdots$ & & ..... & & & & & 30 & & \\
\hline 304 & ....... & ...... & 304 & ..... & & & & & $\ldots .$. & 304 & & ..... & 304 & \\
\hline 305 & 65.94 & & & 305 & & & & & & 305 & & 305 & S & \\
\hline 306 & ........ & & & 306 & & & & & & 306 & & ..... & & 06 \\
\hline 307 & 63.78 & & $\ldots$. & 307 & & & & & & 307 & & 307 & & \\
\hline 308 & ........ & & & 308 & & & & & & 308 & & 30 & & \\
\hline 309 & 64.07 & & & 09 & & & & *309 & & 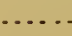 & & .... & 309 & \\
\hline 310 & ........ & & & 310 & & & $\dagger 310$ & & & & & & 310 & \\
\hline 311 & 65.11 & & & 311 & & & & & 311 & & $\cdots$ & $\ldots \ldots$ & 311 & \\
\hline 312 & $\ldots . . .$. & & & 12 & & & & & 312 & $\ldots . .$. & & 31 & & \\
\hline 313 & 64.85 & & & 313 & & & & & & 313 & .. & 313 & [. & \\
\hline
\end{tabular}

* This rock belongs with 288 , resembles it in etructure and character, hut is higher in eilica and feldspar. An exceptional rariety, from talus.

TABLE VII._Mineralogical variation among the diorites of Group IIC.

\begin{tabular}{|c|c|c|c|c|c|c|c|c|c|c|c|c|c|c|}
\hline \multirow{2}{*}{ 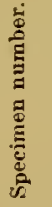 } & \multirow{2}{*}{ 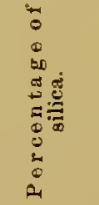 } & \multicolumn{4}{|c|}{ Amount of quarts. } & \multicolumn{5}{|c|}{$\begin{array}{l}\text { Relative amount of pyroxene and } \\
\text { bornblende. }\end{array}$} & \multicolumn{4}{|c|}{$\begin{array}{l}\text { Relative amount of psrox- } \\
\text { ene, hornblende, and bio- } \\
\text { tite. }\end{array}$} \\
\hline & & Little. & $\begin{array}{l}\text { Mod. } \\
\text { erate. }\end{array}$ & $\begin{array}{l}\text { Con- } \\
\text { sirter- } \\
\text { able. }\end{array}$ & Much. & $p$. & $p>h$. & $p=h$. & $p<h$. & $h$. & $(p h)$. & $(p h)>b$ & $(p h=b)$. & $(p h)<b$. \\
\hline 314 & 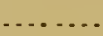 & & & $\ldots .$. & 314 & \multicolumn{2}{|c|}{ * 314} & & & & & $\ldots .$. & \multicolumn{2}{|c|}{314} \\
\hline 315 & $\ldots$ & & $\ldots \ldots$ & $\ldots \ldots$ & 315 & 315 & & & & $\ldots \ldots$ & & & $\ldots \ldots$ & 315 \\
\hline 316 & $\ldots$. & & & & 316 & 316 & & & & & & & ... & 316 \\
\hline 317 & 65.48 & & ...... & $\ldots \ldots$ & 317 & & & .. & & & & 31 & 17 & $\ldots \ldots$ \\
\hline 318 & 65.80 & & $\ldots .$. & & 318 & $\ldots$ & & & 318 & & & & $\ldots \ldots$ & 318 \\
\hline 319 & . & . & $\ldots \ldots$ & ...... & 319 & 319 & & & & ....... & & $\ldots \ldots$ & ...... & 319 \\
\hline 320 & $\ldots$. & & & $\ldots .$. & 320 & & & & & 320 & & & & 320 \\
\hline 321 & 67.54 & & ...... & ..... & 321 & & & .. & & 321 & ... &. & $\ldots .$. & 321 \\
\hline 286 & 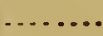 & & & & $286 u$ & & & & & & & & & $286 a$ \\
\hline 275 & & & & & $275 a$ & & & & & $275 a$ & & & & $275 a$ \\
\hline 322 & ....... & $\ldots .$. & $\ldots . .$. & & 322 & & & & & 322 & & & & 322 \\
\hline 323 & 66.05 & $\ldots \ldots$ & $\ldots \ldots$ & $\ldots . .$. & 323 & $\ldots .$. & & $\ldots$ & $\ldots$ & 323 & $\ldots$ & & & 23 \\
\hline
\end{tabular}

* The firet eix rocke in thie group are closely related to the main maes of the diorite of Group IIa. 
Table V presents those varieties of the stock rocks in which the amount of the ferromangesian silicates about equals that of the feldspar and quartz combined. There is no distinction made as to whether the 'rystals occur as phenocrysts or not. 'They are arranged in a series according to their degree of crystallization, the finest grained being at the top, the value of the degrees of erystallization having been already explained (1. 99). The silica percentage is given in all cases where it lats been determined. In the table an attempt is made to express the relative anounts of the quartz, of the homblende and pyroxene, and of the biotite and hornblende and pyroxene. The relative amount of feldspar is not expressed. In a general way it varies inversely as the amount of quartz for this subgroup. The columns under the different divisions of the table express certain relations of the minerals approximately. Under the divisions of quartz, the terms "little," "moderate," "considerable," "much " are used only as comparative terms applicable to this group of rocks throughout its three subdivisions, $\mathrm{II} a, \mathrm{II} b, \mathrm{II} c$, and have no reference to the relative amount of quartz which might be found in another suite of rocks. Consequently, what would be considered "much" quartz in these rocks might be only a moderate amount for another series.

Under the division which shows the relative amounts of pyroxene and hornblende in each rock, the first column, " $p$," indicates that there is pyroxene and no homblende; the next column, that the pyroxene is in excess of the hornblende; the third, that they are equal; and so on. The relative amounts of pyroxene or of hornblende in any two varieties of the rock is not indicated directly. It can be ascertained roughly by considering that in this subgroup the sum of the pyroxene, hornblende, and biotite is nearly constant.

In the next division of the table the amount of the biotite is compared with that of the pyroxene and hornblende combined, in the manner already explained for the previous division.

The first fact brought out by a study of this table is the variability of the quartz percentage, which does not appear to hold a very definite relation to the silica percentage, as in the case of Nos. 281 and 282. But it is observed in studying the thin sections that the quartz is not so noticeable in the fine-grained varieties as in the coarse-grained ones, and may therefore be either overlooked or possibly not so strongly developed. Thus the 
coarse-grained varieties with little quartz are lower in silica than the finegrained varieties with little quartz. (Compare Nos. 297 and 298 with Nos. 272,273 , and 274.) It is, of course, evident that in rocks with variable percentages of the essential minerals which are all silicates there can be no rigid relation between the proportion of any one of these minerals and the silica percentage of the rock within the narrow range of chemical variation that occurs in this group. In it the silica does not vary 7 per cent, and the amounts of the other chemical constituents are the modifying chemical factors. This will be discussed more fully when the chemical composition of the rocks is considered.

The most regular variation is in the relative proportions of pyroxene and hornblende. There is a definite increase in the amount of hornblende and decrease in that of pyroxene as the rock becomes coarser grained. This is specially noticeable in those specimens forming series from one spot, Nos. 268, 269, 270, 271, 279, and 287, and Nos. 277, 278, 281, 284, and 289. The variation in the relative amount of biotite is not so marked, but there is a slight increase from the fine-grained to the coarse-grained end of the series.

The irregularities in the variations of the different minerals could be better understood if the chemical composition of all of the different varieties of the rocks were knownl, but such an investigation is not practicable. The rocks of this subgroup may be classed among the pyroxene-diorites and quartz-pyroxene-diorites. They carry considerable biotite, and pass into quartz-mica-diorite at one end of the series and into pyroxene-porphyrite at the other.

Tables VI and VII include those varieties of rock in which the amount of feldspar and quartz together exceeds that of the ferromagnesian silicates, Table VII including those varieties particularly rich in quartz.

The silica percentage is considerably higher in these rocks than in those of the previous subgroup. The quartz is more uniform, and on the whole is higher. It is very considerably higher in Subgroup II $c$. Pyroxene is absent from most of the varieties, but occurs in small amounts without hornblende in a few instances already noticed. Biotite is more variable in Subgroup II $b$ than in II $c$, where it is the predominant ferromagnesian silicate.

The relation of quartz, biotite, hornblende, and pyroxene to the chemical composition of the different varieties of this series of rocks is not so definite 
ats in the case of the gromp of dike rocks. In geneml, quartz and biotite are more abundant in the more acid varieties of the coarse-grained rocks, but they both aplear in the basic varieties when they are consely crystalline. The relations of homblende and pyroxene to the chemical composition of rocks are not elneidated in any way by the study of this group of rocks. It is evident, however, that in the intrusive rocks of this region hornblende is developed to a greater extent in the basic rocks, in proportion as they are coarser grained, and that pyoxene is more abundant in the fincr-grained forms than in the coarser.

The minemal composition of the quartz-nica-diorite-porphyry, Guoup) III, is very miform, and needs no tabulation. It contains very much quartz, abundant biotite, and almost no homblende; the greater part of the rock is more siliceous than the main body of the diorite, and reaches 69.24 per cent of silica, but a facies of it which is richer in hornblende than the body of the rock has only 65.97 per cent of siliea.

TABLE VIII._Grades of erystallization of the dike and stock rocks of Electric Peak.

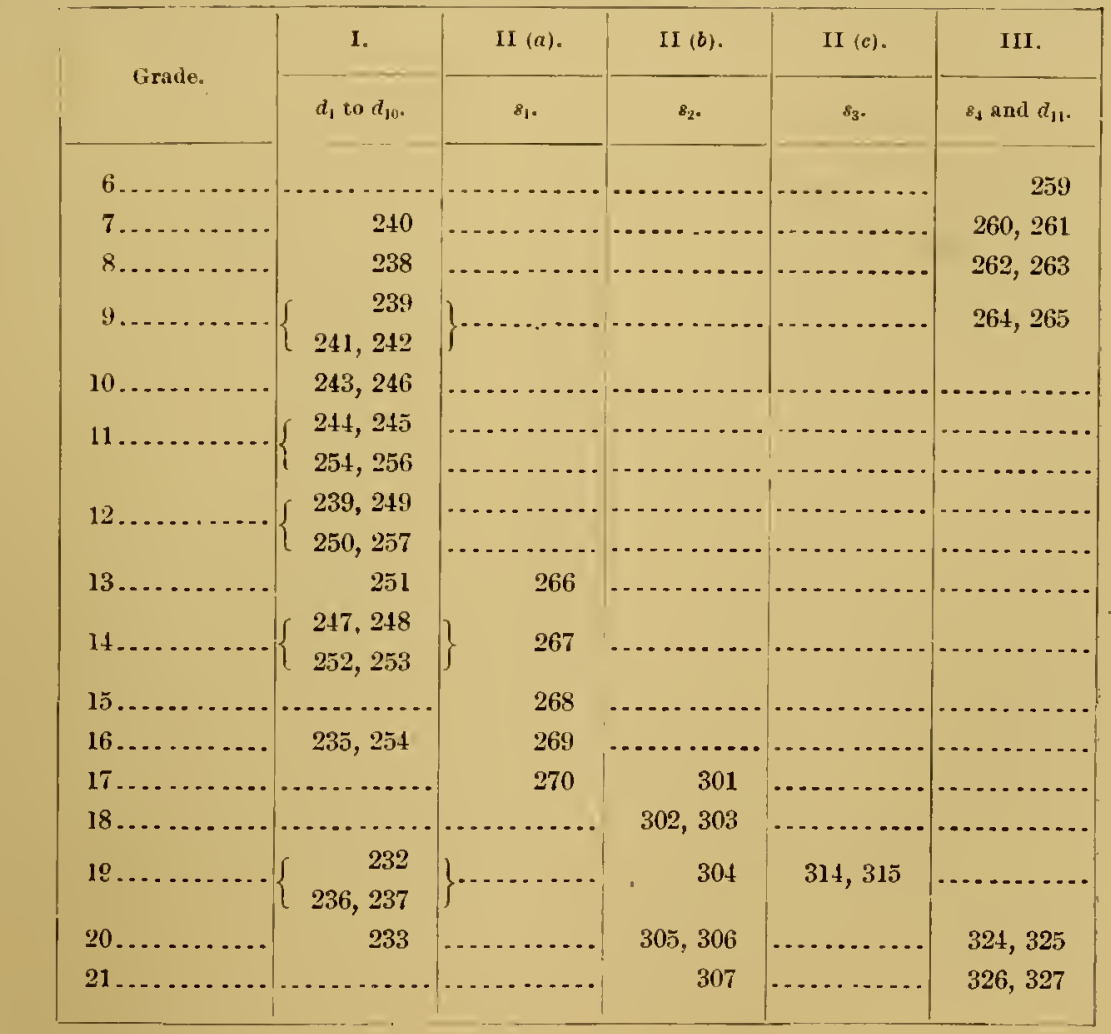

MON XXXII, PT II- 8 


\section{GEOLOGY OF THE YELLOWSTONE NATIUNAL PARK.}

TABLE VIII.-Grades of crystallization of the dike and stock rocks of Electric Peak-Continued.

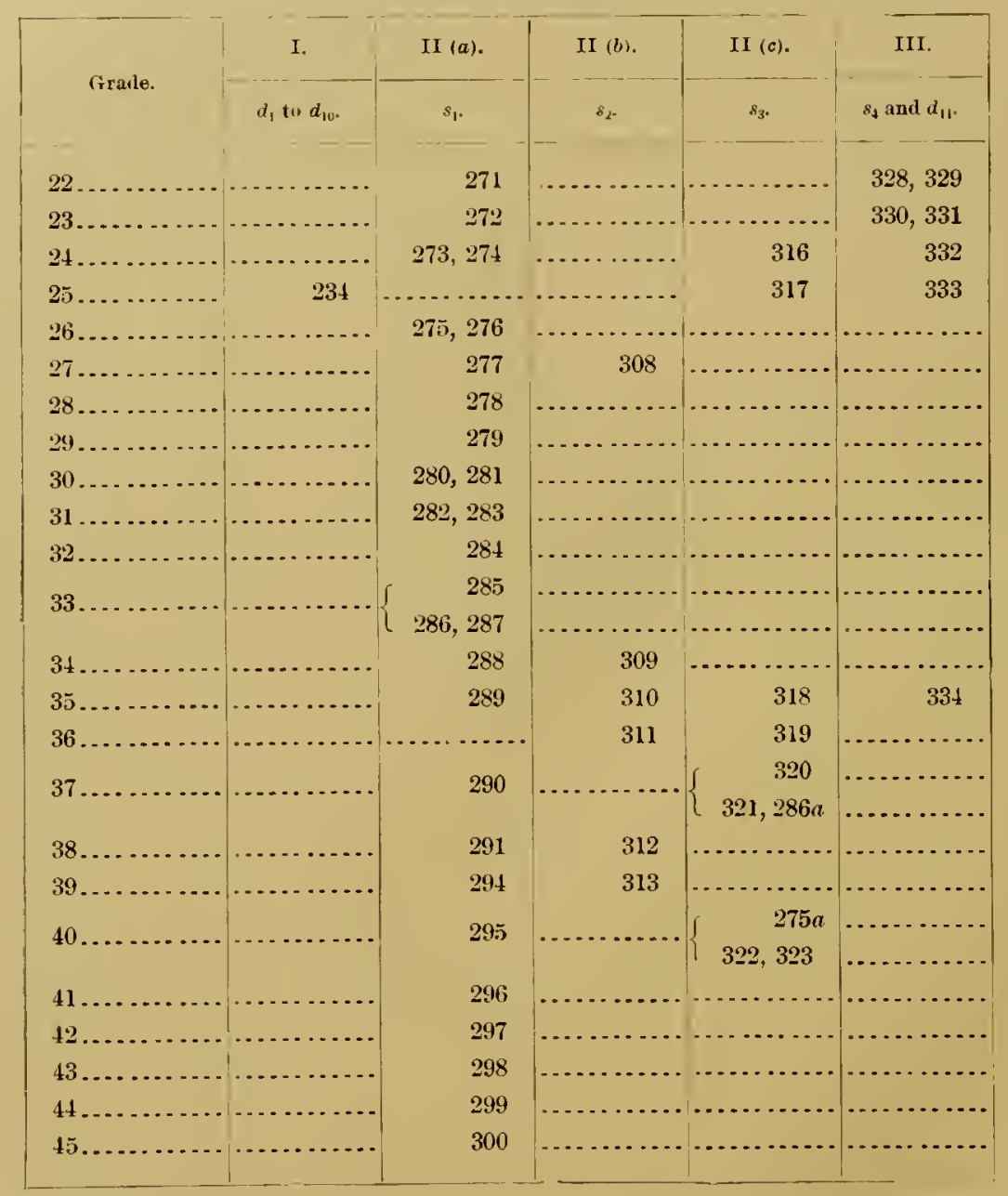

Table VIII expresses the relative degree of crystallization of all the intrusive rocks collected from the stock and dikes of Electric Peak. They are arranged in the groups already described. The breaks in the different columns do not signify breaks in the gradation of erystallization in the rock bodies in the field, but simply that the specimens collected are not from all the different structural phases of the different rocks. However, the clustering of the numbers in particular parts of the scale indicates the prevailing grain of the rocks as they are exposed at the present time. 
It is not possible to draw a line of denaration anywhere in the scale based on the degree of erystallization between rocks that oceur in narrow dikes and those that form parts of nuch larger bodies. A relation between the degree of erystallization and the size of the rock body does not at first appear when all of these oceurrences are considered together. The very important inflnence of several other factors, however, becomes apparent. One is the chemical chanater of the magma, the more basic magnas tending to crystallize coarser than the more siliceons ones under similar physical conditions. Another factor is the previous temperature of the rocks into which the molten magmas were injected, and the consequent differences in the rate of cooling which the molten magmas experience. There may also be other factors which influence the crystallization in certain cases, but they are not evident in the occurrences at Electric Peak. In this locality the chief factor influencing the crystallization appears to have been the temperature of the inclosing rocks at the time of the different intrusions. The next most influential factor appears to have been the chemical character of the magma itself, and the third the size of the intruded mass. In another region the relative importance of these factors may be different.

CHEMICAL COMPOSITION.

The chemical composition of the intrusive rocks at Electric Peak is shown by the analyses in Table IX. Nos. 272 and $3(i 9$ were made by Mr. W. H. Melville, the remainder by Mr. J. E. Whitfield. All are from rocks occurring in the stock and its immediate apophyses. They represent the composition of varions forms of the diorite and diorite-porphyry. The first four analyses, Nos. 295, 267, 273, and 272, are from the main body of the stock, and belong to Subgroup II a. The next four analyses, Nos. 309, 313,311 , and 303 , are from modifications of the main body of the diorite and from one of the lighter-colored reins or dikes which traverse it. They belong to Subgroup IIb. Two more varieties of the main stock are represented by analyses Nos. 323 and 321 . They are quite siliceous, and belong. to Subgroup IIc. Analyses Nos. 329 and 326 are from the large body of quartz-mica-diorite-porphyry, the first being a basic variety of it, and the second corresponding more nearly to the general character of the body of the rock. 
116 GEOLOGY OF THE YELLOWSTONE NATIONAL PARK.

TABLE IX,-Chemical analyses of intrusive rocks from Electric Peal.

\begin{tabular}{|c|c|c|c|c|c|c|c|c|c|c|c|c|}
\hline Constituent. & 295 & 267 & 273 & 272 & 309 & 313 & 311 & 303 & 329 & 323 & 321 & 326 \\
\hline $\mathrm{SiO}_{2}$ & 56.28 & 57.38 & 58.05 & 61.22 & $61.0 \overline{7}$ & 64.85 & 65.11 & 65.60 & 65.97 & 66.05 & 67.54 & 69.24 \\
\hline $\mathrm{TiO}_{2} \ldots$ & .84 & Trace. & 1.05 & .61 & .45 & .91 & .71 & .75 & .42 & .34 & .80 & .65 \\
\hline $\mathrm{Al}_{2} \mathrm{O}_{3}$ & 14.23 & 16.86 & 18.00 & 16.14 & 15.82 & 16.57 & 16.21 & 17.61 & 16.53 & 16.96 & $17.0^{4}$ & 15.30 \\
\hline $\mathrm{Fe}_{2} \mathrm{O}_{3} \ldots$ & 4.69 & 2.49 & 2.49 & 3.01 & 3.40 & 2.10 & 1.06 & .95 & 2.59 & 2.59 & 2.97 & 1.72 \\
\hline $\mathrm{FeO}$ & 4.05 & 5.17 & $4.56^{\prime}$ & 2.58 & 1.44 & 2.15 & 3. 19 & 2.76 & 1.72 & 1.38 & .34 & .69 \\
\hline $\mathrm{NiO}$. & $\cdots \cdot$ & $\ldots$ & ....... & .09 & .05 & $\ldots .$. & $\ldots .$. & ....... & $\cdots$ & ….. & $\ldots$ & $-\cdots$ \\
\hline $\mathrm{MnO} . .$. & .16 & Trace. & None. & Trace. & Trace. & None. & None. & None. & None. & None. & Trace. & Trace. \\
\hline $\mathrm{CaO}$ & 7.94 & 7.32 & 6.17 & 5.46 & 4.43 & 4.01 & 3.97 & 3.72 & 3.37 & 3.37 & 2.94 & 2.98 \\
\hline MgO ... & 6.37 & 5.51 & 3.55 & 4.21 & 3.39 & 2.14 & 2.57 & 1.49 & 2.11 & 2.08 & 1.51 & .95 \\
\hline $\mathrm{Li}_{2} \mathrm{O} \ldots$ & .01 & .39 & None. & $\cdots$ & . & None. & .04 & .03 & .09 & None. & .03 & None. \\
\hline $\mathrm{Xa} O \mathrm{O} \ldots$ & 2. 98 & 3.33 & 3.64 & 4.48 & 4.06 & 3.71 & 4.00 & 4.36 & 3.41 & 4.20 & 4.62 & 4.46 \\
\hline$K_{2} \mathrm{O} \ldots$ & 1.23 & 1.45 & 2.18 & 1.87 & 2.27 & 3.10 & 2.51 & 2.36 & 2.67 & 2.53 & 2.28 & 2.52 \\
\hline $\mathrm{P}_{4} \mathrm{O}_{5} \ldots$ & .40 & 'Trace. & .17 & .25 & .18 & .14 & .02 & .16 & Trace. & Trace. & Trace. & Trace. \\
\hline $\mathrm{SO}$ & Trace. & .21 & .07 & 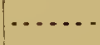 & & Trace. & Trace. & Trace. & .13 & .03 & .26 & .27 \\
\hline Cl ...... & .17 & .17 & Trace. & $\cdots$ & $\ldots$ & None. & None. & None. & .09 & Trace. & .15 & Trace. \\
\hline $\mathrm{H}_{2} \mathrm{O} \quad \ldots$ & .93 & .42 & .86 & .44 & .52 & .35 & .94 & .59 & 1. 23 & .69 & .55 & 1.30 \\
\hline Total. & 100.28 & 100.70 & 100.79 & 100.36 & 100.08 & 100.03 & 100.33 & 100.58 & 100.33 & 100.22 & 101.01 & 100.08 \\
\hline $\begin{array}{r}\text { Less } 0 \\
\text { for } \mathrm{CI} .\end{array}$ & .04 & .04 & & & & & & & .02 & & .03 & \\
\hline & 100.24 & 100.66 & & & & & & & 100.31 & & 100.98 & \\
\hline
\end{tabular}

TABLE X.-Silica percentages of rockis from Electric Peak.

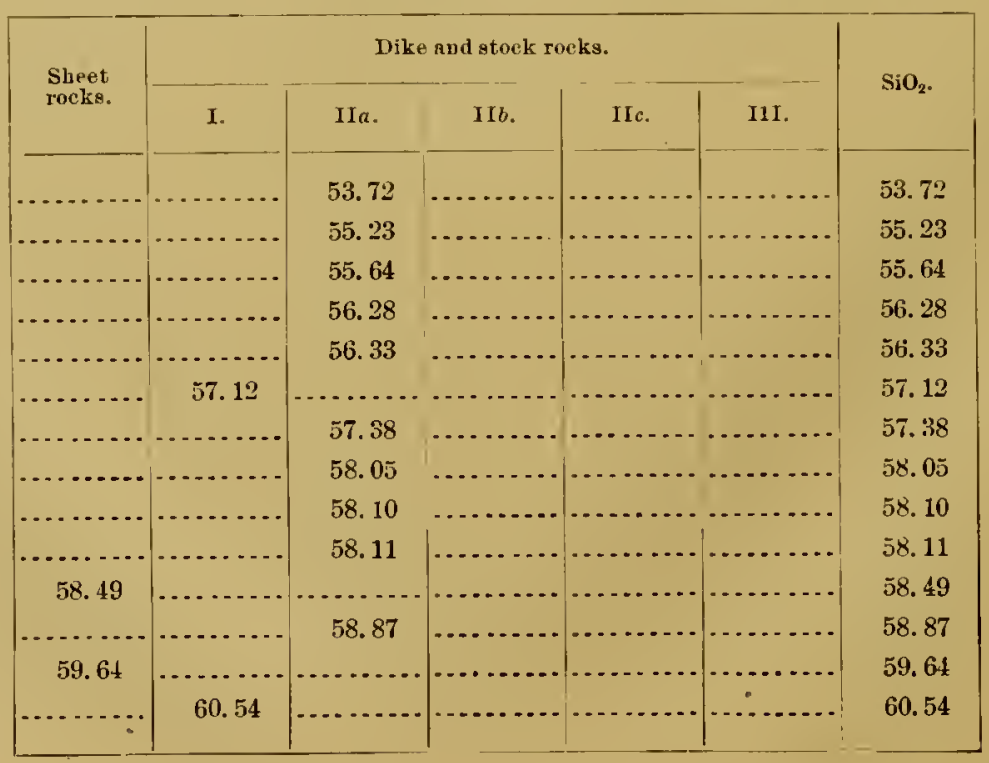


SIIIOA PERCENTAGES OF ELECTRIC PLAK ROCKS.

TalsLE X._- Silica perentages of rocks from Electris Peali-Continued.

\begin{tabular}{|c|c|c|c|c|c|c|}
\hline \multirow{2}{*}{$\begin{array}{l}\text { Shent } \\
\text { rocks. }\end{array}$} & \multicolumn{5}{|c|}{ like aul ster:k roeks. } & \multirow{2}{*}{$\mathrm{SiO}_{2}$. } \\
\hline & I. & $11 a$. & Ilb. & Ilc. & III. & \\
\hline & ..... & 60.56 & $\cdots$ & . & $\ldots \ldots$ & 60.56 \\
\hline$\ldots \ldots \ldots$ & 60.89 & $\ldots \ldots$ & -. & & & 60. 89 \\
\hline 61.50 & $\ldots \ldots \ldots$ & $\ldots \ldots \ldots$ & & -. & & 61.50 \\
\hline .......... & 61.85 & . & . & . & & 61.85 \\
\hline$\cdots$ & $\ldots \ldots$ & $\ldots \ldots \ldots$ & 63.01 & $\ldots \ldots$ & & 63.01 \\
\hline & & $\ldots \ldots \ldots$ & 63.78 & & & 63.78 \\
\hline 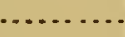 & & $\ldots . . . .$. & 61.85 & & & 61.85 \\
\hline$\cdots$ & & $\ldots \ldots \ldots$ & 65.11 & $\ldots \ldots \ldots$ & & 65.11 \\
\hline . & $\ldots \ldots$ & $\ldots \ldots \ldots$ & ........... & 65.48 & & 65.48 \\
\hline$\cdots \cdots$ & $\ldots \ldots \ldots \ldots$ & $\ldots \ldots \ldots \ldots$ & 6.5 .60 & ......... & & 65.60 \\
\hline$\ldots . .$. & $\ldots \ldots \ldots$ & $\ldots \ldots \ldots$ & .......... & 65.80 & & 65.80 \\
\hline 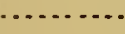 & $\cdots$ & $\ldots \ldots$ & 65.94 & ..... & $\ldots \ldots$. & 65.94 \\
\hline - & $\ldots \ldots$ & $\ldots \ldots \ldots$ & $\ldots \ldots \ldots$ & $\ldots \ldots \ldots$ & 6.5 .97 & 65.97 \\
\hline & & & $\ldots$. & 66.05 & $\cdots$, & 66.05 \\
\hline - & $\ldots \ldots$ & $\ldots \ldots \ldots$ & $\ldots \ldots \ldots$ & 67.54 & $-\ldots \ldots \ldots$ & 67.54 \\
\hline & & & $\ldots$ & $\ldots \ldots$ & 69.24 & 69.24 \\
\hline
\end{tabular}

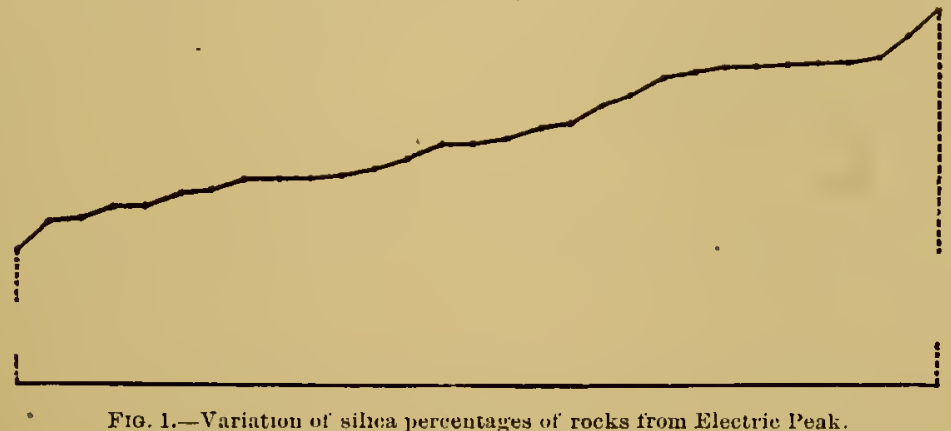

The siluca percentages of a number of varieties of these rocks were determined and are given in Table $X$, together with those from the complete analyses. In a measure they supplement these analyses and demonstrate what is evident from the.microscopical study of the thin sections, namely, that the diorites and porphyries pass through all possible gradations from one extreme to the other. The character of this transition is shown by the diagram, fig. 1, in which each determination is given the same weight. The series is arranged according to the increase of silica. and the silica percentages are plotted as ordinates. 
In Table $\mathrm{X}$ the percentages are all placed in the extreme right-hand column, and also in separate columns corresponding to the groups described in the first part of the paper. From this it is seen that the main body of the diorite varies from 53.72 to 60.56 per cent of silica, and in certain contact forms reaches 67.54 per cent. The dikes of later rocks related to the diorite and cutting the main body of the stock range from 63.78 to 69.24 per cent.

Of the various bodies of magma that have followed one another through the conduit at Electric Peak, there is a variation in chemical composition in each, the different series of changes overlapping one another. Thus the average chemical composition of each subgroup of varieties shifts somewhat, and is more basic for one than for another. But the end varieties of each subgroup overlap, so that the most basic modification of the more acid group is more basic than the most acid end of the more basic group which immediately preceded it.

Since the rocks of Group I belong to outlying dikes of the main stock and are contemporaneous with it, their silica percentages may be placed in the proper subgronp of the stock rocks, making Subgroups II $a$ and II $b$ practically continuous. It appears fiom Table $\mathrm{X}$ that the succession of magmas which came up through the vertical fissures was from a basic one to more and more acid ones, and that the previous intrusions which formed the sheet rocks were of a magma of medium chemical composition.

The variations of the other chemical constituents of these rocks are best comprehended by comparing their molecular proportions. This has been done graphically in the accompanying diagram, fig. 2 , in which the molecular proportions of the principal oxides are plotted as ordinates, those of the silica being taken as abscissas. The origin of abscissas is located some distance to the left.

The first impression derived from the diagram is that of the irregularity of the variations in all the oxides besides silica, especially in the magnesia. Ioreover, these variations appear to be independent of one another. But this apparent independence disappears on closer study. The most striking evidence of comnection between the molecular proportions exists in the case of the two oxides of iron; the ferrons and ferric oxides are noticeably inversely proportional to each other, an increase of ferrous oxide being accompanied by a decrease of ferric oxidle. The total amount of iron 
varies irregularly, decreasing firm the basic to the acid end of the series. While each of the iron oxides is quite independent of the magnesia, it is found upon reducing all the iron to the ferrons state that there is the greatest accord between the iron and the magnesia, both varying in like directions and to nearly the same extent. The magnesia drops rapidly at first, and is rery erratic in the more siliceons end of the series, where it becomes very low.

The most regular variation is in the lime, which decreases steadily from the basic to the acid end of the series. It exhibits little or no connection

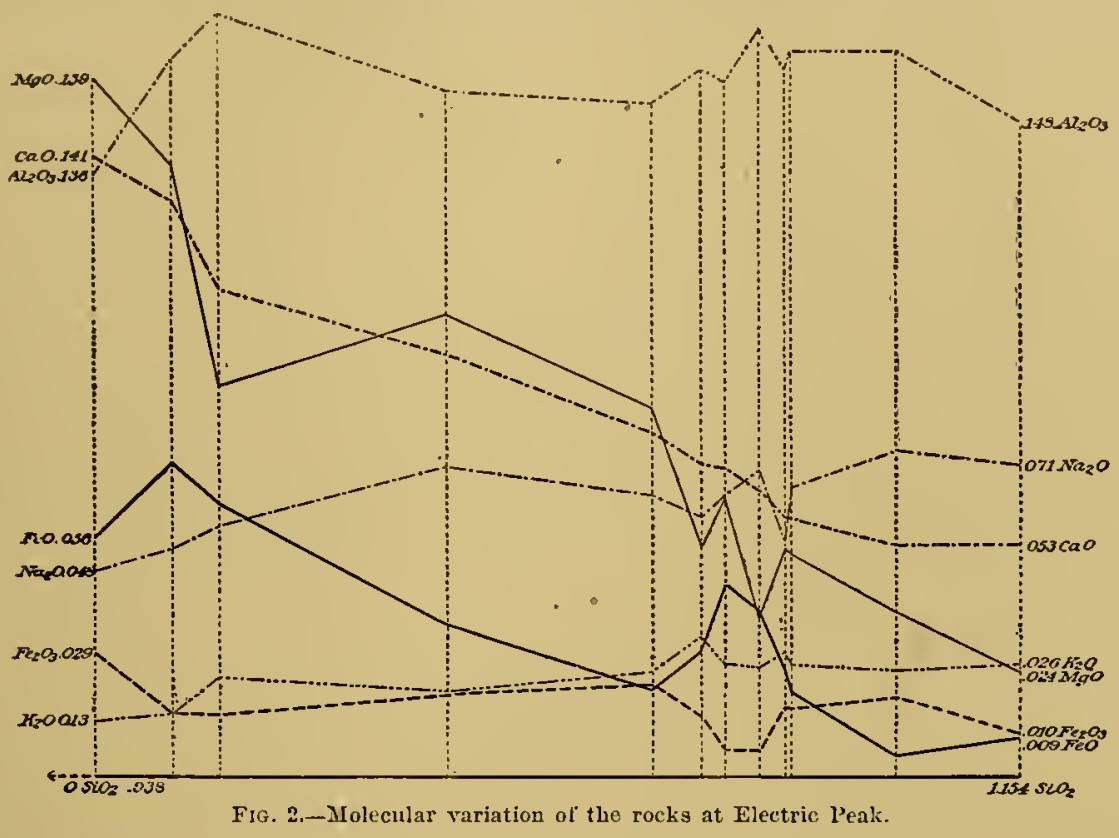

with the other constituents. The molecular proportions of the alumina, though quite irregular between certain limits, maintain a uniformly high position, and are much greater than those of any one of the other constituents except silica. At the extreme basic end of the scale, however, they are equaled by those of both the magnesia and the lime. The alkilies are nost like the alumina in their variations, and remain very nearly uniform, increasing somewhat toward the acid end of the series. The soda molecules are more than twice as numerous as those of potash, which is one of the most noticeable characteristics of the rocks of this locality. In the basic end of the series the alkilies vary together in the same direction, 
while in the more siliceons end they vary in opposite directions. There is a marked accordance between the soda and the alumina, both varying in the same direction, with one exception, though not to the same extent. There is a more strongly marked discordance between the alumina and the magnesia, which, with one exception,. vary in opposite directions.

These irregular variations take place not only among allied varieties of rocks, but even in different parts of one and the same rock body. They find expression in variations in the proportions of the essential minerals.

The origin of this variation is undoulbtedly to be sought in the chemical differentiation of the molten magma. The development of the constituent minerals in the solidified rock is the result of physical forces that combine the chemical constituents of the magma in a variety of ways to form closely analogous crystal compounds. A discussion of the possible molecular condition of molten magmas will not be taken up in this place. A few obvious relations between the mineral and chemical variations, however, may be pointed out. The inverse variation between alunina and magnesia, and the accordance between alumina and the alkalies, affect the relative proportions of feldspars and ferromagnesian silicates, which vary in an inverse ratio. The decrease of the alkaline eartls with the increase of silica and the alkalies shows itself in the diminution of the ferromagnesian silicates and the calcium feldspars, which accompanies an increase in quartz and the alkali feldspars.

The reciprocal variation of the ferrous and ferric oxides indicates the variable oxidation of preexisting ferrous molecules. This should naturally be in accord with the development of minerals containing more or less ferric oxide, the most prominent of which are hornblende and biotite. Such a connection seems to be made out, but data for its complete demonstration are not at hand. It is most significant on account of its bearing on the question of the development of these two minerals in the coarser-grained forms of rocks whose magmas may erystallize under other conditions free from either mineral. It may throw light on the possible action of water vapor as a mineralizing agent.

The order in which the constituents crystallized out of the molten magma to form diorite may be learned by considering the relative ages of the component minerals. It has been pointed out that some crystallized almost synchronously, but that they began to separate from the liquid 
magma at diflerent times. The order in which the different minerals beg:un to crystallize in that portion of the magnia which formed diorite appears to have been as follows: Magnetite, hypersthene, angite, labradorite, hornblende, biotite, oligoclise, orthoclase, quartz. The feldspathic minerals started to crystallize before any of the ferromagnesian minerals had commenced; and the last of the series undonbtedly crystallized after all of the ferromagnesian minerals had been completed. So far as the siliceonsness of the minerals is concerned, the series of ferromagnesian silicates and that of minerals free from iron vary in opposite directions. In the former the range is from lighest silica to lowest; from the metasilicate, hypersthene, to the orthosilicate, biotite. In the second it is from the least siliceons, labradorite, to the most siliceons, orthoclase, or to free silica, quartz.

\section{THE VOLCANIC ROCKS OF SEPULCHRE MOUN'TAIN.}

The igneous rocks of Sepulchre Momntain are partly extrusive, partly intrusire. By far the greater mass consists of subaerial breccias and tuffs, with a small amount of massive lava flows. The intrusive rocks form dikes and larger bodies traversing these breccias. The breccias and flows are andesites of various kinds. The intrusive bodies are andesites and dacite, grading into porphyry-like modifications in places. The tuff-breccia is separable into an older and a newer, or into a lower and an upper, breccia.

THE LOWER BRECCIA.

The lower breccia is about 500 feet thick, and consists mostly of fragments of homblende-mica-andesite, and is generally light colored. It carries a large amount of fragments of crystalline schists, which do not oceur in the overlying upper breccia. It is probable that the lower breccia was ejected from some neighboring center of eruption located in an area of Archean rocks. Such a center occurs a few miles north, at the west base of Sheep Mountain. The lower breccia passes into fine tuff in places, and at the extreme end of the northwestern spur of the mountain it is distinctly bedded, with layers containing bowlders of a rhyolite-porphyry, which has not been found in place in this region. In places the upper part of the breccia is green and partly decomposed, as though weathered before the upper breccia had been thrown upon it. In the northwestern spur of the mountain the upper breccia is seen to rest upon an uneven surface of the lighter-colored 
bottom breccia. There appear's to have been a distinct time break between the ejection of the lower breccia and that of the upper breccia. 'The occurrence of framents of crystalline schists in the bottom light-colored breccia and their absence from the overlying dark-colored breccia is a characteristic difference between these two breccias wherever they have been observed along the northern boundary of the Yellowstone Park.

The andesites from the lower breccia at Sepulchre Homntain vary somewhat in mineral composition, color, and microscopical habit. They are mostly light colored-gray, white, and red; in places dark colored. Some fragments have comparatively large phenocrysts; others are crowded with small ones. The greater number of fragments are horublende-mica-andesite; some have little mica, and grade into hornblende-andesite. Others are dacite, having quartz phenocrysts. The microstructure of the groundmasses of these rocks ranges from glassy and microlitic to microcrystalline. The characters of the minerals and the microstructures are the same as those of the light-colored acid breccias on the Yellowstone River in the neighborhood of Crescent Hill, and also those in the vicinity of Cook City.

It is important to note that there is associated with the lower acid breccia of Sepulcher Mountain an obscure body of massive, vesicular basalt with porpliyritical augites and decomposed olivines. Its exposure is of small extent, and its exact relation to the breccia was not seen. It is anygdaloidal with quartz, agate, and calcite. It does not resemble the recent basalts in the neighborhood, but is similar to basalt associated with the bottom acid breccia at Crescent Hill and in the valley of Cache Creek. Its petrographical character is more fully discussed in Chapter IX, where it is classed with shoshonites.

\section{THE UPPER BRECCIA.}

The upper breccia, overlying that just described, is dark colored at its base and lighter colored in the upper portion. It is at present 3,000 feet thick through the summit of the mountain. 'The lower portion consists almost wholly of pyroxene-andesites, with little or no hornblende. Many fragments are vesicular and basaltic in habit, without megascopic phenocrysts. At the south base of the mountain there are vesicular massive bodies of pyroxene-andesite, with large phenocrysts of pyroxene and 
feldspar. The upper portion of this breccia is nore horublendic, and hornblende-proxene-andesites predominate. 'The transition from the pyoxene-aulesite portion to the hornblende-proxene-andesite portion appears to be gratual. The later breceia is aceompanier by vesicular flows of similin andesite, often quite porons. It is lighter colored in general, but parts are quite dark, with prominent hornblendes, the habit being andesitic, not basiltic. 'There are no evidences of any considerable break or interruption between the higher and the lower parts of this breceia. They appear as a continuous geological body, composed of fragments and flows of andesite which were ejected from one center of eruption during a considerable period of time.

The andesitic material composing this breecia varies somewhat in mineral composition and in megascopical habit, as will be seen from the following descriptions. The variation in the phenocrysts present other than feldspar in the specimens exanined is indicated in Table XI. They are andesites with glassy gromudmass and phenocrysts of plagioclase, hypersthene, and augite in some cases, and with these minerals and hornblende in others.

TABLE XI.-Dineral variation in the upper breccius of Sepulehre Mountain.

\begin{tabular}{|c|c|c|c|c|c|}
\hline \multirow{2}{*}{$\begin{array}{l}\text { Mineral } \\
\text { groups. }\end{array}$} & \multirow{2}{*}{$\begin{array}{l}\text { Specimen } \\
\text { number. }\end{array}$} & \multicolumn{4}{|c|}{ Phenocrssts other than feldspar. } \\
\hline & & Pyroxene. & Hornblende. & Biutite. & Quartz. \\
\hline \multirow{9}{*}{$\mathbf{B}_{\downarrow}$} & 385 & Much .... & & & \\
\hline & 386 & Much ... & $\cdots \cdots$ & & \\
\hline & 387 & Much .... & ....... & & \\
\hline & 388 & Much ....... & …..... & & \\
\hline & 390 & Much .... & $\ldots \ldots$ & & \\
\hline & 391 & Much .... & …..... & & \\
\hline & 392 & Much .... & ............ & 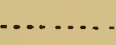 & \\
\hline & 393 & Much ....... & $\ldots \ldots \ldots$ & & \\
\hline & 394 & IIuch ..... & Little...... & & \\
\hline \multirow{3}{*}{$\mathbf{B}_{2} \ldots$} & 396 & Much .... & Little...... & ......... & \\
\hline & 397 & Much ........ & Little.... & $\cdots \ldots$ & \\
\hline & 398 & Mlueh ....... & Little...... & ittle.... & \\
\hline \multirow{5}{*}{$\mathbf{B}_{3}$} & 400 & Huch ....... & Little...... & & \\
\hline & 401 & Much ........ & Some ....... &. & \\
\hline & 402 & Mueh ........ & Some...... & $\ldots$ & \\
\hline & 403 & Mueh...... & Some..... & -........ & . \\
\hline & 404 & Much ........ & Sotne..... & & \\
\hline
\end{tabular}


TABLE XI.-Mineral rariation in the "ppe' lreccias of Sepulchre Mountain-Cont'd.

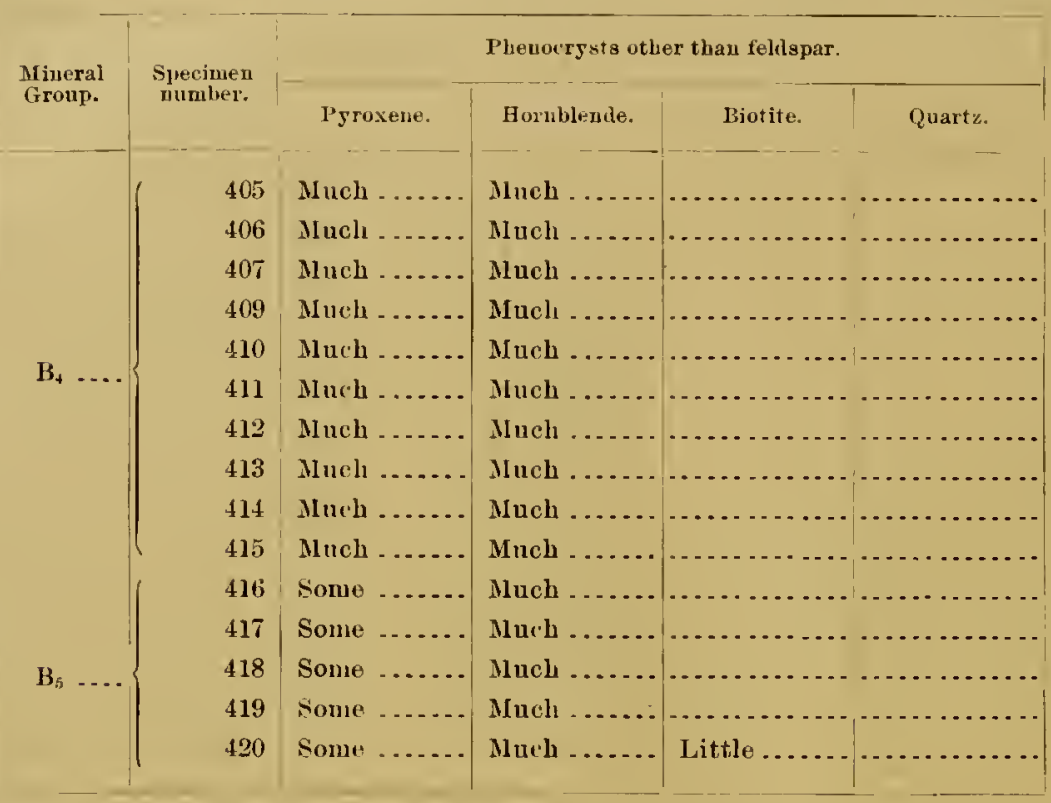

The varieties without hornblende, $B_{1}$ - that is, pyroxene-andesiteshave a groundnass of globulitic brown glass, in slades from dark to light, filled with microlites of feldspar, pyroxene, and magnetite. The size and abundance of the microlites vary. The feldspar mierolites are plagioclase with low extinction angles. Two of the vurieties examined are basaltic in appearance, with a few decomposed olivines among the phenocrysts.

The pyroxenes are both hypersthene and angite, having much the same general appearance in the same rock. Their crystal outline varies considerably in one rock section. Some individuals are bounded by distinct erystal planes, while others are rounded. Some have irregularly jagged outlines, with tongues of glassy groundmass projecting into the crystal. These forms appear to be the result of irregularities of growtl rather than of solution by the magma before its solidification. Inclusions of glass are common: also those of magnetite, and fewer of apatite.

The hypersthene is pleochroic; green parallel to $\mathfrak{c}$, yellow parallel to $\mathfrak{a}$, light red parallel to $\mathfrak{b}$. It is generally light colored in thin section. But one darker-colored erystal with strong pleochroism incloses thin brown plates, arranged in lines at right angles to the vertical axis of the erystal. These inclusions are like those in hypersthene in many coarsely crystalline 
rocks. In this case the rock is ghassy amel vesicular, and shows no signs of any kind of metamorphosing action. The inclusions in the hypersthene appear to be primary, inclosed at the time of the crystallization of the mineral. The lighter-colored hypersthenes are free from them. Occasionally the color varies in concentric zones. In some rocks both kinds of pyroxehe have narrow reddisli-brown horders that are analogous to the black borders around some hornblendes, and appear to be of similar origin. The pyroxene microlites of the groundmass are affectel in the same manner as the phenocrysts; lience the change of condition must lave followed the crystallization of the microlites.

The color of the augite is light green in thin section, and without pleochroism. It is like the augite in the diorites of Electric Peak, both optically and as regards cleavage. Hypersthene and augite are occasionally intergrown in such a manner as to indicate their nearly synchronous crystallization; but when one incloses the other, it is hypersthene that is within, and hence the older. Hypersthene is the more easily decomposed of the two, and changes into a green fibrous mineral, probably bastite.

The feldspar phenocrysts are all lime-soda feldspar, and are mostly labradorite, judging from optical characters. Their ontline in sections is rectangular, sometimes with more than four sides. Zonal structure is pronounced, but the difference in the optical character of the varions zones is not marked. Glass inclusions are frequent. In the larger crystals the central portion is often crowded with inclusions of brown glass containing the same microlites as the surrounding groundmass. The shape of these inclusions is usually rectangular. Many smaller feldspars are almost free from them. Inclusions of magnetite and pyroxene occur. When feldspars and pyroxenes have crystallized in juxtaposition, it is seen that the feldspar is the younger, but that its crystallization began before that of the pyroxene ceased. They were in part contemporaneous.

Magnetite occurs as microscopic phenocrysts. There are five sections of pyroxene-andesites carrying small amounts of homblende and constituting transitional varieties between these rocks and horublende-pyroxeneandesites.

The hornblende is in small irregular crystals, some being rounded and others in angular shapes. It is reddish brown and brownish green, with strong pleochroism. Many of the individuals, especially the rounded ones, 
have a narrow border of magnetite or one of small crystals of pyroxene, feldspar, and magnetite. There are all gradations, from rounded homblendes with opaque borders to small angular pieces of homblende surrounded by comparatively large crystals of pyroxene, feldspar, and some magnetite, which form a group of interlocked crystals in the glassy groundmass. The angular outline of the hornblende and its penetration between the crystals of feldspar and pyroxene would militate against the supposition that the horublende is a remnant of a previous crystal that had been partially resorbed in the groundmass, were it not for the occurrence in one thin section of a group of different crystals with a hexagonal ontline, corresponding to the cross section of the hornblende remnants contained in it which are properly oriented for such a section. The greater part of the group consists of feldspar and pyroxene with some magnetite. It is not to be supposed that these minerals crystallized ont of the melted hornblende substance withont interchange of material from the surrounding magma. The larger groups in the same rock section exhibit no definite outward form, but are bounded by the outlines of the outer crystals, so that we may conclude that the process of resorption of the hornblende phenocrysts was in some cases accompanied by the immediate formation of grains of magnetite and the absorption of the other chemical constituents by the magma, while in other cases the melted hornblende recrystallized in situ as prroxene and magnetite. But in the instances just mentioned the partial resorption of the lornblende was followed by a greater tendency toward crystallization in the magma immediately surrounding the melted hornblende, which led to the development of a group of all the minerals then capable of forming. These minerals are the same in size and character as the small crystals scattered through the glassy groundurass.

In only two sections of the andesites examined was biotite found. It was in small crystals with compound borders similar to those atround hornblende.

The remaining rock sections from this breccia represent hornblendepyroxene-andesites with varying amounts of the ferromagnesian minerals, forming a series with increasing hornblende and decreasing pyroxene. In these andesites the microseopical characters of the pyroxenes are the same as in the rocks just described. The homblende varies in different rocks, 
both in color and in the extent to which it has been resorbed. In some cases there has been no resorption. The erystals when idiomorylic are bounded by the prism, clinopinacoid, and the usual teminal planes. In many cases the form of the erystals is not sharply defined. The color varies from intense red in some rocks to reddish brown, chestnut brown, greenish brown, and brownish green, with the corresponding pleochroism. The color bears no fixed relation to the presence or absence of opaque border, nor to the amount of resorption. It does not appear to be due to secondary alteration of the hornblendes, since the rocks are all fresh and glassy.

The character of the border is not always constant for all the hornblendes in one rock section. Around it in some cases is a narrow margin of magnetite grains; in others the margin is heavy and opaque. Other hornblendes in the same section are surrounded by crystals of pyroxene, plagioclase, and magnetite. In many sections all the hornblendes are alike, with or without borders. There seems to be no relation between the character or degree of resorption and the degree or kind of crystallization of the groundmass; and different phases of resorption occur within very short distances of one another in the same rock. Crystals which do not exhibit other signs of resorption sometimes have large "bays" or pockets of groundmass as inclusions, which may have been originally inclosed at the time of the crystallization of the hornblende. The position of the hornblende with respect to adjacent crystals of pyroxene and feldspar indicates that they. were contemporaneous crystallizations in part. The latest feldspars and pyroxenes are always younger than the hornblende.

The feldspar phenocrysts are all plagioclase, in most cases labradorite, less commonly andesite or oligoclase. Their microscopical characters are very nearly the same as those of the feldspars in the pyroxene-andesites. The groundmass of these andesites in some cases is brown globulitic glass with microlites of pyroxene, feldspar, and magnetite. In most sections it is colorless glass crowded with the same kinds of microlites. It carries microscopic crystals of these minerals which are porphyritical with respect to the groundmass when seen with a microscope, but which in turn form part of the groindmass that carries the megascopic phenocrysts. 
THE DIKE ROCKS.

The dike rocks of Sepulchre Mountain are andesites and dacites, the earliest of which resemble the pyroxene-andesites and hornblendepyroxene-andesites of the breccias. Mineralogically they range from rocks with phenocrysts of hypersthene, augite, and lime-soda feldspar to those with phenoerysts of quartz, biotite, homblende, and lime-soda feldspar. This variation is indicated in Table XII, in which 103 sections of these rocks are arranged according to the proportions of the porplyyritical minerals.

TABLE XII._.Mineralogical marations in the dite rocks of Sepulehre Mountain.

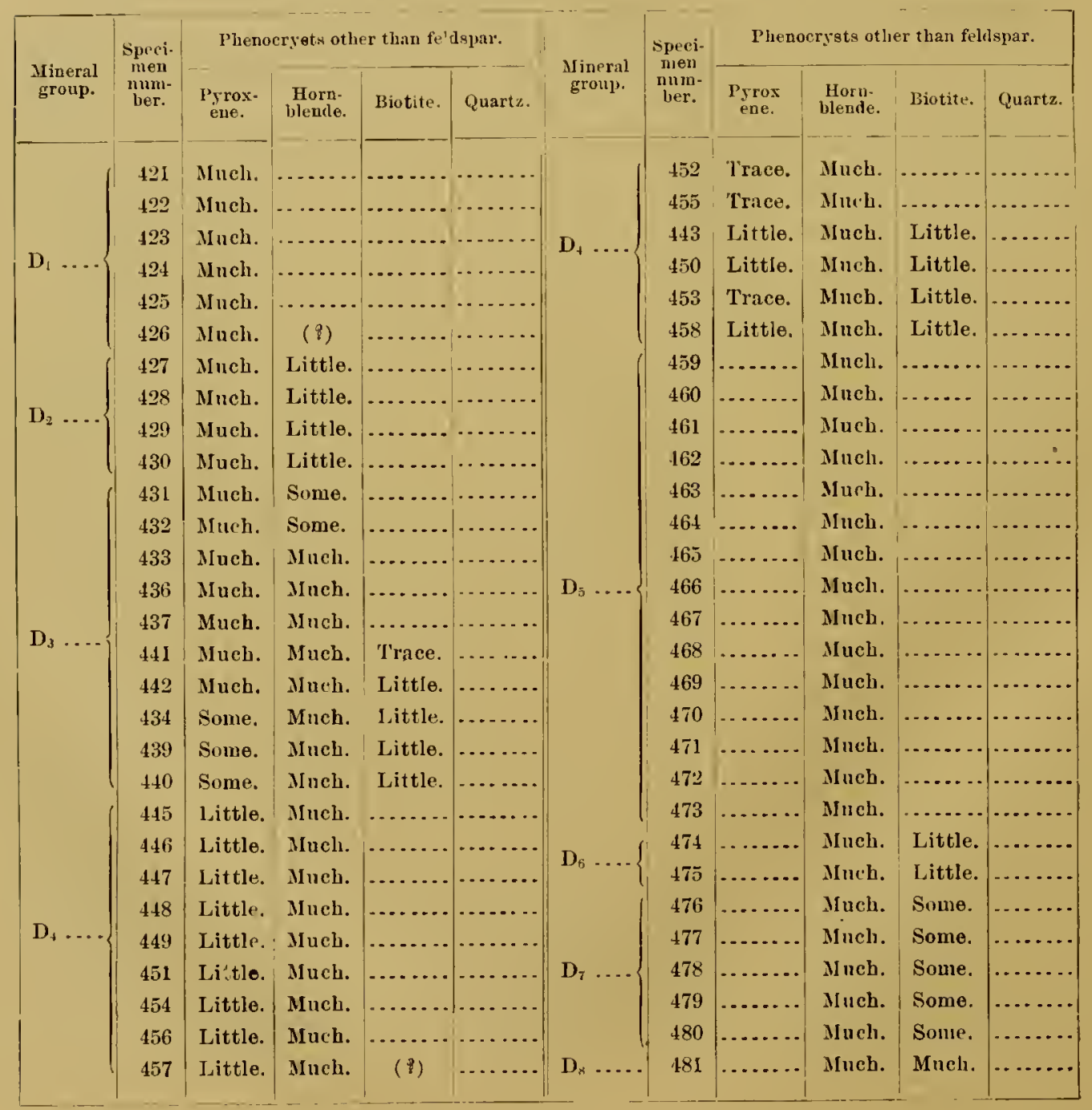


DIKE ROCKS OF SLPULCHRE MOUNTAIN.

TanLE: XII.-Mineralogical variations in the dikerocks of Sepulehre Mountain-Cont'd.

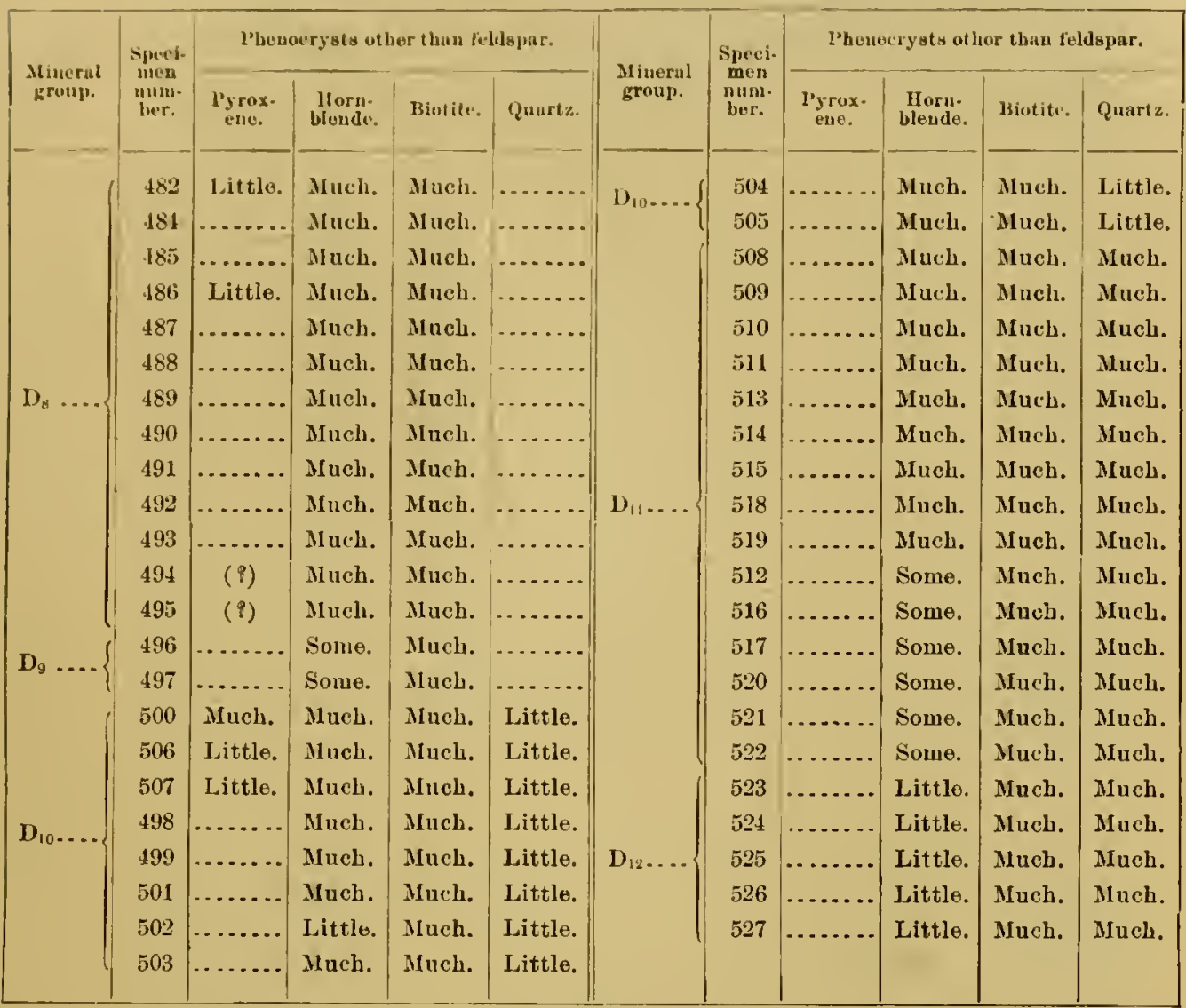

Most of the pyroxene-andesites and hornblende-pyroxene-andesites carry no biotite. In a few cases it is present in small amount. Some hormblende-andesites contain neither pyroxene nor biotite; others have a small amount of botl.. The structure of a glassy pyroxene-andesite dike rock (421) is shown in Pl. XXII, fig. 1. In most of the hornblende-micaandesites there are no porphyritical pyroxenes; they are present in small amounts in a few cases; and they are equally rare in the dacites. As quartz phenocrysts increase in number biotite is more abnndant, and hornblende less so. Lime-soda feldspars are present in all the rocks, ranging from labradorite in the more basic andesites to oligoclase or andesine in dacite.

The microscopical characters of the minerals are the same as in the andesites of the breccias. 'The pyroxenes are hypersthene and augite, the first being more readily decomposed and sometimes completely altered. IION XXXII, P'I $11 \longrightarrow 9$ 
The hornblende is sometimes represented by paramorphs of magnetite and angite in the pyroxene-andesites, often exhibits black borders in the intermediate andesites, and in the more acid andesites and dacites is entirely free from any dark border. Its form and colors are the same as before described for the andesites of the breccias. Biotite is also the same as in those rocks. In one instance it incloses a small crystal of plagioclase.

The fellspars all exhibit polysynthetic twimning. Their cross sections are mostly rectangular in the more basic andesites, and are labradorite. In some of these andesites they appear to be oligoclase. In the more acid andesites and dacites the lime-soda feldspars are larger and have more crystal faces. They appear to belong to several species. Besides numerous glass inclusions, there are a few instances in which feldspar phenoerysts contain opaque needles and grains, arranged in several systems of parallel lines, which are identical with the inclusions in many of the labradorites in the diorite of Electric Peak. They are sometimes accompanied by glass inclusions, which proves their primary character. Quartz phenocrysts are both idiomorphic and rounded in the same rock section. They usually occur in isolated grains, but sometimes several are attached to one another (Pl. XXI fig. 2), just as several feldspar's often are. Glass inclusions are abundant. In only one case were fluid inclusions noticed together with those of glass. Magnetite, apatite, and zircon oceur in their usual forms and in ordinary amounts.

The groundmass of these rocks differs in degree of crystallization, in mineral composition, and in structure. In the more basic andesites it is in many cases glassy, with multitudes of microlites of pyroxene, plagioclase, and magnetite; in many others it is completely crystallized and the outlines of the microlites are no longer sharply defined. In the holocrystalline varieties of these rocks the different degrees of crystallization may be compared with one another by arranging them in a table according to the size of grain of the groundmass. This las been done in Table XIII, in which they have been combined with the specimens of breccia from Sepulchre Mountain, and have been separated into mineralogical groups whose scope may be seen by comparison with Tables XI and XII. The grades of crystallization correspond to those established for the intrusive rocks of Electric Peak, with the addition of five more grades, which embrace two finer-grained degrees of holocrystalline structure and three degrees of glassi- 


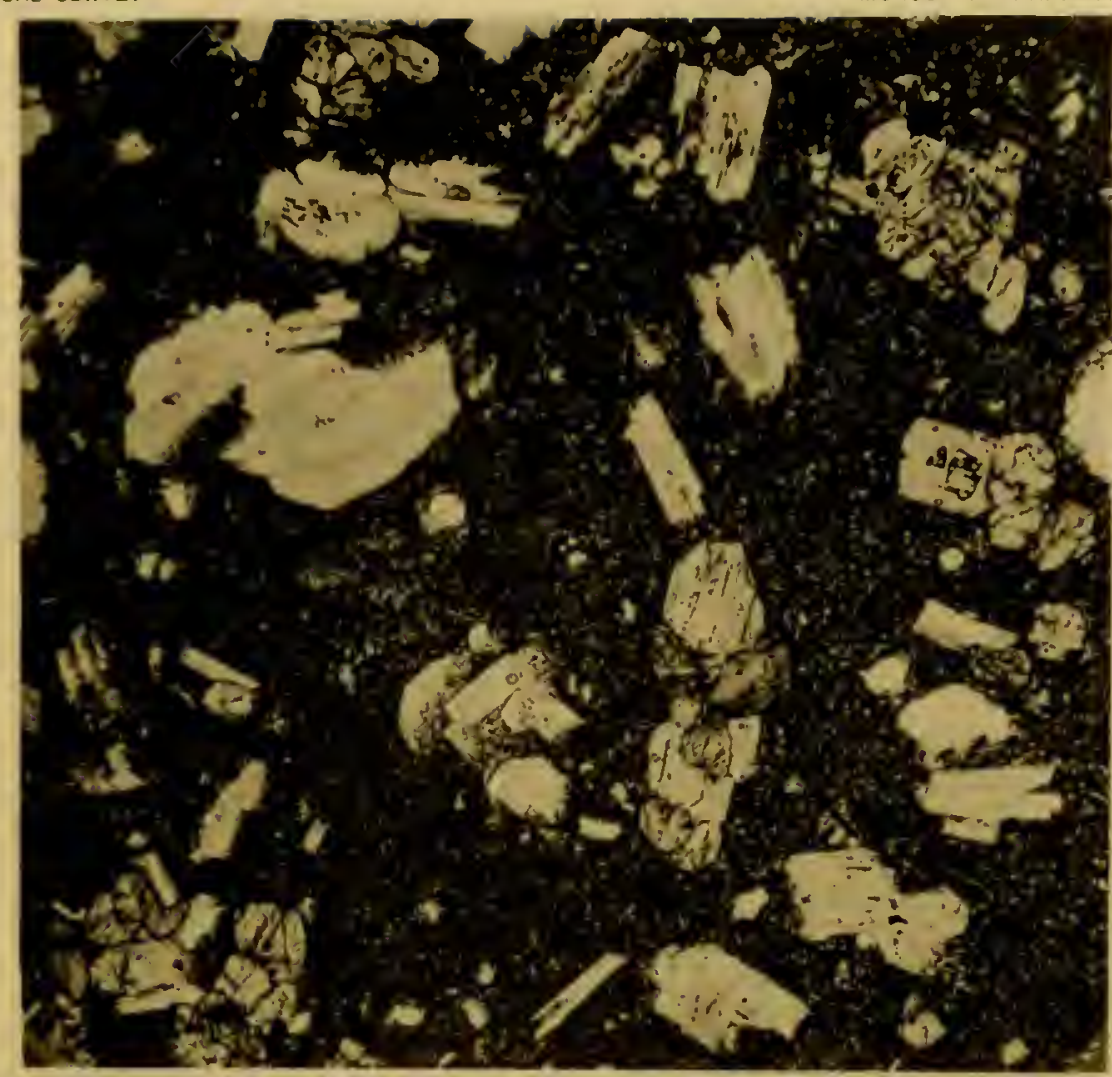

(A) $\times 32$

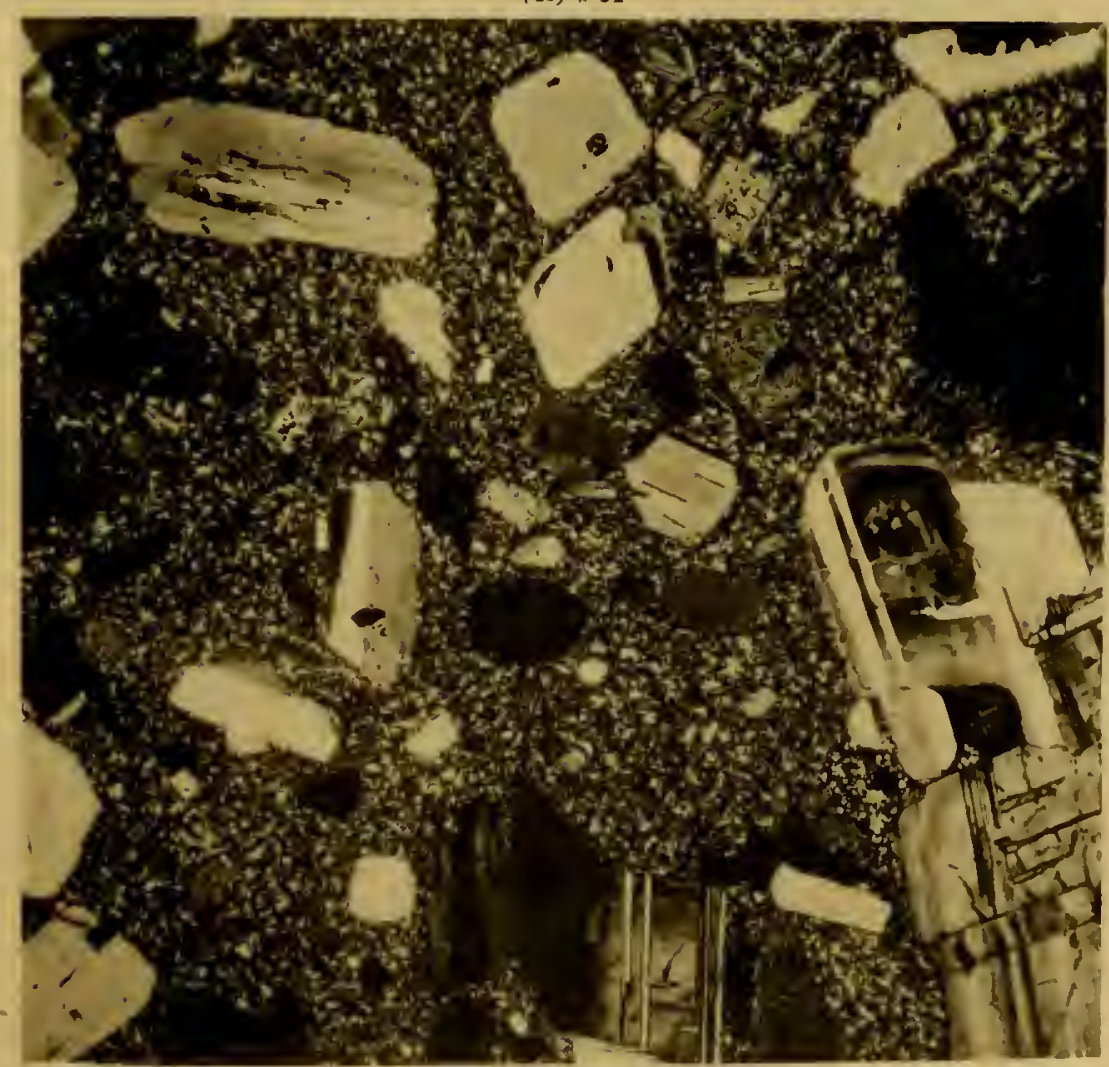

(B) $\times 33$

PHOTOMICROGRAPHS OF PYROXENE-ANDESITE AND DACITE 

ness. The rock shown in l'l. XXII, fig. 1, belongs to grade 2, being microlitic glass. In the dacite shown in Pl. XXII, fig. 2, the grade of erystallization is 9; and in the dacite shown in Pl. XXI, fig. 2, it is 19.

TABLE XIII._Grades of crystullization of the eruptive rocks of Sepulchre Mountain.

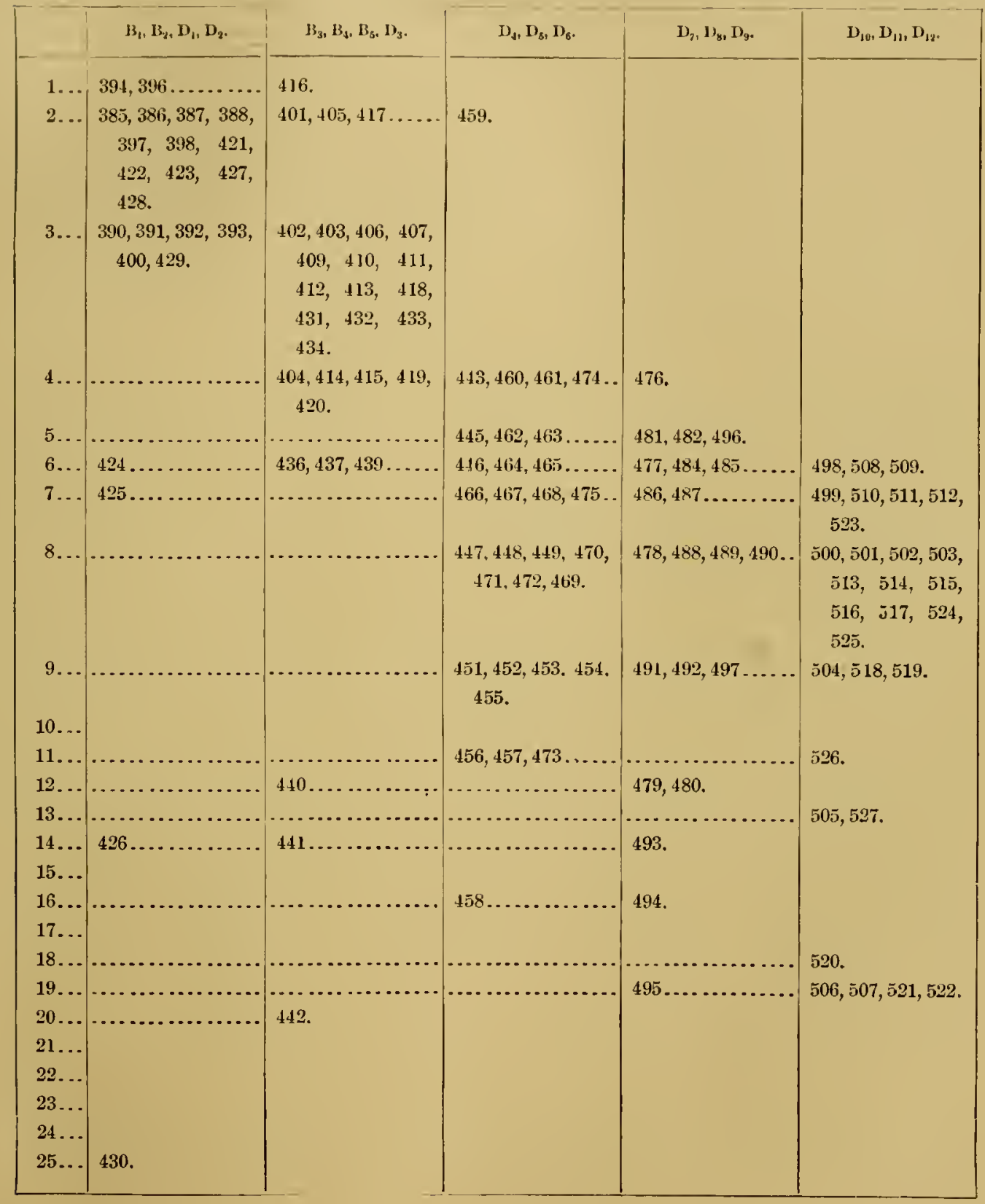


The microstructure of the acid varieties is not the same as that of the basic, so that it is difficult to compare the grain of one directly with that of the other; but since the intermediate rocks possess microstructures intermediate between these extremes, it is possible to establish a kind of relationship, between them, and it is admissible to place them in the same line across the table, it being understood that the correspondence is an approximation.

A glance at Table XIII shows that a large majority of the varieties are very fine-grained forms that have only reached the crystallization of the few smallest-grained forms of the Electric Peak rocks. A small number of them are more coarsely microcrystalline and correspond to the grain of the dike rocks at Electric Peak. A large number are finer grained than any of these rocks, or are glassy. The coarsest-grained forms have been attained by the most basic varieties, but they do not represent bodies of auy considerable extent. Specimen No. 430, grade 25 , comes from a small exposure with no definite limits, surrounded by much finer-grained rocks. It is properly a diorite-porphyry, and carries much biotite of final consolidation, which has not been reckoned with the phenocrysts. The coarsestgrained forms of the acid varieties, however, represent larger bodies and are more abundant in the field.

In explanation of the degrees of crystallization indicated in the table, it may be said that the first three are glassy groundmasses, the first one having fewer microlites than the second. In the third the microlites are closely crowded togetler. The next two represent microlitic structures in which no glass can be detected; they appear to be holocrystalline. In the sixth grade the form of the microlites is more indistinct, but the general structure is the same as before. Beyond this the different degrees indicate increasing grades of a structure which may be described in general as follows: Commeneing with the lowest order, the groundmass is composed of a multitude of indistinct microlites of lath-shaped feldspars; between crossed nicols this aggregation extinguishes light in small patches which bear no fixed relation to the position of the microlites within them. As the dimensions of the latll-shaped feldspars become larger it is observed that. the patches of light and darkness arise from the cementing material between these feldspars. This cement possesses the same optical orientation for small spaces which in cross section produce the patches just alluded to. In 
still coarser-grained forms it becones apparent that the cementing material is quart\% which has erystallized in irregularly shaped pateles inclosing many smaller feldspars. The size of these feldspars and of the interstices between them is taken as the grain of the rock, and not the size of the patehes of quartz. For it is observerl that as the rocks become more coarsely erystalline the feldspars, which are plagioclase, increase steadily in size and each quart\% patch cements fewer of them, until in still coarser grades the quartz forms allotriomorphic individuals between the plagioclases and does not surround any, so that in these varieties of rock the size of grain is judged by the dimensions of the plagioclases and the interstices of quartz. The patchy structure just described is that called micropoikilitic.

In the most siliceous varieties of the rocks the microstructure is different. The smallest-grained forms appear to approach a granular structure, in which, however, the feldspars exhibit a more or less rectangular shape and the quartz slows a tendency to appear in minute, poorly defined dihexahedrons. As the grain becomes larger the form of the quartz grains becomes more pronounced (PI. XXII, fig. 2). They are rndely idiomorphic, with sections that are in many cases equilateral rhombs, extinguishing the light parallel to their diagonals. In the coarsest-grained forms of the dacites these imperfectly idiomorphic quartzes are characteristic of the groundmass, and reach a diameter of from $0.08 \mathrm{~mm}$. to $0.10 \mathrm{~mm}$. (Pl. XXI, fig. 2). Their surface is indented with the ends and corners of small plagioclases, the structure of the groundmass being hypidiomorphic. These quartzes often contain minute colorless inclusions in negative crystal cavities, which have every appearance of being glass and correspond to the glass inclusions in the quartz phenocrysts of the same rocks. The partially diomorphic quartzes in the groundmass are to a slight degree porphyritical with espect to the other constituents, but belong to the final consolidation of the magma. 
GENERAL CONSIDERATION OF THE MINERAL AND CHEMICAL COMPOSITION OF THE ERUPTIVE ROCKS OF SEPULCHRE MOUNTAIN.

MINERAL COMPOSITION.

The mineral variations in the group of rocks forming Sepulchre Inountain are much simpler and require much less discussion than those of the intrusive rocks of Electric Peak. They have already been expressed in Tables XI and XII. From these tables it is evident that the so-called transitional forms of the rocks are as numerous and as important as those forms which would be considered type rocks. There is no particular mineralogical modification of the rocks at this place whicl from its greater abundance or its special mode of occurrence renders it a type rock. On the contrary, the whole accumulation of eruptive rocks which are subsequent to the bottom breccia, with its admixture of Archean fragments, must be considered as a series of volcanic rocks that vary in mineral composition through gradual changes from pyroxene-andesite to dacite.

Starting with those rocks which earry phenocrysts of pyroxene and plagioclase, it is observed that as the hornblende makes its appearance and increases in amount the pyroxene decreases. Biotite accompanies the hornblende in the more acid varieties, and increases in amount with the acidity of the rock. Quartz first appears in small quantities, and increases with the acidity of the rock, the hornblende decreasing at the same time. To this rule there are exceptions, which are indicated in the table. Biotite is found to a slight extent in some of the hornblende-pyroxene-andesites, and pyroxene occurs in small amounts in some of the hornblende-micaandesites. It is, of course, understood that this relation between the essential minerals may be different for groups of andesites in other regions. 
CIIEMIOAL COMPOSITION.

'The chemical composition of the eruptive rocks of Sepulchre Mountain is shown in the accompanying table of chemical analyses:

TABLl: XIV.-Chemical analyses of rocks from Sepulchre Mountain.

\begin{tabular}{|c|c|c|c|c|c|c|c|c|c|}
\hline Constitnent. & 421 & 471 & 407 & 386 & 409 & 487 & 494 & 521 & 523 \\
\hline SiO:.. & 55.83 & 55.92 & 56.61 & 57.17 & 60.30 & 64.27 & 65.50 & 65.66 & 67.49 \\
\hline TiO......... & 1.05 & .94 & .79 & 1.03 & .76 & .32 & .45 & 1.37 & .13 \\
\hline$\Delta l_{0}, O_{3}, \ldots \ldots \ldots$ & 17.11 & 17.70 & 13.62 & 17.25 & 16.31 & 17.84 & 14.94 & 15.61 & 16.18 \\
\hline $\mathrm{Fe}_{2} \mathrm{O}_{3} \ldots \ldots \ldots$ & 4.07 & 3.16 & 5.89 & 2.48 & 4.35 & 3.36 & 1.72 & 2.10 & 1.30 \\
\hline Feo.............. & 3.75 & 4.48 & 2.60 & 4.31 & 1.41 & 1.29 & 2.27 & 2.07 & 1.22 \\
\hline $\mathrm{MnO} \ldots .$. & None. & Trace. & .35 & None. & .13 & None. & .20 & None. & .08 \\
\hline CaO............ & 7.40 & 5.90 & 6.61 & 6.61 & 5.62 & 3.42 & 2. 33 & 3.64 & 2. 68 \\
\hline $\mathrm{BaO} \ldots$ & $\cdots \cdots \cdots$ & ….. & .14 & ......... & .15 & $\ldots \ldots$ & .13 & …..... & ........ \\
\hline $\mathrm{MgO} . . . .$. & 5.05 & 4.34 & 5.48 & 4.83 & 2.39 & 2.00 & 2.97 & 2.46 & 1.34 \\
\hline $\mathrm{SrO} \ldots \ldots \ldots$ & ........ & a...... & Trace. & ….... & Trace. & ........ & Trace? & ........ & -..... \\
\hline $\mathrm{Li}_{2} \mathrm{O} \ldots \ldots \ldots \ldots$ & None. & .09 & ......... & Trace. & - & .03 & a......... & .36 & …... \\
\hline $\mathrm{Na}_{2} \mathrm{O} \ldots \ldots \ldots$ & 2.94 & 4.08 & 3. 13 & 3.44 & 3.99 & 3.84 & 5.46 & 3.65 & 4.37 \\
\hline $\mathrm{K}_{2} \mathrm{O} \ldots \ldots \ldots$ & 1.71 & 2.28 & 2.71 & 2.03 & 2.36 & 2.48 & 2.76 & 2.03 & 2.40 \\
\hline $\mathrm{P}_{2} \mathrm{O}_{5} \ldots \ldots \ldots \ldots$ & .21 & .18 & .06 & .05 & .20 & .16 & .09 & Trace. & .13 \\
\hline $\mathrm{SO}_{3} \ldots \ldots \ldots \ldots$ & Trace. & Trace. & $(q)$ & Trace. & .10 & Trace. & .06 & .13 & $\ldots \ldots \ldots$ \\
\hline Cl $\ldots \ldots \ldots$ & None. & None. & (........ & Trace. & $\ldots \ldots$ & None. & $\ldots \ldots$ & .12 & \\
\hline $\mathrm{CU}_{2} \ldots \ldots \ldots \ldots$ & .......... & ......... & None. & ......... & None. & ......... & None. & & \\
\hline $\mathrm{H}_{2} \mathrm{O} \ldots \ldots \ldots \ldots$ & 1.28 & 1.42 & 2.27 & 1.20 & 2.50 & 1.32 & 1.57 & 1.07 & 2.69 \\
\hline \multirow{3}{*}{ Less $\mathrm{O}$ for $\mathrm{CI}$. } & 100.40 & 100.45 & 100.26 & 100.40 & 100.57 & 100.33 & 100.25 & 100.27 & \multirow[t]{3}{*}{100.01} \\
\hline & .......... & .......... & .......... & ........ & ........ & & & .03 & \\
\hline & & & & & & & & 100.24 & \\
\hline
\end{tabular}

Nos. 421, 471, 386, 487, and 521 were analyzed by Mr. J. E. Whitfield; Nos. 407, 409, and 494 were analyzed by Dr. T. M. Chatard; and No. 523 was analyzed by Mr. L. G. Eakins.

The first, 421 , and the fourth, 386 , are analyses of pyroxene-andesites which carry no hornblende. The first is from a dike near the summit of the mountain; the other is from a surface flow at its southwest base. Nos. 407 and 409 are of hornblende-pyroxene-andesites, occurring as breccia in the upper part of the mountain. No. 471 is of hornblendeandesite, which is an intruded body in the small hill northeast of Cache Lake, at the head of Reese Creek. No. 487 is a hornblende-mica-andesite from the same locality, also an intrusive rock. No. 494 is the same kind of andesite from an intrusive mass at the north base of Sepulchre Mountain, 
and Nos. 521 and 523 are dacites from the ridge south of Cache Lake. The structure of 521 is shown in PI. XXI, fig. 2.

The range of variation in the percentage of silica is abont the same as that of the rocks at Electric Peak. The character of the variations of the other oxides in these rocks is shown by the accompanying diagram, fig. 3 , which represents the variations in the molecular proportions of the essential oxides, and has been plotted in the manner already described.

A glance at this diagran shows that it has the same form as that of the group of analyses of the rocks from Electric Peak. The rariations in

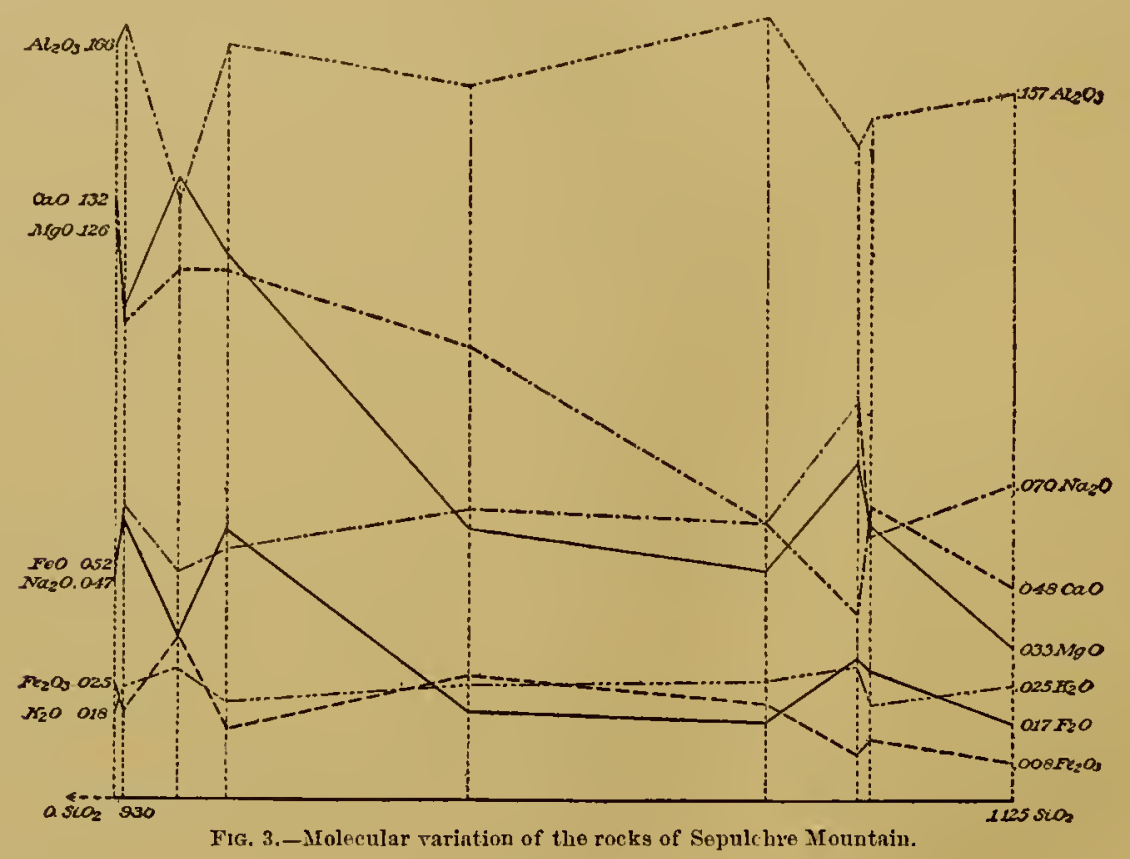

the oxides other than silica are quite irregular for a gradual change in the silica. The alumina varies rapidly in places and retains a high position in the diagram. The alkalies gradually increase with the silica, the soda molecules being twice as numerous as those of potash, and their variations being alike, with one exception. Magnesia raries most widely, and in striking contrast to the alnmina; in each instance they rary in opposite directions. The lime is nearly as irregular as the magnesia, both decreasing rapidly from the less siliceous to the more siliceous end of the series. The two oxides of iron are strikingly reciprocal in their variations, the significance of which has been pointed out in discussing the diagram for Electric Peak. 
In the group of analyses from Sepulchre Mountain the oxidation of the iron bears a noticeable relation to the presence of homblende, biotite, and matgretite in the rocks.

From a stuly of these analyses it is evident that the chemical variations in this group of rocks are the same in character and extent as those in the intrusivo rocks of Electric Peak. Moreover, it appears that the variations between similar varieties of andesite-such as those between different pyroxene-andesites-are as great as, and in some cases greater than, the variations between varieties of andesites which are distinguished mineralogically from one another. Thus, Nos. 421 and 386 are pyroxene-andesites without hornblende, Nos. 407 and 409 are hornblende-pyroxene-andesites, while No. 471 is a homblende-andesite. It is not possible to point to any elemical character of these rocks that is distinetive of this mineral variation, with the exception of the oxidation of the iron, which, though slight, is an important one; for it undoubtedly relates to forces that did not alter the fundamental relation between the bases in the magma, but simply modified it by changing the oxidation of one of them. The last four analyses are of hornblende-mica-andesites and dacites. The chemical variations between them are as pronounced as those between the more basic members of the series, without there being the corresponding differences between the kinds of ferromagnesian silicates, so far as it can be detected microseopically. They all carry lornblende and biotite, and no pyroxene, the relative proportions of these minerals varying. The character and amount of the feldspars differ in these rocks, and so do the abundance and mode of occurrence of the quartz. In Nos. 521 (Pl. XXI, fig. 2) and 523 quartz appears as phenocrysts; in the other rock it is confined to the groundmass.

\section{THE EXTRUSIVE IGNEOUS ROCKS WEST AND SOUTHWEST OF THE GALLATIN MOUNTAINS.}

These are mainly tuff-breccias of andesite, with rarely a massive lava flow of andesite, more numerous flows of basalt, and the great rilyolite lava sheet. Andesitic breccias form the north-south ridge west of the headwaters of Fan Creek, and extensive accumulations of these rocks underlie rhyolite in the northwestern corner of the Park, where they are connected with the range of volcanic mountains farther north. There are other isolated areas of andesitic breccia in the gneissic mountains west of Mount Holmes. In 
all of these localities the tuff-breccias have the same general character as the tuff-breccia of Sepulchre Mountain, just described They vary somewhat in compactness. In all, the fragments are small. The general color is dark, but that of the individual fragments is varied-dark and light grays, witl tones of red. There are abundant small phenocrysts in most instances; some fragments are almost free from them, while others carry larger and more prominent ones. The mineral composition varies slightly among the fragments in any considerable mass. The greater part are hornblende-pyroxene-andesites and pyroxene-andesites. Hornblende-andesites without pyroxene are less abundant. Still less frequent are hornblendemica-andesites, representing the most siliceous rocks, while the least siliceous are olivine-bearing pyroxene-andesites or andesitic basalts, which are much rarer: These varieties naturally grade into one another and are intermingled in the tuff-breccias.

The microscopical character's of the varions andesites from these localities correspond to those of the Sepulchre Mountain andesites. The groundmasses range from glassy to microcrystalline and microlitic. Some of the glasses are colorless, others brown and globulitic. The hornblendes in most cases are brown and reddish brown, seldom green (543), which contrasts them with those in the andesite-porphyries. They often have black borders, especially in the more basic rocks, where they are sometimes paramorphosed to magnetite and pyroxene. The feldspars are plagioclases, more calcic in the less siliceons rocks. They are characterized by numerous glass inclusions and marked zonal structure. The pyroxenes are hypersthene and augite. The olivine in two rocks where it was observed is serpentinized.

\section{COMPARISON OF THE ROCKS FROM ELECTRIC PEAK AND SEPULCHRE MOUNTAIN.}

The geological structure of Electric Peak and of Sepulchre Mountain and the occurrence and character of the igneous rocks in each locality having been described, it remains to point out the relationship of the two groups of rocks to each other and the petrological deductions which may be drawn from their investigation.

To arrive at the relationship of the volcanic rocks of Sepulchre Mountain to the intrusive rocks of Electric Peak, it is necessary to observe, in review of the facts already presented, that the latter cut through Cretaceous 
shales and sandstones, and have imparted to them sufficient heat to metamorphose them for a great distance, indicating the passage of large quanti. ties of molten magna through the fissures, while the lavas of Sepulelure Mountain rest on Cretaceous strata and also carry large blocks of black shale inclosed within them. They plainly show by their 'rrushed and dragged portions that a profound fault has separated the block of Sepulche Mountain from that of Electric Peak, droppling the former down considerably more than 4,000 feet. Consequently the volcanic rocks of Sepulchre Mountain once occupied a higher elevation than the present summit of Electric Peak and its bodies of intrusive rock.

In Electric Peak there is a system of fissures that radiate outward toward the south and southwest, as shown by the dikes of porphyry. At the west base of Sepulehre Mountain there is a system of dikes and intruded bodies that radiate ontward toward the north and northeast. These fissures antedate the great fanlting just mentioned and represent the east and west halves of a system of fissures trending from north and south around to northeast and southwest, which crossed one another at the point where the broadest body of intruded rock is now found. The axis of this system appears to have been inclined toward the east-that is, to have dipped toward the west-and was cut across by the great fault which dropped Sepulchre Mountain.

The igneous rocks that broke through the strata of Eleetric Peak consist of a series of andesite-porphyries, occurring in sheets between the strata, and another series of diorites and andesite-porphyries that were erupted through the vertical fissures just alluded to. The central fissure or fissures became the conduit through which the molten magmas followed one another after suceessive intervals of time. In the outlying narrow fissmres the magmas solidified as dikes of porphyry, while within the heated conduit they consolidated into coarse-grained diorites of various kinds. The magmas of this series of eruptions became more and more siliceous. Their succession is indicated in the table on the next page. 
TABLE XV.-Order of eruption of the rocks at Electric Peak and Sepulehre Mountain.

\begin{tabular}{|c|c|}
\hline Succession of eruptions at Elestric Peak. & Succession of ernptions at Sepulchre Mfonntain. \\
\hline $\begin{array}{l}\text { A. Intrusion of sheets of audesite-por- } \\
\text { phyry from the southwest. }\end{array}$ & $\begin{array}{l}\text { A. Extravasation of andesitic breccia from } \\
\text { some Archean areal. }\end{array}$ \\
\hline $\begin{array}{l}\text { B. Intrusion of dike and stock rocks in } \\
\text { the following order: } \\
\text { Pyroxene-porphyries, grading into }\end{array}$ & $\begin{array}{l}\text { B. Eruption of andesitic breccias and } \\
\text { dikes in the following order: } \\
\text { Pyroxene-andesites, breccia, and flows, } \\
\text { passing into }\end{array}$ \\
\hline $\begin{array}{l}\text { pyroxene- and bornblende-diorites } \\
\text { with biotite of tinal erystallization, } \\
\text { with dikes of pyroxene-and horn- } \\
\text { blende-porphyries, graling into }\end{array}$ & $\begin{array}{l}\text { pyroxene-hornblende-andesites, brec- } \\
\text { cia, and flows, witb dikes of similar } \\
\text { andesites, grading into }\end{array}$ \\
\hline $\begin{array}{l}\text { hornblende-biotite-diorites with bio- } \\
\text { tite of early erystallization, with } \\
\text { dikes of hornblende-biotite-porphy- } \\
\text { ries; }\end{array}$ & $\begin{array}{l}\text { hornblende-biotite-andesites, in dikes, } \\
\text { grading into }\end{array}$ \\
\hline $\begin{array}{l}\text { quartz-biotite-diorite-porphyry with } \\
\text { some hornblende, witl dikes of } \\
\text { quartz-biotite-porphyry. }\end{array}$ & $\begin{array}{l}\text { dacites with phenocrysts of quartz, } \\
\text { biotite, and some hornblende. }\end{array}$ \\
\hline
\end{tabular}

The igneous rocks that formed the breccias and lava flows of Sepulchre Mountain, with their dikes and larger intruded bodies, constitute a series of andesites, basalts, and dacites, which reach a degree of crystallization that places part of them among the porphyries. They commenced with an andesitic breccia that is filled with Archean fragments, which must have been thrown from some neighboring center of eruption located in an Archean area. Such a center exists a few miles to the north. This was followed by a series of magmas that were at first somewhat basic and became more and more siliceous. The series is represented in the right-hand column of Table XV. From this it is seen that the succession of eruptions in each locality was the same after the first period, $A$, in which the magmas evidently came from different sources. Each series of the second period began with basic magmas and ended with acid ones. Their division in the table into four groups is not intended to convey the idea that they belong to four distinct periods of eruption; the whole series in each case is, rather, a single irregularly interrupted succession of outbursts of magma that gradually changed its composition and character. Upon comparing the rocks which have resulted from the corresponding phases of these series of eruptions, the similarity of the porphyritic forms is immediately recognized. 
The nature and distribution of the phenoerysts in the different varieties of andesite and dacite, whieh deternine their megaseopical habit, have their exact counterpart in the different varieties of porphyries. The microseopieal characters of the phenocrysts in the corresponding varieties of porphyries and of the intruled andesites and dacites are identical. 'The eharacter of the valions groundmasses, however, is different in the two groups, being more highly erystalline in the porphyries-many of the andesites being ghlasiy. Many of the finer-grained diorites lave a labit, derived from the distribution of the ferromagnesian silicates and larger feldspars, which resembles that of some of the andesites and dacites that correspond to them chemically.

Finally, the stndy of the chemical composition of the intrusive rocks of Electric Peak and of the roleanic rocks of Sepulehre Mountain proves that these two groups of roeks have identical chemical compositions, for the varieties that have been analyzed are but a few of the many mineralogieal and structural modifications assumed by these magmas on cooling. The analyses serve as indications of the range of the chemical variability of these magmas

From the geological structure of the region, then; from the correspondence between the order of eruption of the two series of rocks; from the resemblance of a large part of the roeks of both series, megascopically and microscopically, and from the ehemical identity of all the roeks of both groups, it is conclusively demonstrated that:

I. The voleanic rocks of Sepulchre Mountain and the intrusive rocks of Electric Peak were originally continuous geological bodies.

II. 'The former were forced through the conduit at Electric Peak during a series of more or less interrupted eruptions.

III. The great amount of heat imparted to the surromding rocks was due to the frequent passage of molten lara through this eonduit.

We have, then, in this region the remnant of a voleano, which has been fractured across its conduit, faulted, and considerably eroded, and which presents for investigation, on the one hand, the lower portion of its aceunulated débris of lavas, with a part of the upper end of the conduit filled with the final intrusions, and on the other hand, a section of the conduit within the sedimentary strata upon which the voleano was built. 
CORRELATION OF THE ROCKS ON A CHEMICAL BASIS.

Correlating the two groups of rocks according to their chemical composition and arranging them as in Table XVI, we see that the homblende-nica-andesites, Nos. 487 and 494, are the equivalents of the quartz-mica-dionites, Nos. 313,311,303,323, and 321, and of the quartzpyroxene-nica-diorite, No. 309. The dacites, Nos. 521 and 523, are the equivalents of the quartz-mica-diorite-porplyyries, Nos. 329 and 326 . The homblende-pyroxene-andesites and the pyroxene-andesites, Nos. 421, 471, 407,386 , and 4199 , are the equivalents of the coarse-grained pyroxene-micadiorite, No. 295 , with variable percentage of quartz, and of the fine-grained diorites, Nos. 272 and 273, and of a fine-grained variety, No. 267.

The dacites and hornblende-mica-andesites included within this correlation are intruded bodies within the breccia of Sepulchre Mountain, and have the same mineral composition as the corresponding porphyries and diorites of Electric Peak. They differ from them in structure and degree of crystallization, as alleady described.

The glassy andesites, with pyroxene and hornblende phenocrysts, however, present the utmost contrast to the chemically equivalent coarsely crystalline diorites. In the former the hypersthene, augite, lomblende, and plagioclise are sharply defined idiomorphic crystals in a groundmass of glass, which is crowded with microlites of plagioclase and pyroxene, besides grains of magnetite. The homblende is brown, occasionally red, and the other phenocrysts have all the microscopical characters which distinguish their occurrence in glassy rocks. In the diorite the hornblende is green; in some cases brown ; and the hypersthene, angite, and hornblende are accompanied by biotite, and are all intergrown in the most intricate manner, with evidence that they commenced to crystallize in the order just given. The labradorite is often clouded with minute opaque particles, which are characteristic of its occurrence in many diorites. It is surrounded by a shell of more alkaline plagioclase, which, with occasional individuals of orthoclase and considerable quartz, closed the crystallization of the magma. Magnetite, apatite, and zircon are the accessory minerals. The quartz contains fluid inclusions, which complete the correspondence of this diorite with typical cliorites of other regions.

From the structure of this region, which has been so finely exposed 
by finlting and erosion, it is evident that of the different magmas erupted a part fomml their way into rertical fissures and took the forn of dikes; part reather the surface and becane lava flows and breceias, while other portions remained in the conduit. Therefore the various portions of the milgmins soliclitied under a variety of physical conditions imposed by the different geological enviromment of each, the most strongly contrasted of which were the rapid cooling of the surface flows under very slight pressure and the extremely slow cooling of the magmas remaining within the conduits under somewhat greater pressure.

TABLE XVI.-Correlution of the two groups of rocks upon a ehemical basis.

\begin{tabular}{|c|c|c|c|c|c|c|}
\hline \multirow{3}{*}{$\begin{array}{l}\mathrm{S}^{2} \mathrm{O}_{2} \\
\text { per } \\
\text { cent. }\end{array}$} & \multirow{3}{*}{ No. } & \multicolumn{3}{|c|}{ Volcanic rocks ot Sepulehre Mronntain. } & \multicolumn{2}{|c|}{ Intrusive rocks of Electric Peak. } \\
\hline & & \multirow{2}{*}{ Name. } & \multicolumn{2}{|c|}{ Easential minerala. } & \multirow{2}{*}{ Name. } & \multirow{2}{*}{ Esseotial mioerala. } \\
\hline & & & Phevocryste. & Groundinass. & & \\
\hline $69.24 \ldots$ & 326 & & & (...... & $\begin{array}{l}\text { quartz mica-diorite- } \\
\text { porplysy. }\end{array}$ & $\begin{array}{l}\text { quartz, liotite, plagioclase } \\
\text { and alkali felispar, horo } \\
\text { blende. }\end{array}$ \\
\hline $67.54 \ldots$ & 321 & & & & quartz-mica-diorite. & $\begin{array}{l}\text { biotite, hornblende, plagio } \\
\text { clase (ortboclase), quartz }\end{array}$ \\
\hline $67.49 \ldots$ & 523 & dacite...... & $\begin{array}{l}\text { quartz, biotite, boro- } \\
\text { blende, plagioclaae. }\end{array}$ & $\begin{array}{l}\text { holocrystalline, } \\
\text { quartz, feld- } \\
\text { spar. }\end{array}$ & & \\
\hline 66.05. & 323 & & & n............... & quartz-mica-diorite. & $\begin{array}{l}\text { biotite, loroblende, plagio } \\
\text { clase (orthoclase), quartz. }\end{array}$ \\
\hline 65.97. & 329 & & & & $\begin{array}{l}\text { quartz-mica-diorite- } \\
\text { porphyry. }\end{array}$ & $\begin{array}{l}\text { biotite, hornblende, plagio } \\
\text { clase (orthoclase), quartz. }\end{array}$ \\
\hline 65.06. & 521 & dacite....... & $\begin{array}{l}\text { quartz, biotite, burn- } \\
\text { bleode, plagioclaae. }\end{array}$ & $\begin{array}{l}\text { lolocrystalline, } \\
\text { quartz, feld. } \\
\text { spar. }\end{array}$ & & \\
\hline $65.60 \ldots$ & 303 & ….... & & .................. & qnartz-mica-diorite. & $\begin{array}{l}\text { biotite, horablende (pyrox } \\
\text { ene), plagioclage (ortbo- } \\
\text { claae), quartz. }\end{array}$ \\
\hline $65.50 \ldots$ & 494 & $\begin{array}{l}\text { horablende- } \\
\text { usica-ande- } \\
\text { site. }\end{array}$ & $\begin{array}{l}\text { hornblende, hiotite, } \\
\text { plagioclase. }\end{array}$ & $\begin{array}{l}\text { holocryatalliue, } \\
\text { quartz, feld- } \\
\text { spar. }\end{array}$ & & \\
\hline $65.11 .$. & 311 & $\ldots \ldots \ldots \ldots \ldots$ & $\ldots \ldots \ldots \ldots$ & ................. & quartz-mica-diorite. & $\begin{array}{l}\text { biotite, hornblende, augite, } \\
\text { bypersthene, plagioclase } \\
\text { (orthoclase), quartz. }\end{array}$ \\
\hline 64.85. & 313 & & & 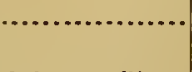 & quartz-mica-diorite. & $\begin{array}{l}\text { horublende, biotite, plagio } \\
\text { clase (orthoclase), quartz. }\end{array}$ \\
\hline $64.27 .$. & 487 & $\begin{array}{l}\text { horohleude- } \\
\text { mica-ande- } \\
\text { site. }\end{array}$ & $\begin{array}{l}\text { hornblende, biotite, } \\
\text { plagioclase, mag- } \\
\text { netite. }\end{array}$ & $\begin{array}{l}\text { holocrystalline, } \\
\text { quartz, feld. } \\
\text { apar. }\end{array}$ & & \\
\hline $64.07 .$. & 309 & .............. & . & 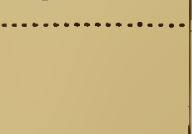 & $\begin{array}{l}\text { quartz-pyr oxen } \theta- \\
\text { mica-diorite. }\end{array}$ & $\begin{array}{l}\text { biotite, hornhlende, angite, } \\
\text { byperstheoe, magnetite, } \\
\text { plagioclase (orthoclase), } \\
\text { quartz. }\end{array}$ \\
\hline
\end{tabular}


TABLE XVI.-Correlation of the two groups of rocks upon "chemical basis-Continued.

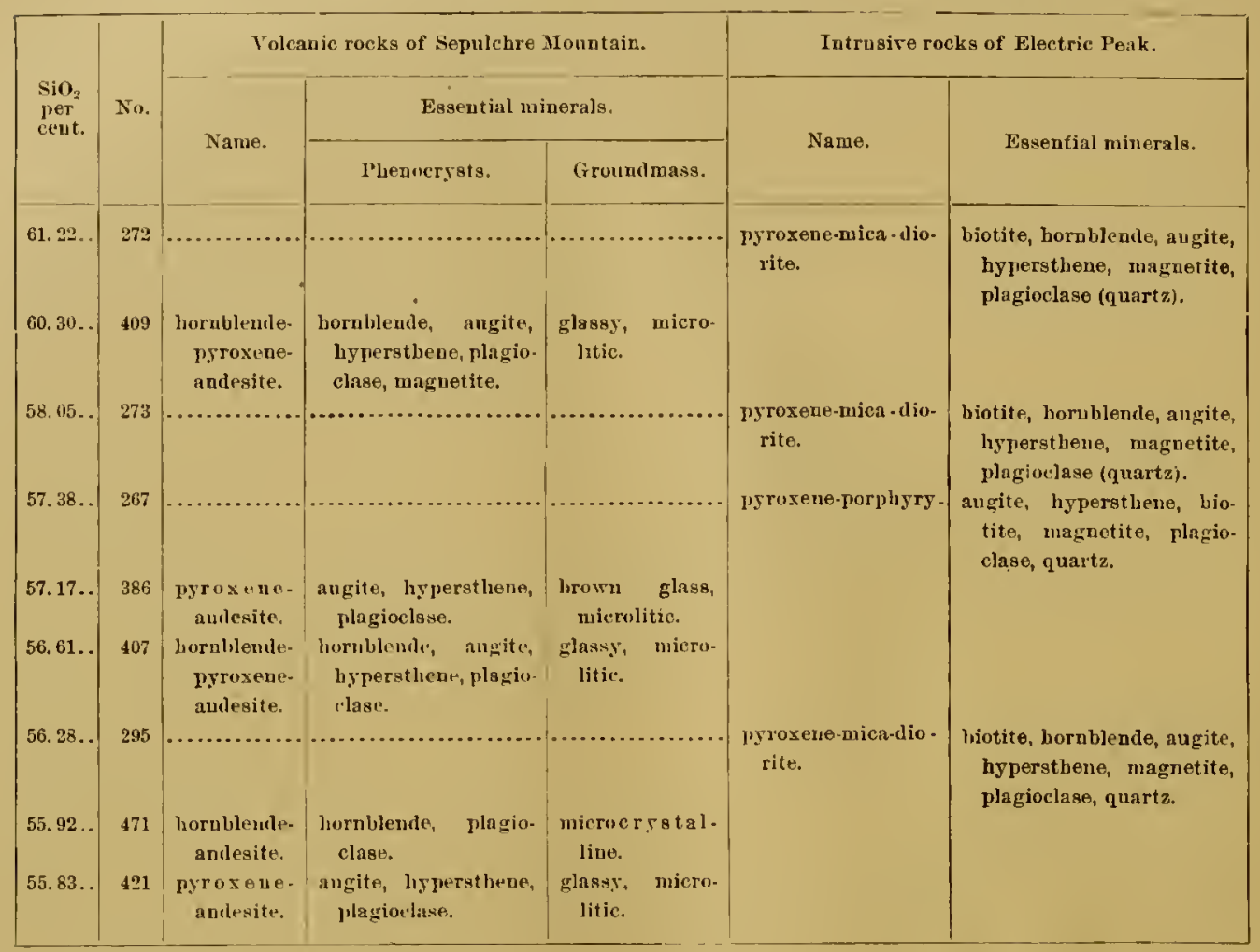

The effect of this diversity of conditions upon the degree of crystallization of the various portions of these rocks is well shown in the accompanying Table XVII, which has been derived from Tables VIII and XIII.

In this table are presented all of the specimens from Sepulchre Mountain and Electric Peak. 'They are arranged in four principal divisions: First, the breccias and lava flows; second, dikes and larger bodies intruded in these breccias; third, dikes in the Cretaceous strata of Electric Peak; fourth, the main stock and its immediate apophyses. These groups are still further subdivided into columns which correspond to mineralogical differences in the rocks, and bear the same letters as the mineralogical subdivisions in Tables III, VIII, XI, and XII. Consequently each of the four principal groups has the most basic members at the extreme left and the most acid ones at the extreme right. The mineralogical range is therefore repeated four times. The table illustrates a number of facts. It exhibits the relative degree of crystallization of the breccias, lava flows, 




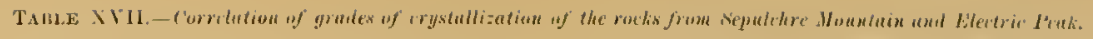

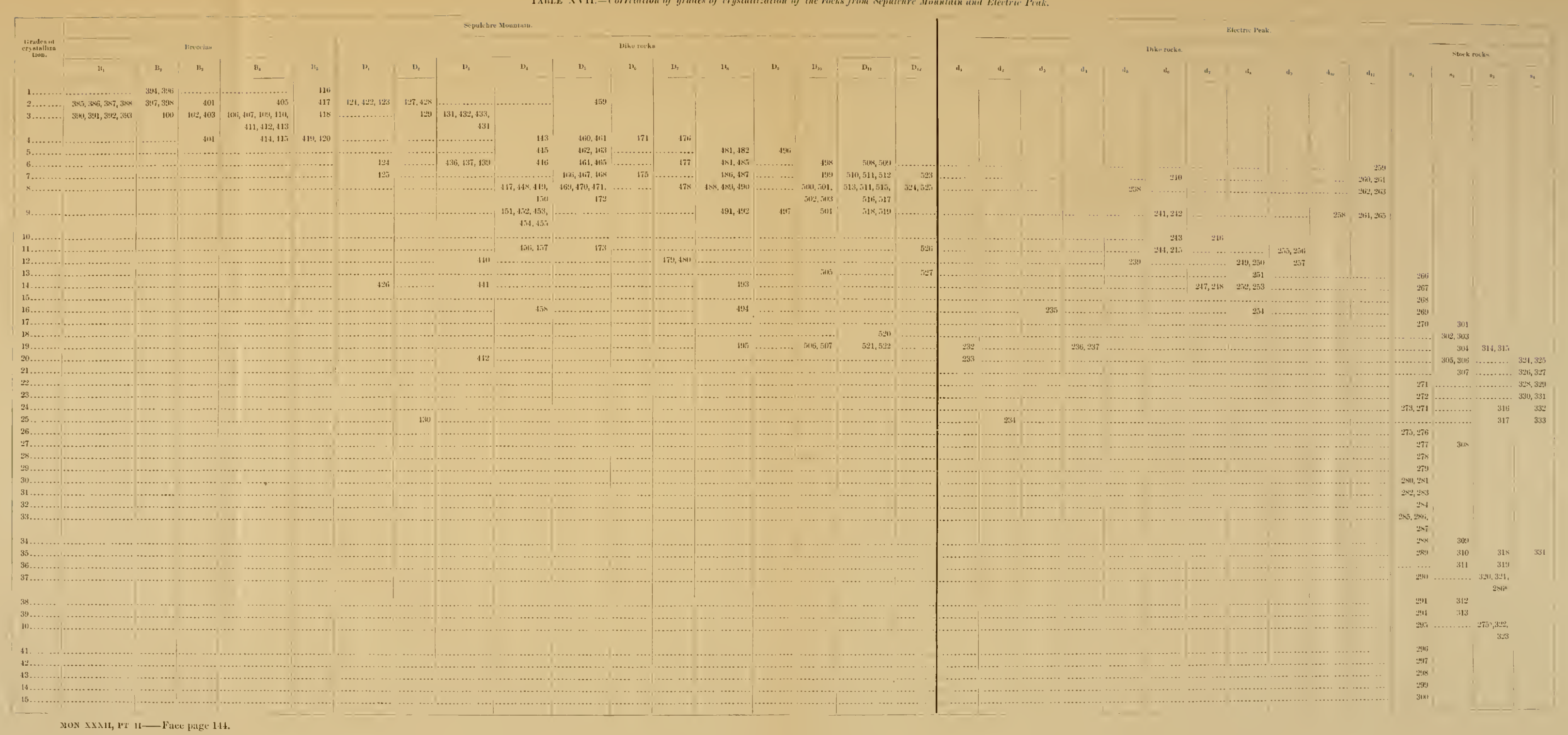



dikes, and stock rocks, and shows that a great mumber of intermediate steps can be recognized between the most glassy andesite and the coarsest diorite. It shows that the dike rocks furnish the connecting link between these two extremes, and that the dike rocks of Electric Peak have the same range of grain as the majority of those of Sepulehre Mountain. But many of those at Sepulche Mountain are still finer grained, and some are glassy, being vesicular also. Between these rocks there is the closest possible resemblance megascopically, and the two groups might have been described conjointly, so far as their petrographical characters are concerned. The variation of grain within each of the four principal divisions is very significant when taken in connection with the geological occurrence of the different rocks. The limited range of variation in the first group is in accord with the fact that all of these rocks are surface ejectamenta. The range in the third group from more erystalline basic rocks to less crystalline acid rocks, as already pointed out, shows the greater tendency of the basic rocks to erystallize. And since the dikes here represented are of nearly the same size, this variation of grain corresponds to differences in the chemical composition of the rocks. On the contrary, the variations in the second group indicate a slightly greater crystallization of the acid rocks. This, however, is due to the fact that the basic rocks in this group, with a few exceptions, occur in small dikes, while the acid rocks for the most part form broad intruded bodies several hundred feet wide. In these cases the size of the mass has had more influence on the degree of crystallization than has the chenical composition of the magma. In the fourth group the basic rocks exhibit a wider range of grain than the acid, being much coarser and also considerably finer grained than the latter. This arises from the fact that the basic rocks form a much larger mass and exhibit great variation of grain, having fine-grained modifications that have been fully discussed in an earlier part of this cliapter.

These diorites and others that cut the volcanic lavas in several localities in this region correspond to the andesdiorites and andesgranites of Stelzner, who described stocks of granular rocks penetrating the andesitic tuffs in Argentina. The study of these Tertiary granular rocks led him to the couclusion that the degree of crystallization of eruptive rocks is in no way dependent on their age, but depends on the physical conditions. MON XXXIl, PT II- 10 
under which the mineralogical differentiation and the cooling of the magma took place. ${ }^{1}$

Study and comparison of the chemical analyses of the two gromps of rocks miler inrestigation demonstrate that the magmas that reached the surface of the earth in this place had exactly the same chemical composition as those which remained inclosed within the sedimentary strata. 'They prove with equal clearness that the different conditions attending the final consolidation of the ejected and of the intruded magmas affected not only their crystalline structure, lut their essential mineral composition. The most marked illustration of this is in the occurrence of biotite in the two series. In the volcanic rocks of this locality biotite is an essential constitnent of the more siliceons varieties, and is only rarely found as an accessory constituent of the rarieties with less than 61 per cent of silica. In the intrusive rocks it is an essential constitnent of all the coarse-grained varieties, even the most basic. In the finer-grained, porphyritic forms it is a constituent of the groundmass to a variable extent. The second most noticeable difference is the presence of considerable quartz in the coarse-grained forms of the basic magmas and its absence from the volcanic forms of the same magmas.

From these observations, then, we see that in this region there are chemically identical rocks which have distinctly different mineral compositions, but which were once parts of a continuous body of molten magma. We are led, therefore, to the conclusion that-

The molecules in a chemically homogeneons fuir magma can combine in various ways, and form lifferent associations of silicate mincrals, producing mineralogically different rocks. ${ }^{2}$

iStelzner, Alfred, Beiträge zur Geologie und Paleontolugie der Argentinischeu Republik, Cassel and Berlin, 1885, p. 207.

"Sie [die Andengesteine] wird uns, wie ich meinerseits glaube, immer mehr und mehr erkensen lassen, dass die grössere oder geringere krystallinitït ernptirer Gesteine keineswegs, wie man so lange und 80 bartn:ickig behauptet hat, ron dem Alter der letzteren abhängig ist, sondern lediglich von dien phrsikalıchen Umstïnlen, unter denen die mineralisebe Differenzirung und Erkaltung ler gluthflïssigen Magmen vor sich ging."

${ }_{2}$ This conclnsion is the same as that stated by Justus Roth:

"Es könneu mineralogisch ganz verschiedene Gesteine iu dieselbe Gruppe gehören, denn feurigtlïssige Massen von gleicher oder sehr nahe gleicher chemischer Zusammensetzung können in verschiedene Nlineralien auseinauderfallen. Die Ursachen, welche diese Erscbeinung bedingen, lasseu sich büchstens wnthmassen und mögen in Unterschieden des Druckes, der Temperatur, des ungeleurteu Merliums, der Unterlage n. s. w. gesucht werden." Die Gesteins-Analysen in tabellarischer Ubersichlt und mit kritischen Erliinterungen, Berlin, 1861, p. xxi. 
In this region of Eleetric Poak and Sepulche Momntain the greatest mineralogical differences aceompany the greatest differences in structure or degree of erystallization; hence we mily insume that the canses leading to each are coexistent. The source of these canses must be sought in the diflerences of geological environment, and these affect the rate at which the heat escapes from the magmas and the pressure they experience during erystallization.

It is to be remarked thiat the most essential mineralogical difference between the intruded rocks and their chemically equivalent extrusive forms is the much greater development of biotite and quartz in the intruded rocks, these minerals being abundant even in the basic intrusions and absent from their basie voleanic equiralents. That their simultaneous development is naturally to be expected in many cases is evident from a consideration of the character of their ehemical molecules and that of other minerals common to these rocks. For if we assume that biotite is made up of two molecules, eorresponding respectively to $\mathrm{K}_{6} \mathrm{Al}_{6} \mathrm{Si}_{6} \mathrm{O}_{24}$ and $\mathrm{R}_{12} \mathrm{Si}_{6} \mathrm{O}_{24}$, and compare these with the molecules of orthoclase, $\mathrm{K}_{2} \mathrm{Al}_{2} \mathrm{Si}_{6} \mathrm{O}_{16}$, of olivine, $\mathrm{R}_{2} \mathrm{SiO}_{4}$, and of hypersthene, $\mathrm{RSiO}_{3}$, we see that molecules which under some conditions might have taken the form of olivine or hypersthene and potash feldspar, which latter may have entered into combination with limesoda-feldspar molecules to form sonewhat alkaline feldspars, may under other conditions combine as biotite with the separation of free silica or quartz; in which case also the feldspars of the rock would be less alkaline.

Another mineralogical difference between the two groups of rocks just mentioned is the greater development of hornblende in the intruded rocks in place of augite, which is ehemieally similar, though it has not been determined whether in this case the homblende of the diorite has nearly the same composition as the angite of the andesite. The probability is that there are considerable differences between them.

The crystallization of quartz, biotite, and hornblende in fused magmas, according to our present knowledge, requires the assistance of a mineralizing agent; for it has been demonstrated by synthetical research that these minerals will not crystallize in the forms they assume in igneous rocks when their chemical constituents are fused and simply allowed to cool under ordinary atmospherie conditions. But they have been prodnced artificially with the aid of the mineralizing action of water vapor and of other gases. 
Now, there is ample evidence, both in the ejected lavas and in the coarsely crystallized rocks in the conduit, that water vapor was uniformly and generally distributed through the whole series of molten magmas, and there is no evidence that there existed in the magmas which stopped within the conduit any more vapors than those which existed in the magmas that reached the surface, or that they were different in the two cases. Hence we conclude that:

The efficacy of these absorbed vapors as mineralizing agents was increased by the conditions attending the solidification of the magmas witlin the conduit.

Moreover, if mineralizing agents are universally present in igneous magmas, and if their action, so far as we can observe it, is controlled by the physical conditions imposed by the geological history of each eruption, we should not regard the presence or absence of certain minerals, relegated to the influence of mineralizing agents, as evidence of the presence or absence of these agents in the molten magma; but we shonld see in it the evidence of special conditions controlling the solidification of the magma, and should seek the fundamental causes of the mineralogical and structural variations of a rock in the geological history of its particular eruption. 


\title{
C H A P T E R I V. \\ DESCRIPTIVE GEOLOGI OF THE NORTHERN END OF THE TETON RANGE.
}

\author{
By Joseph Paxson Indings and Walter Harvey Weed.
}

INTRODECTION.

The Teton Range is the highest and most imposing of the mountain ranges that environ the Yellowstone Park. The three highest peaks, whose spire-like summits and perpetual snow fields are visible from every outlook of the Park, form a well-known feature of Wyoming scenery, giving the mountains the familiar name of the Three Tetons. Only the northern spurs and lesser peaks of this range occur within the region surveyed-that is, north of the forty-fourth parallel of latitude. This northern part presents none of the impressive features of height and scenery that oeem in the main portion of the range farther south, yet geologieally this limited area is of great interest, since it includes the northern end of the Archean muclens of the range, with the flexed and uptumed sedimentary rocks encireling it. The great epochs of geologieal time are all represented in the stratigraphie seetion exposed in these northern peaks, while the relations of the eroded range to the aceumulations of basie volcanie breccias and to the great rhyolite flows of the Park Platean are here revealed.

The area shown on the map (PI. XXIII) inchules an accidented region that is the divide between the waters of Falls River Basin and those of the valley of the Snake. The two most prominent streams, Owl Creek and Berry Creek, eut deeply into the uplifted rocks, exposing Arehean gneisses and the overlying Paleozoie strata. Two prominent summits, known as Survey Peak and Forellen Peak, rise above the general level of the rhyolite platean. The region is well wooded, but is diversified by parks and grassy valleys that add to its attractiveness. The reeently built road 
extending sonthward from the Upper Geyser Basin and the Yellowstone Lake to the southern limit of the Park, and the wagon trail from the Mormon settlements of the Falls River Basin to the great natural meadows of Jackson Lake, make the region readily accessible.

Sedimentary series. - The sedinentary rocks begin with the Middle Cambrian, which rests directly upon the erystalline sclists. The Sheridan quartzite las not been found in this vicinity, nor lave any beds resembling the Algonkim been noticed in the area mapped as Archean. The Paleozoic includes beds of Silurian and Devonian age, whose character and relations appear to be the same as those of like age in the Gallatin Mountains. 'The Carboniferous series presents no features different from those noted in the northern ranges. The Juratrias, on the contrary, presents a far greater development than in the Gallatin Range, and its typical member, the Teton sandstone, forms bright red outcrops that are especially prominent features of the scenery wherever exposed. The Ellis limestones appear in full development and include the impure, shaly, fossiliferous beds which contain an abundant marine fama, and the overlying littoral deposit whose character varies from a conglomerate or coarse sandstone with comminuted shells to a pure crystalline limestone. The Cretaceous, as nuted in Chapter V, in the description of the region lying east of the one here described, is essentially a series of sandstones in which the usual subdivisions are not readily recognizable. The Dakota has been mapped by the occurrences of the basal conglomerate, and the Colorado has been delinited by the upper belt of dark shales that occurs in the saudstones. The Montana group is represented by coarse yellow sandstone, containing numerous fossils. The Laramie has not been found in the exposures of this locality, but is probably buried beneath the rhyolite flows of Pitchstone Plateau. The most northern extension of the Teton Range is a small ontlying area of sedimentary rocks which have been upturned by the dacite-porpliyry that forms the summit of the Birch Hills, 8 miles north of Survey Peak. The structure of the Teton region shows that it is the end of an anticlinal uplift, modified by faults parallel to the axis of the fold; thus, in Forellen Peak the crystalline schists have been faulted against Carboniferous beds, a small area of the Flathead quartzite remaining attached to the gneissic mass. To the west, in the amphitheater at the head of Conant Creek, Cretaceous shales have beeu faulted agtinst volcanic rocks. 


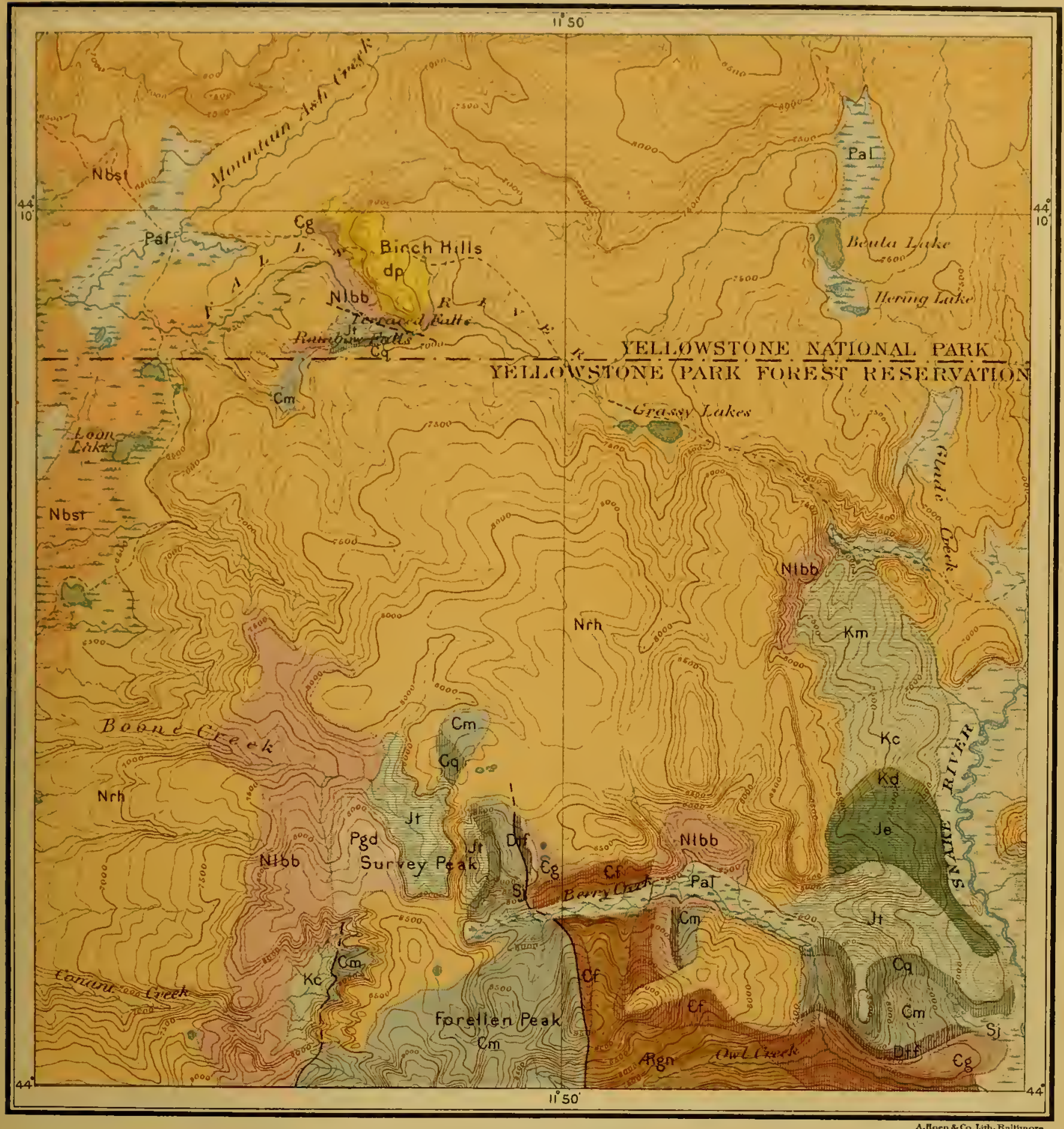

GEOLOGICAL MAP

OF

THE NORTHERN END OF TETON RANGE, YELLOWSTONE NATIONAL PARIK.

LFGEND
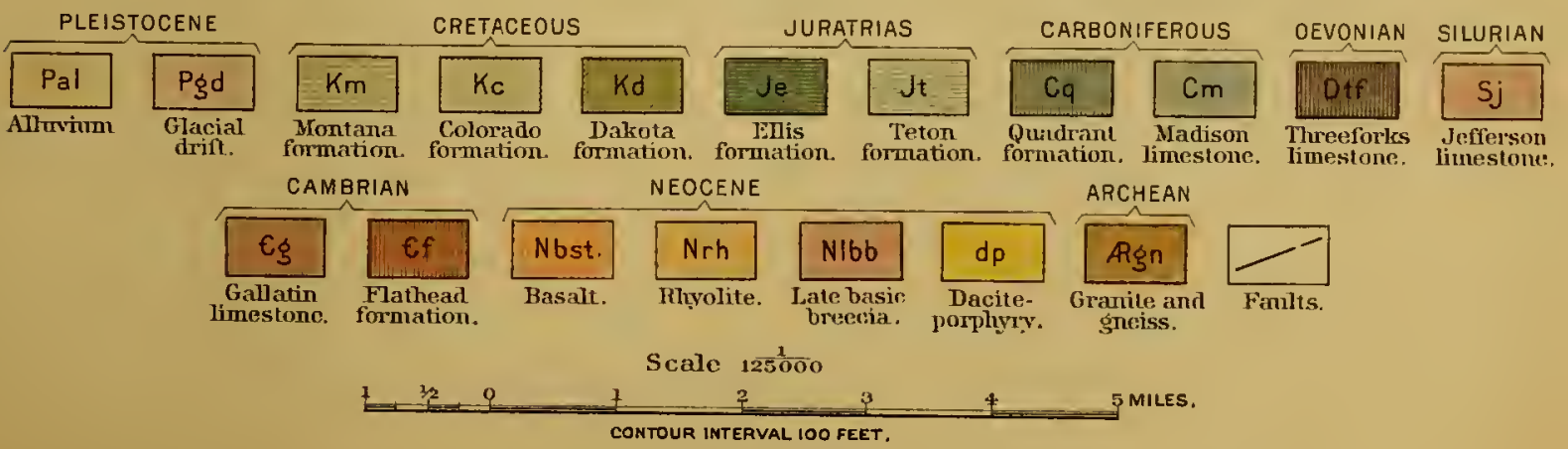



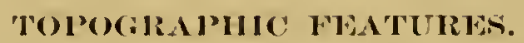

The regrion is about 10 miles widle from east to west, and 7 miles from north to sonth, along the western sicle of Snake River Valley. The highest point, Forellen Peak, is 9,700 feet in altitude, while others of 9,200 and 8,900 feet ocenr north of Berry Creek. The district is almost completely transected by two deeply cut valleys, those of Owl and Berry creeks, flowing into Snake River. The extreme western side of the mountains is drained by Conimt and Boone creeks, tributaries of Falls River. The sides of these valleys are steep and exhibit frequent rock exposures.

The valley of Owl Creek separates the mountain region sitnated within the linits of the map (Pl. XXIII) from the main range lying to the south. The stream has cut a deep gorge at right angles to the uplift, heading in the Carboniferons area south of Forellen Peak and on the slopes of Crimson Peak, a prominent summit that reaches 10,300 feet on the flanks of the range south of the forty-fourth parallel of latitude. That portion of the gorge which is cut in the gneiss to a depth of nearly 3,000 feet shows steep slopes much encumbered with the débris from the crest of the ridge. Overlying the crystalline schists; the sedimentary series is well exposed to the east. This trench, following as it does a line that crosses the strike of the rocks, appears to be an old drainage way deflected by the rhyolite capping which once covered this area, and it probably marks a gulch cut along the contact between the rhyolite sheet and the underlying rocks, a contact which nudoubtedly crossed varying exposures, as the country was much eroded hefore the outflow of the rhyolite.

Berry Creek, which heads in the momntain amphitheater at the north base of Crimson Peak and in the grassy valley lying south of Survey Peak, flows with a general easterly course 4 or 5 miles, then turns abruptly to the south to join Owl Creek, leaving what is clearly the old drainage way across the sedimentary rocks, but which is now occupied by a much diminished stream. It is believed to have been diverted by a small lateral drainage which cut back until it robbed the stream of its headwaters. Like Owl Creek, this stream heads in the Carboniferous area of the western part of the momtains, crosses the uptumed edges of the Survey Peak rocks, flows through an open grassy valley cut in the crystalline schists and across the basic breccias which conceal the Paleozoic berls of 
the valley bottom, and passes through the rliyolite which adjoins the breccias on the east.

Both Conant Creek and Boone Creek head in deep amphitheater-like basins, which have been eut in rolcanic tuff-breccia and easily eroded sedimentary formations, the rims of the basins being formed of rhyolite lava The lower portions of the channels are canyons cut in rhyolite.

The inountainous portion of the district terminates abruptly on the east, along the banks of the Snake River, while outside of the monntains the country stretches northward as a high plateau, with ridges reaching 8,700 and 8,900 feet in altitude near Berry Creek, gradually descending to 7,000 feet in the vicinity of Grassy Lake and Birch Hills. IVest of the mountains long, narow spurs descend somewhat rapidly to the level of Falls River Basin at 6,500 feet.

With this brief sketch of the topographic features in mind we may proceed to consider the geologic structure of the region, beginning with the oldest formations, which are the crystalline schists.

\section{CRISTALIINE AXIS AND REGION FAST.}

The crystalline schists consist of light-pink and flesh-colored gneisses and smaller amomnts of mica-schists and amphibolites. Together they form a steeply pitching axis, about which the overlying sedimentary formations have been folded and broken. The most northerly exposure of the greisses, in Berry Creek, is not higher than 7,800 feet, while on Forellen Peak they reach 9,700 feet, and are still higher in the mountain south of Owl Creek. In the mountains on both sides of this creek the crystalline schists are seen to have an almost vertical boundary on the west, along the fanilt line already mentioned. On the slopes of both these mountains steep, narrow gulches mark the plane of faulting and the contact between the schists and the nearly vertical limestone beds. This plane passes through the summit of Forellen Peak and also through the summit of the peak south.

On the eastern sicle of this crystalline axis the sedimentary rocks overlie it, with a gradually increasing dip toward the northeast. On the south side of Owl Creek the structure is the same as that of Forellen Peak, which is shown on the map. The southern side of the valley is crystalline schists nearly to the summit of the mountain, the eastern portion of which is 
covered by Flathead quartzites and Paleozoic linestones, dipping at low angles toward the northeast.

East of Forellen Peak, on the crest of the mountain, the gneiss is overlain hy indurated sandstones having a strike N. $55^{\circ} \mathrm{W}$. and a dip of $20^{\circ} \mathrm{NE}$. Lower down on the northern side of the ridge lightegray mottled limestones are exposed in a nearly vertical position. They are associated with green micaceous shales and a thin layer of ferruginous sandstone. Although no fossils were found, there is little doubt that the beds belong to the basal portion of the Cambrian. A short distance farther east the limestones strike N. $45^{\circ} \mathrm{W}$., aud dip $30^{\circ} \mathrm{E}$.

The crest of the east ridge of Forellen Peak and the eastern slope of the mountain are covered by a thin sheet of lithoidal rhyolite, like that forming the plateau north of Berry Creek, of which it is unquestionably an extension, being connected with it across the bottom of the valley. The eastem end of the momntain is cut off by the canyon through which Berry Creek flows to join the Owl Creek drainage.

East of the gneiss the sequence of sedimentary beds is quite the same as that observed in the Survey Peak section, to be described (p. 160). The relations of the beds, however, are partially obscured by the sheet of rhyolite just mentioned.

Berry Creek.-In the canyon of Berry Creek, just above its junction with Owl Creek, the sedimentary rocks are well exposed, and a section was made which shows the relative thicknesses of the Cambrian rocks.

\begin{tabular}{|c|c|c|c|}
\hline & $\begin{array}{l}\text { Num- } \\
\text { ber. }\end{array}$ & & Feet. \\
\hline \multirow{6}{*}{ Madison } & 22 & Limestone, crackled, gray, crystalline, dense .......................... & 25 \\
\hline & 21 & Limestone, granular, saccharoilal, buff, weathering white ................ & 75 \\
\hline & 20 & Limestone, magnesian, gray with red layers, also magnesian, with fossils .. & 50 \\
\hline & 19 & 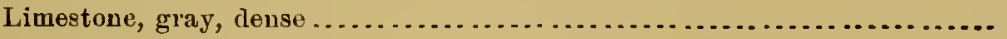 & 10 \\
\hline & 18 & Limestone, gray, containing patches of red magnesian rock ............... & 300 \\
\hline & 17 & 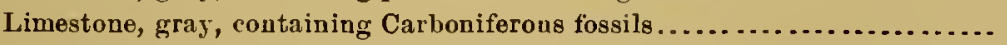 & 2,000 \\
\hline \multirow{3}{*}{ Three Forks. } & 16 & $\begin{array}{l}\text { Limestone, brown, weathering steely gray, with feticl odor and resembling } \\
\text { Devonian; beds arenaceons. }\end{array}$ & \\
\hline & 15 & $\begin{array}{l}\text { Limestone, thinly beddel ; mottling produced by irregular binds of cream- } \\
\text { colored material. }\end{array}$ & \\
\hline & $(14$ & 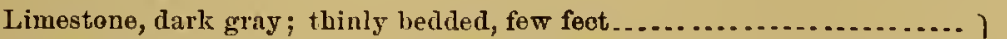 & \\
\hline Jefferson. & 13 & 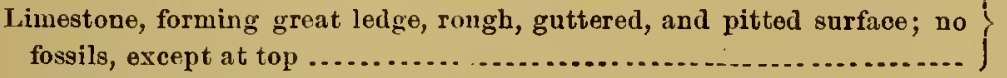 & 150 \\
\hline \multirow{3}{*}{ Gallatin } & 12 & Limestone, gray with sably patches ................ & 100 \\
\hline & 11 & Sbales, gray and red $\ldots \ldots \ldots \ldots \ldots \ldots \ldots \ldots \ldots \ldots \ldots \ldots$ & \\
\hline & 10 & Limestone, forming leavy ledge; bro & \\
\hline
\end{tabular}


Section of sedimentary rocks in Berry Creek Canyon-Continued.

Num-

ber.

9 Shales, with thin binds of limestove $\ldots \ldots \ldots \ldots \ldots \ldots \ldots \ldots \ldots \ldots \ldots \ldots \ldots . . . \ldots \ldots$

8 Shale, green, micaceous; thin lıands of limestone .................... 25

7 Limestone, light gray; dense ....................................... 15

6 Limestone, massive ledge; lavender, weathering yellow ................ 12

Flathead... 5 Limestone, gray, weathering jellow; splintered vertically ............

4 Shales, micaceous, calcareous, green .............................. 5

3 Limestone, irregularly and thinly bedded; chocolate colored............. 60

2 Shales ?; poor exposnre ..................................... 50

1 Limestone, thinly bedded. Strike N. $50^{\circ} \mathrm{W} ., \operatorname{dip} 35^{\circ} \mathrm{NE} \ldots \ldots . . . . . . . . .35$

The slope of the peak to the east of this canyon is benched in a series of steps, whose upper surface corresponds to that of the limestone berls, but exposures are few and unsatisfactory. The summit of the peak is formed of the cherty Teton sandstone, resting upon the white Quadrant quartzites, which here break into small angular fragments. The northern slope of this peak is open and grassy near the summit, but the flanks of the mountain are thickly covered with young pines and fallen timber. At the point where Berry Creek leaves its mountain valley to flow in a succession of cascades and rapids throngh the canyon just mentioned, the Juratrias rocks are well exposed. The lighest beds noticed were soft and micaceous shales, which occur beneath the red Teton sandstones. The beds strike $\mathrm{N}$. $50^{\circ} \mathrm{E}$, and dip $25^{\circ} \mathrm{NW}$. The rocks are fissile micaceous shales, containing much pyrite, and near the entrance of the mountain are warped and twisted into a number of small folds. In the upper part of the canyon the granular white limestones, which are generally buff or creamy yellow on fresh fractures and belong to the Quadrant quartzite, are also well exposed. The Quadrant quartzite series is underlain by a streak of reddish magnesian clays. a part of the limestone series that forms the highest beds of the Madison formation. The fossils are of Lower Carboniferous age, and are most abundant above the hard gray limestones which alternate with the red streaks.

In descending the creek the strike gradually changes from N. $50^{\circ} \mathrm{E}$. to N. $30^{\circ}$ E., this change occurring within a distance of half a mile. Still farther down, the strike veers rapilly toward the west, and near the junction with Owl Creek it has changed to N. $50^{\circ} \mathrm{W}$, which is the general strike of the strata north of Owl Creek, botlı above and below the mouth of Berry Creek. Below the forks the arenacenus fetid limestones of the Jefferson formation extend down the strean until lost in the meadows of Snake River. 
Although the rhyolite lavas of the Park cover and conceal the ligher series of strata which formed the flanks of the Teton uplift, subsequent erosion has laid bare a narrow area immediately west of the Snake River mealows in which the Mesozoic heds are exposed. The attitude of the stratal shows that they form an anticlinal fold that is one of the lesser flexures of the northern extension of the T'eton uplift. This particular fold hats a north-south axis, pitching about $5^{\circ} \mathrm{N}$., the fold dying away in the region covered by the rhyolite sheet.

The rocks forming the peak north of $\mathrm{Owl}$ Creek, whose summit has an elevation of 1,700 feet above Snake River meadows, have already been noted. East of this peak a low elevation, whose summit is but 7,200 feet, presents excellent exposures of the Triassic and Jurassic series. The basal cherty arenaceous limestones of the Teton formation form the south end of the hill and are cut by the small stream west of it. The summit is covered by the red Teton sandstones, whose detritus is abundant, though good exposures are rare. These sandstones, which are the representatives of the great Red Bed series of Wyoming, consist of lavender-colored, pink, and red sandstones, generally fissile, fine grained, and weathering to sandy clays. On the northem slope of this hill the Teton sandstones are overlain by the gray argillaceous limestones and calcareous shale beds of the Ellis formation, carrying characteristic Jurassic fossils. The strike is N. $70^{\circ} \mathrm{E}$, and the dip $40^{\circ} \mathrm{N}$.

Hills west of Snake River.-North of Berry Creek a long and high ridge extends to the shores of the Grassy Lakes. The eastern flanks of this ridge, extending down to the meadows of Snake River, form benched slopes and a broken, hilly country, in which exposures of the sedimentary rocks are often seen, though the surface is largely covered by drift and is overgrown by vegetation. The Teton formation is exposed at the south end of the ridge, a deep cut eroded in the soft sandstone of this horizon continuing the valley of Berry Creek eastward. Above these red sandstones the gray beds of the Ellis formation are seen, forming the 8,500-foot knoll at the south end of the ridge. This formation presents the same two divisions which are so characteristic a feature of its development in the Gallatin Range. The lower part of the series, the Ellis limestone, consists of thinly bedded, impure, argillaceous, gray limestones and lead-colored calcareous shale, weathering readily and containing an abundance of fossils of characteristic Jurassic types. These 
beds, which form the lower and greater part of the formation, are capped by the arenaceous limestone, whose variable nature is its chief characteristic. This bed varies from a pure white or gray, rather coarse granular limestone, composed largely of broken fragments of shells, to a pure sandstone that is occasionally conglomeratic. Near the base the ber is always a limestone and contains carbonaceous remains and fossils of characteristic Jurassic type. The indurated nature of this bed makes it a noticeable feature. It forms good exposures and affords a marked horizon which aids in the working out of the geological structure. The strike of N. $60^{\circ}$ E., noted at 8,150 feet on the slopes, varies rapidly, as the berl shows an anticlinal fold slightly modified by small local flexures. The dip varies from $40^{\circ}$ to $55^{\circ}$. The following section was made of the beds exposed at this locality:

Section in hills west of Snake River.

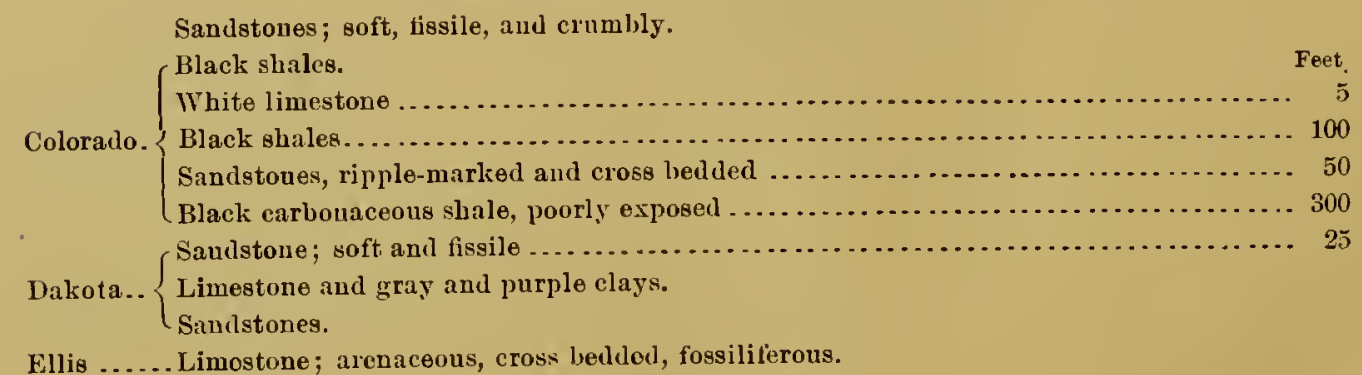

The uppermost beds of this section are exposed about a mile sonth of the mouth of Glade Creek, the beds having a strike of $\mathrm{N} .50^{\circ} \mathrm{W}$. and dipping $30^{\circ} \mathrm{N}$.

The Montana formation consists largely of yellowish sandstones, differing in this respect from the character prevailing in the Gallatin region. The beds form a small but steeply sloped lill west of Glade Creek, near its mouth, being exposed in a bluff 150 feet high and 500 feet long. This exposure shows a fault, bringing soft, gray, argillaceous shales against yellowish and gray sandstone carrying abundant fossils of Fox Hills types. The latter beds strike N. $10^{\circ} \mathrm{E}$. and dip $30^{\circ} \mathrm{W}$.

Higher up the creek flowing past this bluff the stream has cut very soft, thinly bedded, fissile, light-colored sandstones, overlain by sandstones alternating with occasional beds of shale. No fossils were seen at these exposures. The higher slopes are everywhere covered by the soft sandy débris derived from the sandstone, and no exposures are seen. In general 
the northem slopes are mantled by this material. Many of the bare areas seen on these slopes show no ronk in place, but are dhe to the washing out of this soft drift material. The highest stratal seen consist of shate and limestome, exposed back of the rhyolite hill west of the forks of Glade Creek.

No Laramie rocks were identified, but it is probable that the friable sandstones calrying a 4 -foot seam of coal, exposed on the east bank of the Snake below the mouth of Glade Creek, are of this age. The strata at this locality strike E.-W. and dip $35^{\circ}$ N., but on the slope above, at 7,400 feet, the beds strike N. $40^{\circ}$ E. and dip $25^{\circ} \mathrm{NW}$.

volcanic rocks. - The erosion of the sedimentary rocks was unquestionably very great before the extravasation of volcanic material, for basic andesitic tuff-breccia is found in the botton of the valley of Berry Creek, resting upon a very irregular surface of crystalline schist and Paleozoic strata. In places it contains rounded pebbles of gneiss, with some of andesite. It probably occupies what was an ancient valley draining northward, for on the east and west of it sedimentary rocks rise to peaks a thousand and more feet higher than the present lowest exposure of breccia. The breccia forms a group of small hills and knolls, rising 500 feet above the bottom of the valley. It is overlain by massive rhyolitic lava, which also covered a very uneven surface, being at present 600 to 800 feet thick above the breccia and 1,500 feet thick just east of it, where it seems to have filled a depression between the hill of breccia and the eastern sedimentary ridge. Toward the west it thins out over the limestones at the base of Survey Peak, where it is glassy and porphyritic, probably the bottom part of the sheet which, farther east, is lithoidal and thinly laninated, somewhat resembling schist. In this part of the rhyolite the lamination which corresponds to the planes of flow in the lava dip to the north, indicating that the lava had been moving over a northward-sloping surface.

\section{REGION WEST OF THE CRYSTALLINE AXIS.}

West of the fault that bounds the western side of the body of crystalline schists the sedimentary rocks have been upturned at a high angle, causing them to dip steeply at about $80^{\circ} \mathrm{W}$. for a short distance, beyond which they become flatter. This structure is seen in the mountain south of Owl Creek and in Forellen Peak and Survey Peak. In the western 
summit of the mountain south of Owl Creek, steeply upturned limestones dip $80^{\circ} \mathrm{W}$. and appear to be continuons with those, to be described, west of the summit of Forellen Peak. Directly west of them, on the divide south of the head of Owl Creek, massive limestone abuts against them with a low easterly dip. These are the eastern portion of a flat anticlinal arch, whose axis trends north along the western side of the amphitheater at the head of Owl Creek. The western portion, with slight westerly dip, forms the rídge between the headwaters of $\mathrm{O} w \mathrm{l}$ and Conant creeks, the most northerly point of which is Crimson Peak.

crimson Peak.-Here the strata strike S. $50^{\circ} \mathrm{W}$. and dip $7^{\circ} \mathrm{NW}$. The dips farther down the northwest spurs vary from $7^{\circ}$ to $10^{\circ}$ in the same general direction. The red color of the summit, which is so prominent when the mountain is seen from a distance, is due to the red magnesian streaks and patches which occur in the higher beds of the Carboniferous limestones. The summit of the peak, which is 10,300 feet above sea level, shows good exposures of the white Quadrant quartzites, the rocks weathering in great eubical blocks; being of very compact texture, they resist erosive agencies and are in striking contrast to the same series exposed near the junction of Owl and Berry creeks. Fossils collected from the northeastem spur of the mountain prove to be of lower Carboniferous age. Farther down the spur, on the saddle of the divide southwest of Forellen Peak, a horizon of fossiliferons limestone, carrying peculiar concretions of chert, occurs above a brown arenaceous bed that is correlated lithologically and by its stratigraphic position with the Devonian of the Gallatin section. This sandy limestone, which is believed to correspond to the Three Forks limestone, is underlain by fine-grained and dense gray limestone, whose peculiar rough, pitted, and guttered surface makes it a readily distinguishable horizon. This bed corresponds to the Jefferson linestone of the Gallatin Range. These strata continue northward along the western slope of Forellen Peak, having a low dip to the west. They adjoin the nearly vertical limestones that have been faulted against the gneiss in the same manner as in the mountain south of Owl Creek.

Forellen Peak.-Nearly vertical limestones form the western summit of Forellen Peak and the steep narrow spur down its northern flank. The beds forming the summit of the peak are Carboniferous, and 100 feet below them stratigraphically is the dark-gray massive limestone, weathering with 
guttered surface, that hais just been noted. The heds lave at general strike N. $35^{\circ}$ W., and dip $80^{\circ}$ sW. Upon the gneisis, direerly east of the farult, there is Flatlead quartzite, dipping at a low angle toward the northwest. 'The tissile Cambrian formations have been completely displaced at this point.

T'he displacement noted on Eorellen Peak probably diminishes nortlsward and may fade out east of Survey Peak, the steeply dipping strat continuing through this mountain into the hills north of it. Here the lightgray and brown striper linestones of the Madison formation, which form the main mass of Survey Peak, strike N. $25^{\circ} \mathrm{W}$. and dip $70^{\circ} \mathrm{SW}$. At the eastern base of the mountain they have the same strike, but a lower dip, about $25^{\circ} \mathrm{SW}$.

Survey Peak.-On the slopes southenst of Survey Peak the gneiss is well exposed, immediately overlain by the rusty Flathead quartzite with strike N. $70^{\circ} \mathrm{W}$. and $d i p, 15^{\circ} \mathrm{N}$. Above this ledge no exposures are seen for 50 feet, when limestones outcrop, the ledges being conformable in dip and strike to the quartzites below. These limestones are dark gray, mottled with buff spots of sandy material, and resemble the limestones occurring in the Flathead shales. Above these beds the slopes show poorly exposed limestones, eroded by glacial action into well-marked benches. Six hundred feet above the gneiss the beds consist of chocolate-colored cherty limestones, alternating with gray crystalline limestones containing traces of fossils and much cut up by veins and patches of calcite. On the east slope of the mountain the beds are well exposed, forming rough, bare ridges devoid of soil or timber.

The best section of the Paleozoic rocks is to be found north of the creek, in the slopes which fall away from the eastern flanks of Survey Peak. Here we have a continuous series of beds from the Archean to the red shales and clays of the Teton formation. The section given on the next page was measured at this point. 


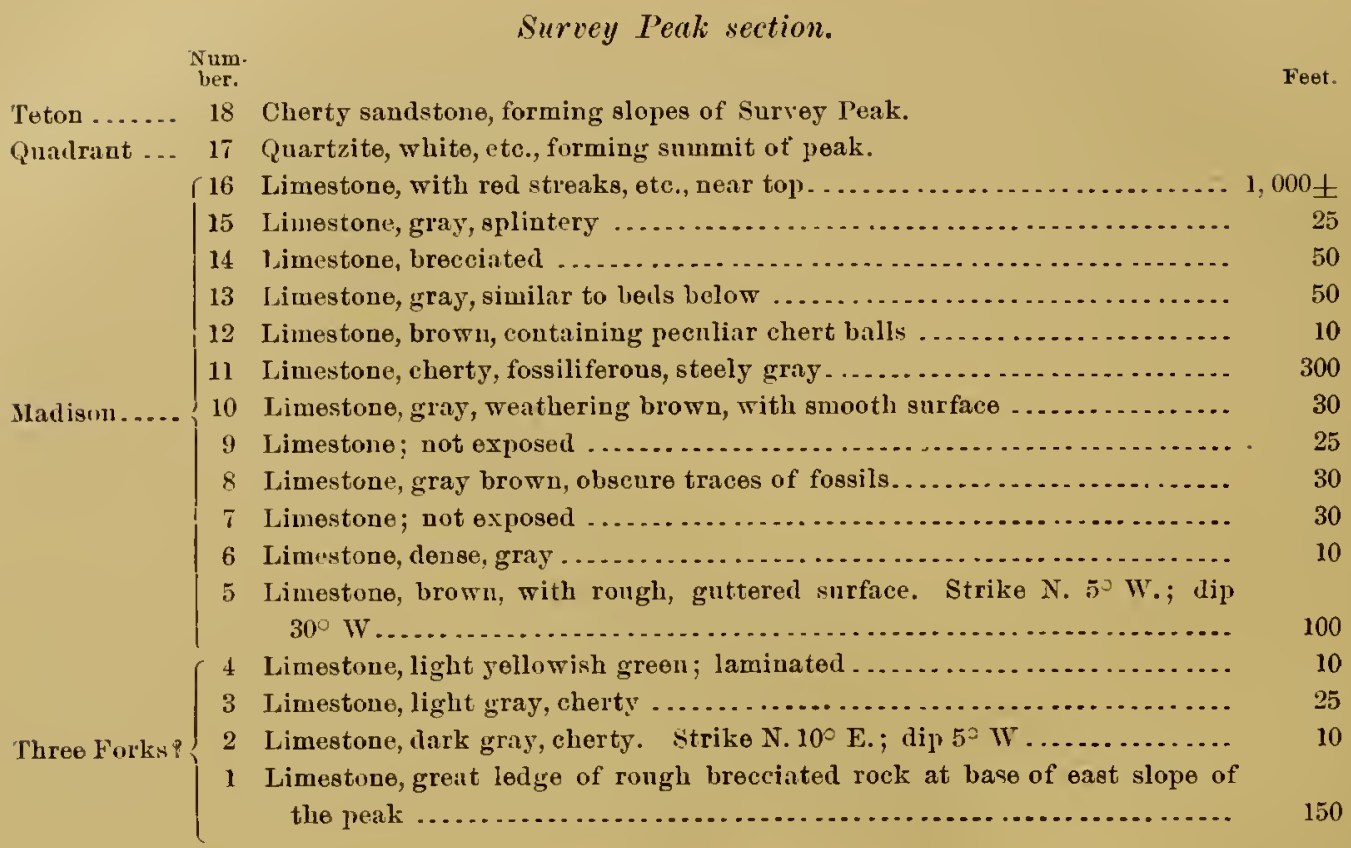

The summit of Survey Peak is formed of the cherty sandstones which occur at the base of the Teton formation, but the western flank of the mountain is covered by a narrow strip of rhyolite that connects the rlyyolite sheet near the head of Berry and Conant creeks with the rhyolite plateans which sweep northward to the geyser basins. This rhyolite west of the peak is about one-fourth of a mile wide, its upper linit being 8,600 feet, and it forms a bench terminated westward by bold cliffs, some 200 feet in height, that form the wall of the Boone Creek amphitheater. The bottom of the sheet dips to the west. The surface of the rhyolite is quite irregular, as the sheet rests upon the steeply upturned Teton shales which have slipped beneath its weight, forming great fissures of varying width, from a few feet to many yards across and often many yards long. Huge masses have become detached and have slid down to the bottom of the amphitheater valley. To the south the rhyolite thins ont against the cherty sandstones, but on a projecting point extends to the flat summit at the head of Berry Creek. Beneath the rhyolite the walls of the amphitheater show the red Teton shales and sandstones well exposed and dipping steeply to the northwest. These Teton sandstones probably extend under the gravelcapped ridge to the west, but no exposures were seen. 
conant creek. - 'l'he Carboniferous limestones of Crimson Peak south of the hear of Berry Creek extend down the northern spur with a dip of $7^{\circ}$ to $10^{\circ}$ NW., as allearly stated, and form the divide to Conant Creck and the ereek sonth of it; but they are covererl with rlyolite farther north, appearing beneath it in soveral spurs projecting into the valley at the heal of Conant Creek. 'The lowor purtion of the rhyolite sheet is rark colored and glassy, becoming lighter colored and lithoidal higher up. On the small spurs the lamination of the lava dips to the northwest, showing that the slope was in this direction. On the divide between Conant Creek and the creek south the limestones terminite abruptly against soft clays and sandstones, presumably of Cretacens age, but of which there are no good exposures, while to the south the massive limestones ean be traeed along a westem escarpment to where they orerlie sandstone and gneiss, which form a group of peaks nortluwest of the main 'Teton Range.

The soft clay shales and friable sandstones on the low saddle south of the lead of Conant Creek dip toward the west and extend northward aeross the basin at the head of Conant Creek. 'Their close proximity to the Carboniferous limestones indicates a fault and considerable displacement between the two, which, however, may not exist farther north; for west of Survey Peak there is suffieient distance between the Teton formation and the northward extension of the shales to allow of the intermediate formations being in plaee.

The divide between Conant Creek and the head of Boone Creek is a narrow ridge composed of well-romded gravel, mostly quartzite. This also forms the lower ends of the two short spurs south. The exact relation of this gravel to the adjacent rocks was not diseovered. Its character and general appearance are those of a recent deposit connected with the glaciation of the region.

volcanic breccia.-The sedimentary area is bounded on the west by an aceumulation of volcanic tuff-breccia that is exposed for a distance of 6 miles north and south, and again farther north in the neighborhood of Birch Hills. The actual extent of the breceia is mnknown, since it is partially covered by rhyolite. A portion of it has been uncovered in Berry Creek. It is well exposed in the valleys cut through it by Boone and Conant creeks. The rocks exhibit rude assorting, but are not bedded, the coarse agglomerates occurning with tuffs and fine breccias without order or arrangement. MON XXX1I, PT 1I-11 
The material consists of basic andesites and basalts, some of which are absarokite and contain orthoclase as an essential constituent. Petrographically they are like the hasaltic breccias of the Absaroka Range.

The breccias are dark colored and often weather into fantastic towers, pinnacles, and cliffs, whose dark rich shades of red, brown, purple, and gray render them highly picturesque. The fragments are angular and subangular and often are several feet in diameter. The best exposures occur just below the amphitheater at the head of Boone Creek. On the north side of Conant Creek, where the exposure is nearly 1,000 feet high, there are indications of rude beeding, dipping westrard.

The breccias were thrown upon the surface of deeply eroded and faulted sedimentary rocks, and unloubtedly were considerably eroded themselves before being buried heneath the rlyolite, which forms the western slopes and spurs and extends beneath the later basalt sheets of the Falls River Basin a long distance westward. The canyons of Boone and Conant creeks cut into it 400 feet and more withont reaching the underlying rocks. The rhyolite is porphyritic and lithoidal as a whole, but at the bottom of the sheet, in contact with the underlying rocks, it is dark-colored obsidian.

Birch Hills. The lireh Hills, whose summits rise prominently above the western border of the plateau, present the most northern exposures of the sedimentary rocks of the Teton uplift. Separated from the northem spurs of that range by the sonthern extension of the great rhyolite plateans of the Park which so effectively conceal all the earlier rocks, this small area, which recent denudation has again exposed to view, presents clear evidence of the same sequence of events so clearly ontlined in the range itself.

The lills consist of a group of pointerl eminences, with gentle eastern slope and steep western declivities. The surface, formerly leavily wooded, is now densely covered with a shrubby growth of black birch, concealing the fallen timber that everywhere strews the ground.

North of Falls River, whose beantiful Rainbow and Terrace falls are near by, the hills consist of dacite-porphyry, forming the two main summits. This rock is light gray and compact, with phenocrysts of feldspar and quartz, and small biotite plates. It is a lolocrystalline, intrusive body, resembling the rock of Bunsen Peak in composition and structure, but more distinctly 
porphyritie, the phenocrysts being langer and fewer. They are: Oligoclase in fine idionorphice erystals, with marked zomal structure and little polysynthetic twinning, sometimes suggesting orthoclase; biotite, in thick idiomorphic crystals, with numerous magnetite inclusions; and corroded quartz, with glass inclusions. 'The groundmass is nierogranular with idiomorphic quartzes, the average grain being about $0.02 \mathrm{~mm}$. in dianeter. It consists of (plarty and feldspar, with small amomits of magnetite and biotite. Apatite occurs in comparatively large colorless crystals, much cracked. Zircon is present in minute prismatic crystals. The chemical composition of the rock is shown in the following analysis, and is nearly identical with that of the Bunsen Peak rock:

Analysis of Aacite-porphyry of the Birch Hills.

[.J. E. Whittield, Analyst.]

\begin{tabular}{|c|c|}
\hline Consticuent. & Per cent. \\
\hline $\mathrm{SiO}_{2} \ldots \ldots \ldots \ldots \ldots$ & 70.24 \\
\hline $\mathrm{TiO}_{2} \ldots \ldots \ldots \ldots$ & Trace. \\
\hline $\mathrm{Al}_{2} \mathrm{O}_{3} \ldots \ldots \ldots \ldots$ & 17.36 \\
\hline 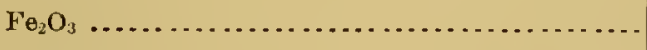 & 1.38 \\
\hline 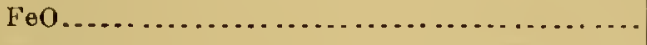 & .79 \\
\hline $\mathrm{MnO} . . . . . . . .$. & None. \\
\hline $\mathrm{MgO} . . . . .$. & .53 \\
\hline $\mathrm{CaO} \ldots \ldots . . . . .$. & 2.74 \\
\hline $\mathrm{Na}_{2} \mathrm{O} \ldots \ldots \ldots \ldots . .$. & 3.69 \\
\hline $\mathrm{K}_{2} \mathrm{O} \ldots \ldots \ldots \ldots \ldots$ & 2.65 \\
\hline $\mathrm{Li}, \mathrm{O} \ldots \ldots . . .$. & None. \\
\hline $\mathrm{P}_{2} \mathrm{O}_{5} \ldots \ldots \ldots \ldots \ldots$ & Trace. \\
\hline $\mathrm{SO}_{3} \ldots \ldots \ldots$ & Trace. \\
\hline $\mathrm{H}_{2} \mathrm{O} \ldots \ldots \ldots \ldots$ & .71 \\
\hline Total ........... & 100.09 \\
\hline
\end{tabular}

Eastward this rock passes beneath the rhyolites, which reach almost to the summit of the hills. On the westward slopes steeply uptumed limestones, somewhat altered, dip toward the igneous rock. The foot slopes show a remnant of the basic breccias covering the eroded limestones and porphyry, and covered in turn by the ubiquitons rhyolite.

The west spur of the northern hill is formed of altered limestones, whose beds strike S. $40^{\circ} \mathrm{E}$., and dip $70^{\circ} \mathrm{NE}$., toward the dacite-porphyrr: The limestone is dense, gray, mottled with yellow, and underlies thinly- 
bedded glanconitic limestones whose lithological character and sequence place them in the Flathead formation of the Cambrian.

Similar rocks are exposed in the bed and walls of Falls River below the Rainbow Falls, where they are covered by a light-colored andesitic tuff or breccia, generally fine grained and much decomposed. This breccia forms low rounded hmmmocks at the base of the hills, and is not yet cut through by the river, whose bed it forms for a mile above the meadows. The exposure in the river bank shows rude bedding, with northwest dip.

South of Falls River the hills are continued in an irregularly accidented area. The rhyolite platean terminates in a wall several hundred feet high, a deep but narrow depression separating the bluff from the sedimentary ridge to the west.

These hills sonth of the river present exposures of the Carboniferous and Triassic beds, forming parallel ridges with benched slope and trending N. $70^{\circ} \mathrm{E}$., the rocks dipping $30^{\circ} \mathrm{N}$. The red, fissile Teton sandstones are well exposed in the lower slopes, weathering into a reddish soil not easily distinguished from that of the red patches of the Quadrant formation.

These red sandstones are here underlain by the cherty horizon of the Teton, resting upon the Quadrant quartzites. The chert occur's in characteristic rolls, rods, and nodular masses, having a chalky surface, and grading at times into the inclosing arenaceous rock. The Quadrant quartzites correspond closely in character to the formation as developed in the Gallatin, consisting of white granular quartzite and interbedded limestones that are often good marbles.

West of the sedimentary area just noted there is an exposure of hornblende-andesite-porphyry. The rock is clearly intrusive and cuts through the Carboniferous limestones.

The Birch Hills, by reason of the compact character of their rocks, present excellent evidences of former glaciation of the region. The rocks occur in rounded ice-worn hummocks, covered with glacial scorings and groovings with general east-west trend. In general the eastern and northern slopes are gentle, while steep cliffs bound the hills to the west and south. 


\title{
C H A P T E R V. \\ DESCRIPTIVE GEOLOGY OF HUCKLEBERRY MOUNTAIN AND BIG GAME RIDGE.
}

\author{
By Arnold Hague.
}

\section{GENERAL FEATURES.}

The country described in this chapter embraces a mountainous area irregular in outline and of great diversity of form. It consists mainly of a series of ridges, trending northwesterly and southeasterly, composed for the most part of Mesozoic rocks. Older sedimentary rocks are well exposed in a number of localities, as well as areas of coarse breccia and broad fields of rhyolite, but the region is essentially one formed of rocks of Cretaceous age.

The southern line of the area described here is sharply defined by the forty-fourth parallel of latitude, coinciding with the southeru boundary of the Yellowstone Park forest reservation. ${ }^{2}$ The broad valley of the Snake separates it from the mountains and uplifted sedimentary rocks of the Teton Range lying on the west side of the river. On the northwest and north the rhyolites of the Park Plateau, reaching their southern limit, rest directly against the upturned edges of the sedimentary beds. In much the same way the western border of andesitic breccias of Two Ocean Plateau sharply delimit this area of sedimentary rocks from the unbroken mass of basic lavas which stretch far away eastward in broad plateans and serrated ridges. In striking contrast to these areas of breccias and rhyolites that strround it, this region stands out strongly marked by its physical features. In a certain way this group of sedimentary ridges rises as an island, or rather as a projecting promontory, into a vast sea of lavas. The irregular

${ }^{1}$ See map of Yellowstone National Park accompanying Part I, and Geologic Atlas U. S., folio 30, 1896. 
outline is in great part due to the sinuous border of accumulated lavas that abut against the steep slopes of uplifted strata. Across its broadest expansion, from Snake River to Two Ocean Platean, it measures about 20 miles. In length it measures nearly 22 miles, stretching northward with decreasing breadth across the forest reservation, gradually dying out in a narrow ridge projecting into the rhyolite body which skirts the west shore of the sonth arm of Yellowstone Lake.

All of the ridges and mountain masses which make up this region are clearly defined by salient topographic features, delimited by deeply eroded valleys, and yet they are all so knit together by outlying spurs and elevated passes as to present a single mountain group, witl a somewhat complex topographic structure and an intricate drainage system. The principal physical features are Big Game Ridge and its extension northward, Chicken Ridge; Pinyon Peak and Bobcat Ridge; Huckleberry Mountain and Wildcat Peak. Several of the high mountains of the Park country are found here, a number of them attaining elevations of over 9,500 feet, but only one, Mount Hancock, the culminating point of Big Game Ridge, reaches an altitnde of over 10,000 feet above sea level. Witl the exception of a narrow strip of country pouring its waters into Yellowstone Lake, this entire region is drained by Snake River or some of its many tributary streams. The main branch of Snake River takes its rise along the west slopes of Two Ocean Platean, flows northerly around the east base of Mount Hancock, and thence, with a sharp curve around the end of Big Game Ridge, runs southerly at the west base of the same mountain. With a gentle sweeping curve it encircles the northern end of Huckleberry Mountain and enters the broad, open plain lying west of this momntainous region. Continuing its course southward, it crosses the forest reservation, and soon after widens ont into Jackson Lake, a short distance south of the limit of the map. With this circuitous course, as thus defined, Snake River nearly surrounds this group of mountains, and on leaving the forest reservation has become a wide, deep stream. Across the broadest expanse of these mountains there runs, in an approximately east-west line, a welldefined watershed from Snake River to Two Ocean Platean. Nortlı of this divide such fine streams as Coulter, Wolverine, and Fox creeks pour large volumes of water into the main Snake. Several mountain torrents, notably Lizard, Gravel, and Mink creeks, flow southward into Pacific 
Creek, which finally aidds its waters to those of the Snake soon after the latter strean crosses the southeru boundary of the area mapped.

The physical features of the country present strikingly varied outlines of mountain, ridge, valley, and upland, with abrupt changes in configuration. Constantly changing rock formations, with accompanying modifications of topographic forms, make the region singularly picturesque, and the altemation of gently undulating and roughly accidented areas causes the region to stand out in slarply defined contrast to the more monotonous Park Plateaul.

Much of the country, especially the more elevated portions, are timberless, but large areas of mountain slope present a diversified park-like appearance, covered with a vigorous growth of coniferous forest. Faulting and folding of strata, with frequent changes in the inclination of beds, have produced conditions favorable to the flow of springs, the many mountain torrents making the region a lighly favored one in its water supply.

The region is well adapted to the haunts of wild animals, and the dominant ridge of the country, characteristically named Big Game Ridge, in former years furnished abundant sport for the liunter in search of bear, elk, deer, and mountain lion.

Unlike the areas of sedimentary beds which make up the Gallatin Range and form the slopes of the Teton or Snowy ranges, the sedimentary rocks of this region do not rest directly upon any exposed body of Archean rocks, nor do they dip away in any one dirsection from a central mass. Within this region no Archean rocks are known. Southward, in the Wind River Range, the Archean presents a bold unbroken mass of pre-Cambrian rocks, but its geological relations with the uplifted sediments of this region can not be determined, owing to the accumulated volcanic material, which conceals everything beneath it in the intervening country. In much the same manner the breccias of Two Ocean Platean and the rlhyolites of the Park Platenu prevent any precise interpretation of the strnetural relations of this region with the country to the north and east.

It is evident that the powerful forces which tplifted this mountain mass acted from several different centers and produced a somewhat intricate structure. The uplifting of the mass was accompanied by profound faulting and folding, and in places by marked compression of strata. Subse. quent orographic novement produced secondary faulting, adding much.in 
certain localities to the difficulties of determining structure. The later intrusion of igneous rocks tended in some places to break up and confuse the position of beds, but only in limited areas is such action especially noticeable, and it may be said to have affected the larger mountain blocks singularly little as regards the disturbance of beds.

Sandstones of the Montana and Laramie formations constitute the more elevated portions of the ridges. Both formations are conformable, and throughont their entire development, from base to summit, the prevailing beds consist of a coarse yellowish-brown sandstone, of varying degrees of purity. In the absence of a characteristic fauma diserimination between the two formations is very difficult, and in most instances impossible without much detailed work, with results not commensurate to the labor.

Fort Pierre beds, which are mainly arenaceous, pass down into nearly similar sandy deposits of the Colorado. The fama which characterizes these lower beds is one possessing a wide vertical range throughout the Cretaceous sandstones, and the line of demareation between the Montana and Colorado is not always easy to draw. It is possible that beds provisionally placed in the Montana may upon further investigation be found to belong to the Colorado, the assignment being based upou their faunal relations rather than upon their lithological habit.

\section{REGION OF WILDCAT PEAK AND HUCKLEBERRY MIOUNTAIN.}

Snake River sharply defines this group of mountains on the west and north. Above the broad valley of the Snake the mountains rise abruptly over 2,500 feet in long rugged ridges whose outlines are more or less obscured by dense forests. Northward, along the gorge of Snake River, the mountain slopes are precipitous and in places rise like eanyon walls above the stream.

Coulter Creek, named in honor of the distinguished botanist, Prof. Jolm M. Coulter, may be taken as the eastern boundary of these mountains. It drains, by numerous tributaries, nearly the entire eastern slope, and pours a large volume of water into the main stream, being the first important affluent above the gorge of the river. The summit of the mountains at their northern end, with an average elevation of 8,700 feet, presents a broken, gently accidented country, easy to traverse and singularly attractive from its park-like character. All the dominant peaks attain nearly the same 
elevation, are flat-topped, and ensily accessible. Numerous groups of coniferous trees, broad areas of grassy upland, and an abundance of water add great charm to the region. South of Wildeat l'eak the country fills away in long monotonons ridges, with nurow intervening valleys, uniform in ontline and dreary in aspect. Structurally this uplifted mass, in its simplest form, presents a syuclinal fold, whose axis, with a broad sweeping curve, strikes obliquely arross the mountains northwest to southeast. This structure is accompanied by local crumpling and folding of beds. Apparently the force uplifting the beds upon the sonthern sirle of the fold came from the direction of the Teton Range. Wherever observed these beds dip persistently into the mountains and away from the Archean mass which forms so broad and continuous a body to the southwest. Owing to the crumbling nature of the beds and the amount of soil, good rock exposures are rarely seen. Along the banks of Lizard Creek and the adjoining valleys to the east and west the beds lie inclined from $20^{\circ}$ to $30^{\circ} \mathrm{NE}$. The axis of the syncline trends across the southern and western slopes of Wildcat Peak, and is lost beneatl the rhyolite forming the steep slopes toward Snake River.

wildcat Peak.-At the base of Wildcat Peak, near the head of Lizard Creek, the beds dip slightly to the northeast, but those forming the summit of the peak belong to the opposite side of the syncline and are highly inclined, many of them standing on edge. Here they trend diagonally across the ridge, with a dip varying from $65^{\circ}$ to $70^{\circ}$. The strata are thinly bedded sandstones, presenting long rows of slab-like exposures. These are underlain by black arenaceous shales, in turn followed by other thin layers of sandstone. The beds striking across the ridge give rise to narrow lateral spurs, with deeply eroded ravines between them. Along the summit of the ridge the same beds may be traced eastward with apparently the same dip and strike. In the open park-like comtry northwest of Wildcat Peak and west of Huckleberry Mountain the beds show a southerly dip, indicating the north side of the syncline. The beds found on botl sides of the axis of this fold have been referred to the Montana formation. It is possible that they include a series of beds which should be assigned to the Colorado, but, owing to the present state of knowledge and the very limited number of organic forms as yet obtained from this region, it has been found impossible to draw any line of demarcation between the two periods 
of the Cretaceous. All the sediments are more or less impure sandstones, and even those characterized by argillaceous deposits are usually sandy. While the organie forms found here may be such as occur elsewhere in the Colorado shales, they are also forms that extend upward into the sandstones of the Montana. These arenaceous shales are well developed in the valley of Lizard Creek, and along the east side of the stream are exposed in a number of localities above the strean bed. From them have been obtained Ostrea, Anomia, Inoceramus, and the widely distributed middle Cretaceous species, Cardium pauperculum.

Beds similar in lithological habit are exposed in the valley to the westward, which in its topographic outline closely resembles Lizard Creek, and still farther westward these rusty sandstones crop out from beneath thin cappings of rhyolite at a number of localities on both sides of the Snake River trail. One such exposure is seen along the trail not far fron where it crosses the summit of the spur which extends westward to Snake River. On the east side of the river, opposite the moutl of Berry Creek, a small exposure of sandstone and shale occurs, striking nearly due east and west and dipping north.

Owing to the limited area exposed and the fact that the surrounding country is mainly covered by drift the outcrop is not indicated on the map. According to Prof. J. P. Iddings, this sandstone carries a seam of coal 4 inches in thickness. Northward, and on the extreme western spur of the ridge, the sandstones and shales are exposed, extending up the hill slope for several hundred feet. Here they striko northeast and soutlrwest, with a dip of $25^{\circ} \mathrm{NW}$. It is possible these beds belong to the Colorado formation, but in the absence of all organic remains they have been placed in the IIontana, together with other beds of similar lithological character found in this region.

Huckleberry Mountain.-The central mass of this group of mountains has been designated Huckleberry Mountain. Its summit is formed of a broad sheet of rlyyolite, slightly inclined toward the south. On nearly all sides this rhyolite capping rises above the underlying rocks as an abrupt wall, which along the east side forms an escarpment over 100 feet in height. This east wall limits the rhyolite in this direction, and the entire eastern slope of the mountain, down to Coulter Creek, exposes only strata of the Inontana formation. The beds dip at low angles to the southeast. Beneath 
the rhyolite of the summit the Hontana beds present a very uneren surface, aud at one point the sandstones project through the capping of lava, which elsewhere forms the top of the monntain. On both the enst and west slopes of Huckleberry Monntain the underlying strata present many of the same general features, being fissile, friable sandstone, crumbling easily, and in places showing signs of cross bedding and other evidences of shallow-water deposition. On the west side, where the sandstones are exposed by erosion of the rhyolite, the beds have yielded Cardium pauperculum, and on the east side, just below the base of the rlyyolite, the same species has been obtained from nearly similar rock. Aganin, near the east end of the long spur making out toward Conlter Creek, in fissile sandstone, inclined $10^{\circ} \mathrm{S}$., there were found the same Cardinm, associated with Ostrea anomioides.

North of Huckleberry Mountain the country suddenly falls away several hundred feet to a nirrow saddle, where the Montana shales are again well shown. Beyond this saddle the country again rises in a prominent point, which, for want of any distinetive appellation, may be designated as North Huckleberry Mountain. In elevation it falls but little below the more southern point, and commands to the north a still more comprehensive view. Geologically the two points possess much in common. A sheet of rhyolite, resting upon the Montana sandstone, forms the top of the table, as already described for Huckleberry Mountain. Probably at one time the two points were comected by a continuous sheet of rhyolite, erosion having since worn away the rock upon the saddle. In the case of North Huckleberry Mountain the rhyolite escarpment faces northward, and the prominent wall of Montana sandstone stretches far away to the eastward till buried beneath the outlying masses of late basic breccia.

The fissile sandstones of the Montana beds are well shown all along the northern slopes of the mountain and in the valley of the strean tributary to Coulter Creek. Northward, the Montana sandstone still forms the summit of the main ridge and eastern slopes, till, near the northern end of the mountain, the beds become decidedly argillaceous, with sandstone occurring as intercalated layers. Although no evidence of a fauma was obtained, the beds, upon their lithological habit in distinction to the arenaceous beds above, have been assigned to the Colorado formation. Their continuity westward is obscured by overlying rhyolite. Montana sandstones occur as the underlying rocks along the entire westem slope of this mountain mass, 
and extend from the open plain of Snake River Valley to the summit of the ridge. At one locality just sontl of the Park boundary Cretaceous elays are exposed in a precipitons bluff at the river, but the slopes of the hills are for the most part obseured by alluvial material, followed higher up by extensive deposits of glacial drift and broad areas of rlyyolite, the latter in places extending from the summit to the plain. An overlying sandy soil nearly everywliere mantles the mountain side, and large forest areas conceal the structure of beds, rendering it most difficult to follow the continuity of strata. Observed dips and strikes indicate that in general the sandstones lie inclined eastward, toward the monntain mass, but witl many local displacements.

Rhyolite- $-\mathrm{By}$ reference to the map it will be seen that the rlyyolite is represented as forming a continuous body from the extreme northern end of the monntain south to the forty-fourth parallel of latitude. This rhyolite is very irregular in outline and represents a comparatively thin flow of lava. Over a large part of the area covered by rhyolite it is doubtful if the lava sheet is more than 100 feet in thickness. In places it las been entirely removed by erosion, leaving isolated patches of sandstone exposed upm the surface. In two loealities it caps the westward spurs fron the summit to Snake River, and at other points lies high up on the mountain sides. It caps the sandstone on the long ridges trending sonthward, and presents a somewhat striking appearance with its long monotonous flows, scarcely 100 feet in thickness, resting upon the deeply eroded arenaceons strata. These long flows stretch southward nearly to Jackson Lake.

This rhyolite body possesses a fairly uniform appearanee from one end to the other; that is to say, it does not vary throughont its mass more than many areas of equal extent on the Park Plateau; indeed, it elosely resembles the rlyyolite of the Park. It is in general purplish gray in eolor and lithoidal in texture. In places it is fissile, and npon Huekleberry Mountain, and in several other localities along the summit, it oceurs in horizontal beds with jointing planes. On Nortl Inckleberry MLountain it is thinly bedded and fissile, the débris slopes being made up of irregular fragments of lithoidal roek.

Dacite. -Near the junction of the Cretaceous rocks with the rhyolite, due west of Hnekleberry Mountain, oceur two or three exposures of igneous rock, that rise in low obseure mounds above the general level of the sand- 
stone. In outline these expostures ane strikingly different from the sindstone, and in their mode of weathering stand out in strong contrast with the sumomeling rhyolite. An examination shows that these rocks are to be classed as dacite. In composition they are more hasic than the rhyolites, and 'an'y a linger proportion of plagioclase, and, in distinction from the rhyolites of the region, hold a considerable amount of biotite. Apparently they are older thin the rhyolite and are exposed by the erosion of the latter rock. Petrographically they are closely related to a dacite occurring in a number of exposiures on the west side of Snake River Valley, and their interest lies in the fact that they are annong the few instances known in the Park of rocks with a dacitic ficies related to rhyolites.

\section{REGION OF SNAKE RIVER GORGE.}

From Lewis River to the month of Coulter Creek the course of Snake River makes an irregular curve of nearly $180^{\circ}$, closely encircling the northem end of the Wildcat Peak and Huckleberry Mountain mass, the mouth of Coulter Creek lying 7 $\frac{1}{2}$ miles due east of Lewis River. Snake River runs through a deeply eroded gorge, which for several miles above Lewis River sharply defines the rlyolite flows of the Sheridan volcano on the north side from the uplifted sedimentary rocks on the south. Against the abrupt wall of Paleozoic rocks the rhyolites were piled up to a great height, and it is along this contact that the river has cut its picturesque gorge. On the north side the rhyolites stand out in a precipitous wall, nearly 400 feet above the river, and thence rise gradually toward the central portion of Mount Sheridan. On the south side a massive wall of limestone rises 1,000 feet to the summit of the mountain. The beds are highly crystalline, light in color, and belong to the Madison limestone.

It is possible that older beds, represented by Three Forks and Jefferson limestones, are exposed in the gorge along the base of the mountain, but the mantle of drift is so heavy and the timber so dense that they have nowhere been recognized.

Above the Madison limestone come the brilliant red sandstones and shales of the Teton formation, standing out conspicuously in contrast with white and blue limestone. Along the summit of the mountain the Quadrant quartzite has nowhere been recognized. Arenaceous limestone lies 
directly beneath the 'Teton beds, but nothing similar to the compact siliceous deposits which characterize the Quadrant quartzites in the Gallatin Range has been observed.

Overlying the Teton beds come the drab limestone, marl, and fine sandstone which mark the Ellis formation, everywhere defined by Jurassic faunia. Fine-grained sandstones which form the uppermost beds of the EIlis formation pass gradually into a coarser and more compact series of sandstones, which here represent the Dakota beds. These in turn are followed by impure sandstones and black shales of the Colorado formation, and these again by the Montana. The latter have already been referred to in describing the geological features north of Huckleberry Mountain. This entire mass of uplifted sediments dips to the south, forming a part of the general synchine which constitutes the Wilcat Peak and Huckleberry Mountain orographic block. About 5 miles east of Lewis River the physical features of the canyon wall change. The Madison limestone, dipping eastward, dies out, and the Mesozoic strata, which to the west are seen only high up on the cliffs, turu and pitch down the mountain slope toward the river. The Mesozoic strata are much fanlted and crumpled, and lie inclined at varying angles. Overlying the Madison limestone the Teton red beds incline to the sontheast, but the dip soon changes, and the beds which make up the long ridge stretching down to the river dip for the most part to the southwest.

Both the Teton and Ellis formations are exposed along the south side of the river, but neither the Dakota nor Colorado have been recognized along the river bank. Good exposures are few. The Dakota conglomerate is not characteristically developed, and the slopes for 200 feet above the river are largely corered by glacial drift. On the ridge south of the river and west of Coulter Peak, where the Ellis beds are well exposed, dipping at a low angle to the sonthwest, the drab limestone has furnished Ostrea strigilecula, Camptonectes, and Rhynchonella myrina. Several hundred feet higher up the ridge, in the arenaceous limestone passing into sandstone, the same species were obtained, together with $R$. guathophora, and at still another locality on the ridge the beds yielded Gryphan planoconvexa. As regards the relative position of the horizons furnishing these species nothing definite can be stated. Still higher up the ridge the course sandstones assigned to the 1)akota formation are well exposed, and above the Dakota 
numerous drainage chamels, tributaries of the westeru affluent of Coulter Creek, afford grood exposures of the higher Cretaceous formations.

\section{RUGION BHEWWEN IEID AND BASIN CREEKS.}

East of Red Creek the gorge of the river narrows, and the clear shallow water presents a striking appearance, flowing for more than half a mile over a smooth, polished floor of 'Teton red beds, witi the highly colored sandstone forming the brilliant banks on both sides of the stream. On the north and east side of Suake River, between Red and Basin creeks, there is a mountain area consisting mainly of Mesozoic rocks. It extends back from the river about 5 miles, and across its broadest expansion measures somewhat less than 4 miles. Rhyolite surrounds it on all sides, except along the river gorge, effectually isolating it from adjoining areas. Geologically this region is closely related to the Mesozoic rocks on the south side of the river, every formation being represented, from the Teton to the Montana, inclusive.

Red Creek, which is appropriately named from the red rocks found on both sides of the stream, marks the eastern boundary of the rhyolite flow, stretching sonthward from the Sheridan volcano. Red Creek enters Snake River through a narrow chasm cut in the sedimentary rocks. At the mouth of the creek there is a bluff of red arenaceous limestone, similar to the Carboniferous limestone found elsewhere underlying the red sandstone of the Teton formation. It has been designated on the map as the Madison limestone, but it may belong to the Quadraut formation, for the upper beds are nearly pure sandstone.

Passing up Red Creek the limestone soon disappears and is overlain by the red sandstone. The stream for nearly its entire length has carved its channel in these beds, which are here exceptionally well exposed, showing the varying character of the sandstones and the intercalated red clays and marls. The formation here has an estimaterl thickness of 400 feet, the heds dipping north and east. Between Red Creek and Basin Creek the beds are pressed into a syncline, followed by a sharp anticline. Overlying the Teton beds of Red Creek come the Ellis and Dakota formations, followed by the black clays and arenaceous shales of the Colorado, which lie in the syncline, the latter formation being characteristically shown in a depression between two ridges of less easily eroded beds. 
To the east of this depression the sandstones assigned to the Dakota formation are clearly defined along the west side of the prominent ridge separating Red and Basin creeks. They pass gradually, without any sharp line of demarcation, over into the Ellis beds, which form the summit of the ridge. The axis of the anticline lies in the Ellis limestone, which is here nearly 200 feet in thickness, and is characterized by a small but welldefined Jurassic famna. Among the species found here are Grypheca calceola var, nebrascensis, Camptonectes pertemistriatus, Gervillia, Pseudomonotis curta, Modiola sulimbricala, Ammonites.

At the east base of the ridge and on the opposite side of the anticline the Dakota sandstones again come in, dipping eastward until finally lost beneath the rhyolite which skirts the edge of the upturned sedimentary beds.

East of Basin Creek the valley of the Snake is broad and open, showing wide alluvial meadow lands, diversified by occasional growths of pine. A short distance below the mouth of Basin Creek the river flows through a narrow chasm before it enters the wider valley near its junction with Coulter Creek. At the upper entrance of this chasm the river cuts through a ridge of coarse breccia, showing a mural face nearly 300 feet in height. This breccia rests upon Montana sandstones, which form the greater part of the hills on the west side of the river. On the east side of this ehasm, about half a nile above the junction of the river with Coulter Creek, occur two outcrops of coal, exposed just above the river bank. These seams of coal along the outcrops measure about 15 inches in thickness. They are overlain by fine conglomerate and underlain by black arenaceous clay. These coals are more or less impure by reason of thin bands of carbonaceous clay. The beds carrying the coal strike N. $30^{\circ} \mathrm{W}$. and dip from $15^{\circ}$ to $20^{\circ} \mathrm{E}$. The bedder sandstones carrying the coal seans pass under the river, but are not exposed on the opposite side, owing to the accumulation of glacial drift. Below the junction of Coulter Creek with the Snake the sandstones dip to the northeast, away from the river, while, as already noted, they dip to the southwest on the opposite side of the stream.

Notwithstanding the occurrence of coal these sandstones are regarded as belonging to the Montana formation, and probably to the upper part, or the Fox Hill terrane. Owing to the great uniformity in the sedimentation 
of these beds and the absenee of menaie remains, it is impossible to determine with precision the position of these conks. Unlike the Montana sandstome north of the Park, these rorks tiectnently carry well-defined coal seams, althomgh beds of eemonic value are fouml mainly in the Lanamie. This coal is probably of the sime ane as that exposed in the banks of the Suake Rivere west of Wildeat l'eak.

\section{ANAKJ: LIVEIR IIOT APIRNGS.}

On the soutl side of the river, below the mouth of Rerl Creek, occums an interesting group of hot springs, more than lalf lidden by dense timber; which at this point comes down to the water's elge. A low chiff of blue cherty limestone is exposed along the bank, beneath which, from a line of springs, there issues a large volume of wam calcareous waters. Near by is a long bench of rhyolite, rising slightly above the stream, and the only one observed on the south side of the river. The thermal waters are probably closely related to this body of rhyolite, but their mineral constituents are derived mainly from the limestone. These springs divide naturally into three groups, but their mode of occurrence is much the same and they are similar as regards the mineral composition of the deposits. The travertine deposits in their mounds, basins, and terraces resemble those found at the Mammoth Hot Springs. They were visited by the writer in 1886 and again in 1891; they presented but slight changes after this interval of five years. The most picturesque and powerful of the springs are sitnated farthest up the river and are built out over the stream upon the edge of an old meadow. It was estimated in 1886 that the volume of water running from these springs reached 50 gallons a minute. This group of springs is shown in Pl. XXIV. For beanty of color and ornamentation of the rim they are unsurpassed by any of those at the Mammoth Hot Springs, althongh by no means equal to them in magnitude of the deposits or in volume of calcareous water poured fortl. The clear water is of the most delieate turquoise-blue color, and the basin is lined with a soft white travertine of extremely fine texture, impalpable to the tonel. The basins which surround the pool are tinted with orange, brown, and red colors, derived from the hot-water algae.

Mr. W. H. Weed has furnished from his notebook the following MON XXXI1, PT. $11-12$ 
description of the springs lying to the westward, written at the time of his visit in the antumm of 1891 :

One spring. issuing from sandy mire, is 2 feet in diameter, and has built up abont the orifice a cleposit of white calcite. It will, however, be buried beneath more sand with the first freshets of the river. The two main springs of the group lie to the west of this one. Beyond these a dark ledge of limestone projects over the slopes terminating the timber bench some 20 feet above the river. The first of these two springs is a bowl with a wide terracel mound of great beauty, the deposits being dense porcelain-like travertine; like that of the first spring noted. The spring attracting most attention throws up a splashing, steaming bolly of water between 2 and 3 feet in height. The smooth, round surface of the bowl is a snowy white, very dense and compact travertine. The ontlet appears as a break in a marble bowl and is a foot deep.

Between this bowl and the springs to the east of it there is a hot-water outHow of the type common at the Mammoth Hot Springs. The spring waters have formed mushroom nodules in the channel and a fungus-shaped horder about the waters. There are also a number of warm.water springs along the edge of the stream, but the springs issue from the gravel and have no well-rlefined basin and no dejosits.

The old travertine deposits form a low bench abont 5 or 6 feet above the river, at a place where the higher bench and the limestones retreat to the south. The area covered does not exceed one-fourth of an acre. The actual area occupied by the springs is, however, more extensive, for following the grassy, willow-covered bench there is an exteusion of the travertine level to the west, where the rocky bluff again comes out to the river.

At the foot of a higher bench back of these low lills there is a stream of lot water which flows west from a recess in the mealow to the base of the cliff and along it to the river. The stream is from 3 to 8 feet wide near its source. The water is warm, but not hot, probably not over $120^{\circ} \mathrm{F}$., judging from the algeous growtls, but the volume of water is very considerable.

The photograph from which the illustration is made is a view down the Snake River gorge and northwest across the river to the walls of rhyolite on the opposite side. Forest Creek, which runs throngh a deep trench in the rhyolite, is shown on the north side of the river, with a gently inclined mass of lava abruptly terminated along the gorge. In the spring the river is a rushing torrent, subsiding after the first melting of the snows, leaving low, broad benches, nade $n$ p of coarse gravels and bowlders. The view was taken in late autumn, when the water stands at its lowest level. 


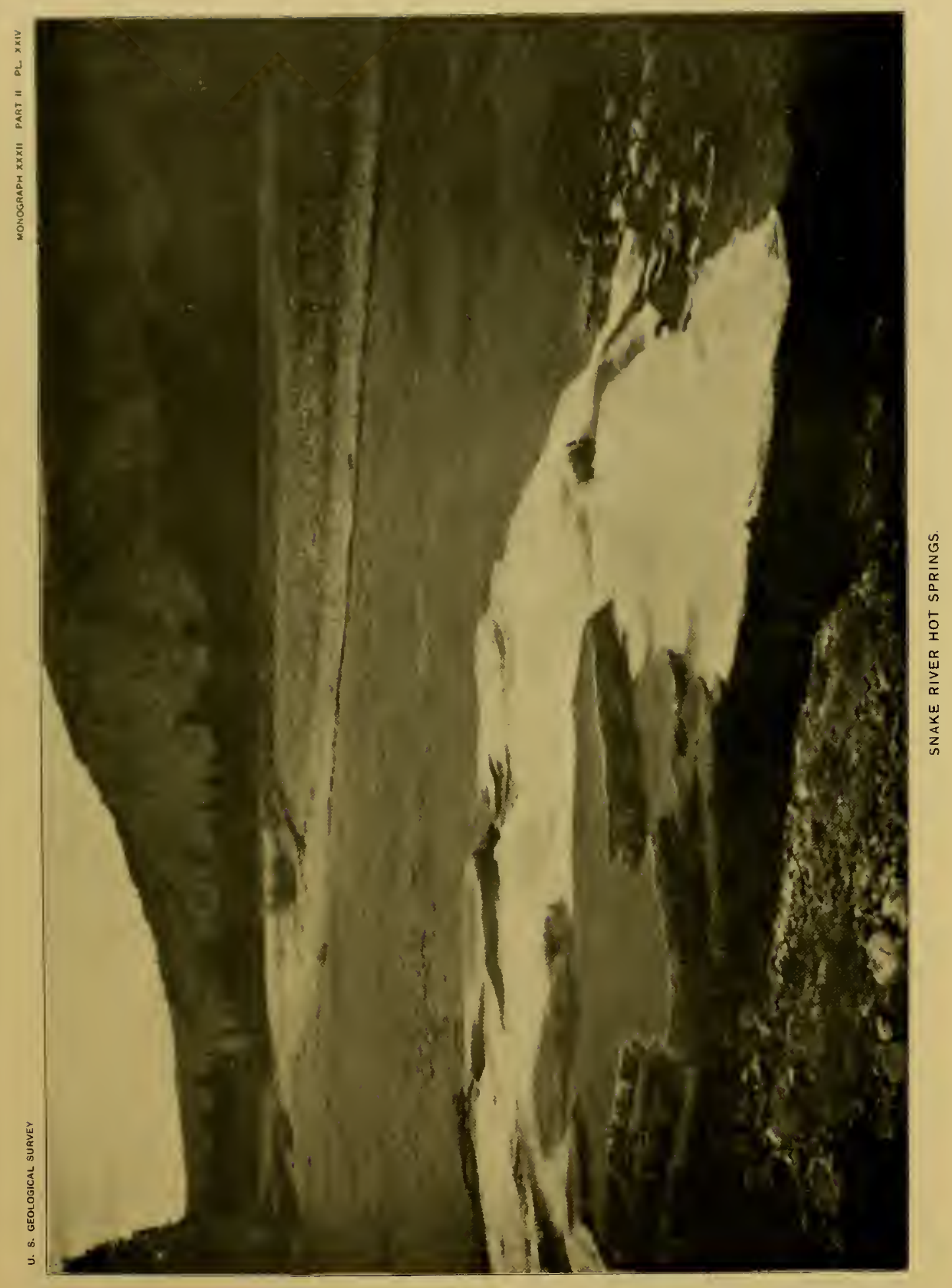





\section{REGION OF COLATHIR CRELE ANT HOIBCAT RIDGE.}

coulter creek.-Conlter Creek, hefore emptying into Snake River, flows through an open basin, and is greatly angmented by the drainage of two such large streans as Harebell and Wolverine rreeks. All these streans lave brought down larege ancumulations of drift material, and the underlying sedincentary rocks are for the nost part obscured by a thick nuntle of gravel, sand, and fine breceia. The mountain slopes smounding this little basin are well terraced, and tive sharply defined benches rise one above the other to a lieight of nearly 200 f'eet. Coulter, Harebell, and Wolverine creeks all enter this basin throngl narrow defiles cut in breccia, with perpendicular walls 300 feet in heiglit in places. Coulter Creek, for nearly 4 miles, has cut its way through this breccia, and it is practically impassable from the number and size of the bowlders which lie piled up along the valley. From beneath this dark, somber breccia Cretaceous sandstones and shales crop out at a number of localities and on the west side of Coulter Creek extend along the base of the momntain, with the breccias lying above.

The main tributary of Coulter Creek from the west has cut through the breccia, and erosion has carried it away from the momtain slopes so as to expose Montana sandstones all the way from Huckleberry Mountain to Coulter Creek. In the region of Coulter Creek the underlying sandstones possess a very irregular surface, and in many places the breccia rests upon them as a thin flow or crust. The sandstones show a prevailing dip to the sonthwest. This body of breccia stands by itself, completely isolated from the vast pile of breccias of Two Ocean Platean and the Absaroka Range. It is very irregular in outline and measures about 8 miles in length, stretching from the source of Coulter Creek northward along the west slopes of Mount Hancock.

On the east side of Coulter Creek the breccia attains an elevation of 8,500 feet, and on the slopes of Mount Hancock reaches nearly the same elevation. Throughout the entire body the breccia presents much the same general habit, a coarse, firmly compacted agglomerate, dark brown or black in color, with a lighter-colored cementing material. Some portions of it are exceptionally coarse. Fragments of well-rounded gneiss and quartz have been observed embedded in the mass. In general it is free from evidence of bedding, as is well shown in the exposures along the main stream. At 
Mount Hancock its mode of weathering is well brought ont by the many abrupt walls of rough, jagged surface and numerous deep trenches along the mountain side, which make travel very difficult and well nigh impossible.

The breccia, while closely resembling the imposing mass of Two Ocean Platean, and probably allied to it in age, is a distinct body, having its source along lines of displacement west of the Big Game Ridge uplift and the continuation northward of the Bobcat Ridge fanlt. It was the result of a powerful local eruption of coarse agglomerate, uniform in its composition, violent in its explosive action, and on ${ }^{1} y$ dimmed in interest by its close proximity to the larger masses of the Absaroka Range. It consists mainly of pyroxene-andesite and basaltic fragmental material.

Near the source of Coulter Creek broad sheets of purple lithoidal rhyolite occur, resting directly upon these basic breccias. On the west side of the strean there occurs an isolated body of rlhyolite, lying on the breccia and completely surrounded by it. This exposure is interesting, as it is evidently a remnant left by erosion, and probably at one time was connected with the larger fields to the east. High up the mountains Coulter Creek bifurcates and the two branches encircle a broad table of rhyolite which lies in the middle of the mountain valley. It is not known on what this rhyolite rests; the base of it is being deeply buried beneath an accumulation of glacial drift and coarse quartz gravel, derived from the Eocene conglomerate of Pinyon Peak.

Bobcat Ridge.-Bobeat Ridge is one of the marked physical features of this part of the country, standing out prominently above the surrounding ridges by reason of its great elevation. The ridge trends northwest and sontheast, and measures abont 6 miles in length. It is a singularly narrow ridge, having an average elevation of over 9,000 feet, with a number of peaks seattered along the summit, which attain altitudes of 9,500 feet or more. At its northern end it is connected with the Wildeat Peak mass and the high country around the head of Coulter Creek. At its southern end it falls away in long dreary spurs toward the valley below, lying just outside the limits of the area shown on the map. Both the east and west sides of this ridge are abrupt and present a rather dreary, monotonous aspect, with little standing forest, as the mountain sides over large areas are covered with fallen and dead timber.

Geologically Bobcat Ridge has not been studied much in detail. A 
fault runs along the west base of the ridge, but the line of displacement can not he tracerl, and its northem end is lost in the breccias and rhyolites. At the extreme northern end, near the bend of Coulter Creek, there is a cappling of rhyolite, but between this rlygolite and the higher parts of the ridge the top of the mountain is covered with loose sind and coarse gravel, derived from the wearing anay of Pinyon Poak conglomerate.

The entire ridge is apparently made up of yellowish-brown sandstones of the IIontana formation. In places the sandstone is massive, but in others it is well hedded. Wherever observerl the beds dip to the southwest, ant the entire ridge is probably a massive block of upper Cretaceous sandstones, dipping away from Mount Hancock and Big Game Ridge.

TREGION OF WOTNERINE CREEK.

Wolverine Creek finds its source high up on the west slopes of Big. Game Ridge, and flows westerly for 9 miles, joining Coulter Creek a short distance above the mouth of the latter stream. Compared with other high mountain streams in this region tributary to the Snake, it runs through a broad open valley, rough and rugged much of the way, but interspersed with green meadows and wide areas of alluvial bottom. The mountains rise high above the strean, the valley being practically shut in by steep slopes and high walls on all sides.

On the north side the long steep spurs of Mount Hancock tower above the valley for 1,500 feet to the summit of Big Game Ridge. On the south side the mountains stand out with even greater abruptness, and are more invegular in outline, with the lower slopes largely covered with timber and heavy accumulations of glacial drift. For the greater part of the distance the valley is cut in saudstones assigned either to the Montana or to the Laramie formation. Near the mouth of Wolverine Creek stands a grand escarpment of somber breceia, presenting a fine section in many ways typical of large masses of this rock.

Beyond this wall the stream bottom is impassable, and the trail ascends a steep hillside, crossing a spur of the mountain for 2 miles through a densely wooded country covered with soil and without any good rock exposures. This spur forms a part of the main mass, lying between Coulter and Wolverine creeks, and as exposed on both streams consists mainly of basic breccia resting upon a base of Cretaceous sandstone. According to Prof. J. P. Iddings, this mass is capped by a broad table of rhyolite 3 miles in length, 
which at its westem end is superimposed upon the breccia. The north slope of this ridge, forming the south wall along Wolverine Creek, consists mainly of bedded sandstones and inpure shales inclined to the southwest, but, owing to the mantle of soil, both the dip and the strike are most difficult to determine.

The mountain slopes along the north side of Wolverine Creek present a remarkable exposure of massively bedded yellow sandstone, with prevailing dips to the south and southwest-that is, toward the valley. No fossils have been obtained from these beds, but they have been assigned to the Montana formation. Higher up the valley they pass by insensible gradations into beds less regular in their sedimentation, carrying clays and earthy material with interbedded ferruginons sandstones. The latter series of beds, from their lithological habit, have been placed in the Laramie, but without any sharp lines of demarcation between the two formations. They lie conformably on the older beds to the north and west, and pass beneath the valley, dipping into the ridge on the opposite side. Dne north of Pinyou Peak, and rising as an abrupt wall on the sonth side of Wolverine Creek, stands a somewhat prominent hill, several hundred feet in height. It affords an excellent exposure across characteristic Laramie strata nearly 200 feet in thickness. These consist of yellowish-brown sandstones, with interbedded blue and black clays, rusty sandstones, and thin carbonaceons layers.

Along the stream bed are exposed outcrops of five distinct, thin seams of impure lignite with more or less fragmentary impressions of plant remains. The beds strike northwest and sontheast, and dip from $25^{\circ}$ to $30^{\circ} \mathrm{SW}$., passing under the mass to Pinyon Peak.

Higher up the valley at several localities the banks along the stream expose arenaceous blue clays and black shales with evidence of carbonaceons material, and in places carrying well-preserved leaves. These beds also dip to the southwest. Again, on the divide between Wolverine and Gravel creeks, and due east of Pinyon Peak, similar beds of arenaceons clays are exposed along the ravines and in the banks cut by numerous small streams. These beds along the summit of the pass dip to the southwest and west and are finally lost beneath the conglomerates of Pinyon Peak. The divide between these two creeks, which lies at an elevation of 8,500 feet above sea level, is cut entirely in the Laramie sandstones. 
Wolverinc creck fora.-These clays and sandy beds of the Laramie late so far failed to yickl any evidence of an invertelurate fanma; at least nothing has been found suthiciently well preserved to deternine their specifie chararters. Plant remains lave been obtained from several of these localities by different members of the Survey, hut mainly by Dr. A. C. Gill, who was a menuler of the field party in the summer of 1887 . Although the collection embraces few species, they have proved to be highly important, not only as deternining by the evidence of organic remains the Laramie age of these beds, but also an indicating the geographical distribution of Cretaceous plants and the association of species found in the same strata.

Prof. F. II. Knowlton, who has studied these plants, has determined seven species, which he lias described in detail, with illustrations, in Chapter XIV of this rolume. The following is a list of species from the Wolverine Creek heds, extending from the north slope of Pinyon Peak to the low pass at the head of Gravel Creek: Asplenium haguei, Onoclea minima, Paliurus minimus, Sequoin lengsfordii, Viburmem votundifolium, Trapa microphylla, and P'uliurus sizyphloides.

Of these species the first three are described for the first time by Professor Knowlton. P. minimus is closely related to P. sizyphioides, a true Laramie species from Black Butte, with which it is here associated. The last four species are also found in the Laramie of Black Butte and Point of Rocks. Asplenium haguei, a small delicate fern, in its relationships is more elosely allied to certain Cretaceous species from Greenland than to those as yet recognized from the Rocky Momntains of the United States. Onoclen minima is also closely related to forms from Black Butte and Point of Rocks. The most interesting among these species is Trapa microplyylla, which is here represented by several fine specimens. It was first deseribed from Point of Rocks, Wyoming.

This identification and grouping of plants carries the Laramie flora of central Wyoming, as developed at Black Butte and Point of Rocks, north of its limits as heretofore recognized. The Wolverine Creek beds undonbtedly belong to the conformable series of Cretaceous sandstones uptumed by the orographie movement which took place at the close of the Laramie epoch. They lie near the top of an immense series of sandstones everywhere uptilted at high angles. 


\section{REGION OF PINYON PEAK.}

Pinyon Peak, from whatever point of view it is looked at, stands out prominently above the surrounding country. It rises boldly above Wolverine Creek for over 2,000 feet, and for more than 1,500 feet above the connecting saddles which relate the peak to the momntains both east and west. To the south the country falis away rapidly, and the peak presents a still more isolated appearance when seen from that direction. In outline it resembles a truncated pyramid rising from an elevated base. Dense timber covers the peak on all sides except where the abrupt cliffs which form so conspicuous a feature of the mountain are too precipitous to permit growth of vegetation.

Pinyon Peak attains an altitude of 9,600 feet above sea level. The summit is flat topped, and the long ridges putting out in all directions from the central mass resemble a very slightly inclined plane, with occasional points rising above the general level. It is this peculiar feature of the peak which, from a distance, gives it the form of a truncated pyramid.

Resting upon the Laramie rocks, which everywhere form the base of Pinyon Peak, comes a remarkable deposit of coarse conglomerate, measuring nearly 600 feet in thickmess. This conglomerate forms the greater part of the summit of the peak and the many long ridges radiating from the central body. Nine-tenths of the conglomerate consists of smooth, highly polished, waterworn material of various-colored quartzites. The prevailing colors are red, white, and yellowish brown, but all so mingled together as to give a general tone of reddish gary to the abrupt walls and escarpments which form so prominent a feature of the deposit. This siliceous material varies from gravel to coarse pebbles and quartzite bowlders measuring 10 and 12 inches in diameter, although the largest are by no means common. Much of the conglomerate is indurated and held together by fine sands and ferruginous material. Occasionally thin beds of friable sandstone are encountered throughont the conglomerate, but they are insignificant in amount and do not appear to be very persistent over any great distance, occurring as lenticular bodies in the coarse conglomerate, then as well-defined strata. Everywhere on the slopes of Pinyon Peak the beds vary greatly in thickness and in continuity. In general it may be said that the conglomerate formation carries more sandstone 
near the base than it does higher up in the deposits. Mingled with the 'puartzite are found rounder and polisher pebhles of granite, gneiss, argillite, and indurated slates, probably derived from Archean and preCambrian land surfaces. Occasional fragments of andesite have been found, indieating a voleanic origin for some of the detrital material. Such pelbbles, however, are hard to find and play no part in the great mass of the deposit. Possibly they may lave been derived from the capping of the breccia found on the top of Pinyon Peak, as described later. Pebbles of sandstone, limestone, and other sedimentary rocks have been picked up in the conglomerate, evidently derived from neighboring Paleozoic and Mesozoic sources. Nean the base of the conglonerate waterwom fragments of coal have been observed associated with gray sandstone and resembling that known to oceur in the Laramie.

Throughout the entire mass of the conglomerate the bowlders present much the same general appearance from base to summit. The characteristic forms of the long ridges radiating from the culminating mass of the peak are due solely to the peculiar erosion of the indurated coarse conglomerate. Erosion has worn deep recesses into the very core of the peak, with broad amphitheaters encircled by nearly perpendicular walls for long distances, absolutely impossible to scale. Along their tops many of these ridges are mere knife edges, barely permitting one to walk in safety. In places the vertical walls rise for over 300 feet without any perceptible change. Enormous amounts of the conglomerate lave been swept away by erosion, the material when once disintegrated being easily transported. Everywhere the lower slopes of Pinyon Peak are covered by loose pebbles and bowlders brought down from higher elevations. Coulter and Wolverine creeks are literally clogged up witl quartzite bowlders, and Gravel Creek, draining the southwest slopes of Pinyon Peak, derives its name from the huge piles of reassorted bowlders which line the valley for miles.

For many years the gravels along Snake River and Pacific Creek in the neighborhood of Jackson Lake have been known to yield a slight amount of gold to mining prospectors, but not in remunerative quantities. Eridences of gold may be found by washing with a pan almost anywhere in the streams coming down from the conglomerate. It is quite likely that this gold has in great part been derived from the conglomerates of the Pinyon Peak formation. In many places the indurated conglonerate and 
associated sands are distinctly bedded. They lie in a nearly horizontal position, or at a low angle of deposition, resting upon the upturned edges of the Laramie rocks.

Local faulting and displacement in the conglomerate may be observed, but this may be attributed to fracturing and slipping of limited masses, due to the wearing away of underlying beds or to ice filling the numerous cracks and ravines found in the rock mass, causing landslicles on a grand scale. That the conglomerate has been subjected to great pressure and movement within the mass is everywhere apparent by the action of the quartzite pebbles on one another. Field study of these pebbles is most interesting from the curious modifications they have undergone under pressure. In some instances they are flattened and rolled; in others they are indented and forced. one into the other. Many of these pebbles are cracked and crushed, in some cases almost ground up, so great has been the pressure exerted upon them. It is curious to observe how these flattened, almondshaped quartzite pebbles, with the pointed end fiactured, have been sharply cut off by dislocation and movement of the mass. Many of the smaller fractured pebbles have smooth surfaces, as if cut off by some sharp instrument. A vast number of the pebbles show a peculiar mottled appearance, being covered by white spots of varying size, probalbly produced by pressure of the pebbles against one another.

The top of Pinyon Peak is capped by a heavy bed of dark basic breccia, male up of angular fragments in every way resembling the breccia, already described, at the junction of Coulter and Wolverine creeks on the west and Two Ocean Plateau on the east.

According to Professor Iddings, who studied the west slope of the peak, the breccia is 300 feet thick. It rests directly on the conglomerate, stretching for nearly half a mile along the east face of the momtain, projecting out like a lava flow over several of the characteristic long ridges. On the west side of the peak it stretches westward or terminates abruptly, with the conglomerate coming to the surface from beneath the breccias. The conglomerate was evidently deposited before the laying down of the breccia. No animal or vegetable remains have as yet been found in these conglomerates and indurated sandstones, consequently no definite statement can be made as to their precise age. That they are younger than the Laramie rocks is evident, as they were deposited unconformably upon the 
mitmonel Cretacens sandstones. In all probability the breceia capping the comglomerate is of the same are as that forming the great mass of Two Ocean Platealu.

It is quite impossible that this emomous mass of basic brecein should hare been poured out over so larere an area of elevated conntry before the depusition of the conglonerate and not have furnished a considerable amomit of material to the latter deposit. A discussion of the age of this conglomerate will be found in Part 1 of this momograph. Evidence is there ardiuced to show that the basic breccia of this region is in all probability of Miocene age and followed the conglomerate. The conglomerate has been referred provisionally to the Eocene period, and has been regarded as a distinct geological formation, to which the name "Pinyon Peak conglomerate" has been given, after the locality where it is so characteristically exposed.

Southwest of Pinyon Peak and connected with it by a long ridge 8,500 feet above sea level, stands an east-west ridge whose culminating point attains an elevation at least 1,000 feet higher. 'This prominent ridge, which has never received any distinctive appellation, measures over 2 miles in lengtl, standing out from the surrounding country like a broad rampart. The underlying rocks of the ridge are apparently all Cretaceous sandstones and have been referred to the Laramie formation, although it is quite possible that IIontana strata may be represented, passing by insensible gradations into higher horizons. The summit of this ridge is capped by a thick deposit of Pinyon Peak conglomerate, which was evidently at one time comnected with the main body of Pinyon Peak. The north slopes of this ridge are covered by dense regetation and by soil, which completely obscure the underlying rocks. On the soutl slopes the sandstones are exposed for a long distance, but near their base the glacial drift comes in and buries everything beneath it.

From the divide at the head of Gravel Creek there is a descent of over 1,000 feet in 5 miles, the country south of Pinyon Peak falling away steadily toward Pacific Creek, which lies just south of the limits of the mapped area. Gravel Creek, characteristically named from the gravels which line its banks, trends due south along the west base of Big Game Ridge. A north-south fault probably runs along the west base of the ridge, although its course has never been determined. The area of country lying between 
Big Game and Bobcat ridges and Pinyon Peak to the north is muderlain by sandstone. Over the sandstone occur large areas of Pinyon Peak conglomerate, and much of the country is strewn with unassorted coarse gravel, derived from the disintegration of the more compact conglomerate. Accumulations of glacial material cover large areas. It is a broken, hilly country, witl great diversity of topographic features, but picturesque and dotted with groves of scattered pine. It is fairly well watered by numerous small streams, but the gravel deposits are usually dry.

\section{BIG GAMF IRIDGE.}

Big Game Ridge is a narrow mountain uplift about 15 miles in length, and rises abruptly above the valley of Pacific Creek along the southern limit of the forest reservation, with a trend slightly west of north ats far as the slopes of Momt Hancock. From the latter mountain, the culminating point, the trend of the ridge changes to northwest, gradually falling away toward the open valley near the junction of Heart and Snake rivers. The eastern boundary of the ridge as far as Crooked Creek is defined by the Snake River fanlt, which approximately coincides with the course of Mink and Fox creeks, the fault crossing the narrow divide separating the two streans. From Crooked Creek the deeply trenched but narrow valley of Snake River defines Big Game Ridge from Chicken Ridge.

Geologically Big Gane Ridge is formed mainly of Cretaceous sandstones, singularly miform in color and texture from one end of the ridge to the other: They have been referred to the Montana and Laramie formations. In broad masses at certain localities the two formations may readily be distinguished by their lithological habit, but they resemble each other so closely near their junction that any line of demarcation must of necessity be drawn somewhat arbitrarily. In the great thickness of Montana sediments developed here, coarse yellowish-gray sandstones are everywhere the prevailing rock, and nowhere has the Pierre shale been recognized as such by its lithological habit. Evidences derived from organic remains are entirely wanting. Rhyolite skirts the ridge in a mumber of places, and, as described farther on, caps the very summit of Mount Hancock, and basic breccias cover the lower slopes north of Harebell Creek.

Gravel Peak.-This peak is situated 3 miles north of the sonthern limit of the mapped area, midway between Gravel and Mink creeks. It has an 
elevation of 9,600 feet above sea level, and is the culminating point of the sonthem end of the ridge. Its interest lies mainly in the conglomerates, which fom the upper 400 feet and which rest upon the mountain in much the same way as they do upon Pinyon l'eak. The gravels are in every way identical, and belong without doulst to the same horizon. Abrupt walls of this conglomerate face east and north, offering good exposures across coarse gravels with polished and crushed pebbles held firmly together by sands. They rest directly upon Laramie sandstones, which dip to the east at low angles, and near the base of the ridge abut unconformably against Madison limestone lying along the east side of the Snake River fault.

Isolated patches of Pinyon Peak beds, left by erosion, rest upon sandstones west of Gravel Peak. They lie at different elevations, but their position may be due to a series of small parallel fanlts found along that side of the ridge. The block of sandstone north of Gravel Peak Ridge and due east of Pinyon Peak presents a northward continuation of the same Cretaceous strata. The ridge trends a few degrees east of north and west of south, with beds dipping at low angles to the east. Beds typical of the upper portion of the Laramie make up the entire ridge. The sandstones are rusty brown in color, with mumerous thin layers of ferruginous material interbedded with friable white sands. Clay bands and thin, shaly, impure sandstone with evidence of cross bedding characterize both slopes.

Fragmental and imperfect plant remains lie scattered over the surface, and certain strata seem to carry a considerable amount of carbonaceous material. Specimens of leaves and twigs were collected, indicating a rigorous flora, but all too imperfect to permit of specific identification. Over the top of the ridge are strewn smoothly polished quartzite pebbles derived from the Pinyon Peak conglomerate, but no beds of the same were found in place. North of the pass from Wolverine Creek to Fox Creek the ridge still shows the lithological habit of the Laramie sandstones. At the north end the massive white beds dip from $5^{\circ}$ to $10^{\circ} \mathrm{SE}$.; in fact, all the beds in this region dip to the southeast.

The line of demarcation between the Montana and Laramie formations is drawn along the southeastern slopes of Mount Hancock, as will be seen by reference to the map.

The basal rocks of the Laramie, as thus defined, trend in a general northeasterly direction. Starting at the south base of Mount Hancock, 
in the valley of Wolverine Creek, they cross the summit of Big Game Ridge, and pass down the steep enst slopes, where they are well exposed on both sides of Snake River just below the mouth of Crooked Creek. It can not be said with any degree of assurance that this line is correctly laid down, but no sandstones to the north or west of it have been recognized as possessing the lithological characters of the Laramie. In the great thickness of sedimentary sandstones represented in the several orographic blocks it is possible that Laramie bers may occur, without geological evidence as to their age.

Mount Hancock-Mount Hancock is not only the most prominent mountain of Big Game Ridge, but it stands ont as one of the most commanding. points along the southern border of the Park. It was named after General Hancock by Maj. J. W. Barlow, who ascended the peak in August, 1871. On a clear day the riew from the summit is unsurpassed, either for detail of topographic features immediately beneath or for the more distant panoramic outline. It commands the Tetons, the dominant peaks of the Wind River Range stretching far south ward, the entire west face of the Absarokas, the Park Plateau with its great lakes, the Snowy Range to the north, and the Gallatin and Madison ranges to the west.

Mount Hancock rises above Snake River at its east base for over 2,000 feet, and above the valley of the Snake at its west base for 2,500 feet. The greater part of the mountain consists of yellowish-gray and white massively bedded sandstone, which extends to within 400 feet of the summit. All the beds forming the upper portion of the mountain have been assigned to the Montana formation, although no organic remains have been obtained from them. The southeastern slopes offer the best exposures of these rocks, which dip to the southeast. It is estimated that there are over 3,500 feet of sandstones. On the narrow ridge of sandstone just south of the summit the beds strike north and south and dip $30^{\circ} \mathrm{W}$. The western spurs of the mountain are largely covered by forests and glacial drift, rendering it difficult to obtain good exposures, but the beds for the most part apparently dip west. North of Harebell Creek basic breccias similar to those found on Coulter and Wolverine creeks, and part of the same mass, extend along the west base of Mount Hancock. They present a most inregular outline, the higher portions reaching an altitude of over 8,000 feet above sea level.

On the summit of Mount Hancock a capping of dark rhyolite stands out boldly, in contrast with the yellowish underlying sandstones. It rises 
over 400 feet in precipitons walls, facing north and east, but on the sonth falls away with débris slopes, permitting ascent to the summit. The mass has a slight inclination to the east, and the greater part of it is lithoidal, very brittle, and jointed in thin fissile layers. At a distance on the slopes it resembles a débris pile of cherty inclurated argillites. This rock is dark gray in color, with small phenocrysts of feldspar and grains of quartz. Obsidian and gray and red punices are well shown here, with the varying modifications found elsewhere in the Park and described in detail in Chapter $X$ of this volume. Momut Hancock is perhaps remarkable for the variations in color of its obsidian. Black, brown, and various shades of red are noticeable, and some of them when highly polished are singularly brilliant. It is this dark, turret-like mass of rhyolite that makes Mount Hancock so conspicuous a landmark over the Park region. The great elevation and complete isolation of this small body of rhyolite are by no means casy to explain.

North of Mount Hancock the slopes of Big Game Ridge fall away rapidly for 4 miles in long timber ridges, mostly buried beneath glacial drift and soil. No rock exposures were observed other than the IIontana sandstones and the low rlyolite hills which border the uplifted sedimentary beds.

\section{CHICKEN RIDGE.}

Chicken Ridge presents a narrow north-south chain of mountains about 12 miles in length. It is a prominent and persistent orographic block, with several culminating points between 9,000 and 9,600 feet above sea level. Over the greater part of this area the momntain slopes are well timbered and well watered. The sonthem end of Chicken Ridge rises abruptly on the east side of Snake River at its junction with Crooked Creek, nearly due east of Mount Hancock. Along its east base the ridge is sharply defined from Two Ocean Platean by the valleys of Crooked and Grouse creeks and the narrow north-south depression lying between the two streams.

The Snake River fanlt, which is described later in this chapter, follows the course of these streams, and the marked contrast, both geologically and topographically, between the opposite sides of the fault serves to accentuate the eastern boundary of the ridge. Northward Chicken Ridge projects into Yollowstone Lake, and its gentle slopes along the base, with broken, accidented hills rising above them, form the picturesque shores of 
the south arm of the lake. The deeply trenched valley of Snake River linits the mountains on the routh and sonthwest, and the rhyolites of the Park Plateau, stretching from Heart River to Yellowstone Lake, submerge between an accmunlation of lava the westem flanks of the momntains to heights varying from 8,000 to 8,500 feet.

Topographically Chicken Ridge is closely related to Big Game Ridge, the latter trending off to the northwest, while the former has a nearly north-south course. Geologically the relationship is still closer, and the Cretaceons strata of Big Game Ridge cam be easily traced crossing the river at several localities. This is specially well shown at the southern end of Barlow Peak, just north of Crooked Creek

Barlow Peak.-Barlow Peak is named by the writer in honor of Maj. J. W. Barlow, of the Engineer Corps of the Army. He conducted the first official exploration to the headwaters of Snake River in 1871. The peak attains an elevation of 9,500 above sea level, and rises 1,500 feet above the river. It forms a well-defined mountain block between Crooked and Sickle creeks, the former stream encireling its southern base, and the latter cntting a deep trench directly across Chicken Ridge, flowing into Snake River 4 miles farther downstream.

Just below the mouth of Crooked Creek, beds assigned to the Laramie are found on both sides of Suake River, dipping to the southeast and east. They eross the spur of the mountain, continuing eastward until lost in the accumulation of drift, and are finally cut off by the Suake River fault. The Laramie sandstones reach nearly to the summit, and along the crest of the ridge are underlain by yellowish-gray sandstones similar to those found high up on the slopes of Mount Hancock. The Montana sandstones cap the summit of Barlow Peak, and along the east slope dip $10^{\circ}$ to $15^{\circ} \mathrm{E}$. From this point they can be traced northward across Sickle Creek, still inclined in the same direction.

Passing down Sickle Creek the underlying beds gradually grade into thinly bedded sandstones, limestones, black shales, and argillaceous sandstones, and are well exposed on both sides of Snake River. Lithologically these beds bear the closest resemblance to the sedimentation of the Colorado formation found elsewhere. The thickness of these black clay shales and interbedded sandstones has been estimated at 600 feet: On the north bank of Snake River, about a quarter of a mile above the mouth of Sickle 
Creek, there were found in the shale a cross-berded sandstone 3 feet in thickness, carrying a nmmber of characteristic Colorado fossils. From this collection Mr. 'T. W. Stanton has identified the following species: Inoceramus mulabundus, I. umbonutus, I. Auccidus, I. acuteplicatus, Baculites asper, Scaphites ventricosus. Along Snake River the base of the Colorado formation is nowhere exposed; consequently no estimate can be made of its thickness; but there are at least 400 feet of fissile impure sandstones and limestones above the heary shale belt assigned to the Montana.

The Colorado formation extends along Snake River for more than s miles, the deep trench of the river exposing a sharp anticline in the shales. A mile below the month of Sickle Creek, on the northwest bank, occurs an exposure of blue elays inclined nearly $70^{\circ} \mathrm{SW}$., while half a mile upstream the beds dip $30^{\circ} \mathrm{NE}$. Near the point where the Colorado fauna was obtained the shales dip from $10^{\circ}$ to $15^{\circ} \mathrm{NE}$. Along the south and west banks of the river the Colorado beds, on the west side of the anticline, rapidly pass beneath the Montana sandstones at the base of Big Game Ridge. On the bottom of Heart River, the stream having cut completely through the flow of rhyolite, there is an exposure of dark clay shale whicl has been referred to the Colorado and may prove to be an extension northward of the Cretaceous shales exposed between Sickle and Crooked creeks.

Between Sickle and Outlet creeks Chicken Ridge is made up mainly of yellowish-gray, brown, and white sandstones, which in their lithological habit closely resemble those found on Mount Hancock and Barlow Peak. Along the soutlıern slope the ruper beds are a very dense steel-gray rock. North of Coulter Creek the beds strike obliquely across the ridge, but northward trend with the ridge in a nearly north-south direction. The general dip varies from $20^{\circ}$ to $30^{\circ} \mathrm{E}$.

South of Overlook Mountain the sandstones are well exposed, and are inclined $30^{\circ}$ E., toward Grouse Creek, with evidences of local faulting, accompanied by variations in dip. Underlying these beds on the west side of Chicken Ridge fissile sandstones with interbedded arenaceous shales prevail. Lithologically these latter beds resemble the Pierre shales of the Montana, and have been correlated with them, although no evidences of organic remains were secured. They form the slopes until obscured by the rhyolite flows, which attain elevations of between 8,200 and 8,300 feet above 
sea level. A sharp contrast is seen between the steep rounded slopes of the sandstone and the irregular outline of rhyolite. The latter is marked by long, narrow drainage clannels, with steep bluffs on the west side, parallel to the valley of Heart River. These bluffs stand out from 20 to 50 feet above the depression. The intervening ravines are the result of ice movements and are occupied by small ponds and meadows carved out of glacial drift.

\section{OU'TLET CANYON.}

This impressive gorge cuts a deep, broad passage completely through Clicken Ridge. In the strict use of the word it is a true canyon, quite unlike any other canyon or drainage channel in this part of the country, and is one of the most interesting geological features to be found within the Park. It affords an instructive section across the range from Gronse Creek to Heart River, with the Montana sandstones constituting the center of the ridge, flanked on both sides by rhyolite hills. Overlook and Channel mountains, on opposite sides of the canyon, form a part of the same monoclinal uplift, the strata striking with the ridge.

The interesting feature about Outlet Canyon is that it at one time served as the discharge for the waters of Yellowstone Lake. This magnificent sheet of water, which now flows northward and drains to the Atlantic through the famous Yellowstone Canyon, formerly discharged by way of the sonth arm through Outlet Canyon to Snake River and thence onward to the Pacific. The discovery of Outlet Canyon as an ancient drainage chamel for Yellowstone Lake was made by the writer in 1889. For several years he had been firmly convinced, by geological reasoning that seemed unanswerable, that this grand lake at one time must have discharged southward, and consequently into the Pacific. All attempts to locate such outlet proved futile till the autumn of that year. It was hidden by dense forests, obscured by glacial drift, and abandoned as a waterway. After the discovery of this old and neglected channel all fresh observations tended to strengthen and confirm the arguments that the lake formerly found its outlet to the south. In the chapters treating of the physiographic features of the Park, in Part I of this monograph, the problems connected with the ancient drainage of Yellowstone Lake are discussed at some lengtl and Outlet Canyon is described in detail in its 


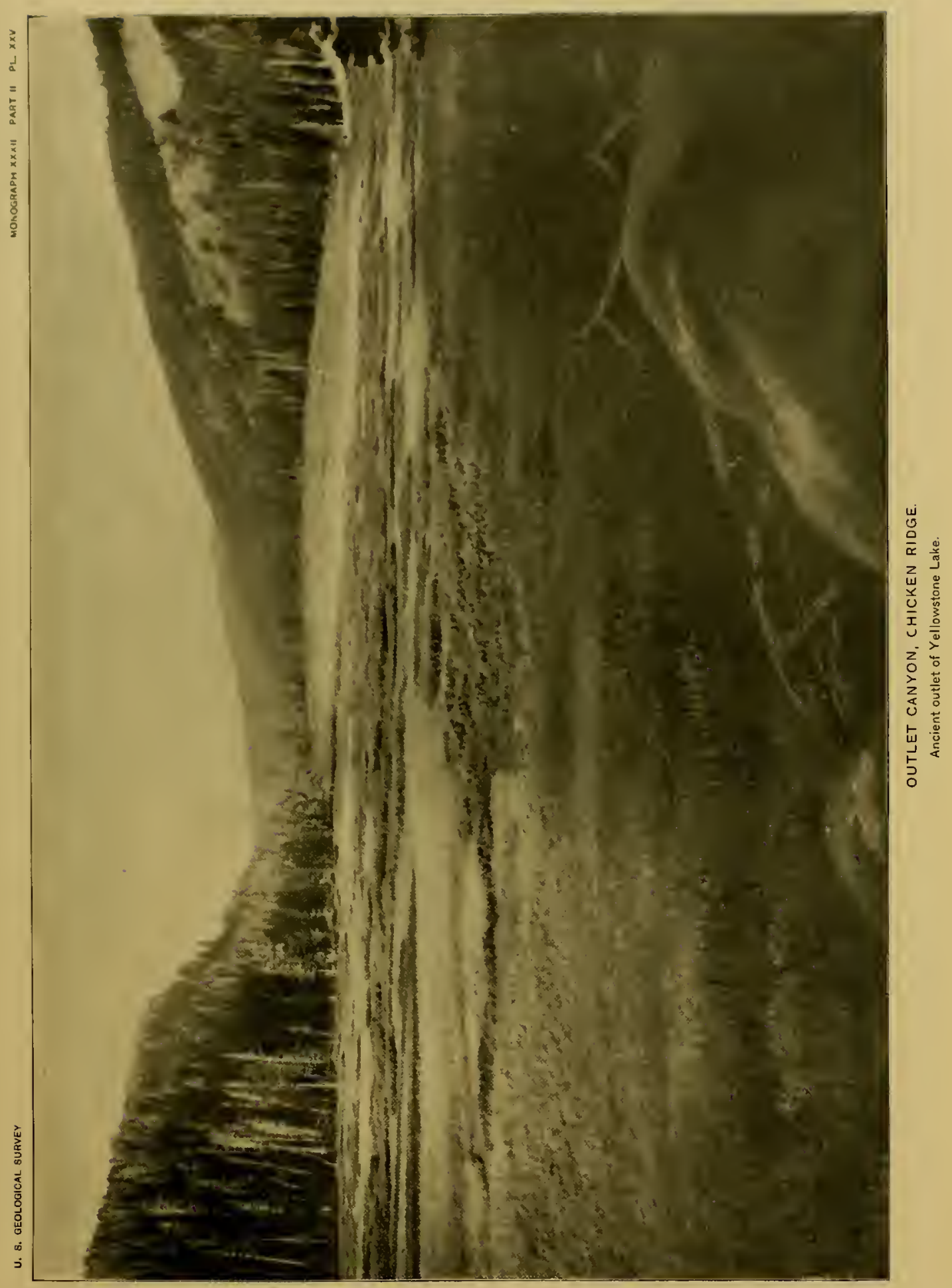



bearing upon the subject. In the present ehapter, therefore, it is only necessary to refer to a few facts an given there, so far as they relate to the geological features of Chicken Ridge.

Pl. XXV is a reproduction from a photograph of the meadow of Ontlet Canyon. 'The view is taken from the top of a low glacial mound, looking eastward toward the crest of the ridge. The Cretaceons rocks forming the walls of the canyon are shown on the right-hand side of the pictme, the bare white ontcrop marking the contact between the sandstone and rhyolite. Along the north wall, shown in the picture, the abrupt precipice consists of rhyolite, rising more than 150 feet above the valley. The densely wooded slopes, as depicted in the illustration, represent fairly well large areas of the Park, covered by a vigorous growth of lodge-pole pine (Pinus murrayana), which, although of poor quality as timber, meets every requirement in preserving the soil from being washed an'ay by freshets and in protecting the snows from the hot suns and dry winds.

Outlet Canyon is a broad, deep gorge, and throughont a long period of time evidently served as the channel for a rapid, powerful strean carrying a large volume of water. To-day its bottom is a flat, grassy meadow with dark, rich soil, through which meanders with sinuous course a sluggish brook of dark, unattractive water. Tall, coarse grasses and low growths of willows line the brook.

During the ice period Ontlet Canyon was undoubtedly occupied by an extensive glacier. Stretching across the bottom of the canyon, between Overlook and Channel mountains, lies an old terminal moraine, whose material consists mainly of sandstone and rhyolite, with occasional fragments of andesite and basalt. This obscure morainal heap to-day marks the course of the continental watershed, serving as a barrier between the waters of the Atlantic and those of the Pacific. From this insignificant and unassorted heap of detrital material a small stream having scarcely any eroding force has cut itself a channel in the glacial drift, but nowhere has it penetrated to the underlying rock. Never since the retreat of the ice has it been anything more than a mere rivulet. The glacial material, overlain by alluvial deposits, completely occupies the bottom of the valley, and only along the abrupt walls of the canyon are Cretaceous rocks exposed. This sluggish stream, which one can easily jump across, emerges from the canyon through a growth of pines, and comes out into the open valley of 
Grouse Creek on the broad 90-foot lacustrine bench of the older and larger Yellowstone Lake.

On the west side of the moraine across which runs the continental divide there is an abrupt descent to a characteristic glacial lake. From this lake flows Outlet Creek, the sluggish stream before mentioned. Across the west end of Outlet Canyon there stretches a somewhat formidable barrier in the shape of a moraine. Upon reaching this barrier the stream deviates to the northwest and cuts its narrow channel through the gravel under the north wall of the canyon. Descending rapidly through the accumulated drift, it comes ont once more upon the old river channel, and soon pour's its waters into Hear't River and out through the Snake to the Columbia.

\section{CHANNEL MOUNTAIN.}

Outlet Canyon north of Chicken Ridge presents many of the same physical features as those noted to the southward, and offers no special points of geological interest. A conical hill which forms the sonthern spur of Channel Mountain affords an excellent bird's-eye view of Outlet Canyon, its mural face rising ligh above the river channel.

From this hill the Moutana formation can be traced nortliward along the summit of Chamnel Mountain, a conspicnons and timbered point 9,000 feet above sea level. 'The sandstones of Channel Mountain do not differ' essentially from those of Mount Hancock and Barlow Peak. From this culminating peak Chicken Ridge gradually falls away toward the lake on the north and east.

Lacustrine deposits skirt the lake shore, attaining an elevation of nearly 8,000 feet above sea level. Still above this in certain localities come the remnants of glacial drift, resting indiscriminately upon rhyolite and Cretaceous sandstones. Rhyolite encircles the ridge on all sides, while the central body consists of the ever-persistent Montana sandstone.

\section{FLAT MOUNTAIN.}

It may be well to call attention to the fact that near the lake shore, at the northwest base of Flat Mountain, there comes to the surface from beneath the rhyolite an outcrop of sedimentary rocks, exposed by the erosion of the lava along the southern prolongation of Flat Mountain arm. A short 
distance above the lake level oceurs an outerop of eompact blue quartzite, for the most part obsenrerl by soil and vegetation. It hias been referred to the Sheridan quartzite of the Algonkian period. Resting uneonformably nyon the Sheridan quartzite is a series of limestones, marls, and sandstmes of the Ellis formation. They extend up the slope of Flat Mountain for about 300 feet, where they are finally lost beneath the rhyolite. In the linestone were found lihynchonella and Camptonectes. The eharacteristic Ellis saudstone has furnished the following species: Rhynchonella gnathophora, Camptonectes pertenwistriatus, Avicula wyomingensis.

WEST IBASE OF TWO OCEAN PLATEAU.

Between Big Game and Chicken ridges and the top of the broad elevated mass of Two Ocean Plateau lies a comparatively narrow strip of country eharacterized by distinctive and peculiar features. It presents an aspect entirely different from that of the country westward, and stands out in strong contrast to it, both in its geology and in its topography. The Cretaceous sandstones which have been so persistent a feature of the country are wanting and other and older rocks come to the surface.

Snake River fault.-This remarkable fault, to which allusion has already been made, sharply defines geologically the east base of Big Game Ridge and Clicken Ridge from the country to the eașt. The line of the fault can be traced for 18 miles from the liead of Grouse Creek southward, beyond the limits of the mapped area, until obliterated by overlying masses of Tertiary breccias. For this entire distance the west side of the fault exposes only Montana and Laramie sandstones. In places the sandstones are obscured by glacial accumulations. Occasional outbursts of basalt are net with along the line of displacement, which coineides with the line of least resistance. On the east side of the fault either Madison limestone of the Carboniferous or the Teton beds of the Juratrias are brought to the surface, but they are by no means so persistently exposed, their continuity being broken by ontlying masses of basic breccia from Two Ocean Plateau. Contacts between the Paleozoie and Mesozoic rocks are admirably shown all the way from Grouse Creek to Crooked Creek. At the latter locality there is a dense black basalt whose outlines are partially obliterated by loose alluvial deposits, but the large detached bowlders and black basaltie soil help to define its area along the line of the fault. Still farther south, 
in the valley of Snake River, similar basalts have broken out. Along Fox Creek the fault is not so readily traced, owing to the broad benches of morainal drift and the occurrence of basic breccia which lie on both sides of the displacement.

These breccias are well exposed in the nore recent cuts along Fox Creek, and in every way resemble those found on Two Ocean Plateau. They are andesitic breccias, firmly held together by finer material, generally colored red from the oxidation of the ferruginous material. West of Fox Creek, on the slope of Big Game Ridge, is an outcrop of rhyolite, interesting from the fact of its being the most easterly exposure of that rock west of Two Ocean Platean. This rhyolite is evidently a remnant of a much larger body of purplish-gray, normal rock, like most of that seen on Flat Mountain. It disintegrates readily into rhyolitic gravel, in rather strong contrast to the weathered and crumbling sandstone.

Along Mink Creek the fault contact between the Cretaceons and Carboniferous is strikingly shown, a great thickness of both rocks being well developed, Mink Creek having cut deeply into the Madison limestone. Pacific Creek below Mink Creek also marks the fault line until it passes beyond the limits of the mapped area.

Pacific creek.-This stream, which has its source along the continental divide, has cut for itself a broad chamnel on both sides of the older valley. The breccias have been worn away, exposing a body several hundred feet in thickness of light-colored crystalline limestone, characteristic of the upper nembers of the Madison limestone. The upper beds are highly siliceous and may possibly belong to the Quadrant quartzites, although no such heary masses of siliceous beds were recognized as to warrant a reference to the overlying formation. An anticline in the limestone crosses Pacific Creek in a northwest-southeast direction, the beds dipping steeply on both sides of the fold. In the valley the limestone lies nearly horizontal.

According to Prof. J. P. Iddings, both the Teton and the Ellis formations are well exposed, overlying the Madison limestone, just sonth of the limits of the area mapped. The red beds have a development fully 600 feet in thickness, and are followed by a gray limestone carrying a bed of white gypsum 5 feet in thickness. Overlying the latter comes a gray fissile limestone, followed by massive beds of limestone characterized by an abundance of fossils. From these beds were collected the following species, which 
definitely deternine their age as belonging to the Eillis formation: Camptonectes platessiformis, C. pertemistriatus, C. bellistriatus, Cyprina iddingsi, Neritine wyomingensis.

Botll the red beds of the Teton and the limestones and sandstones of the Ellis dip steeply down the mountain sides, and are exposed along Pacific Creek below the month of Mink Creek. Here they are abruptly eut off by the Suake River fiult. On both sides of Pacific Creek the limestone bluffs are covered by the basic breccias.

Mink creek.-Undoubtedly the light-colored limestones exposed by the deep, trench cut by Mink Creek are comnected with those of Pacific Creek, the continuity at the surface being broken by andesitic breccias. All along Mink Creek the abrupt walls of light-colored Madison limestone are overlain by the somber breccias; the latter, extending to the topi of the platean, afford a most inpressive view. On the divide between Fox and Mink creeks the limestone is well shown along the fault just southeast of the small lake indicated on the map. Litloologically the beds resemble the upper members of the Madison limestone, passing into coarse crystalline beds of reddish limestone, characteristic of the summit of the formation. Near the top of the ridge the limestones yielded well-preserved specimens of Spirifer centronatus, which has, however, a wide geographical distribution and an extended vertical lange throughout the Madison limestone.

Immediately north of the small lake just mentioned rises a bold and isolated hill 100 feet in height and one-half mile in length, in striking contrast to the surrounding country. It is formed of light-colored pyroxeneandesite, which in its general aspect possesses a remarkable resemblance to rhyolite. The top of the hill is smooth and polished and beautifully glaciated, and the flat-topped summit is marked by long parallel furrows fiequently 20 inches in width and a foot deep, the result of ice movement. In the cavities of the porous rock Professor Iddings has determined the presence of tridymite

As already mentioned, the Madison limestone and Teton formation are exposed along the west base of Two Ocean Plateau. The sedimentary rocks come to the surface from beneath the breccias along the edge of the platean in the deeply eroded valley of Plateau Falls. Thence they stretch nortllward in an unbroken line for nearly 10 miles, finally disappearing beneatl the platean breccias nortl of Grouse Creek. In the 
lateral valley of Plateau Falls the upper members of the Madison limestone are well dereloped, exposing a thickness of nearly 400 feet of beds. They lave yielded Orthothetes infata, found throughout the Madison limestone, and Eudothyra baileyi var. waverlyensis, as yet known only in the upper beds. On a low conical hill in the middle of the valley similar limestones, carrying the same fossils, oecur nearly horizontal, but northward they dip to the east and north. They pass beneath the cherty limestones and red beds of the Teton formation, which northward are also exposed along the west base of Two Ocean Platean, the summit being capped by breccias. Near Crooked Creek the Madison limestone again comes in, inclined southward, with the Teton beds apparently lying within a syncline of the Carboniferous beds.

Between Crooked and Sickle ereeks a prominent bold bluff of limestone, facing westward, shows several hundred feet of Madison, which still farther nortl passes by gradual transition into silicenus limestones and quartzites. According to Mr. W. H. Weed, the latter beds belong to the overlying Quadrant quartzite. This long strip of partially exposed sedimentary strata indicates much folding and faulting, and in places excessive compression of strata. Geologically it is of much interest, as it is probably a remnant of an old mountain range, now for the most part submerged beneath a vast pile of volcanic ejectamenta, which, resting upon the uneven surfaces of the sedimentary beds, caps their highest summits and stretehes eastward for 50 miles aeross Two Ocean Plateau and the Absaroka Range. Bhish-gray limestones again appear from beneath the breccias upon the east side of the Absaroka Range, in a high bluff near the month of Stinkingwater Canyon, earrying Semimula humilis, Spirifer subattemuatus, Spirifer striatus var. madisonensis. They mark the limestone as being a part of the Madison formation, which comes out from beneath the breceias on both sides of the volcanic platean.

\section{TWO OCEAN PLATEAU.}

Two Ocean Plateau forms the most western ontlier of the massive berls of agglomerates that go to make up the Absaroka Range. It presents an imposing pile of volcanie ejectamenta, rising 10,000 feet above sea level in its most elevated portions. The highest portions lie to the eastward, with a gentle dip toward the submerged range which rises here and there above the platean along the east sirle of the Snake fault. The plateau 
stands out as a prominent and sonewhat isolated physical feature, separated from the Absarokats by the wide, flat valley of the npper Yellowstone, and sharply definer on the north by the broud sheet of water known as Yellowstone Lake. The continental divide crosses the summit of the platean with a northeast-southwest course, sending its waters either to the Yellowstone and the Atlantic or the Snake and the Pacific. Owing to its broad mass and great elevation the snows of winter accumulate upon it to great depths, and the rains of summer furnish an abundant water supply. Numerous streams leaving the plateau have trenched deep, narrow lateral canyous into the pile of breccias, which, with steep mural faces, drop abruptly for 2,000 feet to Yellowstone River.

The platean presents a comparatively uniform mass of basic breccia throughout its entire length, from Two Ocean Pass, which defines its southern limit, northward to Yellowstone Lake. Andesitic and basaltic fragments, more or less firmly compacted together by fine cementing material, make up the greater part of the mass. In most respects it is quite like the basic breccias described elsewhere as occurring all along the west slopes of the Absarokas. Exceptionally fine exposures of the mass are shown in the abrupt escarpments along the upper Yellowstone all the way from Atlantic Creek northward to Barlger. Creek. Seen westward across Yellowstone Valley these walls are specially impressive, and are easily studied along the cliffs of Falcon and Lynx creeks. Interbedded in the breccias are occasional flows of compact basalt, lying in beds one above another. They usually rest upon an irregular, uneven surface of the breccia, and, from evidences of weathering observer in the disintegrating breccias, indicate clearly that these basalts were poured ont over a surface exposed to atmospheric agencies for a long period of time. The varying thickness of the basalts, their thickening and thiming, and their entire absence over extended areas prove how irregular and intermittent were the overflows. They are by no means so thick or so persistent as the basalt sheets observed in the earlier basic breccias in the main portion of the range. The heaviest developments of these interbedded flows are seen in the southern end of the platean, but they seldom attain a thickness of 100 feet, and in such instances are made up of a series of individual flows not always continuous.

While the great body of basic breccia consists of coarse angnlar fragments, with here and there basaltic bowlders measuring 2 feet in 
diameter, beds composed of well-worn and rounded material are frequently observed. It is evident that this latter material is water-laid, and in great part assorted by the action of running streams. Much of this material is sandy, consisting of volcanic gravel deposited under water. It is also evident that all this material is volcanic in nature and derived from still ligher sources. These water-laid beds are covered by flows of agglomerate and coarse unaltered breccias derived from explosive action. No dikes were observed cutting the Two Ocean Plateau breccias.

The mass of Two Ocean Plateau, while apparently horizontal as seen almost anywhere from a distance, has a gentle inclination to the north, averaging, however, not more than $3^{\circ}$. It seems probable that the entire plateau has suffered from a slight tilting of the mass. Evidence of such movement may be seen throughout the Absarokas. It would seem that the flow of the coarse brecciated mass at the time of its ejection was from the eastward, but that a subsequent orographic movement was at right angles to it, the mass being tilted northrward, due to the intrusion of masses of granite-porphyry to the southwest.

The east and west sides of 'Two Ocean Plateau are sharply contrasted in the lateral trenches which cut the platean body. Along the Yellowstone Valley they expose masses of breccia 2,000 feet in thickness without cutting through the upper basic breccias, while on the west side, only a few miles across, the walls of the plateau show but a thin covering of breccia, with the Paleozoic and Mesozoic strata lying beneath them. The border line between the sedimentary beds and the breccias follows a sinuous course, with tongues of breccia penetrating into the underlying bodies. One of these tongues is well shown near the junction of Mink and Pacific creeks, where a fine exposure of breccia occurs on the north side of Pacific Creek, while higher up Mink Creek the blue limestones of the Madison formation stand out, capped by the more somber breccias.

Between the brecciated mass of Two Ocean Platean and that lying to the westward at the base of MIount Hancock and along Coulter Creek, there is one marked difference in mode of occurrence. The former shows evidences of material having been transported for a considerable distance, while at the latter locality there is every indication that the source of material thrown out was near its present position, with every evidence of explosive action along a line of profound faulting having an approximately north-south trend. 


\section{CH A P'T E R V . \\ GEOLOGY OF 'THE SOUTHERN END OF' T'HE SNOWY RANGE. \\ By Walter Harvey Weed.}

GENERAI DESCIRIPION.

The northeastem part of the Yellowstone Park embraces a small portion of the great range of mountains which extend northward to the lowlands of the Yellowstone River, a chain known as the Snowy Range. Within the limits of the Park only the extreme southem end of the range occurs, the much accidented and rugged country to the southeast connecting these mountains with the northern part of the eastem mountain range of the Park. The eroded sedimentary rocks of this area are contimued beneath the great accumulations of volcanic materials which have been heaped up to form the Absaroka Range.

The Snowy Mountains constitute the western portion of a high mountainous tract which includes the great peaks of the Beartooth Range, the highest mountains of Montana. This mountainous area is terminated on the west by the broad mountain valley of the Yellowstone River, the region being divided by the deep valley of the Bowlder River into two parts, of which the westernmost, between the Bowlder and Yellowstone valleys, forms the Snowy Range proper. The general structure of this entire mountain tract is that of a broad anticlinal uplift, the central portion of which has been denuded of its former covering of sedimentary rocks and variously modified by faulting, especially at the sonthwestern end, near the Yellowstone Park. The greater part of the region shows the core of crystalline schists, gneisses, and granite which form the central plateaus.

The central portion of the mountains is a broad, flat-topped mass, whose surface constitutes a plateau 10,000 feet above sea level, deeply cut by canyons 3,000 to 4,000 feet deep. Above this plateau the peaks rise a 
thousand or two thousand feet higher. The platean is glaciated, and ponds and lakes diversify the surface, which is almost completely destitute of soil or vegetation. Along the southern flanks of this crystalline axis the overlying Paleozoic strata dip away from the central mass of Archean rocks.

The area embraced within the limits of the Yellowstone Park, although but a small part of the range itself, inchules a part of the Archean massif. The schists and gneisses are deeply trenched by streams flowing sonthward from the mountains and joining the Yellowstone drainage within the Park. Only scattered remnants of the Paleozoic rocks which formerly covered the crystalline schists are now found. To the south very greatly eroded sedimentary masses are now covered by the volcanic breccias.

\section{TOPOGRAPIY.}

The topography of that portion of the Snowy Mountains included within the mapped area presents a variety of configuration, due primarily to the nature of the rock masses. For the purposes of the present discussion the southern limit of the range may be regarded as defined by the Yellowstone River, its enstern fork, Lamar River, and the eastern branch of the latter stream, known as Soda Butte Creek. Within the triangular area thus inclosed we have, to the sonth, the sharp volcanic summits of Druid and Bison peaks and the long, narrow crest of Baronet Peak. To the north and west broad, gently sloping summits extend southward and break abruptly in steep shopes and limestone cliffs to the valleys of the streams that drain the region. The principal drainage of this area is that of Slough Creek and its tributary, Buffalo Creek. The former stream, heading in the glacial amphitheaters of the rugged peak known as Haystack Mountain, flows in a sonthwesterly direction throngh a wide and generally open valley whose sides expose excellent sections of the mountan-forming rocks. The topographic peculiarities of the stream indicate that it is of considerable antiquity. The present valley bottom is deeply filled with alluvium, apparently the result of the damming of the stream in glacial times and the formation of a lake above the narrow canyon which it has cut through Archean gneisses to join Buffalo Creek. The latter strean has, within the limits of the area mapped, cut a valley in Archean gneisses, the gently dipping sedinentary beds which occur upon the flat platean summits on either side being far above its present channel. 


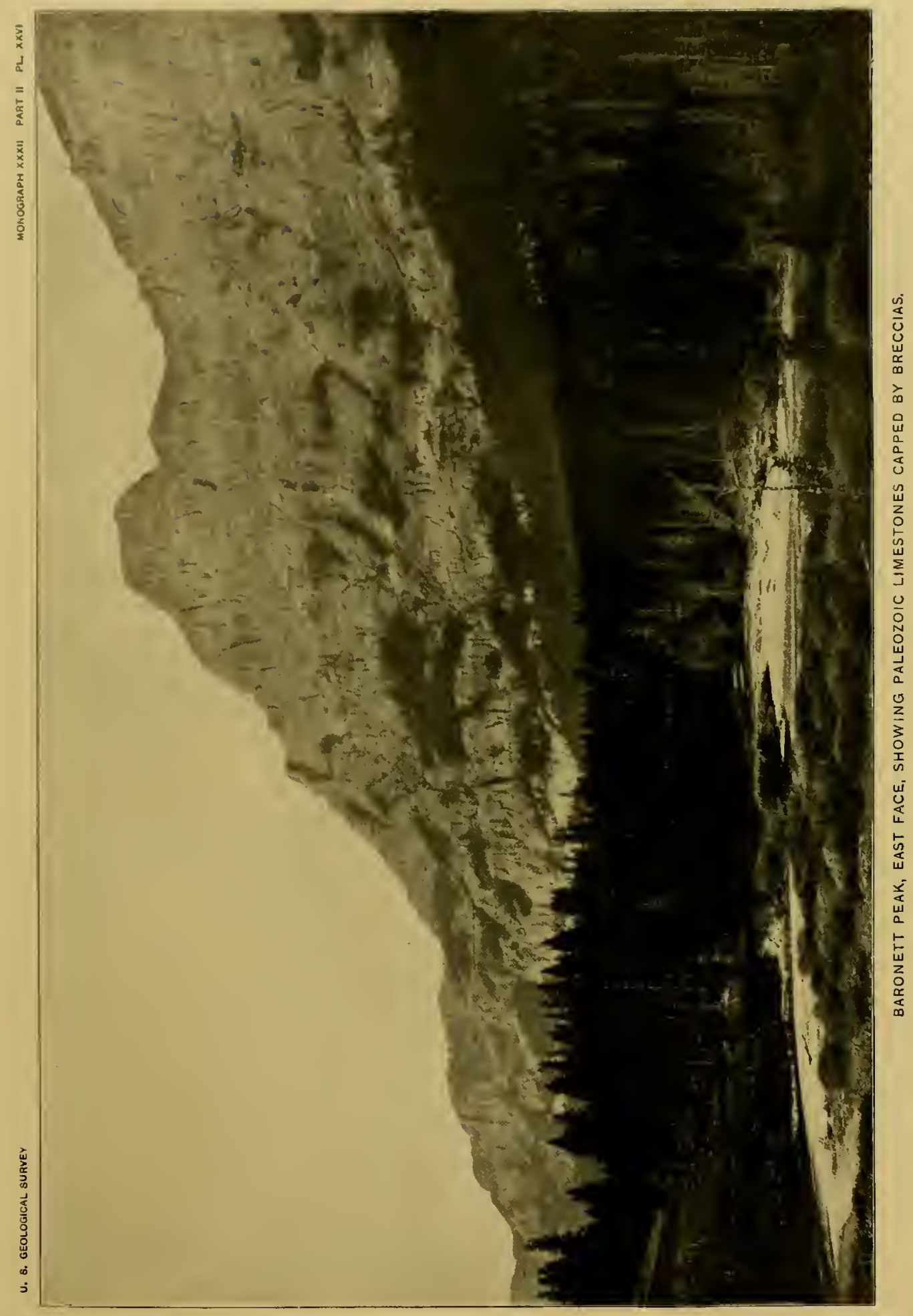



The valley of Lamal River, which terminates the range on this side, is of even greater antiquity, and, as will be shown in Part I, it was onee the principal drainage of this entire region. Isolated patehes of the serlimentary rocks ocenr in the lower part of the valley, where denudation lias remover their covering of voleunic breccias. Soda Butte Creek, which has been assumer to represent the sontheastem boundary of the Snowy liange, presents one of the most impressive mountain valleys to be found within the linits of the Park. The illnstration (Pl. XXVI) of Baronet Peak shows the general character of this valley and the rngged aspect of the ligh peaks which tower above it on either side. Farther up the stream, at the confluence of Pebble Creek, the sedimentary rocks occur in the valley bottom. Above this, in the upper valley near the mining settlement of Cook City, the vallev walls present bold limestone cliffs, over which numerous streams, draining the higher volcanic slopes, fall in a succession of cascades that are of great beauty. The white cliffs of sedimentary rocks stand out in bold relief from the somber volcanic slopes, and their steep walls, presenting an unbroken cliff often extending for miles along the sides of the valley, offer few opportmities of ascent.

\section{SEDIMENTARY ROCKS.}

Any attempt to describe the sedimentary rocks of that small portion of the Snowy Range found within the limits of the Park must be at best a fragmentary sketch of the Snowy Range itself. Of the sedimentary series, only the Paleozoic rocks occur within the limits of this area, nor do these rocks present any very marked differences from those of the same age occurring in the other ranges of the region. The lowest beds exposed are those of the Flathead formation. Above these the Gallatin limestones, which are, within this region, so frequently seen in long lines of cliffs, are well exposed and cover considerable areas. The Silurian, known within this region as the Jefferson formation, presents the best difierentiation of this horizon found within the limits of the Park. Above these shallowwater deposits are the massive limestones and thinly bedded shales of the Three Forks formation, in which Devonian fossils have been found. The highest sedimentary rocks which occur within this region are those of the Madison limestone. 
The sedimentary series everywhere presents undoubted evidence of great erosion following the uplift of the range, antedating the extravasation of the volcanic rocks which now so generally mantle it. That this period of denudation was long is indicated by the profound gorges which were cut in the rocks and carved deeply into the underlying schists. The Mesozoic beds, if present, were entirely removed, and no trace of them has been found within this area or in its immediate proximity. It is further evidence of the long period of uplift and erosion which followed the deposition of the Laramie. ${ }^{1}$

The following table presents a generalized section of the sedimentary formations of the region.

\section{Snovy Mountain section.}

Feet.

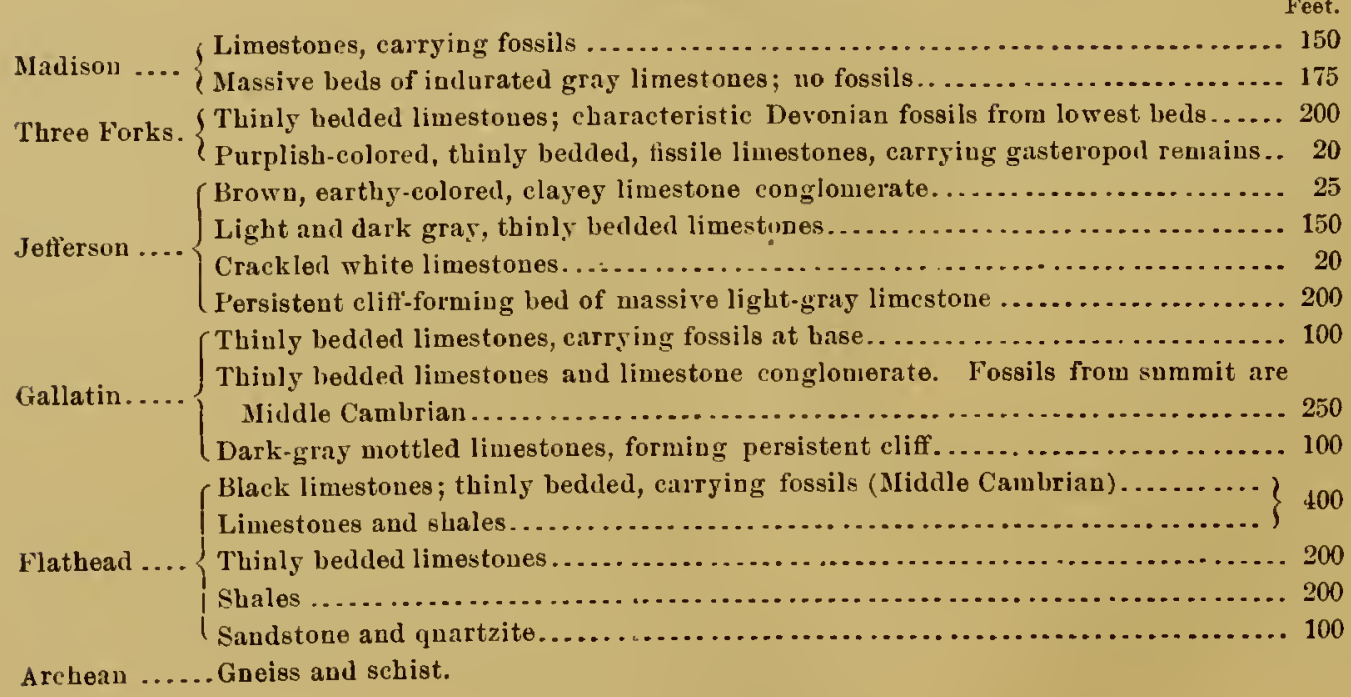

BUFFALO PLATEAU.

This flat-topped mountain tract, lying between Hellroaring and Buffalo creeks, together with adjacent areas across these streams, constitutes the true southern termination of the Snowy Range. The platean is of gneiss, on which remnants of sedimentary rocks now form the highest points. The gneiss presents considerable variety, but consists usually of feldspathic forms, and shows a well-defined lamination toward the east. The surface is glaciated, smooth ice-worn bosses and striated surfaces being common,

${ }_{1}$ The Laramie and the overlying Livingston formation in Montana, by W. H. Weed: Bnll. U. S. Geol. Survey No. 105, Washington, 1893. 
while the southwestern slopes are largely covered by morainal drift. Within the limits of the Park the gneiss forms the west side of the platean to within 100 feet of the top, where it is overlain by a horizontal bed of indurated sandstone, which is undoubtedly the basal bed of the Flathead formation. The rock is mottled with red and white strealss and layers, and resembles the beds exposed on the sonthwestern flank of Bison Peak. The exposure is 100 feet thick, 50 feet of which is vertical cliff. The top of the platean is generally covered with a growth of pine, but where the sandstone prevails the surface is open and grassy and in strong contrast to the gneissic areas. The summit of the platean rises gradually to the east to a high ridge, trending north. Abont 100 feet above the quartzite a thinly bedded mottled limestone occurs, the rocks being horizontal. 'This rock closely resembles the limestones found in the valley of Soda Butte and Slongh creeks. The high point $(9,100$ feet $)$ on this platean, which lies just within the Park line, is formed of massive limestone that weathers witl a very rough surface and shows a few fossils which prove that the beds belong to the Three Forks formation. Two hundred feet below this summit a massive-bedded, coarsely mottled, dark-gray limestone occurs, the strata forming the base of the Gallatin limestone and having a dip of $3^{\circ} \mathrm{E}$. These two prominent beds of massive limestone are readily recognizable horizons, which are as prominent in the Snowy Range as they are in the Gallatin Momtains. The extreme erosion of the old land surface before the deposition of the volcanic breccias and the Cambrian rocks is well illustrated in this area. Basic breccias rest upon the various beds just noted and also upon the gneiss, and in the valleys and lower slopes at the south end of Buffalo Platean the volcanic rocks fill hollows in the greatly eroded surface.

\section{IAAMAR VALIEY.}

The valley of Lamar River, which appears to be one of the most ancient drainage ways of the Park, is cut through a variety of rocks, most of which are volcanic. The gneissic rocks are exposed on the south flanks of Specimen Ridge and are cut through by the river and by its tributary, Slongh Creek. On the west the gneiss forms rough and ingged slopes, but near Crystal Creek the rounded bosses of the summit slope gently to the southeast and pass beneath the adjacent rocks. On the south side of Lamar 
River the gneiss is overlain by a remnant of the limestones that once covered it. The rock sequence of Cambrian and ligher rocks has not been recognized, and it is probable that a fault exists between the exposures of the gneiss and of the limestone, for the latter carries poorly preserved fossils of Carboniferous types, the beds dipping gently to the sontheast at $5^{\circ}$ and forming low rounded knolls near the wagon road. These limestones are somewhat crystalline, have but indistinet bedding, and differ quite materially from the Paleozoic strata seen elsewhere in the vicinity. A thickness of between 200 and 300 feet is exposed in an area whose boundaries can not be closely defined owing to the overlapping rhyolite sheet and the prevailing mantle of drift, but the sedimentary rocks certainly cover the high ground east of the wagon road.

North of Lamar River the western slopes of Bison Peak show wellbedded, dark-colored basic rolcanic breccias, separated from the gneissic hill lying between Slough Creek and Lamar River by a well-marked depression which defines the boundary line between the two rocks. The gneiss is overlain at the highest point on this boundary line by a bed of quartzite, which is of the usual pink and white variety, dipping $5^{\circ}$ S., the strike being N. $12^{\circ} \mathrm{W}$. This quartzite makes a cliff 25 to 40 feet high, that rises abruptly above the lakelet found upon the divide. 'The rock is generally somewhat fissile, well bedded, and of the normal character of the Flathead quartzite.

\section{SIOUGII CREEK.}

The valley of Slough Creek above the confluence of Buffalo Creek presents the picturesque scenery characteristic of this part of the Snowy Range. The broad meadow lands which cover the valley bottom are flanked by gentle slopes, with scattered groves of aspen and pine, above which are the bold cliffs of white limestone that separate the lower slopes from the crags of somber-colored breccias which form the upper part and summit of the monntains. This valley presents the best exposures of the lower Paleozoic series to be found in this part of the Park, and the general section of the sedimentary rocks of the range which has just been given is conpiled from observations made in this valley and in the cliffs of the neighboring valley of Sora Butte Creek.

In the lower end of Slough Creek Valley the slopes on either side 
present sharply contrasting geological conditions. On the north Archem gneisses frevail, and the sedimentary rocks which are present farther up the valley are here entirely absent. The gneisses form bold but sinooth and glaciated exposures, extending down to the valley floor and showing in abrupt hillocks and knolls, rising like islands above the meadows. The Archean rocks present evidence of glaeiation whose movenent was from the northeist, and the present topography is eminently glaeiated. On the opposite side of the valley the sedimentary roeks outerop along the foot slopes of Bison Peak and extend continuously along the valley wall to the Park boundiny. The thinly bedded shales and limestones of the Flathead series form gentle slopes, whose covering of soil and vegetation generally obscures the roeks. The Flathead quartzite is not seen here, the bed being completely coneealed beneath the alhuvial bottom land.

The lower slopes of Bison Peak below Plateau Creek show ledges of a mottled, heary-bedded, massive limestone exposed in eliff's 75 to 100 feet high, the summits of the beds forming flat-topped benehes sloping gently to the south. Nortl of Platean Creek the limestones extend down to the valley bottom, and are well exposed on the slopes to the east, beneh upon beneh of linestone showing on the slopes, with continuous bluffs whieh are extremely diffieult to eross in aseending the mountain. The beds have a strike of $\mathrm{N} .60^{\circ} \mathrm{E}$. and dip $5^{\circ} \mathrm{S}$., the highest ledges exposed being found at an elevation of 6,400 feet, where the breecias rest upon them. These limestones were traeed along the mountain flanks as far north as Elk Tongue Creek. This stream has eut along the contact between the breecias and the limestones, and the exposure gives additional evidenee of the rugged nature of the country at the time the voleanie breecias were laid down. The lower roeks exposed are thinly bedded limestones earrying Middle Cambrian fossils, and the roeks are eovered by groves of aspen and grassy slopes whose charaeter is readily reeognized as differing from that of the breccia slopes above them.

The most eonspicuons exposures of the sedimentary roeks are those on the northern side of this valley, near its upper end, where the limestones form eliffs which extend along the valley slopes for many miles to the northward. The lowest exposures are thinly bedded limestones, light gray in color, with yellowish mottlings, and lithologieally similar to the Flathead limestones seen elsewhere. These strata make steep slopes wlich are MON XXXII, PT II-14 
terraced, the floor of each bench being the bedding plane of the stratum below. These limestones are capped by a thick bed that is the mottled limestone forming the base of the Gallatin formation. This bed is about 200 feet thick, and from the meadow lands of the ralley it can be seen as a persistent cliff that is a readlily recognizable lorizon, and forms an almost impassable barrier in the ascent of the slopes. It is overlain by less massive limestones, eapped by basic voleanic breccias. 'The imegularity of the surface upon which these breccias were deposited is beautifully illustrated by the exposures seen in this escarpment. The face of the cliff shows the massive bed of mottled limestone, with a deep indentation that is clearly a cross section of an old drainage way filled by rolcanic breccias which are now firmly indurated. The top of the mottled limestone bed forms a broad and distinctive bench which extends along the slopes. Above this bench the thinly bedded limestones are seldom seen, and though the slopes are terraced and are open and grass covered, no good exposures are found, owing to the abundance of rounded andesitic drift from reassorted breccia beds which cover the summit of the platean.

At the upper end of the Slongl Creek Valley the mountains close in and the strean flows through a gorge eut in Archean gneiss and massive igneons rocks. At one point the stream forms a picturesque waterfall in which the water, cutting along joint planes of the rock, is separated into two cascades, given the name of Twin Falls. Above this canyon is the upper mountain valley of Slongh Creek, whose bottom is a labyrinth of beaver ponds, sluggish channels, and willow groves, making the name of the stream most appropriate. West of the valley the same sedimentary formations noted are seen in terraced slopes, above which the persistent cliff of mottled limestone is again present, extending northward to the forking of the creek, where gneisses and voleanic breccia replace the sedimentaryrocks. The eastern side of this upper valley of Slongh Creek shows no sedimentary rocks, the dark, heavily timbered slopes rising to sharp craggy summits of voleanic breecias.

\section{SODA BUTTE CREEK.}

Carboniferous limestones are found at the sontheastern base of Druid Peak, and form the valley floor abont the hot-spring cone which has given Soda Butte Creek its name. The rocks are horizontal or but gently tilted 
and belong to the Madison formation. On the north bank of Lamar River, near the mouth of Soda lButte Creek, there is an exposure of 50 feet of limestone. The beils are lorizontal, from 2 to 4 feet thick, and possess a peculiarly rougl, weathered surface, but so far as observed do not earry fossils and are not cherty. Another exposure nearer Soda Butte Creek is found 200 feet above the river, the most prominent ledge being a fissile limestone 20 feet thick, earrying variegrated ehert and Carboniferous fossils. These beds dip west of sonth at $10^{\circ}$. These limestones form the low flattopped knolls which are so distinct a topographic feature of the southeast base of Druid Peak, as they are quite mlike the topography prevailing in the breccia areas. On the shores of the small lakelet which a landslide of breceia has formed on the lower slopes of the peak the beds are tilted, dipping west at $.55^{\circ}$ and striking north and south, but it is probable that they have been disloeated by a landslide.

\section{PEBBLE CREEIX.}

Light-gray, massively bedded limestones are exposed at the mouth of Pebble Creek, forming a rounded knoll on the sonth side of the stream. The rocks eontain rather seanty fossil remains, which prove that the beds belong to the Madison formation. These beds also outcrop along the north base of Abiathar Peak, 1,300 feet above the creek bottom. Pebble Creek has cut a narrow gorge through the limestone, whose beds form vertical walls 100 feet high. The strata are nearly horizontal and are exposed for 300 feet above the chamnel of Soda Butte Creek. Above the mouth of the stream the valley of Pebble Creek shows heavily wooded slopes, with no exposures until, near its head, limestone again appears, being exposed on both sides of the valley beneath a eapping of andesitic breceias, as shown in the accompanying plate (Pl. XXVI). Above the creek on the spur just outside of the Park boundary occurs a thickness of 800 feet of limestones, the beds dipping at a low angle to the sonthwest. The west base of Baronet Peak and the ridge of which it is the highest point show limestones dipping from $1^{\circ}$ to $5^{\circ} \mathrm{S}$. On the south side of Pebble Creek, just north of the limits of the area mapped, but within the Park, about 100 feet lower than the low saddle that indents the ridge, oceurs a mottled Cambrian limestone earrying fragments of trilobites, the rocks being nearly horizontal. 


\section{SODA BLTTE VALLEY.}

For some distance above the mouth of Amphitheatre Creek the valley of Soda Butte is narrow, the stream flowing through a gorge cut in volcanic rocks. Its upper course is, however, through a broad valley, with flat gravelly bottom and with striking cliffs of limestone appearing on either side. The limestones exposed at the mouth of Pebble Creek extend up the western side of the Soda Butte Valley to near the mouth of Amphitheatre Creek. As no exposures appear on the east side of Soda Butte Creek, it is evident that the sedimentary rocks were cut away before the deposition of the volcanic breccias.

An examination was also made of the rocks exposed on the south slopes of the ligh limestone mountain that is capped by breccia and lies north of Soda Butte Creek. The lower slopes of this peak are covered with large blocks of limestone, the talus from the cliffs above. The lowest exposures are of strongly mottled dark-colored linestones, overlain by limestone conglomerates, with light-gray, chert-bearing, massive-bedded limestones above. These rocks show an old surface that is quite irregular. The andesite rests upon a cemented mass of large blocks and fragments of limestone. The heavy limestone belt of Soda Butte Creek above this point is exposed some 500 feet above the stream, the rocks being nearly horizontal.

The following sections, made by Professor Iddings, show the sequence and character of the sedimentary rocks exposed in this vicinity:

Section of beds on north side of Soda Butte Creek.

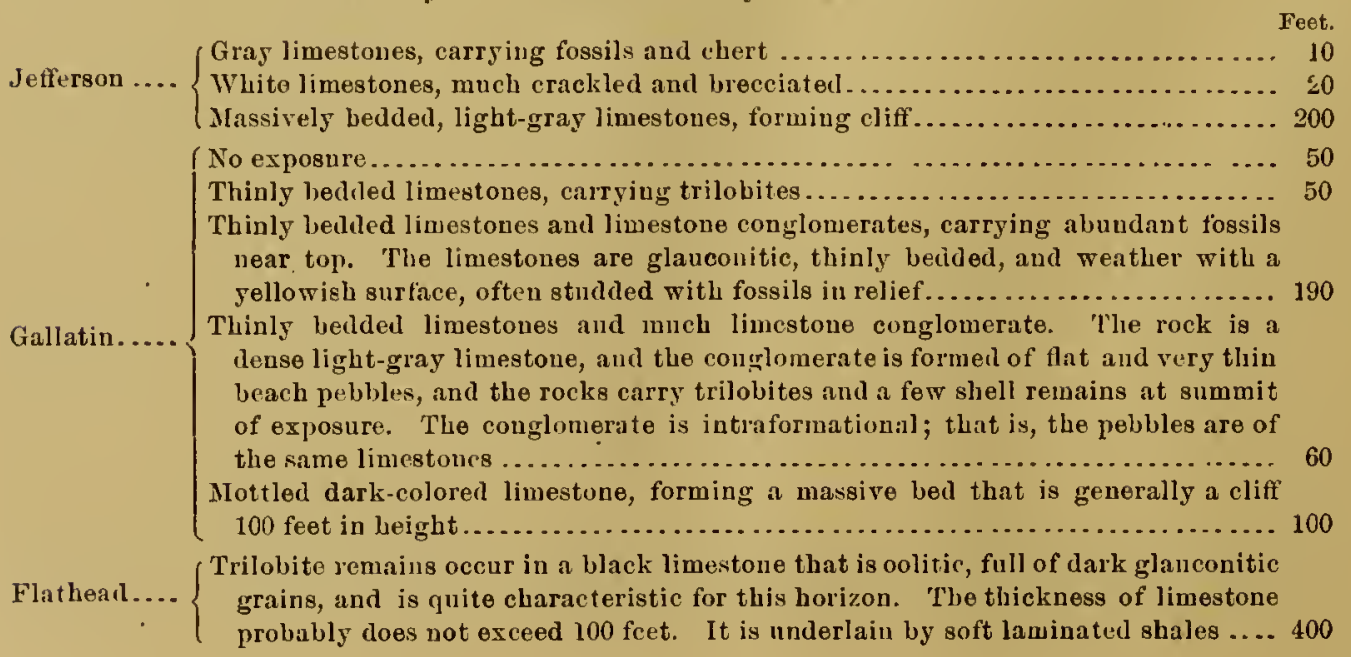


The foregoing section was observed on the north side of Soda Butte Creek, near the forty-fifth meridian, the locality being a mile west of that just moted. Mottled limestones form the lowest stratar exposed, oceurring 1100 feet above an exposure of quartz-porpliyry. 'The lowest bed is a tissile, dark-colored limestone, carrying numerous fragments of trilobites and overlain by a massive, dark-colored, mottled limestone, which is the base of the Gallatin formation, and which here forms a cliff fully 100 feet high. This is the lowest horizon seen on the north side of the creek, but on the south there are patches of shale which belong to the Flathead formation. Above the dark, coarsely mottled limestone cliffis are more thinly bedded, gray limestones and limestone conglomerates. Fossils collected from this horizon are of Cambrim age and were obtained 60 feet above the top of the cliff. At 1,050 feet above the stream similar limestones form projecting ledges, and the rock carries many trilobite spines and a few fossils. The rocks 50 feet higher up are similar and carry similar fossils and a few crinoid stems, which in this region are not commonly found at this horizon. A heavy belt of light-gray limestone, weathering with a rough surface and showing no fossils except crinoid stems, and representing, it is believed, the Jefferson formation, occurs at 1,150 feet above the stream. This belt is about 200 feet thick and is overlain by a white, much brecciated limestone about 20 feet thick, overlain in turn by gray limestones 5 to 10 feet thick, carrying traces of fossils and some chert. These limestone beds are nearly horizontal, although at the west end of the low saddle between Pebble Creek and the Soda Butte Valley they dip $30^{\circ}$ SW. This sudden change in dip is probably due to intrusive quartz-porphyry that may form a laccolithic mass under the horizontal beds that occur at the highest point.

Section of beds at north base of Abiathar Peak.

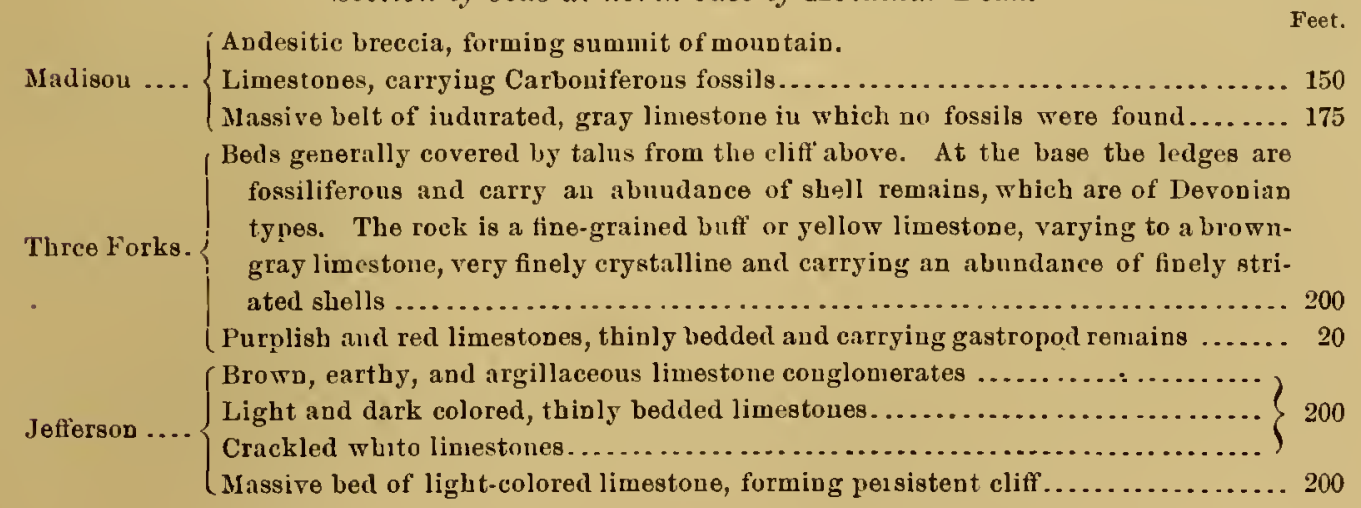




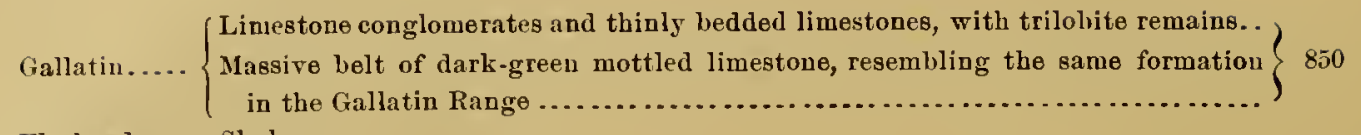
Flathead ...... Shales.

This section was made on the high limestone bluff at the north base of the north spur of Abiathar Peak. At the northwest base of the spur the strata dip to the sonthwest. The dark-colored, coarsely mottled limestone belt which is the base of the Gallatin formation is again exposed, overlain by finely bedded limestones bearing trilobites and by limestone conglomerates. Higher up the slope the massive belt of light-colored limestone belonging to the Jefferson formation weathers in an almost insurmountable cliff extending along the valley wall for a long distance. The top of this bed is about 1,000 feet above the creek. It is overlain by a stratum of broken limestones, followed by light and dark limestone beds without noticeable fossils up to 200 feet above the gray belt. At this point a purplish layer carrying gastropods overlies a brown earthy and clayey layer of limestone conglomerate with a fossiliferous ledge 20 feet above. Fossils collected from these beds show that it belongs to the Three Forks formation. The talus slope for 200 feet above these Deronian strata shows no exposures until we reach the base of a massive limestone about 1,500 feet above the cliff of Jefferson limestone. The limestones composing this upper belt are indurated and not fossiliferons, but the strata exposed above it, at 1,675 feet above the stream, contain numerous fossils. The limestones extend 150 feet higher, where the eroded surface is overlain by dark-colored basic breccias.

'The limestone bluffs extend along both sides of the Soda Butte Valley to Cook City and continue up Republic Creek for 2 miles. Crystalline schists are exposed on the road 100 feet above the Republic Creek road, and also on the lower slopes of Mount Henderson, the gneiss forming obscure outcrops. The Flathead shales are exposed higher up the slopes, at 700 feet above the stream bottom. Above them the dark-colored and mottled Gallatin limestone is exposed, but the rock is much altered and mineralized. Still higher on the south slope of Mount Henderson, east of the road, are altered shales and limestones with hornblende-mica-andesiteporphyry well exposed. The summit of Mount Henderson consists of heavily bedded mottled limestone, broken through by intrusive rock, which cuts across the bedding and also forms intrusive sheets. 


\title{
C H A P T E R V I .
}

THE DISSECTED VOLCANO OF CRANDALL BASIN, WYOMING.

\author{
By Joseph Paxson Iddings.
}

\section{INTRODUCTION.}

The exploration of the country in the northeastern corner of the Yellowstone Park and immediately east of it led to the discovery of a volcano so eroded as to expose its internal structure and to permit the connection or relationship between coarsely crystalline and glassy forms of the same magmas to be distinctly made out. ${ }^{1}$ More or less satisfactory demonstrations of this relationship have been made at different times within the last twenty-five years, but few of them have been based on occurrences where the evidences of the former existence of a typical volcanic cone have been unquestionable.

The classic studies on "The secondary rocks of Scotland," by Prof. John W. Judd, and his memoir "On the ancient volcano of Schemnitz, Hungary," describing the "basal wrecks" of 'Tertiary volcanoes in these regions, while accepted by many as conclusively demonstrating the contemporaneity of the granular rocks and volcanic lavas at these localities, failed to convince a large number, who imagined that the observations might be susceptible of other interpretations.

The dissected volcano of Tahiti, visited in 1839 by James D. Dana, ${ }^{4}$ was considered by him to have been sufficiently eroderl to disclose a granular core, but there was no opportunity offered at the time of his visit to explore

1 Jour. Geol., Vol. I, 1893, p. 606.

'2 Quart. Jour. Geol. Soc. London, Vol. XXXX, 1874, pp. 2:20-302.

${ }^{3}$ Idem, Vol. XXXII, 1876, p. 292.

${ }^{4}$ United States Exploring Expedition during the years 1838, 1839, 1840, 1841, 1842, under the command of Charles Wilkes, U. S. N., Vol. X, Geology, by James D. Dana, Philadlelphia, 1849. 
the mountain thoroughly ${ }^{1}$. The coarsely crystalline bodies of rock noticed by Charles Darwin in the Andes, and found by Prof. A. Stelzner in the andesite lavas of Argentina, lack satisfactory description.

The volcanic center at Electric Peak and Sepulchre Mountain, in the Yellowstone National Park, described in a previous chapter, ${ }^{2}$ furnishes indisputable evidence of the relationship in question and of its former existence as the center of a volcano. However, the geological structure of this locality does not meet our expectations of what a great volcano should look like when deeply eroded. In fact, profound faulting and extensive erosion have left very little of the original volcanic pile.

But no simpler or more obvious model of the internal arrangement of a great volcano could be wished for than that which is exhibited by the deeply cut valleys and steep, high ridges that constitute the drainage basin of Crandall Creek and its immediate vicinity. The coarsely erystalline gabbros and diorites, with smaller bodies of granite, exposed for a height of 3,000 feet, are plainly seen to have been intruded within a vast accumulation of basaltic tuff and scoriaceous breccia, which they have metamorphosed. From this coarsely crystalline mass as center, dikes of fine-grained rock penetrate the surrounding lavas in all directions, the dike rocks becoming finer grained rapidly as they leave the once heated core. They form a network of branches which counect the outlying aphanitic and characteristically rolcanic rocks with the more crystalline dikes near the core, which finally merge into the granular body of the gabbro and diorite. The whole complex is so intimately interwoven that there is not only no possible doubt as to the relative time of eruption of the glassy basaltic scoria and lavas and of the gabbro and diorite, but there appears to be no ground for designating. a part only of the rocks involved in the complex as volcanic.

\section{GEOLOGICAL DESCRIPTION.}

\section{GENERAL FEATURES.}

The tract of country embraced in the description of the volcano of Crandall Basin lies immediately east of the northeastern corner of the Yellowstone Park, and includes an area somewhat larger than that drained

'Also, A dissected rolcauic mountain; some of its rerelatious: Am. Jour. Sci., 34 sories, Vol. XXX11, No. 190, Oct., 1886.

${ }^{2}$ Page 89 . See also The mineral composition and geological occurrence of certain igueons rocks in the Yellowstone National Park: Bull. Philos. Soc. Washington, Vol. XI, pp. 191-220; and The eruptive rocks of Electric Peak and Sepulchre Monntain, Yellowstowe National Park: Twelfth Auu. Rept. U.S. Geol. Survey, Part I, 1891, pp. 569-664. 
27 



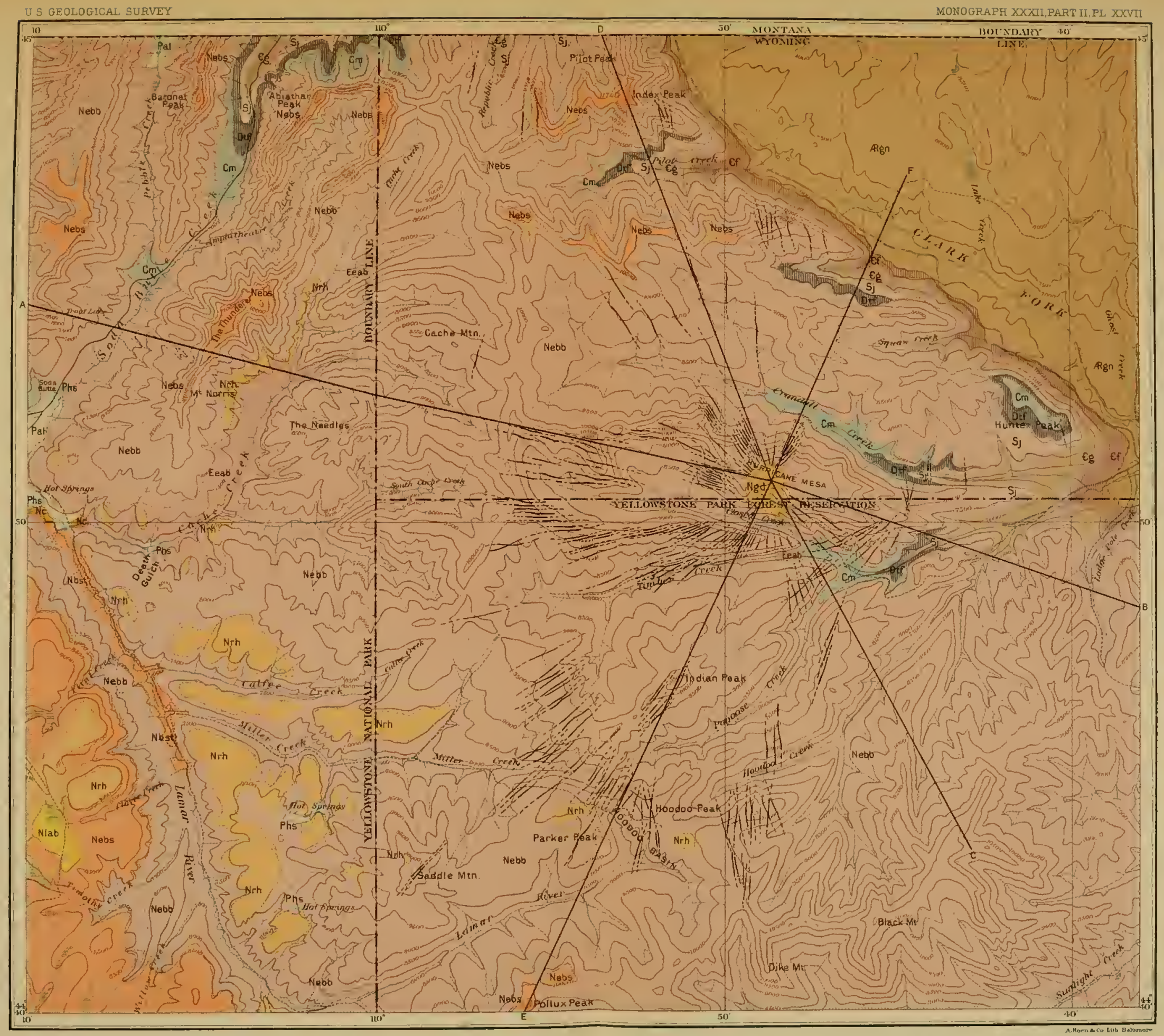

LEGEND

Phs

PLEISTOCENE

Alhivium

NC NEOCENE

Camyon
Conglonerate
.

$\mathrm{Cm} 3$ CARBONIFEROUS Madison
timesione.

Difin ? OEVONIAN

Threftorks
limestone.

Sj 3 SILURIAN

Jefferson
lime:sionte.

$\left.\underset{\substack{\text { Giallatin } \\ \text { limestone. }}}{E_{\xi}}\right\}_{\text {CAMBrian }}$

Ef

Flathead
formation.

D.1.

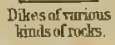

Ngुd.

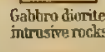

Nrh

Nlab NEOCENE

Late acil
breckia.

\begin{tabular}{|c|} 
Nebs \\
Earlybasic \\
flums
\end{tabular}

Nbst

Basalt.

Nebb

Earty basic
brercia.

Eeab J EOCENE

Earkv acid
breccia.

ARgn T ARCHEAN

Granite and
sneiss

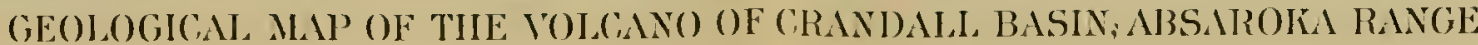

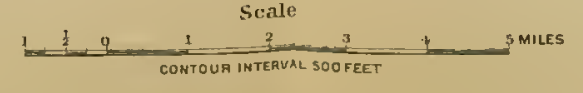



by Crandall Creek, extending a short distance into the Park. It is defined by the accompanying map (Pl. XXVII). The area of volcanic rocks liere represented is but a small portion of the great belt of igneous material that forms the mountains of the Mbsaroka Ramge, which stretehes along the eastern margin of the Yellowstone Park from the Bowlder Platean on the north to the Wind River Mountains on the south. The volemo of Crandall Basin is one of a chain of voleanic centers situated along the northern and eastem border of the Yellowstone Park, which are all distinguished by a greater or less derelopment of radiating dikes, and by a crystalline core, eroded and exposed to a varialble extent. Electric Peak and Sepulchre Mountain constitute one of these centers.

Since the volcanic ejectamenta forming the Absaroka Range have been thrown from numerous centers sitnated at no great distance from one another, it would be impossible to separate the meterials which have originated from the different vents, since they must have intermingled; and it would be incorrect to assume that any particular area of volcanic rocks had been derived exchusively from one center of eruption. But since the material ejected from closely associated vents may be considered to have come from the same general source, or to belong to a connected series of eruptions, we may regard the volcanic rocks occuring in the immediate vicinity of a well-marked center of eruption as representing the various results of volcanic activity which have existed at that place. The area embraced within the limits of the map may not be sufficiently large to include all of the material thrown out from the minor centers of eruption, which, during the period of volcanic activity, must have shifted about within the region of Crandall Basin, but it is large enongh to furnish data from which the geological history of this particular volcano may be derived.

To understand the geology of so limited an area as that represented on the map it will be necessary to explain the general fentures of the surrounding region. A high and massive range of Archean granite and gneiss forms the country north of Clark Fork and stretches in a northwest-sontheast direction. The river channel is situated within this granitic district, near its southern margin. The Paleozoic strata which overlie the Archean rocks have been greatly eroded, leaving an irregular layer of limestone, which dips gradually to the southwest. This limestone forms a cliff along the south side of Clark Fork and extends for considerable distances up the 
valleys of the streans enptying into it from the south. It also extends down the valley of Soda Butte Creek near to the mouth of Amphitheatre Creek, and discomected areas of it occur at the mouth of Pebble Creek and near Soda Butte, as described in the previous chapter. It also forms the head of Pebble Creek and the valley of Slough Creek, a small portion of which is shown in the northwestern corner of the map. The limestone embraces the Cambrian, Silurian, and Devonian, which attain a thickness of only 1,800 feet, the strata of the last two periods being very poorly developed and not exceeding in thickness 400 feet. In most places the limestone extends up into the Carboniferous. The whole series is very poor in fossils within the area of the map, and the identification of the horizons rests on evidences obtained from neighboring sources.

The very irregular form of the eroded surface of the limestone is shown by the variable heights of the limestone cliffs, which range from 400 to 2,400 feet. The highest within the area are in the peak southwest of Cook City, in Hunter Peak, and in the escarpment south of the mouth of Crandall Creek. The extensive erosion which preceded the ejection of the lavas was subsequent to the orographic movement that involved the coal-bearing Laramie strata in this region. Upon this greatly eroded surface were thrown volcanic tuffs and scoria, with occasional streams of lava, until the accumulation exceeded in thickness 4,000 feet. The breccias were traversed in various directions by dikes of lava which filled the crevices made during the later eruptions.

The close of volcanic activity in the ricinity of Crandall Basin was followed by another period of erosion which removed the upper portion of the volcanic accumulation, leaving over 4,000 feet of it in the form of high ridges and peaks, with deeply cut valleys between. The occurrence of nearly horizontal layers, of massive lava alternating with crudely bedded tuffs and breccia, which in places are piled one on another to the number of twenty or more, gives rise to precipitous mountains, which are quite inaccessible from most points of approach. The highest of these is Index Peak, whose steeple-like summit, 11,700 feet in altitude, has not yet been scaled. A view of this peak from Clark Fork gives an idea of its sharpness. (Pl. XXVIII.) The readiness with which the scoriaceous breccil and tuffs are eroded causes the drainage channels to be narrow and rocky, so that the valleys traversing this region are in general very difficult to travel through. 


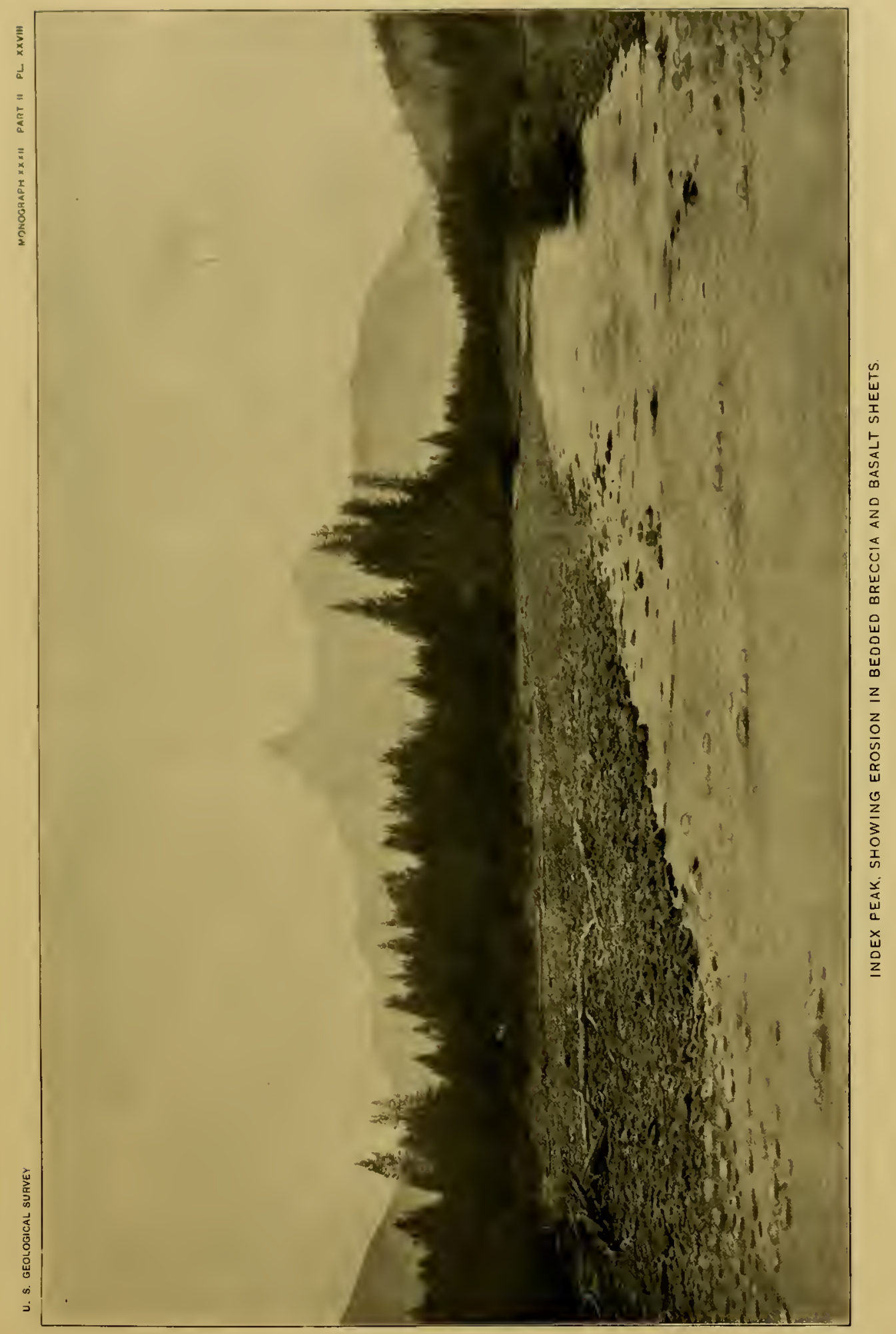



After erosion had reduced the breceial country to very near its present configuration, the region to the southwest was flooded by an immense body of rlyolitic lara. One edge of this rhyolite covered a portion of the lyreccias in a thin sheet, remnants of which are found in the southwestern part of the district. They occur in the most unlooked-for places, as, for instance, at an elevation of 10,000 feet on a narrow spur near the summit of Saddle Mountain and at varions altitudes over its slopes; also near the bottom of Cache Creek Valley, where they form a bench between the levels of 7,500 and 8,000 feet. The rhyolite was erupted from a distinctly different center and after the voleano of Crandall Basin had long become extinct, so that it need not be considered in comnection with the history of this volcano.

After the rlyyolite had been in turn eroded and the valley of Lamar River had been cut 500 feet below the surface on which the rhyolite had flowed, basalt was again erupted and filled the bottom of the valley. The source of this eruption has not been discovered. The periogd of voleanic aetivity may be considered as not yet ended, thongh it is at present confined to such manifestations as are found in geysers, hot springs, and fumaroles, some of which oceur within the district under discussion.

The general features of the region having been sketched, the geology of the volcanic rocks within the area of the map may be taken up and described in greater detail.

EARLY ACID BRECCIA.

The breccias and lavas covering the country are essentially basaltie, but there are remnants of an older breccia which is acid. The term breccia is used for subaerial accumulations of tuff and scoria and fragments of rock derived from explosive action, and it will be seen how great a proportion of all of the material has been subjected to this kind of action. The acid breecia is found underlying the basaltic lavas in several localities in the district. It is exposed about Republic Creek, where it is rudely bedded, the bedding being produced by layers of different mixtures of tuff and angular fragments. They pitch steeply to the south and pass under basaltic breccia, which also is rudely bedded at the bottom, but becomes well bedded higher up. The lower layers dip steeply to the sonth and southwest, but the upper layers are nearly horizontal. The acid breceia is light colored and variegated, and consists of hornblende-mica-andesite 
mixed with some pyroxene-andesite. It is also exposed in the valley of Cache Creek in two places, the larger exposure extending for about 8 miles. Here it is light colored and consists of the same kinds of andesite. It is indurated and somewhat decomposed, and its surface indicates that it was eroded before the basaltic breccia was thrown on it. A much smaller body of hornblende-mici-andesite-breecia occurs in the heart of the distriet within a mile of the center of the volcano. It is at the junction of Closed Creek and Timber Creek, and rests directly on limestone, as it also does in the vicinity of Republic Creek. It appears to have been at one time on the outskirts of the earlier volcanic district, for its lowest portion is composed of layers of andesitic gravel which were deposited by water. It passes up into light-colored breccia of hornblende-mica-andesite, which carries fragments of Archen rocks. Fragments of gneiss and schist characterize the early acid breccia wherever it has been found along the northern boundary of the Yellowstone Park. They have already been mentioned as occurring in that which forms the base of Sepulchre Mountain, and they occur in that at the base of the Washburne volcano. This early acid breccia has been shown by Mr. Hague ${ }^{1}$ to belong to the Eocene period, and to correspond to the Fort Union horizon. Thronghont the remainder of the district the basaltic breceia rests directly on the sedimentary strata, or forms the bottom of the valleys where erosion has not yet cut through them to the underlying rocks. It is to be remarked that the basaltic lavas pass under a second series of acid breccias of hornblende-mica-andesite, which are like the older ones in mineralogical character. The younger or late acid breccias form a considerable part of the Absaroka Range south of Lamar River. Neither the older nor the younger of these accumulations of lornblende-micaandesite appears to have been erupted from what we have called the volcano of Crandall Basin. This was essentially a basaltic center, the last eruptions of which became acid, and in part more basic, but were of small extent.

BASIC BRECCIA AND FLOWS.

A conception of the magnitude and proportions of this volcano must be derived from a study of the geological structure of the basaltic breccia and flows-early basic breccia-for nothing remains to indicate a single line of the original form of the mountain. In place of a volcanic cone

- 'Hague, Arnold, The age of the igneons rocks of the Yellowstone National Park: Am. Jonr. Sci., 4 th series, Vol. I, 1896, p. 450. 
there is a system of narrow ridges and valleys, three of the deepest valley's passing through what was the center of the volcano. The arrangement of the rocks, however, is so marked that there cim be no doubt about the location of the center of volcanic activity or of the general nature of the mountain.

\section{1)ISTINCTLY IBEDDED IBRECCIA.}

'The geologist who approaches the region by way of the Lamar River is impressed with the great masses of almost horizontally bedded breccia which form the chocolate-brown mountains on either side of Soda Butte Creek. They are finely shown in the panoramic sketch by Prof. W. H. Holmes in his report on the geology of the Yellowstone Park, ${ }^{1}$ notices of this portion of the country being found on pages 44 to 49 . The sketch is as faithful to nature as it is artistic, and it is possible to calculate the point from which it was made by reference to the map.

The breccias rise from 2,000 to 3,000 feet above the river, and appear so uniformly bedded as to give the impression that they have been waterlaid; but a nearer view shows their irregularity and proves their subaerial deposition. Upon examination the bedding is found to be crude and ill defined, the layers consisting of tuff with various-sized fragments of scoria and compact rock. Between the layers are accasional sheets of massive lava. In some places the tuff's are quite light colored and are very noticeable among the dark-brown beds. The deposits contain the stumps and loots of trees, whose erect position shows that they have not been disturbed since they were buried beneath showers of dust and stones. Their situation at different horizons in the breccia and their large size indicate how great a time must have elapsed between the explosions which covered the country with débris in beds from 1 to 3 or more feet in thickness.

A more or less distinct and nearly horizontal bedding is characteristic of the breccias forming the mountains west of Cache Creek, inchuding the ridge from Mount Norris through The Thunderer to the great wall surrounding Amphitheatre Creek. The east face of this ridge is shown in Pl. XXIX, from a photograph which was taken from the divide at the head of Republic Creek. The same breccias form the precipitous ridges on both sides of Pebble Creek, and are well exposed in the face of Baronett Peak, 10,300 feet in altitude. 
The horizontally bedded breccias and lava flows extend eastward across the head of Cache Creek to Index Peak and the range of peaks immediately soutl, but the lower portions of these mountains are irregularly bedded. The upper parts, above 10,000 feet, consist chiefly of basalt flows resting one upon another, with occasional intercalated layers of breccia. This is also the case at the summit of the monntains northeast of Amphitheatre Creek, and southward to the summit of Mount Norris.

The ridge between Cache Creek and Crandall Basin, with its western spurs, is composed of nearly horizontally bedded breccias with few lava flows. They carry numerous silicified trunks of trees, whch are exposed in a standing position on the western slopes of the Needles. Similarly bedded breccias extend south of Cache Creek across Calfee and Miller creeks, and form the plateau west of Lamar River and the high mountains south of its head. Here, again, in the upper thousand feet massive basalt flows prevail, forming the top of the platean and the upper portion of the peaks just mentioned. In this vicinity the basalt sheets are plainly seen to slope gradually to the west and southivest, their highest present altitude of about 11,000 feet being found on the summits of Castor and Pollux peaks. Basalt sheets to the thickness of 400 feet cap the summit of Saddle Mountain, at 10,400 feet altitude, where irregularly shaped flows of vesicular and seoriaceous basalt indicate by their position and by the arrangement of the columnar cracking that they flowed down an uneven surface, apparently a drainage chamnel, sloping toward the southwest.

Occasional flows of massive basalt occur in the lower portions of the series of basic breccias and tuffs. A notable one is found near its base over the limestone on Soda Butte Creek and Lamar River, but the great bulk of the lava sheets is at the top of the series. Columnar structure is common to all of these flows except when very thin and scoriaceous, and they possess all of the superficial characteristics and variations of surface flows of basalt. None of those observed in the localities just described appear to have been intruded sheets.

CHAOTIC BRECCIA.

In striking contrast to the almost horizontally bedded breccias and flows are the chaotic and absolutely orderless accumulations of scoriaceons breccia which form the mountains and ridges about the head of Lamar 


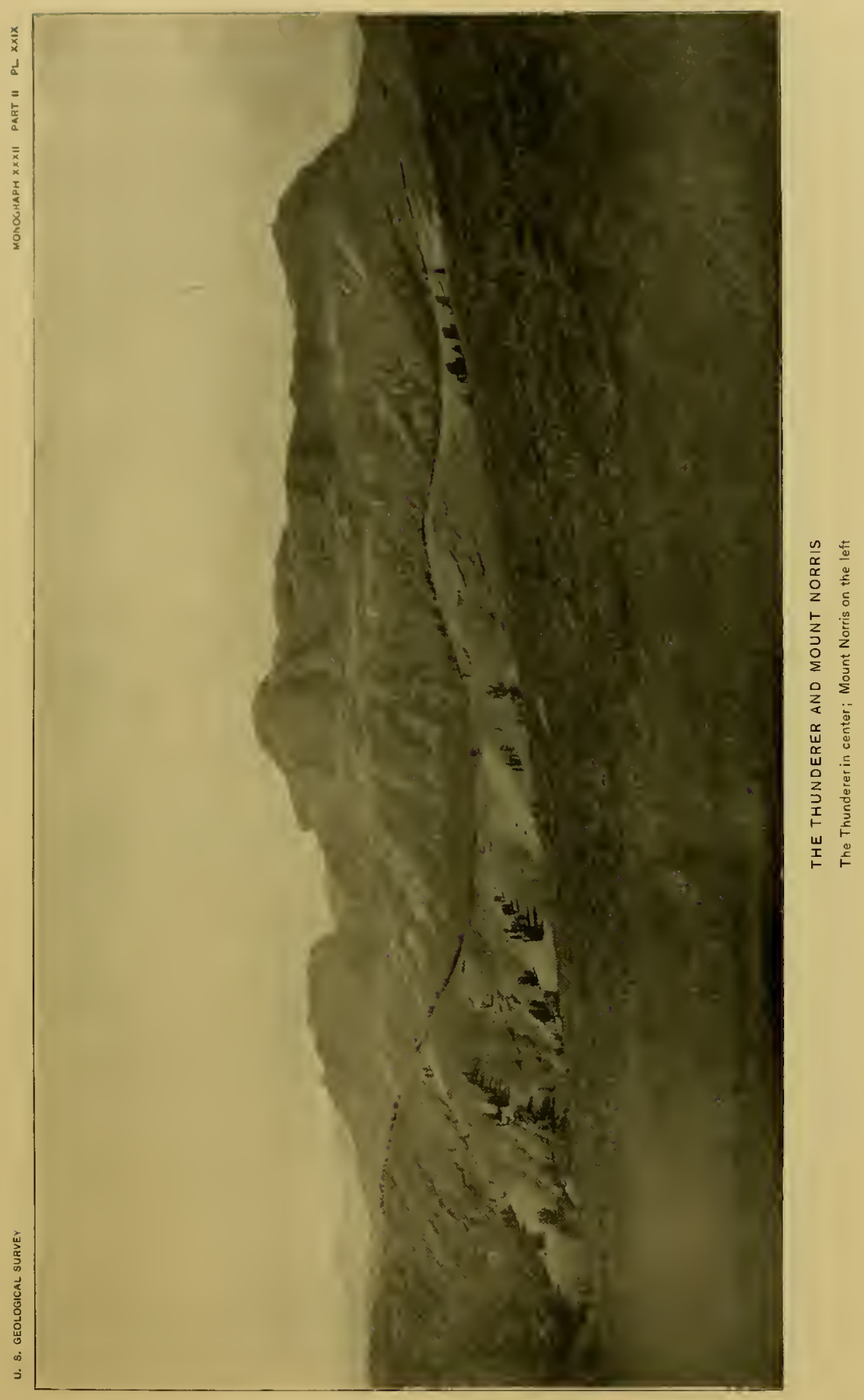





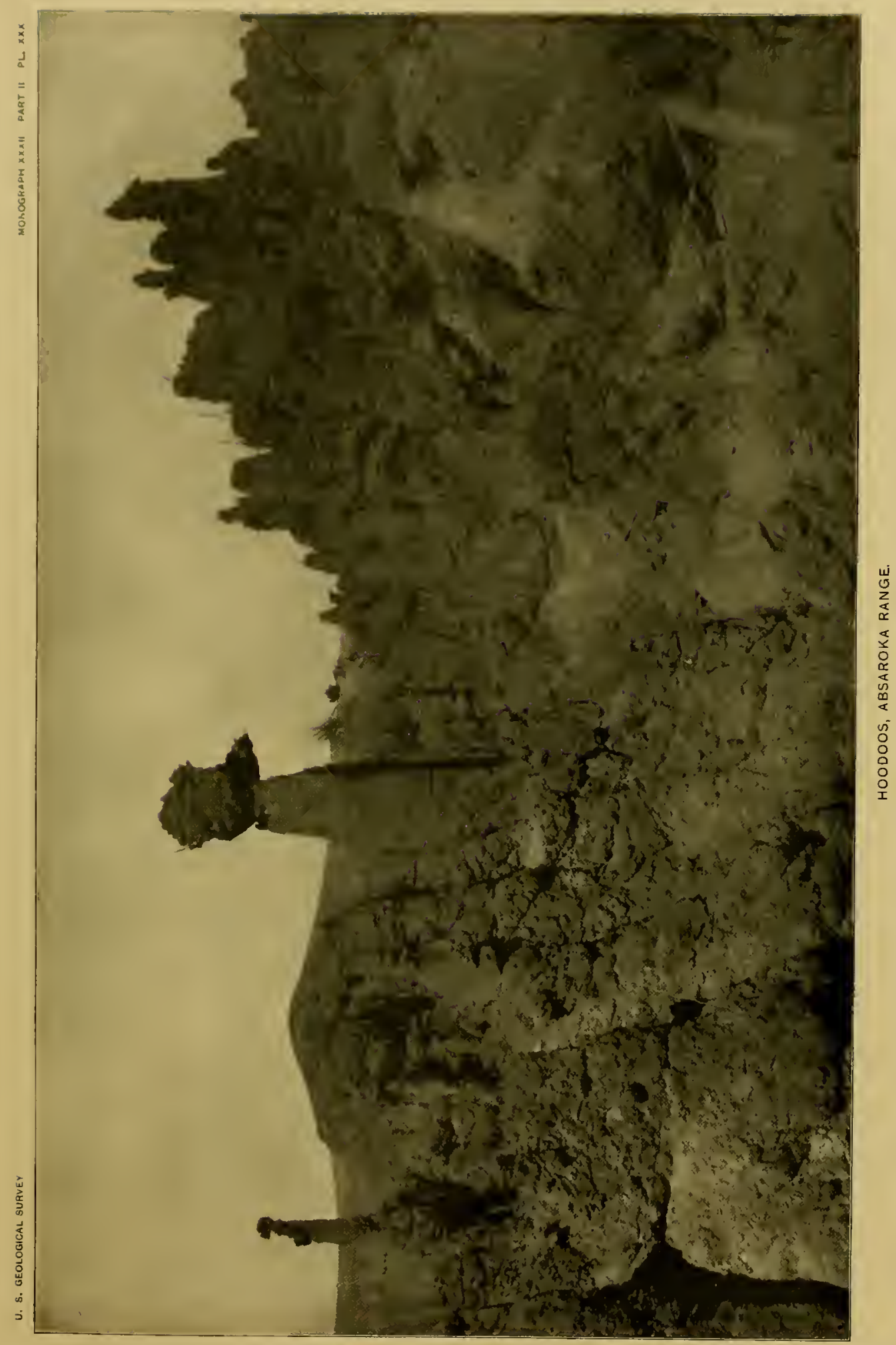



River and Miller Creek and the central portion of Crandall Basin. 'To one who has spent much time anong the wetl-betded breceias of 'Two Ocean Platean and of the greater portion of the Absaroka Range, nothing could be more noticeable than the difference of structure exhibited by the breccias in the locality just mentioned. It is to be renarked, however, that while this difference is so noticeable in extrene cases, there is no sharp line to be drawn betreen the different areas in the field, and from the nature of their origin they often merge into one another.

The most typical exposure of chaotic breccia has become well known for the grotesqueness of the shapes assumed by the rock when cut by erosion into pimmacles and buttresses. The heterogeneous agglomeration of scoria and tuffs with angular masses of various sizes has been carved into turrets of the most irregular and remarkable shapes, whose dark color and forbidding aspect suggest to a fanciful imagination goblins and demons, popularly termed "hoodoos."

The Hoodoo Basin, at the sonthern base of the mountain of the same name, is the best example of this form of erosion. Other occurrences of this character are found in various localities in the district. Some of the grotesque pinnacles are shown in $\mathrm{Pl}$. XXX, from a photograph taken by Mr: Weed. The rocks, though dark chocolate-brown as a whole, often appear on closer examination to be brilliantly colored and variegated, ranging from brick red to purple and pink, and being in places bluish and greenish, and also yellow and brown. These colors are characteristic of the chaotic breccias in a number of localities; as, for example, on the eastern slope of Parker Peak, on the divide between Miller and Papoose creeks, and on that east of the head of Lamar River. There is a noticeable increase in the number of large masses of rock occurring as fragments in the breceia, which often exceed a diameter of 8 feet, some being 20 or more feet thick. The petrographical character of the rocks forning large areas of this breccia is more uniform than in the outlying region of wellbedded deposits, where fragments with quite different habits may be found intermingled. The whole accumulation is, besides, more scoriaceous and slag-like. 
DIKES.

A still more noticeable feature of the central portion of the district is the occurrence of dikes which form prominent walls of rock traversing the country in all directions. They are specially numerous in the region of chatic breccia, but are not confined to it. Owing to the importance attached to the position and trend of the dikes, it has been thought advisable to describe them in considerable detail, in order to assure the reader that their location on the map is the result of careful observation.

In the southwestern part of the district they are most noticeable crossing the spurs at the head of Miller Creek, where they were observed by Superintendent Norris. They are nearly all parallel, and trend northeast and southwest, a few having a more westerly direction. Eight of them cut the slope of the amphitheater at the northern base of Parker Peak. They are from 3 to 8 feet wide, and often rise from 3 to 15 or 20 feet above the ground. They are nearly vertical and parallel, almost straight, with slight curves and sometimes sharp bends, and may be traced by the eye across the spurs in a north-northeasterly direction. The long spur south of the branch of Miller Creek is crossed by several dikes having a northeast trend. They consist of the same kinds of rock as two dikes cntting the summit of Saddle Mountain, which also have the same trend and appear to be continuations of these dikes.

Hoodoo Mountain and the ridge between Lamar River and Timber Creek are traversed by numerous dikes, some of which trend about $\mathrm{N} .10^{\circ}$ W. and N., and others S. $30^{\circ}$ E. and SE. Most of these dikes are from 3 to 8 feet wide.

Proceeding from Hoodoo Mountain northwest and north, one finds that the divide between Miller and Timber creeks is cut by dikes trending northeast; and the high ridge through Indian Peak, and the Peak itself, are traversed by dikes trending N. $30^{\circ}$ E. and N. $20^{\circ}$ E. In this peak, as at Saddle Mountain, the dikes cut the massive flows of basalt, which were therefore some distance beneath the surface of the volcano when the dikes were injected.

The valley of Timber Creek is covered with a heary growth of pines and firs, which obscures the geology and prevents the location of dikes except by closer study than there was opportunity to bestow on it. But the long narrow ridge north of this branch is bare of timber on its crest, 
and is deeply furnowed hy laternl gulches with rocky spmw, whose upper slopes are thinly elarl. The geological structure of this ridge is specially significant and was carefully stndied. 'The breccia composing it at its southern base is basiltic and serriacenus, with nalssive flows of vesicular batsilt of the sime petrographical habit. On one of its southern spurs, about $5 \frac{1}{2}$ miles from its eastern end, a number of dikes trend N. $70^{\circ} \mathrm{E}$. Near the trop of the ridge two trend N. $80^{\circ} \mathrm{F}$., and one trends east. 'They vary in width from 18 incles to 8 feet. A narrew dike near the top trends S. $10^{\circ} \mathrm{E}$.

On the crest of the ridge, about a mile and a half from its western end, there is a light-gray indurated tuff, in places containing small fragments of rock and carrying some plant remains. The northern face of the ridge at this point is an alnost rertical precipice, exposing breccia without a tralce of beddling, utterly clanotic, slaggy, and scoriaceous, containing large fraggments of massive basalt. In soine places it is composed of small angular fragments; in others it is brightly colored, and is cut by dikes which trend a little north of east, very nearly parallel to the crest of the ridge.

About a mile east of this point the breccia consists of vesicular basalt, with very large feldspar phenocrysts. Some masses of this rock are 20 feet in diameter. Near this an amphitheater on the north side of the ridge exposes alternating layers of breccia and lava flows, having a rather steep dip to the southeast. They appear to have been part of a small cone at one time. This part of the ridge is cut by dikes trending a little north of east, and also by a broad dike, 10 feet wide, trending north and south, with a steep lade to the west. Farther east on the crest of the ridge the breccia becomes indurated and weathers into small fragments. It continnes to be indurated eastward as far as explored. It is traversed by dikes trending N. $50^{\circ}$ E., and by one dike, 18 feet wide, ruming S. $85^{\circ}$ E. Farther east there are other dikes entting the ridge in a northeasterly direction and trending toward the two deep gulches on Hurricane Mesa, on the northern side of Closed Creek branch of Crandall Creek. Some of the dikes are narrow, but several are quite large, one being 10 feet and another 18 feet wide. Along the portion of the ridge explored by the writer, a distance of about 4 miles, there are 31 dikes; of these 26 are basalt and 5 are hornblende-mica-andesite. They are not uniformly distributed along the crest of the ridge, but occur in groups of from 3 to 8 , the largest groups MON XXxiI, PT II-15 
being situated at the east. Besides these dikes others were observed at the eastern end of the ridge, and 6 or 7 were found by Mr. Weed at the western end, making over 40 in all.

From the distribution and trend of these dikes it is evident that they radiate from that portion of Hurricane Mesa which is situated between the deep gulches just alluded to. The dikes are not absolutely straight, but trend in general toward this spot. They are more numerous directly south of it, where the ridge is nearest to this center, and are less frequent toward the west, where the ridge is more remote.

The southern slope of the ridge north of Timber Creek is traversed by dikes of the same kinds of rocks as those occurring on the crest, and having similar trends, leaving no donbt that they are contimuations of the same dikes. The breccia cut by these dikes is indurated where they are close together. It is to he remarked that all parts of the country in this vicinity which were explored were found to be travèrsed by dikes, but, owing to the limited amount of time and the difficulty of traveling, a thorongh exploration of the country was not made, and only those dikes which were observed, sometimes from a distance, have been mapped, their probable continuations being indicated by dotted lines.

On the end of the northeastern spur of Indian Peak there are dikes, some of which trend west of north toward the center on Hurricane Mesa, while others trend northeast. Dikes trending wortheast occur on the ridge between Papoose and Hoodoo branches of Crandall Creek.

The structure of Hurricane Mesa and the ridge west is clearly seen from the ridge south of it. A sketch of it was made from a point on the northeast spur of Indian Peak (Pl. XXXI). It shows the ridge with its eastern table-land, from 10,000 to 10,600 feet in altitude, and the western chain of peaks, reaching heights of from 10,400 to 10,800 feet; the valley of Closed Creek, whose bottom has been eroded down to 8,000 and 6,800 feet; the steep narrow ridge south of the latter, whose high point in the middle ground is 9,600 feet, and the valley of Timber Creek, with the divide to Cache Creek, at about 9,500 feet. To the right is the outline of Hunter Peak, at the month of Crandall Creek.

The western head of the valley of Closed Creek, which is the divide to Cache Creek, consists of horizontally bedded breccia with a slight dip to the southwest. It contains a few intercalated flows of basalt and is cut 




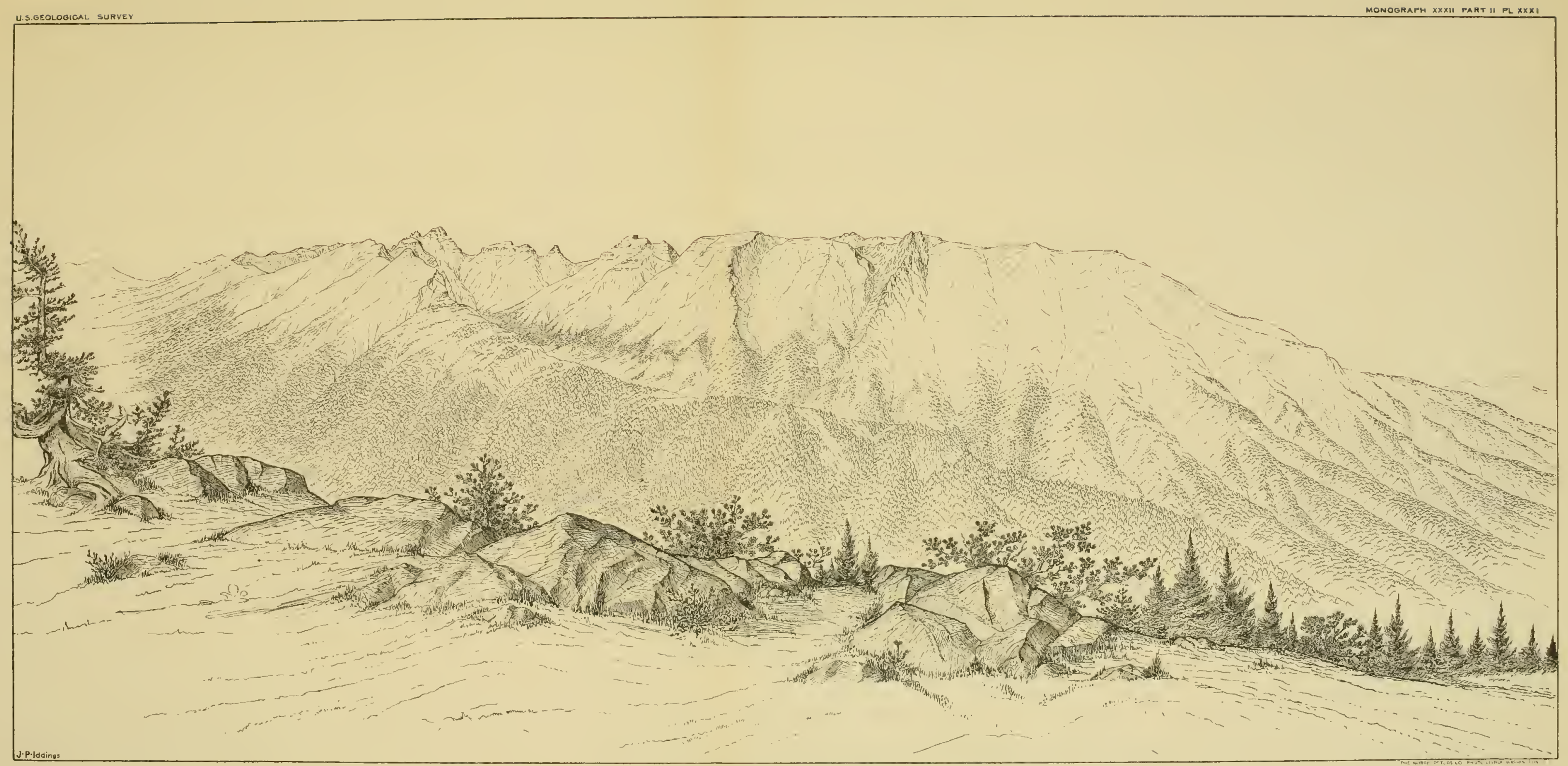




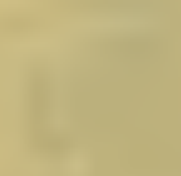


by dikes trending east and west. The berded breccias continne eastward across the saddle to the first peak of the ridge west of Hurricane Mesil. Near the summit of this peak they are cut off and overlain by beds of hreccia dipping slightly toward the enst. 'T'hese berls pass under the massive rocks which form the ruper 600 or 700 feet of the western half of this ridge. The massive rocks form nearly horizontal sheets capping the peaks of this part of the ridge and constituting the top of the flat eastem half or mesa. They exhibit prismatic cracking, and appear to be sheets of basalt intruded in the breccia. Beneatl them the breccia shows no bedding, and in the eastern part of the ridge-that is, in the mesa-it is highly indurated and weathers like. massive crystalline rock with long talus slopes of small fragments.

On the southern side of the head of Closed Creek the bedded breccins of the Cache Creek divide are cut off near the top of the ridge between Closed and Timber creeks, and are overlain by chaotic slaggy breccia, which exhibits a rude bedding, with steep dip to the eastward. Halfway up the northern slope of the ridge, beneath this point, there is a large irregularly shaped body of massive columnar rock intruded in the breccia. Exposures of massive hornblende-mica-andesite were observed by Mr. Weed on the southem side of the ridge opposite to this body.

The southern slope of the ridge west of Hurricane Mesa is traversed by dikes rumning east and west and more or less parallel. As already remarked, the eastem half of the ridge is a high table-land, whose top, at 10,200 feet, consists of a horizontal sheet of basalt, 200 to 300 feet thick. On the south there are steep slopes and spurs, with much slide rock and little vegetation. On the north are four deep amphitheaters, with precipitons walls, and high rocky spurs between them. In the middle of the table-land on the sonthern side are two narrow gulches encircling a round-topped spur. At the western end of this table-land dikes are numerous. Across its sonthwestern spur there are 11 , from 2 to 10 feet wide, trending $\mathrm{N} .70^{\circ} \mathrm{E}$. and S. $70^{\circ} \mathrm{E}$. At the northwestern end of the plateau there are dikes trending northwest, which are well exposed in the wall of the amphitheater. A 10 -foot dike follows the ridge along the saddle and cuts the turreted peak to the northwest. The dikes also cut the basalt sheets. The long spur north of this end of the platean is traversed by 18 narrow dikes trending toward the northwest and converging sontheastward toward the round- 
topped spur in the middle of the platean. Small dikes cut the northern edge of the plateau and a small spur from it, and trend toward the northwest at various angles. They can be seen at a distance of 4 or 5 miles traversing the country to the north in the sane direction, but of course it is only the largest and most prominent that can be recognized in this way.

The balsalt sheet on top of the platean is massive and is jointed in large rectangular blocks. The walls of the amphitheater appear to consist of similar massive rock for a depth of a thonsand feet, but they are highly indurated breccia.

The western half of the mesa is cut off by the gulch west of the round-topped spur, and presents a cliff facing eastward. This is intersected by numerous clikes, one of which is 12 feet wide. The cliff passes sonth into the pimnacled spur west of the gulch.

A high and ninrow ridge extends around the northern side of the head of the twin gulches, and consists of massive rock cut by a few dikes trending nortl. From it a high spur runs toward the northeast. It is composed of chaotic breccia, which is somewhat indurated and is traversed by a number of dikes trending northeast.

The portion of Hurricane Mesa east of the twin gulches is less indurated than that immediately west, and contains fewer dikes. Its northern side was not explored, but undoubtedly exhibits some dikes. Acruss the upper part of the southern slope there is a long straight dike trending soutl of east; and several others occur lower down the slope, and trend toward the round-topped spur. The sontheastern spurs are traversed by 10 dikes, which trend toward the northeast and converge toward a point in the gulch which drains the eastern end of the mesa. Near this point on the long eastern spur the breccia is indurated and a large body of finegrained crystalline rock is exposed, which is probably comected with the center toward whith this group of dikes converge. Near the junction of Closed and Timber creeks a number of dikes were observed, most of which trend toward the northeast. There is a large one trending toward the round-topped spur. Where the two systems of dikes intersect, the dikes from the round-topped spur are found to be the younger, since they cut those trending toward the eastem center.

These observations have been plotted on the map in such a mamer as to show where the dikes have been actually found, the dotted lines being 
introduced to emphasize the structure and indieate where the dikes would lave been found if there had been sufficient time to hunt them out. Slide rock and forest obscure parts of the country, and parts of it have not been visited, as the general character of the geology was recognizable from a distunce. From the data obtained there can be no reasonable question as to the arrangement of the dikes. The great majority of those in Crandall basin radiate from the middle of Hurricane Mesa. A smialler number radiate from a second center, 3 or 4 miles east of the first.

It was during the study of the district, which was traversed along much the same lines as those along which it has just been described, that the conviction forced itself upon the writer that the locality toward which the majority of dikes converged must have been the center of great volcanic activity, and would prove to be the location of what was once the conduit or throat of an ancient voleano, and might possibly exhibit rocks representing a coarsely crystalline development of the magmas which had filled the dikes. It was, consequently, with great expectations that he led his pack train over the uninviting and even forbidding country drained by Crandall Creek, from Miller Creek across the densely timbered valley of Timber Creek, and over the precipitous ridge into the bottom of Closed Creek; and having reached the gulches draining the suspected core, it was with great satisfaction that he found himself surnounded by blocks of gabbros and diorite of decidedly coarse grain. Here was in reality the core of an ancient volcano, the conduit through which lava had risen to the surface, from which it had escaped in lateral fisures through the surrounding rocks, and in which it had eventually solidified.

A description of this core necessarily involves a consideration of the petrographical character of the rocks composing it, which in the case of the other rocks of the district has been deferred to a subsequent part of this cliapter; and in order to maintain a logical sequence in the study of all of the rocks of this rolcano the detailed description of the grannlar core will be given in comection with the petrograply of the rocks. A general statement of its character, however, will be in place here.

The round-topped spur between the twin gulches, frequently referred to, consists of granular gabbro which grades into diorite. Gabbro also forms the bottom of the gulches and extends up the flanks of the precipitous spurs encircling the gulches. The greater part of the spur on the west 
above the timber is gabbro, which here attains its highest degree of erystallization. The outline of the gabbro mass is not well defined against the surrounding breccias, for several reasons. The breccias become highly inclurated as they approach the core, and finally appear as dense aphanitic rock, with jointing planes like those of the finer-grained parts of the massive intruded rocks, and eridences of their originally brecciated character are ahnost obliterated. Iforeover, the gabbro becomes finer grained and darker colored near the encircling rocks, and in some places is so fine grained as to be distinguished with difficulty from the metamorphosed breccia. The shape of the gramular core is very irregular and indefinite, for it is found upon investigation that it does not consist of one continnous body of solidified magma, but is made up of smaller bodies differing in grain and mocle of crystallization and in mineral composition. Many of these bodies appear as dikes or veins cutting one another and the larger masses of gabbro. They penetrate the breccia as dikes of crystalline porplyries, whose identity with the more distant, finer-grained dikes is shown by their megascopical habit and mineralogical character. It is evident that in the immediate neighborhond of the heated conduit they cooled at a rate which permitted them to assume a ligher degree of erystallization than that assimmed by the dikes in the cooler breccias. The transition in grain from the core outward is rapid, and, owing to the variability in the size of the dikes and the differences of arystallization dne to this cause, no definite ratio of change was noted.

Returning to the consideration of the distribution of dikes, it is to be remarked that they abound in the breccias lying north and also east of Crandall Creek. In the most easterly mountain of breccia on the map, and on the northwestern spur of Windy IIonntain, the breccia of which consists of basaltic scoria and flows, there are numerous dikes, some of which trend a little east of south and other's a little west of south. The high limestone escarpment north of Windy Mountain is ent by many small vertical dikes, whose black color contrasts strongly with that of the whitened limestone containing them. In different localities in Crandall Creek where the limestone is cut by dikes it is whitened in the same manner in the vicinity of the intruder rock. These dikes also trend east of sonth, and it is to be observed that there were no signs of a radiation of dikes within the limestone, but the dikes appeared to be located along a system of parallel joints. 
No dikes of volcamic rocks were found in the grneiss and granite along Clark Fork, although the bare and smonthly glaciated surfaces offered ample opportunity for detecting them if present.

'l'he structure of the high ridge north of the npper portion of Crandall Creek is shown in the escanment on its northem side-that is, along the sonthern sile of Clark Fork and of the creek sonth of Index Peak. The basaltic breccias appear to be rudely bedded at varions angles and are cut hy numerous dikes. The top of the western end of the ridge, as already stated, consists of twenty or more basalt sheets, which are nearly horizontal. When viewed from Hurricane Mesa it appears that the low, rngged peak about 4 miles north of the gabbro eore consists of rough berts of breccia dipping steeply eastward. In the middle of the ridge which is being described there is a low arch of breccia beds that are rough and irregular. Higher np on the peaks to the west the bedding is more regular and dips at a low angle to the southwest.

At the eastern end of the ridge the breccias resting on the limestone are traversed by dikes trending $\mathrm{S} .10^{\circ} \mathrm{E}$. One of special importance is 3 feet wide and trends S. $25^{\circ}$ E. It rises 8 or 10 feet above the surface of the gromnd and exhibits horizontal prisms. It will be referred to again on accomlt of its composition and of the presence of large crystals of primary quartz.

The southeastem spur of Index Peak is cut by dikes trending northwest and southeast, and some more northerly. Numerous dikes cut the northern and northwestern spurs of the same momntain, and a few were observed on the ridges surrounding Republie Creek.

In the neighborhood of Cook City we approach another center of eruptive action, which manifests itself in the form of intrusive sheets of porphyry that occur within the Cambrian strata along the valley of Soda Butte Creek, and more especially in the mountains north of Cook City, just beyond the linits of the mapped area. Dikes of similar rocks cut the breccia of Mount Miller, one of the peaks of this group of momntains. Several intrusive sheets occur in the limestone south of Cook City, and are located on the map. They include a dense porphyry, a finegrained gabbro-porpliyry, and homblende-andesite. A few miles west of Cook City there are two small intrusions of dacite-porphyry. 
EXTENT OF EROSION.

As already stated, the rolcanic ejectamenta were thrown over the surface of greatly eroded sedimentary rocks. It appears from a study of the adjacent region that an apparently conformable series of deposits from Cambrian to the Laramie of the Cretaceous had been greatly dislocated and faulted, and in places entirely eroded down to the crystalline schists, before the rolcanic laras of Crandall Basin were erupted, thus representing a period of great orographic movement and denudation. It becomes equally evident from a study of some of the areas of voleanic rocks that, after the earlier of these rocks were extravasated, both orographic movement and denudation took place on a grand scale. The region of Electric Peak and Sepulchre Mountain exhibits the extent of the faulting which cut in two that andesitic volcamo. But in the region of Crandall Basin, which seems to have escaped serions disturbance since the accumulation of the basaltic lava, we may discover a measure of the erosion which has affected this portion of the comtry subsequent to the completion of this volcano, which must lave been active in upper Hiocene time. ${ }^{1}$ Howerer, it should be confessed at the outset that all such calculations must be of the crudest and most general character.

A consideration of the geological structure which has been briefly sketched, and which has been indicated on the map and in three vertical sections acress the district through the gabbro core, leads to interesting conclusions. 'The protile sections (Pl. XXXI) are dramn to natural scale and exhibit the steepness of some of the mountains. The first passes through the core in a direction N. $24^{\circ}$ E., and cuts Pollux, Parker, and Indian peaks, the narow ridge sonth of Hurricane Mesa, and the low hills north, ending in the grueiss on Clark Fork. The second lies N. $20^{\circ} 30^{\prime}$ W., passing from the divide between Candall and Sunlight basins, through the gabbro core and Index Peak, to the gneiss at the head of Soda Butte Creek. The third passes S. $77^{\circ} 30^{\prime}$ E., from Druid Peak across the ralleys of Soda Butte and Cache creeks, cutting the ridge of The Thunderer where it is narrowest, and, traversing nearly the whole length of Hurlicane Mesa, passes tluough the summit of Windy Mominain.

'The chatic accumulations of scoriaceons breccia and the occurrences of steeply dipping beds and lava flows throughout the area of Crandall Basin

' Hagur, Arnold, loc. cit., 1. 452, 
32 


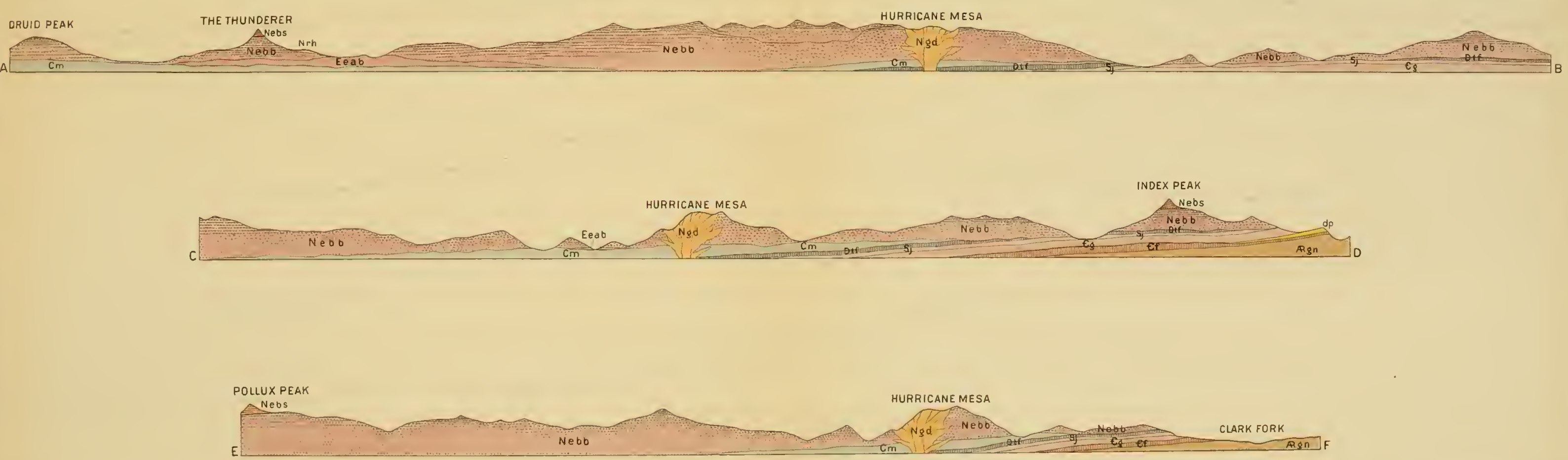

GEOAOGICAL, CROSS SECTIONS OF THE VOLCANO OF CRANI)ALI, BASIN, ABSAROKA RANGE

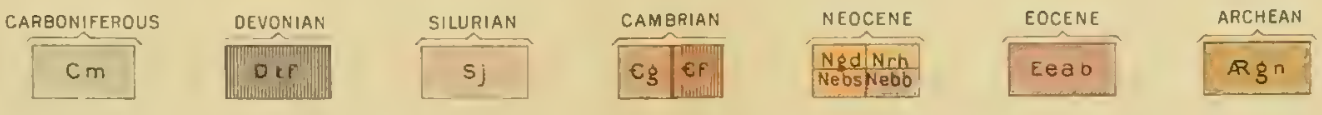

$$
\begin{aligned}
& \begin{array}{r}
1.25 \\
\hline
\end{array}
\end{aligned}
$$



and the country south of it show this to have been the scene of great voleanic activity, which shifted about from place to place, building up and blowing to pieces cone after cone of moderate propontions.

The uniformly bedded tuffs, breceias, and lava flows, which dip at angles not exceeding $5^{\circ}$ and form the mountains west and sonthwest of Crandall basin, show with equal clearness that they cover an area of inaction, where the ejectamenta and lava streams remaned mdisturbed during their acemulation. The same is true of the nearly horizontal beds of lava and breceia which cap chaotic breccias, as at Inclex Peak. Since they begun to accumulate the region beneath them must have remained quiet, however active it had been previonsly, for they exhibit no evidences of upleaval. These subaerial deposits and flows must have been derived from some neighboring center or centers of eruption. The slope of the lava flows toward the west and southwest and their petrographical character prove conclusively that they have been erupted and ejected from centers sitnated in Crandall Basin. While it is evident that the breccia within this basin and the lower portion of the bedded breccia surrounding it came from shifting vents, it seems necessary to assmme that the lava streams which occupy high positions near the summits of the present mountains must have flowed from still higher vents on the slopes or summit of some great rolcano. The exploration of the region has led to the discorery of one large central conduit and a multitude of radiating chamnels which extend to distances of from 7 to 12 miles from the center, besides another smaller center.

The great conduit and its radiating channels belong to a period succeeding that in which the chaotic breccia of Crandall Basin was thrown out, and to one in which the rolcanic energy had concentrated into one place, for the dikes from this gabbro core traverse the country in nearly straight lines, and have not been thrown into confusion by the breaking: out of new center's of eruption. They belong, in fact, to the latest phase of volcanic activity in the district.

The coarsely crystalline character of the rock at the top of the core, as it is exposed at 10,200 feet, as well as the topography of the country, makes it clear that very considerable erosion las taken place since the volcano was active. How great the erosion may have been will appear when the attempt is made to combine the facts just mentioned and to contpare them with what is known of great volcanoes which are still active. 
One of the largest and most thoroughly investigated active volcanoes is Etna, whose majestic cone rises from the sea to a height of 10,835 feet. According to the elaborate study of Etna by Sartorius von Waltershansen, as completed by von Lasaulx, ${ }^{1}$ the central mass and basal portion of this mountain consist of thick beds of tuff (or breccia) traversed by dikes of massive rock, filling clefts which are for the most part nearly vertical. Between the layers of tuff or breccia are sheets of crystalline rock. These are partly comected with the dikes, and have been injected horizontally in the tuff, or they are in part surface flows of lava. 'The beds in the central part of the mountain dip as steeply as $29^{\circ}$, and show by their positions and by the different groups of radiating dikes that the centers of eruption have been shifted from southeast to northwest. The lower flanks of the volcano are composed of more numerous lava flows, and slope at angles of from $2^{\circ}$ to $5^{\circ}$. These lavas liave been mostly erupted from lateral or parasitic cones, the arrangement of which on the surface proves that they all belong to groups in more or less straight lines which exhibit an exactly radial direction from the center of ermption-that is, the present crater of the rolcano. In the earlier period of the building of the mountain, as at present, fissures were formed from the center outward, radially. These fissures often lay close together, and were then almost parallel; through them the molten lavas rose and formed dikes; and where they reached the surface they gave rise to parasitic cones. Modern fissures that are radial to the present crater are those of $1669,1792,1811,1852,1865,1874$, and 1879. There are many others which are approximately radial, and others exhibiting no such arrangement. The lava flows on the flanks of the volcano have reached the surface through the radial fissures connected with the central conduit.

The profile of Mount Etna along a vertical section through the summit, from Catania to Randazzo, drawn to natural scale, is shown in Pl. XXXII. The scale is the same as in the profiles across Crandall Basin- $\frac{1}{125,000}$. The diameter of the volcano in the direction taken is about 27 miles.

Etna is of very recent age, geologically considered, for its lowest rocks rest on Diluvial, or Pleistocene, deposits, since which period it has piled up scoria and lava to a height of nearly 11,000 feet.

From the foregoing there appears to be a close analogy between the 
conditions at present existing in the active basaltic volcano of Etna and those which probably obtained in the basaltic volcano of Crandall Basin. In the last-1named region, as it is now exposer, four-fifths of the volcanic material is fiagmentary cjoctumenta, forming subaerial breccias of angular pieces of massive and scoriaceous lava with tuff or dust. But in the upper parts of the outlying momntains massive flows of lava predominate. In the case of Mount litna it is known that the central mass, as exposed in the Val del bove, is mostly fragmentary ejectamenta, but the surface of the volcano consists of lava flows to a very great extent.

In Vesurius there is a cone of much steeper slope, consisting largely of tuff-breccias, which dip at high angles in the slopes of Monte Somma. The latest eruptions, which form the cone of Vesuvius, have been quiet outflows of lava. A meridional profile of Vesuvius on the same scale as that of Etna is placed under the latter for comparison (Pl. XXXIl).

It is to be remarked that the subaerial breccias and tuffs of Monte Somma, while differing in mineral and chemical composition from those of the Crandall district, resemble them most closely in outward appearance and in the manner of their agglomeration. The subaerial breccias of the Yellowstone Park and its vicinity are for the most part more compact than those of Monte Somma, but exhibit the same structure. Many of them, however, present the same degree of cohesion and all the characteristics of recent ejectamenta.

The volcanoes of the Hawaiian Islands are said to be the results of non-explosive eruptive action, very little fragmentary material entering into the construction of the mountains. But it must be borne in mind that the central portions of the great volcanoes there are not exposed and their true character is not definitely known.

Assuming that the volcano which must have existed in the region of Crandall Basin resembled closely the type represented by Etna, and neglecting the erosion which undoubtedly removed material from above the outlying peaks of horizontally bedded lavas, we may gain some idea of the original form and proportions of this voleano by constructing above the profile sections through its center the outline of Etna, as represented in the plate of sections. Placing the crater of Etna over the center of the dikes of Crandall Basin (Pl. XXXII), and allowing its outer slopes to rest on the summits of the surrounding mountains, we obtain theoretical elevations of the 
Crandall volcano, which, if reckoned from the level of the ancient surface of the limestone in the neighborhood of the gabbro core, are 13,000, 13,400, and 13,800 feet. These results are sufficiently close to one another when it is noticed that the peaks used as datum points lie in an arc of $133^{\circ}$ and at distances of from 9 to 14 miles from the center-from Index Peak in the north to Pollux Peak in the soutl. Moreover, the highest altitude is obtained by using Pollux Peak as a base of reckoning, and this mountain lies within the radius of other volcanic centers near the head of Stinkingwater River, and has probably been built up by lavas from two great centers.

A volcano 13,400 feet in eleration with a radius of 20 miles is not so large as many in existence at the present day. The rolcanoes of Hawaii are familiar examples. Of these, Mama Loa, with an altitude of 13,675 feet, has a maximum radius of about 40 miles and a minimum radius of 20 . Mama Kea, 13,805 feet in height, has an average radius of 20 miles. These estimates, it should be remembered, are taken firom the sea line. 'The heights of these roleanic piles above their actual base, and the real diameters of their cones, are not known. The profile of Kea is shown on the same scale as that of Etma and has nearly the same outline (Pl. XXXII). A volcano with the profile of Vesuvius, if as large in diameter as Etna, would be 5,800 feet ligher, or about 16,600 feet in height.

The conclusion, therefore, that the ancient rolcano of Crandall Basin rose to an elevation of 13,400 feet above the preexisting surface of the limestone is within reasonable limits, and is probably too low. Upon this basis we find that the gabbro core in Hurricane Mesa must have solidified at a distance of 10,000 to 12,000 feet below the level of the ancient crater. Erosion must have removed 10,000 feet from the lighest portion of the volcano to the level of the momitain tops, and 4,000 feet more into the valleys between them, thus cutting 14,000 feet vertically below what was once the summit of the rolcano. At Index Peak the present topograply shows an erosion of nearly 5,000 feet from the summit of the peak to the valley of Clark Fork.

The foregoing estinnates were based on the assmmption that the tops of the lighest mountains of horizontal lava flows had not been materially affected by erosion; hence we must regard the calculated amomit of erosion as a minimum. There seems to be no way of avoiding this conclusion, 
unless we conceive the last act of vuleanism to lawe been the greatest and imagine a gigantic explosion to lave blown the upper part of the voleano into the air and to have left no evilence of snch a culmination of events. On the contrary, the evilence furnished by the structure of the gramular core indieates that the last eruptions were feeble, injecting narrow veins of rock into the bodly of the core.

It is to be remenbered that the erosion which has thus laid bare a basal section of so great a roleano was accomplished after the aceumulation of this rast pile of Dliocene ejections and before the extrusion of the immense flood of rhyolitie lava forming the platean of the Yellowstone Park. In the region of Electric Peak and Sepulchre Mountain there are evidences of orographic novement accompanying this period of denudation, shown in the profound finlting which cut in two that andesitic volcano; but the region of Crandall Basin seems to have escaped serious orographic disturbance.

\section{PETROGRAPIIY OF THE ROCKS OF THE DISTRICT.}

The extrusive rocks of the roicano of Crandall Basin are in the main the same as those found in varions parts of the Yellowstone Park, those of Sepulchre MLountain lraving been clescribed in Chapter III. It will not be necessary to repeat in cletail the characteristics of most of the rocks, but the petrographical features that are distinctive of this volcano will be fully described.

EARLY ACID BRECCIA.

The early acid breccia consists of small fragments and dust of homblende-mica-andesite, homblende-andesite, and hornblende-pyroxeneandesite. The microscopical characters are quite normal. The andesites are partly holocrystalline and partiy glassy. The structures of the groundmass are typical of andesites, and the phenocrysts of plagioclase, hornblende, biotite, hypersthene, and angite exhibit the usual characteristics. The color of the hornblende varies from reddish brown and brown to brownish green, green, and bluish green, and is often strongly pleochroic. In one occurrence there is a little quartz in microscopic phenocrysts. There is a considerable range of composition, and the rocks grade into varieties which are like the more siliceous andesites of the overlying breccias, a small portion of which is hornblende-pyroxene-andesite. They also appear to pass upward into the basic breccias in certain localities, though in others there are evidences of an intermission accompanied by erosion. 
BASIC BRECCIA AND LAVA FLOWS.

The basic breccia is, with some exceptions, dark colored, gray, and reddish brown, and is as a whole basaltic. Variations in mineral composition occur within narrow limits, and are most noticeable in the amounts of olivine and hypersthene. All proportions of olivine exists. According to the preponderance of one or the other the rocks may be classed as basalts or pyroxene-andesites, though their other characters remain much the same. Various modifications of the rock are mingled in the breccias, but to a different extent in different localities. In some cases the material is very uniform in its habit. Of the specimens collected two-thirds are basalt. Hornblende-bearing varieties are extremely rare, and occur in the neighborhood of the early acid breccia.

In most instances the rocks exhibit no large phenocrysts, but carry a multitude of minute tabular feldspars and somewhat larger pyroxenes, with more or less olivine. There are modifications of the rock-which are more numerons within the region of chaotic breccia-that carry tabular feldspars 5 to $8 \mathrm{~mm}$. long, and still others witl the same form of feldspar $30 . \mathrm{mm}$. long, the large feldspars being crowded with inclusions. The rocks are very generally vesicular and scoriaceous, but a part are dense and compact. In thin sections the groundmass possesses an andesitic habit, and consists of brown and red globulitic glass, which is occasionally colorless, with microlites of feldspar and grains of pyroxene and magnetite. In some instances it is opaque through an excess of iron oxide, and in other cases it is holocrystalline. The phenocrysts are plagioclase, angite, magnetite, and more or less hypersthene and olivine. The microscopical characters of these minerals are the same as in other occurrences in this region. A basalt with andesitic habit from Saddle Mountain is shown in Pl. XXXIV, fig. 3.

Hypersthene is more abundant as olivine is less so, and is absent from the rocks with much olivine. Occasionally hypersthene is surrounded by angite with parallel orientation. In some cases augite is brown at the center, with a zonal structure. In most cases it is pale green. The olivine is maltered in many occurrences and completely serpentinized in others. In general the rocks are very fresh, with slight indications of weathering, and only an occasional development of zeolites An unusual and interesting variety of the latter mineral was collected and investigated by Prof. L. V. 
l'irsson, who determined it to be mordenite.' Very glassy forms of rock are found in the breecia on the ridge south of Indian Peak. Some are fragments of black glass with a few small phenoerysts of tabular feldspar. Others are gray and exhibit spheroidal cracking, and constitute masses of considerable size. The black fragments are basalt-andesite glass, which is dark brown and almost opaque in thin section, with few scattered microlites. In some sections the glass is mottled and streaked witl light brown. The microlites consist of feldspar needles and grains of magnetite surrounded by halos of colorless glass, besides a few small augite crystals and serpentinized olivines. There are somewhat larger plagioclases with inclusions of brown glass. The chemical analysis of this rock (analysis 6 on page 260) proves it to be intermediate between basalt and andesite. The gray glassy varieties belong to pyroxene-andesite. In thin section this glass is colorless to light brown, with small crystals of plagioclase and fewer of magnetite, angite, and hypersthene, and in rare instances hornblende.

The variety of basalt with feldspar phenoerysts $30 \mathrm{~mm}$. long is characterized by a slightly different microstructure. The groundmass consists of tabular feldspars, composed of kernels of labradorite with margin of orthoclase, besides smaller augites and magnetite, throngh which are scattered larger microscopic crystals of the same minerals, with patches of serpentine. The phenocrysts are small megascopic labradorite, angite, decomposed serpentine and magnetite, besides extremely large tabular labradorite, with abundant inclusions of glass or groundmass. These basalts are intermediate between normal basalts and the shoshonite described in Chapter IX.

BASALT FLOWS.

The lava flows intercalated in the breccias are all basalt, with variable amounts of olivine, judging from the thirty specimens of them which were collected. None proved to be andesite. In general they come from higher parts of the volcano, and represent later phases of its eruption. But some of them occur among the earlier products, and while it may be said that the basalts formed almost the whole of the later outflows of the volcano, and that the magma became more basic up to this period, it must not be forgotten that the eruptions varied constantly within narrow limits, and that

IOn mordenite: Am. Jour. Sci., 3d series, Vol. XL, Sept. 1890, pp. 232-237. 
in the earlier history of the volcano this variation was within such a part of the chemical scale of variation that the resulting rocks might be called andesites or basalts, but that this difference of name corresponds to no greater difference in composition than that between the varieties of basalt of the later period. It is also probable that flows of pyroxene-andesite occur among the lava streams, but that they were not distinguished in the field.

The greater part of the basalt flows are andesitic in habit-that is, in microstructure-and are like the basalts forming the breccias. None of them are ophitic. The groundmass is in most cases glassy; in others, holocrystalline. Some of them carry large phenocrysts of feldspar and resemble the same variety of breccia in microstructure. Some contain a little orthoclase in the gromdnass, and are intermediate between normal basalt and shoshonite.

INTRUSIVE ROCKS.

OUTLYING DIKES.

As already pointed out, the dikes belong to several converging groups, the largest of which centers in the gabbro core and a smaller one in a focus a fer miles east, while a great number of dikes in the southern part of the district belong to an ontlying volcanic center sitnated near the headwaters of Stinkingwater River.

The rocks constituting these dikes exhibit more variation than the breccias, though the majority of them are like the breccias in composition and labit, being basalt. But toward the end of the period of volcanic activity, as we learn from the structure of the granular core, the composition of the magma became more and more siliceous, and the volnme of the lava erupted, or the size of the fissures from which we estimate this rolume, became smaller. At the same time we learn from certain dikes that peculiar phases of the magma made their appearance, the rocks of which deserve special consideration. It is to be remarked that while the most siliceous modifications of the magma occur within the core, the most basic phases of it are found at considerable distances from the center, with one exception. This accords with the idea that the more siliceous products of differentiation will occur near the center of the reservoir in which differentiation takes place, presumably beneath the cater of a rolcano, while the less siliceous products 
will ocenr near the maryin of the reservoir, away from the crater. ${ }^{1}$ Moreover, it is to be noted that while many of the exceptional modifications of the magma appeall to be connected with the center of eruption in Crandall 13asin, they are more numerous in the sonthern district, about the head of Stinkingwater liver. In describing the intrusive rocks we slabll commence with those which resemble most closely the breccias and surface Hows.

Basalts. -The basalts of the dikes exhibit the same megascopical habit and rariability as those of the breccias. Part of them have a multitude of small phenocrysts of tabular labradorite and augite, and part carry very large labradorites. They appear to be the same varieties of magma which have cooled in clikes, and consequently possess a slightly different groundmass. In a large number of cases the groundmass consists of lath-shaped labradorite and crystals of augite and magnetite in a small amount of microlitic base. 'The angite is occasionally slightly pleochroic. The phenocrysts are tabular labradorite, augite, and olivine, with magnetite and stout colorless apatite. In a number of dikes the groundmass contains orthoclase as margins around the microlites of labradorite. One of the most pronomnced of these varieties (1325) forms a dike on the ridge south of Closed Creek. Its chemical composition is given by the third analysis on page 260 . It is closely related to slloshonite, as pointed ont in Chapter IX. Others contain less orthoclase and are intermediate between shoshonite and normal basalt. To this variety belong most of the dikes at the head of Miller Creek and those eutting the summit of Saddle Mountain.

In some cases the groundmass contains microlitic and globulitic glass base; in other's it is holocrystalline. A glassy basalt from Hunter Peak contains microlitic needles of feldspar; slightly curved, and magnetite grains pointed at the corners, besides augite microlites with magnetites attached. In some occurrences these needles are coated with magnetite and resemble thin black lines.

It is often observed that the face of a dike along the plane of contact is glassy, while the center is holocrystalline. In one instance this contact facies consists of almost opaque brown globulitic glass with much iron oxide in minute rods, and thin feldspar needles witl long forked longitudinal sections shaped like an $H$, the groundmass extending to near the middle of

${ }^{\prime}$ L. V. Pirsson, Complementary rocks aul raliating dikes: Aw. Jour. Sci., 3d series, Vol. L, 1895, p. 120. IION XXXII, PT $11-16$ 
the crystal. Cross sections are square, with large square inclusions of groundmass. Ilmenite occurs in many of the rocks in rod-like crystals, and a small amount of serpentine is present in most of the groundmasses.

Olivine is decomposed to serpentine in most instances, and originally formed small as well as large crystals. In one of the fresher rocks the groundmass contains many small olivines, which are probably the mineral from which the serpentine in the groundmass of the more altered rocks was derived. As a whole, the basaltic dikes are not so fresh as the breccias surrounding them, although they are the younger rocks. Those with large tabular feldspars acquire a very characteristic appearance through the whitening of these crystals, which are strongly contrasted with the dark dense groundmass. The large dark-colored angites are also distinctly noticeable.

Gabbro- and diorite-porphyries and andesites.-The rocks which would be placed under this division in consequence of a microscopical examination probably belong quite as closely to the basalts. With one exception they all occur in close proximity to the granular core, and some of them are included in it. The one exception is a narrow dike of pyroxene-andesite, the groundmass of which is filled with serpentine, indicating the former presence of a magnesian mineral, possibly olivine.

The rocks of this division exhibit all of the modifications of megascopical habit shown by those just described, and resemble them closely in hand specimens. They are, however, more crystalline and present microstructures both distinctive and characteristic, which are related to differences in mineral composition. A few of the andesitic dikes which cut the summit of the plateau west of the core are very fine grained and are considerably altered, and contain chlorite and epidote.

The absence of olivine from most of the more crystalline forms of these rocks appears to be due to the causes which influenced the crystallization of the rocks and not to their chemical composition, for the hand specimens in some cases show what seem to be decomposed crystals of olivine, which in thin section are found to be paramorphs after this mineral.

This group of rocks includes the intrusive sheets on top of Hurricane Mesa and certain dikes. In the immediate neighborhood of the core and within the zone of indurated breccia the massive sheet of intrusive rock appears dense and aphanitic $(1359,1361,1369)$, and carries abundant tabu- 
lar feldspars 5 mun. long and large angites. In thin section it is holocrystalline, the groundmass consisting of short tabular and indistinctly outlined plagioclase, with low double refraction and noderately low extinction angles, besides considerable mignetite and minute grains of epidote and chlorite, which appear to replace pyroxene. The degree of erystallization, compared with the rocks of Electric Peak, varies from grade 8 to 16 . Throughout the description of the more crystalline rocks of this district it has been found convenient to refer to the grades of crystallization established for the series of rocks at Electric Peak and Sepulchre Mountain (Table XVII, Chapter III). This serves to correlate the various phases of crystallization of the rocks of Crandall Basin, not only with one another, but also with those of the district just named.

In the more crystalline forms of this rock the feldspars are more lathshaped, magnetite is abundant, and the ferromagnesian minerals are palegreen angite, some hypersthene, a little biotite, pale-green amphibole, and a little quartz. Apatite occurs in stout crystals. The phenocrysts are large, and are mostly labradorite in idiomorphic crystals and angite, in less regularly defined ones. The labradorite is especially noticeable on account of clouds of dust-like and rod-shaped inclusions, which give it a brownish tint, besides clusters and rows of rounded grains of magnetite, augite, and biotite. Immediately surrounding these larger inclusions is a zone of feldspar substance, free from the cloud of minute inclusions, indicating that the material composing the minute inclusions is the same as that forming the larger ones, which has been concentrated in certain spots into the minerals mentioned. This phenomenon appears in perfectly fresh feldspars which exhibit no cracks or signs of alteration, and in those which are greatly cracked there is no relation between the position of the cracks and the distribution of the inclusions, which frequently lie in crystallographic zones. They are unquestionably primary mierolitic bodies, inclosed at the time of the crystallization of the feldspar, and are not of secondary origin, like those described by Judd in the minerals of certain peridotites. ${ }^{1}$ In the unaltered rock the augite is fresh, and biotite appears as a primary crystallization, but not in phenocrysts. The amphibole is secondary and accompanies the uralitization of the angite. There are patches of inregularly

${ }^{1}$ J. W. Judd, On the Tertiary and older peridotites of Scotland: Quart. Jour. Geol. Soc., Ang. 1885, pp. 37t-389; also, On the relations between the solution planes of crystals and those of secondary twinning, etc. : Min. Mag., Vol. VII, pp. 81-92. 
oriented angite, magnetite, and biotite, which correspond to more definite paramorphs after olivine in some of the other rocks.

Similar rocks occur in dikes within lie margin of the core. They are slightly coarser grained. One (1378) forms a 4 -foot dike near the base of the pimacled spur on the west, and a still coarser-grained form (1418) occurs in a 12-foot dike on the same spur, somewhat nearer the center of the core; its grade of crystallization is about 20. The microstructure becomes more pronounced as the constituent crystals are larger and more distinct. The labradorite las the same kinds of inclusions, but the outlines are in part serrated by the interference of adjacent grains in the groundmass. The rusted paramorphs have outlines more characteristic of olivine. The massive intrusive sheet on the eastern side of the core (1372) is like the last in composition and microstructure, but there is a little more biotite. There is some orthoclase as margins around prisms of labradorite, precisely like the occurrence of orthoclase in shoshonite, but its amount is small. The chemical analysis, No. 11 on page 261 , shows a relatively high percentage of potash, and the rock is closely related to shoshonite, but is a little higher in lime and magnesia and a little lower in alkalies. It is almost a shoshonite-porplyyry or monzonite-porphyry. The two rocks are quite fresh, and exhibit no signs of crushing or other indications of alteration, the large feldspar's being glassy and not cracked. The microstructure of 1372 is shown in Pl. XXXVII, fig. 2. This rock is pyroxene-diorite-porpliyry approaching monzonite-porphyry.

Another variety of massive intrusive rock is exposed at the bottom of the southwest spur of the core $(1377,1379,1383)$. It appears to be a dense aphanitic form of the gabbro, and is probably an apoplyysis or the margin of the core. It is a basalt-porphyry. The porpliyritical crystals of angite rise above the groundmans of the rock on weathered and fractured surfaces. It is to be borne in mind that the chemical composition of this rock (analysis 4 on page 260) is the same as that of some of the basalts of the district, so that the rock is a special phase of erystallization of this magma.

In thin section the finest-grained forms have an andesitic structure in the groundmass. A sliglitly more crystalline variety is still andesitic, but consists of lath-shaped and rectangular plagioclase in a matrix of grains of feldspar, angite, hypersthene, and magnetite, hesides mimute crystals of light-brown biotite. In places the ferromagnesian minerals preponderate. 
In some cases the small platgioclases are clouder brown in the same manner as the larger ones already described. The phenoerysts are light-green augite and paramorphls after (?) olivine. The angite phenoerysts contain much magnetite in minute grains, which are sometimes arranged zonally. One of the thin sections contains several clusters of grains of grass-green augite, slightly pleochroic, which form borders around other minerals. In one instance they inclose grains of quartz, caleite, and pale-yellow garnet, the grains of garnet being mingled with those of augite.

A question now presents itself which is interesting because of its importance in discussions regarding systems of classification of igneous rocks, all of which systems are designed to be as natural as possible. The question is, Which of two lines of relationship is to be followed in a particular instance? We have described the subaerial breccias and lava flows together in a group, and then given with a description of the dikes and sheets of intrusive rocks of similar character. Shall we continue the description of the remainder of the rocks occurring in dikes, which exhibit a wider range of variation than those just described, or shall we follow the dikes continuously a few feet farther into the granular core and take up the consideration of their more crystalline forms? In the first instance we have a natural grouping based on similarity of occurrence and of outward petrographical habit-that is, of general aspect derived from their plase of erystallization, which is combined with variations in mineral and chemical composition. In the second case we have a natural comection based on actual continuity of mass, and when this is not directly traceable in the field the connection is one of identity of chemical composition. With these constant factors are combined the variable ones expressed by differences in mineral composition and in degree of crystallization. In nature these relationships either exist as accomplished facts in regions of extinct volcanoes or they are in process of development in regions of active ones. In the former they exist, not in two groupings such as we have depicted, but as one great complex system of relationships, involving variations in chemical composition and crystalline structure and still more intricate variations in mineral composition. While in regions of active vulcanism we may readily conceive of a number of processes of rockmaking being in action in different places at one time, in the vast complexity of rocks resulting from the working out of these processes it is the 
variable characters which express the active principles of vulcanism whose laws are the ultimate object of our investigations. Hence it is that in the treatment of intricate groups of rocks belonging to any one region we are constantly confronted by questions as to the best methods of studying and of describing the variability of the rocks. In the present instance it will be most advantageous to proceed with a consideration of the development of crystallization in the core of the volcano, postponing the description of the remaining dikes in order to connect them more closely with other bodies of similar rocks from different parts of the Yellowstone Park, which will be described collectively in another chapter (Chapter IX).

GRANULAR CORE AND INTERSECTING DIKES.

Gabbro and gabbro-porphyry.-The western and central portions of the granular core have been explored with as much care as the time allowed, but the eastern part below the summit of the platean was not visited. The main mass consists of coarsely granular rock intersected by dikes or veins from 20 feet to 10 inches in width, which are more noticeable in the margin of the core, where they exhibit a radial arangement. The character and composition of the granular rock vary to some extent. It is a gabbrothat is, it consists primarily of labradorite-bytownite and pyroxene, with biotite and very little, if any, hornblende, with some orthoclase and a little quartz, and grades into facies which are quartz-diorite. In places the alkalies are ligher than in normal gabbro or diorite and lead to the production of considerable orthoclase, yielding varieties of rock approaching monzonite, and in some cases being monzonite. ${ }^{1} \quad$ It becomes finer grained toward the margin of the core, and an idea of its microscopical characteristics is best obtained by following the changes from fine to coarse grain through two series of specimens collected for the purpose.

One series of nine specimens represents the modifications which have taken place within a distance of 100 feet. The finest-grained form (1388) is near the southwest margin of the core on the southwest spur, at a spot 225 feet ligher up the slope than the specimen (1383) already described, which was collected from the massive exposures and which has been called a basalt-porphyry. The two rocks resemble each other in the character of their phenocrysts, but the latter has a finer-grained groundmass.

' Brögger, W. C., Die Eruptivgesteine des Ḱristianiagebietes: II. Die Ernptionsfolge der triadischen Eruptiviresteine bei Predazzo in Südyrol, Christiania, 1895. 
'The first two rocks of the series $(1388,1389)$ are yellowish gray and erystalline, plainly composed of feldspar and ferromagnesian silieates, partly biotite, with small phenocrysts of augite. In thin section they are medium grained, grade 23 of T'able XVII, Chapter III, and consist of lath-shaped, and also short, rounded plagioclase erystals and some of orthoclase. The feldspars are very fresh, but contain a erowd of minute erystals of magnetite, biotite, pyroxene, and apatite. There is a large amount of ferromagnesian minerals in the rock. They are augite and hypersthene in rounded and irregular grains of variable size, besides biotite in very irregularly shaped individuals, and much magnetite. There are a few phenocrysts of augite crowded with magnetite grains in clouds and zones, and in some cases there are characteristic rod-like inclusions. Magnetite, pyroxene, and biotite frequently occur in irregular aggregations. Olivine is present in partly serpentinized individuals. The resemblance of many of these characteristies to those already deseribed for some of the intrusive masses immediately comected with the core will be recognized. The chemical composition of this modification of the rock (analysis 1 on page 260) is like that of basalt. The next two varieties $(1390,1391)$ are coarser grained, grade 27, with a slight modification of the previous structure, eaused by the presence of abundant phenocrysts of tabular labradorite in a groundmass with the structure just described. In places there is a poikilitic structure, occasioned by small rounded plagioclases and pyroxenes being inclosed in a broad individual of unstriated feldspar, which is undoubtedly orthoclase. These poikilitic feldspars act as the cement for the idiomorphic plagioclases and often equal the feldspar phenoerysts in size. There are traces of a graphic intergrowth of quartz in orthoclase. The rock is very fresh and unaltered. There is much hypersthene, angite, and magnetite, some biotite, and a little green hornblende. The labradorite is very clear and fresh, with some transparent rectangular inclusions resembling glass, and in some eases with many inchusions of mierocrystals of pyroxene, biotite, and magnetite. The augite has a purplish tone, is light colored, with many rod- or needle-like inclusions in the larger individuals. Besides the prismatic eleavage there is distinet pinacoidal eleavage. The hypersthene is light colored, with the usual pleochroism. It is occasionally in long prisms, with the color stronger along the margin. Some of the crystals have needle-like inclusions. In both pyroxenes these inclusions exhibit no 
comection with the cracks in the crystals, and are undoubtedly primary. The biotite frequently surrounds magnetite and is attached to it and the pyroxene. In one of the rocks there is a moderate amount of compact green hornblende, which forms borders and intergrowths with pyroxene in exactly the same mamner as in the diorite of Electric Peak. In one of these. forms of the rock one angite has, besides the rod-like inclusions characteristic of this occurrence, others which are immediately comected with distinct cracks and are undoubtedly secondary. This was the only instance of the kind noticed in these remarkably fresh rocks.

The next two modifications of the rock $(1392,1393)$ are still coarser grained, but have the same microstructure. The outline of the porphyritical feldspars is lost in an irregular interlocking of adjacent crystals. The poikilitic orthoclase is more distinct. In the next two phases of the rock $(1394,1395)$ the grain is still coarser, resembling that of a fine-grained granite. They have a saccharoidal texture in hand specimens, which is characteristic of the greater number of all of the rocks of the core. When broken they appear loosely coherent, the crystals parting along faces and cleavage planes rather than in smooth planes across the rock. The microstructure of these forms of the rock resembles that of the preceding, without the porphyritic development. The feldspathic minerals are in excess of the ferromagnesian. The largest-sized individuals of feldspar are the poikilitic orthoclases, but the lath-shaped plagioclase is far more abundant. Some individuals of orthoclase have a marked micrographic and plumose arangement of quartz inclusions, associated with which are long hair-like needles, which in places pass into lines of black dots. They also contain some microcrystals of mica. The ferromagnesian minerals are partly idiomorphic and consist of angite, hypersthene, green hornblende, and biotite in about equal proportions. It is to be remarked that in these gabbros the color of the hornblende is generally stronger and purer green than in the diorite of Electric Peak. The crystals of apatite and zircon are noticeably larger in these modifications of the rock than in the finer-grained ones. In specimen 1395 biotite occur's in liurge interrupted patches. This is characteristic of the coarsest-grained member of the series (1396), which is a gray granular rock that is exposed in large rounded masses, weathering into sand and resembling a crumbling granite superficially. In thin section it exhibits the same microstructure as the previous variety, but is still coarser, being 
grade 43, nearly that of the coarsest rock found at Electric Peak. The minerals are the same as in the last variety, but the ferromagnesian silicates are nore abundaut, uspecially biotite. 'The pyroxenes do not carry many microlitic inchusions. The micrographic structure in scattered patehes is pronounced. Olivine is abient from the more erystalline members of this series of specimens, and the chemical analysis (No. 8 on page 260) shows that the most crystalline portion of the rock is more siliceous and feldspathic than that nearer the margin of the core. 'These rocks are orthoclase-gabbro and orthoclase-gabbro-diorite, approaching monzonite.

Along the crest of the spur toward the northwest the gabbro becomes less coarse and more porphyritic, with abundant tabular feldspars (1397), and assumes the phase of crystallization represented by 1392 , already described.

Another series of specimens represents the gabbro just south of the lake at the head of the west gulch. The coarsest-grained variety (1430, 1431), near the outlet of the lake, is dark colored and granular, but not saccharoidal. It is like 1395 , the coarsest-grained form in the series first described, in degree of crystallization and microstructure, but contains more ferromagnesian silicates, and its chemical analysis (No. 5 on page 260) places it between the extremes of the other series. There is much augite with pinacoidal cleavage and characteristic needle-like inclusions, and less hypersthene, but numerous serpentinized olivines. There is considerable biotite and magnetite, a little orthoclase, and very little quartz. Its microstructure is shown in Pl. XXXIII, fig. 1.

The finest-grained member of this series is porphyritic and medium grained. The plagioclases are duster with black dots and rorls, the margin of the crystals and the smaller grains being free from them. The dots appear to be magnetite in large part, for when recognizable grains of magnetite occur in the feldspar they are surrounded by halos of clear feldspar substance.

Slightly different modifications of the gabbro occur in various parts of the core, some of which have been analyzed chemically, and should therefore be described in more detail than would otherwise be necessary, in order that the analyses may gain greater significance. The gabbro becomes still coarser grained down the west gulch, and a short distance below the lake is quite micaceous (1412). This rock and a large body of gabbro- 
diorite (1399) on the southwestern spur have the same degree of crystallization and the same characteristics. The microstructure is like that of the coarsest variety already described. The essential feldspar is labradorite with a small amount of orthoclase and little micrographic quartz. There are also allotriomorphic grains of quartz, against which the orthoclase is idiomorphic. There is much hypersthene, angite, biotite, and magnetite, with some primary green hornblende. The hypersthene in certain sections exhibits a very fine microscopic lamination, produced by the parallel intergrowth of monochinic and orthorhombic pyroxene, as the optical behavior proves. This lamination is found throughout the hypersthene of this gabbro, but is recognizable only in certain sections and may be easily overlooked. The pyroxenes lave the characteristic inclusions and pinacoidal cleavage. Apatite and zircon occur in comparatively large crystals. The chemical composition of this rock, shown in analysis 7 on jage 260 , is like that of 1396 , No. 8 of the same table.

The lowest exposure of gabbro in the west gulch is about 1,000 feet lower than the lake. It is compact (1437) and dark colored, and is like that near the ontlet of the lake, but is coarser grained, being higher than the highest grade of crystallization found at Electric Peak. One of the coarsest-grained varieties (1411) ocenrs near the lake (Pl. XXXIII, fig. 2). It is once and a half as coarse as the most crystalline diorite at Electric Peak; and on the crest of the west spmr, at about 10,000 feet altitude, a variety (1436) is found which is twice as coarse grained as that at Electric Peak. The feldspars are from 2 to $3 \mathrm{~mm}$. long. The structure is like that last described, but there is more feldspar, and biotite and hornblende predominate orer the pyroxene and magnetite. By its mineral composition as well as its chemical (analysis 9 on page 261) it is shown to be a dionite facies of the gabbro. In some parts of the core the dark-colored gabbro carries small light-colored masses, which are lighly feldspathic.

In this comnection may be described a remarkable variety of crystalline rock which does not occur within the gabbro core, but is found on the northeastern spur of Huricane Mesa, near the center toward which the second group of dikes converge. It is a special phase of crystallization of the magma, whose chemical composition (analysis 10 on page 261) corresponds to certain dioritic facies of the gabbro in the core. The rock (1442) is compact and fine grained, with a crystalline luster and brilliant reflections 

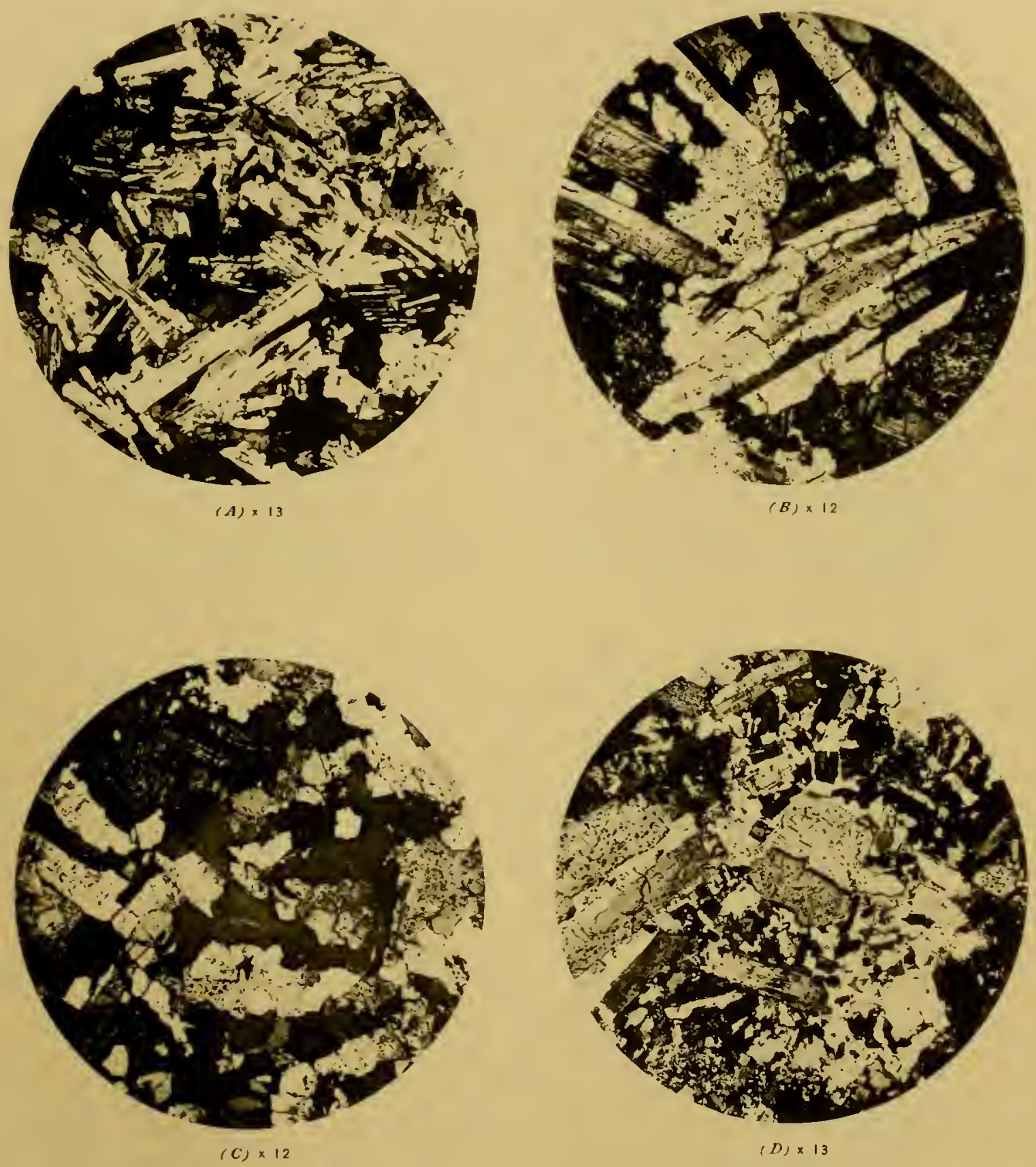

PHOTOMICROGRAPHS OF GABBRO, DIORITE, AND GRANITIC APLITE 



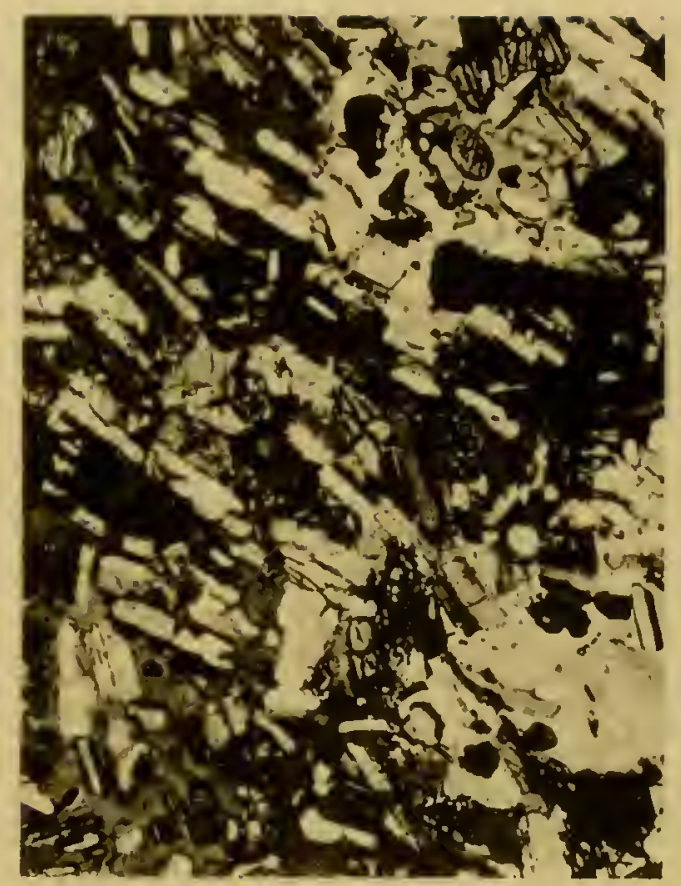

(A) $\times 28$

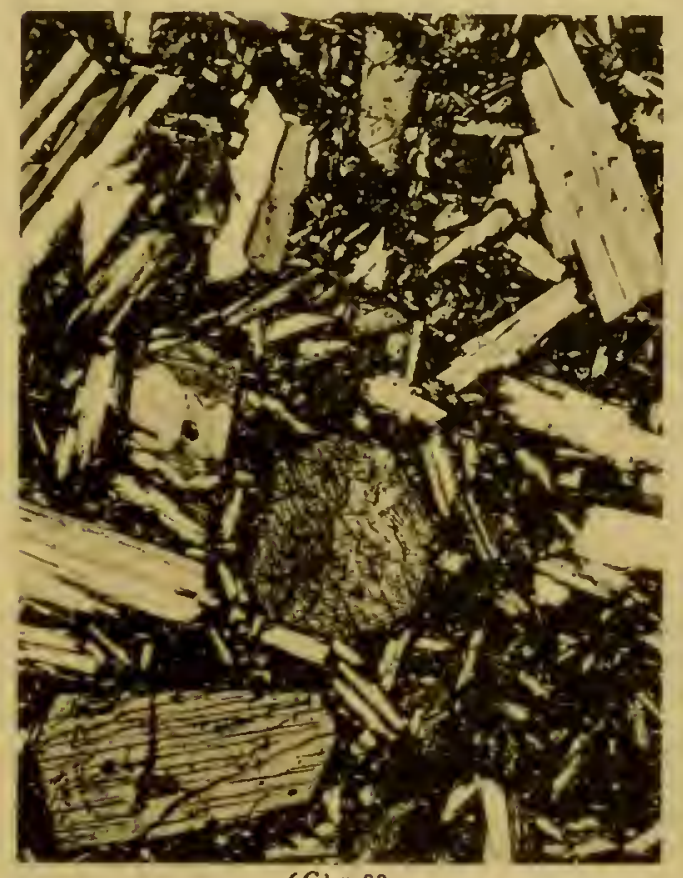

(C) $\times 28$

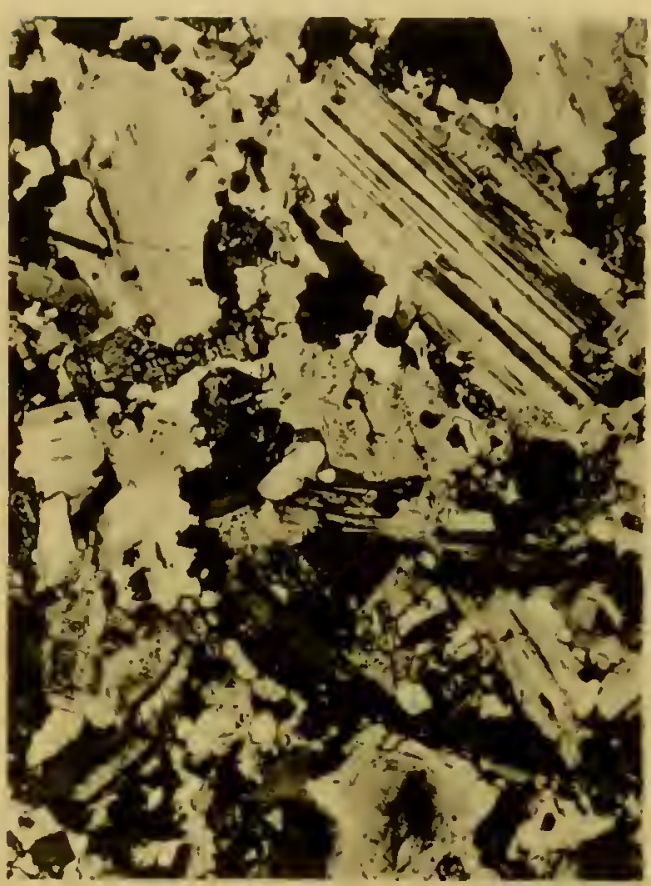

(B) $\times 28$

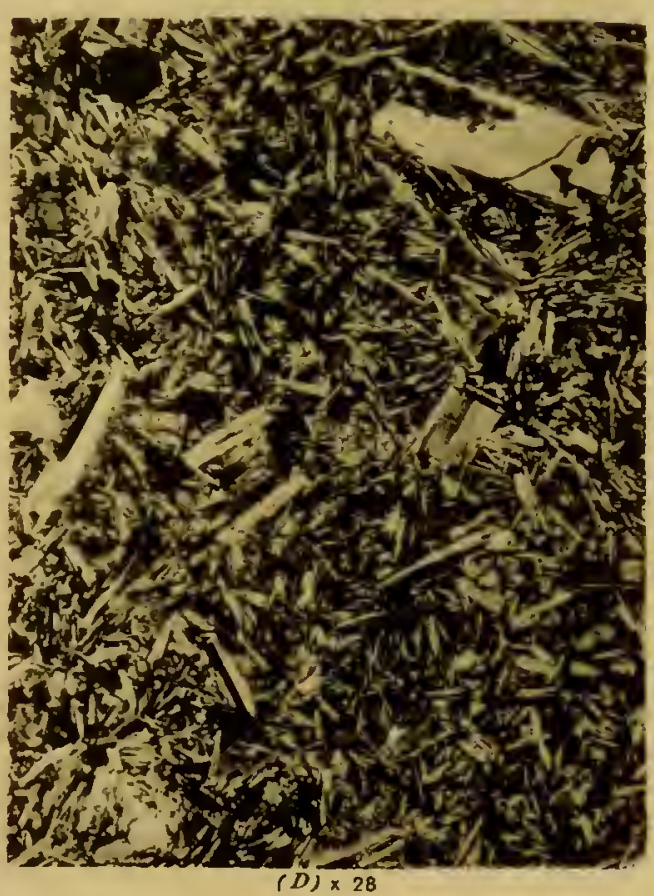



from mottled feldspars 3 mun. long, which are poikilitic. There are no phenocrysts. In thin section it consists of small, stont idiomorphic prisms of plagioclase which have the optical characters of labradorite, besides stout prisms of angite and hypersthene, partly idiomorphic, together with magnetite and a very small amount of biotite. These minerals are scattered irregularly in broad allotriomorphic individuals of orthoclase, which act as a cenenting matrix, but do not equal the plagioclase in amount. It is nearly a monzonite. There is a very little quartz. Its structure is shown in $\mathrm{Pl}$. XXXIV, fig. 1. Apatite occurs in stout and in slender prisms. The hypersthene is rery slightly altered in places; otherwise the rock is extremely fresh. The small amount of biotite is specially notewortly when the chemical composition of the rock is compared with that of 1396 . and 1399 (analyses 8 and 7 on page 260), both of which are rich in biotite.

Returning to the gabbro core, we have to consider a number of intrusions within the main body of granular gabbro and in the aphanitic marginal zone which form dikes representing finer-grained and porplyritic modifications of the gabbro magma. The size and distribution of the phenocrysts of feldspar and pyroxene show their relation to the rocks of the outlying dikes with porphyritical feldspars and pyroxene, as well as to those of the breccias and flows, while their microstructure comnects them with the gabbro. They present intermediate plases of crystallization between the two, and if followed continuously into the surrounding country would commect the granular gabbro with the basalt.

- Of these intrusions or dikes one (1398) occurs on the west spur, at 8,650 feet altitude, cutting the granular gabbro. In thin section it consists of labradorite with irregular outlines in a groundmass of rounded erystals of feldspar, augite, hypersthene, and maguetite, with some biotite and orthoclase and a little quartz. The structure is similar to that of 1383 , but is coarser grained. The phenocrysts of labradorite, angite, and hypersthene have the inclusions characteristic of the gabbro-porphyries.

Another dike of this rock (1413) cuts the galbbro near the outlet of the lake. The dike is 6 inches wide, and the rock is dark gray and crystalline, witlı the same microscopical liabit as the one just described. The microstructure is intermediate between the latter and 1388. The feldspars are dusted at the center, the outer portion carrying many small crystals of biotite, which is specially abundant in this rock. The third occurrence is 
a 2 -foot dike (1387) in the aphanitic zone. It resembles the preceding rock in outward appearance and has the same microstructure, but is coarser grained.

Diorite, quartz-mica-diorite, and diorite-porphyry.-The granular rock of the core changes to a more siliceous facies on the southern slope of the central round-topped spur. The structure of this part of the core will be better understood if its description is commenced at the base of the middle spur, where the lowest exposures of massive rock are dense and aphanitic and dark colored, like the rock at the base of the southwest spur. This is eut by dikes with parallel walls, but higher up the slope their form is not so regular and they widen out toward the center of the core, the rocks composing them becoming coarse grained $(1419,1420)$. The structure of this part of the middle spur is obscured by slide rock, so that any one body can not be traced far. Higher up the core is well exposed and the rock is found to be lighter colored, with a strong resemblance to medium-grained diorite.

The rocks from above 9,000 feet $(1425,1427)$, when studied in thin section, prove to be quartzose and feldspathic facies of the gabbro, with less ferromagnesian minerals, which have the same characteristics as those in the gabbro proper. Their degree of erystallization is about 40 , and the structure is more nearly gramular, since the orthoclase and quartz nearly equal the lime-soda feldspar in amount. They correspond to Brögger's banatite. ${ }^{1}$ The last-named mineral is almost idiomorphic and appears to be andesine. There is no micrographric structure. The rock at 9,300 feet altitude (1425) contains biotite, augite, hypersthene, magnetite, and a little hornblende. There is much. magnetite in the pyroxenes and biotite, but the rod-like inclusions are less common.

The rock (1427) 100 feet higher up has the same grain and structure as the last, but has less ferromagnesian minerals. The andesine, orthoclase, and quartz are the same, except that there is a little micrographic intergrowth of quartz and orthoclase. The orthoclase frequently surrounds plagioclase in parallel orientation. The ferromagnesian minerals are hornblende, biotite, magnetite, and a little pyroxene, which is inclosed and intergrown in the hornblende. The latter is idiomorphic and has an olivegreen color, which is like that of the hormblende in the diorite of Electric Peak. There are mumerous stout crystals of apatite and zircon. One

Brögger, W. C., Die Eruptivgesteine des Kristianiagebietes: II. Die Eruptionsfolge der triadischen Eruptivgesteine bei Prodazzo in Siidtyrol, Christiania, 2895, p. 65. 
zireon inclosed in homblente is surrounded by a plenclumic halo. The chemical composition of this rock (analysis 14 on page 261) is that of a quart\%-mica-diorite rich in orthoclase-that is, banatite.

Higher up the spur, at 10,000 feet, the main borly of rock (1429) becomes finer grained, the feldspars are more nearly idiomorphic, and the quartz forms large, irregular individuals with mieropoikilitic structure, inclosing small feldspars (Pl. XXXIII, fig. 4). T'he plagioclase is andesine, and contains rectangmular inclusions resembling glass. Orthoclase is not so alındant. There is considerable biotite, with angite, hypersthene, and magnetite, but no liornblende.

A still finer-grained form of this quartzose facies of the core occurs north of the top of the middle spur. It is a very fine-grained gray rock (1414), without phenocrysts. In thin section it exhibits a structure similar to that last mentioned, the idiomorphic labradorite-andesine having a border of allotriomorphic feldspar. There is a moderate amount of angite and hypersthene, which occur in groups of small grains rather than in compact individuals, besides magnetite and very little biotite. The chemical analysis (No. 13 on page 261) shows its resemblance to 1427 , as well as the chemical differences between them, which correspond to difference in mineral composition, the latter rock being richer in biotite, orthoclase, and quartz, with nore hornblende than pyroxene.

In some of the thin sections from the body of the core there are traces of decomposition, producing a little chlorite and serpentine, and in some cases uralite accompanying evidences of slight crushing in the feldspars. But the rocks are to a very great extent perfectly fresh and unaltered. The quartzose facies of the gabbro is younger than the main mass of more basic rock, for it is found cutting it as dikes. Thus, a fine-grainerl variety (1419), with the same microstructure and composition as the fine-grained form (1414) on top of the core, cuts the aphanitic zone of more pyroxenic rock at the base of the middle spur. It grades directly into more granular rock (1420), which has the structure and composition of the lower part of the main mass of the spur represented by 1425 .

There is also a 20 -foot dike of this quartzose variety which cuts the gabbro on the sonthwest spur at 9,100 feet and trends toward the sonthwest, while a body of similar rock, whose form was not observed, occurs on the crest of the same spur, more within the core. The rock from this body (1400) has the same composition as that at the base of the middle spur 
(1425), with more hornblende intergrowths. The pyroxenes have the characteristics of those in the gabbro. The microstructure is coarser than that of the 20 -foot dike, which is represented by specimens 1407,1405 , the finer-grained form (1405) being about grade 28 . Rock 1400 has less ferromagnesian minerals and resembles in ontward appearance the fine-grained rock from the top of the core (1414). Its structure is shown in Pl. XXXIV, fig. 2.

Two small dikes of similar quartzose diorite-porphyry cut the aphantic zone at the base of the west spur. 'They are dense and crystalline, without noticeable phenocrysts $(1385,1386)$. The coarser of the two resembles the rock last mentioned in microstructure, and is about grade 27. It has the same mineral composition as the finer-grained rock which occurs in a dike 1 foot wide. The latter (1385) differs from it slightly in microstructure, and is about grade 18. Its pliase of erystallization is specially interesting. In thin section it consists of lath-shaped feldspars of varions sizes, and small grains of feldspar, with considerable quartz, which has a micropoikilitic structure. The groundmass also contains magnetite, biotite, augite, and altered hypersthene. Its most notable characteristic is the development of small phenocrysts of orthoclase in Carlsbad twins with irregular ontlines. The outer portion of these crystals incloses the ferromagnesian minerals, and occasionally plagioclase. There are few phenocrysts of plagioclase. The orthoclase appears to belong to the period of crystallization when the quartz formed in poikilitic individuals of nearly the same size as the orthoclase, but inclosing more plagioclase. The outline between the quartz and the orthoclase is irregular. Thus the porphyritical orthoclase crystals are younger than the lath-shaped plagioclase and ferromagnesian minerals of the groundmass of the rock. The rocks are banatiteporphyry.

There are still more quartzose facies of the magma, which cut the dioritic facies of the middle spur in dikes or veins. $\Lambda$ coarsely crystalline variety (1428) forms a 4-foot dike cutting the main body of rock (1429), which is somewhat finer grained and has been described. The dike rock is about grade 40, and is like the main part of the spur lower down (1425), being of the same degree of crystallization. The microstructure is like that of the latter rock, but there is more quartz and feldspar and less 
ferromagnesian minerals, which are biotite and a little chlorite, but no pyroxene. Some of the chlorite carries zircon with pleochroie halos, and bunches of rutile needles. Magnetite, zircon, sphene, and stout apatite erystals are the accessory minerals. The rock is a quartz-mica-diorite, approaching granite in composition. It has the same microstructure, degree of erystallization, and mineral composition as the quartz-mica-diorite or hornblende-granite (323) which occurs at Electric Peak. The latter, however, contains hornblende besides biotite, and has no chlorite, which in the rock in Hurricane Desa may in part replace hornblende. The chemical composition of the rock at Electric Peak has been determined. Its silica pereentage is 66.05 .

A still more quartzose and feldspathic variety (1424) forms a vein 10 inches wide on the middle spur. It has the general liabit of the rocks of this facies, but is lighter colored and carries less ferromagnesian minerals. Its texture is saccharoidal. In thin section it has a granular structure about grade 40 , and is composed of quartz, orthoclase, and oligoclase, with biotite and magnetite, very little homblende, and some chlorite. The accessory minerals are the same as in the previous variety. It is a fine-grained granite, whose chemical composition is shown in analysis 16 on page 261. Its microstructure is shown in Pl. XXXIII, fig. 3 . There are also narrow veins of white rock, composed of quartz and feldspar, with little ferromagnesian minerals, and numerous small cavities lined with erystals of quartz and feldspar. These veins present the most highly siliceous facies of the rock.

A porphyritic form of the very quartzose facies also occurs on the middle spur. It is not noticeably porphyritic in the hand specimen (1423), but in thin section is distinctly so, with a granular quartzose groundmass, grade 23. It exactly corresponds in microstructure and degree of crystallization, as well as in mineral composition, to the quartz-mica-diorite-porphyry (331) of Electric Peak. The phenocrysts are biotite, andesine, and quartz, and occasionally orthoclase. Their outlines are nearly idiomorphic, but the quartz in some individuals loses its proper form by merging into the smaller quartzes of the groundmass in the manner described for the rocks at Electric Peak. There is considerable sphene and zircon. Its chemical composition (analysis 15 on page 261) is like that of the rock (329) of Electric 
Peak, and is quite the same as that of the quartz-mica-diorite (1427) in which it occurs. From its chemical composition it shonld be classed with banatite.

Less quartzose diorite-porphyries were collected from talus at the southwestem base of the southwest spur, and from that under the cliff west of the lake at the head of the west gulch.

Having been led from the petrographical study of the breccias and flows of glassy basalt and pyroxene-andesite along the converging lines of microcrystalline dikes of like composition to the coarsely granular core of gabbro of the same chemical composition which represents the highest phases of crystallization of these basaltic magmas, and having found the gabbro passing into more siliceous facies which lave been erupted after the main mass of gabbro, and from which have proceeded dikes of finer-grained rocks of similar composition, we may follow these more siliceons dikes out into the surrounding country, and consider in comnection with them the less numerous dikes whose variations of mineral composition express a still further development of facies of the basaltic magma.

'T'hese dike rocks exhibit a wide range of composition, and, together with the dikes already described, form a natural group. The latter represent the main body of magma in this region, of which the rocks to be described may be considered facies by differentiation, the rariations being, on the one hand, toward more siliceous and more feldspathic rocks, and, on the other hand, toward less siliceous rocks, some of which are highly feldspathic, while others are high in ferromagnesian minerals. These dikes appear to have been erupted after the greater number of basalt dikes were formed, but the exact relationship between them was not observed in every case.

Hornblende-mica-andesite-porphyries.-Commencing with the more siliceons varieties, we have a group of light-colored rocks in rarious tones of gray, which are compact, and are filled with small phenocrysts of feldspar, hornblende, and biotite. There is a striking similarity of habit throughout the rocks of the group, which corresponds to the labit of the fine-grained quartz-micadiorite-porphyries already described.

Within the granular core they form a few dikes, one of which cuts the gabbro on the crest of the sonthwest spur, and another, 10 feet wide, cuts it a little higher and trends west. These hornblende-mica-andesite-porphyries 
(1401, 1408) are not quite so rich in quaty as the diorite-porplyyries of the core, but they cary considerable quarty in the grommlmass, and a few crystals of it oceur as plienorrysts. Their crystallization is grade 23 in the first case, and grade 18 in the second.

Near the base of the west spur there is an 8-foot dike of this rock (1384), trending west of sonth, and still lower down the slope there is another (1381). A small dike of this rock euts the southwestern edge of the top of the middle sprur, and in the eliff west of the lake there is a 15-foot dike of it (1367), trending N. $45^{\circ} \mathrm{W}$. Besides these there are indications of other bodies of the same kind, fragments of which are found in the talus in various places. These rocks are fine grained, and resemble the remainder of the dikes of hornblende-mica-indesite-porphyry so closely that in general description will serve for all of them.

The ontlying dikes of this character are found in the immediate neighborhood of the core, the longest noted extending abont 5 miles to the sonthwest. A 10-foot dike of it forms the saddle northwest of the plateau of Hurricane Mesa and trends northwest, being in line with the 15 -foot dike west of the lake.

On the narrow ridge south of Closed Creek there are a number of these dikes, which cut the ridge at a place sonthwest of the core. Five were noted, three of which are 10,18 , and 20 feet wide and trend toward the south and southwest. They fork and branch out in these directions, and dikes of identical rock are exposer on the sonthern slope of the ridge, having the same general trends. They may be traced almost continuonsly, in some instances diagonally, across the steep spurs.

In thin section the rocks are holocrystalline and fine grained, ranging from grade 18 in the dike (1381) at the base of the southwest spur of the core to grade 10 in the most remote dike (1319), which is 4 or 5 feet wide. The habit of the rocks is andesitic, passing into that of andesite-porphyry at the more crystalline end of the series. The gronndmass consists of tabular plagioclase in a matrix of irregular grains of feldspar with a little quartz, besides idiomorphic crystals of magnetite, biotite, lornblende, and pyroxene. Throngh this are scattered larger crystals of the same minerals. 'The megascopic crystals are abundant, and are andesine-]abradorite owith zonal structure and variable smounts of inclusions; and idiomorphic homblende, brownish green with a brown borler, in places intergrown with angite in the MON XXIII, PT $11-17$ 
same manner as in the rocks of Electric Peak. Augite is pale green, and accurs in small amounts. Hypersthene is often lecomposed. Biotite is abundant in the groundmass of some of the rocks when it does not form large crystals. In other cases it is abundant as phenocrysts. Some of the more altered rocks carry chlorite and epidote. Apatite and zircon appear as accessory minerals. When the biotite has been altered to chlorite the zircon inclusions are sometimes surrounded by pleochroic halos.

There are more siliceous and feldspathic varieties of the rock, in which biotite preponderates over homblende. The groundmass carries less ferromagnesian minerals, and a distinctly micropoikilitic structure is recognized in the quartz.

From the foregoing it is evident that we have followed this facies of the magma from the core out into microcrystalline forms, which may be classed as andesitic forms of hornblende-mica-andesite-porphyry, or as holocrystalline andesites. The chemical analysis of the most distant dike of this rock (1319) (analysis 12 on page 261) shows that it belongs to a less siliceous phase of the general magma than the quartz-mica-diorite of the core. No highly siliceous dikes were found outside of the core in connection with this system of intrusions. Similar rocks occur in the neighborhood of Cook City in such a manner as to indicate the presence of another center of eruption near that place.

The more basic dikes which remain to be described, though they are scattered over the district and are somewhat sporadic, may properly be considered to belong to the Crandall center, since varieties of them occur within the core, although the extreme forms do not. They are less numerous than those just described, and vary considerably in mineral composition.

Hornblende-pyroxene-andesite.-There are only two of these dikes which may be classed as hornblende-pyroxene-andesite, but dikes of this rock are more numerous in the neighborhood of Cook City. One of these rocks (1317) forms a dike on the ridge northeast of Indian Peak and trends toward the gabbro core. The other (1368) was found on the top of Hurricane Mesa east of the core, but not in place. It carries large black crystals of hornblende from 10 to $20 \mathrm{~mm}$. long. Both of the rocks mentioned are compact, with hornblende, as the only prominent phenocrysts. In thin section the groundmass is andesitic and holocrystalline, and consists of lath-shaped plagioclase microlites with fluidal arrangement, hesides small patches of 
quarty with magnetite and altered pyroxene. 'The phenoerysts vary in amount and size, and are plagioclase, angite, and lypersthene, with larger crystals of hornblende, which is brown and brownish green and in one of the rocks lass a narrow bordel of matgnetite.

Lamprophyric rocks.- The remeaning dikes do not constitute a distinct group which may be sharply separated from the majority of the rocks of the district, though certain of them possess matked characteristics. Their ehief distinction is an musual mineral combination, but they are comnected with the ordinary rocks of the district by mineralogically intermediate varietics. In general appearance they resemble the rocks with which they are associated.

They are fine-grained rocks, characterized by an abundance of biotite and other ferromagnesian minerals, inchding augite and olivine, with feldspar subordinate in some cases, and partly alkaline, while analeite appears as a secondary mineral in some modifications of the rock. In other cases the rocks are distinctly feldspathic. Because of their unusual composition, and of the occurrence of similar rocks in dikes and lava flows in other parts of the Yellowstone Park, their petrographical description is deferred to Chapter IX, where they are classed as absarokites, shoshonites, and banakites, and are considered as exceptional facies of the normal magma of the region. They seem to represent less common differentiations of this magma than the more numerous rarieties of igneous rocks do, and for this reason may be discussed separately.

MINERAL AND CHEMICAL VARIATIONS OF THE ROCKS.

The rariations in mineral composition of the igneous rocks of this district are evidently dependent on more than the chemical composition of the magmas from which they have crystallized, rocks of the same or of similar chenical composition having different mineral components, which has also been shown to be the case at Electric Peak and Sepulche Momntain.

The range of mineral rariation among the extrusive rocks, when considered in the order of their eruption, is from siliceons andesites with biotite and homblende, through those with hornblende and pyroxene, to pyroxeneandesites, which grade into basalt by decreasing percentages of liypersthene and increasing amounts of olivine.

This is succeeded in a neighboring' part of the country by a recurrence of the same series from homblende-mica-andesite to basalt, and finally by 
rhyolite and basalt. There are three distinct periods of basaltic eruptions and an indefinite number of minor outbursts of the same rock. The study of the whole region shows the frequent recurence of certain lavas.

Among the intrusive rocks the mineralogical variations differ according to the phase of crystallization of the rock. In the finer-grained dike rocks they range from olivine-angite-labradorite-basalts, through those with little or no olivine, to hornblende-pyroxene-andesites and to still more siliceous mica-hornblende-pyroxene-andesite-porphyries, and in another direction to more basic rocks, which range from olivine-augite-mica rocks, through angite-mica rocks, to angite-hornblende-mica rocks with orthoclase and plagioclase.

There is also a mineral variation which accompanies the degree or phase of crystallization of the rock. It is illustrated by the transition from basalt to gabbro. The eharacter of the variation will be shown by a con1parison of the mineral composition of rocks whose chemical composition has been determined to be similar.

Analyses of rockis from the Crandall volcano.

\begin{tabular}{|c|c|c|c|c|c|c|c|c|}
\hline Constituent. & 1 & 2 & 3 & 4 & 5 & 6 & $i$ & 8 \\
\hline $\mathrm{SiO}_{2} \quad \ldots \ldots \ldots \ldots$ & 51.81 & 52.09 & 52.11 & 53.56 & 53.71 & 53.89 & 55.93 & 56.21 \\
\hline $\mathrm{TiO}_{2} \ldots \ldots \ldots \ldots \ldots \ldots$ & .77 & .39 & .53 & .68 & .74 & .49 & .81 & .88 \\
\hline $\mathrm{Al}_{2} \mathrm{O}_{3} \ldots \ldots \ldots \ldots$ & 15.24 & 17.84 & 16.58 & 16.07 & 18.00 & 18.81 & 18. 32 & 18. 24 \\
\hline $\mathrm{Fe}_{2} \mathrm{O}, \ldots \ldots \ldots$ & 3.66 & 4.27 & 3.66 & 3.21 & 3.99 & 4.92 & 2. 39 & 3.26 \\
\hline FeO & 4.86 & 4.56 & 4.99 & 5. 29 & 4.05 & 2.81 & 4.91 & 3.69 \\
\hline MuO ................... & .08 & .14 & .23 & .11 & .24 & .17 & .14 & .17 \\
\hline $\operatorname{Ig} 0, \ldots \ldots \ldots \ldots$ & 8.89 & 5.33 & 6.87 & 7. 23 & ร. 19 & 3.29 & $3.9 \bar{\tau}$ & 3.38 \\
\hline $\mathrm{CaO} . . . . . .$. & 9.06 & 8.03 & 6.43 & 8.77 & 6.88 & 5.12 & 6.17 & 5.91 \\
\hline $\mathrm{Na}_{2} \mathrm{O} \ldots \ldots . . . . . . . . .$. & 2.83 & 3.39 & 3.25 & 3.06 & 3.50 & 3.65 & 4.29 & 4.15 \\
\hline $\mathrm{K}_{2} \mathrm{O} \ldots \ldots$ & 2.08 & 1.98 & 3.20 & 1.94 & 310 & 2.98 & 2. 62 & $3.0^{\circ}$ \\
\hline $\mathrm{P}_{2} \mathrm{O}_{5} \ldots \ldots$ & .18 & .27 & .63 & .18 & .38 & .52 & .56 & .64 \\
\hline $\begin{array}{l}\mathrm{Ni} \cap \ldots \ldots \ldots \ldots \ldots \ldots \ldots \\
\mathrm{Cl}, \ldots \ldots \ldots \ldots \ldots \ldots\end{array}$ & $\cdots$ & $\cdots$ & • & $\ldots$ & ..... & $-\cdots \cdot \cdot$ & $\cdots$ & ... \\
\hline $\mathrm{H}_{2} \mathrm{O} \ldots \ldots \ldots \ldots \ldots \ldots$ & .67 & 1.77 & 1. 99 & .19 & .55 & 2.99 & .22 & .78 \\
\hline 'Total ............ & 100.13 & 100.06 & 100.47 & 100.29 & 100.33 & 99.94 & 100.33 & 100.33 \\
\hline
\end{tabular}

1. Gabbro-porphyry; core on Hurricane Mesa, Crinclall Basin (1388).

2. Basalt; flow, north side of Timber Creek, Cranlall Basiu (1252).

3. Iasalt; dike, rilge south of Hurricane Mlesiı, Crandall Basin (1325).

4. Basalt-porphyry; core, Hurricane Jlesa, Crandall Basin (1383).

5. Gabbro (with mica); core, Hurricane Mesa, Crandall Basin (1430).

6. 13asalt-andesite glass, breceia; ridge south of lndian Peak, Crandall Basin (1241).

7. Orthoclase-trabbro-dliorite (rich in raica); core, Hurricade Mesa, Crandall Basin (1399).

$\Varangle$. Orthoclase-gabbro-diorite (rich in mica); core, Hurri'alle Mesa, Crandall Basin (1396). 
Analyss of rockis from the ('randall rolcano-Continued.

\begin{tabular}{|c|c|c|c|c|c|c|c|c|}
\hline Constituent. & 9 & 10 & 11 & 12 & 13 & 14 & 15 & 16 \\
\hline $\operatorname{sio}, \ldots \ldots \ldots \ldots \ldots$ & $\pi .20$ & 57.32 & 57.61 & (il. 16 & 63.42 & 63.97 & 64.40 & 71.62 \\
\hline $1 \mathrm{riO}, \ldots \ldots \ldots \ldots \ldots$ & .76 & .62 & .77 & .23 & .35 & $.4 x$ & .40 & .08 \\
\hline$A l, O_{1} \ldots \ldots \ldots \ldots . . . . .$. & 19.40 & 17. 29 & 18.43 & 16.17 & 17.16 & 15.78 & 15. 77 & 14.99 \\
\hline $\mathrm{Fe}_{0}, \mathrm{O}_{3}, \ldots \ldots \ldots \ldots$ & 2.49 & 3.89 & 3.63 & 2.89 & 3. 09 & 2.35 & 2.47 & 1.27 \\
\hline $\mathrm{F} n \mathrm{O} \ldots \ldots . . . . . . . .$. & 3.29 & 3.03 & 2.81 & 2.18 & 1.50 & 1.87 & 1.15 & 1.01 \\
\hline$M n 0 \ldots \ldots \ldots \ldots \ldots . . . . . . .$. & $.16^{2}$ & .06 & .10 & Truet. & .04 & .05 & .04 & .17 \\
\hline 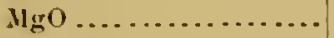 & 2.57 & 3.50 & 3.32 & 3.89 & 1.64 & 2.81 & 2. 12 & .74 \\
\hline $\mathrm{CaO} \ldots$. & 5.68 & 5.81 & 5. 49 & 4.26 & 4.65 & 3.71 & 3.54 & 1.33 \\
\hline$\ldots \ldots \ldots \ldots$ & 4.21 & 3.89 & 4.03 & 3.87 & 4.51 & 4.36 & 4.10 & 3.62 \\
\hline$K, 0 \ldots \ldots \ldots \ldots$ & 2.95 & 3.04 & 3.33 & 3.20 & 3.04 & 4.01 & 3.81 & 4. $\$ 1$ \\
\hline $\mathbf{P}_{i} \mathbf{O}_{5} \ldots \ldots \ldots \ldots \ldots$ & .51 & .50 & .31 & .13 & .26 & .40 & .16 & Trace. \\
\hline $\mathrm{NiO} . . . . . . . . . . .$. & $\ldots \ldots \ldots$ & .10 & $\ldots \ldots$ & ........ & .19 & Trace. & .17 & $\ldots \ldots \ldots$ \\
\hline $\begin{array}{l}\mathrm{Cl} \ldots \ldots \\
11,0 \ldots \ldots\end{array}$ & .86 & .63 & $\begin{array}{r}\text { Trace. } \\
.51\end{array}$ & 2.09 & 44 & .58 & 2.24 & $\begin{array}{c}. . .6 \\
.41\end{array}$ \\
\hline Total ............ & 100.14 & 99.74 & 100.43 & 100.07 & 100.29 & 100.40 & 100.37 & 100.05 \\
\hline
\end{tabular}

9. Dioritic facies of gabbro; core, Huricane Mesa, Crandall Basin (1436).

10. Monzonite; east core, Hurricane Mesa, Craudall Basin (144").

11. Pyroxene-diorite-porphyry, approaching mouzonite-porphyry; iutrusive sheet, Hurricane Mesa, Crandall Basin (1372).

12. Hornblevde-miea-andesite-porphyrs; dike, ridge south of Hurricane Mesa, Crandall Basin (1319).

13. Quartz-diorite (tine grained); core, Hurricane Mesa, Crandall Basiv (1414).

14. Quartz-mica-diorite; core, Hurricaue Mesa, Crandall Iasin (1427).

15. Quartz-mica-diorite-porphyry; core, Hurricane Mesa, Crandall Basiu (1423).

16. Aplite; dike in core, Hurricane Mesa, Crandall Basin (1424).

The chemical analyses show what is known of the composition of the surface flows, dikes, and stock rocks of this district, exclusive of those classed as absarokites, etc. Of these analyses, Nos. 1, 2, 3, 4, 5, 6, 7, 8, 9, 11, 12, and 16 were made by Mr. L. G. Eakins, and Nos. 10, 13, 14, and 15 by the late Dr. W. H. Helville, in the chemical laboratory of the United States Geological Survey. They are arranged according to the increasing percentage of silica, which varies from 51.81 to 71.62 . The range of silica is greater than in the rocks of Electric Peak and Sepulchre Mountain, most of the analyses showing less than 58 per cent silica. The more siliceous rocks in both localities are similar. The variability of the chemical composition of the rocks of this district has been discussed in another place. ${ }^{1}$ The analyses show that the basalts of the district vary in composition within certain limits.

'Iddings, J. P., The origin of igneon rocks: Bull. Philos. Soc. Washington, Vol. XiI, 1892, p. 151. 
Comparin $r$ the first three analyses $(1,2,3)$, it is seen how closely they agree with one another. The first has slightly less alumina and somewhat more magnesia and lime. The second and third are of basalts, the second being a surface flow, and the third a dike. They are rich in olivine, augite, and magnetite, without hypersthene. The third contains large phenocrysts of labradorite, and carries a little orthoclase in the groundmass. The first of the three analyses is of the finest-grained form of one of the series of specimens from the core, and is a gabbro-porplyyry. Its component minerals are plagioclase with much angite, hypersthene, biotite, and magnetite, and a little olivine. Althongh it is richer in magnesia and has only two-thirds as much potash as the third rock, it has developed a great amount of biotite, much hypersthene, and only a little olivine, while the third rock has abundant olivine and no biotite or hypersthene.

Comparing the next three analyses $(4,5,6)$, we find a close correspondence in chemical composition, with a smaller amount of alumina and alkalies in the first and a greater amount of iron, lime, and magnesia. The fifth analysis holds an intermediate place between the fourth and sixth. The greatest rariation is in the magnesia, which is twice as great in the fourth as in the sixth. The rocks represent three very different phases of consolidation. The sixth (1241) is a glass with few crystals of olivine, angite, and plagioclase, and microlites of magnetite, augite, and feldspar. The fourth is a fine-grained basalt-porphyry, composed of plagioclase, augite, hypersthene, biotite, and magnetite, with no olivine. The fifth is coarsely granular gabbro, composed of plagioclase with some orthoclase, a little quartz, much augite (diallage), some hypersthene, considerable biotite and magnetite, and a fer crystals of olivine.

The next two analyses $(7,8)$ are only a little higher in silica than the previous three, and are very similar to that of the basalt-andesite glass (1241) in all other respects. They are analyses of coarsely crystalline gabbro-diorite, which grades into less siliceons rock (1388) within a short distance. There are no analyses of extrusive rocks from this district with the same percentage of silica with which to compare them, but at Sepulchre Mountain there are andesites whose chemical composition has been determined, and with which these may be compared. 
Anulysess of andesites from Sepuledre Monutain.

\begin{tabular}{|c|c|c|c|c|}
\hline Constitnent. & $4 \div$ & til & 407 & 386 \\
\hline 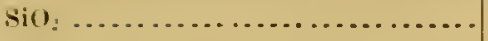 & $55.8 \times 3$ & 55.112 & 5 ti. 61 & 57.17 \\
\hline Tir): ............................. & 1.05 & .94 & $.7 !$ & 1.03 \\
\hline$\Delta 1,(0,1, \ldots \ldots \ldots \ldots \ldots \ldots \ldots \ldots \ldots$ & 17.11 & 17. 70 & 13.62 & 17.25 \\
\hline$F_{n} n_{1} \ldots \ldots \ldots \ldots \ldots \ldots \ldots \ldots$ & 1.07 & 3.16 & $\bar{i} .89$ & 2.18 \\
\hline 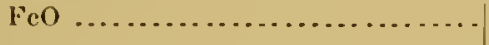 & 3.75 & 4.48 & $2.60)$ & 4.31 \\
\hline $\mathrm{H}_{110} \mathrm{O} \ldots \ldots \ldots \ldots \ldots \ldots \ldots \ldots \ldots \ldots \ldots$ & None. & Trace. & .35 & None. \\
\hline $\mathrm{CnO} \ldots \ldots \ldots \ldots \ldots \ldots \ldots \ldots \ldots \ldots$ & 7. 40 & 5.90 & 6. 61 & 6.61 \\
\hline 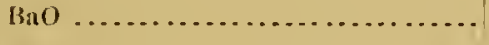 & $\ldots \ldots$ & $\ldots \ldots \ldots$ & .14 & ......... \\
\hline 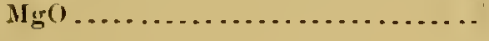 & 5.05 & 4.31 & 5. 48 & 4.83 \\
\hline $\mathrm{SrO} \ldots \ldots$ & & $\cdots \ldots$ & Trace. & ......... \\
\hline $\mathrm{Li}_{2} \mathrm{O} \ldots \ldots \ldots \ldots \ldots \ldots \ldots$ & Nonc. & .09 & $\ldots . . . .$. & Trace. \\
\hline $\mathrm{Na}_{2} \mathrm{O} \ldots \ldots \ldots \ldots \ldots \ldots \ldots \ldots \ldots$ & 2.94 & 4.08 & 3.13 & 3.41 \\
\hline$K_{2} \mathrm{O} \ldots \ldots \ldots \ldots \ldots \ldots$ & 1.71 & 2.28 & 2.71 & 2.03 \\
\hline $\mathrm{P}_{4} \mathrm{O}_{5}, \ldots \ldots \ldots \ldots \ldots \ldots \ldots$ & .21 & .18 & .06 & .05 \\
\hline 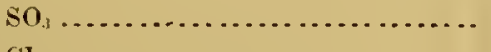 & 'Trace. & 'Trace. & (i) & Trace. \\
\hline C1 & None. & None. & None. & Trace. \\
\hline $\mathrm{H}_{2} \mathrm{O} \ldots \ldots \ldots \ldots \ldots \ldots \ldots \ldots$ & 1.28 & 1.42 & 2.27 & 1.20 \\
\hline Less $O$ for $(1 \ldots \ldots \ldots \ldots \ldots \ldots . . . . . .$. & 100.40 & 100.45 & 100.26 & 100.40 \\
\hline
\end{tabular}

These analyses are higher in magnesia and lime and a little lower in alumina and alkalies. The rocks from which they were made are pyroxeneandesite and hormblende-pyroxene-andesite, without mica or olivine. Their coarsely crystalline equivalents at Electrie Peak are pyroxene-andesiteporpliyry and pyroxene-mica-diorite. The rocks from which analyses 7 and 8 were made are orthoclase-gabbro-diorite. They consist of plagioclase with some orthoclase and a little quartz, much biotite, angite, hypersthene, and magnetite, and a little hornblende, but no olivine. When compared with the corresponding grannlar rocks at Electric Peak, they are found to differ from them in having less hornblende and more angite and hypersthene, with less quartz and considerable orthoclase.

The next three analyses in the table $(9,10,11)$ are slightly more siliceous, and are all from intrusive bodies. They are similar to the previous analyses, but the ninth shows more alumina and less magnesia. This rock is very coarse grained and feldspathic, and is a diorite facies of the gabbro. The tenth is the fine-grained monzonite with the poikilitic orthoclase and little biotite, besides much angite, hypersthene, and magnetite, and 
very little, if any, quartz. The eleventh is a pyroxene-diorite-porphyry approaching monzonite-porphyry, which is very fine grained and is composed of plagioclase, angite, hypersthene, magnetite, and some biotite and a little quartz, with no olivine, but paramorphs after olivine, now consisting of augite, biotite, and magnetite. It also contains microscopic feldspars, which are in part orthoclase.

The twelfth analysis is still higher in silica, with somewhat lower alumina, lower lime, and about the same alkalies. The rock is a dike of hornblende-mica-andesite-porphyry with phenocrysts of andesine-labradorite, hornblende, and biotite, besides a small amount of angite and hypersthene. The groundmass is microcrystalline, and consists of feldspar and the ferronagnesian minerals just named, with considerable magnetite. There is a little chlorite or serpentine. It is interesting to compare this rock with that of the Indian Creek laceolith.

The next three analyses $(13,14,15)$ are of diorites that form part of the core of the volcano. They have nearly the same percentage of silica, but that with lowest silica has highest alumina and lime and low. est magnesia and potash. This rock also differs from the others mineralogically. It is a very fine-grained rock without phenocrysts. It consists of labradorite-andesine and a small amount of orthoclase and quartz, besides a moderate amount of angite, hypersthene, and magnetite, and very little biotite. The second of the three, witl 63.97 per cent of silica, is of a coarser-grained quartz-nica-diorite, composed of andesine with a nearly equal amount of orthoclase and quartz, besides considerable biotite and hornblende, some magnetite, and a little pyroxene. The third of these three analyses is of a quartz-mica-diorite-porphyry, with abundant quartz. The phenocrysts are biotite, andesine, and quartz, and occasionally ortloclase.

It corresponds chemically to the diorite last described, and is alınost exactly the same mineralogically and structurally as one of the quartzmica-diorite-porphyries (331) of Electric Peak, and chemically it resembles another of those rocks (329).

The sixteenth analysis is of a fine-grained granite which forms a 10-inch vein in the diorite. It consists of quartz, orthoclase, and oligoclase, with biotite and magnetite, besides a very little horublende and some chlorite. 
From the foregoing it is evident that magmas which may crystallize into extrusive rocks whose essential minerals are plagioclase, angite, and olivine may crystallize into coarsely grannlar rocks with plagioclase, angite, hypersthene, and biotite, with a small amonut of orthoclase and quartz, witlı or without hornblende; and that olivine may be present in some cases, when the other magnesian ninerals will be less abundant.

Hornblende, which is so inportant a constituent of the diorite of Electric P'eak, plays a very subordinate rôle in the granular roeks of Hurricane llesa. liotite becomes more pronounced as the rocks become more granular. Hypersthene also develops under the same conditions. And orthoclase and quartz make their appearance in the granular equivalents of many basalts. Thus we find minerals that are characteristic of more and more siliceons members of the series of extrusive rocks developed in basic magmas under conditions which render the magmas more highly crystalline and more or less graunlar.

These minerals, then, are in part functions of the chemical composition of igneous magmas, while in part they are functions of the phase of crystallization of chemically identical or sinilar magmas. This is another demonstration of the law that "the molecules in a chemically homogeneous fluid magma combine in varions ways and form quite different associations of silicate minerals, producing mineralogically different rocks."

\section{CRYSTALLIZATION.}

It may be well to call attention to some of the conditions under which the molten magmas within the dikes and the core of the Crandall volcano must have solidified. Referring to the profile sections of the district and the probable outline of the ancient volcano (Pl. XXXII), it is evident that the magmas which cooled within that portion of the core which is now exposed, and those in the dikes within a radius of 2 miles, must have occnpied positions at nearly the same distance beneath the surface of the volcano. And if the former may be considered to have solidified 10,000 feet below this surface, then the latter mnst have solidified 10,000 feet below the surface. The one is as deep seated as the other, and yet their degrees of crystallization range from glassy to coarsely granular. The influence of pressure alone on the crystallization of these rocks is not recognizable in the size of the grain $o r$ in the phase of crystallization. 
The changes of crystallization may be traced horizontally in the immediate vicinity of the core, increasing from the outlying bodies toward the core, the change being rapid near the core and accompanied by induration and metamorphism of the surrounding rocks. It is in great measure independent of the size of the body, since narrow dikes within the core are coarsely crystalline, while much broader ones in the surrounding country are very fine grained.

It was mnquestionably the differences in the temperature of the core rocks and of the outlying breccias which determined the degree of crystallization. The core was undonbterly much more highly heated than the surrounding rocks, and the bodies of magma that solidified within it cooled much more slowly than those injected into the outlying parts of the volcano, or even within a mile of the central conduit.

From this it follow's that the application of the terms "deep-seated" and "abyssal" to coarsely crystalline rocks is misleading, since it is not distinctive and applies equally well to rocks of totally different crystalline characters. The depth at which a magma has solidified appears to be of little moment in comparison with the temperature of the rocks surrounding it.

\section{DEVELOPMENT OF PHENOCRYSTS.}

A consideration of the various mineralogical phases of rocks which have the same chemical composition, as they occur in this district, leads to important conclusions regarding the crystallization of phenocrysts. The great majority of the basaltic dikes carry porphyritical crystals of olivine, angite, and plagioclase in a microcrystalline groundmass of plagioclase, angite, and magnetite. In other varieties the phenocrysts are almost wholly olivine and angite. Within the core there are rocks with phenocrysts of angite and plagioclase, sometimes with olivine, sometimes with paramorphs after olivine. The outlines of these crystals show that their crystallization continued uniuterruptedly into the period of crystallization of the groundmass. These rocks are more generally the fine-grained forms. The greater part of the gabbro does not carry olivine, or at least only in occasional crystals, while the angites possess characters different from those in the basalt; besides which, hypersthene and biotite have developed in crystals as large as those of angite. It is also observed that the apatite and magnetite are differently developed, being in larger and fewer individuals in the coarse-grained rocks. 
From this it is eviclent that magnas of similar chomieal composition, which were crupted at different times, reached positions of like elevation within the volcano in different stages of crystallization. Some carried large crystals of plagroclase, angite, and olivine, some only augite and olivine, and others had no erystals developed in them. For, as shown in the chipter on Electric Peak (Chapter III), the molten magmas must have been completely fluid when they reached those places in the conduit where the character of erystallization referable to the surrounding conditions affected all of the constituent minemals, including the apatite and zircon.

From the fact that the magma which was forced into the outlying dikes must have been the advanced portion of that which stopped in the conduit in any particular eruption, and since the dike rocks are more usually porpliyritic, and the core or stock rocks show by their microstructure and mineral development that they were generally completely fluid when they came to rest in the conduit, it may be inferred that the phenocrysts of the dike rocks were formed in the advanced portion of the magma of a particular eruption, and that the rear part of the magma was in most cases free from them.

The magma having been assumed to be chemically homogeneous, and the influence of pressure not being recognized in the crystallization of these rocks, the most variable condition which remains is the temperature of the rocks through which the magma flowed, and the consequent difference in the rate of cooling of the advanced portion of the magma and of the rear portion. The former would cool more rapidly. While the magma advances through hot rocks it may cool gradually, but when it enters less highly heated rocks the cooling will be more rapid.

There are many reasons for conchuding that the phenocrysts of porphyritic rocks are the result of crystallization which has taken place very shortly before the final solidification or erystallization of the whole rock mass, and that they are comparatively rapid growths, and are not minerals that have existed within the molten magma for any considerable length of time prior to its solidification.

As indicating their rapid growth, we may cite the abundant inchisions of mother liquor with gas eavities, which are of common occurence in phenoerysts in extrusive rocks; and that they could not have existed for any great length of time within the molten magma is proved by the 
uniform distribution instead of the segregation of the heavier minerals in feldspathic magmas, such as phenocrysts of angite and magnetite in rhyolite. The speeific gravity of the former, about 3.3 and 5 , is so much greater than that of even the solidified magma in the form of obsidian, 2.3, that it is diftieult to imagine how fairly large erystals of these minerals could have remainerl suspended for any length of time in this matrix when it was in a fluid state.

Cross' las called attention to certain large crystals of orthoclase in dacite-porphyries ("quartz-porphyrites") and in granular diorites in Colorado, which appear to have crystallized after the magmas of these rocks had been ernpted and had come to rest. And Pirsson has presented, in a paper read before the eleventh ammal meeting of the Geological Society of America, further evidence of the relatively late growth of phenoerysts in many porphyritic rocks.

${ }^{1}$ Cross, W., The laceolitic mountain groups of Colorado, Utah, aud Arizona : Eourteenth Aun. Rept. U.S. Greol. Survey, 1895, p. 229. 


\title{
CHA P TER VIII. \\ THE IGNEOUS LOCKS OF THE ABSAROKA RANGE AND TWO OCEAN PLATEAU AND OF OUTLYING PORTIONS OF THE IELLOWSTONE NATIONAL PARK.
}

\author{
By Joserh Paxson Iddings.
}

\section{INTRODUCTION.}

The voleanic lavis that were erupted from the chain of ancient volcanoes situated along the eastem border of the Yellowstone Park, and from minor vents lying outside of this range, were to a very great extent tuffs and fragmental material. They were thrown over large areas of country, and often traveled long distances, so that after erosion had reduced the size of these vast accumulations of tuff-breccia, not only were the original forms of the bodies destroyed, but deposits that may have been at one time connected have become separate. Thus, it is not always possible to decide whether isolated areas of voleanic breccia belong to neighboring larger bodies or are the result of local eruptions.

In the present chapter no attempt will be made to describe the mode of formation or the history of the lavas of these portions of the Park, or the topographic features of the Absaroka IIountains. Descriptions of these will be found in chapters by Mr. Arnold Hague in Part I. The petrographic treatment of the rocks in this chapter will be confined to an account of their field occurrence and distribution and to a systematic description of their mineralogical characteristics and composition. The account of their occurrence and distribution must of necessity proceed along geographical lines, which may be followed either upon the map of the Yellowstone Park accompanying this monograph or on the atlas sheets of folio 30 of the Geologic Atlas of the United States, issued by the Geological Survey. For convenience, we shall start at the northerr boundary 
of the Park, and mention the lavas forming the mountains east of the Yellowstone River, from the northern boundary southward. Those in the vicinity of Soda Butte Creek and east of Lamar River hare been described in connection with the dissected volcano of Crandall Basin, but their mention again here will serve to make clear the connection of that volcano witl others that combined to form the Absaroka Range. In proceeding from the north southward, the rocks encountered will follow one another more nearly according to the order of their eruption, the youngest being found farthest sontl.

\section{EARLY ACID BRECCIA.}

The volcanic ejectamenta of the Absaroka Range rest upon crystalline schists and sedimentary rocks in the vicinity of the northern border of the Yellowstone Park. The contact is exposed along the valley of Clark Fork, Soda Butte Creek, Slough Creek, and lower Lamar and Yellowstone rivers. In all of these localities there are exposures of light-colored andesitic breccia, often variegated in color. These represent masses of various dimensions, sometimes very large. They rest immediately upon the schists and sedimentary rocks, and are overlain by dark-colored breccia. In some places the two grade into each other gradually; in others there is a welldefined plane of contact, and evidences of a period of erosion, between the deposition of the two breccias. The gradation between the two indicates continuous deposition, or that both belong to a prolonged series of eruptions, during which the composition of the lavas changed. A precisely similar relation between lower acid and upper basic breccias obtains at Sepulchre Mountain, where the rolcanic activity was synchronons with that of the volcanoes of the Absaroka Range.

Exposures of the early acid breccia are few, and their areas are comparatively small, in the region about to be described In the vicinity of Junction Butte, immediately over the gneiss there is tuff-breccia of light-colored acid andesite and trachytic rhyolite, quite the same as those west of Yellowstore River in the neighborhiood of Crescent Hill, and mndoubtedly part of the same formation. These breccia deposits have been more or less worked over by water and rearranged, and include many fiagiuents of gneiss and schist. Similar lavas and breccia with buff-colored tuff $(1025,1026,1032)$ and some massive hornblende-andesite (1024) form the top of the northwestern end of Specimen Ridge. The trachyte is brecciated with lumps of 
tuff and altered perlite having distinct perlitic structure (1027, 1028, 1031, 1032). Thachyte also forms the batse of Junction Butte, and rests upon the gneiss directly mortl. It also foms the banks of the river at the mouth of Slongh Creek. The and andesitic breceia extends several miles farther up the lammer River and is orerlain by a lava sleet of porphyritic bisialt (112!). The breceria is dense and dark colored and might be mistaken for hasic breccia, but contains much biotite and even minute phenocrysts of quatz. The aleil breccia is cut by a 3 -foot dike of pyroxenteandesite, which is dark colored and has small phenocrysts of pyroxene and feldspar (1038). The relative age of these rocks is thus plainly shown in this locality.

Mica-bearing andesitic breccia occurs at the northern base of Specimen Ridge, about a mile west of Crystal Creek. It is green, compact, and carries dark-colored fragments. It may be a mixture with more basic andesites. The only other exposures of the earliest acid breccia in this ricinity are in Cache Creek and near Cook City. These have been described in comnection with the Crandall volcano. The acid breccias in all of these localities are the same. But in some cases there is more or less of an admixture of basic material. Of course there are localities where the basic breccia rests directly upon the nonvolcanic rocks. Either the first acid breccia was not so extensive as the basic breceia or it was completely removed by erosion in some places.

The microseropical study of specimens collected from bodies of the earliest acid breccia shows it to vary in mineral composition, the varieties falling under three classes: Hornblende-mica-andesite, homblende-andesite, and hornblende-pyroxene-andesite. The fragments constituting any large mass often differ considerably among themselves in habit, color, and mineral composition. Sometimes their characters are nearly constant for large bodies of breccia. Massive bodies occur either as lava streams or as intrusive masses. In most places mica-bearing varieties abound. They are seldom absent. But the relative proportions of the different varieties is not constant enough to permit a close estimate to be made of the average composition of the whole. The following analyses represent the chemical composition of the three varieties, one of which has been already given in connection with the description of the Electric volcano. 
Analyses of rocks occurring in early acid breccia, Absarolia Range.

\begin{tabular}{|c|c|c|c|}
\hline Constituent. & 1 & 2 & 3 \\
\hline $\mathrm{SiO}_{2} \ldots \ldots$ & 61.56 & 61.61 & 67.95 \\
\hline $\mathrm{TiO}_{2}, \ldots \ldots \ldots \ldots \ldots \ldots \ldots$ & .87 & None. & .45 \\
\hline $\mathrm{Al}_{2} \mathrm{O}_{3} \ldots \ldots \ldots \ldots \ldots \ldots \ldots \ldots \ldots \ldots$ & 14.73 & 18.62 & 14.98 \\
\hline $\mathrm{Fe}_{2} \mathrm{O}_{3} \ldots \ldots \ldots \ldots \ldots \ldots \ldots \ldots$ & 4.47 & 2. 78 & 2.33 \\
\hline $\mathrm{FeO} \ldots \ldots \ldots \ldots \ldots \ldots \ldots \ldots$ & 1. 23 & .95 & .95 \\
\hline 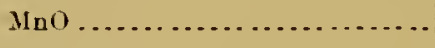 & .34 & Trace. & .09 \\
\hline $\mathrm{MgO} . . . \ldots \ldots$ & 3.57 & .85 & 1.42 \\
\hline $\mathrm{CaO} \ldots \ldots \ldots \ldots . . . . . . . . . .$. & 4.87 & 4.20 & 3.98 \\
\hline $\mathrm{BaO} \ldots \ldots \ldots \ldots$ & ...... & ...... & .23 \\
\hline $\mathrm{Na}, \mathrm{O} \ldots \ldots \ldots \ldots \ldots$ & 5.10 & 437 & 4.39 \\
\hline$K_{2} \mathrm{O} \ldots \ldots \ldots \ldots$ & 2.24 & 2. 36 & 2.86 \\
\hline $\mathrm{Li}, \mathrm{O} \quad \ldots \ldots$ & ...... & .01 & ....... \\
\hline $\mathrm{P}_{2} \mathrm{O}_{5}, \ldots \ldots$ & .04 & .30 & .07 \\
\hline 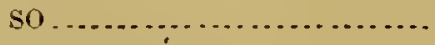 & $\cdots$ & $\cdots$ & .11 \\
\hline Loss at $105^{\circ} \ldots \ldots \ldots \ldots \ldots$ & & ... & .37 \\
\hline Loss red heat. ................. & ...... & $\cdots .$. & .61 \\
\hline \multirow[t]{2}{*}{$\mathrm{H}_{2} \mathrm{O} \ldots \ldots \ldots \ldots \ldots \ldots \ldots \ldots \ldots \ldots$} & 1.42 & .93 & $\ldots \ldots$ \\
\hline & 100.44 & 99.88 & 100.79 \\
\hline
\end{tabular}

The first is a massive rock in the early acid breccia near the head of 'Tower Creek. The second is from the breccia of Crescent Hill, and is above the average in percentage of silica, judging from the mineral composition of the breccia as a whole. The third is from early acid breccia of Sepulchre Mountain, and is considerably above the average for silica. It is probable that the average percentage of silica for the whole of these early acid breccias is 62 or 63 .

These rocks are nsually light gray, with greenish, reddish, and purplish tones, sometimes having darker colors. The appearance of the breccia is generally variegated. It may be loosely aggregated, but is oftener compact and indurated. The habit of the andesite fragments varies from those with abundant small phenocrysts of feldspar, biotite, homblende, and pyroxene to those with fewer and larger phenocrysts of the same minerals, which seldom exceed $5 \mathrm{~mm}$.

'The gromuduass is glassy in some cases, usually colorless glass filled witl rectangular and prismatic crystals of feldspar and fewer microscopic crystals of the other constitnent minerals, including pyroxene in many cases. Or the gromdmass may be microlitic with little or no glass, or holocrystal- 
line grading into micropoikilitic stmetures, which indicate that the rock fiagments are broken portions of volcunic cones where the lavas laad crystallized ats dikes and other intrusive bodies. The shape of the fragments, ustaily angutar, is such as to show that most of the breceia was formed by the explesion of athealy solidified lavas, which had consolidated near the centers of volcanic action. Ferr, if any, exhilit the slaggy surface of bombs.

The phenocrysts are sharply idiomorphic, and zonal structure is well developer in the feldspars, which often contain numerous glass inchusions. The feldspars are almost wholly polysynthetic twins, in the lime-soda feldspar series, their optical properties indicating oligoclase and oligoclaseandesine. Sanidine is seldom present; in fact, is almost entirely absent. It is found in some associated tuffs, but may have been derived from the trachytic lava occurring in the vicinity of Junction Valley. The feldspars are sometimes quite free from inclusions; in other cases they contain minnte crystals of the other constituent minerals, as well as portions. of the groundmass.

Biotite forms six-sided plates, often rather thick. Its color is brown to red, with marked absorption parallel to the plane of cleavage, and sometimes with strong pleochroism between orange, red, and light yellow. Greenish yellows also occur. Frequently the homblende exhibits the same colors as the biotite in the same rock, both being red, or both brown or greenish brown. Apparently the same cause affected the color of both minerals at the same time. Often the biotite is brown when the hornblende is greenish brown, or even green. Biotite resists decomposition longer than hornblende in many cases. It is often free from inclusions, but frequently contains magnetite, apatite, or zircon, and less often the other mineral constituents. In some cases it has a border of magnetite grains, or may be more or less completely changed to a pseudomorph of magnetite with or without pyroxene. This is usually accompanied by like changes in the hornblende.

Hornblende has its customary stout prismatic forms, usually with colors like those of biotite, but green tones occur more frequently than in biotite. The pleochroism is that ordinarily observed. Often free from inclusions, it sometimes abounds in them, glass and magnetite being the common kinds. Paramorphism to magnetite and augite occurs, as with biotite. Intergrowths with pyroxene are occasionally seen. Pyroxenes are more numerous in MON XXXII, PT II-18 
those rocks in which biotite is scarce, but both also occur together, accompanying horublende. The pyroxenes are monoclinic and orthorhombic species. Malacolite or angite is pale green in thin section, with no pleochroism. Hypersthene is more or less pleochroic with pale colors in thin section; green parallel to the prismatic axis, and reddish perpendicular to it. The optical characters are the same as those of these minerals in the pyroxene-andesites, and they will be more particularly described under that heading.

Quartz phenocrysts are occasionally seen in the more siliceous rocks approaching dacite in composition. Microscopic quartz is abundant in the groundmass of the more crystalline varieties.

Magnetite is always present in microscopic crystals, and appears to be the form of iron oxide common to this group of andesites. Titanium oxide is present in only small amounts. It is to be remarked in this comection that titaniferous iron oxide occurs in the rhyolites of this region, where it shows itself in the character of the alteration product, which appears to be lencoxene. Apatite, in short stout crystals, is nsually colorless, but is sometimes gray, yellowish, or red. The latter colors occur when the biotites and hornblendes are more or less reddened. Zircon is always present in small amounts and in minute crystals.

The subdivision of rocks into hornblende-mica-andesites, horublendeandesites, and hornblende-pyroxene-andesites is based on the relative proportions of the ferromagnesian minerals. All three-biotite, hornblende, pyroxene-may be present together, those in very small amounts being left ont of the name of the rock. In general, the first group is the most siliceous, the second next, and the third least of the three. But the transition through the mineralogical series is not strictly coordinate with the transition in the chemical series, so far as the silica is concerned. Moreover, we know that the mineral composition of a rock is not rigidly concordant with the chenical composition. So that rocks that might be classed as hornblende-andesite and others that are hornblende-pyroxene-andesite may be alike chemically.

As already said, some fragments of the overlying breccia are mingled in places with the acid breccia; hence the collections from these masses in some cases contain basic andesites, such as pyroxene-andesite. 


\section{WARLY BASIC BRECCIA ANI) ASSOCIATEI IBASAITIC FIOWS.}

This breceia includes all of the darker-colored hreccia, with some lightcolored breccia, which directly overlies the early acid breccia and which consists mainly of pyroxene-andesites, with some hornblende-pyroxeneandesites and basaltic andesites and basalts.

By correlation it corresponds to the basic breccia of Sepulchre Momtain and that west and sonth of the Gallatin Mountains. It constitutes the great accumulation of basic breccia that formed the bulk of the rolcano of Crandall Basin, inchuling the mountain masses from Index Peak, through those on both sides of Soda Butte Creek to Slongh Creek, south through Fossil Forest and Mirror Plateau, to the mountains surrounding the drainage of Lamar River and the drainage of Crandall Creek. Basic breccia connected with this extends along the mountain range east of the head of the Stinkingwater River and west up to the tributary canyons, and underlies the summits of the northern half of the Absaroka Range within the boundary of the Yellowstone Park.

Basic breccia forms the mountains north of Lamar River, including Bison and Druid peaks and the high ridges on both sides of Pebble Creek and Soda Butte Creek, the bedding in all of these masses being nearly lorizontal, with a slight dip toward the south. They appear to be contimuous with the breccia south of Lamar River, and, as already pointed out in Chapter VII, they may be considered as the outlying base of the Crandall rolcano. In these breccias pyroxene-andesite is the prevalent rock, hornblendic varieties being less common, and basaltic varieties subordinate.

Associated with these breccias-that is, intercalated in them at the baseare several sheets of basaltic rock, which are exposed in disconnected bodies along the bottom of the valley of Lamar River and Soda Butte Creek. They distinctly underlie the great mass of the basic breccia where they are exposed on Soda Butte Creek and near its junction with Lamar River. They also overlie some of the same kind of breccia. The characteristics of these basaltic rocks are sufficiently pronounced to distinguish them from a much more recent basalt, whose eruption was posterior to the excavation of the present valley of Lamar River, and which will be described later on. The older basaltic rock is found over the acid breccia and trachytic breccia in the vicinity of Junction Butte and about the mouth 
of Slough Creek. A remnant caps the breccia on the east side of Yellowstone Canyon, opposite the hot springs above Baronett Bridge (1126). It is dark, dense, and crystalline, with a slightly resinous luster. It has large tabular phenocrysts of plagioclase, some $8 \mathrm{or} 10 \mathrm{~mm}$. long, but none of angite or olivine. Another sheet of basalt at the north base of Specimen Ridge is dark and dense, with many mediun-sized phenocrysts of tabular plagioclase, and fewer of angite (1127). A somewhat similar basalt overlies the acid breccia just east of the mouth of Crystal Creek. It is dense and full of medium and large phenocryst of feldspar and augite. It is partly amygdaloidal with agate and quartz (1128). Over it is another sheet of dense basalt, dark and crystalline, with many large phenocrysts of rectangular and tabular feldspars, and fewer and less noticeable augites (1130).

A similar basaltic rock occurs farther east, at the south base of Bison Peak. It is dense, has a slightly resinous luster, and is filled with large brilliant feldspars and numerous smaller augites, and contains some amygdules of zeolite (1131). Similar basalt occurs at the southwestern base of Druid Peak (1132). It is underlain by a massive sheet, which is dense and crystalline, with abundant large phenocrysts of tabular plagioclase $10 \mathrm{~mm}$. long, and fewer and smaller angites (1133). Farther east, at the first gulch below the mouth of Soda Butte Creek, basalt sinilar to the last is exposed 200 feet above the river (1135). Three miles up Soda Butte Valley a basalt cliff exposes a sheet of dense black rock, with abundant small phenocrysts of feldspar and augite (1137).

These rocks have a peculiar mineral composition that distinguishes them from ordinary basalts. They are like some of the basaltic lavas occurring in the upper parts of this breccia, or overlying it, which are characterized by a varying content of orthoclase, and since they have never been described in detail their specific characters will be given in Chapter IX, which is devoted to a general description of all similar rocks occurring within the Yellowstone Park.

The basic breccias belonging to the main mass of the Crandall volcano, and forming the mountains on Cache and Calfee creeks and the body of Saddle Mountain, extend across Lamar River toward the west and south and constitute the basal portion of Mirror Platean and of the mountains between Lamar River and the head of Stinkingwater River.

Overlying this breccia in Mirror Plateau are numerous sheets of basalt. 
with some intercalated layers of scoria and breccia, forming a compound shect 700 to 1,000 feet thick. This massive sheet caps the northeastern spurs of Mirror Platean and forms the eastern half of its top, passing westward under rhyolite. 'The basalts of this sheet differ somewhat in outward appearance. Some are dark and dense, with small plienocrysts. Others have a semiwaxy luster and belong to the orthoclase-bearing varieties already mentioned.

West of the mouth of Coll Creek irregularly bedded basic breccia forms the lower thousand feet of the ridge between this creek and Willow Creek. Immediately over it is a sheet of porphyritic basalt, with phenocrysts of feldspar and pyroxene. This sheet is 200 feet thick, and constitutes the base of the broad shoulder which sets back from the steep face of the ridge.

East of the mouth of Cold Creek basic breccia forms the lower 1,500 feet of the northern end of the flat-topped mountain east of Pyramid Peak, and rises still higher in the next peak east, which is just beyond the one hundred and tenth meridian. Here, at 9,850 feet elevation, it forms the northern summit of the peak, the breccia being rough and unbedded and dark gray in color (1472). The northern face of the peak is precipitous, and consists of mdely bedded breccia canying masses 3 feet in diameter. The rock bears abundant phenocrysts of pyroxene and feldspar, and is mostly dark colored, in places red. On the sonthern slope of this peak it is composed of very small fragments (1473) in a purplish-red matrix.

Horizontal basalt flows cap the next peak south, whose summit is about 10,025 feet in altitude, and also form the top of the ridge to the east and the smooth table-topped mountain lying sontheast. The basalt on the peak is dense, with few phenocrysts of olivine $(1475,1476)$. It proves to be a leucite-bearing shoshonite, described in Chapter IX. Other flows of basalt in this neighborhood are more porphyritic.

The precipitous exposures on the ridge east, and on the south face of the twin peaks Castor and Pollux, show the lower.parts of these mountain masses to be made of similar dark, rough, and rudely bedded or unbedded breccia. But the upper thousand feet, above the 10,000-foot line, consists of nearly horizontal sheets of basalt of various thicknesses. The slope of the top of the table mountain south is at a slight inclination westward.

The basalt sheets extend westward across the saddle at the southeastern 
end of the flat-topped mountain east of Pyramid Peak, and form the upper 600 feet of this mountain, the bottom of the sheets lying at about 9,000 feet altitude, and resting on basaltic breccia. The character of the different sheets raries somewhat, a highly vesicular and strongly porphyritic basalt (1477) being found at the northern end.

Glaciation has left its marks upon the surface of these table-lands, having planed out lake basins and deposited rounded drift. The extension of the basalt sheets westward is clearly indicated by the topography of Pyramid Peak. From the saddle northward there is a flat bench or series of benches along the eastern base of the pyramidal peak, which broaden out into a flat-topped spur between the branches of Cold Creek. The basalt passes beneath the upper thousand feet of this mountain and descends steeply into the valley of Cold Creek, thence across a broad spur into Mist Creek, north of which it forms the basalt ledges already noticed, which are contimuons with those of Mirror Plateau.

The same or similar basic breccia, topped by sheets of massive basalt, continues southward along the base of the mountain forming the west wall of Stinkingwater Canyon, and extends far up the valleys draining the region lying east of the watershed of the Yellowstone Lake. As in the vicinity of Lamar River, these breccias and lava flows represent the ancient slopes of basaltic volcanoes lying east of the one hundred and tenth meridian. Along Jones Creek, Crow Creek, and Middle Creek basaltic breccia forms the lower portion of the eastern end of the mountain ridges. It is overlain by successive sheets of porphyritic basalt, which, on the northem side of Middle Creek, attain a total thickness of between 900 and 1,000 feet. In each of these three valleys the basalt ledges have given rise to high-shouldered spurs and benches on either side of the valleys, in the same mamner, as on Cold Creek. The surface of the basalt flows descends gradually to the westward, and disappears beneath more recent breccia in the heads of the valleys. The character of the basalt is similar to that near Lamar River. Some of the flows are full of large phenocrysts of feldspar and pyroxene (1530); others exhibit only large olivines (1527).

This early basic breccia, with its associated basaltic lavas of pecnliar composition, continues beyond the divide at the heal of Middle Creek, through Sylvan Pass, and forms the mountains and ridge as far as the shore of Yellowstone Lake at Signal Point. It also occurs in isolated patches at 
the heat of the southwestern branch of Middle Creek, and on the other side of the divide at the head of Rocky Creek, beneath more recent lightcolored acid breccial.

On the southern side of Sylvan Pass breceia of pyroxene-andesite is highly indurated by the many dikes that traverse it, and the pyroxenes are more or less uralitized. At the forks of Middle Creek, east of this, it is full of large phenocrysts of pyroxene and resembles much of the basalt of the Crandall Basin, and at Signal Point and near Park Point, on. Yellowstone Lake, there are hasilts and breccia of this type (1616-1619). Signal Ridge and the mass of Grizzly Peak are composed of pyroxenic breccia withont promment phenocrysts, with some olivine and little or no hornblende, while horublende appears in the breccia at the summit of Grizzly Peak (1521-1525).

An isolated exposure of basaltic rocks belonging to this series occurs at the head of the sontheastern branch of Beaverdam Creek and just north of Coulter Creek. At this place there are two horizontal sheets of porphyritic basalt, one upon the other, and over them is a light-colored tuff of trachytic rock, witl many inclosed fragments of basalt and andesite. This tuff corresponds to the trachytic tuff in the neighborhood of Junction Butte.

Almost precisely similar basaltic lavas and trachytic tuff occur at Two Ocean Pass, beneath the basic andesitic breccia which forms Two Ocean Platean, and though the exact period of eruption of these basaltic lavas, as compared with the basalts of the Crandall volcano, is a matter of uncertainty, still on purely petrographical grounds they may be described in this connection.

On the northern side of Two Ocean Pass there is a ledge of basaltic rocks composed of five sleets resting directly one on another. The basalt of the different sheets varies somewhat and belongs to the group of shoshonites. That of the top one is a dark, dense rock, with rather small phenocrysts of feldspar, angite, and decomposed olivine (1715). The top surface is red, the middle of the flow dense, and the bottom somewhat vesicular. The top has probably been eroded. The sheet below is similar, with numerous large feldspars and altered olivines (1716). . It is vesicular in the upper portion, dense in the middle, and slightly vesicular at the bottom, and is 25 feet thick. Beneath this is a layer of scoria 2 or 3 feet thick, having the character of the underlying flow, which is full of large feldspars, 
is dense in the middle, but vesicular for 2 or 3 feet at the bottom (1717). It is about 20 feet thick and is filled with zeolites (1722) and calcite, which line cavities and cracks.

This sheet rests directly on the slaggy, scoriaceous top of the next lower one, which is a basalt with only a few phenocrysts of pyroxene (1718). It is distinctly vesieular for some depth (1719). The lowest sheet is a dark, dense basalt with numerous phenocrysts of augite and olivine (1720). The top and bottom of the sheet are vesicular (1721). This basalt extends across the valley soutl. It rests on assorted basic breccia, and may be traced west along the northern side of the valley for 2 miles (1724), where it is similar to the upper two sheets at Two Ocean Pass. The more crystalline forms of these basalts have a slightly resinous luster.

The petrographical character of the rocks constituting the early basic breccia is variable within limits, and is slightly different in the two principal localities mentioned, Sepulchre Mountain and Crandall voleano. In all cases it is pyroxene-andesite in large part, grading into hornblendepyroxene-andesite on the one hand and into olivine-bearing andesite and basalt on the other. At Sepulchre Mountain the hornblendic end of the series is more pronounced and the basaltic end is subordinate. But it is to be remembered that the size of the mass of this mountain is insignificant when compared with that of the groups of mountains embraced in the Crandall volcano. The breccias more directly comnected with the Crandall volcano are largely pyroxene-andesites, only a rery small proportion of which carry hornblende. Basaltic forms are very abundant, and true basalts preponderate in the upper parts of the volcano. The bulk of this breccia lies within the district already described as the dissected rolcano of Crandall Basin, and its petrographical characters have been given in Chapter VII.

The basaltic lava flows or streams comected with this breccia, as already pointed ont, occur partly near its base, as do the flows exposed in the lower Lamar River Valley and in the valley of Soda Butte Creek. The greater part constitutes the thick accumulation of lava sheets forming Mirror Plateau and the summits of the mountains immediately south of Lamar River. The petrographical character of these rocks is somewhat variable. A large number of sheets consist of normal andesitic basalt-that is, basalts with abundant phenocrysts of lime-soda feldspar (labradorite-bytownite), 
angite, and olivine, and oceasionally hypersthene, in different proportions in different eases. In some rocks the phenocrysts are large; in others, small. Augite is usually the most prominent mineral. The groundmass is glassy and microlitic, or holocrystalline, with line-sodla feldspar, angite, and magnetite, and having the various modifications of microstructure characteristic of basic andesitic lavas. Olivine, which is abundant, is in some cases partly decomposed to green serpentine, in others to orange or red serpentine, which appears to pass into the mica-like mineral having similar colors and indices of refraction, but marked pleochroism, with strong absorption for rays ribrating parallel to the plane of perfect cleavage. The perfect cleavage appears to be parallel to some plame in the prismatic zone of olivine.

Other bodies of these rocks have an exceptional composition, and for this reason will be deseribed in detail in Chapter IX, together with other similar rocks in the region.

\section{LATE ACID BRECCIA.}

Overlying the massive basalts that top the early basic breccia, and in marked contrast to their dark-gray or black color, are breccias and tuffs of light-colored and brightly variegated andesites. This superposition is clearly shown in Pyramid Peak and on the flat-topped mountain east of it. West of the ponds on the latter mountain there are scattered exposures of compact and also of friable beds of light-gray tuff, composed of small fragments of homblende-mica-andesite and homblende-andesite, with larger rounded and subangular pieces of the same kinds of rock $(1481,1482)$.

Just west of the saddle east of Pyramid Peak the basalt is exposed with overlying beds composed of fine grains of homblende-mica-andesite, acting as a cement for fragments and rounded masses of vesicular basalt, similar to the basalt of the neighborhood. Above this the pyramidal mountain is formed of light-colored andesitic breccia and tuff to its summit. The whole mass is exposed in bold escarpment, and consists of nearly lorizontal beds of tuff and breccia, with layers of large fragments that are subangular, rounded, and also angular. There is great variety of color and habit in the andesite. The greater part is hornblende-andesite, some is hornblende-mica-andesite, and some pyroxene-andesite; portions of it are dense and compact, other portions porous. The beds are brown and gray, some being very thick without distinct bedding. At the southern end of 
the escarpment there is much gray ash with leaf impressions $(1478,1479$, $1480)$.

Similar light-colored breccia extends south and west and forms the npper part of the mountain ridge throngh Cathedral Peak, lying between Cold Creek and Jones Creek. It constitutes the main mass of Mount Chittenden and the low mountains north to Raven Creek, and beyond to Pelican Cone and the ridge west $(1160,1161)$.

In these low mountains the character of the andesites constituting the breccia varies considerably, and acid and basic andesites are often intimately mingler, many fragments being homblendic, while others are wholly pyroxenic. However, it is evident in numerous places that the more siliceous and hornblendic andesites predominate in the lower parts of the mass, and are overlain by distinctly later accumnlations of basic andesite. Thins, at the falls on Raven Creek, at about the 8,200-foot contour of the map, and within a short distance of the limits of the older basalt, hormblendeandesitic breccia is exposed in indurated beds which carry rouncled bowlders of the same rock. It is also found immediately south of this point on the summit of the ridge, where it is capped by dark-colored basic breccia, which is well bedded in places.

On the sonthern side of the meadow at the head of Mist Creek and near the limits of the older basalt, compact breccin of hornblende-andesite is exposed in such a nanner as evidently to be over the basalt, although an immediate contact was not discovered. Similar breccia, not so indurated, however, forms the ridge sonth of this locality. Many of the fragments are light colored, with phenocrysts of feldspar and horublende; others are darker, have less noticeable phenocrysts, and are more pyroxenic (1483). At the knob about the middle of this ridge the hornblendic breccia is capped by a remmant of dark-red basic breccia, the line of contact between the two being plainly visible (1484). Similar relations exist between hornblendic breccia and basic breccia on the ridge across the head of Mist and Cold creeks $(1485,1486)$. The varions altitudes at which the overlying basic breccia is found indicate a very irregular surface for the previously accumulated hornblendic breccia.

The breccia west of Raven Creek forms the mass of Porcupine Cone, which is hornblende-pyroxene-andesite at its summit (1159), mostly light colored. West of the mud springs on Pelican Creek similar andesite occurs, 
that on the top of the ridge being hornblende-mica-indesite $(1160,1161)$. Resting upru the grreat sheet of basalt on top of Mirror l'lateau are areas of andesitic breecia with light-graly tuff. In the ricinity of Mirror Lake the lighti-gray tuff is composed of bits of homblende-mica-andesite (1158), biotite not being very plentiful. Near the falls on Raven Creek the tuff is gray and fine grained (1157), and consists of particles of hornblende-pyroxeneandesite with much homblende. The light-colored breccia of Mount Chittenden is bedded in its northem spur, and carries hormblende and some biotite. The andesitic fragments are subangnlar; many are glassy and light colored; some are pyroxenic and vesicular (1487). Similar breccia forms the western spur (1492). At the northern part of the summit of the peak the breccia contains many large masses of hornblende-andesite with abundant hornblendes (1488 to 1497). The acid breccia in the eastem base of the mountain summit and around the head of Jones Creek is without bedding and occurs in irregularly accumulated bodies. It is overlain by dark-colored, well-bedded basic breccia, consisting of small angular fragments. This is distinct along the crest of the ridge east toward Cathedral Peak and on the sonthern slope of the summit of Mount Chittenden and along the crest of the ridge to the south and southeast. A broad dike of hornblende-andesite-porphyry cuts the sonthem summit of Mount Chittenden, and will be described with other dike rocks.

The character of the upper basic breccia is basaltic on the summit of IIount Chittenden (1504 to 1507), without prominent phenocrysts. Farther sonth, beyond the pass, it is dark pyroxene-andesite (1514). The underlying unbedded breccia at the top of the ridge south of Mount Chittenden is mostly pyroxene-andesite $(1513,1515)$ with little or no homblende. It extends down the long spur westward to Lake Butte, where it overlies massive hornblende-mica-dacite $(1509,1510)$. This rock is light colored; gray and red, with abundant small phenocrysts of quartz, feldspar, homblende, and biotite. It is extremely porous and appears to have been a surficial lava.

Hornblende-andesitic breccia forms the ridge around the head of Crow Creek to Avalanche Peak and its western spur, which lies north of Clear Creek. Just north of Avalanche Peak the breccia is dark colored and homblendic, without bedding, and carries large blocks of hornblendeandesite from 3 to 8 feet long (1511). Northward it passes into lighter- 
colored breccia. The northern face of Avalanche Peak is composed of unbedded breccia, while the breccia of the northwestern spur is bedded. At the northern end of the smmmit of the peak it is variegated and full of hornblende phenocrysts (1516). Hormblende-andesitic breccia forms the main mass of the peak sontheast of Avalanche Peak, and extends along the crest of the mountain ridge eastward between Crow and Middle creeks. Here it rests upon the basalt sheets already mentioned. Sontli of the peak on this ridge, 13 miles west of the one hundred and tenth meridian, it is well exposed in bare bluffs and spurs. It is light-colored, variegated, and well-bedded breccia, mostly homblendic, some fragments having abundant pyroxene phenocrysts $(1528,1529)$.

It is overlain by massive laminated andesite, which is rndely columnar, and forms the high peak just mentioned. This mass was undoubtedly a surficial flow over an uneven surface of breccia which sloped to the north and also to the south at this point. The mass is at present about 400 feet thick, and at its base is dense, gray, and crystalline, with no prominent phenocrysts (1614). Farther east on the crest of the ridge, and 400 feet lower, the same massive andesite forms a capping to the breccia. It is laminated and finely columnar, having large vertical columns in the middle, and smaller ones beneath, with irregular parting at the top (1615). Near it the breccia consists of similar pyroxene-andesite. It can be seen from this ridge that light-colored breccia forms the crest of the ridge north of Crow Creek and overlies the basic breccia and basalt sheets constituting the base of the ridge. The light-colored breccia is in turn capped by massive columnar lava on Silver Tip Peak and on the next peak east. Another remuant of massive andesite rests on the breccia at the head of Crow Creek. It is about 200 feet thick, is jointed horizontally, and consists of homblendeandesite with inconspicuous phenocrysts (1512).

From the summit of the ridge north of Middle Creek it also appears that the mountain mass sonth of this creek is similarly constructed, its lower portion of basic breccia, with basalt sheets, forming high, flat-topped spurs about 1,000 feet above the valley. The upper portion consists of a high ridge of light-colored, well-bedded breccia, with a number of pimnacles on its northern slopes, the pinnacles being beautifully cohmmar, dark-colored rock. The southwestern end of the upper part of this ridge has been visited, and consists of light-colored breccia of hornblende-andesite. The high peak 
on this ridge 4 miles nortleast of Momnt Langford, when seen from the soutlwest, appears to consist of indurated lightit-colored breccia, traversed by umerous dikes. The same ridge a mile southwest of this point is cut by ten dikes within a distance of a mile, and the breceia composing the ridge at this place is hornblende-andesite, with abundant lormblende in most eases, and often with very light-colored tuff. The dikes of this vicinity will be described in connection with the great system of dikes at Sylvan Pass. The light-colorerl hombleudic breccia, which has been traced from its northern linit in the neighborliond of Lamar River, continues southward as far as Iountain Creek. It forms the mountain ridges around the southern head of Nirldle Creek, being well exposed in precipitous amphitheaters on either side of Monnt Langford. The rude bedding of the mass east of the latter peak is abont horizontal. The character of the breccia in places is very variable, but is distinctly hornblendie $(1634,1635)$. Mount Langford consists of nearly horizontal beds of light-colored breccia, and the same is true of its northeastern spur and the ridge west to Mount Doane and north around the head of Middle Creek. On the summit of Mount Langford the breccia consists of andesites of various colors and habits, with small or large phenocrysts, mostly hornblendic. Some fragments are pyroxene-andesite (1632, 1633). On the west slope of Mount Doane, above the saddle, the light-colored hornblende-andesitic breccia contains masses of hornblendemica-andesite, very light gray and pink, with abundant phenocrysts (1636, 1637). This breceia also forms the southern base of Mount Stevenson, the bedding being about horizontal.

The mountain ridge from Mount Stevenson as far as the Yellowstone Lake is composed of dark-colored breccia, in part hornblendic, but mostly of basic andesite $(1623,1624)$. The andesitic breccia in the ridge between Rocky and Beaverdam creeks is similar to that of Mount Langford; light colored, in places dark; largely composed of hornblende-andesites of various habits, together with some basic pyroxene-andesites (1625 to 1631 and 1447 to 1449). The same light-colored breccia forms the ridge east of Beaverdan Creek, from the stream bed to its summit, except in the peak of Ifount Humphreys and that northwest of it, where the light-colored breceia is capped by dark breccia. Bold escarpments on the northwest side of the last-mentioned mountain exhibit nearly horizontal beds of light breccia overlain by similarly bedded dark breccia, the bedding of the two being 
continuous and not interrupted. Occasionally one passes into the other horizontally near the line of contact. The dark upper breccia consists of basic andesites with more or less hornblende in phenocrysts. The greater number are very dark, with minute phenocrysts of feldspar and pyroxene $(1638,1639)$.

Light-colored breccia forms the ridge southwest of this monntain, throughi Coulter Peak, being overlain along the crest by a horizontal layer of basic breccia. The light-colored breccia passes beneath basic breccia at the eastern base of the peak sonth of Beaverdam Creek, the lower breccia being pink and hornblendic, the upper breccia dark colored and pyroxenic, with a little hornblende and some olivine $(1642,1643)$. It is distinctly bedded, and dips about $20^{\circ} \mathrm{W}$. At the head of the south fork of Beaverdam Creek the light-colored breccia overlies two superimposed sheets of basalt, over which is a deposit of trachytic breccia, already referred to. The petrographical character of these basalts and the traclyyte, as well as their geological position with respect to the hornblende-andesite, relates them to the older basaltic period of the Crandall volcano, though they probably were emptied from some other center.

The light-colored breccia continues around the eastern lead of Trappers Creek, from Mount Humphreys to Table Mountain and the Turret. At the head of Mountain Creek, northwest of Eagle Peak, the light-colored breccia consists of light-gray tuff and various-sized fragments of hornblende-andesite (1655 to 1660). These andesites differ in color and habit, a few having large plenocrysts of hornblende. There is occasionally some mica. In places the rock over considerable areas is all of the same material, though apparently brecciated, solid angular masses being cemented by crumbling material of the same character: There are also large masses of somewhat fissile andesite, but nothing resembling intrusive rock in place. Similar andesite forms the northern spur of the peak at the head of Mountain Creek, and is well exposed in the ridge west of the creek to Table Mountain. It is but rudely bedded, and is capped by well-bedded, dark, basic breccia, which forms the platean of Table Mountain. It is also overlain by patches of basic breccia on the peak at the head of Mountain Creek, and passes beneath the mass of Eagle Peak.

At the southern end of the ridge of Table Mountain the liglit-colored breccia is well exposed. It is like that farther north and is highly varie- 
grated (1652 to 1654). It carries large masses of andesite, from 1 to 8 feet in dimeter. 'The bedding is irregular-in some places horizontal, in others dipping $20^{\circ} \mathrm{W}$. It is topped by well-bedded basic breccia, which forms the smmunit of the 'Thret and corers what was ance a very meven suthee of older breccia. 'The light-colored brecein extends down to the valley of Trappers Creek on the west and down to the bottom of Momitain Creek on the east, but the southern end of the ridge for 1,000 feet above the creek is proxene-andesitic breccia, whose relation to the lomblendic breccia was not discovered.

The most southem exposure of what has been definitely recognized as the light-eolored lornblende-andesitic breccia is in the vicinity of the forks of Mountrin Creek. On the eastem bank of the north fork it appears to be somewhat indurated in places. It has abundant hornblendes, and some fragments are homblende-biotite-andesite (1661 to 1666). At one place it eonsists of horizontal layers of tuff with intercalated layers of large waterworn and romded fragments. It is eut by small bodies of intrusive andesite. It forms the lower end of the spur between the main forks of the creek, extending up it to a point 500 feet above the stream, where there is an exposure of massive hormblende-andesite, porous and light red, with some large, stout homblende phenoerysts and segregations of red hornblende and biotite $(1664,1667)$. In this vicinity the homblendic breccia is overlain by dark-colored basic breccia, the superposition being showu in a number of places.

Sonth of this point no distinct accumulation of light-colored hornblendeandesitic breccia has been observed. It is possible, howerer, that the lightcolored layer of breccia at the westem base of the most northern prong of The Trident may represent this series of breccias. It is not separated into thin layers or beds, but weathers into a massive cliff with rertical prisms. The exposed layer is over 100 feet thick, and consists of light-colored tuffs and breccia, with andesitic fragments of various kinds. They are mostly pyroxene-andesite, but many carry a little homblende and others a little nica, while some are decidedly homblendic, as is also the light-gray tuff $(1683,1684)$. This layer is overlain by distinctly bedded, dark-colored breccia, which continnes up to the summit of The Trident.

The tuff-breccia and oceasional lava flows that have just been described consist of andesites, for the most part light colored and homblendic. By far 
the larger number of rocks are hornblende-pyroxene-andesites. With these are intimately mingled hornblende-andesites and hornblende-mica-andesites, and in a few instances dacites. In some places pyroxene-andesites are abundant, so that there is a transition into the orerlying basic breccia. In fact, a distinction between the two is hardly possible except in a broad way, the npper breceia being prevailingly dark colored, and the predominant kinds of rock being pyroxene-andesite and basaltic rarieties, with basalt, and much less hornblende-pyroxene-andesite.

In the acid breccia there are places where fragments of basaltic andesite occur sparingly. Such a mingling of rarieties is natural because of the necurrence of this breccia nom the flanks of roleanoes which are composed of basic andesites and basalts. Curionsly enough, there is less mingling than might be expected, and the contrast between the underlying basalts and the overlying acid breccia is well mark d in many places. The meertainty of limits and the transitional character of the breccia are most marked between this upper acid breccia and the overlying upper basic breccia.

In describing the microscopical clanactern of these rocks, it seems best to follow a mineralogical sequence, rather than to treat the rocks in the order of their relative abundance. In the first case the order would be: Dacite, homblende-nica-andesite, hornblende-andesite, horublende-pyroxene-andesite, pyroxene-andesite (basaltic andesite).

Dacite.--The only rocks belonging to this terrane that are clearly dacite occur in two localities some distance apart: Lake Butte, on the northeast shore of Yellowstone Lake, and the north base of Mount Doane. At the first locality the rock is massive, and is exposed for only a short distance, so that the geological character of the mass is not erident. It was probably a lava flow of considerable thickness, for the sections examined microscopically are holocrystalline. The rock is light colored, gray and red, and extremely porous, but not pumiceons, and hats abundant small phenocrysts of quartz, feldspar, hornblende, and biotite. The quartzes are first recognized under the microscope, when they are found to be very abundant. They are partly idiomorphic, in double six-sided pyramids, more or less rounded. They contain, as inclusions, lumps of glassy groundmass, colorless glass in pyramidal cavities, crystals of biotite, and the other mineral constituents of the rock. In some cases rhombohedral cleavage is noticeable. 
The feldspar phenocrysts are all polysynthetic twins, and are limesoda felulspars, some of which exhibit symmetrical extinction angles indieating libritulorite, but others appear to bolong to more alkaline species. Zonal structure is lighly developerl. Inclusions are not abundant, and consist of occasional crystals of biotite, hornblende, apatite, zireon, and magnetite. The biotite, which is abundant, is in six-sided plates, and also in relatively thick crystals, occasionally the thickness being greater than the wilth. Its color is diuk brown in thin cleavage plates, and strongly pleochroic in sections perpendicular to the cleavage, being pale yellow for light vibrating parallel to at, and almost opaque for that at right angles to this direction. In places the lamellie of a crystal are bent at one end where they appronch another phenocryst, indicating the forcible crowding of these crystals during the movement of the magma before solidification. Inclusions of minute apatite crystals are common; those of magnetite and zircon less so. The hornblende is less abundant than biotite, and is green, with a tinge of brown, witl marked pleochroism, pale brown || a, brownish green $\| \mathfrak{h}$, strong green $\| \mathfrak{r}$. Crystal forms are seldom observed, except in the prism zone, where the unit prism predominates, and both pinacoids may be present. Often the ontline is very irregular. Inclusions of biotite occur, and sometimes apatite and magnetite. It is a later crystallization than biotite. Apatite, magnetite, and zircon are present in their usnal forms.

The groundmass is holocrystalline, very fine grained, apparently microgrannlar, but the indistinct grains when highly magnified are foind to have a micropoikilitic structure-that is, they consist of quartz cement and feldspar microlites. 'There is also a much smaller amount of magnetite in minute crystals, and some shreds of biotite.

The dacite found in fragments in the breccia at the base of Mount Doane (1637) is glassy and pumiceous, with abundant minute phenocrysts of feldspar, quartz, and hornblende, and less biotite. These crystals are nearly all idiomorphic, except when in fragments; or in the case of quartz, when rounded. The quartzes contain numerous inclusions of colorless glass with gas bubble and surrounding strain phenomena. Other inclusions are rare. The feldspars are plagioclase, probably labradorite. They have beautiful zonal structure and frequent glass inclusions. Minute prisms of apatite and crystals of the other constituents are sometimes included. Hornblende is MON XXXII, PT II-19 
abundant and dark brown, witl strong absorption. It incloses some magnetite, and in one case has grown around angite. Idiomorphic and broken crystals occur beside one another: Biotite, with the same color as hornblende, is less abundant. Some erystals are idiomorphic; others are bent and crumpled by the pressure from other phenocrysts prior to the solidification of the mass. Small erystals of these minerals, almost microseopic, oceur in the glassy groundmass. Magnetite, apatite, and zireon are present in idiomorphic crystals. The groundmass is colorless glass with a relatively small amount of very minute crystals. It is pumiceons, with vesicles more or less spherical, or drawn out into spindle-shaped tubes.

Hornblende-mica-andesites. - The varieties of these rocks are microcrystalline andesites with multitudes of minute phenocrysts of plagioclase, feldspar, and hornblende, and fewer of biotite, so that in some cases they might be called mica-bearing hornblende-andesites. In thin sections the hornblendes are seen to be differently colored in different rocks. In some they are green and brownish green, with very slight border of magnetite grains, or none at all. In others they are deep chestnut brown, without borders; in still others, strong reddish brown with pleochroism from orange to red without border, or with narrow magnetite margin. Otherwise they are alike, laving similar forms and inclusions. They are partly idiomorphic. Inclusions are not common. Some contain numerous glass inclusions.

Biotite varies also in color and is easily confused with hornblende in some of the rocks, usmally laving the same colors where the hornblende is brown and red-brown; but where hornblende is green, biotite is brown. Its chief inclusions are magnetite and apatite.

Hypersthene and angite oceur in only a few rocks, and then in very small crystals. In one case hypersthene witl pronounced pleochroism has a dark border, as though from magmatic action. It accompanies red homblendes. In another instance, where the hornblendes are red, the few small augites are nearly colorless.

The plagioclase is toward the labradorite part of the series, exhibiting rather ligh extinction angles and haring forms and inchisions similar to those of the plagioclases of the dacites just described, except that zonal structure is not so frequent, being most pronounced in the larger, nearly equidimensional crystals, and nearly wanting in the smaller, narrow rectangular ones. 
'The groundmass in the different varieties of this rock varies from mierocryptocrystalline and microlitic to microcrystalline with micropoikilitic structure, which is very fine graned, the structures and mineral compositions being typically andesitic.

Hornbende-andesites.-The halbit of these rocks is generally similar to that of the audesites just described $\rightarrow$ a holocrystalline gromdmass with abundant minute phenocrysts of feldspar and hornblende. In one case feldspar phenocrysts are wanting. 'The hormblendes have the same varieties of color and other chanateristics as those in the andesites last described. In most of the cases studied they are red. Black borders occur in some varieties, but with no special connection with any particular nicrostructure of the gronndmass. Biotite is present in several rocks in small amounts. Small crystals of pyroxene are rare. The feldspar phenocrysts are similar to those described in the hornblende-mica-andesites. The gromdmass structures are also similar-holocrystalline and microlitic, with andesitic habit.

Hornbende-pyroxene-andesite.-The 101 thin sections of this kind of andesite which were studied exhibit a range of mineral composition from rocks with much ferromagnesian phenocrysts to others with few, and from varieties with much hornblende and little pyroxene, which are closely comected with hornblende-andesite, to those with more pyroxene than hornblende, which might be classed as homblende-bearing pyroxene-andesites. The groundmass also differs greatly in various rocks, and the amount, size, and shape of the feldspar phenocrysts are equally variable. In general, however, the habit is like that of the rocks just described-a groundmass crowded with small phenocrysts. 'The actual character of the groundmass can be discovered only with the microscope. It is glassy and microlitic in many cases and holocrystalline in others.

The feldspar phenocrysts, which are present in great abundance, are mostly rectangular and elongated in thin sections. They are all plagioclase, and, like those before described, probably labradorite. But there appears to be some variability in the kinds, and some small crystals exhibit extinction angles suggesting anorthite $\left(33^{\circ}\right)$. Polysynthetic twinning is always present to a greater or less extent, and zonal structure is highly developed in some crystals, over 10 alternating zones of light and shade having been counted in one feldspar, which was $0.46 \mathrm{~mm}$. from center to margin, the arerage width of a zone being 0.0002 of an inch. In some cases 
the zones alternate in the values of their extinction angles, so that it would seem as though the composition of the feldspar oscillated between narrow limits from the center ontward. In other cases the center exhibits a higher angle of extinction than the marginal zones, from which it may be inferred that the composition changed interruptedly from the center ontward. The feldspars are sometimes free from inclusions, sometimes crowded with glass inchusions, or these may be arranged in zones. Microscopic crystals of pyroxene, apatite, and magnetite are also included in some-feldspars.

The hornblende is like that in the varieties of andesite just described; not often idiomorphic, except in the prism zone; frequently with dark border, which is sometimes broad and compact. Often the border consists of mimute pyroxenes. Sometimes the hornblende is surrounded by comparatively large crystals of pyroxene, magnetite, and feldspar, the aggregate laving an irregular outline in some instances, and in others having the outward form of hormblende. The colors are red-brown, brown, and, less often, green. Occasionally the color varies in strength zonally. Hornblende incloses both angite and lypersthene in comparatively large crystals, and also in smaller grains, and exhibits the same relations of intercrystallization with the pyroxenes which exist between these three minerals in the diorites of Electric Peak. In one rock (1652) the brown hornblende is intimately intergrown with plagioclase, as in the case of hypersthene in the andesite lava from Hount Hood, Oregon. ${ }^{1}$ The pyroxenes are angite and hypersthene, generally in almost identical small crystals, with like forms in the prismatic zone-unit prism and both pinacoids, together with flat terminal faces. The clearage and twinning are normal. They have nearly the same color in thin section-pale green. But the hypersthene has reddish tones for rays vibrating transversely to the prismatic axis of the crystal. They are distinguished only by the differences in their double refraction and their extinction angles, measured from the prism axis. Their most frequent inclusions are crystals of magnetite. Rarely they inclose red hornblende.

The groundmass of most of the hornblende-pyroxene-andesites studied is glassy and crowded with minute microlites. Often these are so close together that it is not possible to say whether there is any amorphous glassy substance between them. In some cases it is evident that the whole

${ }^{1}$ Iddings, J. P., The eruptive rocks of Electric Peak aud Sepulchre Mountain, etc.: Twelfth Aun. Rept. U. S. Geol. Survey, 1892, p. 612. 
mass is crystallized. The more glassy varieties afford the best opportmity for ohserving the character of the microlites. For this reason it may be best to begin with the description of the most glassy varieties. Of these, some have glass, which is colorless in thin section, with many distinctly crystallized microlites, which, however, are not erowded together. The microlites are feldspar, pronene, and magnetite. The feldspars have not always the same habit. In some varieties of the rock the microscopic feldspars are rectangular, square, and elongated, with lamellar twinning, both albitic and periclinic, the symmetrical extinction angles of $33^{\circ}$ to $35^{\circ}$ indicating anorthite. They range in size from the most minute crystals to those $0.6 \mathrm{~mm}$. long. They are at times indented at the ends. In other varieties of the rock the microlites of feldspar are partly thin tabular crystals, sometimes crossing one another in Carlsbad twinning position. They are lime-soda feldspars yielding lath-slaped eross seetion. In the glassiest rocks the feldspars have the most abundant glass inclusions, which oceur even in microseopic crystals, although the smallest feldspars are quite free from inclusions.

The pyroxene microlites, like those of feldspar, range in size from the minutest to those that might be called small phenocrysts. Augite and hypersthene are both present, but in some cases hypersthene is the prevailing species. Botl pyroxenes occur in prisms, sometimes stout, sometimes slender, occasionally very thin. They are often cracked across as with basal parting, the pieces of crystal slightly separated in some cases. These grade into cases in which the pyroxene prisms are represented by a line of grains whose distance apart equals or exceeds the thickness of the grain. From the resemblance of these grains to the globulites in some of the glassy groundmasses it is probable that these globulites are augite to a considerable extent.

Magnetite crystals are frequently inclosed in the pyroxene in great numbers, but in some cases they are nearly free from them. The magnetite crystals are idiomorphic in many cases, but in others their forms are indistinct. One perfectly developed erystal which was inclosed in a feldspar had the form of a dodecahedron combined with an octahedron. Apatite oceurs in minute hexagonal prisms.

In groundmasses, where the glass is crowded with microlites their forms appear to be the same, but on account of their frequent superposition the forms are not so easily observed. 
In some glassy varieties the glass is brown in very thin sections, and the microlites of colorless feldspar and pale-green angite are distinctly contrasted with the glass. In other parts of the same rock the pyroxene crystals, small and large, are reddened on the surface and have a red opaque margin or incrustation, the smallest crystals being reddened throughout, the large ones only marginally. In these parts of the rock the glass is more often colorless, as though the brown pigment had been segregated about the pyroxenes. But there are cases where reddened pyroxenes occur in brown glass. In one rock the glass is yellow and orange in thin section, and the pyroxenes are reddened and there is a reddish opaque border to many crystals. This is more pronounced about the hypersthenes than about the augites. Brown and yellow glasses grade into one another in one rock. One variety has a beautiful brown globulitic glass base, with the usual microlites. Another groundmass consists of colorless glass, crowded with very minute thin prisms of pyroxene, feldspar, and magnetite. The form of these crystals may be observed when a thin layer of groundmass wedges ont over a large crystal of feldspar: In thicker layers the groundmass appears as a gray felt of these crystals. In the few holocrystalline modifications the microstructure seems to be that which would be cansed by the crystallization of the feldspar microlites against one another. Their outline is lost, and all of the coloring matter of the glass base is concentrated in the ferromagnesian constituents. Sometimes these are distinctly formed pyroxenes, together with magnetite. In other cases there is considerable chloritic or serpentinous material scattered among the feldspars. In several instances the groundmass contains amygdules of what appears to be chalcedony, sometimes coating and inclosing crystals of tridymite. The chalcedony accompanies the opalization of hypersthene, a form of alteration noticed by Küch ${ }^{1}$ in the andesites of Colombia. In general the rocks collected are almost free from decomposition of any kind.

Pyroxene-andesite.-These andesites have essentially the same habit as the horublende-pyroxene-andesites, but are darker colored as a whole. The abundant small phenocrysts are lime-soda feldspar, hypersthene, and angite. In a few cases there is a small anount of hornblende with black border, or

1 W. Reiss and A. Stiibel. Reisen in Siid-Amerika. Geologische Studien in der Republik Colombia. I. Petrographie. I. Die rulkanischen Gesteine. Bearbeitet von Riehard kiich. Berlin, 1892. Reviewed in Jonr. Geol., Vol. I, No. 2, 1893, pp. 164-175: 
of hornblende paramorphs. 'The groundmass is aphanitic and dark gray or black, or lighlit gray, oceasimally red:

In thin section the feldspew phenocrysts are mostly rectangular, with polysynthetic twiming after both laws; relatively strong double refiaction and high extinction angles, indicating labradorite-morthite. Zonal strueture is pronounced, and glass inclusions are abundant, the larger feldspars being sometimes filled with them. The pyroxenes are hyperstliene and angite in variable proportions. In some varieties of the rock hypersthene is greatly in exeess of augite, and is distinctly pleochroic. 1t oceasionally forms small aggregations with labradorite, the crystals of feldspar projecting radially from the margin of the aggregate. Similar aggregates sometimes surround lomblende phenocrysts. Inclusions of magnetite are common, and those of glass less frequent. There are oceasional evidences of the nearly synchronous growth of the pyroxene and feldspar, crystals of the former being interrupted in their growtl by those of feldspar. Rare cases of actual synchronous crystallization resulting in mutual intergrowth have ahready been mentioned. Angite is almost identical with hypersthene in its modes of crystallization and association. They are sometimes intimately intergrown, and are distinguishable only between crossed nicols. Zonal structure is occasionally noticeable in the distribution of color, and in the optical properties, the color varying from pale green to brown and reddish brown. In most eases they are fresh and not decomposed. Rarely they are partly altered into opal. The small individuals of hornblende, usually irregulirly outlined and with magnetite or pyroxene border, are generally reddish brown. Magnetite and apatite are the same as in the other andesites, but are somewhat more abundant.

The groundmass structures of the pyroxene-andesites are almost identical with those of the homblende-pyroxene-andesites. They are mostly microlitic, with prisms of plagioclase and pyroxene and crystals of magnetite. The more glassy modifications have colorless glass, and often brown globulitic glass as the matrix. Not infrequently the glass inclosed in the feldspar phenocrysts is brown while that in the surrounding groundmass is colorless. Brown glass is rather more frequent than in the more siliceous varieties of andesite. Only a few of the specimens examined were holocrystalline. 
Basaltic andesite.-One of the fragments collected has a peculiar character. It has a red glassy and microlitic groundmass with abundant small phenocrysts, in labit being similar to the rocks just described. But the porphyritical minerals are angite, red mica witl variable optic angle, numerous serpentinized olivines, some red hornblende, and very few plagioclase feldspars. There are numerous microlites of plagioclase in the groundmass. The rock is a more magnesian phase of the andesitic magma, related to homblende-pyroxene-andesite. It is not known in any large mass in the region, although it must have existed as a lava flow at some period in the history of the volcanoes of this range.

Segregations are not often noticed, partly becanse they are easily overlooked in the breccia, where the small fragments generally appear with slightly different characters. In the massive bodies associated with the breccia segregations sometimes occur. They are composed of crystals about the size of the phenocrysts, either crystallized together in a hypidiomorphic mass of plagioclase, hornblende, biotite, and pyroxene, with magnetite, or combined as large crystals, with smaller ones forming a relatively coarse-grained gromndmass between $(1652,1667)$.

\section{LATE BASIC BRECCIA.}

The character and mode of occurrence of the basic breccia, which overlies the light-colored and more siliceous breccia, have been indicated in the paragraphs describing the late acid breccia; but they should be restated in greater detail. In the vicinity of Mist Creek the basic breccia overlies the light-colored breccia in several places, and is found to consist of dark-colored pyroxene-andesites, sometimes with hornblende, sometimes with olivine, or both $(1484,1486)$. On the sonth side of the summit of Mount Chittenden, and on the ridges east and sontl, the dark-colored breccia forms well-bedded accumulations whose layers are nearly horizontal and overlie irregularly bedded or wholly unbedded light-colored breccia. The upper breccia is composed of pyroxene-andesites, with more or less olivine, and occasionally homblende. This breccia probably extends down the ridge to Lake Butte (1504 to 1507 and 1514, 1515).

In the vicinity of IIount Humplreys the upper basic breccia overlies the light-colored breccia in distinctly bedded accumulations which are nearly horizontal. The breccia consists of dark-colored pyroxene-andesite, 


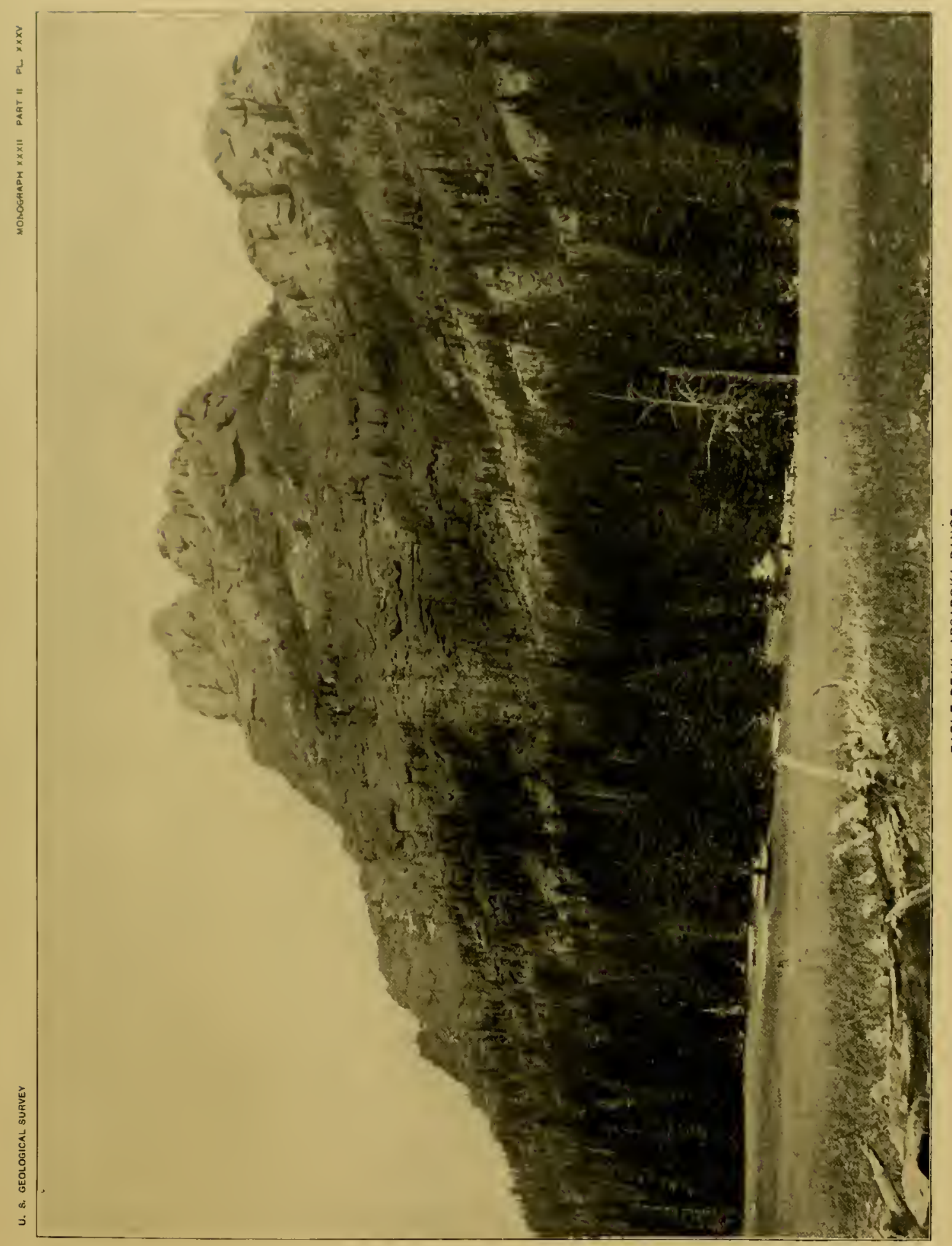



sometimes with hornblende, sometimes with olivine $(1638,1639)$. It caps the ridge to the sontheast and forms its western spur $(1641,1642)$, and also a small point on the southem spur of Coulter Peak. The upper basie breceia becomes thicker and more extensive about the southern end of the areal of earlier breccia. At Momt Humphreys and the peak nortluwest it is about 600 feet thick, while on Table Momntain and the Turret it is about 800 feet thick. It constitutes the mass of Eagle Peak.

'The breccia on the summit of Table Mountain is dark colored and is composed of comparatively small fragments of basaltic andesite, with small phenocrysts (1668). The layers of this mass dip gently toward the west. The mass of Eagle Peak, however, presents a wholly different aspect (Pl. XXXV). The breceia forming this mountain is distinctly bedded, but the layers are not horizontal, dipping at various angles and forming a slight symeline, the dip being to the southeast, away from the light-colored breccia at the liead of Mountain Creek and toward the northwest from the southern end of the momntain. The breccia is more slaggy and scoriaceous, with less tuff than the beds on Table Monntain, and the mineralogical character of the rock is more uniform. It is dark colored, mostly pyroxenic with much olivine, and in places carries some hornblende. There are dense, porons, and vesicular modifications of the rock (1669 to 1676). In places it has been partially altered, producing layers sud patches which are bright red, brown, and yellow, with purple, lavender, and green. The alteration seems to have followed certain layers, but was not confined to them. That there is considerable divergence in the bedding of the breccia may be seen from the eastern side of the mountain. The lower beds dip at steeper angles than the upper ones, the general dip being to the northwest. One massive bed was observed to thin out upward toward the sontheast, and to thicken and separate into several beds toward the northwest.

The mountain range east of the northeastern branch of Momtain Creek is composed of steeply dipping layers of similar dark breccia, in places brightly colored by decomposition. The dip in general is toward the northwest. The high northern portion of this range is composed of nearly horizontal beds of dark breccia. North of this range the mountains are made up of similar breccia in nearly horizontal layers, which occasionally dip steeply toward the north, and thicken in the steep parts of the layers. 
Basic breccia overlies the earlier breccia on the spur northeast of the forks of Mountain Creek, and forms the mountains to the northeast. It is distinctly bedded in places in horizontal layers, with more tuff than in the breccia of Eagle Peak. It is composed of pyroxene-andesites, some with abundant small phenocrysts of feldspar and pyroxene, others with almost no noticeable phenocrysts. Much of it contains olivine. Only a very little carries hornblende (1679 to 1683). Similar dark-colored breccia forms the main mass of The Trident, where it occurs in nearly horizontal layers or beds. These horizontally bedded breccias extend south to Thorofare Creek, and west across the canyon of the upper Yellowstone River, and form Two Ocean Platean.

Two ocean plateau. - The mass of Two Ocean Platean above the valley of the upper Yellowstone River consists of dark-colored andesitic breccia in nearly horizontal layers. The bedding appears much more regular at a distance than upon close inspection, when it is often found to be very irregular. In the vicinity of Two Ocean Pass the layers of bedding dip about $5^{\circ} \mathrm{NE}$. This dipping proves that there has been a clange of position since the breccias were accumulated, and indicates a depression or faulting toward the east, or in the Absaroka Range.

Near the mouth of Mink Creek, and south of it, the breccias are dark colored and basic and are associated with flows of massive basalt with porphyritical feldspar and angite, resembling those at Two Ocean Pass. Over the limestone near the head of Pacific Creek there is basic breccia in the strean chamnel, while on both sides of the valley at higher altitndes are flows of basalt, which cross the valley just west of the divide. These sheets of basalt form a distinct ledge on both sides of the valley, which varies in thickness from 200 to 400 feet, and is rudely colummar. Owing to the peculiar composition of these basalts they lave been classed with the shoshonites from other parts of the Park, and are described in connection with them. Above the western end of the basalt ledge, in the assorted andesitic breccia, there is a layer of unassorted light-colored tuff with large phenocrysts of sanidine and small biotites (1723-1725). There are clay-like lumps through it, and many fragments of basic andesite or basalt. It is overlain by basic andesitic breccia. The same kind of tuff is exposed on the southern side of Two Ocean Pass, in a layer about 30 feet thick. Here it passes upward into fine-grained tuff, which is gray and bedded. 
'This passes 11 , into assorted basic andesitic breceia, in the lower portions of which are lomuderl fimgments of the sandine-bearing tuff or breccia.

In the esearpment of the platean west of 'Two Oeen Pass the lower part of the brecein contains many layer's that are distinctly waterlaid and assorted, the masses of andesite being more or less rounded. But the upper portion is true breccia, angular and mussorted. On the southem side of 'Two Ocean Pass the lower part of the platean mass consists of assorted breccia which in places shows evidence of having been rearanged by water action. Layers of fine sand and gravel and large masses alternate with one another, but the bedding is decidedly irregular. The layers are not of uniform thickness, and are in places cross bedded. This condition continues for abont 1,000 feet above the valley, the upper 1,000 feet consisting of true breccia without waterlaid layers. Here, as elsewhere in the breccia, there are evidences of the former existence of localized bodies of water. The matrix is light colored, with angular fragments of all sizes up to those 6 feet in diameter. The andesites vary in character; some are dark, others light; some dense, others vesicular. They carry phenocrysts of feldspar and pyroxene, with occasional homblende or olivine. The whole mass has a distinct but irregular bedding, clearly seen at a distance. The surfaces of the layers are rough and irregular. They are generally denser at the bottom of each, so that the top of each weathers more easily and causes the line of bedding to become pronounced in exposures. Where layers differ in color and can be traced for any distance, they are observed to thin out laterally, and are not persistent for long distances.

Horizontally bedder breccias form the platean ridges about Jay Creek and those west of the Yellowstone River, and also the mountains at the head of Buffalo Fork of the Suake River, which are the southern extension of this region. Here they have a slight dip to the northeast. They also form the body of Two Ocean Plateau, and are exposed in the lateral canyous cut into it by the tributaries of the Yellowstone. From Atlantic Creek to north of Lynx Creek the petrographical character of the rocks is the same, and there are places where the material has been assorted and rearranged by water action. But the great bulk of the material is purely subaerial ejectamenta. At the head of Lynx Creek, on the continental divide, are remuants of a surficial flow of basalt which extends down the 
present valley for a short distance, and is therefore later than the period in which the valley was eroded. The basalt is light gray and somewhat vesicular, with small phenocrysts of olivine $(1734,1735)$. A similar basalt occurs on Clipmunk Creek (1736).

A small hill on the divide between Fox Creek and Mink Creek is formed of a massive flow of pyroxene-andesite, which is jointed into great slabs and is thinly fissile in places. It resembles many occurrences of rhyolite. It is partly massive and resicular, and is light gray, with small phenocrysts of feldspar and pyroxene (1727). It carries segregations of feldspar and pyroxene, and has eavities containing tridymite $(1726)$. Other portions of the same lava sheet are darkẹr and denser $(1728,1729,1730)$. The breccia along the western margin of the platean is basic, and in places there are remnants of porphyritic basalt. At the southern end of the valley of Fox Creek it is composed of fragments of basic andesite in a light-red matrix, and on the limestone lills east of the month of Crooked Creek it is also basic.

Isolated areas of basic andesitic and basaltic breccia occur overlying very irregular surfaces of sedimentary rocks on the peak south of Pinyon Peak, in the valley of Coulter Creek, in the vicinity of the northern end of the Teton Range, on Berry, Boone, and Conant creeks, and at Birch Hills. The last of these occurrences are described in comnection with the general geology of the northern end of the Teton Range (Chapter IV). Those in the region of Coulter and Wolverine creeks and Pinyon Peak are described by Mr. Arnold Hagne in Chapter V, deroted to the descriptive geology of Big Game Ridge and Huckleberry Mountain.

Of 116 specimens from the upper basic breccia, one-half contain olivine in variable amounts, and may be classed as basalt and basaltic andesite; the other half are free from it, and are pyroxene-andesites and hornblendepyroxene-andesites, the last-named rocks being much fewer than the pyroxene-andesites.

Hornblende-pyroxene-andesite.-The few specimens of this kind of andesite which were studied prove to be glassy microlitic modifications, some with dark-brown glass, one with red glass. Reddish-brown hornblende with magnetite border, or an outer zone of pyroxene, magnetite, and plagioclase, is the usual variety. In one rock brown hornblendes without any border of foreign material occur so closely associated with pyroxene as to inclose 
it in a variety of ways. They form a narrow zone of small prisms around a large angite in one instance, and in another case homblende contains small grains of angite as inclusions. It is also intergrown with pyroxene in the manner alleady described in other occurrences.

Pyrosene-andesites. C The pyroxene-andesites of the late basic breccia are quite the same as those of the late acid breccia just described. Most of them have golassy microlitic groundunseses, the glass being brown in the majority of cases. Some have holoerystalline gromulnasses. The habit of most of the modifications is that producerl by almundant small phenocrysts and a microlitie gromulnass. In some cases distinct phenoerysts are wanting, but there are many microscopic prismatic feldspars in the groundmass, nsually arranged in curving parallel lines, producing fluidal structure.

In a few rocks these rectangular mieroscopic feldspars are in excess of the microlitic groundmass. In the holocrystalline rarieties the dark color of the gromndmass gives way to gray shades. The degree of crystallization does not exceed that of holocrystalline-microlitic or finely microgranular. The phenocrysts are lime-soda feldspar, hypersthene, and angite, with small crystals of magnetite. Rarely hornblende or olivine is present in small amounts.

The feldspars are labradorite-bytownite, with marked twinning and zonal structure, and generally rectangular outline in cross section. Glass inclusions are frequent. In some varieties of this rock the feldspar phewocrysts are anorthite. Hypersthene and augite have the same colors, forms, and microscopical characters as in the pyroxene-andesites already described. In some cases pale-yellowish augites are twimned on the orthopinacoid, and, being cut so as to exhilbit symmetrical extinction angles on both sides of the twimning plane, furnish an inclination of the bisectrix a equal to $42^{\circ}$ to the trace of the twinning plane, indicating hedenbergite or augite. Zonal structure is occasionally exhibited between crossed nicols, and sometimes by variations in color. Glass inclusions are often present. The pyroxenes are mostly fresh and maltered. An alteration of hypersthene to pale-green pleochroic anphibole is sometimes observed, the fibers of amphibole lying parallel to the vertical axis of the hypersthene. A narrow opaque border and a darker-colored margin are sometimes present. Occasionally a serpentinous mass is included and suggests the former presence of olivine. 
The pyroxene-andesite occurring as a massive lava flow west of the head of Mink Creek has a habit somewhat different from that of the pyroxene-andesites already described. It has a smaller number of phenocrysts, which are labradorite, distinctly pleochroic hypersthene, and angite, the pyroxenes being more prismatic than usual. The groundmass when very dense is globulitic and microlitic glass, which is dark colored where the microlites are very minute. Through it are scattered long prismatic microlites of hypersthene, augite, and feldspar. In varieties with larger microlites the color is lighter, and it is seen that pyroxene is more abundant than feldspar; magnetite also is abundant. Apatite occurs in comparatively few large crystals, with brownish color and distinet pleochroism. Tridymite is present in small aggregates.

Basaltic andesite and basalt.-These rocks are like the pyroxene-andesites in habit, both megascopically and microscopically. They consist of an aphanitic groundmass with multitudes of small plienocrysts of feldspar and pyroxene and more or less altered olivine. In some varieties the phenocrysts are almost ahsent, or are of microscopic proportions. The colors of the rocks are darker as a whole than those of most of the andesites. Dark grays to black and red are most common. Light grays occur. Many of the rocks are porous or finely vesicular.

In thin sections the groundmasses are seen to be glassy, with abundant microlites of feldspar, pyroxene, and magnetite, the latter minerals being rather more abundant than in the pyroxene-andesites, and being equal to, or sometimes more numerous than, the feldspars. The microlitic pyroxenes appear to be augite. The feldspars are lime-soda feldspars, apparently about andesine-labradorite, but not always of the same kind. The glass is usually brown globulitic, when in noticeable amount. Holocrystalline modifications occur; they are very fine grained and are formed by the growing together of microlites. Groundmasses so crowded with iron oxide as to be opaque, even in very thin sections, are common.

The feldspar phenocrysts are labradorite-bytownite, in some rocks being more calcic than the proportion $\mathrm{An}_{3} \mathrm{Ab}_{2}$, in other cases having the optical properties of this variety of labradorite. The forms are mostly rectangular and prismatic, tabular forms being common in some rocks. The twiming is according to albite, pericline, and Carlsbad laws, usually all three combined; occasionally nnly two. Zonal structure is pronounced, especially 
in those sections exhibiting little polysynthetic twinning. In a few instances there is il central core of feldspar, first recognized hetween crossed nicols, and this is invariably more calcic than the marginal feldspar. Glass inclusions are the same as in the feldspars of the pyroxene-andesites. Contemporaneous erystallization' witl pyroxene is occasionally observed.

The pyroxene phenocrysts are angite in nearly all the rocks in which olivine is abundant. In a few cases liypersthene is also present, but in smalled amount than augite. Transitional varieties with hypersthene and olivine in reciprocally varying proportions have been mentioned in connection with the rocks in other parts of this region. The angites lave the same appearance and eharacters as in the andesites. The same is true of the hypersthene when present. Olivine occurs in very small idiomorphic crystals, yielding rhombic and chatracteristic six-sided sections. It is in most cases wholly altered either to green serpentine or to the red and orange pseudomorphis which often result from weathering. In the few cases where olivine is still preserved it is colorless in thin section. The serpentinization is quite normal. Both modes of alteration are frequent, but the green serpentinization is probably more common. They do not oceur by the side of one another in one rock section. In only one instance was anytling like a combination of the two observed. The processes appear to be due to local canses, for it is found that all the varieties, with olivine, that were collected at any one locality bear the same kind of pseudomorphls.

Occasionally colorless olivine is coated with opaque iron oxide, which is red by incident light. It occurs in minute grains penetrating the crystal in rows normal to the side planes. The shape of the grain suggests that the original oxide was magnetite. In cross sections the coating appears as an opaque border of variable widtl. In one rock olivine is replaced by calcite.

The irregular and anygdaloidal cavities in these rocks are sometimes filled with secondary minerals, of which chalcedony and hyalite or opal and several zeolites are the commonest kinds. The first two are often associated together, chalcedony coating the walls of the cavity in a spherulitic layer, opal filling the central portion. In one of the pyroxeneandesites the chalcedony of the margin passes into fibrous or platy quartz, which fills the center of the anyygdule, the two being continuous optically as well as in substance. In some sections through such anygdules the central quartz exhibits undulatory extinction, not very unlike that produced 
in quartz by dynanic forces. It is, lowever, in this case the result of aggregate crystallization. Such sections exhibit miaxial interference crosses which are optically positive. The aggregation appears to be made up of thin hexagonál plates, parallel to the basal pinacoid. The aggregation of plates into spherical masses takes place in tridymite, as is well known. Spllernlitic aggregations being only modifications of spherical ones, such structures may be produced by the attempts of thin plates to form spherical clusters. T'he rods would then be at right angles to the rertical axis of the nineral-that is, the apparent fibers would be parallel to $a$, the direction of vibration of the swiftest-traveling ray. The lighter specific gravity of chalcedony, as compared with quartz, wonld seem to be due to inclusions, probably of hyaline silica, since minnte inchusions are observed in thin section, and a variable percentage of water is found upon chemical analysis. Opal replaces the feldspar's in a fer of the rocks studied.

Sometimes the anygdules consist of minute zeolites with very low donble refraction and a marked pinacoidal cleavage with parallel extinction. It is probably heulandite. The spaces between these crystals are filled with a colorless, low-refracting substance, apparently composed of minute spherules or plates, resembling tridymite. But the whole mass is splhernlitic, with delicately fibrous rods that are optically positive. The double refraction is low. There seems to be no structural relation between the minute spherules and the spherulitic structure. One appe:u's to be subsequent to the other. The chemical character of this substance was not discovered. Similar mineral with stronger double refraction occurs in other varieties of the rock. Other secondary minerals, probably zeolites, are present in a few cases $(1682,1675)$.

\section{DIKES AND SURFICLAL FLOWS. \\ VICINITY OF SYLVAN PASS.}

Subsequent to the accumulation of the late acid and basic breccia of the Absaroka Mountains there broke out a series of eruptions whose center of activity was in the vieinity of Sylvan Lake. In this neighborhood the breccias are traversed in all directions by dikes of rocks which have a wide range of composition and which also attained great variety of crystalline structure. 
In the valley of sylvan Pans and on the slopes of the mountains on both sides the lneceias have been highly indurated by the intrusion of dikes elose to one another, and of larger bodies of magnat. 'This is particularly the case on the southern side of the valley. This metmorphism is limited in extent north: and south, but continues a greater distance eant and west. The induration of the breceia and the presence of massive rocks produce momntain slopes very different in elaracter from those of the breceias of the region. The indurated and massive rocks weather in small angular fragments that form long, bare talus slopes, giving to the southern flanks of Avalanche Peak and of the mountain sontleast a smooth, lighlit-colored appearance, which is quite distinctive.

The southem slope of Avalanche Peak has the character just noted. It consists of indurated breceia of lomblende-andesite, traverscl by intrusive bodies of hornblende-mica-andesite and of homblende-andesite. Some of these bodies have been crushed and fractured so as to resemble breccia in places. They furnish evidence of dynamic movements. One body of hornblende-mica-andesite (1532), whose outline is obscured by talus, is altered considerably. The phenocrysts of mica are large, as are also some of hornblende and feldspar It is finer grained and fissile near the southern contact wall, and is distinctly mottled in planes parallel to this contact, and carries inclosed fragments of other rocks. The southern end of the summit of the monutain is formed of a broal dike of hornblendeandesite (1533), compact and gray, with abundant small phenocrysts of hornblende and feldspar. The trend of this dike is east and west, and that of three or four other's cutting the summit of the peak is northwesterly. These are hornblende-andesite. Anotler dike on this summit, trending sonth and nortll, is lormblende-mica-andesite (1534). It is greenish gray and dense, with a multitude of small phenocrysts - white and prominent feldspar's, altered hornblendes, and fresh biotite.

The northern end of the summit consists of massive rock with hornblende and pyroxene phenocrysts. The northem mass of the peak is composed of chaotic breccia of hornblende-andesite not specially indurated. Six dikes cut the northwestem spur, five having a general east-west trend, and one, lower down, a north-south trend. Thlree dikes cut the nortlleastern spur. They have a northeast trend. On the eastern spur there are ION XXXII, PT Il- 20 
three dikes with a southerly trend. One of these dikes consists of hornblende-andesite with many phenocrysts of hornblende and feldspar. The rock is columnar, with horizontal prisms.

In the gulch west of Avalanclie Peak the breccia of hornblendeandesite is indurated, and is cut by bodies of homblende-andesite that lave been much fractured and cracked. Similar indurated breccia forms the ridge west, and is traversed by ten or more dikes of hornblende-andesite with variable trends, mostly north and south or northeasterly. On the west end of this ridge are other dikes, whose trends were not observed.

Other dikes of hornblende-andesite cut the ridge from Avalanche Peak to Mount Chittenden. They have a general north-sonth trend, as indicated on the map, several trending northeast and one east. Dikes may be seen cutting the sonthern face of Silver Tip Peak. At the head of Crow Creek sereral of the dikes traverse the sheet of massive hornblende-pyroxeneandesite, cutting it in different directions.

'These dikes extend into the head of Jones Creek, the most northerly intersecting the eastern edge of the summit of Mount Chittenden. Here this dike is 50 or 60 feet wide, is horizontally columnar, and trends a little ealst of nortl. The rock is hornblende-andesite (1498 to 1500), dense, fine grained, with abundant small phenocrysts of hornblende, sometimes in stellate groups, and less prominent feldspar. No dikes were observed in the momntains northeast of Mount Chittenden, or in those in the vicinity of Pyramid Peak, or in Castor and Pollux peaks.

In the region of Sylvan Pass, the mountain mass of Iloyt Peak consists of indurated breccia of horublende-andesite with some pyroxeneandesite. It is traversed in various directions by dikes, some trending northeast and east, and others southeast. Those cutting the northern crest of the mountain are mostly hornblende-andesite. They are from 4 to 10 feet wide, and in one instance 20 feet. The rock of the 20 -foot dike (1535) is dense, light gray, with a hackly fracture, and is crowded with small phenocrysts of minute feldspars and larger lornblendes, with a very little mica. One of the andesite dikes is very fine grained, with few phenocrysts. The dikes on the south slope are largely covered by talus. Their general trend is toward the southeast. Among them, near the bottom of the slope, are several dikes of quartz-mica-dacite, with phenocrysts of these minerals. Farther down the slope, just east of the divide, there is 
an intrusion of hornblende-nica-andesite (1545), which is dense and dark gray, with abundant hexigonal plates of biotite, munerous feldspars, and inconspicuous altered homblendes.

Inmediately north of the pass is an exposure of granite $(1536,1538)$. It is massive and breaks into lange blocks. The exposure is about 75 feet high and 150 feet long. The rock is fine grained, with porphyritical biotites, resembling those in the andesite just noticed, but less numerous.

Dikes of light-colored andesite cut the high peak east of Sylvan Pass, which is composed of dark-colored basic breccia. They have a general trend a little south of east, and are found traversing the valley of Diddle Creek in the same direction. Here they cut the older basalts. At the upper forks of this creek, a short distance east of Sylvan Pass, there is a great dike of hornblende-mica-dacite (1546), with some quartz phenocrysts and abundant large feldspars. The biotite forms comparatively long prisms, one being $5 \mathrm{~mm}$. in lengtll. They taper slightly toward the ends. The hornblende is more or less decomposed. The dike is 80 feet wide, and forms a high wall on the southern side of the valley, and passes across the south fork of the stream. It is almost vertical, with slight hade to the north, and is distinctly jointed in horizontal prisms. Parallel to this is a smaller dike of compact homblende-mica-andesite with multitudes of minute phenocrysts (1547). The breccia in the immediate vicinity is indurated. Halfway down Middle Creek on the north side are two dikes of dense gray rock with very few phenocrysts of hornblende $(1548,1549)$. They have an east-west trend.

At Sylvan Pass, east of the divide, the valley is filled with masses of rock from the dikes and breccia on either side. Some of the dike rocks are dense crystalline andesite-porphyry, with abundant thin crystals of hornblende $(1538,1539)$; others are less crystallized, with various habits. On the south side of the pass indurated breccia, cut by many parallel dikes of andesite, forms almost vertical cliffs 500 feet high. Some of these dikes are dark colored, dense, and lithoidal, with comparatively large hornblende phenocrysts (1540); others are darker, with abundant, though not so prominent, phenocrysts of hornblende (1541). Some are light gray and compact, with extremely few phenocrysts, while some are altered and green, with spots of epidote $(1542,1543)$. There is, however, not much alteration noticeable in the vicinity, most of the rocks being fresh. The slopes 
west of this cliff on the sonth side of the valley are greatly obscured by soil and drift. The seattered exposures show the breccia highly indurated, and a more crystalline form of intrusive rock. The coarsest-grained variety is a medium-grained diorite (1554), which was not found in place. Several other forms of diorite are found in the morainal accumulations $(1552,1553)$; also a porphyritic variety (1555) with hornblende phenocrysts. At the north base of Grizzly Peak fine-grained diorite-porphyry, with small phenocrysts of hornblende and some biotite, forms a large body extending for about a mile in an east-west direction $(1550,1551)$. It is blue-gray and compact.

$A$ broad dike of lomblende-andesite, 75 feet wide, can be traced for a long distance up the northeast spur of Grizzly Peak. It trends nortl of east. Along the crest of the ridge from Grizzly Peak to Top Notch at least 16 dikes lave been observed, trending at varions angles toward the soutluwest, south, and sontheast. One is a 40 -foot dike of hornblende-micaandesite (1556) trending northeast. It is dark gray, with abundant phenocrysts of feldspar, altered lornblende, and fresh biotite. Five others are of lomblende-andesite. Thikes also cut the upper end of Signal Ridge. On the saddle west of Top Notel Peak a dike of lomblende-andesite, trending northwest and sontheast, is intersected by a 30-foot dike of hornblende-mica-andesite (1557), which trends N. $10^{\circ}$ E. The rock is dense and dark colored, with numerous small phenocrysts of feldspar, decomposed lornblende, and fresh biotite. On the ridge southeast of the summit of Top Notch Peak there are two dikes of hornblende-andesite trending S. $20^{\circ}$ E., which appear to extend across the head of Middle Creek in a southeasterly direction; enst of them, on the spur between the forks of this creek, are several other dikes with the same general trend toward the soutlieast. The summit of Top Notch Peak is traversed by dikes in several directions. A 25-foot dike of hormblende-mica-andesite (1558) trends S. $20^{\circ} \mathrm{E}$. The rock is light gray, and is filled with phenocrysts of feldspar, biotite, and hornblende, and a few of quartz. Another of this kind of andesite trends with the ridge of the summit. A dike of hornblende-andesite east of the summit trends $\mathrm{N} .15^{\circ}$ E., and two others occur northeast of the summit.

All of these dike rocks are holocrystalline with the exception of two, which may be glassy and crowded with microlites or may be holocrystalline. When studied microseopically they are found to be, one, pyroxene-andesite with paramorphs after homblende (1499); five, hornblende-pyroxene- 
andesites $(1498,1500,1533,1540,1541)$; another, the same with a little mina (1535); two, horublende-pyroxene-andesite-porphyry $(1538,1539)$; two, hornblende-andesite with possibly a little pyroxene $(1548,1549)$; eight, lornblende-mica-andesites (1532, 1534, 1556, 1543, 1545, 1557, $1558,1547)$; and one, dacite (1546). The majority of them are thus seen to he homblende-pyroxene-indesites and homblende-mica-andesites, while nore basic and unore acid varieties are comparatively scarce.

The pyroxene-andesite (1499) which is a dike in Mount Chittenden is holocrystalline with typical pilotaxitic microstrneture, prodnced by microlites of plagioclase, angite, altered liyperstlene, and magnetite. The very small phenocrysts are labradorite, angite, and hypersthene, with opaque paramorphs after hornblende, which sometimes have a central portion composed of pyroxene and magnetite. The hornblende-pyroxeneandesites are holocrystalline, with microstructures ranging from pilotaxitic $(1498,1500)$ in the dike rock at the summit of Mount Chittenden, and in a dike on the south side of Sylvan Pass (1540), which rocks have rather large phenocrysts of homblende, through those that are slightly micropoikilitic $(1533,1535,1541)$, to those that are so plainly microcrystalline as to be classed as andesite-porphyry $(1538,1539)$. In these latter varieties quartz is recognizable as a component of the groundmass. It is probably present also in the rocks with incipient micropoikilitie structure.

The phenocrysts are very small and abundant, and vary somewhat in their relative proportions, pyroxene being scarce in some cases, and biotite being present in small amount in one instance (1535). The feldspar, which is abundant, is labradorite, but probably of different compositions, which is indicated by the optical properties. Hormblende is greenish brown, with no black border, but in a few cases with a narrow border of magnetite grains. Intergrowth with augite was observed in one instance. Augite and hypersthene have the characteristics common to these minerals in all the andesitic rocks of this region. They are subordinate to homblende, and generally in smaller crystals. Magnetite and colorless apatite in small crystals may be classed with the phenocrysts. The rock forming a narrow dike on the north side of Middle Creek, halfway down its course, has a quite different character $(1548,1549)$. It consists almost wholly of groundmass, with only a few scattered phenocrysts of greenish-brown hornblende and lime-soda feldspar. The groundmass con- 
sists of twimned prism of plagioclase with low extinction angles. In most cases the rectangular cross sections exhibit high extinction angles; there is some rectangulax, unstriated feldspar with nearly parallel extinction, which may be oligoclase or orthoclase, besides chloritized pyroxene and magnetite. The hornblende-mica-andesites are holocrystalline, with groundmasses that are mierolitic and microcrystalline in some cases and slightly micropoikilitic in others $(1532,1534,1543,1545,1547,1556,1557,1558)$. The phenocrysts, though abundant, are inconspicnons in most eases, but are prominent in a few rocks. They are labradorite, green and greenishbrown homblende, and brown biotite. Magnetite, apatite, and zircon are also present. Hornblende is completely altered to chlorite, calcite, epidote, and quartz in some rocks, the biotite being unaltered. The latter is oftener unaltered. The dike on the summit of Top Notch (1558) is very fresh, with abundant biotite and hornblende, and also some phenocrysts of quartz, which indicate that the rock is possibly a dacite. Allanite is present in chestnut-brown crystals. The 80-foot dike near the upper forks of Middle Creek (1546) is like the last, and contains some quartz phenocrysts. The groundmass is slightly more crystalline, and is hypidiomorphic granular, with minute idiomorphic quartzes and feldspars in prisms and grains. The feldspar phenocrysts are audesine. It is holocrystalline dacite.

The diorite-porphyries found at the base of the north side of Grizzly Peak $(1550,1551,1555)$ have abont the same habit as the hornblendemica-andesite with abundant small phenocrysts, except that they are distinctly more crystalline. The largest crystals are about the size of the phenocrysts in the andesite-1 or $2 \mathrm{~mm}$. long. The remainder of the rock, however, is crystallized into relatively large grains of quartz and feldspar. In thin section the rocks consist of idiomorphic rectangnlar crystals of labradorite, which form the greater part of the rock. With variation in the amount of small grains of quartz and feldspar the structure grades from that of diorite-porphyry to that of a fine-grained diorite. The large body of this rock found in places may properly be called fine-grained diorite, slightly porphyritic. The labradorite has probably the composition indicated by $A n_{1} A b_{1}$. There is little orthoclase and a small amount of quartz. Ferromagnesian minerals are abundant, and are more or less completely altered to uralite and chlorite. They are brown biotite, brownish-green hornblende, and pyroxene. Allanite, epidote, and magnetite are present in 
small amounts. Coarser-grained modifications occur (1552 to 1554 ) that are fine-grained diorite, the average-sized crystals being about 2 mun. in length. They consist of nearly inliomorphic lahbarlorite, very little quartz, considerable brown biotite intergrown with brown homblende, and uralitized pyroxene. In one rock (1554) there is a little angite still unaltered. Apatite is abundint in long, stont prisms, with cross fractures, and sometimes bent or broken. The rocks belong to the group of mica-pyroxenediorites, and are similar to sone of the diorites of Electric Peak.

The very fine-grained granite or granite-porphyry $(1536,1537)$ consists of nearly idiomorphic erystals of labradorite and andesine, abont $1 \mathrm{~mm}$. long, with smaller grains of orthoclase and quartz, besides considerable biotite and magnetite; also small apatites and zircon. There is a little chlorite and calcite. It is a question whether the rock might not be more properly classed as quartz-mici-diorite. It is very similar to the quartzmica-diorite (321) from Électric Peak, which has 67.54 per cent of $\mathrm{SiO}_{2}$, and which may well be classed as granite.

\section{DIKES SOUTH AND SOUTHEAST OF SYLVAN PASS.}

South and southeast of the neighborhood of Sylvan Pass there are dikes and intrusions and surface flows of massive rocks which by their composition and petrographical labit, as well as by their mode of occurrence, appear to belong to the eruptions we have just been describing. It is noticeable, however, that they differ from the intrusive rocks in the inmediate vicinity of Sylvan Pass in the degree of crystallization attained by the groundmasses of the rocks. They are still finer grained. A number of dikes have been observed along the ridge sonthwest of the headwaters of Midale Creek. A large dike cuts the southern slope of the ridge between Mount Doane and Mount Langford, and trends north-northwest with a lade of $60^{\circ} \mathrm{NE}$. It is about 300 feet wide in its lowest exposure, growing narrower near the crest of the ridge. It consists of homblende-andesite $(1559,1560)$, with abundant small phenocrysts of hornblende and smaller feldspars in great abuudance. The groundmass of the rock is light gray and lithoidal, with many small cavities or pores. At the contact it is darker colored. In the center of the dike it is holocrystalline, with slight micropoikilitic structure, while near the margin it is ahnost glassy, with crowded microlites, though in places even here it is holocrystalline. The 
homblende is greenish brown. The feldspars are labradorite. There is a little augite in phenocrysts, and some altered liypersthene and magnetite.

On the peak sonth of Mount Langford a small dike trending east and west consists of very dark-colored and dense hornblende-andesite, with many small hornblende phenocrysts and none of feldspar (1561). The groundmass is globulitic glass crowded with microlites of feldspar and pyroxene. There are many small phenocrysts of augite, besides those of greenish-brown homblende.

The dikes cutting the ridge east of the sonth fork of Middle Creek have a general trend to the northwest, bit vary somewhat and intersect one another. They may be seen traversing the ridges to the northwest and also to the southeast. Other dikes were observed traversing the ridge northeast of the farthest point visited, and it is probable that the country south of Middle Creek is filled with dikes, but none have been mapped in that locality.

The most northerly dike reached on the ridge in question is about 20 feet wide, and trends a little south of west, with steep lade to the nortlwest. It is hornblende-andesite (1562), compact and dark purplish gray, with prominent phenoerysts of hornblende and white feldspar. It splits in plates parallel to the walls of the dike. The groundmass is a crowded mixture of feldspar prisms, brown globulitic particles, and magnetite grains, and is possibly glassy. The homblende is green, and there is a little brown biotite. The feldspars are probably labradorite. Immediately south of this dike a steeply dipping sheet or dike of hornblende-andesite (1563, 1564 ) caps the rilge for a distance of three-eighths of a mile. It is at present from 20 to 50 feet thick, but the upper wall has probably been eroded. The dip is to the southeast. At the northern end of the exposure it is relatively dense and prismatic and light gray; at the southern end it is more porous, or almost vesicular and fissile, and is dark gray (1563). At the bottom plane of contact it is dense, bluish black, and glassy (1564), is rich in phenocrysts of hornblende, with smaller feldspars, and carries scattered segregations of coarsely crystalline hornblende and feldspar. The lighter-colored part of the rock mass is holocrystalline, but microlitic, and slightly granular in places. In the darker parts it is pilotaxitic, and at the margin is glassy, consisting of beautiful brown globulitic and microlitic glass. The phenocrysts are alike throughout-brown homblende, labra- 
dorite, probably with the composition $\Lambda b_{1} \Delta n_{1}$, and a little angite and magnetite. One of the coarse-grained segregations, or simple crystallizations, consists of labradorite and hornblende, in allotrionorphic crystals $1 \mathrm{~mm}$. in cliameter, with magnetite and apatite in irregularly shaped grains. The feldspar and hornblende have the same characters as the phenocrysts in the surrounding andesite, and there can be no doubt as to their being crystallizations firon the same magma. The structure is granitic. This sheet is ent by two dikes of homblende-andesite $(1565,1566), 15$ and 20 feet wide, that trend northwest. They are rather dense and slightly vesicular, with flattened cavities, are light gray, and carry scattered phenocrysts of hormblende and few feldspars. The groundmass is pilotaxitic to hyalopilitic in one case, and lolocrystalline with prismatic and tabular feldspar microlites in the other. The phenocrysts are like those in the andesites just described. Sonth of the inclined slieet are two small dikes trending northwest. They are hornblende-andesite, similar to the last. Another parallel dike, 15 feet wide, consists of gray hornblende-andesite (1568) crowded with minute phenocrysts, some of the hornblendes being prominent. The rock is dense, and is black and glassy near the contact wall (1567). It cracks into small prisms. The gromdmass of the center of the dike is lyyalopilitie, and at the margin is a beantiful brown glass witl abundant microlites of feldspar, pyroxene, and magnetite. The phenocrysts are labradorite, greenish-brown homblende, hypersthene, and less angite, with magnetite.

Another dike, with the same northwest trend, consists of several vertical sheets, from 2 or 3 to 4 or 5 feet thick, inclosing wedges of breccia. It is dark bluish gray, compact, withont phenocrysts (1569), and proves to be a basalt rich in olivine. It exhibits fine prismatic cracking in curved columns perpendicular to the walls of the dike, and is in part thinly fissile parallel to the walls, and in places is fissile across the columns. The rock is dense and glassy near the contact, and consists of an aggregate of prismatic feldspar microlites and more abundant grains of angite and magnetite, with almost microscopic phenocrysts of serpentinized olivine.

Some distance south of the dikes just noted is a dike of dense gray rock withont megascopic phenocrysts $(1570,1571)$. It is a hornblendepyroxene-andesite, and is glassy and black near the contact face. The dike is from 10 inclies to 3 feet wide and trends northwest. The groundmass of 
the central part is pilotaxitic, with some tabular microlites of feldspar. At the margin it is brown glass, with prismatic microlites of feldspar. The minute phenocrysts are liypersthene and angite, and there are very few of homblende.

Another parallel dike, abont 25 feet wide, consists of hornblendeandesite (1572) with small hornblendes and still smaller feldspars. The rock is porons and fissile. The gronndmass is pilotaxitic, with tabular feldspars and microcryptocrystalline portions.

The next dike south is parallel to the last and has a hade of $75^{\circ} \mathrm{S} \mathrm{W}$ It consists of compact dark-gray hornblende-andesite, with many large. phenocrysts of hornblende. There are some small vesicular cavities (1573). The groundmass consists of prisms of labradorite with interstitial material that is nearly isotropic, is somewhat globulitic, and contains magnetite, minute augite, and considerable serpentine, which colors the whole rock. The phenocrysts are brown homblende, labradorite, and a little augite. It is probable that the serpentine has been derived from hypersthene.

The most southerly dike has a general northwest trend, is about 5 feet wide, and consists of compact hornblende-andesite with small scattered phenocrysts of feldspar and hornblende. The rock is dark purplish to reddish, and has weatbered to green, crumbling, rounded masses, leaving a "slide" between indurated breccia walls (1574). The groundmass is pilotaxitic, with much reddish-brown iron oxide. The rocks of these dikes are all andesitic in habit, and are for the most part glassy in thin section; some are holocrystalline. They are probably not as deeply seated intrusions as those at Sylvan Pass.

\section{MASSIVE FLOWS AND INTRUSIONS OF LIGHT-COLORED ANDESITE.}

There are several bodies of massive andesite whose mode of occurrence has not been fully discovered. They occur at the present for the most part at the summits of peaks, and give evidence of having been surficial flows that occupied drainage channels on the ancient surface of the country. But in several instances they appear to have been intrusive borlies, since they are accompanied by branching offshoots or apophyses. The porous or vesicular nature of the andesite composing these bodies makes it evident that they must have consolidated under little pressure, and that if they 
were intrusive bodies they had reached very close to the surface of the breccins.

T'wo of the most conspicuous bodies of massive andesite form the conical summits of Mount Doane and Mount Stevenson, and constitute the upper 500 to 900 feet of these mountains. The mass at Mount Doane consists of liglit-gray compact hornblende-mica-andesite, filled with minute crystals of feldspar, hornblende, and biotite, with a few larger phenocrysts $(1575,1576)$. Near the bottom contact it is dark colored and weathers into small rounded masses. Higher up in the body it is columnar, passing into platy parting, in more or less vertical slabs.

The groundmass of the rock from near the bottom contact is microcrystalline and microlitic, and is gray in thin section. The phenocrysts are greenish-brown hornblende and brown biotite, both without black borders or any noticeable inclusions of magnetite. Magnetite also forms small phenocrysts, the size of the small ones of hornblende and biotite. It is abundant as minute crystals in the groundmass. The labradorite is centrally and also zonally altered to a brown substance, probably kaolin. In the rock from the summit of the mountain the groundmass is slightly more coarsely crystallized, and the structure is almost microgranular, the grains being about $0.015 \mathrm{~mm}$. in diameter. The phenocrysts are the same as in the finer-grained rarieties, but the hornblendes and biotites are filled with minute grains of magnetite, some of the smaller hornblendes being almost completely replaced by it, and also by some pyroxene. Magnetite forms small phenocrysts, and there are a few of augite. The labradorite is ahmost fresh. A cross section of the whole body is shown in the almost vertical cliff at the northern face of the mountain. The massive andesite is seen to be resting on alınost horizontal layers of light-colored breccia, the plane of the bottom contact being curved, and rising several hundred feet at the east and west ends of the section. The andesite body appears to have been a surficial flow which filled an ancient drainage channel.

The same appears to be true of the massive hornblende-mica-andesite forming the top of Mount Stevenson (1577 to 1581). This rock is light gray, with more prominent hornblende than in the mass of Mount Doane, and contains segregations of hornblende and feldspar, with a little biotite. The groundmass of the light-gray rock is holocrystalline, with a mixture of feldspar prisms and grains, besides magnetite and pyroxene grains. The 
hornblendes are surrounded, and in part replaced, by pyroxene and magnetite. Biotite is scarce. The labradorite phenocrysts contain some calcite, and there is a considerable amount of zeolite scattered throngh the rock, which is probably heulandite or mordenite, which are very much alike optically. Another mineral associated with them is in fan-like aggregates of less refractive crystals, and is probably tridymite. There is also considerable calcite. Where the rock is darker, probably near a contact plane (1577), the groundmass is pilotaxitic and the hornblendes are free from magnetite borders. The coarsely crystallized segregations consist of large idiomorphic labradorite and hornblende crystals, with some smaller ones, and skeleton forms of labradorite and some globulitic glass base in places. There are comparatively large crystals of magnetite and apatite and considerable zeolite. Occasional large crystals of biotite occur. It appears to reach a lower altitude on the west side of the mountain. Beneath it there is a layer of rounded and waterworn pebbles of andesite. This would also appear to have occupied the valley of an ancient chamel, and may lave been continuons with the mass of Monnt Doane.

Another large body of homblende-mica-andesite forms the upper portion of the high northwest spur of Mount Schurz. This body is well exposed and was studied on its northwestern and northeastem sides. It rests on nearly horizontal layers of light-colored breccia, but its relations to the darkcolored breccia were, not determined. A fine section across the body is exposed on its northeastern side. It is beautifully colnmnar, the columns standing in various directions. The arrangement of the columns, as well as the slope of the bottom contact with the underlying breccia, which is from both sides inwards, indicates that the andesite occupied a broad channel sloping toward the sonthwest, since the western end of the andesitic mass is lower than the eastern. The altitude of the body ranges from 10,000 to 10,600 feet. The columnar structure is very well developed in curved groups, some of the columms being 40 feet long and 1 foot in diameter. In general the columms start perpendicular to the surface of contact with the breccia. Those in the lower part of the mass are larger than those in the upper portion.

The rock is darker colored near its contact with underlying breccia, and is dense (1582 to 1584), but becomes lighter colored and more crystalline farther from the contact. It is more or less vesicular or porons, 
and is parted into plates parallel to the plane of contact and also into columns perpendientar to the same. The megalseopical lub bit ramies eonsidcrably in different parts of the body. Fifty feet from the northwestern lower contact the rock is full of prominent phenoerysts of feldspar, with smaller biotites and loomblenles (1585). At 75 feet it hils less prominent feldspars and more noticeable hornblende and miea (1586). In the central part of the body it is still lighter colored, and compact, with the same variability of phenoerysts $(1587,1588)$. In the eavities of some of the porous forms there are good crystals of tridymite $(1585,1589)$.

At the ligher parts of the body the rock is darker colored again (1590, 1591). Among the fragments lying at its nortluwestern base are large masses and eolumns of varions modifications of the rock. One column, 8 feet long, is a dark-colored, finely vesicular variety (1592), without prominent phenocrysts. Another variety is still more resieular, with lightitblue coating to the vesicles. It is basaltic in appearance, with noticeable feldspars (1596). Others are dark and basaltic looking, but more compact, with prominent feldspars $(1594,1595)$. They all belong to the large andesitic body.

The liglit-colored rock which constitntes the main mass of this body has a groundmass that is mierocrystalline and microlitic. 'It is very much like that of the rock forming the summit of Mount Stevenson. It eontains much tridymite in elusters of minute erystals and in groups of twinned plates. The abundant small phenoerysts are labradorite, brown hornblende with magnetite and pyroxene border, brown biotite witl magnetite border, and some angite. There is a small amonnt of serpentinized mineral, whieh was probably hypersthene. In the roek from within 75 to 50 feet of the margin of the body the groundmass is mierolitic and possibly glassy. The phenoerysts of hornblende and biotite have only a very narrow inagnetite border in the roek at 75 feet from the contact plane, and none at all in that at 50 feet from the plane.

At the bottom contaet the character of the roek is somewliat changed. The groundmass is hyalopilitie, eonsisting of brown glass filled with microlites. Phenoerysts are ferver, and are labradorite with beautiful glass inclusions, hornblende almost eompletely paramorphosed to pyroxene and magnetite, brown biotite with narrow border of magnetite and pyroxene, many small phenocrysts of angite, and many others that are serpentine 
pseudomorphs and have the outline of olivine in some cases and of hypersthene in others. In one rock section the serpentine is replaced by calcite. This appears to be a more basic facies of the main rock.

The dark-colored, vesicular, and basaltic-looking modifications of the rock, already mentioned as lying at the base of the north slope of the spur, resemble the rock from near the bottom contact in the nature of the phenocrysts, which are more abundant in these rocks. But the groundmass is lighlly glassy, and is fine brown glass with many microlites of feldspar, pyroxene, and magnetite. This is specially true of the most vesicular modification. In it are some small phenocrysts of colorless olivine with narrow border of pyroxene, like that surrounding the serpentine pseudomorphs just described.

The occurrences of massive andesite at Coulter Peak and in its vicinity are most probably intrusive in two instances and surficial in the others. There are four distinct occurrences, three of which have been investigated. 'The rock in all three is the same in composition and habit.

At Coulter Peak it forms the upper 800 to 1,000 feet of the mountain. The rock is light gray, without noticeable phenocrysts, and is quite uniform throughout. There are a few thin crystals of homblende, fewer of feldspar, and sporadically biotite. It is slightly vesicular, especially at the summit of the peak (1605), but in the lower portions is dense and lithoidal (1604); and near the planes of contact with the mnderlying breccia it is dark colored and glassy $(1603,1606)$. The rock at the summit consists of square prisms of twimed labradorite, averaging $0.15 \mathrm{~mm}$. in length, besides shorter rectangular crystals and less well-defined grains with a brownish tinge. These have a slightly lower refraction and are probably more alkaline feldspar, with some minute pyroxene. There is a little magnetite. The small seattered phenocrysts are labradorite, paramorphs after hornblende, with some homblende in the center of the larger ones; occasionally biotite with magnetite border, and more or less completely serpentinized hypersthene. In the lower part of the rock mass the granular feldspars are larger, the whole being slightly coarser grained and lighter colored. Quartz is recognizable among the constituent minerals. Phenocrysts are fewer and the hornblende is less clanged.

At the bottom contact the rock is beautiful brown glass, with microlites of prismatic and tabular feldspar, in part at least labradorite; delicate 
prisms of proxene, for the most part lyypersthene, and little magnetite. 'The few sunall phenoerysts are labradorite, brownish-green horublende with little or no border, hypersthene, and angite. The mass is distinctly columnar, in groups standing at rarious angles and sometimes curved. Near planes of contact the columns are normal to the contact plane. On the southeastern spur the massive andesite overlies dark-colored breccia, and the surface of bottom contact, though quite irregnlar, slopes toward the nortly. At the northern end of the mass the plane of bottom contact dips steeply south, its trend being east and west. On the west spur of the mountain a body of similar massive rock caps breccia, the contact dipping nortl. The breccias bencath the body at Coulter Peak lie horizontal, and the indications point to the massive andesite being a surficial flow in a drainage chamnel trending west.

A large body of similar rock forms the upper portion of the mountain $1 \frac{1}{2}$ miles nortliwest of Coulter Peak. It has the same petrographical characters, but is denser and more crystalline in its main mass, approaching a porplyyry or felsite $(1596,1597,1601,1602)$. Near its contact with the breccia it is dark colored and glassy (1598), becoming lighter oolored and lithoidal at a distance of 6 inches (1599), and still more so at a distance of 10 feet (1600), where it is resicular, with tridymite in good crystals.

The rock representing the body of this mass is similar to that of Coulter Peak in general characters, but is more lighly crystallized. It consists of prisms of labradorite about as large as in the other rocks, 0.15 $\mathrm{mm}$. long, but few in number. The tabular or gramular feldspar is more abundant, and much of it is intergrown with quartz in micrographic and micropoikilitic structure, which is shown in Pl. XXXVIII, fig. 4. Magnetite occurs in minute grains, and there is some serpentine or chlorite. The few small phenocrysts of hornblende and biotite have narrow borders of magnetite in some cases and none in others. At the contact with breccia it is a brown glass, as at Coulter Peak, in this case faintly polarizing, as though devitrified. The beautiful microlites are like those in the other brown glass just described, except that there is more green hornblende, without dark border. At a distance of 6 inches from the contact the general character of the rock is the same, but the brown glass base is replaced by a gray microcryptocrystalline aggregate, which at 10 feet distance is microcrystalline, many of the parts being idiomorplic crystals of feldspar. The 
hornblende has a narrow border of magnetite grains. This body of andesite is columnal and has probably cut up througli the breccias, its plane of contact on one side trending sonthwest and dipping steeply to the southeast. It is exposed in an easterly escarpment, where the massive andesite can be seen eutting irregularly across the layers of breccia. It is also well exposed in a southerly escarpment. In the eastern escarpment there is an inclined sheet or dike of similar rock, which cuts up through the breccia at an angle of about $20^{\circ}$ and thins out. It appears to be an offshoot from the large body. Directly east of this peak, on the ridge north of Coulter Peak, there is another body of massive andesite of the same kind Its plane of contact with. the underlying upper basic breccia is steep and trends toward the northeast. It is also columnar alomg its western exposmre. Near it at the south end is a small intruded sean or dike of similar rock, which is wholly glassy $(1607,1608)$. It is yellowish brown near the margin and dark colored at the middle. It cracks into rounded lumps and has a perlitic structure on a large scale. It is a beantiful yellow glass in thin section, with well-defined microlites of prismatic and of less numerous tabular feldspars, delicate prisms of pyroxene, and grains of magnetite. The very small phenocrysts are brownish-green hornblende without dark border, hypersthene, angite, and labradorite; in all respects like the glassy portions of the rocks just described.

Massive andesite of the same character occurs as intrusive bodies in the valley of Mountain Creek. The largest is at the month of the ralley in the base of the momntain on the north side. Its boundary is obscured by soil and débris. It cracks into plates and is compact and light gray, with a few thin crystals of hornblende (1609). The rock is a fine-grained aggregation of feldspar crystals, quite like the more highly crystallized portion of the rock of Coulter Peak, except that there are fewer prisms and more irregularly shaped grains. The component minerals are the same, and the few small phenocrysts of green homblende and brown biotite inclose much magnetite.

Sereral small intrusive bodies cut the breccia east of the mouth of the north fork of the creek. One is a narrow vertical dike. It is light graly, with a few thin crystals of homblende, and is slightly vesicular. It becomes dark colored and glassy near the contact, and is brecciated in places (1612). Parts of it are compact, reddish brown and mottled, but 
not distinctly brecciater (1613). Microscopically it is the same as the rock of Coulter l'eak, the lithoidal portion being holocrystalline, with ahumlant prismatic microlites of feldspur that exlihit a pronounced fluidal arrangement. The glassy portion consists of clear yellowish-brown glass, with microlites, as in the glass of the Coulter Peak rock. The few small phenoerysts of brownish-green hornblende have margins of loosely aggregated pyroxene and magnetite. The other mass has the same characters. It is dense, gray, and lithoidal, and is partly vesicular with good crystals of tridymite $(1611,1610)$. It also lias the same microseopical characters. A surficial flow of pyroxene-andesite occurs on the summit of the ridge north of Middle Creek, already mentioned in another place.

\section{TRACIITIC RIIYOLITE.}

Closely comected with the early acid breccia on Yellowstone River in the neighborhood of Crescent Hill and Junction Butte are remnants of a lava stream of light-colored lithoidal rock whose most pronounced mineralogical feature is the presence of abundant phenocrysts of sanidine without any of quartz. It passes into breccia in places, and appears to have been contemporaneous with the earlier acid andesitic breccia of the region. Whether the scattered occurrences of this rock in the bottom of one large valley were originally connected and were parts of one large sheet, or whether they belong to several eruptions, is not definitely known.

Areas of this rock occur along the sonth side of Yellowstone River, forming a cliff at about 6,400 feet altitude from Geode Creek around the north base of Crescent Hill to Yanceys. It occurs somewhat higher on the north side of the Yellowstone River west of Hellroaring Creek, lying between 6,600 and 7,200 feet altitude. It extends east around the north end of Junction Valley and forms the base of Junction Butte east of the river. It occurs on the north of Lamar River opposite the butte, and 500 feet above the river, and also near the montl of Slough Creek. Patches of it are found on the end of Specimen Ridge 1,500 feet above the river: Lavas similar to this occur as intimately associated with the basic andesitic breccias north of the Yellowstone Park, on Buffalo Platean and on the flanks of Sunset Peak.

The rock is generally light colored, and varies from white and gray to yellow, buff, brown, red or pink, purplish, and green. In most places it is MON IXXII, PT II-21 
lithoidal to earthy; also compact and dense. In one locality it is glassy and greenish gray, in part perlitic, passing into dark-gray and black glass, and constituting a pitchstone $(683,684)$. In nearly every instance it is mottled with what appear to be inclosed fragments having a different character, and which are mostly tuff of the same rock. They are often flattened, giving the rock a distinct flow structure. The phenocrysts vary in aloundance and size in different modifications of the rock. They are sanidine, plagioclase, and biotite. Sanidine is generally perfectly fresh and exhibits a brilliant cleavage surface, while the plagioclase is often decomposed and is fiesh in only a few cases. Biotite is subordinate in amount.

In places the rock carries many fragments of andesite and of crystalline schist, and passes upward into breccia filled with the latter, and merges into andesitic breceia similar to that already described as underlying it. This relation may be observer at the northern base of Crescent Hill and on the ridge opposite the mouth of Hellroaring Creek. It was the product of eruption of an exceptional modification of magma, rich in sanidine, which occurred early in the period of the extravasation of the hornblende-micaandesite, when crystalline schists formed the surface of the country through which the eruptions took place.

This light-colored porphyritic lava consists of an abundant groundmass, which is in nearly all cases megascopically lithoidal and under the microscope is highly varied in structure. In this groundmass are numerous phenocrysts of sanidine and lime-soda feldspar, which in numerous cases is decomposed. Ferromagnesian minerals are scarce. The only ones recognized megascopically are small biotites. In thin sections of the rock pyroxene is seen, in some cases in almost microscopic crystals. A very little green hornblende occurs in a few cases. The sanidine crystals are $2 \mathrm{~mm}$. long and smaller, and are usually twimned according to the Carlsbad law. Their cross sections are generally rectangular, but they often have irregular outlines, as though fragiments of former well-shaped crystals. The same is also true of plagioclase. The sanidines are very free from inclusions of foreign material; occasional inchusions of glass, apatite, and zircon occur. The pinacoidal clearages are often well developed, but some crystals are almost free from cleavage cracks and are easily mistaken for quartz. The lime-soda feldspar is similar to sanidine in size and general form, but exhibits polysynthetic twiming according to albite, pericline, and Carlsbad laws. In 
at number of eases the symmetrical extinction angles tested by Hichel Léry's method indicate that the feldspar is labuadorite as ligh in lime as $\mathrm{Ab}_{2} \mathrm{An}_{3}$. In other rock sections the only symuetrical extinetion mules are low, but they are few, and may possibly belong to labradorite. 'These feldspars also are quite free from inclusions. They are more easily decomposed than sanidine, and in a number of rock sections are completely altered, while the sanidine is fresh. The usual alteration is to a microcrystalline aggregate witl low double refatetion, probably kaolin. Occasionally the feldspar is replaced by calcite. Biotite occur's in irregularly outlined erystals of very small size. It is brown and has a very small optic angle. Augite, when present, forms idiomorphic and also irregularly shaped crystals, apparently fragments of larger crystals. Its colors and general character are the same as those of the augite in the associated andesites. The same is true of the few small fragments of green and brownish-green hornblende. Ilmenite, or titaniferons magnetite, is present in comparatively large microscopic crystals and grains. Its character is indicated by its alteration product and its form, since it alters to a white opaque mineral crossed by lines in three directions. It is similar to the occurrence of titaniferous iron oxide in the rhyolite of the region. With it are associated colorless apatite and zircon. There are a few yellow, almost isotropic, pseudomorphs, possibly after hypersthene.

The groundmass is in many cases brecciated, and is made up of patches with different kinds of microstructure. It also contains fragments of other rocks, such as andesite and the crystalline schists. Large fragments of the latter are found in places, and the massive lava grades into tuff-breccia in some localities. Only a small part of the rock is glassy and unaltered (683). Numerous thin sections show that the rock was once glassy in many places but has become nore or less completely devitrified. The glassy form consists of glass that is globulitic and brown in places, witlı streaks and lumps that are colorless, and microlitic and trichitic, with pyroxene and magnetite, quite like some rhyolitic glasses. It has eutaxitic and flow structures and is spherulitic in places. Perlitic cracking is developed to some extent. Small lumps with beautiful brown glass full of microlites, and others containing angite and hypersthene, and holocrystalline pieces of pyroxeneandesite in this glassy lava, suggest that its eruption was subsequent to that of pyroxene-andesite, which is the case for similar trachytic lava farther 
north on Buffalo Plateau and southeast of Sunset Peak. These rocks are also identical microscopically with this glassy modification of the trachytic lavas north of Crescent Hill.

Other parts of the rock are brecciated flows, with lumps that are devitrified perlitic glass, with microgranular and microeryptocrystalline portions. These retain the small phenocrysts and microlites intact. Some are composed of minute firagments of glass with very irregular shapes, welded together as in many rhyolites. They are devitrified and microcryptocrystalline. Some of the groundmasses are coloret yellow, orange, or red by cloulded particles of hydrous oxide of iron. Less often the color is green, from ehloritic infiltration.

The gromulmass is wholly deritrified in many cases where the feldspar phenocrysts are still fresh. In a number of instances the rock is wholly altered, both kinds of feldspar having been reduced to kaolin, and the other phenocrysts being decomposed and the gromdmass reduced to a microcrystalline to microcryptocrystalline aggregation. One modification of the rock is somewhat andesitic, all of the feldspar phenocrysts being lime-soda feldspar' (709).

The chemical composition of the rock is shown by analysis 1 . It is of a variety (679) which has fresh phenocrysts of sanidine in abundance and fresh labradorite and a little biotite. The groundmass is deritrified, and there is some chlorite. The loss npon ignition is high and indicates partial alteration. If anhydrous the silica would be $6 b^{b}$ per cent, and the rock would be about on the dividing line between quartz-soda-trachyte or highly siliceons soda-trachyte and rhyolite. The presence of labradorite in a rock with so little lime and so much soda is surprising, and it is evident that the orthoclases must be rich in soda. The chemical composition of the very similar rock near Sunset Peak on Bear Gulch, mapped in the Livingston folio (No. 1) of the Geologic Atlas, is shown in the accompanying analysis 2. It is higher in silica and in alkalies, the potash being exceptionally high for rocks of this region. This rock is chemically trachytic rhyolite. Mineralogically all of these rocks are characterized by the absence of quartz as phenocrysts. The groundmass is highly siliceous, and quartz is present in the microcrystalline modifications. 
Analyses of trachytic rhyolite.

[Analÿsts: 1, J. K. Whithe]d; 2, I, G. Eakins.]

\begin{tabular}{|c|c|c|}
\hline Constituent. & 1. & 2. \\
\hline 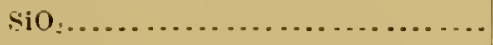 & 61.65 & 69.45 \\
\hline $\mathrm{TiO}_{2} \ldots \ldots \ldots \ldots \ldots \ldots \ldots . . . . . . . . . . . . .$. & Trace. & .19 \\
\hline 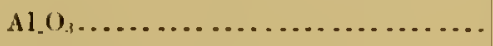 & 17.80 & 14.92 \\
\hline $\mathrm{Ie}_{\mathrm{g}} \mathrm{O}_{3} \ldots \ldots \ldots \ldots \ldots \ldots \ldots \ldots \ldots \ldots \ldots \ldots$ & 2.33 & 3. 16 \\
\hline 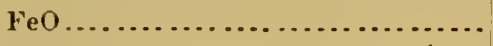 & 2. 10 & .23 \\
\hline $\operatorname{MnO} \ldots \ldots \ldots \ldots \ldots \ldots \ldots \ldots \ldots$ & Trace. & .07 \\
\hline $\mathrm{BaO} \ldots \ldots \ldots \ldots \ldots \ldots \ldots \ldots$ & $\ldots \ldots \ldots$ & .03 \\
\hline $\mathrm{CaO} \ldots \ldots \ldots \ldots \ldots \ldots \ldots \ldots \ldots$ & 1.73 & 1. 19 \\
\hline $\operatorname{Mg} O \ldots \ldots \ldots . \ldots \ldots \ldots \ldots$ & .81 & .05 \\
\hline $1, \mathrm{i}, \mathrm{O} \ldots \ldots \ldots \ldots \ldots$ & .17 & ......... \\
\hline $\mathrm{Na}_{2} \mathrm{O} \ldots \ldots \ldots \ldots \ldots \ldots$ & 4.18 & 3.19 \\
\hline$K_{2} \mathrm{O} \ldots \ldots \ldots \ldots \ldots \ldots \ldots$ & 2.83 & 5.95 \\
\hline$P_{2} O_{3} \ldots \ldots \ldots \ldots \ldots$ & I'race. & .06 \\
\hline $\mathrm{SO}_{3} \ldots \ldots \ldots \ldots \ldots \ldots \ldots \ldots$ & .43 & 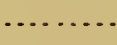 \\
\hline \multirow{2}{*}{$H_{2} 0 \ldots \ldots \ldots \ldots \ldots \ldots \ldots \ldots$} & 3.06 & 1.69 \\
\hline & .100 .09 & 100.18 \\
\hline
\end{tabular}

Trachytic tuffs similar in composition occur in two other localities in the Park. One is on the sonth fork of Beaverdam Creek, where it overlies shoshonite, and the other is at 'Two Ocean Pass, where it occurs in the bottom of the andesitic breccia near the basaltic lavas (shoshonite). They are all alike in being composed of a glass y groundmass, with phenocrysts of sanidine and lime-soda feldspar, besides biotite, magnetite, or ilmenite, and many inclusions of other rocks, pyroxene-andesites for the most part $(1650,1722$, and 1725). In the rock from Two Ocean Pass there are labradorite crystals and fragments and numerous broken augites, as well as pieces of andesite. In this rock it is possible that the labradorite crystals may liave been derived from the andesite dust. The presence of labradorite in association with orthoclase in parts of this rock corresponds to the similar association of these two feldspars in shoshonite and banakite, and indicates a genetic relationship, which is also indicated by the close association of these rocks in the field. 
C H A P T E R I X.

\title{
ABSAROKITE-SHOSHONITE-BANAKITE SERIES.
}

\author{
By Joseph Paxson Indings.
}

\section{IXTRODECTION.}

There are certain basaltic-looking rocks associated with the older andesitic breccias in varions localities within the Park, which form lava flows in mọst cases and dikes in others, and which more rarely constitute part of the basic breccia itself. They are usually quite subordinate in anount, judging from the extent of their exposures, but, considering the probable size of their original masses, before being exposed by erosion they must have had very considerable volumes. As flows they are basaltic in character, being dark colored and heary, with olivine among the phenocrysts in most cases. They are massive and compact or vesicular. They are porphyritic in some cases, but not noticeably so in others, and generally exhibit a semiwaxy luster that suggests the presence of nepheline, which, however, is not present. The waxy luster is due to the alkali feldspar in the groundmass. They are often dull greenish black owing to the serpentinization of olivine. As dikes they are basaltic in some cases and trachytic in others, being gray in various shades, and having a somewhat waxy luster in the rocks of darker shades. The luster, as in the case of the flows, is due to the alkali feldspars, as there is no nepheline. They are porphyritic or not in different cases, and range from aphanitic to phanerocrystalline. As will be seen later, they represent a rather wide range of composition, both chemical and mineralogical, and though genetically related and connected by gradual transitions, so that they constitute a natural group, they could not be embraced by any one definition and must be divided into several classes. 
The chict chalmateristics of the most basic class are the presence of abundant phenoerysts of olivine and angite and the absence of any of feldspar. 'The groundmats nily be anything from al dark glass to an almost phamerocrystalline lightegray mass. It is oftener aphanitic and dark greenish gray. The phenocrysts are large and pronounced in many cases, but are rery small in others. The microscopical characteristics will be given at length. Cliemically they are low in silica, from 46 to 52 per cent; low in alumina, from 9 to 12 per cent; high in magnesia, from 8 to 13 per cent: comparatively high in alkalies, with potash considerably higher than soda, except in one case. The molecular ratio of the alkalies to silica is 0.08 and 0.09 . After the crystallization of abundant phenocrysts of olivine and angite the remainder of the magma, owing to the low alumina and to relatively high alkalies, was so constituted that alkali-feldspathic minerals, in the form of orthoclase or leucite, might crystallize out, which they did or not according to the conditions under which solidification took place.

The principal characteristic of the second class is the presence of phenocrysts of labradorite, together with those of augite and olivine, in a groundmass that is nsually dark greenish gray, with a semiwaxy luster, but which may be glassy or phanerocrystalline, and which when distinctly crystallized contains a notable percentage of orthoclase. They range from varieties rich in olivine and angite, which, with decreasing labradorite, grade into rocks of the first class, to varieties with few olivines or angites.

Chemically they contain from 50 to 56 per cent of silica. Alumina is moderate to high, from 17 to 19.7 per cent. Lime and magnesia are moderate to low, the former from 8 to 4.3 per cent, the latter from 4.4 to 2.5. The alkilies are moderately high, with potash comparatively high for rocks of this region, with like amounts of silica, from 3.4 to 4.4 per cent, the soda ranging from 3 to 3.9 per cent. The molecular ratios of the alkalies to silica is 0.10 and 0.11 . After the crystallization of phenocrysts of labradorite, olivine, and angite, the remainder of the magma was rich in alkali-feldspathic material, usually that of orthoclase, which shows itself in the groundmass according to conditions of erystallization.

Rocks corresponding chemically to both of these classes occur with no megascopic phenocrysts, and in varions phases of crystallization, from glassy to holocrystalline, and almost phanerocrystalline; consequently they differ from them not only in microstructure but in the minerals that have 
been developed. They occur both as lava flows and as dikes, but no special characteristics ean be comnected with either mode of occurrence, except that the more highly crystallized forms are found as dikes. Not all the dikes, however, are more crystalline than all the lava flows.

Rocks of the third class are known mostly in the form of dikes, and in only a few localities. The rocks are highly feldspathic, with small amount of ferromagnesian minerals, and these chiefly biotite with subordinate angite. The phenocrysts are labradorite in a gromndmass rich in orthoclase. Chemically they have 51 to 61 per cent of silica, 16.7 to 19.6 per cent of alumina, 3.5 to 6 per cent of lime, 1 to 4 per cent of magnesia, 3.8 to 4.5 per cent of soda, and 4.4 to 5.7 per cent of potash. The ratio of alkalies to silica is 0.13 and 0.14 . Since much of the calcium and sodium goes into the phenocrysts of labradorite, the feldspathic groundmass is rich in potash and is largely orthoclase. The rocks stand at the end of the series, representing the variation reached when all the phenocrysts are labadorite and when biotite occurs instead of olivine and augite.

The division of the series into three parts is wholly artificial and for convenience. There is gradation from one end to the other, and from the middle of the series into the normal basaltic rocks of the region, which will be pointed out later. The three classes will be described under the names absarokite, shoshonite, and banakite.

\section{ABSAROKITE.}

All of the rocks here classed as absarokites carry abundant phenocrysts of olivine and augite, except two (1282 and 1624). These are classed with them on the ground of chemical identity. The rocks occur in the Absaroka Range, and also in other parts of the Yellowstone Park, being found upon Mirror Platean $(1151,1152)$, within the region of the Crandall rolcano (1282, 1277, 1306, 1307), at Signal Point, Yellowstone Lake (1617, 1618), at Two Ocean Pass $(1719,1720)$, on Coulter Creek (1743), about the headwaters of Conant Creek $(1745,1751)$, and in the Ishawooa Canyon (1698). The absarokite is found as bowlders on the west shore of Yellowstone Lake, south of Bridge Bay, probably coming from Signal Point, on the east shore. 
The chemical composition of six of these rocks is shown by the following anilyses, the chanacteristic features of which have already been indicated:

Analyses of absurolites.

\begin{tabular}{|c|c|c|c|c|c|c|}
\hline Congtituent. & 1 & 2 & 3 & 4 & 5 & 6 \\
\hline $\mathrm{SiO}_{2}, \ldots \ldots \ldots \ldots$ & 48.28 & 48.95 & 48.36 & 51.76 & 49.71 & 51.68 \\
\hline 'TiO: ............... & .88 & .49 & 1.18 & .47 & 1.57 & 1.08 \\
\hline $\mathrm{Al}_{3} 0_{3}, \ldots \ldots \ldots \ldots$ & 11.56 & 12.98 & 12.42 & .12 .36 & 13.30 & 14.07 \\
\hline $\mathrm{Fe}_{2} \mathrm{O}_{3}, \ldots \ldots \ldots \ldots$ & 3.52 & 3.63 & 5.25 & 4.88 & 4.41 & 4.71 \\
\hline FeO............... & 5.71 & 4.68 & 2.18 & 4.60 & 3.37 & 4.57 \\
\hline $\mathrm{M}_{u} \mathrm{O} \ldots \ldots \ldots \ldots$ & .13 & .13 & .13 & .11 & .17 & Trace. \\
\hline $\mathrm{BaO}, \ldots . . . . . .$. & ............ & ......... & .29 & .......... & .46 & ....... \\
\hline $\operatorname{Mg} O \ldots . . . . . . . .$. & 13.17 & 11.73 & 9.36 & 9.57 & 7.96 & 7. 72 \\
\hline $\mathrm{CaO} \ldots . . . . . . . .$. & 9.20 & 7.66 & 8.65 & 7.14 & 8.03 & 6.65 \\
\hline $\mathrm{Na}_{2} \mathrm{O} \ldots \ldots . . . . . .$. & 2. 73-2.89 & $2.3 \mathrm{i}$ & 1.46 & 1.99 & 1.49 & 2.45 \\
\hline $\mathrm{K}_{2} \mathrm{O} \ldots \ldots \ldots$ & $2.17-2.22$ & 3.96 & 3.97 & 3.83 & 4.81 & 4.16 \\
\hline $\mathrm{P}_{2} \mathrm{O}_{5}, \ldots \ldots \ldots$ & .59 & .67 & .84 & .56 & .66 & .72 \\
\hline $\mathrm{Cr}, \mathrm{O}, \ldots \ldots \ldots$ & n.......... & $\ldots . .$. & Trace. & $\ldots$ & Trace. & $\mathrm{SO}_{3} .13$ \\
\hline Cl ............. & .18 & $\ldots \ldots$ & 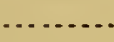 & . . . . . . . & ........ & $\mathrm{Li}_{2} \mathrm{G}$ Trace. \\
\hline $\mathrm{H}_{2} \mathrm{O} \ldots \ldots \ldots \ldots$ & 2.96 & 3.16 & 5.54 & 3.05 & 4.07 & 2. 09 \\
\hline Total ....... & 100.08 & 100.35 & 99.93 & 100.32 & 100.01 & 100.03 \\
\hline Less O for Cl ........ & .0 .4 & & & & & \\
\hline & 100.04 & & & & & \\
\hline
\end{tabular}

1. Leucite-absarokite, Ishawoon Canyon, Wyoming. Analyst, J. E. Whitfield. (1698.)

2. Absarokite, dike at head of Lamar River. Analyst, L. G. Eakins. (1306.)

3. Absarokite, dike south of Clark Fork River. Analyst, L. G. Eakins. (1277.)

4. Absarokite, lava flow, head of Raven Creek. Analyst, L. G. Eakins. (1151.)

5. Absarokite, dike, divide east of Cache Creek. Analyst, L. G. Eakins. (1282.)

6. Absarokite, lava flow, Two Ocean Pass. Analyst, J. L. Whitfield. (1720.)

The six analyses are arranged according to decreasing percentage of magnesia. The first two liave the highest; the second two, over 9 per cent; the fifth and sixth have 7.96 and 7.72 , which are not very high for a rock so low in silica. There is an inereasing range in alumina and in potash. The second, third, and fourth analyses are closely alike. The first and last two are not so much alike that they might not be considered separately. The chief differences are in the magnesia and alkalies, but they are related in other respects. 'They all exhibit considerable loss upon ignition, corresponding to the amomut of hydration due to alteration or to the presence of zeolitic minerals.

As already said, the rocks here grouped together differ somewhat in 
the mineral composition of the groundmass as well as in its microstructure. The rock with the largest grain and most highly developed crystallization is that whose chemical composition is given in the first analysis (1698). It was not found in place, but was collected from a bowlder 3 or 4 miles from the junction of the streams in Ishawooa Canyon. It is nearly holocrystalline, and was probably an intrusive rock in the form of a dike. It consists of abundant phenocrysts of olivine and angite, about $3 \mathrm{~mm}$. in diameter and smaller, and of a subordinate amount of gray crystalline groundmass. In thin section the olivine is colorless and very free from inclusions, with almost no serpentinization. The augite is pale green, with high extinction angle, reaching $42^{\circ}$. It incloses some olivine and magnetite. The form of these phenocrysts is only partially idiomorphic, the outline being quite jagged in some cases, and the reentrant angles being occupied by orthoclase, as thongh the crystallization of the olivine and angite had continued into the period in which the feldspars of the groundmass were forming. There was no hiatus between the crystallization of the phenocrysts and that of the groundmatss. The two were commected and contimons. The gromdmass consists of crystals of orthoclase and lencite, which are nearly idiomorphic, althongh the mass is holocrystalline, except for occasional possible remnants of glass base, which form angular patches between the crystals. There are also small irregularly shaped crystals of angite and olivine, with magnetite and much apatite in long slender needles. The orthoclase and leucite are not uniformly mingled, but are clustered in groups. The orthoclase is in rectangular prisms, twimned according to the Carlsbad law, and about 0.4 mm. long and smaller. Very rarely they contain minute cores of limesoda feldspar, with symmetrical extinction angles of $30^{\circ}$, corresponding to labradorite. The substance of the feldspar is very fresh and unaltered. The lencite is partly idiomorphic, partly allotriomorphic, and in some cases exhibits the characteristic double refraction, though most crystals are isotropic. Central aggregations of minute angite grains occur. In places a clondy alteration has set in, resulting in a zeolitic mineral whose exact nature has not been determined. Owing to the small amount of material collected, no separations or partial malyses were attempted. The determination of the alkalies was repeated and found to accord closely with the first determination.

The needles of apatite are very delicate and traverse the feldspathic 
crystals of the grounduass in all directions, but do not penetrate the phenocrysts of ulivine and angite, indicating that the formation of the apatite was not annong the earliest of the crystallizations, but took place when the groundmass crystallized. ${ }^{1}$

The development of orthoclase and lencite from a magna so low in alkalies and with so little potash is notable. 'The almost total absence of lime-soda feldspar is plainly due to the low percentage of alumina, which was nearly all combined with the alkalies to form alkali-feldspathic minerals. It is evident that both the orthoclase and lencite must be rich in soda. The formation of lencite was undoubtedly controlled by the low percentage of silica, which if higher would have formed a polysilicate of all the aluminum and alkalies, instead of a metasilicate and polysilicate. The earliest compounds to crystallize-olivine and angite-consumed the magnesia and lime, witl irou oxide and some alumina, and possibly some soda. It is evident that the remaining magma contained lime in sufficient amount to satisfy the phosphoric exide, besides a little that combined with alumina and silica to form labradorite. Horeover, the alkalies and alumina were left in the proper proportions to form alkali-feldspathic minerals. In a molten condition they did not exist as molecules of these minerals, yet we see the indication of an influence that controlled the proportions of the partially dissociated elements. At the time of the crystallization of the alkali-feldspathic constituents there were small amounts of ferromagnesian silicates still liquid, which crystallized at this time.

The rock most closely related to the one just described in chemical composition occurs as a dike, 4 feet wide, on the divide between Lamar River and Crandall Creek, south of Hoodoo Mountain. It is dark colored $(1306,1307)$ and aphanitic, with abundaut large crystals of angite 5 to 10 mun. in diameter and smaller phenocrysts of olivine. On the sides of the dike a thin layer of the rock is glassy and black.

In thin section the body of the dike is lolocrystalline and very fine grained. The groundmass consists of indistinctly outlined lath-shaperl feldspars with low angles of extinction, besides an indistinct feldspatlic mineral as cement, which is clondy. The lath-shaped feldspars appear to be, in part at least, orthoclase with minute lath-shaped cores of lime-soda feldspars.

'Arnold Hagne, Notes on the occurrence of a lencite rock in the Absaroka Range, Wyoming Territory: Am. Jour. Sc1., 3d series, Vol. XXXVIII, July, 1889, pp. 43-47. 
Nothing resembling leucite or suggesting it is present. This feldspar matrix is crowded with microscopic crystals of augite, magnetite, and brown biotite in thin tablets and long narrow crystals which often resemble hormblende. In one part of the rock ilmenite accompanies magnetite. The groundmass of the edge of the dike is brown glass with microlites of angite and some of plagioclase. These microlites have dark-brown clouds attached to their ends, or in the case of augite are colored brown.

The augite phenocrysts are light green in thin section and are filled with irregularly shaped inclusions of crystalline groundmass containing ilmenite rods, which are not generally found in the groundmass of the rock outside of the augites. These ilmenite rods within the inclusions of one augite lie in several orientations, apparently with rhombohedral symmetry. Although they are confined to the inclusions of groundmass and do not penetrate the angite substance, their shape and arrangement suggest the microscopic rod-like inclusions in the diallage and hypersthene of gabbro, which may possibly be imenite. The angites alsc inclose small crystals of olivine and magnetite.

The olivine phenocrysts are sharply idiomorphic and of very pure substance, with small inclusions of magnetite and glass and occasionally bays of groundmass. It is sometimes twinned in pairs of attached crystals, the twimning plaue being (011). There is a slight serpentinization along the surface and cracks in some cases. The olivine crystals are much smaller than those of augite, but are more numerous. The appearance of this rock in thin section is shown in Pl. XXXVI, fig. 1.

It is to be observed that the glassy groundmass of the marginal surface of the dike is unlike the groundmass of the main body of the dike in mineral composition. Biotite is not developed, and the only feldspars are the microlites of plagioclase, which may correspond to the cores in the lath-shaped orthoclases of the main body of rock. As compared with the leucite-bearing rock from Ishawooa Canyon (1698), it is to be noted that the phenocrysts of angite and olivine in the dike rock just described are not quite so numerous as in the Islawooa rock, while there is much more angite in the groundmass, besides abundant biotite. The microscopic crystals of feldspar are not so large and distinct, and nothing corresponding to lencite can be seen. Chemically the rock is richer in potash, with about the same per cent of soda. Alumina is slightly higher, and 
U. S. GEOLDGICAL SURYEY

MONOGRAPH XXX\| PART \| PL. $X X X V$
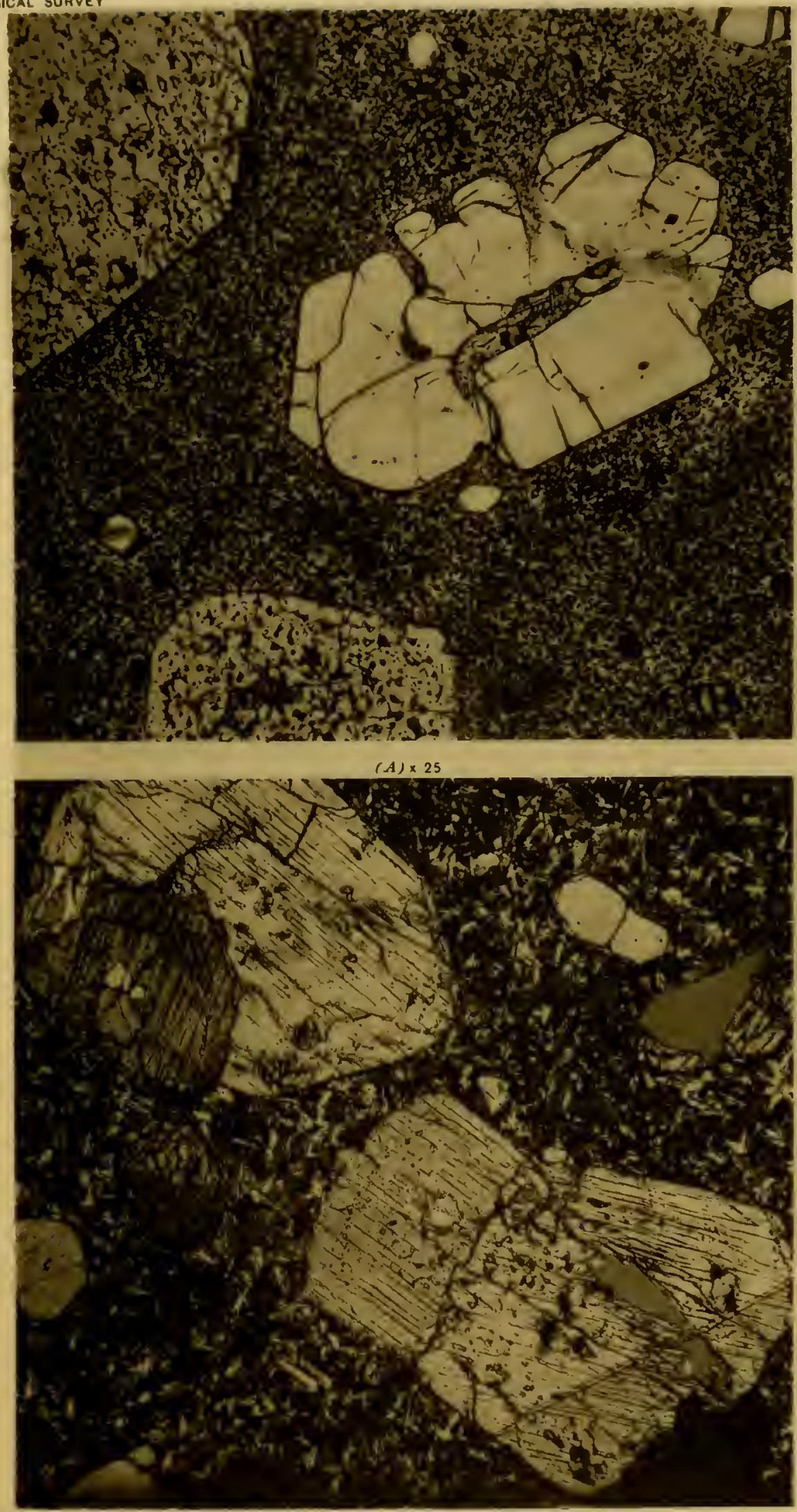

(B) $\times 37$

PHOTOMICROGRAPHS OF ABSAROKITE 

mannesia and lime are slightly lower. There is a little more silica. The high loss on ignition indicates that there is a hydrous silicate in the groundmass, possibly a zeolite. As has been printed ont in another place, ${ }^{1}$ the lencite in one rock with abumlant olivine may be representer hy biotite and less olivine in the other, with in increased amount of orthoclase. The less distinet erystallization of the second rock prevents a perfectly satisfactory comparison. 'They illustrate, lowever, what mineralogical differences may exist among rocks with almost the same chemical compositions.

The next two rocks whose analyses are given still further illustrate the same thing. One (1277) is a dike 3 feet wide on the high ridge south of Index Peak and of Clark Fork River, in places woathering out from the andesitic breccia in a wall 8 or 10 feet high, with horizontal columus. The second (1151) is a surficial lava flow east of the head of Raven Creek on Miror Platean. Chemically they are almost identical, and nearly the same as the dike south of Hoodoo Mountain, just described. They have slightly less magnesia, and the lava flow has 3.4 per cent more silica than the dike rock. The latter experiences considerable loss upon ignition.

The dike rock (1277) is dark greenish gray, aphanitic, with small megascopic phenocrysts of augite and occasional large grains of quartz with angite shells. The quartzes are cracked and filled with calcite. In thin section the few megascopic crystals of angite are crowded with inclusions of gromumass, and resemble the augite phenocrysts in the rock last described. The other constituents may be considered as parts of the groundmass, which is holocrystalline and consists of much pale-green augite, brown biotite, and magnetite, with a subordinate amount of feldspathic matrix. There are larger angites which are colorless at the center and green on the margin, with a zonal strncture, besides many small serpentinized olivines. The feldspathic matrix is largely decomposed. It is partly lath-shaped feldspar, which is orthoclase with prismatic cores of plagioclase, and often in radiating groups suggesting orthoclase or albite-oligoclase. Besides the recognizable feldspar there is much clondy microcryptocrystalline material with no definite form, except a very frequent occurrence of spots with an approach to the outline of an isometric mineral. These are often darker colored at the center, and suggest the former presence of p. 176.

'Iddings, J. P., The origin of igneous rocks: Bull. Philos. Soc. Washington, Vol. X1I, 1892, 
lencite. The occurrence of lencite in similar rocks in this region makes this highty probable. In one thin section of the rock there is much transparent allotriomorphic mineral, which is in part isotropic, but is also doubly refracting. This is undoubtedly analcite. It is probably secondary, as it is found in resicular earities, sometimes accompanied by other zeolites. The large rounded grains of quartz which occur sporadically through the rock are single individual crystals and not aggregations. The originally dihexahedral form of the crystal, slightly rounded, can be seen on some of the individnals, and in the shape of the cavities in the rock from which they may have fallen when the rock was broken. They are surrounded by a shell of angite crystals with some brown altered glass, as in other instances in basaltic rocks. The substance of the quartz is extremely pure and free from inclusions of foreign matter, or of gas and liquid. In some cases there are a few dihexahedral inclusions of altered groundmass or glass.

This rock resembles that forming the dike south of Hoodoo Mountain in the general character of the groundinass, except that the phenocrysts of olivine and augite are almost microseopic, and may be considered part of the groundmass. The ferromagnesian minerals are about the same in each, and the feldspathic components are obscure, with indications of alkaline character.

The rock of the lava flow east of the head of Raven Creek (1151,1152) is dark gray, with abundant small megascopic phenocrysts of olivine and augite. In thin section these crystals are quite fresh and like those in the rocks of this class already described. There is a slight serpentinization of the olivine. The groundmass consists of small rectangular prisms of orthoclase, sometimes with minute cores of prismatic labradorite, besides abundant micioscopic crystals of augite and magnetite. There is some serpentine, which occupies angular spaces between the feldspar crystals, and may replace glass base. The feldspars are distinctly crystallized, and their orthoclastic character is unquestionable. They resemble the orthoclase crystals in the leucite-bearing rock from Ishawooa Canyon. No lencite, however, was nbserved in this rock. Only a very small part of the groundmass is limesoda feldspar. There is no biotite and no analcite. Apatite occurs in delicate needles. The absence of biotite may be correlated with more pronounced orthoclase and abundant olivine, and the absence of leucite accords with the higher percentage of silica in the rock as compared with the rock from Ishawooa Canyon. 
The fifth rock of this clats, of which the ehemical analysis has been given, oceurs ans a massive body in the andesitic breccia on the sontheast fork of Cache Creek. Another rock of like chanater forms a narrow dike on the divide between Cache and Crandall ereeks $(1282,1283)$. They are aphlanitic, hownish-gray rocks, without phenecrysts, but having minute brown pseutomorphs, presumably after olivine. The rocks are identical in every respect and carry occasional rounded grains of dark-colored, crackled quarty, incloset in a thin green shell.

In thin section these rocks are holocrystalline and fine grained, consisting of thin latll-shaped feldspars, frequently grouped in fan-like clusters. They are not distinctly striated, and are probably orthoclase. Others are plagioclase with low angles, and some are irregularly bounded and obscure. 'This matrix is crowded with idiomorphic crystals of pale-green augite, dark-brown biotite, ${ }^{1}$ and magnetite, the ferromagnesian minerals equaling the feldspar in amount. There are a few porphyritical augite groups, which are almost colorless at the center, with pale-green margins. The psendomorphs have the outline of olivine. The feldspars exhibit slight alteration, but the augites and biotites are perfectly fresh. In places there are ilmenite rods.

There is considerable serpentine scattered through the rock in small aggregations of pale-green spherulites. Mineralogically the, rock is very similar to the quartz-bearing dike rock (1277) from the ridge southeast of Index Peak, which it resembles megascopically. Chemically it is slightly higher in alumina and potash, and slightly lower in magnesia and lime. The high loss on ignition is most likely due to the serpentine, which was probably derived from olivine.

Fortunately, this phase of the magma is found in immediate connection with the gabbro core on Hurricane Mesa, Crandall Basin. It forms the dense bluish-black margin (1422) of a 4 -foot dike, the middle of which is gray and crystalline (1421). The dike cuts granular rock near the base of the middle spur of the core. The aphanitic marginal rock (1422) carries a few small micas, but no prominent phenocrysts. In thin section it has the

1 When first studied, some of the brown minerals were considered to be brown hornblende, bnt a careful review fails to establish the presence of horublende. Some of the biotite plates are loug and narrow, and when they overlie a erystal of feldspar they appear to possess a donble refraction not found in other biotite plates, which led to their being mistaken for hornblende. The rock was doubtfully named horablende-minette in the list of rocks whose analyses were given in Table III in the paper on The origin of igneons rock, in Bull. Philos. Soc. Washington, Vol. XII, p. 199. 
same habit as the rock last described, consisting of colorless feldspar crowded with idiomorphic crystals of pale-green angite, brown biotite, and magnetite, which predominate over the feldspar. 'There is a little brownishgreen hornblende, and many paramorphs of olivine, the centers of which in some cases are surrounded by a border of magnetite, and outside of this, biotite. Along a seam in the rock there is much secondary green hornblende, which replaces the pyroxene for some distance on both sides of the seam. The feldspar matrix has a variable structure and is perfectly fresh. In places it consists of comparatively long and broad individuals of unstriated feldspar with low double refraction and almost parallel extinction, which is presumably orthoclase. These prisms are chustered in radiating groups inclosing the ferromagnesian minerals, the cementing feldspar prisms being much larger than the other minerals. In other parts of the section the feldspars are small, lath-shaperl in some cases, and granular in others. None of the feldspar is distinctly striated.

The rock from the middle of the dike (1421) differs considerably from that of the margin. In thin section it is seen to be more feldspathic and is coarser grained. The feldspar is mostly striated plagioclase with borders of orthoclase. The plagioclase kernels are sometimes altered and cloudy. There is a very little quartz. The microstructure of the rock is produced by ill-defined lath-shaped crystals and some grains. There is considerable augite, changed to uralite, much biotite, little magnetite, and numerous paramorphs of olivine. It is probable that there was some primary hornblende in the rock before uralitization set in. The margin of the dike is richer in ferromagnesian minerals and magnetite, and the feldspars are more alkaline and represent a phase, of differentiation of the gabbro magma brought about within the dike.

Rocks from other parts of this region which are like those just described in mineral composition and structure are the following: Massive lavas associated with basic andesitic breccia at Signal Point on Yellowstone Lake $(1617,1618,1619)$, corresponding to the lava flow (1151) east of the head of Raven Creek. One modification (1618) has much orthoclase in the groundmass and little lime-soda feldspar, and contains crystals of isotropic or faintly doubly refracting mineral clouded yellowish in transmitted light, which, from analogy with similar olivine-augite-orthoclase rocks from this region, is or was most probably lencite. Brown biotite, probably secondary, 
and needles of apatite complete the resemblanee between this roek and that just referred to. It appears to be an intermediate variety between the latter and certain orthoclase-bearing basaltic rocks from the head of Conant Creek, to be clescribed presently $(1,338)$. Its appearance in this section is shown in Pl. XXXVI, fig. 2.

Another modification of the lava at Signal Point (1617) contains much orthoclase in the groundmass, no isotropic mineral, but considerable reddish brown mica, which appears to be secondary and accompanies chlorite or serpentine. It is sometimes sharply idiomorphic, and has a small axial angle. There is also some red oxide of iron. Another variety has a nearly opaque groundmass, with reddish-brown color, carrying phenocrysts of angite and olivine like those in the rocks associated with it. In very thin section the groundmass is seen to contain mnch iron oxide and feldspathic mincral, partly in lath-shaped microlites, altered to faintly doubly refracting snbstance. The rock is undoubtedly a somewhat altered, opaque, scoriaceons modification of this kind of rock.

The massive lava flows at Two Ocean Pass belong in part to this same class of rocks, but vary somewhat in composition in the different sheets, which directly overlie one another. The rock most closely resembling those just described forms the second sheet from the bottom $(1720,1721)$. Its chemical composition is shown in analysis 6, p. 329. It contains similar phenocrysts of angite and olivine, with none of feldspar. The feldspar of the groundmass is almost wholly orthoclase, sometimes in simple prismatic crystal, sometimes in Carlsbad twins. It is nearly idiomorphic. There is a small amount of isotropic mineral as interstitial filling between orthoclase prisms. It has a slightly lower index of refraction. It may possibly be glass. The groundmass also contains augite, magnetite, serpentine, redbrown biotite, and needles of apatite. No lime-soda feldspar was observed. The groumdmass is holocrystalline, the average size of the component orthoclase being about $0.07 \mathrm{~mm}$. wide by $0.14 \mathrm{~mm}$. long. Chemically it differs from the most typical absarokite by being higher in alumina and lower in magnesia, approaching shoshonite in chemical composition, with which rock it is associated in the field.

The scoriaceous portion of this rock (1721) is almost opaque in thin section, and in very thin edges is seen to consist of minute crystals of magnetite, pyroxene, and a feldspathic mineral whose character is not recognizMON XXXir, PT II-22 
able. The rock of the sheet immediately overlying this one is very vesicular $(1718,1719)$ and carries fer phenocrysts. In thin section it is extremely fine grained, and consists of microlites of feldspar, augite, and magnetite. The feldspars are prisms of lime-soda feldspar with outer zones of orthoclase.

Modifications of these rocks in which the lime-soda feldspar cores within the orthoclase are more frequent and larger, and which constitute transitional varieties between absarokite and basalts rich in olivine and augite, occur in the breccia south of the head of Conant Creek. They have abundant small phenocrysts of augite and serpentinized olivine (1745), the same minerals occurring in the groundmass with magnetite and considerable feldspar. There is much red oxide of irnn through the mass in thin fibers and as coatings of the smallest augites, magnetites, and olivine pseudomorphs. The microscopic feldspars are nearly idiomorphic, though the rock is holocrystalline. They are rectangular, partly tabular, partly prismatic, and consist of a central idiomorphic crystal of lime-soda feldspar with polysynthetic twinning and ligher refraction than the marginal zone, which is not striated, but is in Carlsbad twins. The relative sizes of these two parts of each complex crystal are variable. In some cases the kernel exceeds the shell; in others, the reverse. The outer portion is orthoclase; the imner feldspar is labradorite. The latter is clouded with minute specks or inclusions; the orthoclase is quite pure. There is a little light-brown mica. Other breccias north of this consist largely of basalts somewhat related (1747 to 1750). They are characterized by phenocrysts of augite and olivine, without any of feldspar. Augite and olivine both contain glass inclusions, often in abundance, and the angite incloses olivine. The augite is pale brownish green, sometimes with zonal structure; the olivine is colorless. The groundmass is the same as in the rock from near the head of Conant Creek (1745), but is finer grained.

A similar rock occurs west of Glade Creek on Coulter Creek (1743). The augite and olivine phenocrysts are freer from inclusions. The groundmass is holocrystalline and consists of labradorite and orthoclase, angite, some serpentinized olivine, serpentinized prisms that probably were orthorhombic pyroxene, magnetite, and thin needles of apatite. There is a very little brown mica.

Intermediate between absarokite and shoshonite are rocks (1623) that are dark gray with a waxy luster, which have abundant phenocrysts of 
olivine and angite, with fewer of labradorite. They are holocrystalline and consist of plagioclase with orthoclase and some analcite, besides augite, magnetite, and delicato needles of apatite.

\section{SIIOSIIONITE.}

The rocks ehassed as shoshonites are more numerous than the absarokites, and embrace a somerwhat wider range of composition. They occupy the middle ground, as it were, in this series, and pass by gradual transitions into alsarokite, banakite, and the normal basalts of the region. They occur associated with absarokite, and consequently at the same localities. Their principal occurrences are on the Lamar River, Mirror Plateau, in Crandall Basin, in the Stinkingwater and Ishawoon canyons, on the southeast fork of Beaverdam Creek, and at Two Ocean Pass, one of the heads of the Shoshone or Snake River. This is the locality from which the rock was first collected and identified as an orthoclase-basalt. The rock also occurs on Grayling Creek and west of The Crags, southwest of Gallatin Mountains. Host of the rocks are characterized by prominent phenocrysts of labradorite, together with those of angite and olivine. A few are without feldspar phenocrysts, but quite a number are without megascopic phenocrysts and are correlated with the porphyritic forms on chemical as well as mineralogical grounds. A small number are leucite bearing. The chemical compositions of eight of these rocks are given in the following table. To these are adder three analyses of transitional varieties. The analyses are arranged so as to bring those most alike by the side of one another. As already said, the mineralogical variations range from an abundance of olivine and augite to a pancity of them, which corresponds to the chemical variation from higher magnesia and lime to lower magnesia and lime, and the corresponding changes in the alumina and alkalies in the opposite direction. In describing these rocks those that are chemically and mineralogically alike will be considered first, and afterwards those that are chemically alike but mineralogically different. 
GEOLOGY OF THE YELLOWSTONE NATIONAL PARK.

Analyses of shoshonites and transitional rocks.

\begin{tabular}{|c|c|c|c|c|c|c|c|c|c|c|c|}
\hline Constituent. & 1 & 2 & 3 & 4 & 5 & 6 & 7 & 8 & 9 & 10 & 11 \\
\hline $\mathrm{SiO}_{2} \ldots$ & 50.06 & 51. 75 & 53.49 & 52.86 & 52.49 & 54.86 & 56.05 & 54.97 & 50.99 & 52.11 & 53.71 \\
\hline $\mathrm{TiO}_{2} \ldots$ & .51 & .86 & .71 & 1.04 & .81 & .69 & .98 & .97 & .67 & .53 & .74 \\
\hline $\mathrm{Al}_{2} \mathrm{O}_{3}$ & 17.00 & 17. 48 & 17.19 & 17.51 & 17.89 & 17.28 & 19.70 & 18.38 & 15.62 & 16.58 & 18.00 \\
\hline $\mathrm{Fe}_{2} \mathrm{O}_{3}$. & 2.96 & 6.42 & 4.73 & 5.18 & 5.76 & 4.08 & 3.74 & 3.06 & 8.47 & 3.66 & 3.99 \\
\hline $\mathrm{FeO} \ldots$ & 5.42 & 1.46 & 3.25 & 3.31 & 2.08 & 2.28 & 2.32 & 4.22 & 1.43 & 4.99 & 4.05 \\
\hline $\begin{array}{l}\text { MnO ... } \\
\text { NiO.... }\end{array}$ & .14 & Trace. & .14 & Trace. & .09 & .19 & Trace. & Trace. & $\begin{array}{r}\text { Traee. } \\
.07\end{array}$ & .23 & .24 \\
\hline $\mathrm{BaO} .$. & $\cdots$ & ..... & .06 & ....... & .30 & .37 & $\ldots .$. & ....... & ........ & $\cdots$ & . \\
\hline $\mathrm{MgO} \ldots$ & 3.61 & 4.05 & 4.42 & 4. 18 & 3.49 & 4.19 & $2.5 \mathrm{i}$ & 2.38 & 5.23 & 6.87 & 5.19 \\
\hline $\mathrm{CaO} \ldots$ & 8.14 & 8.20 & 6.34 & 6.51 & 7.01 & 5.42 & 4.34 & 5.43 & 6.53 & 6.43 & 6.88 \\
\hline $\mathrm{Li}_{2} \mathrm{O} \ldots$ & ........ & Trace. & ....... & .04 & ....... & ….... & $\cdots$ & .03 & ........ & ...... & $\cdots$ \\
\hline $\mathrm{Na}, \mathrm{O} \ldots .$. & 3.53 & 3.33 & 3.23 & 3.22 & 3.18 & 3.94 & 3.29 & 3.45 & 3.39 & 3.25 & 3.50 \\
\hline$K_{2} \mathrm{O} \ldots \ldots$ & 3.40 & 3.72 & 3.86 & 3.41 & 3.73 & 3,96 & 4.44 & 337 & 3.05 & 3.20 & 3.10 \\
\hline $\mathrm{P}_{2} \mathrm{O}_{6} \ldots \ldots$ & .66 & .67 & .43 & .53 & .55 & .48 & .66 & .42 & .53 & .63 & .38 \\
\hline C1 ..... & $\ldots . .$. & Trace. & .... & .16 & & & & Trace. & & & \\
\hline $\mathrm{SO}_{3} \ldots \ldots$ & - . . . . & .17 & & .22 & & & - & .03 & ....... & & \\
\hline $\mathrm{CO}_{2} \ldots \ldots$ & $\ldots . .$. & ......... & ....... & & & $\cdots$ & ….. & 2.92 & ....... & $\ldots . .$. & $\cdots$ \\
\hline \multirow[t]{2}{*}{$\mathrm{H}_{2} \mathrm{O} \ldots \ldots$} & 4.85 & 2.26 & 2.17 & 1.76 & 2.63 & 2.16 & 1.86 & .82 & 3.87 & 1.99 & .55 \\
\hline & 100.28 & 100.37 & 100.02 & 99.93 & 100.01 & 99.90 & 100.14 & 100.45 & 99.85 & 100.47 & 100.33 \\
\hline
\end{tabular}

1. Shoslonite, lava sheet, Lamar Rirer, south of Bisun Peak. Analyst, L. G. Eakins. (1131.)

2. Shoshonite, lava flow, northeast base of Sepulchre Monntaiu. Analyst, J. E. Whitfield. (379.)

3. Shoshonite, lava sheet, sontheast fork of Bearerdam Creek. Analjst, L. G. Eakins. (1647.)

4. Shoshonite, lava sheet, sontheast fork of Beiverdam Creek. Analyst, J. E. Whittield. (1651.)

5. Leneite-shoshonite, lava sheet, monutain east of Pyramid Peak. Analyst, L. G. Eakins. (1476.)

6. Olivine-free shoshonite, dike northeast of Indian Peak. Analyst, L. G. Eakins. (1316.)

7. Shoshonite, lava sheet, Two Ocean Pass. Analyst, J. E. Whitfield. (1715.)

8. Shoshonite, summit of Bally Mountain, Bear Gulch, Mlontana. Analyst, J. E. Whitfield.

9. (P) Hornblende-basalt, dike near head of Stinkingwater Caujon. (1462.)

10. Orthoclase-hearing basalt, dike, rilge sonth of Hurricane Mesa. (1325.)

11. Orthoclase-bearing gabbro, core, Hurricane Mesa, Crandall Basin. (1430.)

The rock whose chemical composition is shown by the first analysis is exposed as a surficial lava flow at the base of Bison Peak on Lamar River (1131). It is dark gray, with a waxy luster, and carries abundant phenocrysts of labradorite, angite, and olivine, and some small amygdules of zeolite and calcite. In thin section it is holocrystalline, the groundmass consisting of lath-shaped lime-soda feldspar and considerable orthoclase in zones surrounding the plagioclase microlites and also in twinned prisms, besides angite, magnetite, and a little serpentine. The phenocrysts of labradorite are twinned, with very narrow lamellæ. Those of angite and 
olivine are like the phenoerysts of these minerals in absarokite; the olivine is partly serpentinized.

Similar lava nccurs at the nortl base of Specimen Ridge (1127). In this the phenoerysts of feldspar are labradorite with about the composition $\mathrm{Au}_{3} \mathrm{Ab}$. The groundmass is partly globulitic and microlitic glass, containing many rectangular orthochise erystals with lath-shaped lime-soda feldspars at their center, some of which prove to be labradorite $\left(\mathrm{An}_{3} \mathrm{Ab}_{2}\right)$; most of them exhibit low angles, and may be andesine-oligoclase. Some small rectangular plagioclases withont orthoclase margins are labradorite $\left(\mathrm{An}_{3} \mathrm{Ab}_{2}\right)$. There is nearly as much orthoclase as plagioclase in the groundmass. There is, of course, angite, apatite, and magnetite, as in the other rocks. Other modifications of this rock have a less lighly crystallized groundmass, in which orthoclase has not been developed. Such forms could not be distinguished microscopically from some ordinary basalts. Other rocks of this type with glassy and microlitic gromumasses occur at the creek south of Opal Creek (1143), and in a cliff 3 miles up Sorta Butte Creek (1137). A holocrystalline rock of this cliaracter forms a dike on Timber Creek, Crandall Basin (1328). Another forms a lava flow on the mountain east of Pyramid Peak (1474, also 1457). A modification with small phenoerysts occurs as a surface flow at the falls of Timothy Creek on Mirror Plateau (1153), and elsewhere on this plateau (1155), and is exposed in association with andesitic breccia beneath rhyolite west of The Crags, southwest of Gallatin Momntains (580). It has also been found in bowlders east of the lower Geyser Basin.

Another basaltic rock belonging to this class because of its chemical composition occurs in an obscure exposure at the north base of Sepulchre Nountain. It appears to have been a surficial flow of lava contemporaneons with the acid andesitic breccias at that place. It is dark greenish gray $(379,381)$, with few megascopic phenocrysts of augite and serpentinized olivine, and without any of feldspar, and is vesicular, with amygdules of agate and quartz. In thin section it is holocrystalline, with lath-shaped plagioclase microlites surrounded by a zone of orthoclase, which is in considerable amount. There are also prisms of angite and crystals of magnetite. Apatite needles are abundant. Its chemical composition is shown in the second analysis of the table just given. It resembles the first one closely except in the oxidation of the iron. The lime-soda feldspars are confined to the grounchmass, in the form of microlites. 
The rock whose chemical composition is given in the third and fourth analyses occurs as a massive sheet beneath another of very similar character on the southeast fork of Beaverdam Creek. It is dark purplish gray, with numerous phenocrysts of labradorite, augite, and serpentinized olivine (1647, 1648, and 1651). A lighter-colored modification (1649) carries porphyritical biotite and white amygdules of zeolite. In thin section it is holocrystalline, and resembles closely the rock from the south base of Bison Peak (1131), except that the olivine is serpentinized. The groundmass is similar and there is considerable orthoclase. In the variety with biotite there are cloudy isotropic patches, which may be analcite. The massive lava immediately overlying it is similar in general appearance, but contains leucite, and will be described later in connection with the banakites.

The rock whose chemical composition is given by analysis 5 is a massive surficial flow on the top of the mountain east of Pyramid Peak, resembling in general appearance the lava flow from the same place already cited as similar to that from the base of Bison Peak, but the phenocrysts are ferver and smaller $(1475,1476)$. The two specimens collected differ slightly in grain. They are holocrystalline and very fine grained, with an abundance of angite and magnetite microlites in the groundmass. The feldspars are minute lath-shaped crystals and allotriomorphic grains, with low double refraction. There are spots where minute grains of augite and magnetite are clustered together and are inclosed in a yellowish substance which is almost isotropic and has the outline of leucite. These impure leucites are scattered through the rock and are not very numerous. They are very small and can not be more definitely identified. Their outline and inclusions are characteristic. The groundmass carries irregular patches of light-brown nica, small phenocrysts of angite and serpentinized olivine, and still fewer larger crystals of augite and olivine. It is a lencite-bearing modification of this nagma without any chemical differences in composition.

The rock of analysis 6 (1316) is from an 18-inch like on the ridge northeast of Indian Peak. It is gray and aphanitic, witl abundant small phenocrysts' of angite and lime-soda feldspar, with rather low extinction angles. In thin section it is seen to be holocrystalline and very fine grained, consisting of indistinetly outlined feldspar microlites, in part alkaline, with low double refraction and no polysynthetic twinning. There is a subordinate amount of idiomorphic microlites of biotite, prisms of augite, and grains of 
mingnetite. There is no olivine, and it is this fact which chiefly distinguishes it from the other varieties of these rocks.

Another dike (1318) in the same place resembles the one just lescribed in mineral composition, except that the only phenocrysts are small angites. 'Two other dike rocks in this vicinity $(1344,1354)$ are like these in mineral composition, with phenocrysts of labradorite and angite, but none of olivine. In one case (1344) the microlites of plagioclase are surrounded by orthoclase margins.

The rock of the seventh analysis (1715) is the uppermost of the five surficial lava sheets that overlie one mother at Two Ocean Pass. It is derk gray, with a waxy luster, and carries scattered phenocrysts of feldspar and serpentinized olivine. In thin section the gromdmass is seen to be holocrystalline, and is composed of orthoclase crystals, both idiomorphic and allotriomorphic, with much magnetite and angite and some chlorite or serpentine, with red-brown biotite and hair-like needles of apatite. There are comparatively large but microscopic dusted apatites among the phenocrysts, showing this mineral in two generations. The large apatites are comparatively abundant, and were in part inclosed in the olivine, which is wholly serpentinized. The feldspar phenocrysts are labradorite, with highly developed polysynthetic twimning. Several crystals are clustered together into groups. In the rock of the second sheet (1716) the feldspar phenocrysts are labradorite-bytownite, being decidedly basic, with high extinction angles and relatively strong double refraction. Rectangular inclusions, probably feldspar, are numerous; also considerable magnetite and angite, and some serpentine. The gromidmass is like that of the top sheet, except that the orthoclase crystals sometimes have a small mucleus of lime-soda feldspar. These nuclei are sometimes colored green from serpentine, when they are easily confounded with partly altered pyroxene. In other respects the rock is like the uppermost sheet. The rock of one of these sheets (1724) on the north side of Pacific Creek, 2 miles west of Two Ocean Pass, is like the one last described, with somewhat larger phenocrysts of labradorite, $5 \mathrm{~mm}$. long. They have the same character and inclusions as the labradorite phenocrysts of the last-mentioned rock. The olivines are entirely altered to serpentine. The groundmass has the same composition and structure. Some serpentine in the groundmass occupying spaces between idiomorphic orthoclases may replace small interstitial bits of glass; 
otherwise the rock appears to be holocrystalline. In one specimen (1714) there is less serpentine, and considerable colorless mineral with lower refraction than orthoclase, which is not isotropic, but has weak double refraction. The microstructure of this rock and the character of the large feldspar phenocrysts are shown in Pl. XXXVII, fig. 1.

The rocks of the other two sheets (1717 to 1719) are scoriaceons and vesicular, and are microlitic with much opaque mineral. They are somewhat altered, and their exact mineral composition can not be made ont. They are related in general character to the rocks associated with them. A rock of the same kind as the more crystalline forms from Two Ocean Pass is found on Fox Creek (1731). Shoshonite, quite like that at Two Ocean Pass, with pronounced orthoclase in the groundmass, but carrying phenocrysts of hypersthene and angite and less, olivine, with large labradorites, occurs west of the summit of Baldy Mountain, east of Bear Gulch, just north of the Yellowstone Park. Its chemical composition is shown in analysis 8. It is low in magnesia and is chemically more like the shoshonite of Two Ocean Pass than the others. There are no carbonates discoverable in the thin section of the rock corresponding to the considerable percentage of carbon dioxide in the analysis. The rock is very fresh, and it is possible that the material analyzed contained fragments of limestone or of calcite.

Very similar rocks occur on Lamar River 2 miles above the month of Slongh Creek (1129), and also a short distance below the moutl of Soda Butte Creek $(1136,1135)$. They are surficial lava sheets and have phenocrysts of feldspar and very small ones of augite and olivine The groundmass is nearly the same as that just described. Other rocks like the last named are from the spur of Mirror Platean south of Flint Creek (1147), and from the north side of Grayling Creek west of the end of Crowfoot Ridge (578), and from a point west of The Crags (579). All of these were lava flows that poured out upon the surface of the earth.

A comparison of the chemical analyses and of the rocks of this grouj, besides making evident the relationships already noted, also shows what mineralogical differences may obtain for rocks of nearly the same chemical composition. Some of these differences have already been described in the case of the leucite-bearing varieties. Other differences may be mentioned. The lava flow from the southeast fork of Beaverdam Creek (1647) and the dike rock from the ridge northeast of Indian Peak, though nearly alike 
U. S. GEOLOGICAL SURVEY

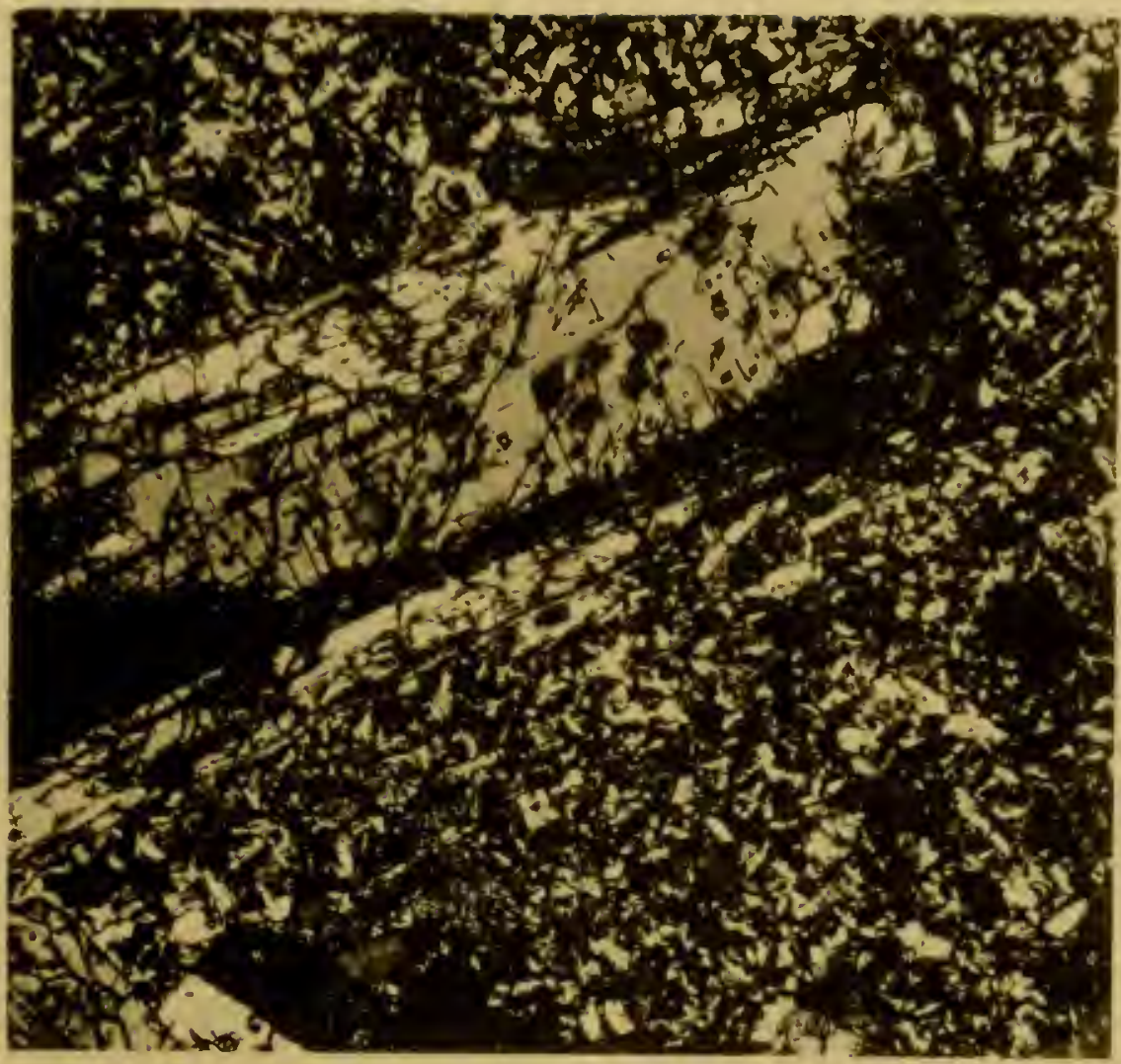

(A) $\times 35$

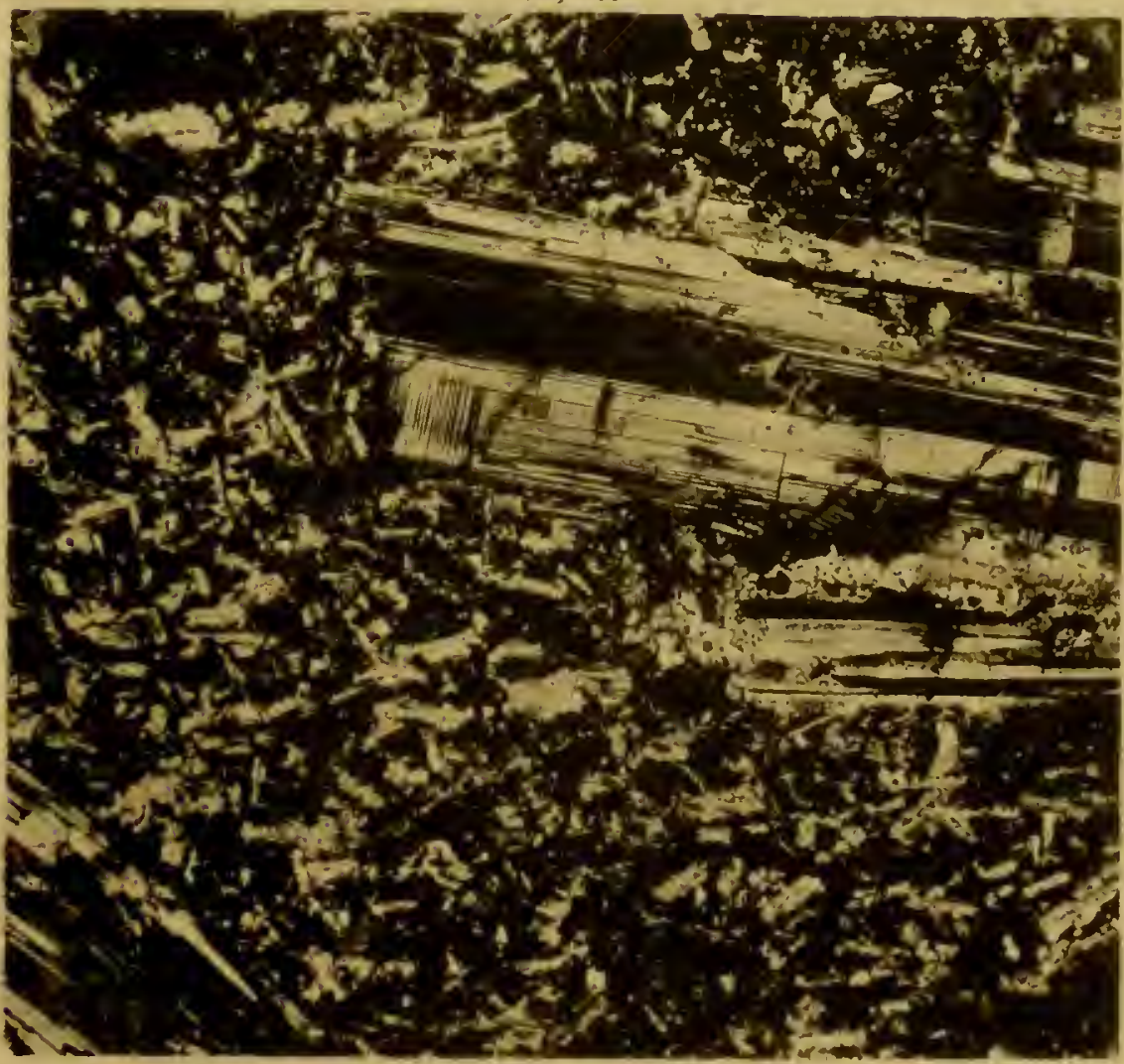

(B) $\times 36$

PHOTOMICROGRAPHS OF SHOSHONITE AND DIORITE-PORPHYRY 

chemically (analyses 3, 4, and 6i), are quite unlike mineralogically. The first las abundant phenocrysts of labradorite, olivine, and angite, while the second contains no olivine. The groundmass of the first contains some brown mica which may be secondary, while that of the second contains much mica that is primary. Other differences will aplear when several rocks which are closely related to shoshonites lave been described. The chemical analyses of three of these are appended to the table on p. 340-Nos. 9, 10, and 11. These rocks are not so different chemically from normal basalts, except that alkalies are rather lighler, and potash is specially so. The alkalies are like those in analyses 1 to 5 ; magnesia is ligher than in shoshonites, and more nearly that of normal basalts.

Analysis 9 is of a dike rock from near the head of Stinkingwater River (1462). The rock is very dark gray, with long megascopic crystals of hornblende, and some of angite, but none of feldspar. In thin section it is holocrystalline. The groundmass is composed of lath-shaped plagioclase with low extinction angles and of cryptncrystalline material, probably an alteration product, besides angite and magnatite, and considerable serpentine, which is evidently the alteration product of small olivines whose original form is still preserved. The phenoerysts are large loornblendes with irregular outlines and a border of magnetite grains, and smaller angites. There are none of feldspar. The rock might be called a homblende-basalt, with feldspar averaging, about the composition of oligoclase. It is possible that some orthoclase may exist in the groundmass, but it was not recognized in the rock, section. The shoshonite nearest to this rock in chemieal composition is the lower sheet from the southeast fork of Beaverdam Creek (1647), analyses 3. It differs from it mineralogically in not having: hornblende, in having large phenocrysts of labradorite, and in the presence of orthoclase in the groundmass.

The rock whose composition is given in analysis 10 is a basalt-like lava, forming large blocks in the basic breccia on the ridge south of the core of Crandall volcano (1325). It carries large phenocrysts of labradoritebytownite, and abundant ones of olivine and angite. The groundmass is holocrystalline, and consists of inregularly lath-shaped feldspars that are labradorite at the center and orthoclase in the margin. Orthoclase is in subordinate amount. Augite, magnetite, and some serpentine, with delicate needles of apatite, are the other constituents. It is like the shoshonites already described, but is richer in labradorite. 
Analysis 11 is that of a hypidionorphic granular pyroxene-diorite or gabbro (1430) from the volcanic core on Hurricane Mesa, Crandall Basin. It consists of crystals 1 or $2 \mathrm{~mm}$. in diameter, which are labradoritebytownite, nearly idiomorphic, a moderate amount of orthoclase, always allotriomorphic, and a very little quartz, besides much augite with diallagic character; some hypersthene, considerable biotite and magnetite, with apatite and a few serpentinized crystals of olivine. The structure and microscopical characters are the same as those of the gabbro of this volcanic core, which are fully described in Chapter VII. The orthoclase does not form a margin around the crystals of labradorite, but occurs as independent crystals.

Transitional varieties between shoshonite and the normal basalt of the region are numerous. Chemically they are recognized by lower percentages of alkalies and higher magnesia. Mineralogically they are recognized in the more crystalline forms by the smaller amount of orthoclase margins to the labradorite crystals; but in the less crystalline forms, where the groundmass is partly glassy, or where the feldspar microlites are very minute, or where the groundmass is nearly opaque with iron oxide, as in many scoriaceous forms of basalt, it is not possible to recognize orthoclase, and the exact character of the rock is uncertain unless its geological continuity with coarser-grained forms or its chemical composition be known. A number of basaltic rocks collected from the Yellowstone Park belong in this category. Some are seen to contain very little orthoclase (1137, $1143,1150,1304,1353)$. In others the presence of orthoclase is questionable $(1145,1303,1459,1460,1470,1471,1526,1697,1703)$. Others have groundinasses that are but slightly crystallized. Coarse-grained equivalents of these transitional varieties occur in the granular core as orthoclasegabbros.

Transitional varieties between shoshonite and highly feldspathic forms closely related to banakite occur as dikes in the breccia near the head of the canyon of the Stinkingwater River $(1468,1455)$. One is a gray, finegrained rock, resembling diorite in outward appearance. It consists of cloudy feldspars, which are mostly allotriomorphic orthoclase with partly altered kernels of plagioclase whose exact charactei is not determinable, besides small crystals of labradorite and a small amount of an allotriomorphic, isotropic mineral which is also clouded. With these is a considerable amount of augite, biotite, and magnetite, and fewer serpentinized olivines. The angite is idiomorphic in part. The other rock, which miglit 
very well be a coarser-graned portion of the one just deseribed, is whiter in color and coarser grained, and is full of irregularly shaped tablets of biotite, from 1 to $3 \mathrm{~mm}$. loroad. It las the same mineral composition as the first one, except that biotite is more abundant, and some of the foldspars are 2 mm. long.

\section{BANAKITE.}

The most feldspathic rocks of this series, which occur as dikes associated with dikes of shoshonite and absarokite, are not so numerous. A larger proportion of them, however, have been analyzed. They occur in Crandall Basin, in Islawooa Canyon, and near the head of Stinkingwater River. A leucite-bearing variety forms a lava sheet near Beaverdam Creek. Their chemical composition is shown by the analyses in the accompanying table:

Analyses of banakite and quartz-banakite.

\begin{tabular}{|c|c|c|c|c|c|c|c|c|}
\hline Constituent. & 1 & 2 & 3 & 4 & $5 a$ & $5 b$ & 6 & 7 \\
\hline $\mathrm{SiO}_{2} \ldots \ldots \ldots \ldots$ & うั1.82 & 52.63 & 51.46 & 52.33 & 52.93 & 51.56 & 57.29 & 60.89 \\
\hline $\mathrm{TiO}_{2} \ldots \ldots \ldots$ & .71 & .81 & .83 & .71 & .72 & .65 & .72 & .49 \\
\hline $\mathrm{Al}_{2} \mathrm{O}_{3} \ldots \ldots \ldots \ldots$ & 16.75 & 16.87 & 18.32 & 18.70 & 19.67 & 21.00 & 18.45 & 17. 14 \\
\hline $\mathrm{F}_{0} \mathrm{O}_{3} \ldots \ldots \ldots \ldots$ & 4.56 & 4.52 & 4.61 & 4.95 & 3.07 & 5.17 & 4. 38 & 3.32 \\
\hline $\mathrm{FeO} \ldots . . . . . . . .$. & 3.36 & 3.11 & 2.71 & 1.83 & 3.50 & 2.76 & 1.20 & .95 \\
\hline $\operatorname{Mn} 0 \ldots \ldots \ldots$ & .23 & .10 & .17 & .03 & .15 & Trace. & Trace. & .09 \\
\hline $\mathrm{NiO} \ldots \ldots . . . . . .$. & & ....... & ........ & .14 & $\ldots \ldots$ & $\ldots . . .$. & .12 & .19 \\
\hline $\mathrm{BaO} \ldots \ldots \ldots$ & .26 & .29 & $\ldots \ldots$ & $\ldots \ldots$ & .21 & $\ldots \ldots$ & ........ & (......... \\
\hline $\operatorname{MgO} \ldots \ldots \ldots \ldots$ & 4.03 & 3.69 & 2.91 & 2.69 & 2.88 & 2.52 & 2.08 & 1.16 \\
\hline $\mathrm{CaO} \ldots \ldots \ldots \ldots . . . . .$. & 4.94 & 4.77 & 6.03 & 4. 71 & 4.69 & 4.83 & 3.57 & 3.58 \\
\hline $\mathrm{N}_{\mathrm{z}_{2}} \mathrm{O} \ldots \ldots \ldots \ldots$ & 3.91 & 3.86 & 4.11 & 4.51 & 4.20 & 4.37 & 4. 43 & 4.54 \\
\hline $\mathrm{K}_{2} \mathrm{O} \ldots \ldots \ldots \ldots$ & 5.02 & 5.17 & 4.48 & อั. 45 & 4.75 & 4.13 & 5.43 & 5. 71 \\
\hline $\mathrm{Li}_{2} \mathrm{O} \ldots \ldots . . . . . .$. & & ........ & $\ldots \ldots$ & $\ldots \ldots$ & $\ldots . . .$. & .13 & ........ & ........... \\
\hline $\mathrm{P}_{2} \mathrm{O}_{5} \ldots \ldots \ldots \ldots$ & .52 & .63 & .86 & .81 & .59 & .69 & .46 & .27 \\
\hline $\mathrm{SO}_{3} \ldots \ldots \ldots$ & - ...... & $\ldots \ldots$ & $\ldots \ldots \ldots$ & ......... & $\ldots \ldots$ & .21 & $\ldots \ldots$. & .......... \\
\hline $\mathrm{H}_{2} \mathrm{O} \ldots \ldots \ldots \ldots$ & 3.97 & 3.65 & 3.89 & 3.45 & 2.73 & 2.27 & 2.18 & 1. 61 \\
\hline Total .......... & 100.08 & 100.10 & 100.38 & 100.31 & 100.09 & 100.29 & 100.31 & 99.94 \\
\hline
\end{tabular}

1. Banakite, dike, head of Lamar River. Analyst, L. G. Eakins. (1309.)

2. Banakite, dike, Hoodoo Monntain. Analyst, L. G. Eakins. (1296.)

3. Banakite, dike, Ishawooa Canyon. Analyst, L. G. E'ákins. (1699.)

4. Banakite, dike, near head of Stinkingwater River. Analyst, W. H. Melville. (1466.)

5a. Leucite-banakite, lava sheet, southeast fork of Beaverdam Creek. Analyst, L. G. Eakins. (1643.) (1643.)

5b. Lencite-luanakite, lava sbeet, southeast fork of Beaverlam Creek. Analyst, J. E. Whitfield.

6. Quartz-banakite, dike, near head of Stinkingwater River. Analyst, W. H. Melville. (1463.)

7. Quartz-banakite, dike, neur head of Stinkingwater River. Analyst, W. H. Melville. (1469.) 
The rocks of analyses 1 and 2 form dikes, the second one occurring on the south face of Hoodoo Mountain and the first one on the divide south, the two dikes trending in the same direction, a little east of south. The rock is the same in both $(1296,1309)$. It is light gray and aphanitic, with a glistening luster. There are prominent phenocrysts of black augite and rusted spots of serpentinized olivine, but no porphyritical feldspar. In the rock from Hoodoo Mominain (1296) there are numerons anyggdules of white stellate zeolite.

In thin section the rocks are holocrystalline, with more feldspar than ferromagnesian minerals. The feldspar is lath-shaped and tabular, with irregular outlines. The crystals are simple twins with low extinction angles, and are orthoclase with kernels of plagioclase, which is mostly altered, the centers of the crystals being decomposed in many cases. There is considerable serpentine scattered through the rock. The ferromagnesian minerals of the groundmass have the same characters as in the allied rocks; they are angite and biotite, with magnetite, and some ilmenite in rod-like shapes; apatite occur's in needles. 'The rocks contain much analcite, forming clusters of erystals, which are partly cloudy but mostly transparent. They frequently fill cavities, and sometimes occupy spaces whose outlines appear to have belonged primarily to isometric minerals, while in places the irregular ontline and inclosure of other minerals make it appear to be a part of the original gromndmass of the rock. It is to be remarked in this connection that basalts with abundant crystals of analcite which appear to be primary minerals have been found and described by Lindgren $^{1}$ in the Highwood Mountains, about 200 miles north of this district. The dike on the divide south of Hoodoo Mountain is parallel to that of the absarokite (1306) whose chemical composition is shown in analysis 2 of the table on p. 329.

A rock from the ridge west of Rocky Creek (1624) is almost identical with that just described. The groundmass is nearly panidiomorphic. The orthoclase is pronounced, and there is much biotite and angite, besides grains of an isotropic mineral, probably analcite. Its microstructure is shown in Pl. XXXVIII, fig. 1.

Others of the same kind are from Hoodoo Basin (1302), from the south

${ }^{1}$ Tenth Census, Vol. XV, 1886, p. 727; also Pruc. C'alifornia Acad. Sci., $2 d$ ser., Vol. JII, p. 51. 
side of the amphitheater at the hear of Stinkingwater River (1460), and from a dike on the Ishawooa (1702).

'The rock of the third analysis (1699) is similar to the last, but is more fellspathic. It forms a dike in the Ishawooa Canyon. It is dark gray and waxy looking, with tabular phenocrysts of feldspar, and many smaller ones. In thin section it is holocrystalline, with abundant lath-shaped twins of orthoclase, having a rectangular central inclusion of labradorite $\left(\mathrm{An}_{3} \mathrm{Ab}_{2}\right)$. There is an isotropic cement between the feldspars, which in places is clondy, and may be analcite or sodalite. Biotite and augite are abundant in small crystals, besides magnetite and a little serpentine, which appears to liave been derived from small olivines. The phenocrysts are labradorite $\left(\mathrm{An}_{2} \mathrm{Ab}_{3}\right)$, some of which have borders of orthoclase. There is also a large individual of isotropic mineral without erystallographic boundary. This rock is shown in Pl. XXXVIII, fig. 2.

A closely related rock (1466) from a dike near the head of Stinkingwater River has alnost the same chemical composition (analysis 4). It carries more phenocrysts of serpentinized olivine. In thin section it is coarser grained than the last variety, and the feldspars are more altered and less distinct. The mineral composition is like that of the rock just described, but a few of the augites are bright green, indicating an approach to ægirite-augite.

Analyses $5 a$ and $5 b$ of the table on page 347 are of a lencite-bearing variety (1643), previonsly allnded to as forming a massive surficial sheet of lava immediately overlying the shoshonite which occurs on the southeast fork of Beaverdam Creek, and whose chemical composition is given in analysis 2 of the table on page 340. Its chemical composition is but slightly different from that of the rock last described (1466), analysis 4 . The rock is dark gray, with a somewhat waxy luster, and carries small phenocrysts of feldspar, serpentiniżed olivine, and a few augites. In thin section it is holocrystalline, and has a groundmass of microscopic leucites and unstriated feldspars, which appear to be orthoclase, but may be plagioclase with low angles of extinction, besides angite and magnetite and some serpentine. There are a few patches of light-brown mica. The phenocrysts are labradorite, serpentinized olivine, and ferver angites, magnetites, and stont apatites. The crystals of leucite have the characteristic form and inclusions, and in places are somewhat altered. 
This rock grades into denser, finer-grained, forms (1601), and also into vesicular forms $(1645,1646)$, which are purplish gray and somewhat decomposed. In these varieties the groundmass is finer grained and the leucites are more obseure, being filled with a cloud of minute dots with only a narrow margin of pure substance around them. The remainder of the groundmass consists of microlites of feldspar, angite, and magnetite, with some serpentine. Phenocrysts are few and are labradorite, serpentinized olivine, and magnetite. Leucite is abundant, and the greater part of the groundmass appears isotropic between crossed nicols.

The rocks of analyses 6 and 7 belong to this series both mineralogically and chemically, but are somewhat more siliceous, having 5 to 9 per cent more silica. They might properly be given specific names, but at present we prefer to class them with banakite, under the name quartzbanakite, although the amount of quartz is very small. The two rocks analyzed are closely alike in alkalies and lime, but the first is lower in silica and slightly ligher in alumina, iron oxide, and magnesia. They differ somewhat in mineral composition, though both are characterized by abundant feldspar and biotite. The first one (1463) is a gray rock, distinctly crystalline, with a few megascopic crystals of feldspar and mica. In thin section it is seen to be holocrystalline, and is composed of lath-shaped, rectangular, and allotriomorphic feldspars, with considerable brown biotite, in part idiomorphic, besides magnetite and a little angite, partly decomposed. There is very little quartz and calcite. 'The central part of the feldspar crystals is lime-soda feldspar, in some cases labradorite, judging from the optical properties. The marginal part is orthoclase, which forms a considerable portion of the feldspar, but is subordinate to the plagioclase.

The second one (1469) is a light-gray rock with numerous small tabular feldspars and some large ones, and few phenocrysts of biotite. Most of the megascopic feldspars exhibit polysynthetic twinning, but a few appear to have the brilliant unbroken cleavage of sanidine. None of these, however, are found in the thin sections prepared, in which all the feldspar phenocrysts are polysynthetic twins. In thin section the rock is seen to be holocrystalline and nearly panidiomorphic, the feldspar of the groundmass being in small rectangular to lath-shaped crystals with fluidal arrangement (PI. XXXVIII, fig. 3). The rock also contains a comparatively small 


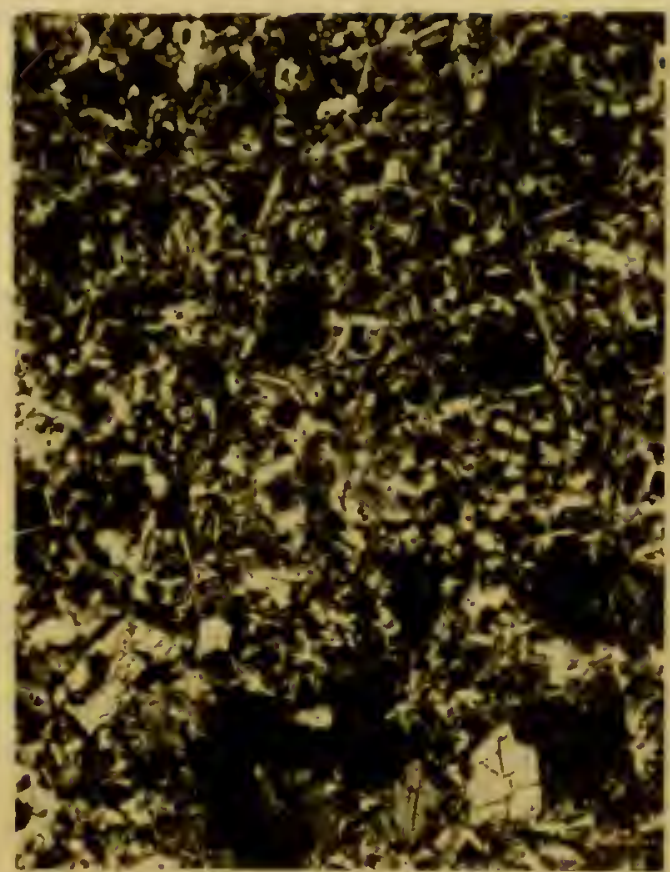
(A) $\times 25$

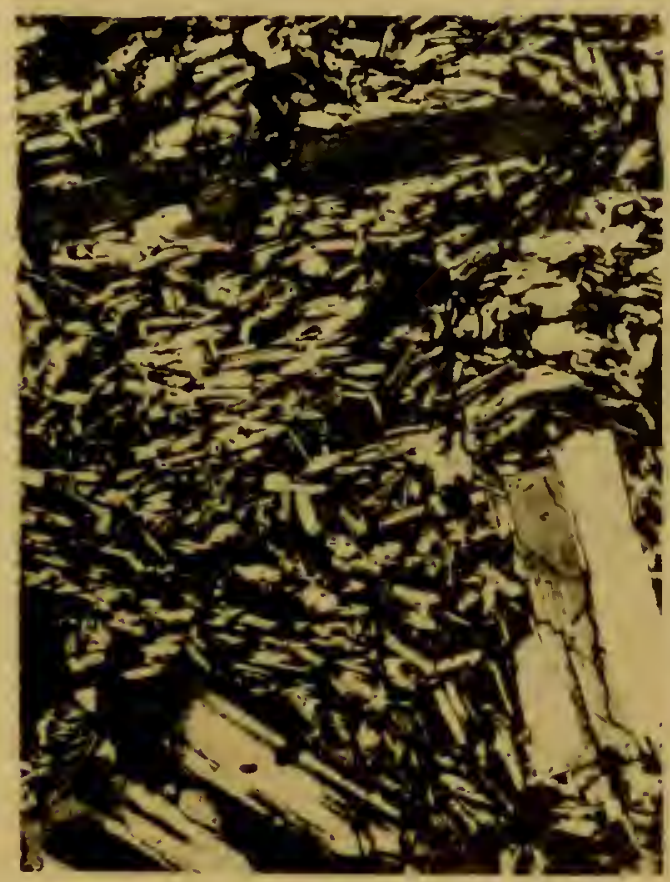

(C) $\times 30$

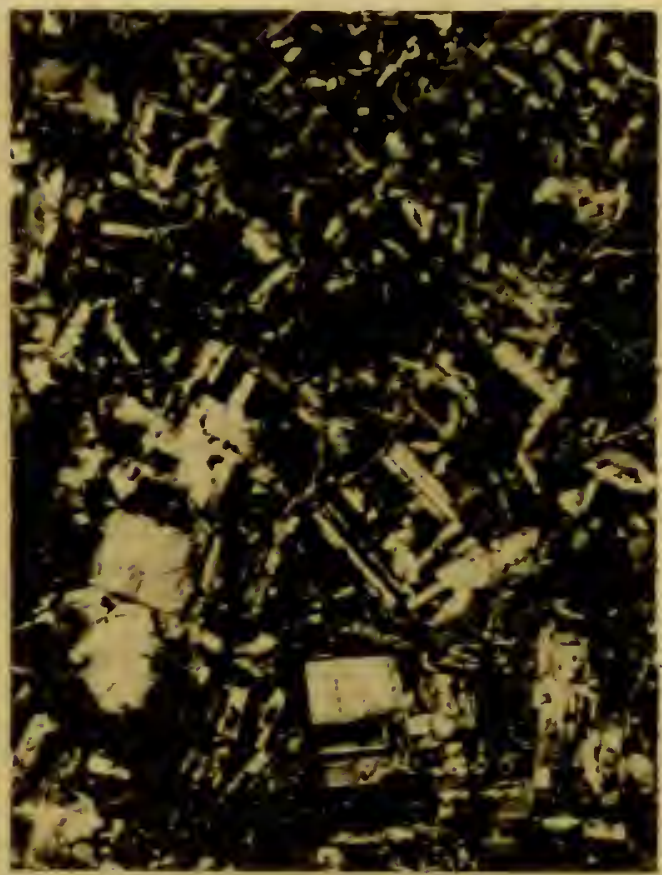

$($ B) $\times 28$

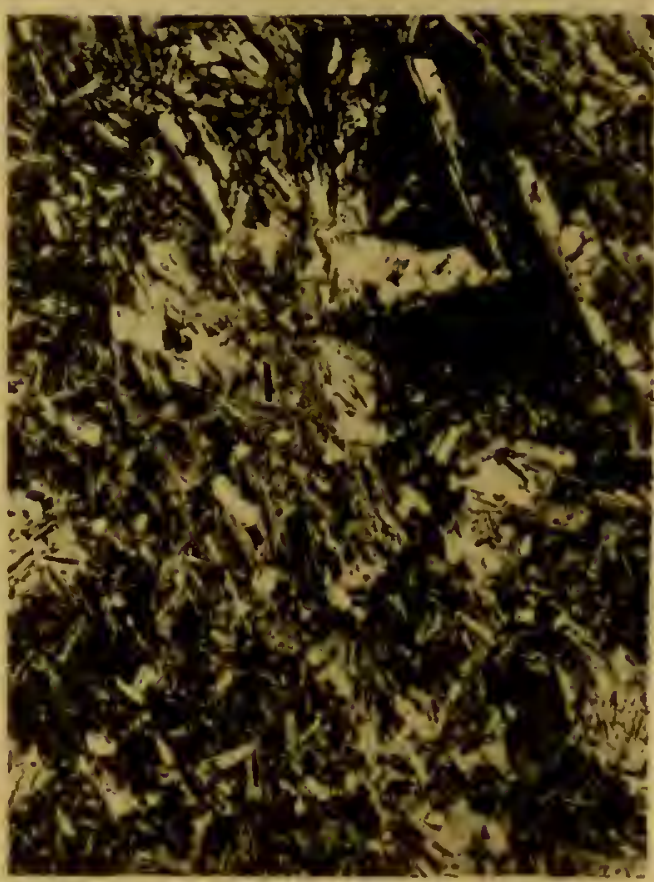

(D) $\times 42$ 

amount of biotite, very little magnetite and augite, and some colorless apatite. The feldspar plienocrysts are labradorite, while the feldspar of the groundmass is mainly orthoclase, with kernels of fresh feldspar that has the optical claracters of oligoclase. 'There is very little quartz, and some little cllorite or serpentime. The feldspars of this rock are quite fresl, as are also the biotites. A coarser-grained and more altererl modification of this rock occurs in another dike near the head of the main stream (1467). The feldspars of the groundmass are not idiomorphic, but acicular, with the microstructure characteristic of syenite-porphyries. The mineralogical analogy between banakite and shoshonite is chiefly in the association of labradorite phenocrysts with orthoclase microlites. Biotite and angite are common to some varieties of both, while olivine is present in one variety of banakite and is conmon to most shoshonites. These rocks are the highly feldspathic modification of shoshonite magma, and are complementary to absarokite, which represents the least feldspathic modification of the same magma.

\section{SIMILAR ROCKS IN MONTANA.}

Rocks almost identical witlı absarokite occur in the region about Bozeman, Montana, and have been thoroughly described by Merrill ${ }^{1}$ in a bulletin of the United States National Musemm. They are intrusive bodies in part, and have been described under the head of questionable basalt and lamprophyre. They are more or less decomposed in some cases and quite fresh in others. Their mineral composition and habit are like those of the rocks here called absarokite. The phenocrysts are olivine and monoclinic pyroxene, whose chemical composition in the case of the rock from near Fort Ellis is that of clurome-diopside. The rock itself is unusually rich in magnesia and comparatively low in iron oxide, so that it is probable that the monoclinic pyroxenes in the other absarokites are not such pure diopsides, but are most likely malacolites or angites. The pyroxene in the coarse-grained shonkinite of Square Butte, Montana, which is related to absarokite chemically, has been shown by Weed and Pirsson to be augite. There are no phenocrysts of feldspar, and the groundmass contains orthoclase, or when not distinctly crystallized is found to be comparatively rich in potash and soda. The chemical compositions of the rocks

\footnotetext{
1 Merrill, Geo, P., Notes on some eruptive rocks from Gallatin, Jefferson, and Madison counties, Montana: Proe. U. S. Nat. Mns., Vol. XVII (No. 1031), 1895, pp. 637-673.
} 
described by Merrill are shown in the first four analyses in the table, which is introduced here for comparison with those of absarokite in the Yellowstone Park.

Analyses of absarokite and similar rocks.

\begin{tabular}{|c|c|c|c|c|c|c|c|}
\hline Constitnent. & 1 & 2 & 3 & 4 & 5 & 6 & 7 \\
\hline $\mathrm{SiO}_{2} \ldots \ldots \ldots$ & 46.90 & 49.13 & 50.82 & 51.65 & 50.03 & 52.33 & 54.15 \\
\hline $\mathrm{TiO}_{2} \ldots \ldots \ldots \ldots$ & .41 & .42 & .59 & .55 & .61 & .14 & Not det. \\
\hline $\mathrm{Al}_{2} \mathrm{O}_{3} \ldots \ldots \ldots \ldots$ & 10.17 & 9.05 & 11.44 & 13. 89 & 14.08 & 15.09 & 18.92 \\
\hline $\mathrm{Cr}_{2} \mathrm{O}_{3} \ldots \ldots \ldots \ldots \ldots$ & .33 & .39 & .03 & .80 & Trace. & $\ldots . .$. & \\
\hline $\mathrm{Fe}_{2} \mathrm{O}_{3} \ldots \ldots \ldots \ldots$ & 1.22 & 3.57 & .25 & 2. 70 & 2.92 & 4.31 & \multirow{2}{*}{ 6. 79} \\
\hline FeO $\ldots \ldots \ldots \ldots$ & 5.17 & 5.05 & 8.94 & 4.80 & 6.11 & 4.03 & \\
\hline $\mathrm{MnO} \ldots$ & .10 & .15 & .19 & .15 & .08 & .09 & Not ilet. \\
\hline $\mathrm{MgO} \ldots$. & 20.98 & 17.21 & 14.01 & $11.5 \% 6$ & 10.73 & 6.73 & 1.90 \\
\hline CaO............. & 6.20 & 5.68 & 8.14 & 4.07 & 7.46 & 7. 06 & 3. 72 \\
\hline $\mathrm{Na}_{2} \mathrm{O} \ldots \ldots$ & 1.16 & 2.01 & 1.79 & 2.99 & $1.46^{\circ}$ & 3.14 & 5.47 \\
\hline $\mathrm{K}_{2} \mathrm{O} \ldots \ldots \ldots$ & 2.04 & 2.24 & 3.45 & 4.15 & 2.61 & 3. 76 & 8.41 \\
\hline $\mathbf{P}_{2} \mathrm{O}_{5} \ldots \ldots \ldots$ & .14 & .38 & .20 & .21 & .42 & 1.02 & Not clet. \\
\hline $\mathrm{BaO} \ldots \ldots \ldots$ & $\cdots \cdots$ & .05 & .06 & .19 & .04 & .07 & Cl. 42 \\
\hline $\mathrm{SO}_{3} \ldots \ldots \ldots \ldots$ & ........ & $\ldots \ldots$ & $\cdots$ & .19 & ......... & $\cdots \cdots$ & \\
\hline $\mathrm{H}_{2} \mathrm{O}$ at $100^{\circ} \ldots$ & 1.04 & .84 & .... & 1.30 & ........ & 2.68 & $\ldots \ldots . .$. \\
\hline $\operatorname{Ign} \ldots \ldots \ldots \ldots$ & 4.38 & 3.50 & .58 & 1.89 & 3.70 & …... & Not det. \\
\hline Total ........ & 100.54 & 99.67 & 100.49 & 101.09 & 100.28 & 100.45 & 99.81 \\
\hline
\end{tabular}

1. Fort Ellis, $2 \frac{1}{2}$ miles sontheast of Bozeman, Montana. Analyzed by T. M. Chatard.

2. Bear Creek, Madison Valley, Montana. Analyzed by T. M. Chatard.

3. South Bowlder and Antelope Creek, Montana. Analyzed by L. G. Eákins.

4. Cottonwood Creek, Mlontana. Analyzed by T. M. Cbatard.

5. Cottonwood Creek, Montana. Analyzed by L. G. Eakins.

6. Cottonwood Creek, Montaua. Analyzed by L. G. Eakins.

7. Cotton rood Creek, Montana. Analyzed by G. P. Merrill.

The variability of these rocks within certain limits is evident, the greatest range being in magnesia. While not exactly alike chemically, they agree in being low in silica and alumina, high in magnesia, comparatively high in alkalies, with high potash. The rock from which the fifth analysis was made is a transitional variety between absarokite and the normal basalt of the region.

The sixth analysis is from an intrusive rock called augite-porphyrite by Merrill. It corresponds to shoshonite in alkalies, but is lower in alumina and higher in magnesia and lime. It is intermediate between shoshonite and absarokite. It is associated with the rocks whose chemical composition is given by analyses 4 and 5 , and plainly belongs to this series. 
Near the absarokite of Cottonword Creek is a syenitic rock which corresponds in some respects to the banakite of the Stinkingwater region, in that it is higlly feldspathic with abundant biotite and some pyroxene. Its microstructure is that of trichyte-porplyyy. Chemically (analysis 7) it is much richer in alkalies, having 8.44 per cent of potash and 5.47 fere cent of sodia, and, as Merrill points ont, is quite like the sodalitesyenite of Square Butte, Montana, described by Lindgren. ${ }^{1}$ They are more alkaline feldspathic modifications of magmas which have yielded absarokite and the somewhat similar magma which at Square Butte has erystallized into the coarse-grained rock called shonkinite. ${ }^{2}$

This new type of granular crystalline rock consists essentially of angite and orthoclase, with biotite, olivine, magnetite, albite, and anorthoclase, with accessory nepheline and sodalite, and other minerals. Its chemical composition, as shown in the accompanying malysis, is similar to that of the absarokites of the Yellowstone Park, except in the higher percentage of lime, but the low silica and alumina and the relatively high alkalies, with high potash and high magnesia and line, show its chemical relation to this group.

In the Little Belt Mountains of Montania ${ }^{3}$ there are rocks almost the same as absarokite chemically, but coarsely crystalline, as at Square Butte. And Weed and Pirsson have described the petrographical characters of the rocks from Yogo Peak, whose chemical composition, together with that of the rock's from Square Butte, Highwood Mountains, is shown by the analyses in the table on the following page.

${ }^{1}$ Lindgren, !W., Eruptive rocks from Montana: Proc. California Acad. Nat. Sci., 2d series, Vol. I11 (Part I, 1891), 1893, np. 45-47.

"WVed, W. H., and Pirson, L. V., Highwood Hountaius of Montana: Bull. Geol. Soc. America, Vol. VI, pp. 389-422, pis. 24-26.

${ }^{3}$ Weed, W. H., and Pirsson, L. V., Igueous rocks of the Yogo Peak, Montana: Am. Jour. Sci., 3d series, Vol. L (No. 300, Dec., 1895), pp. 467-479.

yoN XXxII, PT II- 23 
Analyses of igneous rockir firom. Fogo Peal and Square Butte, Montana.

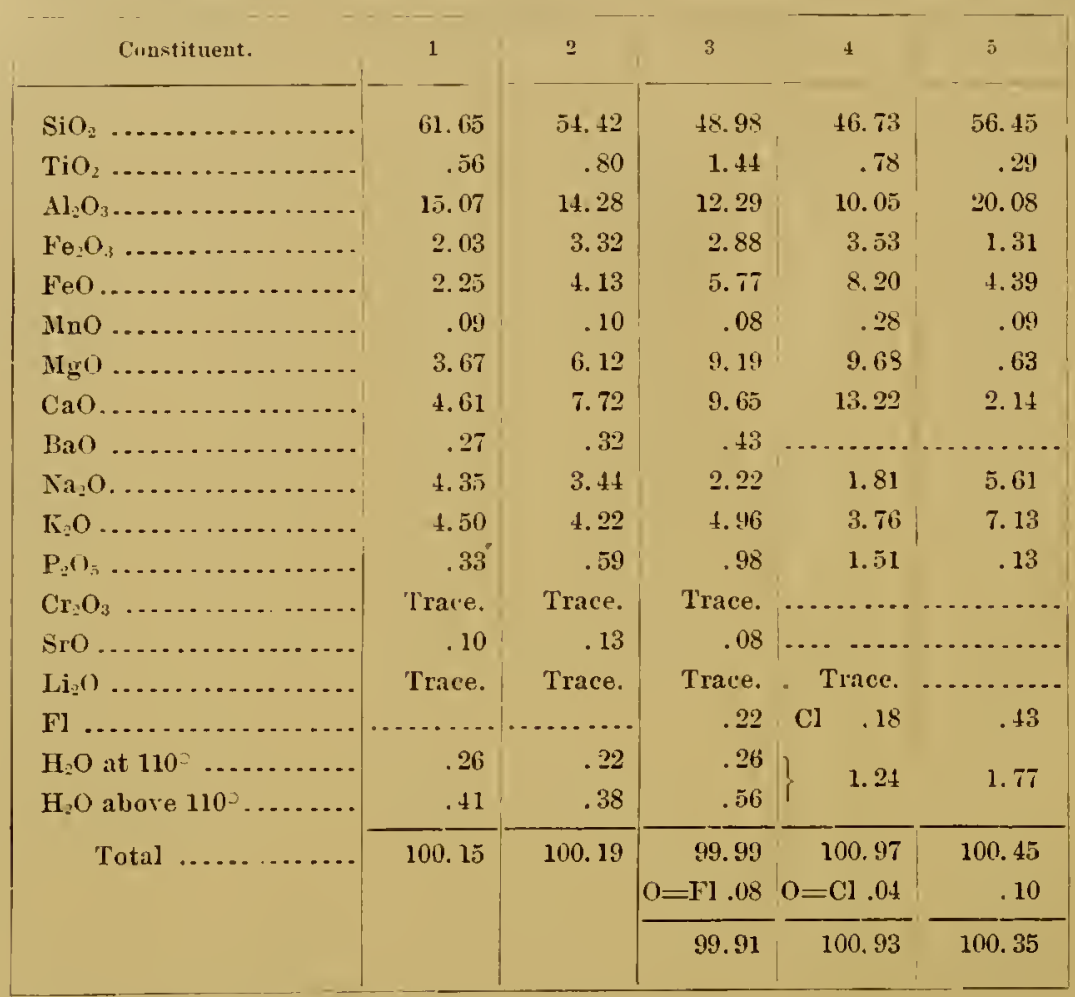

1. Syenite, Yogo Peak. Analgzed by W. F. Hillebraud.

2. Monzonite, Yogo Peal. Analyzed hy IT. F. Hillebraucl.

3. Shonkinite, Yogo Peak. Analyzed by W. F. Hillebrand.

4. Shonkinite, Square Butte. Analyzed by L. V. Pirsson.

5. Sodalite-syenite, Square Butte. Analyzed by W. H. MeJville.

These author's state that the three rocks from Yogo Peak grade into one another, and are facies of one mass, whose rariations are the result of differentiation. They are granular crystalline, and consist essentially of orthoclase and augite in different proportions, with subordinate amounts of plagioclase, biotite, magnetite, and in the syenite, homblende, and in shonkinite, olivine, besides accessory minerals. In the syenite orthoclase exceeds augite, in monzonite ${ }^{1}$ orthoclase equals angite, and in shonkinite augite exceeds orthoclase. Chemically the series from Yogo Peak is characterized by comparatively low almmina, with relatively high potash,

${ }_{1}$ The rock called rogoite in the paper cited has been shown by these authors in a subseqnent paper to he the same as Brögger's monzonite, aud the name yogoite has been withdrawn. See The Bear Paw Mlouptains of Montana: Am. Jour. Sci., 4 th series, Vol. J, 1896, pp. 351-362. 
which is nearly constant. The sum of the alkalies decreases with decrease of silica and alumina. Magnesia and lime are fairly ligh. In the two rocks of Square Butte the shonkinite is like that of Yogo l'eak, but alumina and alkalies are somewhat lower, and magnesial and lime higher. The syenite of Squire Butte, the complementary rock of shonkinite, is high in allunina and alkalies and very low in magnesia and lime, with very high potash. In these two cises we find shonkinites as extreme forms of differentiations in connection with syenitic rocks quite different from one nnother in chemical composition, one being comparatively low in ahmina and the other high, the smm of the alkalies in one case being 8.85 per cent and in the other 12.74 per cent. In each instance the associated rocks are facies of one igneous mass. A comparison of the series of differentiation products just described shows to what extent they may differ from one another in neiglaboring regions. 


\section{CHA P TER X.}

\section{THE RHYOLITES.}

\section{By Joseph Paxson Iddings.}

\section{INTRODUCTION.}

The rhyolite of the Yellowstone National Park occurs almost wholly as extrnsive surficial lava flows in the form of nearly horizontal sheets, some having enormous proportions. In only one locality does it assume the character of a voleanic mountain, in which place it occurs as breccia and also as intrusions and surface flows. It constitutes the great platean of the Park, and sends out arms into valleys in the surrounding ranges of mountains, and is found in isolated remmants upon their slopes. Owing to its great areal extent, and also to the fact that it is in places more than 2,000 feet thick, its volume is very large. It is exposed to view in many cliffs and bare slopes tlroughout the region, and has been studied in detail in many places.

Its two most striking petrological characteristics are the uniformity of its composition chemically and mineralogically and the multiformity of its physical aspect. With a range of only 5 per cent in the silica, and of much less in the other constitnents thronghout miles of material, there is the greatest diversity in the appearance and texture of the rock, even within the limits of a few feet. Its color may be white, black, yellow, red, brown, or grays of various tones, which may be uniform for broad areas, or mingled in blotches, streaks, and layers, or finely speckled in small spots. Its huster may be dull and stony or vitreous and brilliant, aud its texture may be rough or smootl as the rock is porons, vesicular, and pumiceous, or dense and compact. In some localities the characters are quite uniform for a large extent of rock; in others they are highly diversified. In order to convey a proper idea of the relatious of these various modifications to one 
mother and to show their origin, it will be necessary to describe the ficld occurrence and megascopical claracteristics in a number of localities within the P'ark, and afterwards to treat systematically tho microscopical characters.

\section{. MHGASCOPICAT, CHARAC'TERS.}

\section{VICINITY OF MAMMOTH HOT SPRINGS.}

The rhyolite at the Golden Gate, where the road to the Geyser Basins passes along the face of a rocky clift' at the south end of Terrace Mountain, is a dense, light purplish-gray rock, separated into distinct horizontal layers, and jointed by irregulur rertical cracks, which canse it to weather in pimnacles of angular blocks. In the lower part of the cliff the rhyolite is dense and dark purple, passing up into lighter-colored and more porous forms, with occasional flattened cavities and yellow spots. The rock has a stony lithoidal groundmass, in which glisten small crystals of quartz and sanidine $(1775,1776)$.

It also forms a prominent cliff, 100 to 150 feet ligh, along the top of the southern portion of the west escarpment of Mount Everts, which is well shown in the panoramic view of this mountain, by W. H. Holmes, which accompanies his report on the geology of the Yellowstone National Park. $^{1}$

Here the rhyolite is massive, with a rude columnar structure. It is reddish purpie and lithoidal, with many small phenocrysts of quartz and feldspar. Near the northern end of the sheet, on the summit of Mount Everts, it passes into a grayish-white rock, finely porous in spots (1762). Beneath the rhyolite sheet there is a deposit of rhyolitic dust or ash about 4 feet thick, in places more, which, as Holmes has pointed ont, is beautifully and delicately laminated in light and dark grays, brown, and buff's. The top of the sandstone strata on which this ash rests is covered with a thin layer of small fragments of the same kind of sandstone and sandy soil, only a few inches thick. Upon this is a layer of rhyolitic ash or sand, passing up into very tine white dust (1763), formed of microscopic angular particles of glass and a small amount of crystalline grains. This is thinly lammated. Over it are alternating layers of coarser rhyolitic sand and finer dust, all laminated, with the thimnest possible lines, which are

'Twelfth Aun. Rept. U. S. Geol. aud Geog. Surv. Terr. (HaJden), for 1878; Part II, Pl. XXxII. 
persistent and perfectly parallel to one another and to the plane of contact of the overlying massive rhyolite. This friable portion passes upward by insensible gradations into dark-purple dense rock with abundant phenoerysts, almost indistinguishable from the orerlying rock, from which, however, it is separated by a thin layer of black perlitic glass (1769) less than one-fourth of an inch thick. A sinilar deposit of dust underlies the rhyolitic sheet in the momtain north of Terrace Mountain, where it has been indurated in the same manner.

The rhyolite sheet of Mount Everts extends over the whole southern half of the top of the mountain and down the slopes of the southeastern spur's to the valley, and orerlies a thin sheet of vesicular basalt which is exposed in a number of places. It is found near the top of the plateau wall south of Lava Creek, where it is about 150 feet thick, and extends south into the great plateau. In the neighborhood of Osprey Falls, east of Bunsen Peak, the same rhyolite sheet is exposed in the cliff near the falls. Beneath it is a deposit of light-gray rhyolitic dust, which grades upward into more compact rock and then into dark glassy rock immediately beneath the massive rhyolite. The rhyolite sheet is from 100 to 150 feet thick and overlies 8 sheets of basalt, which are superimposed nearly horizontally, and it is in turn overlain by a 50 -foot sheet of basalt, the whole series, including the rhyolite, being finely columnar. The surfaces of the columns of the rhyolite and of those of basalt are very similar in color, owing to weathering and to the lichens, so that the two rocks are scarcely distinguished from one another at a distance, the rhyolite appearing as dark as the basalt. Near the falls, however, the rhyolite columms are longer and straighter, and become granular at the upper ends, where they weather into pinnacles.

The rhyolite forming the cliff at the Golden Gate continnes as a nearly horizontal sheet northward beneath the travertine deposit on Terrace MLountain, and forms the top of the hill north of this, where it is from 150 to 200 feet thick. It is exposed in a bold cliff heading an amphitheater on the northeast side of this mountain, and has the same characters as in the cliff on Mount Everts. It is dark purple, lithoidal, and full of rather large phenocrysts. In the top of the cliff it is in places glassy and perlitic, aud contains large vesicles. Beneath the sheet, as already mentioned, there is a deposit of rhyolitic dust, whose upper portion is indurated like that on 
Hount kverts, the material from both localities being identical. The rlyolite sheet continues north until it reaches the andesitic breceia forming the southeast spur of sepulchre Momitain, npon which it rests, its lower portion inclosing framgments of andesite. It extends along the base of the south slope of Sepulche Momitain west to the divide between Glen and heese creeks, and forms the bench of dark-purple rock with small phenocrysts south of Cache Pond, and also an isolated remmant of lightreddish earthy rhyolite overlying the andesite on the west base of Sepulchre Momutain.

From this we see that in the neighborhood of the Mammoth Hot Springs the rliyolite has a very uniform character, being mostly lithoidal, except in one place on the old Norris road northwest of Terrace Momtain, where a small mass of dark-colored rhyolitic perlite is exposed, which, as Holnes has remarked, "is similar to that forming the under surface of most of the rlyolitic flows in this region." In this vicinity, however, the under surface of most of the rhyolite sheet has only a thin film of perlitic glass along its contact with the underlying rhyolitic tuff. The tuff deposit has not been observed on Glen Creek, nor at the head of Reese Creek, nor does it underlie the most northern remmant of rhyolite which ocenrs on the west side of Bear Guleh, north of the Park boundary.

\section{OBSIDIAN CLIFF.}

The rhyolite which forms the platean country and the flat-topped bluffs, 300 or 400 feet high, on both sides of Willow Park along Obsidian Creek is a lithoidal to earthy roek, reddish purple in darker and lighter shades, and fillegl with brilliant phenocrysts of quartz and sanidine, the latter exhribiting a blue iridescence in many localities. Rlyolite of the same character continues to form the platean as far south as the Norris Geyser Basin, being well exposed all along the road. It also extends east to Lava Creek and forms the west base of the mountains west of Tower Creek, overlying andesitic breccia and reaching an altitnde of 8,800 feet.

At the northern end of Beaver Lake the lithoidal rhyolite is overlain by a great flow of rhyolitic obsidian, which covers the ligh country to the east in a sheet 75 to 100 feet thick and has accumulated in an ancient valley to the depth of 200 feet. The stream erosion of this thicker mass has 
formed Obsidian Cliff," whose shining black colmmus of glass rise 100 feet above the road.

The cliff stretches for half a mile from the outlet of Bearer Lake along the east side of Obsidian Creek, being 150 to 200 feet high near the lake and becoming lower northward. The upper half is a vertical face of rock, the base of which is obscured by débris of large blocks of the same material. The obsidian sheet extends eastward up the rude benches to the top of the platean 400 feet above Beaver Lake. Along the west edge of this table-land it forms a cliff about 50 feet high, which extends, south to the Lake of the Woods.

Following the obsidian back from the face of this upper cliff, over the hummocky surface of the plateau, the black glass becomes filled with gas cavities and passes into banded pumiceous rock, and finally into light-gray pumice. This covers the surfice of the platean for $2 \frac{1}{2}$ miles eastward, to the valley of Solfatara Creek. Here again the lava flow is exposed in a cliff, the lower portion of which is black and red obsidian. Toward the south the obsidian flow extends a mile beyond the Lake of the Woods, and northward it crosses the east-west drainage that cuts off the higher portion of the platean a distance of some 5 miles. The original thickness of this lava flow is not known, since the upper pumiceons portion has been eroded to a variable extent. The denser obsidian portion is from 75 to 100 feet thick.

The point at which the obsidian broke through the older rocks has not been discovered, but it is evident that the lava forming Obsidian Cliff flowed down from the high platean in a northwest direction into a preexisting valley. The planes of flow in the lava clearly indicate that it crept down the slope back of Obsidian, Cliff and accumnlated in the bottom of a channel between rhyolite hills.

The most noticeable feature of this body of obsidian is its columnar structure, which is confined to the southem end of the cliff. It is shown in Pl. XXXIX. The glassy columns rise from a talus slope that extends 50 feet up the cliff. They are vertical prisms 50 or 60 feet highl, and vary in width from 2 to 4 feet near the south end of the cliff, the width of each column being quite constant throughout its length. On the soutl face of

'Idrlings, J. P., Obsidian Cliff, Yellowstone National Park: Seventh Anu. Rept. U. S. Geol. Survey, 1888, pp. 249-295. 


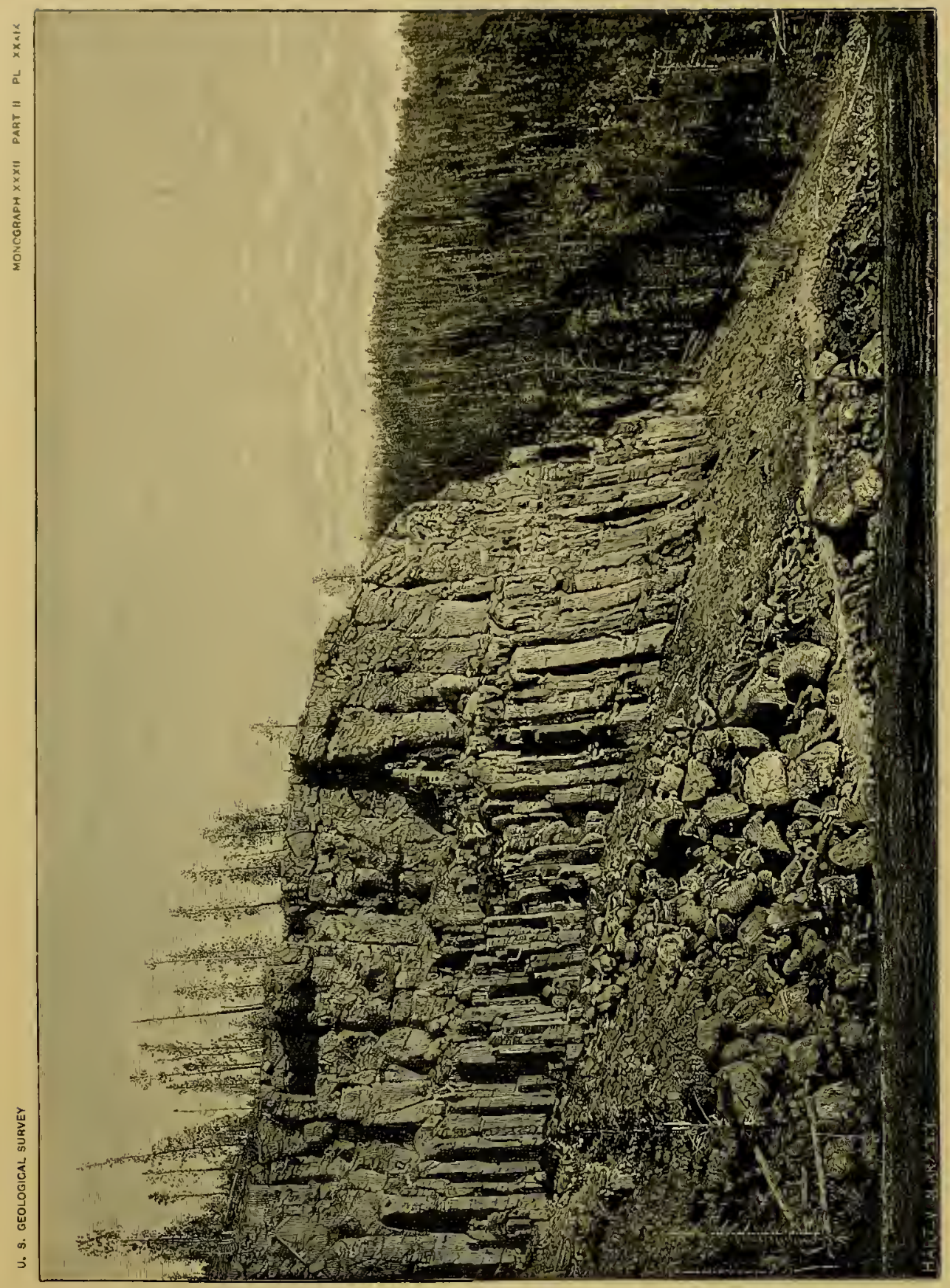

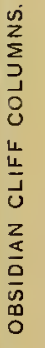





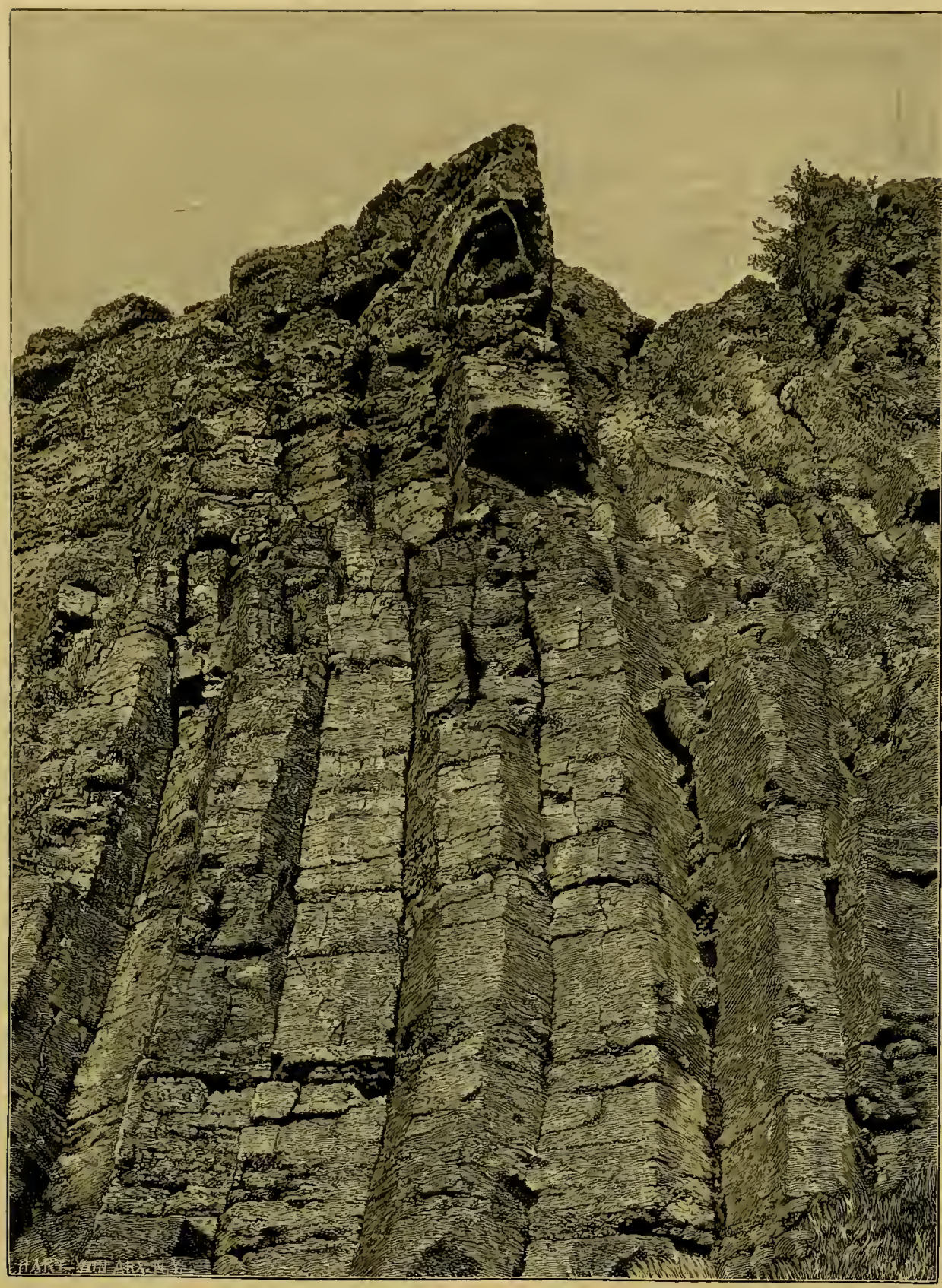

TOP OF COLUMNS, OBSIDIAN CLIFFS 

this end of the cliff the columns are the same, but grow less clearly defined toward the cast, where a sharp bend in the lava sheet has formed gaps in the rock and has destroyed the continuity of the mass. Beyond this the colunms incline considerably toward the west, as though the underlying surface of contact sloped toward the west also. The columns in the main face of the cliff are tilted $15^{\circ}$ to the eastward, and the planes of flow which cross them have an average dip of $10^{\circ} \mathrm{E}$., indicating that the underlying surfice at this place sloped toward the east. The columns become broader to the north, the largest being 20 feet in width, and with the change in the character of the rock from glassy to lithoidal they grade into massive blocks formed by vertical cracks farther apart. 'The columns lave four, five, and six sides, which are unequally developed, but at a distance the general effect is quite regular.

The obsidian forming the lower part of the columns is dense and black, and transparent only on very thin edges. It is traversed by loands or layers of small gray spherulites. In this part of the columns there are almost $n$ cavities or lithophyse, and but little contortion of the layers. Higher up, the obsidian is less massive and contains large lithophyse flattened parallel to the plane of flow. The tops of the columus pass into obsidian, which for 10 feet is quite dense, but above this is full of large cavities which honeycomb the mass. This may be seen in the photograph of the columns (Pl. XL). This upper portion, about 50 feet thick, is divided by vertical cracks into broad quadrangular blocks. The sides of the columms are comparatively straight, and are independent of the flow structure within the mass, which is indicated by the spherulitic layers that traverse the rock in parallel planes more or less contorted These layers pass through the columns at all angles, exhibiting abrupt folds and curres, which have been cut across sharply by the columnar cracks. The crystalline spherulitic layers formed planes of weakness, along which transverse cracks were produced. There is another kind of parting, which took place while the lava was still molten, but when it was so viscous that in places where vertical layers pulled apart in flowing down the slope the gaps did not close up. These are of only exceptional ocemrence.

The columnar portion of the west face of the cliff extends for only a few hundred feet northward, the character of the rock also clanging in this direction. The spherulitic and lithoidal layers also become more frequent, 
mntil the black glass appears as thin bands in a light-gray rock, and finally the whole mass is a laminated lithoidal rock. The lithoidal form of the rock is not found in the thimner portions of the lava flow, but only where it has accumulated in the ancient channel. It is split into thin plates along the planes of flow, owing to the differences in texture of the alternating layers, which vary in degree of erystallization. This delicate lamination and variability of crystallization will be referred to again, after the microscopical characters have been described.

Owing to the fact that the sphernlitic structure, which is highly developed in the obsidian at this place, is typical of that which occurs in a great number of other localities in the Yellowstone Park, it seems advisable to describe it in considerable detail, in order to give a clear impression of this very characteristic mode of crystallization. The spherulites form isolated spherical borlies or groups of spheres, often so intimately intergrown as to form layers in the rock. Their snbstance is husterless and stony, dull bluish gray and pink. They are of various sizes, the larger ones frequently being hollow or porous.

The simplest form of the megascopic sphernlites is that of small darkblue spherules, about the size of a mustard seed, embedded in the black obsidian. When broken, they appear lighter gray within, have a dense porcelain-like texture, and exhibit slight indications of a radially fibrous structure. They are usually located along fine lines of minute dots on the surface of the obsidian. The small blue sphernles are generally crowded together along these lines, or more properly along the planes of which these lines are the traces, and which are planes of flow. Sometimes a number of layers will lie close together with the thimnest possible sheet of black glass between them, or they will mite to form a band a fourth of an inch thick, whose surface is covered with protruding hemispheres. Occasionally groups of spherules are prolonged in one direction, forming parallel ropes through the black glass.

The surface of the sphernles is brown or red, and constitutes a plane of weakness between the spherulite and the glass, along which the two separate with ease, leaving a dull pitted surface on the obsidian. The arrangement of the sphernlites in the plane of flow is quite irregular; though occasionally in arborescent figures.

Sphernlites about the size of peas have an agate-like banding in con- 
centric shells, combined with a radially fibrous structure. Their form is more ol less spherical, sometines being depressed on one side, or they are elongated into gomol shapes. They are frequently aggregated in botryoidal and kidney-shiped groups. 'Their surfice, where separated fiom the obsidian, has a delicate velvety blonm, like that of a peach, which in rich shades of brown and terra cotta contrasts strongly with the black glassy matrix.

The langer spherulites, an inch or more in dianeter, are usually lighter colored, in shades of reddish gray, often laving a blue center. They lave a more eartly texture than the small ones, and a distinct, radially fibrous structure, with satiny luster. In some cases there is a granular spotted appe:urance in the outer portion, and frequently a distinctly concentric structure is present, the shells being either broad and dense or of the most delicate thinness. The surface of these spherulites is often ridged with rings r'uning garallel to the flow planes of the rock, closely resembling the surface of concretions in sedimentary rocks. Their shapes vary from spheroidal to flattened disks and hemispheres and irregular forms resulting from the interference of spherules that have grown close together.

The delicate banding of the rock which marks its flow structure passes uninterruptedly through all these sphernlites, although it is not always recognizable without the aid of a lens. This indicates that the spherulites were formed after the lava came to rest and when the parallel layers of flow had become motionless. There is no definite order in which the different kinds of spherulites crystallized. Sometimes the larger ones have developed first; in other cases, the smaller ones.

The spherulites are not all solid; the larger ones especially are more or less porous, often cavernous. The large earthy ones, which appear densest, have microscopic cavities between the crystals composing them. Others have a saccharoidal textmre and are made up of slightly adhering crystals. Many of them have porous or open cavities within their mass, the periphery often forming a solid crust or shell, like the rind of a cantaloupe. In some cases these cavities ramify through the heart of a spherulite and are coated with brilliant crystals. The porous spherulites often resemble pithy berries, while the more open ones appear to have shrunk and cracked apart, like the heart of an overripe watermelon. This character is illustrated in figs. 1 and 5 of Pl. XLI. The cavity is confined to the limits of a single spherulite when this occurs isolated in the rock; detached ones with per- 
fectly continuous shells are often very hollow within. Isolated spherulites in dense black obsidian, without the trace of eracking, are sometimes half hollow, presenting a white skeleton of crystalline fibers and nodules, or concentric shells which are dotted with minute pellets of tridymite. This form, which is a typical lithophysa, is represented by fig. 3 of Pl. XLI. The shells are usually so delicate that parts of them fall ont when the rock is broken. On the white frosted substance of these lithophysæ rest the honey-yellow crystals of fayalite, ${ }^{1}$ which have not yet been attacked by atmospheric agencies. In most other cases the porous nature of the inclosing rock, when lithoidal, has allowed these agencies to attack the fayalite, when it is usually more or less altered to an opaque metallic substance, through the formation of ferric oxide. Cavities are less frequent in the small blue spherulites, but occasionally the smallest spherules are white and porous; and in places along the spherulitic layers, or through the black glass, there are granulated bands of small cavities with a white, gray, or pink coating.

Besides the thin blue layers with spherulitic structure, the obsidian is also banded by light-gray ones of a more crystalline or porcelain-like nature. As these become more mumerous the rock assumes a lithoidal or stony appearance and grades into purplish-gray rock, delicately banded with blue-a lithoidal rlyyolite, or lithoidlite in this case, since there are no phenocrysts in it. This rock is thinly fissile in plates parallel to the banding, which are sometimes not more than one-sixth of an inch thick (Pl. XLII). Occasionally the rock breaks into blocks which bear the strongest resemblance to silicified wood.

The lithoidite is completely spheralitic, but the spherulites are microscopic and have a character somewhat different from that of those just described, the megascopic ones being almost all porous or hollow. The rock abounds in lithophyse of great delicacy and beanty, and often of great size, the largest being a foot or more in diameter. An idea of their abundance is given by fig. 2 of Pl. XLIII, which represents a slab of lithoidite, in natural size. The lithophyse in this rock are mostly hemispherical, and consist of concentrie sliells which arch over one another like the petals of a rose (fig. 4 of Pl. XLI and fig. 1 of Pl. XLIII). The shallower ones present small rose-like centers sumounded by thin circular shells (fig. 2 of $\mathrm{Pl}$.

1 For a description of these fuyalite cristals see the paper on Obsidian Cliff, alleady cited, p. 270. 


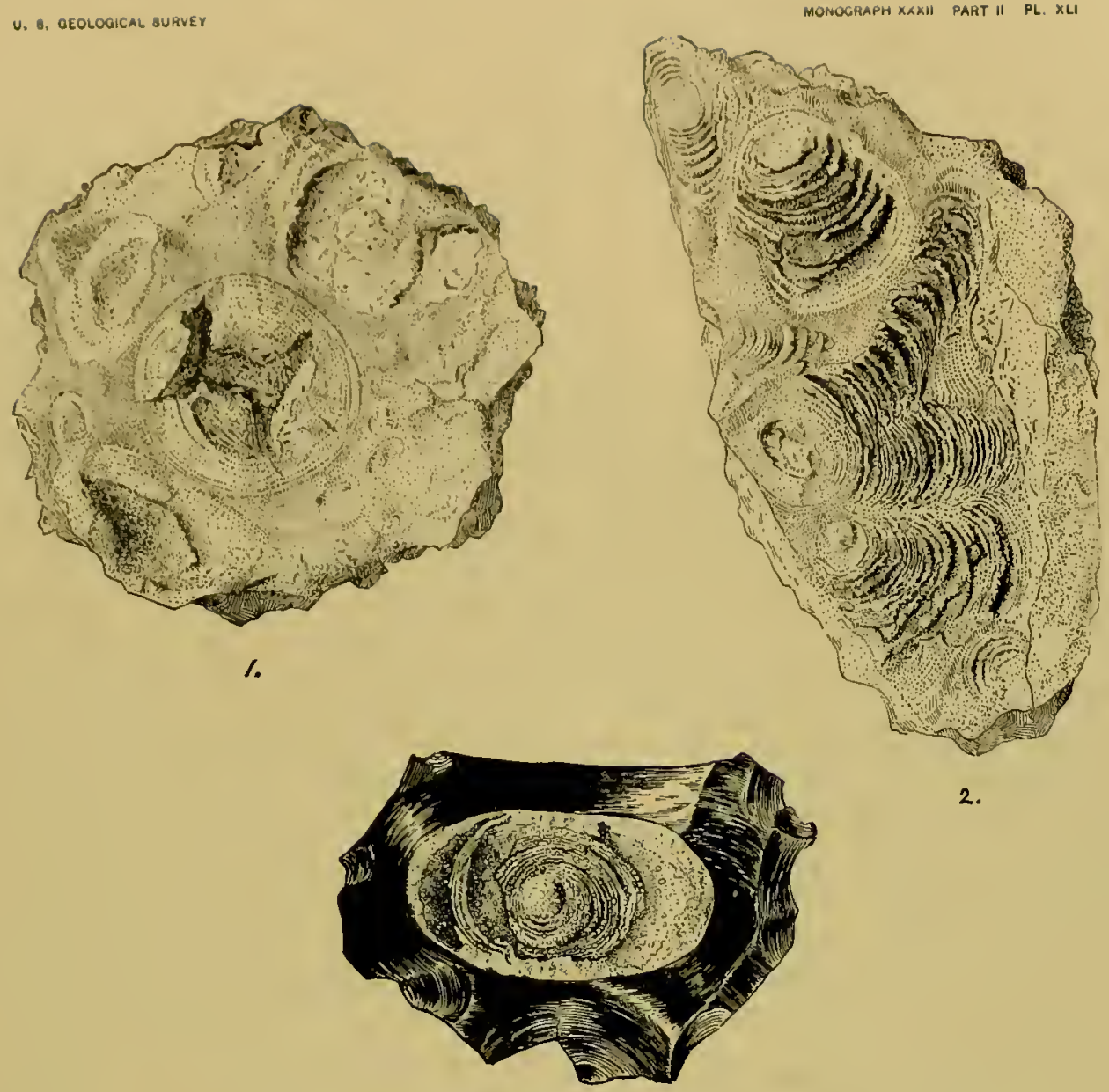

3.
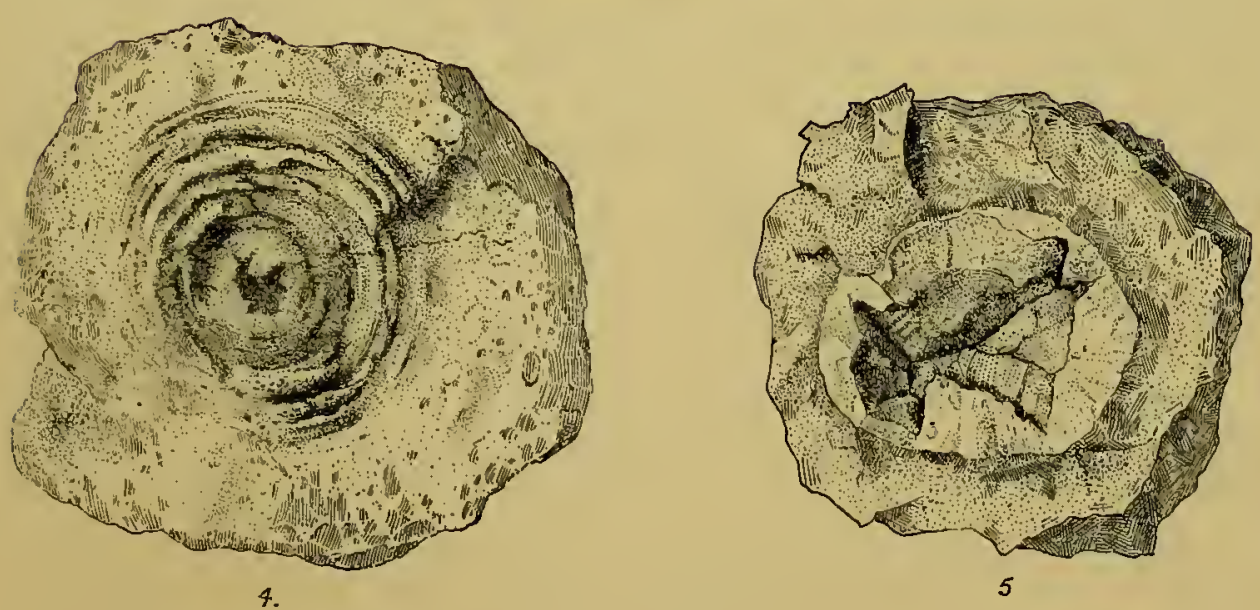

LITHOPHYSAE 



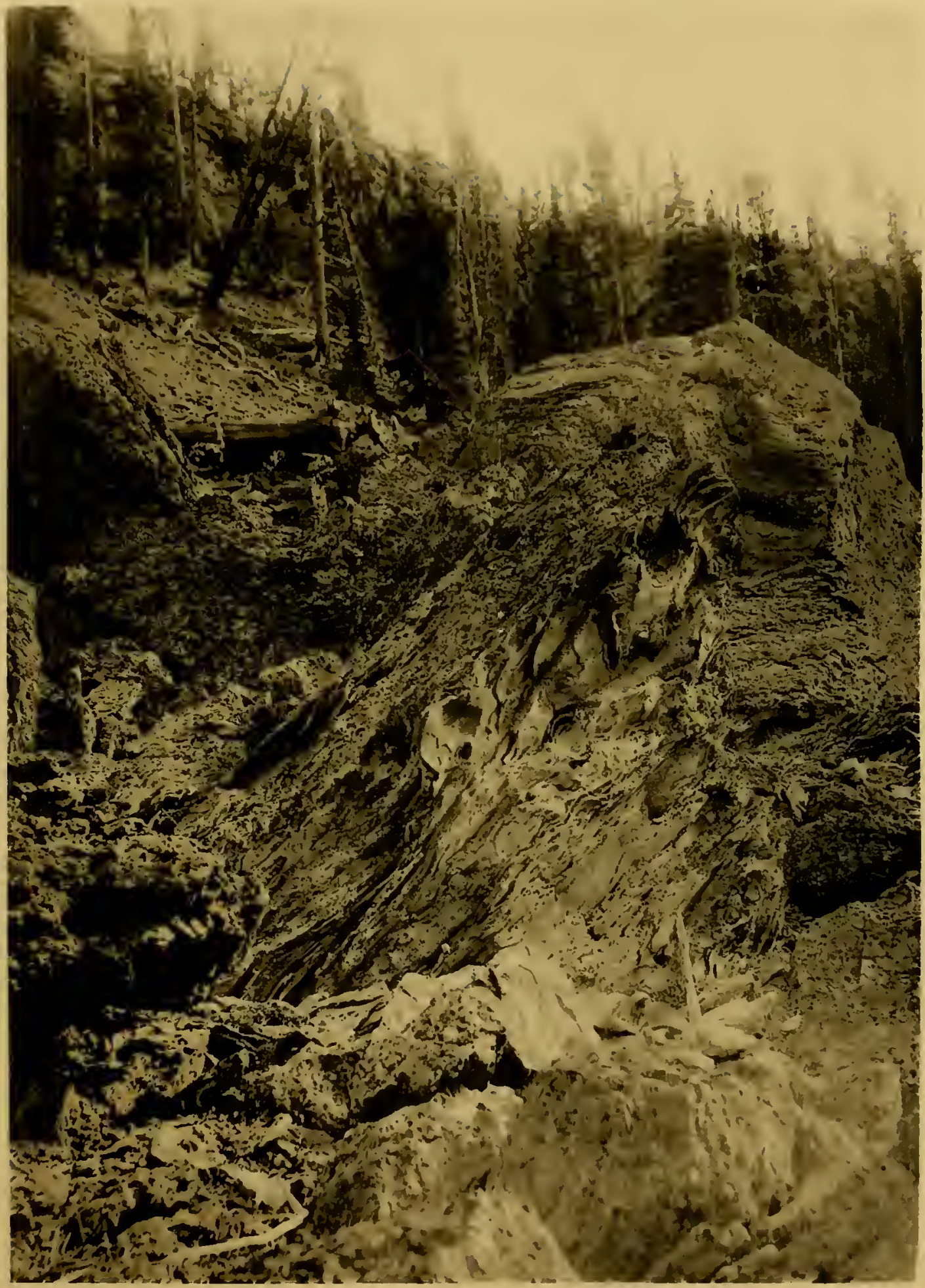

FISSILE LITHOIDAL RHYOLITE, OBSIDIAN CLIFF 


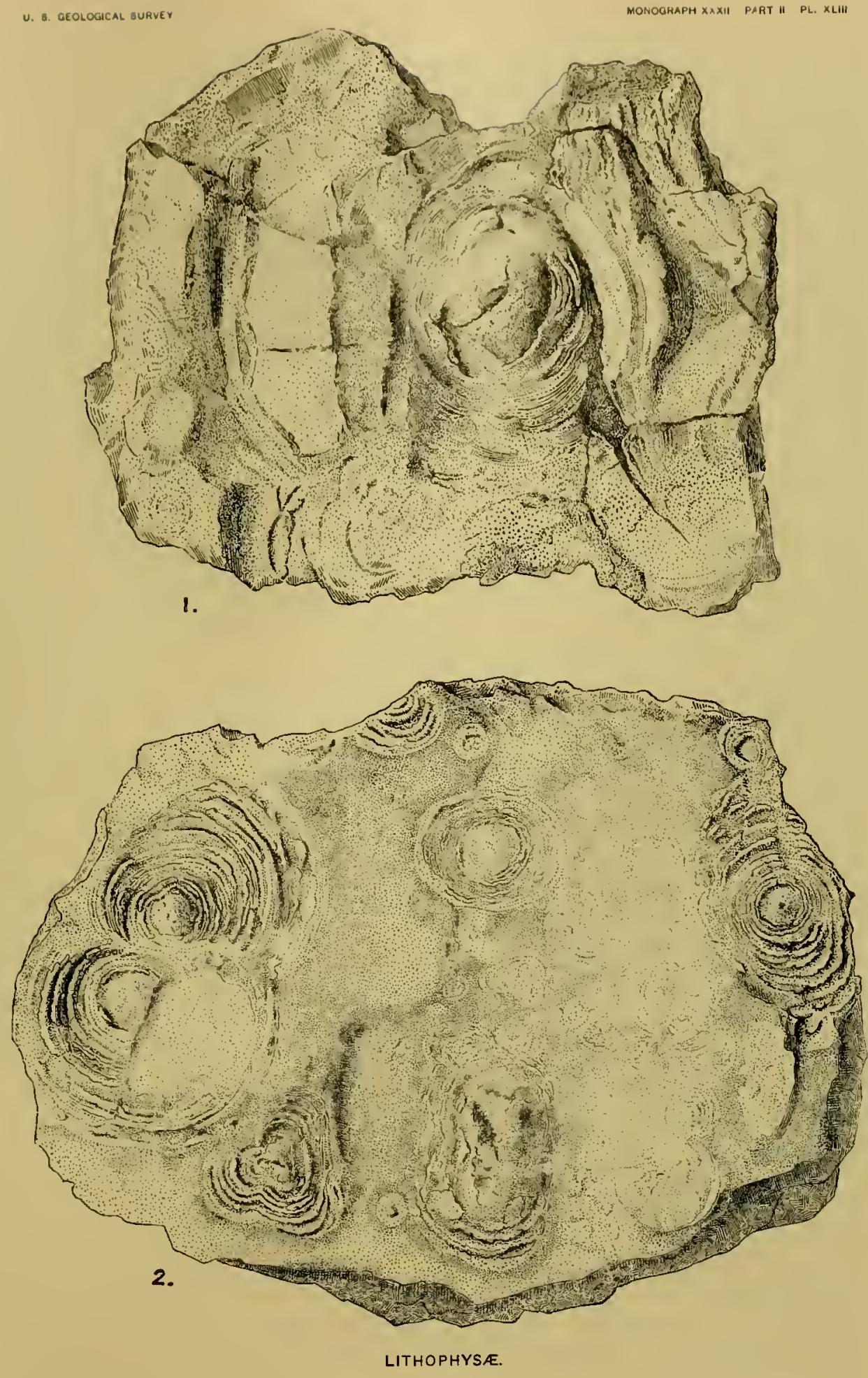



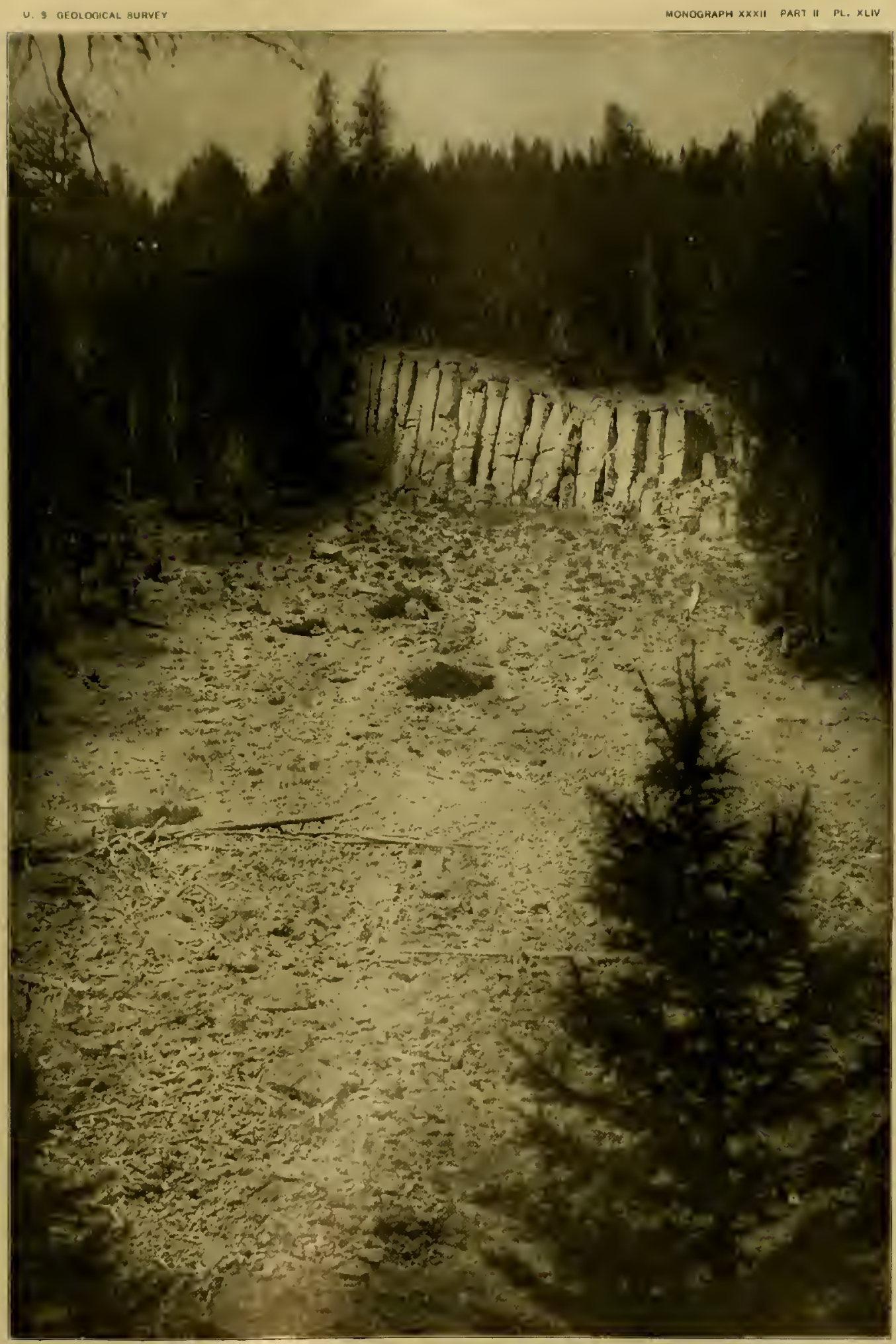

COLUMNAR RHYOLITE, WEST SIDE OF OBSIDIAN CREEK. 

XLIII). The disks are sometimes oval, and are sometimes romposed of several sets of shells, which have been started from centers near together and have developed in sections, giving a scalloped form to the curves. Others are eecentric or send out long curving arms, as fig. 2 of PI. XLI.

The concentric shells are generally very thin, and often so close together that in one instance fifty occur within a radius of 2 inehes. They are very fiagile and crunble under the touch, being made up of small and slightly allhering crystals of brilliant quartz and orthoclase. In the lithophysa represented on natural scale by fig. 1 of Pl. XLIII the rose-like center is surrounded by delicate shells. The outer portions to the right and left are somewhat massive, though finely porons and crystalline, and are traversed by well-marked shrinkage cracks, which gape open from the base of the rock to which the lithophysa adhered, and clearly indicate the contraction of the massive portion. In the cavities between some layers of the laminated lithoidite there are small tibular crystals of sanidine, with blue iridescence. They are Manebach twins, the basal pinacoid being the tilbular plane. They contain soda and potash in equal molecular proportions. ${ }^{1}$

In recapitulation, then, this rhyolitic lava is a flow about 100 feet thick, except where it has piled up in a small valley. It is glassy, except the lithoidal portion in the valley, and is free from phenocrysts The obsidian is dense in the lower part of the sheet and carries numerons splierulites. Large vesicles ocemr in the upper portion, and toward the surface of the flow the spherulites disappear and the glass becomes filled with gas eavities and passes up into pumice. The lithoidal portion is filled with lithoplyysæ and has numerons porous layers. These characteristics repeat themselves in the rhyolite in various parts of the Park.

The columnar structure which is so rell developed in this obsidian is also observed in the rhyolite in many other places in this region. It occurs in the porphyritic lithoidal rhyolite on the west side of Obsidian Creek, directly opposite the eliff, and is shown in the accompanying illustration (Pl. XLIV). These columns are short and stout, about 15 feet high and 2 or 3 feet broad. They are traversed by pronounced jointing, which splits the rock into plates parallel to the planes of flow. From the inclination of these it would appear that the original surface of the lava sloperl northward 
somewhat more steeply than does the present ridge. Similar columnar strncture occurs in the purple lithoidal rhyolite (1815) on Winter Creek, 2 miles west of this locality.

CANYONS OF GIBBON RIVER AND MADISON RIVER.

The lava forming the high bluff back of the Paint Pots and just east of the Gibbon River as it leaves the Geyser Meadow is a variety of rhyolite somewhat different from that forming the plateau comtry roundabout. It is lithoidal and porphyritic, like the occurrences already described, but is dull steel-gray in color, and full of minute, irregularly shaped cavities, producing a very rough fracture. The phenocrysts are mostly small white feldspars, which are plagioclase, and much ferrer transparent samidines, and very rarely quartz; small augites may be seen with a lens. The rock appears more like a basalt than a rhyolite. It passes southward along the east side of the river into light-purple lithoidal rhyolite with similar plagioclases, but much more quartz and samidine.

The Gibbon River after leaving Geyser Meadow cuts a narrow canyon, 500 to 600 feet deep, through rhyolite, which is almost entirely lithoidal, but of variable character. On the west side it is exposed in high vertical cliffs of dark lithoidal rock with pronounced banding or flow structure, which is greatly contorted. Back of the hot springs on the east side there are a number of angular fragments of reddish-brown glassy rhyolite full of small phenocrysts of quartz and feldspar (1852). These are probably not in place. The west wall near the bridge consists of reddish-purple lithoidal rhyolite, full of irregular pores, and crumbling. It is rich in phenocrysts of quartz and feldspar $(1851,1853)$, and is a nevadite, strictly speaking. The great massive cliff weathers into columnar pimnacles, which are very characteristic of crumbling rhyolite. The denser variety of the rock weathers into fragments with smooth surfaces and sharp erlges.

At the falls of the Gibbon the rhyolite is reddish and lithoidal, passing into glassy rock, that at the base of the falls being black obsidian full of porphyritical crystals, which is so thoroughly cracked that it is difficult to obtain a compact hand specimen of it $(1855,1856)$.

The canyon made by the Madison River below the junction of the Gibbon and Firehole rivers has been cut 1,700 feet through the rhyolite mass without reaching the underlying rocks. The canyon presents fine 
exposures of rhyolite. A rule columnar structure is plainly seen in the rhyolite, which is evidently one thick sheet and not a succession of thin sheets superinposed on one another.

The fince of the cliff on the north side of the canyon exhibits long, slender, vertieal columns of rhyolite, 200 feet high, with shorter ones somewhat inclined. The upper part of the eliff is tratersed by approximately horizontal joints, which arch orer the tops of the vertical columns, il structure similar to that in the upper part of the glassy end of Obsidian Cliff. The rhyolite at this point is lithoidal, with numerous small phenocrysts, and is banded dark and light purple. The lighter-colored parts are finely porous (1857). West of this prominent point the rhyolite is massive, in nearly horizontal layers, and weathers into rounded pimnacles, which are shown in Pl. XLV. The rock from this mass breaks into great rounded blocks, like granite, and weathers into angular sand. It is literally crowded with phenocrysts of quartz and sanidine, with abundant small rusted angites, and is a nevadite. In places it has a dark-purple banded groundmass and is somewhat vesienlar (1858). Parts of it are filled with hollow spherulites, which are highly crystalline and porous, with gaping cracked hollows at their centers, which are encrusted with tridymite and minute feldspars, with larger crystals of quartz exhibiting the characteristic steep rhombohedral faces, $\frac{2}{3} \mathrm{R}$. There are also a few rusted fayalites. In some instances there are indications of concentric shells $(1859,1860)$. The same nevadite forms the summit of the highest point of the north wall of the canyon (1862). From a distance it appears as though there were a thinner sheet of rhyolite overlying a very thick one, the top of the lower flow weathering away and leaving the bottom of the upper one dense and well defined, but this appearance may be deceptive, since the rock occurring in the talus at the base of the slope is all one variety, very rich in phenocrysts. The apparent difference may arise from slight variation in the physical character of the rock at that place.

MADISON PLATEAU, NORTH OF THE LOWER GEYSER BASIN.

The northwestern arm of the rhyolite platean, west of Obsidian Creek and Gibbon River and north of the Madison River, covers all the lower portion of the northwestern corner of the Yellowstone Park, reaching. up the slopes of the Gallatin Mountains to altitudes of 8,000 and 8,600 feet. 
It forms the long flat-topped spurs extending out from the base of these mountains, and passes under the Pleistocene valley of the Madison River. It carries on its surface a few remnants of a once extensive basalt sheet, and in places has been eroded down to the underlying rocks, which are mostly. gneiss. Throughout most of this area the rhyolite is lithoidal, reddish purple, and slightly porphyritic. Phenocrysts are not very abundant in the rock southwest of Mount Holmes (1816) and in that found in the vicinity of Gneiss Creek and its northeast branch (1818 to 1820). At its extreme northwestem end, north of Fan Creek, the rliyolite overlies a conglomerate of andesitic fragments, and is exposed in a cliff 200 feet higl, the lower portion being dense and lithoidal, the upper part containing lithophyse. Small lithophyse are also foind tilling the dark-purple rhyolite on the summit of the ridge to the west.

At the base of the west slope of the platean south of Cougar Creek the lava is glassy black obsidian, closely resembling that of Obsidian Cliff, except that it carries a few small phenocrysts. It is splherulitic, with small blue spherulites (1864) and smell lithophyswe containing quartz, tridymite, and fayalite. Part of the obsidian is filled with small lithophysa, which are mostly hollow, gaping spherulites, with rery distinct delicate prisus, which radiate from what was once the center of the pasty spherule, and consequently alpear to have been formed prior to the cracking and gaping. of the spherule. The sides of the lollows are dotted with brilliant pellets of tridymite. These very hollow lithophysa, some of which exhibit a tendeney toward concentric shells, existed as hollow bodies with very slight but rigid shells before the surrounding magma solidified, for a number of them have been crushed in such a manner as to prove that the thin shells were rigid and that the matrix was very viscous and the pressure not very great; for the glass has not forced its way into the cavities, and in one case did not fill up the space made by the eracked shell.

At the west end of Madison Canyon the river euts through lithoidal rhyolite, which forms the western foothills of the platean south of the river. It is light eolored, with lithophysie and spherulites, and in one place is full of irregular cavities which are coated with crystals of quartz and hematite. The quartz is prismatic, with the unit rhombohedrons and a steeper one less strongly developed, but perfect when present. The hematite is in thin tablets with crystal faces, and is usually twinned (1867). 


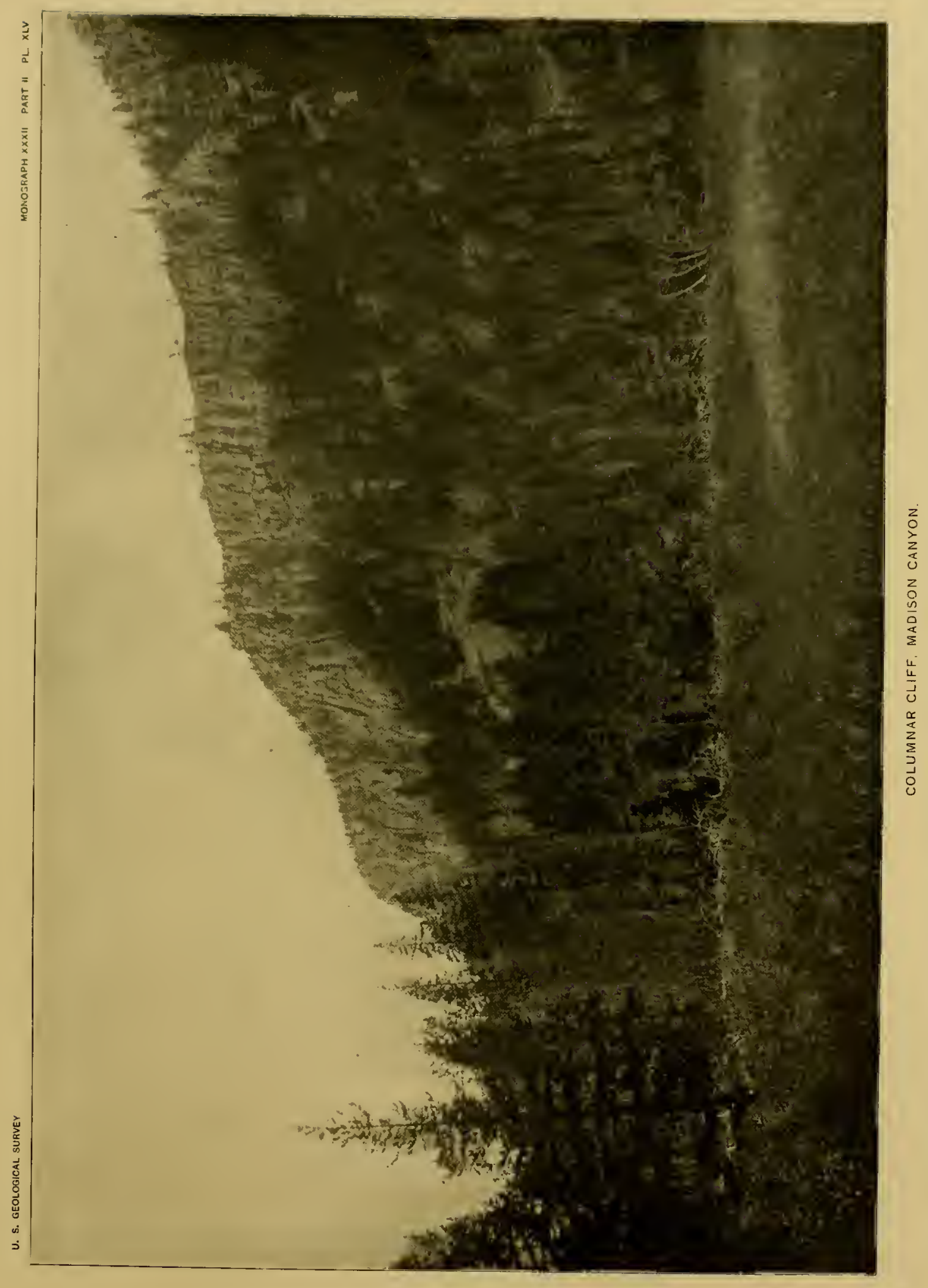



The top of the platean south of Madison Canyon is almost entirely glassy rhyolite, perlite, and obsidian. At the westem edge of the top, near the road, is black porphyritic obsidian, which is vesicular in layers, the vesicles in places having been elongated in one direction and flattened in a plane perpendicular to the layers. With it is associated a grayish-white pumice of the same magma, into which it undoubtedly passes $(1865,1866)$. 'The edge of the platean north of Sentinel Creek is partly lithoidal rlyyolite, reddish purple, with abundant prominent sanidines and smaller quartzes $(1877,1878)$, some of it containing beautifnl white lithophyse with concentric shells (1873). But the greater part of the rock is obsidian or perlite, with the same phenocrysts as the lithoidal portion of the rock. Much of it is spherulitic, having abundant small blue or red spherulites, both compact and porous, with radial fibration and concentric zones. Through these spherulites the phenocrysts are scattered indiscriminately, not appearing to act as a nucleus. Larger sphernlites occur, and more typical lithophysa (1874 to 1876), and the obsidian in places is red and black, especially in the small alcoves and arroyos along the southern edge of the plateau. The eastern side of this block of table-land is a cliff from 300 to 500 feet high, at the base of which runs the Firehole River. The rock is lithoidal and banded, while along the east bank of the river above the falls the rhyolite is glassy for the most part.

\section{VICINITY OF LOWER GEYSER BASIN.}

On the east bank of Firehole River east of Madison Platean the rhyolite occurs with marked layer structure. The layers, which are bent and folded, trend almost parallel to the direction of the stream. The rock exhibits great variability. Some of it is lithoidal, dense, purple, and banded. Much of it is black perlite, with small blue spherulites in layers, so crowded together as to leave but small patches of perlite glass; other layers are microspherulitic (1869). Large spherulites are seattered through the rock, together with numerous phenocrysts of sanidine and quartz, which exhibit no comection with the layer structure so far as their clistribution is concemed, but show a tendency for the longer crystals of feldspar to lie more nearly parallel to the linyers than transverse to them.

The perlite outcrops in long ridges parallel to the river, and stands in nearly vertical layers of alternating characters, including spherulitic perlite, MON XXXII, PT II- 24 
purer glass, and red pumice, with layers of lithophysa. This is shown in Pl. XLVI, which represents sereral masses of this rock that liave been eroded into rude monuments situated about a mile above the lower falls. The vertical layers are well shown in the illustration. The small monument is filled with lithophysie. A few liundred yards above the falls, on the east bank, there is an exposure of black perlite bearing very large lithophysa, from 1 to 2 feet in dianeter (1870). This is slown in PI. XLVIl. Some are compact spherulites, with little if any cavity, purplish red in color, and breaking with radiating cracks. Others have distinct concentric shells, onefourth of an inch thick, with a spherical nucleus, which is shrunken and cracked, and have large cavities. The radiate erystallization is very pronounced in the more porous parts of the lithophysa, and the feldspar rays can be seen with a pocket lens. They are studded with minute brilliant and transparent crystals of tridymite, and the sides of the cavities are spotted with pseudomorphs of fayalite, like those at Obsidian Cliff.

The rock in which these remarkible bodies occur is a black and gray perlite, full of small spherulites and phenocrysts, some layers of the rock being very dense. They stand vertical and in places are much bent. Most of the perlite is very crumbling, and consists of gray glassy shells, surrounding rounded and subangular grains of black glass, which weatler out into black sand. The small spherulites are beantifully banded in concentric shells, being blue at the center and red ontside (1868).

Where the river near this place cuts a narrow gorge through the rliyolite, the rock is lithoidal and banded. Farther south, at the end of the ridge east of the river, about 2 miles below the mouth of Nez Percé Creek, there is a breceia of perlite and lithoidal rhyolite carrying fragments of an almost fibrous variety (1871), pieces of which were found west of the road 4 miles north of the Lower Geyser Basin (1872). It is lithoidal and porphyritic, and is traversed by long, slender pores so close together as to produce a fibrous structure, the fibers curving around the phenocrysts. The sides of the elongated vesicles are coated with white pellets of tridymite, the rock itself being dark slate color.

Brecciated rliyolite occurs a short distance to the sontheast, in the first low ridge north of the Nez Percé Creek. North of this the low ridges are covered with light-red pumiceous glass, delicately banded with black, producing the most perfect and beautiful lamination. It is rich in phenocrysts 


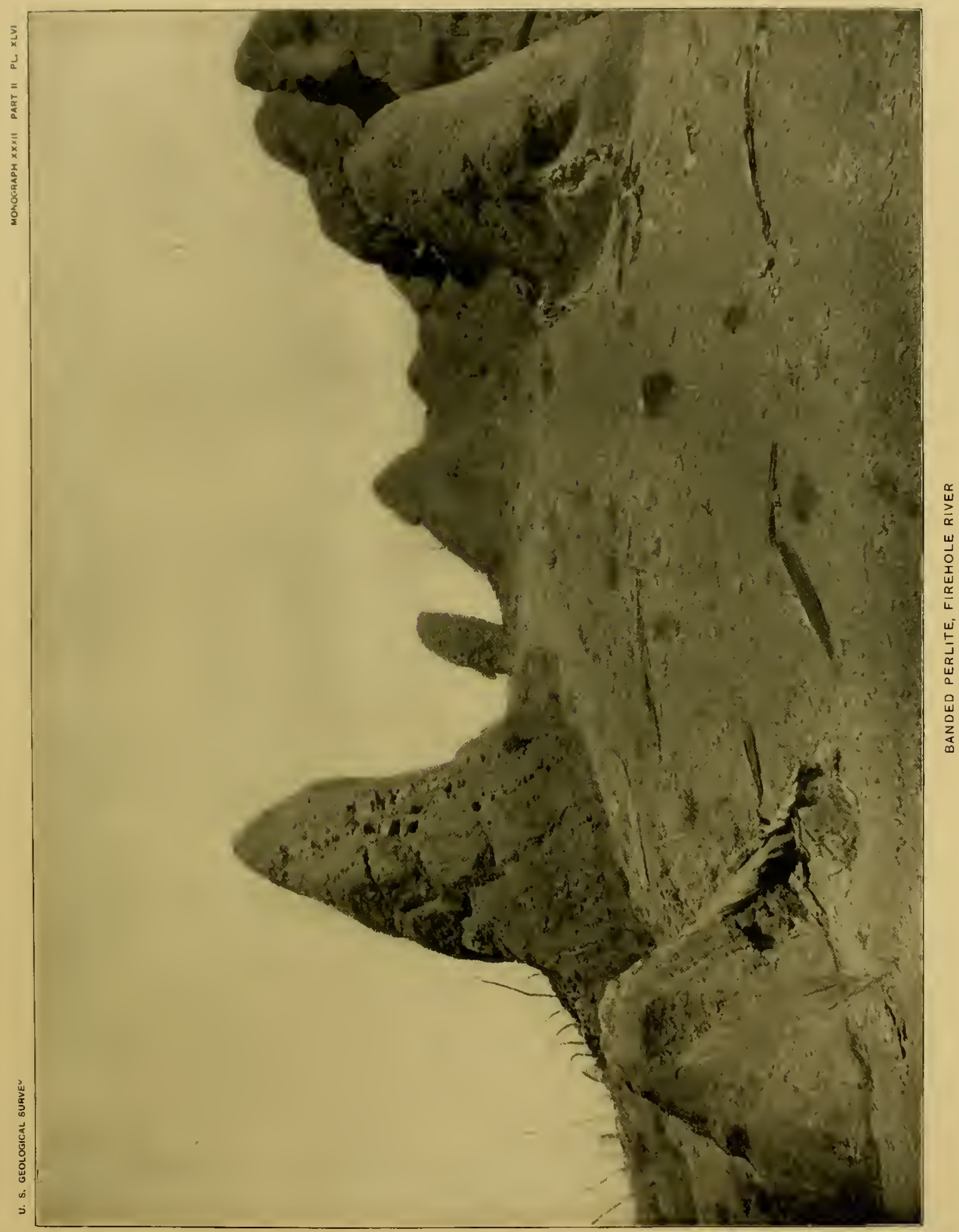





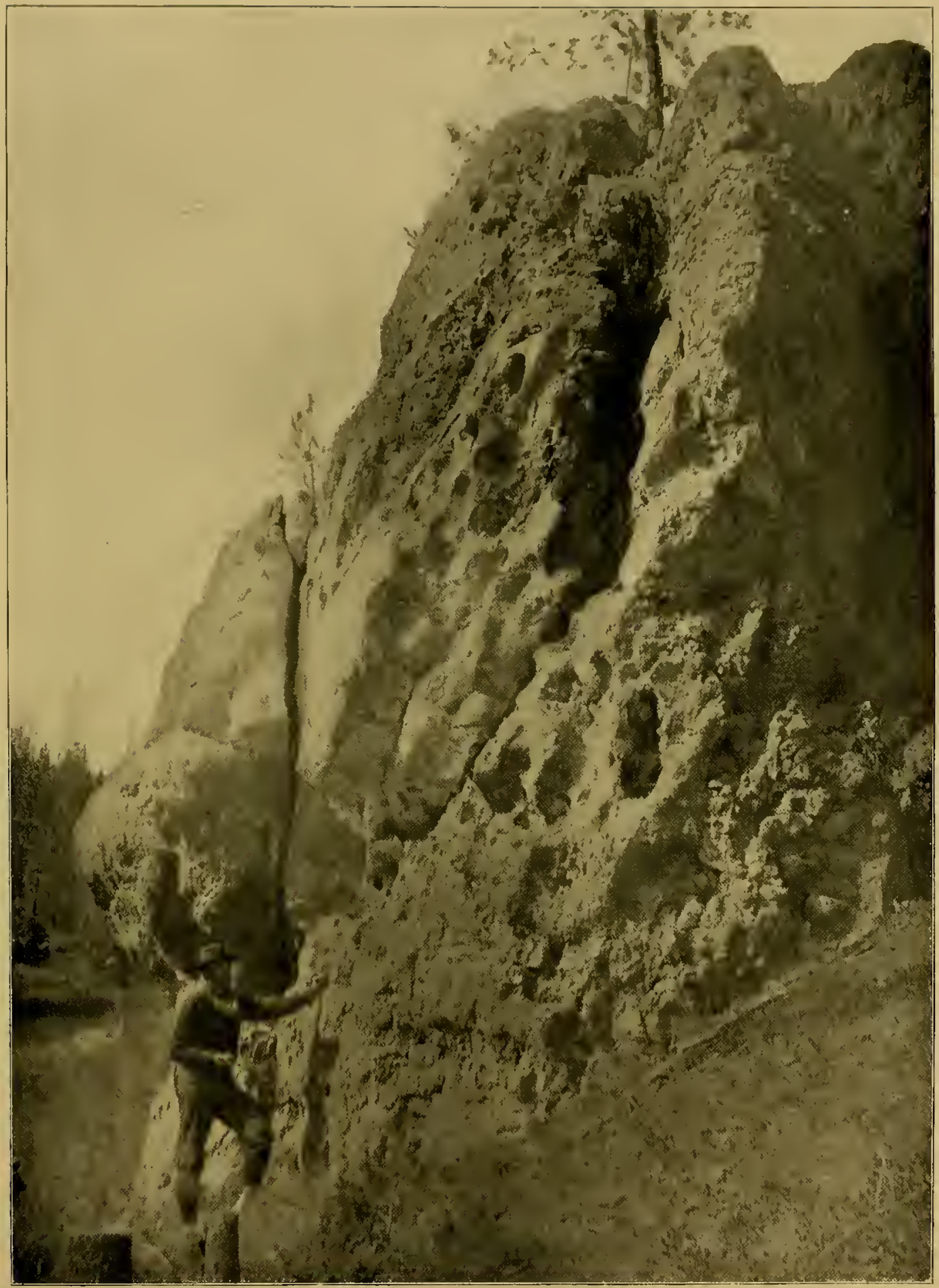

PERLITE WITH SPHERULITES, FIREHOLE RIVER, 

of saniline and smaller quartzes, the larger feldspars lying parallel to the lamiuation (1879). This punnice passes into dark-graly porpliyritic perlite, full of red and blue splierulites (1882). In places it contains lithophysse several inches in diumeter, with wide gaping centers, which have been crushed and dislocated to some extent, and into the cavities of which the viscous matrix was in some instances forced.

Rhyolite exhibiting variations similar to those just described-lithoidal, glassy, perlitic, puniceous, spherulitic or with lithophysa-forms the plateim northeast of the Lower Geyser Basin and north of Nez Percé Creek $(1890,1891)$. On its southem edge, about 3 miles east of the Lower Geyser Basin, the bluff exposure is rhyolite, which is lithoidal and beantifully laminated, or, perhaps more properly speaking, streaked in layers, the dark purplish-gray roek being marked with lighter-colored lines or streaks, which appear to be more highly erystallized, and are spotted with minute round holes about the size of a pin point (1884). In a neighboring exposure, where the bluff on the sonth side approaches the river, the banded rhyolite is light reddish purple streaked with yellow (1883). It is filled with plienocrysts of sanidine and smaller quartzes, which, however, are scarcely noticeable except on close examination, because of their transparency and the general mottling of the rock. The rock is parted in parallel plates, which appear to be independent of the direction of the flow structure and stand at all angles in the cliff. In one place the jointing is semicircular.

The plateau south of Nez Percé Creek and east of the Lower Geyser Basin is of the same character as that north. Lithoidal rhyolite alternates with much glassy rhyolite, which is in many places a very fine gray perlite. Southwest of the broad valley at the forks of Nez Percé Creck there is a breccia of gray perlite, some fragments of which are of large size. It is both compact and resicular to pumiceous, the vesicles being flattened and elongated (1885 to 1887). The sontheast branch of this stream cuts a narrow gulch through black, porphyritic obsidian, which is so thoronghly cracked that it weathers into a black sand. Glassy breccia oceurs in other places over this platean (1889). A very remarkable form of compactly spherulitic rhyolite is also found sparingly. It is megascopically axiolitic, the spherulitic erystallization having taken place from short, curved planes that cross one another at all angles, and also from most of the phenocrysts which act as nuclei of small sphernlites. The result is a brown 
and blue mottled roek which on a smooth jointing surface exhibits a curious pattern of curved blue lines and spots (1892). The numerous gulches and small canyons around the east and southeast corner of the Lower Geyser Basin afford excellent opportunities for studying the character of the rhyolitic lava in this neighborhood. Fine exposures of perlite and obsidian, more or less spherulitic and usually associated with lithoidal rhyolite, are found in many places.

On the north side of the mouth of the canyon south of that draining into Hot Lakes spherulitic rhyolite is exposed in which spherulites from the size of large shot to an inch in dianeter constitute almost the entire rock mass. In places where they are very closely packed together the exposures when seen from a short distance have the appearance of evengrained conglomerate or bits of pebbles or coarse gravel. Exposures of such character occur many feet in vertical thickness and many yards in horizontal extent. Farther up this canyon vesicular rhyolite and fine gray perlite are exposed $(1916,1920)$.

Similar gray perlite with very perfect perlitic structure forms the bluff on the east side of the Firehole River opposite Excelsior Geyser. It is full of small phenocrysts and is slighitly vesicular $(1904,1905)$. In places it is lithoidal. It is separated into nearly horizontal layers by joints which curve down to the northward at a somewhat steeper pitch than the slope of the hill, indicating the descent of the lava into a basin-like depression to the nortl and the subsequent erosion of the top of the hill. There is a tendency to prismatic jointing. The slope of the bluff farther south is covered with a fine sand of perlitic grains. Porphyritic rlhyolite of the same variable character forms the spurs around the drainage of Rabbit Creek.

The spur of the plateau sonthwest of the Lower Geyser Basin has a precipitous wall on the north and east sides, which exposes lithoidal porphyritic rhyolite, the top of the plateau being almost wholly glassy perlite and cracked obsidian, which form the canyon of the Little Firehole River near its falls $(1922,1923)$.

UPPER GEYSER BASIN.

Though the plateans on all sides of the Upper Geyser Basin are normal rlyyolites like the various forms just described, the rock in the immediate vicinity of the great geysers of this basin is abnormal. It is a dull 
lithoidal rock, slate color speckled with light graty, carrying abundant phenocrysts of feldspar, most of which are white or yellow and exhibit brilliant striated clearage planes. There are none of quartz. This rock resembles that forning the bluff at the southeast comer of Geyser Meadow. It is exposed in the rommled lills back of the Splendid Geyser (1924), and in tabular masses back of the Grand (1926), and forms the west bank of the Firehole River east of Old Faitlful Geyser. The microscopical features will be described in another place. lts extent and its relation to the normal rlyolite of the neighborhood were not made out. Perlite with large sphernlites occurs on the bank of the Firehole River a short distance above Old Faithful Geyser $(2166,2167)$ :

Above the Upper Geyser Basin the road along the Firehole River traverses rhyolite like that of the platean, for the most part lithoidal, and weathering into crumbling sand. Through it the river has cut a narrow rocky channel which is filled with great masses of rhyolite that have fallen from the steep sides. Just below Keplers Cascade the river passes through a narrow gate in a channel not more than 2 feet wide. The cut exposes vertical layers of spherulitic rhyolite, mostly lithoidal (1933), the layers crossing the stream at right angles.

Following the sontheast branch of the Firehole River to the pass of the old trail near the north end of Shoshone Lake, one traverses country covered with lithoidal and glassy rhyolite. For long distances the road lies in a fine glassy sand derived from the disintegration of perlite. The cliff that stretches for 3 miles along the south side of the road presents a variety of phases of rlyolite. At its western end it is lithoidal and very porous and vesicular, with here and there patches and streaks of glassy rock. Farther east the glassy rock predominates, with smaller masses of lithoidal rhyolite. Near the pass south of the road well-banded lithoidal rock abounds, and at the pass glassy and spherulitic modifications occur, as varied as those of Obsidian Cliff. The resicular lithoidal rock at the west end of the cliff is light bluish gray, discolored by brown and yellow stains. It carries numerons phenocrysts, which are so transparent as to be easily overlooked. The small irregular vesicles are not distributed uniformly through the rock, as is usually the case in basalt, but are very unequally scattered, being abundant in some spots and almost absent from others. This is a very common mode of occurrence in the lithoidal rhyolite of this region $(1934,1935)$. The 
well-banded lithoidal portion near the pass is dark slate colored, striped with layers of light purplish gray, often of the utmost delicacy, in this respect resembling the laminated lithoidal part of Obsidian Cliff. There are occasionally small carities with transparent tabular crystals of sanidine and some of quartz. The phenocrysts are abundant, and consist of sanidine, plagioclase, and quartz, with numerous rnsted crystals of a ferromagnesian mineral, which has been found to be angite. The longer phenocrysts lie more or less parallel to the lamination (1937). Some of the obsidian contains small black spherulites, the size of small shot. Other parts of it are streaked with red and brown glass (1936). The most perfect perlitic structure is developed in places, together with curiously crenulated cavities that traverse the rock in streaks and are coated with crystalline grains, which in some instances appear to be fragments of broken pluenocrysts of feldspar (1939-1940) that have been dragged apart along the line of the cavity.

MADISON PLATEAU SOUTH OF THE GEYSER BASINS.

The whole of this platean is rhyolite, mostly black glassy obsidian, with porphyritical crystals, in places sphernlitic. This alternates with pumiceons glass, which occurs in bands or layers. The alternation of dense and pumiceons glass is very persistent over the whole top of the platean, but the majority of outcrops consist of the denser obsidian, since the pumiceous portions of the rock have been more easily eroded. The character of the country and of the rocks is very monotonous and uniform, varied only in the neighborhood of Summit Lake by small areas of hot springs and fumaroles. The top of the platean southwest of the Upper Geyser Basin is glassy, but the lower part of the bluff along Iron Spring Creek is lithoidal gray rhyolite, more or less porous and vesicular. The shallow drainage chamnels, as they approach the edge of the platean, drop into deep ravines, where are large streams of water which are not met with on the top of the platean. The water comes from the edge of the platean, out of the mass of the rliyolite, the upper portion of which is porous and vesicular, while the lower part is dense and compact. The smaller of the streams draining sontlwesterly into Boundary Creek, east of Buffalo Lake, cuts a gulch 150 feet in the erlge of the blnff which forms the enst wall of the basin of Buffalo Lake. The gulch has vertical, rocky walls, exposing a fine section of the rhyolite lava, the flow of which has been greatly contorted. The lowest 
portions of the cliff are bluish-gray lithoidal shyolite, passing up into black and red obsidian (1951) with small phenocrysts. The rock is richly splerulitic, with large lithopluysar in thick layers. The lava sheet is slaggy on top, with layers that have been stretehed and cracked transversely. From the structure of the lava it is evident that the flow poured down a steep slope westward into the valley basin of Buffalo Creek. T'he present eastern wall is a bhuff 150 to 200 feet high. Farther down Boundary Creek, as far as the bluff north of Falls River Basin, the rhyolite is lithoidal, but the bluff west of the falls of Boundary Creek, forming the edge of the platean, is black and red splerulitic and porphyritic obsidian (1950). The same observation was made by Professor Penfield in traveling from Madison Lake across the southern end of the plateau to Falls River Basin. The whole surface of the country is black obsidian and grayish-white pumice $(1941,1942)$, which is porphyritic with large sanidines and smaller quartzes, but as the level of the basin is approached the rock grows lithoidal.

On the continental divide south of Madison Lake the black obsidian is in some places finely vesicular and in others spherulitic, with small lithophysa coated with tridymite pellets and containing a small amount of fayalite. It incloses many angular fragments of very fine-grained basalt, which is often highly vesicular and which has the petrographical characters of the so-called "recent basalts." Similar inclosed fragments of basalt were found in various places northwest of this locality. They indicate the existence of basalt flows in this vicinity prior to the outbreak of the top sheet of rhyolite, but no large body of basalt was observed.

\section{BECHLER CANYON.}

Bechler River cuts a fine canyon through the great rhyolite mass, thus separating Madison Plateau from Pitchstone Plateau. The canyon trends in a northeast-sonthwest direction and exhibits a very marked difference between its western and eastern walls. The former is a rather persistent bluff 800 feet high, while the latter is from 1,000 to 2,000 feet in height, presenting the greatest thickness of rhyolite exposed within the Park.

The rock of the country forming the northern head of Bechler River has the character of that on the surface of the plateaus, the rhyolite being mostly glassy and pumiceous, in some places crowded with spherulites, in 
others perlitic. Parts of it are lithoidal. Before the valley commences to canyon, at an altitude of about 7,900 feet, the stream cuts its way through lithoidal rhyolite, well laminated and much contorted, with most of the layers standing in a vertical position. Below this the stream contimnes to cut throngh dark-gray porphyritic rhyolite, which is lithoidal and finely banded, while on the top of the western wall at the upper end of the canyon proper the rock is glassy and beautifully splherulitic in irregularly shaped forms, inclosing grains of obsidian, and producing the appearance of large axiolites on the surface of the rock in a manner already described. It also contains small hollow spleerulites, distinctly fibrous (1946), and passes into highly resicular to puniceous lithoidal rock, light bluish gray in color (1945).

Half a mile above the month of Bechler Canyon the rock exposed in the stream bed is dense lithoidal rhyolite (1949). It forms the bed of the stream up to near Colomnade Falls, which is about a mile above the mouth of the canyou. Here the rhyolite is orerlain by a horizontal sheet of basalt which is at the same altitude as that of the great basalt sheet in Falls River Basin, a tongue of which must have flowed up into the canyon. It gives rise to Colonnade Falls, where the stream drops 60 feet from a ledge of rock into a basin partly inclosed by a semicircular wall of columnar basalt. At the base of this wall the large rertical colnmms are 30 feet high; they pass up into irregularly cracked basalt, which at the top is massive and resicular, forming a layer which projects orer the face of the wall. The ret columnar rock forms a dark background for the free-falling water with its rainbowed mist, while the banks, kept moist by the shifting spray, are covered with a luxuriant growth of ferns on the one side and of Howers on the other.

A lumdred yards upstream is Iris Falls, about 40 feet high, of different character. It is broad and is broken by large masses of rock at its base. The rock is porphyritic rhyolite, which is a later flow than the basalt, and must lave been a small one in the bottom of the canyon. The lower portion of this later flow of rhyolite is glassy, being a splerulitic obsidian (1961), and is brecciated with inclosed masses of older rhyolite. It grades upward into lithoidal rock which is light gray colored (1948). This passes up, at the top of the falls, into black, glassy, and spherulitic forms again. Half a mile farther upstream is another waterfall, of 50 feet, having the same general character as the last. It cuts through the later 
sheet of rhyolite, which is finely exposed on the east wall. In the bottom portion of the flow are large masses of inclosed rock. The central layer is masive, with well-marked plames of flow. $\Lambda$ short distance upstrean are fine double cataracts, and above these are others in continuous succession, the river descending in all about 150 feet. The rocks on both sides of the canyon appear to be soaked with water, which runs into the river from a multitude of small streams and springs along the base of the walls.

\section{FALLS RIVER BASIN.}

Falls River Basin, which in reality is a terrace of the great platean, at an altitude of from 6,300 to 6,500 feet, is about 15 miles long and 8 miles wide. It is a portion of the rast rhyolitic lava flow, which is partially covered by a thin sheet of basalt. The river has cut its way down to the rhyolite, which forms the bed of the stream from a point 1 mile below the mouth of Boundary Creek down as far as explored, below Boone Creek. The rhyolite is lithoidal and fissile, and at the falls below the mouth of Falls River there is evidence of more than one flow of rhyolite. The upper of these falls is a cataract. The middle one is a beautiful fall, 15 or 20 feet high and about 200 feet wide, with a cascade in low steps above it. At the west end of this fall there is a low archerl cave, formed by a sheet of dense, gray, glassy rhyolite, with small phenocrysts (1952), orerlying a mass of brecciated glassy rhyolite, which is more easily eroded. Above the gray layer the rhyolite is glassy and spherulitic (1956), passing up into banded lithoidal rock. The exposure appears to be that of the bottom of a lava flow. The third waterfall is broad and low, not more than 5 feet high. About 2 miles above the mouth of Boone Creek there is another fall, where the river cuts 50 feet into the rhyolite, leaving isolated blocks of the rock standing like monuments in the stream. The rhyolite forms a bench on both sides of the river, with bluffs of basalt 100 feet high standing back a short distance. This branch canyon of the Snake River begins to assume the same geological character which the deeper canyon of the main stream possesses in the neighborhood of Shoshone Falls, Idaho, where numerous sheets of columnar basalt overlie a glassy and lithoidal dacite of peculiar characters, which closely relate it to the rhyolite of the Yellowstone National Park.

The valley of Conant Creek, just north of the forty-fourth parallel of 
latitude, is cut into lithoidal rhyolite, which is somewhat spherulitic and is filled with small phenocrysts (1955). This rhyolite continues south beyond the limits of the area explored and forms the northwestern base of the foothills of the Teton Range up to an elevation of over 8,000 feet. Where it has been cut across by the valley of Conant Creek its contact with the underlying rocks is seen to be very steeply pitched to the west, indicating how steep the preexisting surface must have been at this place. The rlyyolite near the contact is rudely columnar. It is part of the great lava flood which buried the slopes of the northern foothills of the same range, and is found overlying sedimentary and Archean rocks and volcanic breccias of andesite which had accumnlated on them. About the head of Conant and Boone creeks and along Berry Creek thin tongues of the rhyolite sheet, continuous with the heavy mass of Pitchstone Plateau, have been left in favored places, and have escaped the erosion which must have considerably modified the contour of the surface in the vicinity of this high range of mountains. These portions of the lava lie at higher altitudes than the top of the platean north, and even exceed in some places the highest elevation of the main bolly of Pitchstone Plateau. In two points north of Berry Creek the altitude of the present surface of the rhyolite is 8,900 feet, and just east of Forellen Peak it reaches 9,300 feet, resting in a thin sheet on sedimentary rocks.

The petrographical character of the rhyolite varies somewhat in this neighborhood, but the variations are mainly due to the fact that the exposures are in many cases at or near the bottom of the lava flow, where it has been affected by coning in contact with underlying rocks. Thus, on the west slope of the momitain north of the head of Conant Creek the mass of the rhyolite is lithoidal and but slightly porphyritic, but near the bottom of the flow it is in places black obsidian (1958) with a fine mottling that is almost imperceptible and is more pronounced in a gray, glassy form of the rock (1954) from the same locality, which is similar to that at the middle falls on Falls River (1952). In places the lithoidite is light bhuish or purplish gray and has large flattened vesicular cavities intimately related to hollow spherulites and lithophysa $(1953,1957)$. These exhibit characteristic $V$-shaped cracks, and have evidently resulted from the gaping open in spots of a riscous substance. They are coated with yellowstained crystals of the same minerals as those which occur in lithophyse, 
and aromel the carity the rock is lighter colored. Another moditication of the rock, which lais numerons snall phenorysts of quartz, occurs 2 miles northeast of Survey l'eak. It is laminated and fissile in thin plates, resembling a selist (1960). A similar form of rhyolite is found on the long spur east of Snake River, opposite the mouth of Ow] Creek. The rhyolite capping the limestone on the divide between Berry and Conant creeks belongs to the nevadite type, being filled with phenocrysts. Near its contact with the limestone it is dark slate colored, glassy, and spherulitic (1959). It grades upward into lighter-colored, purplish, and yellow lithoidlal nevadite, full of inegularly shaped cavities. It weathers in great rounded and ronghened masses like granite. The same is true of the rhyolite in the neighlorhood of Birch Hills, in the valley to the northeast, and at Terrace Falls. Here the coarsely porphyritic, reddish-purple rhyolite, or nevadite, lhas been weathered and eroded into great rounded towers 100 feet high, which resemble exposures of coarsely crystalline granite.

It is to be remarked that while the rhyolite in the vicinity of Birch Hills is lithoidal along the valleys cut by both forks of Falls River at altitudes of from 6,700 to 7,000 feet, yet within the amplitheater at the head of Mountain Ash Creek the stream at 7,000 feet cuts a narrow canyon throngh porons and glassy rhyolite, which also forms the spur on the north side of the amphitheater at 7,350 feet, where it is black porphyritic obsidian and perlite. This is 1,200 to 1,500 feet below the edge of the Pitchstone Platean, where the rhyolite is black and red spherulitic obsidian with many phenocrysts (1972). Farther down Mountain Ash Creek, at an altitude of 6,800 feet, where two branches unite at the crest of Union Falls, 80 feet ligh, the rhyolite is lithoidal. The occurrence of glassy forms of rlyyolite in the bottom of this amphitheater overlying lithoidal ones indicates that this was the surface of a flow, and not the interior portion of one which has been exposed by the erosion of a vast amphitheater.

\section{PITCHSTONE PLATEAU.}

One of the most interesting exposures of rhyolite is that furnished by the high spur between the branches of Glade Creek, a tributary of the Snake River, which enters the latter about 5 miles north of the forty-fourth parallel of latitude. The spur is from 600 to 1,000 feet light, and at its southern end presents a ligh bluff of lithoidal rock, exhibiting greatly 
contorted bands of flow. Its base consists of a talus of large blocks. The rhyolite is lark gray, speckled with white and brown. It bears many phenocrysts of white plagioclase and fewer of quartz and sanidine, besides many small rusted crystals of angite $(1964,1966,1967)$. Throngh the rock are scattered cavities of various sizes and shapes with gray or white walls, which are coated with brilliant crystals of quartz, tridymite, or sanidine, with opaque crystals of fayalite. The quartzes lave been studied by Professor Penfield, who has found them to have a simple but very unusual development. In addition to the common quartz forms-prism and unit

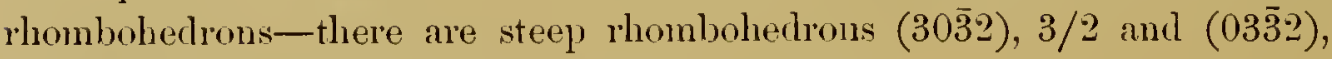
$3 / 2$, and narrow trapezohedral faces $\pm 3 / 2-3 / 2{ }^{1}$

The same rare forms oecur on the quartzes in the lithophysa at Obsidian Cliff and in other localities within the Yellowstone Park. The white walls of these carities vary in thickness from mere lines to an inch, and some of them have a distinctly spherulitic structure witl widely gaping centers. They are in part hollow spherulites of a peculiar character, very closely related to the irregular cavities in the rock, which could not be temed spherulites. The outer margin of the hollow sphernlites is not sharply defined against the groumdmass of the rock, as in most instances. The radial fibration is not recognizable by the maided eye, and a concentric zonal structure is observed in only a portion of them. The most characteristic feature of these hollow spherulites is the occurrence of comparatively large quartz erystals in two habits, usually in different parts of the cavity. One form of the quartz consists of stout crystals, seldom orer $2 \mathrm{~mm}$. in diameter, in one instance $5 \mathrm{~mm}$., very transparent, with a pale smoky to amethystine color. The others are slender white prisms, $10 \mathrm{~mm}$. long. The transparent crystals are often located on a nearly flat side of the cavity, while the white prisms, intersecting in all directions, form a kind of network which oceupies the thicker part of the center of the spherulite. The light-eolored streaks and more crystalline parts of the rock are punctured with minute round holes. Along the cliff to the westward the rock passes into laminated lithoidal rhyolite with open layers incrusted with the same minerals as those in the cavities just described.

The rhyolite on the second ridge east of Glade Creek is black and

'Iddings and Pentield, The ninerals in hollow spherulites of rhyolite from Glade Creek, Wyoming: Am. Jour. Sci., 3d series, Vol. XLII, 1891, p. 39. 
brown obsillian, with many phenoerysts and suall spherulites. The spherulites have crystallized arouml phenocrysts as muclei in many cases. Tluere are also small crenulated cavities, which lie indiserinninately in the glass and spherulites and ane coated with minute arystals $(1968,1969)$. These curious cavities nceur in the rock of Obsidian Cliff and elsewhere in the l'ark.

RED MOUNTAINS.

On the erke of the platean of myolite which lies between the Yellowstone Lake and Snake River rises a small group of mountains, whose highest peak at the entstern end is IIomut Sheridan (10,200 feet). It is an east-west ridge with four prominent spurs trending north and south, separated by deep amplitheaters. Its summits are from 1,500 to 2,000 feet above the plitean, but the eastern peak is 2,700 feet above Heart Lake, which lies at its base. The slopes and spurs on the east and north are short and steep, and ouly the southern ones fall away gradually to the level of the platean. 'These mountains are of rhyolite, whose character in the body of Mlount Sheridan differs somewhat from that of the plateau. On the steep northeastem spur south of the Heart Lake Geyser Basin much of the rhyolite is white and gray lithoidal rock, with a moderate number of small phenocrysts, in some places very few, and belonging to the variety liparite. The main mass of Mount Sheridan and the ridge immediately west is composed of this dense liparite, which is light purplish gray in color and fissile in thin plates (1980). Similar rhyolite occurs near the top of the ridge and on the summit of Mount Sheridan, where it is coated with hyalite in places and contains many transparent crystals of tridymite in thin fissures (1984). The rlingolite on the top of the ridge and on the upper northern slope and sumnit of Mount Sheridan is brecciated, but it is con1pact, and is evidently brecciated flow rock and not an aggregation of loose fragments and dust, which is the case with almost all of the andesitic breccia of this region. In places on the summit the rhyolite is brown and glassy, and the brecciated portion is intersected by dikes of massive banded lithoidal rhyolite of no considerable extent. This appears to be the only instance in which anything resembling a dike of rlyyolite has been observed in the Yellowstone Park. All of the rhyolite exposures observed by the writer appeared to be surface flows of lava resting upon older rocks. In the cases where later bodies of rhyolite have been recognized they have always been 
in the form of surficial flows, the orifices or fissure throngli which they reached the surface not being exposed to riew. This is most noticeably the case in the outlying remmants of thin sheets whose plane of contact with the nuderlying rocks is frequently observed.

The eastern face of Mount Sheridan is composed of massive white and gray liparite, like the northeastern spur. The upper portion of the long northern spur consists of a heary flow of rliyolite, about 700 feet thick, which appears to have the same character as the plateau rock.

In the neighborthood of Lewis and Shoshone lakes the rhyolite exhibits variations from lithoidal to glassy forms. The bluff west of Lewis River at the crossing of the old trail, $2 \frac{1}{2}$ miles below Lewis Lake, exposes very fine lithoidal rhyolite, mottled dark and light gray, which is porphyritic and banded (1971). The top of the plitean west and north of Lewis Lake is nostly glassy or hyaline rhyolite-black and red obsidian and perlite, which is spherulitic and porphyritic (1973). This may be observed along the trail between the two lakes. The character of the rhyolite on the east side of Shoshone Lake near its outlet is particularly varied. It is porphyritic and is streaked with black and red glass and blue spherulitic layers, besides blue lithoidal portions, weathering pink on the exposed surface. The lake beach is made up of very irregularly shaped pebbles of this rhyolite, which are but partially rounded and form a beautiful variegated sand.

\section{VICINITY OF YELLOWSTONE LAKE.}

The most striking variability in the rhyolitic lava, however, is found along the shores of the Yellowstone Lake. The many miles of coast offer numerous bluffs which have been cut into the surface of the great rhyolite sheet, and the slightly glaciated liils of the platean country immediately west of the lake shore present all possible modifications of this variable lava.

A grood example of this is found in the cliff on the second point sonth of the mouth of the West Arm of the lake and the first one north of Flat Mountain Arm. Here red and black glassy forms occur, separately and also intimately mixed. The rock is porphyritic and more or less spherulitic. There are masses of black obsidian completely shattered by irregular cracks, which cause it to crumble readily into small angular fragments, and 
others of dark and light brownish-red obsidian carrying dark-blue sphernlites with gray, browu, or purple onter shells, also completely cracklerl. blark and red streaked olssidians alternate in layer's with bands of densely splerenlitic material, and accasionally of porous spherulites. In plares the lannination is rery pronounced, and thin splierulitic layers, when lnoken from the obsidian, are covered with wat-like excrescences, which are protmeling spherulites, ribbed with parallel lines corresponding to the planes of limination of the rock. Parts of the rock are fissile and consist of lightbrown glass streaked with black and red in small blotches, and even rather large lumps, which have been drawn ont into lenticular shapes during the flow of the rock (1994 to 1998).

Pumiceous glassy rhyolite forms the top of the platean in many places about the TVest Arm of the lake. Soutluwest of Riddle Lake the drainage exposes light-gray pumice overlying black, glassy, porphyritic rhyolite or obsidian. Lower downstream, near the forks, the rhyolite is lithoidal, purplish gray, and banded, and is accompanied by black glassy varieties carrying spherulites, which are the commoner kinds over this part of the platem.

In the immediate vicinity of Duck Lake light and dark gray pumice and perlite form a brecciated flow (1986 to 1989), while farther west the rhyolite is in places lithoidal. At Rock Point porphyritic obsidian with small spherulites occurs in a brecciated mass. The surface of the spherulites and of the glass immediately in contact with them, as well as that of the obsidian blocks, is dark red, like other portions of the body of obsidian in many places. There is also black perlite with small lithophysa; and light-brown and black, streaked and blotched perlite, and silvery-gray fibrous pumice (2003, 2004). .

An idea of the great diversity of the rhyolite along the west shore of the lake may be gotten from several typical exposures in the neighborhood of Bridge Bay, from which extensive collections have been made. On the sonth side of Bridge Creek, about a mile west of the lake, a branch stream has cut into brecciated pumiceous and hyaline rhyolite. It is porpliyritic and partly spherulitic crackled obsidian and perlite, with many small roughened cavities. The brecciated portion contains some fragments which are 2 feet in diameter. A highly vesicular modification of it is almost fibrous, owing to the elongation of the vesicles, which have been drawn out 
in thin tubes. This form of the rock is microspherulitic or lithoidal, with some glassy portions, and the breccia, which is largely composed of this material, is the sanne as that which occurs on the Firehole River a short distance below the Lower Geyser Basin (2020 to 2023). A more varied occurrence is crossed by the trail in a coulée about a mile south of Bridge Creek. It is mostly glassy and is full of phenocrysts of quartz and feldspar. One black projecting mass of rock consists of finely resicular to pumiceous perlitic obsidian. This grades into a light reddish-brown pumiceous breccia inclosing framents of white punice with light-lorown borders and small fragments of light-brown pumice and pieces of black obsidian. This passes into a dense red perlite mottled with black and gray, and the latter grades into reddish-brown and also dark drab-colored perlite, which in turn passes into spherulitic obsidian banded with minutely spherulitic or lithoidal layers full of small roughened cavities. It is scoriaceous in places and exhibits a great variety of colors on weathered surfaces (2013 to 2019). All this variation of texture and color takes place within a distance of 100 feet. Farther soutl the rhyolite becomes more lithoidal in places, purplish lithoidal and spherulitic bands being intermingled with obsidian and perlite. It is often roughly vesicular and slag-like (2014). The modifications of rhyolite just described constantly recur over the plateau in this vicinity.

A still more raried assortment of rhyolite is found in a low bluff on the lake shore lalf a mile south of Bridge Bay. It consists of brecciated pumice and scoria, with some massive lava, and appears to be the surface or the forward end of a flow of porphyritic rhyolite. The colors of the rock, all of whose virieties appear to be textural modifications of one magma, range from jet black through different shades of gray to almost white, besides reds which are dark liver colored to pink, and browns that are reddish and others that approach yellow. These colors occur separately in large masses or are combined in brecciated bodies in blotches and streaks, or as mottlings and bandings in massive rock. The greater part of the rock is glassy, but some of it is lithoidal. There is black crackled obsidian grading into perlite banded by delicate layers of spherulites. Some of it is more spherulitic and carries hollow sphernlites, which are distinctly fibrons on the inside and are coated with tridymite pellets. There is dense black obsidian so filled with hollow spherulites as to appear like a porous or vesicular rock. Black, red, and brown obsidians occur together, with and without spherulites, some of which are blue and red, while others are porous and 
lollow. A pitehy hack obsidian with bluish metallic luster is filled with minute pores that give it a rough fracture surfice, besides some larger pores which are puniceous and generally oceur about the phenocrysts, some of the larger feldspurs appearing to lawe been fractured and dragged apart.

Another form of obsidian is so finely vesionlar as to be almost a pumice; it is rark gray colored, with grains of black glass scattered through it. Others are lighter gray, and the most pumiceous rock is silvery white and fibrous. In the larger cavities the grlass las been drawn out to the finest threads, like spun glass. Among the phenocrysts the few light-green angites are plainly recognizable. There is black glass with bright yellow pumiceous spots, and sanidine crystals which have split open down the middle lengthwise, and others irregularly cracked and pulled apart, the cracks not having become filled witl the glass, which must lave been expanding into pumice at the time. This grades into rock in which the yellow pumice preponderates over the black glass. There is perlite of black, red, and brown glass intimately mingled and banded, witl feldspars arranged nearly parallel to the planes of flow; also a light-red dense perlite with small black spots. There is a light-red, lithoidal, fibrous, vesicular variety with irregular patches and remnants of black glass, besides light-gray lithoidal rock, with streaks of dark-gray and black glass and porous and scoriaceons portions. Some of these forms of the rhyolite are masses in the breccia, but the more finely brecciated material presents a still more variegated appearance. The most striking breccia is a liglit-red, also reddish-brown, finely porous glass filled with lumps of light-gray glass of all sizes which is finely porous and minutely crackled, besines others of dark-gray pumice and rounded lumps of highly inflated resicular black glass. Some of the black glass is compact and occasionally sphernlitic. Another form of breccia consists of fragments of black and red obsidian in a matrix of smaller fragments of the same, most of which are red, apparently cemented together by a porcelain-like material, which is pink or white. There is distinct evidence of plasticity and flow in the form and arrangement of the small pieces of glass, and the porcelain-like portion is a crystalline modification of the magma, which can be traced into spherulitic patches. The reddening of the glass seems to have occurred subsequent to its breaking "p, for the fragments of black obsidian have a red margin or surface of rariable thickness.

MON XXXII, PT II- 25 
NATURAL BRIDGE.

Bridge Creek has receired its name from a small natural bridge of rhyolite which spaus a narrow gulch through which runs a tributary to the main creek. This bridge, which is shown in the illustration (Pl. XLVIII), consists of two vertical slabs of lithoidal rhyolite, parts of the contorted layers of lava flow, which stand about vertical in this place. The vertical layers just east of the north end of the bridge are shown in Pl. XLIX. They are slightly eurved and are separated by open crevices with roughened scoriaceous walls. Of the two slabs forming the bridge the eastern, or that seen in the illustration, is 2 feet thick at its ends and thimner in the middle. There is a space of 2 feet between it and the western slab, which is 4 feet thick. The span of the arch is about 30 feet and its rise about 10 feet, the top of the bridge being some 40 feet above the creek. The eastern slab is traversed by two rertical cracks, and by horizontal ones just below the base of the arch. The rhyolite is porphyritic and lithoidal, dark bluegray, mottled with light gray, and distinctly banded in places. It bears numerons hollow spherulites of considerable size and many small lithophysx with delicate concentric shells, but no small megascopic dense spherulites. The lithoidal rock alteruates with glassy layers of black perlite having dense splierulitic bands and some large dense spherulites (2048 to 2052$)$.

The large hollow' spherulites have been crushed while the matrix was plastic, though not liquid, for the broken shells have been dislocated and the sides of the spherulite forced in and the cavity partly filled by the matrix. But this was not liquid enough to enter rery far into the hollow cavity, nor has it filled up the cracks on the outside of the shells. It is ericlent that there was motion in the lava after the large hollow spherulites had formed, and that they were rigid crystalline bodies. It is quite as evident that the delicate lithophyse of various sizes were not formed before the lava came to rest, becanse they hare not been crushed in any case, although their shells are often much thinner than those of the hollow spherulites. Moreorer, their eccentric and irregular shapes are nore or less in accord with the crooked and distorted banding which marks the planes of flow in the rock. They have the same character as those at Obsidian Cliff and are highly crystalline; but the fayalites have been changed to light-yellow opaque pseudomorphs, and the iron has been 


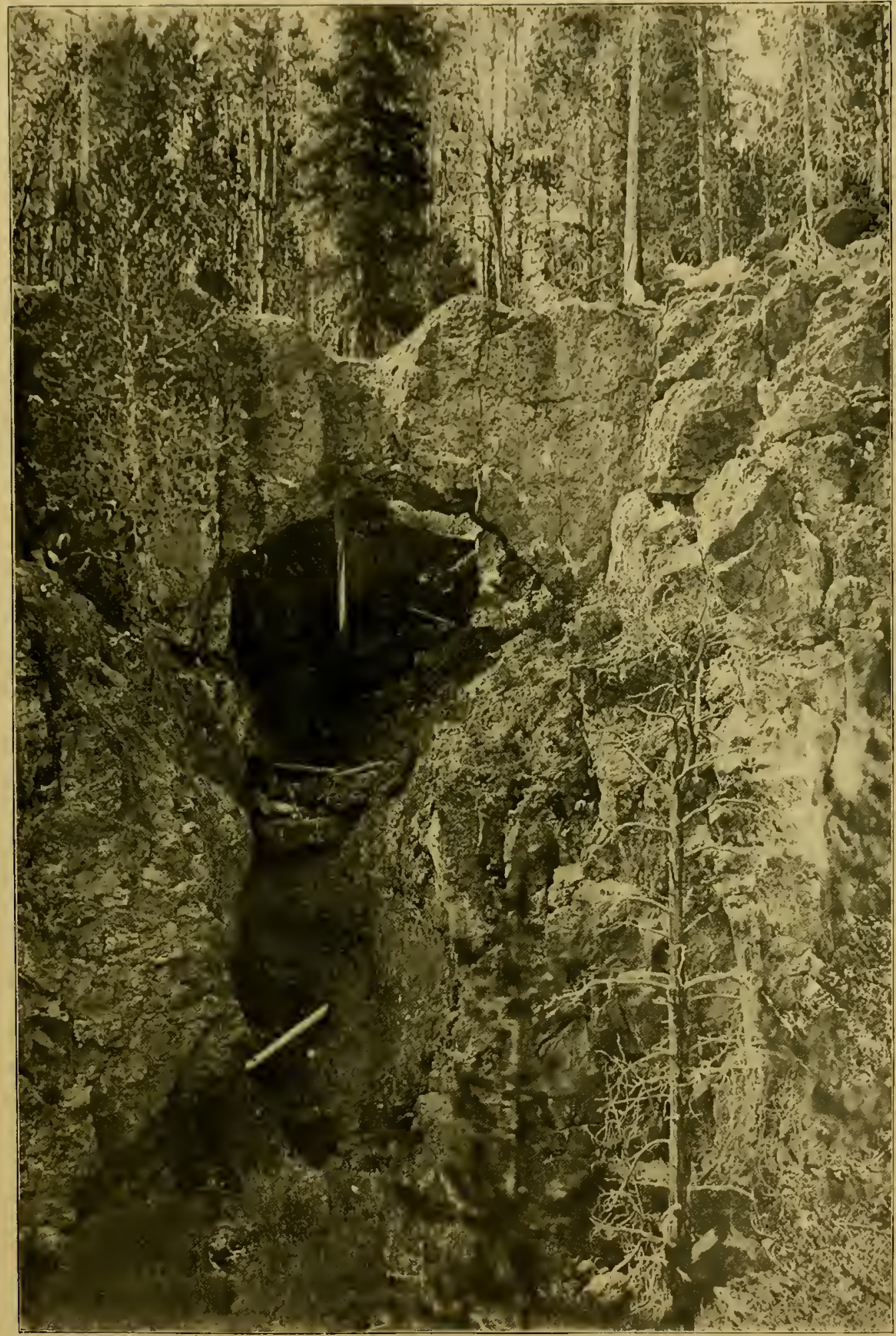

NATURAL BRIDGE, EAST SIDE OF YELLOWSTCNE LAKE. 



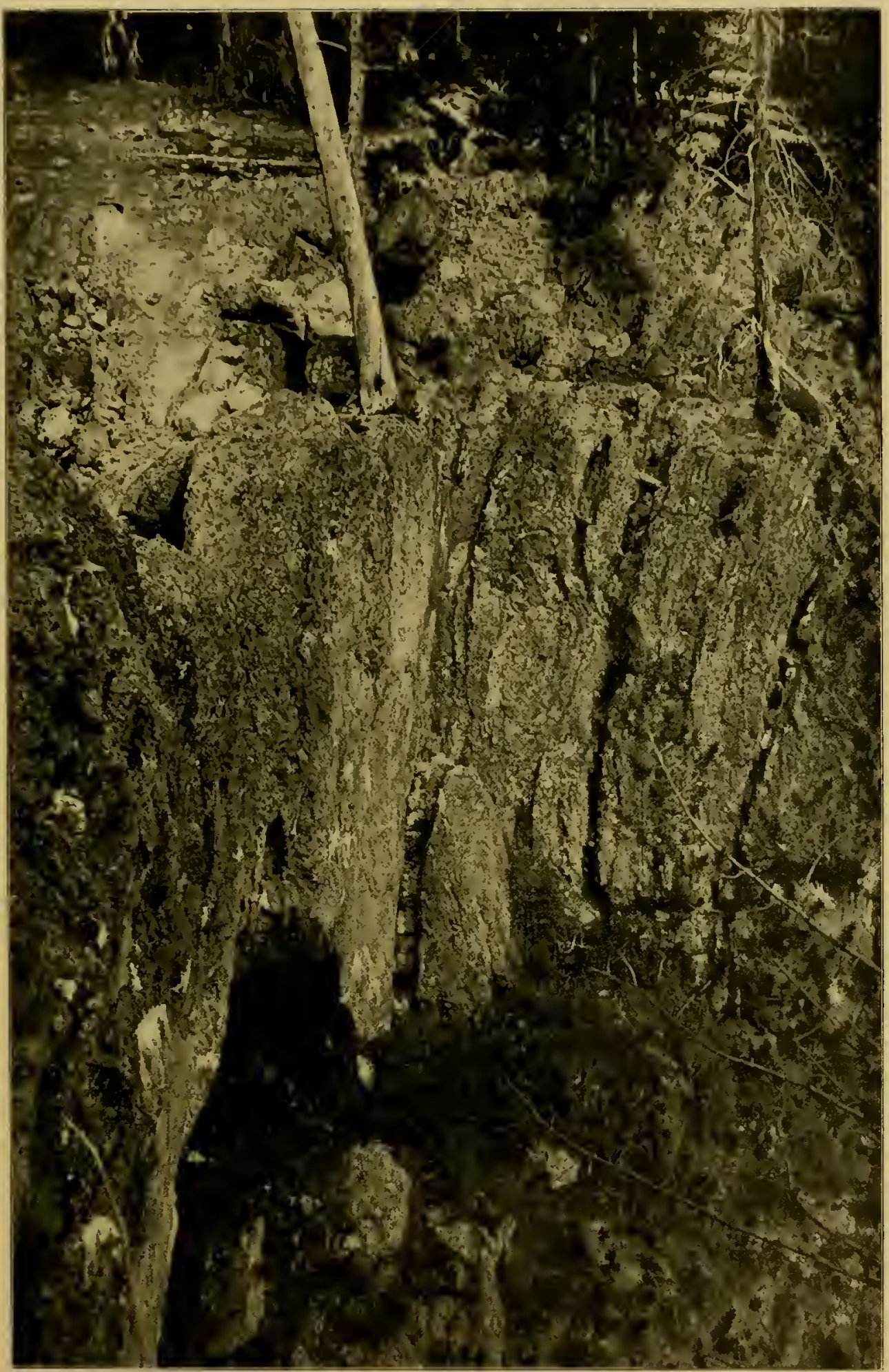



concentrated to stout tablets of hematite, with brilliant crystal faces, some of them set upon the finyalite pseulomorphs, and of later origin. ln some of the lithophysa hematite occurs without pseudomorphis of fiyalite. The Natural Bridge is one of the best localities for the study of these hollow forms of crystallization.

NORTH AND EAST OF YELLOWSTONE LAKE.

The spur of the platean lying west of the outlet of Yellowstone Lake, and known as the Elephant Back, is ribbed and grooved by numerous drainage chanmels that cut deep gulches down its slopes and permit the nature of the mass of lava foming it to be observed. The surface of the slopes and the top of the plateau consist for the most part of glassy forms of rhyolite, strongly porphyritic. Black obsidian, passing into red pumiceous breccia like that south of Bridge Creek, is the prevailing rock, with occasional areas of lithoidal rhyolite. The obsidian is markedly banded with parallelly oriented feldspars and layers of spherulites, some of them red, porous, and distinctly fibrous, with white pellets of tridymite, the feldspar fibers radiating from the center of the spherulite, thongh often separated from it by an open space $(2066,2068)$. But as the drainage channels are followed from the top of the platean downward the glassy forms become less abundant, and in the deeper gulches the whole mass of the rock is lithoidal and well banded (2067). This relationship between the lithoidal and the glassy forms of rhyolite is the nsual one for the large flows; the upper surface is glassy and more or less pumiceous, the lower part of the mass is lithoidal, and the bottom of the flow, when exposed, is glassy for a variable thickness in many eases, but not in all.

Along the Yellowstone River 3 miles below the outlet of the lake, about opposite the mouth of Thistle Creek, the rhyolite is lithoidal and purplish gray, not noticeably banded, and full of phenocrysts, of which the quartzes are more perfectly crystallized than in the greater number of cases noticed. This characteristic becomes more pronounced in the resicular brecciated rhyolite which forms a massive exposure about 2 miles below the head of Thistle Creek. In this rock well-developed double pyramids of quartz, with smooth crystal faces, project into the carities of the rock and from broken surfaces. The sanidine is iridescent in blue and sometimes in more brilliant prismatic colors. Farther up the creek the rhyolite 
is dense and dark colored. But on the summit of the peak, 9,000 feet high, at the head of the creek, it is light pink and gray, eartly in texture, and brecciated like a tuff, with fragments of andesites, and with phenocrysts like the vesicular brecciated rock lower down the creek. There is no evidence, however, that it is a tuff, but it appears to be a finely brecciated massive rock, of the same kind as the rhyolite opposite the month of Thistle Creek, except that the latter is denser and not brecciated (2059 to 2064).

Along the east sliore of Yellowstone Lake the rhyolite extends from the vicinity of Pelican Creek on the north as far sonth as Brimstone Basin, a small area of hot springs 2 miles sonth of Colmmbine Creek. It forms a sheet of lava which constitntes the table-land and flat-topped spurs between the lake and the Absaroka Mountains, reaching an elevation of about 8,500 feet. Tongnes of it extend up the long valleys and are found at still higher altitudes. In the valley of Sylvan Lake it forms a massive bluff on the north side, which reaches 8,700 to 8,800 feet elevation. This is several humdred feet higher than the divide in Sylvam Pass; still it has not been found east of the watershed in the valleys draining into the Stinkingwater River: In the next valley north of that of Clear Creek the rlyyolite sheet is found at 9,000 feet. The rock thronghout the greater part of this area is massive, lithoidal, purplish, and porphyritic. The glassy and pumiceons parts which probably formed its surface have been eroded away.

VICINITY OF YELLOWSTONE RIVER.

The surface of Central Platean, which extends from the Elephant Back west to the head of Nez Percé Creek, and around the west end of Hayden Valley northward, is covered, like the country sonth, with glassy rhyolite. It is mostly porphyritic black obsidian, more or less spherulitic, and is in places vesicular. On the sonth branch of Alnm Creek, a short distance from the road, the obsidian is spherulitic and carries lithophyse and hollow spherulites from 1 to 6 inches in diameter (2072, 2073). The obsidian in places is traversed by jointing planes, along which the surface of the rock is smooth and polished, but slightly uneven and warped. The crystals of quartz and feldspar have been cut across smootlly in most instances, though in many cases the plane of jointing has curved around the end of a crystal, or followed the clearage of the feldspar when this was nearly coincident with the plane of jointing. A small elevation and depression extends for 
a short distance rirom eateh of the larger erystals, all being parallel and pointed in one direction. They appear as though they had resulted from the resistance offered $\mathrm{by}$ the phenocrysts to a shearing stress. The hill south of the hot springs east of Marys Lake is formed of porphyritic perlite, full of small hollow spherulites and lithophysa, which have been partly altered by the action of heated rapors, which come up through it and deposit crystals of sulphur. The phenocrysts of feldspar and the spherulites are much decomposed, the quartzes and groundmass remaining unaltered. The hollow spherulites are partly filled with opal, and less often with sulphur (2070).

The top of the platean from the north side of Hayden Valley to Gibbon River and Grebe Lake is corered with porphyritic glassy rhyolite or obsidian, in places spherulitic. This is the character of the rock along the road from the Yellowstone Falls to the valley of the Gibbon, and along the west bank of Yellowstone River from Alum Creek to Cascade Creek. At the north side of the montl of Otter Creek there is much silver-gray pumice, which is beantifully fibrous, exhibiting a satin-like sheen when the light is reflected from the sides of the fibers, but appearing dark gray and vitreous on transverse surfaces. It is filled with phenocrysts (2084 to 2089). A somewhat similar pumice, or more correctly, a highly vesicular porphyritie perlite, occurs in a small gulch west of the Upper Falls of the Yellowstone. It forms a loosely adhering breceia of pumice and perlite. Some masses of perlite are quite dense, with only small vesicles, but most of it is greatly inflated, with flattened eavities. In places the perlitic structure is not complete, leaving kemels of irregularly shaped obsidian, which weather out and cover the ground with black sand (2080 to 2083). In the meadow of Cascade Creek south of Dumraven Peak the rhyolite exposed in the creek bed is finely vesicular lithoidal rhyolite, purplish gray, with many phenocrysts of plagioclase and fewer of sanidine and quartz (2092, 2093). The rock closely resembles that which forms the bluff at the southeast corner of Geyser Meadow and also the rock of the Upper Geyser Basin. VICINITY OF THE GRAND CANYON OF THE YELLOWSTONE.

Since the topugraphic and scenic features of the Grand Canyon, and the character and condition of the rocks forming it, are described in detail by Mr. Arnold Hagne in Part I of this monograph, it is not necessary 
to repeat any of the petrographical description of the rhyolite in this, its most notable, exposure. There is, however, an occurrence of columnar cracking in an inconspicuous locality which is of considerable petrological interest on account of its bearing on the general question of the production of prismatic parting, and which may properly find a place in this chapter.

The fine columnar parting on the east side of the canyon nortl of Agate Creek are deseribed in Part I. Here the columns are 80 feet long and several feet in dianeter. But the prismatic cracking to be deseribed oecurs in a small gulch on the west wall of the canyon a mile south of Deep Creek. The rhyolite forming the upper part of the plateau at this place is lithoidal and porplyyritic, light purplish gray, with a rough fracture. It is jointed in broad blocks which weather into rough granitelike masses. This passes downward into more distinctly columnar, denser rhyolite, which is exposed on the south side of the gulch in a beautifully columnar eliff 300 feet high. The rertical columns are so regular in shape that they may be easily mistaken at a little distance for basaltic ones.

On the north side of the gulch there is a ledge of colummar basalt 100 feet thick resting upon gravel and andesitic breccia. Immediately overlying the basalt is the bottom contact of a younger flow of rinyolite. The lowest portion is tuffaceous and yellow, passing upward into denser material, and this into dark-gray, brownish, porphyritic glass, which has cracked in thin, straiglit prisms, some quadrangular, others irregularly shaped. The prisms vary in size from 4 to 8 inches long and from one-third to threefourths of an inch thick, and thicker. This glass grades into lithoidal purplish rock, which is also cracked into small prisms and columns. Some of these are 3 or 4 feet long and 4 inches thick; others are very small, about 6 inches long, and irregularly shaped, like prisms of starch. They are more or less curved, and occur grouped together in the form of large blocks, whose relation to the original form of the whole mass was not made ont. They appear to have resulted from a shrinkage within these blocks. The jointing planes which constitute the faces of these prisms or columns intersect the many porplyyritical erystals of quartz and feldspar, producing sinooth faces, which show that the groundmass of the rock was rigid when the eracking took place. The small columns, in their shape and arrangement, are precisely like those formed in dried starch. 
NORTHEASTERN CORNER OF YELLOWSTONE PARK.

Toward the northeast the rhyolite sheet thins out and overlies the andesitic and older rocks, which had previously been greatly eroded. East of the Yellowstone Canyon the platean top consists of rhyolite, into which hare been ent the canyons of Broad, Deep, and Agate creeks. The rhyolite reaches an altitude of 9,000 feet where it is found in contact with the basalt of Mirror Platean, and also on the peak northwest of the headwaters of Broad Creek. At the latter place the rock is red, glassy, and somewhat pumiceous (2058), with abundant phenocrysts and included fragments of obsidian Down the drainage channels from the summit of this point the rhyolite is denser and vesicular and contains large lithophysæ, while still lower down it is deuse, banded, and lithoidal. In the cliff east of Mirror Lake the rock is dense, has small phenocrysts, and exhibits characters that are found in the parts of the sheet near its bottom contact. There is rhyolite along the west base of Amethyst Mountain and Specimen Ridge, where it constitutes the margin of the great plateau. Beyond this to the north and east it occurs only as disconnecterl remuants, which lie at all altitudes on the slopes and summits of mountains and in the bottoms of valleys, in ahnost every instance forming a bench or table of greater or less prominence.

Southeast of Mirror Platean rhyolite forms a flat-topped spur between Mist and Cold creeks, lying between the altitudes of 8,750 and 8,300 feet. East of the mouth of Cold Creek it forms a flat spur, and stretches from 8,000 to 8,600 feet, reaching to within 200 feet of the bottom of Lamar River, while on the spur east of this it lies between 8,200 and 8,650 feet elevation In each of these occurrences the rhyolite is lithoidal, purple, and porphyritic.

The flat spurs and ridges on the east side of Lamar River from the base of Saddle Hountain to Cache Creek are rhyolite, which also occurs in isolated patches within 200 feet of the river at Opal Creek and at the south base of Bison Peak, and also within a short distance of Amethyst Creek. The character of the rlyolite in these places is quite the same, being purple and lithoidal, with small phenocrysts $(2135,2155,2161)$. This is also the character of remnants of the rliyolite sheet that occur on the north side of the northwest end of Specimen Ridge (2158), and in a bench north of the mouth of Lamar River, 600 feet above the stream (2157), and 
also on the east slope of Garnet Hill (2160). All of these patches are undoubtedly portions of one continuous sheet, which has been almost completely eroded.

Remnants of the rhyolite sheet lie high up the slopes of Saddle Mountain, even near its summit. One area is on the west spur of the peak southwest of Saddle Mountain, at an altitude of from 9,200 to 9,500 feet. Near the bottom contact the rhyolite is dense and dark colored; higher up in the mass it is somewhat fissile, forming thick slabs. It is lithoidal, with traces of black glass, and is dark colored and carries small phenocrysts and lithophyse (2141). It rests directly upon basaltic breccia.

On the northwest spur of the peak of Saddle Mountain, about 700 feet below the summit, there is a small patch of rhyolite forming a nearly horizontal sheet not more than 150 feet in length. It rests upon basaltic breccia, which is plainly exposed in the steep faces of the narrow ridge. At the bottom of the rhyolite is white rhyolitic tuff; over this is fissile, light-gray, lithoidal rhyolite with small phenocrysts (2137). This passes up into dark-colored spherulitic and glassy rhyolite with lithophysæ and small phenocrysts (2138), similar to the rhyolite on the spur to the west. There are patches of rhyolite at varions altitudes on the northwest spur, down to 8,000 feet. At about this altitude in the gulch south of this spur and of Miller Creek there is a small group of fumaroles in rhyolite that is partly dense and light gray, and is jointed in rectangular plates and small straight prisms, and is partly perlitic and glassy (2145 to 2149).

Rhyolite covers the southern portion of the flat-topped spur north of Miller Creek, and patches of it occur on the ridge near Parker Peak, at 9,500 feet, and on the south slope of the divide at the head of Lamar River, at 9,800 feet. In the last two places the rock is partly lithoidal, with small phenocrysts, and partly glassy. Some of it is fissile and some of it massive, carrying lithophyse. None of it has been found on the north side of the divide, in the drainage basin of Crandall Creek. Scattered patches of it occur on both sides of Cache Creek, and a long narrow tongue extends along the west side for 4 miles, being sitnated between altitudes of 7,000 to 8,000 feet. In all these cases the structure of the rhyolite masses is that of surface flows, resting on an uneven surface of older rock, and nowhere in this vicinity was any of it exposed in the form of a dike or other intrusive body. 


\section{MIROSCOPICAT, CHATACTERS OF 'THE IRISOLITE.}

From the description of the megascopical characters and the mode of oecurence of the rhyolite just given, it is evirlent that the rock varies greatly in the mamer of its solidification and erystallization in restricted areas, as well as throughout the whole region. Its microscopical characters, therefore, may be expected to be equally varied. An examination of 315 thin sections of this rock shows that this is true within certain limits. There is great variability anoug the sections, but it is confined to a definite range of crystalline structures and to a linited number of minerals, and is so often repeated in the rocks from different localities that a clear idea of the microscopical characteristics of the rhyolite can be given only by treating them systematically for the whole region. It then becomes a comparatively simple undertaking.

The phenomena investigated by a microscopical study are expressions of the mode of solidification of the lava and the extent or degree and the manner of its erystallization. The mode of solidification of the rhyolitic lava in this region is that of a surface flow of variable thickness. The lava has been in part inflated and chilled into pumice, or has exploded and formed tuff. Parts of it have solidified to dense glass, sometimes rendered vesicular by large gas bubbles. But the greater mass of it has solidified in the central parts of deep flows or streams, forming lithoidal rock, whose crystalline character can not be recognized by the maided eye. The pumiceous portion occurs at the top of the flows, and passes downward into dense glass, which in deep flows passes into lithoidal rock. The latter constitutes the center of the flow, and generally passes again into glass at the bottom, which may or may not pass into pumice, or more usually into tuff, the pumice having been ground to pieces beneath the weight of the lava stream.

The extent or degree of crystallization in most cases manifests itself in two ways: One is in the amount and kind of porphyritical minerals present; the other is in the amount of microscopical crystallization that has taken place in the rock, which has led to the production of microlites and aggregations of two or more minerals in various kinds of arrangement. It is evident in many instances that the first-mentioned group of products resulted from a process of crystallization that antedated the arrival of the lava at the surface of the earth, for the porphyritical crystals are scattered 
uniformly and generally through large masses of rock, withont reference to the boundaries of the rock body-that is, they are uniformly scattered through the pumiceous, compaet, glassy, and lithoidal portions of the lava flow in a giren locality, or are entirely absent from all of them. It is quite as evident that the second grot:p of crystallization products cane into existence after the lava reached the surface, and to a great extent after it had ceased to flow. The reasons for this will appear upon studying the microstructure of the varions forms of rlyolite, for they will be found to exhibit a definite relation to the form of the body of the rock.

It does not follow from this that the porphyritical erystals or phenoerysts were developed prior to the act of eruption of the lava; on the contrary, it las been shown elsewhere ${ }^{1}$ that the phenocrysts of rocks were probably crystallized during the act of eruption, and that in some cases their growth continued uninterruptedly into the period of final crystallization of the whole magma. But in the case of the rhyolite of this region there is nothing to indicate what were the conditions of crystallization in different parts of the rlyyolite lava previous to its arrival at the surface of the earth. There is simply the fact that in places, or in particular flows, phenocrysts are entirely wanting, and that in others they are few or are very abumdant, and that they may be small in some cases and large in others. The rlhyolitic lava of Obsidian Cliff is an example of a comparatively small flow in which no phenocrysts have been developerl. The main body of rlyolite, however, is variable in this respect; but the variations obtain for larger areas of lavi. Let us first consider the microscopical characteristics of the phenocrysts.

\section{PHENOCRYSTS.}

The minerals that have crystallized porphyritically are quartz, saniaine, plagioclase, angite, and magnetite. In this category may be included zircen, though its crystals are always microscopic in size. Its period of erystallization is the same as that of the phenocrysts. 'The same may be said of pseudobrookite, which is closely assaciated with the iron ores and zircon, and also of apatite and allanite, which occur sporadically. 
QUALT\%.

The phenoerysts of quarty vary in anomit and in size in clifferent parts or borlies of the rhyolite. They may be wholly absent or quite abundant. In some cases they are 4 or 5 mm. in diameter; in others, any size less than this, generally from 2 to $4 \mathrm{~mm}$. They are noticeably smaller than the sanclines in most instances. Their crystal form is that of hexagonal hypyramids, formed by the equal development of the plus and minus unit rhomboherlrons, together with small prism faces, but the erystals are often rounded to a greater or less extent (Pl. LIV, fig. 4). They are generally much cracked, the cracks being largely spheroidal, so that the quartzes on rock surfaces usually appear as rounded grains. In some iustances their crystal form is preserved and they fall from the rock in perfect double pyramids. Owing to the highly fractured condition of the quartz, much of it falls out when thin sections of the rock are prepared, and a false impression may thus be gotten of its relative abundance unless the thin section is compared with the rock. In some varieties of the rhyolite it is in excess of the other constituents, and from this proportion its relative amount decreases until it is entirely absent in some varieties, which may be rich in feldspars.

Its microscopical characteristics are much the same in all varieties of rhyolite from the Yellowstone Park. Its substance is colorless and very pure, except for well-defined inchusions of glass, and very rarely crystals of other minerals. Individuals of quartz differ in one rock section both as to outline and as to inclusions. Distinctly idiomorphic crystals occur by the side of rounded ones. Some quartz sections are free from inclusions, while others in the same rock section contain a few or many inclusions of glass and bays of groundmass (Pl. LI, fig. 1). 'The glass inclusions usually occupy pyramidal cavities, or they may be rounded; they are seldom irregularly shaped. They generally contain one gas bubble, whose size appears to vary in proportion to the volume of the glass in any one section. In some instances there are uo gas bubbles present.

The inclosed glass is in some cases colorless, in others brown, as in the illustration just referred to, usually one character or the other prevailing throughout the quartzes of a rock section. But often colorless and brown inclusions occur by the side of one another in the same quartz crystal. It frequently happens that the glass inclosed in the quartz is different in character from that forming the gromdmass of the rock, when this is glassy. 
The inclosed glass may be colorless and that of the groundmass strongly colored, yellow, brown, or red; or vice versa. It often happens that the inclosed glass remains such, though the groundmass of the rock becomes holocrystalline. In a few instances the colorless glass inclusions contain minute idiomorphic crystals, which are probably angite, for in one case a comparatively large crystal exhibits the optical characters and green color of augite. One glass inclusion contains twenty of these crystallites. In another section two colorless glass inclusions contain curved trichites. No fluid inclusions lave been observed.

In the great majority of cases each quartz phenocryst is a single individual, with perfectly uniform optical orientation, and no indication of intemal strain or displacement, except around the glass inclusions in a fer instances. In several rock sections some of the phenocrysts of quartz consist of two or three quartzes grown together, with more or less divergent orientations. They are partly idiomorphic and partly rounded.

In most of the rlyolite sections the quartzes occur entirely isolated from phenocrysts of other minerals. With the exception of sanidine, it is almost never observed in juxtaposition with other minerals, a common occurrence among the phenocrysts in andesites, where sereral kinds of minerals are often crystallized in chusters. The phenocrysts of quartz in this rhyolite almost never inclose fragments or crystals of magnetite, zircon, angite, phagioclase, or sanidine, so that the relative period of crystallization of these minerals with respect to quartz would be a matter of conjecture were it not for the fact that intergrowths of quartz and sanidine in direct comnection with the phenocrysts of these minerals occur in more than one modification of this rliyolite. The intergrowth possesses the well-known micrographic structure, which is often strongly and beautifully developed.

This micrographic intergrowth is of two kinds, or rather it is the result of two different phases of crystallization. In some cases it belongs to the period of crystallization in which the phenocrysts of quartz and sanidine were produced; in others it was formed when the groundmass of the rock crystallized. The latter corresponds to its more common occurrence in certain quartz-porphyries and granite-porphyries, and will be referred to again in comection with the description of the groundmass of the rhyolite. The micrographic intergrowth which belongs to the first period of crystallization in the rhyolite is specially well developed in the 
lighly inflaterl pumice from near the moutl of Otter Creek, on the west side of Yellowstone River, albove the Upper Falls (2084, 2088, 2(189). In this punice of colorless grlass, almost free from microlitic crystallization and filled with gas eavities, there are comparatively large phenocrysts of quartz and sanidine. In places where two of these minerals lie near each other they are connected by a micrographie patch, the quartz substance extending irregularty beyond the boundary of the feldspar. In one case a Carlsbad twin of sanidine is filled with quartz shreds, having one orientation, and a simple crystal of sanitine is intergrown with quartz at one ent (Pl. LIV, fig. 1). Isolated micrographic patches occur in the pumice sections. The structure is comparatively coarse, and the form of the intergrown minerals is clearly shown.

The micrographic growth is not only attached to distinctly idiomorphic phenocrysts, but to a great extent has crystallograplic boundaries. Its character as a primary crystallization in the molten rhyolitic magma is beyond question, for, besides the crystallographic evidence just given, is the fact that the phenocrysts with which it is connected contain glass inclusions which occasionally occur within the intergrowth itself, being easily recognized by their brown color, the surrounding glass being colorless. The intergrowth of quartz and sanidine proves that the crystallization of the phenocrysts of these minerals was contemporaneous. Its occurrence in highly inflated glass proves that its formation anterlated the inflation of the punice, which took place on its arrival at the surface of the earth.

A slightly different micrographic crystallization is found in the rhyolitic pumice on the west shore of Yellowstone Lake, about a mile sonth of Bridge Bay (2024, 2029). In one section a plienocryst of quartz has a partial micrographic fringe, which consists of minute intergrowths of quartz and feldspar, with the general form of feldspar crystals, that project from the quartz phenocryst at various angles, as though it were "sprouting" with feldspar. The quartz of the fringe has the same orientation as that of the phenocryst. In the same rock section are several isolated micrographic intergrowtins of great delicacy and beauty, like the microscopic ones in the obsidian of Obsidian Cliff. In this instance also it is evident that the micrographic crystallization antedated the inflation of the pumice.

In the holocrystalline varieties of the rhyolite there are instances in which quartz phenocrysts extend indefinitely into the surroming ground- 
mass, quartz belonging to the final crystallization of the rock having attached itself to the quartz phenocryst with the same orientation (Pl. LIV, fig. 4). The original form of the phenocryst can generally be detected by a faint line of impurities. This structure will be described in connection with that of the groundmass.

\section{SANIDINE.}

The phenocrysts of feldspar are partly idiomorphic, partly rounded, and often fragmental. They consist of orthoclase and plagioclase, which are present in different varieties of the rlyolite in varions proportions. In some cases orthoclase is the only feldspar present; less frequently plagioclase is the predominant, if not the only, feldspar in porphyritical crystals. The orthoclase usually possesses the habit of sanidine, and may be described under that name.

Sanidine usually occurs in simple crystals, 5 to $7 \mathrm{~mm}$. long, and also in Carlsbad and Baveno twins, the latter being uncommon. When in unbroken erystals, its usual form is a rectangular prism with truncated edges, furnishing square cross sections and rectangular longitudinal ones, often witl the customary terminal planes. It is less frequently in tabular Carlsbad twins. Occasionally it has irregular ontlines, caused by rounded intrusions of the groumdmass, indicating a partial resorption of the magma. In many cases it occurs in angular fragments, and sometimes the crystals are split in two and the parts are separated by a stream of gromdmass. In some crystals the clearage planes are well dereloped and close together; in most instances they are poorly developed and the crystals are traversed by irregular cracks. (Pl. L, fig. 1; Pl. LI, fig. 4.) The substance of the sanidine is generally very pure and free from decomposition, but inclusions of glass and groundmass are common. They are numerous in some forms of the rock, and are partly confined to crystallographic cavities and partly oceur in irregularly shaped ones. The glass inclusions are often colnuless, often brown, the two kinds occuring in the same crystal. Frequently they contain more than one gas bubble, sometimes as many as thirteen, which is in striking contrast to the single bubble in those in the quartz phenocrysts. Inclusions with several bubbles are generally found in the feldspars in punice. Crystallites are less common in the glass inclusions than they are in those in the quartzes. Sanidine occasionally incloses crystals of augite and magnetite. It frequently surrounds crystals, of plagio- 
clase with nearly parallel orientation, and sometimes extends outward in micrographice intergrowth with quarty in the manner alrealy described, the felckpall substance of the intergrowth having the same orientation as that of the inclosed sanidine.

Some crytals of feldspar with rectangular outline or cleavage, which appear to he orthochistic, exlibit a very faint striation between crossed nicols, which is not sufficiently distinet to be positively determined as multiple twinning, but which suggests the microcline twimning which Miigge ${ }^{1}$ observed in the sanidine of certain trachytes of the Azores. An inregular optical behavior between crossed nicols is sometimes observed, by which the extinction of light is unevenly distributed over the section of the feldspar.

PLAGIOCLASE.

The phenocrysts of striated feldspar have much the same general characters as those of sanidine, but they are usually smaller and exhibit a great number of thin strix, or lamellæ, twimed after the albite law, rarely after that of pericline. They are sometimes in Carlsbad twins. The optical behavior indicates that they are oligoclase or albite. In a few instances the symmetrical extinction angles indicate labradorite. Such crystals yield square sections. They carry the same kinds of inclusions as sanidiue, but often a greater amount of them. Small rectangular glass inclusions occur in abundance in some plagioclases, while otlers are honeycombed with inclusions of groundinass which equal the feldspar in amount. Inclusions of augite are more common than in sanidine, and less frequently those of magnetite, zircon, and apatite. Plagioclase is often inclosed by sanidine, as already remarked, which sometimes only forms a thin shell around a portion of the plagioclase crystal, and may take part in the micrographic structure of the groundinass. But the plagioclase in these rhyolites has not been observed to enter into micrographic intergrowth with or to inclose quartz.

\section{PrRoxene.}

The ferromagnesian phenocrysts in all of the rhyolite of this region belong to the pyroxene group, with the exception of a small amount of microscopic biotite in the rhyolite of Glade Creek. Fayalite is a product

I Miigge, O., Petrographische Untersuchungen an Gesteinen von den Azoren: Nenes Jahrbuch fiir Mineŕa]., 1883, vol. 2, pp. 189-244 (p. 204). 
of the final consolidation of the magma, and is not included among the phenocrysts. In most instances the pyroxene is angite, which occurs in almost all of the thin sections examined, but is present in variable amounts. Like the other phenocrysts, it is sometimes idiomorphic, with the crystal form usual to its occurrence in similar rocks, or it may be partially rounded, or in fragments. The crystals range from $3 \mathrm{~mm}$. long to microscopic ones. The color is green, which is strong grass green in moderately thick sections, and pale green in thin ones. Its substance is very pure, with comparatively few inclusions, which are for the most part magnetite or ilmenite, zircon, and pseudobrookite, and rarely apatite. In one instance angite incloses a nearly idiomorphic crystal of quartz which is almost the same size. In this particular case the angite is the younger of the two minerals; it is the only case in the 315 thin sections in which phenocrysts of these two minerals may be observed in conjunction. The angite is usually associated witl crystals of iron oxides, zircon, and pseudobrookite.

In many cases the augite has a narrow opaque border, or a transparent red one, undonbtedly composed of iron oxide. Rarely there is a narrow border of brown glass surrounding the angite, when the glass of the gromndmass is colorless. Occasionally fragments of angite show that the crystal was inclosed in the black shell before it was broken-that is, the corrosion took place before fracturing. The iron oxide sometimes penetrates cracks in the angite. In one crystal there is a set of secondary inclusions like delicate needles, which are arranged along cracks and lie parallel to one another and to the orthoaxis of the crystal. In rliyolite that has been subjected to the action of thermal waters the augite has been completely decomposed and replaced by secondary minerals.

In a few cases an orthorhombic pyroxene is also present in small amount. It is faintly pleochroic, and appears to be hypersthene, though possibly enstatite. It seldom occurs independently of augite, and is generally inclosed within the latter with parallel orientation.

MAGNETITE AND TITANIFEROUS IRON OXIDE.

Magnetite and titaniferous iron oxide are prominent porphyritical constitnents of these rhyolites, although they are usually of microscopic proportions-that is, they stand out plainly as relatively large crystals in distinction to those forming the groundmass, and slow by their mode of 
occurrence and grouping that they belong to the phinse of erystallization in which the larger phenocrysts were formed. The same may be said of zircon, pseudobrookite, ip atite, and allanite.

In most cases it is not possible to determine whether the iron mineral present is magnetite or ilmenite. Cleavage lines intersecting at $60^{\circ}$ are recognized in partially decomposed crystals, which occur in more or less altered rhyolite from the west wall of the Grand Canyon of the Yellowstone $(2090,2102)$. In other cases of altered rlyyolite the iron oxide has been converted into a white oparpue substance, indicating the presence of titmic oxicle, whose general presence in the rlyyolite of this region is shown by the widespread occurrence of pseudobrookite, as well as by its chemical determination. In most cases the iroin mineral is perfectly fresh. Its form is often crystallographic, but quite as often irregular. Some crystals are definitely magnetite; others are not determinable by their outline, but differences of luster are sometimes recognized. It occurs in isolated grains from $0.15 \mathrm{~mm}$. in diameter to smaller, and also in groups of several grains. It is generally attached to augite crystals, which sometimes inclose as many ats nine grains in one section.

ZIRCON.

Zircon is almost universally present in well-developed microscopic crystals, which are stout prisms with very simple forms, often consisting of the unit prism and pyramid, with corners truncated by the ditetragonal pyramid (311). The zircons are colorless, with few inclusions; occasionally irregularly shaped inclusions and prismatic ones are numerous. The amount of zircon present in different varieties of the rock varies from none to relative abundance, one large grain of magnetite having, as many as ten crystals of zircon attached to or included in it.

\section{PSEUDOBROOKITE.}

Pseudobrookite is almost as constant an accessory ingredient of these rhyolites as zircon. It is not quite so abundant, but attains larger dimensions, in one case reaching a length of $0.09 \mathrm{~mm}$., but usually being much smaller. Its determination rests wholly on its optical characters. It generally occurs in idiomorphic crystals, whose habit differs somewhat. The more common forms are short stout prisms with pyramidal terminaMON XXXII, PT II- 26 
tions, or minute erystal grains; also long slender prisms, which are flat and lathlike. In a few cases it occur's in thin prismatie plates, not wholly regular in outline. It is evidently a biaxial, orthorhombic nineral with ligh index of refraction and brilliant luster. Its color varies from fox red to reddish brown and opaque, and there is usually complete absorption parallel to the longer axis of the prism. Cleavage or inclusions were not observerl. It is closely associated with iron oxide and zircon, being attached in many cases to the former. But it often oceurs isolated.

\section{ALLANITE AND APATITE.}

Allanite occurs in only one of the specimens of rhyolite examined-that (2059) from the head of Sour Creek. Three or four crystals of it are formed in two thin sections of this rock. They are considerably larger than the erystals of pseudobrookite, but resemble them in exhibiting an almost total absorption. The color is chestnut to olive brown.

Apatite is present in very small amount and is only occasionally observed. It forms minute hexagonal prisms.

\section{GROUNDMASS.}

In studying the different phases of groundmass in the various modifications of this rhyolite, we should commence with those exhibiting the least degree of erystallization and proceed to those exhibiting the greatest. No other rocks possess the variability of microstructure in their groundmasses that is found to exist in those of the acid lavas, especially the most siliceous. The microstructure of the groundmass of rhyolites not only varies in different parts of the same rock body to a very considerable extent, but in an area of a few square millimeters the rariations are strongly marked, glassy and holoerystalline structures occurring together in some instances within the field of vision of a microscope. This variability arises from a lack of homogeneity in the constitution of the most highly siliceous magmas at the moment of their eruption upon the surface of the earth. The demonstration of this comnection was furnished by the earlier studies ${ }^{1}$ on the rocks now being described, and will be reviewed in the general discussion of these roeks.

In a systematic deseription of all the modifications of structure exhibited

IObsidian Cliff, Yellowstoue National Park: Serenth Anu. Rept. U. S. Geol. Survey, 1888, y. 286. 
by the rhyolites of the Yellowstone National P'ark, we slath consider, first, those most nearly anor phous-that is, almost completely glassy; and sul)sequently, those with more and more erystallized mineral constituents, $1 r^{\circ}$ those in which the mineral crystals have attained their most advanced development. This method of procedure will separate for the time neightboring portions of one rock whose connection can be pointed out subsequently; but it has the alvautage of allowing a comparison of all similar structures and the selection of those which offer the best illustration of the probable explanation of the cause or origin of the structure under discussion.

GLASSES FREE OR ALMOST FREE FROM MIROLI'LES.

Glasses absolutely free from microlitic crystallization are seldom met witl, but many of them lave so few microlites that they may be classed with the former as glasses free or almost free from microlites. Such glasses may be colorless in thin section, or colored to a greater or less degree. 'The colorless glasses free from microlites are in almost every instance highly pumiceous, so that the glass solidified in thin rods or films, and it is found that those portions of the mass not so highly inflated carry abundant microlites. It must therefore have been the sudden expansion of the inclosed vapors, and the consequent chilling of the magma, that prevented the microlitic minerals from crystallizing before the magma soliditied. In such cases it is evident that the magma reached the surface of the eartl in a wholly amorphous condition, except for the phenocrysts, which may or may not have been developed. In one instance a pumiceous glass is full of microlites, which must have crystallized before the rock became pumiceous.

Colorless pumice free from phenocrysts forms the upper portion of the obsidian flow on the plateau southeast of Obsidian Cliff. It is slightly microlitic. Pumices free from microlites, but with more or less phenocrysts, oceur on Madison Plateau south of Madison Canyon, on the edge of the plateau west of Yellowstone River near the moutl of Otter Creek, on the west shore of Yellowstone Lake south of Bridge Creek Bay, and in other localities. The gas cavities in these pumices are sometimes microscopic, and are generally elongated, spindle-shaped or drawn out to long thin tubes. Occasionally they appear to contain a small amount of liquid. In many cases the cavities are comparatively large, as in ordinary pumice. In some instances it is evident, from the confusedly twisted and curved arrangement 
of the glass fibers and films, that the inflated glass mass settled back upon itself, or collapsed, after the escape of much of the gas. This is possible from the fact that after a magma has been rendered pumiceous it may still remain viseons before its temperature is reduced to the point of soliclification. It has been observed during the artificial fusion of obsidian that rhyolitic pumice will retain its expanded form at a temperature at which it is viscous enough to be easily compressed or penetrated by a rigid body. Hence, in a moving stream of rhyolitic lava, portions which lave been inflated to pumice may be forced while yet plastic into more compact masses by the movement of the lava, and they may be expected to exhibit some indications of their former pumiceous condition. When we remember the enormous extent of many of the-streams of rhyolite in this region, we may easily imagine the formation of pumice over the surface of an intensely heated area of lava, thus permitting of its subsequent welding.

An example of collapsed pumice is found in that which ocenrs on the plateau forming the continental divide soutlwest of Madison Lake (1942). It is a colorless glass free from microlites and with phenocrysts. It is partly pumiceous, but the bubbles are small, elongated, and greatly twisted, as are also the glass fibers and films, which curve about one another in endless complication. 'Their form is indicated by faint lines, which may mark films of gas, or may be the boundary between glasses with slightly different refraction and color. Parts of the glass are faintly yellowish, and most of it exhibits the double refraction common to perlitic glass. A perlitic structure is present in portions of the glass. The direction of vibration of the slowest-traveling ray is normal to the perlitic cracks and to the surface of the fiber's, which should also be the direction of the least stress, the fracture having relieved it. It is observed in some cases that there is a distinct margin to the cross sections of some of the glass rods, and this margin has a faint color and different refraction from that of the center. It is more strongly refracting parallel to the direction of vibration of the slowest ray, normal to the surface or boundary of the rod. The central part of the rods and perlitic masses exhibits an opposite state of strain. Thus, within the glass rod the direction of vibration of the slowest ray coincides with that of the axis of the rod-that is, the direction in which it was stretched. Bnt in the marginal portion the direction of vibration of the slowest ray is normal to the first; it must therefore be due to some other 
canse, as alreacy intinated. 'This doulble condition of refraction does not appear on thin rods taken from a parallelly fibrons pumice. There is only the adjustment of refraction proluced by the stretching.

Colored olasses free from microlites are rather more frequent among the rhyolites of the Yellowstone Park than colorless ones. They are largely pumiceous, or are collapsed punice. The colors in thin section are dark seal brown to yellow, less frequently orange and red. In most cases the coloring matter can not be resolved into discrete particles, but appears to have been in solution. It seldom happens that the glass is of miform color throughont the extent of a rock section. It is usually variegated, brown and yellow, and either or both of these occur with colorless glass. Brown glass pumice occurs on the west shore of Yellowstone Lake and elsewhere. In it the brown color grades into yellow along the margin of gas cavities and along the surface of rods; in some places the contrast is sharply marked. It is not due to a thimning of the glass. The color is different in kind, and its distribution is very similar to that of the interference phenomena in the colorless pumice. In the brown glass, however, no double refraction is noticeable. A change from brown to colorless takes place in the same manner, and in some cases the transition is from. brown to yellow, and then to colorless. It is evident that in these instances the change of color is connected with the inflation of the glass into pumice. In other cases a cause is not so apparent. But the fact is obvious that the change has been from darker to lighter color, from brown to colorless. It is often observed that the inclusions in phenocrysts are brown, while the groundmass surrounding them is lighter colored or colorless. In one case (1909) the glass inclusions are brown, and the bays of groundmass in the phenocrysts are brown and yellow, the groundmass as a whole being yellow, with some patches of brown scattered through it. These appear to be remnants of a once brown glass ahmost wholly changed to yellow. A collapsed brown and yellow glass pumice is shown in Pl. LI, fig. 1. It carries phenocrysts of quartz and sanidine, with glass inchisions and "bayss." In a few cases colorless glass rods are seen to have yellow margins, as though the change had been from colorless to yellow.

In numerous cases a pumiceous character is entirely wanting. The mass is compact glass, but it consists of irregularly shaperl streaks and patches of different color. These twist and curve about one another and 
appear like a perfectly welded mass of strips or ribbons and irregular fragments of variously colored glass. In some cases their shape closely resembles that of fragments of pumice pressed together and welded (Pl: L, figs. 1, 2, and 3). In others it appears as though such fragments had been drawn ont and twisted by a movement of the mass (Pl. LI, fig. 2). Undonbtedly this has been the case, but it is donbtful whether all the streaked and variegated glasses have passed through the process of inflation, collapse, and welding with subseqnent flow. However, the distinctly ontlined and strongly contrasted streaks and ribbons of varionsly colored glass, are with difficulty explained in any other mamer. Another possible explanation will be given in comection with the development of microlites. This streaked arrangement of colored glasses has been called "eutaxitic" structure.

\section{GLOBULITIC GLASS.}

The colored glasses are in many cases crowded with minute dots or particles, which are the pigment, the glass itself being colorless. Such glasses are said to be globulitic. The comnection between the globulitic and colored glasses is well shown in certain banded and streaked colorless and orange glasses, as well as in brown, yellow, and colorless ones. In the former it is observed that the orange-colored bands in places become globulitic with minute orange or yellow particles. As these particles become more distinct and larger they are farther apart and are usnally darker colored, in extreme cases becoming opaque black grains, disseminated through colorless glass. Brown glass in like mamer passes into colorless glass with brown globulites, which may be opaque in the extreme forms. Such globulitic glass may appear bluish by transmitted light when not in focus, owing to dispersion of the light. It is evident that the globulitic pigment is a segregation, and eventually a crystallization, of the coloring matter, which sometimes permeates the glass as though in solution. There is a distinct contraction or condensation of the coloring material, for bands which grade from colored glass to globulitic, and into those with crystalline grains, become thinner and narrower, often resulting in a film of particles, or in a contracted belt noticeably smaller than the undifferentiated belt. In some cases of welded pumice of variously colored glass the general color is yellow or orange (2058). Some fragments are colorless at the center, with yellow margins, while the larger fragments are either 


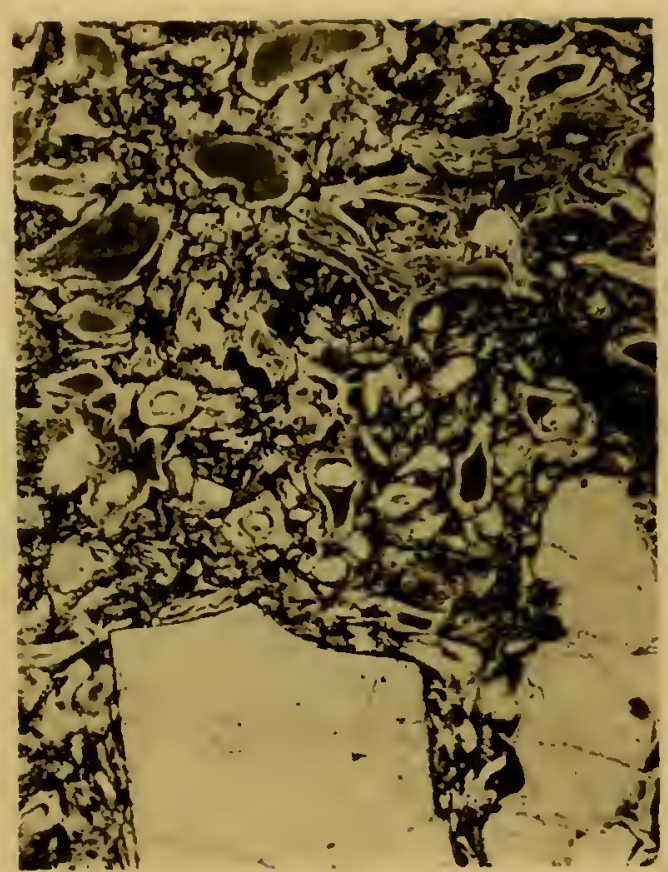

(A) $\times 32$

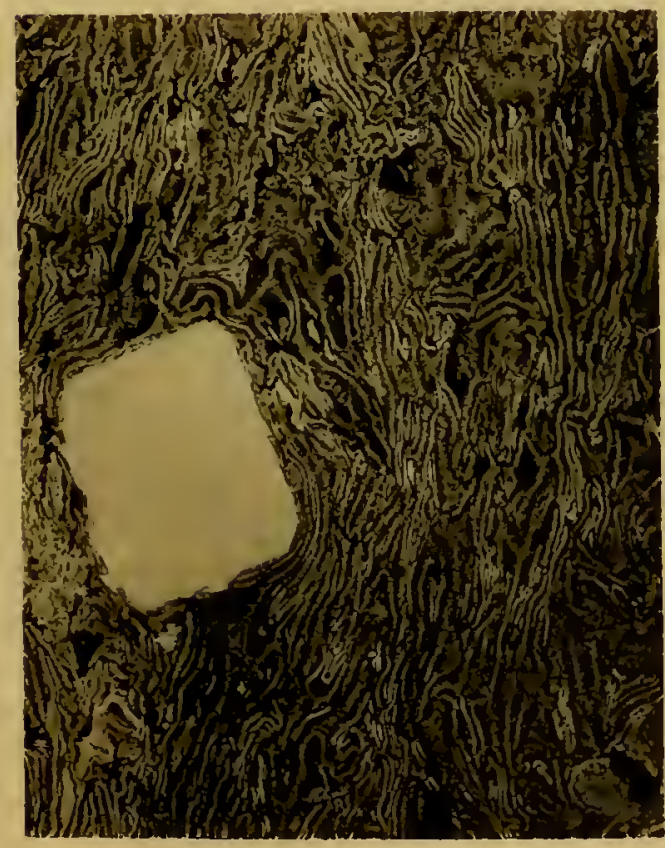

(C) $\times 47$

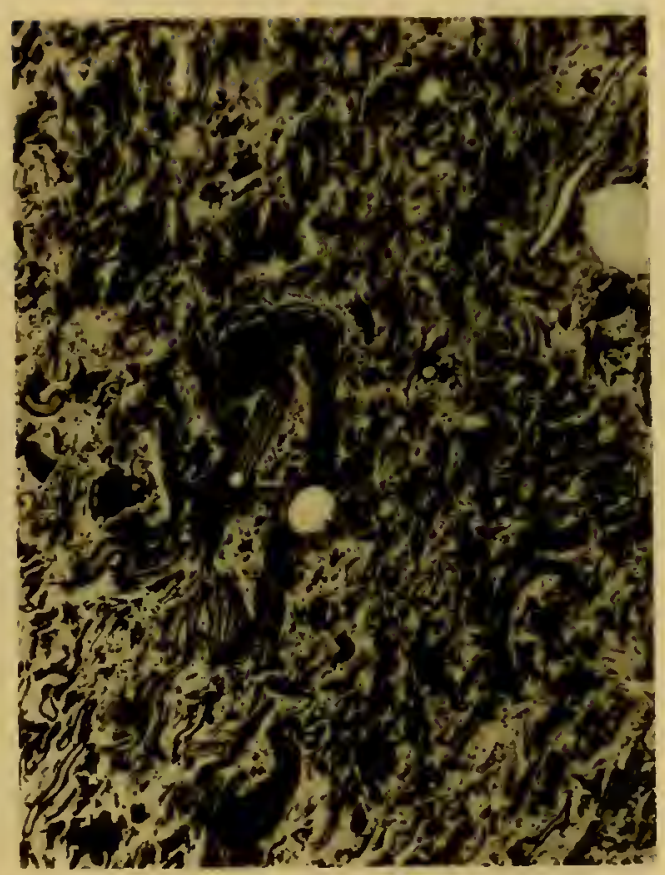

(B) $\times 32$

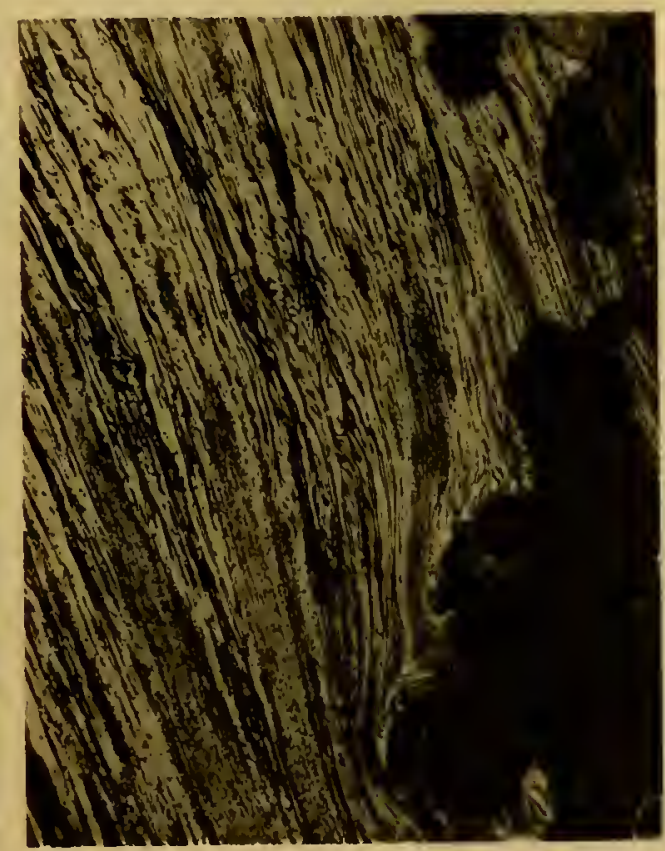

(D) $\times 32$ 

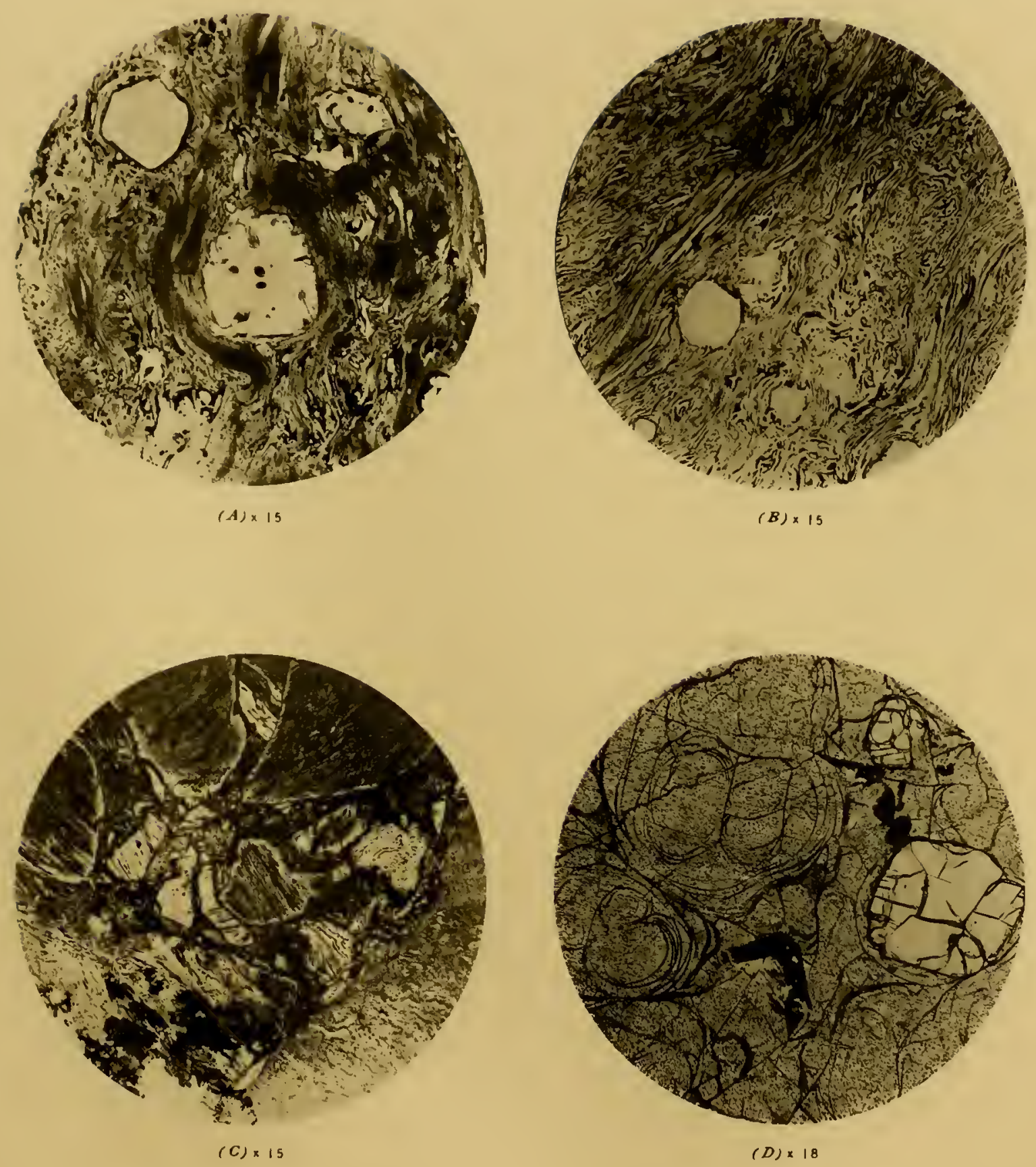

PHOTOMICROGRAPHS OF RHYOLITIC GLASSES 

Yellow, grading in places into grlobulitic brown surrounded by a colorless zone with a yellow margin, or the central portion is colorless with swarms of minute grains, the margin being as in other cases. The minute grains are hright yellow in incident light, and almost opaque by transunitted lighlt. With high magnifying lens they appear to be partly transparent, but no doulble refraction is noticeable.

In other cases these globulites are represented by microlites, many of which are opaque grains, apparently magnetite, together with others which will be deseribed. The transition of yellow and brown colored glass streaks into globulites and microlites is well shown in the colored obsidian from Obsidian Cliff, represented by fig. 1 of Pl. XVI in the Seventl Annual Report of the United States Geological Survey, in which the curved and contorted bands of color and streams of trichites produce grotesque shapes in thin section, like imitations of varions forms of organic nature. From this it appears that the tones of yellow, orange, red, brown, and black are due to different states of axidation of the iron in the magma, which may be erystallized out as magnetite and sometimes subsequently oxidized to the ferric state, as shown by the red color of many trichites in incident light, or the iron oxide may be disseminated in minute particles whose precise character is not determinable, or the coloring matter may be in solution. In some parts of Obsidian Cliff the red and black streaked glass is brecciated, the angular fragments being welded into a compact mass, as shown in Pl. LI, fig. 3. An extremely delicate banding is slown in Pl. L, fig. 4, caused by alteruating streaks of colorless and red and yellow globulitic and trichitic glass. The folding of the streaks is well shown. They pass through faint spherulitic growths.

A frequent microstructure is one produced by thin films of globulites and particles like dust, which appear to be scattered in planes through colorless glass. The films curve and fold about one another in the most intricate manner, producing the effect of thin veils. This structure appears to have resulted from the welding together of fragments of glass, as in the case of certain colored glasses already described. This veil structure is often retained after the whole mass has become crystalline, and serves to indicate one of the phases through which the magma has passed. 
MCROLITIC GLASS.

Most of the rhyolitic glasses in the Yellowstone Park are microlitic. The microlites may be uniformly scattered through the glass, or they may be abundant in alternating layers or bands, or they may occur irregularly in patches and streaks with colored and globulitic glass, as already mentioned They are usually distributed miformly in massive obsidian, but often exhibit a somewhat parallel arrangement, or, more properly, a slight variability in abundance in parallel planes, which mark the planes of flow or movement within the magma. This may be seen in Pl. LV, fig. 1 . This variability is more pronounced in portions of the glass which are partly vesicular or pumiceous-that is, where dense microlitic obsidian passes into pumiceous nommicrolitic glass, as in the upper portion of the lava near Obsidian Cliff and elsewhere.

The character of the microlites may be sumised from their shape and color in some cases, and from their optical behavior in others, or by tracing similar forms from the minutest to those large enough to be recognized. In this way it is found that they are undoubtedly magnetite, augite, feldspar, and quartz, and rarely hormblende and hematite, and probably psendobrookite. Magnetite occurs in minute crystals and grains, isolated or attached to prisms and needles of augite. The opaque hair-like trichites, straight and curved, in some cases are separated into rows of opaque grains resembling magnetite. In other cases they form threads on which are strung transparent rhombic plate-like microlites, as in the illustration, Pl. LII, fig. 6. Such microlites have a pale-greenish tinge.

Feldspar microlites are sometimes thin plates parallel to the clinopinacoid, with the outline formed by basal plane and prism or orthopinacoid. They are often in Carlsbad twins, in juxtaposition and cruciform. These are probably orthoclase. In some less siliceous glasses the feldspar crystals are tabular and rectangular with projecting comers. With these are associated lath-shaped crystals, forked or fibrous at the ends, which are probably oligoclase.

Quartz occurs in minute hexagonal pyramids, whose form and double. refraction can be distinctly recognized. They range in size from 0.002 to $0.015 \mathrm{~mm}$. in diameter. They may easily escape detection, and were overlooked in the obsidian of Obsidian Cliff when the first study of it was made. They are not found in all the rhyolitic glasses in the Yellowstone 
Park which carry microlites. In parts of the obsidlim of Obsidian Cliff they occur with feldspar nicrolites and slightly larger micrographlic intergrowths of quarty and feldspan in banded swams, alternating layers being nearly free from microlites. It was the presence of the microscopic micrographic intergrowths in association with feldspar microlites which led the present writer to infer the presence of quartz microlites, although quinty had not been observed in such form before that time. ${ }^{1}$ If quartz crrstallized synchronously in conjunction with feldspar to form such micropraphic microlites, and if the feldspar also crystallized alone, why had not cuartz also crystallized by itself at the same time? After a very short search the quartz microlites were. found in recognizable individuals.

In the colored glasses, in some instances, a few dark-colored microlitic prisms and grains occur surrounded by a light-colored zone or "lialo," which indicates the concentration of the coloring matter in the microlite. In parts of the punice at Obsidian Cliff there are microlitic grains, probably augite, each of which is surrounded by a minute sphere of colorless substance, about $0.023 \mathrm{~mm}$. in dianeter, with a higher index of refraction than the surrounding glass. In another pumice (1909) the outline of the colorless bodies is seen to be jagged, as though made up of crystal indiriduals, and in some cases they project beyond the glass walls of resicular cavities. They are noticeably doubly refracting, and may be incipient spherulitic growths.

The various kinds of microlites are not always present in like amounts. In many cases the glass appears to swarm with trichites and microlites of angite, in short prisms and grains. In some cases the trichites seem to be magnetite; in others they are augitic needles. In a compact glass (1941) from the platean south of Madison Lake, which is colorless in thin section, there are long, curved, opaque trichites which are gronped about thin layers of opaque grains, the trichites themselves in many cases consisting of opaque grains, as though the trichite had been disjointed by shrinking. With these are very tew other microlites.

In some of the obsidian at Obsidian Cliff $(2210,2241,2242)$ the microlites are mostly feldspar and quartz with needles of angite and a few mag-

${ }^{1}$ The observation by Dr. Kiich of quartz microlites in the dacitic glasses of Colombia was not known to the writer at the time this investigation was made. W. Reiss und A. Stiibel, Reisen in SiidAmerika. Geologische Studien in der Republik Colombia. I. Petrologie. I. Die vulkanischen Ges. teine, bearbeitet von Richard lïich. Berlin, 1892. 
netite grains, and a few needles which are possibly pseudobrookite. In an obsidian from the plateau northeast of Obsidian Cliff, which carries many shrunken hollow spherulites (2215), there are seattered microlites of great beauty. The largest are micrographic intergrowths of quartz and feldspar which sink to the minutest dimensions; also tabular feldspar, simple and in Carlsbad twins, as well as some rectangular forms with horned corners; pyramidal quartz, one of the larger individuals containing a glass inclusion; hexagonal plates of hematite or ilmenite, opaque, with metallie luster; prisms of angite, some knobbed at the ends, like bones; and oceasional dark-green prisms of homblende.

In the same neighborhood is obsidian with duller lnster and a greenish tinge, which is less siliceous and approaches dacite in chemical composition. It consists of compact colorless glass (2164) with a multitude of microlites. Many are angite in prisms, many are feldspar, while some are magnetite. The feldspar microlites are mostly tufted or horned and some have multiple twinning. A very few are in Carlsbad twins. There are some larger microscopic crystals of feldspar and angite, but no microscopic phenocrysts. There are no microlites of quartz and no trichites. Another part of this obsidian is still richer in augite, with smaller feldspar needles and magnetite grains. The microstructure is almost andesitic.

In some of the compact, mierolitic glasses perlitic structure is highly developed, as shown in Pl. LI, fig. 4. Its eharacter is too well known to need description in this place.

FORMS OF GROWTH OF MICROSCOPIC CRYSTALS.

There is a marked tendency exhibited by the microseopic crystals in rhyolitic magmas to form intergrowths and also compound groups of crystals. The well-known graplic intergrowth of orthoclase and quartz is one of the most characteristic. Microscopic examples are of frequent occurrence and have been deseribed in the paper on Obsidian Cliff.' They can be traced from megaseopie gronps in which the nature of the component minerals ean be determined to micróscopic ones of the minutest dimensions in which only the general form, erystalline strueture, and general optical behavior ean be recognized. Sucl groups are seen in thin section to consist of several individuals of feldspar intersecting one another,

iseventh Avu. Rept. U. S. Geol. Survey, 1888, pp. 274-276. 


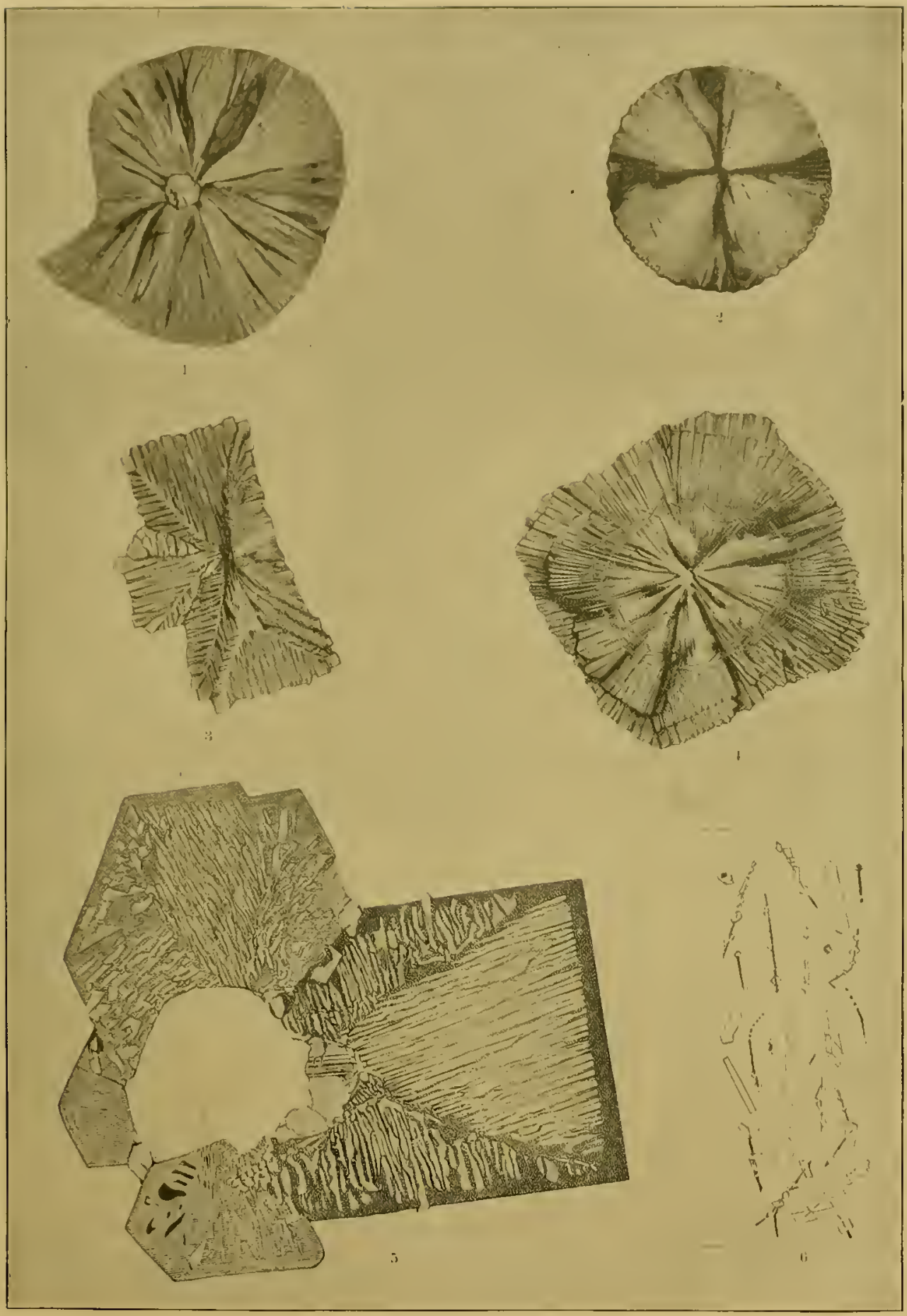

SPHERULITES. 

each individual having a filorous structure in several directions, and in places a granular structure. 'This is shown in I'l. LII, fig. 3, which represents a section through two individuals of feldspar with nearly rectangular outline. The fibration lies almost perpendicular to the sides of the rectangles. The outline of the rectangles is serrated by the projection of minute crystals. The identity of sucli forms with intergrowths of quartz and feldspar is apparent. An illustration of a large group is introduced for comparison (Pl LII, fig. 5). It is similar to the graphic structure associated with phenocrysts in rhyolitic pumice, already described. Such intergrowths are primary crystallizations from the molten magma, and exhibit the idiomorphic outline of quartz or feldspar when large enough to be recognizable.

As the number of feldspars which combine in a group increases, the ontline of the cluster becomes more and more oval or circular and the form of the feldspar individnals is lost. An ilhustration is given in Pl. LII, fig. 4 , in which the feldspars wedge out toward the center, their onter ends making an almost continuons outline. The fibration is in wedge-shaped sets and does not radiate uniformly from the center. In this case the extinction of light between crossed nicols is quite irregular, as shown in the illustration. This is due to the variable orientation of the feldspar crystals, which have a generally radiate arrangement, and also to that of the quartz, which is more irregular. Other compound growths which are analogous in structure and optical behavior to the micrographic are certain kinds of spherulites that occur in great profusion in most of these rhyolites. The simplest and smallest of this class of spherulites are minute colorless spheres, 0.2 to $0.05 \mathrm{~mm}$. in diameter. They have a fibrous structure noticeable in strongly convergent light, and exhibit a more or less well defined dark cross between crossed nicols. The arms of these crosses change their shape and split into branches near their outer ends during the rotation of the section (PI. LII, fig. 2; also Pl. LIII, fig. 1).

In some cases a colorless fibrous margin surrounds the micrographic groups; its character and length of fiber correspond to those of the microspherulites just described. From its optical behavior it appears to be a crystallographic continuation of the materials of the micrographic kernel. These spherulites are often in rows and layers (PI. LIII, fig. 1), and sometimes their centers are so close together along straight lines that in thin section they produce the effect of transparent fibrous bands (Pl. LIII, fig. 1). Such a band of colorless spherulites is shown in Pl. LV, fig. 1. It 
traverses larger brown spherulites. They are also shown in bands of more or less isolated spherulites within the brown spherulites. These spherulites are represented megascopically by minute dots arranged in lines on the surface of some obsidian.

Spherulites similar to these, but slightly larger, occur crowded together in bands or in irregular areas, in which case the rock is lusterless and lithoidal, and is nsually colored gray in various shades. In thin section the finely spherulitic portions may be crowded with trichites in the same manner as the surrounding glass is. These are more perfect as the spherulitic structure is more minute, and their form and arrangement in fluidal lines are lost when the spherulites are coarser. In these cases they are sometimes crowded out toward the margin of the spherulites, or they may be accumulated in radial lines.

The small spherulites exhibit an extremely minute granulation by transmitted light, and appear brown; but by incident light this is white, evidently in consequence of the reflection of light from innumerable snall surfaces or cracks. In small spherulites lying isolated in, and also bordering, areas of greater crystallization the centers of the spherulites are granulated and brown, while the margins are often colorless and transparent. In some cases the centers of the spherulites are colorless and the outer zone is brown. In such spherulites the fibers of the outer zone are more delicate than those at the center. In these spherulites the direction of vibration of the fastest ray (axis of greatest elasticity) lies approximately parallel to the direction of the radial fibers. The spherulites bordering more crystalline areas in lithoidal rhyolite have sometimes continued their crystallization a short distance into these areas, when they exhibit distinct prismatic rays that project beyond the apparent periphery of the spherule and resemble the teeth of a cogwheel. Sometimes the projecting prisms assume a comparatively large size. Such forms are represented by $a$ and $b$, fig. 4. The projecting prisms have crystallographic boundaries and extend with uniform optical orientation toward the center of the spherulite. Their form and optical behavior show them to be crystals of orthoclase elongated in the direction of the clinoaxis, with the direction of ribration of the fastest ray nearly paraliel to the sides of the prism. The extinction angle varies from $0^{\circ}$ to $12^{\circ}$, being usually low. The high limit of the extinction angle in the clinodiagonal zone, as well as the chemical composition of the rock, 
and of the spherulite, since there alppears to be but one variety of fetdspar present, indientes that the orthochase is rich in sodit, the molecular ratio of the protash to the soda in the rock being 1 to 1 .

'The projecting prisuls ale free from the gramulation which is at the center of the spherulites. In some instances this assumes a radliating, feather-like structure which suggests the micrographic intergrowth of feldspar and quantz. This is undoubtedly its true character, as shown elsewhere; so the small spherulites are unquestionably compesed of orthoclase prisms elongated in the direction of the clinoaxis, which radiate from a center, and are intergrown with quartz in a micrographic manner. When the margin of pure feldspar was being crystallized, the free silica remained
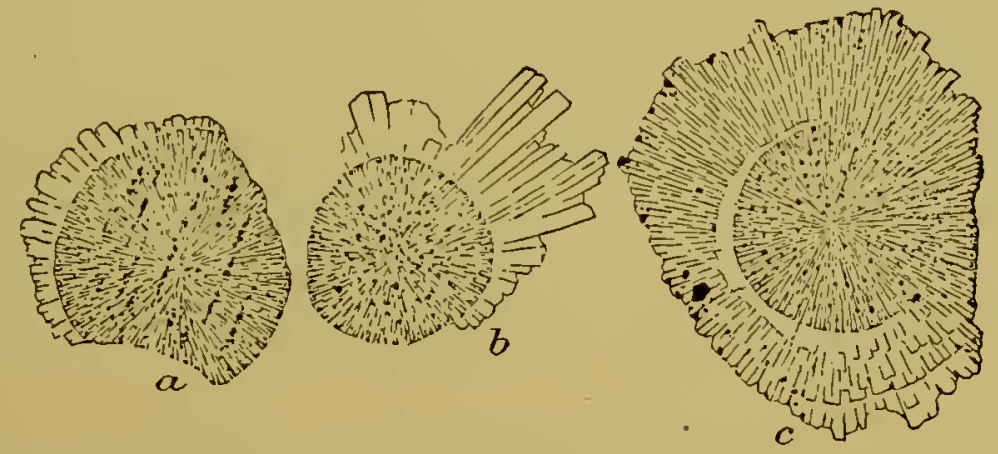

Fig. 4.-Sections of splerulites with projecting prisms of or hoclase aud a crescent-shiped helt free from granulation.

uncrystallized until subsequently, when it filled the interspherulitic spares with tridymite or quartz, according to circumstances.

There are instances in which the clear zone of feldspar does not occur on the margin of the spherulite, but forms a crescent-shaped transparent belt within it ( $c$ of fig. 4 above, and fig. 2 of Pl. LIV). The optical behavior of such spherulites shows that the feldspar fibers or prisms are continuous from center to circumference, and that it is simply the granulated or featherlike intergrowth that was interrupted. This is in accord with other signs of a lack of uniformity of microstructure in these lighly siliceous rocks.

Still larger forms of this kind of spherulites are the small megascopic, blue-gray spherulites, which are from less than $1 \mathrm{~mm}$. to $5 \mathrm{~mm}$. and rarely $10 \mathrm{~mm}$. in diameter. In thin section they have much the same characters as the mieroscopic ones. They are distinctly fibrous in sections, the fibers not all radiating from a single point. They often have a micrographic 
group or minute spherulite at the center. Between crossed nicols the dark arms seldom form a distinct eross, but split into many arms, some making an angle of $45^{\circ}$ with the principal sections of the nicols (Pl. LII., fig. 1).

These larger spherulites are generally traversed by streams of trichites and minute spherulites which continne the flow lines of the rock through the spherulite without change of direction (Pl. LV, fig. 2). But in some cases these interpositions have been crowded into radial and circular lines (Pl. LV, figs. 3 and 4, and Pl. LVI, fig. 1). These produce the bands or zones of color in the small spherulites. Often the trichites and grains are red by incident light, as though the magnetic oxide had been changed to ferric oxide, and it is noticeable that the black trichites and nearly colorless microlites in the glass as they pass into spherulites become red, as though they had encountered an oxidizing agent not active in the surrounding glass.

The shapes of spherulitic growths are not limited to spheres, but may be hemispheres, disks, and sectors, or plune-like (Pl. LVI, fig. 1), or in a brush like a fox's tail. They may also appear in thin section in the form of fibrous bands or fringes with all possible curvatures. All the spherulitic growths just described may be referred to stellate groups of prisms of orthoclase elongated parallel to the clinoaxis, and intergrown with quartz whose orientation is not known to be fixed with respect to the feldspar prisms.

There are other kinds of spherulitic structures in these lavas which have crystallized in a different manner. Their nature may be understood from a consideration of certain forms of microlitic growth assumed by orthoclase in these magmas.

Prisms or needles of feldspars sometimes occur associated together in nearly parallel groups, or in more or less divergent ones. In some cases they are separated from one another by glassy groundmass; in other cases by a colorless, almost isotropic mineral, probably tridymite, as will be shown subsequently. These needles are straight or curved, and sometimes have a rough, jagged outline, sometimes a smooth one. Long delicate feldspar needles, the spaces between which are filled with tridymite, are shown in Pl. LVI, fig. 2. The rock also carries dark-brown spherulites, which are nearly opaque in the figure. The cross sections are generally six-sided or rhombic, with the acute angle truncated by a plane more largely 


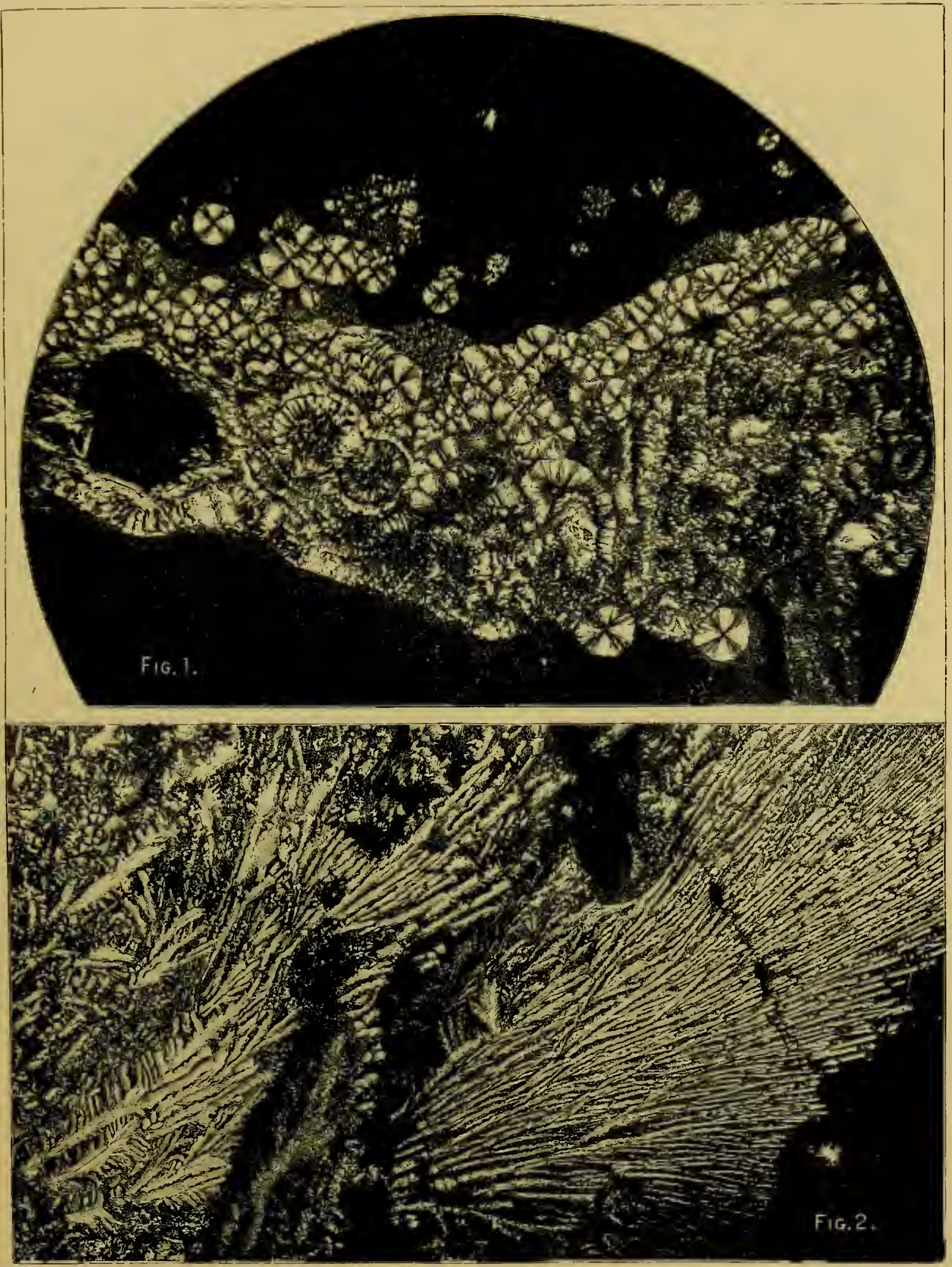





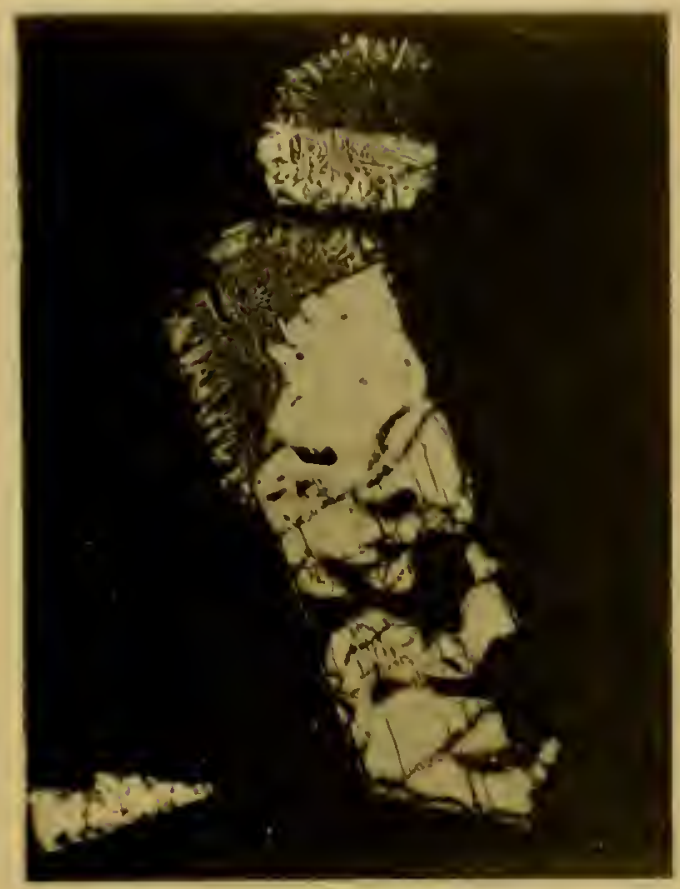

(A) $\times 27$

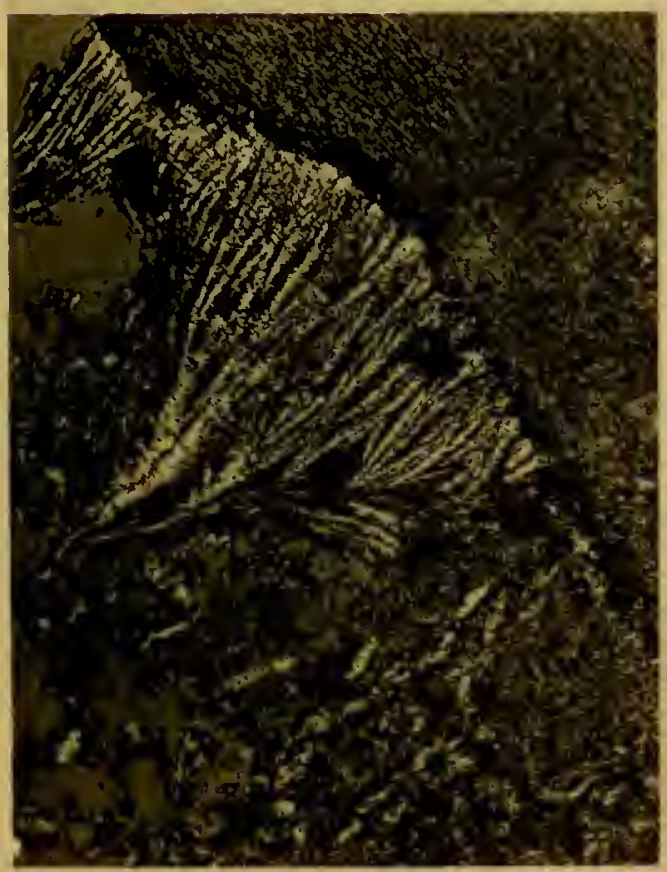

(C) $\times 50$

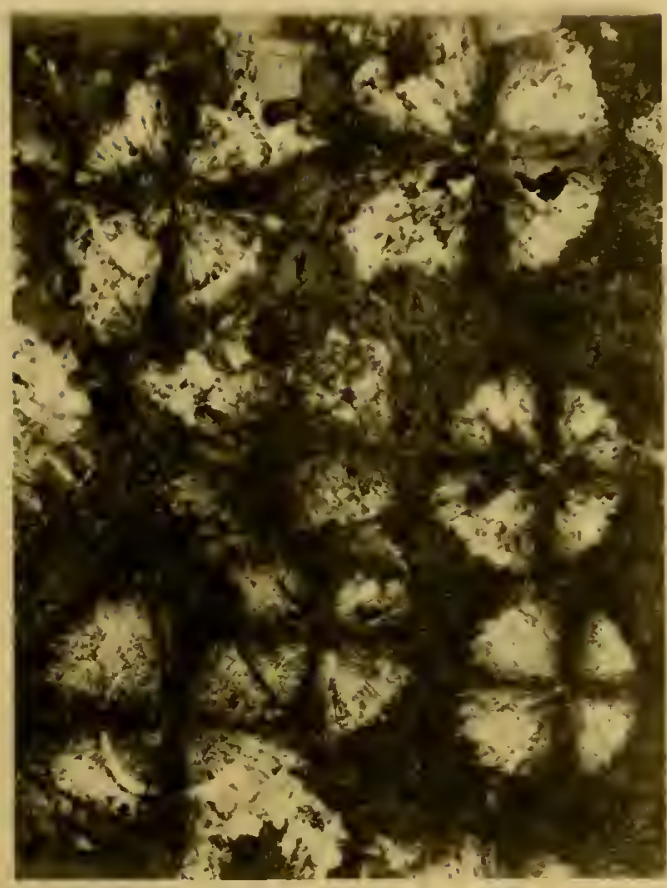

(B) $\times 46$

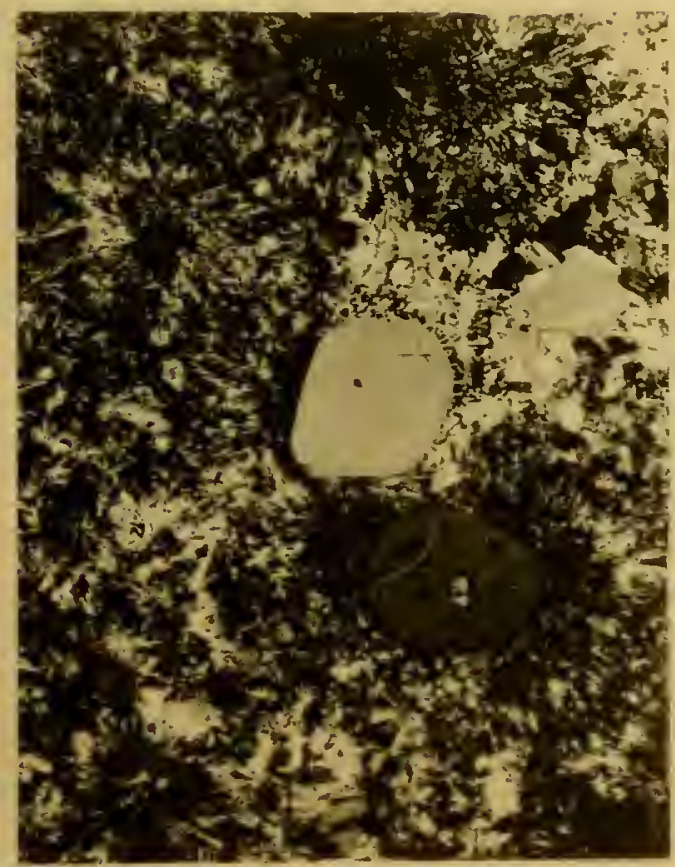

(D) $x<2$ 


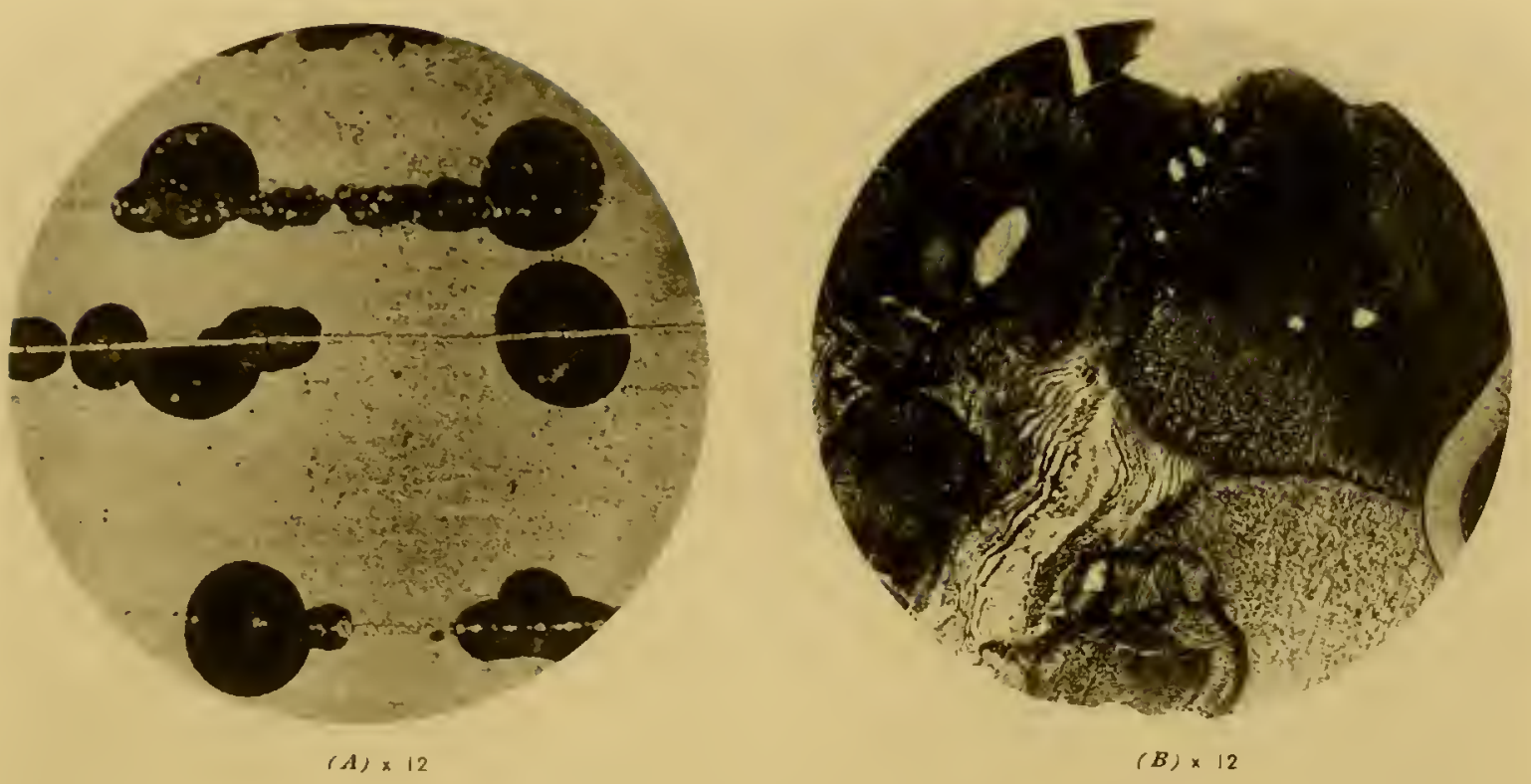

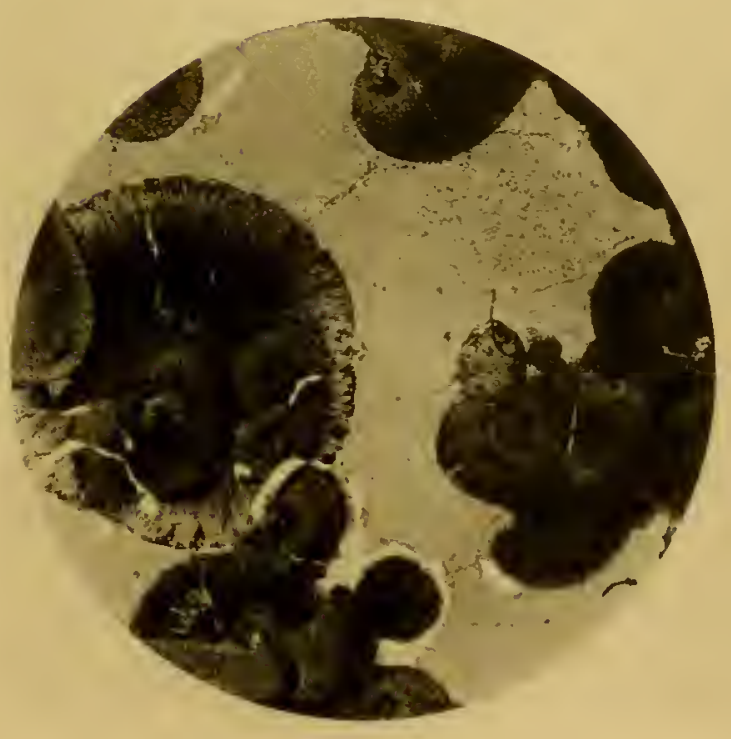

(C) $\times 12$

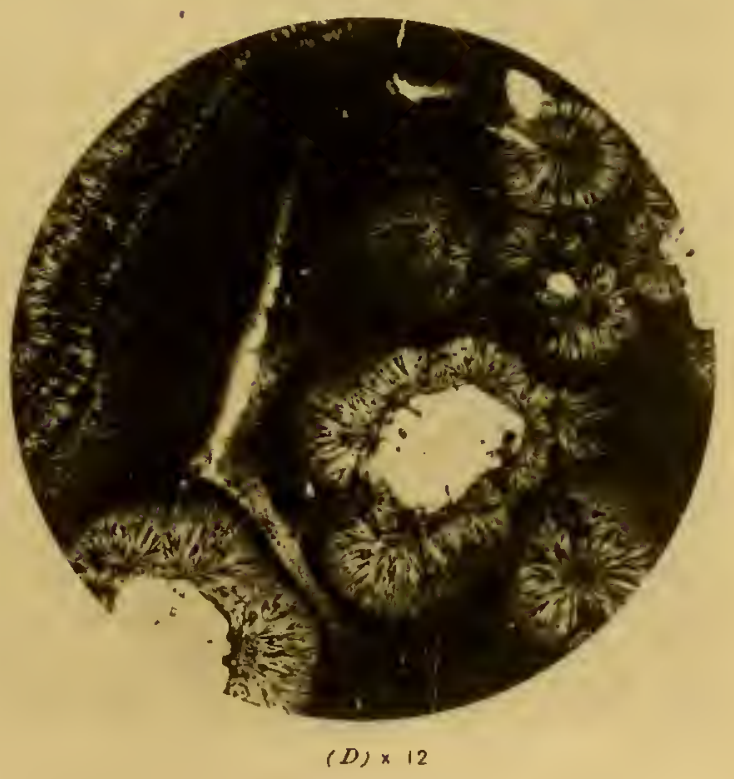

PHOTOMICROGRAPHS OF SPHERULITIC STRUCTURES 

developed than the others. In some cases the sections are twimned parallel to the broad plane. In the rlombic sections the extinction is diagonal and no twinning is noticeable. The long prisns or needles are twimed in nearly all instances, the composition plane being parallel to the length of the prisin. The direction of ribration of the fastest ray is nearly parallel to the direction of the length of the prisms, proving them to be elongated paraltel to the clinoaxis. The twinning is after the Manebach law; and the cross sections slow that the crystals have a clinodome with basal plane and possibly with clinopinacoids.

These erystals branch out in two different ways. In some cases they appear to split, the parts being slightly inclined to one another at first, and becouning more divergent farther on. This is shown in the right-hand half of PI. LIII, fig. 2. Botlı parts are twimned in the same mammer and have the same optical orientation-that is, each is a prism parallel to the clinoaxis. By this method a succession of branchings takes place, the prisms becoming more and more numerons and thimer, often terminating in a spherical surface, the aggregation in thin section resembling a rounded bush of branching stems, especially when the prisms terminate in broad leaf-like fronds, which often happens (Pl. LIV, fig. 3). In other cases the branching of the long, twimned prisms is seen to obey a crystallographic law. Short prisms project from opposite sides of the Manebach twin at an angle corresponding to that between the vertieal axis and clinoaxis, abont $64^{\circ}$ (left-hand half of Pl. LIII, fig. 2). These branches are prisms parallel to the vertical crystallographic axis. They are sometimes long and slender, and are curved to a position parallel to that of the prism or stem from which they branch; in such cases the bundle of feldspar needles will consist of numerons prisms elongated parallel to the vertical axis, and a central one elongated parallel to the clinoaxis. The optical orientation of prisms parallel to the vertical axis will differ according as the plane of the optic axes lies in the plane of symmetry or is at right angles to it. In the first case the direction of vibration of the slowest ray will always make a small angle with the axis of the prism, or be parallel to it. In the second case the speed of transmission of the ray vibrating in the direction of the prism axis will sometimes be less and at other times greater than that of the ray vibrating at right angles to it, according to which side it is viewed from. Closely allied to these growths and associated with them are delicate rays 
or needles of feldspar which are composed of minute stout prisms attached to one another end to end, in parallel position, producing a rude microscopic rod with meven sides. These prisms are elongated parallel to the vertical axis, and for the reason just given are optically sometimes negative and sometimes positive, or they may all be positive. They form branching arborescent growths, and constitute rays of spherulites, usually of considerable size. A phase of this kind of spherulitic growth is shown in $\mathrm{Pl}$. LVI, fig. 3. Between the feldspar rays there are minute grains of tridymite, which are often clustered in small spherical pellets with cavities between them. Such spherulites are porous. In the more coarsely crystalline spherulites, with large cavities, the same kind of feldspar crystals may be seen with a low magnifying power. Both kinds of feldspar prisms often occur in the same spherulite.

Some spherulites are composed of a dense micrographic spherulite. at the center, which passes ontward into the branching variety, which may be porous to a greater or less degree, the free silica being in the form of tridymite. In some areas of the tridymite grains between comparatively coarse prisms of feldspar (Pl. LVI, fig. 2) there are crude spherulitic aggregations of tridymite, probably composed of interpenetrating tablets.

\section{LITHOPHISA.}

The microstructure of the lithophysa can not be studied so easily as that of the more compact spherulites, because of the slight coherence of the crystals composing them and the difficulty of preparing thin sections. But in many cases the component crystals are large enough to be seen with a pocket lens, and their character and arrangement can be made out. It is evident in the case of hollow or gaping porous spherulites, which are one phase of lithophyse, that the mass consists of short prisms of orthoclase or sanidine attached to one another end to end, in a manner already described for some spherulites. These jointed rods of feldspar radiate from what was the center of the spherulite, the gaping appearing to lave taken place after their crystallization. With them are associated tridymite, quartz, and fayalite. When there is no marked banding in the surrounding rock mass, the hollow spherulite may have the form represented in cross section in Pl. LVII, fig. 1. When pronounced banding is present in the groundmass, 
it often traverses the hollow spherulite and the graping or spaces are between the liverers, ats in fig. 2.

In lithophyse proper there are concentric shells of arystals and concentric spaces between them, an in fig. 3 of the same plate. The minute feldspar prisms in the sletl stand radially with respeet to the center of the lithophyse; the other minerals have no definite arrangement. Often the tridymite occurs in minnte pellets, lotting the sliells. The concentric shells correspond to the concentric bands of color and of varying composition which chancterize certain solid spherulites. They probably result from a pulsation in the act of crystallization, such as has been observed in the growth of crystals and spherulites of artificial salts when the latter grow very rapidly. It is due to the lowering of the saturation of the surrounding mother liquor, caused by the sudden liberation of heat in the act of crystallization, and to the rapid extraction of crystallizing molecules. The spasmodic adrance of the erystallization appears to have produced layers that were more coherent than others, and the latter became the open spaces upon the shrinkage of the partly crystallized magma before its final crystallization. The position of the quartz, tridymite, and fayalite upon the surface of these shells in some cases indicates that they formed after the spaces did. When the groundmass is markedly bander the lithophysa are often modified, as in fig. 4 of Pl. LVII. Similar structures occur in hemispherical lithophysæ, as shown in figs. 5 and 6 . The presence of these cross walls proves that the shells are not the result of expanding gas bubbles, but must have been formed by the contraction of the magma within the boundary of the lithophysa at the time of its formation. In a very few cases there appear to be evidences of a slight expansion, which is shown in the arching of the layers of the groundmass over the lithophysa, as in fig. 7. But it is quite possible that the curving of the layers may have antedated the formation of the lithophysa, and have led to its formation. When we consider that the known condensation of mass in the passage of anhydrous glasses of orthoclase and quartz into the crystal form is abont 10 per cent in the first case and 16 per cent in the second, and when we remember that hydrous glasses possess still greater volume than the anhydrous ones, we are prepared to understand the comparatively large cavities which often occur in these forms of rapid crystallization. In the case of the deuse spliernlites, we must assume that the condensation was more gradual, though rapid, and MON XXX11, PT $11-27$ 
was uniformly toward a center, the surrounding magma closing in about the growing crystals, which must always happen in the case of phenocrysts, thongh generally by inappreciable stages, owing to the comparative slowness of their growth.

The origin of lithophyse must be due to the more abundant presence of water vapor in spots in the magma, the greater viscosity of the surrounding magma and its generally viscous condition, the very rapid crystallization of jointed rods of feldspar and attendant condensation, followed by the further condensation of the remainder of the mass upon the crystallization of the silica, which must have taken place in the presence of highly leated water vapor. The mimerals produced are like those erystallized artificially in closed tubes in the presence of highly heated water vapor. ${ }^{1}$

In certain cases the spherulitic growths appear to be little more than incipient crystallizations, although the spherulites may be megascopic. They are only faintly doubly refracting, and probably consist of extremely minute fibers. Where such spherulites occur in colored banded glass the irregularly twisted bands pass through the brownish-gray spherulites withont interruption, but their bright colors are changer to brown, with the formation of opaque grains (PI. L, fig. 4). Within such spherulites in some cases there are delicate branching trichitic needles, radiating from the center, which are probably angitic, besides other delicate curved needles with high index of refraction and strong double refraction, whose character was not made ont.

In some forms of rliyolite the appearance of welded glass fragments or veil structure is retained, although the mass is faintly doubly refracting and may be spherulitic in part, incipient spherulitic neelles traversing the rock in various directions without regard to the former lines of flow, which are marked by opaque dustlike particles. In these cases it is evident that the spherulitic crystallization took place after the molten mass had come to rest.

'Friedel and Sarasin, Bull. Soc. minéralogie, 1879, vol. 2. p. 15x; ibid., 1880, vol. 3, 1. 171; Comptes reuclus Acad. sc.i., Paris, 18\%1, vol. 12, p. 137t; ibid., 1883, vol. 97, 1p. 290-294. K. von Chrustschoff, Am. Chemist, 1883; Tsehermaks mineral. Mittheil., vol. 4, 1. 536. Stanislas Mleunier, Comptes rendus Acad. sci., Paris, vol. 93, 1881, 1. 737. De Haldat, Aunales chimie, vol. 46, p. 70; Nenes Jahrbuch fiir Mineril., 1833, p. 680. A. Daubrée, Etudes syuthétiques, etc., P’ıris, 1879, pp. 15t-179. For a historical review of the theories regarding the formation of lithophysip, sae page $2 \times 7$ of the author's paper on Obsilian Cliff, in the seventh Anuual Report of the U. S. Geological Survey. 
In certain kinds of rhyolite, apparently composed of welded glass fragments, there is a microspherulitic growth which hears a definite relation to the form of the supposed glass tragments. The teldspar fiber's are in groups, which are approximately nomal to the outline of the fragments, and radiate inward. Where the fragment hard a rudely triangular shape the central part often attainet a greater degree of erystallization than the margin, and sometimes consists of distinct crystals of feldspar with tridymite or atuarty and a small amount of ferronagnesian mineral. Where the fiagments were long and narrow the spherulitic growth from the sides inward produced the effect of parallel fringes-"axiolites" of Zirkel. This tendency to develop sphernlitic growtls. from old surfaces or cracks is shown in another modification of the rock in which the axiolitic structure can be seen megascopically. In hand specimens these varieties appear to be dark lithoidal or glassy rocks, traversed in all directions by narrow spherulitic bands. In the glassy forms of the rock the black glass inclosed by the lithoidal bauts occasionally falls out, like a kernel from a shell, proving the spherulitic portion to be a growth along intersecting planes.

In thin section it is observed that the spherulitic bands have a dark line along their centers, as though they were ancient cracks. They intersect one another in some cases, but are not persistent in others. Their behavior toward phenocrysts when present is the same as that of perlitic cracks. They encircle them, but never traverse them ( $\mathrm{Pl}$. LV, fig. 4). They do not often oceur in as many concentric circles as ordinary perlitic cracking, but they are unquestionably of the same general character, namely, the cracking of an amorphous glissy substance. The sphernlitic crystallization is subsequent to the cracking and is located along the cracks. It is like other forms of spherulitic growths in these glasses, and is evidently only a special case. In one instance similar spherulitic growth had formed about the edge of an open crack in such a manner as to show that the magma had been so viscons previons to its last movement that a small gap in it was not closed. Upon its walls pellets of tridymite formed. It must have been after it had reached this highly- riscons state that this particular spherulitic crystallization took place. In cases where perlitic glasses contain spherulites it is observed that the perlitic cracks encircle spherulites in the same manner as they eucircle phenocrysts, and do not traverse them. The perlitic cracking is subsequent to the spherulitic crystallization and is 
confined to the glassy groundmass. In the rather uncommon occurrences just noted, where a cracking has been follower by crystallization, it is probable that the shrinkage and cracking tonk place in a lighly heated, stiff mass, which was subsequently welded together, as the collapsed pumice may have been-that is, it may have been surrounded by a hotter portion of the same hava flow and its temperature may have been raised to some extent. Instances of this kind of structure are found on the continental divide south of Madison Lake and on the summit of the west wall of Bechler Canyon, 5 miles from its month $(1945,1946)$, and also in the vicinity of the Lower Geyser Basin.

From the foreyoing it appears that certain forms of crystallization which unquestionably take place in molten magmas at or near their point of solidification, and which may be classed as pyrogenous and primary, may take place in a mass at a time subsequent to the development of features which seem to be dependent upon a certain amount of rigidity of the magma, such as the formation of cracks. Such rigidity is generally supposed to indicate perfect solidification and completed pyrogenons crystallization; and undoubtedly it does in most cases. But rigidity has a relative significance, and what is rigid with respect to a force acting through an extremely short period of time may be plastic toward the same force acting through longer time. Hence a highly viscous magma may be torn to fragments by an explosion, or be highly inflated by the sudden expansion of vapor, and in some cases be still viscous. Generally, however, the sudden expansion and escape of inclosed vapors tend to lower the temperature of the magmi and increase its viscosity. Buit it may not necessarily be solid or rigid. Similarly, shrinkage cracks may be produced in a viscous mass by sudden contraction before the mass lias solidified and while it is still highly heated, the fracturing being due to the rapidity of clange of volume, and not necessarily to the absolute amount of contraction. Such sudden contraction of unsolidified lavas is not of common occurrence, it would seem, but the instances of postperlitic spherulitic crystallization just described indicate its occasional occurrence.

In the massive glasses which are striped and marked with bands of various color it is sometimes noticed that lines of color traverse the mass like ancient fractures which closed up before the solidification of the mass. They pass across the lines of flow, which sometimes end abruptly against 
these lines, appearing as though fanlted and displaced to a slight extent. In many instances the arrangenent of the streaks of color is such ats to indicate that the compact mass was once an aggregate of fragments of similar magma, the lines of flow having various orientations in the different fragments. They have been welded into one contimous lomogeneous mass. In those varieties of rhyolite in which the first kind of spherulites are developed-namely, the compact ones which are closely related to micrographic intergrowtls-there are irregularly shaped areas between bands and clusters of microscopic spherulites which exhibit a different sort of crystallization. They are more highly crystalline-that is, the size of the individual crystals is larger. The spherulites bordering these areas generally terminate in distinct prisms of orthoclase, which have already been described, while isolated crystals of orthoclase of similar habit and size lie in various positions within the more crystalline area. The cement to these crystals in some instances is tridymite, in minute grains or in welldeveloped twimned crystals with characteristic wedge-shaped cross section. In other cases the quartz forms the cement, and is wholly allotriomorphic, producing a micropoikilitic structure (Pl. LIV, fig. 4). In places some of the feldspar prisms are nearly parallel to one another, so that the interstitial quartz appears in the shape of thin strips or needles, which is misleading, producing the effect of idiomorphic crystals. This quartz is unquestionably of igneous or of aqueo-igneous origin, occupying the same relation to the orthoclase as does the tridymite in the other cases, the derelopment of one or the other depending on very slight differences of physical condition, as demonstrated by experiment. In some experiments both forms have been produced together. Often the tridymite is accompanied by gas cavities of variable dimensions. With the orthoclase and quartz or tridymite are some magnetite and small amounts of ferromagnesian minerals. The latter differ in character in different oceurrences, and may be fayalite, mica, or tourmaline, and in rare instances possibly garnet. The fayalite forms comparatively large individuals, allotriomorphic with respect to the feldspar, sometimes with an opaque border, which may entirely replace the original individual.

Tourmaline and mica are found in minute crystals about $0.025 \mathrm{~mm}$. long and $0.01 \mathrm{~mm}$. thick. They are abundant in places, or lie scattered throught the tridymite and quartz, and also in the margin of the bordering 
spherulites. Sometimes they oceur together, but usually independently. The tourmaline is recognized by its strong absorption and by its other optical properties. Its color is brownish green to colorless. The mica is green, and also yellowish brown to reddish. The green mica is easily confounded with the tommaline, but may be distinguished by the direetion of the absorption. The toumaline and mica are idiomorphie, and must have crystallized just before the onter portion of the small sphernlites did, and also before the tridymite and quartz in which they lie. They are confined to the region of these interspherulitie spaces and are not found seattered indiscriminately through the spherulites. A mineral which is probably garnet occurs in 'the same mamer as toumaline and nica, and forms irregular grains, which are colorless and isotropie and have a ligh index of refraction. Occasionally the more coarsely crystallized quartz and feldspar in the interspherulitic spaces are traversed by opaque material segregated in curved layers, suggesting the structure of Eozoon. In Pl. LV, fig. 2, these streaks appear to be continuations of the lines of triehites that traverse the spherulites and originally marked the flow planes in the lava. They have been displaced by the crystallization of the larger erystals of feldspar and quartz.

In the banded lithoidal ringolite the layers, often mieroseopie in size, consist of minute sphererlites alternating with various modifieations of the (rystallizations just deseribed. These are really holoerystalline, with gas cavities, a phase of miarolitic strueture. The size of the cavities is sometimes considerable, and may be observed megascopieally, giving rise to planes of weakness in the roek along which it splits. The microspherulitic layers may also grade into glassy layers, so that holocrystalline and glassy layers alternate with one another in some modifications of rhyolite, notably in certain parts of Obsidian Cliff. This is illustrated in Pl. LVI, fig. 4, representing a section across laminated lithoidite. Hicrospherulitic layers alternate with layers containing comparatively large feldspar crystals with quartz and tridymite. In one layer the coloring matter is segregated in streaks, like ribs.

\section{MICROGRANULAR STRUCTURE.}

While the glassy and spherulitic structures are those most commonly found in the rhyolites of the Yellowstone Park, several modifications of 

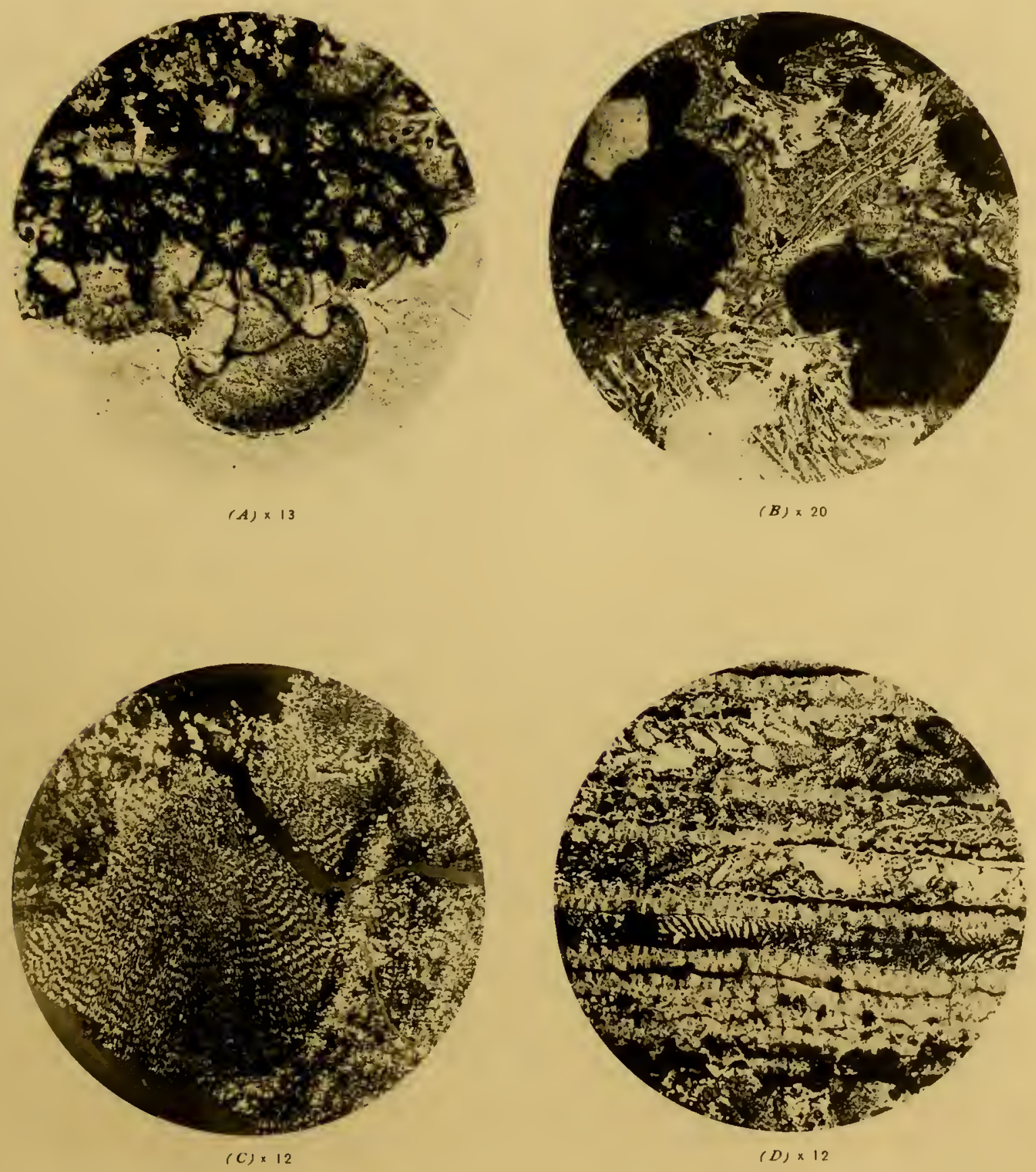


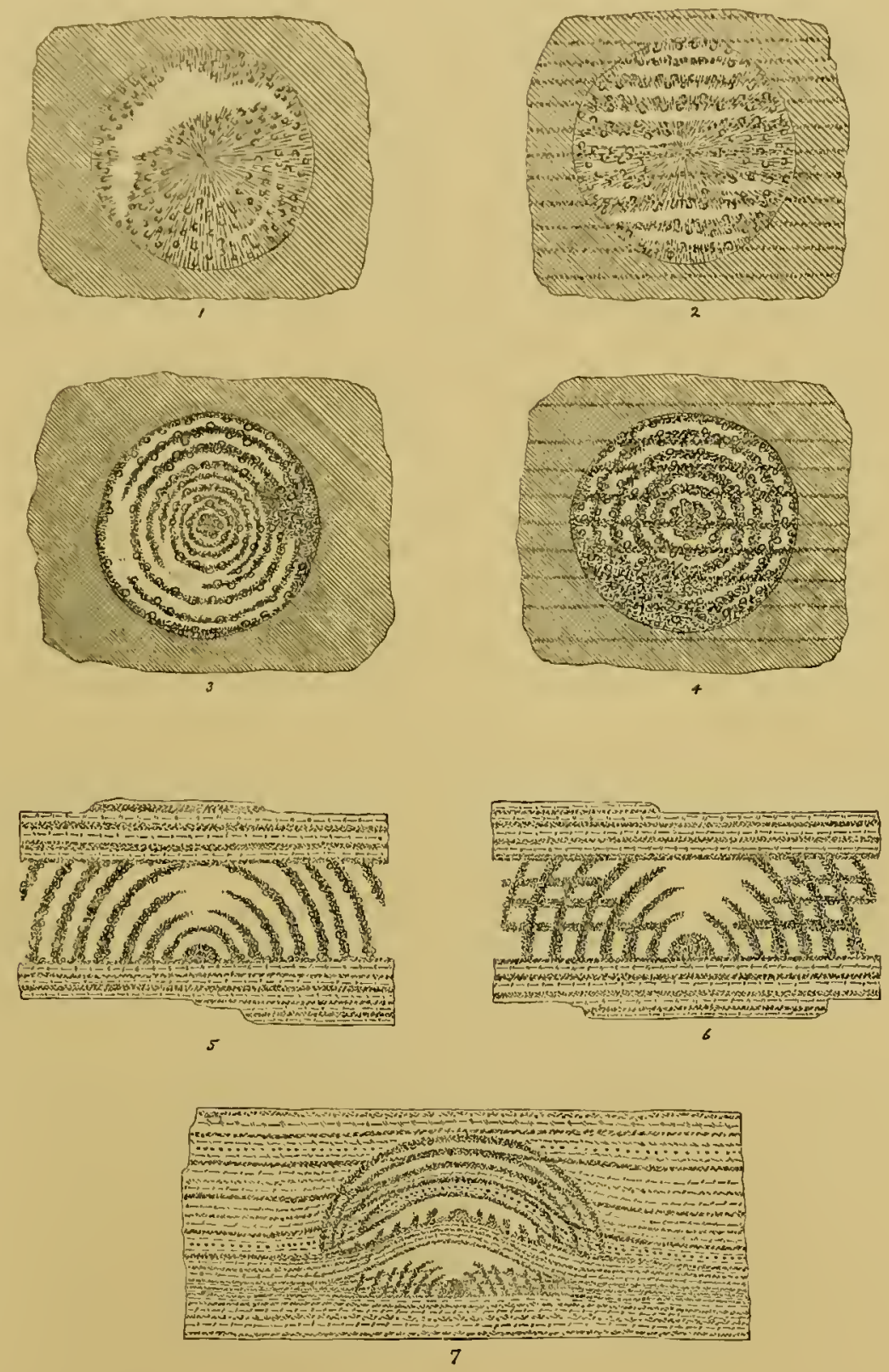

DIAGRAMS OF LITHOPHYSAE 

the rock exhibit a more or less evenly gramular microstructure, which may be microcrystalline or mierocryptocrystalline. In places it is hypidiomorphic: in others the grains are so minute as not to be distinctly discemible. In some calses this structure accompanies a distinct flow structure which is marked by opaque grains. In others no flow strncture is noticeable. It appears to be a primary crystallization in many cases, even where a flow structure is observer, when it must have been a crystallization accompanying the final solidification of the rock. But it is undonbtedly secondary in some instances, which are not of frequent occurrence among the extremely little altered rhyolites of the Yellowstone Park.

RELATIONS OF TIE VARIOUS MICROSTRUCTURES TO ONE ANOTHER IN TIE ROCK MASS.

The various microstructures which have been described in detail in a systematic mamner occur together in quite different combinations. Pumice is found associated with dense glass, and grading into it. Usually the surface of a flow is pumiceous, as at Obsidian Cliff, but the easily abraded pumice has undonbtedly been carried away by glaciation in most places. It is not, however, a necessary accompaniment of obsidian flows, as is shown by such lava streams in the island of Lipari. It was probably more frequent in the Yellowstone region. Pumiceons and compact glass is often intermingled over the surface of the plateaus. The dense glass is usually microlitic and often spherulitic, but in no ease has pumice been found to contain spherulites. They occur in vesicular obsidian.

The various kinds of microlitic glass may be found in close association with one another, and all the different forms of incipient crystallization and spherulitic aggregation may be found in a single specimen of rock, even in one thin section. It oftener happens that a particnlar form of spherulitic growth prevails throughout a considerable mass of rock. But in such occurrences as the rhyolitic flow at Obsidian Cliff there are parts of the mass in which there is great variability in the microstructure within short distances. In a great many localities it is clearly seen that the thick flows of rhyolitic lava were pumiceous and glassy at the top and glassy for some distance downward, nsually with megascopic splierulites. They then became lithoidal by the development of microspherulitic structure, as in the lithoidite at Obsidian Cliff. The microcrystalline to microcryptocrystalline 
modifications exist in some cases near the bottom of the lava sheet, but no definite mode of occurrence has been made out. In places the bottom part of the flow is glassy and dense; in places it rests on a bed of pumiceous tuff and is lithoidal; that overlying the rhyolitic tuff on Mount Everts is microcrystalline (1762). The indurated tuff, indistinguishable from the overlying massive lava, exhibits a fragmentary glass structure, with some axiolites, and occasional spherulitic structure independent of the outline of the fragments, while parts of the mass are isotropic.

\section{LAMINATION AND BANDING.}

Lamination and banding are highly dereloped in the lithoidal portion of the rhyolitic flow at Obsidian Cliff. They are very generally present in a higher or lower degree in all the rhyolites of the Park. In fact they form one of the commonest characteristics of acid lavas, and are equally uncommon among the basic ones. They are clearly due to the spreading out through flowage of a more or less heterogeneous riscous fluid. Homogeneous portions of the mass, of whatever shape, will spread out and flatten during the flow of the whole body of lava, becoming thin lenticular layers if the spreading or flow is sufficiently extended. A mass consisting of portions which differed from one another in color or composition would become, after spreading out upon the surface of the earth, a body made up of layers of different color or composition, which would wedge out in thin edges between one another. A cross section of such a body would exhibit a more or less streaked, banded, or laminated structure according to the original size of the different portions and to the extent of the spreading.

In the case of the lithoidite at Obsidian Cliff, it can be shown that the cause of the differences in the layers was unquestionably the different amounts of water vapor present in them. For in the lithoidite the layers differ in their degree of crystallization, some being glassy, others microspherulitic, others more coarsely so and porous, while others are nicrogranular with larger cavities. Some layers have locally developed crystallization in the form of large spherulites and lithophysæ. In the obsidian the differences consist in layers of spherulites, large and small, in bands of lithophyse, and in layers abounding in micrographic feldspars, microscopic spherulites, microlites, and trichites-that is, in the different phases of crystallization. Near the surface of the lava flow the laminated 
condition of the rock shows itself in layers of compact glass full of microlites which alternate with layers full of gas cavities and with little or no microlites. And in the lighly pumiceous part of the flow it is seen that the inflation of the glass is more marked in some layers, while there are spots in which the inflation is specially pronounced. These differences in the pumiceous parts of the rock are due to variable amounts of water vapor in the layers of the lava; and similar differences must have existed in lower parts of the same lava sheet. Moreover, the kinds of minerals crystallized are those whose formation is known to be aided by the presence of water vapor and other vapors. Further, the localization of more abundant water vapor, which gave rise to specially inflater spots in the pumice, is undoubtedly the cause of the crystallization of isolated spherulites in the compact glass.

The greater frequency of lamination and localized crystallization in acid lavas as compared with basic ones is a consequence of the generally greater viscosity of acid lavas at the time of their eruption. The basic rocks have a considerably lower melting point and are much more liquid up to very near the temperature of solidification. Hence diffusion would take place more rapidly and the magma would be more homogeneous, other things being equal. The heterogeneity of the acid lavas, so far as known, is confined to the distribution of vapors, presumably of water, and suggests that the water thus irregularly disseminated has not existed within the magma long enough to become uniformly diffused. It must therefore be looked upon as water absorbed near the earth's surface. Whether there may also have existed water vapor in the magma having a much longer commection with it, is more difficult to demonstrate, though it is highly probable. 
GEOLOGY OF THE YELLOWSTONE NATIONAL PARK.

\begin{tabular}{|c|c|c|c|c|c|c|c|c|}
\hline & 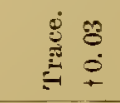 & & & & & $\stackrel{\leftrightarrow}{\stackrel{1}{\longrightarrow}}$ & $\stackrel{\odot}{\stackrel{+}{ \pm}}$ & $\begin{array}{l}\exists \\
\pm\end{array}$ \\
\hline & 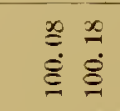 & 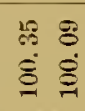 & 结 & 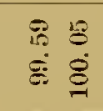 & $\begin{array}{l}\frac{\infty}{0} \\
\stackrel{g}{1}\end{array}$ & 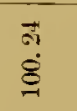 & 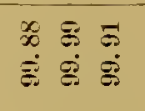 & 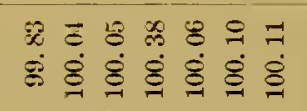 \\
\hline$\stackrel{9}{=}$ & 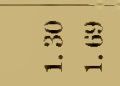 & $\stackrel{8}{*}$ & \%ి & 角 & $?$ & 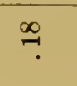 & $\underset{8}{P}$ & 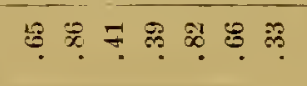 \\
\hline $\mathscr{F}^{\infty}$ & sit & 鸹 & תึ & & & $\vdots$ & {$\left[\begin{array}{c:}\bar{a} \\
\vdots\end{array}\right.$} & 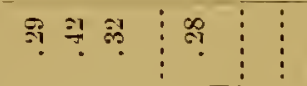 \\
\hline$\overbrace{}^{\circ}$ & 总 & 竞 & $\subsetneq$ & $\stackrel{\infty}{\cdots}$ & $\exists$ & 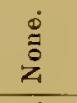 & 部离 & 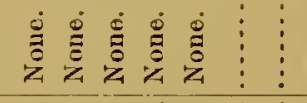 \\
\hline 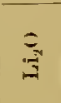 & 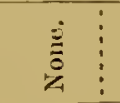 & $\begin{array}{l}8.00 \\
-8\end{array}$ & 递 & & ! & & 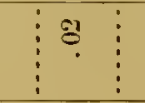 & की \\
\hline 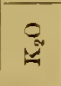 & 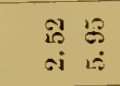 & 㴅 8 & $\stackrel{9}{\leftrightarrow}$ & 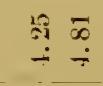 & \% & 象 & 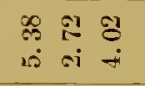 & 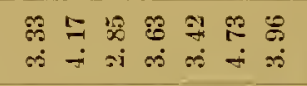 \\
\hline 产 & 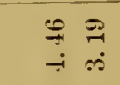 & 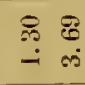 & $\stackrel{8}{\circ}$ & : & $\stackrel{8}{\square}$ & $\stackrel{\Re}{:}$ & \begin{tabular}{lll}
$\infty$ & $\infty$ \\
$\infty$ & $\infty$ \\
\hdashline$i$ & 8 \\
\hdashline$i$ & $\infty$
\end{tabular} & 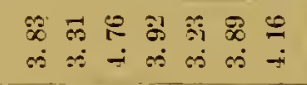 \\
\hline : & 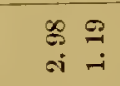 & 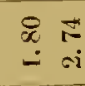 & $\stackrel{8}{\circ}$ & $\stackrel{9}{=}$ & 里 & 앙 & 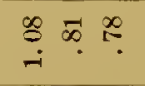 & 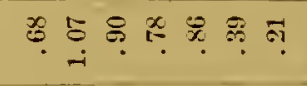 \\
\hline$\underline{\underline{y}}$ & 量: & 吕路 & 8 & $\stackrel{?}{?}$ & है. & $\stackrel{8}{8}$ & 电 & จ \\
\hline 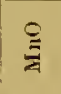 & 莺点 & 宅 竞 & $\stackrel{g}{g}$ & $\pm 气$ & $\because$ & 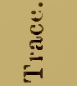 & 总离 & 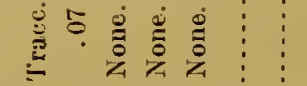 \\
\hline 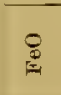 & $\stackrel{8}{8}:$ & ㅇํำ & 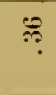 & $\stackrel{\Xi}{\Xi}$ & $\overrightarrow{\mathrm{F}}$ & $\stackrel{\circ}{-}$ & \&. : & 或 \\
\hline 部 & i: & 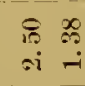 & 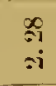 & 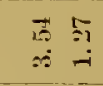 & $\begin{array}{l}= \\
\Delta i\end{array}$ & 施 & $\because \underset{-i}{8} \overline{0}$ & 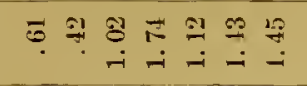 \\
\hline से & 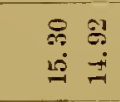 & 是是 & 政 & 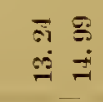 & 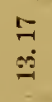 & 5 & 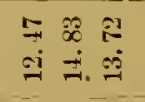 & 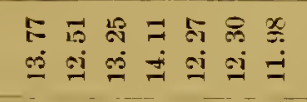 \\
\hline$\approx$ & $\stackrel{1}{8}=$ & 部 & 离 & $\cong \cong$ & $\dddot{\vartheta}$ & ㅇํㄹ. & : & 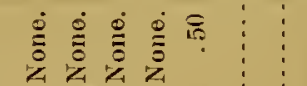 \\
\hline$\frac{\check{O}}{n}$ & 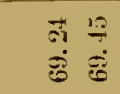 & 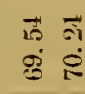 & 웅 & 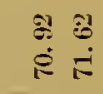 & $\stackrel{\substack{x \\
i}}{i}$ & 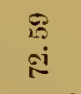 & 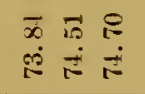 & 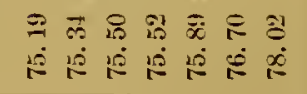 \\
\hline & 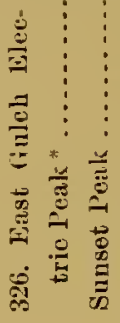 & 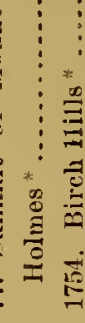 & & 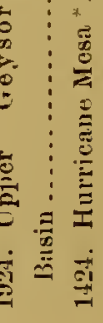 & & 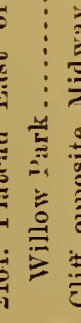 & 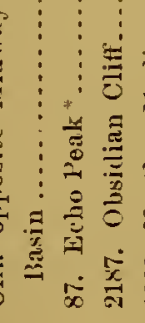 & 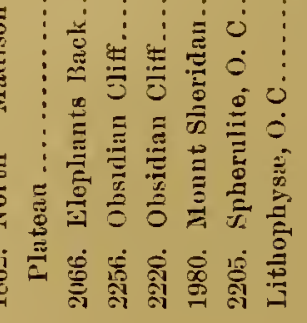 \\
\hline
\end{tabular}




\section{VARLATONS IN COMPOSITION AMONG TIE RHYOLITES.}

The havals which would be classed together as rhyolites on account of their fichl relationships and similarity of labit are found to differ somewhat in composition, both chemical and mineralogical. The chemical composition of the commonest and also of the extreme varieties is shown by the analyses in the accompanying table. With them have been placed for comparison analyses of the most siliceons intrusive rocks from several localities in the Park.

The range of silica in the rliyolite is from 70.92 to 75.89 per cent. Four varieties contain between 74.70 and 75.89 per cent. They are the flow forming Obsidian Cliff, in part obsidian, in part lithoidite; lithoidal rock at Mount Sheridan; obsidian from the Elephant Back, and lithoidal rhyolite from Madison Plateau north of the canyon. These represent the normal rhyolite of the region. Another variety of rhyolite, which appears to be a common form and carries abundant quartz phenocrysts, has 71.85 per cent of silica. It is lithoidal and is part of the great mass forming the table-topped spurs at the head of Tower Creek. A variety of obsidian occurring north of Obsidian Cliff and apparently a portion of the obsidian flow of that locality, though not certainly so, contains 72.59 per cent of silica. This rock is more of a pitchstone than obsidian, and has a dull resinous luster. The variety lowest in silica, with 70.92 per cent, constitutes the lava in the immediate vicinity of the Upper Geyser Basin. It is lithoidal and dark colored, without noticeable phenocrysts of quartz.

Alumina varies but slightly in these rhyolites, from 12.27 to 14.11 per cent. The alkalies are morlerately ligh, being 6.65 to 8.50 per cent, with soda in excess of the potash in most cases. The alkaline earths are the most variable, lime ranging from 2.25 to 0.68 per cent, magnesia from 1.05 to 0.07 per cent, and ferric oxide from 3.54 to 0.42 per cent. Ferrous oxide forms 1.55 to $0.08 \mathrm{per}$ cent, the sum of the iron oxides ranging from 4.20 to 1.63 per cent. There is about 0.30 per cent of titanium oxide in three cases, and none was found in three other cases. Phosphorous pentoxide was found only in the less siliceous varieties.

The chemical composition of the rhyolite from the head of Tower Creek is not wholly in accord with the mineral composition and habit of the rock, which has abundant glassy feldspars and quartzes, plagioclase being 
prominent. There are some small crystals of augite and magnetite. The mineral composition is not rery different from that of many other rhyolites, but there are minute inclusions of dark-colored rock not clearly recognizable, probably basalt. This would explain the rather abnormal amount of lime and the low silica.

The chemical composition of the lava from the Upper Geyser Basin is in accord with the mineral composition and habit of the rock, which represents the least siliceous varieties occurring in the Yellowstone Park. The rock is dull brownish gray, with numerous small phenocrysts, which are mostly white feldspars. These are plagioclase, apparently oligoclaseandesine, the presence of orthoclase being doubtful. 'There is no quartz. Magnetite is in comparatively large grains; augite is partly altered, and has dropped out in preparing the sections. Apatite and zircon occur. The groundmass is microspherulitic, with brownish spherulites and numerous strongly doubly refracting needles, dotted with minute opaque grains. These are altered microlites of augite with attached grains of magnetite. These brownish microsplerulites with dark needles are characteristic of this variety of rhyolite, which might properly be classed as dacite. Occurring, as they do, as rather infrequent modifications of the great bodies of rhyolite, they are here treated as dacitic facies of rhyolite. Exposures of this rock occur back of the Grand Geyser and in a small hill near the Splendid Geyser, in the Upper Geyser Basin. It forms the bluff west of the Paint Pots, near the road in Geyser Meadow, where the finely vesicular rocks resemble a basic andesite or basalt in outward appearance, but contain phenocrysts of quartz, sanidine, and plagioclase. 'There are other' localities, less accessible, in which dacitic facies of the rhyolite occur.

The chemical composition of pitchstone north of Obsidian Cliff is that of a dacitic rather than of a rhyolitic glass, and yet the microscopical characters indicate a closer relation to basalt, or augite-andesite. There are, in fact, small inclusions of basalt scattered through the glass. The cliaracter of the microscopic crystals and their similarity to those of the inclosed basalt have been pointed out. The comparatively high percentage of lime and magnesia, and the much greater amount of soda than of potash, correspond to these mineralogicnl characteristics, and are not wholly due to the inclusions of basalt. The different specimens of this dull obsidian 
or pitchstone exhibit a grudual transition in the character and proportions of the microseopic crystals or microlites from those of normal obsidian to the abnormal basaltic facies (2164). It is to be noted that this facies is not dacitic in its habit, although the silica percentage is 72.59. Snch facies are uncommon. The oceurrence, as well as its transition into obsidian with lithophysa, suggests that its magma is a transition form between riryolite and basalt.

The slight variations in composition which are expressed by the mineralogical cluracter of the rhyolite in different places do not appear to be comected with any particular locality, although they are sometimes characteristic of large areas of rhyolite. They recur in all parts of the region, and appear to be oft-repeated modifications of the magma, dependent as much on physical conditions as on chemical variability.

From the table of chenical analyses (p. 426) it is seen that the most siliceous facies of the Holmes bysmalith, which occurs along its margin at Echo Peak, is almost identical chemically with portions of the lava flow at Obsidian Cliff, while the main mass of the bysmalith lias nearly the composition of the dacitic facies of the rhyolite at the Upper Geyser Basin, but is lower in potash and higher in alumina. The fine-grained granite from the volcanic core of the Crandall volcano has almost exactly the same composition as the rhyolite from the Upper Geyser Basin. The dacite-porphyries of Bunsen Peak and Birch Hills have nearly the composition of the rhyolite from Tower Creek and of the abnormal obsidian from the platean east of Willow Park, but they are higher in alumina and a trifle ligher in lime, with a little less silica. The quartz-mica-diorite-porphyry from the volcanic core of Electric Peak, though nearly as high in silica as the rhyolite of the Upper Geyser Basin, is distinctly higher in lime and lower in potash. On the other hand, the trachytic rhyolite from the flanks of Sunset Peak, north of the Park boundary, while agreeing with the rhyolite of the Upper Geyser Basin in most of its chemical composition, is lower in soda and higher in potash.

The rocks here compared with the rhyolite are the more acid phases of magmas that belong to much earlier periods of eruption. They show the tendency of these magmas to differentiate into facies whose composition approaches that of the rhyolite more or less closely. 
INTERMYGLED RIYOLITE AND BPASALT.

In several localities, chiefly on the plateau west of Beaver Lake and on the south bank of Gardiner River south of Bunsen Peak, there are lavas whose abnormal appearance is striking. At the first-mentioned locality the rock is partly lithoidal and dark gray, with phenocrysts of feldspar and quartz, partly purplish gray to reddish, and finally porous or resicular. The latter contains small phenocrysts of feldspar, generally lath-shaped or tabular, besides quartz grains, and occasionally olivine. The resicular cavities have minute white pellets of tridymite. Other parts of the same rock are dark gray and lithoidal or glassy, with dull gray spherulites, 8 or $10 \mathrm{~mm}$. in diameter and smaller. These are distinctly radially- fibrons and slightly porous, in some parts of the rock passing into hollow splierulites $(1804,1806)$. These rarious modifications of the rock grade into one another and intermingle in streaks without any distinct line of demarcation between them. The appearance is that of a completely fused mass of somewhat differently constituted materials. In places in this vicinity the spherulitic glassy rhyolite incloses distinct fragments of basalt (1802).

The microscopical characteristics are somewhat different from those of normal rhyolite. The glassy portion in thin section is in places colorless and sometimes perlitic. The number of microlites varies; in some places they are searce, in others abundant. They consist of rectangular feldspars, and some with pointed corners. There are microlites of quartz and microprisms of angite, with a few of homblende, and in some instances minute hexagonal plates of hematite or biotite. In places the colorless glass grades into brown along the contact with basalt. The brown glass contains crystals from the basalt, and appears to have been produced by a fusion of the latter, larger crystals of feldspar occasionally projecting into the brown glass. The colorless ghass has penetrated resicular cavities in the basalt and has partly fused the latter. The brown glass grades into globulitic and trichitic colorless glass by the concentration of the coloring material. By a more distinct crystallization there arise angite prisms and needles with minute grains of magnetite attached to their surface; also thin curved needles or "hairs" of augite, to which are attached clusters and clonds of minute specks of magnetite. The extremely delicate lair-like needles of angite are straight or curved and sometimes curled up at the end. Occasionally the stouter needles are broken into lines of "margarites" whose 
angitic chanacter is unquestionable. These angite needles often project from the basalt into the glass. In one case the colorless glass contact zome contains moss-like aggregates of red and opanue iron oxide attached to angite needles.

Spherulitic crystallization las taken on a variety of forms. In several instances it produces a border against the basalt, radiating into the glass, in which there are also isolated spherulites of the same character-that is, distinctly fibrons and faintly doubly refracting, with no well-marked dark arms. Where megascopic spherulites occur they are distinctly fibrons and porous, with spleerules of tridymite. 'The fibers or microprismis are mostly optically positive; occasionally negative. These spherulites surround phenoerysts and also fragments of basalt. Some smaller spherulites are brown in transmitted light and have brown curved rays or fibers, distinct from those of feldspar. In the rhyolite-basalt fusion on Gardiner Rirer the augite needles associated with the sphernlites have been beautifully developed, and will be described in that connection.

The phenocrysts of quartz are sometimes rounded; those of sanidine in: certain cases possess a marginal zone which is clouded, and appears to contain another transparent mineral. This exhibits uniform orientation throughout. Porphyritical plagioclase is less common. Fragments of basalt and detacher crystals from it are scattered through the rhyolitic rock. In one instance the rock mass had more of the appearance of basalt than of rhyolite, and yet contained rounded phenocrysts of quartz with numerous olivines, occasionally in skeleton forms, and plagioclase and angite, with one individual of sanidine. The augites in the basalt are pale green in thin section; those from the rhyolite are stronger green.

With the pellets of tridymite which are attached to the sides of cavities in the basalt are occasional projecting crystals of brownish-green hornblende. Parts of the rhyolite are holocrystalline, with an almost microeryptocrystalline texture and hypidiomorphic structure, in which the shapes of feldspar crystals are recognizable.

In the intermingling of rhyolite and basalt on the south side of Gardiner River, south of Bunsen Peak, the resulting product is quite the same as that just described. Most of the rhyolitic portion, however, is holocrystalline, in part microsphernlitic. A smaller part is glassy. The brown fibrous spherulites exhibit numerous dark arms, and are optically negative. 
They also contain delicate needle-like prisms of augite, speckled with magnetite grains. These radiate from the center of the spherulite and are curved and forked, or branch into fern-slaped groups, with the branches making an angle of about $36^{\circ}$ with the main stem. Some spread in fan-like forms; others branch at nearly $90^{\circ}$, the branching prisms being different lengths. The cross sections are those of augite prisms bounded by prism faces and a pinacoid. The ontlines are often indistinct, as though the prisms consisted of a number of parallel crystals. The extinction angle reaches $42^{\circ}$.

It is evident, both from the occurrence of large fragments of basalt completely surrounded by rhyolite and from the microscopical character of the rocks, that the rhyolite fused the basalt and was the more recent eruption. The rhyolite must have been in a completely fused condition when it came in contact with the basalt, so that its temperature was higher than that of the melting point of basalt. The latter was not melted at any considerable distance from the contact with rlyolite, but behaved as though dissolved in the rhyolitic magma along the contact. 


\title{
C H A P T E R X I . \\ RECENT BASALTS.
}

\author{
By Joseph Paxson Iddings.
}

The recent basalts are those that were erupted after the extravasation of the rhyolite or during the period of rhyolitic eruptions. They are in most cases distinguishable from those basalts that were associated with the early andesitic breccias, and which have been described in comnection with those breccias. They occur immediately overlying the rhyolite, or intercalated between rhyolite sheets, or directly beneath them, in such a manner as plainly to be closely comnected with them in respect of the time of eruption. In many cases the basalt has been partially removed by erosion, leaving isolated patches and sheets scattered over the rhyolitic platean. Remmants of once extensive sheets of recent basalt occur west of the Gallatin Mountains and The Crags, overlying rhyolite. They are scattered over the platean south and occur in the broad valley of the Madison River. These basalts are characterized by the scarcity or total absence of noticeable phenocrysts. They are mostly dark gray and porous or minutely vesicular. They are extremely fresh and maltered, and the feldspars, when large enough to be seen megascopically, are brilliant microtine. Phenocrysts of microtine are sometimes scattered sparsely through the rocks. In a very few instances rounded grains of quartz were observed.

In a gray porous basalt with multitudes of minute feldspars and numerous brilliant phenocrysts of microtine, which is found on the ridge on the northern side of Madison Platean (589), there is a narrow streak through the basalt of vesicular and perlitic glass, which is mottled white and dark gray. It is apparently rhyolitic, and is probably the result of a fusion of the two rocks, resembling the occurrence of intermingled basalt MON XXXII, PT II-2S 
and rhyolite found on the plateau ridge 1 mile west of Beaver Lake (1804 et seq.) and just described in connection with the rhyolite.

The basalt sheets along Gardiner River, around the base of Bunsen Peak, and at Osprey Falls, and those in the valley of Lava Creek and at Undine Falls and in this vicinity, occur partly overlying rhyolite, partly beneath it. At Osprey Falls there are eight horizontal sheets of colmunar basalt directly overlain by a similar sheet of colmmiar rhyolite, which in turn is overlain by a horizontal sheet of columnar basalt. Owing to the dark color of the surface of the columns of rhyolite, all of the lava sheets appear alike when seen from a short distance. The rhyolite sheet is a thin edge of the great sheet of the plateau south. The petrographical character of the basalts at this place is like that of those just described-dark gray, with abundant minnte feldspars and occasionally larger ones of microtine. The same is true of the basalts in the valley of Lava Creek and of those at Undine Falls. Here the position of the sheets is like that of those at Osprey Falls, but their relation to the rhyolite is not so plaiu. Just north of this valley, along the crest of the south face of Mount Everts, there are several exposures of basalt directly underneath the rhyolite sheet which tops the mountain. The basalt is dark colored, vesicular, and scoriaceous, with few small phenocrysts of feldspar and pyroxene (618 to 621). In another exposure it is more crystalline and vesicular, with numerons phenocrysts of medinm-sized microtine, and a few of olivine (622).

Remnants of basalt sheets occur on both sides of Yellowstone Valley from near Gardiner to Broad Creek, and also up the Lamar Valley. In some cases the time of their eruption, relative to that of the rhyolite, can not be learned. But in most cases their position with respect to other formations is such as to correlate them with the recent basalts. Petrographically also they resemble them.

In the neighborhood of Tower Falls basalt forms a massive sheet resting directly upon andesitic breccia, and has the kind of columnar structure characteristic of surficial lava streams. On the west side of the canyon, north of the falls, it forms a vertical cliff 150 feet high, with beautifully developed columnar structure, shown in PI. LVIII. The lowest part consists of deuse basalt, cracked into vertical columns, 2 to $2 \frac{1}{2}$ feet wide and 5 to 12 or 15 feet high. These merge upward through continuous rock into small, slender columns, which curve slightly torvard centers near the top of 
the cliff, where the basalt is vesicular. The small columns are 3 to 4 inches in diameter. All the columns, linge and small, have a wavy outline, with cross markings, like crude cliseling. In places the top of the cliff projects beyond the base, and sheets of small columns hang down like curtains.

The petrographical characters of these basalts is described in a later part of this chapter. The younger basalts in the valley of Lamar River, near Ametlysst, Soda Butte, and Opal creeks, are dense and dark gray and sometimes vesicular. They are aphanitic, rarely with small phenocrysts. Similar basalt occurs at the mouth of Miller Creek. In nearly all these occurrences the basalt sheets are columnar.

Basalt covers the rhyolite over the bottom of Falls River Basin. It must have formed a thin sheet of lava, for it has been cut through by the drainage channels, which are for the most part in rhyolite. The basalt forms ledges or low cliffs a short distance back from the streams, in some cases crossing them and giving rise to waterfalls. It seems to have stood at about the altitude of 6,500 feet around the margin of the basin and up the canyon of Beckler River. On Boone Creek, 4 miles above its moutl, it is very porous and also vesicular, very fresh, purplish and steel gray, and is filled with minute feldspars and some larger ones, also clusters of feldspars and olivine, which has a submetallic luster $(1760,1761)$. North of the mouth of Mountain Ash Creek it is denser and also vesicular, is gray and also mottled, and has few phenocrysts $(1757,1758)$. At Iris Falls, on Beckler River, it is dark gray and highly vesicular, without phenocrysts (1759), the lower portion of the flow being columnar in vertical prisms, 30 feet high. These basalts extend south and southwest and constitute the great lava plains of the Snake River Valley in Idaho.

The recent basalts differ among themselves in habit and microstructure, and some of them resemble closely some of the older basalts; but the greater number of them are distinctly different from the older basalts. In general they are dense, dark rocks, almost free from megascopic phenocrysts. Some are partially ophitic, and a great number are closely related to these, but are so fine grained that an ophitic structure has not been developed. For convenience of description they may be classified under. the following heads:

(a) Ophitic.

(b) Related to ophitic, but finer grained. 
(c) Very fine grained, with small feldspar phenocrysts.

It must not be forgotten, however, that these are often merely phases of crystallization that may sometimes occur in one and the same rock body.

\section{OPHITIC BASALT.}

The basalts with ophitic structure are very fine-grained, holocrystalline rocks, with very few small phenocrysts of lime-soda feldspar, in some cases none. They occur in all parts of the Park, having been found at a number of places on Yellowstone River, in the sheet opposite Tower Falls (661), near Garnet Hill (652), in the sheets at the mouth of Blacktail Deer Creek (625), and in those near Bear Gulch and elsewhere. It is a structural facies of the basalt underlying rhyolite on Mount Everts (622) and occurs in the basalt on the rhyolite plateau $(588,596)$. It also forms a facies of the basalt of Falls River Basin (1758). The proportions of the mineral constituentsaugite, labradorite, olivine, and magnetite-vary in different rocks. In some, augite is in excess of feldspar; in others, they are nearly equal to each other. The ophitic angites range from 0.5 to $1 \mathrm{~mm}$. in diameter; while the inclosed feldspars average $0.1 \mathrm{~mm}$. in length. The basalt overlying gneiss on the summit of Hellroaring Peak, just north of the Park boundary (658), las the greatest amount of augite and magnetite and rod-shaped iron oxide (itmenite?), with subordinate labradorite and olivine. The olivine is in small, nearly idiomorphic crystals, and also in a few small phenocrysts, besides a few of labradorite. A basalt from the plateau soutliwest of the Gallatin Mountains (588) is similar, but the labradorite is more abundant, and olivine in minute crystals, slightly reddened on the surface, is very abundant. Augite and magnetite are plentiful. There are no megascopic phenocrysts. Others are similar, but are finer grained. In one case (1041) augite and labradorite (about $\mathrm{An}_{3} \mathrm{Ab}_{2}$ ) are in nearly equal proportions, and magnetite and olivine are less than in the two previous cases. There are no megascopic phenocrysts. This structure is shown in Pl. LIX, fig. 1. The basalt from north of the mouth of Mountain Ash Creek, Falls River Basin (1758), is like the last in composition, but has small phenocrysts of long prismatic labradorite and olivine. These four rocks are almost perfectly fresh, and are holocrystalline, with numerous small pores. The basalts occurring near. Junction Butte and opposite Tower Fall $(652,654,661)$ are also holocrystalline, but have relatively more labradorite in tabular crys- 


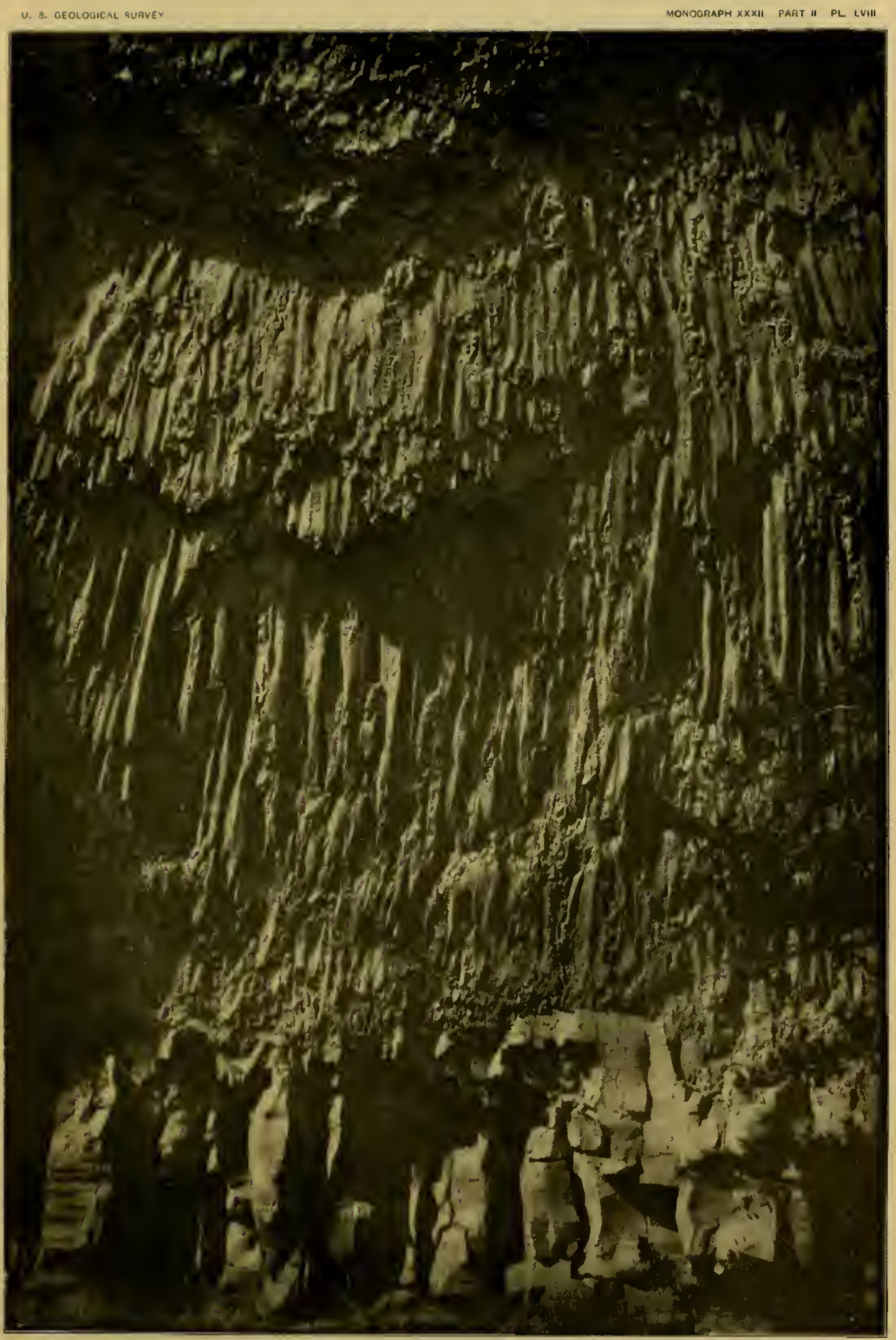

COLUMNAR STRUCTURE, YELLOWSTONE CANYON 


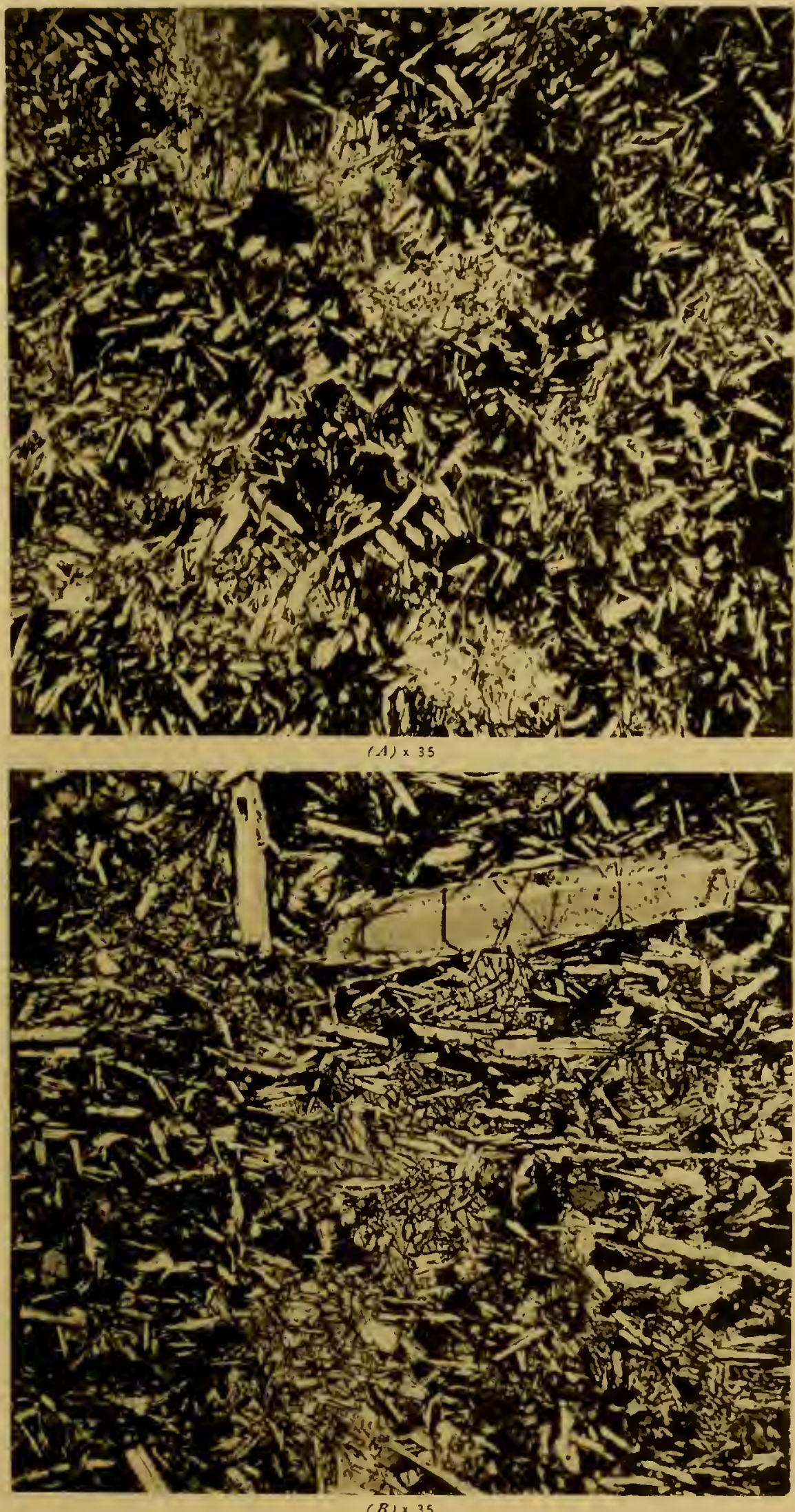

PHOTOMICROGRAPHS OF BASALT 

tals, with not so high double refraction as in the previous rocks. There is serpentine, resulting from the partial alteration of olivine. The iron oxide is mostly in rod-like crystals. The ophitic form of the basalt beneath rhyolite on Mount Everts (622) is like the first ophitic basalts in composition. The angite is about the same size, but the labradorite prisms are larger, and there is considerable globulitic and microlitic glass base scattered through the mass. Olivine is abundant in microscopic crystals. A few labradorites form phenocrysts. The rock is full of irregular cavities. The top sheet of basalt near the mouth of Bear Gulch, east of Gardiner, and another basalt flow in this vicinity, are like the last one, but in these there is an approach to a parallel arrangement of the feldspar prisms inclosed in the angite crystals (Pl. LIX, fig. 2).

\section{BASALTS RELATED TO THOSE WITH OPHITIC STRUCTURE.}

These basalts resemble those just described in mineral composition and in the character of the minerals, except that augite occurs in smaller crystals and grains, and not in relatively large micropoikilitic ones. Angite occupies about the same spaces as when it takes part in ophitic structure, but is in aggregates of small crystals. Olivine and magnetite are the same as in the ophitic rocks. There is a small amount of microlitic glass base.

Another modification of the basalt beneath the rhyolite on Mount Everts (623), and a vesicular basalt from the northern base of Prospect Peak (634), are finer-grained rocks, like the ophitic form of the first. mentioned basalt in composition, but with only a part of the augite inclosing labradorite, and thus being partly ophitic, the remainder of the augite being in small allotriomorphic grains between idiomorphic feldspars. The ferromagnesian minerals are in excess of feldspar, and magnetite is abundant. The chemical composition of the basalt from the north base of Prospect Peak (634) is shown by the following analysis. In this rock lime is considerably higher than magnesia, and soda is greatly in excess of potash. 
Analysis of basalt from the north base of Prospect Peak.

\begin{tabular}{|c|c|}
\hline Constituent. & Per cent. \\
\hline $\mathrm{SiO}_{2} \ldots \ldots .$. & 48.49 \\
\hline $\mathrm{TiO}_{2} . .$. & 2.19 \\
\hline $\mathrm{Al}_{2} \mathrm{O}_{3} \ldots \ldots \ldots \ldots \ldots \ldots \ldots \ldots$ & 18.35 \\
\hline $\mathrm{Fe}_{2} \mathrm{O}_{3} \ldots \ldots \ldots \ldots \ldots \ldots \ldots$ & 7.63 \\
\hline FeO & 1.21 \\
\hline $\mathrm{MnO} \ldots \ldots \ldots \ldots \ldots \ldots \ldots \ldots \ldots \ldots \ldots \ldots \ldots$ & None. \\
\hline MgO $\ldots \ldots \ldots \ldots \ldots \ldots \ldots \ldots \ldots \ldots$ & 6.72 \\
\hline $\mathrm{CaO} \ldots \ldots \ldots \ldots \ldots \ldots \ldots \ldots \ldots$ & 10.40 \\
\hline $\mathrm{Na}_{2} \mathrm{O} \ldots \ldots \ldots \ldots \ldots \ldots \ldots \ldots \ldots \ldots \ldots$ & 3.02 \\
\hline $\mathrm{K}_{2} \mathrm{O} \ldots \ldots \ldots \ldots \ldots \ldots \ldots \ldots$ & .57 \\
\hline $\mathrm{P}_{2} \mathrm{O}_{5} \ldots \ldots \ldots \ldots \ldots \ldots \ldots \ldots \ldots \ldots \ldots$ & .20 \\
\hline $\mathrm{SO}_{3}, \ldots \ldots \ldots \ldots \ldots \ldots \ldots \ldots$ & .52 \\
\hline $\mathrm{Li}_{2} \mathrm{O} \ldots \ldots \ldots \ldots \ldots \ldots \ldots \ldots \ldots \ldots \ldots \ldots$ & .02 \\
\hline $\mathrm{H}_{2} \mathrm{O} \ldots \ldots \ldots \ldots \ldots \ldots$ & .67 \\
\hline Total ................. & 99.99 \\
\hline
\end{tabular}

The basalt from another exposure on Mount Everts (618) and one from Falls River Basin (1757) have a little ophitic augite and much that is in grains. It is in excess of feldspar. A basalt from the south side of Lava Creek below Undine Falls (613) is richer in feldspar and the olivine is altered; otherwise it is similar to the basalts just described. The basalt from 4 miles above the moutl of Boone Creek (1739) and one from the Snake River Valley $(1760,1761)$ have no ophitic augite, but the prismatic labradorite is idiomorphic and the general character of the rock is the same as that of those just described; there is, however, considerable microlitic base, and ilmenite rods are numerous. Olivines are small, and the darkcolored minerals are in excess of the feldspar: The basalt from Iris Falls, Bechler River (1759), is very fine grained and partly ophitic, with minute feldspar phenocrysts.

The basalt overlying dacite-porphyry east of Bunsen Peak (606) is very much like the ophitic basalts. The lath-shaped labradorite is similar to that in the foregoing, but in places shows a slightly parallel arrangement. Basalts from numerous localities in the Park $(582,584,589,591$, $598,603,614,615,624,627,632,655,663,671$ ) are quite the same as the one last mentioned, but vary slightly in the relative proportions of augite and feldspar and in the size of the component crystals. All are holocrystalline, or nearly so. In some modifications of these rocks $(605,614)$ the 
labratorite prisms are more nearly parallel, with fluidal arrangement (Pl. XXXIV, fig. 4). Some of the phenocrysts of labradorite-bytownite are almost free from polysynthetic twinning, having but two or three parts. Others $(597,612,1139)$ ire nearly the same, with small grains or crystals. And still others $(593,610,611,636,1138,1141)$ are like the last, but contain more augite than feldspar.

\section{VERY FINE-GRAINED BASALTS WITH MINUTE PHENOCRYSTS.}

In the still finer-grained modifications of these basalts, which are very numerous, the lath-shaped or prismatic labradorite crystals range in size from about $1 \mathrm{~mm}$. long to extremely minute microlites. They are in a mass of magnetite grains and minute augite grains or crystals, sometimes with brown glass base, as in the coarser-grained forms, some resembling the foregoing rocks in microstructure $(581,616,626,662,1140)$. The average length of the labradorite prisms is $0.06 \mathrm{~mm}$. Even in thin section they are very dark gray. When still less crystalline they are darker, being nearly black in thin section. There is more microlitic glass base, which is crowded with grains of magnetite, some forming skeleton aggregates of the usual stellate or cruciform shapes $(619,637,653,660)$. One variety from beneath the rhyolite sheet on Mount Everts (621) has an almost panidiomorphic structure, the augites being in minute prisms. Olivine is scarce.

A modification of the fine-grained structure with feldspar prisms of nearly uniform size is one in which many small prisms of labradorite are in a groundmass of minute grains of magnetite and augite, about $0.01 \mathrm{~mm}$. in diameter, and olivine also forms small phenocrysts $(594,607,609,638,639$, 666). The finest-grained form consists of a groundmass of grains of magnetite and angite $0.004 \mathrm{~mm}$. in diameter, and very minute feldspars, with many small phenocrysts of labradorite and olivine, about $0.5 \mathrm{~mm}$. in length and smaller $(586,587,599,1796)$.

In all of these 69 recent basalts, with the single exception of the few almost microscopic augites in a basalt on Gardiner River, south of Bunsen Peak (1796), no augite phenocrysts occur. The most usual ones are labradorite, and less often olivine. In most cases there are no distinct, megascopic phenocrysts. Moreover, none of these basalts possess andesitic structure. If more coarsely crystallized, they would probably have all become ophitic. 


\section{H A P T E R X I I.}

\section{PALEOZOIC FOSSILS.}

SECTION I.-CAMBRian Fossils.

By Charles Doolittle Walcott.

The Cambrian famma of the Park includes 10 species that are referred to the upper division, and 21 that are referred to the middle and lower divisions, of the Middle Cambrian fauna. Of these, Acrotreta gemma is common to the upper and middle divisions. The Middle Cambrian fauna includes the following species:

Haguia sphrerica.

Obolus (Lingulepis) acuminatns var. meeki.

Iphidea sculptilis.

Iphidea (sp. undet.).

Acrotreta gemma.

Platyceras primordialis.

Hyolithes primordialis.

Aguostus biclens.

Agnostus interstrictus.

Agnostus tumidosus.

Ptychoparia penfieldi.

Ptychoparia antiquata.

Ptychoparia (sp. undet.).

Crepicephalus texanus.

Ptychoparia (Lonchocephalus) bamulus ?

Ptychoparia (Lonchocephalus) wisconsensis.

Ptychoparia (?) diademata.

A rionellus (sp. undet.).

Liostracus parvus.

Solenopleura weedi.

Zacanthoirles (sp. undet.).

Bathyuriscus? (sp. undet.).

This fauna is more intimately related to that of the Black Hills and the Upper Mississippi Valley in Wisconsin and Minnesota than to the Middle 
Cambrian fauna of Nevada or British Columbia. There are no indications of the Lower Cambrian or Olenellus fauma. The upper-division fauna is also strongly related in its Brachiopoda to the Mississippi Basin fauna. It includes the following species:

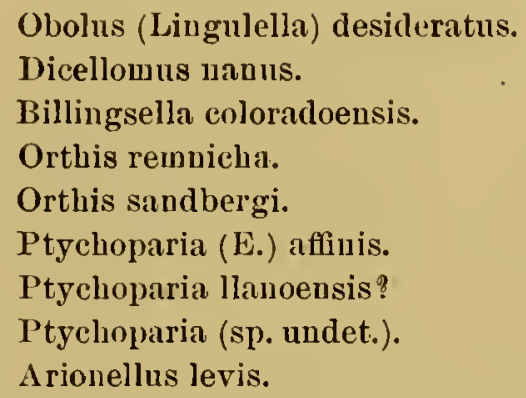

The species common to the Cambrian fauna of the Park and the Upper Mississippi Valley are as follows:

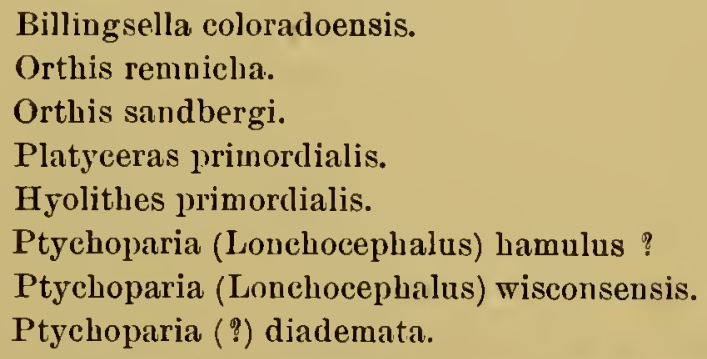

Of other species, Agnostus billens and Agnostus interstrictus are closely related to $A$. josepha, and it is quite probable that Dicellomus namus and Ptychoparia antiquata will be found in the Upper Mississippi Valley fauna.

Billingsella coloradoensis, Orthis remnicha, and Crepicephalus texanus are found in the Cambrian rocks of central Texas, and Ptychoparia antiquata and Crepicephalus texanus occur in the Middle Cambrian of northern Alabama.

It is anticipated that a large addition will be made to this fauna when the Cambrian collections from the Gallatin Valley north of the Yellowstone National Park are studied. The purpose of this paper is to describe and illustrate only the species found within the limits of the Park and the immediately adjoining Absaroka Range on the east.

Preliminary examinations of the collections were made from year to year as the specimens were brought from the field and reports were made to Mr. Arnold Hagne. When it was found possible to make a detailed study, I requested Mr. G. H. Girty to prepare the brachiopods contained in the collection, and I am indebted to him for assistance rendered in this direction. 


\title{
DESCRIPTIONS OF GENERA AND SPECIES.
}

\section{CAMBRIAN.}

\author{
HAGUIA n. gen.
}

Spherical bodies without any central axis or opening; with irregular lacunæ or canals separated by irregular walls of varying thickness that are built up of minutely granular carbonate of lime. The outer wall is perforated by the apertures of the numerous canals.

The genus is based on small spheroidal bodies that occur ou slabs of limestoue scattered among the fragmentary remains of trilobites (Ptychoparia (L.) wisconsensis, P. (?) diademata) and the two valves of Billingsella pepina. The transverse sections recall at once sections of Protopharetra densa Bornemann, ${ }^{1}$ but there is no central axis or cavity. Dr. Bornemann regards Protopharetra as a lower stage of development of Archæocyathus forms, but Dr. Hinde is inclined to consider it as a distinct generic type. ${ }^{2}$ The form now under consideration is clearly distinct from the cup-shaped and branching forms of the Archrocyathinæ and evidently the simplest type of the family. In fact, were it not for the absence of spicules and the presence of a canal system, somewhat like that of Protopharetra densa, I should refer it at once to the sponges $I t$ is on the border land between the corals, as represented by the Archæocyathinæ, and the sponges, with a tendency to the latter, which would have placed it among them previous to Dr. Hinde's studies.

\section{HAGUiA SPHÆRICA n. sp.}

Pl. LXIII, figs. $6,6 a$.

Small spherical bodies, varying from 2 to $8 \mathrm{~mm}$. in diameter, formed of minutely granular carbonate of lime. The irregular laminæ or canals are filled with crystalline calcite. The canals penetrate the outer wall and give the outer surface a roughened appearance, owing to the irregular disposition of the openings. In one section there is a rough radial arrangement of the canals, but in several others there is no trace of any regularity.

Nova Acta, Leop.-Carol. Deutscher Akad. Naturforscher, Vol. LI, Pt. I, 1886, Pl. VIII, fig. 8.

${ }^{2}$ Quart. Jour. Geol. Soc. London, 1889, Vol. XLV, p. 136. 
Formation and locality: Middle Cambrian, Flathead formation; north side of Soda Butte Creek, below saddle on ridge between Pebble and Soda Butte creeks, Yellowstone National Park.

\section{OBOLUS Eichwald.}

\section{Subgenus LINGULEPIS Hall.}

Lingulepis Hall, 1863: Sixteenth Aun. Rept. New York State Cab. Nat. Hist., p. 129. Lingulepis Meek and Hayden, 1864: Pal. Upper Missouri, Pt. I, p. 1.

Lingulepis Hall, 1867: Trans. Albany Institute, Vol. V, p. 106.

Lingulepis Hall and Clarke, 1892: Eleventh Ann. Rept. State Geologist New York (author's el.), p. 231, PI. I, figs. 16, 17.

Lingulepis Hall and Clarke, 1892: Pal. New York, Vol. VIII, Pt. I, pp. 59, 163.

Lingulepis Walcott, 1897: Am. Jour. Sci., 4th series, Vol. III, p. 404.

Type, Lingula aeuminata Conrad sp.= Lingula pinniformis Owen.

A comparison of a series of specimens of Obolus (Lingulepis) acuminatus from the Potsdam terrane and the base of the Caleiferons formation of Saratoga, Washington, Franklin, and Jefferson counties, New York, and from the same horizons in Ontario, Canada, with a large series of specimens from the St. Croix sandstone of Wisconsin, leads to the conclusion that Obolus (Lingulepis) pinniformis is a synonym of obolus (Lingulepis) acuminatus. This makes Obolus (Lingulepis) acuminatus the type of the subgenus Lingulepis, the original deseription of the geuus being based upon specimens from the St. Croix sandstone of Wisconsin.

The further study of the types of the species that have been referred to Lingulepis results in the elimination of all of them from the subgenus with the exception of Obolus (Lingulepis) acuminatus and its variety meeki.

The species that have been referred to Lingulepis lieretofore are now referied as follows :

Lingulepis dakotaensis M. and $\mathrm{H}_{.}=$Obolus (Lingulepis) acuminatus.

Liugulepis pinniformis Owen = Obolus (Lingulepis) acuminatus.

Lingulepis minima Whitfield = Obolus (Lingnlepis) acumiuatus.

Lingulepis perattenuata Whitfield $=$ Obolus (Lingulella) perattenuatus.

Lingulepis cuneolus Whitfield = Obolus (Lingulella) cuneolus.

Lingulepis ella H. and W.= Obolns (Lingulella) ella.

Lingulepis mativalis Hall = Obolns (Lingulella) matinalis.

Lingulepis mæra $H$. and $W$. = Obolus (Lingulella) mæra.

Lingulepis ? minuta $H$. and W. = Obolella minuta.

Lingulepis morsensis Winchell (Miller) = Iingula morsii.

Lingulepis prima $M_{\text {. and }} \mathrm{H}_{\text {. }}=$ Dicellomus politus. 
In a review of the Cambrian Brachiopoda, now being prepared, the Cambrian species referred to the subgenus Lingulepis will be fully illustrated.

Obolus (Lingulepis) acuminatus var. Meeki Walcott.

Pl. LX, figs. 1, $1 a$.

Lingulepis meeki Walcott, 1897 : Am. Jour. Sci., 4th series, Vol. III, p. 405.

Shell small, attenuate, marked by rather strong concentric lines and striæ of growth, and by interrupted irregular radiating striæ.

Ventral valve narrow, elongate; beak acuminate, rostral slopes long, nearly straight, passing gradually into the curvature of the anterolateral margins, and posteriorly meeting at a very acute angle; front strongly rounded. Lenth of valve, $8 \mathrm{~mm}$.; widtll, $3.5 \mathrm{~mm}$., the widest portion being near the anterior extremity. Beak slightly upcurved, the longitudinal median line straight, or even slightly concave from the apex of the beak to the middle, where it begins to slope gently to the frontal margin; transverse curvature very slight anteriorly, more convex near the beak.

Dorsal valve more convex than the ventral, linguliform; beak depressed, bluntly rounded, curving evenly and gradually to the semitruncate anterior margin.

The interior markings of this shell have not been ascertained, but the external characters are such as to make a reference to the genus Lingulepis more than probably correct. The flat acute-acuminate ventral valve, with its elevated or retrorse beak, which is not covered by the smaller dorsal shell, is peculiarly characteristic of Lingulepis.

There is a form from Texas, probably identical with Obolus (Lingulella) perattenuatus, that might be mistaken for this species, but it is an undoubted Lingulella, and does not show the external characteristics of Lingulepis. A comparison with the young and narrow specimens of $O$. (L.) acuminatus shows it to be clearly distinct from that species; the posterior rostral slopes of $O$. (L.) acuminatus possess a peculiar incurving which is not shown in the variety meeki.

Formation and locality: Middle Cambrian, upper beds of Flathead terrane, Crowfoot section, Gallatin Range, Yellowstone National Park. 


\section{OBOLUS Eichwald.}

Subgenus LINGULELLA Salter.

Obolus (Lingulella) desideratus Walcott.

I'I. LX, figs. $2,2 a$.

Obolus (Iingulella) desideratus Waleott, 1898: Proc. U. S. Nat. Mus., Vol. XXI, p. 399.

Shell small, subovate, with the ventral valve obtusely acuminate, and the dorsal valve broadly ovate. Valves are strongly convexed, with the ventral valve fully as much so as the dorsal. There is a little variation in the outline of the valves, some being slightly more rounded posteriorly than others.

The surface of the shell is marked by fine, concentric lines of growth and, between them, very fine, slightly irregular strix. A few rather narrow indistinct undulations radiate from the umbo toward the front and lateral margins. When the outer shell is partially exfoliated the outer surface of the inner layer is marked by very fine indistinct radiating strix. There are a few traces of small, scattered pits or punctæ on the inner surface of the shell. The shell is thin and is formed of an outer layer and one or more inner layers or lamellix.

The average length of the ventral valve is about $4 \mathrm{~mm}$.; width, $3 \mathrm{~mm}$. A dorsal valve $3.5 \mathrm{~mm}$. long las a width of $3 \mathrm{~mm}$.

A cast of the interior of a dorsal ralve shows an area of medinm length, divided midway by a narrow, clearly defined pedicle groove. The area of the dorsal valve is short. Nothing is known of the interior of the ventral valve, but in a cast of a dorsal valve may be seen traces of the main vascular sinuses and central median ridge, and of the central muscle scars.

observations.-This species from the Upper Cambrian may be compared with the Middle Cambrian O. (L.) ferrugineus of the Atlantic Basin fauna. Compared with the Rocky Mountain species it is intermediate between $O$. $(L$.$) menticulus and O$. (L.) rotundatus. It nay also be compared with $O$. (L.) granvillensis of eastern New York, upper Olenellus fauna.

What appears to be an identical species also occurs in the upper beds of the Secret Canyon shale just beneath the Hamburg limestone, 1,200 feet lower in the Eureka district Cambrian section. 
Formation and locality: Upper Cambrian, Gallatin limestone, Crowfoot section, Gallatin Range, Yellowstone National Park; Hamburg shalo near Hamburg mine, Eureka district, Nevada. A variety also occurs in the Secret Canyon shale 1,200 feet below the Hamburg shale.

\section{DICELLOMUS Hall.}

Dicellomus Hall, 1873: Twenty-third Ann. Rept. New York State Cab. Nat. Hist., p. 246. Obolella Hall, 1892: Pal. New York, Vol. VIII, Pt. I, p. 72.

When proposing that the genus Dicellomus include Obolella polita, Profes or Hall stated that the grooving or emargination of the apices of both valves and the thickening of the edges of the shell on each side below the apex, together with the form and character of the muscular impressions, would separate the species from Obolella. Again, in 1892, Messrs. Hall and Clarke gave a fuller description of Dicellomus politus, but owing to the poor character of the material, he did not feel confident that it should be recognized as generically distinct from Obolella chromatica. Material now in the collections of the Geological Survey clearly shows that Professor Hall's provisional conclusion was correct, and that Dicellomus politus is generically distinct from Obolella chromatica. The generic characters are also finely shown by specimens of Dicellomus nana (M. and H.) from the Little Rocky Mountains of Montana, and also by the interior of the ventral valve, figured by Meek and Hayden. The cast of the interior of the ventral valve is shown by fig. $3 c, \mathrm{Pl}$. LX, and the interior of the ventral valve from the Black Hills by fig. 3d, PI. LX. These will be found to differ from the illustrations of Obolella polita given by Professor Hall, ${ }^{1}$ but the material from which the figures were drawn was poor, and, to a certain extent, the drawings are somewhat constructive, as stated by Professor Hall. ${ }^{2}$ From the specimens before me, as shown by figs. $4,4 a, \mathrm{Pl}$. LX, it is clear that Dicellomus politus and $D$. namus are congeneric. Further illustrations of the characters of $D$. politus will be given in a review of the Cambrian Brachiopoda. 


\section{Dicellomus Nanus M. and H. sp.}

Pl. LA, figs. $3,3 a-d$.

Obolelle nana Meek and Hayden, 1861: Proc. Acad. Nat. Sci. Philadelphia, 2d series, Vol. V, 1. 435. Billings, 1862: Paleozoic Fossils, Vol. I, p. 67. Hayden, 1863: Am. Jour. Sei., 2d series, Vol, XXXIII, 1. 73. Meek and Hayden, 1864: Pal. Upper Missouri, Pt. I, p. 4, PI. I, figs. 3a-d. Whitfield, 1880: U. S. Geog. and Geol. Surv. Rocky Mountain Region, p. 340, PI. II, figs. 14-17. Hall and Clarke, 1892: Pal. New York, Yol. VIII, Pt. I, p. 69.

Only a single specimen of the onter surface of a ventral valve of this species occurs in the collection. It has the characteristic appearance of the species. The species also occurs in abundance in the Little Rocky Mountains to the north, in Montana, and also to the eastward in the Black Hills.

The specimen from the Park is illustrated, and, in addition, the types from the Black Hills and two specimens from the Little Rocky Mountains.

Formation and locality: Upper Cambrian, Gallatin limestone (upper portion); Crowfoot section, Gallatin Range, Yellowstone National Park.

\section{IPHIDEA Billings.}

\section{IPHIDEA SCULPTILIS Meek.}

Pl. LX, figs. 5, 5a-c.

Iphidea (??) sculptilis Meek, 1873: Sixth Ann. Rept. U. S. Geol. and Geog. Surv. Terr., for the year 1872, p. 479 .

Kutorgina minutissima Hall and Whitfield, 1877: U. S. Geol. Expl.40th Par., Vol. IV, p. 207, PI. I, figs. 11, 12.

Kutorgina sculptilis Waleott, 1884: Mon. U. S. Geol. Surv., Vol. VIII, 1. 20, Pl. I, figs. 7, 7a-b; PI. IX, fig. 7.

In the description of Iphiclea (??) sculptilis, Mr. Meek decided that, as the shell had a very narrow, slightly flattened margin on each side, representing a false area, and as there seemed to be a wide, open, triangular foramen, it could not be referred to the genus Acrotreta or the genus Iphidea. He was not positive that there was not a permanent pseudodeltidium present, but, assuming the absence of that structure, and with the probability that when all the characters of the shell were known it would be found to belong to a different genus, either of the Brachiopoda or of some other group, he would propose for the genus the name "Micromitra." 
A study of the material collected from the same horizon at a point not far distant from the original locality shows the presence of a false area and a pseudo-deltidium of the same character as that of Iphidea bella, the type of the genus Iphidea. There is, however, a difference in the two forms that might possibly be considered of subgeneric value. The surface of Iplidea bella is covered with fine concentric strix, while the surface of Ipliclea sculptilis is marked by very fine, sharp, elevated, concentric lines that coalesce or bifurcate irregularly, imparting a peculiarly interrupted wavy appearance that is highly characteristic. The variation in the surface character is continued still further in Iphidea pannula White, in which the surface is marked by a very fine network of oblique raised lines that divide it into minute porelike pits, which cause it to resemble under the lens the texture of finely woven cloth. The difference in character of surface between Iphidea pamula and I. sculptilis is the same difference as between the surface characters of Trematis and Lingulella; and the difference in surface characters between the two species mentioned, on the one hand, and Iphidea bella and I. labradorica, on the other hand, is equally important, as the latter have the plain concentric striæ and lines of growth that are characteristic of the species, while the former have highly ornamenterl surficces. If we should find the genus on the surface characters of the shell, it would be necessary to place I. bella, I. labradorica, and I. prospectensis under one genus, I. ornatellu (Linnarsson) and I. sculptilis under another, and I. panmele and I. coclata under still another. There are, however, specimens of $I$. pannula on which the outer portions of the shell show the surface characters of I. bella; and more or less complete transitions may be found between the varying types of surface ornamentation.

There are too many similarities in form to warrant us in removing I. sculptilis from Iphidea without the evidence of interior markings to prove that it is generically distinct.

Formation and locality: Middle Cambrian, Flathead terrane (lowest fossiliferous bed); Crowfoot section, Gallatin Range, Yellowstone National Park. It also occurs in the Middle Cambrian shales of Antelope Springs, Utah. 
Irinusa sp. undet.

1'l. IS, fig. li.

Dorsal ralve senicircular, slightly convex. Hinge line somewhat shorter than the widtl of the shell below; nearly straight, the rostral angle about $180^{\circ}$. Beak small, not elevated. Surface olnamentation consists of extremely fine radiating and undulating concentric striae that can be seen in detail only with a strong magnifying glass. Shell substance horny.

This form is associated with 1 . sculptilis, and, juclging from external characters, is closely related to it. The surface ornamentation is of the same character, and, in the absence of the ventral valve, it is difficult to distinguish any specitic characters on which to base a new species, although the shell is much larger than that of typical I. sculptilis.

Formation and locality: Same as last, for Ipllidea sculptilis.

\section{ACROTRETA Kutorga.}

Acrotreta gema Billings.

Pl. LXIl, figs. 2, 2a-e.

Acrotreta gemma Billings, 1865: Pal. Foss., Vol. I, p. 216, figs. 201a-f.

Acrotreta subconica Meek, 1873: Sixth Ann. Rept. U. S. Geol. Surv. Terr., p. 463.

Acrotreta attenuata Meek, 1873: Ibid., p. 463.

Acrotreta pyxirlicula White, 1874: Geog. and Geol. Expl. Surv. W. 100th Merid.:

Prelim. Rept., Invert. Foss., p. 9. White, 1875: Ibid., Final Rept., Vol. IV, p. 53, Pl. III, figs. 3a-d.

Acrotreta gemma Walcott, 1884: Mon. U. S. Geol. Surv., Vol. VIII, p. 17, Pl. I, figs. $1 a, b, d, f$; Pl. IX, figs. 9, 9a. Walcott, 1856: Bnll. U .S. Geol. Snrv. No. 30, p. 98, PI. VIII, figs. 1, 1a, b. Walcott, 1891: Tenth Ann. Rept. U. S. Geol. Surv., p. 608, Pl. LXVII, figs. 5. 5a-e. Hall and Clarke, 1892: Pal. New York, Vol. VIII, Pt. I, p. I02, figs. 55-57. (?) Matthew, 1895: Trans. New York Acad. Sci., Vol. XIV, p. 126.

This species was described and illustrated by me in Bulletin No. 30, Monograph VII, and the Tenth Ammual Report, of the United States Geological Survey. It occurs with both the Middle and the Upper Cambrian faunas in the Park.

Formation and locality: Middle Cambrian, Flathead terrane, ranging from the lowest terrane; Gallatin terrane, upper beds; Crowfoot section, Gallatin Range; spur at southeast head of first branch from head of Gallatin Valley, south side; Yellowstone National Park.

MON XXXII, P'I II-29 


\section{BILLINGSELLA Hall.}

Billinysella Hall and Clarke, 1592: Pal. New York, Vol. VIII, P’t. I, p. 230, Pl. VII A, figs. 1-9.

Billiygsella coloradoensis Shumard.

Pl. LXI, figs $1,1 a-d$.

Orthis eoloradoensis Shmmard, 1860: Traus. St. Louis Acad. Sci., Vol. I, p. 627.

Orthis pepina Hall, 1863: Sixteenth Ann. Rept. New York State Cab. Nat. Hist., p. 134, PI. VI, figs. 23-27. Hall, 1867: Trans. Albany Iustitute, Vol, V, p. 113. Whitfield, 1882: Geol. Wisconsin, Vol. IV, p. 170, Pl. I, figs. 4, 5.

Orthis? (Orthisina?) pepinu Hall, 1883: Second Ann. Rept. New York State Geologist, Pl. XXxVII, figs. 16-19.

Billingsella pepina Hall and Clarke, 1892: Pal. New York, Vol. VIII, Pt. I, p. 230, Pl. VII, figs. 16-19; Pl. VIlA, figs. 7-9.

This species was described by Shumard, in 1860, as from the Potsdam sandstone of the New York series, near the head of Morgans Creek, Burnett County, Texas. He states that "the general form of the shell is very similar to a species in my cabinet from the Potsdam sandstone of Miunesota."

In 1863 Professor Hall described a similar shell, from the sandstone above Lake Pepiri, Minnesota, under the name of Orthis pepina, stating that when compared with Orthis coloradoensis from Texas the species is much smaller, the length of the ventral valve is greater, and the strix are finer. However, a comparison of an extended series of specimens collected in the Upper Cambrian of Bumett County, Texas, leads me to believe that the specimens from widely separated localities all belong to the one species Billingsella coloradoensis.

The size and form of these species appear to be remarkably constant wherever found, as is also the surface ornamentation, which consists of fine concentric strix and slender radiating costre, which are often mequal in size. The concentric strixe are unusually well shown in the material from Texas, while the radiating costre are very fint. On specimens from the St. Croix sandstone of Lake Pepin, Minnesota, the costre and the concentric: strixe and lines of growtl are strong and well shown in the casts of the outer surface of the shell. The generic characters are finely shown by specimens from the Gallatin Range in the Park, in which the characteristic muscular scars of the ventral valve of Billingsella are well preserved; also 
the high, nearly vertical areal, and the large delthyrium, partially closed by a convex deltidium.

Formation and locality: Upper Cambrian, Gallatin terrane, Crowfoot section, Gallatin Range; also on the north slope of the Crowfoot Ridge, on the south side of the Gallatin Valley, and on the divide between Panther Creek and the Gallatin River.

\section{OR'THIS Dalman.}

Or'this (?) Rexinicha Winchell.

Pl. LXI, figs. 3, 3a; Pl. LXII, figs. 1, 1a-đ.

Orthis remnicha. Wiuchell, 18s6: Fourteeuth Aun. Rept. Geol. and Nat. Hist. Surv. Minuesota, p. 317, Pl. Il, fig. 7 .

Shell of medim size, usually slightly transverse, with an oblong, oral outline for the ventral valve, and a subquadrate to semicircular ontline for the dorsal valve. Valves moderately convex, with an almost straight hinge line that varies in length from nearly the greatest width of the shell to twothirds the greatest width; cardinal angles varying from $90^{\circ}$ or less in the extreme forms, with ears somewhat angular, to the other extreme, where they are very obtuse and liave the appearance of being almost rounded, their angle being not less than $120^{\circ}$. Cardinal area narrow but well developed on each valve, and divided by a rather large delthyrium.

The ventral (pedicle) valve has in some specimens a shallow mesial depression, and in some examples it is slightly flattened toward the cardinal angles; beak small and curving down toward the hinge line, beyond which it projects slightly. Dorsal (brachial) valve slightly less convex than the rentral. Beak small, scarcely projecting beyond the hinge line.

Surface marked by bifurcating, radiating coste, that vary on shells of similar size from 16 in the space of $5 \mathrm{~mm}$. to 3 in the same space. This variation is shown in the specimens from the Park, as well as in those from Texas and Wisconsin. In well-preserved specimens very fine, radiating, raised strix occur both on the costæ and on the intervening depressions. These are shown on the casts of the shells fiom the St. Croix sandstone of Winfield, Wisconsin, and on the larger shells from the limestones of the upper Middle Cambrian horizon of Texas and the Park.

The interior of the ventral (pedicle) valve shows a slightly raised, 
rather small muscular area, and the interior of the dorsal (brachial) valve a slightly elevated area upon which oceurs a narrow, short median septum. The crural plates are also well shown. In casts of the interior from the St. Croix sandstone of Wisconsin the dental lamellæ of the ventral valve are finely shown, and in the dorsal valve the median septum and crural plates.

This is one of the most variable shells that occur in the Cambrian fauna. Its range of variation is such in all of the widely separated localities in which it occurs that one would scarcely hesitate, if in possession only of the extremes, to identify two well-marked species. The variation is not only in the radiating costre, but also in the general form of the shell. It is proposed to illustrate this variation somewhat fully in a memoir on the Brachiopoda of the Cambrian fauna.

Formation and locality: Near base of Upper Cambrian, Gallatin terrane, Crowfoot section, Gallatin Range, Yellowstone National Park. It also occurs at a sliglitly lower horizon on the south side of the Gallatin Valley, and specimens were collected farther to the north by Dr. A. C. Peale, opposite the mouth of Pass Creek, in the Gallatin Valley, Montana.

\section{Orthis (?) SANDbergi Winchell.}

PI. LXI, figs. $2,2 a-d$.

Orthis sandbergi Winchell, 1886: Fourteenth Ann. Rept. Geol. and Nat. Hist. Surv. Minnesota, p. 31s, Pl. II, tigs. 8, 9.

Shell small, transverse, subquadrate in outline, exclusive of the acute angular ears. Valves slightly convex, with a straight hinge line longer than the greatest width of the shell; cardinal area narrow but well developed on each valve and divided by a rather large open delthyrium.

The ventral (pedicle) valve slightly flattened at the ears, rising toward the center with a convex triangular swelling, broadening from the narrow beak to the front; beak small, rounded, and extending slightly beyond the hinge line. Dorsal valve flattened at the ears, with well-marked rounded ridges rising between the ears, and a rather broad, well-defined median sinus; beak very small, slightly encroaching upon the hinge line.

Surface marked by fine, regular, radiating strix, between which one or more faint intermediate stria are sometimes visible; under favorable con- 
ditions very fine concentric stria can be seen, and there are also ustally present more or less distinctly marked lines of growtl.

The generic climacter of this species las not been fully ascertained, but the material from the Park and specimens from the typical locality at Red Wing, Minnesota, lead me to think that this can not be referred to the genus Billingsella. It appears to be an Orthis of the Plectorthis group of Hall and Clarke.

A comparison with specimens of Orthis sandbergi from the typical locality at Red Wing, Minnesota, shows the two shells to be specifically identical, as far as the comparison of casts in sandstone can be made with well-preserved shells on the surface of a limestone slab. This is the only species of the type known to me in the Cambrian fauna. It is a type that is developed in the Ordovician fama, and I think it will be found to occur in the Calciferous-Chazy fauna of New York and the St. Lawrence Valley.

Formation and locality: Upper Cambrian, north side of Elk Pass, between Buffalo and Slongh creeks, Yellowstone National Park.

\section{PLATYCERAS Conrar. \\ Platyceras prinordialis Hall? \\ PI. LXIII, fig. 1.}

Platyceras primordialis Hall, 1863, Sisteenth Ann. Rept. New York State Cab. Nat. Hist., p. 136, PI. VI, fig. 28.

A single species of Platyceras occurs on a slab of limestone in association with Billingsella pepina, Ptychoparia (L.) wisconsensis, and Ptychoparia (?) diadematus.

So far as can be determined from a comparison of the single specimen, it is probable that the forms are identical.

Formation and locality: Middle Cambrian, Gallatin terrane, nortlı side of Soda Butte Creek, below saddle on ridge between Pebble Creek and Soda Butte Creek, Yellowstone National Park. 


\title{
HYOLITHES Eichwald.
}

\author{
HYolithes primordialis Hall.
}

PI. LXIII, figs. $2, ? \because a$.

Thecu primordialis Hall, 1861: Anı. Rept. Progress Geol. Surv. Wisconsin, p. 48. Hall, 1862: (ieol. Rept. Wiscousin, Yol. I, p. 21, fig. 5. Hall, 1863: Sixteenth Anı. Rept. New York State Cab. Nat. Hist., p. 135*, Pl. VI, figs. 30, 31.

Pugiunculus primordintis Hall, 1863: Ibid., p. 135*.

Theca (Pugiunculus) gregarin M. and H., 1861: Proc. Acad. Nat. Sei. Philadelphia, 2d series, Vol. V, p. 436. M. and H., 1864: Pal. Upper Missouri, Pt. I, p. 5.

Hyolithes (Theca) primordialis Hall and Whitfickl, 1873: Twenty-third Ann. Rept. New York State Cab. Nat. Hist., p. 242, Pl. II, fig. 3.

Byolithes primordialis? White, 1874: Expl. Surv. West 100th Merid., I'relim. Rept., Invert. Foss., p. 6.

Hyolithes primordialis White, 1875: Ibid., Final Rept., Vol. IV, Pt. I, p. 37, Pl. I, figs. 5a-e. Whitfield, 1883: Geol. Wisconsin, Vol. IV, p. 175, Pl. I, fig. 12. Walcott, 1884: Mou. U. S. Geol. Surv., Tol. VIII, Pal. Eureka District, pp. 23, 24.

Forms of this species occur at several localities, and are identical with those found in the Middle Cambrian St. Croix sandstone of Wisconsin. 'They vary in length from 1 to $5 \mathrm{~cm}$. The young individuals when grouped together in the limestone are very closely related to, if not iclentical with, Thec greyaria. ${ }^{1}$ The type specimens of the latter were found near the head of Powder River in the Bighom MIountains of Idalo Territory, now in Wyoming.

Formation and locality: Middle Cambrian, Flathead formation, Crowfoot section, Gallatin Range; Clark Fork Valley, south side, between Lodge Pole and Reef creeks; and bluff on south side of Pebble Creek, north of saddle to Soda Butte Creek, Yellowstone National Park.

\section{AGNOSTUS Brongniart.}

\section{Agnostus interstrictus White.}

Pl. LXIII, figs. $3,3 a$.

Agnostus interstrictus White, 1874: Geol. and Geog. Expl. West 100th Merid., Prelim.

Rept., Invert. Foss., p. 7. White, 1875: Ibid., Final Rept., Vol. IV, Pt. I, p. 38 , PI. II, 5a, 乙. Walcott, 1S86: Bull. U. S. Geol. Surv. No. 30, p. 149, Pl. XVI, figs. $6,6 a$.

A comparison of the specimens from the Gallatin Range with the type specimens from the Springhouse Range of Utah leads to the conclusion 
that they represent the sime species. There are no good specimens of the head, but there is one very well preserved pygidinm. This and the type specinem are illustrated.

Formation and locality: Middle Cambrian, Flathead formation, Crowfoot section, Gallatin Range, Yellowstone National Park.

Agnostus bidens, Meek.

Pl. LXIII, figs. 4,4 ,

Agmostus bidens Meek, 1873: Sixth Ann. Rept. U. S. Geol. aud Geog. Surv. Terr., for 1S72, 1. 463. Walcott, 18s4: Mon. U. S. Geol. Surv., Vol. VIII, p. 26, PI. IX, figs. $13,13 \%$.

The specimens representing this species include the head and pygidium only. There is considerable similarity between this species and $A$. interstrictus and A. josephus, the latter from the St. Croix sandstone of Wisconsin. They all belong to the Middle Cambrian fama, and it will be only after a careful examination with an extended series of specimens that the specifie characters are well determined.

The originals of the type specimens were found on the east side of the Gallatin River, above the town of Gallatin, they being associated with essentially the same fauna as that with which they occur in the Gallatin Range.

Formation and locality: Middle Cambrian, Flathead formation, Crowfoot section, Gallatin Range, Yellowstone National Park.

\section{Agnostus tumidosus Hall and Whitfield.}

Pl. LXIII, figs. 5, $5 a$.

Agnostus tumidosus Hall and Whitfield, 1S77; U. S. Geol. Expl. 40th Par., Pt. II, p. 231 , Pl. I, tig. 32 .

This species is represented by a small cephalie shield, and there is an associated pygidium that is referred to it. The species was founded upon a small head discovered in the Eureka district of Nevada. It is a strongly marked speeies and not liable to be confused with any other species of the genus from the Cambrian rocks of the Rocky Mountain region.

Formation and locality: Middle Cambrian, Flathead formation, Crowfoot section, Gallatin Range, Yellowstone National Park. 


\section{P'TYCHOPARIA Corda.}

\section{Ptychoparia PENFieldi 11. sp.}

Pl. LXV, figs. $4,4 a, b$.

Of this species there are in the collection the central parts of the head, the interior of one free cheek, and one pygidium. The general form of the head is transverse, semicireular; the frontal rim strong, rounded, and separated from the frontal limb and free cheeks by a well-defined rounded furrow; posterior lateral angles prolonged into slencler spines. Glabella truncato-conical; nearly as broad at the base as long; marked by three pairs of glabella furrows, which penetrate abont one-fourth the distance across; the posterior pair bend slightly backward and penetrate toward the center. Fixed cheeks narrow and separated from the glabella by a welldefined clorsal furrow, from the narrow posterior rim by a rather-broad, clearly defined furrow; anteriorly they merge into the rather narrow frontal limb. Palpebral lobes narrow and elearly defined by a groove from the fixed cheek; they are nearly one-third the length of the cheek; ocular ridges barely discernible above the general surface of the cheek. The posterior lateral lobe of the fixed cheek extends outward, so as to give a total length from the glabella outward somewhat greater than the width of the glabella at the base. The associated free cheek has a strong marginal rim and well-marked furrow between it and the main body of the cheek, which reaches up to the palpebral lobe.

Pygidium small, semicirenlar; axial lobe strongly defined and marked by three segments and a short terminal portion; lateral lobes marked by three rather broad segments that merge into the smooth outer rim. Surface apparently smooth.

Formation and locality: Middle Cambrian, Flathead terrane, Crowfoot section, Gallatin Range, I'ellowstone National Park.

\section{Ptychoparia antiquata Salter sp.$$
\text { Pl. LXV, figs. 7, } 7 \text { a. }
$$

Conocephalus antiquatus: Quart. Jour. Geol. Soc. London, Vol. XV, p. 554, fig. 2.

This species was founded on an entire trilobite sent to the great exposition in London in 1851. It was said to have been discovered somewhere 
in the State of Georgia. From the occurrence of large numbers of entire speeimens on nodules in the Coosal Valley, in Alahanna, a few miles west of the Georgia State line, it is thought probable that the specimen referred to came from that locality. A comparison of a series of specimens from the Coosa Valley locality with the Gallatin Range specimens shows a very close resemblance between them. The Alabama specimens lave two marked variations in the frontal limb and border; in one the limb is gently rounded to a marked groove that separates it from a strong roumded frontal rim; in the other, the groove in the frontal rim curves backward from each side toward the glabella so as to indent the frontal linb. As a result of the comparison, it is found that the range of variation anong the individuals of P. antiqueta includes not only the Gallatin species but also the varieties of it.

Formation and locality: Middle Cambrian, Flathead formation, Crowfoot section, Gallatin Range; bluff on south side of Pebble Creek, north of saddle to Soda Butte Creek; on ridge near Crowfoot section, Gallatin Range, Yelfowstone National Park. East of Dead Indian Creek, Absaroka Range, Wyoming.

\section{Ptychoparia (E.) afFinis Walcott. \\ Pl. LXV, fig. $S$.}

Ptychoparia (E.) affinis Walcott, 1881: Mon. U. S. Geol. Surv., Vol. VIII, p. 54, Pl. X, fig. 12.

With the material at hand it is impossible to make a positive identification with the type species from the Upper Cambrian of the Eureka district, Nevada. There is, however, a striking similarity in the only portions we have for comparison, the center of the head.

A similar species occurs in the Cambrian beds of Honey Creek, Burnett County, Texas, and it is probable that the specimens from the three widely separated localities are identical.

Formation and locality: Middle Cambrian, Gallatin limestone, Livingston section, at lead of Davis Creek, Snowy Range, Montana. 


\section{Ptychoparia llanoexsis Walcott (?) \\ Pl. LXIV, fig. 4.}

Ptychoparia llanoensis Walcott, 1590: Proc. U. S. Nat. Mus., Vol. XIII, 1. 272, Pl. XXI, tigs. 3-5.

The fragments that have been compared and provisionally identified with this species show only the central portions of the head. The frontal rin and border, separated by a narrow, raised, cremulated line on the cast of the under surface of the test, and the glabella, appear to be identical with those of some of the specimens of $P$. llanoensis.

Formation and locality: Middle Cambrian, Livingston section, at head of Davis Creek, Snowy Rangre, Montama.

\section{Ptrychoparia sp. undet.}

Pl. LXIV, fig. 5.

This is a rather strongly marked form, of which only the central portion of the head is preserved. It differs from other described species in having the frontal rim project inwardly almost to the front margin of the glabella. A figure is presented of the only specimen in the collection. The head may be compared with the head of Ptychoparin teucer, from the red sand rock of Highgate Springs, Vermont. ${ }^{1}$ It is possible that this is a strongly marked variety of $P$. antiquata.

Formation and locality: Middle Cambrian, Flathead formation, near Crowfoot section, Gallatin Range, Yellowstone National Park.

\section{Ptychoparia (?) sp. mindet.}

\section{Pl. LXIV, fig. 3.}

This is a clearly marked form, represented by the central portion of the head. The small eye lobes and strong postero-lateral limbs suggest Ptychoparia cryon. Hall, ${ }^{2}$ but the glabella is less elongate and the frontal limb is marked by a rounded rim.

Formation and locality: Middle Cambrian, Crowfoot section, Gallatin Range, Iellowstone National Park. 


\section{CREPICEPHALUS Owen.}

Crepicephulus Oren, 1852: Rept. Geol. Snrv. Wiseonsin, Iowa, and Minnesota, 1. 576, Pl. 1, fig. s: Pl. I A, tigs. 10, 16, 18. IIall, 156i3: Sixteenth Ann. Rept. New York State Ilus. Nat. Hist., 1. 147. Hall and Whittield, 1577: Rept. Geol. Expl. 40th Par., Vol. IV, Pt. II, p. 209. Whitfield, 1876: Rept. Reconnaissance from Carroll, Montana, to Yellowstone National Park (Lndlow), p. 141. Whittield, 1880: Rept. Geology and liesources of the Black Hills (Jenuey), p. 341. Whitfield, 18s2: Geol. Wisconsin, Vol. IT, p. 1S:. Walcott, 1884: Bull. U. S. Geol. Surv. Yo. 10, 1.36. Waleott, 18sli: Bull. U. S. Geol. Surv. No. 30, 11). 206, 207.

Attention was called to this genus in $1886,{ }^{1}$ but in giving an entire fignre of C. terums I will repeat the description given by Dr. Owen, and also add a few remarks.

Dr: Owen proposed the generic name Crepicephalus for some fragmentary remains of trilobites, the characteristic features of the central portion of the head of which he described, and he also gave figmes of the associated pygidia. The description of the central portion of the head is as follows:

The rather flat slipper-shaped glabella is tapering and slightly acuminated anteriorly, with a faint ridge in the median line; two small and very superficial depressions, and a posterior faint furrow, very partially divide the glabella. The theial sutures run nearly parallel to the margin of the glabella, and join a thickened, corllike, anterior narrow border, inelosing a convex area, narrower in front than at the sides. Oblique plications can sometimes be traced on the cheek plate, in advance of the eye, converging toward the apex of the glabella.

In his remarks on the genus, he refers to figs. 10, 16, and 18 of $\mathrm{Pl}$. IA, as illustrating the central portions of the cephalic shield of the genus. The comparison of these figmres with typical specimens of Crepicephalus (Owen's Dikellocephalus) iowensis shows clearly that the types of the genus Crepicephalus should have been referred to this species. He also refers to the associated pygidia which are illustrated by his fig. 8 of Pl. I and fig. 16 of Pl. IA, a comparison of the pygidium of Crepicephalus ionensis with these figures showing it to be identical.

In the description of fig. 13 (Pl. I) the species wisconsinensis is referred with a (?) to the genus Crepicephalus. No reference, however, is made to it in the text. Professor Hall, in referring to the genus, ${ }^{2}$ speaks of this as the only species designated by Dr. Owen, and states that it offers no distinction, in regard to the head, from a species placed under the genus Lonchocephalus. 
He considered it difficult to sustain this genus, or either of them, upon the characters given, and referred all to the genus Conocephalites.

Messrs. Hall and Whitfield, in deseribing Cambrian trilobites from Utah and Nevada, discussed the genus Conocephalites and revived Crepicephalus as a subgenus equivalent to Loganellns of Devine. They did not, however, describe the genus Crepicephalus, but referred a number of species to it which possess more or less distinctly marked "slipper-shaped" glabellæ. Professor Whitfield subsequently used the genus in his description of Crepicephalus (Loganellus) montanensis; ${ }^{1}$ also in the Paleontology of the Black Hills of Dakota." But later (1882) he omitted reference to Loganellus in describing Crepicephalus onustus. ${ }^{3}$

In 1884 I stated that Crepicephalus might be used as a subgenus of Ptychoparia on account of its peculiar pygidium, but, from a recent study of an entire specimen of the type species and of C. texumus, I think that we can with propriety use it as a full generic term. The essential elements of the head are generically identical with those of the head of Ptychoparia striata, but the pleura of the thoracic segments and the pygidinm vary in a marked mamner. The pleura terminates in the graceful backward-curving acuminate points so characteristic of many species of Paradoxides. This may not be considered a character of generic value, but it gives a marked aspect to the body of the trilobite in both C. iocensis and C.texuns. The pygidium of $C$. iowensis is short, broad, and provided with two long postero-lateral spines which appear to be an extension of the border, but in reality are the lateral extension of one of the segments of the pygidium. This feature is more clearly shown in the pygidium of $C$. texanus. The combination of characters in the head, thorax, and pygidium clearly distinguishes the genus from Ptychoparia and other genera of the Conocephalidx.

\section{Crepicephalus texanus Shumard sp.}

Pl. LXV, fig. 5 .

Arionellus (Bathyurus) texamus Shumard, 1861: Am. Jour. Sci. and Arts, 2d series, Vol. XXXII, p. 218.

Arionellus tripunctutus Whitfield, 1876: Rept. Reconnaissance from Carroll, Montana Terr., on the Upper Missonri, to the Yellowstone National Park (Ludlow), p. 141 Pl. I, figs. 3-5.

Numerous heads of this species occur in a dark-greenish-colored oolitic

${ }^{1}$ Bull. U. S. Geol. Surv. No. 30, p. $141 . \quad$ Loc. cit., pn. 341-343. $\quad{ }^{3}$ Loc. cit., p. 182. 
limestone, with a few fiagments of the pygidium. The material is too poor to properly illustrate the species, and a figure is introduced that was drawn from specimens collected in the Niddle Cambrian shaly beds of the Coosa Valley, Alibama. A detailed deseription of the species and full illustrations will be given in a memoir on the Middle and Upper Cambrian faumas, now being prepared.

The type specimens of the species were deseribed by Dr. Shminard from Llano County, Texas. I collected a series of specimens from the type locality, and a comparison of these with those from Moss Agate Springs, near Camp Baker, Montana (described as Arionellus tripunctatus by Whitfield), and the Coosa Valley, Alabama, shows them to belong to one species.

Formation and locility: Middle Cambrian, Flathead terrane, north side of Soda Butte Creek, below saddle on ridge between Pebble Creek and Soda Butte Creek; Flathead terrane, Crowfoot section, Gallatin Range, Yellowstone National Park.

\section{Ptychoparia (Lonchocephalus) hamulus Owen?}

Lonchocephalus hamulus Owen, 1852: Geol. Rept. Wisconsin, Iowa, and Minnesota, p. 576, Pl. IA, figs. S, 12.

Conocephalites hamulus Hall, 1863: Sixteenth Ann. Rept. New York State Mns. Nat. Hist., p. 166, Pl. VII, figs. 43, 44; Pl. VIII, figs. 25, 26.

One imperfect head is all there is in the collection on which to base the presence of this species. Little nore can be said than that there is a form which represents it.

Formation and locality: Middle Cambrian, Flathead formation, north side of Soda Butte Creek, on ridge between Pebble Creek and Soda Butte Creek, Yellowstone National Park.

\section{Ptychoparta (Lonchocephalus) wisconsensis Owen sp. Pi. LXIV, figs. 1, 1a-c.}

Crepicephalus (?) wisconsensis Owen, 1852: Rept. Geol. Surv. Wisconsin, Iowa, and Minnesota, description, Pl. 1, fig. 13.

Dicellocephalus latifrons Shumard, 1863: Trans. St. Louis Acad., Vol. I1, p. 101.

Conocephalites visconsensis Hall, 1863: Sixteenth Amn. Rept. New York State Cab. Nat. Hist., p. 164, PI. VII, figs. 39-41; Pl. VIII, figs. 't2-24, 27, 28.

This species occurs in abundance in thin-bedded limestone in the northeastern portion of the Park. It is associated with Ptychoperia (?) dia- 
demata, an association which also occurs in the Middle Cambrian St. Croix sandstone of Wisconsin. Numerous heads occur, but only one fragmentary pygidium has been seen. An illustration of the pygidium is taken from a specimen found in the St. Croix sandstone 4 miles southeast of Lake City, Minnesota.

Formation and locality: Middle Cambrian, Flathead formation, north side of Soda Butte Creek, below saddle on ridge between Pebble and Soda Butte creeks, Yellowstone National Park.

\section{Ptychoparia (?) diademata Hall sp. \\ Pl. LXIV, figs. 2, 2a-c.}

Conocephalites diadematus Hall, 1S63: Sixteenth Ann. Rept. New York State Cab. Nat. Hist., p. 167, Pl. VII, figs. 36-38; Pl. VIII, figs 18, 21.

This species is associater with Ptychoparia (L.) wisconsensis. The central portions of the head are quite abundant and associated with the separated free cheeks. Two finely preserved hypostomas and one imperfect pygidium also occur on the slabs of limestone. The pygidium is illustrated by a specimen from the St. Croix sandstone, found in the bluff near Hudson, Wisconsin.

Formation and locality: Middle Cambrian, Flathead formation, north side of Soda Butte Creek, below saddle on ridge between Pebble and Soda Butte creeks, Yellowstone National Park.

\section{ARIONELLUS Barrand.}

\section{Arionellus levis 11. sp.}

Pl. LXY, tig. 1.

It is with little doubt that the specimen illustrated is referred to this genus. It has a strongly convex, minute head, $4 \mathrm{~mm}$. in length; glabella nearly as broad as long; narrowing slightly toward the broadly rounded front; glabella furrows barely risible as four short, slightly depressed lines. It is separated from the fixed cheeks and fiontal limb by a narrow groove, which is all that breaks the general convexity from the frontal margin back to the occipital furrow. The occipital furrow is deeply impressed between the glabella and the very narrow depressed occipital ring. Fixed cheeks slightly convex, sloping abruptly toward the facial sutures; anteriorly they 
pass into the rather broad frontal limb, which slopes directly downward to the frontal margin, without any frontal groove or rim. The palpebral tobes are sitnated opposite a point abont two-thirds the distance from the posterior to the anterior margin of the glabella.

Formation and locality: Middle Cambrian, Gallatin limestone, Crowfoot seetion, Gallatin Range, Yellowstone National Park.

Arioxelues sp. undet.

Pl. LIV, fig. 2.

Only the central portion of the head of this species is known. It is so distinct a type that I do not hesitate to refer it to the genus Arionellus. The glabella is elongate, subconical; the glabella furrows are indicated by very slight depressions, and the occipital furrow is almost obliterated. Fixed cheeks as broad as the glabella and merging into the broad, rounded, anterior frontal limb. The palpebral lobes are broken away and there does not appear to be any frontal rim, the gently rounded slope from the glabella to the margin being umbroken. The specimen strongly recalls specimens of Arionellus from the Paradoxides zone of Newfoundland.

Formation and locality: Middle Cambrian, Flathead formation, north side of Soda Butte Creek, below saddle on ridge between Pebble and Soda Butte creeks, Yellowstone National Park.

\section{LIOSTRACUS Angelin.}

\section{Liostracus parvus $11 . \mathrm{sp}$.}

\section{Pl. LAV fig. 6.}

This form is represented by the central portions of three small hearls. The glabella is a little longer than broad; sides subparallel, broadly truncated in front; three pairs of small glabella furrows are slightly indicated; occipital furrow narrow and slightly impressed; occipital ring narrow at the sides, broader at the center, and provided with a short occipital spine. Free cheeks broad, convex, and separated from the glabella by a welldefined dorsal furrow; anteriorly they merge into the narrow frontal rim; ocular ridges narrow, passing almost directly outward from a point opposite the anterior pair of glabella furrows to the anterior end of the small, narrow palpebral lobe; anterior rim nearly flat and distinguished from the 
frontal lobe by its smoothness and by being nearly flat; posterior lateral limb of fixed cheeks strong and extending obliquely ontward and backward from the base of the palpebral lobe; posterior rim narrow.

Surface slightly granular under strong magnifying power.

Formation and locality: Middle Cambrian, in bluff south side of Pebble Creek, north of saddle to Soda Butte Creek, Yellowstone National Park.

\section{SOLENOPLEURA Angelin.}

\section{SOlenopleura? WeEd1.}

Pl. LXV; figs. 9, 9a.

Of this species, only the central portions of the liend occur in the collection. The entire individual attained considerable size, as the largest head has a length of $20 \mathrm{~mm}$. The characteristic features of the head are also shown in heads $9 \mathrm{~mm}$. in length.

The glabella is obtusely conical, having a width at the base in the largest specimen of $10 \mathrm{~mm}$., and a length from the center of the accipital furrow to the frontal limb of $13 \mathrm{~mm}$. It is separated from the strong rounded occipital ring by a relatively broad, well-defined furrow. The posterior pair of glabella furrows is indistinctly shown by very shallow grooves in the case of the largest individnals; on the smaller individuals it is not shown, except by a smooth spot. The glabella is separated from the fixed cheeks and frontal limb by a well-marked dorsal furrow, and as it is quite convex it stands ont in clear relief from the general surface of the head. Frontal limb short, $1.5 \mathrm{~mm}$. in length in the large specimen. It is separated from the strong rounded frontal rim by a well-defined groove; laterally it passes into the free cheek, which is of medium width. The palpebral lobe is of medium size and situated at a point opposite the transverse central line of the glabella. A faintly defined occular ridge extends abruptly backward across the fixed cheek from a point a little back of the front of the glabella to the front angle of the palpebral lobe. It is defined more by the presence of a slight groove in front of it than by the elevation of the ridge itself. The posterior lateral limb of the fixed cheek extends outward two-thirds of the width of the glabella at the base; it is separated from the posterior rin by a well-defined furrow. 
Fragments of the free cheeks associated with the glabellat show that they are convex and that the strongeremded rim is seplanated from the clieek proper by a well-marked groove.

The cintire surface of the head, with the exception of the oceipital grenve and the groove within the outer rim, is strongly pustulose, the pustules being scattered irregularly over the surface. Where the true test is hroken away the pustules are shown on the surface of the cast.

This species resembles Buthyurus conicus Billings, from the Caleiferons formation of nortleastern New York and St. Timothy, Canada. It differs, however, in the strongly marked frontal rim and the form of the glabella. ${ }^{1}$ It may be also compared with Hall and Whitfield's Crepicephalus $(L$.) maculosus. ${ }^{2}$

Formation and locality: Niddle Cambrian, Flathead formation, Crowfoot section, Gallatin Range, Yellowstone National Park.

\section{ZACONTHOIDES Walcott.}

\section{Zaconthoides sp. undet.}

\section{Pl. LXV, fig. 3 .}

Hear moderately convex; glabella convex, subelavate, narrowing very slightly from the anterior toward the posterior end; marked by three pairs of slightly impressed glabella furrows, the posterior pair cutting in obliquely backward toward the oecipital furrow. Occipital furrow narrow, but distinctly impressed; occipital ring strong and provided with a shon't strong spine, which projects from the upper posterior margin; fixed cheetss narrow anteriorly and a little less than half the widtl of the glabella opposite the posterior margin of the palpebral lobe; anteriorly they pass down to the frontal rim, there being practically no frontal limb, the giabella extending directly down to the margin The palpebral lobe is nearly lialf the length of the glabella; anteriorly it extends to a point opposite the anterior grabellit furrow and posteriorly to a point opposite the occipital furrow.

The largest specimen of this species is $3 \mathrm{~mm}$. in length; a second, a smaller one, oceurs on the same piece of limestone. It is possible that they

' Geol. Surv. Canadi, Pal. Fossils, Vol. I, 186., p. 353, fig. 341 b.

2U. S. Gevl. Expl. Fortieth Par., Vol. 1V, 1877, ?. 215, I’. II, fig. 21.

MON XXIII, P'T II-30 
represent the young of $Z$. spinosus. ${ }^{1}$ The head differs in details, but not more so than between the young and adults of $Z$. typicalis. ${ }^{2}$

Formation and locality: Middle Cambrian, Flathead formation, Crowfoot section, Gallatin Range, Yellowstone National Park.

\section{BATHYURISCUS Meek?}

Pl. LXIV, fig. 6.

A single specimen of the pygidium is placed provisionally under this genus. Its principal characters are well shown in the figmre. It is associated with Hyolithes primordialis, and is probably from the Middle Cambrian horizon. The genus Dolichometopus Angelin might include this form, but with the material at land it is difficult to make any detailed comparison of generic character's.

Formation and locality: Middle Cambrian, Flathead formation, enst of Dead Indian Creek, Absaroka Range, Wyoming. 


\section{PLATE LX.}




\section{PLA TE LX.}

Fig. 1. Obolus (Lingulepis) acuminatus var. meeki.

1. Ventral ralve. $\times 3$.

1u. Dorsal valve, $\mp 3$.

Fig. 2. Obolus (Lingulclla) desideratus

2. Tentral rilve. $\times 6$.

2a. Dorsal valve. $\mp 6$.

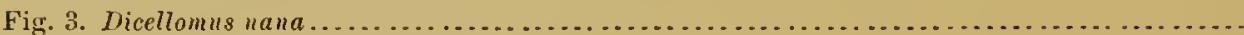

3. V'utral valve, from Gallatin Rauge. $\mathrm{x} 6$.

3a. Dorsal valve, from Littlo Rocky Mountains, Montana. $\mathbf{x}$.

37. Ventral valve (type specimen of Meek aul Hasden) from Black Hills, South Dakota. $\times 6$.

3c. Cast of intorior of ventral valve, from Litile Rock Mountains, Montana. $\mathbf{x} 6$.

$3 d$. Cast of interior of ventral valve (type specimen of Meck and Hayden), from Black Hills, Sonth Dakota.

Fig. 4. Dicellomus politus .....................
4. Interior of clorsal valve. $x 6$.

4a. Interior of ventral valre. $\times 6$.

Fig. 5. Iphidea sculptilis.

5. Summit riew of reutral valve. $x 4$.

5a. Sinle view of tig. $5 . \times 4$.

5 b. View of the broken false area aud pseurlo-deltidimm of fig. $5 . \quad x 4$.

5c. Surface of fig. 5, greatly enlargel.

Fig. 6. Iphidea sp. nudet

6. Dorsal valre rleseribed in the text. $x 4$

$\$ 68$ 


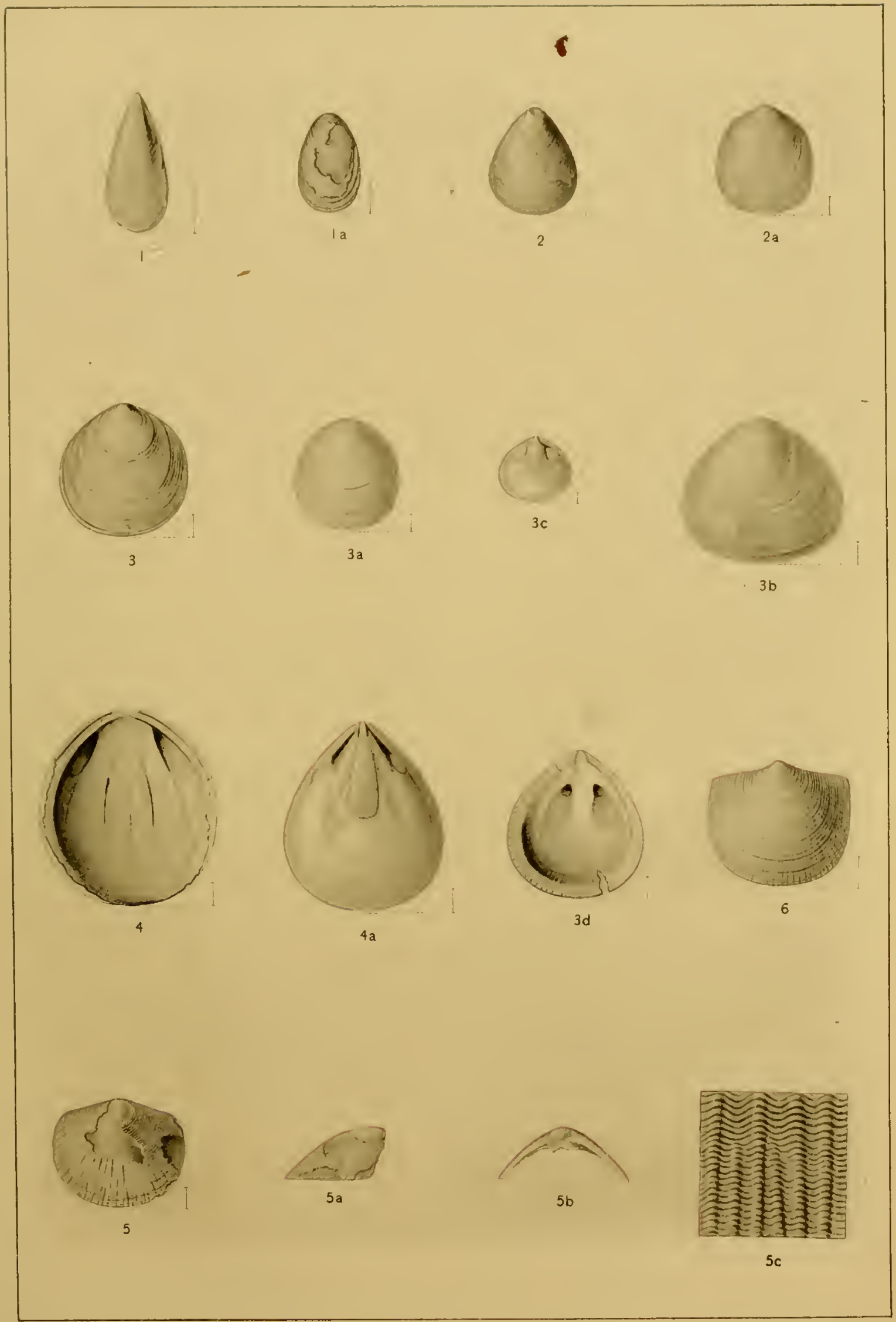

CAMBRIAN 



\section{PLATE LXI.}


PL A TE LXI.

Fig. 1. Rillingrella coloradoensis............................................ Page. 450

1. Ventral valve, from Gelatin Range. $\times 2$.

ia. Dorsal valve, from sane locality as fig. $1 . \quad \times 2$.

ib. Interior of dorsal valve, from same locality as fig. $1 a . \quad \mathrm{x} 3$.

cc. Interior of ventral valve, from same locality as fig. $1 . \times 3$.

17. Cast of interior of ventral valve, Gelatin Range. $\times 3$.

Fig. 2. Orthis (?) sandbergi

452

2. Ventral valve. $\mathrm{x} 3$.

$2 a$. Dorsal valve. $\times 3$.

ab. Interior of ilorsal valve. $\mathrm{x} 6$

ac. Interior of ventral valve. $\times 3$.

$2 d$. Enlargement of fig. $20 . \times 12$.

Fig. 3. Orthis remnicha .

451

3. Interior of dorsal valve. $x 3$.

$3 a$. Interior of ventral valve. $\times 3$.

470 

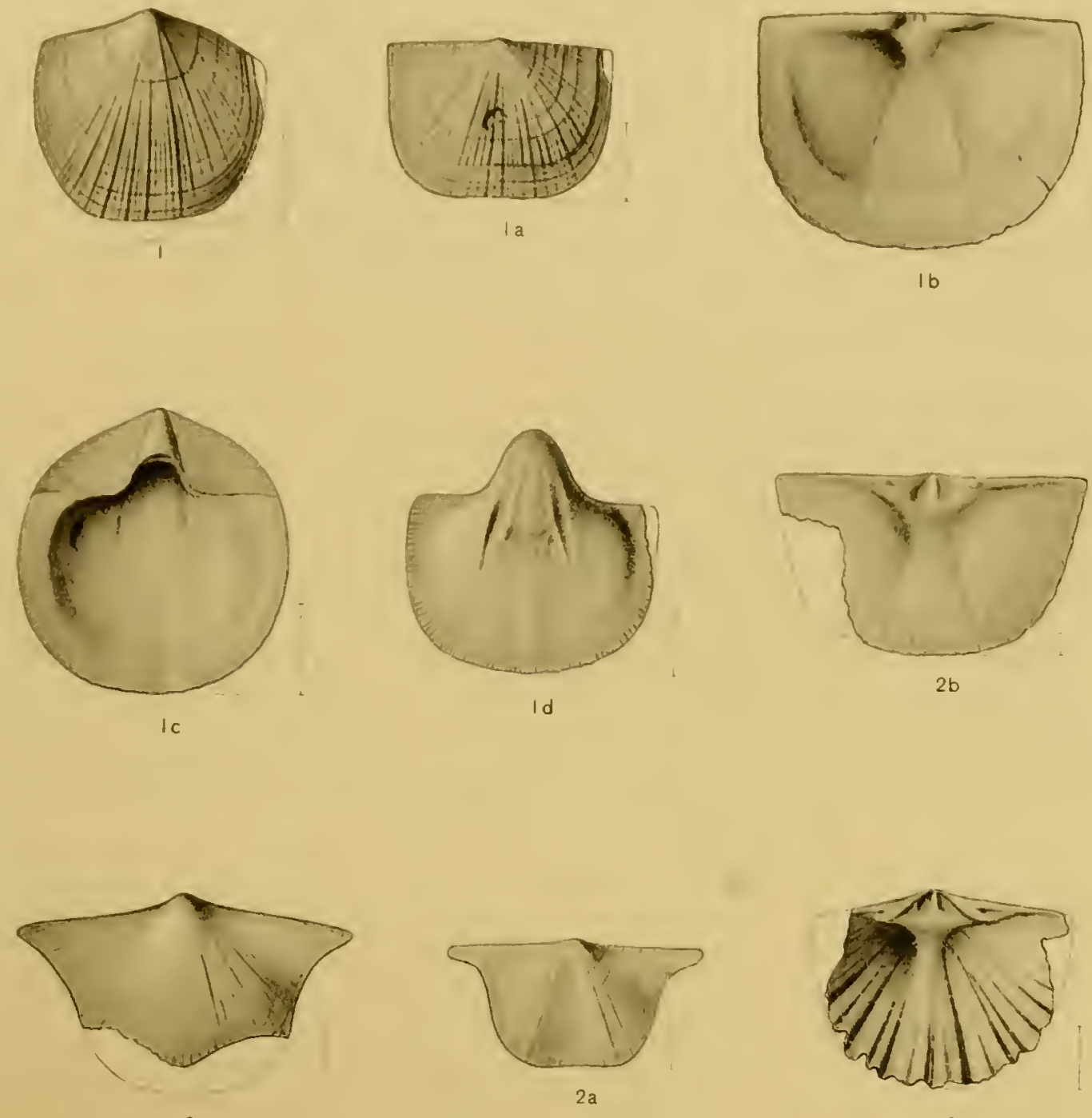

2

3
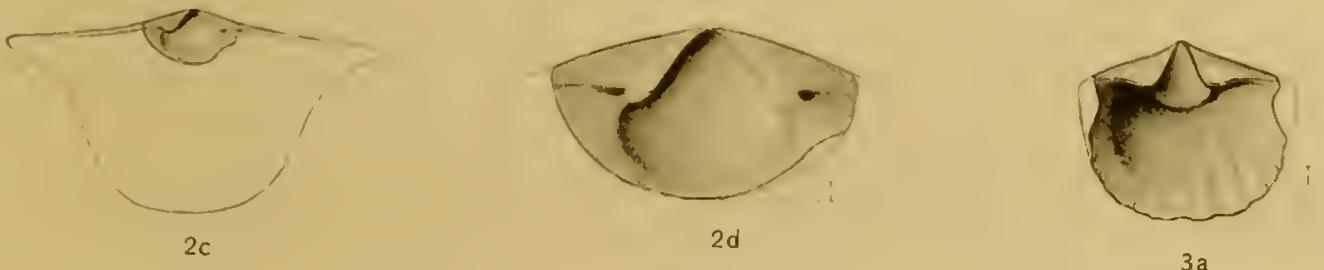



\section{PLATE LXII.}




\section{PLATH L X I I.}

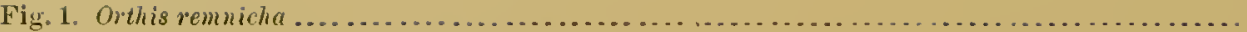

1. Rather strongly costate dorsal valve. $\times 2$.

1a. Finely costate ventrai valve. $\times 3$.

1b. Finely eostate dorsal ralve ou same bit of rock as fig. la. $\times 3$.

1c. Strongly costate ventral aud dorsal valves. $x 3$.

1d. Dorsil and ventral valves, showing fine raliating stri; ou custiv, $x 3$.

Fig. 2. Acrolveta gemme

2. Summit view of rentral valve. $\times 6$.

2a. Posterior view of ventral valve. $x 6$.

$2 b$. Side view of ventral valve.

$2 c$. Summit viem of cast of interior of ventral valve, $x 6$.

2d. Dorsal valve. $\mathrm{x} 4$.

2 e. Interior of dorsal valve. $\mathrm{x} 6$. 


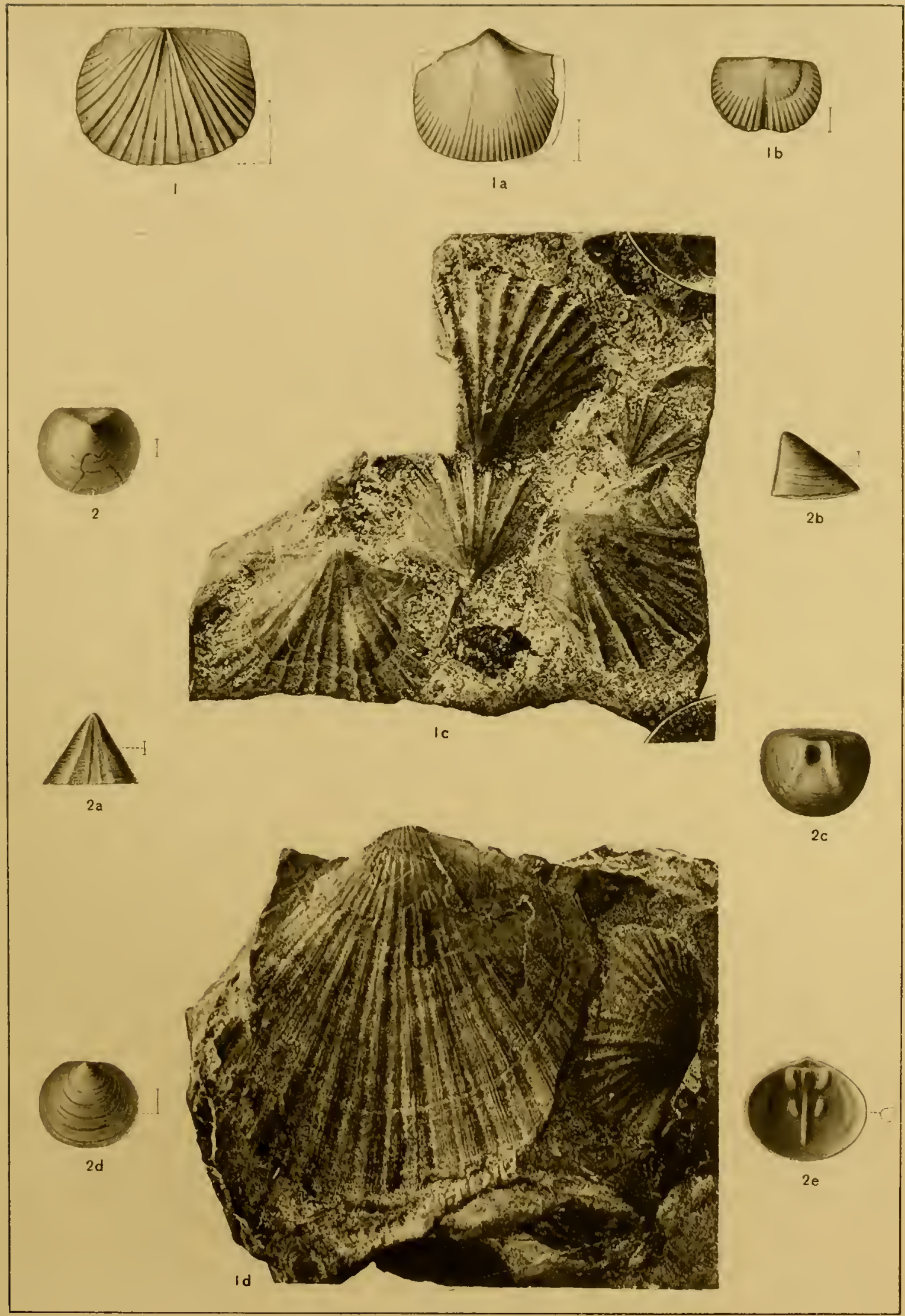

CAMBRIAN 



\section{PLATE LXIII.}




\section{PLA TE L XIII.}

Fig. 1. Platyceras primordialis.

1. Cast of interlor of shell.

Fig. 2. Hyolithes primorlialis

2. View of tat side and two sections of a large specimen.

2a. Reproduction of photograph of a slab of saudstone, with unmerous specimens of $H$. primorlialis, from the St. Croix sanistone of Wisconsin. 'The small shells are ilentical with $H$. gregaria of II. and $\mathrm{H}$.

Fig. 3. Agnostus interstrictus

3. Entire specimen, from Antelope Springs, Utab.

3a. Pygidinm, from Gallatin Range. $\times 6$.

Fig. 4. Agnostus bidens

4. Cephalic shield. $\times 6$.

4a. Pygidium. $\times 6$.

Fig. 5. Agnostus tumidosus .

5. Cejuhalic slield. $\times 6$.

5a. Pygidium, associated with fig. 5. x 6 .

Fig. 6. Haguia spharica .........................................
6. Ruprouluction of photograph of thin section. $\times 8$.

6a. Drawing of thin section, $\mathrm{x} 9$. The light-colored spaces are the fillings of the canale. They correspond to the darker spaces of the photograph. 


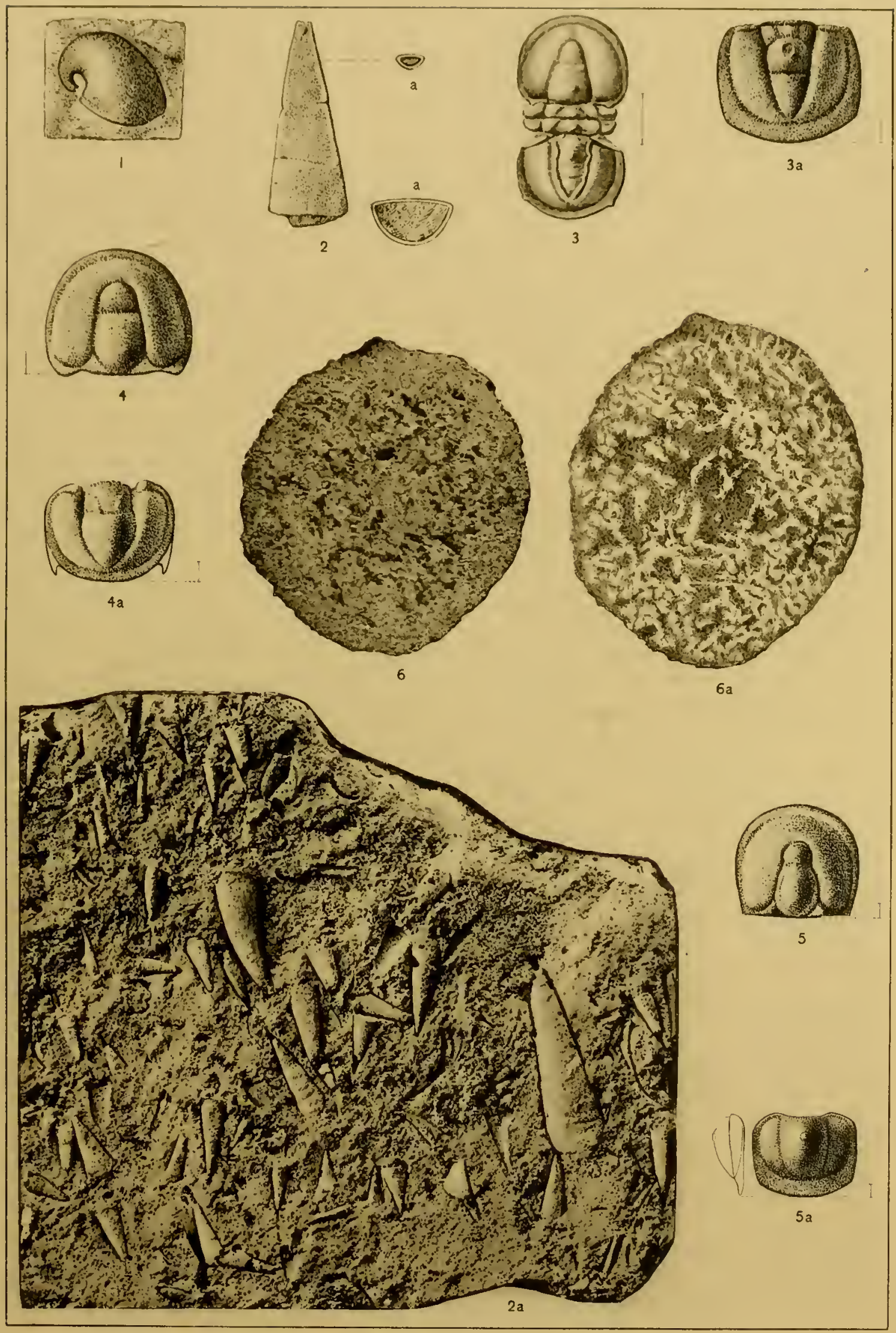

CAMBRIAN 



\section{PLATE LXIV.}




\section{PLATE LXIV.}

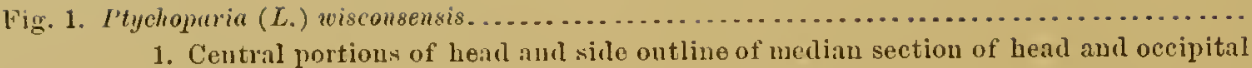
spine.

1a. Free cheek associated with fig. 1.

1b. Central portions of beal of specinen from the st. Croix sandstone of Wisconsin. After Hall.

1c. Pygidium from the St. Croix sandstone of Wisconsiu.

Fig. 2. Ptychoparia (?) diademata

2. Ceutral portions of hearl.

2a. Freo cheek associated with fig. 2.

2b. Hypostoma, issociated with fig. 2.

2c. Pygirlium from the St. Croix sandstome of Wisconsin.

Fig. 3. Plychoparia sp. undet.

3. Central portion of hear. $\mathrm{x} 3$.

Fig. 4. I'tychoparia llanoensis

4. Reprouluction of illustration of the type sperimen.

Fig. 5. Ptychoparia sp. undet.

5 . Central portion of heal of the only specimen in the collection.

Figr. 6. Rathyuriscus sp. undet.

6. Fignre of the specimen referred to in the text.

476 

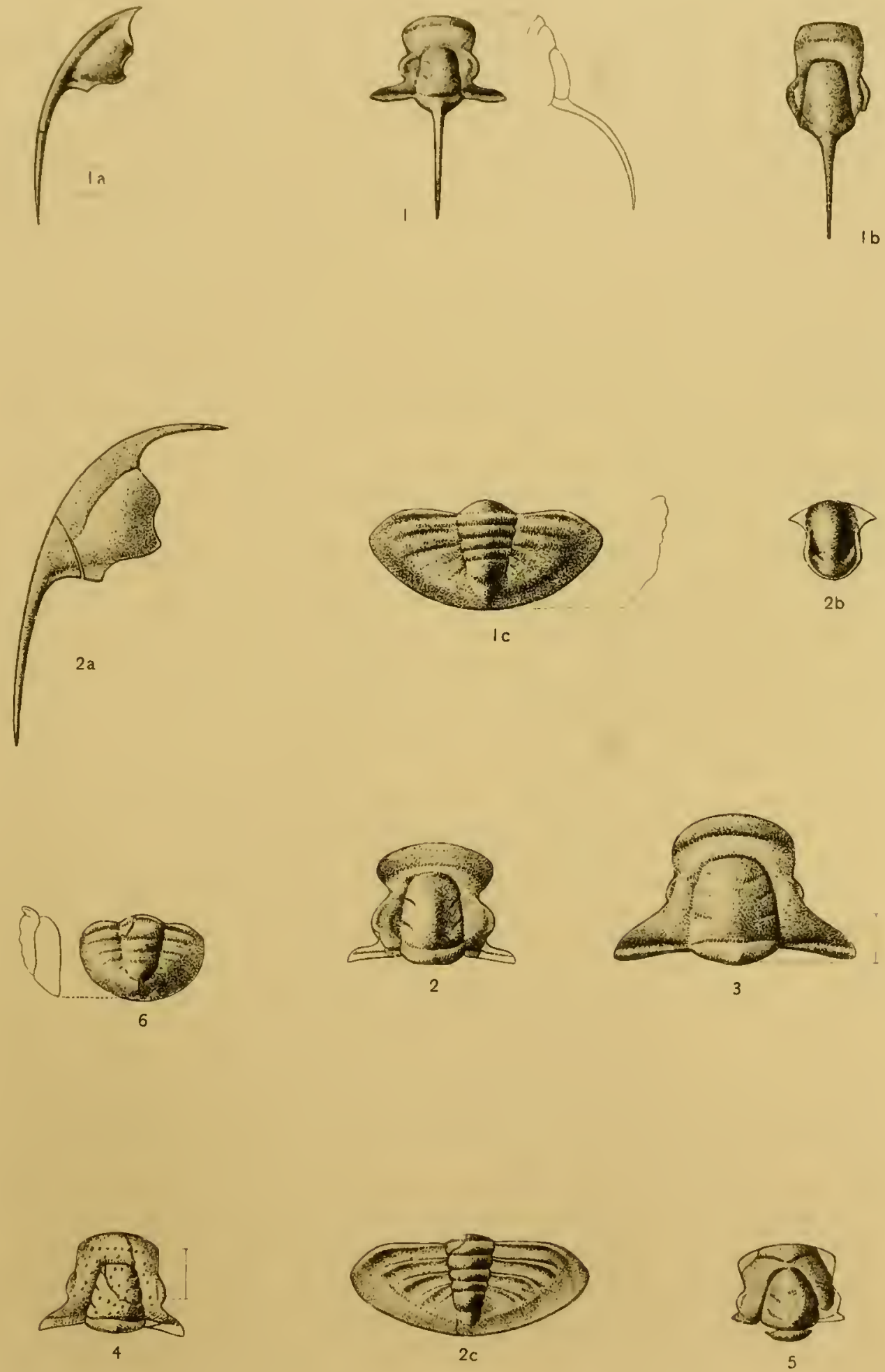

CAMBRIAN 



\section{PLATE LXV.}




\section{P L A T E L X V}

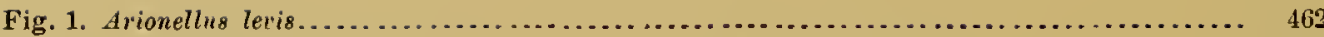

1. Central portious of head of type specimen, and side ontline. $\times 4$.

Fig. 2. Arionellus sp. uudet

2. Figure of specimen referred to in text.

Fig. 3. Zacanthoides sp. undet.

3. Central portions of head. $x 5$.

Fig. 4. Ptychoparia penficldi

4. Central portions of head.

4a. Free cheeks, associated in same layer with fig. 4.

4b. Associated pygidium.

Fig. 5. Crepicephalus texanu.

5. Partially restored drawing from specimens in the Middle Cambrian shales of Alabama.

Fig. 6. Liostracus parvus.

6. Central portions of head of type specimen. $x 6$.

Fig. 7. Ptychoparia antiquata

7. Entire individual, slightly restored. $\times 2$.

7a. Side outline of head of a variety of this species. $x 2$.

Fig. 8. Ptychoparia (E.) affinis .

8. Reproduction of figure of type specimen.

Fig. 9. Solenopleura (i) weedi

9. Central portions of hear of type specimen.

$9 a$. A small head, showing same general characters as fig. 9. 


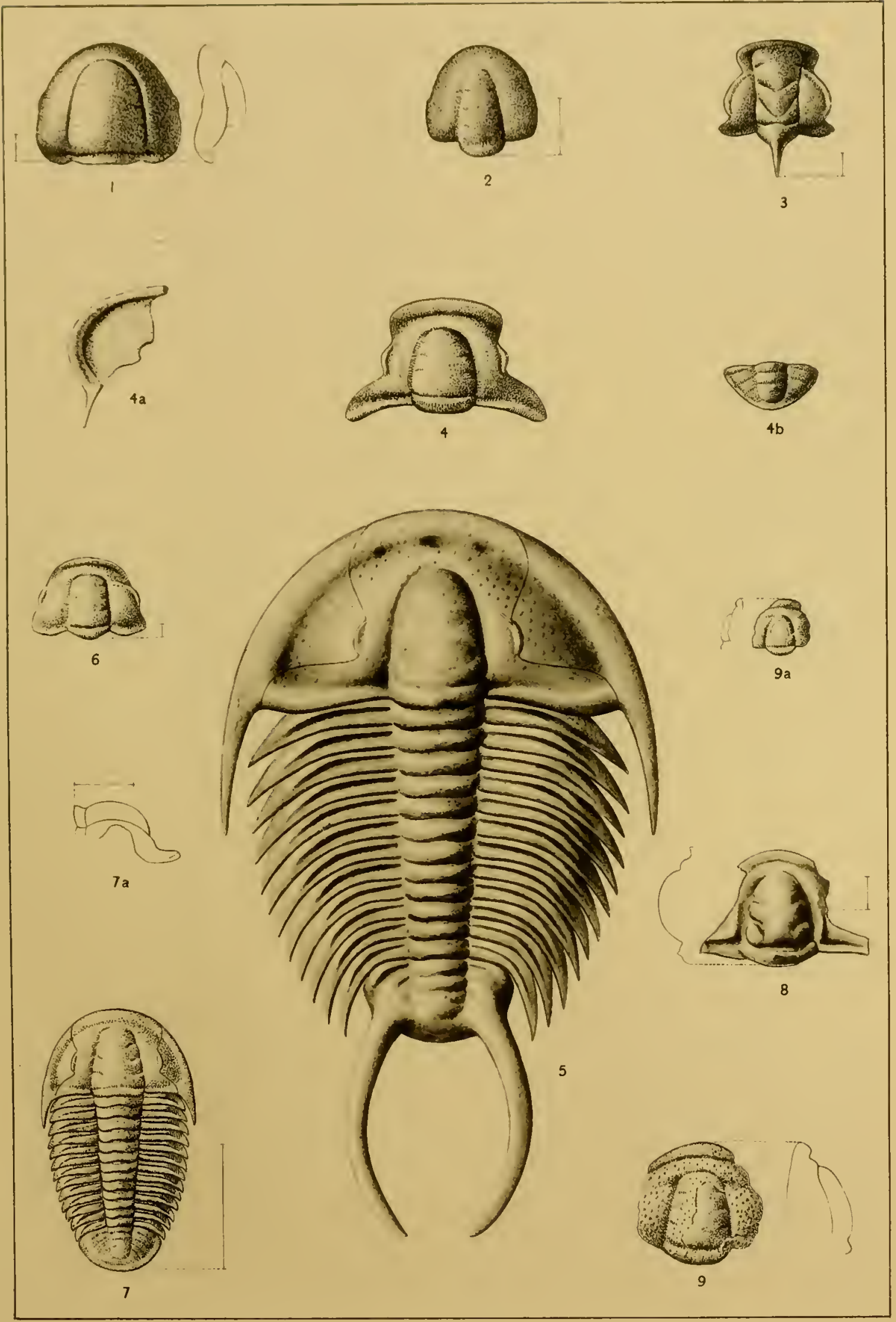

CAMBRIAN 

SECTION II.-DEVONIAN AND CARBONIFEROUS FOSSILS.

By George H. Girty.

INTRODUCTION.

In the following pages are described the Paleozoic faunas, with the exception of the Cambrian, which have been found in the Yellowstone National Park. The point of interest in this connection is the presence of the Devonian and the apparent absence of the Coal Measures in this region. The Ordovician and Silurian are also absent, and the only Paleozoic formations indicated by the collections are the Cambrian, the Devonian, and the Lower Carboniferous.

The great bulk of the material was furnished by the Madison limestone, whose fauna, though showing close relations only with that of the Kinderhook period, may have survived nearly through the Mississippian. The fauna is essentially that described by White and by Hall and Whitfield, but it is more extensive than that recorded by them.

Deronian types are rare and constitute a fauna more scanty, though nearly akin to that described by Meek and by Walcott from the Rocky Mountain region of Nevada.

The collections which I have had the privilege of examining were made by the geologists of the Yellowstone National Park survey, whose careful stratigraphic observations rendered easier the solution of many

As is well known, the principal Iiterature dealing with the paleontology of the Devonian ancl Lower Carboniferous in the Rocky Mountain region consists of a report by Meek and another by Hall and Whitfield in King's U. S. Geol, Expl. 40th Par., Vol. IV, 1877; a report by White in Wheeler's . Expl. and Surv. W. 100th Merid., Vol. IV, 1875; and a monograpl by Walcott, Mon. U. S. Geol. Surver, Vol. VIII, Pal. Eureka District, 1884.

Meek has aiso identified certain Mississippian horizons in this region: Prelim. Rept. U. S. Geol. Surv. Wyoming, otc., Hayden, Fonrth Ann. Rept., 1871, p. 288; 1bid., Fiftl Ann. Rept., p. 76 ; ibid., Sixth Ann. Rept., pp. 432-433. 
problems that would otherwise have been left in doubt. To them I desire in this place to make ample acknowledgments, and especially do I wish to express my obligation to Mr. Charles Schuchert, of the United States National Inseum. A preliminary study of this collection was made by him before the work was assigned to me, and he also supplied me with facilities in the National Musemun, gave me free access to the Mruseum collections for comparison, permitted the nse of his Bibliography of North American Brachiopoda, then unpublished, and placed at my disposal his fine collection of brachiopods and his no less extensive knowledge of the same. It gives me pleasure also to acknowledge my obligations to Mr. John L. Ridgway, by whom the greater number of the drawings accompanying this report were made.

DEVONIAN.

The material believed to be of Devonian age is unsatisfactory in that it is scanty and often poorly preserved, while the species represented are almost the worst that could have been selected for stratigraphic correlation. Consisting mostly of corals, with a few gastropods and brachiopods, it would be difficult, massisted by the richer though related fauma of Nevada, to affirm of some of the local representations anything more than that they are older than the Carboniferous and younger than the Ordovician. The strata represented fall into three groups, distinguished somewhat by their lithologic character as well as by the fossils which they carry. ILore extensive collections would probably show a closer connection than now appears.

The age of the exposure on the north side of Soda Butte Creek has not been definitely ascertained. It is represented only by an undetermined species of Farosites, in a fragmentary condition. The most likely reference would be to the Silurian or Devonian, for if Carboniferous the coral belongs to none of the few related species known in Carboniferous rocks. The locality is therefore provisionally referred to the Devonian, since no fossils of Silnrian age have been recognized in the Yellowstone Park.

The locality at Wall Canyon, Clark Fork Valley, stands by itself. It is represented only by Pleurotomaria isacsi (?) (a solitary specimen), both fossil and matrix being highlly siliceons. P. isauesi was described from Lower Devonian strata, probably of the age of the Schoharie grit, but its range is not known, and my identification is questionable. 
From the hase of the bluff om Little Sunlight Creek only Atrypa reticularis is known, a small contrely plicate variety. It is similar to, perhaps identical with, the type figured hy Walcott (ILon. U. S. Genl. Survey, Vol. VIII, 1884, I'l. XIV, figs. 6, 6in, 6h), and mentioned als oceurring in the upper part of the formation (p. 150). Ifeek cites the same form (King's Rept. C.S. (reol. Expl. 40th Par., Vol. IV, 1877, p. 39) from Piñon Station, Treasure Hill, White Pine district, ete, and figures it on Pl. III, figs. 6, 6a.

The horizons of Bighom P'nss, Gallatin Range, near the divide between Gallatin Talley and Panther Creek; the east slope of Antler Peak, Gallatin Range; and the south slope of the same, can be correlated with one another and constitute a separate group. The matrix is a calcareous sandstone; and the included fossils, almost exclusively corals, are crudely silicified. The common fossils are Clatopora sp., Pachyphyllum sp., Cyathophyllum crespitosum (?), and Actinostroma sp. Every indication points to the Devonian age of this bed. The genus Actinostroma is characteristic of, though not restricted to, Devonian rocks. Cyathophyllum crespitosum, as identified in this country, occurs in Upper Helderberg strata. The genus Pachyphyllum is characteristically Devonian, and Cladopora sp. is more closely related to certain Upper Helderberg forms than to any I have found described.

The material from the south side of Soda Butte Creek, northeast of Abiathar Peak, Absaroka Ringe, from northwest of Abiatlar Peak, Soda Butte Canyon, and from the north side of saddle west of Mount Miller, Absaroka Range, represents, perhaps, the same horizon as that from The Gate, Fossil Hill, and Eureka district, whose fauma, as rlescribed by Meek and by Walcott (loc. cit.), is quite similar, as far as it goes. In the Yellowstone Park this consists of Atrypa missouriensis, Spirifer engelmanni, Athyris vittata var. triplicata n. var., Pleurotomaria (?) sp., Pachyphlyllum sp., Cyathophyllum cespitosum (?), etc. Atrypa missouriensis is, I believe, the same form figured by Walcott as A. desquamata Sow. (loc. cit. Pl. XIV, figs. 4, 4a), and by Meek as $A$. reticularis var. As in their collections $A$. missonriensis was associated with the small, coarsely plicate Atrypa, which I have found alone at Little Sunlight Creek, it might perhaps be better to regard the latter as forming one of the group of localities under consideration. This group, on the other hand, is comnected with the other previonsly mentioned (Bighom Pass and Antler Peak) by having in common Cyathophyllum ccespitosum (doubtful identification) and Atrypa missouriensis. A bed at the south side MON XXXII, PT II-31 
of Soda Butte Creek, northeast of Abiathar Peak, Absaroka Range, is unique in the collection, and may fitly be called a gastropod limestone. The rock consists of comminuted organie remains cemented by a shaly limestone, and carrying certain small gastropods in great abundance. Two of the types represented are described below, under the names of Platystoma minutum. and Loxonema delicutum, but the others, of which there are perhaps three or four genera and some half dozen species, are too poor for either identification or deseription. They are small, and nearly all badly eroded, and often concealed by a matrix from which they are not easily separated. It has therefore proved difficult or impossible to acquire data even for certain generic references; but Loxonema, Pleurotomaria, Murchisonia, Platystoma, and perhaps other genera are probably present. The associated brachiopods show this fauna to be of Middle Devonian age.

It can be affirmed beyond question that all the localities here diseussed occur below the Carboniferous. Indeed, there is a decided faunal break between them and the great series of beds regarded as representing the base of that formation, so much so that the two groups have not a single species, and scarcely even a single genus, in common. At the same time, I believe that the lower series is neither wholly nor in part Silurian, but that it was in fact laid down in Lower or Middle Devonian time, representing the Hamilton, or perhaps the Upper Helderberg, of the New York system. Many of the generie identifications strongly suggest a Deronian facies, or, at worst, are ambignous, while the specific references, though often doubtful, all point to the Devonian rather than the Silurian age of these strata. Finally, the fauma seems to be rather closely related to that of the White Pine district, ete., above referred to, of which Meek says (loc. cit., p. 6): "Hence we can not doubt that these beds belong to the Devonian, and probably to about the horizon of the Hamilton group of the New York series." 
Tab'e of Irevonian species.

\begin{tabular}{|c|c|c|c|c|c|c|c|c|c|}
\hline specres. & 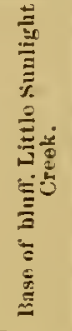 & 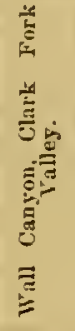 & 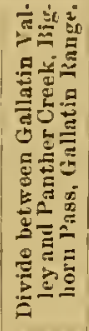 & 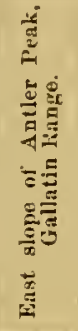 & 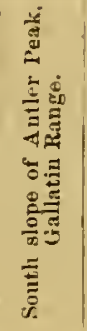 & 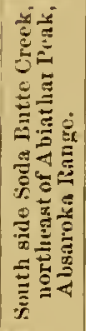 & 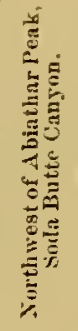 & 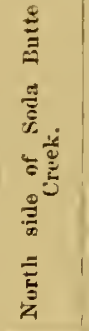 & 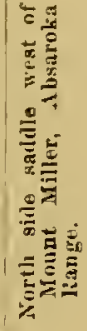 \\
\hline Actinostroma sp ..................... & & & $x$ & 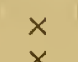 & $x$ & & & & \\
\hline $\begin{array}{l}\text { Cyathophyllum ciespitosnm (?) } \ldots \ldots \ldots \ldots . . \\
\text { Pachyphyllum sp ........................ }\end{array}$ & & & $x$ & $x$ & $\cdots$ & & & & \\
\hline Cladopor: sp $\ldots . . . . . . . . . . . . . . . . .$. & & & $x$ & & & & & ... & \\
\hline $\begin{array}{l}\text { Favosites sp } \ldots \ldots \ldots \\
\text { Spirifer engelmanni } \ldots \ldots \ldots \ldots \ldots\end{array}$ & & & & & ...... & $x$ & & $x$ & \\
\hline 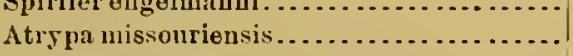 & $\cdots$ & & & ...... & $\times$ & $x$ & $x$ & $\ldots \ldots$ & $\times$ \\
\hline 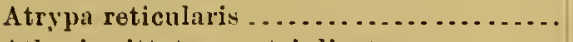 & $x$ & & & & & & & $\cdots$ & $\ldots$ \\
\hline Athyris rittata var. triplicata n. var....... & & & & & & $x$ & & & \\
\hline Pleurotomaria (१) sp................... & & & & & & & & …. & $x$ \\
\hline Plenrotomaria isaacsi (?) $\ldots \ldots \ldots \ldots \ldots \ldots$ & & $x$ & & & & & & $\cdots$ & \\
\hline Platystoma minntun n. sp ............... & & & & & & $x$ & & $\ldots .$. & \\
\hline Loxonema delicatum n. sl,$\ldots . . . \ldots \ldots . . .$. & & & & & & $\times$ & ....... & & \\
\hline
\end{tabular}

\section{LOWER CARBONIFEROUS.}

The Madison limestone has been divided by the geologists of the Survey, upon lithologic characters, into nine beds, ranging from 24 to 32 , both inclusive, of their section scheme. The following table, representing in condensed form the stratigraphic succession ascertained in the Yellowstone National Park, was kindly supplied by Mrr. Arnold Hague, geologist in charge of the Yellurstone National Park survey:

Qualrant quartzite.

Madison limestone.

Bed.

32. Four strata of light-gray, more or less cherty limestone

Feet.

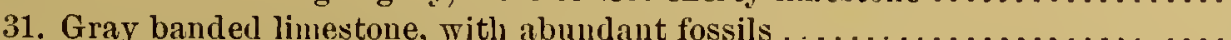

655

.

29. Light-gray and brown, very finely crystalline or granular limestone....... 85

2S. Limestone, crystalline, light gray and generally massive............ 200

27. Limestone, dark gray and butf, very argillaceous, thick and thin bedded... 50

26. 15 feet of quite pure and 60 feet of thin-bedded argillaceons limestone, both containing fossils . ............................ 75

25. Coarsely crystalline, dark gray limestone.................... 80

24. Liméstone, finely crystalline and massive below, cherty in its ppper portion.. 60

Total.

Three Forks limestone. 
All the eridence available seems to indicate that the Iadison limestone is faumally a unit and can not be subdivided on the basis of its contained fossils.

Although the fauna comprises many Kinderhook species, I doubt whether it can justly be regarded as representing the Kinderlook alone; possibly it is equiralent to the major portion of the Mississippian. The exact correlation of this fauna has proved impossible, but its affinities seem to be rather with the Kinderhook than with any other division of the Lower Carboniferons.

The following table represents the various species of invertebrates recognized in the Madison limestone and their range through the nine beds whose character and succession have just been described. The table is defective in that a number of localities from which collections were made lave not been located in the section scheme previonsly given, and consequently the data so furnished could not be tabulated. And again, the collections from many localities are so meager as not to contain, probably, many of eren the commoner species. Other sources of error exist in the possibility of incorrect reference of the localities to their true horizon in the section, and of mistaken identifications in the course of paleontologic work. IIuch care has been taken to minimize both these sources of error, and it is believed that the accompanying table is a fair statement of the character and range of the fauna of the Madison limestone.

Table showing the range of Lower Carboniferous species.

\begin{tabular}{|c|c|c|c|c|c|c|c|c|c|}
\hline \multirow{2}{*}{ Species. } & \multicolumn{9}{|c|}{ Number of bed. } \\
\hline & 24 & 25 & 26 & 27 & 28 & 29 & 30 & 31 & 32 \\
\hline Eudothyra bailey i var. parra n. var.... & & & & & $\ldots$ & & & & $x$ \\
\hline Holasterella wrighti var. americana u. ra & ... & $\cdots$ & … & .... & $\ldots$. & ... & & & …. \\
\hline Anlopora geonetrica n. sp............ & & & $x$ & & & $\cdots$ & & & $\cdots \cdots$ \\
\hline Sgringopora aculeata n. sp .............. & & & & $\cdots$ & $\cdots \cdots$ & $x$ & 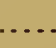 & $\cdots$ & $x$ \\
\hline Syringopora surcularia n. sp ............. & $\ldots$. & $\cdots$ & $\cdots$ & $x$ & $x$ & $\cdots$ & $\ldots$ & & $x$ \\
\hline Nichelinia placenta ................... & $x$ & $\cdots$ & & …. & ….... & $\cdots$ & $\ldots$. & ....... & ...... \\
\hline Menopbгllum (?) excilvatum n. sp........ & $x$ & $x$ & & $x$ & $\times$ & … & $x$ & $\times$ & ...... \\
\hline Lithostrotion sp....................... & … & & & $\cdots \cdot \cdot$ & $\times$ & $\cdots$ & & …... & ….. \\
\hline Clisiophyllum teres n. sp............ & $x$ & & $x$ & $x$ & $x$ & $x$ & & $\because \cdots$ & $\times$ \\
\hline Platycrinus symmetricus .............. & $\cdots$ & & $x$ & 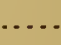 & ….. & $x$ & & & 8 \\
\hline Seaphiocrinus sp $\ldots \ldots \ldots \ldots \ldots \ldots$ & & & & & $\times$ & & & . & .... \\
\hline 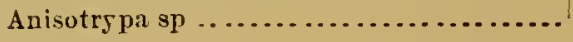 & & & & & & & & $\times$ & \\
\hline
\end{tabular}


Table shoning the range of Lower Curboniferous species-Continued.

\begin{tabular}{|c|c|c|c|c|c|c|c|c|c|}
\hline \multirow{2}{*}{ Sprocies. } & \multicolumn{9}{|c|}{ Number of bed. } \\
\hline & 24 & 25 & 26 & 27 & 28 & 29 & 30 & 31 & 32 \\
\hline 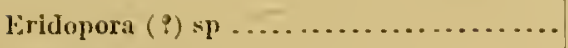 & ...... & ...... & $\ldots \ldots$ & & $\ldots \ldots$ & $\ldots \ldots$ & $\ldots \ldots$ & $\ldots \ldots$ & $x$ \\
\hline 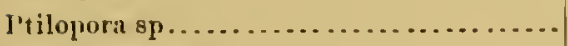 & $\times$ & $\ldots .$. & ...... & $\ldots \ldots$ & ....... & ...... & $\ldots$ & $\ldots \ldots$ & ...... \\
\hline Stictoporella (?) sp.................... & ...... & ..... & (....... & $\ldots . .$. & $\times$ & ....... & ...... & ...... & ...... \\
\hline Fcnestella, 5 s] $\ldots \ldots \ldots \ldots \ldots \ldots . . . . . . . .$. & - ..... & - . . . & ....... & $\ldots \ldots$ & ....... & $\ldots \ldots$ & ...... & ...... & ..... \\
\hline Archimedes $s p \ldots . . . . . . . . . . . . .$. & ..... & ...... & $\ldots \ldots$ & ...... & ....... & $\ldots \ldots$ & $x$ & $\ldots \ldots$ & (...... \\
\hline Crania lavis $\ldots \ldots \ldots \ldots \ldots \ldots \ldots \ldots \ldots \ldots$ & $x$ & -..... & ..... & $\ldots .$. & $\ldots \ldots$ & ....... & ...... & ...... & ...... \\
\hline Rhipidomella nichelini .............. & $\ldots . .$. & ..... & $\ldots \ldots$ & $x$ & $\ldots \ldots$ & ...... & $\ldots \ldots$ & $\ldots \ldots$ & ...... \\
\hline nrthothetes in:equalis . . . . . . . . . . . . . & $\times$ & $x$ & $\times$ & $\times$ & $\times$ & $\times$ & $x$ & $\times$ & (...... \\
\hline Orthothetes sp ........... & $\cdots \cdots$ & - n... & ...... & $\ldots \ldots$ & $\ldots \ldots$ & $\ldots \ldots$ & $\ldots . .$. & $\cdots$ & $\times$ \\
\hline Derbya keokuk (q) $\ldots . \ldots \ldots \ldots \ldots \ldots \ldots$ & $\cdots \cdots$ & (..... & (....... & & $\ldots \ldots$ & $\ldots \ldots$ & $\ldots .$. & $\times$ & (..... \\
\hline Leptiena rhomboidalis . . . . . . . . . . . . . . . . & $\times$ & $x$ & ...... & $\ldots .$. & ...... & $\cdots \cdots$ & $\ldots .$. & $\ldots \ldots$ & ...... \\
\hline Chonetes loganensis .................... & $\times$ & $x$ & $x$ & $x$ & $\times$ & $\times$ & $x$ & $x$ & $x$ \\
\hline Chovetes ornatus ....................... & $\times$ & $x$ & $\times$ & 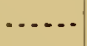 & ...... & $\cdots \cdots$ & $\times$ & $\ldots \ldots$ & ...... \\
\hline Productella cooperensis.................. & $x$ & $\times$ & $x$ & & $-\cdots$ & $\ldots$ & $x$ & $x$ & \\
\hline Productella alifera $11.8 p \quad \ldots \ldots \ldots \ldots \ldots .$. & $\cdots \cdots$ & $\times$ & - . . & $\ldots \ldots$ & (...... & - . . . & ...... & $\ldots .$. & $\ldots \ldots$ \\
\hline Productus scabriculus . . . . . . . . . . . . . . . . & $x$ & $\times$ & $x$ & & $x$ & & (....... & ...... & \\
\hline Productus parviformis n. sp ............... & $\cdots \cdots$ & $x$ & - . . . & -...... & $\cdots \cdots$ & 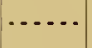 & $\times$ & $\times$ & -.... \\
\hline Productus gallatinensis n. sp............. & $\times$ & $\times$ & $\times$ & $x$ & ...... & (........ & $\times$ & 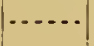 & ( . . . . . \\
\hline Productus lavicosta $\ldots . \ldots \ldots \ldots \ldots \ldots \ldots$ & $x$ & $x$ & $x$ & $x$ & $\times$ & $x$ & $\ldots .$. & $x$ & $x$ \\
\hline Productus semireticulatus .............. & $x$ & $x$ & $x$ & $x$ & $x$ & $x$ & $\times$ & $\times$ & $x$ \\
\hline Camarophoria ringens .................. & - & $\times$ & (..... & ...... & $\times$ & ...... & $\ldots . .$. & & $\ldots \ldots$ \\
\hline Camarotochia herrickana $n . s p \ldots . . . .$. & …. & ..... & $\times$ & $\times$ & $x$ & ...... & $\cdots \cdots$ & & \\
\hline Camarotøchia metallica ................. & $\times$ & $\times$ & $\times$ & $x$ & $x$ & $x$ & $\times$ & & - $\ldots$ \\
\hline C'amarotcechia sappho (१) ................ & & $x$ & & & & & $\cdots+$ & & \\
\hline Camarotrechia camarifera (?) ............ & ..... & ..... & $\times$ & (...... & $x$ & & $x$ & $|\ldots \ldots|$ & \\
\hline Camarotcechia sp $\ldots \ldots \ldots \ldots \ldots \ldots \ldots \ldots$ & $\cdots$ & $\times$ & (....... & & & & $\ldots$. & & \\
\hline Liorbynchus bagnei n. sp . . . . . . . . . . . & $x$ & $-\ldots$ & ...... & $\ldots \ldots$ & $\ldots \ldots$ & & $\ldots \ldots$ & & \\
\hline Dielasma utah........................... & $\times$ & $\ldots .$. & x & $x$ & $x$ & & $\ldots \ldots$ & & \\
\hline Spiriferina solidirostris $\ldots \ldots \ldots \ldots \ldots \ldots \ldots$ & $x$ & ..... & $x$ & $x$ & $\cdots \ldots$ & $\times$ & $\times$ & $\times$ & ..... \\
\hline Spirifer centronatus . . . . . . . . . . . . . . & $x$ & $x$ & $x$ & $x$ & $\times$ & $x$ & $x$ & $x$ & \\
\hline Spirifer centronatus var. semifurcatus u. var & …. & 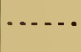 & $x$ & $x$ & $x$ & & $\ldots$ & $\cdots$ & \\
\hline Spirifer subattenuatus .................. & & & & & $\ldots \ldots$ & & & & \\
\hline Spirifer sp $\ldots \ldots \ldots \ldots \ldots \ldots \ldots \ldots \ldots \ldots$ & $\cdots \cdots$ & & ... & & $\times$ & & & & \\
\hline Spirifer marionensis (१) . . . . . . . . . . . . . & & & & & & & & & $x$ \\
\hline 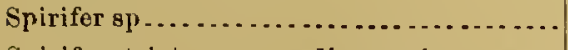 & $\cdots \cdots$ & & & & & $x$ & - & & $\cdots \cdot$ \\
\hline Spirifer striatus var. madisonensis n. var... & $x$ & $\cdots \cdots$ & $\ldots \ldots$ & $\ldots \ldots$ & $\cdots \cdots$ & & & & \\
\hline 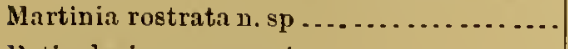 & $x$ & $x$ & $x$ & $\times$ & $\ldots \ldots$ & $\ldots \ldots$ & $\times$ & $\times$ & $\times$ \\
\hline lieticularia coopereusis . . . . . . . . . . . . . & $x$ & $x$ & $x$ & $x$ & $x$ & $\times$ & $x$ & $x$ & - $\ldots$ \\
\hline Reticularia cooperensis var .............. & $\cdots \cdots$ & $\times$ & $\cdots \cdots$ & $\ldots \ldots$ & $x$ & $\cdots \cdots$ & $\ldots \ldots$ & & $\cdots$ \\
\hline Reticularia (?) peculiaris . . . . . . . . . . . . . & $\times$ & & $x$ & -..... & ..... & -..... & $\cdots$ & & $\cdots$ \\
\hline Reticularia (?) subrotundata ............. & $\cdots$ & ..... & (...... & - & $-\cdots$ & $\ldots$ & $\ldots \ldots$ & $\cdots$ & $\cdots$ \\
\hline Syringothyris carteri ................... & & $x$ & $x$ & & & & & & \\
\hline
\end{tabular}


Table showing the range of Lover Carboniferous species-Continued.

\begin{tabular}{|c|c|c|c|c|c|c|c|c|c|}
\hline \multirow{2}{*}{ species. } & \multicolumn{9}{|c|}{ Number of bed. } \\
\hline & 24 & 25 & 26 & 27 & 28 & 29 & 30 & 31 & 32 \\
\hline Eumetria verneviliana................ & $x$ & $x$ & $x$ & $x$ & $x$ & & & & \\
\hline Athyris lamellosil................... & ..... & .... & ..... & ..... & ... & & & & \\
\hline Athrris inciussata......................... & .... & .... & … & & $-\cdots$ & , & $x$ & & \\
\hline Seminula marlisoneusis v. sp........... & ..... & .... & .... & 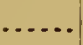 & $\cdots$ & 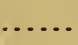 & $?$ & & $x$ \\
\hline Semiunla unadisonensis var. pusilla n. var. & $\ldots$. & ..... & $x$ & ..... & $x$ & ...... & .... & & \\
\hline 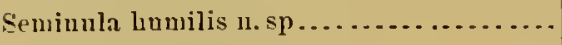 & $x$ & 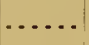 & $x$ & $\times$ & $x$ & $x$ & ..... & $x$ & \\
\hline Seminula immatura $1 . \mathrm{sp} \ldots . . . . . . . .$. & $x$ & $\cdots$. & 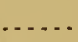 & 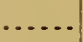 & & 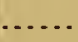 & & & \\
\hline Cliothyris crassicardinalis .............. & $\times$ & $x$ & $x$ & $\times$ & $\times$ & $x$ & $x$ & $x$ & \\
\hline Cliothyris crassicardiualis var. nana 1 . var. & $\ldots .$. & $x$ & & 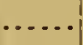 & $\cdots$ & ........ & & ..... & \\
\hline 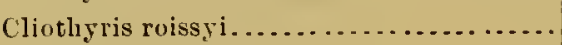 & $x$ & & $\ldots .$. & $x$ & .... & ...... & $\ldots$ & ..... & ... \\
\hline C'onocartium pulchellum (?) ......... & $x$ & & 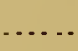 & & & & & & \\
\hline 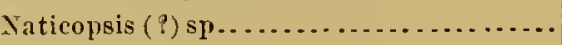 & $\times$ & .... & $\cdots$ & & ..... & $\ldots$ & $\ldots$ & $\cdots$ & \\
\hline Platyceras, $5 \mathrm{sp} \ldots \ldots . . . . . .$. & $\ldots$. & $\ldots$. & ….. & & -..... & 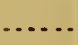 & & & \\
\hline 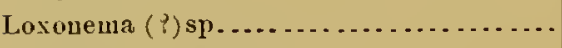 & ...... & -..... & $x$ & ....... & ..... & $\cdots$ & $\ldots$ & $\cdots \cdot$ & \\
\hline 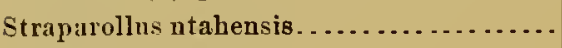 & $x$ & $\ldots .$. & $x$ & $x$ & $x$ & ...... & & $x$ & \\
\hline Proetus peroccidens........... & $x$ & $\times$ & ….. & ..... & …. & $x$ & & $x$ & \\
\hline 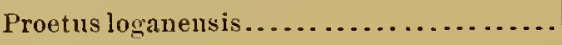 & ..... & ...... & & & & & & $x$ & \\
\hline
\end{tabular}

The following data are derived from the table just given, and go to show that the Madison limestone fauna is practically a unit, evincing very little progressive differentiation, and not affording sufficient evidence to warrant its subdivision upon paleontologic considerations.

Serenty-nine species have been recognized in the nine beds which go to make up the formation. Of these, 4 species have not been assigned to any particular bed, because it has not been ascertained what position the localities from which they came would occupy in the type section. These, with 5 species of Platyceras and 5 of Fenestella, lave not been taken into consideration in collecting the following data. Therefore only 65 species have been considered in making up the tables from which these data are supplied. Of these 65 species, 29 are found to be rare and seattered anong. single beds, but some 17 or 18 are common, and may be said to range from the bottom to the top of the formation.

If the nine beds constituting the Madison limestone be artificially divided into three groups of three beds each, the central group is represented by 38 species, only 6 of which are not found in the upper or the lower group, 
while the upper Madison, ${ }^{1}$ represented by 33 species, and the lower Madison by 47 species, have 21 species in common. In other words, 64 per cent of the forms found in the lowest beds oceur also in the middle berls, while t5 per cent survire inte the upper beds; 60 per cent of those in the middle beds are found also in the upper, and 64 per cent of those in the upper are introdueed in the lower Madison. These percentages include species which were found in only a single locality, and which, thongh perhaps alien to the beds in which they are not reeorded, at the same time can not be said to be chanacteristic of that which alone provided them. Although the table (see p. 484) shows a number of speeies in the upper portion of the Madison which have not yet been found in the beds below, it would scareely be true to say that they materially elanged its character.

The fauna of the Madison limestone is elosely related to that which was described in reports by White, ${ }^{2}$ by Hall and Whitfield, ${ }^{3}$ and probably also by Meek. The elose relationship of this fama with that of the Kinderhook formation of the Mississippi Basin was recognized by the authors mentioned. Writing in regard to this correlation in 1877 , White says (loe. cit.): "The collections of the expedition contain fossils from only three localities that I have definitely referred to the sul)-Carboniferous period. These localities are Mountain Spring, Old Mormon road, Nevada; Ewells Spring, Arizona (upper horizon), and a place below Ophir City, Utah. The collection made at the first-named locality is the most characteristic and important one of all, and is referred to the horizon of the Kinderhook formation, to which horizon it is not improbable the others also belong." And again: "The ease is far different, however, with the colleetion from the Momntain Spring locality, which I refer without hesitation to

\footnotetext{
1 In making ont these percentages certain species, as fir as my data go, are found to have skipped one or more beds in rortieal distribution. In such case the specics have been counted as occurring uninterruptedly hetween the points of highest and lowest occurrence.

"Wheeler's Rept. U. S. Geog. Surv. W. 100th Merid., Vol. IY, 1877, pp. 12-17, 1. 79 et seq.

${ }^{3}$ Kiug's Rept. Geol. Expl. 40th Par., Vol. 1V, 1877, 1'. 251 et seı.

"Hayden, 1873, Prelim. Rept. U. S. Geol. Surv. Wyoming, etc, Sixth Ann. Rept. (for 1872), pp. 432-433. Meek here cites a fanna from Mystic Lake; canyon, east side of Madison River; Brilger Peak, near Fort Ellis; Blacktail Deer Creek, north side of Gros Ventres Butte; Flathead Pass, north side Heurys Lake; canyon west of Gallatin River (all in Mlontana), and Camp 19, ldaho, of which he says (p. 433): "In looking over the collections from these localities I have been quite impressed with the similarity of their general facies (withont being quitesure that any of the species are ideutical) to the fituna of the Waverly group of Ohio, now known to belong to the Carboniferous." Nost of these localities are in the vicinity of Yellowstone National Park, and probably are in the Madison limestone.
} 
the Kinderhook group" (p. 14). The fauna of this locality seems to include the following species: Platycrimus sp., Actinocrinus viaticus, Productus parens, Strophomena rhomboidulis, Spirifer centronatus, S. striatus, S. extenuatus, S. (MLatinia) peculiuris, Spirigera monticola, S. obmaxima, Terebratula (Dielasma) lumlingtonensis. The Madison limestone contains the following equivalent or identical species: Platycrinus symmetricus of the same type as the form figured by White; Productus parriformis n. sp., considered to be different from $P$. parvus $\mathrm{M}$. and $\mathrm{W}$., but the same as $P$. parvus White; Leptena rhomboidlalis; Spirifer centronatus; S. striatus var. madisoncusis n. var., which I believe to be varietally different from S. striatus of White, though corresponding to it in the fauna: Syringothyris curteri, representing the closely related S. extenuatus ${ }^{1}$ of White's fauna; Reticulariu (?) peculiaris; Athyris incrussutu."

Dielasma utah, which I have recognized in the Yellowstone National Park collections, is probably the same as D. burlingtonense; at least, with the limited material at my command, I am unable to find any characteristic difference. Some of the species from the other localities also have their analogues in the Madison limestone fauna. S. haveyi White may be one of the two species of Syzingoport described below, although the original description is insufficient for identification. Conocarlium pulchellum (?) of this report is certainly of the same type as, and may be identical with, $C$. trigonale White, which is unfortmately unidentifiable, while Euomphahts luxus is represented by Strapmollus utahensis, both closely allied forms.

Hall and Whitfield also describe a similar fama from the limestone of Dry Canyon, Oquirrh Mountains; and from Ogden, Little Cottonwood, and Logan canyons, in the Wasatch Range, Utah. This fauna is described and figured under the name of the Waverly group, and is said (loc. supra cit., p. 201) to contain an assemblage of fossils considered to be "of about the age of the Waverly group of Ohio and the yellow sandstones of Bur-

1 Some of the specimens which I have idlentitied as $S$. carteri can not he said to difier in any essential particnlar from that figurerl by white as $S$. extenualus.

${ }^{2}$ This form is very close iudeed to White's Spirigera obmaxima in form aud general characteristics. Strictly speaking, A. incrassala is a true Athyris, while Spirigera obmaxima belougs to the subgenus Cliothyris. In point of lact I have not been able to discorer spines on White's specimens, and they may prove to be the same as the form which I have called $A$. incrassata.

${ }^{3}$ The Waverly gronp of Ohio is now known to be composite in its nature aud to contain several different faunas. The lower portion, Herrick has been led to believe, is Devonian, and the upper portion corresponds to the Kinderhook and the Burlington-keoknk phases of the Mississippian. A close acqnaintance with the Waverly faunas, involving several years of collecting and study, has convincer me that Herrick is altogether mistaken in this view. The whole of the Waverly, includiug 
lington, lowa, which lave been referred to the sume age." The following' species are described as "Fossils of the Waverly group:" Michetime sp., Streptorhymchus "quivalvis, S. inflatus, Strophomena rhomboirlalis, Chometes loganensis, Sprivifera centronata, S. allun-pinensis, Athyris claytoni, A. planosulcata (?), Rhymchonelln pustulose (?), Tevebratula utah, Euomphalus (Straparollus) utahensis, E. laxus, E. (Struparollus) ophirensis, Troetus peroccidens, I'. logumensis. The following nay be mentioned as identical or cognate forms ocenring in the Madison limestone: Michelinia plucenta (probably the same as Micheliniu sp. of Hall and Whitfield's report), Orthothetes incqualis (the same as Streptorhynchus equivalvis), Leptcum momboidalis, Chonetes loganemsis, Sprifer centronatus ( $S$. alba-pinemsis seems to be only an insignificant variation from this form), Martiniturostrata n. sp. (the same as Athyris planosulcata (?) of Hall and Whitfield), Camarotachia metallica (the same form which Hall and Whitfield identify as Rhynchonella pustulosa (?)), Dielasma utah, Straparollus utahensis, Proctus peroccidens, and $P$. loganensis. Of the forms grouped under the heading "Fossils of the Lower Carboniferous" (p. 265), Productus semireticulatus, P. Ievicosta, and Spirifera setigera (probably the form recognized below as Reticularia cooperensis var.) are found in the Madison limestone.

Meek ${ }^{\prime}$ cites a fauna from various localities in Montana and one in Idaho which is probably identical with that of the Madison limestone. The lists which accompany this notice are of a preliminary character, and but few species are identified specitically. Still, the genera involved, together with such brief descriptions as are appended, as well as the close relation geographically of his localities to the Yellowstone National Park, render it probable that he was dealing with the Madison limestone fama. Meek expresses himself as being impressed with the similarity of its general facies to that of the Warerly group of Ohio.

The famal lists given by Peale ${ }^{2}$ constitute essentially the same fama

the Bedford shale and ascending to its latest stratuu, is unloubtedly Carboniferous. The fauma of the Cuyahoga shale, using the term to include the outcrops at Lodi, Mlediua, Bagdad, Wernouth, and the lower (?) beds at Riclifield, which Herrick wishes to refer to the Devonian, is certainly the same as that of the Chouteau limestone, which Meel includes as typical ir his description of the Kinderhools period (Am. Jour. Sei. (2), Vol. XXXII, 1861: pp. 169 et seq., 288). Above the Cuyahoga shale follow representatives of the liurlington and keokuk horizons.

It is probably that portion of the Waverly famas which is found in the Cuyahoga shale that Hall and Whittield have in mind in this reference, as they mention the sellow sandstones of Burlington, which, with the Chontean limestone. are supposed to be typical kiuderhook.

ISixtb Ann. Rept. U. S. Geol. Surv. W snmingr, etc. (lor. cit., pl. $432-433,465$ et seq.)

${ }^{2}$ The Paleozoic section in the viciuity of Three Forks, Montana: Bull. U. S. Geol. Surv. No. 110 1893, pp. 33-39. 
as that of the Madison limestone, and had the material heen worked by the same haud the specific determinations would doubtless have been more uniform. The two areas are geographically closely related.

Considering the fanna of the Madison linestone as a whole, it can be pointed out that, of the 79 species known from this formation, 29 were described from or have been identified in Kinderhook beds of Ohio, Michigan, and the Mississippi Valley-that is, about 37 per cent of the Madison limestone fama consists of Kinderhook sprecies. These are: Michelinia placenta, Platycrimus symmetricus, Crania lovis, Rhipidomellu michelini, Orthothetes incequalis, Derbya Kcokuk (?), Leptanu rhomboidalis, Chonetes loganensis, ${ }^{1}$ Chonetes ormatus, Productella cooperensis, Productus levicosta, P. semireticulatus, Cemmerophoria ringens, Cumarotarhia herrickana n. sp., C. metallica, C. camarifera (?), C. sappho (?), Dielasmu utah, ${ }^{2}$ Spiriferina solidirostris, Spirifer centromatus, S. subattematus, S. marionensis (?), Reticularia cooperensis, R. (?) peculiaris, R. (?) subrotumetata, Syringothyris carteri, Athyris lemellosa, Chiothyris crassicurdinalis, and Conocarlium putchellum (?).

After making the necessary deductions from this list, some of whose identifications are rather in the nature of approximations, it still must be apparent that the fama of the Madison limestone laas many peculiaritics of the earlier Mississippian, and in particnlar shows a marked aftinity throughout with the Kinderhook fanna.

Taking a more general view of the fama, the presence of Syringothyris speaks for lower Mississippian, since it is not known there above the Keokuk, and the same is true of Leptana rhomboirlulis, since it does not occur ahove the lower Burlington. It must be noted, however, that these forms appear to be restricted to the lower portion of the Madison also. 'The absence of Productus punctatus from this formation is evidence in the same direction, as it is introduced in America in the Keokuk, and in general there is to be noticed in the IIadison limestone fauna an absence of those highly differentiated and often peculiar species which characterize the beds of the middle and upper. Mississippian. This is perhaps most noticeable in the Spiriferoids and Productoids, for they are the commonest forms. In the Madison these comprise a fer comparatively simple, stable, and persistent

${ }^{1} A$ form, probalily the same, is common in the Cuyahoga shale of northern Ohio, fiassing noually as C. illinoisensis.

:Probably a șnongm for 1 \%, burlingtonense. 
forms, often real Kinderhook types, which, however, do not pass over into the highly developed aud differentiated ipecies belonging to the same genera in the Mississippi Valley in Burlington time and later.

On the other hand, several genera in the Madison limestone show by their presence that we are not dealing with a pure Kinderhook famna. Here must be mentioned the genera Arehimedes, Martinia, Seminnla, and Endothyra. Arehimedes is not known below the Keokuk, nor Endothyra below the Warsaw. Species of Seminula have been deseribed from the Kinterhook, and Martinia is well represented in the Devonian, oceurring also in the Mississippian and Coal Measures; but an experience of several years in the Waverly group of Ohio and adjacent States seems to confirm the statement that these genera are rare indeed in the Kinderhook fama. It is significant that in the Madison limestone Archimedes and Endothyra are found only in the upper portion, while Seminula and Martinia range througliout.

Such species as Derbya keokut: (?), Camarophoria ringens, Camarotechia metallica, and Eumetriu verneuiliana demand individual consideration in discussing the age of the Madison limestone.

If Rhynchonella metallica was really originally found in Upper Carboniferous rocks, either it must have an extraordinarily long range or else this is an instance of the danger in making identifications on external characters from a single specimen; for between the type and the material from the Madison limestone I can find no specific distinction.

Derbya keokuk (?), whose identification is based upon a single poorly preserved specimen, is known in Indiana associated with Syringothyris and a Waverly fama. While Eumetria verneniliane is characteristic of the upper Mississippian, we find in the Kinderhook Acambone osagensis Swallow, Hustedia triangularis Miller, Eumetria (?) altirostris White, Retzia circularis Miller, R. plicata Miller, and $R$. popecune Swallow, all Retzioids and of a more or less similar type. It is noteworthy that the form which I have referred to Eumetria vernenitiana is confined to the lower beds of the Madison. It may really be one of the species just mentioned, but in its present condition can not be distinguished from the better-known form with which I have identified it. Camarophoria ringens was described from the Burlington chert of Missouri, but the form which I have called by that name is present in the Kinderlook famma as well. 
No one familiar with the passage beds between the Devonian and and the Carboniferous would hesitate to refer even the basal portion of the Madison limestone to the latter. Yet the famna of the Madison, and espeeially, perhaps, that of the lower portion, is not without Devonian affinities. These are vesterl ehiefly in the genera Productella, Aulopora, and Miehelinia, and in the speeies Camarotochia sappho (?) and Spirifer subattemuatus. Productella aliferu n. sp., it will be noticed, is confined to the lower portion of the formation, but $P$.cooperensis, a highly eharacteristic Kinderhook species, begimning in the lowest bed of the Madison limestone, survives almost to its upper limit. . Anlopora grometrica n. sp. is found at only one locality in our collections, which oecurs a little below the middle of the formation (bed 26). Michelinia seems to be restricter in its occurrence to the lowest bed. Comarotechia sappho (?) also is found toward the base, in bed 25 , while $S$. subattenuatus has not been located in any bed of the section seheme.

As is well known, C. sappho and $S_{p}$. sulbaticnuatus oceur in both Deronian and Carboniferous deposits.

The following conclusions have been drawn from the evidence afforded by the table of distribution of species given on page 484, some of which has already been dwelt upon: (1). The fanna of the Madison limestone can be referred wholly and withont question to Carboniferous time; (2) it has a marked Kinderhook facies; (3) it is essentially the same famna as that described by White, by Hall and Whitfield, and by Meek, and by them referred to the Kinderhook or Waverly; (4) the fama is not separable into independent units, but must be regarded as a whole.

The last statement should perhaps be qualified to some extent, for while a large percentage of types, often primitive and indicating a Kinderhook famna, are persistent almost to the very top, at the same time there are umquestionable indications of advaneing derelopment, while certain adnixtures, sometimes specific, sometimes generic, indicate an age much later than the Kinderhook. For instance, the only representatives of the Devonian genera Aulopora and Michelinia are confined to the lower portion of the Madison, as are also the speeies Lentcna thomboidalis, Productella alifera n. sp., Camarotachia sappho (?), and Sysingothyris carteri, while Endothyra baileyi var. perva n. var., Derbya lieoliztl (?). Archimedes sp., and Seminula madisonensis n. sp. (of the type of S. sulquarlyatu and S. subtilita) are peeuliar to the upper portion. At the same time it will not be amiss to recall again that 45 
per cent of the finum of the lowest third of the Matison persists into the upper third, numy of the speciss being of Kinderlook age, or primitive and allied to Kinderhook species: that such genera as Martinia and Seminula range from the very hottom to the top of the Madison; and, in general, the incompleteness of nuch of the data tabulated, by reason of which the many species known at present from a single horizon, and giving an individual facies to different portions of the series, miglit on fuller information be fouml to liave a more extenderl range. A complete recond would doubtless show even less progressive differentiation in the series than now appears.

The fact that Eumetrin iernerilima is apparently restricted to the lower beds remains an interesting anomaly.

I do not believe that the facts warrant an exact correlation of the Madison limestone with the Kinderhook horizon of the Mississippi Basin, although the Kinderhook affinities of its fauma are obvious. The evidence of such genera as Endothyra, Eumetria, Archimedes, and other forms aheady mentioned, can not be set aside, and the probabilities involved in placing the Madison limestone, 1,700 feet thick, to offset the 300 feet $^{1}$ of shales, sandstones, and limestones of the Kinderhook in the Mississippi Valley, are significant.

A more probable intexpretation of the facts observed seems to be that the Madison limestone represents a large portion, possibly even the whole, of the Lower Carboniferous period, being a Kinderlook fama which through uniformity of conditions of enviroument had maintained its essential characters long after its contemporary fauna to the east had been superseded.

This would presuppose a nearly continental distribution of the Kinderhook fauna during early Mississippian time, which, indeed, we have some

I In Missonri the Lonisiana limestone (Keyes, 1894, Geol. Surv. Missouri, Vol. IV, p. 51 et seq.) is said to have a thickness of over 60 feet, the Hannibal shales or Vermicular sanclstone of over 70 feet, and the Chontean limestone of nearly 100 feet, making a maxiwum thickness of 230 feet. The same anthor (loc. cit., p. 46) gives a section at Burlington, Iora, in which the Kinderhook is giren a nuximnm of 110 feet of limestones, sandstodes, and shales. Dana (Manual of Geology, 4th ed., 1895, pp. 637-639) gives the "linolustone" below the Keoknk in Indiana a maxinum thickness of 500 feet. In Michigan the Iarshall group, the equivalent in part of the Kinilerhook, is said to have 173 feet of grit aud sandstones, the overlying Napoleon group having 123 feet of shale and sandstones. In Ohio the Waverly gronp has a maximum thickness of 1,150 feet, chiefly shales and sandstones (Orton, Gcol. Snrv. Ohio, Vol. VII, 1893, p. 4), or, as is averaged in the same table, 500 to 800 feet. However, Herrick considers a portion of this to be of Deronian age, while the rest represents the Kinderbook, Burlington, and Keoknk periods. 
evidence for believing to have been the case, but no cataclasmic interposition of barriers is necessary to account for the individnal conrse of derelopment which the famna seems to have pursued in the Rocky Mountain region and in what is now the Mississippi Valley.

The approximate uniformity of the Madison limestone is evidence of a protracted period of quiet and uniform physical conditions, while the rapid alternation of sediments in the typical Mississippian would seem to indicate frequent and important changes in enviromment which find equal expression in the varied famnas that have resulted. The wide separation of the two regions geographically would readily permit of their independent development, both faunally and physiographically.

Still, the conchusion is not warranted that the Madison limestone represents the entire period of Mississippian deposition. In Montana, at "Old Baldy," near Virginia City, Meek las reported fossils of the Chester group, with a probability of the lower formations being present; and from near Fort Hall, between Ross Fork and Lincoln Valley, in Idaho, the same anthority has identified many species characteristic of the oolitic beds of the St. Louis group at Spergen Hill, Indiana. ${ }^{1}$

These localities are both comparatively near the Yellowstone National Park region, and it is hard to believe that if the Madison limestone was contemporaneons in part with either of these periods the fauna shonld not clearly indicate it. Indeed, Meek, commenting upon certain collections made at varions localities in Montana not far from the Yellowstone Park, and from a horizon which I believe to be equivalent to the Madison limestone (see ante, p. 487), makes the following statement: "At the same time that I would refer the beds from which these fossils were obtained to the Carboniferons, it should be remarked that we have every reason to believe that they belong to a lower horizon in the series than those from which nearly all the collections from 'Old Bally' Momtain were obtained; also, than the fossiliferous beds on the divide between Ross Fork and Lincoln Valley, Montana." (Loc. cit., p. 433.)

We may therefore conclude that the Madison limestone does not probably represent the period of the Generieve group, but, while showing distinct affinities with the Kinderhook, may have persisted throngh the period of the Osage group as well.

'Hayden, Sixth Ann. Rept. U. S. Geol. Surv. Territories, etc., for 1872, 1873, pl. 433, 434. 
The finct that the entire Coal Measure series is lacking in this region, or, if represented at all, finds expression in the unfossiliferous Quadrant (quartzite, makes it probable thiat the sane forces which resulted in the nondeposition or renoval of the orerlying formation affected the later portion of the Lower Curboniferous time in the same way.

Table showing the representation of zoologieal groups in the Malison limestone funna.

\begin{tabular}{|c|c|c|c|c|}
\hline & $\begin{array}{c}\text { Total } \\
\text { species. }\end{array}$ & $\begin{array}{l}\text { Identified } \\
\text { species. }\end{array}$ & $\begin{array}{c}\text { New } \\
\text { spucies. }\end{array}$ & $\begin{array}{l}\text { Waverly } \\
\text { species. }\end{array}$ \\
\hline l'rotozoa ............ & 1 & 1 & 1 & \\
\hline Spouger........................ & 1 & 1 & 1 & … \\
\hline 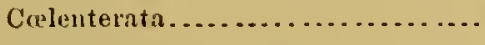 & $i$ & 6 & 5 & 1 \\
\hline Crinoiclea ....................... & 2 & 1 & & 1 \\
\hline Bryozoa......................... & 10 & $\cdots$ & .. & $\ldots$ \\
\hline Brachiopola ...................... & 47 & 43 & 14 & 29 \\
\hline Lamellibranchiata ............... & 2 & 1 & 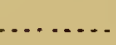 & 1 \\
\hline 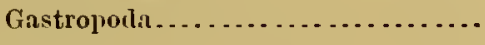 & 8 & 1 & & $\ldots$ \\
\hline Trilobita ........................... & 2 & 2 & $\ldots \ldots \ldots$ & $\ldots$ \\
\hline
\end{tabular}

It will be seen from the foregoing table that an musnally large percentage of the fauna of the Madison limestone, not only in the number of specitic types, but in the abundance in which they are found, consists of brachiopods. Most conspicuous for their rarity" are the lamellibranchs, of which only two specimens, representing two different species, ${ }^{1}$ have been collected. This is, perhaps, explained by the consideration that the Madison limestone is usually rather pure in composition, no true shales occurring interbedded with it. On the other hand, crinoids, which we might expect to find abundantly in such extensive calcareous deposits, are also comparatively rare. Other organic types appear, perhaps, in not far from the average proportion.

Two localities are interesting as presenting a local or perhaps more than local development of the Marlison limestone famma. One, the cherty limestone of Crowfoot Ridge, Gallatin Range, forms the upper portion of bed 24 of the section. The fauna consists of Productus semireticulatus, Menoplyyllum (?) excavatum, Nuticopsis (?) sp., Platycerus form a, Cliothyris roissyi, C.crassicardinalis, Spirifer striatus var. madisonensis n. var., Spirifer centronatus,

${ }^{1}$ One of these, very fragmentary (but perhaps referable to Cypricardinia consimilis Hall or $C$. scitula Herrick), is not mentioned in the report following. 
Syivifirinu solintirostris, Liorhynchus huguei n. sp., Camurotochin metallica, I'rorluctella cooperensis, Chonctes ornatus, Orthothetes inflatus, Crania lavis, I'tilopora sp., Fenestella sp. Of these L. huymei, Naticopsis (?) sp., Platyceras sp., Cramin levis, Ptilopora sp., and Fenestclla sp. lave not been identified elsewhere in the Madison limestone, with whose fanna, however, that of these localities is very elosely relaterl.

The red heds exposed at the hearl of Comant Creek, 'Teton Range, may also be separated from the Madison limestone, with which lithologically as woll as fammally they are slightly comnected. The matrix is a red calcareous shale, more shaly than is common in the Madison limestone, in which the fossils are, as a rule, very batly erusher. The fauna, which is scantily known and, on accomt of the condition of the material, inadequately identified, consists of Semimula madisonensis 11. sp., Spirifer marionensis (?), Oithothetes sp., and Eridopora (?) sp. None of these is unquestiomalsy identical with species found in beds below, though they are perhaps questionably distinct. This locality is provisionally referred to bed 32 , the highest in the formation. More evidence may show it to be later than the Warerly.

\section{DESCRIPTIONS OF SPECIES.}

\section{DEVONIAN.}

(CELENTERATA.

\section{ACTINOSTROMA Nicholson, 1886.}

\section{ACtinostroma sp.}

At least one species of Stromatoporoid is represented in this collection; but the material, badly weathered and poorly silicified, scarcely affords the promise of more than a generic identification. Therefore it has not been studied by means of microscopic sections. A careful examination shows a large concentrically laminate comostem. The lamina are nore or less contorted, and the dirision into latilamine is not apparent. The very fine lamina are connected by minute radial pillars, which on favombly exposed surfaces are seen to be continuous. This is the well-known characteristic structure of the genus Actinostroma, very abundant in Devonian strata in both hemispheres. 
Formation and locality: Three Forks limestone, near the divide between Gallatin Valley and Panther Creek, Bighorn Pass, Gallatin liange, bed 21; S. L. Pentield. East slope of Antler Peak, Gallatin Range; A. C. Gill. South slope of Antler Peak, Gallatin Range; J. P. Iddings.

PACHYPHYLLUM Edwards and IIaime, 1850.

\section{Pachyphyllum sp.}

Corallum attaining large size (the present specimen measures $150 \mathrm{~mm}$. in longest diameter and is fragmentary). Corallites small (9 to $10 \mathrm{~mm}$. in (liameter), separated by mural zones of about $2.5 \mathrm{~mm}$. Septa, 32 to 34 in number, and alternating in size.

The specimen studied is a massive weather-worn fragment, which does not show the exterual surface of the corallum, nor the nature of the calyces. The rock has also suffered considerably from compression, for, though the limestone is scarcely altered, the corallites are flattened and the lines of the septr and spongy exothecal and dissepimental tissue often broken and discontinuous. The corallites vary much in size, owing probably to difference in age, but are more uniform where the corallum is crowded. The average of mature cells is, perhaps, as above stated. That measurement, however, relates to the septate portion only. The mural tissue is very finely vesicular and is not penetrated by the septa, which are about 34 in number. They are strong, but have not the Acervularia-like expansion so strongly developed as in P. devoniense. Longitudinal sections show alternating stripes of finely vesicular mural tissue and the longitudinally banded septate portion. This is occupied by dissepimental plates, but the presence of complete tabula has not been ascertained.

While I am convinced that this species is as yet undescribed, and althongh the character's established are sufficient to enable one to distinguish it from any forms known and to recognize it again at the type or adjacent localities, yet I have not felt justified in proposing for it a new name, since the material is scarcely suitable for illustration; and it is not improbable that from other stations, more or less remote, new types will subsequently be described, which it will not be possible to separate from this, owing to the imperfections of the latter.

The only species which, so far as I am aware, have been referred to MON XXXII, PT II- 32 
this genus in this country are the three mentioned by Miller in his North American Geology and Paleontology, viz: P. devoniense, P. woodmani, and $P$. solitarium. The last mentioned of these can scarcely be referred to the genus Pachyphyllum, since it is described as a simple coral with an epitheca (or theca) and without exothecal tissue. Pachyphyllum woodmani was originally mentioned by White as Smithia woodmani. ${ }^{1}$ Hall and Whitfield describe and figure it ${ }^{2}$ under the name of Puchyphyllum woodmani, saying "the exsert form of the cells, and their limitation by an outer wall, are features which do not exist in Smithia, but pertain to the genus Pachyphyilum." In point of fact, Pachyphyllum seems to be a symonym of Smithia. The gentus is characterized by Edwards and Haime as follows: "Corallum compound, increasing by lateral gemmation. Corallites not separated by an individual epitheca, but united in their lower portion by a large development of costæ and exothecal tissue; septa and tabulx well developed. Pachyphylhum is distinguished from all other Cyathophylloids by the development of the costr and exothecal tissue." ${ }^{3}$ The description of $P$. bouchardi, the type (ibid.), accords with the generic description, but, unfortunately, by some oversight, it was not figured by the authors. Althongh there is the nsual reference lieading the specific description, there is no corresponding plate or description of plate in the accompanying atlas. I am not aware that it has subsequently been figured. Smithia is described by the same authors in the following terms: "Corallum conpound, astreiform, multiplying by submarginal gemmation. Corallites intimately comnected, having the same structure as Acervularia (i. e., with two walls; septocostal structure well developed between the walls; much less in the central area. No columella. Tabula little developer), except that they lack external walls and that the septocostal rays are more or less confluent. No columella." (Loc cit., p. 142.)

A comparison of the two genera shows that they are at least very closely related. One great distinction, implied rather than expressed, is that in Smithia the one wall is regarded as homologous with the imner wall of Acervularia, the intercellular tissue being then simply confluent intermural tissue of adjacent cells. In Pachyphyllum, on the other hand,

1 Geol. Rept. Iowa, 1870, Vol. I, p. 188.

"Twenty-third Aun. Rept. New York State Cab. Nat. Hist., p. 231, Pl. IX, fig. 9.

${ }^{3}$ Hist. Nat. des Coralliaires, Vol. III, Paris, 1857, p. 391. 
the imperfect wall is regarded as equivalent to the theca of most rugose corals, the outer wall of Acervularia, while the surrounding tissue is exothecal in nature, a sort of conenchyma. If this distinetion can be established, the two genera would be widely different in fact, however difficult it would be to distinguish them in practice. However, there seems to be little if any reason why the single, imperfect central walls in both genera should not be homologons with each other and with the imperfect imner wall of Acervularia. Thus the two differentiating characters mentioned by Hall and Whitfield fall to the ground, for in neither genus are the corallites linited by an onter wall. As to the exsert form of the cells, this character is not mentioned in the generic description of Pachyphyllum, but $P$. bouchardi is described with "Walls strong and distinct; calyces circular, deep, with edges rather elevated." This character, then, is not regarded as of generic value, and in the type species is not especially striking. The chief points of distinction which can be drawn from Edwards and Haime's description (leaving out their view of the homologies of the inner wall, which I hold to be questionable) come to this, that Pachyphyllum has very extended tabulze, while Smithia has them only slightly developed, a character which, taken alone, is of doubtful generic importance.

Smitlia is generally regarded as a syuonym for Phillipsastræa, but Edwards and Haime claim that it is distinguished from the latter by the presence of a columella. If constant, this would seem to be a good character. After studying the type species, Nicholson states that Phillipsastrea (= Smithia) has essentially the structure of Heliophyllum-i. e., with carinate septa, fossula, and without an inner wall. If Smithia is indeed synonymous with Phillipsastræa, then Pachyphyllum is a quite different thing. But if Smithia and Pachyphyllum are as Edwards and Haime have described them, it seems probable that the latter is a synonym of the former.

It is possible that three types are included among the five species referred to Pachyphylhm. One of these, $P$, solitarium, I think, beyond a doubt, must be placed elsewhere. Or, is it perhaps the initial cell of a Pachyphyllum colony? Another type which is structurally near Smithia is that represented by $P$. bouchardi and $P$. woodmani. A third type is found in $P$. devoniense and the form above described. It is 
characterized by a mural zone of vesicular tissue, which is not penetrated by the septa. Edwards and Haime say that in P. devoniense this zone is traversed by the costæ, which are not very pronounced, but distinct. This is scarcely apparent in the figure, but, if so, the form represents an intermediate stage between P. bouchardi and Pachyphyllum sp., where the thick costæ terminate in the mural zone without penetrating it.

Formation and locality: Three Forks limestone, north side of saddle west of Mount Miller, Absaroka Range; Lonis V. Pirsson.

CYATHOPHYLLUM Goldfuss, 1826.

\section{Cyathophyllum cespitosum Goldfuss (?)}

Cyathophyllum crespitosum Goldfuss, 1826. Petrefacta Germanix, p. 60.

In the calcareous sandstone, associated with specimens of Actinostroma, Pachyphyllum, Atrypa, etc., is a species of Cyathophyllum, which may be identical with C. cespitosum Goldf. It consists of isolated fragments of cylindrical corallites, which have about forty alternately long and short septa, a tabulate central portion, and a vesicular outer zone. In size, general character, and in specific detail, as far as determinable, these strongly resemble Goldfuss's species, and may, like it, when entire, have grown in tuftlike masses. Indeed, the small diameter and the cylindrical form of the corallites are favorable to such an interpretation. C. ccespitosum is already known to occur in American strata, being found in Upper Helderberg rocks.

Formation and locality: Three Forks limestone, near the divide between Gallatin Valley and Panther Creek; Bighorn Pass, Gallatin Range, bed 21; S. L. Penfield. East slope of Antler Peak, Gallatin Range; H. C. Gill. North side of saddle west of Mount Miller, Absaroka Range; Louis V. Pirsson.

\section{CLADOPORA Hall, 1852.}

\section{Cladopora sp.}

Like the other corals from the same bed, specimens of Cladopora are coarsely silicified and considerably weathered. The branches are circular, and about $5 \mathrm{~mm}$. in diameter. The pores are nearly circular, small (about $0.25 \mathrm{~mm}$. in dimneter), and separated from each other by a distance about 
equal to their own diameter. What the slape of the orifice may have been originally it is impossible now to determine. In its present condition the corrallum resembles C. labiosa and C. pinguis, both of Rominger, ${ }^{1}$ but more especially the form figured as a variety of $C$. labiosa. ${ }^{2}$

The form under discussion resembles C. labiosa in the slenderness of the stem, but the pores are more distant, and at present not labiate. It resembles $C$. pinguis in the thick interstitial tissue between the cells and in the less labiate condition of the latter; but the branches are less robust and the cell apertures apparently smaller.

Formation and locality: Three Forks limestone, near the divide between Gallatin Valley and Panther Creek, Bighorn Pass, Gallatin Range, bed 21 ; S. L. Penfield.

FAVOSITES Lamarck, 1812.

Favosites sp.

PI. LXVI, fig. 8a.

Corallum rather small, about $50 \mathrm{~mm}$. (?) in diameter; cells small, very closely tabulate, tabulæ being about $0.5 \mathrm{~mm}$. apart. Number of rows of mural pores, character of the same, and nature of the epitheca, not known.

The material submitted was not found in place. It consists of a fragmentary silicified example, which, while showing some characters very plainly (e. g., the tabulation), has others obliterated so that specific identification of the form is impossible. It can, however, be affirmed that it does not belong to any Carboniferons representative of the genus, at least such as are yet described, and it can therefore with great probability be regarded as belonging to Devonian or Upper Silurian time.

Formation and locality: Three Forks limestone, north side of Soda Butte Creek, Absaroka Range; J. P. Iddings. 


\title{
BRACHIOPODA.
}

\author{
ATRYPA Dalman, 1827.
}

Atrypa reticularis Limé.

Pl. LXVI, figs. $1 a, 1 b, 1 c$.

Atrypa reticularis Linué, 1767 : Systena Natur:e, ed. xii, Vol.I, p.1132. Hall,1552: Pal. New York, Yol. II, p. 72, Pl. XXIII, figs. 8 , Sa-8n; p. 270, Pl. LV, figs. 5a-5u. Billings, 1863: Logan, Geol. Surv. Canada, Rejt. Progress 1843-1863, p. 318, figs. 335a-335c; p. 38t, figs. 416a-416c. Hall, 1867: Pal. New York, Vol. IV, p. 316, Pl. LII, figs. 1-3, 7-12; Pl. LIII, figs. 3-19; Pl. LIIIA, figs. 22, 23 . Neek aud Worthen, 1868: Geol. Surv. Illinois, Vol. III, p. 432, Pl. XIII, fig. 11. Heek, 1877: King's U. S. Geol. Expl. 40th Par., Vol. IV, p. 38, PI. I, figs. 7, Ta; Pl. III, fig. 6. White, 1880: Second Ann. Rept. Indiana Burean Statisties aud Geology, p. 502, Pl. V, figs. 7, s, 9. Walcott, 1884: Mon. U. S. Geol. Surv., Vol. VIII, p. 150, Pl. XIV, figs, $6,6 a, 6 b$. Beecher and Clarke, 18s9: Mem. New York State MIus. Nat. Hist., p. 51, Pl. IT, figs. 12-20. Hall and Clarke, 1893: Pal. New York, Vol. VIII, Pt. II, p. 165, fig. 153; Pl. LV, figs. 1-17. Herrick, 1895: Geol. Ohio, Vol. VII, Pl. XX, fig. 7.

This well-known and universally distributed form needs no further description. It has as yet been identified from but one locality in the Yellowstone National Park, is represented entirely by casts, and is a small, coarsely plicate form, similar to that from the Lockport (often called Niagara) limestone, and identified by Walcott from Upper Devonian strata.

Formation and locality: Three Forks limestone, base of bluff, Little Sunlight Creek; Armold Hague. Silurian and Devonian throughout the world.

$$
\begin{gathered}
\text { Atripa missouriensis Miller. } \\
\text { Pl. LXVI, figs. } 2 a, 2 b, 2 c .
\end{gathered}
$$

Atrypa reticularis (var.) Meek, 1877: King's U. S. Geol. Expl. 40th Par., Vol. IV, p. $38, \mathrm{Pl}$. III, fig. 6 a.

Atrypa desquamata Walcott (non Sowerby), ISS4: Mon. U. S. Geol. Surv., Vol. VIII, p. $150, \mathrm{Pl}$. XIV, figs. $4,4 a$.

Atrypa missouriensis Miller, 1894: Eighteenth Anu. Rept. State Geologist of Indiana, 1893, p. 315, Pl. IX, figs. 19-21.

Shell rather small, subcircular, variable in shape. Dorsal and ventral valves moderately and equally convex, finely striate, not at all or only obscurely marked by distant concentric strixe, which, moreover, are not 
squamose. Beak of the ventral valve small, not much incurved; area small. Anterior margin distinctly but not strongly sinnate.

There can be little doubt that this is the same form for which Miller proposed the name Atrypm missouriensis, and which had been previously referred to by lleek ats Atrypu reticularis and by Walcott as Atrypue desqunmetu (loc. cit.).

A. missomicnsis is described from Middle Deronian rocks (probably IInnilton age), and the type locality is 3 miles from Otterville and 17 miles west of Sedalia, Missouri. A form, probably referable to Miller's species, is found at Fulton, Missouri, in rocks of Hamilton age, and with this the material from the Yellowstone National Park is very closely allied, perhaps specifically identical. It is possible that the finely striated variety of $A$.reticularis, mentioned by Walcott ${ }^{1}$ and said to resemble a variety from the Hamilton and Chemmig groups in Iowa, may also be placed in the list of synonyms.

A. missomiensis occurs in considerable abundance at several localities in the Yellowstone Park, but it is rarely found associated with Atrypa reticuluris, which is known from the same region. The two forms are thus distinct in distribution as well as intrinsic character, when this region alone is contemplated, and the natural tendency is to refer them to different species, but in riew of the almost miversal distribution of $A$. reticularis, and its equally extensive range of variation, perhaps a varietal distinction is all that is warranted. Only a monographer will be competent to determine specific limitations in this protean type.

$A$. desquamata in this country is nothing more than $A$. reticularis with an erect beak, area, and unconcealed foramen; and the same appears to be equally true of the European forms. This character or group of characters seems scarcely of specific value, but in any case the same peculiarities of surface, etc., which distinguish $A$. missouriensis from $A$. reticularis serve to differentiate it from $A$. desquamatu also. Although it is a mature form, A. missouriensis is characterized by neologic traits, and agrees very closely with young examples of A.desquamata as figured by Davidson." Still, full-grown shells are the only ones with which we are justified in comparing it.

'MIon. U. S. Geol. Surv., Vol. VIII, 1884, p. 150.

${ }^{2}$ British Fossil Brachiopoda, Vol. III, Part VI, Pl. XI, tigs. 6, $6 a$. 
Formation and locality: Three Forks limestone, south slope of Antler Peak, Gallatin Range; south side Soda Butte Creek, northwest of Abiathar Peak, Absaroka Range; J. P. Iddingrs. North side of saddle west of Mount Miller, Absaroka Range; Louis V. Pirsson. Near Otterville and Sedalia, Missouri.

\section{SPIRIFER Sowerhy, 1815.}

Spirifer englelmanni Meek.

Pl. LXTl, figs. $3 a, 3 b, 3 e, 3 \pi$.

Spirifera enge'manni Meek, 1860: Proc. Acad. Nat. Sci. Phila., p. 308. Meek, 187т:

King's U. S. Geol. Expl. 40th Par., Vol. IV, p. 41, Pl. III, figs. 3-3a.

Spirifer cngelmanni Mleek, 1876 : Simpson's Rept. Expl. Gt.. Basin. Terr. Utah, 1. 34t,

Pl. I, figs. $1 a-1 c$.

There is only one example of this species. Though otherwise apparently identical with the smaller forms of $S$. engetmanni, it is abnormal in this, that the strong plication bounding the sinus bifurcates, the two imner ribs lying upon the sides of the sinus. I have not observed this in S. engelmami from Nevada, but have seen dorsal valves with a shallow median sulcus on the fold, so that there is little reason for believing that such irregularities do not occur on the other valve as well. The specimen could scarcely be a young individual of $S$. disjunctus, for that species has finer plications, which are distributed in large numbers on both fold and sinus.

Formation and locality: Three Forks limestone, soutl side Soda Butte Creek, northwest of Abiathar Peak, Absaroka Range; J. P. Iddings. Middle Devonian, Neils Valley, Utah; White Pine District, Nevadi.

\section{ATHYRIS HcCoy, 1844.}

Athyis vittata var. triplicat'a 11 . var.

Pl. LXYI, figs. $4 a, 4 b, 4 c$.

Shell small, subcircular. The two valves moderately and equally convex. Ventral valve marked by a broad, shallow median sinus. On either side is a faint sinuation separated from the median one by a sharp ridge. Dorsal witl well-defined, square fold, bounded on either side by an angular depression, after which follow, one on each side, two other slight folds. All the plications of this shell are discernible for only a short distance back from the unargin. Width, $9 \mathrm{~mm}$.; length, nearly the same. 
The shell is so badly exfoliater that its surface characters are unknown, and the generic reference, as a whole, is doubtful. It resembles Athyris vittuta of the Coniferous and Hamilton groups, and $A$. angelica of the Hamilton, some examples of which approach this shell, though not very closely. It finds a close ally in $A$. angelica var. occidentulis Whiteares (Cont. Canadian Pal., Vol. I, Pt. III, 1891, p 227, Pl. XXXII, figs. 3-3a), from which it differs chiefly in having an additional low fold on either side. The two forms resemble each other more than either $A$. angelica or $A$. vittata. Whiteaves's shell is probably wortlyy of specific distinetion, and the relation between it and the form from the Madison linestone would be best expressed by making the latter a variety of the former. The name of my shell would then be Athyris occirlentalis var. triplicata.

Formation and locality: Three Forks limestone, soutl side of Soda Butte Creek, northwest of Abiathar Peak, Absaroka Range; J. P. Iddings.

\section{GASTROPODA.}

PLEUROTOMARIA Defrance, 1824.

\section{Pleurotomaria isaacsi Hall and Whitfield. (?) \\ Pl. LXVI, figs. $5 a, 5 b$.}

Pleurotomaria isacsii Hall and Whitfield, 1873: Twenty-third Rept. New York State Cab. Nat. Hist., p. 23s, Pl. XII, figs. 6, 7.

The form which I have referred to Hall and Whitfield's species occurs as an isolated specimen of a large gastropod shell. As far as the somewhat imperfect condition of the material permits a comparison, the specimen from Yellowstone National Park is very close to $P$. isuacsi. It is a large flattened shell, about $59 \mathrm{~mm}$. in diameter, agreeing in size, general proportion, and peritreme section with the species to which I have referred it. On the other hand, the spire is a little more elevated than the specimen figured by Hall and Whitfield, the whorls a little more angular in section, with the upper sirface obliquely plane or slightly coneave. The shell appears to be without ornamentation.

Pleurotomaria isaacsi is from the Lower Devonian, probably the Schoharie grit.

Formation and locality: Three Forks limestone, Wall Canyon, Clark Fork Valley; Arnold Hague. Lower Devonian, near Raymond Station, Iowa. 


\section{Pleurotonaria (?) sp.}

A rather large gastropod shell, broken and embedded in limestone. Height, about $22.5 \mathrm{~mm}$.; dianeter at base, $25 \mathrm{~mm}$.; whorls, five or six. Umbilicus extending through three or four whorls. Apparently without ornamentation. Cross section of whorl subquadrate, the upper and lower faces converging centripetally, the distal and proximal faces converging toward the apex. Shell thick, interior section of whorl nearly circular.

The matrix inclosing the specimen is weather'worn so as to form a transverse section somewhat more than half through the shell. From this the above notes were taken. The surface as represented by section is mornamented, for the line representing the outer face is simple and entire. Although a certain identification is impossible, this fact operates against referring the form to Pleurotomaria. It may go with the genus Palæotrochus, but is distinct from anything yet referred thereto.

Formation and locality: Three Forks limestone, north side of saddle west of Mount Miller, Absaroka Range; Louis V. Pirsson.

\section{LOXONEMA Phillips, 1841.}

\section{LOXONEMA DELICATUM n. sp.}

Pl. LXVI, fig. 6a.

Shell very small, elongate. Spire consisting of about five volutions; whorls well rounded and suture line depressed. Aperture nearly circular.

The specimen described is a cast, not showing any surface characters. It is found associated with Platystoma minutum and other gastropods (see ante, p. 482).

Formation and locality: Three Forks limestone, south side of Soda Butte Creek, northeast of Abiathar Peak, Absaroka Range; J. P. Iddings.

PLATYSTOMA Conrad, 1842.

\section{Platystoma minutum n. sp.}

Pl. LXVI, figs. $7 a, 7 b$.

Shell extremely small, conical, flattened. Spire low and consisting of about three volutions. Aperture somewhat oblique, elongate, elliptical. Surface nearly smooth, ornamented, if at all, only with lines of growth. 
This species occur's at the soutl side of Solla Butte Creek, northeast of Abiathar Peak, Absaroka Range, associated with Loxonema delicatum and an number of other gastropod forms too imperfect for description (see ante, p. 482).

Formation and locality: Three Forks limestone, south side of Soda Butte Creek, nortleast of Abiathar Peak, Absaroka Range; J. P. Iddiugs.

\section{LOWER CARBONIFEROUS.}

\section{PROTOZOA.}

ENDOTHYRA Phillips, 1845 .

\section{Fndothyra baileyi var. parva n. var.}

Pl. LXXI, tigs. 13u, 13l, $13 e$.

This form is known only by microscopic sections and therefore very inadequately; but the correctness of the reference to Endothyra seems unquestionable, and I am even in doubt whether it is varietally distinct from Hall's species. So far as my observations go, it is never much over half the size of Endothyra baileyi, ${ }^{1}$ and is more simple-i. e., less numerously. chambered. Although these characters are ordinarily of questionable diagnostic value, appearing as it does in quite different associations, the Western form seems worthy to be classed as a distinct variety. And it is not improbable that a study of the shell under auspices more favorable than by microscopic sections will more fully justify the distinction. This form should be compared with E. bowmani Phillips and E. lobata Brady, which Brady ${ }^{2}$ consider's to be the same as E. baileyi. They are less robust and more simple forms.

Formation and locality: Madison limestone, White Mountain, Absaroka Range; Arnold Hague. Amphitheater east of Bannock Peak, Gallatin Range, bed 30; Snake River Valley, west of Two Ocean Plateau; W. H. Weed.

' See Pl. LXXI, figs. $12 a, 12 b$.

${ }^{2}$ Palieontographical Soc., Vol. XXX, p. 92, Pl. V, figs. 1-4. 


\section{PORIFERA.}

HOLASTERELLA Carter, 1852.

\section{Holasterella wrighti var. americana 11. var.}

Pl. LXXI, fig. 11 1 .

The only trace of sponge remains which has been observed in Yellowstone National Park consists of two or three delicate silicified spicules, which, for lack of a better designation, I have called by the above name. While closely related to Carter's species, ${ }^{1} \mathrm{I}$ think it is undoubtedly distinct. At the same time, in view of the limited amount of material at my disposal, I do not feel justified in proposing a new specific name, while the occurrence of the form seemed worthy of notice and a name of some sort desirable.

The spicules in question are of the regular hexactinellid type. The six arms are stout and short, each quickly subdividing into four long tapering branches. These are set at an acute angle with one another, and ornamented with fine nodes, which tend to an arrangement in transverse rows, giving the branches a finely annulated appearance.

The genus Holisterella, so far as I am aware, is restricted in its range to Lower Carboniferous strata; and this is the first notice of its occurrence in this country.

Formation and locality: Madison limestone, divide between Gallatin Valley and Panther Creek, near Bighorn Pass, Gallatin Range, bed 24; Arnold Hague.

\section{CELENTERATA.}

\section{AULOPORA Goldfuss, 1826.}

AUlopora geOMETRICA 11 . sp.

Pl. LXVII, fig. 6a.

Corallum free (?), spreading. Corallites small, each regularly budding off two other individuals, which diverge at an angle of about $120^{\circ}$, so that the colony as a whole presents a regular network with hexagonal openings. Length of corallites about $5 \mathrm{mmm}$; d diameter, from 1.25 to $1.5 \mathrm{~mm}$

'see Carter, 1880: Ann. Mag. Nat. Hist., Vol. VI, p. 209, t. 14b, tigs. 1-17; and Hinde, 1883: Cat. Foss. Spouges, Brit. Mns., p. 153, Pl. XXXII, figs. 4-4g. 
This species is interesting as being the first representative of the genns Aulopora described from the Carboniferous rocks of this country. The form in question presents some apparent divergences from typical Aulopora liabit and strueture, such as, if they could be established, would be sufficient for generic differentiation. However, I have but one specimen of the species, and it does not afford conclusive evidence on the points in question. The corallum appear's to have been free, or at all events to have outrun the surface on which it was ereeping, and the unannexed portion to have been broken away; for there is no evidence of attachment in its present condition. The corallites are small and eut up internally by infundibuliform dissepimental tissue, somewhat as in Syringopora. At least, there are usually to. be seen one or more cylindrical walls internally concentrie with the theca. It may be thought, and perhaps correctly, that this is the initium of a Syringoporoid colony. As against this view, it may be stated that no such colonies are known from the locality in question, nor would the hypothetical colony restored from this initium probably agree specifically with any yet discovered in the Yellowstone Park.

Formation and locality: Madison limestone, Bighorn Pass, Gallatin Range, eherty belt; Arnold Hague.

\section{SYRINGOPORA Goldfuss, 1826.}

Syringopora aCulEata n. sp.

PI. LXVII, figs. $5 a, 5 b$.

Corallum large, never favositiform; corallites small, radiating, separated by distances varying from one-half to five or six times the diameter of the average corallite. Usually about 1 diameter apart.

Corallites about $1.5 \mathrm{~mm}$. in diameter. Septa represented by spines set in about twenty-five vertical rows. The number appears to be variable, and can not be stated with exactness. The spines are long and very numerous, so that they form a striking feature in any transverse or longitudinal section. Dissepimental struetures well developed, spinose, vesiculose infundibuliform, the dissepimental plates converging very gradually.

Formation and locality: Madison limestone, White Mountain, Absaroka Range; Arnold Hague. Crowfoot Ridge, Gallatin Range, bed 29; J. P. Iddings and W. H. Weed. 


\section{SYRINGopora surcularia 12. sp.}

Pl. LXVII, figs. $4 a, 4 b$.

Similar to the above, but larger. Average diameter of individual corallites, $2.5 \mathrm{~mm}$. Walls thickened by stereoplasma. Infundibuliform dissepimental tissue well developed, spinulose; the spines appear as nodes of greater or less prolongation, often radially directed between parallel dissepinents. They are irregular, however, have no constant connection with the spiniform septa, and never give the corallite the septate appearance of rugose corais.

This species is, in a general way, very close to the preceding, but the eye differentiates them at a glance on the basis of size. The walls of S. surcularia are more thickened by stereoplasma than are those of $S$. aculeata, and the septal spines, which are embedded in it, appear to be relatively not so long, so numerous, nor in so many rows.

Both species are easily distinguished from $S$. multattenuata IIcChes., by the fact that the corallites in the latter often grow in contact and are scantily supplied with septal spines.

Formation and locality: Madison limestone, White Mountain, Absaroka Range; Upper Gallatin Valley, west of Bighorn Pass; Arnold Hague. Crowfoot Ridge, Gallatin Range, bed 28; J. P. Iddings and W. H. Weed. Hear of Gallatin River, west of Three River Peak; Arnold Hague.

\section{MICHELINIA DeKoninck, 1842.}

\section{Michelinia placenta White.}

Pl. LXVII, figs. $3 a, 3 b$.

Michelinia (?) placenta White, 1883: Twelfth Anu. Rept. U. S. Geol. Geogr. Surv. Terr', Pt. I, p. 15i, Pl. XXXIX, figs. 1a-1

This species is known at two localities in the Yellowstone National Park. It appears to be the same form described by White, from Sedalia, Missouri, where it occurs at the top of the Choutean limestone. I have not seen specimens from White's locality, but his description and figures show the two forms to be very similar.

Formation and locality: Madison limestone, east side of Gallatin River west of Electric Peak; divide between Gallatin Valley and Panther Creek, near Bighorn Pass, Gallatin Range, bed 24; Arnold Hague. Top of the Chouteau limestone, Sedalia, Missouri. 
MENOPHYLLUM Milne Ldwards and Haime, 1850.

Menophyllum (?) excavatum $11 . \mathrm{sp}$.

Pl. Lxvil, figs. $1 \imath, 1 b, 1 c, 1 \rrbracket, 1 e, 1 f$.

Corallum simple, regularly and rather rapidly expanding, rery slightly curved. Length of an arerage specimen, $41 \mathrm{~mm}$; diameter at the top, $23 \mathrm{~mm}$. Septa of two series. Calyce very deep, half or more than half the entire length of the corallum. In the calyce the primary septa are short and the secondary septa shorter still. Below, only the primary septa are well dereloped. They are there sometimes so thickened by stereoplasma as to make the bottom of the corallum almost solid. There is no columella nor dissepimental derelopment, but a well-marked fossula is always present.

The deep calyce muinterrupted by transverse partitions, the smaller number of septa, and large fossula, strongly characterize this form

There is only one species of Menophyllum known heretofore, $M$. tenuimarginatum; and M. excavatum is, so far as I am aware, the first reference made to the genus in this country. This reference may, however, perhaps justly be called in question, since $M I$. tenuimarginatum is said to possess crescentshaped tabule, and to be allied to Amplexus, while $M I$ excavatum is without tabula and dissepimental tissue. On the other hand, as seen in transverse sections, the structure of the two forms seems to be so closely analogous that I can not but believe that, if not congeneric, $M$. excavatum is at least nearly allied to MI. temuimarginatum. It resembles the genus Cyathaxonia in being without tabulæe or dissepiments, but differs from it in lacking a columella as well. I have avoided the gemus Petraia, which is perhaps founded on a similar type, for it is little known and can scarcely be regarded as well established. Nor do I believe a reference to Zaphrentis to be warranted, for, as before stated, $M$. excavatum is without endothecal structure except the septa, and the mamner in which the ends of all the septa are bent to form an inclosing wall for the fossula is very characteristic.

Compared with $M I$. tenuimarginatum, $M I$. excavatum has fewer primary septa, and those of the second order are not so well developed.

The structures of the earlier corallum of this coral have not been observed. The secondary septa attain only an inconsiderable derelopment. There are about twenty-six primary septa, which are bent at the ends and so united as to leave a large fossula, reaching to the center of the theca. The 
fossula is bisected by a cardinal septum, which also reaches to the middle and is there connected with the other septa. The theca and all the septa, except the cardinal septa, are sometimes so thickened by stereoplasmic deposits as to form a nearly solid mass, obscuring details of arrangement. This description is taken from a section below the calyce, well down in the septate portion.

A section through another coral, apparently at a somewhat later stage than the above, shows a very interesting condition. The septa on one side of the theca, abont fifteen in number, are inclined toward a point, eccentric, and lying within the diametral segment moder discussion. Their ends are bent and connected by a thick stereoplasmic deposit into a counterseptal wall. There are twelve other septa. Of these, six on one side and five on the other are inclined toward the risceral wall aforesaid, and their bent ends are mited into a partition which, in one case, appears to connect with the comterseptal wall, and in the other is still free. This leaves a wide terminally inflated fossula, but the septum occupying it, or cardinal septum, is very short. There is no stereoplasmic thickening.

Another section through the same specimen, at a point fartlier from the apex, shows the primary septa (twenty-nine in number) inclined and with bent terminations as before described, but not extended so as to form by their ends three visceral partitions-a counterseptal and two alar. The secondary septa are represented by low ridges. The fossula is strongly marked. It is partly distinguished by the nondevelopment of the fossular septum, which is scarcely more strong than the two secondary septa between which it stands; and all the septa diminish in size as they approach the cardinal septum.

Another section, farther toward, yet still some distance from, the mouth of the calyce, shows thirty short primary septa with as many still shorter secondary septa. The general position alone of the fossula is indicated by the obsolescence of the septa in that region.

Formation and locality: Madison limestone, near summit of ridge, west end of Hunter Peak, Absaroka Range; Upper Gallatin Valley west of Bighorn Pass; Arnold Hague. Crowfoot Ridge, Gallatin Range, bed 25, lower part of bed 27, bed 31 ; J. P. Iddings and W. H. Weed. South of Forellen Peak, Teton Range; S. L. Penfield. South base of Quadrant Mountain, Gallatin Range; J. P. Iddings. Crowfoot Ridge, Gallatin Range, cherty limestone, top of bed 24; A. C. Gill. 


\section{ILTHOS'TRO'TION Lllwy', 1869.}

\section{Lithostrotion :pl.}

Corallum compound, massive. Corallites small, about $7 \mathrm{~mm}$. in diameter, polygonal. There are usually in the neiglborhood of thinty radiating septa, alternately long and short. 'The longer ones extend almost to the center. Transverse sections show that the whole interseptal space is more or less vesicular. 'Toward the peripliery the vesicular tissue is coarse, stretching in extended loops, among which, in some individuals, the peripheral ends of the septa lose themselves. In others the septa can be traced quite to the inclosing wall. Toward the center the vesicular appears to give place to dissepimental tissue, and regularly a series of these dissepiments equally distant fiom the center are thickened and joined together to form a sort of inuer wall. This inner wall is circular in section, having a diameter of about $4 \mathrm{~mm}$. The septa, too, appear thicker and denser at this point, so that the demarcation between the inner and outer zones is well marked. In the inner zone is found localized dissepimental tissue, which usually unites to form one or two concentric sheaths about the columella. The latter is linear, often united at either end with two opposite septa which bisect the corallite and give it a conspicuons bilateral symmetry. The other primary septa terminate in one of the columella sheaths, as do often all the primary septa.

The calyces are deep, flaring toward their mouth. The columella projects from the center of each, ligh, thin, and knifelike above, but below thicker and complicated with ridges. About thirty alternating septa are present, of which the primary ones descend into the calyce and mite with the columella at its thicker complicated base.

Longitudinal sections where not central show an onter vesicular zone, the strong vesicle walls curving downward and overlapping, thus forming by their inner surface the so-called immer wall of the theca. Within this are the vertical, parallel, cut edges of the septa intersected by dissepiments, or what appear sometimes to be upward-arehing tabula. In a section through the columella the septa are not seen, only the upcurving tabule, cut by the linear columella.

Formation and locality: Madison limestone, Crowfoot Ridge, Gallatin YON XXXII, PT II-33 
Range, bed $28 ;$ J. P. Iddings and W. H. Weed. Head of Gallatin River, west of Three Rirer Peak; Arnold Hague.

\section{CLISIOPHYLLUM Dana, 1846.}

\section{Crisiophyllun teres $11 . \mathrm{sp}$.}

Pl. LXVII, figs. $2 a, 2 b, 2 c, 2 \pi$.

Corallum of medium size, tapering, slightly curved, and often laterally compressed; but little marked by constrictions and irregularities of growth. Length from 75 to $100 \mathrm{~mm}$.; diameter of about $25 \mathrm{~mm}$. There are fiftythree septa of the first order; secondary septa short and coalescing with the prinary ones. Columella small, complex, composed of radiating and concentric plates. The primary septa extend to the center and are there comnected with the columella, about which they twist. Dissepimental tissue present in moderate abundance. Fossula well marked, sitnated on the convex side, bisected by the fossular septum.

This description is not taken from any one specimen, but is the result of observations made on somewhat fragmentary material from sereral localities.

The specimen figured is a somewhat undersized individual, from the summit of Three River Peak, referred to this species. A section taken where the diameter is only $7.5 \mathrm{~mm}$. shows thirty-two (primary) septa, which are thick and straight, joining the columella, like radii drawn from the center of a circle, and not twisting around it, as they do later. The columella is large, apparently solid, showing a dianetric line of greater density in the direction of the fossular reptum. Fossula large. Dissepiments numerous and rather regularly disposed, but not enongh to suggest tabulze, which appear to be absent. No secondary septa have ret made their appearance.

A section taken near the distal extremity, where the diameter is about 14 mm., shows a different condition. It appears to intersect a basinshaped tabula, or perhaps the floor of the calyce, for we see the appearance of a strong immer wall, which is evidently traversed obliquely by the plane of the section. It is decidedly eccentric, being only about $2.5 \mathrm{~mm}$. firom the periphery at the fossula and twice as far at the opposite diameter. This tabula is apparently dissepimental in its nature, and not an imner wall, becanse it does not begin at the bottom of the theca, becanse it is seen in section to be strongly divergent, and because it depends for its expression 
upoit the primary septa, hetween which it is renewed at each interval. The luinary septil are more mumerous here, and the peripheral portion, like the flow of the calyce, is dense with stereoplasma: but within the seement wall they become suddenly extremely thin, sweeping in a strong curve about the rather large, solicl colmuellat. Dissepiments nearly absent. The secmuling septa also liave appeared, but bend abruptly to the left (looking into the theca) and mite with the prinary septa. The columella at this point hiss become distinctly compound.

Formation and locality: Madison limestone, limestone bluff north of Little Sunlight Creek, Alssarokil Range, 600 feet above the stream; White Momitain, Absaroka Range; Arnold Hagne. East side of Gallatin River, west of Electric Peak: divide between Gallatin River and Pantlier Creek, Gallatin Range; W. H. Weed. Crowfoot Ridge, Gallatin Range, bed 28; J. P. Iddings and Wr. H. Weed. East slope of Survey Peak, Teton Range; S. L. Pentield. Summit of Three River Peak.

\section{ECHIXODERMATA.}

\section{PLATYCRINUS Miller, 1821.}

\section{Platrorinus sminetricus Wachsmuth and Springer.}

Platycrinus symmetricus Wachsmuth and Springer, 1890: Geol. Surv. Illinois, Tol. VIII, p. $186, \mathrm{PI} . \mathrm{X} Y$, fig. 8 .

The material examined is msatisfactory in that it has not permitted the determination of the structure of the arms with absolute certainty, while the character of the rault is completely hidden. The suture lines of the five basals are quite invisible, forming an apparently solid and rather lauge basal disk. The first radials, as in P. symmetricus, are slightly ligher than wide; indeed, the whole calyx structure appears to be as Wachsmuth and Springer have described it, exeept that the suture lines are not indented as in the Iowa form, the whole surface being in the plane of curvature. The absence of this eharacter (the impressed sutme lines) may be the result of weathering.

There are, apparently, thirty arms with the same structure as those of P. symmetricus, but I can not assert this absolntely.

P. haydeni Meek, described from Montana, ${ }^{1}$ differs from the form in

${ }^{1}$ Meek, 1873: Ann. Rept. U. S. Geol. Surv. Terr. for 1872, P. 469 ; White, 1883: Ibid. for 1878, Pt. I, p. 122, Pl. XXXIII, fig. Ta. 
question in being much smaller and in having twenty instead of thirty arms. The constituent plates appear to he sculptured, and to have elerated margins, while this is not the case with the form refered to $P$. symmetricus, although preservation may have obscured this character.

I believe this species to be itlentical witli that which White described and figured as Platycrimus sp.," althongh it is impossible to be certain upon this point, as neither material is rery good.

Formation and locality: Madison limestone, divide hetween Gallatin River and Panther Creek, Gallatin Range; head of Conant Creek, Teton Range; W. II. Weed. Kinderhook beds, Legrand, Iowa.

\section{SCAPHIOCRINUS Hall, 1858.}

\section{SCaphlocrinus sp.}

This form has a rather small cup-shaped calyx, about $19 \mathrm{~mm}$. high and $19 \mathrm{~mm}$. in greatest diameter. There are five large basals, above which are a number of smaller plates; but the summit of the calyx is incomplete and the ontline of the plates is obscured by exfoliation, so that even the generic position is only approximately correct.

Formation and locality: Madison limestone, Crowfoot Ridge, Gallatin Range, bed 28; J. P. Iddings and W. H. Weed.

\section{BR YOZOA.}

\section{ANTSOTRYPA Ulrich, 1883.}

\section{ANISOTRYPA sp.}

This genus is not yet known below the Keokuk. It is represented in the Vellowstone National Park collection but from one locality and by a single species. This grows in a hollow club-shaped zoarim, enlarged and roumding at one end. I iameter of the branch, from 5 to $7 \mathrm{~mm}$. Height of the zooidal tubes, which measures the thickness of the zoarium, is very slight, anonuting to less than $1 \mathrm{~mm}$. Diameter, abont $0.4 \mathrm{~mm}$. The zooidal tubes seem to be nearly uniform in size, and I have not been able to distinguish clusters of larger cells. Such may, howerer, exist.

This species appears to be distinct from any known representation of the genus. 
Formation and locality: Madison linestone, Crowfont Ridge, Gallatin Rimge, hed 31: J. P. Idlings and W. H. Weerl.

\section{ERIDOPORA UTricli, 1882.}

\section{Liminorora (?) sp.}

Quite abumdant at the liead of Conant Creek, Teton Ramge, on speecimens of Seminulu matisonensis, is a low inerusting bryozoan, whose exact affinitics anong known forms 1 latre been miable to deternine. It seems to be related to the genns Fistulipora. The colony is not maculate, the (cell walls rather thick, the cells very short, usually nearly square and arranged in somewlat curving rows, about four in the space of $1 \mathrm{~mm}$. Often at the angle between four cells, sometimes situated laterally between two of them, may be seen one or perhaps two minute interstitial cells, which are not seen on the surface (?). Younger, or perhans better preserved, parts of the colony show the terminal portions of the cells to be cylindrical, slantingly superjacent, somewhat contracted at the circular (?) aperture. It is owing probably to erosion that the distal portions of the colony are missing, which leaves exposed below the angular crowded cells of the colony, as seen under ordinary conditions.

For a Fistuliporid the intermediate cells are extremely scarce.

Formation and locality: Madison limestone, lead of Conant Creek, Teton Range; IV. H. Weed.

\section{PTILOPORA McCoy, 1844.}

\section{Ptilopora sp.}

Zoarimm, an extended, Fenestella-like frond. Reverse: Midrib large, about $0.5 \mathrm{~mm}$. in diameter, very prominent, cylindrical, without ornamentation except for a merlian row of strong distant nodes. Branches given off pinnately at an angle of about $30^{\circ}$. Occasionally from these secondary branches, branches of a third series are developed, but on the distal side only, at the same angle $\left(30^{\circ}\right)$. The midrib is conspicuonsly larger than the branches, which are uniform and about fourteen in $1 \mathrm{~cm}$. Dissepiments of nearly the same size as the branches, and, like them, without ornamentation. Fenestrules square to rectangular, with an angular outline; about fourteen in $1 \mathrm{~cm}$. 
Obverse: Midrib with two or three rows of small, circular, zoceial apertures (exact number not ascertained). Branches with a double row of alternate circular apertures, three to four opposite ench fenestrule, making about fifty in $1 \mathrm{~cm}$.

The gemus Ptilopora ranges fiom the Hamilton to the base of the Coal Measures, but, after occuring in the Hamilton, it does not reappear until the Burlington, where a single species is known. The form from the Yellowstone National Park is distinct from anything yet described.

Formation and locality: Madison limestone, Crowfoot Ridge, Gallatin Range, top of bed 24 ; J. P. Iddings.

\section{STICTOPORELLA Ulrich, 1882.}

\section{STICTOPORELla (?) sp.}

By this name I wish to designate a frondose Bryozoan colony not more than $1 \mathrm{~mm}$. thick, but fully $2 \mathrm{~mm}$. across, and apparently bifurcate, or at all events bilobate. Both surfaces are alike, showing the circular apertures of numerous thick-walled pores, which are about $0.5 \mathrm{~mm}$. apart (measuring from the farthest walls), and without any conspicuous order of arangenent. The intervening space is filled in with a large mumber of more or less circular mesopores, and the surface as a whole is raised at intervals into low rounded monticules, which factor seems not to affect the size or risposition of the zooidal openings.

Formation and locality: Madison limestone, Crowfoot Ridge, Gallatin Range, bed 28; J. P. Iddings and W. H. Weed.

\section{FENESTELLA Lonsdale, 1839.}

This genus is represented at several localities, and by a number of forms, but as the material is both fragmentary and poorly preserved, and when fragmentary can not always be distinguished from Archimedes, nor even from Ptilopora, I have not attempted to make specific determinations.

At the locality on the east side of Lamar Valley, montl of Soda Butte Creek, Absaroka Range, there are probably two forms present. One has rery slender branclies and thin dissepiments, leaving elongate angular fenestrules from 2 to $3 \mathrm{~mm}$. long and $0.5 \mathrm{~mm}$. broad. This is a very regular 
form; the branches are thin, straight, and panallel, and the bifureations intrequent. The other species is finer, more delicate, and very irregular. The material at this locality is preserved an red ferruginons impressions in an ocher-colorer argillacenus limestone, and no details of structure could be ascertained.

At the head of Conant Creek, Teton Range, Fenestella is the most common fossil present. It is preserverl chiefly as cants in a lard, whitish limestone, and two species can probably be distingnished. The first is very regular in growth and attains large size. One incomplete fragment is 5.) cul. across. The clissepiments and branches are nearly equal in size, the fenestrules oval or subcircular. Mensuring radially, there are ten or eleven fenestrules in $10 \mathrm{~mm}$., and sixteen or seventeen measuring transversely. There are three cells opposite each fenestrule. Another probably distinct species is quite similar in general appearance, but more delicate than the last. Fenestrules nearly circular, eighteen or nineteen occurring in a radial direction of $10 \mathrm{~mm}$., and twenty-five or twenty-six in the same distance measured at right angles to the first.

Another species is found in bed 28, Crowfoot Ridge, Gallatin Range. The frond is quite regular, branches the same size as the dissepiments. The fenestrules are long, elliptical, eleven or twelve in $10 \mathrm{~mm}$., radially measured, and seventeen in transverse direction. Twelve or thirteen zoceia are found opposite four fenestrules (thirty-four to thirty-six in $10 \mathrm{~mm}$.). Another type, from the top of bed 2t, Crawford Ridge, Gallatin Range, is perhaps specifically related to the last. It is somewhat coarser, with stronger branches and dissepiments. Fenestrules oval, about nine in $10 \mathrm{~mm}$. radially and fifteen or sixteen transversely. Eleven to thirteen zoceia opposite three fenestrules (about thirty in $10 \mathrm{~mm}$.).

\section{ARCHIMEDES Lesnemr, 1842.}

\section{ArCHanedes al.}

The axis of this form has not been observed, but the peculian mamer in which the branches overlie one another can not be mistaken, and makes the generic reference certain. It has not been possible to make sufficiently detailed observations on which to base a specific description. The branches are rather slender, not frequently bifurcating, about twenty-six in the space 
of $1 \mathrm{~cm}$. Dissepiments more slender, regular, miform, twenty to twentythree in the space of $1 \mathrm{~cm}$. Fenestrules a little longer than wide, subquadrate in ontline, angular. Zooecia in two rows, circular, about three to each fenestrule, anoming to between fifty and sixty in the space of 1 cm. It will be seen that while the description shows this fom to be close to several known species (A. distans, A. inmumatus of the Chester, A. negligens of the Keokuk), it is not specifically the same as any of them. Several other Fenestellids aecur in the same beds, but their condition does not warrant the attempt to identify them.

Formation and locality: Madison limestone, south of Forellen Peak, Teton Range; S. L. Penfield.

\section{CRANIA Retzins, 1781.}

Crania lavis Keyes.

P'l. LxVIII, fig. 1^.

Cruni laris Keỵes, 1894: Geol. Surv. Missouri, Vol. V, Pt. II, p. 40.

The single specimen by which this species is represented is somewhat crushed, but appears to be of an elliptical or subcirenlar shape, the larger dianeter being $23 \mathrm{~mm}$, the shorter about $19 \mathrm{~mm}$. Beak lying in the short diameter, and eccentric with regard to the longone. Side nearest to it somewhat truncated. Convexity moderate, about $7.15 \mathrm{~mm}$. Surface smooth, withont radiating stria, but with fine concentric lines of growth.

Keyes's description, which is unaccompanied by figures, is very brief and contains little which is of value in identifying species. According to the original description, C. lacis is rather above the medium size, somewhat depressed, apex subcentral, ontline subcircular; truncate. Smootl but for fine concentric lines. In all these points the Yellowstone National Park form agrees with C.laris, which is furthermore said to ocenr in rocks of Waverly and Burlington age.

Only four species of Crania have been rescribed from Carboniferous strata: Crania lavis Keyes, Crania rowleyi Gurley, Crania permiana Shumard, and Craniu modesta White and St. Jolm. The first two are of Waverly age, the last two of Upper Carboniferous. It is extremely improbable that either C. modestu or C. permiana would be found in these beds associated with low Lower Carboniferous fossils, while C. rovleyi is 
much smaller than the form muder discussion, and ornamented with closely arranged radiating strixe. Thus there is presumptive as well as direct evidence that the individual here referred to C. Levis keyes is correctly identified.

Formation and locality: Madison limestone, Crowfoot Ridge, Gallatin Rauge, top of bed 24 ; J. P’. Iddings. Chontean limestone, Louisiana, Missouri. Burlington limestone, Louisiana, Missouri.

\section{RHIPIDOMELLA Oehlert, 1880.}

\section{Rhipidonella michelini Léveillé.}

Terelratula michelini Léveillé, 1835: Mém. Soc. Géol. France, 1st serıes, Vol. II, 1). 39, Pl. II, figs. 14-17.

Orthis michelini Yandell and Shumard, 1847: Ooutributions Geol. Kentucky, p. 21. Winchell (A.), 1865: Proc. Acal. Nat. Sci. Phila., p. 116. (?) Winchell (A.), 1870: Proc. Am. Phil. Soc., Vol. XI, p. 251. (?) Hall, 1853: Second AmI. Rept. New York State Gcologist, PI. XXXYI, figs. 19-21.

Rhipidomella michelini Hall and Clarke, 1892: Pal. New York, Vol. VIII, Pt. 1, pp. 191-225, Pl. 6a, fig. 12.

This form is rare, and the material almost too poor for identification. As far as it is possible to judge, it is identical with $R$. michelini as identified from the Waverly of Richfield, Summit County, Ohio, and from Cuyahoga County, Ohio. The latter is a small form, subcircular; width, $9.5 \mathrm{~mm}$; length slightly less, not very gibbous, marked by about one hundred regular striae.

Rhipidomella michelini occurs in two localities in the Yellowstone National Park.

Formation and locality: Madison limestone, amphitheater east of Bamnock Peak, Gallatin Range, bed 27; east side of Lamar Valley, mouth of Soda Butte Creek; W. H. Weed. Waverly age, south of Louisville and near Lebanon, Kentucky; Nerrark, Granville, Richfield, Bagdad, ete., Ohio; Shafers, Pennsylvania; Lake Valley mining district, New Mexico. 
ORTHOTHETES Fischer de Waldheim, 1830.

OrThothetes IN.EQUaLIS Hall.

Pl. LxVIII, fig. $3 a$.

Orthis inequalis Hall, 1858: Geol. Surv. Iowa, Vol. I, Pt. II, p. 490, Pl. II, figs. 6a-6c. Streptorhynchus incequelis A. Winchell, 1865: Proc. Acad. Nat. Sci. Phila., p. 117.

Streptoryhnchus equiralvis Hall and Whitfield, 1877: King's U. S. Geol. Expl. toth Par., Vol. IV, p. 252, Pl. IV, figs. 1, :2.

Streptorhynchus cruivalvis Hall, 1S83: Second Ann. Rept. New York State Geologist, Pl. 4:, figs. 20-23.

Orthothetes incrqualis Hall and Clarke, 1892: Pal. New York, Vol. VIII, Pt. I, Pl. $9 a$, figs. 20-23.

Orthothetes incqualis is extremely abundant in the limestones and calcareous sandy slates of the Yellowstone National Park. The largest shells measure $25 \mathrm{~mm}$. in length by $38 \mathrm{~mm}$. in breadth, but the average is somewhat smaller than this. The shape is semicircular. The ontline is somewhat contracted at the cardinal extrenities, and the linge line slightly shorter than the greatest width of the shell. The surface is marked by numerons elevated, sharp, radiating strix, abont fourteen in the space of $5 \mathrm{~mm}$, which leave between them intervals wider than the strix themselves, from which they abruptly rise. They do not bifurcate, but in the widening intervals which result from their radiating direction new stria are from time to time introduced. They sometimes become much crowded through the center of the shell and around the periphery. The stria are not all of the same size. Sometimes they are alteruately large and small; sometimes every fourth one is large, but more often there is no conspicuous arrangement. They are crossed by numerous fine coucentric strix characteristic of the genus. As a result of the surface structure just mentioned, casts of the exterior are misleading in that they seem to present a form with broad, close-set, and bifurcating radiating plications.

The dorsal valve is usually gibbous, but sometimes is more gently curved. As a rule the curvature is regular from beak to frontal margin, with a somewhat prominent umbo; but forms occur where the umbo is flattened and there is a point of prominent elevation in the middle of the valve; or, where the shell is depressed, with almost a geniculation near the margin. 
The ventral valve is nearly flat. Sometimes it is slightly convex, but nsinally the unbonal region alone is convex and the ontlying portions of the shell are somewhat exeavated.

Both valies are often marked by concentric eorrugations, due to merqual growth, while old shells are sometines plicated into loose and irregular radiating folds or corrngations along the periphery.

The generic identifieation of this form, als represented in the Yellowstone National Park, I can not regard as doubtful. The septum in the ventral valve characteristic of Derbya, the only other gemus with which it conld be confused, did not exist here.

Orthothetes inflatis is somewhat larger than $O$. incequalis. The lieight of the area is said to be one-third as great as its width, and three times the width of the formen. It is described as differing from O. incequalis in liaring a much more ventricose dorsal valve and in the much greater height of the area of the ventral valve, in which the foramen is about three times as ligh as wide, while in that species it is much wider than high. The strie are also coarse and more elevated.' In the Yellowstone National Park form the area is many times as wide as high and the formen is very slightly higher than it is wide. The dorsal valve is also much less inflated than the corresponding valve figured by Hall and Clarke (loc. cit., Pl. 9a, fig. 24)

I have not identified 0 . inflatus in the collection studied.

Formation and locality: Madison limestone, near summit of ridge, west end of Hunter Peak, Absaroka Range; limestone bluff north of Little Sunlight Creek, Absaroka Range, 600 feet above streem; Arnold Hague. East side of Gallatin River, west of Electric Peak; divide between Gallatin River and Panther Creek, Gallatin Range; east face of Antler Peak, Gallatin Range; saddle west of Antler Peak, Gallatin Range; amphitheater west of Bamoek Peak, Gallatin Range, bed 26; amphitheater east of same, bed 28; W H. Weed. Crowfont Ridge, top of bed 25; J. P. Iddings and G. M. Wright. Same, bed 26; lower part of bed 27; upper part of hed $2 \bar{i}$; beds $28,29,31$; J. P. Iddings and W. H. Weed. South of Forellen Peak, Teton Range; northwest slope of same; S. L. Penfield. West of Antler Peak, Gallatin Range; north of Bighom Pass, Gallatin Range; A. C. Gill. Crowfoot Ridge, Gallatin Range; top of bed 
24; J. P. Iddings. Head of Conant Creek, Teton Range; north of Owl Creek, northeast slope of T'eton Range; north end of Teton Range, north of Owl Creek; Snake River Valley, east of Two Ocean Platean; W. H. Weed. Limestone bluff soutl side of Soda Butte Creek, northwest of Abiathar Peak; J. P. Idding's. Nortl side of Nortl Fork of Mill Creek, Snowy Range; Louis V. Pirsson. Under quartzite ridge north side of Burnt Fork. Kinderhook age, Burlington, Iowa; Dry Cauyon, Oquirh Mountain, Utah; Montaua.

\section{OrThothetes sp.}

This species is represented by a single imperfect specimen, which seems to differ from any of the other forms recognized in the collection. It is about the size of Derbya licokuk(?), and much larger than Orthothetes incqualis, but the surface ornamentation is different from either. While the striae in D. keokili (?) are rounded and contiguous, in this form they are namow and threadlike, more as in $O$. incequalis, the space between any two stria being wider than the striae themselves. Thus the surface as a whole is more coarsely striate than in 0 . incqualis, although the strixe themselves are of the same size and character.

This form is without the median septum peculiar to the geuns Derbya.

Formation and locality: Madison limestone, head of Conant Creek, Teton Range; W. H. Weed.

\section{DERBYA Waagen, 1884.}

\section{Derbya keokuli Hall (?)}

Orthis erenistria Yandell and Shumard, 1S49: Contributions Geol. Kentucky. pp. 19, 21. Orth is keokuk Hall, 1S5s: Geol. Surv. Iowa, Vol. I, Pt. II, 1) 640, Pl. XIX, tigs. $5 a, 5 b$. lieyes, 1895: Geol. Surv. Missouri, Vol. V, Pt. II, p, 63.

Streptorlynchus keokuk Hall, 1S83: Secoud Aun. Rept. New York State Geologist, Pl. XLI, figs. 1-3.

Derbya keokuk Hall and ('larke, 1s92: Pal. New York, Vol. VIII, Pt. I, p. 262, Pl. XI, figs. 1-3.

This form occurs only at a single locality, and the material present is highly musatisfactory. It seems to be nearer to $T$. keokul than to auy Strophomenoid shell with which I am acquainted, but its exact generic position can not be ascertained. It is about twice the size of even the largest specimen of Orthothetes incqualis, finely and evenly striate, the strix round, proximate, and crossed by fine, lamellose, concentric stria. 
Formation and locality: Marlison linestome, Crowfoot Ridge, Gallatin Ranger, berl 31; I. 1'. Idlings amd W. H. Weed. Keokuk age, Keoknk, lowi; Warsaw and Nanvou, Hlinois; New Providence, lndiana; Clark Comuty, Missomir; Nevarlis.

LEPTANA Dahman, 1828.

\section{Liptexa RHomboidalis Wilckens.}

Conchita rhomboidalis Wilckens, 1769: Naehricht von selten Versteinerungen, p. 77, Pl. VIII, figs. $43,44$.

Lepteme tennistriate Hall, 1S47: Pal. New York, Vol. I, p. 108, Pl. 31A, figs. 4t-4g. strophomena rhomboidalis White, 185j: Wheeler's Expl. Surv. W. 100th Merid., Vol. IV, p. 55, Pl. T, fig. 万. Hall and Whittield, 1877: King's U. S. Geol. Expl. 40th Par., Vol. IV, p. ״53, Pl. IV, fig. 4. Waleott, 1884: Mon. U. S. Geol. Survey, Vol. VIII, p. 118.

Leptena rhomboidalis Hall and Clarke, 189: Pal. New York, Vol. VIII, Pt. I, p. 279, Pl. VIll, figs. 17-31; Pl. 15A, figs. 40-42; Pl. 20, figs. 21-24.

The amazing stratigraphic and geographic range of this species makes it too well known to require any additional description. It is a comparatively rare form in the Yellowstone National Park, and is foumd only in the lower part of the Madison limestone.

Formation and locality: Madison limestone, Crowfoot Ridge, Gallatin Range, top of bed 25; J. P. Iddings and G. MI. Wright. West of Antler Peak, Gallatin Range; A. C. Gill. Crowfoot Ridge, Gallatin Range, top of bed 24; J. P. Ildings. East side of Lamar Valley, montl of Soda Butte Creek, Absaroka Range; Arnold Hagne. Universally distributed, from the Trenton to the Waverly.

CHONETES Fischer de Waldheim, 1837.

Chonetes loganensis Hall and Whitfield.

Pl. Lxv11I, figs. $5 a .5 b, 5 e$.

Chonetes logamensis Hall and Whitfield, 1877: Kring's U. S. Geol. Expl. 40th Par., Vol. IV, p. 252, Pl. IV, fig. 9.

This form is very abundant in the Carboniferons limestones of the Yellowstone National Park. Specimens liave been examined from a number of localities, and they can be referred without hesitation to C.loganensis Hall 
and Whitfield. In general, C. loganensis is almost exactly similar to C.illinoiscusis Worthen. Hall and Whitfield say (loc. eit., p. 254): "The species resembles somewhat $C$. illinoisensis 'Vorthen, from the Burlington limestone, in the size and convexity of the valve, and also in the strie, but differs in the greater proportional length of the hinge line and in the flattening of the mesial portion."

Chonctes logenensis is lescribed and figured with submucronate alar extensions, but this claracter is a restoration, for the type specimen is imperfect; and an incorrect one, for a study of considerable material, including Hall and Whitfield's, as well as my own, slows that the prevailing form is subcircular with parallel rectilinear sides which meet the linge line at nearly a right angle, the corners being usually either rectangular or rounded.

The mesial Hattening referred to is well shown in the type specimen, but it is not a constant character, and, in fact, the currature seems to be most often regular and even. On the other hand, specimens of $C$. illinoiscnsis Worthen, from one of the type localities, shows exactly the same range of valriation, some having a distinct sinus or flattening, just as has been observed in C. logunensis. In general I lave been mable to discover any constant differences which might distinguish the two species.

The surface ornamentation of C. loguncusis, wherever shown on areas which are not, as usmal, badly exfoliated, consists of fine, flexuous, often bifurcate, radiating strix, which are rather angular and are separated by interspaces about equal to their own diameter. These are crossed by very fine, threadlike, concentric strie.

The average size of mature shells is: breadth, $14 \mathrm{~mm}$.; length, $10 \mathrm{~mm}$; but the dimensions run $u$ p as high as $16 \mathrm{~mm}$. in breatth by $11.5 \mathrm{~mm}$. in length. The radiating stria number abont one limudred and fifty.

It is impossible to confuse this with the only other species of Chonetes known from the Tellowstone National Park. The radiating stria are finer and much more numerons, the shell itself is less tumid, and the outline is more quadrate.

Formation and locality: Madison limestone, Hunter Peak, Absaroka Range; White Mountains, Absaroka Range, just below Quadrant quartzite; T. A. Jaggar. East side of Gallatin River, west of Electric Peak; east of Antler Peak, Gallatin Range; saddle west of Antler Peak, Gallatin Range; amphitheater east of Bamock Peak, Gallatin Range, bed 27; 
Ir. H. Weed. Crowfont Ridge, Gallatin Ramge, top of hed 25, bed 26, bed 28, hed 29, bed 31: J. I'. lddings : and G. 11. Wright. South of Forellen l'akk, T'eton Ramge; northwest slope of sime; S. L. Penfield. Head of Conint Creek, Teton Range; north of Owl Creek, northeast slope of Teton Range; north of Owl Creek, north end of Teton Range; IV. II. Weed. limestone bluff south side of Sorda Butte Creek, northwest of Abiathar Peak, Ahsaroka Ringe; J. P. Iddings. North side of north fork of Mill Creek, Snowy Range; J. P. Iddings and Lonis V. Pirsson. Slide east side of Callatin liver, below Fan Creek; under Quartzite Ridge, north side of Bunt Fork. Beds of the age of the Waverly group, Wasateh Range, Utal.

\section{Choxetes ornatus Shmmard.}

\section{Pl. LXVIlI, figs. $4 a, 4 b, 4 c, 4 d$.}

Chonetes ornata Shumard, 1855: Geol. Rept. Missonri, p. 202, Pl. C, figs. 1a-1e. Keyes, 1894: Geol. Surv. Missouri, Vol. V, Pt. II, p. 53, P'l. XXXVIII, fig. 2.

This also is a common speeies in the limestones of the Park, though perhaps less abundiunt than the preceding. It differs somewhat from Shnmard's description, but agrees with specimens which, I have every reason to believe, are correctly referred to Shumard's species.

This form is often quite highly inflated with flat and depressed triangular wings, a character not sufficiently emphasized by the author. Another mislending point is that the species is described and figured as if with subnucronate alations. I have not seen this feature, at least to any extent, in a series of specimens from both the Choutean and Lithographic limestones. Usually the eardinal angle is but slightly less than $90^{\circ}$. However, it often happens that the anterior portion of the shell is concealed by rock, so that the apparent shape is that of Shumard's figure. This condition is quite deceptive, but I have rarely failed to find the nearly square alar angle upon removing the superineumbent matrix. In its large forms this species measures $13 \mathrm{~mm}$. (over 6 lines) along the linge line, and $8 \mathrm{~mm}$., or nearly 4 lines, in length, while some imperfect examples evidently exceed these dimensions. These data are derived from the study of material from the Mississippi Valley.

In the Yellowstone National Park representatives of Chonetes ornatus are in nearly perfect accord with the larger forms coming from Missouri. 
Breadth, $14.5 \mathrm{~mm}$., or more; length, 8 to $8.5 \mathrm{~mm}$. Radiating strix from forty to fifty in number, often bifurcating toward the anterior border, crossed by numerous thread-like concentric strix. Number of spines not determined with certainty; two or three, perhaps more, on either side of the beak.

There can be no difficulty in distinguishing this species from C. loganensis, even where both occur in the same beds. It is somewhat smaller, more coarsely striate, and very much more gibbons. The alation also is more striking and forms a characteristic feature.

The smaller type of $C$. ornatus has sometimes been confused with $C$. logani var. aurore Hall; but the surfice ornamentation of the latter is very distinctive.

I venture to predict that this species, or at least the form from the Choutean lmestone, will be found to be the same as C.loguni Norwood and Pratten.

Formation and locality: Madison limestone, enst side of Gallatin River, west of Electric Peak; Crowfoot Ridge, Gallatin Range, bed 25; J. P. Iddings and G. M. Wright. Sonth slope of Quadrant Mountain, Gallatin Rimge; A. C. Gill. South base of same; cherty belt, Bighorn Pass, Gallatin Range; J. P. Iddingss. Crowfoot Ridge, Gallatin Range, bed 24; A. C. Gill. North of Owl Creek, northeast slope of Teton Range; W. H. Weed. Limestone bluff sonth side of Soda Butte Creek, northwest of Abiathar Peak, Absaroka Range; J. P. Iddings. Chonteau limestone, Louisiana and Hamibal, Missouri.

\section{PRODUCTELLA Hall, 1867.}

Productella cooperensis Swallow.

Pl. LXVIII, figs. $s a, s b, s c, g a, s b$.

Productus cooperensis Swallow, 1860: Traus. St. Louis Acad. Sci., Vol. I, p. 640. Winchell (A.), 1865: Proc. Acad. Nat. Sei. Philadelphia, p. 115.

Shell small. Ventral valve strongly arched, beak rather produced and incurved. Ventral valve slightly concave or subplane over the risceral region and more or less sharply geniculate near the margin. Surface marked by nearly obsolete spiniferons ridges and by strong cuncentric wrinkles, especially noticeable about the posterior portion and near the 
linge. The ears of the ventral valve are furnished with a bunch of spines. The dorsal valve is similarly ornamented except that it does not appear to be spinose and the ralliating ridges become grooves. However, as the convex sicle is usually presented to view, the sufface seems a counterpart of the other valve. Viewed from this side, two broad, strong, slightly divergent grooves are seen near the hinge line, marking off the somewhat upturned ears.

Pl. LXVIII, figs. $9 u, 9 l$, slow a type which I had thought to constitute a distinct variety, but more careful comparison shows that this conclusion was not warranted.

$P$. cooperensis is said by Swallow to be common in the Clouteau limestone of Cooper County, Missouri. I have studied a large series of specimens from the Choutean limestone of Stevens Fork, Missouri, and Choutean Springs, Cooper County, Mlissouri. This material agrees with Swallow's description and is specifically identical with the specimens from the Yellowstone National Park.

$P$. cooperensis proves to be a variable form. Many of the differences noticed are without doubt due to differences in age, but a considerable range of variation can not be ascribed to this factor: The ventral valve is sometimes low and flat, like that figured by Hall, ${ }^{1}$ but often it is highly arched. The dorsal valve is moderately concave, semielliptical; beak small, depressed. Often nearly plane at first, or sometimes concave, but later becoming geniculate at the margin, and the geniculate portion is often considerably prolonged. There is also a variation in size, some large sleells being depressed and immature in appearance, while much smaller ones are highly arched and look fully grown. No reliance can be placed upon the spines for specific identification. They are scattered over the surface, sometimes irregularly, sometimes in rows, sometimes nearly absent. There is often a bunch of strong spine bases on the rather small ears; but this, too, is not a constant feature.

'The specific integrity of $P$. concentrica Hall, $P$. shumardiana. Hall, and $P$. pyxilata Hall has often been questioned. As early as 1865 Winchell $^{2}$ stated the opinion that $P$. shumardiana and $P$. pyxidata, are both synonyms

${ }^{1}$ Geol. Surv. Iowa, Vol. I, Pt. II, Pl. VII, fig. 2.

2 Winchell, 1865 : Proc. Acad. Nat. Sci. Philadelphia, p. 115.

MION XXXII, PT $11-34$ 
for $P$. concentrica, and in 1888 Herrick" says: "Productus shumardiana is doubtless identical with $P$. spinulicostatus H., $P$. concentricus H., and $P$. pyxilata H."

I believe that Productella shmmartiana and $P$. concentrica are distinct, but the former is probably identical with $P$. pyxidata. I also feel confident that $P$. cooperensis will be found to be the same as $P$. concentrica, but, not having the material to prove the point, I have used Swallow's name, which, however, will have to be dropped in case my suspicions prove correct.

Productus cooperensis (?) of Winchell ${ }^{2}$, from Sciotoville, I believe to be a quite different species, and have accordingly omitted this citation from the synonymy.

Formation and locality. Madison limestone, Crowfoot Ridge, Gallatin Range, top of bed 24; J. P. lddings. Same, lower part of bed 27; J. P. Iddings and W. H. Weed. East side of Gallatin River, west of Electric Peak; George M. Wright. East face of Antler Peak, Gallatin Range; IV. H. Weed. Crowfoot Ridge, Gallatin Range, top of bed 25; J. P. Iddings and G. M. Wright. Summit of Three River Peak, Gallatin Range; J. P. Iddings. North of Owl Creek, northeast slope of Teton Range; W. H. Weerl. Kinderhook age, Burlington, Iowa, Cuyahoga shale of the Waverly group, Richfield, Lodi, Bagdad, Burbank, Cuyahoga Falls, ete.; Chouteau limestone, Stevens Fork, Missonri; Chouteau Springs, Cooper County, Missouri.

\section{Productella alifera 1. sp.}

\section{PI. LXVIII, figs. 10a, 10b, 10c.}

Shell rather above medium size. Ventral valve strongly arched both. longitudinally and transversely. A transverse section near the umbo would be subquadrate, broadly flattened on top (but not impressed); sides curving sharply downward, but turning again near the margin for a slightly projecting lip. Longitudinal section also slightly flatteried abont the middle; posterior slope strongly deflexed and incurved; anterior slope falling more gently and reflexed toward the margin. Sometimes, however, this valve is geniculate in frout and somewhat spread out posteriorly. The beak is formed by the gradual convergence of the lines defining the body. 
of the shell, which falls anvy quite rapidly on either side, giving rise to large produced and flattened ears. This is a rariable feature, however, and the lateral nargins nay meet the hinge line at nearly right angles.

Dorsal ralve only slightly convex, but geniculate toward the anterior margin.

Surface nearly smooth, marked by numerous gentle rugosities, and by very fine, confused, radiating strix, which nay be the result of exfoliation joinerl with shell strueture.

The dimensions of a slightly undersized auriculate specimen, figured on Pl. LXVIII, fig. 10e, are: Length, $25 \mathrm{~mm}$.; width at hinge line, $44 \mathrm{~mm}$.; width a little in front of hinge line, $25.5 \mathrm{~mm}$. The largest specimen observed, a spreading individual, with a nearly vertical posterior outline, measures $54.5 \mathrm{~mm}$. in length; width probably about the same.

Formation and locality: Madison limestone, limestone bluff south side of Soda Butte Creek, northwest of Abiathar Peak, Absaroka Range; J. P. Iddings.

\section{PRODUCTUS Sowerby, 1814.}

\section{Productus scabriculus Martin.}

Pl. LXIX, figs. $7 a, 7 b, 7 c, 7 d$.

Anomites scabriculus Martin, 1809: Petrefacta Derbiensia, p. 8, Pl. XXXVI, fig. 6. Productus scabriculus Norwood and Pratten, 1854: Jour. Acad. Nat. Sci. Philadelphia. (2), Vol. III, p. 17. Marcon, 1858: Geol. North America, 1. 47, Pl. V, fig. 6. Newberry, 1861: Ives's Rept. Colorado River of the West, Pt. II, p. 125. ? Geinitz, 1866: Carbon. und Dyas in Nebraska, p. 54.

This form was at first identified with Productus newberryi Hall. It closely resembles the figure of P. newberryi (Pal. New York, Vol. VIII, Pt. I, 1892, Pl. XVII, fig. 1)1 (non figs. 2 and 3), but a comparison with specimens made me doubt the correctness of the identification. I have been able to examine a large series of $P$. newberryi from Bagdad, near Medina, Burbank, and other localities in the Cuyahoga shale, in Medina County. It is perhaps the most abundant form at these localities next to Chonetes illinoisensis? and Hall's figure seems to me quite misleading in regard to the surface ornamentation. The figures show numerous close-set

\footnotetext{
${ }^{1}$ Figs. 2 and 3 of this species seem to be different from $P$. newberryi. The surface ornamentation does not appear, but it is a much more profoundly arched shell, and comes from a difierent geologic horizon.
} 
spine bases shaped like small rose thorns, tapering at either end. In the specimens which I have examined (none of them, it may be noticed, quite attain the size shown in the figure) the posterior portion alone presents this appearance, and even there the spine bases are so long as to resemble discontinnous strie. They taper only in one direction anteriorly, and end suddenly and acutely, looking like slender spines, appressed or in demirelief. The termination, however, itself formed the base for a small spine. These ridges then are longer, more distant, and differently shaped from the figure. The ridges grow stronger, broader, and more continuous as the shell increases in size, so that the whole anterior margin is regularly and strongly marked with spine-bearing stria, from ten to twelve in $10 \mathrm{~mm}$. I do not know the condition of Hall's types; but I have noticed that in localities such as Burbank, where the shell substance has been leached away, leaving casts in the sandstone, these are apt to show the features represented in the figure.

The surface ornamentation of $P$. scabriculus is similar to that figured for $P$. newberryi, consisting of fine, numerous, elongated, spiniferous pustules, the spines being sitnated near the anterior end; and it is also very similar to, though somewhat finer than, that of $P$. papulate of the Hamilton group. This is, however, different from the Waverly specimens of $P$. newberryi, and the shape is also different, being more highly arched, less spreading, and with a more produced incurved beak. In shape and surface this form is very similar to P. scabriculus from the Carboniferous of Glasgow, Scotland, the chief difference arising from the fact that in the latter the pustules are somewhat more coarsely distributed and show conspicnous, though irregular, inequalities in size.

The dorsal valve of this species, as seen at a different locality from the specimen figured, when viewed from the convex side, is crossed by numerous fine concentric wrinkles, and is covered with fine pustules, smaller and more closely arranged than those of the other valve. The casts of small spines can be seen among the pustules The ventral valves associated with these are of the normal type.

I have retained the collected synonymy of this species, although I doubt whether any of the citations are really identical with the form under discussion or with $P$. scabriculus. $P$ scabriculus, it should be noticed, is in Europe a Devonian and Lower Carboniferous form, while all or nearly all 
the eitations in this comtry have been from the Coal Measures. Norwood and Pratten, however, have identified this speeies from the "Mountain limestone" of I'aris, Missouri.

Formation and licality: Madison limestone, east side of Gallatin River, west of Electric Peak; Crowfoot Ridge, Gallatin Range, top of bed 25, top . of bed 26; J. P. Iddlings and W. H. Weed. North side of north fork of Mill' Creek, Snowy Range; Louis V. Pirsson.

Productus gallatinensis n. sp.

Pl. LXVIII, tigs. 11a, 11b, 11c, 11d, $7 a, 7 b, 7 c$.

Dorsal valve not known. Ventral valve small, strongly arched, the curves on eitler side of the most elevated point being nearly alike. Beak small, rapidly expanding, produced, so that the small distinct ears occur about one-third the shell length in front of the apex. Top of the shell broad, flattened, but not simuate; sides nearly plain and vertical. The width slightly exceeds the greatest length, and is about one and one-half times the height. The visceral region is marked by numerous distinct concentric wrinkles, and the shell is ornamented with fine, straight, radiating. striæ which bifurcate on the anterior portion. A few large spine bases can be seen on the anterior portion of the shell.

Figs. $7 a, 7 b, 7 c$, of Pl. LXVIII, represent a form which was at first identified as Productella arcuata Hall, but which I now regard as only a variety of $P$. gallatizensis. It is represented from only one locality, the top of bed 25, Crowfoot Ridge, Gallatin Range, and is there found associated with true $P$. gallatinensis. The shape is narrower and more elongate, while the strix have not the even, rigid, wirelike appearance characteristic of the latter. It differs from $P$. arcuata in having the strie finer and more regular and strong.

The relations of $P$. gallatinensis, $P$. parviformis, and $P$. semireticulatus are close, and I am almost disposed to regard them as only varieties of the same type. $P$. gallatinensis is smaller than $P$. semireticulatus, more arched, finer striated, narrower, and with more vertical sides. However, some of the variations of either type approach each other closer than the figured specimens would indicate. Still more nearly related to the species under discussion is $P$. parviformis. In shape the latter appears to be a miniature reproduction of $P$. gallatinensis, but the surface ornamentation is of about the same fineness. 
Formation and locality: Madison limestone, Limestone bluff north of Little Sunlight Creek, Absaroka Range, 600 feet abore the stream; Arnold Hague. Divide between Galiatin River and Panther Creek, Gallatin. Range; W. H. Weed. Crowfoot Ridge, Gallatin Range, bed 25, bed 26, lower part of bed 27, npper part of bed 27; J. P. Iddings and W. H. Weed. Sonth of Forellen Peak, Teton Range; S. L. Penfield. Head of Conant Creek, Teton Range; W. H. Weed.

\section{Productus Lævicosta White. \\ Pl. LXIX, figs. 9a, $9 b, 9 c$.}

Productus lavicostus White, 1860: Jour. Boston Soc. Nat. Hist., Yol. VII, p. 230.

(?) Hall and Whitfield, 1877 : King's U. S. Geol. Espl. 40th Par., Vol. IV, p. 266, Pl. V, figs. 7, 8. Keyes, 1895: Geol. Surv. Missouri, Vol. V, Pt. II, p. 41, Pl. XXXVIII, fig. 1.

This is the type identified by Hall and Whitfield as P. levicosta and figured by them in King's U. S. Geol. Expl. 40th Par., Vol. IV, Pl. V, figs. 7, 8. The figure there given is somewhat restored, and in view of new material, which unquestionably belongs to the same species, appears to be only partially correct. The broken portion consists of the ear's, which, instead of being small and inconspicuous, are rather large, marked by the same fine strix which traverse the body of the shell, and in addition by strong longitndinal wrinkles, together with, in some cases, numerous spine bases.

This is one of the most common species in the Yellowstone National Park and in some localities is found in great abundance. As there represented it appears to answer. White's description in every detail.

Formation and locality: Madison limestone, White Mountains, Absaroka Range, just below the Qnadrant quartzite; T. A. Jaggar. East side of Gallatin River, west of Electric Peak; divide between Gallatin River and Panther Creek, Gallatin Range; W. H. Weed. Crowfoot Ridge, Gallatin Range, top of bed 5; J. P. Iddings and G. M. Wright. Same, top of. bed 26, lower part of bed 27 , berl 31 ; J. P. Iddings and W. H. Weed. East slope of Survey Peak, Teton Range; S. L. Penfield. Summit of peak west of Antler Peak, Gallatin Range; south slope of same; J. P. Iddings. North of Bighorn Pass, Gallatin Range; A. C. Gill. Head of Conant Creek, Teton Range; W. H. Weed. Kinderhook age, Burlington, Iowa; Louisiana, Missouri; Oquirrh Mountains, Utal. 


\section{P'roductus semineticulatus Martin.}

P']. LAIX, figs. $8 a, s b, 8 c, 8 l$.

Anomites semireficulatus Martin, 1509: Petrefacta Derloiensia, 1) 7, PJ. XXX]I, figs. 1, 2; P'l. XXXIII, lig. 4 .

Productus semireticulatus Norwood and Pratten, 1854: Jour. Acad. Nat. Sei., 2d series, Vol. III, p. 11. Ilall, 1858: Geol. Surv. Iowa, Vol. I, Pt. II, p. 637. NIeek, 1872: Final Rept. U.S. Geol. Surv. Nebraska, p. 160, Pl. V, figs. 7a, 7 . White, 1S75: Wheeler's Expl. Surv. W. 100th Mericl., Vol. IV, p. 111, P1. VIII, fig. 1. Meek 1877: King's U. S. Geol. Expl. 40th Par., Vol. IV, p. 69, PI. VII, fig. 5. Hall and Whittield, 1877: ibid., P. 267, Pl. Y, figs. 5, 6. Dawson, 1878: Acadian Geol., 3d ed., 1. :96, fig. 9T. White, 1884: Thilteenth Rept. State Geologist Indiana, p. 125, PI. XXIT, figs. 1-3. Herrick, 1885: Bull. Denison Univ., VoI. II], I. 31, Pl. I, fig. 26; Pl. III, fig. 24; Pl. VII, fig. 11; Pl. X, fig. 6. Hall and Clarke, 1892: PaI. New York, Vol. VIII, Pt. I, Pl. XVIIA, figs. 16-18; Pl.XVIII, figs. 11-13; Pl. XIX, figs. 19-23. Keyes, 1895: Geol. Surv. Missouri, p. 50, Pl. XXXVI, fig. 4.

The specinens assembled under this name come from a number of localities and present considerable rariation. Taken as a whole, the size is smaller and the beak more attenuated than specimens from the Coal Measures often show. The median sinus, which often constitutes a marked character in those forms, is either indistinct or not developed at all, while the concentric wrinkles, which produce along the stria the characteristic reticulate appearance, are less strongly marked and are confined to a more limited area.

The ventral valve figured (PI. LXIX, figs. $8 a, 8 b, 8 c$ ) is distinctly more coarsely striate than other individuals from the same locality, while material from other localities is more finely striate still. The figured specimen has about ten stria in $10 \mathrm{~mm}$. along the margin, while others, perhaps the greater number, have abont fifteen. Again, the dorsal valve (fig. $8 d$ ) is, though quite large, nearly flat over its entire area. This specinen has a transverse dianeter of about $33 \mathrm{~mm}$., while other individuals, only $23 \mathrm{~mm}$. across, already show a well-marked geniculation. These data show about the character and range of the variation observed.

A form identical with this accurs in the Chouteau limestone at Black Water, Saline County, Missouri; Chouteau Springs, Cooper County, Missouri, etc; and in the Cuyahoga shale of the Waverly group at Richfield, Summit County; Bagdad, Medina County, etc. It is closely related, perhaps identical, with $P$. flemingi var. burlingtonensis, as identified by Hall and 
Whitfield.' It differs in having the simus less strongly developed, but is otherwise indistinguishable. P. Alemingi var burlingtonensis of the West, however, differs from the true type seen at Burlington, Iowa, by being more coarsely striate and less distinctly bilobed. In many respects $P$. semireticulatus of this region resembles $P$. newberryi var. amnosus from the Waverly sandstone of Ohio, but the strix in the latter, as seen in the figure, are more angular, more irregular, and show a tendency to be discontinuous.

Formation and locality: Madison limestone, near summit of ridge, west end of Hunter Peak, Absaroka Range; Arnold Hagne. East side of Gallatin River, west of Electric Peak; divide between Gallatin River and Panther Creek, Gallatin Range; east face of Antler Peak, Gallatin Range; amphitheater west of Bannock Peak, Gallatin Range, bed 26; W. H. Weed. Crowfoot Ridge, Gallatin Range, top of bed 25; J. P. Iddings and G. M. Wright. Same, bed 27, bed 28, bed 29, bed 31; J. P. Iddings and W. H. Weed. South side of Gallatin Valley, bed 32; J. P. Iddings. Northwest slope of Forellen Peak, Teton Range; S.L. Penfield. Summit of Three River Peak, Gallatin Range; J. P. Iddings. Crowfoot Ridge, Gallatin Range, cherty limestone, top of bed 24 ; A. C. Gill. Head of Conant Creek, Teton Range; W. H. Weed. Chouteau limestone. Black Water, Saline County, Missouri; Chouteau Springs, Cooper County, Missouri.

\section{Pronucters parviformis 11. sp.}

Pl. LxVIII, figs. $6 a, 6 b, 6 c, 6 d$.

Productus parvus White, 1875; Wheeier's Expl. Surv. W. 100th Merid., Vol. IV, p. 83, Pl. V. figs. $6 a, 6 d$; non Productus parvus Meek and Worthen.

Shell very small. somewhat wider than long. Surface ornamented by fine, even, radiating strix, which sometimes exhibit a tendency to become confluent, as in $P$. costatus.

Ventral valve deeply arched, making considerably more than a semicircle; front view subquadrate, with nearly parallel sides and slightly curved upper outline. About the beak are a few deep concentric wrinkles, and the entire surface is crossed by fine concentric lines. Occasional spines of comparatively large size are scattered over the surface, especially near the anterior margin, on the heavier compound plications when present.

${ }^{1}$ King's U. S. Geol. Expl. 40th Par., Vol. IV, p. 265, Pl. V, figs. 9-12. 
'The only dorsal valve observed is that figured. It is nearly flat at first, and geniculate, with well-marked, somewhat pointed ears.

The material from the Yellowstone National Park seems to be identical with the form identified, deseribed, and figured by White as Productus parvus (loc. cit.).

Compared with Meek and Worthen's figures of that species, $P$. parviformis is seen to be uniformly smaller, narrower in proportion to the width, more deeply arched, and more elongate. It seems like a miniature form of $P$. gallatinensis, with which I have at one locality found it associated, and of which, although no intermediate forms have been observed, I am almost disposed to regard it as a variety.

Formation and locality: Madison limestone, Crowfoot Ridge, Gallatin Range, top of bed 25; J. P. Iddings and G. M. Wrighlit. Same, bed 30, bed 31 ; J. P. Iddings and W. H. Weed. South of Forellen Peak, Teton Range; S. L. Penfield. Mountain Spring, Nevada.

\section{CAMAROPHORIA King, 1846.}

\section{Camarophoria ringens Swallow.}

Pl. LXIX, figs. $1 a, 1 b, 1 c$.

Rhynchonella ringens Swallow, 1860: Trans. St. Louis Acad. Sci., Vol. I, p.653. Keyes, 1895: Geol. Surv. Missouri, Vol. V, Pt. II, p. 102.

Camarophoria ringens Hall and Clarke, 1893: Pal. New York, Vol. VIII, Pt. II, p. 214. Rhynchonella (sp.) Keyes, 1895: Geol. Surv. Missouri, Vol. I, Pt.II, Pl. XLI, figs. 8, 11.

There is a little doubt that the form under discussion is identical with that described by Swallow under the name Rhynchonella ringens. His was a large shell (length, 1.90 inches; breadth, 1.43 inches; thickness, 0.99 inch), triangular in outline, marked by about fourteen large plications, eight of which were in a broad shallow sinus. More recently Keyes (loc. cit.) eites the species and says there are twelve plications.

The material from the Yellowstone National Park is seanty. Shell large, acuminate-ovate. Dorsal valve flat on top, bending abruptly at the sides and at the front. Ventral valve shallow.' Beak long, sharp, not mueh incurved, apparently pierced by a triangular or oval foramen, without deltidial covering. The surface is marked by twelve or fourteen large but somewhat lax, rounded plications, two or three of which on the lateral slopes are not very distinct. Two or three plications are on the fold, 
though the exact number is difficult to ascertain, as that feature is almost obsolete.

If this is not Rhynchonella ringens of Swallow it must be a new form, for there is no other representative of the genus with which it could be confused. C. subtrigona Meek and Worthen, the nearest form, is yet considerably different. However, if this reference is correct, Swallow's specimen may have been abnormal in having so many plications on the fold, as it is certainly a larger and more nature individual.

In any case the stratigraphic value of this species remains unaltered, for I can vouch for the identity of the Yellowstone National Park material with a form from the lower Burlington chert of Louisiana, Missouri, which passes among local collectors as $R$. ringens.

$R$. ringens was clescribed fiom the chert beds of the Fncrinital limestone of Callaway County. Swallow (loc. cit.) cites the species from the Burlington of Callaway and Marion counties, while two forms, illustrated by Pl. XLI, figs. $8 a, 8 b$, and 11 (Geol. Surv. Missouri, Vol. V, Pt. II), probably referable to $C$. ringens, were found, the one in the Burlington limestone, the other in the Kinderhook shales.

Formation and locality: Madison limestone, Crowfoot Ridge, Gallatin Range, top of bed 25; J. P. Iddings and G. M. Wright. Same, bed 28; J. P. Iddings and W. H. Weed. Keokuk age, Callaway County, Missouri. Burlington age, Callaway and Marion counties, Missouri. Kinderhook shales, Missouri.

\section{CAMAROTECHIA Hall, 1893.}

The following species occur in the lower divisions of the Madison lincstone. They have been referred to Hall and Clarke's genus, Camarotochia, although the generic characters have not been ascertained in detail. Yet a process of exclusion makes it very probable that this reference is correct.

All the shells have a strong median septum in the dorsal valve, while the ventral valve is aseptate, but with two converging dental lamine in the beak. These characters, together with their geologic position, form, nature of fold and sinus, plications, etc., throw out most of the other genera and subgenera into which the Rhynchonelloid type has been divided. 
Camalotuchila herkiekana 11. sp.

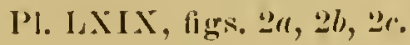

Ventral valve rather shallow, most prominent a little behind the middle, flattened in front ind at the sides. Outline nearly that of a square. Simus shallow, begimning near the niddle of the shell; marked by two strong plications, on either side of which are five or six other's slightly finer.

Dorsal valve considerably wider than long, sectoriform, more gibbous than the ventral; sides reflexed. Fold not very high, marked by three strong angular plications. On either side are five plications, the more lateral tivo smaller than the others.

This species oceurs in about the same beds as C. metallica, but is seldom associated with it at the same locality. It is readily distinguished from $C$. metallica by its somewhat large size, less strong fold and sinus, and coarser and less numerous plications. Of these, C. metallica has five on the fold and eight on either side, while C. herrickana has but three on the fold and five on each side.

This species has not been observed with the two valves in conjunction, but it seems to have been a much less inflated form.

It is possible that this species might correctly be referred to some one of the numerous Rhynchonellids described from the Marshall group by Winchell. I have studied his descriptions with care, but none cover the characters of this form sufficiently closely to warrant an identification in default of both illustrations, and identified material.

Length of a single ventral valve, $10.5 \mathrm{~mm}$.; width, $12 \mathrm{~mm}$. Length of a separate dorsal valve, $8.5 \mathrm{~mm}$; width, $10.5 \mathrm{~mm}$.

This same form, or one probably only varietally distinct from it, is found at Pellas, Marion County, Iowa.

Formation and locality: Madison limestone, limestone bluff north of Little Sunlight Creek, Absaroka Range, 600 feet above the stream; Arnold Hague. Divide between Gallatin River and Panther Creek, Gallatin Range; amphitheater east of Bannock Peak, Gallatin Range, bed 28; W. H. Weed. Crowfoot Ridge, Gallatin Range, top of bed 26, upper part of bed 27, bed 28; J. P. Iddings and W. H. Weed. North end of Teton Range, nortlı of Owl Creek; W. H. Weed. Choutean limestone, Pellas, Marion County, Iowa. 
Camarotachla metallica White.

Pl. LXIX, figs. $3 a, 3 b, 3 c, 3 d, 3 e$.

Khynchonella metallica White, 1874: Wheeler's Expl. and Surv. W. 100th Merid., Prelim. Rept., p. 20. White, 1875: Ibid., Final Rept., Tol. 1V, p. 129, Pl. X, figs. $10 a, 10 \pi$.

Rhynchonellu pustulosu (?) Hall and Whitfield, 1877: King's U. S. Geol. Expl. toth Par., Vol. IV, p. $25 \overline{7}$, Pl. IV, tigs. 12-14.

This species was described by White from Carboniferous (Upper Carboniferous ?) rocks. It was found associated with Hemipronites crenistria and Spivifer comeratus. My material occurs in the lower beds of the Mardison limestone, whose fauna is regarded as closely related to that of the Kinderhook period. As far as is shown by a careful comparison with the type specimen, this Waverly form is identical with White's species, and were the latter of more nearly the same age I should consider the reference umquestionable. As has been said, Rhynchonella metallica was described from Old Potosi mine, and $H$. crenistria and $S$. cameratus are cited from the same locality.

Spirifer camerutus is closely related to S. striatus, and has sometimes been mistaken for it, while almost any Lower Carboniferous Orthothetes or Derbya might pass as Hemimonites crenistria. Therefore, it is not impossible that $R$. metallica was derived from lower strata than White supposed.

It is also more than probable that $R$. metallica is another representative of the genus Camarotochia, which fact is not without some stratigraphic bearing, as Camarotcechia is not known in Upper Carboniferous rocks, nor indeed as yet above the Waverly.

The form here under discussion is the same as that described and figured as R. pustulosa (?) by Hall and Whitfield, in King's U. S. Geol. Expl. 40th Par., Vol. IV, p. 257, Pl. IV, figs. 12-14, where it is cited from Waverly rocks. The material from Yellowstone National Park, though scanty from any one place, the localities being numerous, aggregates a number of specimens which agree with one another and exactly with $R$. pustulosa (?) Hall and Whitfield; but all are without the punctate shell structure characteristic of true Rhynchopora pustulosa. C. metallica is also much smaller than mature R. pustulosa, with thinner, sharper, and finer plications. These, as stated by Hall and Whitfield, are more numerous than in $R$. pustulosa, and five of them instead of four (as in the latter) regularly surmount the fold. 
This same slell is found in the Chontean limestone of Cooper County, Missonri, and at the base of the Lower Carboniferous at Providence Landing, Missouri, and at Blackwater Bridge, Saline County, Missouri.

Formation and locality : Madison limestone, Hunter Peak, Absaroka Range; Aruold Hagne. Limestone bluff north of Little Sunlight Creek, Absaroka Range; Arnold Hague. East side of Gallatin River, west of Electrie Peak; divide between Gallatin River and Panther Creek, Gallatin Range; amphitheatre east of Bamock Peak, Gallatin Range, bed 28; IV. H. Weed. Crowfoot Ridge, Gallatin Range, top of bed 25 ; J. P. Iddings and G. M. Wright. Same, bed 26 ; J. P. Iddings and W. H. Weed. South of Forellen Peak, Teton Range; S. L. Penfield. Northwest slope of same; S. L. Penfield. South slope of Quadrant Hountain, Gallatin Range; north of Bighorn Pass, Gallatin Range; Crowfoot Ridge, Gallatin Range, bed 24; A. C. Gill. Same, top of bed 24 ; J. P. Iddings. Head of Conant Creek, Teton Range; W. H. Weed. North of Owl Creek, northeast slope of Teton Range; W. H. Weed. Upper Carboniferous, Lincohn County, Nevada. Waverly age, Wasatch Range, Utal. Chouteau limestone, Cooper County, Missouri; Providence Landing, Missouri; Blackwater Bridge, Saline County, Missouri.

\section{Camarotechia sappho Hall (?).}

Rhynchonella sappho Hall, 1860: Thirteenth Rept. New York State Cab. Nat. Hist., 1. 87. Herrick, 188s: Bull. Denison University, Vol. III, 1. 40, PI. V, tig. 1; PI. VII, fig. 25. Herrick, 1895: Geol. Ohio, Vol. VII, PI. XXI, fig. 1.

Rhynchonella (Stenocesma), sappho Hall 1867: Pal. New York, Vol. IV., 1. 340, PI. LIV, figs. 33-43.

Camarotochic suppho Hall and Clarke, 1893: Pal. New York, Vol. VIII, Pt. II, p. 192. Pl. LV1I, figs. 10-14.

The specimen which represents this type is larger than any in the collection referred to the genus Camarotœchia. When perfect it must have measured $16 \mathrm{~mm}$. in length by $21.5 \mathrm{~mm}$. in width. It is a rather flat, explanate shell, resembling in this respect $C$. herrickana rather than the other forms represented in the Yellowstone National Park. The lateral slopes are nearly straight or slightly concave, and extend abount half the entire length of the shell, where they are met by the deeply bowed anterior margin. The fold is not high, but can be traced to the rostral region. It is traversed by six small, rounded plications, and about seven others are to 
be found on each of the sides. In every respect this very closely resembles Hall's species, although only a provisional reference is possible, owing to insufficient material. C. sappho first makes its appearance in beds of the Marcellus period, but is known to extend up into the upper Waverly (Herrick, 1888, loc. cit., p. 40).

Formation and locality: Madison limestone, Limestone bluff south side of Soda Butte Creek, northwest of Abiathar Peak, Absaroka Range; J. P. Iddings. Marcellns to Warerly, Leroy, Geneseo, and York, New York: Licking County, Ohio.

\section{Camarotechla camarifera Winchell (?).}

Rhynchonella camarifera Winchell(A.), 1862: Proc. Acad. Nat. Sci. Philadelphia, p. 408.

This species is represented in a somewhat fragmentary mamer, and the material is too poor for illustration. It resembles C. herrickana, but at the same time seems to be specifically distinct from it. Shape ovate; length equal to or slightly exceeding the width; convexity moderate. Sides straight, meeting at the beak in something less than a right angle; front deeply rounded. Plications rounded, four on the fold and three in the sinus, with five or six on the sides. The plications are nearly straight and not very divergent, which makes the shell look longer than it really is. It ean be distinguished from C. heirickane by the somewhat different arrangement of plications on fold and sides. The proportions of the shell are also different. The plications are slightly finer, less angular, and not so strongly outcurved at their extremities. The nearest described species which I have found is C. camarifera of Winchell.

Length, $10 \mathrm{~mm}$; width, $9.5 \mathrm{~mm}$.

Formation and locality: Madison limestone, Crowfoot Ridge, Gallatin Range, bed 26, bed 28, bed 30; J. P. Iddings and W. H. Weed. Marshall group, Point aux Barques, Michigan.

\section{Camarotechia sp.}

Pl. LXIX, figs. $4 a, 4 b$.

This species is represented by a single specimen, which seems to be distinct from any type occurring in the collection from the Yellowstone National Park. It was found at the limestone bluff on the south side of 
of Soda Butte Creek, northwest of Abiathar l'eak, Absaroka Range, a locality which has already fumished several new species, and seems to possess a somewhat distinct local fauna.

Cameroterchin sp. consists of a single dorsal valve. The shape is slightly oval, length and wilth about equal; curvature of the outline regulan, and not angular where the anterior margin meets the lateral slopes. Extremely gibbous, the thickness of the valve being more than half the length or width. Fold not very high, but defined to the vicinity of the beaks. It is marked by five rounded plications, and a like number are to be found on the two sides.

This form seens to be related to C. orlicularis, of Chemung age.

Formation and locality: Madison limestone, limestone bluff south side of Soda Butte Creek, northwest of Abiathar Peak, Absaroka Range; J. P. Iddings.

\section{LIORHYNCHUS Hall, 1860.}

\section{LIORHYNCHUS HAGUEI 11 . sp.}

Pl. LXIX, figs. $5 a, 5 b$.

Shell rather large, tumid. Ventral valve flat in effect; subquadrate in outline; beak strongly incurved; fold deep. Thus the anterior and posterior angles of the quadrate shell are strongly flexed in one direction, while the lateral angles are prominently elevated. Dorsal valve very rotund; fold high ; sides strongly recurred. The surface is smooth (?), sometimes showing varices of growth. Fold and simus alone plicate. Stria on the sides of the shell entirely obsolete. There are five plications on the fold, neither sharp nor strong. The central three are slightly larger than the lateral ones, which are not defined on the outer side, but lie in the regular curvature of the shell. Four nearly obsolete plications in the sinus.

The general appearance of the shell suggests the genus Pugnax, but a reference to that type is impossible by reason of internal structures. A section across both valves near the beak shows that the dorsal valve is provided with at well-developed median septum, and that the ventral valve has two converging laminar plates in the rostral region.

Liorhynchus haguei is very close to L. greenianum Ulrich, of Keokuk (?) age, from New Albany, Indiana, but the latter has three coarse plications 
on the fold, while the former regularly has five fine ones. L. haguei also resembles to a certain extent $L$. kelloggi of the Hamilton group, but it is more gibbous, with a higher fold, while the latter lias, as a rule, six to ten plications on fold and sinus, with five or six faint lateral plications.

Comparison can also be made with Liorhynchus (Pugnax?) striatocostatum Meek and Worthen, which has three or four plications on the fold and two or three nearly obsolete ones on either side. The fold is lower, broader, and more quadrate, and the plications surmounting it are much coarser, than in $L$. haguei, which has the lateral plications either entirely lacking or more indistinct. The latter appears also to be without the fine striate surface ornamentation of Meek and Worthen's species.

Formation and locality: Madison limestone, Crowfoot Ridge, Gallatin Range; cherty limestone, top of bed 24 ; A. C. Gill.

DIELASMA King, 1859.

Dielasma utah Hall and Whitfield.

Pl. LXIX, figs. $6 a, 6 b, 6 c$.

Terebratula utah Hall and Whitfield, 1877: King's Geol. Expl. 40th Par., Vol. IV, p. 255 , Pl. IV, fig. 18.

The type of this species is a dorsal valve, with a pentagonal outline and a punctate shell. The rectilinear outline is not constant, however, for, on a block of limestone from the same locality containing other type material (Athyris planosulcata?), is a second specimen whose outline is regularly curred.

The material from the Yellowstone National Park agrees with the above so perfectly in general form, proportion, size, etc., that I am confident both belong to the same species.

Although it has not been possible to determine the internal characters of this form, it has been referred to the genus Dielasma because of its geological position, punctate shell, and characteristic shape of the ventral valve.

Dielasma utah very closely resembles D. formosum Hall, which occurs in' the Mississippi Valley, in strata of Keokuk age; but D. utah is found in the lower beds of the Madison limestones. 
Dielusma muleyi Hall and Clarke ${ }^{1}$ (non Worthen) and Terebratule gorbyi S. A. Miller.2 are clusely related forms, but I lave not been able to examine them personally.

It is probable that $I$. utuh will prove synonymous with $D$. burlingtonense White, of the same geologic lorizon, but the scanty material of the former species, joined to the very inadecnate description of the latter, renders it impossible to rletermine this point.

Specimens of $I$. Inrlingtonense White from the Cuyahoga shale as exposed at various points in Summit and Medina counties can not be distinguished from I). uteh by any characters that I have been able to liscover.

Formation and locality: Madison limestone, limestone bluff north of Little Sunlight Creek, Absaroka Range, 600 feet above the strean; Anold Hagne. East side of Gallatin River, west of Electrie Peak; Crowfoot Ricige, Gallatin Range, bed 28; J. P. Iddings and W. H. Weed. Lower Carboniferons, Cottonwood Divide, Wasatch Range, Utah.

\section{SPIRIFERINA d'Orbigny, 18:8. \\ Spiriferiva solidirostris White.}

Pl. LXXI, fig. 10 \%.

Spirifer solidirostris White, 1860: Jonr. Boston Soc. Nat. Hist., Vol. VII, p. 232. Spiriferina solidirostris White, 186: Proc. Boston Soc. Nat. Hist., Vol. IX, p. 24. A. Winchell, 1s65: Proc. Acad. Nat. Sci. Philatelphia, p. 120.

This is not a common species in the Yellowstone National Park. It has been observed at a number of localities, but is represented by only one or two specimens at each. These correspond so entirely witlı S. solidirostris, as far as characters are indieated, that I refer them very confidently to White's species. The area, shape of shell, number and character of plications, and surface ornamentation are exactly as White has described them. The largest specimen, a ventral valve of unnsual size, measured $21.5 \mathrm{~mm}$. in width by $12.5 \mathrm{~mm}$. in length; but the one figured (Pl. LXXI, fig. 10a), which measures $15 \mathrm{~mm}$. in width by $12 \mathrm{~mm}$. in length, is perhaps nearer the average.

'Hall and Clarke, 1895: Pal. New York, Vol. v111, Pt. 11, 1'l. LXXxl, figs. 27, 28.

"S. A. Miller, 1892 (for 1891): Seventeenth Rept. State Geologist Indiana, p. 687, Pl. NIII, figs. 3, 4. MON XXXI1, P' IT-35 
The identifications of this species are usnally incorrect, the current type of spesimens differing markedly from the original description, which is appended below. S. solidirostris Herrick ${ }^{1}$ is an eximple of this, and the form he las figured can not be inchded with White's type.

"Shell rather small, nearly semicircular, wider than long, widest at the linge line, where it is sometimes extended into submucronate points, rounded in fromt.

Dorsal ralve mole convex from beak to front than transversely. Beak scurcely prominent, slightly projecting beyoud the hinge line.

Ventral valve about twice as deep as the opposite one, regularly arcuate from beak to front, but a little depressed near the cardinal extremities. Area large and well defined, foramen narrow, beak acute, incurved, and becoming solidified as the foramen is progressively closed. Dental plates strong, projecting a little forward of the linge line. From six to eight prominent plications on each side of the mesial fold and sinus, which decrease regularly in size toward the hinge extremities. Sinns rather broad and deep, distinctly defined even to the point of the beak. A slightly elevated ridge extends along its bottom, and a corresponding depression along the mesial fold.

Mesial fold prominent and widely separated from the plications. Surface marked by fine, lamellose, concentric stria, which arch upon the plications and the ridge in the mesial sinus, and doubly arch upon the mesial fold."

White's reference of the species to Spiriferina is undombtedly correct. Shells from the Madison linestone show the characteristic finely punctate structure.

Formation and locality: Madison limestone, east side of Gallatin River, west of Electric Peak; George M. Wright. Divide between Gallatin River and l'anther Creek, Gallatin Range; amphitheater east of Bamock Peak, Gallatin Range, bed 28; IV. H. Weed. Crowfoot Ridge, Gallatin Range, bed 26, bed 27, bed 31 ; J. P. Iddings and W. H. Weel. South of Forellen Peak, Teton Range; S. L. Penfield. West of Antler Peak, Gallatin Range; Antler Peak, Gallatin Range; A. C. Gill. Summit of peak west of Antler Peak, Gallatin Range; J. P. Iddings. Sonth slope of Quadrant Mountain,

'Herrick, 1888: Bull. Denison University, Vol. III, P. 47, Pl. II, figs. 9-11; Pl. V, lig. 13; also Geol. Ohio, Vol. V11, Pl. XII, tig. 13. 
Gallatin Range: north of Bighorn Pass, Gallatin Range; A. C. Gill. Cherty belt, Bighom Pass, Gallatin Ranger; J. P. Iddings. Crowfoot Ridge, Gallatin Ringe, hed 24 ; A. C. Gill. North of Owl Creek, northeast slope of 'Teton Range; IV. H. Weed. North side of south fork of Mill Creek, Snow! Range; Lonis I. Pirsson. Slide, east side of Gallatin River, below Fan Creek. Kinderhook age, Burlington, Iowa; Hamburg, Illinois; Sciotoville, Ohio.

\section{SPIRIFER Sowerby, 1815.}

SPIRIFER cextronatus: Winchell.

Pl. LXX, figs. $3 a, 3 b, 3 c, 3 \pi$.

Spirifer centronutus Winchell (A.), 1S65: Proc. Acad. Nat. Sci. Philadelphia, p. 118. White, 1875: Wheeler's Expl. Surv. W. 100th Merid., Tol. IV, p. S6, Pl. V. figs. $S a-8 c$.

Spirifera centronatu Hall and Whitfield, 1877: King's U. S. Geol. Expl, toth Par.. Vol. IV, p. $25 \pm$, Pl. IV, tigs. $5,6$.

Spirifer centronutus is by far the most abundant and universal form in the Yellowstone National Park. It has been identified at nearly every locality from which collections have been made, and appears often to have been present in large numbers. The species is already known in the Rocky Ifountain region from the reports of C. A. White and of Hall and Whitfield. I have compared my material with their types, and also with specimens from the Waverly rocks of Richfield, Ohio, and all are without doubt specifically identical.

Spirifer centronutus usually develops four equal plications on the fold and three in the sinus, with sixteen or more (usually) simple plications on the wings. The linge line is always the widest portion of the shell. The anterior outline is curved, with a tendency to become quadrate. In other words, the shape is sometimes that of the smaller segment of a circle, sometimes more tumid below, with angular or mucronate extension at the hinge line. Always transverse. Area of the ventral valve not very broad; beak incurved, small. Sinus beginning at the extremity of the beak. It is there relatively deep, and sharply defined on either side by a prominent plication, but grows broader and shallower, somewhat losing definition below. Subsequently a central rib develops in the sinns, and this is at about the same time supplemented by two others, one on either side, 
sprung as bifurcations from the two prominent bounding ribs. Thus there are normally three plications in the sinns. In addition, the shell is marked by about thirty-two radii, sixteen on either side of the sinus, which makes an aggregate of thirty-seven plications for the entire valve. Usually at maturity these are all nearly or quite of a size. Sometimes, howerer, the two bounding rilss remain prominent, while those in the sinus are almost undereloped. This constitutes the variety S. albapinensis, and represents the condition of most young shells. Bifurcation is common anong the alar ribs, but occasionally a shell will have nearly all its plications bifurcate.

The area of the dorsal valve is narrow; beak small, inconspicuous. There is a low but usually well-marked fold, on which at first are only two plications. These subsequently bifureate, giving four plications on the fold of mature shells. Bifurcation is centrifugal and does not result in the formation of primarily equal ribs. The narrower ridges are in each case toward the wings, while the two original ribs remain central and contignous.

The surface ornamentation consists of fine radiating strix, parallel to and superimposed on the radiating ribs. These are interrupted by a system of concentric imbricating lamellie, as in S. biplicatus.

The chief deviation from the type above lescribed consists in an increase in the number of stria, accompanied by a diminution in their size, so that four or five strie are found in the sinus, and twenty or more on the wings.

I believe that this species will be found to be synonymous with $S$. biplicatus, but until proved I have employed the name of the better-known form.

Formation and locality: Madison limestone, near summit of ridge, west end of Hunter Peak, Absaroka Range; limestone bluff north of Little Sumlight Creek, Absaroka Range, 600 feet above the stream; east side of Gallatin River, west of Electric Peak; Upper Gallatin Valley, west of Bighorn Pass; Arnold Hague. Upper Gallatin Valley, divide between Gallatin River and Panther Creek, Gallatin Range; east face of Antler Peak, Gallatin Range; saddle west of Antler Peak, Gallatin Range; amphitheater west of Bannock Peak, Gallatin Range, bed 26 ; amphitheater east of Bannock Peak, Gallatin Range, bed 30; W. H. Weed. Crowfoot Ridge, Gallatin Range, bed 25; J. P. Idlings and W. H. Weed. Same, top of bed 25; J. P. lddings and G. M. Wright. Same, top of bed 26, lower part of 
loed 27, upper part of bed 27 , hed 28 , bed 31 ; J. I'. lddings and W. II. Weed. Pars between Fox and Mink creeks, west of Two Ocean Platean; Amold Hagne. Last slope of Survey Peak, 'Teton liange; south of Forellen l'eak, Teton Range; nortliwest slope of same; S. L. Penfield. Antler Peak, Gallatin liange; west of same; A. C. Gill. Summit of peak west of Antler Peak, Gallatin Range; sonth slope of same; sumnit of T'hree River Peak, Gallatin Range: J. P. Iddings. South slope of Quadrant Mountain, Gallatin Range; A. C. Gill. South base of same; J. P. Iddings. North of Biglın'n Pass, Gallatin Range; Crowfont Ridge, Gallatin Range, bed 24; A. C. Gill. Bighom Pass, Gallatin Range; J. P. Iddings. Head of Conant Creek, Teton Range; north end of Teton Range, north of Owl Creek; east side of Lamar Valley, mouth of Soda Bitte Creek, Absaroka Range; W. H. Weed. Limestone bluff soutl side of Soda Butte Creek, northwest of Abiathar Peak, Absaroka Range; J. P. Iddings. North side of north fork of Mill Creek, Snowy Range; J. P. Iddings and Lonis V. Pirsson. Warerly age, Cuyaloga Falls, Richfield, Lodi, Bagdad, ete., Olio; Black Hills, Dakota; Wasateh Range, Utah; Iountain Spring, Nevada.

\section{SPIRIFEr Centronatus var. Semirurcatus 11. var.}

Pl. LXX, fig. $4 a$.

This form is related to S. centronatus and to S. mesicostalis, standing about midway between them. It seems to me to be sufficiently out of the range of ordinary variations of S. centronatus to be described as a distinct variety.

It is of the imbrex type, semielliptical in ontline, fold and sinus strongly expressed; surface ornamented with regular imbricating growth lines and strong radiating ribs. Of the latter there are ten or eleven upon the wings and two somewhat larger ones upon the median fold. These, however, show a constant tendency to bifureate, which often results in the formation of four plications; but the median furrow of the fold is stronger than the two others. Length of the dorsal valve is 30.5 mm. transversely; longitudinally, $12.5 \mathrm{~mm}$.

The dorsal shown by Pl. LXX, fig. $4 a$, can be almost exactly mated in size, in shape, and in the number, size and distribution of the plications by specimens of $S$. mesicostalis. This, however, is rather small for mesicostalis, and I have not observed, in a large series of this species, any tendency toward bifurcation in the two plications on the fold. Compared witls $S$. 
biplicatus var. semifurcutus, $S$. centronatus has somewhat smaller and more numerous plications, and the fold, which is perhaps not quite so elevated, is sumounted by four or more equal radii.

Formation and locality: Madison linestone, Hunter Peak, Absaroka Range; 'T'. A. Jaggar. Near summit of ridge, west end of Hunter Peak, Absaroka Range; Arnold Hague. Crowfoot Ridge, Gallatin Range, top of bed 26; J. P. Idding's and W. H. Weed. Under Quartzite Ridge, north side of Burnt Fork.

\section{Spirifer sumattenuatus Hall.}

Spirifer subattemutus (by mistake, Spirifer submucronata) Hall, 1858: Geol. Surv. Iowa, Vol. I, Pt. II, p. 504, Pl. IV, figs. 3a-3c.

spirifer subuttenuta Winchell (A.), 1862: Proc. Acad. Nat. Sci., Philadelphia,

p. 4C5. Whiteaves, 1891: Contributions to Canadiau Palieontology, Vol. I, 1. 223.

Shell rather small, semicircular, alar angles somewliat rounded to sharp. On either sile of the fold and sims there are eight to ten comparatively large radiating ribs, which are crossed by strong concentric imbricating ridges. Tery variable in the number of plications on fold and sinus. One dorsal valve shows a low fold with two strong radii equal to those on the wings. Another specimen has a lather ligh fold with a very faint median furrow. One ventral valve, on the other hand, shows a sharp median ridge in the rather deep sinns, while still another has the sinus simple for over half its length, when suddenly four low plications, somewhat smaller than the rest, appenr in it. Length of this last specimen, $10.5 \mathrm{~mm}$; width, 15 mm. Another example is considerably larger than this.

The form in question seems to be closely allied to $S$. centronatus, from some varieties of which it is not widely separated. It also bears some resemblance to $S$. strigosus Meek and $S$. aryentarius Meek, to the latter in point of size, to the former in the plications of fold and sinus. S. argentarius and S. strigosus are both described from Devonian strata; so is S. subuttenuatus, but it is known to occur in the Waverly also. The material studied is msatisfactory.

Formation and locality: Madison limestone, Stinkingwater Valley, below mouth of the canyon, Absaroka Range; Amold Hagne. Chemung age, Independence and Buffalo, Iowa; Rock Island, Illinois; Naples, New York; Athabasca River, Canada. Marshall group, Point aux Barques, Michigan. 


\section{SPIRIFER MARIONENSIS Shmmirl (?)}

Spirifer marionensis Shmmard, 185i): Geol. Lept. Missouri, p. 203, Pl. C, figs. Sa-Se. IIall, 185s: Geol. Surv. Iowa, Vol. I, I't. II, p. 501, Pl. VI, figs. Ia-1c. IIall and Clarke, 189.): Pal. New York, Vol. VIII, Pt. II, Pl. XXXI, fig. IJे. Spirifon marionensis Winchell (A.), 1870: I'roc. Am. Phil. Soc., Vol. XI, p. 252. Hall, IS8:3: Second Ann. Rept. New York State Geologist, Pl. LVI, fig. 15. Herrick, 1SSs: Bull. Denison University, Vol. III, p. 43, Pl. VI, figs. 2-4; Pl. VII, fig. 11; Vol. IV, p. 26, Pl. II, fig. :.

This form is found only at the hear of Conant Creek, Teton Range. The material, which is much crushed and broken, so far as ascertained, can well be refered to Shmmard's species. It is much larger and more coarsely plicate than S. centronatus, and much resembles $S$. striatus of this report, except that the surfice is crossed by numerous lamellose concentric strice, whereas the other is smooth. A satisfactory identification is rendered impossible by the character of the material.

Formation and locality: Madison limestone, head of Conant Creek, Teton Range; IV. H. Weed. White Mountain, Absaroka Range, just below Quadrant quatzite; T. A. Jaggar: Choutean age, Louisiana and Hannibal, Missouri; Portsmouth and Sciotoville, Ohio.

\section{SPIRIFER STRIATUS var. Madisonensis $n$. var.}

$$
\text { Pl. LXX, figs. } 2 a, 2 b, 2 c, 2 d \text {. }
$$

This form in general appearance resembles $S$. striatus Martin, of the Momntain limestone of various European localities. It does not attain so large a size as is often seen among specimens of S. striatus, and the strix are coarser and less numerous than in some of the forms figured by Davidson.

The matcrial under discussion approaches most elosely to certain specimens from Cork, Ireland, with which it has been compared, but certain differences obtain which are worthy of at least rarietal distinction. The area in S. striatus var. maclisonensis is higher, even in specinens of considerably smaller size; the ventral beak more overhanging, and the foramen higher in proportion to its width. The outline shape of both types is nearly the same, likewise the number and size of the strix. 'The fold is somewhat higher in the Irish form, and cousiderably more angular. The striæ bifurcate in the immediate vicinity of the beak, and often again 
near the anteriur margin. In the rariety madisonensis the strix bifureate near the anterior margin, but can be traced backward to their origin at the beak without bifurcation. In neither form are the striae interrupted by imbricating lamellx.

Hall and Whitfield distinguish two types among the forms from Utah, which they refer to $S$. strictus. The one which is lower in the stratigraphic series is said to be transversely elongaterl, while the higher one is abont as long as wide, and has finer, more angular, and more fasciculate striæ. Their material is so crushed that it is impossible to institute a satisfactory comparison, but if $S$. striutus var. madisonensis is identical with either of these, it must be with the former (lower) type. It differ's distinctly from the form figured on Pl. Y, figs. 13, 14 (loc. cit.), which is somewhat larger; the area, instead of being nearly straight and rertical, is deeply curved, at first nearly horizontal, then resurgent; the fold is sudden, high, and thin.

Spirifer striutus var. madisonensis, when mature, can be readily distinguished from $S$. centronatus, with which it is associated. It is much larger, the fold and simus less defined, plications more numerons, but less sharp, and not covered with the imbricating concentric lamellæ which wellpreserved surfaces of S. centronatus show.

The largest specimen, an incomplete rentral valve, measures $55 \mathrm{~mm}$. in breadth. Another shell measures $5.5 \mathrm{~mm}$. in breadth by $35 \mathrm{~mm}$. in length, which is perhaps near the average. Young specimens, however, are broader in proportion to their length, and can scarcely be distinguished in shape from S. centronatus of the same size.

Formation and loeality: Madison limestone, Stinkingwater Valley, below month of the canyon, Absaraka Range; Arnold Hague. Crowfoot Ridge, Gallatin Range, cherty limestone, top of bed 2t; A. C. Gill.

\section{SPIRifer sp. \\ Pl. LXX, fig. $1 a$.}

This form is known only from an incomplete dorsal ralve, hut it is so striking that it seems worthy of some notice. It is very transverse, the width being $51 \mathrm{~mm}$. and the length $16.5 \mathrm{~mm}$. Shape triangular: trumcate in front; wings acutely angular, mucronate (?). The fold is undefined and scarcely at all raised above the general curvature of the shell, surmonnted by four or five bifurcated plications. On either side are found 
about twenty other plications, which (on the cast) granlually become finer and more obsolete until they disappear and the extreme alar portion is smootl. I know of no type with which this can aptly be compared except S. forbesi, of the l3urlington group.

Formation and loeality: Madison limestone, east slope of Survey Peak, Teton Range; S. L. Penfield.

\section{SPIRHilir sp.}

A solitary specimen, not referable to any of the forms yet recognized in the Yellowstone National Park. It is a large sluell, probably when complete not less than $63.5 \mathrm{~mm}$. wide by $44.5 \mathrm{~mm}$. long: a ventral value. There is a broad, shallow sinus, which, together with the wings, appears to be covered by comparatively fine, obscure, radiating strie. The entire rostral cavity is filled with shell deposit, as in S. plenus, of the Burlington. Externally this form approaches Syringothyris; the beak is erect and the whole shell has what may be called a hemiconical shape; but it is developmentally not a true species of that genus.

Formation and locality: Madison limestone. Snake River Valley, west of Two Ocean Platean; W. H. Weed.

\section{MARTINIA McCoy, 1844.}

Maktinia rostrata 11. sp.

Pl. LXX, figs. $5 a, 5 l, 5 c, 5 l, 5 e, 5 \%, 5 y$.

Athyris planosulcata Hall and Whitfield, 1877 (pars): King's U. S. Geol. Expl. 40th Par., Vol. IV, 1). 257, Pl. IV, fig. 10.

Shell large, obese, lozenge-shaped; when young, wider than long; when old, length and width about equal. Ventral valve productiform; beak prominent, incurved over a moderate-sized area. Foramen large, open. Hinge line half or three-fourths the whole wilth of the shell. Surface smooth; marked by a shallow sinus extending to the extremity of the beak, where it is defined; less marked below and accompanied by a flattening of the whole valve. Dorsal valve rounded behind, converging in front in somewhat straight lines, whose junction is anticipated by the truncation of a very low fold. Beak prominent, but not produced. Transrerse curvature gentle and even, or sometimes formed by the two planes of an obtuse dihedral angle, whose edge is the median line. Highest point is at the umbo. 
Mature specimens can scarcely be mistaken for anything else in the same beds. The smooth surface and area with triangular foramen would suffice to ristinguish even young shells firom C. crassicardinalis, which they most resemble, but when these characters are obscured the prominent beak and mesial sulcus of the ventral valve are diagnostic. There is some similarity with Spirifer (Martinia) glaber Martin, to which l believe this type to have been usually referrerl. 'The produced and overhanging beak and large area of $M$. rostrutu are well-marked specific characters. The fold and sinus of $M$. glalwa are stronger than the same features of $M$. rostrata, where, in fact, they are but slightly developer, and often exhibit a tendercy to bifurcate, manifested by a median sulcus and ridge of more or less depth, never seen in the latter.

The synonymy of this form includes, so far as I am aware, besides $S$. glaber, of varions authors, only Athyris plemosulcuta (?) Hall and Whitfield (non Phillips), figured in King's U. S. Expl. 40th Par., Vol. IV, p. 257, Pl. IV, fig. 10, which appears to be a young specimen of $M$. rostrata. Width of large specimen, ventral valve, $38 \mathrm{~mm}$; lengtl, $35.5 \mathrm{~mm}$. Width of medium-sized specimen, ventral valve, $29 \mathrm{~mm}$; length, $25.5 \mathrm{~mm}$. Widtl of large specimen, dorsal valve, $51 \mathrm{~mm}$; length, $34.5 \mathrm{~mm}$. Wirth of medimu-sized specimen, dorsal valve, 29 mm.; length, $23.5 \mathrm{~mm}$.

Formation and locality: Madison limestone, east side of Gallatin River, west of Electric Peak; G. MI. Wright Amphitheater west of Bamock Peak, Gallatin Range, bed 26; IV. H. Weed. Crowfoot Ridge, Gallatin Range, top of bed 25; J. P. Iddings and G. M. Wright. Same, lower part of bed 27 , bed 31 ; J. P. Iddings and W. H. Weed. South side of Gallatin Valley, bed 3\%; J. P. Iddings. West of Antler Peak, Gallatin Range; A. C. Gill. South slope of peak west of Antler Peak, Gallatin Range; summit of Three River Peak, Gallatin Range; J. P. Iddings. Sonth slope of Quadrant Mountain, Gallatin Range; north of Bighorn Pass, Gallatin Range; A. C. Gill. North of Owl Creek, northeast slope of Teton Range; W. H. Weed. Limestone bluff south side of Soda Butte Creek, northwest of Abiathar Peak, Absaroka Range; J. 1'. Idding's. 


\section{RETICULARIA MACoy, $18+4$.}

\section{Reticularia cooperrensis Swallow.}

Pl. LAX, figs. $9 a, 9 b, 9 c$.

Spivifer cooperensis Swallow, 1860: Trans. St. Louis Acad. Sei., Vol. I, p.613. Keyes, 1895: Geol. Surv. Missouri, Vol. V, Pt. II, p. 78.

Spirifer hirtus White and Whitfield, 1862: Proc. Boston Soc. Nat. Hist., Vol. VIII, 1. 293. ? Winchell (A.), 1865: Proc. Acnd. Nat. Sci. Philadelphia, p. 119. Hall and Clarke, 1895: l’al. New York, Vol. VIII, Pt. 1I, PI. XXXVIII, fig. 14 (? Pl. LAXXIT, tigs. 36, 37).

? Spirifer cooperensis Mleek and Worthen, 1866: Geol. Surv. Illinois, Vol. II, p.155, Pl. XIV, tig. 5.

The specimens here refered to $R$. cooperensis Swallow have been compared with material from the Chonteau limestone of Cooper County, Missomi, where Swallow's types were found. The unusually perfect agreement exlibited in the two forms leaves no donbt of their specific identity. The same form occurs in the Warerly at Richtield, Ohio.

Althongh Spirifer cooperensis Meek and Worthen is retained in the synonymy of this species, I believe they were dealing with a distinct though similar form. It is only about half the size of mature $R$. cooperensis, and has a distinct fold with three or four plications on either side, more as in R. peculiaris Shumard. In fact, it seems highly probable that they were dealing with the shell described by $\mathrm{Hall}^{1}$ from the same (Goniatite) beds, three years previously, as Spirifer semiplicatus. On account of differences mentioned above, I believe this constitutes a distinct specific type, although Hall may have included in his description some of Swallow's species.

Meek and Worthen seem to be in error when they state that Swallow refers to his species "obscure, radiating plications" (Meek and Worthen, loc. cit., p. 156). He does, indeed, speak of "punctate and plicate folds" and "concentric folds marked with small pits and short longitudinal plications," but this had reference to the delicate longitudinal fluting's of the lamine, dne to the spines or their bases (a character shown in all the specimens examined) rather than to the large radiating folds shown in Meek and Worthen's figrure. 
Spirifer hirtus, from the same beds and the same region as $R$. cooperensis, may almost certainly be placed in the synonymy of the latter species.

Formation and locality: Madison limentone, east side of Gallatin River, west of Electric Peak; Upper Gallatin Valley, west of Bighorn Pass; Arnold Hagne. Amphitheater west of Bannock Peak, Gallatin Range, bed 26; W. H. Weed. Crowfoot Ridge, Gallatin Range, top of bed 25 ; J. P. Iddings and G. MI. Wright. Same, top of bed 26, top of bed 27, bed 28, bed 31; J. P. Iddings and W. H. Weed. South of Forellen Peak, Teton lange; S. L. Penfield. South slope of peak west of Antler Peak, Gallatin Range; J. P. Iddings. North of Bighorn Pass, Gallatin Range; A. C. Gill. Head of Conant Creek, Teton Range; W. H. Weed. Choutean age, Chouteau Springs, Missouri; Rockford, Indiana; Burlington, Iowa; Hickman County, Temnessee; Richfield, Bagdad, etc., Ohio.

\section{RETICULARIA COOPERENSIS var. .}

Pl. LXX, figs. $6 a, 6 b, 6 c$.

Spirifera setigere Hall and Whitfield, 1877: King's U. S. Geol. Expl. 40 th Par, Vol. IV, p. 270, Pl. V, figs. 17,18 .

This form is once again as large as $R$. cooperensis, of which, for the present, I regard it as a variety, but $I$ an not in a position to designate any other character on which a differentiation can be made. The single specimen found in the collection stands out so strikingly fiom the material referred to $R$. cooperensis that it is significant of further difference, but the specimen is so exfoliated and rushed that a detailed comparison, which might bring out constant important contrasts in surface ormamentation, etc., is impossible.

As far as the limited material permits me to judge, the same form occur's in the Eureka district and at Dry Canyon, Utah, where it has miformly been identified as $R$. setigera Hall, of the Chester limestone, which it strongly resembles. Howerer, in the Yellowstone National Park it is in the lower part of the Carboniferens series, associated with Waverly forms ( $R$. cooperensis, etc.).

A comparison with specimens of $R$. setiger from Chester, Illinois, shows that the Warerly form is of about the same size, but more transverse, beak less incurved, area higher and larger. As has been salid, a comparison of the surface ormamentation of the two forms is not possible. 
Compared with the Burlington form, R. conperensis var. is smaller, less transverse: fold and sinus less pronounced; area proportionally not so broad.

The specimen figured is from the Eurekis district, Nevada. The original shape and proportions are better maintained.

Formation and locality: Madison limestone, Crowfoot Ridge, Gallatin Range, top of bed 25; .J. I'. Iddings and G. M. Wright. Lower Carboniferons, Eureka district, Nerada; Dry Canyon, Utah.

\section{Reticularia (?) PeCuliakis Shumard.}

Pl. LXX, figs. $s a, s b$.

Spirifer? peeuliaris Shunard, 1855: Geol. Rept. IIissouri, p. 202, Pl. C, figs. 7a, 7 .

Spirifera (Martinia) peenliaris White, 1575: Wheeler's Expl. Surv. W. 100th Merid.,

Yol. 15, p. 90, Pl. V, figs. $7 \pi, \tau$.

This species is so rare in the Yellowstone National Park, and its preservation is so unsatisfactory, that any less striking form could seareely be identified.

It can be distinguished from $R$. subrotundata by its larger and less numerons plications, of which there are only six or seven on either wing, while the fold and sinus are simple.

R. peculiaris is found in the yellow sandstone at Burlington, Iowa, and in the brown limestone of Choutean age at various places in Missouri.

I am not confident that this is correctly referred to Reticularin. Exfoliated specimens from the Choutean limestone appear to have possessed a finely lamellose-spinose surface.

Formation and locality: Madison limestone, summit of Three River Peak, Gallatin Range: J. P. Iddings. East side of Lamar Valley, month of Soda Butte Creek, Absaroka Range; W. H. Weed. Kinderhook age, Cooper County, Missouri; Mountain Spring, Nevada.

\section{Reticularia (?) subrotundata Hall.}

Pl. LXX, figs. $\tau a, \tau b$.

Spirifera subrotundata Hall, 185̃8: Geol. Surv. Iowa, Vol, I, Pt. II, p. 521, Pl. VII, fig. s. Keyes, 1895: Geol. Surv. Missouri, Vol. V, p. 78.

I lave this species from a single locality beyond the confines of the Yellowstone National Park, but associated with a fauna clearly identical with that of the Madison limestone. 
The ventral valve is strongly arched in an antero-lateral direction, somewhat flattened transversely, with a broad, shallow sinus which can be traced quite to the beak, losing distinctness as it grows broader. Beak high, strongly incurved. Areal triangular and not well defined. Foramen large and high. Surface marked by about twenty-six fine, low plications, about six of which lie in the sinus, and with about ten on either wing. The shell is superficially marked by imnumerable fine pits, much resembling the punctation in the genus spiriferina, but this character is restricted to a thin outer layer, beneath which the shell substance is fibrous and impunetate. This appearance is probably secondary, resulting from an originally spinose exterior, which, with the general character of the species, elongate shape and olsolescent plications, distinguishes it from any representative of the genus Spiriferina, and seems to denote an alliance with Reticularia.

As regards its specific position, a comparison with typical Spirifera subrotumlata Hall, fiom the yellow sandstone of Burlington, Iowa, leads me to believe that it is identical with that species.

li. sutbrotundate is in many ways comparable to $R$. peculiaris, but the character of the plications affords an easy hasis for discrimination. Ri. subrotundate has finer and more numerous plications, of which six or more are in the fold and sinns, while in $R$. peculiaris the fold and sinus are undivided.

The same form occurs in the lower Burlington of Pike County, Missouri, and seems to lave been usually identified as R.peculiaris.

Formation and locality: Madison limestone, Little Belt Momtains, east side of Belt Creek, 5 miles above Monareh, Montana; W. H. Weed. Lower Burlington cheit, Pike County, Missouri.

\section{SYRINGOTHYRIS A. Winchell, 1863. \\ SYringothriris CAHTERI Hall.}

I'l. LXXI, figs. 1u, 1b, ic.

spirifer carteri Hall, 1857: Tenth Ann. Rept. New York State Cab. Nat. Hist.. p. 170. (partim) Meek, 1875: Pal. Obio, Vol. Jl, 1). 285 (not his figures = S. textu llall).

Spirifer (Cyotia?) hannibalensis Swallow, 1860: Trans. St. Lonis Acad. Sci., Vol. 1, p. 647 .

Syvingothyris typa Winchell, 1863: Proc. Acad. Nat. Sci. Philadelphia, 1?. 7. Winchell, 1870: Proc. Am. Phil. Soc., Vol. X1, p. 252. Hall and Clarke, 1893: Pal. New York, Vol. V1Il, Pt. II, p.48, tig. 40. Hall and Clarke, 1895: Pal. New York, Vol. VIII, Pt. II, Pl. XXVI, tigs. 6, 7, 10; Pl. XXVII, figs. 1-3. 
Spirifir cuspidutus Nleek, 1865 : P'roc. Acad. Nat. Sci. Philidelphia. Vol. XVII, 1. 275. Meek, 1s67: Am. Jour. Sei., Vol. XLVII ("2), p. 407.

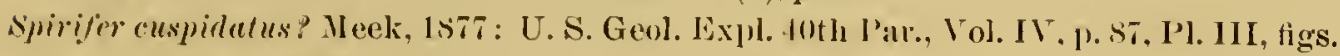
11. 11" (non Martin).

Syringothyris cuspridutus: Walcott, 18s4: Mon. U. S. (ieol. Surv., Vol. VII1, Pal. Eureka District, p. 219 (non Martin). Ilerriek, 1888 (partim): Bull. Denison Univ., Tol. III, p. 4I, Pl. I, lig. 7; PI. Il, lig. 17 (not Pl. V, ligs. 4-7 = S. herriclii). Syringothyris curteri Sehuchert, 1890): Ninth Anu. Rept. New York State Geologist, 1. 30. Keyes, 1895: Geol. Surv. Missouri, Vol. V, Pt. Il, p. 87, l'l. XL, fig. 10. stmingothyris hannibalensis Hall and Clarke, 1895: Pal. New York, Vol. VIII, Pt. II, Pl. XXV, tigs. 33-35.

I have adopted for this species the synonymy composed by Schuchert, ${ }^{1}$ who has given the specific limitations of these forms more detailed study than any other investigator. The material from the Yellowstone National Park inchudes only four specimens, one of which is the external cast of a dorsal valve, shown on Pl. LXXI, fig. 1 ; the others are three ventral valves, exfoliated so as to be almost internal casts. These specimens agree well with Hall's description and with Meek's ${ }^{2}$ figures of Spriver cuspidatus (?) which are here reproduced for reference. The dorsal cast shows the peculiar' "textile" surface ornamentation of the genus, and the shell substance, where preserved, gives evidence of being punctite. Therefore, although the characteristic structures of foramen and beak have not been observed, reference to the genus and to the species under the gems seems to be justified

It should be noticed that one of the ventral valves above referred to has every character of the specimen figured by White as Syringothyris extenuatus (Wheeler's Rept. U. S. Geogri. Surv. W. 100th Merid., Tol. IT, 1877, p. 88, Pl. T, figs. $9(t-9 d)$.

Formation and locality: Madison limestone, divide between Gallatin River and Panther Creek, Gallatin Range; IV. H. Weed. Crowfont Ridge, Gallatin Range, top of bed 25: J. P. Iddings and G. M. Wright. Limestone bhuff south side of Soda Butte Creek, northwest of Abiathar Peak, Absaroka Range; J. P. Iddings. Waverly and Burlingtou age, Licking County, and Bedford, Cuyahoga County, Ohio; Burlington, Iowa; Marion and Pike comties, Missouri: White Pine and Eureka districts, Nerada; near Clendemin, Montana.

'Nunth. Ann. Rept. New York State Geologist, p. 30.

2U. S. Geol. Expl. 40tl Par., Vol. IV, Pl. III, tigs. 11, 11 a. 


\title{
EUMETRIA Hall, 1864.
}

\author{
Eumetria verNeliLiana Hall.
}

Pl. LXVIII, figs. 12a, 12b.

Retziø rerneuilana Hall, 1855: Geol. Surv. lowa, Vol. 1, Pt. 11, p. 657, Pl. XXIII, figs. 11-1d. Hall, 185s: Trans. Albany [ust., Vol. IV, 1. 9.

Retzia vera Hall, 185̃s: Geol. Surv. Iowa, Tol. I, I't. II, 1) 704, Pl. XXVII, figs. 3a-3e.

Hall, 1863: Sixteenth Rept. New York State Cab. Nat. Hist., p. 55, figs. 1-3, 1. 69.

hetzia rerneuili Hall, 1863: Ibid., 1. 55, fig. 2.

Eumetria remenilanu Whittielı, 1s5: Bull. Am. Mns. Nat. Hist., Vol. I, p. 50, Pl. VI, figs. 2S-30.

Eumetria vermeniliana Ilall, 1883: Tweltth Rept. State Geologist, Indiana, p. 335, P1. XXIX, figs. $28-30$.

Letziu rudiulis Walcott, 1854: MIon. U. S. Geol. Surv., Vol. VIII, p. 220, Pl. VII, figs. $5,5 a(54 ?)$.

Eumetria verneuiliana and veru Hall and Clarke, 1893: Pal. New York, Vol. VIII, Pt. II, P. 117, figs. 104, 105; I'l. LI, figs. 13-26, 34-37; Pl. LXXXIII, figs. 26, 27.

In the Mississippi Yalley Enmetria remeniliana is confined to the St. Lomis and Chester dirisions of the Lower Carboniferous series. It includes a 11 mber of shells varying extremely in size, proportion, and surface senlpture, but which it has not yet been possible to subdivide and establish as independent specitic types.

The same type of shell, however, appears much earlier in the Lower Carboniferons; for in the Kinderhook division we find Eumetrin altirostris White, ${ }^{1}$ Hustedia triangularis Miller, ${ }^{2}$ Acambonu osugensis Swallow, Retzin? circularis Milles, ${ }^{4}$ Retzia? plicutu Miller, ${ }^{5}$ and Retzia popcana Swallow, ${ }^{6}$ all externally similar and more or less closely related forms.

The genus Acumbona includes mostly species from Lower Carboniferons horizons, but the internal structure of the genns is imperfectly known, and externally it is inseparable from Eumetria, even Eumetria verneniliana.

E. verneniliun, as it oceurs in the Madison limestone, does not attain the size often seen in specimens from the Mississippi Talley. It is, on the

11862. P'roc. Boston Soc. Nat. Hist., Vol. IX, 1. 28.

1894. Eighteentlı Anu. Rept. Geol. Surv. Iudianil, p. 315, I'l. IX, figs. 25, 26.

31860. 'Trans. St. Louis Acad. Sci., Vol. I, p. 653.

41894. Eighteenth Ann. Rept. Geol. Surv. Indiaua, p. 316, P1. 1X, figs. 32-34.

${ }^{5}$ 1894. Ibiclem, 1). 316, Pl. IX, figs. 29-31.

1860 . Trins. St. Louis Acad. Sci., Vol. I, p. 654. 
whole, small, finely plicate, and profusely punctate, but showing considerable variation in size, shape, and plication. The largest specimen is $16 \mathrm{~mm}$. long and of the sane widtlı; but it is badly crushed. Another example, more nearly the average size, is $11.5 \mathrm{~mm}$. long and the same in width; it has about twenty-eight strix. A third specimen is $14 \mathrm{~mm}$. long, $5.5 \mathrm{~mm}$. wide, and is ornamented with about thirty-eight strice. These data show the range of variation among the specimens in the collection.

I have not been able to verify the generic reference of this form by the study of internal structure, but on external evidence it can not be distinguished from the species to which I have referred it.

It is probable that Terelratula marcyi Shumard belongs to this same specific type, and if so, as it has priority of date over Eumetria verneuiliana by four years, the name will have to be changed to E. marcyi.

Formation and locality: Madison limestone, Limestone bluff north of Little Sunlight Creek, Absaroka Range; Arnold Hague. East side of Gallatin River, west of Electric Peak; amphitheater east of Bannock Peak, Gallatin Range, bed 28; W. H. Weed. Crowfoot Ridge, Gallatin Range, top of bed 25; J. P. Iddings and G. M. Wright. Same, top of bed 26, top of bed 27, bed 28; J. P. Iddings and W. H. Weed. Slide east side of Gallatin River, below Fan Creek. St. Louis and Chester horizons, Washington and Crawford counties, Arkansas; Floyd County and elsewhere in Indiana; Alton, Illinois; Green County, Missouri; Iowa; Cumberland Mountain, Tennessee.

\section{ATHYRIS MeCoy, 1844.}

\section{Athyris lamellosa Léveillé.}

Pl. LXXI, fig. $7 a$.

Spirifer lamellosus Léveillé, 1835̃ : Mém. Soc. Géol. de France, 1st series,Vol. II, p. 39, figs. 2 I-23.

Athyris lamellosa Meek, 1875: Pal. Ohio, Vol. II, p. 283, Pl. XIV, fig. 6a,6b. IIall and Clarke, 1893: Pal. New York, Vol. VIII, Pt. 11, p. 90, Pl. XLVI, figs. 16-20. Herrick, 1858: Bull. Denison Univ., Vol. III, p. 49, Pl. II, fig. 7.

This species has been identified in the Yellowstone National Park from one locality only, where, however, it can scarcely be considered rare. As there exhibited, it more nearly resembles the form figured by Herrick from the lower "Waverly" of Ohio (loc. cit., Pl. II, fig. 7) than that of Meek (loc. cit. MON XXXII, PT II- 36 
Pl. XIV, fig. 6), or Hall and Clarke (loc eit., Pl. XLVI, figs. 16-20). This will be seen by comparing the figure given on Pl. VI, fig. 7a, which represents a somewhat crushed, exfoliated specimen, with the illustration above eited. The rather unusual variation in shape among these forms, especially in regard to the length and straightness of the linge line, may in part be accounted for by the fact that some of the specimens are casts, "the thick shell of the rostral region when present causing the hinge to appear shorter." (I'eek, loc. cit., p. 285.)

I suspect that none of the forms will prove to be quite identical with A. lamellosa of Léveillé. Compared with Léveille's illustrations the specimens from the Yellowstone National Park are less elongated transversely, and lack the high, sharp fold and sinus that characterize the type, which has in addition the projecting lip of the anterior margin bilobate through an acute emargination. A still further point of difference is that in the American forms the beak is uniformly smaller and incurved so as to conceal the foramen, which is well shown in the type.

Athyris ashlandensis of Herrick may be a synonym of A. lamellosa.

In the exfoliated condition in which the shell occurs it might be referred a priori to either Athyris (sensu stricto) or Cliothyris. The only related forms with which it is necessary to compare it are Athyris incrassata and Cliothyris crassicardinalis White, and Cl. roissyi Walcott. It can without difficulty be distinguished from Cl.crassicardinalis, for it is much larger and more transverse, with a distinct though low median fold and sinus. On the other hand, it is considerably smaller than either A. incrassata or Cl. roissyi Walcott. The shape is transversely elliptical, with a long and nearly straight hinge line, while the other forms are subquadrate in outline, witl a much curved hinge margin.

Formation and locality: Madison limestone. Waverly to Keokuk, Europe; Sciotoville, Ohio; Licking County, Ohio; Lebanon, Kentucky; Crawfordsville, Indiana; New Hexico.

\section{Athyris incrassata Hall(?)}

Athyris incrassata Hall, 1858: Geol. Surv. Iowa, Vol. I, Pt. II, p. 600, Pl. XIl, fig. 6. Hall and Clarke, 1893: Pal. New York, Vol. VIII, Pt. II, p. 90, Pl. XLVI, fig. 21 ; Pl. LXXXIII, tig. 39.

The shell for which $l$ have used this name is.represented only by an imperfect cast of the ventral valve. It must have measured between 50 and 
$75 \mathrm{~mm}$. across, with the length about the same. The surface appears to be smooth except for numerous fine growth-lines, and there is also a shallow median sinus.

The large size of this shell is the only characteristic which is practicable for identification, and I know of only tro species of Athyroids to which it could possibly be referred, Cliothyris obmaxima and Athyris incrassata. The spinose surfice of $C$. olmaxima puts it ont of the question, while $A$. incrassutu often appears quite smooth. Still I am not at all clear that this specimen is properly referred to $A$. incrassatu.

I am inclined to believe that Cliothyris obmarima White ${ }^{1}$ would more properly be referred to Athyris incrassuta, and that it is perliaps identical with the species under discussion. So far as can be ascertained in the fragmentary and exfoliated condition of White's material, that form did not possess the spinose surface, nor any of the characters of Cliothyris.

Formation and locality: Madison limestone, northwest slope of Forellen Peak, Teton Range; S. L. Penfield. Burlington age, Burlington, Iowa; Quincy, Illinois; Hannibal, Missouri.

\section{SEMINULA McCoy, 1844.}

\section{Seminula madisonensis $\mathrm{n}$. $\mathrm{sp}$.}

Pl. LXXI, figs. $2 a, 2 b, 2 c$.

Shell of medium size, subpentagonal in outline, somewhat longer than broad. Surface marked by thick lamellose growtl-lines, whose edges are smooth, and not prolonged into sheeted or spinose frills as in Athyris (sensu stricto) or Cliothyris. Sometimes marked by fine radiating strix, which are not the result of exfoliation of the fibrous shell structure, but may nevertheless be structural. Convexity moderate.

Ventral valve rather flat, with a shallow angular sinus which can be traced indistinctly nearly to the beak. Beak rather large and not strongly incurved. Dorsal valve broadly angular in cross section; fold defined for a short distance by shallow converging sulci. The rostral angle of the ventral valve is nearly $90^{\circ}$; that of the dorsal valve is obtuse. $11.5 \mathrm{~mm}$.

Length of the type specimen, $19 \mathrm{~mm}$.; width, $16.5 \mathrm{~mm}$; thickness,

${ }^{1}$ Wheeler's Rept. U. S. Geogr. Surv. W. 100th Merid., Vol, IV, 1877, p. 94, Pl. V, fig. 12. 
This shell occurs in the upper beds of the Madison limestone, and as it bears at first sight a strong resemblance to the general type of $S$. subtilita Hall, I referred it to that form. A comparison with specimens of $S$. subtilita from the type locality, near Weston on the Missouri River, reveals certain differences which seem to prove the two forms distinct.

S. subtilita ${ }^{1}$ is somewhat larger than S. madisonensis, narrower in proportion to its length, with the widest portion near the anterior margin, so that the outline is subtriangular: S. madisonensis, on the other hand, is widest near the middle of the shell, and the ontline is pentagonal.

The sinus in S. subtilita is broad and shallow, not apparent more than one-third the shell length back of the anterior margin. The anterior sinuosity is nearly rectilinear, with subparallel sides. The dorsal valve, on the contrury, can scarcely be said to have any corresponding fold, as that structure falls into the general curvature of the valve, which is highly arched. In S. madisonensis the sinns is no deeper than in S. subtilita, but it is angular and can be traced back to the umbonal region. The sinnosity is triangular and the fold is defined for a short distance by lateral sulci.

In shells of the same size $S$. subtilita is more obese than the other, the dorsal valve especially being highly tumid, particnlarly about the beak, which is narrow, high, and pinched. The ventral beak also is more deeply incurved than is the case in S. madisonensis, and the rostral angle is more acute.

Formation and locality: Madison limestone, head of Conant Creek, Teton Range; W. H. Weed.

Seminula madisonensis, var. Pusilla, $\mathrm{n}$. var.

Pl. LXXI, figs. $3 a, 3 b$.

In bed 28, Crowfoot Ridge, Gallatin Range, and also probably 600 feet above the stream at the limestone bluff north of Little Sunlight Creek, Absaroka Range, occurs scantily a small Seminula which I provisionally refer to $S$. madisonensis as a variety of the same. It is specifically distinct from other members of the genus observed, and is perhaps distinct from S. madisonensis also.

I have seen only four or five specimens of this type, but these indicate that it is much smaller than $S$. madisonensis, and more elongate; the ventral 
valve more highly arched both longitudinally and transversely; sinus not so distinct.

Length, $11 \mathrm{~mm}$; width, $9 \mathrm{~mm}$.

Formation aud locality: Madison linestone, limestone bluff north of Little Sunlight. Creek, Absaroka Range, 600 feet above the stream; Arnold Hague.

\section{Seminula humilis 11. sp. \\ PI. LXXI, figs. Ga, $(i), 6 c$.}

Shell moderately gibbous, small, circular. Surface smooth, except for a few growth-lines.

Ventral valve nearly circular, but for the beak, which is rather large and strongly incurved over the other valve, completely concealing the foramen, which appears only where broken back through the rostral shell.

Dorsal valve circular in ontline, moderately curved; beak somewhat prominent by reason of a slight flattening on either side. The dorsal valve has an indistinct fold and the ventral valve an insignificant sinus, which are perceptible only by a simuosity in their anterior margins.

Length of a medium-sized specimen, $15 \mathrm{~mm}$; breadth, $14.5 \mathrm{~mm}$.; thickness, $9 \mathrm{~mm}$. Length of a somewhat smaller individual, $12.5 \mathrm{~mm}$.; breadth, $11.5 \mathrm{~mm}$.; thickness, $7.5 \mathrm{~mm}$.

Were it not that $S$. wasatchensis is an Upper Carboniferous form, while this one is found in the lower beds of the Lower Carboniferous, I would have unhesitatingly referred it to White's species. The great anterior thickening of the shell, which appears to individualize the latter type, is due to old age, and can not be considered a specific character. Otherwise, if occurring in the same beds, the two forms could scarcely be distinguished.

Seminula humilis also approaches Spirigera formosa and $S_{p}$. euzona, both of Swallow. These forms, however, are marked by a high fold and corresponding deep sinus, while Sp. formosa is said to have a punctate shell, and radiating striæ when exfoliated (fibrous shell structure?). These characters are decisive in separating Swallow's species from the one in question.

Formation and locality: Madison-limestone, Hunter Peak, Absaroka Range; T. A. Jaggar. Crowfoot Ridge, Gallatin Range, lower and npper part of bed 27, bed 28, bed 31; J. P. Iddings and W. H. Weed. Stinkingwater Valley, below mouth of the canyon, Absaroka Range; Aruold 
Hague. West of Antler Peak, Gallatin Range; A. C. Gill. Summit of peak west of same; eherty belt, Bighorn Pass, Gallatin Range; Crowfoot Ridge, Gallatin Range, top of bed 24; J. P. Iddings. Head of Conant Creek, Teton Range; W. H. Weed.

\section{Seminula 'immatura $11 . \mathrm{sp}$. \\ Pl. LXXI, figs. $5 a, 5 b, 5 c, 5 r$.}

Shell rather small, ovate, gibbous. Length somewhat exceeding the width. Dorsal valve full, highest at the umbo, without a fold, but slightly emarginated in front; beak smail, inflated, deeply incurved. Ventral valve oval, beak small, incurved so as to conceal the true foramen. There is a shallow sinus, which, however, is perceptible only near the anterior margin, forming there an upturned projecting lip to fill in the emargination of the opposite valve, and producing a sinuonsity in their line of union.

Length, 18.5 mm.; width, $15 \mathrm{~mm}$.; thickness, $12.5 \mathrm{~mm}$.

Stratigraphically this is the lowest of the Seminulas obtained in the Yellowstone National Park, of which S. madisonensis is the highest. The obsolete fold and simus, the regular, deeply arehed valves, the evenly rounded, ovate shape, the tumid dorsal nubo and incurved beak, and the small resupinate ventral beak are all characteristic, and sharply differentiate it from the latter.

Compared with S. humilis, it is considerably larger, more tumid; ventral beak smaller and narrower; beak of the dorsal valve larger, more inflated and incurverl.

Formation and locality: Madison limestone, west of Antler Peak, Gallatin Range; A. C. Gill.

\section{CLIOTHYRIS King, 1850.}

This genus (or subgenus) is practically coextensive with the species Cl. roissyi Léveillé, as the latter at present stands. Partly because the character of the surface ornamentation renders it difficult to secure wellpreserved specimens, the discrimination of species in this group, if indeed it has been systematically attempted, has not, I believe, proved successful.

The Athyris roissyi question has thus become too complicated through the prolonged sedimentation of cliothyroid forms to admit of its ready solution. That it is desirable to subdivide this group is obvious; that it will 
be possible to effect this scientifically by the use of constant characters scems probable. Just what chanacters will assune such import, a detailed critieal study of the gentus will develop. Therefore, I have ventured to recognize certain types in the Y'ellowstone Nationial Park collections which I feel confident to be distinet from Cl. roissyi of Léveillé. Whether these will ultimately prove tenable or be synonymic with other names from different horizons, future investigations will disclose.

\section{Cliothyris crassicardinalis White.}

Pl, LXXI, fig. S .

Athyris cressicardinalis White, 1860: Jour. Boston Soc. Nat. Hist., Vol. VII, p. 229.

This species is referred to the genus Cliothyris on the strength of a clause in the original description, which states that "occasional specimens show fringes of considerable length" proceeding from the squamose growthlines. This, in conjunction with the shape, which is not markedly wider than it is long, seems to make this reference secure. On the other hand, not haring had access to specimens from the type locality, and as the species has never been figured, I can consider my identification as only provisional.

In the Yellowstone National Park the type here called Cl. crassicardinalis ranges from the bottom to the top of the Madison limestone. It is seen to be a rather small, nearly circular shell, slightly wider than long, lenticular. Fold and sinus indicated only by a slight emargination of the anterior outline. Beaks small and pointed, that of the ventral valve being usually incurved so as to conceal the foramen. The surface is corered with numerous imbricating lamellose expansions, which under good preservation are seen to be subdivided into long spines. The large specimen figured on Pl. LXXI, fig. $8 a$, measures $15 \mathrm{~mm}$. in width by $14 \mathrm{~mm}$. in length, but the average size seems to be somewhat less than this.

This form is perhaps identical with the one figured in Mon. U. S. Geol. Surv., Vol. VIII, Pl. XVIII, fig. 5, under the name of Athyris hirsuta.

It is often extremely difficult in practice to separate $\mathrm{Cl}$. crassicardinalis from other forms found in the same beds-that is, when one or both are ill preserved in one way or another. Exfoliated specimens might easily be referred to the allied genera Athyris or Seminula. On the other hand, where single valves occur embedded in limestone, from which they break exfoliated and with the convex side upward, concealing the area, it is very 
difficult to distinguish even ventral valves from the genera Reticularia and Martinia. It is only by a careful system of comparison of the poor with more perfect specimens that the proper affinities can be ascertained.

The greatest difficulty is experienced in the case of Semimula humilis, especially when the material is seanty and poorly preserved.

Unfortunately, this is the usual condition. The characteristic surface ornamentation renders the genus Cliothyris peculiarly liable to exfoliation. Usually the spines have been broken away, their base giring the lamellæ a scalloped appearance. When the shell is entirely gone, casts of the interior show only a few heavy growth-lines. When exfoliation has obliterated surface characters, reliance must be placed upon other peculiarities in distinguishing Cl.crassicardinalis from Seminula humilis. The shell of the former is less convex and the beaks are more attenuate. These characters do not always afford satisfactory results; yet I am unable to designate others. The two species occur together at several localities, notably from the upper part of bed 27, Crowfoot Ridge, Gallatin Range, but it so happens that they are there especially well preserved and their distinctive characters shown in the clearest manner.

Where the area is concealed, exfoliated specimens might well be taken for the young of Martinia rostrata or the reverse, but the latter will be seen to have a more prominent beak, and to be provided on the ventral valve with a shallow but perceptible sinus reaching to the extremity of the beak. Reticularia cooperensis is more transverse and the ventral valve more elevated.

Formation and locality: Madison limestone, limestone bluff north of Little Sunlight Creek, Absaroka Range, 600 feet above the stream; Arnold Hague. Upper Gallatin Valley; divide between Gallatin River and Panther Creek, Gallatin Range; east face of Antler Peak, Gallatin Range; W. H. Weed. Crowfoot Ridge, Gallatin Range, top of bed 25; J. P. Iddings and G. M. Wright. Same, upper part of bed 27, bed 28, bed 29, bed 31; J. P. Iddings and W. H. Weed. Summit of peak west of Antler Peak, Gallatin Range; south slope of same; summit of Three River Peak, Gallatin Range; south base of Quadrant Mountain, Gallatin range; cherty belt, Bighorn Pass, Gallatin Range; J. P. Iddings. Crowfoot Ridge, Gallatin Range, bed 24 ; A. C. Gill. North of Owl Creek, northeast slope of Teton Range; W. H. Weed. Kinderhook age, Burlington, Iowa. 


\section{Cltothyris Crassicaruinalis, vay. nana. 11. var.}

I'l: LXXI, fig. $9 u$.

The form liere referred to is a rare one, and I am in clonbt whether to consider it only young or dwarfed specimens of $\mathrm{Cl}$. crassicurdinalis, a true variety of the same, or a distinct species. Its occurrence is restricted to two or three localities, where it is not uncommon to find familiar types represented by unusually small individuals. It has not been possible to ascertain whether this shell is a true Athyris (sensu stricto) or belongs to the genus Cliothyris, thongh the circularity of its ontline favors the latter reference.

The shell is rery small, nearly circular in shape, molerately convex. Beaks small, surface ornamented by numerons close, regular, imbricating, concentric lamellæ. It occurs in a limestone and is always more or less exfoliated. There is no fold or sinus, but both valves have a mesial flattening, which in some shells is quite marked. In size, shape, and general appearance this form is very close to specimens of $\mathrm{Cl}$. hirsuta from Spergen Hill, Indiana.

Length, about 0.30 inch; width, nearly the same.

Formation and locality : Madison limestone, east side of Gallatin River, west of Electric Peak; Crowfoot Ridge, Gallatin Range, top of bed 25; G. M. Wriglit.

\section{Cliothyris roissy Walcott (non Léveillé).}

Athyris royssii Walcott, 1881: Mon. U. S. Geol. Surv., Vol. VIII, p. 280, Pl. XVIII, figs. $9,9 a$.

I have referred to this species a single large Athyroid which, though so exfoliated as to appear almost smooth, yet bears so strong a resemblance to the specimen referred by Walcott to Cl. roissyi (loc. cit.) that I can not but believe them identical. There is, however, one striking difference, namely, in the size of the ventral beak, that in my collection being of medium size, the other extremely minute. But as both specimens are more or less crushed, it seems that this is only an appearance due to relative displacement of the two valves.

'The generic position of the form figured by Walcott, which shows very clearly the overlapping spinose lamellæe characteristic of Cliothyris, is 
beyond all question. Not so the specimens figured by Meek, ${ }^{1}$ and doubtfully referred by him to Léveille's species. In comparing this form with the one under discussion, I find it different not only from it but also from the European type. The shell is large, thick, transversely elliptical; fold but slightly defined, sinus broad and shallow, with a sharp median sulcus; surface lamellose with thick layers, which, on the best-preserved surfaces, slow no trace of having been produced into spines. The ventral beak is rather large, not strongly incurved, and instead of being furnished with a romond pedicle aperture, as shown in the figure, a careful study of the rostral portion discloses that this appearance is due to a fracture which has also partially removed the shell covering the arch of the beak, and that below the point where the pedicle opening is indicated in the figure there is the anomalous character of an open triangular delthyrium. These facts are developed from a study of the type material itself, which in the figured specimen alone preserves the rentral beak entire, or nearly so. As the form seems to be distinct from anything yet described from the same horizon, I propose for it the name Athyris mira.

The specific identity of $\mathrm{Cl}$. roissyi Walcott with Léveille's species I hold to be doubtful.

That form as figured by its author is smaller $(34.5 \mathrm{~mm}$. in width by 22.5 $\mathrm{mm}$. in length) and more deeply folded, the two depressions defining the fold being so deep and triangular as to give the shell a trilobate appearance. The fold is surmounted by a faint sulcus (?), resulting in a slight emargination of the anterior border, Beak not incurved, so that the open round formen is a noticeable character. The surface is marked by not very numerous but strong lamellar expansions, whose ragged edges suggest that they may have been the origin of the characteristic spinose ormamentation of the genus Cliothyris. In the specimens from the Yellowstone National Park and the Eureka district the fold and sinus are scarcely discernible. The latter has a small, sharp beak, whose deep incurvatmre completely conceals the foramen. That from the Yellowstone National Park shows an indefimable aperture, partly beneath the beak, partly broken through it. This contradietion is doubtless due to the same displacement which makes the beak of one specimen seem so small, that of the other comparatively so large.

1877. King's U. S. Geol. Expl., 40th Par., Vol. IV, Pl. IX, figs. $3,3 a, 3 b$. 
Formation and locality: Madison limestone, Crowfoot Ridge, Gallatin Range, bed 28; J. P. Iddingss and W. H. Weed. Same, top of bed 24; J. P. Iddings. Keoknk to Kaskaskia; Europe; Mississippi Valley; White Pine and Lureka districts, Nevadia; Salt Lake City, etc., Utah; Lake Valley mining distriet, ete., New Mexico; Lake County, Colorado; Guatemala; Bonjardin and Itaitnba, Brazil.

\section{CONOCARDIUN Brom, 1835.}

\section{Coxocardium l'ulchillum White and Whitfield (?)}

Pl. LX VI, fig. $14 a$.

Conscardium pulchellum White and Whitfield, 1862: Proc. Boston Soc. Nat. Hist., Vol. VIII, p. 299.

In the absence of identified material 1 am not sure that the reference to White and Whitfield's species is correct, for I have but a single specimen, so that it is impossible to determine the range and normal expression of the shell; while C. pulchellum has not been figured, at least by its authors; and a description unaccompanied by illustrations, especially in this genus, is almost sure to be unsatisfactory.

My shell is small, not very convex. Truncation of the anterior margin slightly concave, nearly the same length as the straight hinge line, which it meets at an obtuse angle. Posterior cardinal angle rounded. Ventral margin sloping and curving from the posterior angle to the anterior truncation. Posterior wing somewhat flattened and coneentrically rugose. Surface otherwise marked by about twenty-five radiating strix, which are strong and abrupt, leaving between them spaces greater than their own diameter. Length along the linge line, $6.5 \mathrm{~mm}$; greatest diameter (from posterior cadinal angle to the junction of the ventral margin with the anterior truncation), $12.5 \mathrm{~mm}$.

This species seems to have some points of resemblance with C. napoleonense Winchell, but it is nearer White and Whitfield's form.

C. A. White ${ }^{1}$ has proposed the name Conocardium semiplenum for a form from the same region as that under consideration. It belongs likewise to the same type of shell, as comparisons are made with $\dot{C}$. trigonale Hall, which $C$. putchellum also resembles. It is not improbable that he may have 
had in hand the same form with which I am dealing, but his descriptive remarks are too general to render the species identifiable.

Formation and locality: Madison limestone, Crowfoot Ridge, Gallatin Range, bed 24; A. C. Gill. Kinderhook age, Burlington, Iowa.

\section{NATICOPSIS McCoy, 1844.}

\section{Naticopsis (?) sp.}

PI. LXVI, fig. $13 a$.

There is only one specimen of this gastropod, an internal cast in a siliceous matrix. The peritreme is incomplete and there is no telling to what extent the lower whorls are broken away. Specific identification is therefore out of the question. It appears to belong to the genus Naticopsis.

Formation and locality: Madison limestone, Crowfoot Ridge, Gallatin Range, top of bed 24; J. P. Iddings.

\section{LOXONEMA Phillips, 1841.}

\section{Loxonema (?) sp.}

\section{Pl. LXVI, fig. $9 a$.}

This species consists of the cast of a rather large elongate gastropod shell, probably belonging to the genus Loxonema. The specimen consists of four whorls and part of a fifth, and is very gradually tapering. It somewhat resembles $L$. tenuilineatum Swallow, of the Choutean limestone, but the sides converge less rapidly and the peripheral outline of each whorl is much flattened. The shell must have been very thin, for the convolutions are now almost in contact.

Length of the imperfect specimen, $27 \mathrm{~mm}$.; width at the base, $12.5 \mathrm{~mm}$.; width at the top, $7.5 \mathrm{~mm}$.

Formation and locality: Madison limestone, Crowfoot Ridge, Gallatin Range, top of bed $26 ;$ J. P. Iddings and W. H. Weed. 


\section{STRAPAROLLUS Montfort, 1810. Straparollus utamensis Hall and Whitfield.}

Pl. LXVI, figs. $10 a, 10 b, 10 e$.

Euomphalus (Straparollus) utahensis Hall and Whitfield, 1877: King's U. S. Geol. Expl. 40th Par., Vol. IV, p. 259, Pl. IV, tigs. 20-23.

This genus is represented in the collection from eight or ten localities, but the specimens are in so poor condition, being worn or broken, that a specific identification was a matter of difficulty. The beds from which the material was derived are mostly the lower strata of the Madison limestone, but some specimens, indistinguishable from the others in their present imperfect condition, occur near the very top of the same formation.

It was evident at first sight that the Yellowstone National Park form was close to Enomphalus luxus IVhite, and Eu. utahensis Hall and Whitfield. After a careful comparison of the three types the balance of the evidence seemed to favor an identification with Eu. utahensis, and a section through one of the specimens justified the conchsion. It will be remembered that the two species just mentioned are both from the Rocky Mountain region, occurring in Waverly locks, and often found at the same locality. Eu.luxus is somewhat smaller than Eu. (Straparollus) utahensis. The whorls are flattened on top, with a slight distal carination. In S. utahensis, however, there is a strong carination on the summit of each whorl, from which the sides slope away nearly plane, one toward the center, the other toward the periphery. This proved to be the case with the specimen sectioned, but it is not at all improbable that some of the other smaller specimens may belong to Eu. luxus.

The shell of S. utahensis is thin, but thickened on top and on the two sides to form the carinations (PI. LXVI, fig. 10c). The outer side of each whorl as well as the top is carinated, and the shell on the inner side is also considerably thickened, but indented to receive the carina of the preceding whorl. The interior cross section, therefore, is circular or elliptical, and all distinguishing characters are lost when the shell is reduced to a cast.

This species should be compared with Enomphalus obtusus Hall (Geol. Surv. Iowa, Vol. I, Pt. II, p. 523), which was described from the Oolitic limestone of Burlington, Iowa. 
Formation and locality: Madison limestone, east side of Gallatin River, west of Electric Peak; divirle between Gallatin River and Panther Creek, Gallatin Range; summit of Antler Peak, Gallatin Range; amphitheater east of Bamnock Peak, Gallatin Range, bed 30; W. H. Weed. Crowfoot Ridge, Gallatin Range, top of bed 26 , lower part of bed 27 , bed 28 , bed 31 ; J. P. Iddings and W. H. Weed. Waverly age, Dry Canyon, Oquirrh Mountains; Ogden and Logan canyons, Wasatch Range, Utah.

\section{PLATYCERAS Conrad, 1840.}

This genus is represented by specimens which are rather scarce numerically and as to size much below the average. Taken as a whole, they are closely similar to the group of Waverly Platycerata figured by Keyes in Geol. Surv. Missouri, Vol. V, Pl. LIII, figs 1a-1d, 2-8, 9a, 9b. In a genus where the species vary so enormously within thenselves-where, in fact, it may almost be said that there are no species-my material is much too scanty and fragmentary to show the range of specific variation and afford the concept of a specific type. Accordingly, no elaborate effort has been made to identify the material with existing species, much less to propose new names, and it has seemed best to describe each form without using specific appellations.

\section{Form A.}

This form is found on Crowfoot Ridge, Gallatin Range, from the top of bed 24. It is small and loosely coiled. The apex is wanting, but the whole specimen appears to have completed little more than lialf a turn. The apical portion is twister slightly to the left (looking at the anterior peripheral face), and the base expands rapidly, but unsymmetrically, flaring a little more on the side toward which the apex is turned-the left. There is a broad carination on the front face, delimited by the two shallow grooves. Aperture subcircular. This form appears to be close to $P$. cormforme, ${ }^{1}$ Winchell, but that shell is said to be planorboid, while in this the apex is distinctly turned to the left. It also resembles $P$. vomerium ${ }^{1}$ of the same author in size and in the nature of the carination. Both these species are of Waverly age.

'Winchell, 1863: Proc. Acad. Nat. Sci. Philadelphia, pp. 18, 19; and Keyes, loc. cit., Pl. LII, figs. $3 a, 3 b$. 
Formation and locality: Mandison limestone, Crowfoot Ridge, Gallatin Range, top of bed 24; J. P. Iddiugs.

\section{FORM 13.}

Shell very small, not spirally turned; of a conical or pyramidal shape, much inclined. The front is edged or sharply rounded; the back, under the apex, is flat, meeting the right side, which is more inflated than the left, at an angle. The angle at which the posterior face meets the left side is truncated. Peritreme subquadrate.

Formation and locality: Madison limestone, north of Bighorn Pass, Gallatin Range; A. C. Gill.

\section{Form C.}

Larger than either of the two already described, yet not very large; much flattened transversely, very rapidly expanding. The right-hand face of the fossil is somewhat flat; more inflated on the other side. Very abruptly rounded in front and behind. But slightly inclined, so that a line let fall from the apex onto the posterior extremity of the peritreme would be nearly perpendicular to the plane of the base.

Formation and locality: Madison limestone, north of Bighorn Pass, Gallatin Range; A. C. Gill.

\section{ForM D.}

Pl. LXVI, figs. $12 a, 12 b, 12 c$.

Small, gradtually expanding and closely inrolled for about one volution; then very rapidly expanding for abont half a volution, which is highly inflated and not in contact with the involved portion. The latter is minute and turned to the left. The peritreme is broken, but appears to have been subquadrate. The sinistral side of the large whorl (that toward which the involved apex turns) is somewhat flattened; the anterior end is sharply rounded. Another angular turn, sinistro-posterior in direction, would bring this subplanate face to the original one at an acute angle were not their junction truncated or broadly rounded (?). Height about two-thirds the antero-posterior diameter. A line from the most posterior point of the peritreme tangent to the involutions would be about perpendicular to the plane of the base. 
This form, thougl considerably smaller, is closely similar to the specimen identified by Keyes as Capulus paralius Winchell, and figured on Pl. LIII, fig. $1 d$, of the work cited.

The largest of these forms is about $9 \mathrm{~mm}$. in height, with a maximum basal measurement of $12.5 \mathrm{~mm}$.

Formation and locality : Madison limestone, east side of Gallatin River, west of Electric Peak; south slope of Quadrant Mountain, Gallatin Range; A. C. Gill.

\section{FORM E.}

Pl. LXVI, figs. 11a, 11b, 11c, $11 d$.

Shell rather small, thongh larger compared with the other forms in this collection. Very rapidly expanding. Laterally compressed, being flatter on the sinistral side, away from which the small coil is turned. Dextral side more inflated; dorsum sharp, almost carinate. Shell marked by concentric growth-lines, sinuous, following the shape of the peritreme. Peritreme oval in outline.

This should be compared with P. nebrascense Meek, ${ }^{1}$ and more especially with Capulus paralius Winchell, as figmred by- Keyes (loc. cit., Pl. LIII, figs. $1 b, 1 c$ ), which is perhaps not identical with Winchell's type, shown by fig. $1 a$ of the same plate.

Formation and locality: Madison limestone, east side of Gallatin River, west of Electric Peak.

\section{CRUSTACEA.}

PROETUS Steininger, 1830.

\section{Proetus peroccidens Hall and Whitfield.}

PI. LXXI, figs. $14 a, 14 b$.

Proetus peroccidens Hall and Whitfield, 1877: King's U. S. Geol. Expl.40th Par., Vol. IV, 1. 262, Pl. IV, figs. 28-32.

This species is represented in the Yellowstone National Park collections by three cephalic shields (without the free cheeks), which are in exact agreement with the description and figures of $P$. peroccidens. Each of the three heads was found at a separate locality, but one of them occurs on the

\footnotetext{
' White, 1877: Wheeler's U. S. Geogr. Surv. W. 100th Merid., Vo]. IV, p. 159, Pl. XII, figs. 5a-5d.
} 
same block of limestone which carries the pygidium referred to $P$. loganensis. 'They' are without surface ornamentation. The oceipital ring is narow and not strongly marker. The glabella is moderately ligh, reaches nearly to the anterior margin, evenly rounded in front, about once and a half as long as wide, sides parallel the greater distance, but expanding suddenly behind. Marked by three or four pairs of transverse furrows. Of these, only the posterior one is well defined, and it is bent backward at its inner end so as to be aluost continuous with the occipital furrow. Frontal border narrow, thick, elevated. Greatest width of the anterior portion of the head, as limited by the suture line, just equal to the length of the glabella. The suture lines contract gradually, but round out strongly for the palpebral lobe, the most convex portion of which is not more than one-fourth the length of the head, forward from the posterior edge.

Formation and locality: Madison limestone, east side of Gallatin River, west of Electric Peak; G. M. Wright. Crowfoot Ridge, Gallatin Range, bed 31; J P. Iddings and W. H. Weed. East slope of Survey Peak, Teton Range; S. L. Penfield. Waverly age, Ogden and Logan canyons, Wasatch Range, and Dry Canyon, Oquirrh ILountains, Utah.

\section{Proetus loganensis Hall and Whitfield.}

Pl. LXXI, fig. 15a.

Proetus loganensis Hall and Whitfeld, 18j7: King's U. S. Geol. Expl. 40th Par., Vol. IV, p. 264, Pl. IV, fig. 33.

The identification of this species rests upon a single pygidium which, but for being considerably smaller in size, is exactly identical with that figured as the type of $P$. loganensis. The surface is without ornamentation. The axial lobe is high, marked by eleven annulations including the terminal ones. The lateral lobes have nine ammulations each, which extend down upon the border and become obsolete upon the margin near the edge of the shell. It occurs associated with $P$. peroccidens.

Proctus peroccidens and P. loganensis, both of Hall and Whitfield, rest upon three structural units-a small momamented pygidium, a large pygidium with more amnulations, ornamented with pustules or nodes, and a head with free cheeks more nearly corresponding in size with the larger pygidia, but destitute of the ornamentation which characterizes them. The YON XXXII, PT II-3i 
lieads and larger pygidia were referred by the anthor to $P$. peroccidens, and the small type of pygidium was described as $P$. loganensis.

In the Yellowstone National Park collections no pygidia of the type of $P$. peroccidens (the unornamented form) have been observed, but the large heads have been identified as $P$. peroccidens, and the small pygidia as $P$. loganensis. As the pygidium and a large head occur associated at the same locality, even on the same slab of limestone, there is some presumptive evidence that they should be referred to the same specific type, especially as there is only one kind of lead and one kind of pygidium known from the Park. The fact that both portions are without ornamentation supports this view. The disparity in size, especially when viewed in comnection with a similar condition of affairs in Utah, is opposed to it.

One of three hypotheses seems probable. Both species (and the pygidia show that they are two) may have had mornamented cephalic shields, similar in detail and size; or, since it is now known that the two species occur in the same beds, Hall and Whitfield may have been in error in referring the cephalon from Dry Canyon to the associated pygidia; or, the smooth, plain heads do not belong to the smooth pygidia with which they are associated in the Yellowstone National Park, but (what is not intrinsically improbable) to the ornamented nodose pygidia with which they occur at Dry Canyon, as Hall and Whitfield have suggested. More evidence will be necessary before the point involved in this uncertainty can be ascertained.

Formation and locality: Madison limestone, Crowfoot Ridge, Gallatin Range, bed 31; J. P. Iddings and IV. H. Weed. Waverly age, Logan Canyon, Wasatcl Range, Utah. 


\section{PLATE LXVI.}




\section{P L A T E L X V I.}

Fig. 1. Atrypa reticularis

a. Trpe usually found in Yellowstone National Park; after Walcott.

$b$. Lateral view of same; after WaIcott.

Devonian, Eureka distriet, Nevada.

c. View of another specimen; after Meek.

(?) Middle Devonian, Piñon station, White Pine districi, Nevada.

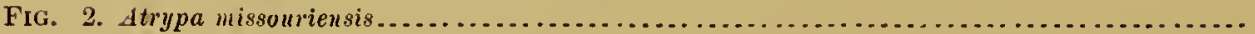

a. Rostral view of a small individual, of a type common in Yellowstone National Park; after Walcott.

b. Ventral aspect of same; after Walcott.

Devonian, Lone Monntain, Nevada.

c. Dorsal viow of another speermen; after Jeek.

Middle Deronian, Piñon station, White Pine district, Nevada.

FIG. 3. Spirifer enyelmamni

a. An anterior view; after Meek.

b. Cardinal view, showing area and foramen; after Meek.

c. Sicle view of samo; after Ileek.

d. Doraal view of same; after Meek.

Middle Devonian, Nevada.

FIG. 4. Athyris rittata var. triplicata n. var

a. Lateral view of type specimen.

b. Dorsal view of same.

c. Anterior view of same.

Three Forks limestoue, south side of Soda Butte Creek, nortliwest of Abiathar Peak, Absaroka Range.

FIG. 5. Pleurotomaria isaacsi (?)

a. Specimen doubtfully identitiell with Hall and Whitfield's speeies.

$b$. Side view of same.

Three Forks limestone, Wall Canyon, Clark Fork Valley.

Fig. 6. Loxonema delicatum n. sp

a. View of type specimen, enlarged.

Three Forks limestone, south side of Soda Butte Creek, northeast of Abiathar Peak, Alssaroka Range.

FIG, 7. Platystoma minutum n. sp

a. Apical view of type specimen, enlarged.

b. Lateral aspect of same, enlarged.

Three Forks limestone, south side of Soda Bntte Creek, northeast of Aliathar Peak, Absaroka Range.

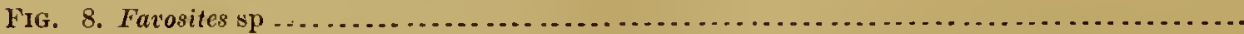

a. Silicified example, showing size of corallites and character of tabulation.

Three Forks limestone, north side of Soda Bntte Creek, Absaroka Range.

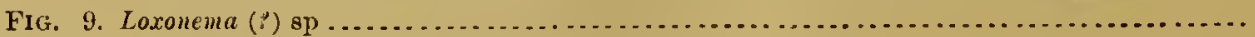

a. Lateral view of au internal cast.

Madison limestone, Crowfoot Rirlge, Gallatin Range, top of bed 26. 


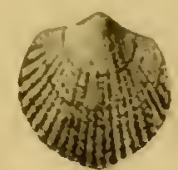

Ia

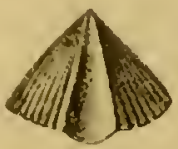

3 a

$5 b$

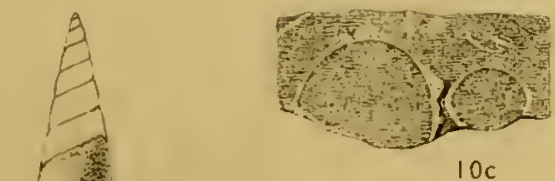

$10 \mathrm{C}$

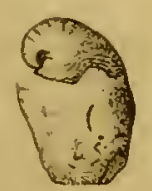

I a
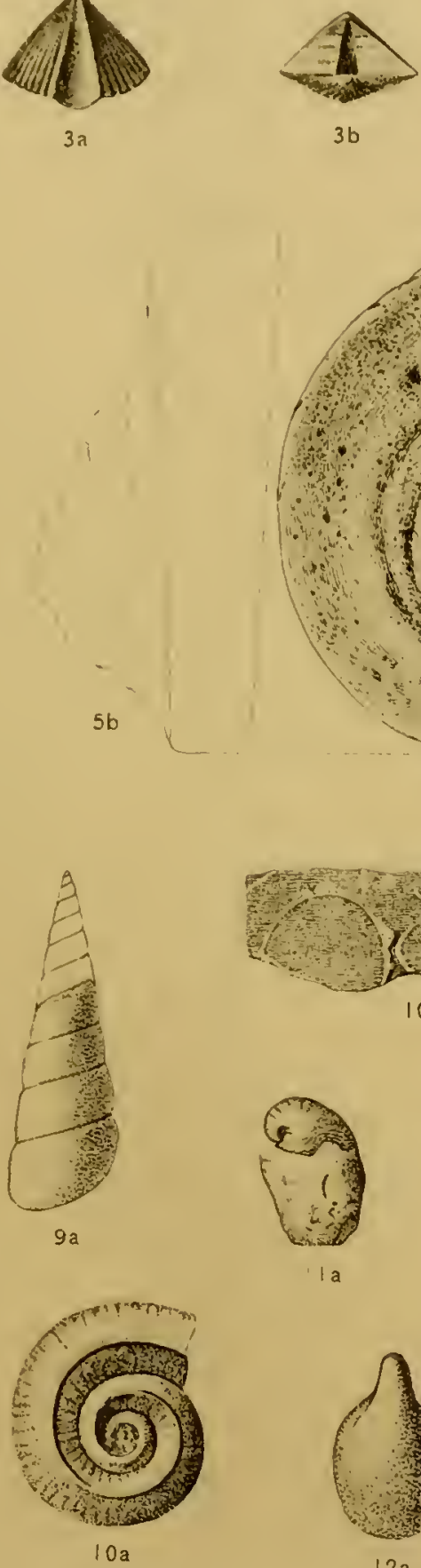

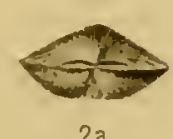

2 a
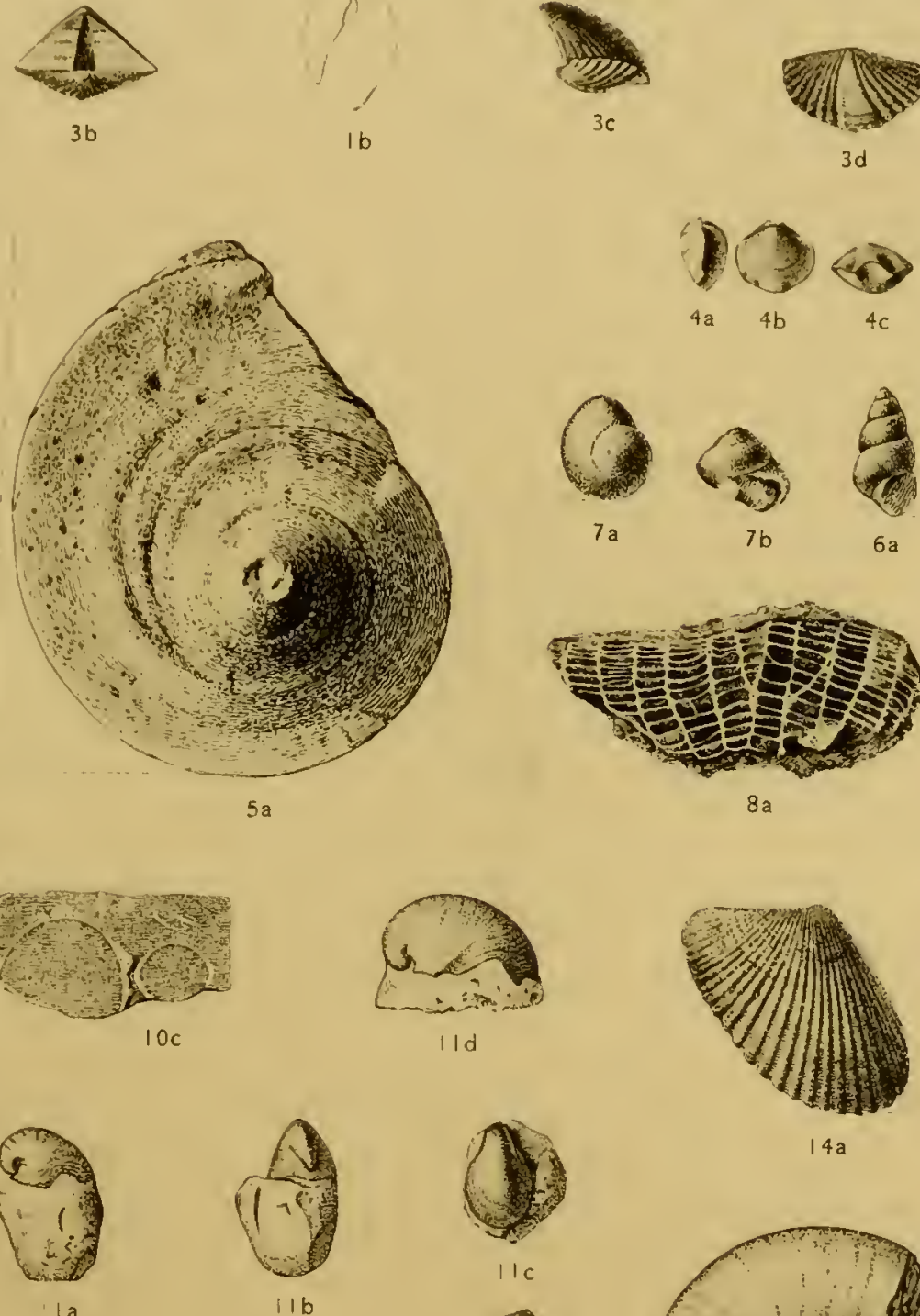

$3 d$
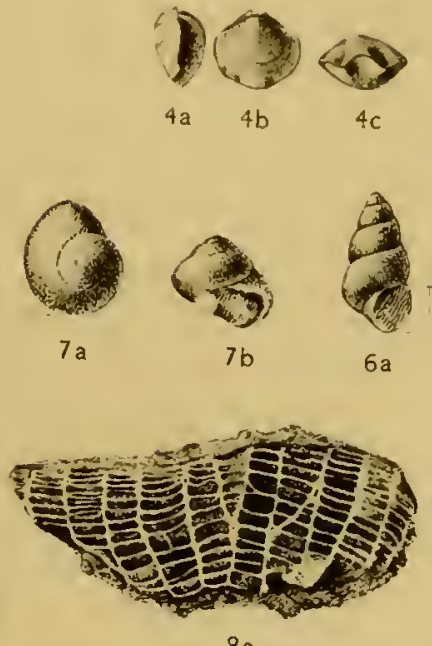

$8 a$

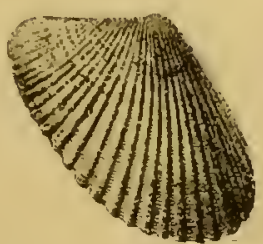

$14 \mathrm{a}$

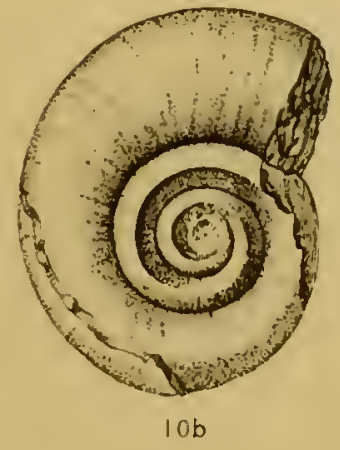

DEVONIAN AND LOWER CARBONIFEROUS

THREE FORKS ANO MAOISON LIMESTONES 

Fig. 10. Straparollus utaheusis

a. Apical view of a small specimen; after llall and Whitfielı.

b. Apical view of a larger, somewhat exfoliaterl sperimen; after Hall and Whitfield. Winerly age, Dry Canyou, Utab.

c. Scction throngl it specinen from Yellowstone National lark.

Mitdison limestene, east side of Gallatiu River, west of Electric l'eak.

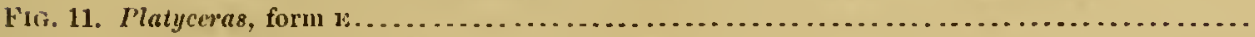

a. Lateral view of a small example attached to an exfoliated base of Platycrinus symmetricus.

b. Posterior view of same.

c. Same seeu from above.

d. Side view of a larger specimen.

Madisou limestone, divide between Gallatin River and Panther Creek, Gallatin Range.

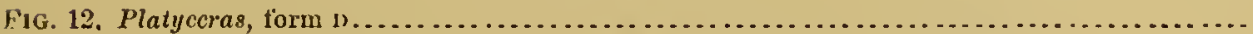

a. View of specimen resting ou its base, as seeu from above, enlarged.

b. Side view of same.

c. Posterior view of same.

Madison limestone, south base of Quadrant Mountain, Gallatin Range.

FrG. 13. Naticopsis ( $\%)$ sp

a. Iuterual cast of a specimen from the lower part of the Madison limestone.

Madison limestone, Crowfoot Ridge, Gallatin Range, top of bed 24.

FIG. 14. Conocardium pulchellum (?)

a. View of the only specimen found, enlarged.

Madison limestone, Crow foot Ridge, Gallatiu Range, bed 21. 



\section{PLATE LXVII.}




\section{PLATE L X VII.}

FIG. 1. Menophyllum (?) excaratum n. sp

a. View of a typical example of this species.

Madison limestone, Crowfoot Ridge, Gallatiu Range, lower part of bed 27.

b. Longitudinal section of another specimen, showing, bnt not completely, the depth of the calyce.

Mallison limestone, Crowfoot Ridge, Gallatin Range, bed 31.

c. Transverse section of another specimen taken through the calyce, showing septa of two orders slightly developed.

Madison limestone, Crowfoot Ridge, Gallatin Range, lower part of bed 27.

d. Transverse section of the same specimen, taken a little lower down. Indications of the fossula and the commencement of the fossular wall can be seen. Septa of th' second order are not shown in the drawing, but appear in the original section as sniall projecting points.

e. Another section of tile same, still more proximal. The large fossula is well developed; the fossular wall and aborted fossular septum are well shown. Septa of the second order are representcd by low ridges, two of which, not shown in the figure, are found on either.sicle of the fossular septum.

$f$. Transverse section through another specimen referrer to this species. The fossular septium here is extender clear through the fossula to the opposite wall, bisecting it, and tho whole is much thickened by stereoplasma.

Madison limestone, Crowfoot Ridge, Galjatin Range, bed 31.

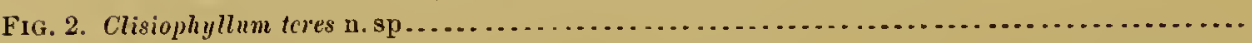

a. Trausverse section showing fossula, columella, and tabula (?). The latter is not adecuately represented in point of continuance and distinctness. Secondary septa, not shown in the figure, can be seen in the original. $x 2$.

b. Another section a little more proxinal than the above, and showing much the same characters. $\times 2$.

c. Another section still more proximal, from the same specimen. The figure shows a somewhat too great development of dissepimental tissue. $x 2$.

d. Another section of same, still more proximal. $\mathrm{x} 2$.

Madison limestone, summit of Three River Peak, Gallatin Range.

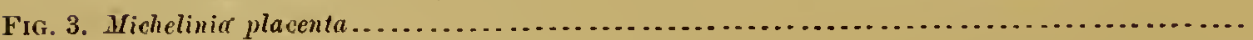

a. Lower or epithecal surface of a specimen.

Madison limestone, divide between Gallatin Valley and Panther Creek, near Bigborn Pass, Gallatin Range, bed 24.

b. Another spocimen, showing size and other characters of the cell aperturce.

Madison limestone, east side of Gallatin River, west of Electric l'eak.

FIG. 4. Syringopora surcularia $\mathrm{n} . \mathrm{sp} \ldots \ldots \ldots \ldots \ldots \ldots \ldots \ldots \ldots \ldots \ldots \ldots \ldots \ldots \ldots \ldots \ldots \ldots$
a. Portion of a section showing size and arrangewent of the corallıtes.

a. Portion of a section showing
b. An enlargement of the sane.

Madison linestone, Crowfoot Ridge, Gallatin Range, bed 28.

Fig. 5. Syringopora aculeata n. sp

a. Portion of a section of the type specimen, showing size and arrangement of the corallites.

$b$. An enlargement of the same.

Madison limestone, Crowfoot Ridge, Gallatin Range, bed 29.

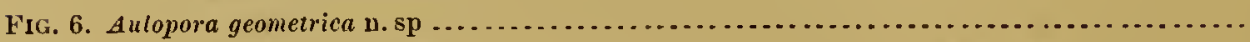

a. Portion of the corallun of type specimen, showing size and arraugement of the corallites.

Madison limestone, cherts belt, Bighorn Pass, Gallatin Range. 


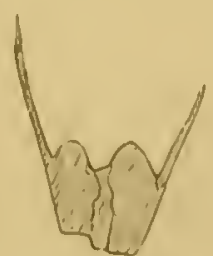

Ib
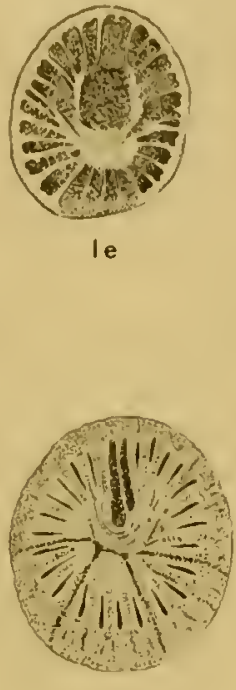

If
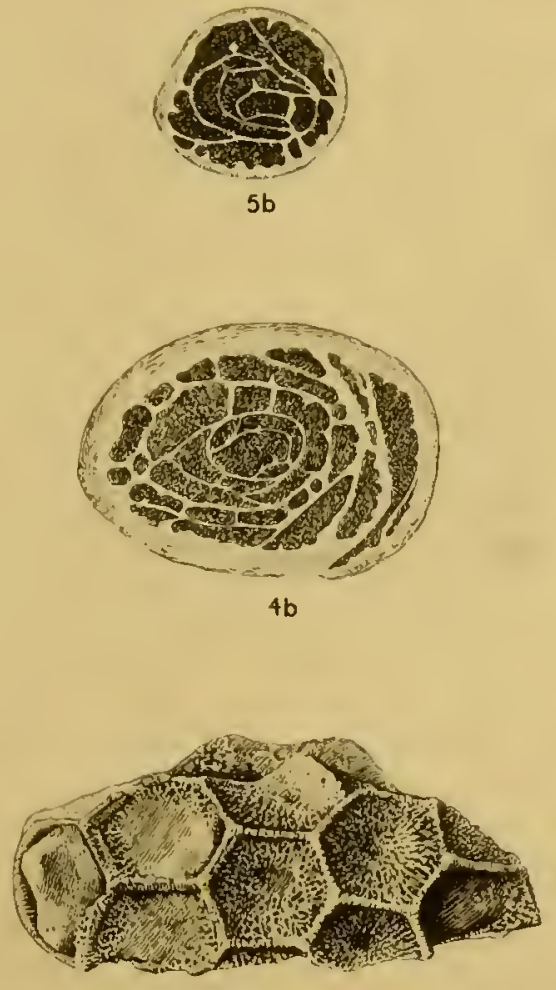

36

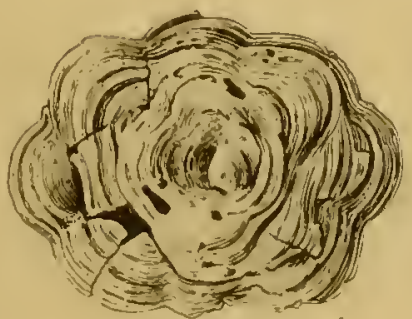

$3 a$
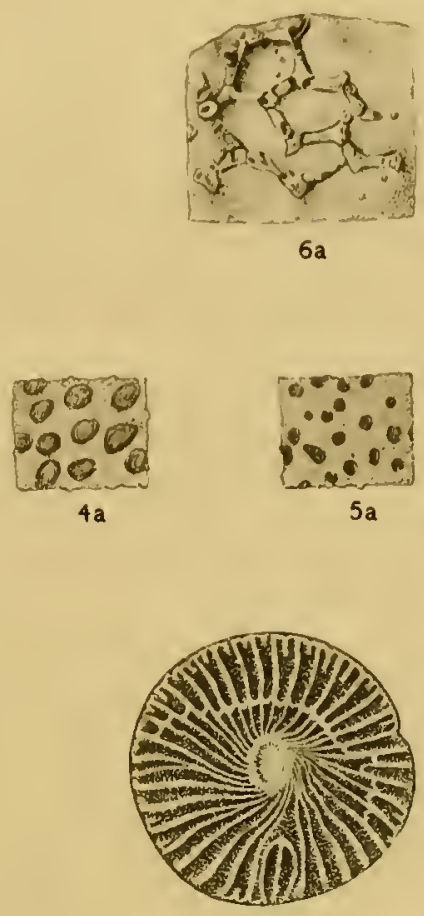

$2 \mathrm{~b}$

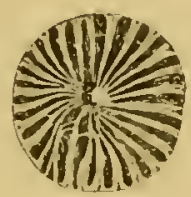

$2 d$

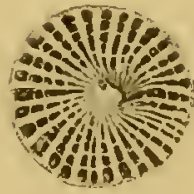

$2 \mathrm{c}$

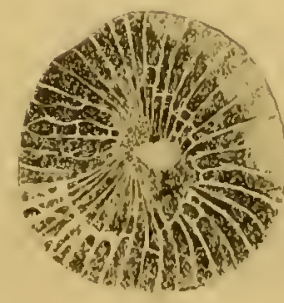

$2 \mathrm{a}$ 



\section{PLATE LXVIII.}




\section{P L A T E L X V I I I.}

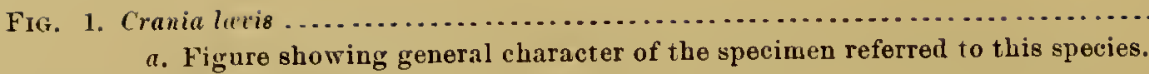

IIadison limestone, Cromfoot Rilge, Gallatiu Range, top of bed 24.

FIG. 2. Orthothetes inflatus.

a. Figure, after Hall and Whitfeld, showing character of an unusually large specimen.

Waverly age, Dry Cảnyon, Utah.

FIG. 3. Orthothetes inaqualis

$a$. Figure, atter Hall and Whitfield, showing the character of this species.

Waverly age, Ogden Canyon, Utal.

FIG. 4. Chonetes ornatus.

a. View of an average specimen showing outline and surface ornamentation, slightly enlarged.

$b$. Enlargement of the surface.

Iadisun linestone, east side of Gallatin Rirer, west of Electric Peak.

c. Auother, more auriculate specimen, situilarly enlarged.

Madison limestone.

d. Another, very obese specimen, natural size.

Madison limestone, east side of Gallatin River, west of Electric Peak.

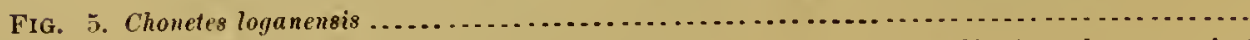

a. View of type specimen showing slight mediau sinus; cardinal angles somewhat restored; after Hall and Whitfield.

Waverly age, Logan Canyon, Utah.

b. A characteristic specimen, from Yellowstone National Park, with rounded cardinal angles aud withont a sinus.

Madison Iimestone, Crow foot Ridge, Gallatin Range, top of bed 25.

c. A lorsal valve, twice enlarged, showing shape and character of the very finely striate surface.

Madison linestone, east side of Gallatin River, west of Electric Peak.

FIG. 6. Productus parviformis $\mathrm{n} . \mathrm{sp} . . . . . . . . .$.
a. Lateral view of a typical exanple.

$b$ (lower figure). Posterior view of same.

c. Outline of same, ventral aspect.

Madison limestone, Crowfoot Ridge, Gallatin Range, top of led 25.

$b$ (upper figure). A dorsal valve referred to the sanie species.

Iadison limestone, sonth of Forellen Peak, Teton Range.

FIG. 7. Productus gallatinensis n. $\mathrm{sp.} \mathrm{(See} \mathrm{also} \mathrm{fig.} \mathrm{11).}$

a. Anterior riew of a characteristic specimen.

b. Posterior view of same.

c. Side view of same.

Iradison limestone, Crow foot Ridge, Gallatin Range, top of bed 25. 


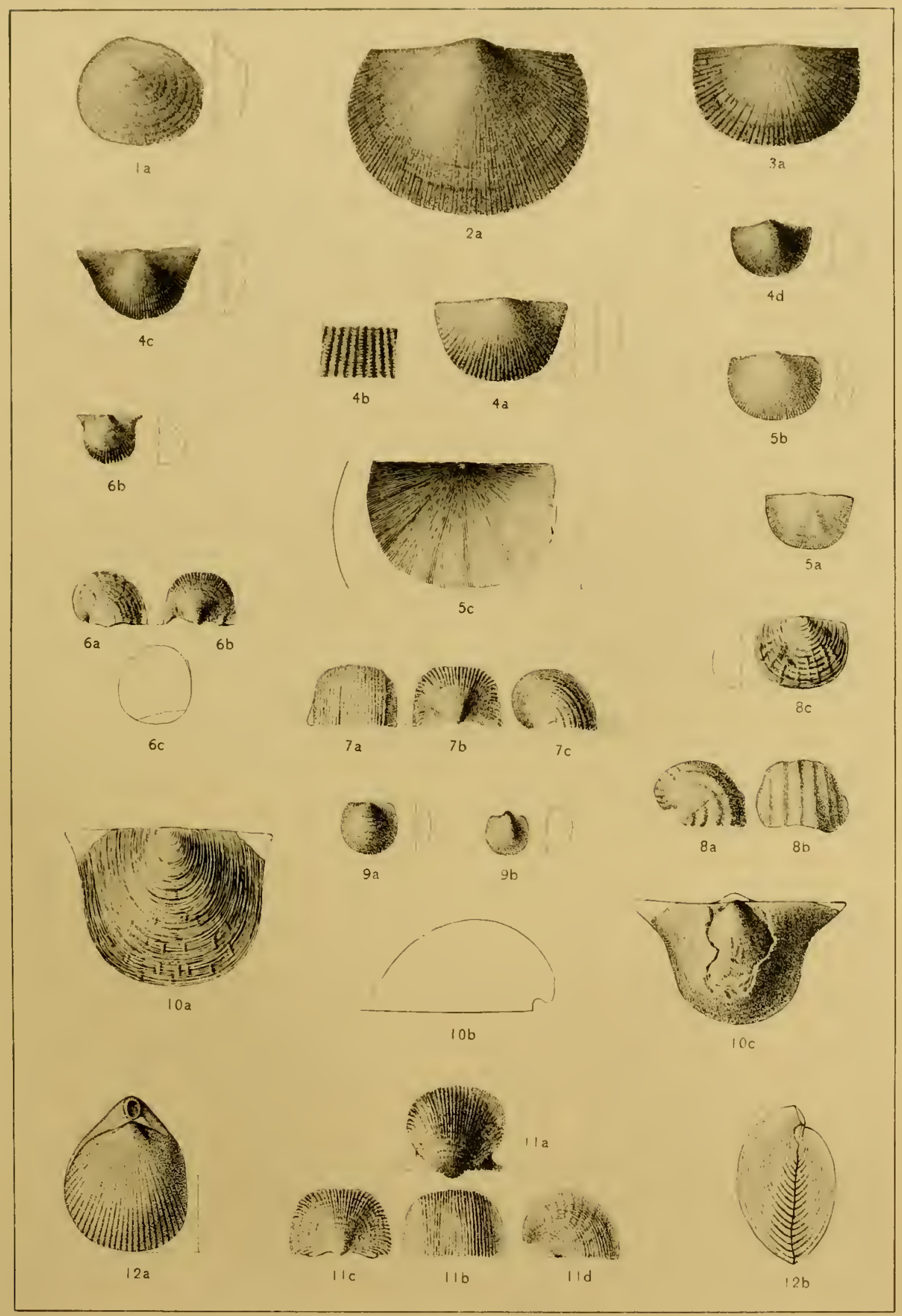

LOWER CARBONIFEROUS-MADISON LIMESTONE 



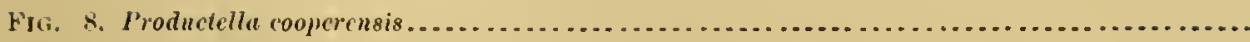

a. Lateral view of a specimen identified as Productclla cooperensis.

b. Anterior view of same.

c. A dorsal valve associatch with the above and referred to the same species. Madison limestone, Crowfoot Ridge, Gallatin Range, top of hed 24.

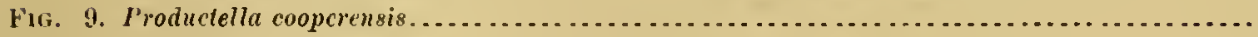

a. A dorsal valve of a type common in Ycllowstone National Park.

b. Ventral valve of the rame species.

Marlison limestone, Crowfoot Ridge, Gallatin Range, top of bed 25.

Fig. 10. Productella alifera n. sp.

a. A dorsal valre of a common size and shape.

$b$. Outline view of a highly vaulted ventral valve.

c. A very auriculate ventral valve.

Madison limestone, limestone bluff sonth side of Soda Butte Creek, northwest of Abiathar Peak, Absaroka Range.

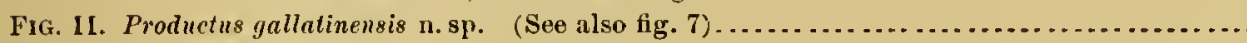

a. Ventral view of the type specimen.

b. Anterior view of same.

c. Posterior view of same.

d. Side view of sime.

Madison limestone, divide between Gallatin River and Panther Creek, Gallatin Range.

FIg. 12. Eumetria rerneniliana.

a. Dorsal view of a somewhat crushed specimen of a type common in Yellowstone National Park. $x 2$.

b. Side view of same, $x 2$.

Madison limestone, Crow foot Ridge, Gallatin Range, top of bed 25. 

PLATE LXIX. 


\section{P L A T E L XIX.}

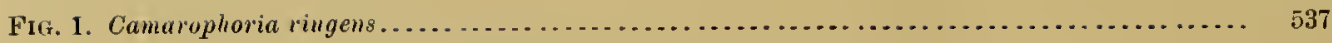

a. Ventral view of a large speeimen.

Madison linestone, Crowfoot Ridge, Gallatin Range, top of bed 25.

b. Dorsal view of a smaller specimen.

c. Side view of same.

Malison limestone, Crowfoot Ridge, Gallatin Range, bed 28.

Fig. 2. Camarotorchia herrickana $\mathbf{n . s}$

a. (by nistake left uunumbered on plate) Ventral valre, slightly enlarged.

Madison limestone, Crowfoot Ridge, Gallatin Range, top of bed 25.

b. Dorsal valve, similarly enlarged.

c. Anterior view of same.

Malison limestone, divide between Gallatin River and Panther Creek, Gallatin Range.

FIG. 3. Camarotrichia metallica.

a. Dorsal view of a specimen identified by Hall and Whitfeld as Rhynchonella pustulosa (?); after Hall and Whitfield.

Waverly age, Dry Canyou, Utal.

b. Dorsal view of a large specinen frow Yellowstone National Park.

Madison limestone, divid. between Gallatin Rivel and Panther Creels, Gallatin Range.

c. Anterior view of a smaller a specimen from Yellowstome National Park.

d. Side view of same.

e. Dorsal view of same.

Madison limestone, northwest slope of Forellen Peak, Toton Range.

FIG. 4. Camarotochia sp
a. Dorsal valve. $\times 2$.
b. Front view of same. $\times 2$.
Madison limestone, limestone bluff sonth side of jodia Bntte Creek, northwest of Abiathar Peak, Absaroka Range.

FIG. 5. Liorhynchus hayuei n. sp

a. Dorsal view of type specimen.

b. Lateral view of same.

Madison limestone, Crowfoot Ridge, Gallatin Range, cherty limestone, top of bed 24.

Fig. 6. Dielasma utah................................
a. Dorsal view of an imperfoct example.

a. Dorsal view of an
$b$. Side view of same.

Madison limestone, Crowfoot Ridge, Gallatin Range, bed 28.

c. Ventral view of type specimen; after Hall and Whitfield.

Waverly age, Cottonwood divide, Wasateh Range, Utah.

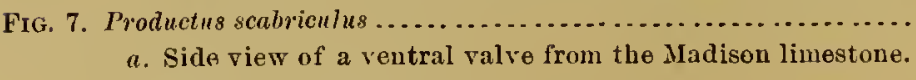

b. Posterior viow of same.

c. Outline of samo, looked at from above.

d. Surface ormamentation, enlarged.

Madison limestome, Crowfoot Ridge, Gallatiu Range, top of bed 25. 


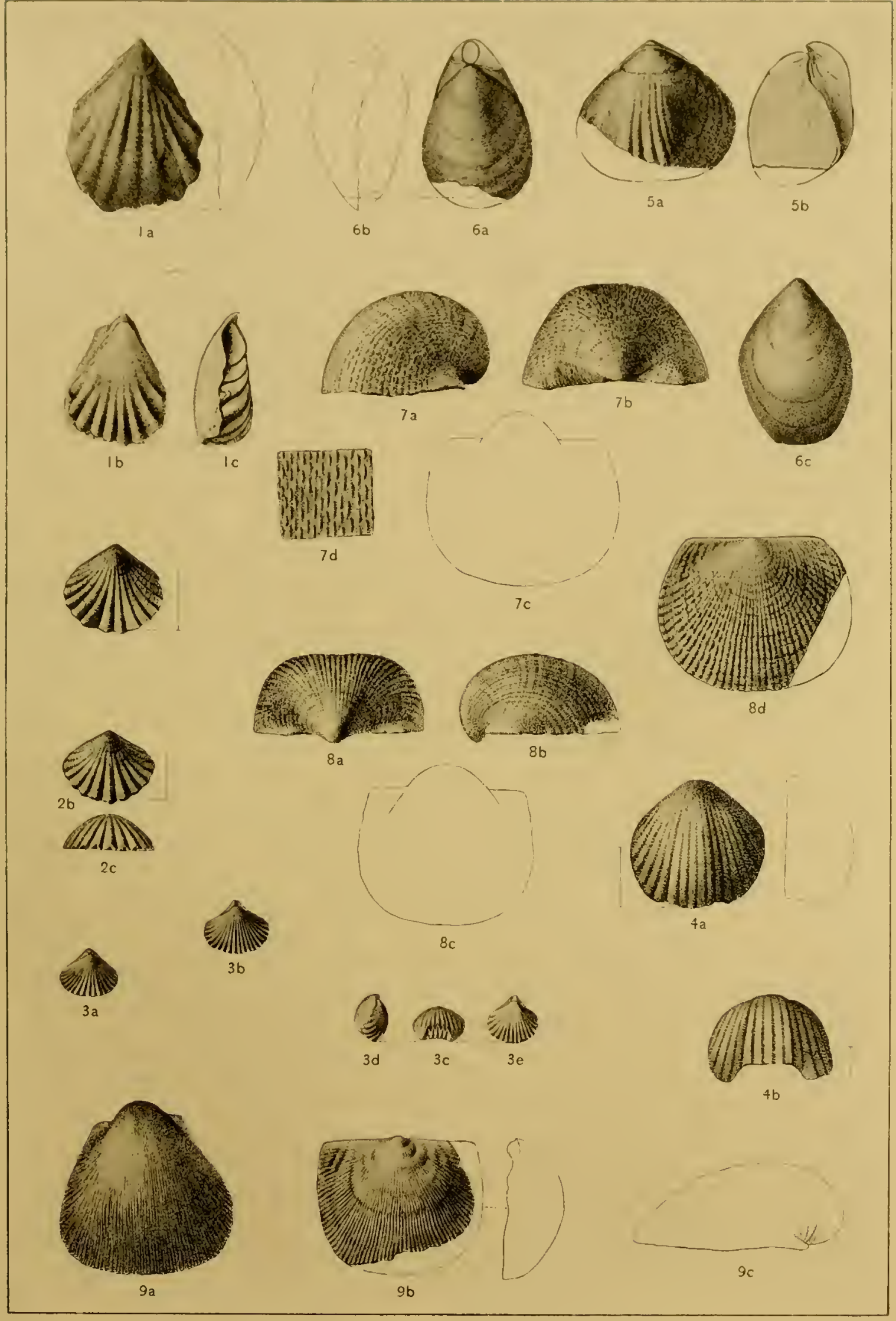

LOWER CARBONIFEROUS-MADISON LIMESTONE 



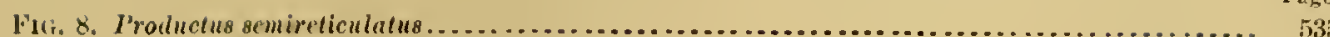

a. Ventral valve, posterior viow.

b. Lateral aspect ot same.

c. Ontline as seen from above.

Miulison limestone, Crow foot Ridge, Gallatin liange, lower part of bed 27 .

d. Dorsal valve of same species.

Matison limestono, head of Conant Creek, Teton Range.

Fis. 9. Productus laricosta.

a. Ventral vilve of a speeimen from Utah, restored; after Hall and Whitfield. Waverly age, Dry Canyon, Utah.

b. A ventral valve from the Madison limestone, flat and immature in expression. Malison limestone, Crow foot Ridge, Gallatin Range, top of hed 25.

c. Lateial outline of a ventral valve of the usual type.

Madison limestone, Crowfoot Ridge, Gallatin liange, lower part of bed 27. 



\section{PLATE LXX.}




\section{PLA TE LXX.}

FIG. 1. Spirifer sp

a. View oi an unidentified dorsal valve.

Madison limestone, east slope of Survey Peak, Teton Rauge.

F1G, 2. Spirifer striatus var. madisonensis n. var

a. Dorsal view of a large specimen.

$b$. Side view of same.

Madison limestone, Crowfoot Ridge, Gallatin Range, top of bed 24

c. Dorsal view of a somewhat smaller specimen.

d. Side view of same.

Mladison limestone, Crowfout Ridge, Gallatin Range, cinerty limestnne, top of bed 24 .

FIG. 3. Spirifer centronalus..............................................
a. Veutral valve of a characteristic form; after White.

Waverly age, Mountain Spring, Old Mlormon road, Nevada.

b. A characteristic dorsal ralve; after Hall and Whitfield.

Waverly age, Dry Canjon, Utah.

c. Another type, probably no moro than varietally distinct from Spirifer centronatus, described by Hall and Whitfeld as Spirifer albapinensis; after Hall and W' hittield.

Waverly age, Logan Canyon, Utah.

d. A soung specimen of the general type of Spirifer albapinensis, referable to spirifer centronatus; after Hall and Whitfield.

Wraverly age, Dry Canjon, Utah.

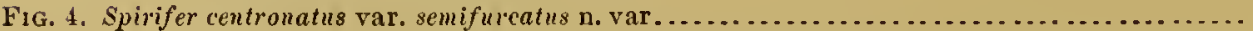

$a$. A dorsal valve of this type in which the incipient bifurcation of the two plications surmonnting the fold is less apparent thin usnal.

Madison limestone, Crow foot Ridge, Gallatin Kange, top of bed 26.

Fig. 5. Martinia rostrata n. sp.

a. Ventral view of a rather young specimen.

$b$. Outline of the same, viewed from one side.

Madison limestone, east sicle of Gallatin River, west of Electric Peak.

c. Ventral view of an old specimen.

d. Lateral outline of same, slowing the elevated and prodnced beak.

Madison limestone.

e. A large dorsal valve, referred to this species.

$f$. Front view of same in ontline.

Madison limestone, Crow foot Ridge, Gallatin Range, top of bed 25.

g. A very young ventral valve, described by Hall and Whitfield as Athyris planosulcata (?). After Hall and Whitfield.

Warerly age, Logau Cauyon, Utah.

FIG. 6. Reticularia cooperensis var due to growth. Between these lie finer strice, the bases of the claracteristic spinulose fimbriations.

b. Lateral outline of same.

c. Posterior view of same.

Eureka dıstrict, Novada, Lower Carboniferous. 


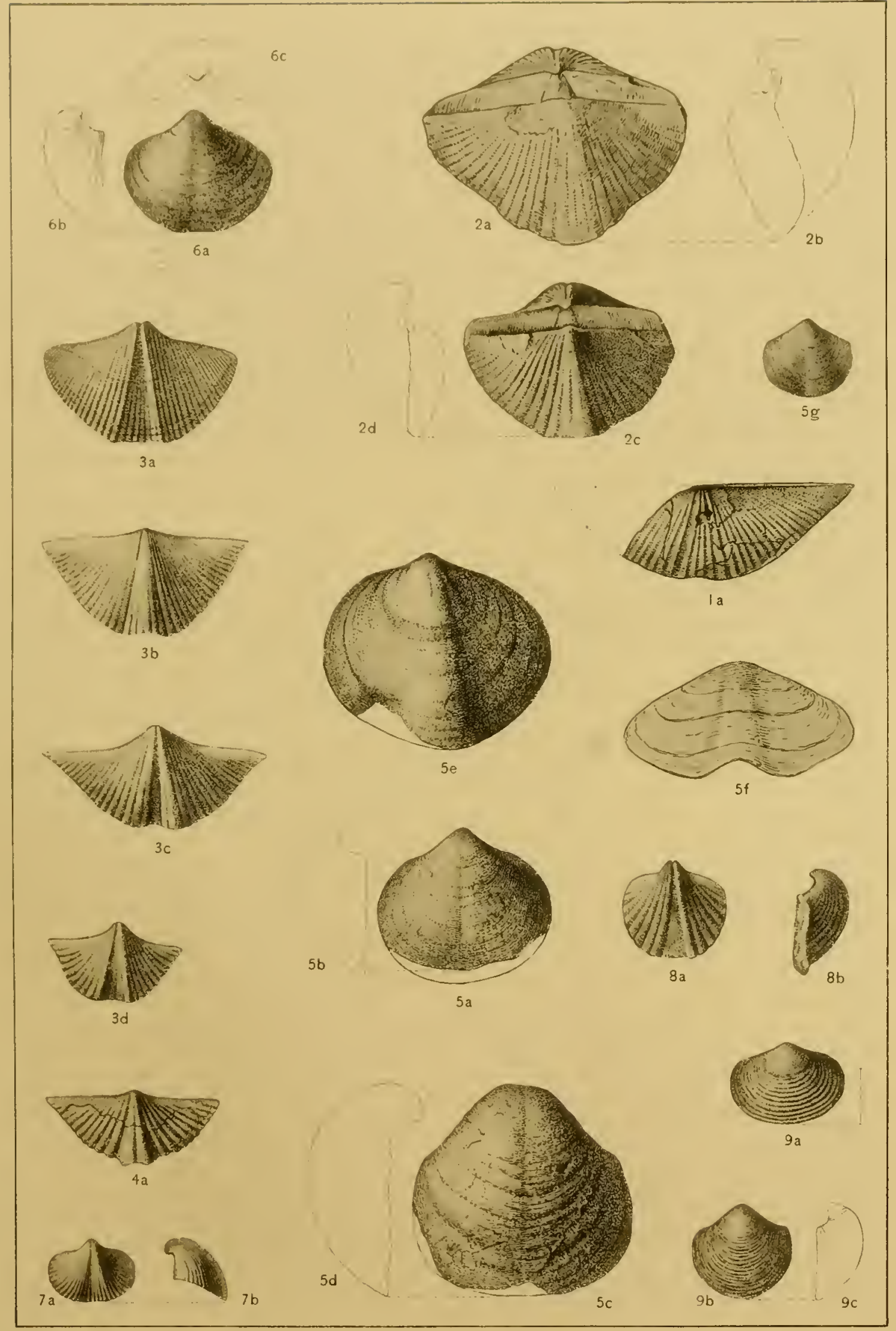

LOWER CARBONIFEROUS-MADISON LIMESTONE 

a. View of a veutral valve.

b. Sicle view of samo.

Madison limestone, near Monareh, Montana.

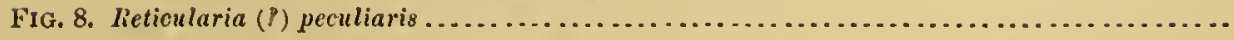

a. Ventral valve, identified by White with Shunarl's species; after White.

b. Side view of samo; after Whito.

Waverly age, Mountain Spring, Old Molmon roal, Nevada.

Fig. 9. Reticularia cooperensis ............................
a. A dorsal valve, identified as $R$. cooperensis.

Madison limestone, Crowfoot Ridge, Gallatin Range, top of bed 26.

b. A rentral valve from another locality.

c. Sicle ontline of samo.

Madison limestone, Crowfoot Ridge, Gallatin Range, upper part of bed 27. 



\section{PLATE LXXI.}




\section{PLATE LXX I}

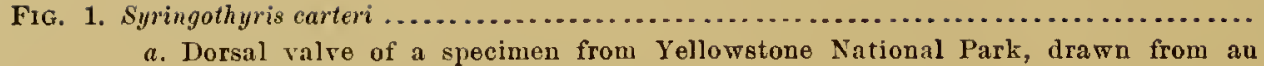
impression of a natural mold.

Madison limestone, limestone bluff south side of Soda Butte Creek, northwest of Abiathar Peak, Absaroka Range.

b. Anterior view of an entire example of the same species; after Meek; figured by that anthor as Spirifer (Syringothyris) cuspidatus.

c. Cardinal view of same, showing higb area and foramen, and, within the latter, the transverse septum and internal tube; likewise after Meck.

Lower Carboniferons (?), White Pine district, Nerada.

FIG. 2. Seminula madisonensis $\mathrm{n} . \mathrm{sp}$.

a. Dorsal view of type specimen.

b. Side view of same.

c. Interior of a ventral valve, showing hinge teeth, pedicle carity, and posterior and anterior adluctors.

Madison limestone, hear of Conant Creek, Teton Range.

FIG. 3. Seminula madisonensis var. pussilla 1 . var

a. Ventral valve of t5pe specimen, showing shape, enlarged.

b. Lateral view of same.

Madison limestone, Crowfoot Ridge, Gallatin Range, bed 28.

Fıg. 4. Seminula subtilita.

a. Dorsal view of a characteristic specimen from the type locality, for comparison with Seminula madisonensis.

b. Side view of same.

c. Anterior view of same,

Upper Carboniferons, near Weston, on the Missouri River.

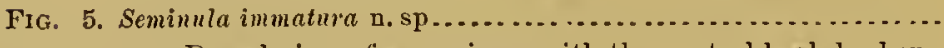

a. Dorsal riew of a specimen with the ventral beak broken.

b. Side view of same.

c. Dorsal view of another specimen which is somewhat crushed.

d. Side view of same.

Madison limestone, west of Antler Peak, Gallatin Range.

FrG. 6. Seminula humilis n. sp

a. Dorsal view of a rather large specimen.

b. Side view of same.

c. Dorsal vier of a smaller spccimen from the same locality.

Madison limestone, Crow foot Ridge, Gallatin Range, npper part of bed 27.

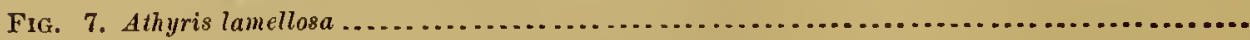

a. Ventral view of a badly exfoliated specimen.

Madison limestone, Yellowstone National Park.

FIG. 8. Cliothyris crassicardinalis.

a. Dorsal view of a specimen showing the usual characters of size and shape, but almost completely exfoliated.

Madison limestone, north of Owl Creck, northeast slope of Teton Range. 


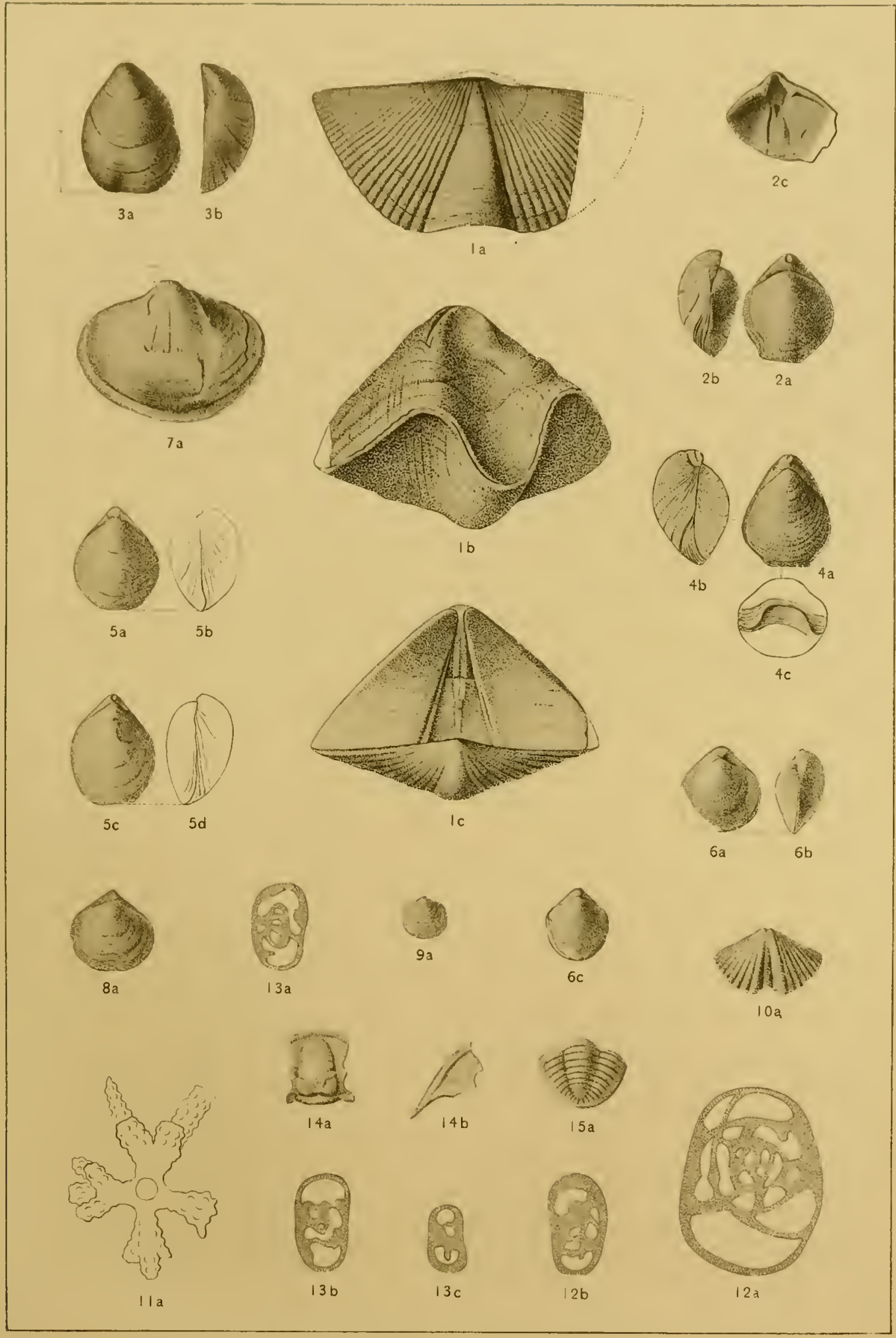

LOWER CARBONIFEROUS-MADISON LIMESTONE 



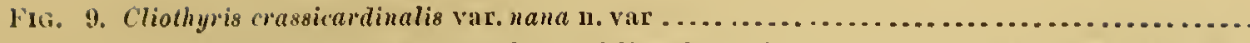

a. Vontral view ot a somowliat exfoliated speeimen, whieh is rogarded as varietally distinct from the above.

Madison limestone, Crowfoot Ridge, Gallatin Range, top of bed 25.

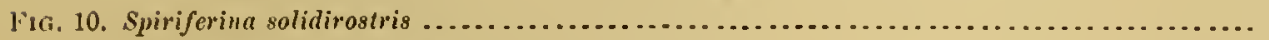

a. Ventral valve characteristic of this species.

Marlison limestone, amphitheater east of Bannoek Peak, Gallatin Range, berl 28.

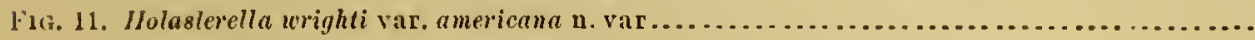

a. View of an isolated spienle magnitied abont twenty diameters.

Madison limostone, divide between Gallatin Valley and Panther Creek, near Bighorn Pass, Gallatin Range, bed 24.

Fiı. 12. Endothyra baileyi

a. An example from Spergen Hill, Indiana, of a not unusual size. $x 12$.

b. Another, smaller speeimen from the same locality. x 12.

Warsaw group, Spergen Hill, Indiana.

Fla. 13. Endotlyya baileyi var, parra n. var.

$a, b$. Two specimens of the ordinary eharacter, from the Madison limestone. $x 12$.

c. A small specinen from the Madison limestone. $\mathrm{x} 12$.

Madison limestone, White Monntain, Absaroka Range.

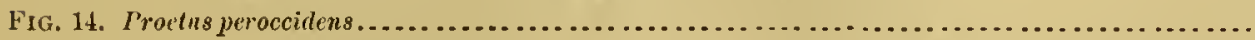

$a, b$. Cilabella and free eheek of the kind occurring in the Madison limestone; after Hall and Whitfield.

Waverly age, Dry Canyon, Utah.

Fig. 15. Proetus loganensi

a. Pygidium of a type associaterl with the abeve in the Madison Iimestone; after Hall and Whitfield.

Waverly age, Logan Canyon. 


\title{
C H A P T E R X I I I.
}

\author{
MESOZOIC FOSSILS.
}

\author{
By T. W. Stanton.
}

The Mesozoic fossils obtained in and near the Yellowstone National Park and submitted to me for study include 78 species of invertebrates, of which 31 are Cretaceous, 46 are Jurassic, and 1 is from beds of supposed Triassic age. The number of species from a single horizon is not large enough to be dignified with the designation "fauna," excepting, perhaps, in one or two cases; yet the study of these fossils and the comparisons made with known horizons liave led to some general results that are worthy of brief discussion. The subject will be treated by geological horizons, and after reviewing the general considerations an annotated list of the species with descriptions of new forms will be given.

\section{TRIASSIC.}

The Teton formation, of supposed Triassic age, yielded a ferw specimens of a Lingula at a locality on the summit of Quadrant Peak. This fossil resembles Lingula brevirostris M. and H., from the Jurassic of the Black Hills, but in the absence of other fossils it should be given little weight in determining the age of the beds. Linguloid shells are so slightly differentiated that it would not be safe to distinguish, by them alone, even between Paleozoic and Mesozoic. The determination of the age of this formation must, for the present at least, rest on the evidence of stratigraply and lithology. The paleontologist can only say that the underlying beds yield Carboniferous fossils, while the overlying formation has a welldeveloped Jurassic fauna. 
The only marine Triassic fossils that have been found in the Rocky Mountain region are from the Lower 'Trias, beneath the "Red Beds" in sontheastern Idaho" The very few fossils that have been obtained from the Red Beds farther south (in New Mexico and southern Colorado) seem to be of fresh-water origin.

In California and Nevada, however, marine Triassie beds are well developed, and have yielded a varied fauna which is as yet mostly undeseribed.

\section{JURASSIC.}

The Jurassie fossils form much the largest and most important part of the Mesozoic collection. The fauna is not large, but most of the species are abundantly represented, and in number of species it compares favorably with the Jurassic of other parts of the Rocky Mountain region. The collections are from many localities in two general areas-one, which yielded the most fossils, in the northwest corner of the Park, on the headwaters of Gardiner and Gallatin rivers and near the Yellowstone; the other on the slopes of Sheridan Peak and farther sonthwest of Snako River.

The fossils from all these localities evidently belong to a single fanna, though two zones are recognizable, distinguished more by lithological differences than by famal peculiarities. The upper zone of arenaceous limestone has yielded an abundance of Rhynchonella gnathophora, R. myrina, Ostrea strigilecula, Camptonectes pertenuistriatus, C. bellistriatus, and a few other forms. Most of these also occur in the underlying calcareous clays and marly limestones associated with many other species, of which the most abundant are Pleuromya subcompressa, Pholadomya kingi, and Gryphea calceola var. nebrascensis.

The same fauna is represented in the beds just beyond the northern limits of the Park, at Cimnabar Mountain, where fossils that are included in the present report were obtained by Dr. A. C. Peale in 1872. These were identified and some of the species named by Prof. F. B. Meek, ${ }^{2}$ but it was not until 1880 that they were illustrated and more fully described by Dr. C. A. White. ${ }^{3}$ Still earlier Captain Raynolds had brought back Gryphea calceola var. nebrascensis and a few other fossils of this horizon from

'See White, Triassic fossils of southeasteru Iraho: Auu. Rept. U. S. Geol. Surv. Terr. for 1878, pp. 105-118.

${ }^{2}$ Ann. Rept. U.S. Geol. Surv. Terr. for 1872, pp. 471-474.

${ }^{3}$ Idem for 1878, pp. 143-153, Pls. XXX VII and XXXVIII. 
Wind River Valley, and they were described by Meek and Hayden, ${ }^{1}$ who had previonsly ${ }^{2}$ announced the discovery of Jurassic fossils from the Black Hills. These Black Hills fossils are fully described and illustrated in the Paleontology of the Upper Missouri. Subsequent geological explorations and surveys have shown that the marine Jurassic is widely distributed in South Dakota, Wyoming, Montana, Idaho, and Utah, and have made considerable additions to the fauna that have been described by White, ${ }^{3}$ Hall and Whitfield, ${ }^{4}$ Meek $^{5}$ and Whitfield. ${ }^{6}$ All of these authors seem to have assumed that the fossils they described belonged to a single fauna. At least they made no attempt to recognize distinct horizons in the Jurassic. The meagerness of the fama-usually only a few species having been obtained at any one locality - was perhaps sufficient reason for not making attempts of this kind. Prof. Alphens Hyatt's recent comprehensive studies of the earlier Mesozoic fammas of the United States, and especially of California, where all the greater divisions of the Jura are developed, have led him to express the opinion that both the Upper Jura (Callovian or Oxfordian) and the Middle Jura (Oolite) are represented in the Rocky Mountain region. ${ }^{7}$ In the former lie places the Jurassic of the Black Hills, and of Rerl Buttes and Aurora, Wyoming, with probably some localities in Utah. Of the Middle Jura he says: "The Oolite certainly seems to have been found by Dr. Peale near the lower canyon of the Yellowstone in Montana, and out of the few fossils from Utal described by Dr. White some are closely similar to those of the inferior Oolite at Mount Jura."

It has already been stated that this collection of Dr. Peale's belongs to the same horizon that is represented in the Park. It contained the following species:

Ostrea strigilecula.

Gryphrea planoconvexa.

Camptonectes platessiformis.

Pinna kingi.

Gervillia montanaensis.

Morliola subimbricata.

Trigonia americana.
Trigonia montanaensis.

Astarte meeki.

Cypricardia haguei.

Pleuromya subcompressa.

Pholadomya kingi.

Goniomya montanaensis.

${ }^{1}$ Proc. Acad. Nat. Sci. Phila., 1861, p. 437, and Paleontology of the Upper Yissouri, 1865, pp. 74 and 80.

${ }^{2}$ Proc. Acad. Nat. Sci. Phila., 1858, pp. 46, 49-59.

${ }^{3}$ U. S. Geog. and Geol. Expl. West of 100th Meridian, Vol. IV, Pt. I, 1875.

${ }^{4}$ U. S. Geol. Expl. 40th Parallel, Vol. IV, Pt. II, 1877.

${ }^{5}$ Idem, Pt. I, 1877, and Simpson's Rept. Expl. Great Basin, Utah, 1876.

"Newton and Jenney's Rept. Geol. Black Hills of Dakota, 1880, pp. 344-382.

'Bull. Geol. Soc. Am., Vol. III, 1892. pp. 409-410. 
Besides the species named, there are fragments of two species of ammonites, and several other forms are represented by casts or other imperfect material. All of the species named in this list, excepting Goniomya montanuensis, occur at various localities in the Park, as shown in the amotated list of species (p). 60ð-631).

Comparatively few Jurassic fossils are known from Utah, and they are probably all from one horizon. According to the various reports published, as well as personal observation in both the norther'n and southern parts of the Territory, the fossiliferous zone is a calcareous bed near the base of the local Jurassic sections. In Weber Canyon it has yielded Cucullea haguei, Plewromya subcompressa, Pentacrinus asteriscns, and a few other forms; in Thistle Canyon the peculiar Lyosoma powelli was obtained, and in a collection made by Mr. Robert Forrester on San Rafael River I have recognized Trigonia americana and Pholadomya lingi, all of which occur in the Park. For these reasons I regard all of the fossiliferous Jurassic beds now known in Utah as belonging to the same horizon that is so well represented in the Yellowstone National Park.

The question still remains whether the Jurassic of the Black Hills belongs to a higher horizon. There are some facts in faror of the opinion that the Jurassic fossils of the two regions may not be contemporaneous. For example, a number of the most abundant species in the Yellowstone National Park region, sucl as Pleuromya subcompressa, Pholadomya kingi, and Cypricardia hagnei, have not been reported from the Black Hills. The Yellowstone species of Trigonia, Modiola, and Gervillia are also distinct. Pseudomonotis (Eumicrotis) curta, which is one of the most abundant species in the Black Hills, is represented in the Park collection by a single doubtful specimen. No example of Cardioceras cordiforme has been found in the Yellowstone National Park, and several other common Black Hills forms are either absent or rare there.

On the other land, there is a considerable list of species common to the two regions, among which may be mentioned:

Pentacrinus asteriscus.

Rhyuchonella inyrina.

Rhynchonella guathophora.

Ostrea strigilecula.

Gryphaa calceola var. nebrascensis. ${ }^{1}$
Camptonectes bellistriatus.

Camptonectes platessiformis.

Avienla wyomingeusis.

Belemnites densus.

'The Black Hills specimens of this species are all small. 
Many of the species that are considered distinct are closely related. It should be remembered, also, that we know only fragments of the fauna that must have existed at that time if it approached in size those that are now living. Whitfield records only 43 species from all the Black Hills country, and we now have about the same number from the Yellowstone region. If more exhaustive collections were made in both districts, it is probable that the list of common species would be considerably increased, but even as the record stands it shows rather clase relationship of faunas. Possibly the lowest Jurassic beds in the Yellowstone region may be slightly older than the lowest in the Black Hills, but the difference in age can not be great-not great enough, as it seems to me, to put them in different divisions of the Jura. Throughout all the Rocky Mountain region, wherever marine Jurassic strata are found they are only a few lnundred feet in thickness and they rest directly on the Triassic "Red Beds" or on older formations. It does not seem possible that Upper Jurassic marine beds could have been deposited in the Black Hills and Wyoming without leaving any traces in the Yellowstone, Montana, and Utah - that is, the stratigraphic relations and the geographic distribution of the marine Jurassic of the Rocky Mountain region are in favor of the idea that all of these deposits were made contemporaneously in a single sea.

\section{CRETACEOUS.}

Dakota (3) formation.-The collection shows that several horizons of the Cretaceous are represented in the Park. The lowest of these, according to the geologists, is a thin bed of limestone, not far above the local base of the Cretaceous section, that is filled with fresh-water gastropods and a few Unios. This fauna at once suggests a comparison with the fresh-water forms (Lioplacodes veternus and Viviparus gilli) from beds of supposed Jurassic age overlying the marine Jura in Wind River Valley, Wyoming, but these forms are not represented in the Park collections.

The few species obtained do not show their generic characters very distinctly; still it is evident that they are not closely related to the freshwater Bear River fauna of southwestern Wyoming nor to the few fresh-water forms known from the Dakota of Nebraska, both of which seem to hold about the same stratigraphic position as this bed. There is one other possibility, and that is that the Lower Cretaceous Kootanie formation is 
represented here. It has been recognized by means of its fossil plants at Great Falls, Montana, and in the Black Hills, but its fresh-water mollusks are almost entirely unknown, and the few that have been seen are entirely different from these. All that can now be said concerning the age of these fossils is that they come from a bed that is conveniently referred to the Dakota on account of its stratigraphic position. I have named three of the most common forms of gastropods from this bed, so that they may be definitely referred to, although they are rather obscure and misatisfactory species.

colorado formation-The marine Cretaceous beds on Snake River one-fourth to one-half mile above the mouth of Sickle Creek may be directly correlated with the upper part of the Colorado formation as it is developed on the Missouri River near Fort Benton. The locality near Sickle Creek has yielded:

Iuoceramns uudabundus M. and H. Iuoceramus flaccidus White.

Inoceramus umbonatus $M$. and $H$. Baculites asper Mort. (?)

Inoceramus acuteplicatus n. sp.

Scaphites ventricosus M. and $H$.

All of these, except the third and fourth, occur together in the upper part of the so-called Fort Benton shales on the Missouri, and associated with them are Inoceramus exogyroides M. and H., I. deformis Meek, I. tenuirostris M. and H., Veniella mortoni M. and H., and Pholadomya papyracea M. and $H$, and a few undescribed species.

This well-characterized zone was included in the Fort Benton shales by Meek and Hayden when they gave that name to the "No. 2 " of their Cretaceous section, and they regarded all these dark shales near Fort Benton as the equivalent of the shales underlying the Niobrara limestone in Nebraska, Kansas, Colorado, and elsewhere. The fact is, however, that the Niobrara also is represented by shales in this upper Missouri region, and the fossils indicate that this zone is really the equivalent of the upper portion of the Niobrara. The evidence for this statement rests on the occurrence of several of the above species in the Niobrara limestone and overlying shales of Colorado and in the equivalent Austin limestone of Texas, and also on the absence of all these species except Veniella mortoni from beds lower than the Niobrara in the same region and elsewhere. In Colorado Inoceramus deformis is the most characteristic species of the Niobrara limestone. Recently Mr. G. K. Gilbert has collected Inoceramus umbonatus from shales in the Niobrara above the limestone near Pueblo, 
Colorado, and it is probable that the type of I. faccidus came from about the same horizon. I. umbonatus and I. exoyyroides are reported from the Austin limestone of Texas, and Baculites asper (?) occurs in the same formation. The European I. involutus, which is very closely related to, if not identical with, I. umbonutus, is also confined to the Emscher Mergel, according to Schliiter, which appears to be the homotaxial equivalent of the Niobrara.

The fact that within the Colorado formation experience has shown the various species of Inoceramus to be good guide fossils for the different zones gives this evidence of a few species greater weight than it would have otherwise.

The name Colorado formation has come into general use for the combined equiralents of the Fort Benton and Niobrara, and it is a very convenient term, especially in the regions where the lithological differences are not clearly marked.

A fragment referable to Scaphites ventricosus, obtainerl on the sontheast spur of Electric Peak, wakes it probable that the shales there also belong to the upper part of the Colorado formation. The same horizon is represented at Cinnabar Mountain, just north of the Park, though no Cretaceous fossils from that place are included in these collections. Professor. Meek examined fossils obtained there in 1872 and listed ${ }^{1}$ Scaphites ventricosus, Baculites asper (?), and undetermined species of Thracial, Trigonia, Inoceramus, and Ostrea.

There are two other localities in the northern part of the Park, on Fan Creek and the north brinch of Gardiner River, that have yielded an abundance of Ostrea anomioides, a species that occurs in the Colorado formation at several localities in Montana.

Montana formation.-The Fort Pierre and Fox Hills divisions of the Meek and Hayden section are frequently combined under the nane Montana formation for reasons similar to those that caused the union of the Fort Beuton and Niobrara. In the western part of the Rocky Mountain Cretaceous area it is often difficult to draw a sharp line between even these two broader divisions. The lower part of the section is distinctively Colorado and the upper part distinctively Montana, but there is frequently a doubtful zone in which the faunas are more or less blended. This is especially true in northern Utah, at Coalville, and in western Wyoming, where both the 
Colorado and Montana formations contain several heavy beds of sandstone with closely related littoral faunas. ${ }^{1}$ It is evident that the seashore remained in that region throughout nearly all of Upjer Cretaceous time, giving the shallow waters and sandy bottom favorable to the continuance of the littoral fauma that was early established there. The Colorado formation is easily recognized in these sections by the occurrence of a number of widely distributed characteristic species, but for some unexplained reasou very few of the species that characterize the Montana formation farther east and north occur there.

This phase of the Cretaceous is well developed on Hams Fork, in western Wyoming, and it extends northward from there nearly to the sonthern boundary of the Park, for it is well represented in the collection from in sandstone on Glade Creek and at other localities near Snake River in the same region. Fossils are abundant, but only about 20 species were obtained. Judging from the fauna, the horizon is not very far from that of the Colorado shales near Sickle Creek-probably a little above them-and it is provisionally referred to the lower part of the Montana formation. Several of the species occur at Coalville, Utah, and in sonthwestern Wyoming, and some of them there range down into the Colorado formation.

More thorough collecting from all the Cretaceous beds exposed in the Yellowstone National Park, and a little farther north and east, will probably give both phases of the Upper Cretaceous famnas in one section and enable us to assign these sandstones to a more definite place in the standard Upper Cretaceous section.

In the following list of species references are usually given only to the first description and to publications in which the species is figured. For fuller references consult Boyle's Catalogue of American Mesozoic Invertebrates: Bull. U. S. Geol. Surv. No. 102.

${ }^{1}$ See, for a fuller discussion of this subject, The Colorado formation and its invertebrate fanua : Bull. U. S. Geol. Surv, No. 106, pp. 37-46. 


\section{ANNOTATED LIST OF SPECIES, WITH DESCRIPTION OF NEW FORIIS.}

\section{TRIASSIC (?) SPECIES.}

LINGULA sp. undet.

A few specimens of Lingula from beds on the summit of Quarlant Peak, supposed to be of Triassic age, closely resemble the Jurassic Lingula brevirostris $\mathrm{M}$. and $\mathrm{H}$. from the Black Hills.

\section{JURASSIC SPECIES.}

\section{ECHINODERMATA.}

Pentacrinus asteriscus Meek and Hayden.

Pentacrinus asteriscus Meek and Hayden, 1858: Proc. Acad. Nat. Sci. Phila., p. 49. White, 1875: Geogr. and Geol. Surv. W. 100th Meridian, Vol. IV, Pt. I, p. 162, Pl. XIII, figs. $6 a, b$. Clark, 1893: Bull. U. S. Geol. Surv. No. 97, p. 26, Pl. III, figs. $2 a-d$.

Pentacrinites asteriscus Meek and Hayden, 1865: Palæont. Upper Missouri, p. 67, Pl.

III, figs. 2a, $b$, and fig. in text. Whitfield, 1880: Geol. Black Hills Dakota, p. 345 , Pl. III, figs. $1,2$.

Pentacrinus whitei Clark, 1893: Bull. U. S. Geol. Surv. No. 97, Pl. III, figs. 4a-c.

This species, which is known only from portions of the columns, occurs in collections from divide between Fawn Creek and Gallatin Valley, from the slopes of Mount Sheridan, and from west of Snake River, nortl of Berry Creek.

The joints of the columns vary in diameter, in thickness, and in the depth of the reentrant angles, but they do not vary more in these respects than do the different portions of the stem in a single individual of a recent Pentacrinus. The joints of the upper part of the column are always thinner, more distinctly star-slaped, and differ in all other details from those of the lower portion.

The name $P$. whitei was proposed by Prof. W. B. Clark for large, thin joints with deep reentrant angles, but the author of the species informs me that he has abandoned the name for reasons similar to those just given, and in a forthcoming monograph of the Mesozoic Echinodermata of the United States he will refer all the known American Jurassic Pentacrini to P. asteriscus. 


\section{HCHINOIUEA.}

Fragmentary calsts of one ar more species of echinoids were obtained near the lower eanyon of the Yellowstone liver and at a locality north of Berry Creek, a tributary of Suake River. They are doubtless new species, but they are not sufficiently well preserved for generic determination, and we must therefore wait for arditionil and better material.

\section{BRACHIOPODA.}

\section{RHYNChONeLLa MYrina IIall and Whitfield.}

Rhynchonella myrina Hall and Whitfield, 1S77: U. S. Geol, Expl. 40th Parallel, Vol. IV, Pt. II, p. 284, Pl. VII, figs. 1-5. Whittield, 1850: Geol. Black Hills Jakota, p. 347 , Pl. III, fig. 6 , not fig. 7 .

The type of this species is a finely plicate shell with alsout eight plications in the median sinus. In Prof. R. P. Whitfield's later publication he has united with it the much more coarsely plicate forms, with only three or four plications in the median sinus, that have usmally been referred to $R$. gnathophora. As the munerons specimens in the present collection do not show the intermediate varieties of forn and sculpture, I prefer to treat them as distinct species.

Typical R. myrina occurs at a number of localities in the northwest corner of the Park and near Snake River southwest of it, in the hard arenaceous limestone.

Rhymchonelat gathophora Meek.

Pl. LXXII, figs. 1-4.

Rhynchonella gnathophora Heek, 1864: Geol. Surv. California, Palieont., Vol. I, p. 39, Pl. VIII, figs. 1a-f:

Rhynchonella gnathophore? Hall and Whitfield, 1877: U.S. Geol. Expl. 40th Parallel, Vol. IV, Pt. II, p. 2St, Pl. VII, fig. 6.

Rhynchonella myrina (H. and W.) Whitfield, 1S80: Geol. Black Hills Dakota, p. 347, Pl. III, fig. 7, not fig. 6.

Rhynchonellu sp. Mleek ant Hayden, 1865: Palieont. Ulper Missouri, P. 71, Pl. III, fig. 4.

The specinens referrerl to this species have nearly the same outlines as $R$. myrina, but they are somewhat more capacious and much more coarsely plicate. The type of $R$. myrince has thirty plications on each valve, with HON XXXII, PT II-39 
eight in the median sinus, while the plications on these shells vary from fourteen to twenty, with three or four in the median sinns, three being much the more common number. A few specimens lave only two.

I have not seen Meek's types from the Jurassic of California, but specimens from the Mormon sandstone near Taylorsville (probably Meek's original locality) have been kindly loaned by Professor. Hyatt for comparison. These are larger than any of the Utah or Yellowstone specimens, and none of them las less than four plications in the median sinus, but in all other respects they agree quite closely. All the figmred specimens from the Black Hills and Rocky Mountain region above referred to have been examined, and I have no doubt of their specific identity; In Yellowstone National Park, where the species is very abundant in the npper zone of the Jurassic and occasionally occurs in the underlying shales, the specimens are usually small, many of them being no larger than the one from the Black Hills tigured by Meek and Hayden.

It is known from northwestern Colorado and from the Uinta Mommtains, Utah, and it occurs in the Park near the northern and Lake heads of Fawn Creek; on south slope of ridge south of Gray Momntain; south side of Fan Creek Pass; on saddle at head of Fawn Creek, northeast of Monnment Peak, in beds 100 feet above principal fossiliferous horizon of Jurnssic; in saddle west of south head of Gardiner; 4 miles north of second crossing of Snake River, at 7,500 feet elevation; on hill northeast of Momt Everts; on ridge south base of northwest slope of Flat Mountain; at Mammoth Hot Springs, on main terrace.

\section{PELECTPODA.}

\section{Ostrea strigilecula White.}

Ostren strigilecula White, isi5: U. S. Geog. and Geol. Surv. W. 100th Meridian, Vol. IV, Pt. I, p. 163, Pl. XIII, tigs. 3a-d. 18st: Fourth Ann. Rept. U. S. Geol. Snrv. 1. 28!, PI. XXXY, tigs.!-11. Whitfield, 1s80: Geol. Black Hills Dakota, 1. 348, Pl. III, tigs. 8-12.

Specimens referable to this small and somewhat obscure species were collected from almost every locality with Rihymchomella gmathophora and on northeast spur of peak west of moutl of Conlter Creek; west end of ridge sontheast of Mink Creek; Mount Sheridan; lower limestone on Fawn Creek plateau; east end of northeast sjur from Signal Peak; saddle in ridge west of south head of Gardiner. 


\section{Ostrind BNGLLMANN Meek.}

Ostrea enyelmumi Meek, 1860: Proc. Acad. Nat. Sci. Phili., 1. 311. 18ifi: Simpson's lept. Expl. (ireat Basin, U tah, p. 355, Pl. III, fig. 6. Meek and Hayden, 1865: Paliont. Upper Missouri, p. 73, figs. A, B. White, 1884: Fourth Aun. Rejt. U. S. Gieol. Surv., p. 2s!, Pl. XXXIV, figs. 3, 4.

$\Lambda$ few fiaments and immatme specinens of this species were obtained near the head of drainage of northeast valley of Fan Creek and top of hill 3 miles southeast of Giarel Perak.

\section{Griphia planoconvexa Whitfield.}

PI. LXXII, tigs. 9 and 10.

Gryphere planoconrex, Whitfield 1856: Ludlow's Iiept. Iieconnaissance from Carroll, Montana, to Yellowstone Park, l. 142, Pl. II, tigs. 9 aud 10.

Shell of medium size, subcircular in outline; attached valve moderately convex with rather prominent beak, and in most specimens with an obscure shallow furrow which separates a rather broad triangular lobe from the body of the shell; upper valve varying fiom nearly flat to deeply concave; surface marked only by lines of growth and inegular concentric undulations. The cartilage pit is very broad and shallow.

An arerage specimen measures $57 \mathrm{~mm}$. in length, $50 \mathrm{~mm}$. in height, and $27 \mathrm{~mm}$. in thickness of the two valves mited.

This form was mentioned by Meek" as "Gryphaea, a small species of the form of $G$. dilatata." It also resembles some varieties of the Upper Cretaceous $G$. vesicularis and Ostrea putinu. Whitfield's type, from the Bridger Momtains, Montana, is somewhat more convex than any of oul specimens, and the figure does not show any furrow or lobe, but I have no doubt that it is the same variable species.

The specimens figured are from near lower canyon of Yellowstone River, collected by Dr. A. C. Peale, and ridge soutliwest of second crossing of Snake River, collected by Mr. WT. H. Weed. It was also obtained on north slope of ridge north of Gray Mountain; on divide at head of Farn Creek; ridge west of soutl branch of headwaters of Gardiner, and near Snake River 3 miles west of mouth of Coulter Creek.

${ }^{1}$ Aun. Rept. U. S. Geol. Surv. Terr. for 1872, p. 472. 
Gryphea calceola rar. nebrascensis Meek and Hayden.

Pl. LXXII, figs. $\overline{5}-\bar{\imath}$.

Gryphere calceola var. nebrascensis Meek and Hayden, 1861: Proc. Acad. Nat. Sci. Phila., p. 437. 1865: Palieont, Upper Missouri, p. 74, Pl. Ill, figs. 11t-e and figs. A-E on p. 75. Whitfield, 1850: Geol. Black Hills Dakota, p. 349, Pl. 1II, figs. 13-16. White, 1884: Fourth Ann. Riept. U. S. Geol. Surv., p. 290, PI. XXXV, figs. $1-5$.

This is one of the most abmdant species in the lower fossiliferous zone of the Yellowstone National Park Jurassic, occurring in the collection from south slope of ridge sonth of Gray Mountain; south end of northeast spur of Signal Peak; east side of Fan Creek Pass; hear of north fork of Fawn Creek; sardle in ridge west of south branch headwaters of Gardiner; sumnit of wagon road between Sentinel Butte and Terrace Mountain, 1 mile from head of Swan Lake Valley; hills west of Snake River, 4 miles south of second crossing; on north side of old road to liammoth Hot Springs, and slopes of Mount Sheridan.

The species was originally described from the Wind River Mountains and from the Black Hills, though the specinems from the latter locality are all very small. Similar small specimens, howerer, are rery abundant in the Park collections.

\section{Lina chanabarensis 11 . sp.}

PI. LXXII, fig. $S$.

Shell small, obliquely elongate oval in outline; beaks large and promiwent; hinge line short, the triangular ears being small and inconspicuous; anterior side straight or slightly concave; josterior side broally convex and prominent; surface marked by lines of gruwtl and by about twenty prominent rounded radiating ribs, which are not quite equal in breadth to the spaces between them.

The species is represented by only two right valves, the larger of which is figured. It measures $16 \mathrm{~mm}$. in its greatest dimension, obliquely downward and forward from the beak, and $10 \mathrm{~mm}$. across the middle of the shell at right angles to that line: ('onvexity about $4 \mathrm{~mm}$.

No American .Jurassic species has been described with which this should be compared, except, perhaps, the form from Sigutlat Lake, British Columbia, referred by Whiteaves to Lima duplacuta Sowerby, from which 
Lima cinnabarensis is distinguished by its simple equal ribs. It has more resemblane to the Cretacents Lima utahensis of the Colonado formation.

Locality: Cinnabar Mountain, Montana, where it is associated with Pleuromya subcompressen, I'holedomye lingi, Trigoniu montmaensis, etc.

\section{Genum CAMPTONECTES (Agassiz) Meek.}

Shells belonging to this genus are very abundant in the Jurassie of the Rocky Inountain region. In Yellowstone National Park almost erery Jurasic locality has yielder specimens, but in many cases they are fragmentary or mere casts that can not be assigned to species with any confidence. Five Anerican Jurassic species have been described, of which three at least are sufficiently well characterized to be easily distinguished when good specimens are examined. These are Camptonectes bellistriatus (to which a new variety is added below), C. platessiformis, and C. stygins.

The types of C. extemuatus are casts in sandstone that show neither sculpture nor the forms of the ears. It may be a distinet species, but it is more probable that it is either the young of $C$. bellistrictus or the form afterwards named $C$. peitemuistriatus by Hall and Whitfield. I do not feel quite certain that the latter is distinct from C. Lellistriatus, young specinens of which when slightly exfoliated would be very similar; but in the present collection there are many specimens that can be most conveniently referred to $C$. pertemuistriatus, and the name is therefore retained. All of the species mentioned excepting $C$. stygins are represented in these collections.

Camptonectes beluistriatus Meek.

Pl. LXXII, fig. 12.

Pecten bellistriata Meek, 1860 : Proc. Acad. Nat. Sei. Phila., 1) 311.

Camptonectes bellistriatus Meck and Hayden, 1S65: Palæont. Upper Missouri, p. 75, figs. A-D. Meek. 1876: Simpson's Rept. Expl. Great Basin, Utah, p. 356, Pl. III, figs. 3a-d. Ilall and Whitfield, 1 S77: Rept. U. S. Geol. Expl. 40th Parallel, Vol. IV, Pt. II, 1. 289, Pl. VII, fig. 13. Whitlield, 18s0: Geol. Black Hills Dakota, p. 351, Pl. IV, figs. 6-11.

?. Camptonectes cxtenuatus (M. and H.) Hall and Whitfield, 1S77: Rept. U. S. Geol. Expl. 40th Parallel, Vol. IV, Pt. II, p. 290, Pl. VII, fig. 18.

Imperfect specimens that appear from general form and details of sculpture to agree with this well-known species were collected at head of Fawn Creek, upper bed; divide between Fawn Creek and Gallatin Valley; 
south slope of ridge south of Gray Mountain; saldle in ridge west of south branch of headwaters of Gardiner; north side of Norris road pass; hill southwest of second "rossing of Snake River; west end of ridge southeast of month of Mink Creek, and 1 mile from hearl of Swan Lake Valley, on nortl side of road to Mammoth Hot Springs.

As supplemental to the published descriptions, it may be stated that the left valve is considerably more convex than the right and that both valves have the same sculpture. The smooth right valve figured by Whitfield $^{1}$ is either exfoliated or, possibly, another species. The anterior ear in that figure is different in form from that of $C$. bellistriatus, as may be seen on comparison with our figure of a specimen identified by Meek from the Bighorn Mountains.

The small specimen figured by IIall and Whitfield as C. extemutus is an immature left valve of this species or of C.pertemistriatus.

Camptonectes 13ellistriatus var. instans 11. var.

Pl. LXXII, fig. 13.

This variety, as far an known, is smaller than the typical form of the species, from which it differs in laving the radiating, impressed, punctate lines less closely arranged and consequently fewer in number, and it also differs in the outlines of the ears. The anterior ear is comparatively broader, with a narrower and deeper byssal notel, and the posterior ear is somewlat smaller and slightly less oblique. Left valve of this variety unknown.

The specimen figured, which is from near the somrce of Gardiner River, has the following dimensions: Height, $38 \mathrm{~mm}$.; greatest length, 38 mm.; length of linge line, $19 \mathrm{~mm}$.

The variety has also been collected east of Small Lake, head of Fawn Creek, and in north wall of Fawn Creek.

Camptonectes pertenuistriatus Hall and Whitfield.

Pl. LXXII, fig. 11.

Camptonectes pertenuistriutus Hall and Whitfield, 1877: Rept. U. S. Geol. Expl. 40th Parallel, Vol. IV, Pt. II, p. 291, Pl. VII, fig. 17.

Cf. Camptonectes extenuutus Meek and Hayden, 1865: Palizont. Upper Missouri, p. 78, Pl. III, tig. 6.

The original type in the National Inseum is a young individual, 
slightly flattened by pressure and somewhat exfoliated. The radiating stria are barely visible unler a lens, and they are considerably exagrgerated in the original enlinged figrure. It differs firom typical examples of $C$. bellistriutus in its more slender form and smoother surface, the radiating striae being almost olsolete, thongh it is sometimes difficult to determine whether this is a natural feature or due to exfoliation. The doubt as to its identity with $C$. extenuatus has alrealy been mentioned.

In the Park it is most common in the upper fossiliferons band of the Jura, occurning on Gardiner River southeast of Electrie Peak; soutl slope of ridge soutl of Gray Mountain; saddle west of south head of Gardiner; west of Snake River, 4 miles sonth of second crossing; top of hill 3 miles southeast of Gravel Peak, northwest of Flat Mountain; ridge south of Mammoth Hot Springs, on main terrace; east slope of Mount Sheridan, and ridge soutlı of Mount Sheridin.

\section{Camptonectes platessiforyis White.}

Cumptonectes platessiformis White, 1876: Geol. Uinta Mountains, p. 93. 1880: Ann. Rept. U. S. Geol. Surv. Terr. for 1s78, p. 143, Pl. XXX VII, fig. $5 a$.

Camptoneetes extenuatus (M. and H.) Whittield, 1880: Geol. Black Hills Dakota, p. 353, Pl. IV, fig. 4.

Not Camptonectes? extenuatus Meek and Hayden, 1865: Palient. Upper Missouri, 1). 78 , Pl. III, tig. 6 .

This species is more slender than C. bellistriatus, the height from beak to base being considerably greater than the length, and it is apparently somewhat nore convex. The seulpture is coarser than in the typical form of that species, but the radiating lines are somewhat more closely arranged than in the variety tistans. The most important difference, however, is in the ears, which in the left valve are very lirge and have the form of rightangled triangles, so that the hinge line is almost as long as the greatest length of the shell. No good specimens of the right valve have been seen, but an internal cast from the lower canyon of the Yellowstone shows that it has a deep byssal sinus, and that the posterior ear is nearly rectangular, instead of having the very oblique form seen in C. bellistriatus. From $C$. pertemistriatus this species may be easily distinguished by its much coarser sculpture and by differences in ontline.

The specimen figured by Whitfield in the Geology of the Black Hills as $C$. extenuatus is clearly identical with $C$. platessiformis, as may be seen 
by comparing the two specimens. After studying the types of $C$. cxtematus I ran see no reason for referring to it this coasely sculptured form, which also differ's in outline. As lias already been stated, the types of C. extemuatus are unrecognizable casts in sandstone, showing neither the sculpture nor the form of the ears. It is probably either C. bellistriatus or C. pertenuistriatus, and in consideration of this doubt I prefer to use the later name, $C$. pertemistriatus, because it is better characterized.

The figured specimens of $C$. platessiformis above referred to came from the south hase of Aquarius Plateau, southern Utal, and east of Belle Fonrche River, near Bear Lodge, Black Hills. Those in the present collection were obtained near the head of sontheastern valley of Fan Creek; north side of Fan Creek Pass; top of hill 3 niles sontheast of Gravel Peak, and near the lower cunyon of the Yellowstone.

\section{Aricula (GXYTOMA) WrOMINGETsis $11 . \mathrm{sp}$.}

Pteria (Oxytoma) munsteri (Bronn) Meek and Hayden, 1865̃: Palzont. Upper Missonri, 1) S0, tigs. $a-b$.

I'teria or Aricula mucronatu Mleek and Hayden, 1865: Ibidl, p. S1, suggested name for the species in case it proves rlistinct.

Ariculu (Oxytoma) mucronata (M. and H.) Whitfield, 1S80): Geol. Black Hills Dakota, p. $35 \overline{7}, \mathrm{Pl} .1 \mathrm{Y}$, tigs. $1, \ddot{ }$.

Not Oxytoma mucronta (Meek) Whiteaves, 18st: Geol. Sarv. Canada, Mes. Foss., Vol. I, pl. 23s and 251, Pl. XXXI, fig. 9, Pl. XXxill, tig. 6.

Not Avieula mucronute Gabb, 1S64: Palieont. California, Vol. I, 1. 30, Pl. V, tig. $2 \pi$.

A new name is proposed for this fairly well known species for the following reasons. In Meek and Hayden's original work it was provisionally referrer to A. musteri, with the statement that it would probably prove to be distinet, and if so it shonld be named Pteria mucronata. A comparison with figures of $A$. mumsteri shows that they are not identical in either form or sculpture, and latel authors have recognized the American fossil as a distinct species under Meek and Hayden's snggested name. This name call not be used for it, however, because it was previously applied by Gabh to an entirely different species from the Triassic of California.

The fossil from the Lower Cretaceons of Queen Charlotte Islands referred to this species by Whiteares seems to me to be specifically distinct.

The collections from the Yellowstone National Park contain only two small immature specimens from the foothills at the base of north slope of 
Flat Mountain. It was originally described from Wind River Valley, Wyoming, and it also occuss in the Black Hills. The type is Meek's figured specimen, No. 1893, United States National $M$ Husenm collection.

\section{I'seudomonotis curta (Hall)?}

A ricula (.) custa Hall, 1852: Stansbury's Rept. Gt. Salt Lake Exp., 1). 412, PI. IV, figs. $1 a, b$.

Wumicrotis curtu (1lall) Meek and IIayden, 1865: Palaront. Upper Missouri, p. S1, Pl. 11I, figs. 10u-ll.

Pseutomonotis (Eumicrotis) curta (Hall) Whitfield, 1850: Geol. Blaek Hills Dakota, p. 35.t, I'l. Il I, tigs. $20-25$.

A single inperfect specimen from summit of ridge between Red and Basin creeks is doubtfully referred to this species. The hinge and umbonal region are wanting, and the identification is based simply on general form and surface sculpture of the tiagment. The species is abundant in the Jurassic of the Black Hills. 'The original spelling of the specific name custu seems to hare been a typographical eror that was corrected by Meek, and the form curta las since been followed.

\section{Gervillia montanaensis Meek.}

Gervillia montanuensis Meek, 1s73: Amn, Rept. U. S. Geol. Surv. Terr. for 1572, p. 472. White, 1880: Ilem for 1878,1 . 145, Pl. Xxrvil, tigs. $1 a$ and $b$.

Distinguished by its large size and its long posterior wing. The types are from near the lower canyon of the Yellowstone, and it has been collected on divide between Fawn Creek and Gallatin Valley; east side of Fan Creek Pass; Cinnabar Monntain, and summit of ridge between Red and Basin creeks, near Sheridan Peak.

\section{Gerviliaia sj).}

A smaller and much more slender species of Gerrillia is represented by fragments from east end of northeast spur from Signal T'eak, stream ber west of Quadrant, jr., and saddle in ridge west of sonth head of Gardiner River.

\section{Moniola submbricata Meek.}

Modiola (T'ulsella) sulimbricata Meek, 1873: Anu. Rept. U. S. Geol. Surv. Terr. for 1872 , p. 472.

Volsella subimbricatı White, 1850: Idem for 1878, p. 145, I'l. XxxVI1, figs. 2a-c.

This species seems to be widespread, but not very abundant at any 
place. A few specimens were obtained on divide between Fawn Creek and Gallatin Valley; saddle in ridge west of south head of Gardiner; litls west of Suake River 4 miles south of second crossing; top of hill 3 miles sontheast of Gravel Peak; ridge between Basin and Red creeks, and slopes of Mount Sheridan.

\section{Pinna kingi Meek.}

Pinu kingi Meek, 1877: U. S. Geol. Expl. 40th Parallel, Vol. IV, Pt. I, p. 131, Pl. XII, tigs. $9,9 \%$.

A few fingments of this species were obtained in ridge west of sonth head of Gardiner, and on north side of old road between Terrace Momntain and Sentinel Butte. The species was described from IVeber Canyon, Utah.

\section{Cucullea haguei Meek.}

PI. LXXIIJ, fig. 1.

Cucullere hrguei Meek, 1877; U. S. Geol. Expl. 40th Parallel, Vol. IV, Pt. I, P. 134, Pl. XII, figs. I $", b$.

The type of the species came firom Weber Canyon, Wasatch Range, Utah. In ILeek's figure the radiating stria of the body of the shell are somewhat exaggerated and the concentric lines are not given quite as much prominence as they nsmally lave. On most of the Yellowstone National Park specimens the radiating lines are prominent and widely separated on the anterior third, and are numerous on the umbones, but all excepting the anterior ones usually fade ont before reaching the middle of the shell. The fine, regnlar, closely arranged roncentric lines cover the whole valve.

Some of the casts show the horizontal teeth at both ends of the hinge line characteristic of Cucullax, but there are no traces of the ridge bordering the posterior muscular impression that is seen in typical species of that genus.

The specimen figured is from a locality near Sentinel Butte. The species is also represented in the collection from north side of Fan Creek Pass; saddle in ridge west of south head of Gardiner River: summit of wagon road between Sentinel Butte and Terrace Mountain; Cinnabar Mountain, and west side of Snake River north of Berry Creek.

\section{Trigonda hMERICANa Meek.}

Trigoniu americumu Meek, 1873: Anı. Rept. U. S. Geol. Surv. Tern. for 1872, \}. 472. White, 1880: Idem for I878, P. 148, Pl. XXXVIII. tig. 1 a, $b$.

A single specimen fiom ridge northwest of second arossing of snake 
liver. 'l'he type anne from spring Canyom and lower canyon of the Yellowstone, Montani.

Trigionta elegantissima Meek.

P. LXXIII, tig. 2.

Trigoniu flequntissima Mleek, 1873: Anu. liept. U. S. Geol. Surv. Terr. for 1872, p. 474.

Shell small, subtrigonal in outline, moderately convex, with prominent, acute, recurved beaks; prsterior umbonal ridge prominent, angular, and "urved; anterior end broally rounded; posterior end subangular below at the extrenity of the umbonal ridge and forming a convex slope to the beak abore: escutcheon not distinctly marked; posterior area depressed and bearing mmerous equal, fine, radiating lines; remainder of surface with regular, closely aranged, small concentric ribs that show a tendency to bend downward toward the fiont.

Length of figured specimen, $21 \mathrm{~mm}$; height, $14 \mathrm{~mm}$.; convexity of single valve, $4 \mathrm{~mm}$.

This species is closely related to $T$. americana, from which it differs in ontline, and more especially in having mush smaller and more numerous concentric ribs. In specimens of $T$. americana no larger than the type of this species the spaces between the ribs are at least a millimeter wide.

Meek's original description, given in a footnote to the list of fossils from Devils Slicle, Cimmabar Mountain, Montana, is as follows: "A small species of the type of $T$. costata, but having the concentric or horizontal costre on the sides of the valves very delicate, closely arranged, and but slightly larger than the radiating ones on the posterior dorsal region, or corselet. 'The ralres are rather' compressed, about one-fourth longer' than wide, and have the posterior umbonal slopes acutely angular:" A single valve corresponding to this description, but not labeled, is in the original collection from Cinnabar Mountain studied by Meek, and this is probably his type. The specimen figured was collected at the same place by Mr. IV. H. Weed.

\section{Trigonia montanaensis Meek.}

Trigonia montannensis Meek, 1873: Ann. Rept. U. S. GeoJ. Surv. Terr. for 1S72, p. 472. White, 1880: Idem for 1878, p. 247, Pl. XXXVII, fig. $2 a$.

The types are from the locality near the lower canyon of the Yellowstone. A few specimens were obtained 1 mile from Swan Lake Valley, 
nortl of old road to Nammoth Hct Springs; Cimnabar Mountain; saddle in ridge west of south branch of Gardiner River; south slope of ridge south of Gray Mountain, and east end of northast spur from Signal Peak.

\section{Astarte meeki 11. sp.}

\section{Pl. LXXII, figs. 3-5.}

Shell of medium size, subcircular in outline, moderately convex; beaks prominent, median in position; dorsal margin descending rapidly from the beaks, with a convex curve iehini and slightly excavated in front; anterior, posterior, and ventral margins forming a regular curve; surface marked by numerous fine, regular, concentric coste. Margin crenulate within.

One of the types, an average-sized specimen, has the following dimensions: Length, $16 \mathrm{~mm}$.; height, $14 \mathrm{~mm}$.; convexity of single valve, about 3 mm. The largest specimen in the collection is $23 \mathrm{~mm}$. in lengtlı and 20 mm. in height. Associated with these there are several more elongated shells, one of which is figured, that I was at first inelined to regard as at distinct species, but it is probable that the difference in form is due to distortion by pressure.

Compared with Asterte preckedi White this species is proportionally somewhat more elongate, less convex, and the concentric seulpture is much finer and more regular. The species was first noticed by Meek, who mentioned it as "Astarte (?)" in a list of Jurassic fossils collected by Dr. Peale near the lower canyon of the Yellowstone. It occurs in the enllections from head of Gardiner, Sentinel Butte, Cimmabar Mountain, west side of Snake River nortlı of Berry Creek.

\section{Astarte sp.}

Another species of Astarte is represented by fragmentary specimens which show the specific features fairly well, but as they are not sufficient for a good illustration the species lias not been named. It is a very elongate form, with strong, regular, concentric ridges. In its younger stages, as shown by the lines of growth, it is a short subtriangular form, but later it rapidly increases in lengtl and the posterior end becomes obliquely truncate. It occurs on the divide at head of Fawn Creek, Sentinel Butte, Cimabar Mountain, and near lower canyon of Yellowstone River. 


\section{Tancredia? KNowltoni n. sp.}

Pl. LXXIII, tig. 1i.

Shell small, obliquely suborate in outline; beaks prominent, submedian; dorsil margin behind the beaks descending lapidly to the broudly romelerl posterior end, which is most prominent below; anterior end rounded, nost prominent above, somewhat more narow than the posterior end; ventral margin gently convex; posterior umbonal ridge with a tendency to become angular; surface marked by fine lines of growth.

Length, $15 \mathrm{~mm}$; height, $12 \mathrm{~mm}$; convexity of single valve, abont $2 \mathrm{~mm}$.

The hinge is unknown and the generic reference is based merely on external form. The species seems to be congeneric with the species from the Black Hills referred to Tancredia by Whitfield, though the difference in outline prevents its reference to any of his species.

From shales on wortl side of road near Sentinel Butte, collected by Prof. F. H. Knowlton.

\section{Protocardia shumardi Meek and Hayden.}

Cardium shumardi Meek and Hayden, 1860: Proc. Acad. Nat. Sci. Phila., p. 182.

Protocurdia shumardi Meek and Hayden, 1865: Palxont. Upper Missouri, 1). 98, figs. $\Delta$ and $B$ in text.

The collection contains several specimens of a small Protocardia that seem to belong to this Black Hills Jurassic species. 'They have the ontlines of that species, though some of the shells are nearly twice as large as the figure of the type. 'The body of the valve is markerl only by fine lines of growth, and the posterior area bears about eight to twelve radiating ribs that are broader than the interspaces.

Collected on the divide between Fawn Creek and Gallatin Valley; head of north fork of Fawn Creek; Sentinel Butte, and Cinnabar Mountain.

\section{Cyprina? Cinnabaremsis $11 . \mathrm{sp}$.}

Pl. LXXIII, figs. 7 and 8.

Shell of medium size, moderately convex, subcircular in outline, with prominent submedian beaks; dorsal margin excavated in front of the beaks, gently sloping behind, and in both cases passing gradually into the rounded ends; posterior end in some individuals slightly straightened, so as to become 
almost vertically subtruncate; ventral margin broadly rounded; surface sculpture unknown. There is a very obscure posterior umboial ridge, and the muscular and pallial impressions are not clearly shown on the cast.

One cast showing impression of part of hinge has three strong cardinal teeth, of which the posterior one is very long and oblique. The specimen is not in condition to show whether lateral tecth are present.

Height of an a verage shell, $28 \mathrm{~mm}$.: length, $32 \mathrm{~mm}$.; convexity of two valves uniterl, $15 \mathrm{~mm}$. The largest specimens in the collection have the corresponding dimensions alout one-fifth greater.

The only described American .Jurassic species with which this need be compared is Dosinia jurassica Whitfield, which is a smaller, more convex species, with less prominent beaks and slight differences in ontline. It is not probable that the two species are closely related.

Collected from Cimnabar Mountain; divide between Fawn Creek and Gallatin Valley; east end of northeast spur from Signal Peak; saddle in ridge west of soutl head of Gardiner River: head of Fawn Creek northeast of Momment Peak, and ridge between Basin and led creeks, near Sheridan Peak.

\section{Crprina? idmingsi 11. sp.}

\section{P'I. LXXIII, fig. 9.}

Shell small, convex, suboval in outline; beaks ratluer prominent, sulbmedian; dorsal nargin sloping gently from the beak to the posterion end, slightly excalvated in front of the heak and descending rather more rapidly; anterior and posterior ends broadly and ahost equally rounded; rentral margin gently convex; posterior umbonal slope with a subangular ridge extending from the beak to the postero-basal margin; surface with obscure lines of growth and a few irregular concentric undulations near the free margin.

Lengtl of largest specimen, $24.5 \mathrm{~mm}$.; height, $18.5 \mathrm{~mm}$; convexity of botlı values, about $12 \mathrm{nnm}$.

This species differs from C. cinnabarensis in its smaller size, proportionally greater convexity, more elongate form, narrower posterior end, less prominent heaks, and more distinct umbonal ridge. Its generic position is doubtful, an its hinge characters are entirely miknown.

From sacldle at head of Fawn Creek northeast of MLonument Peak, 
and (the type) fimm west end of ridge somtleast of month of Wink Creek, where it was collected by Protessor Idding's.

\section{Crilicarila? haguli n. sp.}

P1. LXXIII, figs. 11-13.

Shell large, inflated, subquadrate in outline; beaks rery prominent, strongly curver inward and forward, approximate, and projecting far beyond the hinge line; posterior umbonal slope with a prominent angular ridge descending from the beak to the postero-basal angle and dividing the surface of the shell into two distinct areas, of which the posterior is obliquely flattened, while the rest of the shell is pretty evenly convex; dursal margin, exclusive of beaks, gently descending behind and excavated in front; anterior end broadly rounded; posterior end obliquely truncate; ventral margin almost straight; surface sculpture not known, but probably consisting only of lines of growtl.

The two figured specimens, both of which are probably somewhat distorted in different directions, give the following measurements:

\begin{tabular}{|c|c|c|}
\hline Length. & Height. & $\begin{array}{c}\text { Convexity } \\
\text { of bith } \\
\text { valies. }\end{array}$ \\
\hline$m m$. & $m m$. & $m m$. \\
52 & 49 & 40 \\
65 & 52 & 40 \\
\hline
\end{tabular}

The shorter specimen is more nearly of normal proportions than the other.

The species is represented by about twenty-five specimens, all of which are internal casts, and, as the details of the hinge have not been satisfactorily made out, the generic reference is only provisimal. Inpressions of a part of the hinge show the presence of two or three strong cardinal teeth and make it reasombly certain that the shell belongs to the Cyprinidæ. The casts also show the adductor muscular inpressions and the pallial line. The anterior scar is rather large, semilunar, and (on the cast) much elerated, while the posterior one is somewhat smaller and scarcely at all elevated.

There are no American species with which this need be compared, but Cypricartiu bethonica d'Orb., as figured by Morris and Lycett in Mollusca 
of the Great Oolite, Pt. II, p. 75, Pl. VII, fig. 8, seems to be a closely related form.

It occurs at east end of northeast spur from Signal Peak; saddle in ridge west of scintl branch of head of Gardiner; liead of Fawn Creek northeast of Monument Peak and Cimnabar Monntain. Specimens collected by Dr. Peale at Devils Slide, Cimnabar Momntain, were labeled and listed by Meek is "Cucullae."

\section{Pholadoniya kingi Mleek.}

\section{Pl. LXXIV, figs. 1-3.}

Pholadomye lingi Meek, 1873: Ann. Rept. U. S. Geol. Surv. Terr. for 1872, 1. 473. White, 1580: Ilem for 1878, p. 150, Pl. XXXVII, figs. " and $b$.

This abundant species varies considerably in seulpture, and the fact that almost every specinen in the collection is distorted in varions ways by pressure canses it to appear much more variable in both form and sculpture than it really in.

The type specimen figured hy White, which is itself somewhat distorted, has eleven radiating costae on the central region of the ralve, thongh they are not quite so prominent as they are represented in the drawing above referred to. Most of the specimens from the Park have fewer (usmally not more than eiglit or nine) costre, and on flattened specinens these are sometimes barely visible.

Pholudomyue nevarlanu Gabb, fiom the Lials of Volcano, Nevada, is evidently a related species, and Professor Hyatt ${ }^{2}$ has treated $P$. Kingi as a synonym of it. Compared with Gablis figure and lescription, however, P. Tingi is smaller and more slender and lass the beaks farther from the anterior end. The costre also are differently aranged. Professor Hyatt has compared for me specimens of the Iellowstone form with those from California referred to $I$ '. nevaduna, and he is now inclined to regard them as distinct. It is at least safer to keep them separate mil direct comparison can be nade with Gabb's type, which seems to be lost, or with specinems from the original locality.

The species occur in the collection from divide between Fawn Creek and Gallatin Valley; east end of northeast spur from signal Peak; saddle 
in ridge west of south branch head of Gardiner; heal of Fawn Creek northeast of Monument Peak, Cinnabir Mountain.

PHoladomy inaquiplicata $\mathrm{n}$. sp.

Pl. LXXIY, fig. t.

Cf. Pholatomyu multilineata Gabb, 1869: Am. Jour. Couchology, Vol. V, p. 10, Pl. V, tig. (i.

Shell small, rentricose, elongate suboral in outline, with prominent approximate beaks situated near the anterior end; anterior and rentral margins forming a nearly regular curve, which is most prominent a little behind the middle; posterior end rounded, slightly subtruncate above; surface marked by about twenty radiating coste that vary both in size and in distance from each other and cover the whole valve, exeepting a very small space in front and a larger one in the postero-dorsal region.

Length, $39 \mathrm{~mm}$.; height, $31 \mathrm{~mm}$; convexity of both valves, $24 \mathrm{~mm}$.

Pholadomya multilineata, which is associated with $P$. nevadana, seems to be about as closely related to this species as $P$. nevadana is to $P$. lingi. $P$. multilineata is larger than $P$. incequiplicata, has more numerons costre (about thirty, according to Gabb), and is more angular at the posterior end, besides differing somewhat in other details of outline.

Only a few specimens were collected on divide between Fawn Creek and Gallatin Valley, where it is associated with $P$. kingi.

\section{Honomya gallatinensis n. sp.}

Pl. LXXIV, figs. 6 and 7.

Shell of medium size, oblong subcylindrical; beaks rather prominent, incurved, approximate, and sitmated near the anterior end of the shell; dorsal margin in front of the beaks declining rapidly to the broadly rounded anterior end, which passes by a gentle curve into the nearly straight dorsal margiu. Surface marked by lines of growth and irregular concentric undulations. The posterior end gapes slightly.

Length, $85 \mathrm{~mm}$; height, $42 \mathrm{~mm}$; convexity of both valves, $36 \mathrm{~mm}$.

This species apparently belongs to the subgenus Homonya as defined in Zittel's Handbuch der Palæontologie, but Fischer does not recognize the group and divides the species that have been referred to it between Areomya and Pleuromya. The specimens from Yellowstone National Park do not MON XXXII, P'T $11-40$ 
show the structure of the hinge nor other details of the interior that are used as generic characters.

The type is from the divide between Fawn Creek and Gallatin Valley. The species is represented by nine other examples from Fan Creek Pass, head of Gardiner; saddle in ridge west of south branch of head of Gardiner; head of Fawn Creek northeast of Monument Peak, and Cinnabar Mountain.

\section{Pleuromia subconpressa Meek.}

PJ. LXXIV, figs. 8-11.

Myacites (Pleuromya) subcompressa Meek, 1873: Ann. Rept. U. S. Geol. Surr. Terr. for 1872, p. 472. 1877: U. S. Geol. Expl. 40th Parallel, Vol. IV, Pt. I, p. 136, Pl. XII, figs. 6, 6a.

Mynacites subcompressus (Meek) White, 1850: Ann. Rept. U. S. Geol. Snrv. Terr. for 1878, p. 151, Pl. XXXVIII, figs. 5a-e.

This most abundant species, which was originally described from Weber Canyon, Utal, is represented by several hundred specimens, from every Jurassic locality in the Park region at which fossils were collected from the lower argillaceous limestone and shale. Almost every specimen is more or less distorted, and every variation in form is seen that a thin-shelled elongate species can be made to assume when embedded in soft strata and subjected to pressure. In addition to these accidental distortions, it is evident that the species is naturally quite variable in both form and sculpture, some individuals being nearly smooth while others are marked by rather strong concentric plications. Extreme variations approach the plicate Pleuromya welerensis Meek on the one hand and the nearly smooth elongate Pleuromya nevotoni Whitfield on the other: The extent and directions of variation are fairly well shown by White's figures above cited, though some of these forms are slightly modified by pressure.

Single specimens representing three or four extreme varieties could be selected that if taken alone might be regarded as distinct species, but when the attempt is made to classify the entire large collection coming from practically one horizon and a limited area; it is found that none of the distinctions will hold good.

The specimens figured show sone of the principal variations in form, and were selected from those apparently least modified by accidental distortion. They are from Fan Creek Pass, divide between Fawn Creek and 
Gallatin Valley, hills west of Snake River 4 miles soutlı of secoud crossing, aud Cinnabar Mountain.

The general custom of recent authors is followed in using the name Pleuromya instead of Myacites.

\section{Thracia weedi il. sp.}

PI. LXXV. figs. 1-3.

Shell of medium size, thin, compressed, elongate, subelliptical in outline; beaks rather prominent, submedian; dorsal margin sloping rather rapidly and almost equally before and behind the beaks; anterior end broadly rounded, most prominent below; posterior end subtruncate; ventral margin slightly convex, somewhat sinuous toward the posterior end; posterior umbonal ridge narrow and sharply defined; surface marked by irregular concentric undulations and by numerous fine lines of growth.

The specimens selected for illustration, which are of average size, have the following dimensions, respectively:

\begin{tabular}{|c|c|c|}
\hline Length. & Height. & $\begin{array}{c}\text { Conrexity } \\
\text { of both } \\
\text { ralres. }\end{array}$ \\
\cline { 1 - 2 }$m m$. & $m m$. & $m m$. \\
29 & 19 & 4 \\
26 & 18 & 5 \\
34 & 26 & 5 \\
\hline
\end{tabular}

All the examples in the collection have suffered more or less accidental compression and distortion in the rocks, so that they show considerable variation in outline, and probably on account of this compression they do not show the posterior gape that they should have if they really belong to the genus Thracia.

The species differs too much in outline and proportions from the two forms of Thracia (?) described from the Jurassic of the Black Hills to require detailed comparison.

The types are from stream bed west of Little Quadrant Mountain and from saddle in ridge west of south head of Gardiner River. Other specimens were collected at head of Fawn Creek, northeast of Monument Peak. 


\section{Thracia? montanaensis (Meek)?}

Pl. LXXIII, fig. 10.

Corimya montanaensis Meek, 1873: Ann. Rept. U. S. Geol. Surv. Terr. for 1872, p. 474.

Shell small, subquadrate in outline, convex, with prominent beak situated a little in advance of the middle; dorsal margin nearly straight, declining slightly on each side of the beak; anterior end broadly rounded, forming almost a right angle with the dorsal margin above, and uniting with the convex ventral margin below by a regular curve; posterior end obliquely truncate; posterior umbonal ridge subangular and accompanied by a narrow depressed area or groove; surface marked by lines of growth.

Length, $17 \mathrm{~mm}$; height, $14 \mathrm{~mm}$; convexity of single valve, $4 \mathrm{~mm}$.

The above description is drawn from a single valve from "Devils Slide, Cimmabr Mountain, Yellowstone River," which may be the original type named by Meek in the report above referred to, though it was not labeled by him. It was named in a list of fossils from this locality, with a footnote saying that "This is very similar to some varieties of $C$. glabra Agassiz, but it is a smaller, proportionately shorter, and more convex shell, with the anterior margins just in front of the beak more excavated."

\section{Anatina (Cercomya) punctata il. sp.}

\section{Pl. LXXIV, fig 5 .}

Shell of medium size, not so slender as the typical forms of the subgenus; beak prominent, somewhat in advance of the middle of the shell, directed backward; dorsal margin almost straight and descending slightly in front of the beaks, concave behind; anterior end broadly rounded, subangular above; posterior end much more narrow and rounded, ventral margin slightly sinnous; surface of the shell divided into two distinct areas by a narrow well-defined groove that descends almost vertically from the beak to the ventral margin; anterior area marked by broad concentric ridges and sulcations and by very fine lines of growth, the latter continuing over the posterior area; middle third of the posterior area slightly more convex and prominent than the rest and bearing about nine distinct granular radiating lines. In addition to this sculpture, which is seen on internal casts, a mold of the exterior of the shell shows that the entire surface bears radiating lines of minute tubercles, which are most prominent on the posterior 
area, and give the punctate appearance that suggested the specific name, thongh it can liardly be considered a specific character, since it is common in this and related gencra.

The species is represented by three imperfect valves from the divide between Fawn Creek and Gallatin Valley, south slope of ridge sonth of Gray Momutain, and west side of Snake River north of Berry Creek. The specimen figured, which is from the second locality mentioned, measures $39 \mathrm{~mm}$. in length and $19 \mathrm{~mm}$. in height.

In the well-defined radiating lines of the posterior area this species resembles the Upper Cretaceous forms to which Conrad gave the name Anatimya.

\section{Anatina (Cercomya) sp.}

Another species of this genus is represented by a single specimen from the east side of Fan Creek Pass, which is too imperfect for illustration and full description. It is much larger than $A$. punctata, measming $76 \mathrm{~mm}$. in length, and it differs from that species in the outline of the anterior end and in the entire absence of radiating lines on the posterior area.

\section{GASTROPODA.}

\section{Neritina wyomingensis $11 . \mathrm{sp}$.}

\section{Pl. LXXV, figs. 4 and 5.}

Shell small, consisting of abont two and a half or three rapidly increasing volutions; spire very low and inconspicnous; last whorl slightly shouldered and forming about nine-tenths of the visible bulk of the shell; surface smooth, with rather distinct lines of growth near the aperture, which has the thin sharp outer lip and straight inner lip with broad flattened columella characteristic of the geuus. The inner lip is smooth, or nearly so, but the specimens are not in condition to show whether it bears minute denticulations.

Height of the type, $6 \mathrm{~mm}$.; greatest breadth, $6 \frac{1}{2} \mathrm{~mm}$.

This species has a superficial resemblance to Neritina? phaseolaris White from the Jurassic of Utah, but, besides slight differences in form, the colnmella in that species is not flattened and the inner lip is not straight, so that it has been referred to Lyosoma.

The only other described American Jurassic Neritina is N. nebrascensis 
M. and H., which is much larger and more slender in form, differing in all its details from this species, which is somewhat similar in form and size to Neritina pisum Meek from the Upper Cretaceons of Utal.

The type was collected by Prof. A. C. Gill about 3 miles southeast of Gravel Peak.

\section{Lysoma powelli White.}

Neritina powelli White, 1S76: Geol. Uinta Mountains, p. 110.

Lyosoma powelli White, 1880: Ann. Rept. U. S. Geol. Surv. Terr. for 1878, p. 153, Pl.

XXXVIII, figs. $6 a-d$.

One well-preserved specimen was obtained on saddle at head of Fawn Creek, northeast of Monument Peak, and another on ridge south of Mammoth Hot Springs, on main terrace. The species has not before been reported from any locality excepting at the mouth of Thistle Creek, Spanish Fork Canyon, Utah.

Botl Zittel and Fischer are inclined to make Lyosoma a synonym of Otostoma d'Archiac, an Upper Cretaceous subgenus of Nerita, but Lyosoma really has the thin imer lip without any callus or flattening of the columella, while the Cretaceous form has been shown to have the characteristics of Neritina in these respects.

\section{'Turritella sp.}

A single small specimen from 3 miles sontheast of Gravel Peak has the form of this genus, but is insufficient for specific description. It consists of six flattened whorls with channeled sutures.

\section{Natica? sp.}

A naticoid form is represented by imperfect internal casts from Fan Creek Pass, saddle west of south head of Gardiner, head of Fawn Creek northeast of Monument Peak, and near Sentinel Butte.

It is probably undescribed, being very much larger than Natica? lelia Hall and Whitfield, which is the only described naticoid shell from the Jurassic of this western interior region.

\section{CEPHALOPODA.}

\section{Oppelia? sp.}

Ammonites are rare in the Yellowstone National Park collection, and the few that were obtained are too fragmentary and badly preserved for accurate classification.

One species is represented by, two flattened specimens, about 3 inches 
in dianeter, from the diride between Fawn Creek and Gallatin Valley. This is a nearly smooth, discoid, involute form, with narrow umbilicus and rounded abdomen. The onter two-thirds of the body whorl appears to have been entirely smooth. On the other third the abdomen is crossed by small ribs, giving it almost a dentate ontline; and on earlier stages these ribs are relatively longer and more prominent, passing nearly halfway across the flanks of the shell. In general form and sculpture this species resembles Oppelia sulplicatella Vacek, ${ }^{1}$ from the Oolitic of Cap San Vigilio. The septa are not preserved.

Fragments of larger individuals that may belong to the same species were obtained on Fan Creek Pass, saddle in ridge west of south head of Gardiner, and from Cinnabar Monntain. They are less compressed than the specimens above described, but with the material at hand it is impossible to determine whether this difference is due to accidental distortion. Some of the fragments show strong plications on the abdomen. A large specimen, $S$ inches in diameter, from limestone on ridge south of Sheridan Peak, appears to be related to the forms above mentioned, though it is somewhat more involute, and is so much weathered that all the surface characters and the finer subdivisions of the septa have disappeared. The specimen is septate throughout. The septa appear not to have been very complex and the lateral saddles are very broad. It is possible that this specimen should be referred to Ammonites henryi MI. and H., which it somewhat resembles both in general form and in the septa.

\section{Perisphinctes sp.}

Collections obtained by Dr. Peale near the lower canyon of the Yellowstone contain fragments of two species of Ammonites that probably belong to Perisphinctes, judging from the sculpture. Fragments of one of these species were also obtained on saddle in ridge west of sonth head of Gardiner River.

Belemites densus Meek and Hayden.

Belemnites densus Meek and Hayden, 1858: Proc. Acad. Nat. Sci. Phila., p. 5s. 1S65: Paliont. Upper Missouri, p. 126, Pl. IV, figs. 10a-c; Pl. V, figs. 1a-i. Meek, 1876 : Simpson's Rept. Expl. Great Basin, Utah, p. 35s, Pl. III; figs. $4 a, b$. Whitfield, 1S80: Geol. Black Hills Dakota, p. 381, Pl. VI, figs. 15-19.

This species, which is abundant in the Jurassic of the Black Hills and

${ }^{1}$ Abhandl, K.-k. geol. Reichsaustalt, Vol. XII, p. 82, Pl. XI, figs. 1-5, 1886. 
various localities in Wyoming, is represented in the Yellowstone National Park collection by only a few specimens, from saddle in ridge west of south head of Gardiner; west of Snake River 4 miles south of second crossing and 3 miles south of mouth of Glade Creek.

\section{CRETACEOUS SPECIES. \\ DAKOTA (?) FORMATION. ${ }^{1}$}

\section{PELECY PODA.}

Unıo sp. undet.

Several casts of a small species of Unio were collected with the gastropods named below in Three Forks Valley, Montana, and on Fawn Creek Plateau. The species is doubtless new, but the material is insufficient for description.

\section{GASTROPODA.}

Goniobasis? pealei 11. sp.

Pl. LXXV, fig. 6.

Shell small, slender, eıongate, consisting of about eight convex whorls; apex of spire acute; upper third of each whorl slightly flattened, so that it is most prominent below the middle; suture linear, deeply impressed; surface nearly smooth, being marked only by fine lines of growth, and on some specimens by faint indications of spiral lines. The full form of the aperture is not shown on any of the specimens, but it appears to have been suboval and slightly produced in front. Shell apparently not umbilicated.

Length of an average specimen with eight whorls, $14 \mathrm{~mm}$.; breadth of borly whorl, $7 \mathrm{~mm}$.

This species is very doubtfully referred to Goniobasis, though it seems to be related to G. gracilenta Meek, from the Judith River beds. In general aspect and in the form of the whorls it resembles some recent species of Pomatiopsis, but the form of the aperture and the absence of an umbilicus separate it from that genus.

The specimen figured was collected by Dr. A. C. Peale in Three Forks 
Valley, Montana. Other examples were obtained in the Gallatin Range and at several points in the nortlwestern part of Yellowstone National Park from fresh-water beds of the Cretaceous section of that region.

Goniobasis? nerebescens 11. sp.

Pl. LAXY, fig. 7.

Shell of about the same length as the preceding, but more robust in form, consisting of only about five rapidly increasing convex whorls; surface nearly smooth, with fine lines of growth; other features, as far as known, the same as in G.? pealei.

Length of an average specimen, $13 \mathrm{~mm}$; breadth of body whorl, $7.5 \mathrm{~mm}$.

Nearly all the specimens are in the form of imperfect internal casts retaining portions of the shell, but of course not showing the generic features fully. It seems to be related to G.? pealei.

The type is from the same horizon as the preceding on Fawn Creek, and it occurs in this bed at several localities in that region.

$$
\begin{gathered}
\text { Amicola? CRETACEA n. sp. } \\
\text { Pl. LAXV, fig. } 8 \text {. }
\end{gathered}
$$

Shell small, conical, consisting of four or five rapidly increasing convex whorls; suture deeply impressed; surface marked only by lines of growth; aperture oval.

Height, 9 mm.; breadth of last whorl, $6 \mathrm{~mm}$.

Occurs with the preceding species on Fawn Creek.

\section{COLORADO FORMATION.}

\section{PELECTPODA.}

Ostrea anomioldes Meek.

Ostrea anomioides MIeek, 1873: Ann. Rept. U. S. Geol. Surv. Terr. for 1872, p. 488. White, 1880: Idem for 1878, p. 10, Pl. XI, figs. 4a, b. 1884: Fourth Aun. Rept. U. S. Geol. Surv., 1. 291, Pl. XXXIX, figs. 4 and 5. Stanton, 1894: Bull. U. S. Geol. Surr. No. 106, p. 55, Pl. I, figs. 5 and 6.

This species, which was originally described from the Missouri River below Gallatin, Montana, is abundant in sandy shales near the base of 
the Colorado formation on ridge north of north head of Gardiner and on north side of Fan Creek.

Inoceranus umbonatus Meek and Hayden.

Inoceramus umbonatus Meek and Hayden, 1858: Proe. Acad. Nat. Sci. Phila., p. 50. Meek, 1876: U. S. Geol. Surr. Terr., Vol. IX, p. 44, Pl. III, figs. 1a, b, c; P]. IV, figs. $1 a, b$ and $2 a, b$. Stanton, 1894: Bull. U. S. Geol. Surv. No. 106, p. 81, Pl. XYIII, figs. 1 and 2.

One specimen was collected on north bank of Snake River one-fourth mile above the mouth of Sickle Creek. The species is abundant in the shales of the upper part of the Colorado formation on the Missouri River below Fort Benton, Montana, and it has recently been collected by Mr. G. K. Gilbert in the Niobrara shales near Rocky Ford on the Arkansas River below Pueblo, Colorado. It also occurs in the Austin limestone of Texas.

Ivoceranus undabundus Meek and Hayden.

Inoceramus undabundus Meek and Hayden, 1862: Proc. Acad. Nat. Sci. Phila., p. 26. Meek, 1876: U. S. Geol. Surv. Terr., Vol. IX, p. 60, Pl. III, figs. 2a, $b$. Stanton, 1S94: Bnll. U. S. Geol. Surv. No. 106, p. St, Pl. XVI, figs. 1 and 2.

Occurs with the preceding at the locality on Snake River, and also on the Missouri below Fort Benton.

\section{INOCERAMUS FLACCIDUS White.}

Inoceramus fiaccidus Thite, 1876: U. S. Geog. and Geol. Surv. W. 100th Meridian, Vol. IT, p. 17s, Pl. X YI, figs. $1 a$ aud $b$. Stanton, 1S94: Bull. U. S. Geol. Surv. No. 106, p. S0, Pl. XIII, fig. 1 .

Occurs with the preceding, and at the same horizon, one-fourth mile farther up Snake River. It has hitherto been found only in the Niobrara shales near Pueblo, Colorado.

\section{INOCERAMUS ACUTEPLICATUS n. sp.}

Pl. LXXV, figs. 9 and 10, and Pl. LXXVI, fig. 1.

Shell large, moderately convex, elongate, with the height much greater than the length; hinge line rather short, oblique to the longer axis of the shell; beak prominent, acute, near the anterior end of the hinge line; anterior side gently convex, posterior nearly straight; base broadly rounded, with a tendency to angulation at the junction with the sides; surface marked 
by lines of growth and by regular, narrow, elevated, concentric ridges that are about one-third as wide as the interspaces. These ridges are somewhat stronger on the anterior lalf of the shell than on the posterior, and in very large specimens they tend to become obsolete, making the basal portion of the shell nearly smooth.

The above description is drawn mainly from a large right valve (Pl. LXXVI, fig. 1) from the Siekle Creek locality. The specimens associated with it and having the same general form and seulpture are all much smaller. These are not distinguishable from specimens from sandstone believed to belong to a higher horizon on Glade Creek. There are small left valves in the collection from both localities, and one of those from Glade Creek is figured. It is proportionally more convex than the right valve, and the beak is more prominent and more curved. The concentric ridges are very prominent on the convex median region, and fade out toward the border's.

The largest type specimen measures $201 \mathrm{~mm}$. in its longest diameter, and $135 \mathrm{~mm}$. at right angles to that line.

This species is related to $I$. fiagilis and $I$. altus, all three belonging to the typical section of Inoceramus. It differs from both of them in being more strongly plicate, in its shorter, slightly more oblique hinge line, and in other cletails of outline.

Locality and position: On Snake River one-fourth mile above the mouth of Sickle Creek, associated with I. umbonatus, Scaphites ventricosus, ete., in sandy shales of the upper part of the Colorado formation, and near the mouth of Glade Creek in a sandstone supposed to belong to a higher horizon.

\section{Corbula subtrigonalis Meek and Hayden.}

Corbula sabtrigonalis Meek and Hayden, 1856: Proc. Acad. Nat. Sci. Phila., p. 116. White, 1880: Ann. Rept. U. S. Geol. Surv. Terr. for 1878, p. s0, Pl. XXY, figs. 6a-f. White, 1883: Third Ann. Rept. U. S. Geol. Surv., p. 442, PI. XIX, figs. 10-13. Stanton, 1894: Bull. U. S. Geol. Surv. No. 106, p. 123, Pl. XXVII, figs. 7 and 8 .

This species and its variety perundata were obtained in black shales supposed to belong to the Colorado formation near Electric Peak and on the Cone head of Gardiner River. These forms were originally described from the Laramie, but they are known to range as low as the Colorado formation in southwestern Wyoming. 


\section{CEPHALOPODA.}

\section{BaCUlites asper Morton?}

Baculites asper Morton, 1834: Synopsis Org. Rem. Cret. Gr., p. 43, Pl. I, figs. 12 and 13;

Pl. XIII, fig. 2. Stanton, 1894: Bull. U. S. Geol. Surv. No. 106, p. 16i, Pl. $X X X V I$, figs. 4 and 5.

Occurs with Inoceramus acuteplicatus, etc., at the locality one-fourth mile above the mouth of Sickle Creek, and is abumdant associated with the same fauna on the Missouri River below Fort Benton, in the upper part of the Colorado formation. It is also found at Cimnabar Mountain.

\section{Scaphites ventricosus Meek and Hayden.}

Scaphites ventricosus Meek and Hayden, 1862: Proc. Acad. Nat. Sci. Phila., p. 22.

Meek, 1876: U. S. Geol. Snrv. Terr., Vol. IX, p. 425, Pl. VI, figs. 7a, b, and Sa, b.

Stanton, 1894: Bull. U. S. Geol. Surv. No. 106, p. 186, Pl. XLIY, figs. S-10;

Pl. XLY, fig. 1.

Several specimens from the localities above mentioned on Snake River, and a fragment believed to belong to this species from the black shales of Electric Peak.

It occurs well preserved at Cimnabar Mountain just north of the Park, and with the preceding species below Fort Benton.

\section{MONTANA FORMATION. ${ }^{1}$}

\section{BRACHIOPODA.}

\section{Lingula subspatulata Hall and Meek.}

Lingula subspatulata Hall and Meek, 1854: Mem. Am. Acad. Arts and Sci., Vol. Y, p. 380, Pl. I, figs. 2ı, $b$. White, 1876: U. S. Geog. and Geol. Surv. W. 100th Meridian, Vol. IV, p. 169, Pl. XY, fig. $4 a$.

Two specimens from sandstone overlying bituminous shale on Rattlesnake Creek, probably same horizon as the remainder of the species mentioned below. 


\section{PFLECYPOI)A.}

Ostrea solmniscus Meek.

Ostrea soleniseus Meek, 1871: Proe. Am. Philos. Soc., Vol. XI, p. 435. White, 1880: AnI. Tiept. U. S. Geol. Surv. Terr, for 1878, p.9, Pl. XI, figs. 2a, b. 1884: Fourth Aun. liept. U. S. Geol. Surv., p. 300, Pl. XLII, fig. 1. Stanton, 1894: Bull. U. S. Geol. Surv. No. 106, 1. 56, Pl. II, fig. 1; Pl. III, figs. 1 and 2.

This species is abundant in both the Colorado and Montana formations at Coalville, Utah, and in sonthwestem Wyoming. It was obtained near the second crossing of Suake River, just south of the Park.

\section{Ostrea sp.}

A small species related to $O$. pellucida $M$. and $H$. occurs at the same locality with the preceding.

\section{Anomia sp.}

A small species resembling A. mopatoris White is represented by several casts from Glade Creek, Lizard Creek, and near second crossing of Snake River.

\section{Avicula nebrascana Evans and Shumard.}

A vicula nebraseana Evans and Shumard, 1857: Trans. Acud. Sci. St. Louis, Vol. I, p. 38. Pteria (Oxytoma) nebrascana (E. and S.) Meek, 1876: Rept. U. S. Geol. Surv. Terr., Vol. IX, p. 34, Pl. XVI, fig. 3a, b; Pl. XXVIII, fig. 11. Whittield, 1850: Geol. Black Hills Dakota, p. 385, Pl. VII, fig. 4.

Several specimens from the locality near the mouth of Glade Creek. It is a widely distributed species in the Fort Pierre shales of the Montana formation.

\section{Avicula LINGUæFormis Evans and Shumard.}

Avicula lingucformis Evans and Shumard, 1854: Proc. Acad. Nat. Sci. Phila., p. 153. Pteria linguiformis (E. and S.) Meek, 1876: Rept. U. S. Geol. Surv. 'Terr., Vol. IX, p. 32, Pl. XVI, figs. Ia-d. Whitfield, 1880: Geol. Black Hills Dakota, p. 384, PI. VII, figs. 2 and 3.

This species nccurs with the preceding on Glade Creek and has about the same geographic and vertical range.

\section{INOCERAMUS ACUTEPLICATUS 11. sp.}

Numerous small specimens referred to this species from locality near the mouth of Glade Creek. (See description on page 634.) 


\section{ArCa sp.}

A single imperfect specimen, probably of an undescribed species, from the locality near the second crossing of Snake River.

Nucula sp.

A cast near mouth of Glade Creek.

\section{Cardium pauperculum Meek.}

Cardium pauperculum Meek, 18i1: Aun. Rept. U. S. Geol. Surv. Terr. for 1870, p. 306.

White, 1879: Idem for 1877, p. 291, Pl. IX, fig. 3\%. Stanton, 1894: Bull. U. S. Geol. Surv. No. 106, p. 99, Pl. XXII, figs. 9-12.

Cardium subcurtum Meek, 1873: Ann. Rept. U. S. Geol. Surv. Terr. for 1872, p. 476.

1877: U. S. Geol. Expl. 40th Parallel, Vol. IV, Pt. I, p. 152, Pl. XV, fig. $3 a$.

This is the most abundant species in the sandstones near Glade Creek, near second crossing of Snake River, and on Lizard Creek.

It is common in the Colorado formation at Coalville, Utah; in southwestern Wyoming, and in Huerfano Park, southerm Colorado. In these localities it is not known to range as high as the Montana formation.

\section{Baroda WYomingensis Meek.}

Tapes ryomingensis Meek, 1871: Ann. Rept. U. S. Geol. Surv. Terr. for 1870, p. 310. Baroda wyomingensis Meek, 1873: Idem for 1872, p. 493. White, 1879: Idem for 1877, p. $293, \mathrm{Pl} . \mathrm{X}$, figs. $3 a, b$.

A single specimen from Glade Creek.

It is possible that this species belongs to Conrad's genus Legumen, described from the Cretaceous of Ripley, Mississippi. I have elsewhere expressed the opinion that Baroda is probably a synonym of Legumen, which is a prior name.

\section{Donax cuneata Stanton. \\ Donax(?) oblonga Stanton.}

Both these species occur on a single hand specimen from near the second crossing of the Snake River. The type of $D$. cuneata was collected in sandstone of the Colorado formation at Old Bear River City, sonthwestern Wyoming, ${ }^{2}$ and $D$. oblonga came from the same horizon at Coalville, Utah. D. cuneata occurs also in the Montana formation of the Coalville section. 
Mactra warkenana Meek and Hayden.

Mactra warenana Meek and Hayden, 1856 : Proc. Aead. Nat. Sei. Pliila., p. 271.

Mactra (Cymbophora?) warrenana (M. and H.) Meek, 1876: Rept. U. S. Geol. Surv.

Terr., Vol. IX, p. 208, Pl. XXX, figs. ia-l.

Casts in sandstone apparently belonging to this species are abundant near Glade Creek. The species is widely distributed in the Montana formation.

\section{Mactra arexaria Meek?}

Mactra (Trigonella?) arenariu Meek, 1877: U. S. Geol. Expl. 40th Parallel, Vol. IV, P't. I, p. 15t, Pl. XIT, fig. 5.

This species is abundant in the Montana formation at Coalville, Utah. A single cast that seems to belong to it is associated with the preceding species near Glade Creek.

\section{GASTROPODA.}

\section{Grrodes DEPRESSA Meek.}

Gyrodes depressa Meek, 1877 : U. S. Geol. Expl. 40th Parallel, Vol. IV, Pt. I, p. 159,

Pl. XV, figs. 1, 1a. Stanton, 1594: Bull. U. S. Geol. Surv. No. 106, p. 135, Pl. XXIX, figs. 11-14.

Common in the sandstones on Glade Creek. It was originally described from the Colorado formation at Coalville, Utal, and is found at the same horizon in Huerfano Park, Colorado. The genus Gyrodes has not hitherto been reported from the Montana formation of the Rocky Mountain region, but it is well represented in beds of the same age in the Atlantic and Gulf border region. In fact, Gyrodes petrosa (Morton) from the Ripley formation is scarcely distinguishable from $G$. depressa.

\section{Cerithium? sp.}

A small, slender form of doubtful affinities, represented by an internal cast from sandstone on Huckleberry Mountain.

Prrula? sp.

A fragmentary cast from Glade Creek. 


\section{CEPHALOPODA.}

Scaphites ef. ventricosus Meek and Hayden.

A mere fragment from Glade Creek, resembling this species in sculpture. (See p. 636.)

\section{Placenticeras placenta (DeKiay)?}

Ammonites placenta DeKay, 1827: Anu. New York Lycenm Nat. Hist., Vol. II, p. 278, Pl. V, fig. 3.

Placenticeres placenta (DeKay) Meek, 1876: Rept. U. S. Geol. Surv. Terr., Vol. IX, p. 465, Pl. XXIV, figs. $2 a, b$.

A fragment probably belonging to this, well-known species was collected near the second crossing of the Snake River. The species is abundant and widely distribnted in the Montana formation and its equivalents, and a few specimens of it, or of a very closely related species, have been obtained in the Colorado formation. 


\section{PLATE LXXII.}

HON XXXII, PT II-41 


\section{P L A T E L X X I I.}

Page.

Binyuchowella gmathophora Meek?

609

Figs. 1, 2. 'Two viows of a small specimen from near Snake River; wlargen $1 \frac{1}{2}$ diameters.

3, 1. Simila views of a larger example from war Vormiliou Canyon. worthwestern Coloralı; enlarged 1 thameters (Uniterl States Jational II

Gryphea calcela var. Mrbascensis $\mathrm{N}$, and $\mathrm{H}$

612

lic. 5. Nmall left valre with stiong striat; enlarged $1 \frac{1}{2}$ diameters.

6.7. Two views of a larger spceimen; natural size.

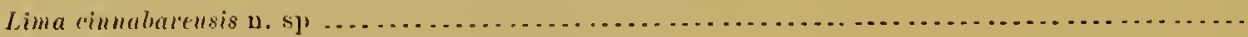

FIt, R. Right valv'; eularged $1 \frac{1}{2}$ diasseters.

Gryphun plawoconrexa Whittield.

Fig. 9. Left valye liom near lower rapyou of the Yullowstone (I nited States Natioual Mlusemu, No. 1236!).

10. Right valve from uear Suake River.

('auptonectes pertenuistriatus $\mathrm{H}$, ant $\mathrm{WT}^{\top}$

Fur. 11. Riglut valw from Flat Monntuiu, slightly listorted. 'lhe obscure ladiatiug rilges are probably acrilental.

rimintonectes bellistrialus lleek

Fis, 12. Right valve fun the lighorn Monntuins, Wyoming (Initel States National Jinseum, No. 1885).

C'amptouectes hellistriatus var. distans n. val

Fif. 13. Right ralve. 

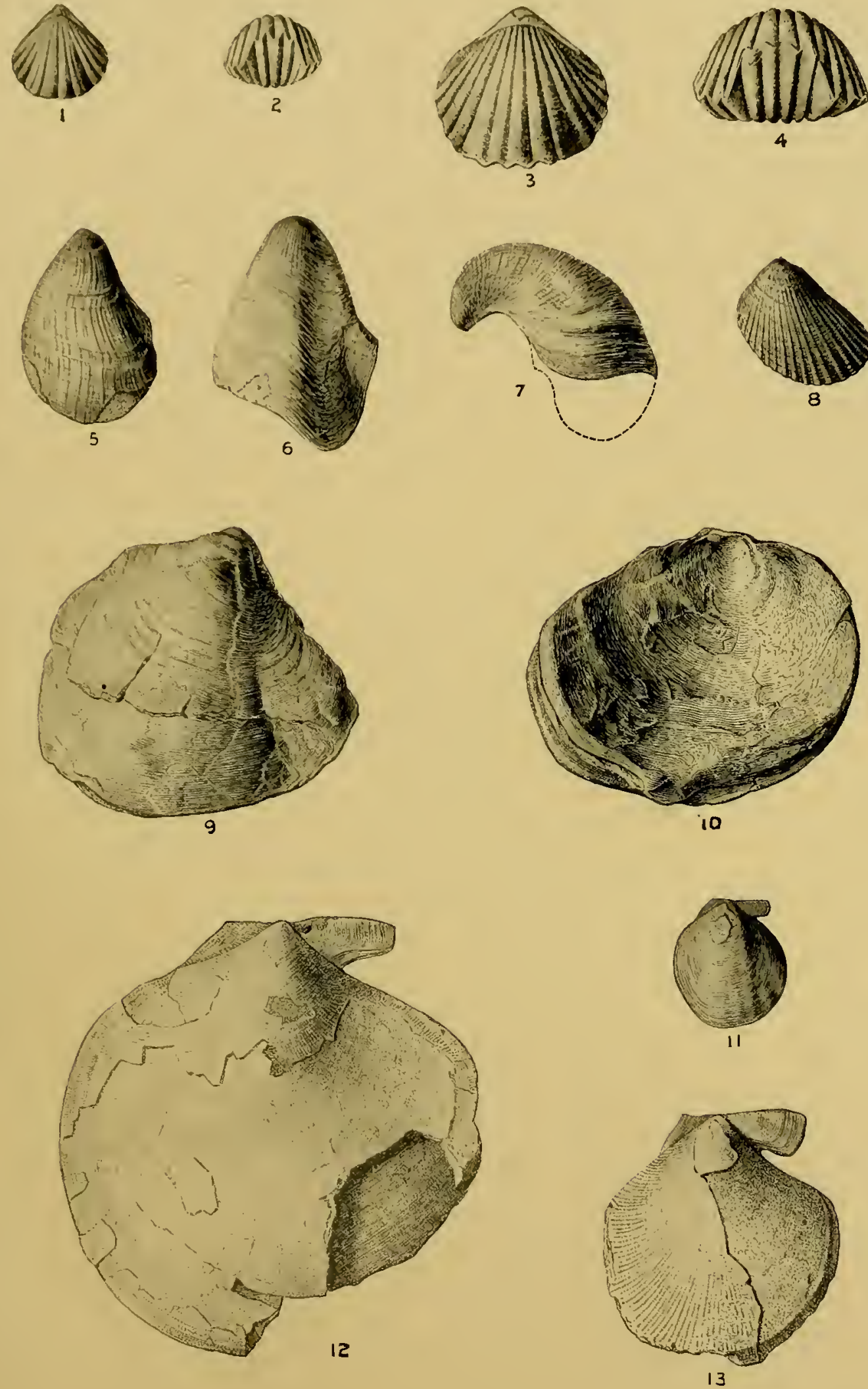

JURASSIC. ELLIS FORMATION. 



\section{PLATE LXXIII.}




\section{P L A T E L X X I I I.}

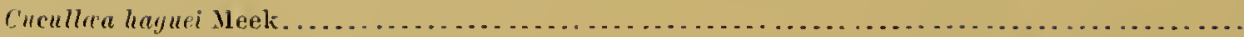

Frf. 1. Left walve slightly thattened and showing both surface sculpture and hinge inpression; enlarged 2 diameters.

Trigonia elegantissima Meek.

Fici. 2. Left ralve; enlargel $1 \frac{1}{2}$ diameters.

dstarte meeki n. sp ...

Fig. 3. Right ralve fron Cinualsar Mlountain; enlarged $1 \frac{1}{2}$ diameters.

4. Left valve from lower canyon of Yellowstone; enlarged $1 \frac{1}{2}$ diameters (United States National Ilnselım, No. 1237t).

5. Elongate right valve, probably distorted by pressure, and showing inpressiou of the crenulate interior margin; enlarged 2 diameters.

Tancredia? Knorcltoni 11. sl1

Fig. 6. Cast of right valve; enlarwel $1 \frac{1}{2}$ diameters.

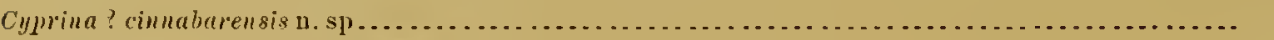

Figs. 7,8 . Tro views of an internal cast, one of the types.

Cyprina? ildingsi n. sp

Fic. 9. Right valve of the type.

Thracia? montunaensis ( $110 \mathrm{el})$ ?

FIr. 10. Right valve, supposed to be Meek's original tspe; enlarged $1 \frac{1}{2}$ diameters. Cypricardia? haguti n. sp

Figs. 11, 12. Two views of an arerage specimen, internal east.

13. Right valve of a large elongate specimen.

641 

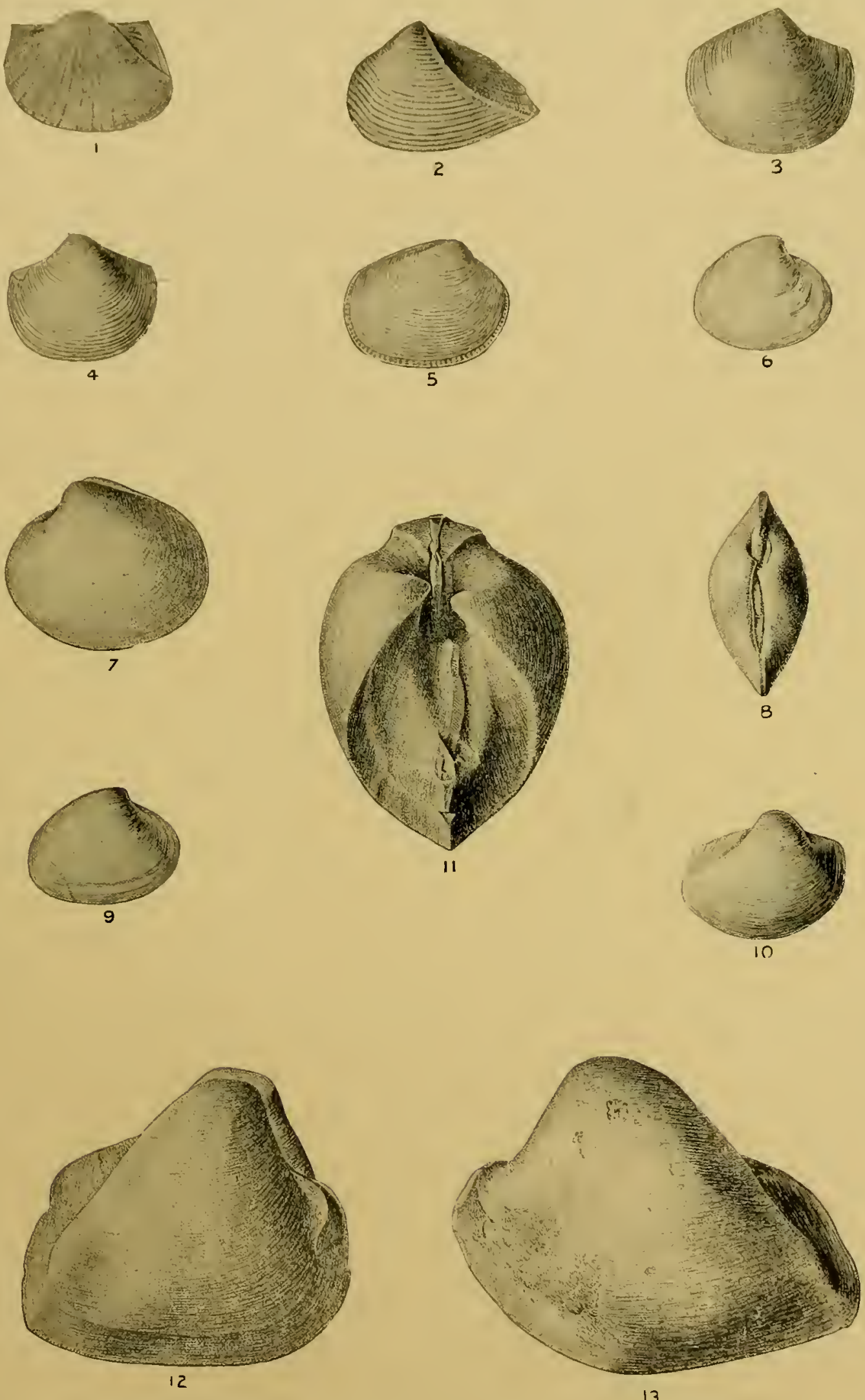

JURASSIC ELLIS FORMATION 



\section{PLATE LXXIV.}




\section{PLA TE L I X I V}

Firis. 1, 2. Two views of Meek's trpe (United States National Mnseum, No. 7815).

3. Left ville of unnsually smooth form.

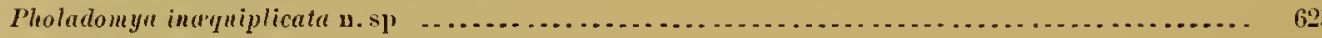

Fici. 4. Right valve of the type.

FIi. 5. Left valve of the type. The senlptme is somewhit restored.

Homomya gallatinensis n. sp....

Ficis. 6, 7. Two views of the type, an interoal cast.

Plenromya subcompressa Ieek

Fiss. 8-11. Specimens showing variation in outline and sculpture of forms assigned to this species. 

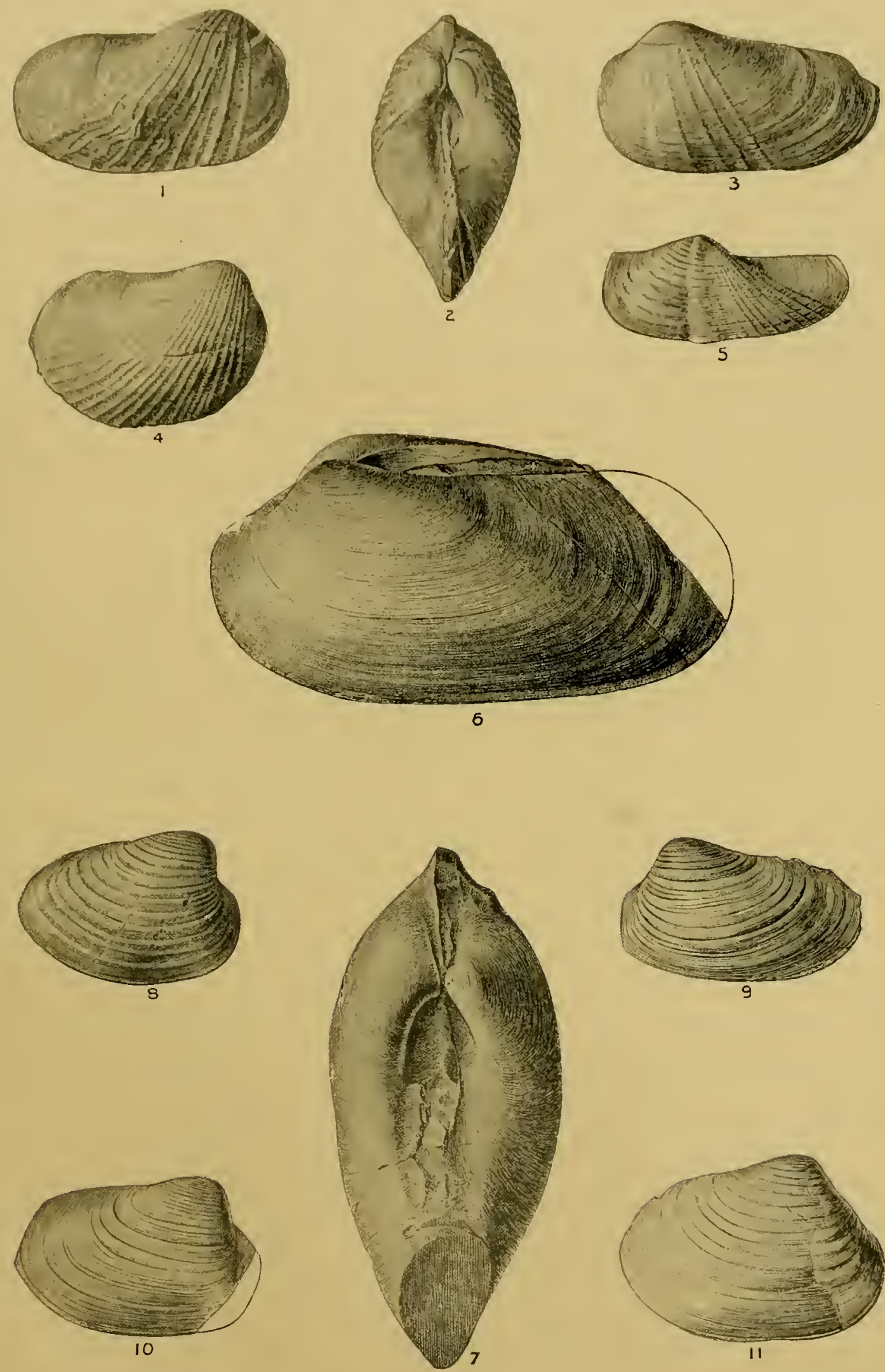

JURASSIC. ELLIS FORMATION, 



\section{PLATE LXXV.}




\section{P L A T E LX X V.}

\section{JURASSIC SPECIES}

Thracia veedi n. sp.

VIG. 1. Right valve of usual size and outline.

2. Left valve of a shorter form.

3. Left valve of an elongate specimen.

Neritina wyomingensis n. $\mathrm{sp}$

FIGs. 4, 5. Opposite views of the type; enlarged 3 diameters.

CRETACEOUS SPECIES.

Goniobasis? pealei $\mathrm{n.} \mathrm{sp}$

Fis. 6. An average speciuen; enlarged 2 diameters.

Goniobasis? increbescens n. sp.

FIG. 7. A medium-sized specimen; eularged 2 rlameters.

Amnicola cretacea $1 \mathrm{~s} . \mathrm{s}$ )

F1G. 8. An averatre specimen; onlarged 2 diameters.

634

Fig. 9. A small left valve snpposerl to belong to this speeies.

10. A small right valve, (See Pl. LAXVI for additional figure.)

648 

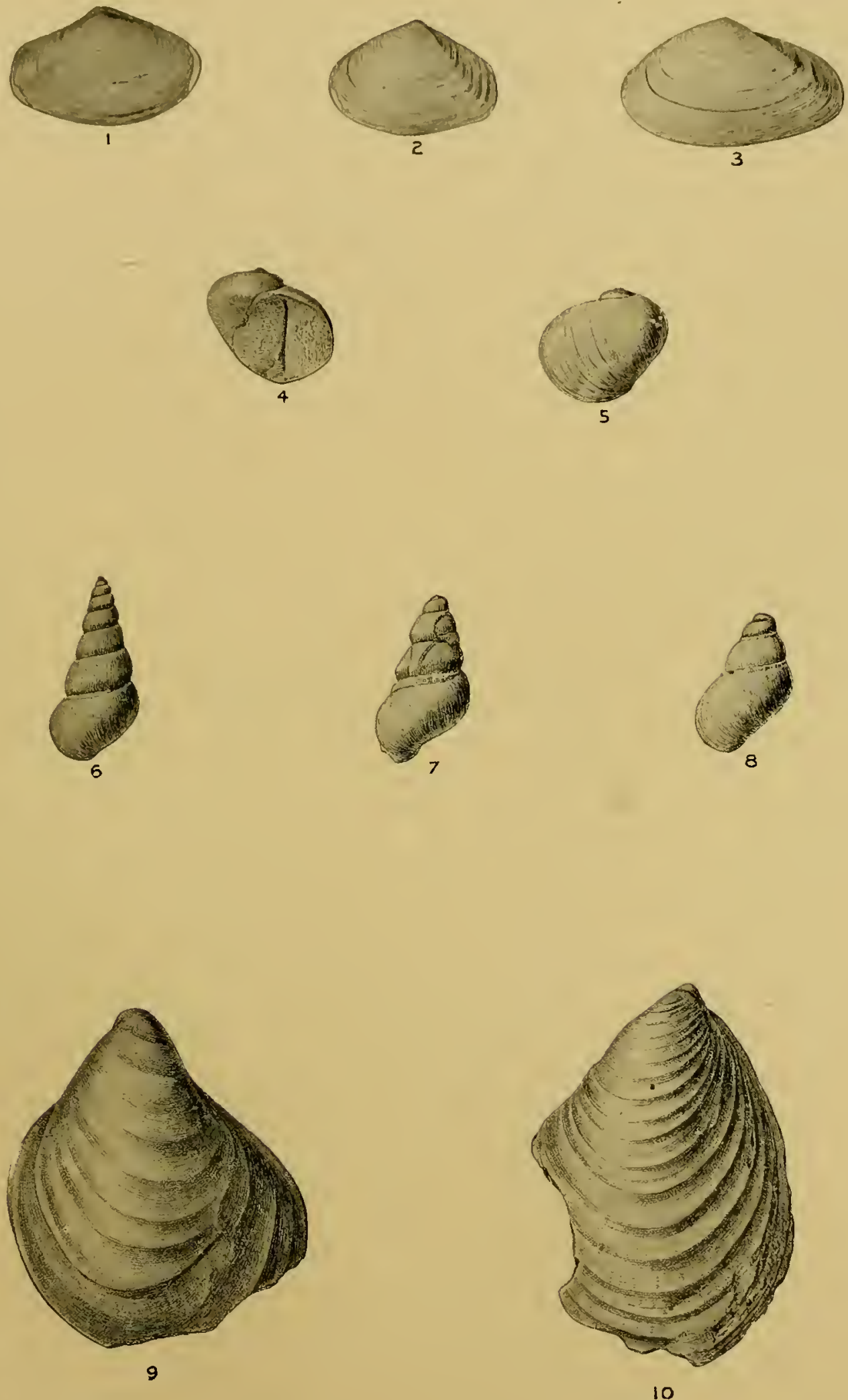

JURASSIC AND CRETACEOUS ELLIS, DAKOTA, AND MONTANA FORMATIONS 


\section{PLATE LXXVI.}




\section{PLA TE L X X VI.}

FIi. 1. A large right valve, forming the principal type specimen. (See Pl. LAIV for additioual figures.) 


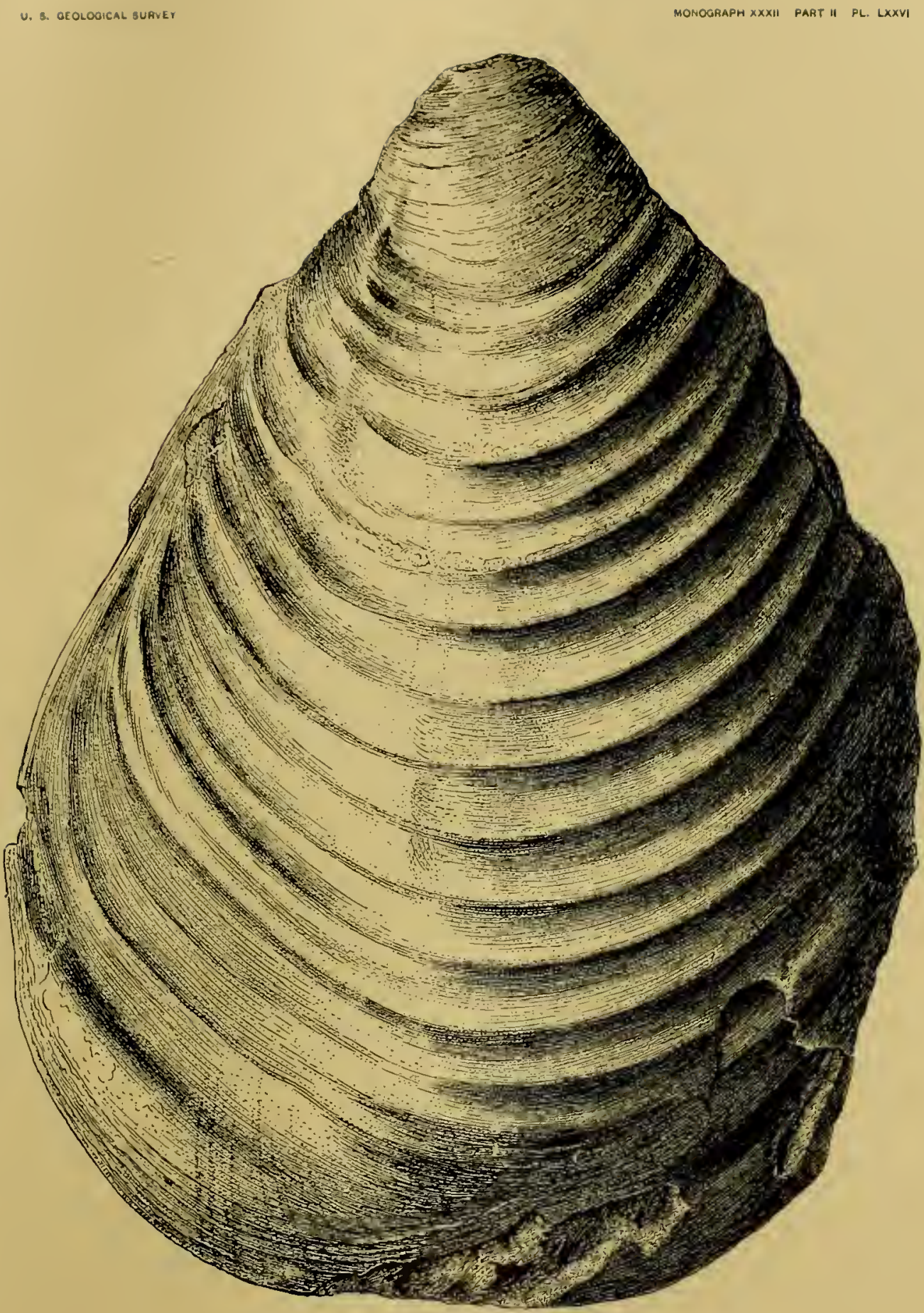

CRETACEOUS COLORADO FORMATION. 



\title{
C H A P T E R X I V.
}

\section{FOSSHL FLORA OF THE YELLOWSTONE NATIONAL PARK.}

\author{
By Frank Hall Knowlton.
}

HISTORICAL SUMMARY OF WORL ON THE FOSSIL FLORA.

As nearly as I have been able to determine, the first collection of fossil plants made in the Yellowstone National Park was obtained by members of the United States Geological Survey under Dr. F. V. Hayden, in 1871. They were found in two localities, and were recorded by Prof. Leo Lesquereux, ${ }^{1}$ as follows: "Divide between the source of Snake River and the southern shore of Yellowstone Like," and "Near Yellowstone Lake, among basiltic rocks." It has not been possible to rediscover these localities, and several of the species remain unique.

In the following year (1872) the Park was again visited by a party uncler Dr. Hayden. The members of this party investigated the northeastem portion of the Park and discovered the rich plant deposits on the Yellowstone River, a short distance below the moutlı of Elk Creek. The actual collectors were Messis. A. C. Peale, Joseph Savage, and O. C. Sloane. The plants representerl tive species, which were determined by Professor Lesquereux."

The Fossil Forest, that has since become so widely known, was first described by Mr. W. H. Holmes in 1878. ${ }^{3}$ He visited and quite thoroughly explored the Fossil Forest and vicinity and made a small collection of plants that were submitted to Professor Lesquereux. Most of these plants were determinerl to be new to science, but they were neither named nor

Ann. Rept. U. S. Geol. and Geog. Surr. Terr. for 1871, 1p. 295, 299.

:Op. eitu, Rept. ior 1872, p. 403.

${ }^{3}$ Op. cit., Rept. for 1878 , Pt. II, pp. $47-50$. 
described. Holmes pointed out the fact, since abundantly confirmed, of the succession of forests that have been entombed one above another. His section of Ametlysst Mountain shows clearly this remarkable phenomenon.

In October, 1874, Dr. Otto Kuntze, a celebrated German botanist, then on a botanical exploring journey around the world, visited the Park and made some interesting observations on the process of petrifaction of trees now going on in the vicinity of the geysers and hot springs. His paper was not printed, however, until his return to Germany in $1880 .{ }^{1}$

The thorough exploitation of the Park was begun and carried on for several years by the Yellowstone Park Dirision of the present Geological Survey. In 1883 the work was extended toward the northeastern portion of the Park, and collections of greater or less extent were made at many places. In 1885 the Fossil Forest section was worked out, and large collections were made by Mr. Arnold Hagne, Mr. W. H. Weed, Mr. George Mr. Wright, and Prof. J. P. Iddings.

In the summer of 1857, Prof. Lester F. Ward and I spent about six weeks in the vicinity of the Fossil Forest, making large collections of fossil wood and leaf inpressions. The exact localities are enumerated below.

The following season I spent two months in the same area, discovering many new beds of plants and more thoroughly exploring and collecting from beds previously known. These are also recorded in the following list of localities.

LIST OF LOCALITIES AT WHICH FOSSIL PLANTS HAVE BEEN COLLECTED IN THE YELLOWSTONE NATIONAL PARK.

1871.

Divide between the source of Snake River and the sontheru shore of Yellowstone Lake; Hayden survey. (Not since observed.) found.)

Near Yellowstono Lake, amoug basaltic rocks; Hayden survey. (Not since

1872.

Yellowstone River below month of Elk Creek; A. C. Peale, Jusejh Savage, antl O. C. Sloane.

1878.

Amethyst Momutain in vicinity of Fossil Forest; W. H. Holmes.

'Dis Ausl:and, 1880, pp. 361-364, 390-393, 669-672, 684-689. 
1883.

Andesitie breecia near gulch northrest of peak west of Dunraven; J. P. ldulings, September 12, 1853 . (Finld Nos. S6, 77.)

Needle Hill near Yancegs; W. II. Weed, Outober !, Is83.

Tąer Creek; Arnolıl Lagne, September 16, 1Ss3. (Field Nos. 1030, 1031.)

1884

Fossil Forest section, lower stratum; Arnold Hagne, September 24, 185. (No. 1:21.)

Fossil Forest seetion, mildle stratum; Arnoll Hague, September 24, 1854. (No. 1220.)

Fossil Forest seetion, upper stratum; Arnold Hague, September 24, 1584. (Nos. 1217, 1218, 1219.)

Sandstone on top of ridge west of Hink Creek; Arnold Hagne. (No, 2332.)

1885.

Sigual Hill; W. U1. Weed, September 28, 1585.

Head of Tower Creeli; T. П. Weed, September 25, 1855.

East slope of ligh hill three-foniths mile south from Yanceys; George 11 . Wright, September 4,1385 .

Near top of south mall of eanyon of Yellowstone River, about 1 mile up stream from month of Hellroaring Creek; George W. Wright, September 9, 1885 .

Fossil Forest section, No. I of section; W. H. Weed and George M. Wright, September 19, 1585 .

Fossil Forest seetion, No. 15a of section; W. H. Weed and George M. Wright, September 19, 1885.

Fossil Forest section, No. 22e of section; W. H. Weel and George II. Wright, September 20,1855 .

Fossil Forest section, No. 20 of section; W. H. Weed and George M. Wright, September $20,1885$.

Fossil Forest section, No. 26 ot section; W. H. Weed and George H. Wright, September 20, 1885 .

Top of Mount Everts, west fice, nearly opposite bridge over Gardiner River, between Mimmoth Hot Springs and Gardiner; George M. Wright, July 7, 1885.

1887.

Fossil Forest, bed No. 1, lowest bed about 7,700 teet altitucle; Lester F. Ward aud F. H. Knowlton, August, 1857.

Fossil Forest, bed No. 2; Lester F. Ward and F. H. Knowlton, Angust, 1857.

Fossil Forest, bed No. 3, "Magnolia betl," 300 feet above bed No. 1; Lester F. Ward aud F. H. Knowlton, Angust, 1887.

Fossil Forest, bed No. 4, "Aralia bed," 42.5 feet above bed No. 1; Lester F. Ward and F. H. Kuomlton, Angust 20), 1ssi. 
Fossil Forest, bed No. 5, "Salix bed," about 400 feet above bedl No. 1; Lester F. Ward and F. H. Knowlton, August 19, 1Ssi.

Fossil Forest, bed No. 6, "Platanus bed," 4 "5 feet above bed No. 1; Lester F. Warl aud I. H. Knowlton, Angust 19, 1S57.

Fossil Forest, berl No. 7 , highest bed. 510 feet abore beil No. 1: Lester F. Ward and F. H. Knowiton, Angust, 1ssi.

Hill back of Yanceys, near stauling trunks: Lester F. Ward and F. H. Knowltou, Angust 10. 18si.

Cliff west of Fossil Forest lidge. near Chalcedony Creek, lowest bed, altitude about 7,900 feet; Lester F. Ward aud F. H. Knowlton, August 15, 1S5.

Clift' west of Fossil Forest Ridge, upper berl, 250 feet above lower berl; Lester F. Ward ant F. 11. Knowlton, Angust 15, 1857.

East end of Fossil liorest Mountain, bed on same horizon as fossil trunks; Lester F. Wart and F. H. Linowlton, August 13 and 22, I8st.

Specincen Iidge, head of Crystal Creek, opposite month of Slongh Creek, "Platamns bed." altitude about 7.510 feet; Lester F. Warl and F. 11. Kuowltou, August 24, 185i.

Specimen Riulge, opjosite month of Slongh Creek, "Quercus berl," 100 feet above "Platanus bed;" Lester F. W:urd and F. H. Knowlton, Angust 25, 1S57.

North of Piuyon Peak, on Wolverine Creek, altitule 7,900 feet; Arnold Hague, August 10, 1SSi.

1888

Yellowstone River, one-Lalf mile below mouth of Elk Creck, bottom of JJuff; F. H. Knowlton, Angust 29, 1888.

Yellowstone Iiver, one-half mile below mouth of Elk Creek, 30 or 40 feet ahore the river; F. H. Knowlton, August 2T, 1 sSs.

Yellowstone River, one-half mile below month of Elk Cieek, top of bluff; F. H. Kinowlton, Augnst $2 \pi$, ISSS.

Bluff on Yellowstone River, 1 mile below month of Elk Creek; I'. H. Kuowlton, Augnst 4, 1888 .

Cliff ou Yellowstone River, short distanee above month of Hellroaring Creek; F. H. Knowlton, August 10, 1SSS.

Sontheast sirle of hill above Lost Creeb, hed No. I; F. H. Knowlton, Angust S, $18: 35$.

Sontheast sirle of hill above Lost Creek. bed No. 2. F. H. Knowlton, Angnst S, 1 sss.

Sontheast side of hill above Lost Creek, heds No. 3, 4, 5; F. H. Kinuwlton, August S, 1SSS.

Sonthern end of Crescent Fill, 300 feet above wagou roal; F. H. Knowlton, August 9, $18 S 8$.

Sonthern end of Crescent Hill, "Plitanus bed": F. H. Knowlton. Angust 9, 1SSS.

Fortheast side of Crescent Hill, olposite suall pont in slope, altitule about 7,500 teet; F. II. Knowltou and (i. E. Cnlver. August '2, 1 sss. 
The Thumberer, opposite Somla Butte; F. Il. Kinowlton and (x. Li, Culver, Angust $2 !), 155 \%$.

bast bank of Lamar liver, between Gache and Calfee areks; F. H. Kónowlton aml 4i. L. Culver, dugnst 21, ISs8.

Ilill on roal just above Yanceys; li. H. Kunrlton, Angust 6, 1s8s.

Ifill neal the Yancey fossil trunlis; F. II. Knowlton, Angust 28,158 .

Mount Liverts, ne:n smmmit of west end; F. H. Knowlton, July 27, $188 \mathrm{~s}^{2}$

Mount Lrerts, coal opening on side facings the Gardiner River (fiagments); F. H. Knowltou. July 26.1885 .

\section{DESCRIP'TION OF RNOWN FOSSIL PLANTS FRONI THE LARAIIIE OF THE YELLOISTONE NATIONAL PARK.}

\section{Asplenium haguei 11. "N.}

Pl. LXXYII, tigs. 1, ?.

Frond thin, delicate, lanceolate in outline, bipinnate, slender, straight; pimne alternate, seattered, oblong-laneenlate in shape, cut into few coarse divisions which are eithere entire or again cut into few obtuse teeth; nerration obscure, consisting of a delieate midvein and few forked branches fiom it.

This delieate little form is represented by a dozen or more specimens. The longer fragment (fig. 2 ) is about 4.5 ('m. in length and about $1.5 \mathrm{~cm}$. broad. The others are more fragmentary.

Nothing like this has been before reported from the Lanamie group. It has some resemblance to Sphenopteris ynyottii Lx., ${ }^{1}$ from the Green River group at Florissant, Colorado, but is much smaller and of decidedly different shape.

It is not certain that it belongs to the geenus Asplenimu, as no fruit has heen observed, hut it resembles, at least generically, a number of forms so referred from the Cretaceons of Cremland. For the present it may be retained in this gemus.

I have named it in honor of the collector, Mr. Arnold Hagne, of the Uniterl States Geological Survey.

Habitat: North of Pinyon Peak, on Wolverine Creek, Yellowstone National Park; collected by Arnold Hague, Augnst 10, 1887. 


\section{ONOClea minima M. $\mathrm{sp}$}

Pl. LXXVII, figs. 11-15.

Fertile frond unknown; sterile frond small, apparently deltoid in outline, deeply pimnatifid into short, rounded, obtuse pimne, which are perfectly entire or are cut into few large, coarse teeth; nervation as in the living O. sensibilis.

This fine little species is represented by a dozen or more specimens, the best of which are figured. They are all apparently fragments, and consequently it is impossible to make ont the real shape of the frond with any certainty. One of the most perfect specimens (fig. 13) is abont 3.5 cm. long, and represents the upper portion of a frond or possibly pinnule, if it is a large compound frond. The larger fragment (fig. 15) is $4.5 \mathrm{~cm}$. long and about $4 \mathrm{~cm}$. broad, but it is broken at both ends and there is no means of determining how long it was originally. Fig. 12 at first sight seems to be entirely different from the others, but on conparing it with fig. 14 the only difference observable is that one is cut into a few coarse teeth and the other is entire. The nervation seems to be the same in all and to be identical with that of the living sensitive fern.

Regarling this interesting species, I am somewhat meertain as to the shape of the frond, and less so as to the genus to which it belongs. Two of the most perfect forms (figs. 11, 13) seem to have come from the upper portion of a frond similar in general shape to the sterile frond of Onoclen sensibitis; but, on the other hand, figs. 12 and 14 have much the appearance of being deeply lobed pimne, resembling some of the lower ones in O. sensibilis. Hore material will be necessury to settle this point, but in the meantime the species is characteristic enough to be readily distinguishable, and hence is available for geological purposes.

This species was at first thought to be identical with a plant that has been described under the MS. name of Whorlucurtin cremutu, which comes from Point of Rocks, Wyoming. This latter is known only from a mere fragment, however, and if alditional material conld be obtained it might show them to be the same. At present $W$. cremta miay be distinguished as being much larger and in having undulate-crenate margins which are minutely serrate. The nervation is practically the sime in botll.

Onoclea minima has some resemblance to O. sensibilis fossilis from the Fort Union group, near the month of the Yellowstone. It differs in being 
harlly me-fifth the size and in laving the lobes obtuse and contrely toothed instead of acute and entire. The nervation is nearly the same in both.

The species under consideration has also the sane nervation as Wooducurdiu preureolutu from Cresecent Hill, but differ's essentially in size and slinge.

The resemblance to Woodwardia latiloba Lx., from the Denver group of Colorado, is still more remote.

Habitat: North of Pinyon Peak, on Wolverine Creek, Yellowstone National Park; collected by Aruokl Hague, Augnst 10, 1887. (Field No. 3031.)

Axema subcretacea (Sap.) Gard. and Ett.

Anemiu suberetaceu (Sil).) Gard. and Ett.: Monogr. Brit. Eoc. Fl., VoI. I, Pt. II, p. 45, I'l. VIII; PI. IX, 1 S $\$ 0$.

Gymnogramma haydenii L.: Ann. Rept. U.S. Geol. and Geog. Surv. Terr., p. 295, 187I

(1872); Tert. Fl., p. 59, Pl. V, figs. 1-3,1878.

The type locality of this species is described as "Divide between the source of Snake River and the southern shore of Yellowstone Lake." It has not since been found inside the Park.

Habitat: As above given.

Sequola langsuorfir? (Brgt.) Heer.

Pl. LXXYII, fig. J.

It is with some hesitation that I refer this fragment to this species. It is small and not well preserved, but the leaves appear to be decurrent and to approach closer in character to this species than to any other with which I an familiar.

Habital: North of Pinyon Peak, on Wolverine Creek, Yellowstone National Park; collected by Arnold Hague, Angnst 10, 1887.

Sequola Reichenbachi (Gein.) Heer.

Sequoiu reichenbaehi (Gein.) Heer: Flor. Foss. Arct., Vol. I, p. 83, PI. XliII, figs. $1 d$, $2 b, 5 a, 186 \mathrm{~s}$.

Abietites dubius Lx. ex p. Lesquerenx: Tert. Fl., p. 81, PI. VI, figs. 20, 21, 21a. Knowlton: Bull. U. S. Geol. Surv. No. 105, p. 46, 1893.

Two small worn fragments are referred to this species. They are obscure, but with little doubt are correctly referred to this form.

Habitat: Mount Everts; about 100 feet above coa! mine on west end, below Mammoth Hot Springs; collected by F. H. Knowlton, July 26, 1888 . MON XxxII, PT II- 42 


\section{Phragmites falcaita n. sp.}

Pl. LXXVIII, fig. 5.

Leaves narrowly lanceolate, with a long acuminate apex; nerves rather sparse, about ten in the width of the leaf; intermediate nerves obsolete.

This species rests upon the fragment figured, and, scanty as the material is, differs markedly from the species with which it is associated and to which it is most closely related-that is, $P$. alaskana Heer.

The fragment is $8 \mathrm{~cm}$. in length and $11 \mathrm{~mm}$. in width. It tapers for a distance of $5 \mathrm{~cm}$. to a long, sharp point, thereby differing from $I^{\prime}$. alaskicuna, which is "obtuse or obtusely mucronate." The primary nerves are $1 \mathrm{~mm}$. apart and reasonably distinct. The secondary or fine nerves can not be made out, owing to the poor state of preservation.

Habitat: Mount Everts, near summit of west end; collected by F. H. Knowlton, July 27, 1888.

\section{Geonomites schimperi Lx.}

Geonomites schimperi Lx.: Tert. Fl., p. 116, Pl. X, fig. 1 (1878).

Sabal major? Ung. Lesquereux: Fifth Aun. Rept. U. S. Geol. and Geog. Surr. Terr., p. $295,18 \div 1(1872)$.

This species was collected with Anemia subcretaceu, and the specimens on which it is based are preserved in the United States National Museum. The species has not been since collected.

Habitat: "Divide between the source of Snake River and the southern shore of Yellowstone Lake."

\section{Mirica bolanideri? Lx.}

Pl. LX.'VIII, fig. 4.

Myrica bolanderi Lx.: Tert. Fl., p. 133, Pl. X VII, tig. 17 (1878).

Ilex undulata Lx.:' Seventh Aun. Rept. U.S. Geol. and Geog. Surv. Terr., 1873 (1574), p. 416.

I refer this single fragment with some hesitation to this species. It differs slightly from the type specimen, which also appears to be the only one thus far mentioned. The one under discussion is about the same size

"When this was trausferred to Mrrica, the specific uame undulata became preoccupied by $M$. undulata (Heer) Schimp., Pal. Vég., Vol. II, p. 546 (1870-1872). 
and has the same toothing in the upper portion, differing only in being a little more acute than the type. The basal portion is wanting.

The locality which afforded the origrinal specinen is muknom (ef. 'T'ert. Fl., p. 133), but from the fact that it was sent to Lesquereux witlo a lot of material from near Florissant, Colorado, it was assmmed to belong to the Green River group. It is preserved in the eollection of the United States National Mnsemm (No. 1652), and alpean's to have actually come from the Florissiut shale.

IIabitat: Mount Everts, near summit, on westem end; collected by 1. H. Knowlton, July 27, 1888.

\section{Quercus ellisiana Lx.}

\section{Pl. LXXVII, fig. it.}

Quercus ellisiam" Ix.: Fifth Ann. Rept. U.S. Geol. and Geog. Surv. Terr., 1871 (18i2), p. 297 ; 'T'ert. Fl., 1). 155, Pl. Xx, figs. 4, 5, 7, 8, 18 is.

A considerable number of specimens that leave no doubt as to the correctuess of their determination.

The example figured is only partially preserved and is much larger than is nsual in this species. It has, however, the shape and nervation of Q. ellisima, and I refer it with some liesitation to this form.

Habitat: Mount Everts, near the summit of the west end; collected by F. H. Knowlton, July 27, 1888 . 'The figured specimen was collected by George M. Wright, July 7, 1885, on the top of Mount Everts, on the west face.

\section{Malapoenna Weediana? Kun.}

Malapoenna reerliana Kn.: Bull. U. S. Geol. Surv. No. 152, p. 142, 1898.

Litsea weediana kinu.: Bull. U. S. Geol. Surr. No. 105, p. 55, 1893.

Teranthera sessiliftora Lx. ex. p. Lesquereux: Tert. Fl., p. 217, Pl. XXxr, fig. 9, 1878.

There is a single, much broken fragment that appears to belong to this species. It is too fragmentary to be positive.

Habitat: Top of Mount Everts, west face; collected by George M. Wright, July 7, 1885.

\section{Paliurus mininus 11. sp.}

Pl. LXXVII, figs. i-9.

Leaves thin, membranaceous, nearly circular in ontline, very slightly wedge-slaped at base, rounded and obtuse at apex; margin perfectly 
entire; equally five-nerved from the base, with an occasional branching of the outside nerve, making the leaf' appear seven-nerved; midnerve thin, straight, passing to the upper border; other nerves of same strength, camptodrome, arching in bows and joining the midvein or midrib; lateral branches few, at an acute angle; finer nervation not preserved.

This fine charateristic species is represented by a number of fairly well preserved examples, the best of which are figured. They are about 2.8 cm. in length and about the same in width. They are nearly circular in slape, being slightly wedge-shaped at the base, but perfectly obtuse at the apex. The nerves are all of about equal strength and divide the space of the blade into approximately equal areas. They occasionally branch, especially the thin central ones.

This species is mulonbtedly quite closely allied to several described forms. From Paliurus colombi Heer ${ }^{1}$ it differs in shape and nervation. It is very much like some of the small leares of $P$. zizyphoides Lx., ${ }^{2}$ from the Laramie of Erie, Colorado, and Black Buttes, Wyoming, but they differ in having the nerves arising from the midrib well above the base of the blade. The species under discussion las precisely the same shape and much the same nervation as Zizyplus meekii $\mathrm{Lx} .{ }^{3}$ but this differs essentially in having a dentate margin.

On the whole it may be characterized by its circular shape, entire margin, and five nerves from the base.

Habitat: North of Pinyon Peak, on Wolverine Creek, Yellowstone National Park; collected by Arnold Hague, Angust 10, 1887.

\section{Paliurus zazyphoides? Lx.}

Pl. LxxVIII, fig. 3.

Paliurus zizyphoirles Lx.: Tert. Fl., p. 274, Pl. LI, tigs. 1-6, 1878.

This very small leaf is broken at the base and otherwise obscure, but seems to belong to this species.

Habitat: North of Pinyon Peak, on Wolverine Creek; collected by Arnold Hague, August 10, 1887.

'Lesquereux, Tert. F'l., p. 273, Pl. L, figs. 13-17.

${ }^{2}$ Op. cit., PI. LI, fig. 2.

${ }^{3}$ Op. cit.. p. 275, Pl. LI, figs. 10-14. 


\section{DOMBEYOPAS PlatTANOIDES $\mathrm{Lx}$.}

\section{Pl. IXXXIII, fig. 1.}

Dombeyopsis platanoides Lx.: Tert. Fl., p. 254, Pl. XLVII, figss. 1, 2, 1878.

A single specimen.

Habitat: Top of Mount Everts, west face; collected by George M. Wright, July 7, 1885.

\section{Andromeja grayana Heer.}

Andromeda grayana Heer: Fl. Foss. Alaska, p. 34, Pl. VIII, fig. 5. Lesquerenx: Tert. Fl., 1. 234, Pl. XI, fig. 4. Knowlton: Bull. U. S. Geol. Surv. No. 105, p. 56.

Habitat: Mount Everts, near the summit of the west end; collected by F. H. Knowlton, July 27, 1888.

\section{Trapa? microphylla Lx.}

Pl. LXXVII, figs. 3, 4.

Trapa? microphylla Lx.: Tert. Fl., p. 295, Pl. LXI, figs. 16-17. Ward: Types Laramie Fl., p. 64, Pl. XxVIII, figs. 2-5.

This is undoubtedly the same species as that figured by Lesquereux from Point of Rocks, Wyoming, and by Ward from Burns Rancl, on the lower Yellowstone. It shows more the habit of the specinen figured by Ward, but has the general nervation of all the specimens referred to this species.

In fig. $15 a$ of Tertiary Flora the leaflets are petioled, while in fig. 15 they are clearly similar to Professor. Ward's examples.

These curious but well-marked leaves can not possibly belong to the genus Trapa as we now understand it, but as I am at present absolutely unable to suggest any other affinity, I can do nothing but leave their correct determination to be settled by future workers.

Habitat: Nortl of Pinyon Peak, on Wolverine Creek; collected by Arnold Hague, August 10, 1887. 
Diospyros stenosepala Heer.

Diospyros stenosepala Heer. Lesquereux : Fifth Ann. Rept. U. S. Geol. and Geog. Surv. Terr., p. 296, 1871 (1872).

Habitat: "Divide between the source of Suake River and the southern shore of Yellowstone Lake."

\section{Fraxinus denticulata Heer.}

Pl. LXXVIII, fig. 6.

Fraxinus denticulata Heer: Fl. Foss. Aret., Vol. I, p. 118, Pl. XVI, fig. 4; PI. XLVII, fig. 2. Lesquereux: Tert. Fl., p. 228, PI. X L, figs. 1, 2.

Several well-preserved specimens that are referred with certainty. Besides these there are several other well-preserved examples, of which the one figured is perhaps the best, that are somewliat larger than the types, but still appear to belong with them. The nervation is obscure, but the shape and toothed margin are quite similar.

Habitat: Mount Everts, near summit of the west end; collected by F. H. Knowlton, July 27, 1888.

\section{VibURNum ROTUNDIFoLiUm L $\mathrm{x}$.}

Pl. LXXVII, tig. 10; Pl. LXXVIII, figs. 2, 8, 9.

Tiburuum rotundifolium Ix.: Tert. Fl., p. 225, Pl. XXxVII, fig. 12; Pl. XxxVIII, fig. 10; Pl. LXI, tig. 23.

There is considerable difference in size among the specimens, but they seem to belong together, and to approach quite closely to Lesquereux's species. The small leaf shown in fig. 9, for instance, is certainly the same as the plant figurer by Lesquerenx (loc. cit., Pl. LXI, fig. 22), while fig. 8 is like fig. 10, Pl. XXXVIII (loc. cit.).

Habitat: North of Pinyon Penk, on Wolverine Creek; collecterl by Arnold Hague, Angust 10, 1887. 
FOSSIL FLORA.

Table ahouing geological distribution of Laramie plants.

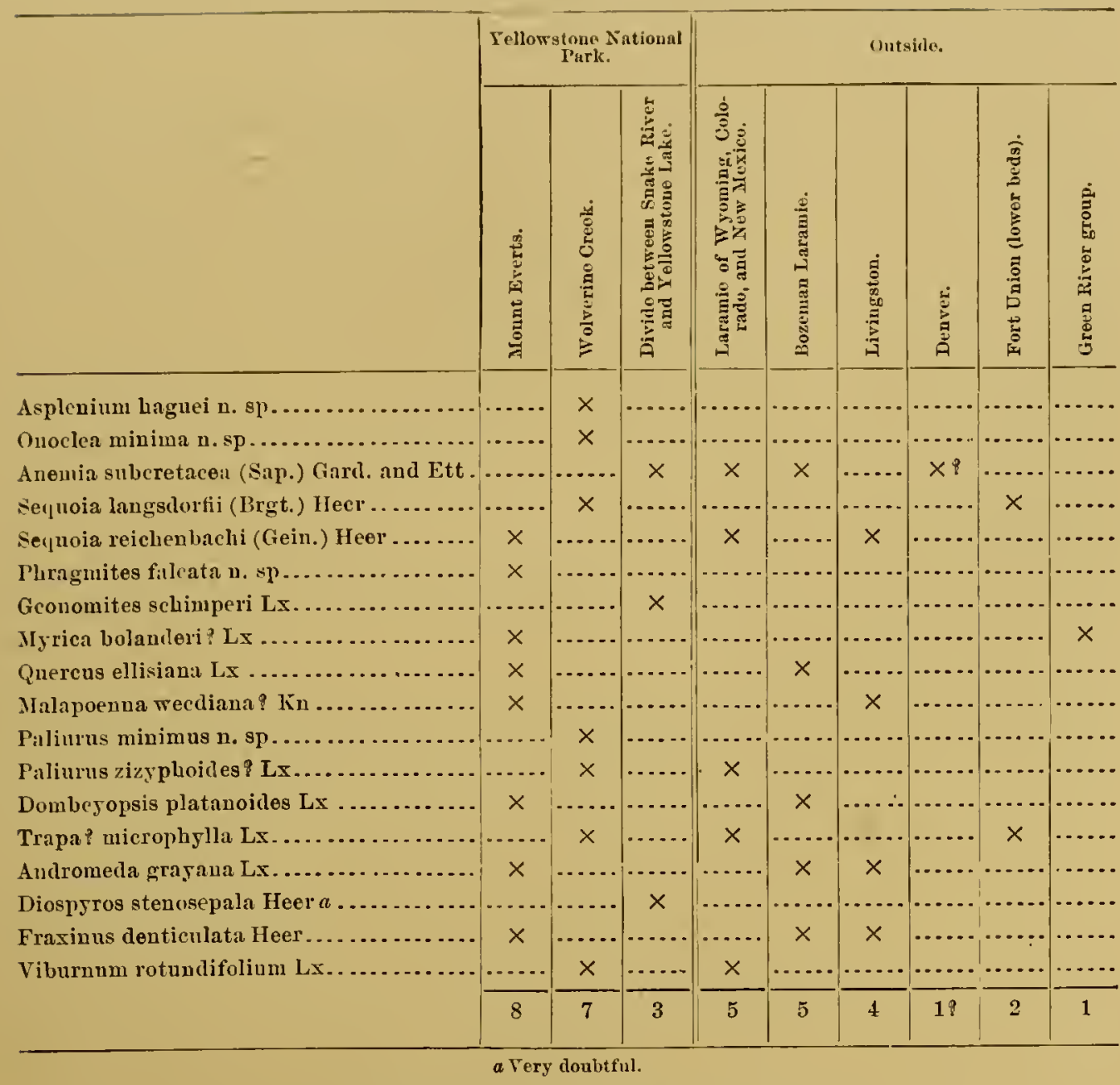

DISCTSSION OF IARAMIE FIORA.

It will be observed that there are only three localities within the Yellowstone National Park that have afforded Laramie plants, viz: Near the summit of Mount Everts, the valley of Wolverine Creek, and the more or less doubtful locality known as "divide between the source of Snake River and the sonthern part of the Yellowstone Lake." It has not been possible to relocate the latter place, but as it is in a regicn in which Laramie strata are known to occur, and several of the species represented have since been found in Laramie strata outside, it is assumer to be correct. 
This flora embraces only 18 species, of which number 8 are confined to the Mount Everts locality, 7 to Wolverine Creek, and 3 to the abovementioned doubtful locality.

Of the 8 species found at Mount Everts, 1 (Phragmites falcata) is deseribed as new, and 2 species (Quercus ellisiana and Dombeyopsis platanoides) have never before been found outside of the so-called Bozeman Laranie. The 2 species regarded as doubtful (Myrica bolanderi and Malapoenna veediana) depend on a single fragment each and are obviously of no value in determining the age. They are found normally in much higher horizons of the 3 remaining species, Sequoia reichenbachi has been found in the Livingston bers, but is also found in the true Laramie, and abundantly in still older strata. Andromeda groyane and Fraximes denticulata lave been found in both Laramie and Livingston beds in the Bozeman area.

The evidence of the fossil plants confirms that derived from the study of the stratigraphy, namely, that the beds near the summit of Mount Everts are of Laramie age.

Of the 7 species from Wolverine Creek, 3-Asplenimm haguei, Onoclea minima, and Palimns minimus-are described as new. The first of these does not appear to have any very close relatives in North America, but apparently finds its nearest analogue in certain species from the Cretaceons of Grecnland. Onoclea minima, on the other hand, is rery close indeed to a fern from Point of Rocks, Wyoming, that has been described under the manuseript name of Woodworlin crenata. The Wyoming plant depends on two or three small fragments, which, as pointed out under the diagnosis of Onoclea, are hardly sufficient to properly characterize it. It is quite possible that when new material shall be obtained these two plants will be found identical. Paliurus minimus is perhaps nearest to $P$. zizyphoides from Black Buttes, Wyoming, and Erie, Colorado. The 4 remaining species are distributed as follows: Seqnoin langsdorfii is represented by 1 small branchlet, and the identification is probably correct, as it is an easily recognized species. It has a wide geological and geographical distribution, being especially abundant in the lower Fort Union beds. Palimus minimus is doubtfully identified in this material. As stated above, it is a true Laramie species. Viburnum rotundifolium is also a Laramie species. It has never before been found outside of the type locality, which is Point of 
Rocks and Black Buttes, Wyoming. 'T'he most interesting species is Trapa? microphyllu. It is represented by several perfectly characteristic specimens. This species was first described from l'oint of Rocks, Wyoming, and was found later by Professor. Wand in lowest Fort Union berk, near the moutl of the Yellowstone River. The Wolverine Creek specimens approach closest to Professor Ward's specimens. Professor Ward is of the opinion that these lower beds represent the Laramie, since the plants in them differ from those in the undoubted Fort Union beds.

The three species from the divide between Snake River and the sonthern part of Yellowstone Lake are of little value in determining the age. Creonomites schimpri las never been found in any other locality, and Diospyros stenosepalu is rery doubtful indeed. It lais not since been collected, and the specimen on which Lesquereux based lis determination can not now be found. The only remaining species, Anemia subcretarea or Gymmogramma haydenii of Lesquereux, has a wide distribution, having been found in the Laramie, Denrer, and Eocene.

\section{DESCRIPTION OF FOSSIL PLANTS FROM THE TERTIARI OF THE YELLOIISTONE NATIONAL PARL.}

PLANTS, EXCLUSIVE OF FOSSIL WOOD.

\section{FILICES.}

\section{WOODWARDIA PREAREOLAA'TA $11 . \mathrm{sp}$.}

Pl. LXXIX, fig. 1.

Frond pinnate; pinnæ alternate, lanceolate, with slightly undulate margins, connate at their bases, forming a broad wing on the rachis; nerration strongly reticulated, consisting of one or two rows of long lacune next to the main rachis and along the secondary rachis, and the remainder forming large polygonal, slightly elongated, meshes.

Unfortunately the specimen figured represents the only example found. It is far from perfect, being only a segment from the middle of a frond, and consequently no idea can be gained of the outline of the whole frond. The segment of the main rachis is $8 \mathrm{~cm}$. long. The pinnæ are regularly 
alternate-that is, are the same distance apart. They are at least $6 \mathrm{~cm}$. in length and $2 \mathrm{~cm}$. in width. The full length and form of the apex could not be determined. The nervation is well shown in the figure.

This species is undoubtedly very closely related to the living Woodwarlia areolata (L.) Moore-so closely, in fact, that it is hardly possible to separate them satisfactorily. The pinne are alternate, of the same shape, and have identical nervation in botl. The only difference is that the margins of the pinnie are entire in the fossil and more or less serrate in the living species. It is possible that more material of the fossil form would show differences in this respect and bring them absolutely together.

This new fossil species much resembles Onoclea sensibilis fossilis Newberry, from the Fort Union group, but it differs in having strictly alternate pimne that are as far apart as it is possible to be. The pima are also without lobes of any kind, being only slightly undulated. The nervation differs slightly in producing more elongated areole in O. sensibilis fossilis.

In nervation $W$. preareoluta resembles $W$. latiloba Lx., from the Denver group, but differs markelly in having the pimne unlobed.

Habitat: Northeast side of Crescent Hill, opposite small pond; collecterl by F. H. Knowlton and G. E. Culver, August 2, 1888.

\section{Asplenium indingas 11. $\mathrm{sp}$.}

\section{Pl. LXXIX, figs. 2, 3; Pl. LXXX, figs. 9,10.}

Frond large, at least twice pimnate; main rachis thick, slightly zigzag; pimne alternate, remote, standing at an angle of $30^{\circ}$ to $45^{\circ}$, long-lanceolate, tapering to a rather slenrler apex, rachis strong, often abruptly curred upward, cut into numerous alternate, oblong, obtusely-acuminate pimunles with upward-turning points; nervation of pinnules simple, consisting of a slender midnerve and about 9 pairs of unforked, close, parallel branches, which are slightly arehed forward in passing to the borders; sori oblong, nearer the margin than the midnerve.

This fine species is represented by a large number of well-preserved specimens. It appears to have been a very large fern, possibly several times pinnate, but none of the specimens slow the larger connections. The largest rachis with pinne attached is $4 \mathrm{~mm}$. thick, but on the same stone, and 
evidently of the same species, are stems or rachises fully 8 mm. thick. 'There is some evidence to indicate that they were combined into a very large frond, but it is not conclusive. 'The longest example is about $20 \mathrm{~cm}$. long and spreads abont $9 \mathrm{~cm}$. The longest pimm (PI. LXXX, fig. 9) is preserved for $9 \mathrm{~cm}$. and still lacks the terminal portion. The pimme vary in width from 10 to $24 \mathrm{~mm}$, depending upon the portion taken.

The pinna are cut into oblong acuminate pimmules, the sinus sometimes extending to within one-third of their length of the base, brit nsually to abont laalf the length. Pinmules with a slender midnerve and 7 to 10 , usually 9, pairs of close, unforked nerves. The lower nerves of adjoining pimmles unite at a low angle and pass upward and end in the sinus.

Fruit dots were observed only on one small fragment (Pl. LXXIX, fig. 2). They are obscure, but as nearly as can be made out they are oblong and near the margin of the pimmles. Unfortunately none of the larger specimens are frniting, but apparently they all belong to the same species.

I do not recall any fossil species to which this seems to be allied. A number that have been described resemble it, but none closely enough to constitute specific similarity.

I have named this species in honor of Prof. Joseph P. Iddings, of the University of Chicago, who pointed out the locality which afforded the best specimens.

Habitat: Yellowstone River, above mouth of Hellroaring Creek (figs. 3,10 ); bank of Yellowstone, one-half mile below month of Elk Creek, base of bluff (figs. 2, 9); collected by F. H. Knowlton from Fossil Forest Ridge, bed No. 6, "Platamus bed," August, 1888. One specimen collected by Lester F. Ward and F H. Knowlton, Augnst, 1887.

\section{Asplenium ahanum 11. sp.}

\section{Pl. LXXIX, figs. 5-8, $8 a$.}

Frond simple, pimnatifid, sometimes nearly pinnate below, long lanceolate in outline, from a regular obtusely wedge-shaped base, and extending into a long slender apex; cut into numerons, mainly alternate, ovate, sharppointed lobes, those at the base being sometimes cut nearly to the rachis, those above less and less mutil the apex is nearly entire; nervation of the 
lobes or pinnules consisting of a strong midnerve passing to the tip, and 6 or 8 pairs of alternate once-forked lateral nerves; fruit dots not seen.

This large and striking species is the most abundant fern found in the Park. It is represented in the collection by fully 40 specimens, all from one locality. The largest example (fig. 7 ) is $17.5 \mathrm{~cm}$. long and $2.5 \mathrm{~cm}$. broad, and still lacks the terminal portion. It has a stipe $8 \mathrm{~mm}$. long and 2 $\mathrm{mm}$. thick. Fig. 5 is $16 \mathrm{~cm}$. long and $23 \mathrm{~mm}$. broad, and lacks both base and apex. Some of the fronds must hare been fully $25 \mathrm{~cm}$. long.

This species is well characterized. It has a thick grooved rachis $(1 \mathrm{~mm}$.) and a slort thick stipe. The lohes or pimules are irregularly orate, separated usually to the middle by a sharp sinus, and having a sharp upwardpointing apex. The nervation consists of a strong midnerve ending in the apex and about 7 pairs of alternate forked branches. As in the former species, the lower nerves of adjacent lobes unite and pass upward to the sinus. Occasionally there may be an unforked nerve, but it is the exception.

This species is associated in the same beds with $A$. iddingsi and much resembles it, differing, however, in haring apparently simple fronds that are uniformly larger than the pinnæ of the former species, and in having the nervation of the lobes always forking (see fig. 8 and 8a). It differs further in having a short stipe and in haring the upper portion nearly or quite entire.

The correctness of this generic reference is of course a matter of more or less doubt, as no fruiting specimens have been found, but the fern appears to be allied generically at least to $A$. iddingsi. It is certainly a well-marked species for geological purposes.

Habitat: Yellowstone River, one-half mile below mouth of Elk Creek, Yellowstone National Park, at base of bluff; collected by F. H. Knowlton, August, 1888.

\section{Asplenium erosum? (Lix.) Kn.}

Pl. LXXX, fig. 6.

Asplenium erosum (Lx.) Ku.: Bull. U. S. Geol. Surv. No. 152, p. 45, 1898.

Pteris erosa Lx.: Tert. Fl., j. 53, Pl. IV, fig. 8.

This appears to be the same as described by Lesquereux, but is obscure and difficult to make out. None of the specimens are complete, and all have the nervation rery poorly preserver. The margin seems more erose than 
the type, and the nerves may not fork. It is possible that it is a new species, but until better material can bo obtained I have preferred to retain the specimens under this species.

Habitat: Yellowstone River, onc-lalf mile below montl of Elk Creek; collected by F. H. Knowlton, Augnst 13, 1888 (fig. (6). Yellowstone River; wall of canyon above mouth of Hellroaring Creek; collected by W. H. Weed, October 13, 1887.

\section{Aspleniugi remotidens n. sp.}

Pl. LIXX, fig. 7 .

Pinne large, corlaceous, broadly lanceolate, taper pointed, obtuse and unequal sided at base; nargin with few remote sharp teeth; midvein strong; lateral veins at an angle of about $45^{\circ}$, simple or forking once some distance above the midrein; sori not seen.

The very perfect example figured is the only specimen obtained. It is $11 \mathrm{~cm}$. in length and $2.5 \mathrm{~cm}$. broad. It is broadly lanceolate with a slender tapering apex and obtuse unequal-sided base. The nervation is very obscure. It is probable that all of the lateral veins fork, but it was not possible to make this out, and the figure shows many as unforkerl. The ones that are made out to have the fork show it some distance above their base.

This species is very closely allied to, if not indeed identical with, Asplenium erosum (Lx.) Knn., ${ }^{1}$ from the Denver formation of Colorado. It has exactly the same shape, but differs in having few remote teeth, and in the branching of the veins. In $A$. erosum the veins fork at the base and oceasionally above the middle. In any case the species are very close together and may be combined at any time if future material from the Yellowstone National Park shows variation in the characters now relied upon for their separation.

Habitat: Yellowstone River, one-half mile below mouth of Elk Creek, at base of bluff; collected by F. H. Knowlton, August, 1888.

Dryopteris WEEUII 11. sp.

Pl. LXXX, fig. s; Pl. LXXXI, fig. 2.

Frond twice pinnate; pinnæ probably lanceolate in outline; pinnules

${ }^{1}$ Under Pteris erosa Ix., Tert. Fl., p. 53, Pl. IV, fig. 8; Cret. and Tert. FI., p. 121, Pl. XIX, fig. 1. 
opposite or subopposite, nearly at right angles to the rachis, long-lanceolate, rather abruptly acuminate, cut to within a very short distance of the rachis; nervation simple, consisting of a strong straight midvein and numerous (about 20) pairs of opposite, parallel, unbranched, lateral nerves; fruit dots small, round, on the backs of the nerves midway between the midvein and the margin.

This beantiful species is represented by sereral specimens, the best of which is shown in fig. 8. The pinnules are opposite or subopposite. They are long, slender, and pointing upward. Thle nervation is very regular, consisting of the strong midvein and 18 to $20 \mathrm{or}$ more pairs of opposite parallel veins. The fruit dots are distinct, though small, and borne on the veins midway between the midvein and margin.

'This species is closely allied to Lastrea goldiana (Lx.) Knn.,' from the Denver beds of Golden, Colorado. It does not so closely resemble the figure given by Lesquereux as it does certain forms that have been referred to it in my forthcoming monograph of the Laramie and allied formations. The type of the species is described by Lesquerenx as having 5 to 7 pairs of nerves, while the forms that I have referred to it have 10 pairs, with no other apparent difference. Dryopteris weedli, as stated, lias 18 to $20 \mathrm{or}$ more pairs. The pinnules are from 10 to $16 \mathrm{~mm}$. long and about $5 \mathrm{~mm}$. broad, whereas those of $L$. goldiana are only 7 to $9 \mathrm{~mm}$. long and $3 \mathrm{or}^{\circ} 4$ min. broad.

From this it is clear that these two species are quite closely related, and possibly a larger series of specimens might show them to be identical, but for the present it is best to regard them as different.

I have named this species in honor of Mr. Walter Harvey Weel, by whom the first specimens were collected.

Habitat: Yellowstone River, breccia in wall of canyon above mouth of Hellroaring Creek (Pl. LXXXI, fig. 2); collected by Walter Harvey Weed, October 13, 1887. Cliff on Yellowstone River (left hand), short distance above month of Hellroaring Creek (Pl. LXXX, fig. 8); collected by F. H. Knowlton, Auginst 10, 1888.

\footnotetext{
1 'This was first called Aspidium goldianum by Lesquereux (Seventh Anu. Rept., 1873 p, 393), but was later clianged to Lastrea (Goniopleris) goldiana (cf. Tert. Fl., p. 56, Pl. IV, tig. 13).
} 


\section{Dryopteris Naxtholithexse 11. Ap.}

I'l. LXXXI, fig. 1.

Frond pinnate?; pinne linceolate; pimnles opposite, lanceolate-deltoid, obtuse, cut to within one-third of their length of the base, much arched upward at the point; nerration simple, consisting of well-marked midrein and 9 or 10 pairs of opposite, parallel, unbranched lateral veins; sori large, round, on the backs of the veins at about one-third of their length from the midrein.

Of this well-marked species the single specimen fignred was the only one found. It is not preserved entire, the fragment being about $5 \mathrm{~cm}$. in length. There is therefore no means of knowing whether or not it was simple or compound. The portions of the pinne preserved are of the same width thronghout, showing that they probably came from the middle portion. The pinnules are opposite and arise at an angle of $30^{\circ}$ or $40^{\circ}$ from the rachis. They are lanceolate-deltoid in shape, and about $12 \mathrm{~mm}$. long and $5 \mathrm{~mm}$. broad, being much arehed upward at the extremity. The fruit dots are large, round, and placed on the backs of the reins near the midvein.

This species is allied to Dryopteris weedii, from which it clearly differs in having nuch shorter, arching pinnules, only 9 or 10 pairs of nerves, and larger frnit dots which are nearer the midvein. The nerration is the same in character, but differs, as stated, in number of pairs of reins.

From Lastrea goldiana this species differs in much the same manner. It has more arching pinuules, and is quite different in general appearance. The number of pairs of nerves is, however, about the same; all of which goes to show that these three species are closely related.

Habitat: Fossil Forest Ridge, Yellowstone National Park, bed No. 6, "Platanus bed;" collected by Lester F. Ward and F. H. Knowlton, August $19,1887$.

\section{Devallia? montana 11. sp.}

Pl. LXXIX, fig. 4.

Frond thin, twice pimnate, possibly more compounded; rachis strong; pinnæ alternate, lanceolate, ending in a sharp, hair-like point; cut into 5 
or 6 lobes or pinnules, the sinuses toward the base going nearly to the secondary rachis, more entire near the apex; lower pinnules or divisions 2 or 3 toothed, all, but especially the terminal pinmules, ending in long, slender, outward-pointing teeth; nervation simple, consisting of a strong secondary rachis with rather delicate nerres pointing to the pimules; the nerves near the base two or three times branching, the branches entering the teeth; nerves near the extremity unbranched.

The small fragment figured represents all that was found of this species. It is only about $30 \mathrm{~mm}$. long and $25 \mathrm{~mm}$. broad, the pinne being $17 \mathrm{~mm}$. in length and approximately $10 \mathrm{~mm}$ in width.

Notwithstanding the smallness of the fragment, there is enough to show that it differs markedly from any other form in the Park flora. I am quite at loss, however, to indicate its generic affinities. I have placed it under Devallia tentatively, and can only hope that subsequent material will serve to fix more satisfactorily its position.

Habitat: Fossil Forest Ridge, Yellowstone National Park, bed No. 3, "Mfagnolia bed," collected by Lester F. Ward and F. H. Knowlton, August 16-19, 1887.

\section{Lygodium kaulfisis Heer.}

PI. LXXX, figs, 1-3.

Lygodium neuropteroides Lx.: Tert. Fl., p. 61, Pl. V, figs. $t-7$; Pl. VI, fig. 1.

According to Gardner, ${ }^{1}$ the Lygodium neuropteroides of Lesquereux is absolutely identical with $L$. kaulfusii of Heer. Lesquereux was shown specimens of the true L. kiaulfusii from the British Eocene and pronounced them "positively identical" with his species from the Green River group and later formations. A glance at Gardner's ${ }^{2}$ figures shows that it is impossible to separate the American specimens.

This species was found at two localities in the Yellowstone National Park, namely, on the Yellowstone River below the mouth of Elk Creek, and on the north bank of the Lamar River between Cache and Calfee creeks. The specimens from below Elk Creek are in hard, rather coarsegrained rock at the base of the section. They are very large, having lobes 
8 cm. long and 2 cm. broad, and very much resemble a figure of this species given by Newberry, 'from the Pacific coast.

'The speeimems from the Lamar River are nuclı slenderer, being $7 \mathrm{~cm}$. long and less than $1 \mathrm{~cm}$. broad. Some of them, as fig. 2 , are very small and delicate. In nerration the specimens from both localities agree perfectly, as they do with European specinens.

Habitat: Yellowstone River, one-lalf mile below mouth of Elk Creek, at base of section; collected by F. II. Knowlton, August 13, 1888. North bank of Lamar River, between Cache and Calfee creeks; collected by F. H. Kunwlton, August 21, 1888.

\section{OsMunda AFFinis Lx.}

Pl. LXXX, figs. 4, 5.

Osmumter affinis Lx.: Tert. Fl., p. fiv, Pl. IY, fig. 1.

The Park collection contains specimens of several detached pinnules that it seems necessary to refer to this species. They are about the same size as Lesquereux's type specimen, but are better, in that they show the bases of the pinnules.

In the collection of Denver group plants recently worked up there are a number of specirrens of this species, some of which are very fine. One in particular, which has been figured for the forthcoming monograph of the Laramie and allied formations, is very large and perfect. It has a long zigzag rachis with numerous sessile pinnules alternately attached. They have a distinctly heart-shaped base, a slightly undulate margin, and a tapering but obtuse apex. In all these particulars, as well as in nervation, the Park specimens agree. The latter are a little shorter than the Denver specimens, and one is a trifle broader, but the differences are unessential. There is no knowing the part of the frond from which they came, and this may readily account for discrepancies.

Habitat: Southeast side of hill north of Lost Creek, Yellowstone National Park, bed No. 1, about 6,550 feet altitude; collected by F. H. Knowlton, August 5, 1888. 


\title{
EQUISET ACE.E.
}

\author{
Equisetum haguer $11 . \mathrm{sp}$.
}

Pl. LXXXI, figs. 3, 4.

Stem simple, striate, articulate; articulations rather long; sheaths short; teeth long, appressed, sharp-pointed.

This species is represented by numerous fragments, many of which, however, show the sheaths. The stem is from 4 to $6 \mathrm{~mm}$. broad and the articulations are 5 to $6 \mathrm{~cm}$. in lengtl. It is plainly striate, with usually 9 ribs. The sheaths, which are darker in color than the stem, are 6 or $7 \mathrm{~mm}$. in length and are provided with closely appressed, very sharp-pointed teeth, about 3 mm. long.

If there are 8 or 9 ribs now visible in the flattened stems, it seens safe to assume, inasmuch as they were cylindrical, that they have 16 or 18 ribs, and an equal number of teetl.

It was at first supposed that these specimens could be referred to $E$. limosum L. [see following species], ${ }^{1}$ as identified by Lesquerenx from material collected by Hayden from basaltic rocks near the Yellowstone Lake; but an examination of the type specimen preserved in the United States National Museum (No. 41) shows that they can not be the same. Lesquereux's specimen las only 4 or 5 ribs visible, making, as he says, about 10 for the entire diameter, while this has 16 to 18 , and possibly as many as 20 . The segments of the stem are only about $1 \mathrm{~cm}$. in length in Lesquerenx's specimen and 6 or $7 \mathrm{~cm}$. in the one under discussion. The sheaths are also longer and the teeth sharper in $E$. haguei.

Among living species this seems to approach closely to E. 7 imosmm L.; more closely, in fact, than does the specimen referred to $E$. limosum by Lesquereux.

I have named this species in honor of Mr. Arnold Hague, who pointed out the locality where it was found.

Habitat: Sontheastern end of liill north of Lost Creek, Yellowstone National Park, bed No. 5; collected by F. H. Knowlton, $188 s$. 


\section{Equisfrum LesquereuXiI Kn.}

Equisetum lesquereurii Kn.: Bull. U. S. Geol. Surv. No. 15*, p. 94, 1898.

Equisetum limosum Lim. Lesinereux: Fifth Aun. Rept. U. S. Geol. and Geog. Surv.

Terr., 1871 (1Ni2), p. 299); 'Tert. Fl., 1. 69, Pl. VI, tig. ̃.

As already stated under $E$. hagnei, the type specimen of this species is in the United States National IInsemm (No. 41). The figure given in Tert. Fl. (Pl. VI, fig. 5) is much more perfect than the specimen proves to be. The figure shows 7 ribs and the same number of teeth, which would make at least 14 ribs for the whole stem. The specimen shows only 4 or 5 ribs, and the sheaths and teeth are very obscure.

As it seems very mulikely that it should belong to the living species, I have rentured to change it, and have named it in honor of Professor Lesquereux.

Habitat: "Neai Yellowstone Lake, anong basaltic rocks."

\section{Equisetum canaliculatum $11 . \mathrm{sp}$.}

Pl. LXXXI, figs, 6, 7 .

Stem large, about 50-ribbed; articulate; articulation long; sheath obscure, but apparently short; teeth mumerous, short-appressed, sharppointed.

This species is represented by the two fragments figured and a number of other doubtful ones, which are hardly enough to properly characterize the species; but they seem to differ from all described species likely to occur in this region, and I have ventured to give them a new name. More perfect material may bring out the relationship.

The longest stem (fig. 6) is about $6 \mathrm{~cm}$. in length, and the broadest on that piece of material is $13 \mathrm{~mm}$. The other specimen (fig. 7 ) is $5 \mathrm{~cm}$. long and $21 \mathrm{~mm}$. broad. The ribs are distinct, yet not specially strong. They number, as nearly as can be made ont, about 25 on a side, or approximately 50 for the entire diameter. The length of the segments can not be made out. The sheath is also obscure. It may be that fig. 6 represents a single sheath; if so, it is long, but the other specimen gives slight evidence of having a short sheath. The teeth are short and appressed and end in slender points. As near as can be made out, there are about 25 teeth in riew. or something like 50 for the whole stem. 
The two stems shown in the upper part of fig. 6 show a distinct line of tubercles about the slight constriction. They probably represent the lower portions of the stems.

Habitat: Yancey Fossil Forest, beds near the upright stumps (fig. 6); collected by F. H. Knowlton, August 28, 1888. End of Specimen Ridge, opposite Junction Butte, near large upright stumps; collected by Lester F. Ward and E. C. Alderson, August 25, 1887. Yellowstone River, one-half mile below Elk Creek, at base of bluff; collected by F. H. Kunowlton, August 27, 1888. Cliff west of Fossil Forest Ridge; collected by Ward and Knowlton, August 15, 1887.

\section{Equisetum Deciduun n. $\mathrm{np}$.}

PI. LXXXI, fig. 5.

Stems large, many-ribbed, articulate, sheathed; sheaths short, without teetll.

This form is represented by several specimens, all very fragmentary and obscure. It has the stem $15 \mathrm{~mm}$. in diameter, and the sheath 14 $\mathrm{mm}$. in length. The diaphragm is clearly shown in 2 specimens, and appears to have been thick. The sheath is close and without teeth, which probably inideates relationship of this species with living species, such as E. hiemale, E. robustum, etc., having deciduous teeth.

Habitat: Yellowstone River, one-half mile below the mouth of Elk Creek, base of bluff (fig. 5); collected by F. H. Knowlton, August 27, 1888. Fossil Forest Ridge, bed No. 6, "Platanus bed;" collected by Ward and Knowlton, August 19, 1887.

\section{CONIFERE.}

\section{Pinus gracilistrobus n sp.}

Pl. LXXX, fig. 12.

Cone lanceolate, about $12 \mathrm{~mm}$. in diameter and about $45 \mathrm{~mm}$. long (neither base nor apex preserved); scales in 7 or 8 rows, regularly rhomboidal in shape, about $6 \mathrm{~mm}$. in transverse and about $5 \mathrm{~mm}$. in vertical dimension; scales umbonate, with usually 3 slight projections on the lower angle.

The specimen figured is the only one found of this species. At first 
sight it seems hardly possible to have so long and narrow a cone with so large scales, but this cone is preserved entire-that is, it has been pressed flat, and by turning it around the entire series of seales may be made out. It is now pressed into an elliptical shape, with a long diameter of abont $12 \mathrm{~mm}$. and a short diameter of ahout $5 \mathrm{~mm}$. Its length, as alrealy stated, is approximately $45 \mathrm{~mm}$.

I have not been able to find any fossil species with which this can be compared. There are a number having scales of much the same shape, but none with the same sized cone.

Habitat: Fossil Forest Ridge, Yellowstone National Park, bed No. 7, "Castanea bed," collected by Lester F. Ward and F. H. Knowlton, August 16-20, 1887.

\section{Pinus premurrayana $11 . \mathrm{sp}$.}

PI. LXXXII, fig. 5 .

Cone narrowy ovate-conical, rounded at base and gradually narrowed above to a very obtuse and rounded apex; scales thick, regularly rhomboidal, transversely wrinkled, each provided with a rounded blunt umbo, or possibly with a short, stout spine.

This species is represented by the single specimen figured, and is the most perfectly preserved cone $\mathrm{I}$ have ever seen, being preserved entire, with little or no distortion. It is about $8 \mathrm{~cm}$. in length. It is broadest at base, where it is about $2.5 \mathrm{~cm}$. in diameter, from which point it tapers gradually to the apex, where it is about $1 \mathrm{~cm}$. in diameter. The scales are very tightly closed, showing that with little doubt the cone was serotinous. They are quite regularly rhomboidal, being about $10 \mathrm{~mm}$. long and $6 \mathrm{~mm}$. high, and appear to have been transversely wrinkled. The tip is thick, raised, and was provided, in all probability, with a short, stout spine.

In seeking the probable affinities of this cone, a number of interesting problems are presented, first of which is the state of maturity. It is, of course, a well-known fact that all cones are tightly closed after fertilization and until the seeds are matured. In the majority of cases the scales open for the discharge of the ripe seeds, yet in a number of species they remain closed, or practically so, for many years. The seeds of these serotinous cones may retain their vitality for years-a provision for the continuance of the species.

Whether the cone under consideration is immature, and has the scales 
closed on this accomnt, or is a strictly serotinous form, is a difficult matter to decide. On the whole it seems probable that it was nearly or quite mature, and should be placed among those with normally closed scales.

The next question is, What is the age of this cone? - that is, is it a cone of a recent species or does it represent an extinct form? The phenomena are so active in the Park at the present time that it is perhaps possible for a cone of this kind to be replaced with silica within a comparatively short space of time. It however came from a part of the Park where the hot-springs phenomena have ceased for a long period, and this lends color to the idea that it is not of very recent origin. The probability is, therefore, that it lepresents an extinct rather than a living species.

This cone clearly belongs to the pitch pines and not to the soft or white pines, and in determining its affinities this latter group must be excluded. At the present time there are 3 species of pines growing in the Yellowstone National Park, as follows: Pinus scopulorum, P. Hexilis, and P. contorta murayana. Of these, $P$. flcxilis belongs to the white pines and the others to the so-called pitch pines, and of these the last, or $P$. contorta murayana, is by far the most abundant.

I have shown this cone to a number of botanists familiar with the present flora, and there seems to be much diversity of opinion as to its probable relationship. Mr. F. V. Coville, botanist of the Department of Agriculture, inclines to regard it as allied to an immature cone of $P$. scopulorm, but a careful comparison fails to sustain this view. Mr. George B. Sudworth, dendrologist of the Department of Agriculture, regards it as most closely allied to $P$. contorta murayana, the lodge-pole pine, and I lave so considered it. It is of approximately the same shape as mature cones of this species, but is longer and rather narrower. It is not improbable, as suggested by Mr. Sudworth, that it represents a form which was the immediate ancestor of $P$. contorta murayana, and I have given it the tentative name of premurrayana.

Habitat: East of the Yellowstone Iake, Yellowstone National Park. Collected by members of the Yellowstone National Park division of the United States Geological Survey.

Pinus sp.

Cone lanceolate?, abont $16 \mathrm{~mm}$. in diameter, length of part preserved $18 \mathrm{~mm}$; scales 5 rows in part preserved, probably about 10 or 12 in 
whole cone, approximately square (or, better, rlomboidal), $5 \mathrm{~mm}$. in each direction; each seale marked by a distinct umbo, and with a prominent ridge along the lower part.

The specimen described is also the only one observed. It is possible that it may be the same as $P$. gracilistrobus, as it comes from the same beds, but it is nearly twice the size, and differs slightly in the character of the seales and their markings.

Neither the base nor the apex is preserved, and it is therefore impossible to know the length, but there is a slight indication that the part preserved is near the upper end, as it is slightly narrowed. This may, however, be due to the poor state of preservation.

As stated under P. gracilistrolus, it is hardly worth while to attempt working out affinities with such imperfect material.

Habitat: Fossil Forest Ridge, Yellowstone National Park, bed No. 7, "Castanea bed;" collected by Lester F. Ward and F. H. Knowlton, August $16-20,1887$.

\section{PinUS MaCROLfis 11. sp.}

Pl. LXXX, fig. 11.

Scales thick, spatulate, rounded above, slender below, with a raised margin or rim.

The mere fragment figured represents all that was found of this species. It consists of portions of 9 scales, arranged in 4 spiral rows. They are broadly spatulate, being rounded above and narrow below. The largest one is $13 \mathrm{~mm}$. in length, $6 \mathrm{~mm}$. broad in the upper portion, and about $3 \mathrm{~mm}$. in the lower portion. The scales were thick and have a strong raised rim.

There is every evidence that this was a large cone, but it is so fragmentary that nothing can be made out but the few scales. It is useless to attempt to work out affinities, except that it was probably a white pine.

Habitat: Cliff west of Fossil Forest Ridge, Yellowstone National Park; collected by Lester F. Ward and F. H. Knowlton, Angust 15, 1887.

\section{Pinus wardi n. $\mathrm{sp}$.}

Leaves linear, long, apparently in twos, ribbed, not terete.

There are a considerable number of fragmentary specimens that seem in all probability to belong to this genus. They are slender, needle-like 
leaves, about $1 \mathrm{~mm}$. broad and at least $8 \mathrm{~cm}$. in length. They appear to have been ribbed, or at least not terete in cross section. In no case has the point or base of the leaves been observed, but from the fact that two leares seem to be found side by side, it seems quite probable that they were arranged in twos, as in the living Pinus edulis Engel., P. contorta Dongl., etc.

These leaves have a more or less close resemblance to certain described species, but they are too indistinct and poorly characterized to make any comparison raluable.

Habitat: Fossil Forest Ridge, Yellowstone Tational Park, bed No. 4, "Aralia bed;" altitude about 8,175 feế; collected by Lester F. Ward and F. H. Knowlton, August 20, 1887.

Pinus iddingist 11. sp.

Pl. LXXXII, figs. 8,9 .

Leaves linear, very long, teretish, ribbed, in bundles of three, sheath obscure, but apparently short.

The collection contains a number of needle-shaped leaves that without doubt belong to Pinus. They are about $2 \mathrm{~mm}$. broad and at least $13 \mathrm{~cm}$. long, but none are preserver entire. They appear to be associated in threes, and in one case (see fig. 8) the upper portion of a sheath is preserred with three leaves arising out of it. As near as can be made out, the leaves are round on one side and flat and clanneled on the other.

I have named this species in honor of Prof. Joseph P. Iddings, the collector.

Habitat: Andesitic breccia near gulch northwest of peak west of Dumraven; collected by Joseph P. Iddings, September 12, 1883.

\section{TAXites olRiki Heer.}

\section{Pl. LxXXII, figs. 1, 4, 5.}

Sereral specimens of this fine species were found. They agree closely with the figures given by Heer ${ }^{1}$ of specimens from Atanekerdluk, Greenland.

Habitat: Walls of the canyon of Yellowstone River above mouth of Hellroaring Creek, Yellowstone National Park; collected by Walter Harvey Weed, October 13, 1887. (Field No., 2961.) 


\section{Sequola coutrerde Heer.}

The naterial which I incline to refer to this species was found at only one locality within the Park, namely, the northeast side of Crescent Ilill. It was abundant and fairly well preserved. It consists of masses of slender branches with short acute appressed leaves, in some casos with recurving or at least spreading tips. In a number of cases the male aments were preserved. 'They are on short, slender branches covered with short scales. The aments are male up of few small, irregular scales.

There is undoubtedly much confusion in regard to this species. According to Gardner, ${ }^{1}$ much of the material referred to by Heer and others, from Greenland especially, should be relegated to another species, which he proposed to call S. whymperi. Gardner is also of the opinion that portions of the foliage have by varions authors been separated as Glyptostrobus ungeri. These, as he points out, are usually associated witl Sequoia cones, and are "never" accompanied by any trace of the persistent and very distinct cones of Glyptostrobus." I believe this to be true, and consequently I would refer to Sequoia conttsice the numerous specimens figured by Lesquereux as Glyptostrobus ungeri, from the Green River group of Florissant, Colorado. I am also of the opinion that the specimens from the Fort Union group, at the mouth of the Yellowstone, described by Newberry ${ }^{3}$ under the name of Glyptastrabus europeus Brongt., should be placed under Sequoia couttsice. I have never seen any of these specimens, however, and base this conclusion on the figures. I have seen a number of specimens from near the same place, collected in later years, and they seem to bear out this conclusion. Some of the material from the so-called Laramie of Canada also appears to be properly referable to this species. The whole subject needs thorough revision, with specimens at hand from all localities, and until this can be had no determinations can be regarded as final.

Habitat: Northeast side of Crescent Hill, opposite small pond, Yellowstone National Park; collected by F. H. Knowlton, August 2, 1888.

'Monog. Brit. Eoc. Fl., Vol. II, Pt. I, Gymnosperma, p. 39.

${ }^{2}$ Cret. and Tert. F1., p. 139, Pl. XXII, figs. 1-6a.

${ }^{3}$ See Cret. aud Tert., Pl., XI, figs. 6-8. 


\section{Sequoia langsdorfi (Brongt.) Heer.}

Pl. LXXXII, tig. 2.

Sequoia langsdorfii (Brongt.) Heer.: Fl. Tert. Helv., Vol. I, p. 54, Pl, XX, fig. 2; Pl. XXI, fig. 4 .

This is by far the most abundant and widely distributed conifer found in the Yellowstone National Park, with the possible exception of Sequoia magnifica, known only from the internal structure. It occurs in many places and in a variety of forms-that is to say, the branchlets and leaves are of various sizes, showing that they have come from many individuals and from different parts of the tree. They are not of the same size and character as specimens from the Fort Union group near the mouth of the Yellowstone, ${ }^{1}$ being rather smaller and not so spreading, but they are very much like the typical leares figured by Heer ${ }^{2}$ from Greenland.

In all cases, however, the attachment of the leaves appears to be characteristic of this species. In one exceptional case the cellular structure of the leaf conld be made ont. This agreed perfectly with one given by Heer (loc. cit., fig. 21).

In one or two cases male aments were observed which much resemble those figurerl by Heer (loc. cit., tig. 19).

Habitat: Fossil Forest Rirlge, beds Nos. 4, 6, and 7; collected by Lester F. IVarl and F. H. Knowlton, Angust 16-20, 1887. Cliff west of Fossil Forest Ridge, altitude abont 7,900 feet; collected by Lester F. IVard and F. H. Knowlton, Angust 15, 18>7. East bank of Lamar River, between Cache and Calfee creeks; collected by F. H. Knowlton, Angust 21, 1888. Southeast side of hill above Lost Creek, bed No. 1; collected by F. H. Knowlton, Angust 9, 1888. Yancey fossil trees; collected by F. H. Knowlton, Angust, 1888. South end of Crescent Hill, about 300 teet above main wagon road, bed 6 feet below "Platmuns bed;" collected by F. H. Knowlton, August 9, 1888 . Northeast side of Crescent Hill, opposite pond; collected by F. H. Knowlton, August 2, 1888. Yellowstone below mouth of Elk Creek, bottom of bluff; collected by F. H. Knowlton, August 29, 1888. Also obtained by Mr. Arnold Hagne (September 4, 1897) from 
the south side of Stinkingwater Valley, at a high bluff east of the mouth of Cring Creek, Wyoming.

$$
\text { SEQuora, cones of. }
$$

Pl. LXXXI, fig. 8; PI. LXXXII, figs. 6, 7 .

.The specimens figured are fairly representative of these organisms. They are quite fragmentary, yet appear to be cones. They are found in the same beds with Sequoia langsdorfii, but not in actual comnection with that species, and I liave preferred to keep them distinct, at least for the present.

Habitat: Fossil Forest, berls Nos. 5 and 6; collected by Lester F. Ward and F. H. Knowlton, August, 1887.

\section{TYPHACEE.}

\section{Phragmites? latissima n. sp. Pl. LXxxIII, fig. 5 .}

Leaf very broad; strix fine, close together.

The fragment figured represents all that has been collected of this form. It is, of course, quite insufficient for proper diagnosis, yet it seems to be different from anything litherto described from that region. It is certainly quite unlike anything found in the Yellowstone National Park.

It must have been a very large leaf, for the fragment is over $3 \mathrm{~cm}$. broad, and it was probably a thick leaf. The strie are very fine, straight, and close together. It differs in size and fineness of strix from $P$. alaskana, to which it seems to be most nearly related.

I have given it a new name with great relnctance, for it is too fragmentary to found a new species on, but for the present it may remain as above.

Habitat: Northeast side of Crescent Hill, Yellowstone National Park; collected by F. H. Knowlton and G. E. Culver, August, 1888.

\section{SPARGANIACEE.}

\section{Sparganium stygium Heer.}

Sparganium stygium Heer. Cf. Ward: Types of the Laramie Fl., p. 18, Pl. III, figs. 6, 7. These specimens do not agree in all particulars either with those figured 
by Professor Ward or with the types as shown by Heer. They are quite obscure, but in all probability they are identical with Heer's form.

Habitat: Yellowstone River, one-half mile below the mouth of Elk Creek, Yellowstone National Park; collected by F. H. Knowlton, August, 1888 .

\section{CYPERACEE.}

\section{Cyperacites angustior (Al. Br.) Schimper.}

Cyperteites ungustior (Al. Br.) Schimp.: Pal. vég. Vol. II, p. 414, 1870.

Cyperites angustior Al. Br. Lesquereux: Anu. Rept. U. S. Geol. and Geog. Surv. Terr., 1872 (1873), p. 403.

This species was identified by Lesquereux, but the material can not now be found.

Habitat: "Elk Creek, near Yellowstone River; collected by A. C. Peale, Joseph Sarage, and O. C. Sloane."

\section{Crperacites giganteus n. $\mathrm{sp}$.}

Pl. LXXXlI, fig. 10.

Leaves large, thick, with strong midvein and numerous close nerves.

This species, although fragmentary, is represented by several leaves and stems. The largest is $18 \mathrm{~cm}$. in length and about $7 \mathrm{~mm}$. in width. It has a well-defined midnerve or vein and numerous close veins. It was evidently of very firm texture.

Habitat: Yellowstone River, one-half mile below mouth of Elk Creek, at base of bluff; collected by F. H. Knowlton, August, 1888

\section{Cyperactes? sp.}

PI. LXXXIII, fig. 4.

This fragment is all of this species, whatever it may be, that has thus far been found. It was at least $2.5 \mathrm{~cm}$ broad and had a well-marked keel. The veins are strong, about $1 \mathrm{~mm}$. apart, with a fine intermediate, vein. There is altogether too little of it to venture a specific description or determination.

Habitat: Cliff west of Fossil Forest Ridge; collected by Ward and Knowlton, August 15, 1887. 


\section{Crperacites? sp.}

Pl. LXXXIII, fig. 6.

The fragment figured is the only specimen of this kind in the collections, and it is too imperfect to be of much value. It is about $3 \mathrm{~mm}$. broad, and appears to be two-ribbed-that is, two of the ribs are slightly stronger than the others. The fossil is rather faint, but there seems to be only one slender rib between the strong ones.

With so small a fragment it is impossible to be certain even of the generic reference, but in this respect it seems to agree with forms that have been referred to Cyperacites. It is left for future material to determine its status.

Habitat: Northeast side of Crescent Hill, Yellowstone National Park; collected by F. H. Knowlton and G. E. Culver, August, 1888.

\section{SHILACEE.}

\section{Smilax LaMiaRENSIS $11 . \mathrm{sp}$.}

Pl. CXXI, figs. $3,4$.

Leaves large, of firm texture, ovate or ovate-oblong, rounded truncate at base, abruptly and obtusely acuminate at apex, margin entire; 3-nerved or obscurely 5-nerved; petiole splitting into 3 equal branches, the middle of which passes straiglit to the apex, the others bending out to half the distance between midrib and margin, then curving toward and entering the tip; the lateral strong nerves branch on the outside, begiming first at the base of the blade, this branch sometimes reaching up to or near the apex or becoming lost near the middle; sometimes there are lateral strong. nerves with 5 or 6 branches on the outside, all of which unite in broad loops to produce a false fifth nerve.

This species is represented by several large, finely preserved examples. The largest, represented in fig. 4 , was $9 \mathrm{~cm}$. broad and at least $14 \mathrm{~cm}$. in length, and the smallest (see fig. 3 ) about $4 \mathrm{~cm}$. broad and probably about $8 \mathrm{~cm}$. in length.

In outline the leaves are broadly ovate or ovate-oblong, with a rounded truncate or cordate base. The apex in some cases appears to be long and 
rather obtusely acuminate, in other cases quite abruptly and obtusely acuminate.

The nervation is strongly marked. The petiole splits at the very base of the leaf, almost outside of the blade, into three equal divisions, one of which, the middle one, answering to the midrib, is straight and ends in the apex. The others arch out regularly and pass around and enter the apex also. Each lateral strong nerve or rib branches on the outside, the lowest branch, which originates just inside the lower margin of the blade, sometimes passing up and entering the apex with the other, at other times being lost below the middle of the blade. In still other instances there are 5 or 6 branches in the outside of the lateral ribs which join by a broad loop, forming a false nerve. In all cases this outside interrupted nerve is much lighter than the others.

Smilax appears to be rarely found fossil in North America, as only 5 species have been detected. Of these, 3 are from the Dakota group, and 1 each from the Laramie and Miocene. None of them is at all closely related to tlie one under discussion.

Smilax lamarensis seems to be closely related to a number of living forms. Thus the smaller rounded leaves are quite like S. rotundifolia L., both in shape and nervation, while the larger forms are hardly to be separated from S. piseudo-china L. It is certainly closer to living American forms than any heretofore described from this country.

Habitat: Last bank of Lamar River, between Cache and Calfee creeks; collected by F. H. Knowlton and G. E. Culver, August, 1888. Fossil Forest Ridge, bed No. 6, "Platanus bed," 1 large specimen; collected by Lester F. Ward and F. H. Knowlton, August, 1887.

\section{MUSACEE.}

\section{Musophylum complicatum Lx.}

Pl. LxxxmI, fig. 1.

Musophyllum complicatum Lx.: Tert. Fl., p. 96, Pl. XV, figs. 1-6.

This species was described by Lesquereux from a "shale over a thin bed of coal, 8 miles sontheast of Green River Station, Wyoming," in what he at first regarded as the Washaki group, but which he later ${ }^{1}$ decided was 
the true Green River group. 'This locality lias not since been visited, and in fact can not now be satisfactorily located. It is more than probable, howerer, that the former determination of horizon is correct.

So fin an I now know, this is the second time this species las ever been fomml. It is represented by 5 or 6 tairly well preserved specimens, which agree prerfectly with Lesquereux's specimens and figures.

On one of the specimens there are a number of thick stems or stipes. They are longitudinally striate as lescribed by Lesquereux, and bear only fragments of the leaves preserved. In the specimen figured we lave a narrow leaf preserved almost entirely. It is about $5 \mathrm{~cm}$. broad and $7 \mathrm{~cm}$. long, as preserved, with perfectly entire margins. In still another specimen the stipe, with portions of the lamina attached, is fully $20 \mathrm{~cm}$. long. There is no evidence from these specimens of the leaves having been as broad as lescribed in some of the original specimens, but Lesquereux also speaks of narow-leaved forms.

Habitat: Northeast side of Crescent Hill, opposite small pond, Yellowstone National Park; collected by F. H. Knowlton, August 2, 1888.

\section{JUGLANDACEE.}

\section{Juglans CALIFORNiEA LX.}

Juglans californica Lx.: Foss. Fl. Aurif. Grav. Deposits, Mem. Mus. Comp. Zoöl., Vol. VI, No. 2, 1878, p. 35, Pl. IX, fig. 14; Pl. X, figs. $2,3$.

There are 2 specimens which I refer to this species. They are of the same size and nervation as the leaf shown in fig. 2, Pl. X, of Lesquereux's paper.

Habitat: Fossil Forest Ridge, bed No. 6, "Platamus bed;" collected by Ward and Knowlton, August 19, 1887. East bank of Lamar River, between Cache and Calfee creeks; collected by F. H. Knowlton and G. E. Culver; August 21, 1888.

\section{JUGLANS RUGOSA Lx.}

Juglaus rugosa Lx.: Cf. Tert. Fl., p. 286, Pl. LV, figs. 1-9.

The collections contain a number of very perfectly preserved specimens that undoubtedly belong to this species. Besides these there are a number of fragments that probably belong to it.

Habitat: Fossil Forest Ridge, beds Nos. 3, 5, 6, 7; The Thunderer; 
Hill above Lost Creek, bed No. 4; Crescent Hill, 6 feet below Platanus bed; Yellowstone River nearly opposite Hellroaring Creek; collected by Ward and Knowlton, 1887, 1888.

\section{JUgLANS SCHIMPERI LX.}

Juglans schimperi Lx.: Tert. Fl., P. 287, Pl. LVI, figs. 5-10.

The collection contains a number of well-preserved examples that seem without doubt to belong to this species. The type is described by Lesquereux as having the margins slightly undulate. The Park specimens are slightly undulate, and also very slightly toothed. The nervation is absolutely the same in both.

Habitat: Andesitic breccia near gulch northwest of peak west of Dunraven; collected by Joseph P. Iddings, September 12, 1883.

\section{Juglans LaURifolia in. sp.}

PI. LXXXIII, figs. 2, 3.

Leaves large, membranaceous, lanceolate or ovate-lanceolate, slightly unequal-sided, narrowed to a wedge-shaped base and rounded to an acuminate apex, margins remotely and slightly denticulate; midrib thick below, becoming much thinner in the upper part; secondaries about 10 pairs, thin, alternate, emerging at an angle of $45^{\circ}$ or $50^{\circ}$, camptodrome, much curving, ascending near the margin for some distance, where they arch by numerous loops; intermediate secondaries occasional; nervilles very irregular, much branched; finer nervation forming irregularly quadrangular areolæ.

'This species is represented by a number of well-preserved leaves. They are from 9 to $13 \mathrm{~cm}$. long and 3 to $5 \mathrm{~cm}$. wide, and are somewhat unequal-sided, the difference in the width of the sides being about $4 \mathrm{~mm}$. This species is marked by its large size, remotely denticulate margin, and strong nervation.

Among fossil species, Juglans laurifolia is somewhat related to J. egregia Lx., ${ }^{1}$ from the Auriferous gravels of California. The leaves of the latter species differ, however, in being obovate-lanceolate, with the broadest part above the middle, and in having quite numerous, fine, sharp teeth. 
The nervation is somewhat similar, except that the secondaries are more munterons.

The relation between.$J$ lanrifolin and $J$. dentirilutu Heer, from the Green River ${ }^{1}$ group, Carbon, Wyoming, etce, while apparent, is much more remote than in the case of the California species. This species has very merfual-sided leaves, with large and more numerous teeth and more muncrons arched secondinies.

IIabitat: Hill above Yanceys and near the upright fossil trees; collected by F. I. Knowlton, Angust 28,188 . Also fomul on southern spur. of Chass Momntain, altitude 10,100 feet; collected by F. P. King for Amold Hagrue, August 11, 1897.

\section{Juglaxs CRescentia 11. sp. \\ PI. LXXXIV, tig. S.}

Leatlets large, of firm texture, lanceolate, narrowing to a long acuminate apex, truncate and slightly mequal-sided at hase; margin perfectly entire, slightly undulate; midrib thin, straight; secondaries 15 or 18 pairs, altenuate, at an angle of $35^{\circ}$ to $45^{\circ}$, camptodrome, forking below tine margin and joined to the one next ahove, forming a series of strong bow:; intermediate secondaries frequent, about midway between two secondaries, thin and soon vanishing or rarely passing to the loop made by the secondaries; a series of small loops are pröduced by outside branches from the large bows which nearly or quite reach the margin; finer nervation dividing the space between the secondaries and intermediate secondaries by large quadrangular areolation.

This fine species is represented by a number of beautifully preserved specimens. The best is the one figured, which is $20 \mathrm{~cm}$. in length and nearly $4.5 \mathrm{~cm}$. in width. As stated in the diagnosis, it is truncate and slightly mequal-sided at the base and long acuminate at the apex. The margin is slightly undulate, but not otherwise cut or serrated. The secondaries are numerons, about 16 or 17 pairs, and strictly alternate. They fork at half or two-thirds of their length from the midrib and, uniting with the one next above, form a series of broad, strong loops well inside the margin. The finer nervation is very perfectly preserved, forming large but quite regularly quadrangular areoli.

MON XXXII, PT $11-44$

${ }^{1}$ Tert. Fl., p. 289, PI. LVIII. fị. 1. 
Among described forms this has some resemblance in shape to $J$. schimperi Lx., ${ }^{1}$ from the Green River group of Coloralo, but differs markedly in the forking of the secondaries. It is undoubtedly very close to J. acuminatu Heer, ${ }^{2}$ which in turn is hardly to be distinguished from the $J$. rugose of Lesquerenx. Additional material of all these will be necessary to settle the status of each.

Habitat: Northeast side of Creseent Hill; collected by F. H. Knowlton and G. E. Culver, Angust 2, 1888. Fossil Forest, bed No. 6; collected by Wand and Knowlton August, 1887.

\section{Hicoria antiquorum (Newby.) Kin.}

Hicoria antiquorum (Newby.) Kñ.: Bull. U. S. Geol. Surv. No. 152, p. 117, 1898.

Carya autiquorum Newby.: Later Extinct Floras, p. 72 ; Ill. Cret. and Tert. Plants,

PI. XXIII, figs. 1-4. Lesquereux: Tert. Fl., 1. 259, Pl. LWII, figs. 1-5.

The collection contains a number of somewhat fragmentary specimens, but the characteristic teeth and nervation suffice to enable their certain reference to this species.

Habitat: Fossil Forest Ridge, bed No. 5, "Platanus bed;" collecterl by Ward and Knowlton, Augnst, 1887.

\section{Hicoria CREsCENTIA 11. sp.}

Pl, LXXXIY, fig. .

Leaflet thick and firm, elliptical-lanceolate, iniequilateral; rathere long wedge-shaperl at base and apparently narrowed above to an acuninate apex; margin serrate, teeth small, sharp; midrib rather thick, straight; secondaries about 15 pairs, alternate, irregular; at obtuse angles, arching upward, ravely forked, craspedodrome, or subcraspedodrome, either arching near the margin and sending branches to the teeth, or dividing and sending weaker terminations into the teeth; intermediate secondanies occasional, short, and soon disalpearing; nervilles numerous, mainly pereurent, approximately at right angles to the secondaries; finer nervation forming rather large quadrangular areolac.

The specimen figured is the only one referred to this species, and unfortmately it lacks both base and apex. It is now abont $7 \mathrm{~cm}$. long and 


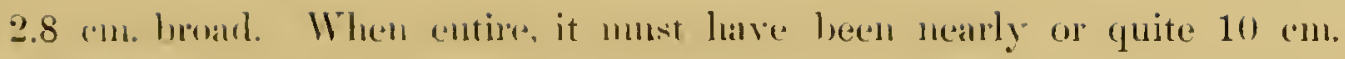
in length.

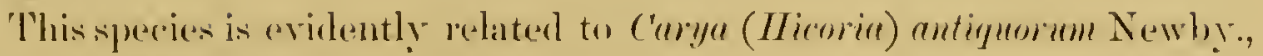
and it may possibly be an anomalous form of that species. It alppears to differ essentially, lowever, in being very nuch smaller, less mequal-sided, and in having larger and less mumerous teeth. The secomblaries ane much the sime in both, arept that they are more decidedly camptodsome in ('. (1)intiqu(t)rum.

It is also stgenestive of Juglans nigella Ung., as identified by- Ward ${ }^{1}$ from the lower Yellowstone River.

Habitat: Northeast side of Crescent Hill, opposite small pond, at an altiturle of about 7,500 feet; collected by F. H. Knowltor and G. E. Culver, July 27, 1888.

\section{HiCOR1A CULVERI 11. Sp.}

Pl. LxxxIII, fig. 7 .

Leaflets thin, slightly inaequilateral, rather long obovate, narrowed from above the middle to a long wedge-shiped base, and upward to an acminate apex; margin toothed from above the lower third, teeth flat, obtuse; niclrib slender; secondaries about 10 pairs, alternate, irregular, camptodrome, arching upward and joining by a broad curve, with branches ontside entering the tecth; intermediate secondanies occasional, joining the secondary below; nervilles very irregular, broken; finer nervation forming irregular meshes.

The fine specimen figured appears to be a terminal leaflet, as it is only slightly inequilateral. It is perfect, except at the apex It is preserved for $8 \mathrm{~cm}$., and was probably 9.5 or $10 \mathrm{~cm}$. long. It is $2.7 \mathrm{~cm}$. broad at the widest point, which is high above the middle. From this point it tapers regularly to the base and appears to pass rather abruptly to an acuminate apex.

This species has the same slape and arangement as Rhus bemtirei Lx.," from John Day Valley, Oregon, but differs in the serration of the nurgins and in the finer nervation. It seems likely that Lesquereux's species is a Hicoria rather than a Rhus.

${ }^{1}$ Types of the Laramie Fl., p. 33, Pl. XV, fig. 1.

"Proc. U. S. Nat. Ilus., Vol. XI, 18s8, p. 15. Pl. IA, tig. 2. 
Among living species $H$. culveri appears closer to $H$. ovatu (old Carya alba Nutt.), which has, however, sharper teeth and more regular nervilles. The secondaries and their branches entering the teeth are much the same in both.

Habitat: Yellowstone River, one-half mile below month of Elk Creek; collected by F. H. Knowlton and G. E. Cnlver, August, 1888.

IYRICACEE.

MYrica scotTit Lx.

Pl. LXXXIV, fig. 6.

Myrica scottii Lx.: Cret. and Tert. Fl., p. 147, Pl. XXxin, figs. 17, 18.

A single fairly well preserved leaf, that seems wirhout question to belong to this species. It has been found before only at Florissant, Colorado.

Habitat: Yellowstone River, one-half mile below Elk Creek, at base of bluff; collected by F. H. Knowlton, Angust, 1888

MYrICA WARDII 11. sp.

\section{Pl. LXXXIV, tig. 4.}

Leaf of firm texture, lanceolate, long wedge-slaped at base, obtusely denticulate from some distance above the base; midrib thick; secondaries thin, lather scattered, alternate or subopposite, emerging at an angle of abont $50^{\circ}$, arching evenly around and joining the one next above at a little distance from the margin, their mion forming a continuous marginal line, from the ontside of which small veins enter the obtuse teeth; nervilles thin, pereurent.

Unfortmately the fragment figured is the only specimen of this form collected. This is $5.5 \mathrm{~cm}$. long and about $12 \mathrm{~mm}$. wide. When entire, it was probably $10 \mathrm{~cm}$. or $12 \mathrm{~cm}$. in length.

This species resembles more or less closely a number of described species, yet undoubtedly differs from all. Thus, in the matter of the intramarginal nerve it resembles $M$. torreyi Lx., from the Montana and Laramie, but is much larger and has a greater number of parallel secondaries. In size and slippe $M$. wardii is much closer to $T$. polymorpha Schimp. ${ }^{2}$ from 
F'lorissant, Coloralo. It differ's essentially in harmg rather numerous secondaries, whieh parallol enter the somewhat sharper teeth. M. fallax Lx., also from Florissunt, is evidently related, but has much larger, slanp tectli, and nervation as in $M$. polymoryhlu $\mathrm{L}$.

1habitat: Fossil Forest Ridge, berl No. 5, "Salix bed;" colleeted by Warl and Knowlton, August 19, 1887.

\section{MYRICA LAMARENSIS 11. sp.}

\section{1'l. LXXXIt, fig. \%.}

Leat firm in texture, narowly lanceolate, narowed below, apparently acuminate at apex; margin at some distance above the base, provided with numerous, snall teeth; petiole short; midrib rather thick, straight; nervation pimate, camptodrome, the secondaries joming and forming a thin line from inside the border; other nervation destroyed.

'The little leaf lus only the lower portion preserved. It is now $3.5 \mathrm{em}$. in length, and when entire was probably not less than 6 cm. long. It is only $7 \mathrm{~mm}$. broad, and has a short petiole abont $2 \mathrm{~mm}$. in lengtl. The nervation is also destroyed, except the nidrib and about a dozen secondaries, which are seen to be alternate. They arch and join, produeing a marginal line just inside the margin.

This little leaf does not appear to have any very close relative in this eountry. Those approaching nearest, perhaps, are the narow leaved species so common at Florissant, Colorato, such as $M I$. fallax Lx., ${ }^{2}$ and $M I$. scottii Lx. ${ }^{3}$ They differ markedly, howerer, in the sharply serrate margin and craspedodrome nervation.

Myricu banlisicfolia Ung., as figured by Heer from the Baltic Mioeene, is perhaps nearer to on species. This has the narrowed base and similar teeth, but differs in the apex and in the nervation.

Habitat: East bank of Lamar River, between Cache and Calfee ereeks; collected by F. H. Kuowlton, August 21, 1888.

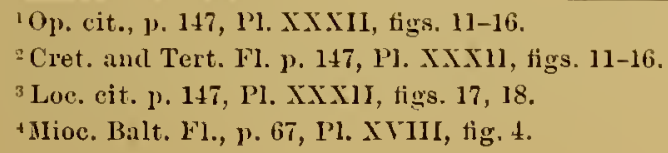




\section{SAIICACEE.}

\section{Populus glanduliteka Heer.}

\section{Pl. LXXXIV, fig. 1.}

Populus glandulifer, Неer. Lesquerenx: Cret. and Tert. Fl., 1. 226, Pl. XLY'A, figs.

3, 4. Warl: Types of the Laramie Fl., p. 19, Pl. IT, figs. 1-4.

The collection contains 3 specimens with very fine rounded or sharp teeth, that are referred without hesitation to this species, as figmed by Lesquereux and IVand, from the typical Fort Union group of the lower Yellowstone. 'The best of these is figurenl.

Habitat: Tellowstone River, one-halt mile below the mouth of Elk Creek; collecterl by F. H. Kunwlton, August, 1888.

\section{Populats sleciosa Ward.}

\section{I'l. LXXXIY, fig. 3.}

Populus speciosu Warl: Types of the Laramie Fl., p. 20, Pl. V, figs. 4-7.

The Park collection contains something over 50 specimens that are referred to this species. They are very perfectly preserved, and the petiole is in some anses $8 \mathrm{~cm}$. in length. There can be no question as to their correct reference to the Fort Union species. I should also incline to refer to this species certain of the leaves deseribed as Populus amblymbucha Ward and $P$. oxyrlyndla Ward, from the same beds. The very slight differences separating these forms seem lardly to be worthy of specific rank.

Habitat: Yellowstone River, one-half mile below mouth of Elk Creek; collected by F. H. Knowlton, August, 1888.

\section{Popult's zadiachi Heer.}

Popuhus sudduchi Heer: Fl. 'Tert. Helv., Vol. III, p. 307. Lescuerenx: Cret. and Tert. Fl., p. 158, I'l. XxxI, tig. S.

A few specimens were obtained that must be refered to this species.

Habitat: Late acid breccia, Pyranid Peak; collected by Aruold Hague, 1897. 


\section{Populus xaxtholthexsis 11. ip.}

\section{Pl. IAXXY, figs. 1, 2.}

Leares lange, nearly round in ontline, but a little broader than long, truncate or slightly heart-shalued at base, runded above; margin strongly toothed; teeth in lower portion simple and munded, others, along the side of the hade, inclinerd to be donble-toothed-that is, each large tooth lats one or 2 smaller rounded projections; petiole long. slender; blade 7 -nerved; central or milrils strong, straight, pair of ribs nearest the midrib originating at a little distance above the base of the biade, arching around and reaching the apex near together, other 2 pairs arising from the apex of the petiole and dividing equally the remaining portion of the blade; midrib with about 3 pairs of secondaries in the upper part, next pair of ribs with 4 or 5 branchess on the outside, other ribs with numerous branches which anastomose, producing large irregular areas, with minute branches to the teeth; nervilles numerons, mainly broken, ocensionally percurent; finer nervation quadrangular.

The 2 beantiful specimens figured are the only ones referred to this species. Fig. 1, which lacks the upper portion, is $9.5 \mathrm{~cm}$. broad and 7.5 cm. long. It has the petiole preserved for $5.5 \mathrm{~cm}$. Fig. 2, which lacks a portion of one side and a fragment at the apex, is $8.5 \mathrm{~cm}$. in length and $10 \mathrm{cml}$. in widtl. The petiole is not preserved.

The relation of this species is evidently with Populus genatrix Newby., ${ }^{1}$ from the Lower Yellowstone. This is about the same size and much the same shape, except that it is more prolonged at the apex. The margin is described as having "rather small, appressed teeth," while those of I'.xantholithensis are larger, sometimes double, and never appressed. The former species was described by Newberry as "3-nerved," although the figure shows it to be clearly 5 -nerved. The present species is just as clearly 7-nerved. The nnidrib and its branches also differ markedly in the two forms.

This species has also some aftinity with certain of the forms described by Professor Ward from the lower Yellowstone, but the relationship is not alose.

' Later Ext. F1., p. 64; III. Cret. and Tert. Fl., Pl. NIl, tig. 1. 
Habitat: Yellowstone River, one-half mile below the mouth of Elk Creek, top of bluff; collected by F. H. Knowlton, Angust, 1888.

\section{Populus daphogenoides Ward.}

Pl. LXXXIV, fig. 2.

Populus daphnogenoides Ward: Types of the Laramie Fl., p. 20, Pl. YII, figs. 4-6.

The collection contains some 20 specimens that are referred to this species. They have the same general character, but are a little larger, with a more prolonged point and rather stronger nervation. There are no essential differenres, however.

Habitat: Yellowstone River, one-half mile below the mouth of Elk Creek, top of bluff; collected by F. H. Knowltor, Ingust, 1888.

\section{Populus balsamoides Göpp.}

PI. LXXXTI, fig. 1.

Populus balsamoiles Göpp. Lesquerenx: Cret. and Tert. Fl., p. 248, Pl. LT, figs. 3-5.

The fragment figured is the ouly specimen of this species detected. It represents the basal portion of a medium-sized leaf, and agrees satisfactorily with the figures of this species as given by Lesquerenx.

Habitat: Cliff west of Fossil Forest Ridge; collected by Ward and Konowlton, Anğust 15, 1887.

\section{Populus? vivaria 11. sp.}

\section{PI. LXXXYI, fig. ?.}

Leaf thick, roundish, or broadly elliptical in ontline, tonthed to near the base; teeth large, acute; nervation pimate, camptodrome, or inperfectly craspedodrome; secondaries strong, opposite or subopposite, emeroing at varions angles, forking near the margin, the branches arching into bows and apparently sending branches from the outside to the teeth; nervilles obscure, but apparently percurrent.

This doubtful species rests on the single fragment figured. It was apparently about $10 \mathrm{~cm}$. long and $7 \mathrm{~cm}$. wide. It has some resemblance to certain species of Populus from the Fort Union group of the lower Yellowstone, as, for example, $P$. grewionsis Ward, but differs in the branching of 
the lower large secondary, and somewhat in the teeth. The nerves are also clanspedodrome in l'yperiopsis.

It is really too fingmentary and uneertain for identification, yet it differs from anything che fomn in the collection, and is simply named in a purely provisional mamer, awaiting subsernent collections.

Halbitat: West enrl of Fossil Forest Ridge; collected by Ward and Kinowlton, August 15, 188 .

\section{Salix varians Heer.}

Pl. LXXXV, fig. 3.

Salix ravians Heer: Fl. Tert. Helv., Yol. II, Pl. LXY, figs. 1-3, 6-16.

The eximple figured certanly belongs to this species. It is the same shipe, but a little larger, and las the saime erose-dentate margin and the sane midrib and general nervation.

Habitat: Lamar River, between Cache and Calfee creeks; collected by Knowlton and Culver, August 27, 1888.

\section{Salix angusta Al. Br.}

Salix ungustu Al. Br. Lesquereux: Tert. Fl., p. 16s, PI. XXII, figs. 4, 5; Cret. and Tert. Fl., p1. 157, 247, PI. LV, fig. 6.

This species, originally described by Heer from the Swiss Tertiary, has been found by Lesquereux in the Green River group at Florissant, Colorado, and in the Hiocene of Oregon. A number of doubtful fragments were reported from Spring Canyon in the Bozeman coal field, but they are too fragmentary to be of any ralue.

Habitat: Lamar River, between Cache and Calfee creeks; doubtful fragments; collected by F. H. Knowlton, August, 1888; also specimens No. 1967 of Hague's Park collection.

\section{Salix ladateri Heer.}

Salix lavateri Heer: Fl. Tert. Helv., Vol. II, p. 2s, Pl. LXVI, figs. 1-12; Fl. Foss. Alask., Pl. II, tig. 10. Lesquereux: Proc. U. S. Nat. MIus., Vol. XI, 1s8s, p. 35.

Habitat: South end Crescent Hill, bed 25 feet above "Platanus bed;" collected by F. H. Knowlton, August, 1888. 


\section{Salix elongata? O. Web.}

Salix elongata O. Web. Lesquerenx: Tert. Fl., p. 169, Pl. XxII, figs. 6, 7.

A single quite well preserved specimen that seems to belong to this species. The nervation, however, is not well preserved, but as nearly as can be male out it may be referred to this form.

Habitat: Fossil Forest, lower stratum, No. 1221 of Hague's Yellowstone National Park collection; collected by Arnold Hague, September 24,1884 .

\section{BETULACEE.}

\section{Betula iddingri 3. sp.}

PI. LXXXYI, figs. 4, 5.

Leaves membranaceous, ovate; slightly unequal-sided, rather abruptly romided to the hase, more prolonged above; margin regularly toothed from near the base, teeth slightly mequal, a little looked; nervation pimate and craspedollome; midril well marked, straight; secondaries about 10 pairs, mainly alternate, occasionally opposite, arising at an angle of about $45^{\circ}$, straight or nearly so, terminating in the larger teeth, often with forks near the margin, all of which enter the other teeth; nervilles obscure, but apparently percurent and at right angles to the secondaries; finer nervation not preserverl.

This species is representerl by 3 very perfect leares, all of which are preserved on the same piece of matrix The most perfect one figured is 8 cm. in length and $4.5 \mathrm{~cm}$. wide, while the other is about $8 \mathrm{~cm}$. long and less than $4 \mathrm{~cm}$. wide. The petiole belonging to this specimen is $7 \mathrm{~mm}$. in lengtl.

This species somewhat resembles a number of described forms, as, for example, Betulu stevensoni Lx., ${ }^{1}$ from Carbon, Wyoming, from which it differs somewhat in shape, number of pairs of secondaries, and in the more regularly serrate margin. Betula elliptica Sap., as identified by Lesquerenx ${ }^{2}$ from John Day Talley, Oregon, is perlaps closer, yet this differ's in having only 6 or 7 pairs of secondaries and also in the teeth. Betula parce-dentata Lx., from the same locality, las the same kind of teeth, but differs in size. 
Besides these, belonging to the geenns Betulat, there are a mumber of others mure or less resembling this leaf; e. on., Almus curpinoides Lx., ${ }^{1}$ from Bridge Creek, Oregom, and Cerlustrus ondus Wart, from the Fort Union gremp of Momtana.

Among living species this appears to be elosest to Betulu lutea Michx., but eren this is somewhat remote. In the future it may be thought best to place this fossil species under some other gemus, for which, no donl,t, reasons may be found, hut for the present it seems best to place it in Betula.

Betullu cequalis Lx., ${ }^{2}$ from the Auriferous gravels of California, is evidently closely related; hut this differs in being much narrower, more wedge-shaped at base, and in having fewer and smaller teeth. B. prisca Ett., as figured by Ward ${ }^{3}$ from the uppermost Fort Union, near the mouth of the Yellowstone River, is similar but much smaller.

This species is named in lonur of Prof. J. P. Iddings, of the University of Chicago, who pointed out the locality at which it was first collected.

Habitat: Vellowstone River, one-halt mile below the mouth of Elk Creek, top of bluff; collected by F. H. Knowlton, Angust, 1888. Hill above Lost Creek, bed No. 2; collected by F. H. Knowlton, August 5, 1888.

\section{Corylus inacquarrit (Forbes) Heel.}

\section{Pl. LXXXVI, fig. 3.}

Corylus macquarryi (Forbes) Heer: Urwelt d. Schweiz, p. 321, 1865.

The collection contains a single well-preserved specimen that is referred with some little hesitation to this well-known species. It has the proper slape, including the heart-slaped base and identical nervation, but differs slightly in the marginal dentation. In the typical form the margin has numerons rather small, sharp, upward-pointing teeth, while the one under consideration has fewer, rather blunt teeth. It may not be the same, but rather than make a new species I have referred it to C. mucquaryi.

Habitat: Fossil Forest, middle stratum, Hague's Yellowstone National Park collection (No. 1220); collected by Armold Hagne, September 24, 1884 .

'Op. cit., p. 243, Pl. LI, fig. 5 .

`Mem. Mus. Comp. Zö̈l., 1878, p. 2, Pl. I, figs. ?-4.

${ }^{3}$ Types of the Laramie Fl., Pl. XIV, tig. 2. 


\section{FAGACEE.}

Fagus antipofil Abich.

Fagnus antipofii Abich. Lesqnereux: Ann. Rept. U. S. Geol. and Geog. Surv. Terr., 1572 (1873), 1) 403.

Identified by Lesqueremx, but not since observed.

Habitat: "Ellk Creek, near Yellowstone River; A. C. Peale, Joseph Savage, and O. C. Sloane."

\section{Fagus undulata 11. sp.}

Pl. LXXXV, figs. 4, 5.

Leaves small, of very firm texture; elliptical with a broadly wedgeshaped base and apparently obtuse apex; margin regularly molulatetoothed, the teeth being regularly rounded and separated by similarly rounded sinuses; midrib strong, straight; secondaries numerous, opposite, parallel, mbranched, all entering the obtuse teeth; nevilles rery numerous, at right angles to the secondaries, usually broken and anastomosing, although sometimes irregularly percurrent; fimer nervation producing small, iregularly quadrangular areolation.

This fine species is fortmately represented by several very perfectly preserved examples, the two figured showing both the basal and apical portions. They vary in length from 6 to $10 \mathrm{~cm}$. and in width from 2.75 to 4 cm. The margins are rery regulary molulate-toothed, the sinuses being almost an exact reverse of the nearest teetl. The wedge-shaped base is, however, without teeth for a short distance. The secondinies are at an angle of about $45^{\circ}$. They are parallel, and all enter the obtuse teetl. All of the finer nervation is beatifinlly preserved and is seen to be irregularly quadrangular.

This species does not approach closely to any living species known to me. It is perhaps nearest to certain forms of the common American $F$. ferruginea Ait, but the living form differs in being proportionately broader, and when toothed has sharp teeth, quite like Castanea, and pointing upward.

Among the 80 or more fossil species that have been described from various parts of the world, there are several that our species more or less closely resembles. Of these, $F$. dentata Göpp., as identified by Heer ${ }^{1}$ in the 
Locene beds at Atmelierlluk, Greenlamd, perlaps approaches most closely. They are, luwever, larger leaves, with conser, more aente teeth and fewer strietly alternate secondaries. 'The leares of $F$. undulatu are quite mlike the type specimen of $r$. dentatu as described by Göppert ${ }^{1}$ from the Tertiary of 'Schossnity as indeed are the leaves doubtfully so identified by Heer.

The Yelhowstone National Park leares are also quite like leaves of Fingus custunecefolin Ung., as figured by Heer ${ }^{2}$ from the same beds. These were afterwards referrerl by Heer ${ }^{3}$ to his Castanea ungeri on what seems to me to have been insufficient grounds. There is hardly any difference between these and leaves of $F$. mudulata, except that the teeth are a little slarper. It is probable that they should be placed together, but as the status of Heer's plants is somewhat unsettled, I have preterred to keep them sepurated for the present.

Göppert has also described another species, $F$. attenuta, from Schossnitz, which is really quite close to $F$, undulatu. It is about the same size and has rounded teetl, but there is uniformly a tooth between two of the teetll which are entered by the secondaries. In $F$. undulata every tooth is entered by a secondary.

Fayus antipofi Abich, as figured by Heer, ${ }^{4}$ from the so-called Miocene of Alaska, is not greatly unlike the species under consideration. It has the outline, parallel secondaries, and finer nervation, but not the same kind of teeth. There are a number of other species, as $F$. attantica Ung., F. feronice Ung. ${ }^{5}$ as figured by Lesquereux ${ }^{6}$ from Elko, Nevada, etc., that resemble $F$. unculutu in one or more particulars, but not by any means sufficiently for specific identity.

But among all fossil forms, two of the leaves described by Heer as Custumea unyeri, ${ }^{7}$ from the supposed Miocene of Alaska, are undoubtedly nearest to the species under consideration. They are of about the same size and shape, but have teeth a little more acute. The secondaries are numerous, parallel, and enter the teeth as in Fayns undulatu, but in origin

${ }^{1}$ Tert. Fl. v. Schossnitz in Sehlesien, Gürlitz, 1855, p. 18, Pl. Y, fig. 11.

${ }^{2}$ Fl. koss. Aret., Vol. I, p. 106, Pl. X, tig. Ta; 1'I. XLVI, figs. 1-3.

${ }^{3}$ Luc. cit., Vol. 11 (Fl. Foss. Alask.), p. 32.

${ }^{+}$Loc. cit., Pl. VII, tig. 4.

${ }_{5}^{5}$ Chlor. Prot., Pl. XXVII, fig. 2.

${ }^{6}$ Tert. Fl., p. 146, Pl. XIX, figs. 1-3.

7 Fl. Foss. Aret., Vol. II (l.l. Foss. Alask.), Pl. V1I, figs. 1, 2. 
they are uniformly alternate instead of opposite. The 2 leares figured by Heer I regard as very doubtful. From their general facies they are much more likely to belong to Fagus than to Castanea. The other leaf figured with them ${ }^{1}$ does not appear to be the same, and is probably a Castanea, although somewhat anomalous. They are found associated in the same beths with 2 species of Fagus, from which they are hardly to be separated.

Habitat: Bluff on Yellowstone River 1 mile below mouth of Elk Creek, and about same distance above mouth of Hellroaring Creek: collected by F. H. Knowlton, August 4, 1888.

\section{Castanea pulchella $11 . \mathrm{sp}$.}

\section{Pl. LXXXYI, figs. 6-8; Pl. LXXXYII, figs. 1-3.}

Querens arymeja Ung. Lesquerenx: Cret. and Tert. Fl., p. ״45, Pl. LIV, fig. 4.

Leaves of very thick, firm texture; long-linceolate in outline, with wedge-shaped base and long, slender, acuminate apex; margin evenly and regularly toothed; teetlı large and sharp, separated by prominent sinuses, or more obtuse with shallower sinuses; petiole long, slender; midrib strong, straightit; secondaries very numerous, opposite or altemate, parallel, all, except two or three of the lowest, entering the teeth; nervilles well preserved, numerous, at right angles to the secondaries, mainly broken.

This fine species is represented by a very large series of specinens, nearly all in excellent state of preservation. They range in size from about 8 to $20 \mathrm{~cm}$. in length and from 2 to $6 \mathrm{~cm}$. in wilth, while the petiole in some cases is $3.5 \mathrm{~cm}$. long and rather slender. They are lanceolate in outline, with a long wedge-shaped base, which is without teeth for some distance, and a very long slender apex provided with numerous strong teeth. The teeth of the margin are numerous and regular, in some cases, as in fig. 2 of Pl. LXXXVII, being very large and sharp, while in others they are less prominent. They are, however, all sharp and upward pointing. The secondaries are numerons, parallel, and entering the teeth. The finer nervation is well preserved, the nervilles being numerons and mainly broken in crossing.

It is with some hesitation that these leaves are described as new to science. At first they were thought to be the same as the leaves from 


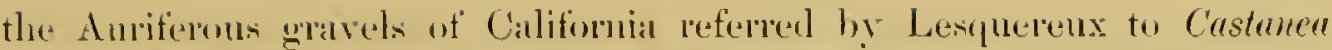
ungeri hecer, hut a careful stmly of the Yellowstone National Pank material, comprising nealy 100 sperinems, and of a fine collection fiom Independence Hill. l'laner Comty, California, has emvincerl me that they ane distinct, althongh alosely related. The Califomial species differ in laving a shorter petiole, in the werlge-shaped hase being destitute of teeth for a greaten" distance, in having serrate margins ather than Castanea-like teeth, and in laving in genelal closer secomlanies. This study has also brought ont the fact that Lesquereux could hadly have been correct in irlentifying the Califomial specimens with Castanen ungeri as figured by Heer ${ }^{2}$ from Aliski. As alpeady stated moler Fagus mululata (p. 700), it is more than probable that 2 of the leares figured by Heer (loc. cit., Pl. VII, figs. 1, 2) should be restored to Fagus, and the other is certainly specifically distinct from the California leaves. The California specinens, as stated, differ also fiom the Yellowstone National Park species, and should probably be given a new name.

Lesquerenx identified ${ }^{3}$ as puevens drymeja Ung., a single leaf from Bridge Creek, Oregon, that nust certainly be the same as Castanea mulchella. It is, for eximple, absolutely indistinguishable from fig. 7 of Pl. LXXXVI and fig: 2 of Pl. XXXVII. A comparison of certain of the European figures of Q. Hrymcja makes it more than probable that it was not correctly identified among the Bridge Creek material. The leaf figured by Lesquereux is referred to C. pulchella, and Q. Arymeja should be stricken from the westcoist flora, at least so fir as it depends on this particular specimen.

It was at first thought best to separate the small leaves represented in fig. 7 of Pl. LXXXVI and figs. 2 and 3 of Pl. LXXXVII, as a distinct species, but the only difference is one of size, and in the large series at hand this breaks down. All gradations from the smallest to the largest may be found, which is quite in accord with the well-known differences in size of leaves to be found ou living Castanea.

Habitat: Fossil Forest Ridge, Yellowstone National Park, bed No. 7, altitude about 7,250 feet; collected by Lester F. Ward and F. H. Knowlton, August 16-20, 1887. Yellowstone River, one-halt' mile below mouth of Elk

${ }^{\prime}$ Cret. and Tert. 1'I., p. 246, Pl. LIl, figs. 1, 3- $\overline{7}$.

2 Fl. Fuss. Aret., Vul. 11 (Fl. Foss. Alask.), p. 32, Pl. VII, figs. 1-3.

${ }^{3}$ Cret. and Tert. 11., 1. 245, 1'l. LIV, hig. 4 . 
Creek, bluff 300 feet above stream; collected by F. H. Knowlton, August 27, 1888. Junction Butte Fossil Forest, altitude about 7,450 feet; collected by Lester F. Ward and F. H. Knowlton, August 25, 1887.

\section{Quercus grossidextata 11. sp.}

Pl. LXXXYII, fig. 7 .

Leaf large, coriaceons, broadly lanceolate (base destroyed), apex acuninate; margin strongly toothed, the teeth sharp, upward pointing; midrib perfectly straight; secondaries about 8 or 9 pairs, alternate, at an angle of $45^{\circ}$, craspedodrome, slightly arching npward, ending in the large teeth; nervilles strong, at right angles approxinately to the midrib, mainly pereurent, but occasionally forked or broken, finer nervation not retained.

Unfortunately this fine species is represented by the single specimen figured, and this, it may be seen, lacks the basal portion. The part retained is $10 \mathrm{~cm}$. long and $4.5 \mathrm{~cm}$. wide. It was probably 14 or $15 \mathrm{~cm}$. in length when perfect. It has the margin strongly toothed, the teeth with long, rounded or sharp points, each of which is entered by a secondary.

Habitat: Fossil Forest Ridge, bed No. 5; collected by Ward and Knowlton, August 19, 1887.

Quercus consimlis? Newby.

Pl. Lxxrvil, tig. 6.

Quereus consimilis Nemby.: Proc. U. S. Nat. MIns., Vol. V, p. 505, 1882 [1883]. Quercus breneri Lx.: Cret. and Tert. Fl., 1 . ¿46, Pl. LIV, figs. 5-8.

This is only a fragment of the base of a leaf. It does not agree absolutely with the figures of Lesquerenx, but rather than make it a new species I have referred it provisionally as above.

Habitat: Yellowstone River, one-half mile below mouth of Elk Creek, at top of bluff; collecter by F. H. Knowlton, August, 1888.

\section{Quercis? Maginifolia $11 . \mathrm{sp}$.}

Pl. LxxxyII, tig. 1.

Leaf large, of firm texture, long, broadly obovate, narrowed to the base, rounded-obtuse at apex; margin at base entire, remainder of margin 
destroyed, but probably toothed or lubed; midrib thick, straight; secondaries about 18 pairs, alternate, at vaurions angles, eurving npward, apparently (amplodrome; finer nervation entirely effaced.

The figured specinen is 1 !) cmo in length, and was probably at least 22 cull. in length when entire. It is about $7 \mathrm{~cm}$. broad in the widest part, which is above the middle of the leaf. Unfortunately the margin, with the exception of a small portion neal the base, is destroyed, and consequently it is impossible to properly characterize this leaf. There is, howerer, a little evidence to show that the margin was not entire for the whole distance, but this is too valgue to be of much value.

1 hinve referred this leaf provisionally to the genus Quercus, from its resemblimce to certain living forms, but it will be necessary to see additional material before the correctness of this view can be tested.

Iabitat: Yellowstone River, one-half mile below mouth of Flk Creek, at top of bluff; collected by F. H. Knowlton, August, 1888.

\section{Quercus furuinervis americana Kn.}

PI. LXXXYIII, fig. 5 .

Quercus furcinere is americana Ku.: Bull. U. S. Geol. Surv. No. 152, p. [92, 1898.

Quercus furcinervis Rossm. Lesquerenx: Cret. and Tert. Fl, p. 244, PI. LIV, figs. 1, 2.

The specimen here figured is certainly the same as that figured by Lescinereux (loc. cit., Pl. LIV, fig. 1) for this species.

Habitat: Fossil Forest Ridge, bed No. 5; collected by Ward and Knowlton, August 19, 1887.

\section{Quercus weEdir $12 . \mathrm{sp}$.}

\section{Pl. LXXXVII, fig. 4 .}

Leaves membranaceous, orate, rounded at base, acuminate at apex, margin strongly, irregularly toothed, teeth minutely spiny-pointed; nerration pimate; midrib straight; secondaries about 8 pairs, alternate, at an angle of about $45^{\circ}$, flexuose, craspedodrome, entering the teeth or forking near the margin and the branches passing into the teeth, or with strong nervilles crossing between 2 secondaries and sending a branch to the intermediate teeth; nervilles numerous, strong, at various angles, MON XXXII, PT II- $4 \overline{5}$ 
percurrent or forked and broken; finer nervation beautifully preserved, forming quite regular, large areolæ.

This beanciful species is represented by a considerable number of more or less perfect leaves, the best of which is figured. This fignred example is $11 \mathrm{~cm}$. in length and nearly $6 \mathrm{~cm}$. in width. Others are only $7 \mathrm{~cm}$. long and $3.5 \mathrm{~cm}$. wide. None larger than the one figured were obtained.

One of the marked features of this species is the number of teeth, there being quite regularly twice as many as the number of secondaries. These intermediate teeth are usually a little smaller than the others, and are supplied with a branch from the middle of a strong nerville, which crosses between 2 secondaries at some distance below the margin. This character is so constant and so peculiar that it may even be of generic value, but for the present the species may be retained in the genus Quercns.

This species has a more or less close resemblance to a number of described fossil forms. It is, for example, somewhat like Quercus vibumifolia Lx., ${ }^{1}$ from Golden, Colorado, Black Buttes, Wyoming, etc. This is more wedge-shaped at base, has more irregular teeth, which are supplied by branches from the forking secondaries. Quercus gröntandica Heer ${ }^{2}$ as figured from Spitzbergen also belongs to this group, but is a much larger leaf, with relatively smaller teeth and forked secondaries.

The very much larger leaf figured by Newberry as a young form or variety of Platanus haydenii Newby ${ }^{-3}$, and coming from the Fort Union beds at the month of the Yellowstone, also belongs near this group. It is impossible to see any generic, or even specific, differences between this figure of $P$. haydenii and Heer's figure above referred to of Qucrcus grönlandica. They must certainly be the same.

All of the species mentioned seem to be very close to the one under consideration, but they differ constantly by the manner of the supply of nerves to the secondary teeth.

I have named this species in honor of Mr. Walter Harvey Weed, who collected the best specimen observed.

Habitat: Fossil Forest Ridge, middle stratum; collected by W. H. Weed. Bed No. 6, "Platanus bed;" collected by Ward and Knowlton, August 19, 1887.

${ }^{1}$ Tert. Fl., p. 159, Pl. Xx, fig. 11.

${ }_{2}^{2}$ Fl. Foss. Aret., Yol. II, Jioc. FI. Spitzb. (K. Vetensk. Akad. Haudl, Vol. VIII, No. 7), PI. XII, fig. 5.

${ }^{3}$ Illustrations Cret. anı T'ert. Fl., Pl. XXI. 


\section{Querce's sp.}

\section{Pl. LXXXIX, fig. 7.}

'This is a fiagment of the base of what appears to have been a large, thick leat. It has a thick miclrib, and alteruate, thin, parallel, straight secondaries, which arise at an angle of about $45^{\circ}$. None of the finer nervation is preserved.

This hats some resemblance to the basal portion of what has been described as Q. culveri (p. 708), but it was several times larger than this and lacks the marginal tootling. They come from the same beds.

Habitat: Yellowstone River, one-half mile below mouth of Elk Creek, at base of bluff; collected by F. H. Knowlton, Angust, 1888.

\section{Quercus olafseni Heer.}

Quercus olafiseni Heer: Fl. Foss. Aret., Vol. I, p. 109, Pl. XLVI, fig. 10. Lesquerenx:

Cret. and Tert. Fl., p. 224, Pl. XLVIII, fig. 4; p. 245 , Pl. LIV, fig. 3.

There are a number of examples of this species, some of which are very well proserved. They are, with the exception of some minor details, identical with the figures given by Heer and Lesquerenx. Thus only occasionally are they doubly dentate, and the secondaries rarely branch. They are undoubtedly the same as the leaves figmed by Lesquereux.

'This species was reported by Lesquereux from the Bad Lands of Dakota (Fort Union group), and from Table Mountain, California (Miocene?).

Habitat: Yellowstone River, one-half mle below the mouth of Elk Creek, top of bluff; collected by F. H. Knowlton, Angust 27, 1888.

\section{QUERCUS YANCEYI 11. Sp.}

Pl. LXXXIX, fig. 2.

Leaf of firm texture, broadly lanceolate, somewhat wedge-shaped at base and acuminate at apex, with undulate toothed margin; midrib strong, straight; secondaries 9 or 10 pairs, alternate, remote, emerging at a low angle, curving upward, the lower ones arching along the border, upper ones entering the teeth or often arching along and joining the one next above; nervilles few, irregular, broken; finer nervation forming irregular areolre. 
The leaf figured is the only one of this species observed. It is $10 \mathrm{~cm}$. long and $17 \mathrm{~mm}$. wide in the broadest part, which is about the middle. The entire leaf, with the exception of a fragment at the base, is preserver. The margin is entire for the lower third, then it is mndulate-toothed, the teetll being rounded or rarely with a minute sharp point. In the lower part the secondaries arch and join, while those above either enter the teeth or join by a long loop and send a branch from the outside to the teetl. The finer nervation is well preserved, forming irregular meshes.

This beautiful species does not seem to be very closely related to any fossil oak with which I am familiar. Perhaps its nearest relative is $Q$. laurifolia Newby., ${ }^{1}$ from "burned shales, over lignite beds, Fort Berthold, Dakota," the age of which is not well indicated, but is certainly 'T'ertiary. It has only very faintly undulate-toothed margins, and the secondaries are at a more acute angle than in the one under discussion.

I lave named this species in lonor of Mr. John Yancey, proprietor of the stage station, and the namer of the fossil forest near by.

Habitat: Yancey Fossil Forest; slope near the standing 1runks; collected by Lester F. Ward and F. H. Knowlton, August 10, 1887.

\section{Quercus CUlveri 11. sp.}

Pl. LXXXVII, fig. 5.

Leaf small, of thick, firm texture, approximately oblong in general outline, obscurely 3-lobed; margin strongly, irregularly toothed; teeth obtuse or rounded, pointing outward, separated by broad, shallow sinuses; petiole slender; midrib rather slender, nearly straight; secondaries 6 pairs, subopposite, emerging at an angle of about $45^{\circ}$; or the 2 lower pairs only $25^{\circ}$, all nearly straight and entering the teeth; third pair of secondaries longest, entering the lateral lobes, with branches on the lower side which pass to smaller teeth; nervilles strong, apparently broken; finer nervation not preserved.

This beantiful species is represented only by the specimen figured. It is a small leaf, being abont $7.5 \mathrm{~cm}$. long, including the petiole, which does not seem to be entirely preservel, and $5 \mathrm{~cm}$. broad bewteen the lateral 
lobes. As alremly stated, the leat is olsenrely oblong in general ontline, heing slightly wedge-shaped at base and having the strongest teeth or lateral lobes at about two-thirds of the distance from the base. 'The apex is not preserved, but julging from the contour it must have been rather obtuse. The teetlu of the matrin are also rather obtuse. The nervation is strongly craspedodrome, the secondaries or branches all entering the teeth. Only a few nervilles are preserved and those appear broken. None of the ultimate nervation has been preserved.

This species is quite unlike any American fossil species with which I an familiar. Annong living species it approaches quite closely to oceasional leares of ?. prinoilles Willd., of the eastem United States. The living. leaves incline to be more wedge-shaped at base and to have stronger teeth separated by deeper simuses. It is hardly probable that the resemblance is close elough to warrant the assumption that Q. minoides has actually deseended from this fossil form.

I take pleasure in having named this fine species in honor of Prof. George E. Culver, some time professor of geology in the University of South Dakota, who assisted me in making the collection of plants in the Yellowstone National Park.

Habitat: Bank of Yellowstone River, one-half mile below the mouth of Elk Creek; top of bluff 300 feet above stream, in white, coarse-grained tuff; collected August 28, 1888, by F. H. Knowlton and G. E. Culver.

\section{QUERCUS HESPERIA 1 . sp.}

Leaf of firm texture, broadly lanceolate in outline, passing from about the middle down into a long wedge-shaped base, rather abruptly pointed at apex; margin with few (8 to 10) strong, sharp, upward-pointing teeth; midrib strong; secondaries 10 to 12 pairs, alternate, straiglit or slightly curving, ending directly in the teeth; intermediate secondaries frequent, about midway between the secondaries, disappearing about halfway between midrib and margin; nervilles irregular, producing large, coarse areolation; finer nervation similar.

The specimen upon which this species is foumded is nearly perfect, lacking only the tip. It is $6 \mathrm{~cm}$. long and a little more than $2 \mathrm{~cm}$. wide. The lower half of the leaf is regularly wedge-shaped and the upper portion is 
apparently rather abruptly pointed. The teetl are strong and sharp-pointed, with ronnded simuses.

This species seems to be allied to Q. boweniana Lx., from California, but differ's essentially in laving much larger, sharper teeth and straight secondaries. It is also allied to Q. yanceyi which has undulate or slightly toothed margin and ferver, more curved secondaries. It somewhat resembles a leaf that has been described as Hicoria culveri, which, however, differs in the teeth, and in having a camptodrome instead of a craspedodrome nervation.

Habitat: Yellowstone River, one-half mile below mouth of Elk Creek, at top of binff; collected by F. H. Knowlton, August, 1888.

\section{DRYOPYLLUI LONGIPETIOLATUM $11 . \mathrm{sp}$.}

Pl. LxXXYIII, figs. 6, 7.

Leaves lanceolate, long wedge-shaped at base, long narrowly acnminate at apex, margin regularly undulate-toothed, the teeth sharp, upward pointing, separated by rather shallow sinuses; petiole very long, slender; midrib thick, straight; secondaries numerous, alternate, 12 pairs or more, at a low angle in the lower part, more acute above, slightly curving ontward in passing to the margin, all ending in the teeth: nervilles at right angles to the secondaries, obscure but apparently mainly percurrent; finer nervation destroyed.

This species is represented by a number of specimens, none of which are complete in a single example, but by combining several a good idea of the species is given. The length appears to have been about $20 \mathrm{~cm}$. and the width in the middle $4 \mathrm{~cm}$. The petiole is long, being $2.5 \mathrm{~cm}$, and possibly not all preserved. In the larger leaves the secondaries are quite remote and distinctly alternate. They arch slightly in passing to the teeth.

The leaves of this species were at first confounded with leaves of Castanea pulchella, with which they occur in the same beds, but they differ in the longer petiole, the smaller teeth, and in the irregular, arching secondaries, with an occasional intermediate secondary between. The teeth of the upper third of the leaf are also of a different character. 
Among species of Dryophyllum this species has some resemblance to D. aquamarum Ward ${ }^{1}$ from Black Buttes, Wyoming. The latter differs in being broadest below the middle, undulate or simnate toothed, and in having more numerous, often camptodrome, secondaries. D. subfulcutum Lx., ${ }^{2}$ from Point of Roeks and Hodges Pass, Wyoming, also has some resemblance, but is much smaller, with nore numerous close secontaries.

Inabitat: Fossil Forest Ridge, Yellowstone National Park, bed No. 7, "Castanea bed;" collected by Lester F. Ward and F. H. Knowlton, August $16-20,1887$.

\section{ULMACEE.}

Ulaus patido-fulva? Lx.

Pl. LXXXVIII, fig. 2.

Ulmus pseudo-fule Lx.: Mem. Mns. Comp. Zoöl., Vol. VI, p. 16, Pl. IV, fig. 3, 1878.

The fragment figured is all that has been found of this form, and it is doubtfully referred to this species.

Habitat: Lamar River, between Cache and Calfee creeks, Yellowstone National Park; collected by F. H. Knowlton, August, 1888.

\section{Ulmus minima? Ward.}

Ulmus minima Ward: Types of the Laramie Fl., p. 45, Pl. XxII, figs. $3,4$.

A single sinall broken specimen is referred donbtfully to this species. It is of about the same size, but las the secondaries at a little lower angle, and has the nervilles well preserved. They are strong and pereurrent. The margin is toother, but the teeth are not well preserved.

This leaf is found on the same piece of matrix with Ficus tilicfolict? Al. Br.

Habitat: IIountain back of Yanceys, near the fossil trees; collected by F. H. Knowlton, August, 1888.

${ }_{1}$ Types of the Laramie Fl., p. 26, Pl. X, figs. 2-t.

${ }^{2}$ Cf. D. bruneri Ward, now referred to D. subfalcatum: Trpes of the Laramie F1., p. 27, Pl. X, tigs. 5-8. 
Ulumes Rhamisfolia? Ward.

Ulmus rhaminfolia Ward: Types of the Laramie Fl., p. 45, Pl. XXIII, fig. 5.

This species is also represented by a single, much broken leaf, with only a small portion of the margin preserved. It has the size and nervation of Professor Ward's species, and is with hardly any donbt the same.

Habitat: Yellowstone River, one-half mile below the mouth of Elk Creek, top of bluff; collected by F. H. Knowlton, August, 1888.

$$
\text { Ulmes, fruits of. }
$$

Pl. LxxxvIII, figs. 3,4 .

As it is impossible to determine the species of Ulmus to which these fruits belong, or properly to characterize them, I have preferred to leave them unnamed specifically.

Habitat: Yellowstone River one-half mile below mouth of Elk Creek, top of bluff; collected by F. H. Knowlton, August, 1888.

\section{Planera longifolia Lx.}

Planera longifolia Lx.: Tert. Fl., p. 159, Pl. XXYII, figs. 4-6; Cret. and Tert. Fl., p. 161, Pl. XXIX, figs. 1-13.

The collection contains some 40 more or less well-preserved examples of this species, which agree very well indeed with the varions figures given by Lesquerenx. A number are so well preserved that the finer nervation is retained. The nervilles are numerous, parallel, and mainly percurrent.

Habitat: Fossil Forest Ridge, bed No. 3 (30 specimens); bed No. 5 (10 specimens); collected by Ward and Knowlton, Angust, 1887.

\section{URTICACEE.}

\section{Ficus deformata 11. sp.}

Pl. XCI, fig. 2.

Leaf large, thick, long-oborate, slightly unequal-sided at base, abruptly rounded above to an obtuse apex and rather abruptly narrowed below; margin entire, conspicuously indented or deformed on one side, the margin of indentation rounded; midrib thick; secondaries thick, 10 or 12 pairs, 
alternate, energing at an angle of $35^{\circ}$ to $45^{\circ}$, ("urving upwarl, camptodrome; none of the finer nervation preserver.

This leaf is $15.5 \mathrm{~cm}$ lomg and almost $8 \mathrm{~cm}$. wirle in the broadest part, which is high above the midlle of the blade. It is long-obovate, obtuse at apex, and rery broally or obtusely wedge-shaped at base. 'The margin is entire except for a curions indentation on one side, which las probably resulted from an injury of some sort. This indentation passes nearly to the midrib and has rounded lobes. The secondaries adjacent to this are also distorted, heing much emped. The finer nervation is not preserved.

It is possible that the fraginent of the base of a leaf described and figmed on Pl. LXXXIX, fig. 7, is the same as this species, but it is obviously impossible to be certain of this. It is also undoubtedly related to, and is possibly identical with, $F$. asimincelia Lx., ${ }^{1}$ from Placer County, California. This has the same shape and nervation, but for obrious reasons it is best to keep them separate, at least until additional specimens can be obtained.

Habitat: Yellowstone River, one-lialf mile below mouth of Elk Creek, base of bluff; collected by F. II. Knowlton.

\section{Ficus ungeri Lx.}

Pl. XCI, fig. 3.

Ficus ungeri Lx.: Tert. Fl., p. 195, Pl. XXX, fig. 3; Oret. and Tert. Fl., 1. 163, Pl. XLIY, figs. 1-3.

Habitat: Yellowstone River, 1 mile below month of Elk Creek, west side; and about same distance above Hellroaring Creek; collected by F. H. Knowlton, Angust 4, 1888.

\section{Ficus sp.}

\section{Pl. LXXXIX, fig. 3.}

This is too fragmentary to permit even the generic determination, but it seems to belong to Ficus. It consists of the base of a thick leaf having a thick midrib, with rather thin parallel secondaries and a short rery thick petiole.

Habitat: Yellowstone River, one-lialf mile below month of Elk Creek, base of bluff; collected by F. H. Knowlton, August, 1888. 
Ficus shastensis? Lx.

Ficus shustensis Lx.: Proc. U. S. Nat. Mus., Vol. XI, 1888, p. 28, PJ. XI, fig. 3.

This species was described by Lesquereux from Shasta County, California. It was said to be $6 \mathrm{~cm}$. long and $3.5 \mathrm{~cm}$. broad, and with a very thick petiole. The Park leaf is $8 \mathrm{~cm}$. long and $4.5 \mathrm{~cm}$. wide, and lacks the petiole. The nervation appears identical, but $I$ have hesitated to make a positive identification on such scanty material.

Habitat: Lamar River, between Cache and Calfee creeks, on the same piece of matrix as Salix angusta and Lyyodium kaulfusii; collected by F. H. Knowlton, August 27, 1888.

\section{FicUs sORdida Lx.}

Ficus sordida Lx.: Mem. MIus. Comp. Zö̈l., Vol. VI, No. 2, 1S78, p. 17, Pl. IV, figs. 6, 7.

A single fragment, representing the lower side of a leaf of about the same size and nervation as fig. 7 of Lesquereux's plate.

Habitat: Specimen Ridge, Fossil Forest, "Platanus bed;" collected by Ward and Alderson, August 25, 1887.

\section{Ficts deissifolia n. sp.}

Pl. LXXXIX, fig. 1; Pl. XC, figs. 1, 2; Pl. XCI, fig. 1.

Leaves large, very thick, mequal-sided, irregular long-obovate, broadest at or above the mirldle, obtuse above, narrowed below to a rounded truncate or slightly heart-shaped base; margin entire or very slightly undulate; petiole not preserved; midrib rery thick, slightly flexuose; secondaries 8 or 9 pairs, lower opposite or subopposite, others alternate; lower secondaries thin, nearly at a right angle with midrib, others irregular, remote, at various angles, much arching upward, occasionally forked, all camptodrome, and joining by broad loops; middle secondaries sometimes branched on the outside, the brancles joining by broad loops near the margin; nervilles strongly marked, mainly broken, producing by union large quadrangular areas; finer nervation producing irregular quadrangular areas.

This fine species differs markedly from all others obtained in the Yellowstone National Park, and is quite unlike any American form. The smaller leaves are 13 or $14 \mathrm{~cm}$. long and 5 or $6 \mathrm{~cm}$. broad, while the larger 
examples are fully $25 \mathrm{~cm}$. long and nearly or quite $10 \mathrm{~cm}$. broad. They are broadly obovate, being broadest usually above the middle. At base the leares are narrowed into a small rounded, truncate, or even henrtshaped part. Above they appear rather abruptly narrowed into an obtuse прех.

'The nervation is strongly marked. The midrib is very thick, as are most of the secondaries, especially in the middle, when they pass to the broad portion of the blade. They are then alternate, thick, and sometimes forked, and not rarely branched on the outside. The secondaries and their branches are arelied and joined by broad bows.

Habitat: Southeast side of Crescent Hill, largest specimen ( $\mathrm{Pl}$. LXXXIX, fig. 1); Yellowstone River, one-half mile below mouth of Elk Creek, one peculiar, somewhat donbtful, specimen; also one from base of bluff (Pl. XC, fig. 1); hill above Lost Creek, typical specimen. All of the above collected by F. H. Knowlton, August, 1888. Specimen Ridge, Fossil Forest, opposite Slough Creek, "Platanus bed" and bed 100 feet above same; specimens numerons; collected by Lester F. Ward and E. C. Alderson, August 25, 1887. Fossil Forest Ridge, bed No. 5, "Salix bed," one broken specimen; collected by Ward and Knowlton, August 9, 1887.

\section{Ficus haguei n. sp.}

Pl. NC, fig. 3 .

Leaf thick, broad, rounded-ovate, apparently rounded and truncate at base and rather abruptly acuminate at apex; margin entire; midrib thick, perfectly straight; leaf palmately 3-ribbed from above the base, apparently a pair of thin secondaries originating from or near the base of the lamina, then a pair of rery strong subalternate ribs or secondaries, at an angle of about $45^{\circ}$, which arch upward; above this pair, in the upper part of the blade, are 4 or 5 pairs of alternate thinner secondaries at a lower angle; all of the secondaries are joined some distance from the margin by a broad loop, with another series of smaller loops outside these, at least in the lower portion of the leaf; a number of irregular intermediate secondaries occur between the primary secondaries; nervilles thin, irregular.

The specimen figured is the only representative of this strongly characterized species. It unfortmately lacks both base and apex, but the por- 
tion preserved is $8 \mathrm{~cm}$. long and nearly $8 \mathrm{~cm}$. wide. There is, of course, no means of knowing the configuration of base and apex, but from all indications it is probable that the base was rounded-truncate and the apex abruptly acminate. It is well characterized by secondaries, of which the lower prominent pair are strongest and arch up and join by a broad loop to the secondaries above, producing a palmately ribbed leaf.

I an uncertain as to the correctness of this generic reference, but it seems to approach closer to Ficns than any other. In any case, it is so well marked that it can be readily recognized. It does not appear closely related to any fossil species with which I am familiar, but among living species it has considerable resemblance to $F$. nodosa Tey. and Binn., and $F$. procera R., both from British India.

The species is named in honor of the discoverer.

Habitat: Fossil Forest Ridge, middle stratum; collected by Arnold Hague, September 21, 1884.

Ficus 'Tlliefolia? Al. Br.

A fragment of the basal portion of a large leaf, apparently of this species. It is, for example, very much like the figure given by Lesquereux, ${ }^{1}$ from the Auriferous gravels of California.

Habitat: Hill above Yanceys and near the fossil trees; collected by F. H. Knowlton, August, 1888.

\section{Ficus astminefolia Lx.}

Ficus asimincefolia Lx.: Oret. and Tert. Fl., 1). 2.50, Pl. LVI, figs. 1-3.

A single deformed leaf, which aglee: in nervation with this species and with the upper portion of another perfect leaf.

Habitat: Fossil Forest Ridge, bed No. 3, "Magnolia hed;" collected by Ward and Knowlton, Augnst, 1887. Yellowstone River, one-half mile below mouth of Elk Creek, base of bluff; collected by F. H. Knowlton, August, 1888.

Artocarpus? quercoides 11. sp.

Pl. XCII, fig. 1.

Leaf large, thick, 5 (7?)-lobed, lower lobes large, rounded; upper lateral lobes smaller, turning upward, of about the same size at apex as 
central or teminal lobe, all sepanated by broul, rounderl simuses; midrib very thick below and to the middle of the leaf, from which point it rapidly diminishes to the apex; secondaries mumerons, alternate, at angle of $30^{\circ}$ to $45^{\circ}$, about 4 in each lobe, except the small central lobe, the mper ones passing to the apex of the lobe, the other curving near the margin below it; slont secondaries pass up to and arch along above the simuses, accasionally in the npper part forking and passing on both sides; nervilles strong, percurrent, nearly at righl angles to the secondaries; finer nervation not preserved.

The specimen figured is the only one obtained of this remarkable and highly chameteristic leaf. It is not perfect, yet it appears to represent practically all of the leaf. The part preserved is $14 \mathrm{~cm}$. long and $9.5 \mathrm{~cm}$. broal between the upper lobes. It was probably at least $17 \mathrm{~cm}$. in length, and if there were 7 lobes it was of course much larger. It was probably 12 to $14 \mathrm{~cm}$. broad between the lower lobes. The width at the middle simus is a little less than $3 \mathrm{~cm}$. It is strongly 5 -lobed, and, following the analogy of Artocarpus lessigiana (Lx.) Kin., may have been 7-lobed. There is, however, no evidence that it had more than 5 lobes. The lower lobe is $5.5 \mathrm{~cm}$. wide at a distance of $1.5 \mathrm{~cm}$. from the midrib, while the upper lateral lobe is fully $6 \mathrm{~cm}$. wide at the same distance from the midrib. The extreme length of the npper lobe is less than $5 \mathrm{~cm}$., the apex being curved around and up. The secondaries, as pointed out in the diagnosis, are about 4 in muber in each lobe. They are about $1 \mathrm{~cm}$. apart, the upper one only entering the apex of the lobe. The only trace of the finer nervation consists of a few strictly percurrent nervilles.

I am in doubt as to the proper generic reference of this leaf. When it was collected in the field, the conclusion was hastily formed that it was an oak, but the nervation is not at all that of this genus. It seems to have rather a moraceous character, but I have not been entirely successful in finding affinities. It has some resemblance to species of Ficus, but on the whole approaches closest to Artocarpus. Compared with living species it is of the A. incisa type, yet of course differs in marked peculiarities, having, for example, only five instead of many lobes. Among fossil species this undoubtedly approaches $A$. lessigiana (Lx.) Kn., ${ }^{1}$ found in the Laramie and Denver formations of Colorado, Wyoming, etc. The Yellowstone leaf has much the 
shape and thick midril, of the other, but differs essentially in having 3 or 4 secondaries instead of 1 in each lobe. It is, howerer, a leaf sufficiently well characterized to permit it to be readily recognized, and if material is hereafter found that will throw additional light on its affinities, it can be easily transferred to its proper genus. For the present it may remain under Artocarpus.

Habitat: Yellowstone River, one-half mile below mouth of Elk Creek; collected by F. H. Knowlton, August, 1888.

\section{IAGNOLTACEE.}

\section{Maginolia califorica? Lx.}

Magnolia californica Lx.: Foss. Pl. Aurif. Gravels, Mem. Mus. Comp. Zoöl., Vol. V'I, No. 2, 187S, 1. 25, Pl. VI, figs. 5-i.

A single specimen, of which only the upper part is preserved. It has, so far as can be made out, the shape and nervation of this species, but it is so much broken that its positive identification is not possible.

Habitat: Fossil Forest Ridge; Hague's No. 1960.

\section{Magxolia spectabilis 11. sp.}

Pl. XCIII, figs. 1, ?.

Leaves very thick, coriaceous; broadly elliptical-lanceolate in outline, with regularly rounded base and rather abrupt obtusely acmminate apex; margin perfectly entire, not undulate; midrib thick, straight; secondaries about 18 or 20 pairs, alternate, regular and parallel or slightly irregular on emergence from the midrib, becoming parallel above; secondaries either forking near the margin or arching along and joining the one next above in a series of loops, with a series of smaller loops outside; intermediate secondaries usually numerous, sometimes passing nearly to the junction of the primary ones, or becoming lost at one-half or two-thirds of the distance from midrib to margin, irregular and not parallel to other secondaries; nervilles numerous, irregular, broken, approximately at right angles to the secondaries; finer nervation beantifully preserved, forming strongly marked quadrangular areolx.

This fine species is represented by a large number of well-preserved specimens. The larger leaves are fully $20 \mathrm{~cm}$. long and 7 or $8 \mathrm{~cm}$. wide, 
and some of the smaller ones 12 or $15 \mathrm{~cm}$. long and 4 to $6 \mathrm{~cm}$. wide. The leaves are thick and leathery, and evidently belonged to an evergreen species.

It is altogether probable that the leaves obtained by Mr. W. H. Holmes in 1878 from Amethyst Mountain and identified by Lesquerenx as Magnolia lanceoluta Lx., ${ }^{1}$ really belong to this species. As nearly as can be made out from Holmes's description of the locality, ${ }^{2}$ it is the same as that which afforded the specimens under discussion. But a careful comparison of these numerous leaves with the figures given by Lesquereux, as well as with specimens from the Auriferons gravels, makes it certain that they can not belong to MI. lanceolata. Magnolia spectabilis differs in being broader, more rounded at base, with secondaries more curred and with numerons intermediate secondaries. A still greater point of difference is in the texture of the leaf. Of M. lanceolata, Lesquereux says:" "This leaf is not coriaceous, rather of a thin substance," while M. spectabilis is thick and distinctly coriaceous or leathery. The finer nervation is not preserved in $M I$. lanceolata, so it is not possible to compare that point.

From further evidence it appears that these identical specimens were again submitted to Lesquereux in $\mathbf{1 8 8 7}$, and he then identified them with M. inglefieldi Heer, ${ }^{4}$ a species that he has also reported from Lassen County, California, Green River group, etc. It is certainly much more closely related to this than to $M$. lanceolata, as may be seen from Heer's figures ${ }^{5}$ and specimens identified with it from California. It is of the same shape and size as $M$. spectalilis and is described as being coriaceous, but it differs somewhat in having the secondaries more scattered, apex irregular, etc. The finer nervation also differs. They are undoubtedly close, but seem to be sufficiently distinct for specific separation.

Among living species the affinity of $M$. spectabilis is unquestionably with M. grandiffora L., or Mr. foetida Sargent, as it is now called. The size, outline, texture, and nerration are practically the same.

According to Sargent, ${ }^{6}$ the direct ancestor of Mragnolia fotida was

\footnotetext{
'Mem. Mus. Comp. Zoöl., Vol. VI, p. 24, Pl. VI, fig. 4.

${ }_{2}^{2}$ Twelfth Ann. Rept. U. S. Geol. and Geog. Surv. Terr., 1878 (1883), Pt. II, 1. 49.

${ }^{3}$ Loc. cit., p. 24.

${ }^{4}$ Cf. Proc. U. S. Nat. Mus., Vol. X, 1887, p. 46.

${ }^{6}$ Fl. Foss. Arct., Vol. VII, I883, p. 121, Pl. LXIX, fig. 1; Pl. LxXXV, fig. 3; Pl. LXXXVI, fig. 9.

${ }^{6}$ Silva of North America, Vol. I, p. 3.
} 
probably $M$. ingleficldi as exemplified from Greenland, the type locality. As already pointed out, this speeies is also the closest relative of M. spectabilis, which in turn is elosely allied to $M$. fotida. It is possible that $M$. ingleficldi, the earliest arctic representative, was pushed down by the invading ice, occupying under a slight variation (II. spectabilis) the Yellowstone National Park, and surviving at the present day as $M$. fotida.

Habitat: Fossil Forest Ridge, bed No. 3, "Magnolia bed;" collected by Ward and Knowlton, August, 1887.

\section{Magnolia Mitrophylda 11. sp.}

Leaf thick, elliptical-laneeolate in ontline, with slightly undulate entire margin; midrib very thiek, straight; secondaries $t$ or 5 pairs, alternate, very irregular, at an angle of $30^{\circ}$ to $45^{\circ}$, much curved upward, forking near the margin, the fork joined by the branch from the secondary next below; intermediate secondaries present, irregular; nervilles irregular; finer nervation obseure.

A single broken fragment is the only example of this species observed. The part preserved is $6 \mathrm{~cm}$. long and $4 \mathrm{~cm}$. wide.

This leaf was associated on the same piece of matrix with M. spectabilis, yet differs by the characters enumerated.

Habitat: Fossil Forest Ridge, brd No. 3, "Magnolia bed;" collected by Ward and Knowlton, August, 1887.

\section{Magnolia Culveri 11. sp.}

\section{Pl. XCII, fig. 5.}

Leaf large, membranacenus, broadly ovate, truneate at base, obtusely pointed above; petiole short; midrib thin, straight; secondaries 6 or 7 pairs, altemate, at an angle of $40^{\circ}$ or $45^{\circ}$, forking some distance below the margin, camptodrome by broad loops; intermediate secondaries oceasional, som lost in the middle area between the secondaries; nervilles numerous, irregular, thin, broken; finer nervation producing large irregularly quadrangular areas.

The specimen figured, which is that best preserved, is $14 \mathrm{~cm}$. in length, including the petiole, but lacks the apex. It must have been some $15 \mathrm{~cm}$. long when perfect. It is broadest just below the middle, where it is $8 \mathrm{~cm}$. wide. The petiole is $1 \mathrm{~cm}$. long and moderately thick. 
This the species helongs rertainly to the genns Magnolial, ats attested by the shape and the forking, camptodrome secondaries. It is, however, quite milike any of the other species found in the Yellowstone National P'ark. Perhaps its closest relation is MI. culifomica Lx., ${ }^{1}$ from the Challk Bhuffis of California. It is different in shape, being ovate insteat of broadly oval, and has somewhat different secondaries. The large quadrangular finer nerration is similar in both.

It does not approach very closely to either of the living American species, being perhaps elosest to $M$. acruminata L., the well-known cucumber tree. ${ }^{2}$ The slape of the leaves is practically the same, but the nervation differs somewlat.

I have named this species in honor of Prof. George E. Culver, who assisted in making the collection from this place.

Habitat: East bank of Lamar River, between Cache and Calfee creeks; collected by F. H. Knowlton and George E. Culver, August, 1888.

\section{Magrolia? Pollardi n. sp.}

Pl. LXXXI, figs. 9, 10.

Petals of firm texture, elliptical or elliptic-ovate in outline, narrowed below, rounded-obtuse above; nervation of numerous approximately parallel nerves about $2 \mathrm{rmm}$. apart.

The best preserved of these 2 specimens (fig. 9) has $7.5 \mathrm{~cm}$. in length preserved, and wats probably fully $8.5 \mathrm{~cm}$. in length when perfect. It is $3 \mathrm{~cm}$. broad in the middle, and is narrowed at base to a point of attachment some 5 or $6 \mathrm{~mm}$. broad. The upper point is unfortmately destroyed, but it seems probable, from the appearance of the margin and nerves, that it was obtuse. The nerves arise from the basal part and run approximately parallel, spreading slightly in the middle and converging toward the apex. In the middle these nerves are between 3 and $t \mathrm{~mm}$. apart, but in the apex they are separated by only about $2 \mathrm{~mm}$. There is some evidence of intermediate nerves, or possibly cross veinlets, but these are so indistinct that a positive statement concerning them can not be made.

The other specimen (fig. 10) is a trifte over $5 \mathrm{~cm}$. in length, but lacks both upper and lower parts. It was probably 6.5 or $7 \mathrm{~cm}$. in length when

${ }^{1}$ Meur. Mus. Comp. Zoöl., Vol. VI, No. 1, p. 25, Pl. VI, figs. 5, 7.

${ }^{2}$ Cf. Sargent: Silva of N. A., Vol. I, Pls. IV, V.

ION XXXII, PT II-46 
perfect. It is exactly $3 \mathrm{~cm}$. in width at the widest portion, which is a little above the midule. There is no indication of the form of the base, as it is destroyed The apex was quite obvionsly obtuse. The nerves are less distinctly preserved than in the other specimen, but by careful search they can be made out as shown in the figure. Beyond these nothing can be made out.

It is with some hesitation that these specimens are described as petals of Magnolia. They were at first supposed to be spathe-like growths of some monocotyledonous plant, and their identitication as Magnolia petals was first suggested by Mr. C. L. Pollard, of the United States National Musem, in whose honor I take pleasure in niming the species. The probability of their being petals of a large-flowered Magnolia is greatly strengthened by the fact that undoubted Magnolia leaves in abundance are found in the rarious beds of the Yellowstone National Park, whereas no monocotyledonons plant has been found to which these apparently could have belonged. There is a facies to the specimens that is difficult to describe and wholly impossible to show in a figure, which is rery suggestive of Magnolia petals. The manner in which they curve and narow on the rock, although this appearance may of course be only accidental, is very similar to the petals of certain large-flowered forms-such, for exanple, as $M$. comspicua. In any case they are distinctive forms that may be readily recognized, and, for the purposes of geologic correlation, are of undoubted value. Several botanists to whon the specimens have been submitted agree that their reference to Magnolia is fully warranted, and for the present at least they may be so considered.

Habitat: Yellowstone River, one-half mile below the mouth of Elk Creek (fig. 10); collected by F. H. Knowlton, Angust, 1888. Fossil Forest Ridge, opposite Slough Creek; collected by Lester F. Ward, August, 1887.

\section{LALRACEF.}

\section{LAURUS P'RIMGENLA? Ung.}

Pl. XCI, figs. 4, 5.

Laurus primigenia Ung. Cf. Ward: Types of the Laramie Fl., p. 47, Pl. XXIII, fig. 8.

The much broken specimens are the only ones of this species found. Their identification is open to doubt, yet they are obviously the same as 


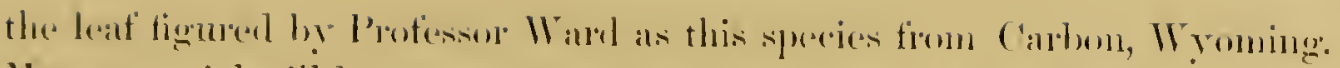
Hore material will be necessaly befole its status can be fixed with certainty".

Habitat: Yellowetone River, laalf a mile below month of Elk Creek,

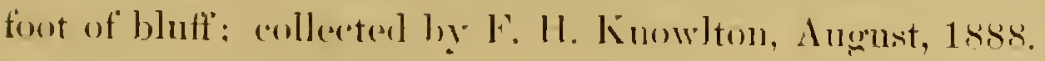

\section{L.AURUS PliRDIT'A 11. ill.}

\section{1'. XCI , tigs. 1-5.}

Leares coriaceons, broally lanceolate, wedge-shaped at base, obtusely acmunate at apex; margins entire, but very slightly molulate; petiole short, stout; midrib thick, straight secondaries 7 or 8 pairs, alternate, camptodrone, arising. at an angle of $40^{\circ}$ or $45^{\circ}$ and curving upward and arching alomg near the margin and forming numerons broad loops or bows; nervilles numerous, inegular, mainly forked, approximately at right angles to the midrib; finer nervation not preserved.

The collection contains a number of specimens of this species, none of them, howerer', quite perfect. 'They are about 15 cm. long and about 4.5 cm. broad. The 5 specimens figured show well the character of the species. They are broadly lanceolate, with a regularly narrowed base and apparently a rather obtuse apex. The secondaries are about 7 pairs, which arch much upward and along the borders. The nervilles are numerous, mainly at right angles to the midrib, and irregnlar and often broken.

This species has some resemblance to Laurus grandis Lx., ${ }^{1}$ from the Auriferous gravels of California, differing in being smaller, narower, and not so obtuse at apex. The resemblance is close enough, however, to make it reasonably certain that the 2 species are quite closely related.

Persea pseudo-curolinensis Lx., ${ }^{2}$ from Table Momtain, Califomia, is somewhat similar, but differs in being broader, more obtuse, and in having finer nervation.

Habitat: Hill above Yanceys and near the standing fossil trees; collected by F. H. Knowlton, Angust 28, 1888. Near same locality; collected by George M. Wright, September 24, 1885. 
LaURUS Montana 11. sp.

Pl. NOY, fig. 2.

Leaves large, evidently coriaceous, elliptical-lanceolate, narrowed gradually (?) to the petiole and (?) upward to an aeuminate apex (?), slightly unequal-sided in the upper part; margin entire; midrib thin, straight; secondaries 5 or 6 pairs, alternate, the lower at a very acute angle, upper ones slightly less so, all, but especially the lower ones, with numerous branches on the outside, which join and form broad loops just inside the margin; nervilles strong, percurrent, approximately at right angles to the secondaries; ultimate nervation not preserved.

The leaf by which this fine species is represented unfortunately lacks both base and apex, but is otherwise well preserved. It is $10 \mathrm{~cm}$. long as now preserved, and was, when entire, probably at least $14 \mathrm{~cm}$. in length. The widtl is $5.3 \mathrm{~cm}$. As stated, it is a little $(3 \mathrm{~mm}$.) wider on one side of the millrib than the other, making it slightly unequal-sided. The nervation is peculiar, consisting of about 5 pairs of secondaries, of which the lower, on the narrower sile of the leaf, legins well toward the base and passes up to the middle of the blade, with numerous branches on the outside at right angles to the midrib. The lower secondary on the broad side of the leaf is very thin and short, and anastomoses with a branch from the lower portion of the second secondary. This latter is strong, and passes above the middle of the leat, and lais only 4 or 5 branches on the outside, all being at an acute angle with the midrib. The other secondaries have 1 or more branclies on outside, and also a number of strong nervilles.

This species appears to be related to some of the forms figured by Lesquerenx as Laurus grandis, ${ }^{1}$ from California, and may possibly be an anomalous form of this species. It is larger, more rounded, slightly unequalsided, and has quite different nervition. It also resembles $L$. culfornica $L x .{ }^{2}$ from the same place.

Habitat: Yellowstone River, one-half mile below mouth of Elk Creek, base of bluff; collected by F. I. Knowlton, August, 18 s 8. 


\section{Laures princeps Heer.}

Pl. $\mathrm{XCV}$, tig. 3.

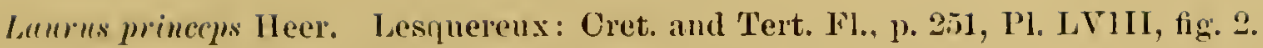

'The finc leat shown in the plate is absolutely perfect. It has the sance size, shape, and nervation as fig. 2 of Lesquerenx's plate (loc. cit.).

Habitat: Yellowstoue River, one-lalf mile below moutl of Elk Creed, base of bluff; collected by F. H. Knowlton, August, 1888.

\section{LAURUS CALIFORNICA Lx.}

Laturus californica Lx. : Cret. and Tert. Fl., p. 250, Pl. LVII, fig. 3; Pl. LVIII, figs. 6-8.

Habitat: Fossil Forest Ridge, beds Nos. 3, 5, and 6; Specimen Ridge, Fossil Forest, opposite Slough Creek; collected by Ward and Knowlton, August, 1887. Northeast side of Crescent Hill, opposite small pond, altitude 7,500 feet; collected August 2, 1888, by F. H. Knowlton and G. E. Culver.

\section{LAURUS GRANDIS Lx}

Pl. XCIII, fig. 3 ; Pl. XCV, fig. 1.

Lau'us grandis Lx.: Oret. aud Tert. Fl., 1). 251, Pl. LVIII, figs. 1, 3.

Habitat: Fossil Forest Ridge, beds Nos. 3, 5, and 7; collected by . Wrard and Knowlton, August, 1887. Specimen Ridge, Fossil Forest, head of Crystal Creek; collected by Ward and Alderson, August 25, 1887. Hill above Lost Creek; collected by George M. Wright, September 24, 1885.

Persea pseudo-Carolinensis Lx.

Pl. $\mathrm{XOV}$, fig. 4.

Persea pscudo-carolinensis Lx.: Auriferous Gravels of Califoruia, Mem. Mus. Comp. Zoöl., Vol. VI, No. 1, p. 19, Pl. VII, figs. 1, 2.

The specimen figured, which is the best one found, agrees closely with the figure of this species given by Lesqnereux (loc. cit., fig. 1).

Habitat: Specimen Ridge, Fossil Forest, head of Crystal Creek; collected by Ward and Knowlton, August 25, 1887. East bank of Lamar River, between Cache and Calfee creeks; collected by F. H. Knowlton, August 21, 1888. 


\section{MaLapoexna lanarexsis 11. sp.}

Pl. XOIII, figs. 4, 5; Pl. XCVI, fig. 5.

Leaves thick, coriaceous, ovate-oblong, tapering downward to a long werlge-shaped base and upward to an acuminate or obtusely acuminate apex; margin entire; mirlib thick, straight; nervation pinnate, consisting of 2 pairs of opposite thick ribs or secondaries, of which the lower pair arise near the base and pass up for nearly half the length of the blade, while the other arise some distance mp and pass nearly or quite to the apex; several pairs of small secondaries arise from the midrib in the extreme upper part of the blade; ribs with occasional branches on the outside; nervilles apparently percurrent.

This species is representer by several specimens, 3 of the best of which are figured. Unfortunately none of the specinens are perfect. The larger and best-preserved specinen has 9 cm. retained, and must have been $110.12 \mathrm{~cm}$. in length when complete. This specinen is $4 \mathrm{~cm}$. wide. Another example has $7 \mathrm{~cm}$. of the upper portion preserved and is about $4.5 \mathrm{~cm}$. wide. The small one figured is not quite $4 \mathrm{~cm}$. in length and about 1.5 ('m. in widtl.

Among living species M. Iamurensis rery much resembles Tetranthera (Litsen) dealbata R. Br., from Australia, and also approaches Litsea glanca Seib., from Japan-that is, it approaches these living species closely enough to make it certain that the generic reference is correct. Among the fossil species, Tetrunthre precursoria Lx., ${ }^{1}$ from the Barl Lands of Dakota, is quite suggestive. This speeies is somewhat obovate instead of ovate-oblong, and has about 4 pair's of secondaries, which do not differ in size as they do in M. lamerensis.

Habitat: East bank of Lamar River, between Cache and Calfee creeks; collected by F. H. Knowlton, August 21, 1888. Yellowstone River, onehalt mile below mouth of Elk Creek; collected by F. H. Knowlton, August 2ī, 1888 .

\section{Li'TSEA E'UNEA'TA 11. sp.}

Pl. XCII, figs. 2-4.

Leaf membranaceous, broadly lanceolate, wedge-shaperl at base and narrowed in about the same mamer at apex; midrib rery thick, straight; 


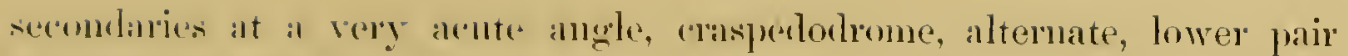
thimest, those above much thicker, humching on the musicle, branches at anl ante :llghle, craspedolrome; intermediate secomdanies several, generally lont in the space between the secondanies; nervilles strong, at various angles, mainly prement; finer nervation inegular.

No preteret example of this species has been fomm, the fragments finured being all that we have to represent it. The specimen showing the werlgershaped base is only $5 \mathrm{~cm}$. long, hut was probably $10 \mathrm{or} 12 \mathrm{~cm}$. in length when perfect. It is 4 cm. wille. The larger of the others is the wedge-shaperl apieal portion, and is 6 enr. long, with the probability of its having been at least 12 cm. long. The small specinen was probably hardly more than 8 or $9 \mathrm{~cm}$. in length when perfect. The upper portion appears to have nore numerous secondaries than the lower part. They are also branched on the outside.

Habitat: Iellowstone River, 1 mile below the month of Elk Creek; collected by F. II. Knowlton, Angust, 1888.

\section{Cinnamonium spectamile Heer.}

Pl. XCIT, fig. li.

Cinnamomum spectubile Heer: Fl. Tert. Helv., Tol. II, p. 91, PI. XCVI, figs. 1-8.

The leat figured, which appears to be the only one obtained, differs slightly from the fignes of the European form to which it is referred. The lower pair of secondaries, for example, are nearer the base of the leaf than in the figmes given by Heer, but, granting the slight differenees, I have hesitated to make it a new speeies.

Habitat: Tower Creek, Yellowstone National Park; collected by Aruold Hague (field No., 1036), Angust 16, 1883.

\section{PLATAYACEE.}

Platanus gulllelihe Göpp.

Pl. XCVI, fig. 1; Pl. xCVII, fig. 5.

This species is very abundant, being represented by over 125 more or less perfect specimens. Some of these-as, for example, the one figmedare particularly perfect. They liffer somewhat in size, the average being about 7 or $8 \mathrm{~cm}$. broad between the lobes and $S$ or $9 \mathrm{~cm}$. in length. An oeeasional one is $14 \mathrm{~cm}$. broad and about the same length. 
These leares agree well with the usual description and figures of this species, especially as given by Lesquerenx ${ }^{1}$ from Carbon, Wyoming.

Habitat: Fossil Forest Ridge, Yellowstone National Park, bed No. 1, the lowest bed, rare; bed No. 5, rare; bed No. 6, the "Platanns bed," most abundant locality, over 75 specimens moted: bed No. 7 , rare; collected by Lester F. Ward and F. II. Knowlton, August, 1887. East end of Fossil Forest Mountain, middle bed, 755 feet above valley below; specimens rare; collected by Ward and Knowlton, August 13 and 22,1887. Specimen Ridge, opposite Slongh Creek, rare; collected by Ward and Knowlton, Augnst, 1887. Hague's Yellowstone National Park collections (field No., 1960), Fossil Forest section, very abundant; collected by G. Mi. Wright and Walter H. Weed, September 20, 1885. Hagne's Yellowstone National Park collections (field No, 1217), Fossil Forest section, upper stratum; collected by Amold Hagne, September 24, 1884. Hague's Yellowstone National Park collections (field No., 1219), rire; collected by Arnold Hague, September 24, 1884. South end of C'rescent Hill, 6 fect below "Platanns bed;" collected by F. H. Knowlton, August 9, 1888.

\section{Platanls montana 11. sp. \\ Pl. AC'VI, figs. 2, 3.}

Leaves membranaceous, somewhat ronghened, rounded-oblong in shape, decurrent on the petiole, rounded above or acuminate, possibly slightity 3-pointed; margin simply undulate tomthed; nervation obscurely palnate; petiole stout; midrib thick, straight; secondaries several (about 5) pairs, the lowest some distance above the base of the blade, emerging at an ingle of alwot $30^{\circ}$, passing nearly straight to the border and ending in a small marginal tootl, with several branches on the outside approximately at right angles to the midrib and ending in marginal teeth; second pair of secondaries strong, arising at an angle of $45^{\circ}$, much arching npward and ending either in the margin or possibly in short lobes, with several strong forking branches on the outside, the terminations ending in the teeth; other secoudaries also occasionally forked on the ontside; nervilles strong, occasionally percurrent, but mainly forked or broken; finer nerration quadrangular.

This species is based on a number of mure or less fragmentary leaves, the best of which are figured. The most perfect specimen is $12 \mathrm{~cm}$. 
lomg and about 10 em. Iroat. It was probably, when living, at least 15 com. long.

'The marked feature of this leaf' is that it is not strictly palmately nerwed, having, an pointed ont in the diagnosis, the 2 lower pairs of secondaries with branches on the outside which end in the marginal teetl. Otherwise it is hardly to be distingnished from Plutunns raynoldsii Newby., as figured loy Lesquerenx ${ }^{1}$ from the Denver, beds of Golden, Coloralo. This species was described by Newberry ${ }^{2}$ as having the margin doubly serrate, lut a number of specimens referred to it by Lesquerenx have the margin undulate, dentate, or even entire. Newberry's type had 3 lobes or points in the upper portion, while certain of Lesquerenx's specimens were rounded and entire above.

The smaller leaves from the lower Yellowstone described by l'rofessor Ward under the name of Greviopsis populifolic, ${ }^{3}$ especially fig. 4 of his plate, approach the leaves under discussion. These, as he has alleady pointed out, are suggestive of I'. raynoldsii. They can hardly belong to Grewiopsis.

Whether the leaves firom the Yellowstone National Park should be regarded as new to science or referred to Platanus raynoldsii is an open question. They agree closely enough in size, shape, and marginal dentition, but differ in the nervation. It is possible that this character may be of sufficient importance to keep them distinet, and also to exchde them from the gemus Platanus, but for the present at least, and until better material can be obtained, they may remain as above.

Habitat: East slope of high hill about three-fourths of a mile south from Yanceys; collected by George Mr. Wriglit, September 4, 1885.

\section{LEGUMINOSE.}

\section{Acacia macrosperma n. sp.}

Pl. XCVIII, tig. 8 .

Legume large, more than $8 \mathrm{~cm}$. long and $2.2 \mathrm{~cm}$. wide, broad linear, passibly constricterl, with obtuse, regularly rounded end; apparently surrounded by a wing $5 \mathrm{~mm}$. broad; seeds numerons, large, oblong, $10 \mathrm{~mm}$. long, $6 \mathrm{~mm}$. broat.

\footnotetext{
1 'Tert. Fl, Pl. XXVI, fig. 4; Pl. XXVII, figs. 1-3.

${ }^{2}$ Later Ext. Fl., p. 69; Ill. Cret. and Tert., P1. XVIII.

${ }^{3}$ 'Types of the Lar:mie Fl., 1. 90, Pl. Xi, figs. 3-5.
} 
This species appears quite unlike any species before found in America, lout is not greatly mulike A. micromluglla Heer from the Swiss Tertiary. The latter species is not quite as broad as A. macrosperma, and has not the end preserved. The seerls are about the same size in both.

Habitat: Fonsil Forest Ridge, bed No. 7, "Castanea bed;" collected by Ward and Knowlton, August 16-20, 1887.

\section{ACACIA LAMARLYSis 11. sp.}

Pl. XCV1ll, tig. (i.

Legume linear, broal, more than $7 \mathrm{~cm}$. long, and $1.7 \mathrm{~cm}$. broad; end pointed; apparently with marginal wing 2 or 3 imn. wide; seeds oval, 10 mm. long, 8 nmm. wide.

This may possibly be the same as A. macrospermu, but it appears to differ essentially in being narower and in having an acuminate instead of an obtuse termination. The alpparent wing and the seeds are much the same in both.

Habitat: Lamar River, between Cacle and Calfee creeks; collected by Knowlton and C'ulver, August 21, 188 s.

\section{ACACIA WARDII 11. sp.}

\section{Pl. ACYIll, fig. 7 .}

Legme narrow, linear, constricted, if $\mathrm{cm}$. long, 9 mum. wide in the 1noandest portion and $5 \mathrm{~mm}$. wide at the constricted point; point of attachment reduced to a slight extension, opposite extremity with a decided curved beak; seeds apparently present, lout obscure.

This species differs markedly from the others just described, and also, so far as I know, from any heretofore found.

Hahitat: Fossil Forest Ridge, bed No. 4, "Aralia bed;" collected by Ward and Linowlton, August 16-20, 1887.

\section{LEguMINosites LEsqUEREUXIANA Kin.}

PI. LXXXIX, fig. 4.

Lequminosites lesquereuxiana Fin.: Bull. U. S. Geol. Surv. No. 152, 131, 1898.

Leguminosites cassioides Lx.: Tert. Fl., p. 300, Pl. LIX, tigs. 1-4.

Habitat: Northeast side of Crescent Hill opposite small pond; collected by F. H. Knowlton and G. E. Culver, August 2, 1888. 


\section{ILGLMNOSITES IAAMAREASIS 11 . Sp.}

Pl. LAXXIX, figs. $5,6$.

Leathets thin, oblong-lancenlate, rounderl-truncate at base, long ac'mminate at apex; nidrib strong, perfectly straight; secondaries about? pairs, alternate, at an angle of $45^{\circ}$, slightly enring upward; remainder of nervation not retainerl.

This little leaflet is $6 \mathrm{~cm}$. in length and $17 \mathrm{~mm}$. in width. It is very regularly romuled, almost truncate at base, and apparently regularly narrowed above into an acuminate apex. The petiole, if there was one, is not preserved. The secondaries are alternate and camptodrome, and about $S$ or 9 patirs.

The nearest related species is Leguminosites lesquereuxiana, ${ }^{1}$ from the Green River beds of Green River, Wyoming, and also Spring Canyon, Montana. This differs in being larger, broader, and more oblong-ovate than the one under discussion. The relationship is evidently close, and perhaps more material would show closer affinity than I have recognized.

This species also resembles some of the species of Leguminosites from the Tertiary of Switzerland, as, for example, L. proserpince Heer. ${ }^{2}$ There can be no question as to the correctness of the reference to this genus.

Habitat: East bank of Lamar River, between Cache and Calfee creeks; collected by F. H. Knowlton, August, 1888.

\section{ANACARDIACEE.}

\section{RuUs MIXTA? Lx.}

Rhus mixta Lx.: Mem. Mus. Comp. Zoül., Vol. VI, No. 2, 1. 30, Pl. IX, fig. 13.

A single small and somewhat fragmentary specimen. It resembles the smaller of the two specimens figured by Lesquerenx.

Habitat: East bank of Lamar River, between Cache, and Calfee creeks; collected by F. Fr. Knowlton, August 21, 1888. 


\title{
CELASTRACEE.
}

\author{
Celastrets culveri n. sp.
}

I'l. XOVII, tig. 4.

Leaves membranaceous, orate-lanceolate, apparently rather abruptly. rounded at the base, but gradually narrowed above to an obtusely acuminate apex; margin with rather remote, small, sharp, outward-pointing teeth; midrib thick below, mnch thimner above; secondaries about 10 pairs, alternate at an angle of $35^{\circ}$ or more, much curved uprard, camptodrome very near the margin, with branches outside entering the small, weak teeth; intermediate secondaries occasional, thin, disappearing before reaching lalf the distance to the margin; nervilles percurent; finer nerration obsenre.

This species is represented by '2 well-preserved leaves, both, mufortumately, representing the npper portion only. The longest specimen is $10 \mathrm{~cm}$. in length, which is probably not far from its original full length. It is a little over $5 \mathrm{~cm}$. broad at a point which seems to be some distance below the middle. Judging from the contonr near the base, it seems probable that it was either truncate or, possibly, heart-shaped at base. The teeth of the margin are peculiar, being scattered, small, sharp, and outrard pointing.

This species appears to find its nearest relative in some described from the Fort Union group along the lower Yellowstone. Thus it resembles Celastrus curvinervis $\mathrm{T}^{\text {ard }}{ }^{1}$ in shape and nerration, but differs considerably in size and wholly in the teeth. Celastrus ovatus $\mathrm{IT}^{\mathrm{T}} \mathrm{ard}^{2}$ has somewhat the same shape, but differs considerably in nerration and in the teeth. Sereral of the other species described by Professor Ward ${ }^{3}$ also resemble this in one or more particulars, but none closely enough for specific identity.

I take pleasure in naming this fine species in honor of Prof. G. E. Culver, who assisted in collecting at this place.

Habitat: Yellowstone River, one-half mile below the mouth of . Elk Creek, top of bluff; collected by F. H. Knowlton and G. E. Culver, August, 1888 . 


\section{Celastrus inaliualis 11. sp.}

Pl. XCVIII, fig. :3.

I. af of firm texture, elliptical-obovate in outline, strongly unequalsided, rounded, obtuse above, and namowed below into an apparently wingul petiole; magin strongly simute-dentate from above the lower thir! or half of the blade; midrib thin, approximately straight; secondaries 10 or 12 pairs, lower pair's opposite, other's alternate, two lower pairs, and about 6 secondaries on the larger side of the blade at right angles to the midrib, those on narrow side of blade and in mper portion of other sicle from right angle to $45^{\circ}$ or more, all camptodrome, arching upward abruptly near the margin and apparently joining, sending brancles from the outside to the teeth and other parts of the margin; nervilles and finer nervation obsolete.

This species, as exemplified by the specimen figured, is very peculiar. It is $7 \mathrm{~cm}$. long and a little more than $4.5 \mathrm{~cm}$. wide. It is abruptly obtuse at apex and appears to be expanded at base into a winged petiole.

The margin in the lower portion is quite entire, while above it is strongly sinnate-toothed. The nervation is markedly peculiar. The lower secondaries are at right angles with the midrib, as are several more on the broader margin, while those on the narrow side of the blade all arise at a less angle and curve abruptly near the margin. Those in the extreme tip of the blade curve very much after the manner of Cornus. All send branchies from the outside to the teeth. The finer nervation is not preserved.

This species is wholly unlike any with which I am familiar. It possesses the character described by Professor $\mathrm{Ward}^{1}$ as especially characteristic of the American fossil forms of this genus, namely, the arching of the secondary nerves near the extremities, with short subsidiary nerves to the marginal teeth. Its mnequal-sidedness, winged petiole, and sinuate teeth above the middle of the blade seem to still further rharacterize it.

Habitat: Yellowstone River, one-half mile below the mouth of Elk Creek, base of bluff; collected by F. H. Knowlton, August, 1888. 


\section{Celastrus ellipticus 11. sp.}

\section{Pl. XCVII, fig. 3.}

Leaf of firm texture, nearly regularly elliptical in outline, abruptly rounder above to an obtuse apex and below to an almost truncately rounded base which is slightly decurrent along a short petiole; margin irregularly sinuate-toothed from a short distance above the base; midril) rather thick, passing straight to the apex; secondaries about 15 pairs, alternate or subopposite, at an even angle of about $35^{\circ}$, straight; distal termination of secondaries unknown; nervilles and finer nerration obsolete.

This perfect leaf is $7 \mathrm{~cm}$. long and $4.5 \mathrm{~cm}$. broad. It is rery slightly unequal-sided, the difference being, however, hardly $3 \mathrm{~mm}$. It is very regularly elliptical, with a sinuate dentate margin, which begins abont one-fourth the length of the leaf from the base, the lower portion being entire. The nervation is very regular, consisting of abont 15 pairs of secondaries, which emerge at an angle of abont $35^{\circ}$ and rmu straight toward the margin, but the mammer of the termination at the margin can not be made out, from lack of preservation. It is probable that they arch abruptly near the margin and send secondary nerrilles to the teetl. None of the nervilles or finer nerration can be made out.

It is possible that this species is closely related to $C$. incequalis, just described, as they come from the same beds, but it seems hardly probable. This latter species, as already pointed out, is very unequal-sided, with large sinuate teetl, and peculiar arrangement of secondaries. C. ellipticus, on the other hand, is almost regular in shape, has twice as many and smaller sinnate teetl, and regular secondaries.

This species does not approach closely to any described species of Celastrus with which I am familiar.

Habitat: Yellowstone River, me-half mile below the month of Elk Creek, at base of bluff; collected by F. H. Knowlton, August, 1888.

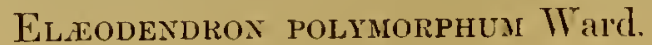

\section{Pl. XOVII, fig. 1.}

Elcodendron polymorphum Ward: Types of the Lamamie Fl., 1. 84, Pl. XXXYII, figs. $1-7$.

The fine specimen figured is referred with some doubt to this species. It has much the same shape, serration, and type of nervation as $E$. poly- 
morphum, but differs in being much larger and in having more numerons and choser secondaries. It is undoubtedly close to this species, and rather than make it a new species I lave refered it to this.

Habitat: Yancey Fossil Forest, near the standing trunks; collected by F. H. Knowlton, August, 1888.

\section{ACERACEN.}

Acer vivarium n. sp.

Pl. XCVIlI, tig. 4.

Leaf membranaceous, palmately 3-lobed, narrowed below to a wedgeshaped base, sinuses rounded, mirldle lobe lanceolate-icuminate, as long or longer than the body of the blade below the sinuses; lateral lobes at an acute angle (points not preserved); margins remotely toothed with small, sharp, upward-pointing teeth; midrib, or central rib, strong, straight, slightly stronger than the lateral ribs, which arise from the midrib just above the base of the blade at an angle of about $70^{\circ}$ and pass up straight to the points of the lateral lobes or curve slightly outward; lateral ribs with several pairs of secondary branches, those on the outside beginning just above the base of the blade and passing straight or with a slight upward curve to or entering the teeth; secondaries on the upper or inside, beginning below the sinus, which the lowest one enters, the others probably entering the teeth; middle lobe with about 6 pairs of altemate secondaries arising at an angle of $70^{\circ}$ or $75^{\circ}$, and passing up nearly straight, to end in the teeth or fork just below the teeth, one branch entering and the other going upward near the margin to the one above; nervilles numerous, mainly percurrent; finer nervation beautifully preserved, forming quadrangular areolæ.

The example figured is the only one observed of this species. It is about $10 \mathrm{~cm}$. long and $6 \mathrm{~cm}$. broad. The central lobe is about $5 \mathrm{~cm}$. long and a little more tlan $2 \mathrm{~cm}$. wide. The lateral lobes appear to have been about $2 \mathrm{~cm}$. wide and of an unknown length.

This leaf belongs to the Acer trilobatum group, so many forms of which were described by Heer from the Swiss Tertiary. In shape it is most like $A$. trilobatum productum, ${ }^{1}$ but differ's in having ouly very small, sharp teeth. It is 
also somewhat like A. trilobatum tricuspidatum Heer, as figured by Professor Ward from the Fort Union ${ }^{1}$ group, differing in being much more wedgeshaped at base, and in the angle of the lateral ribs and secondaries.

Habitat: Fossil Forest Ridge, bed No. 3, "Magnolia bed;" collected by Ward and Knowlton, August, 1887.

\section{ACER, fruit of. \\ PI, XOVIII, fig. 5.}

The collection contains sereral of these fruits, the best of which is figured. While they are very definite and clearly belong to Acer, they are not usually regarded as being sufficiently distinctive for specific reference. A number have been figured and named also, but I have preferred not to name these. They may possibly belong to the preceding species, but of this there is no proof.

Habitat: Crescent Hill above Yanceys; collected by W. H. Weed, September 28, 1885.

\section{SAPINDACEIF.}

\section{Sapindus affinis Newby.}

Pl. CII, figs. 1-3.

Sapindus affinis Nerby. : Later Extinct Floras, p. j1; Ill. Cret. and Tert. Pl., Pl. XXV, tig. 1.

The material upon which this determination is based is ample, as it consists of fully 100 specimens, all more or less well preserved. These specimens differ so much in size that it was at first thought that at least 2 species must be represented, but after a careful study it has been found impossible to draw any satisfactory line between them. There are all gradations of size from the little slender leaflets, hardly $4 \mathrm{~cm}$. long, to the large ones, fully $10 \mathrm{~cm}$. long:

In the only published figures of this species by Newberry the nervation is not shown, but the National Museum contains the original Newberry material, and on studying this it is found that the nervation agrees perfectly with the specimens from the Yellowstone National Park. It may 
also be noted that Newberry's material does not show the leaflets as petiolerl, but in the description of S. alfinis he say's, "leaflets * * * sessile or short-petioled." Many of the detacherl leaflets in his material, named in his handwriting, are distinctly short-petioled, in which particular the Park sperimens agree. Some have, it is true, rery short petioles, yet all seem to have them.

In only two cises have leaflets been found in this collection attached to the rachis, and these have both been figured.

Habitat: Yellowstone River, one-lnalf mile below the mouth of Elk Creek; found throughout the section, and most abundant at the bottom; collected by F. H. Knowlton, August, 1888.

\section{? Sapindus alatus Ward.}

Sepindus alatus Ward: Types of the Laramie Fl., p. 68, PI. XXXI, figs. 3, 4.

This specimen is the only one that I venture to refer to this species. It was found in the same beds with the abundant S. affinis Newby., and possibly may be an abnormal or unusual leaflet of that species. It is, however, more regular, and has the thick or winged petiole of $S$. alatus.

Habitat: Yellowstone River, one-lialf mile below the mouth of Elk Creek, Yellowstone National Park; top of bluff, 300 feet above the river; collected by F. H. Knowlton, August, $188 \mathrm{~s}$.

\section{Sapindeis grandifoliolus Ward. \\ Pl. XCIX, figs. 1, 2; Pl. CII, fig. $t$.}

Sapindus grandifoliolus Ward: Types of the Laramie Fl., 1. 67, Pl. Xxx, figs. 3-5; I'l. XXXI, figs. 1-3.

Several small doubtful leaves are referred to this species. One in particular has some resemblauce to leaves of Juglans ruyosa Lx., but seems to be closer to the Sapindes gramdifoliolus of Ward.

Habitat: Fossil Forest Ridge, bed No. 6, "Platanus bed;" collected by Ward and Knowlton, Augnst, 1887. Also found on the south side of Stinkingwater Valley, on a high bluff east of mouth of Crag Creek, collected by F: P. King for Arnold Hague, September 4, 1897.

HoN XXXII, PT II- 17 


\section{Sal'INDUS gRandifoldoloides 11. sp.}

Pl. C, fig. 2.

Leaflets large, of fir'm texture, orate-lanceolate, unequal-sided, rounded at bise to a well-marked winged petiole, apex acute, slightly falcate; midrib of moderate streingth, straight; secondaries abont 7 or .8 pairs, strongly alternate, emerging at a low angle and soon curving up and passing along near the border; the secondaries on the narrower side of the leaflet emerge at a greater angle $\left(30^{\circ}\right.$ to $\left.45^{\circ}\right)$ than on the opposite side; finer nervation not preserved.

The specimen figured is absolutely perfect so far as outline and principal nervation go. It is just $10 \mathrm{~cm}$. long and $3.7 \mathrm{~cm}$. wide in the broadest portion, which is a little below the middle. The margin is slightly molulate, almost toothed in one part.

Thus species so closely resembles Sapindus yrandifoliolus Ward ${ }^{1}$ from the Fort Union gromp, that I have named it grandifolioloides. It differs, however, from the latter in being more markedly inaquilateral and in having a winged petiole. It also has fewer secondaries than $S$. grandifoliolus.

This species is also related to S. obtusifolius Lx., found in the Fort Union group. From this it differs in having half the number of secondaries and a winged petiole, otherwise being much the same.

Professor Ward's $S$. ulatus ${ }^{3}$ from the same place as $S$. granulifoliolus has a winged petiole, but differs in being much smaller and in having a broken, loose nervation. It is possible, however, that if more material could be obtained it conld be referred to one or the other of these evidently related forms.

Habitat: Northeast side of hill above Lost Creek, bed No. 1, collected by F. H. Knowlton, August 8, 1888.

\section{SapiñUS WARDII 11. Sp.}

Pl. XCVIII, figs. 1, 2; Pl. XCIX, fig. 5.

Leaflet coriaceous, broadly lanceolate, rounded wedge-shaped at base, with long acmminate falcate apex; margin perfectly entire; midrib thick,

${ }^{1}$ Tspes of the Laramie Fl., p. 67, P1. XXX, figs. 3-5 (1887).

${ }^{2}$ Cret. and Tert. F1., p. 235, Pl. XLVIII, figs. 5-7 (1883).

${ }^{3}$ Op. cit., p. 68, Pl. XXXI. fig. 3,4 (1887). 
passing through the middle of the blade; secondaries about 8 pairs, alternate, strongly camptodrome, foming loroud loops at a marked distance fion the mitrgin, ocrasionally with a series of smaller loops ontside; intermediate secomlaries oceasional; nervilles few, pereurrent; fines nervation forming large quadranguluar meshes.

The sperinems figured are the only ones olserved of this species. The best preserved is a little orer 10 ('m. in length and 4 cm. broad. It is mirked by the long, slender, and falcate apex, and the peculiar looped secondaries, which are joined far inside the margin. One side of the basal portion of the leaflet is missing, but from the direction of the secondaries it is probable that it was somewhat unequal-sided.

Fig. 1, Pl. XCVIII, which laeks both base and apex, must lave been at least $13 \mathrm{~cm}$. in length, and was probably longer. The other (fig. 2, Pl. $\mathrm{XCVIII)} \mathrm{was} \mathrm{about} \mathrm{the} \mathrm{size} \mathrm{of} \mathrm{the} \mathrm{best-preserred} \mathrm{example.}$

These leaflets rery closely resemble Fraxinus affinis Newby., ${ }^{1}$ from Bridge Creek, Oregon. This has the same type of nerration, but is mueh smaller, very slightly unequal-sided, and with more numerons and more regular looped seeondaries. The finer nervation is identical in each.

There is some doubt as to the correetness of the reference of Newberry's leaf to the genus Fraximus. This nunch resembles the gemus Sapindus and may possibly belong to it. Sapindus grandifoliolus Ward ${ }^{2}$ from the Fort Union group, for example, has much resemblance in general character to these leaves. It would seem that they should all be in the same genus. However, the leaflet under consideration is undoubtedly closely allied to what Ward has called Sapindus, and for the present they may remain there.

I have named this characteristic species in honor of Prof. Lester F. Ward, who was present when it was collected.

Habitat: Fossil Forest Ridge, bed No. 5; collected by Lester F. Ward and F. H. Knowlton, August 16-19, 1887. Yellowstone River, one-half mile below month of Elk Creek; collected by F. H. Kunwlton, August,
1888 .

\footnotetext{
'U. S. Nat. Mus., Vol. V', 1882, p. 510; Plates (iued), Pl. XLIX, fig. 3.

${ }^{2}$ Types of the Laramie Fl., l’. 67, Pl. XXX, figs. 4, 5.
} 


\section{RHAMNACEE.}

\section{Rhannus Reclinervis Heel.}

Rhamnus rectinervis Heer: Fl. Tert. Helv., Vol. III, p. S0, Pl. CXXV, figs. 2, 6. Lesquereux: Tert. Fl., p. 279, Pl. LII, figs. 12-15.

This species was first detected in the Park by Lesquereux, ${ }^{1}$ and the present collection contains a number of specimens that may be similarly referred. They are all entire, in which respect they resemble fig. 14 of Lesquereux's plate (loc. cit.).

Habitat: Fossil Forest Ridge, bed No. 3, "Magnolia bed;" bed No. 7, "Castanea bed;" collected by Ward and Knowlton, August, 1887.

\section{Paliurus colombi Heer:}

Pl. CI, tig. ‘.

Paliums colombi Heer. Lesquereux: Tert. Fl., p. 273, Pl. L, figs. 13-17 (1878).

'The little specimen figured appears to be the only one obtained in the area under discussion. It is of the same size and shape as many of the figures of this species, but seems to differ slightly in liaving 2 strong secondaries on one side of the midrib. It, however, approaches certain of the figures given by $\mathrm{Heer}^{2}$ of arctic examples of this species.

Habitat: Head of Tower Creek; collected by W. H. Weed, September 25,1885 .

\section{Zizyphus sERrulata Ward. \\ Pl. (II, figs. 4, 5.}

Zizyphus serrulata Ward: Types of the Laramie Fl., p. 73 , Pl. XXXIII, figs. 3, 4 (1857).

The two figured examples agree very closely with the figures given by Professor Ward. They both have teeth well marked, and thus agree with fig. 4 (loc. cit.). They are not quite so well preserved as the types, and do not slow the finer nervation, but there can be no doubt as to their identity.

Habitat: Yellowstone River, one-half mile below the mouth of Elk Creek, top of bluff; collected by F. H. Knowlton, August, 1888. 
VITACEL.

Cresus haguei 11. sp.

Pl. CI, fig. :.

Leaf membranaceons, quadrangular-ovate, truncate or possibly slightly heart-shaped at base and aemminate at apex, lateral lobes short, obtuse; margin toothed, the teeth low, obtuse or somewhat acute; nervation paluate, midrib thin, perfectly straight, lateral ribs of same strength as midrib, arising at an angle of $45^{\circ}$, passing directly to and terminating in the obtuse lateral lobes; ribs with 4 or 5 branches on the outside, which terminate in marginal teeth; secondaries absut 4 pairs, alternate, at same angle as the ribs and terminating in the teeth; nervilles thin, sparse, percurrent or often broken.

This fine leaf is $8.5 \mathrm{~cm}$. long, $5.2 \mathrm{~cm}$. broad between the lobes and 6.5 cur. broad in the widest part, which is only a short distance above the base. In outline it is what may be called quadrangular-orate-that is, between ovate and square. It is palmately 3 -ribbed, the lateral ribs being at an angle of about $45^{\circ}$ and of the same strength as the midrib. They pass straight to and terminate in the short lateral lobes, and have 4 or 5 outside branches which also terminate in the marginal teeth.

The relation of this species is undoubtedly with Cissus purroticfolia Lx., ${ }^{1}$ from the Green River gronp. This latter species differs in being relatively longer, without especially marked lateral lobes, with larger, more obtuse teeth, and unforked outer branches of the lateral ribs. There are also more secondaries in the upper part of the leaf. These, however, are but slight differences, and are possibly only such as might be expeeted in individual variation. But as only one example las been found in the Yellowstone National Park, there is no means of knowing what may be allowed for individual variation, so I have preferred to keep them separate.

I take pleasture in naming this species in honor of Mr. Arnold Hagne, who collected it.

Habitat: Fossil Forest Ridge, middle stratum; collected by Anold Hague, September 24, 1884. 


\author{
STERCULIACE. \\ Pterospermites haguei n. $\mathrm{s} p$.
}

Pl. XCIX, fig. 4.

Leaf of firm texture, broadly oblong in outline, slightly inxquilateral, truncate at base, obtusely pointed at apex; margin, except at base, irregularly serrate, the teeth small, sharp, upward pointing; midrib strong, flexuose; secondaries 6 pairs, alternate, at an angle of about $45^{\circ}$, flexuose, craspedodrome, or subcamptodrome, with branches outside entering the teeth; lower pair of secondaries forming a series of broad loops; nervilles strong, mainly broken; finer nervation not preserved.

The figured specimen of this species is $11 \mathrm{~cm}$. long and nearly $7 \mathrm{~cm}$. broad. As stated, it is quite regularly broad-oblong in shape, with sparsely toothed margins except near the base. The lower pair of secondaries form a series of broad loops, while the upper ones are mainly craspedodrome.

This species is evidently ruite closely related to $P$. minor Ward from the Fort Union group near the mouth of the Yellowstone. Fig. 2 (loc. cit.) is especially like this species, but differs in being hardly half the size and in being markedly heart-shaperl at the base. It perhaps should be referred to this ipecies except for the fact that the other 2 leaves included by Professor Warl are so very different that they can hardly be allied to the one under discussion.

Habitat: Fonsil Forest Ridge; collected by Amold Hagne (No. 1219).

\title{
CREDNERIACEE.
}

\section{Credneria? Pachiphylat $17 . \mathrm{sp}$.}

Pl. CI, fig. 6.

Leaf large, thick, romul-orate, romderl and trmeate or very slightly learr-shaped at base, abruptly acuminate at apex; margin apparently coarsely sinuate-toothed; petiole long. $(4.5 \mathrm{~cm}$.$) , thick (4 mm.); midrib$ thick, passing to the apex; secondaries 6 or 7 pairs, the 3 lower pairs (of which the very lowest is slender and near the margin) opposite and arising from alnost the same point at the base of the blade, wthers alternate, all 
seemingly arapedodrome, oceasionally branching near the margin; finer nervation not preserverl.

The specimen figned is the only one that has been foumd. It is 14 cm. long without the petiole, which is $4.5 \mathrm{~cm}$. in length. Both sides of the leat are destroyed, lout it was probably about 10 (om. wide.

Habitat: Íellowstone River, one-lalf mile below mouth of Ellk Creek, blutt about 40 feet above the river: collected by F. H. Knowlton, Augrust 27,1888 .

\section{TILIACEL.}

Tilia populifolia Lx.

Tilin populifolit Lx.: Cret. and Tert. Fl., p. 179, Pl. XXXIV, figs. \&, 9.

A single large, fairly well preserved specimen is all that has been found of this species. It is referred with very little doubt to Lesquereux's species, which was before known only from Florissant, Colorado. It is a little less heart-shaped at base than fig. 8 (loc. cit.) of Lesquereux's plate, but in the discussion of this species Lesquereux describes it as "round or subcordate at base." The teetl are of precisely the same character, being only slightly smaller. The thick petiole and fine palmate nervation are identical, as is the other secondary nervation.

Habitat: Yellowstone River, one-half mile below the mouth of Elk Creek, top of bluff; collected by F. H. Kinowlton, August 27, 1888.

\section{GREWIOPSIS? ALDERSONI 11. sp.}

Leaves of firm texture, broadly obovate, truncate or slightly heartshaped at base, obtusely acuminate above; margin entire at base, slightly undulate-toothed above; midrib thick, straight; nervation pinnate; secondaries about 6. pairs, alternate, at an angle of $45^{\circ}$, camptodrome; lowest pair subopposite, arising some distance above the base of the blade, with 3 or 4 tertiary branches from the outside which are camptodrome and arch well inside the margin: upper secondaries occasionally forked near the margin; nervilles stroug, percurrent.

I refer several specimens to this somewhat doubtful species. Neither of them are perfect, but as far as can be made out the average length appears to have been about $9 \mathrm{~cm}$. and the width about $6 \mathrm{~cm}$.

It is donbtful if these leaves belong to the genus Grewiopsis, but at 
present I am unable to suggest a closer affinity. They have the same size, shape, and approximately the same nervation as G. platanifolia Ward, ${ }^{1}$ from the Fort Union group, differing, however, in not having a toothed margin. Professor. Ward writes that the specimen npon which his species was founded is quite obscure, and it is possible that they may really be nearer alike than appears from the drawings. Additional material is needed to fix their status.

I have ventured to call this a new species, and have named it in honor of Mr. E. C. Alderson, who accompanied the expedition on which it was obtained and assisted in making the collections.

Habitat: Specinen Ridge, opposite mouth of Slongh Creek and near head of Crystal Creek; collected by Ward and Kinowlton, August, 1887.

\section{ARALIACEF.}

\section{Aralia whightil 11. sp.}

I'l. OI, tig. 1.

Leaf firm, corlaceous, narrow in general outline, palnately 3 (possi bly 5) lobed; central lobe largest, long, ovate-lanceolate, slender-pointed; lateral lobes slender-lanceolate, laalf the length of the central lobe; all margins perfectly entire; basal prortion of leaf unknown; primary nervation palmate; middle lobe with a pair of opposite nerves nearly at riglit angles to the midrib, which pass to the simus, those above with about 10 pairs of alternate camptodrome secondaries, which are mnch curved upward and arched along near the margin; intermediate secondaries occasional; lateral lobes with a strong midrib and about 8 pairs of alternate or subopposite much-arched camptodrome secondaries; finer nelvation consisting of very fine quadrangular areolation.

This very peculiar species is mnfortmately represented by only the fragmentary leaf figured. The basal portion is entirely destroyed and it is therefore impossible to determine whether there were 5 or only 3 lobes. There is some evidence in firvor of its laving been 5-lobed. The sinuses separating the lobes are somewhat rounded. The central lobe is very much the larger. From the sinus it has $6 \mathrm{~cm}$. preserved and must have been $8 \mathrm{~cm}$. or more in length when entire. In the broadest part, 
which is about one-fourth of its length from the simns, it is $2.5 \mathrm{~cm}$. Inoar. The lateral lobes are alwont 8.5 ('m. long, not enlarged upward. At base they are $1 \mathrm{~cm}$. broad, from which print they taper gradually to a slender acuminate apex. The nervation has heen described in the diagnosis, and may also be clearly made ont fiom the excellent figure.

It is hardly possible to compare this species with described forms, from the far that it is so fiagmentary that the perfect form can not be made out. The characters of the larger middle lobe and the very much smaller lateral lobes seem to be so marked that it is strongly separated from any deseribed species. Aralia angustilobu Lx., from the Chalk Bluffs of Califormia, perhaps is closest to this species, yet it differs markedly. It will be necessary to wait for additional inaterial before its exact character can be made out.

I hive named this species in honor of Mr. George M. Wright, one of the collectors of this and many other vahuble specimens in the Yellowstone National Park.

Habitat: Fossil Forest (No. 22e of section); collected by Wright and Weed, September 20, 1885.

\section{Aralia motata Lx.}

Pl. C, tig. 1.

Armlia notata Lx.: Tert. Fl., p. 23i, Pl. XXXIX, figs. 2-4. Ward: Types of the Laramie Fl., P. 60, Pl. XXVII, fig. 1.

Plutumus dubia Lx.: Hayden's Anı. Rept. 1873 (1874), p. 406.

The collections contain about 50 specimens that evidently belong to this species. None of them are albsolutely perfect, yet the general character cim be made out. They come from three localities, one of which, the Yellowstone below Elk Creek, was given as a type locality by Lesquereux. ${ }^{2}$

There appears to have been a tendency among later writers to regard this as the same as Newberry's Platames nobilis ${ }^{3}$ from the Fort Union group, which indeerl it much resembles. They were both very large species, not often preserved entire, but they seem to liffer essentially. On this point Lesquereux says: "This species (A. notuta) seems very chosely allied to

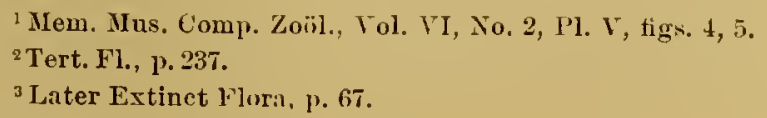


Platames nobilis Newby.; I should not hesitate to consider it as identical, but for the character of the lateral nerves, which are described by the author as straight, and terminating in the teeth of the margin. In this species the borders are entire and the lateral nerres camptodrome. The difference may be merely casual, for one of the specimens from Tromblesome Creek has the close secondary reins camptodrone along the borders of the inner side of the lobes, while on the outer side the borders are obscurely cut by a few small teeth, into which the reins enter as craspedolrome. Other specimens, thus of Elk and Tellow creeks, ${ }^{1}$ have the characters of $P$. nobilis."

It rould thus appear that Lesquereux himself inclined to regard the Park specimens as being referable to Platamus nobilis, but in the 50 or nore specimens that I have studied from this place I have not found one showing the teeth and craspedodrome nervation of $P$. nobilis. They all have the distinctly camptodrome nerves, as shown in Lesquerenx's tigures. I have therefore devided to keep them under Aralia.

The further question of the correctness of this generic reference, or rather of the relation of this Arolin notutu to the genus Platanus, will not now be taken up. Janko has saicl ${ }^{2}$ that Platanus nobitis "non est Platanus," while on the other hand Professor Ward has suggested ${ }^{3}$ that several of the so-called species of Aralia may have to be mited into a group, under the name of Protoplatams, representing the ancestor's of Platanus. A small specimen of this species, obtained by Prof. J. P. Iddings from a gulch northeast of the peak west of Dumraren, is exceptionally well preserved, at least as regards the finer nervation. This is very regularly square, being only about $0.25 \mathrm{~mm}$. in size. The leaf appear's to have been rather thick, possibly coriacenus.

No other specimen that I have seen has this finer nerration so well preserved.

Habitat: Fossil Forest Ridge, Tellowstone National Park, bed No. 7, "Castanea bed", about 25 specimens; collected by Lester F. IVard and F. H. Knowlton, August 16-20, 1887. Southeast end of hill above (north) Lost Creek, bed No. 4, 2 leaves; collected by F. H. Knowlton, August 8, 1888. Tellowstone River, one-half mile below month of Elk

'Probably Elk Creek on Yellowstone Rirr. l'. H. K.

${ }^{2}$ Alistammungr d. Plitanen, lenglers 1,ot. Jitbrh., Vol. XI, 1889, p. 456.

Tryes of th. Laramie Fl., l. 63. 
Creck, top of blutl; collected by F. II Knowltom, August 27, 1888 . Andesitic breccia, neal gulch northwest of peak west of Dumraven; collected by J. P. Iddings, september 12, 1853 . Also fomm on Orerlook Momutain, in breceila, at : an altitude of 10,070 feet; collected by Arnold Hague, August fi, 1s:17. Somthern spur of Chaos Mountain, at an altitude of 10,100 feet; collected by Arnold Hagne, August 11, 1S:97. South side of Stinkingwater Valley, on high bluff east of month of Crag Creek; collected by Arnold Hague, September 4, 1897.

\section{Aralia serrulata 11. sp.}

Pl. CI, fig. 3.

Leaf' :pparently subcoliaceons, palmately 3-lobed, middle lobe longest, ovate, obtuse; lateral lobes short, pointing upward; borders sharply serrulate, with small, sharp, upward-pointing teeth; secondaries numerons, close, alternate, at an angle of $25^{\circ}$ to $40^{\circ}$, curving upward and entering the teeth, or sometimes camptodrome with ontside branches to the teeth, usually 1 tooth between the 2 entered by two contiguous secondaries, which is supplied with a branch from the middle of a percurrent nerville, which crosses just below it; nervilles numerous, mainly percurrent and approximately at right angles to the secondaries; finer nerration quadrangular.

This fine and apparently characteristic species depends upon the single example figured. It lacks the entire lower portion of the leaf, but 2 lobes are entirely preserved, and a large portion of the other. The central lobe is $4.5 \mathrm{~cm}$. long to the sinus, and the lateral one about $1 \mathrm{~cm}$. higher than the sinus. The distance between the lateral lobes is $8.5 \mathrm{~cm}$.

This species has exactly the same size and shape as many of the 3-lobed specimens of Aralia notata Lx., ${ }^{1}$ found in the same beds.

The main difference is in the sharply serrate margins, the teetl extending even down to and through the sinus, and in the secondaries or branches from them entering the teeth. Occasionally, as indicated under the diagnosis, some of the secondaries are camptodrome, as all are in A. notata, with outside branches passing to the teeth. These species are evidently closely related and may possibly be the same, although probably not, for in 100 specimens of $A$. notata not one was found that possessed these teeth.

As pointed ont under the discussion of Aralia notata (see ante, p. 745),

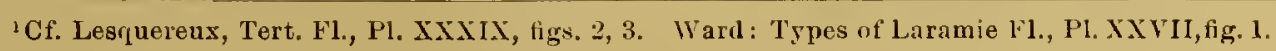


there was some tendency to refer it to Platams nobilis Newby., which is sometimes slightly toothed. The teeth of the species nuder discussion are distinctly aralioid, and not at all like those of $P$. nobilis.

Aralin sermlate is distantly related to $A$. digitata Ward, ${ }^{1}$ from the Fort Union beds. 'This latter species is 3-lobed, or, more often, 5-lobed, with the lobes enlarged upward, and serrate with shallow teetl only near the apex. A. macrophylla Newby., ${ }^{2}$ from the Green River group of Wyoming. has the lobes serrate, but the teeth are large, coarse, and often scattered, and, moreover, the leaf is twice the size of this and always 5-lobed.

A number of species of Aralia have been described from California, but none of them agree with $A$. semulata.

Habitat: Yellowstone River, one-lialf mile below the mouth of Elk Creek, top of bluff; collected by F. H. Knowlton, August, 1888.

Aralia whitceyi Lx.

Pl. XCIX, fig. 3.

Aralia whitneyi Lx.: Foss. Pl. Amrif. Gravels, Mem. MIns. Comp. Zoöl., Vol. VI., No. '2, 1878, p. 20, Pl. V, tig. 1. Hayden's Amu. Rept. 157s, Pt. II, p. 49.

This fine species was described by Lesquerenx from the Auriferous gravels of Chalk Bluff, Nevada County, California, and was also recognized by him in material collected by MIr. WT. H. Holmes on Fossil Forest Ridge ${ }^{3}$ in 1878. The specimens liere referred to this species eome from probably the same locality as that which afforder Holmes material. They are, with one exception, larger leaves than described in the type. None of the specimens are perfect, and henee it is difficnlt to determine the exact size, but they must have been 15 to $20 \mathrm{~cm}$. long and probably broader.

The small specimen mentioned is referred with some hesitation to this species. It is only about $9 \mathrm{~cm}$. broad and $7 \mathrm{~cm}$. long, but otherwise hardly differs.

Habitat: Fossil Forest Ridge, Yellowstone National Park, bed No. 4, "Aralia bed," small leaf only; bed No. 7, "Platanus bed:" Specinen Ridge, Fossil Forest, opposite Slough Creek, and near head of Crystal Creek, "Platanus bed;" several large fine leaves.

'Types of the Iaramie Fl.. p. 62, Pl. X.VIII, fig. 1.

${ }^{2}$ Proc. U. S. Nat. Mus., 1882, 1. 513; Plates (ined.), Pl. LxVII, fig. 1; Pl. LXVIII, fig. I.

${ }^{3}$ Cf. Harklen's Aun. liept., 1878, P’t. II, p. 79. 
Aralia :p.

This fiamment is the only one of this type observed, and is too poor to arlunit of satisfactory irlentification or characterization if it be new. It cousists of a portion of what appears to be the central lobe and 2 lateral lobes of a 3 -lobed tom. The sinuses are romoled and the mirlle lobe is enlarged above, with the margins entire. A secondary nerve passes up to the sinuses, and the lobe has about $5 \mathrm{or}^{\circ} 6$ pairs of alternate much archer camptodrome secondaries. It is quite mlike any other for'm observed, so far as can be made out.

Habitat: Hagne's Yellowstone Park collection, Fossil Forest section, No. 22c; collected by Wright and Weed, September 20, 1885 (field No., 1959).

\section{CORNACEF.}

Convus Newberryi Hollick.

Pl. CIII, fig. 6.

Cormus Nerberryi Hollick, in Knowlton: Bull. U. S. Geol. Surv. No. 152, p. 77, 1898. Cornus acuminuta Newby: Later Extinct Floras, ete., Ann. Lyc. Nat. Hist. New York, Vol. IX, 1868, 1. 71; Ill. Cret. and Tert. Pl., Pl. XX, figs. 2-4; Plates (ined), Pl. XXXVII, figs. 2-4.

Represented by a nmmber of well-preserved leaves, agreeing well with Newbery's figures and description.

Habitat: Yellowstone River, one-half mile and also 1 mile below mouth of Elk Creek, at top of bluff; collected by F. H. Knowlton. Also found on soutli side of Stinkingwater Valley on high bluff east of the mouth of Crag Creek; collected by Arnold Hague, September 4, 1897.

Cornus wrightil n. sp.

Pl. CIII, tigs. $4,5$.

Leaves of firm texture, elliptical-lanceolate, narrowed below and apparently slightly decurent, rather obtuse at apex; margin perfectly entire; midrib rather. thin, slightly flexuose; secondaries 4 or 5 pairs, lower pair opposite, others altemate, at various angles, curving along the margin and in the npper part, tuming by a broad bow to the apex; nervilles few, . approximately at right angles to the midrib; finer nervation not preserved. 
Several specimens of this interesting species are known. The most perfect one is figured, and is $7 \mathrm{~cm}$. in length, and yet lacks a small portion of both base and apex. It is a little more than $2.5 \mathrm{~cm}$. broad. It is quite regularly elliptical-lanceolate in shape, with a rounded, rather obtuse apex and a more narrowed base. The secondaries appear to be uniformly of 4 pairs, those in the upper portion of the leaf arching around and entering the point.

This species has some resemblance to the preceding species, which differs, however, in being much larger and in having an acuminate apex and numerous ( 8 or 9 ) secondaries. 'They can not be identical.

It difters from Cornus ovalis Lx., ${ }^{1}$ from Table Momntain, California, in shape and nervation, this species being oval, with obtuse base and apex.

Among living species this has considerable affinity with C. paniculata l'Her., especially with certain of the narow-leaved forms.

I have named this species in honor of Mr. George M. Wright, one of the collectors.

Habitat: Fossil Forest section, Hague's Yellowstone Park collection, No. $22 c$ of section; collected by Wright and Weed, September 20, 1885.

\section{ERICACEE.}

\section{Arctostaphylos elliptica 11. sp.}

Pl. XCVII, fig. 2.

Leaf very thick, leathery; elliptical in shape, obtuse above, slightly wedge-shaped at base; midrib thick, slightly flexons: secondaries about 5 pairs, alternate, lower ones short, at a low angle, upper ones at an angle of about $45^{\circ}$, soon curving upward and arching abont near the margin to join the one next above; nerrilles strong, percurent; finer nervation obsolete.

This fue little leaf is alnost perfect. It is $4.5 \mathrm{~cm}$. in length and $18 \mathrm{~mm}$. in width. The petiole is about $3 \mathrm{~mm}$. long and is rery thick, as is the flexuous midrib. The secondaries are also strong, the upper ones arching and joining in the upper part of the leaf.

This leaf is very thick, showing that it was of firm, leathery texture. It is eridently related to the bearberry (Arctostaphylos uvu-ursi) in shape, 
texture of the leat, and nervation. It difters in being ahmost twice the size of the living form and in la ving wanse nervation. It has also al short petiole.

11abitat: Yollowstone River, one-half nile below mouth of Elk Creek; collected by F. iI. Knowlton.

\section{EBEXACEF.}

IMOSPYros mRACHYSEPALA Al. I3r.

Jiospyros bruchyscpala AI. Br. Warl: Types of the Laramie FI.. I. 104, Pl. XILIX, figs. $1, \stackrel{2}{2}$

A finely preserved leaf, almost identically the same as Ward's fig. 2, except that the secondaries are a little closer together.

Habitat: Fossil Forest Ridge, bed No. 4, "Aralia bed;" collected by Ward and Knowlton, Angust, 1887.

\section{DiOSPYROS LAMARENSIS n. sp.}

Pl. XCV, tigs. 5, 6; Pl. دCVI, tig. 4.

Leaf membranaceons, regularly elliptical or ovate-elliptical, equally rounded at base and apex, or slightly broader at base; petiole not preserved, apparently with a slight wing; midrib thin, straiglut; secondaries 7 or 8 pairs, alternate, thin, camptodrome, arising at an angle of $45^{\circ}$ or $50^{\circ}$, passing straight toward the borders, near which they arch and join by loops to the secondary next above; intermediate secondaries occasional, thin, usually joining the secondary next below; finer nervation consisting of numerous irregular nervilles, producing irregularly quadrangular areola.

This species is about $5 \mathrm{~cm}$. long and a little more than $3 \mathrm{~cm}$. wide, and is quite regularly elliptical in shape. As stated, the petiole is not preserved, but judging from the base of the blade it seems probable that it was slightly winged. The lower pair of secondaries arise from the very base of the blade and are very thin; the others are all alternate and camptodrome. One of the other leaves figured is approximately of the same shape, but has slightly more indication of having had a winged petiole. It is rounded at base and has a Joose nervation, as in the other.

This species is closely related and possibly identical with Diospyros sopeana Lx., ${ }^{1}$ from Florissant, Colorado. This latter species differs in being

${ }^{1}$ Tert. Fl., p. 232, Pl. XL, fig. 11; Cret. and lert. Fl., p. 175, Pl. XXXIY, tig. 3. 
more or less distinctly wedge-shaped at base, and is obovate rather than elliptical in shape. The nervation is similar in both.

D. lamarensis is also like certain leaves of $D$. brachysepala Al. Br., from Florissant and the Fort Union group of Montana. ${ }^{1}$ The leaves from the Fort Union group are rather larger, and lave the secondaries at a different angle and are without the peculiar finer nervation. It seems best, however, to keep them distinct, at least for the present.

Habitat: Lamar River, between Cache and Calfee rreeks; collected by F. II. Knowlton, August, 1888. Fossil Forest; collected by Arnold Hague, September 24,1884 .

\section{Diospyros haGuei h. sp.}

$$
\text { Pl. C, fig. } 3 .
$$

Leaf coriaceons, elliptical, entire, obtuse at apex and base; petiole thick; midrib thick, flexnose; secondaries about 6 pairs, alternate, rery irregular, the pair at the base of the blade thin, vanishing near the margin, next pair strongest, passing to the upper part, camptodrome, brancling on the ontside and forming broad loops well inside the margin; upper secondaries smaller, camptodrome, forming broad loops; nervilles sparse, strong, percurrent; finer nervation obsolete.

This species rests on the fine, nearly perfect leaf figurerl. It is $7 \mathrm{~cm}$. long, including the petiole, which is $14 \mathrm{~mm}$. long and $2 \mathrm{~mm}$ thick. The blade is nearly regularly elliptical in shape and $3.3 \mathrm{~cm}$. broad. The nervation is peculiar, as may be drawn from the description and figure. All of the secondaries except the lower pair are camptodrome, forming by mion with the one next above a series of broad loops some distance inside the margin.

This type of nervation is peculiar and is clearly that of Diospyros. It approaches quite closely to certain small-leaved forms of $D$. virginiena $L$. Among fossil forms it somemhat resembles Diospyros obtusa Ward, ${ }^{2}$ from Serenmile Creek, Montana, in the Fort Union group. The latter species is of approximately the same size and shape, but differs in the details of nervation. It is, howerer, quite close.

I have named this species in honor of Mr. Arnold Hagne, of the Uniter States Geological Survey.

Cf. Lesquerenx Cret. and Tert. Fl., Pl. XXXIV, fig. 1, 2; Ward, Types of the Laramie Fl., Pl. XlIX, fig. 1, 2.

"Types of the Iaramie Fl., p. 105, Pl. XLLI, fig. 5. 
Habitat: Yellowstone River, one-half mile below the mouth of lik Creck, bise of bluff; collected by F. H. Knowlton, August, 1888.

\section{OLFICLA.}

Fraxinus wrightit n. sp.

Pl. XO, fig. 4 .

Leaflet small, membranaceons in texture, oblong in outline, mequalsided, wedge-shaped at base, obtuse at apex; margin with few irregular scarcely pointed teeth; midrib strong, slightly flexuose; secondaries about 7 pairs, alternate, at varions angles, flexuse, camptodrome or subcraspelodrome, mostly arehing and joining by bows some distance inside the margin, sometimes entering the teeth, and usually with outside branches to the minute, often obtuse, teeth; nervilles numerous, irregular, all forked or' broken; finer nervation producing irregular quadrangular meshes.

The specimen figured, which was the only one found, is $4 \mathrm{~cm}$. Jong and $2.2 \mathrm{~cm}$. wide. It is deeidedly inequilateral, with a wedge-shaped base, and undulate-toothed margin. The nervation is camptodrome, witl the secondaries arched and joined by broad bows well inside the margin, or occasionally with a secondary entering a tooth, thus becoming craspedodrome. The finer nervation is beautifully preserved, producing very irregularly quadrangular meshes

The relation of this species is undoubtedly with Fraximus heerii $\mathrm{Lx} .{ }^{1}$ from Florissant, Colorado. Lesquerenx's species differs in being much larger and narrower, with merely undulate margin. The nervation is strictly camptodrome, but otherwise identical.

I have named the species in honor of Mr. George MI. Wright, by whom it was collected.

Habitat: Yellowstone River, below Elk Creek, top of bluff; collected by George M. Wright, September 9, 1885.

Phíllites crassirolia n. $\mathrm{sp}$.

Pl. CII, fig. 5; PI. CIII, fig. 1.

Leaves very large, thick, apparently rudely oval or orbicnlar in outline; base rounded or slightly heart-shaped, upper portion rounded (?); margin 
entire or undulate; petiole usually very thick ( $7 \mathrm{~mm}$. in diameter); midrib thick (5 mmn.), straighth, splitting above into 2 equal branches; secondaries thick, straight, alternate or subopposite, often forking, craspedodrome or subcanptodrome, the secondaries or their branches nnited by broad loops with branches from the outside to the margin; nervilles very numerous, strong, manly percurrent, yet often forked or broken; finer nervation, producing large, mainly irregular, quadrangular areolae.

This species is based on a number of fiagments that are insufficient to show the true chanacter. Two of the largest are figured, showing what is assumed to be the base and upper portions. The largest is $13 \mathrm{~cm}$. long and about $10 \mathrm{~cm}$. wide, but this conld have been only a fragment of the original size. This specimen (fig. 5 of Pl. CII) is peculiar in that the midrib splits in the upper portion into 2 equal branches, both of which are again branched on the outsirle. This leaf appears also to have been 2 -lohed at the apex, all of which may be albummal and due to an injury to the midrib. The nervation in the upper portion quite markedly camptodrome.

The lower portion that $I$ have assumed to belong to this species loas an exceedingly thick petiole, of which only a fingment is preserved, and also at thick midrib. They appear so different that it seems hardly probable that they can be identical, but rather thin nultiply unsatisfactory species they nay remain as above mutil additional material ean be obtained. None of the margin except the very base is preserved.

On account of the fragmentary nature of these leaves, I am unable to deternine with satisfinction the proper genus to which they should be referred. In this uncertainty I have placerl them provisionally under Phyllites.

Habitat: Cliff on west end of Fossil Forest Ridge; Fossil Forest Ridge, near head of Crystal Creek, various beds; collected by Ward and Knowlton, August, 18s7, and by W. II. Weed, September 20, 1885.

\section{Carpolithes osseus Ix.}

Carpolithes osseus Lx.: Ann. Rept. U. S. Geol. anl Geog. Surv. Terr., 404, 1872 (1873).

A very doubtful species, of which the type is lost and the species not since obtained.

Habitat: "Elk Creek, near Yellowstone River; A. C. Peale, Joseph Sarage, and O. C. Sloane." 


\section{Carptes penuncluates n. sp.}

Pl. CIII. fig. 3.

Fruit romd, apparently 4 or 5 celled; pedicel short, thick.

'This fragmentary fruit is landly worthy of description, for it may be so deformed by pressure that it can not be recognized again.

Among the described fruits of this heterogenenus class $C$. vibumi Lx.." from lilack Buttes, Wyoming, is perhaps closest, but probably the resemblance is only" superficial

Habitat: Yellowstone River, one-lialf mile below the mouth of Elk Creek, top of blnff' (with Ulmus fruits); collected by F. H. Knowlton, August, 1888.

\section{FOSSIL FORESTS.}

'The fossil forests of the Yellowstone National Park are, beyond question, the most remarkable of their kind that lave thus far been discovered in any part of the world. Isolated pieces or stumps of fossil wood are of common occurrence, being found in almost all quarters of the globe, from near the point farthest north that was reached by the Greely Arctic Expedition to southern South America; from Spitzbergen and Nova Zembla to South Africa and Australia, and geologically from the Devonian to beds in process of formation at the present day. In many localities there are aggregations of $\operatorname{logs}$ and stumps that are worthy to be dignified by the name of fossil forests; as, for example, in Chalcedony Park, near Holbrook, Arizona; near Calistoga, California, and in the ricinity of Cairo, Egypt. But in all of these places, so far as known, all or most of the trunks are prostrated and lie seattered about in the greatest confusion. In some cases there is evidence that the logs were transported by currents before being fossilized. The fossil forests of the Yellowstone National Park and vicinity, on the other hand, are not only more extensive in area, but the trees are almost all standing upright in the exact positions in which they grew originally. Many of these trunks, standing on the slopes and steeper hillsides, rise to a lieight of 20 or 30 feet, and are covered with lichens and blackened and discolored by frost and rain. At a short distance it is hard to distinguish them from the near-by living relatives. The following account by Prot

${ }^{1}$ Tert. Fl., p. 305, Pl. LX, fig. 26. 
W. H. Holmes, the discoverer of these fossil forests, shows the impression first made by the sight of them:

As we ride np the trail that meanders the smooth river bottom, we have but to turn our attention to the cliff's on the right hand to discover a multitnde of the bleached trunks of the ancient forests. In the stceper middle portion of the monn. tain face, rows of upright trunks stand ont on the ledges like the columns of a ruined temple. On the more gentle slopes, farther clown, bnt where it is still too steep to support vegetation, save a few pines, the petrified trunls fairly cover the surface, and were at first supposed by us to be the slattered remains of a recent forest. ${ }^{1}$

Fossil trees or fragments of wool of greater or less size are found in many parts of the Park, but their distribution is mainly confined to the northern and northeastern portions. The forests of standing trees are all found in the vicinity of the Lamar River, the most striking being exposed on the slopes and cliffs of Amethyst Mountain and Specimen Ridge. Nearly all of these forests are easily accessible from the well-traveled road between the Mammoth Hot Springs and the town of Cooke, Montana.

As the visitor enters the area drained by the Lamar River and by the smaller streams rumning into the Yellowstone below the Grand Canyon, evidences of proximity to the fossil forests are soon at hand. In the bed of every stream pieces of wood, often of considerable size, may be found. These pieces have in many cases been carried miles from their original source by the torrents incident to the melting of the snows in spring. In this way the pieces of wood have become rounded and worn and at remote distances are changed into smooth, rounded pebbles.

The first forest to be visited is near Yanceys, and is known as Yanceys Fossil Forest. It is located about 1 mile south of the hotel, on the middle slope of a hill that rises about 1,000 feet above the little valley. It is reached by an easy trail, and as one approaches, a number of trunks are observed standing rppright among the stumps and trunks of living trees, and so much resembling them that a near view is necessary to convince the visitor that they are really fossil trunks. Only two rise to a considerable height above the surface. The larger one is about 15 feet high and 13 feet in circumference; the other is a little smaller. The roots are not exposed, so that it is impossible to determine the position of the part in view. Its original lengtl can not, of course, be ascertained. It is also impossible to

\footnotetext{
' U. S. Geol. and Geog. Survey of the Terr., Hayden's Twelfth Annual Report, 1878 (1883), p. 48.
} 
determine the original diancter, as the bark is in no case preserved. 'The standing trees are both conifers, and belong to the genus Cupressinoxylon.

Above these standing trunks many others are visible, but the disintegrating forces of nature keep them at about the same level as that of the surrounding rock, from the fact that they tend to break up easily into small fringments. Some of these trunks rise only a few inches, while others are nearly covered by the shifting débris. They vary in size from 1 to 4 feet in diameter, and are so perfectly preserved that the amnual rings can be ensily counted. The internal structure is also in most cases nearly as perfeet as though the tree were living. The cells still retain their delicate markings, and often their perfect form.

There are numerons fossil leaves found in the rocks about the bases of these trees, but none apparently corresponding to the trunks; that is, the trunks are all coniferous, while the leaves are dicotyledonons; but from the nature of the case a coniferous trunk is much more readily preserved than a dicotyledonous one.

The next forest that claims attention is the one mentioned by $\mathrm{Mr}$. Holmes, and is the one most frequently visited by observers. It is known locally as the Fossil Forest, and is exposed on the northern slope of Amethyst Mountain, opposite the month of Soda Butte Creek. The trunks may be easily seen from the road along the Lamar River and quite a mile away. They stand upright-as Holmes has said, like the pillars of some ancient temple-and a closer view shows that there is a succession of these forests, one above the other, through the entire 2,000 feet of this mountain. That is to say, in early Tertiary time a magnificent forest flourished in this region, which was buried under the débris ejected from volcanoes of greater or less size that are supposed to have existed in this vicinity. The trees were surrounded by silica-charged waters and were tumed to stone. The area on which they grew was probably undergoing a very gradual submergence and the trees were slowly entombed. This is shown by the fact that the trees are in an upright position and were not broken by the incoming material which covered them.

After the first forest was entombed, quiet was restored for a sufficient length of time for a second forest to grow above it. Then volcanic activity was renewed, and the second forest was buried and silicified as the first had been. This process was repented until 2,000 feet of volcanic material had 
been accumulated and not fewer than fifteen forests were entombed. Then the rolcanoes ceased their activity and final quiet was restored. Probably an upward tendency was given to the area, but it must have been very gradual and not attended by the distortion which so frequently accompanies momtain building. The disintegrating action of frost and rain immediately set in and las carved out this mountain, in the heart of which may be read the story of its origin.

In the foothills and several hundred feet above the valley there is a perpendicular wall of breccia, which in some places attains a height of nearly 100 feet. The fossil trunks may be seen in this wall in many places, all of then stancling upright in the positions in which they grew. Their upright position proves that if there have been changes of level they have been gradual and in the same plane, as otherwise the trunks would be variously inclined. Some of these trunks, which are from 2 to 4 feet in diameter and 20 to 40 feet in lheight, are so far weathered out of the rock as to appear just ready to fall, while other's are. only slightly exposed. Niches mark the places from which others have already fallen, and the foot of the cliff is piled high with fragments of rarious sizes.

Above this chiff the fossil trunks appear in great numbers and in regular succession. As they are perfectly silicified they are more resistant than the surounding matrix, and consequently stand out above it. In most cases they are only a few inches above the surface, but occasionally one rises as high as 5 or 6 feet.

The largest trunk observed in the Park is found in this locality. It is a little over 10 feet in diameter, which includes a portion of the bark. It is rery much broken down, especially in the interior, a condition which very probably prevailed before fossilization. It projects abont 6 feet above the surface.

The most remarkable of all the forests, however, is located on the westen'n end of Specimen Ridge, about 1 mile southeast of Junction Butte and opposite the mouth of Slongh Creek. It was first brought to the notice, of the scientific world by Mr. E. C. Alderson and the writer, who discovered it in August, 1887. It is found on the higher portion of the ridge, and is several acres in extent. The trees are exposed at rarious lieights on a rery steep hillside, and the remarkable feature is that most of them project well above the surface. 
One of the largest and best-preserved trees stands at the very summit of the slope. It is $26 \frac{1}{2}$ feet in circunference without the bark, and rises about 12 feet in height. The portion of this huge trunk preserver is the base, and below ground it becomes somewhat enlarged and passes into the roots, which are as large as the trunks of ordinary trees. The roots are embedded in the solid rock, as slown in the figure (see Pl. CIV).

This trunk is a true Sequoia, and is so closely allied to the modem redwood (Sequoin sempervirens) of Califomia as to be hardly distingnishable from it. It wonld be interesting to learn the height this tree attained, but it seems safe to assume, from what we know of its living representative, that it must have been more than a hundred feet high.

Just below the large trunk, on the steep lillside, are two more standing trees (see Pl. CVI), which we may imagine to lave formed the doorposts of the "ancient temple" of which Holmes speaks. They stand about 20 feet apart and rise about 25 feet in height. They are both abont 2 feet in diameter and are also withont the bark.

In other parts of the area there are standing trees which attain a height of 12 to 20 feet They are all under 2 feet in diameter. In a few cases the bark is also preserved. It is hardly ever more than 3 inches in thickness.

Scattered about over the area are a great many trunks that rise only a few inches above the surface. These vary in diameter from 2 to 5 feet. They are often hollow in the center and have the cavity lined with brilliant amethyst crystals.

- One of the larger trees appears to have been prostrated before it was fossilized (see Pl. CVIII). It is about 4 feet in diameter and is exposed for a length of 40 feet. There is nothing to indicate the portion of the trunk in its relation to roots and branches, but neither shows on the exposed part. There is no appreciable diminution in diameter, and consequently it must have been a very tall trunk.

The matrix about the bases of these trees, as well as those in the Fossil Forest, contains numerous impressions of leaves, branches, and fruits. In the Fossil Forest there are at least 6 horizons at which plant remains occur. These are separated by a few inches, or in some cases by many feet. In the forest last described, which may be ealled the Junction Butte Forest, there are only 2 or 3 plant horizons. 
Most of the trunks in all three of the described forests are coniferons. but occasionally a dicotyledonous trunk is found, showing that the forest was to some extent a mixed one. It is of course more than probable that the leaves found in the matrix about the bases of the trees were at one time attached to them, but as they have nerer been found in association, it is manifestly impossible to correlate them.

The next fossil forest in rank of size is, perhaps, the one found on Cache Creek, about 7 miles above its month. It is exposed on the south bank of the creek, and covers several acres. The trunks are scattered from bottom to top of the slopes, through a height of probably 800 feet Most of the trunks are upright, although there is only now and then one projecting more than 2 or 3 feet above the surface. The largest one observed was 6 feet in height and about 4 feet in diameter. While most of the trunks appear to the naked eye to be coniferous, there are a number that are obviously dicotyledonous. It is certain, however, that the conifers were the predominant element in this as in the other fossil forests.

The slopes of The Thunderer, the mountain so prominently in view from Soda Butte on the south, have also numerous fossil trunks. They are mainly upriglit, but only a very few are more than 2 feet above the surface. There were no remarkably large trunks observed, the average diameter being less than 2 feet.

Mount Norris, which is hardly to be separated from The Thunderer, has a fossil forest of small extent. The trees are of about the same size and characteristics as those on the larger mountain.

Forests of greater or less extent, composed mainly of upright trunks, are exposed on Baronett Peak, Bison Peak, Abiathar Peak, Crescent Hill, and Miller Creek. In fact, there is hardly a square mile of the area of this northeastern portion of the Park withont its fossil forest-scattered trunks or erratic fragments.

The vast area to the east of the Yellowstone Lake has never been explored thoroughly from the paleobotanical side, but enough is known to be certain of the presence of more or less fossil wood. The stream beds contain occasional fragments, which is a sufficient indication that trunks of trees must be near at hand. 


\title{
DESCRIPTION OF SPECIES.
}

\author{
SBquUIA Magnilica H. ST.
}

Pls. CIY, GV, CX, CXI, OXYII, figs. 1-6.

Diagnosis.-Trunks often of great size, 6 to 10 feet in diameter, 30 feet high as now preserved, bark when present 5 or 6 inches in thickness; ammal rings rery distinct, 2 to $3 \mathrm{~mm}$. broat; fall wood reduced to narrow bands of 3 to 15 rows of thick-walled cells; cells of spring and summer wood large, hexagonal or often elongated; resin tubes numerous, composed of short cells; medullary rayss numerons, of a single series or occasionally with a partial double series of superimposed cells; wood cells with one or two rows of small cireular pits.

Transverse section.-In this section (Pls. CX, CXI) the strueture appears beautifully preserved. The rings are rather narrow, being only. 2 or $3 \mathrm{~mm}$. broad, or often only $1 \mathrm{~mm}$. They are rery sharply demarked, even to the naked eye. Under the microscope the rings are found to consist of a band of thick-walled cells that is nerer more than 15 rows of cells deep and often is reduced to 2 or 3 rows. The cells composing the spring and summer wood are of uniform size and inclined to be hexagonal in shape. Those of the fall wood are, of course, compressed.

The resin cells are mumerous and may be readily distingtished by the dark contents. They occur mainly in the spring and summer wood.

The medullary rays seen in this section are long, straight, and separated by usually about 3 rows of wood cells.

Radial section.-This section (Pl. CXVI, figs. 2-3) is the least satisfactory of all. The wood cells show well under the microscope, but their markings are very obscure. By prolonged search it is made out that the pits are in 1 row, or sometimes 2 parallel rows. They are small, as far as can be made out, and are too obscure for satisfactory measurement.

The rays are composed of long, ummarked cells.

Tangential section.-This section (See Pl. CXVI, fig. 1) is very satisfactory. The wood cells are long and unmarked. The resin ducts are numerous, but seattered, the cells being twice or three times as long as wide. In many cases they are filled with or contain masses of dark material, representing the resin now turned to a carbonaceous mass. 
The medullary rays are composed of 1 , or in some cases of a partially double, series of 2 to about 25 superimposed cells. They are large and quite thick walled. The average number of cells in each ray is about 12 .

This species is closely related to the living Sequoia sempervirens Endl., more closely than any other fossil species with which I am familiar. They are hardly to be separated by any well-defined characters. The living wood has the same clearly marked ammal rings, resin cells, partially double rays, and pits on the wood cells. The medullary rays in the living wood are provided with numerous round pores or markings. These seem to be absent from the fossil specimens, but, as ahready related under the diagnosis, the fossil is not well preserved in the radial section and they may have been present there when it was living. The dimensions of the various elements are much the same in the living and fossil specimens, thus leaving no doubt as to their close affinity.

In size of trunks these species are also similar. The largest trunks observed in the Yellowstone National Park belong to S. magnifica. They range in size from 4 to 10 feet in diameter, one of the largest being shown on Pl. CV. This is $26 \frac{1}{2}$ feet in circunference and stands upright on the hillside. It is 12 feet high, and represents the base of the trunk, as the large roots are well preserved. Their height is of course unknown, but one was fortmately prostrated before fossilization (Pl. CVIII), and is 40 feet long, with no apparent diminution in cliameter. It is altogether likely that they may have been equal in height to some of the living representatives.

I have thought best to give this fossil species a name different from that of the living tree, notwithstanding the fact that they are evidently so closely related. The fossil comes from a locality remote geographically from the living redwood, and, moreover, from a horizon that, although comparatively recent, is so ancient as to make it extremely improbable that the type has actually been living for so long a period. There can, however, be no doubt that the living redwood is the direct descendant of this remarkable tree that was once so abundant in the Yellowstone National Park.

Habitat: Specimen Ridge, Fossil Forest at head of Crystal Creek, Fossil Forest on Cache Creek, etc.; collected by F. H. Knowlton, August, 1887-August, 1888. 


\section{Pityoxilon aldersoni in. sp.}

Pls. CVI, CxII, CxIII, CxviII, figs. 3，4; Pl. CxIx, fig. 2.

Diagnosis.-Trunks of large size, 3 to 5 feet in dianeter; ammal rings very distinct, often 8 or $9 \mathrm{~mm}$. broad, very sharply denarked; resin ducts numerous, large, scattered, occurring in late summer and fall wood; wood cells long, witl a single irregular row of medium-sized pits; medullary rays in a single series, or occasionally with divided cells; rays from 2 to 25 cells high, the average being about 10 or 12 cells.

Transverse section._-The ammal rings are very distinct, being plainly discernible to the naked eye. Some of the broadest rings are fully $9 \mathrm{~mm}$. wide, and none are less than $6 \mathrm{~mm}$. The demareation between fall and spring wood is very pronounced (see fig. 4 of Pl. CXVIII and 2 of Pl. CXIX), the cells of fall being small, compressed, and thick-walled, while those of the early spring wood are rery large, and, of course, thin-walled.

The cells of the spring and summer wood contimue for a width of $5 \mathrm{~mm}$., but little, if any, diminished in size. Then they become slightly snualler and thicker-walled and pass gradnally into the fall wood.

The resin ducts are rery large. They are not found in the summer wood, but occur irregularly in the early fall and late fall wood.

The medullary rays, as observed in this section, are straight and separated by from 3 to 8 or 10 rows of wood cells. The individual cells are apparently long.

Radial section.-Notwithstanding the fact that the wood seems to be perfectly preserved, it does not reveal the structure well in this section. The wood cells are seen to be sharp-pointed where they join. They are, of course, broad in the spring and summer wood, and very narrow and thickwalled in the fall wood. It is very difficult to make out the pits, but in exceptionally well preserved portions a few may be faintly seen. They are scattered, but in a single series. They are so obscure that no satisfactory measurements can be made.

The medullary rays in this section are long, thick-walled, and without markings, so far as can be made out.

Tangential section.-This section is very plain. The medullary rays are numerous and in a single series, although occasionally a ray may be observed in which there are 2 series of cells for a short distance. In such cases the 
cells are always smaller than the ordinary ray cells. The number of cells making up each ray ranges from 2 to 30 or more, but the average number is about 8 to 15 .

The rays in which there is a resin duct are rather rare. The duct is large, taking up all the width of the ray. The remainder of the ray is 3 rows of cells high in the middle and is reduced to 1 at the extremities.

The wood cells show clearly in this section. They are not provided with pits or ofler markings.

Habitat: Specimen Ridge, Fossil Forest, near head of Crystal Creek; collected by F. I. Knowlton, August, 1887. Yancey Fossil Forest; collected by F. H. Knowlton, August, 1887.

\section{Pityoxylon amethistinua $\mathrm{n}$. $\mathrm{sp} .^{1}$}

Pls. CVII, CVIII, CXIV, CXV, CXVIII, figs. 1, 2.

Diagnosis.Trunks of small or medium size; annual rings sharply demarked, 3 to $8 \mathrm{~mm}$. broad; resin ducts numerous, scattered, but mainly in fall wood; wood cells long, sharp-pointed, provided with a single row of scattered, small, somervhat irregular pits; medullary rays numerous, in a single series of 2 to 12 cells, the average being about 5 or 6 .

Transverse section.-Much like the preceding species, except that the rings are narrower, the cells of spring and summer wood are smaller, and the late fall cells have thinner walls. The resin ducts are also much the same, being in general only a little smaller. A few are found in the summer wood, but most of them are in the fall wood. The rays are not nearly so numerous as in the last species. They are often separated by as many as 25 rows of wood cells.

Radial section.-The radial section of nearly all woods from the Yellowstone National Park is more or less obscure. The one under consideration is no exception to this rule, and it is only after considerable search that the pits can be determined. They are in a single row (see Pl. CXVIII, fig. 1)

' In 1888 Dr. J. Felix, of Berlin, visited, and collected fossil wool in, the Yellowstone National Park. The resnlts of his work were published in Zeitschrift der Dentschen geologischen Gesellschaft, for 1896. He described six species of fossil wood, of which number 1 hare recognized fonr. The following two species were not figured, and as the locality whence they came is more or less in donbt I have not included them in the systematic enumeration. They are as folluws: Pityoxylon fallax and Cupressinoxylon eutreton. They may be illentical with certain of the species I bave described, but of this I am nncertain. 
and are rather small. They are so obseure that it is impossible to make trustworthy measurements.

The medullary lays, as seen in this section, are composed of long, thinwallerl cells, and so fiur as can be determined they are withont pits or other markings.

Tangential section.-This section (Pl. CXVIII, fig. 2) shows the structure rery phinly. The medullary rays are abundant and always in a single series, except the large compound ones. The number of cells in each ray varies from 2 to 10 or 12 , the average number being about 6 . The compound rays inclosing the resin ducts are rather small, with three rows of cells in the middle portion. No markings can be made ont on the wood cells in this section.

This species is very closely allied to the one preceding, and should perhaps be referred to it. The main points of difference are the following: Narrower anmual rings; smaller resin ducts, that are occasionally found in the summer wood; smaller wood cells throughout; smaller and shorter compound medullary rays; ordinary rays always in a single series of 2 to 12 cells (average 6 ) instead of from 2 to 30 or more (average 12).

Habitat: Specimen Ridge, Fossil Forrest, near head of Crystal Creek; collected by F. H. Knowlton, August, 1887.

\section{LAURINOXYLON PULChRUM $11 . \mathrm{sp}$.}

\section{Pls. CXVI, CXIX, figs. 3-5; Pl. CXX, fig. 1.}

Transverse section.-Amnual ring very distinct to the naked eye, 2 to $4 \mathrm{~mm}$. broad. The demarcation between the rings results from 10 or 12 layer's of thicker-walled cells, representing the late fall wood, and from the greater abundance of ducts in the immediately following spring wood.

The wood cells are small and arranged in serial rows except in the vicinity of the ducts, where they are somewhat irregular (see fig. 1 of $\mathrm{Pl}$. CXX). Surrounding the ducts, and sometimes filling the remainder of the space between rays, the cells are larger and not so completely seriated. The ordinary wood cells are about $0.01 \mathrm{~mm}$. in diameter, and those near the ducts 0.015 or $0.02 \mathrm{~mm}$. There is an occasional row of the large-sized wood cells along a ray, as in fig. 1 of Pl. CXX.

The ducts are very plainly shown in this section. At least half of them are single and nearly or quite circular in section. Of the remainder, 
most are double, while occasionally there are 3 in a row or series, and exceptionally as many as 4 . The number in a square millimeter is only from 4 to 6 . The smallest of the single ducts range in diameter fiom 0.03 to $0.06 \mathrm{~mm}$. The largest observed are $0.21 \mathrm{~mm}$. in long diameter and $0.16 \mathrm{~mm}$. in short diameter. The largest double duct-that is, when there are two together-is $0.31 \mathrm{~mm}$. The largest of the series of 3 is 0.36 mm., and the largest of the few in series of 4 is $0.44 \mathrm{~mm}$. The average diameter of large and small ducts is probably about $0.12 \mathrm{~mm}$.

The medullary rays are 1 to 3 cells wide, and run irregularly among the ducts. They are about $0.01 \mathrm{~mm}$. broad.

Radial section.-The wood cells are long, slender, and apparently sharppointed. There is evidence also that some of these are divided up into short cells by square divisions.

The medullary rays form plates of short, rather thin-walled cells. They are from 0.02 to $0.04 \mathrm{~mm}$. in diameter and from 0.05 to $009 \mathrm{~mm}$. in length. They do not appear to be marked, yet there is some evidence that there were minute pits; but the specimens are not well enough preserved to be certain of this.

The duets shown in longitudinal section (Pl. CXIX, fig. 3) are very pronounced. The individual cells are from 0.10 to $0.20 \mathrm{~mm}$., or sometimes more, in length. The walls sre covered with small round pits, which occasionally pass into regular scalariform markingss (see figs. 4 and 5 of Pl. CXIX.) Each duct is surnunded by a mass of tissue from 2 to 6 or 8 layers of cells thick, of which mention was made under the discussion of the transverse section. The individual cells of this sheath are of about the same size and appearance as the large cells of the medullary rays.

Tangential section.-The fine photonicrographic reproductions of this section (Pl. CXVI) give a far better idea of the structure than any description can. The medullary rays, it will be observed, are very mumerous (about 3 to each square millimeter). They are from 1 to, exceptionally, 4 layers of cells broad and about 12 lavers high, the extremes being 5 and 20 .

This plate shows admirably the ducts and related tissue. The one in the center of the plate shows well the manner of division, although the magnification is hardly sufficient to show the pits or markings.

This species is one of the handsomest with which I an familiar. It has affinities with a number of described forms, as, for example, Laurus 
triscriata Caspary, from the 'Tertiary of l'russia. From this it differs in the arrangement of ducts and in rays, and somewlat in the markings. It is also evidently allied to the two forms from the 'Tertiary of Arkansas, Laurimaxylon branneri $\mathrm{K}_{n}{ }^{2}$ and L. lespereuxiana $\mathrm{K} n .^{3}$

The gemus Lamrus was evidently abundant in this flora, and it is to be expected that the trunks would be occasionally preserved. It is of course proballe that this wood may belong to a species that has also been described from the leares, but there is manifestly no means of comecting them.

Habitat: Specimen Ridge Forest, near head of Crystal Creek, Y'ellowstone National Park, a prostrate log: collected by F. H. Knowlton. August $25,1887$.

\section{Perseoxylox aromaticum Felix.}

Perseoxylon aromaticum Felix: Untersuehung iiber fossile Hiilzer, v. Stiick: Zeitsehr. d. Dentsch. geol. Gesell., Jahr. 1896, p. 2j4, 1896.

Laurinoxylon arumaticum Felix: Die Holzopole Ungarns, p. 27, Pl. I, tig. 7; II, fig. 7, 9.

This species was detected by Felix in his visit to the Y'ellowstone National Park in 188s. I did not meet with it.

Habitat: Vicinity of Yanceys, Yellowstone National Park. Collected by J. Felix, 1888.

\section{Plataninium haydeni Felix.}

\section{Pl. CXX, figs. 3-i.}

Plataninium haydeni Felix: Uutersnchung ïber fossile Hölzer, v. Stiick: Zeitschr, d. Dentsch. geol. Gesell. Jahr. 1896, p. 251, 1896.

Transvarse section. - T'he ammul rings are faint, yet they may be seen with the naked eye. They are abont $2 \mathrm{~mm}$. broad. The medullary rays are very distinct in the weathered specimen.

Under the microscope the structure is shown to be well preserved. The wood cells are not arranged 'in radial rows, but are quite irregularly placed. They are large (0.01 to $0.03 \mathrm{~mm}$.) and angular, being 3 to 6 sided by compression.

\footnotetext{
${ }^{1}$ Einige fuss. Fülzer Prenssens: Abhandl. z. geol Specialk. v. Prenssen n. Thiiringischen Staten, 1889, p. 60, Pl. XI, figs. 6-12; Pl, XII, figs. 1-5.

${ }^{2}$ Fossil' woods and lignites of Arkansas: Aun. Rept. Geol. Survey Arkansas, 1889, Vol. 11, p. 256, 1'1. IX, figs. 8-9; Pl. X, figs. 1, 2; P1. X, fig. 4.

${ }^{3}$ Op. cit., p. 258, Pl. X, figs. 3,4 ; Pl. XI, figs. 3,4 .
} 
The ducts (Pl. CXX, fig. 4) are very numerous. They occupy at least one-third of the area, exclusive of the rays. They are almost always single, although often placed close together, especially in the beginning of the spring wood. They are uniformly oblong in shape. In the spring wood the arerage size is $0.09 \mathrm{~mm}$. in long and $0.06 \mathrm{~mm}$. in short diameter. In the fall wood they are from 0.03 to $0.06 \mathrm{~mm}$. in long and 0.025 to 0.05 mm. in short diameter.

The annual ring consists of a layer of slightly thicker wood cells, but it is mainly distinguished by the abruptly larger ducts in the spring wood (see fig. 4 of Pl. CXX).

The medullary rays are very abundant as seen in this section. They are from 1 to 10 or 15 cells broal. Fully 30 per cent of the area is covered by the medullary rays. The rays uniformly contain a black carbonaceous substance, these making them stand out in bold relief.

Radial section.-The most prominent feature in this section (Pl. CXX, fig. 5 ) is the medullary rays. They form high plates of usually short cells with black carboniceous contents. The ducts are also prominent, and appear to be marked with scalariform thickenings; but as they are quite obscure, this is not positive.

Tangential scction. -The structure of this section is very clearly revealed under the microscope. The medullary rays are very numerous. They range from 1 to 10 or 15 layers of cells broad and more than 100 high. The cells are round, thin-walled, and usually or not at all compressed. They take up, as already stated, finlly 30 per cent of the space. In some cases the rays are $0.5 \mathrm{~mm}$. long and $0.35 \mathrm{~mm}$. broad (cf. fig. 3 of Pl. CXX).

The wood cells are long and sharp-pointed. So far as can be made out, there are few if any square divisions of the cells.

The ducts, of course, show well in this section, but the markings, if present, are now obscure.

This species is quite closely related to the living Platanus occidentalis L., the common sycamore or plane tree. The living wood shows the indistinct annual ring, the irregular wood cells, and numerous medullary rays almost identical with the fossil wood. There are certain minor points of difference, such as markings on the rays, lignification of the ducts, etc., but they are certainly close enough to make their generic identity reasonably sure. 
The fant that l'atamus leaves ane very abumlant in the beds surrounding the fossil trunks makes it extremely probable that the generic reference is correct. It is of course also probalble that some of the leaves belong to the wool here describerl is different, but as they hive never been found attached, it is manifestly unsate to assume that there was ever organic union.

A number of fossil species latre been deseribed from various parts of the world; none, however, from North America. The general agreement between these and the one under consideration is close, but the specific differences are marked in certain cases. One of the nearest forms is Platumus klebsii Cass.., ${ }^{1}$ from the Tertiary of Prussia. It differ's in important minor characters, as does $P$. borealis Casp., ${ }^{2}$ from the same place. The two species described by Felix, Plataninium porosum Felix and $P$. regulare Felix, have only general resemblance.

In the original MSS., which was submitted in March, 1896, I had of course given this another specific name, and it may still prove to be different from the P. haydeni of Felix. Unfortunately Felix has not figmred lis species, and it is difficult, from a mere teclnical description, to be entirely certain of their identity. It is reasonably certain, however, that they are identical, and I have so regarded them.

Habitat: Specimen Ridge Forest, near head of Crystal Creek, Yellowstone National Park. From a trumk 6 inches in diameter and about 1 foot in height; collected by F. H. Knowlton, Angust 25, 1887.

\section{Rhamacinium radiatim Felix.}

\section{Pl. CXVIII, figs. 6, 7; Pl. CXIX, fig. 1.}

Rhamnacinium rudiatum Felix: Untersuchung iiber fossile Hölzer' : Zeitschr. d. Deutsch. geol. ('iesell., Jahr. 1896, p. 252, PI. VI, fig. 3, 1896.

Transverse section. - Annual ring broad $(7 \mathrm{~mm}$.), very indistiuct, consisting of only 1 or 2 rows of slightly thickened wood cells and rather abrupt presence of numerous large ducts in succeeding spring wood. Ducts very numerous, in radial rows. A few of the ducts are single, but mainly they are contiguons, with 2 to $10 \mathrm{in}$ a series. The nsual number is 3 or

\footnotetext{
${ }^{1}$ Einige foss. Hölzer Preussens : Abhaudl. \% geol. Speciall. v. Prenssen 11. Thïringisehen Staaten, 1889, Pl. VIII, figs. 1-24.

${ }^{2}$ Op. cit. , Pl. IX, figs. 1-11.

MON XXxlI, PT II 49
} 
four. The ducts occupy nearly one-half of the area, thus producing an open, soft wood. The longest series of ducts, embracing 10 , is $0.50 \mathrm{~mm}$. in length. Series of $t$ or 5 having a length of $0.30 \mathrm{~mm}$. are common. The small single ducts are 0.05 to $0.07 \mathrm{~mm}$. in long and 0.04 to $0.05 \mathrm{~mm}$. in short diameter. The average short diameter of all ducts is abont 0.07 (1) $0.08 \mathrm{~s}$ min.

The wood cells are arranged in distinct radial rows. They are rather large and thin-walled, also showing that the wood was a sott, porous one.

The medullary rays in this section are rather numerous. They are $2 \mathrm{or}$ sometimes 3 cells wide, and the cells are short and thin-walled.

Radial section. The ducts appear especially mmerous in this section. The marking on the walls is rather obscure, but they seem to be mifimly provided with minute pits.

The rays form high plates of short, thin-walled cells, apparently with small circular or oblong pitlike markings.

The wood cells are rery long. They have sharp-pointed extremities and thin walls.

Tangential section. CThis section is very characteristic, the most prominent feature being, of course, the cut-off ends of the medullary lays. The rays are various, being 2 or rarely 3 or 4 layes's of cells wide. The number of vertical rows is very indefinite, being rarely less than 10 or more than 30. The cells are rectangular, being often twice as long as wide. Some of the cells in the middle of the ray are more or less irregular in shape. All are very thin-walled.

The wood eells are the same as in the radial section.

The ducts are also prominent. Ther have oblique partitions and the walls are provided witl round pits. The markings on the walls are not different from those to be olserred in the radial section, but they happen to he better preserved.

In my original MIS. this form was described under the new generic nane of Populoxylon, from its undoubted cluse resemblance to woul of living Populus. It is with some hesitation that I transfer it to Felix's species, for they do not agree in every particular. On the whole, however, it is more than probable that they are the same, and I have so regarded them The generic diagnosin, hased npon the wood from the Park only, 
may be drawn up as follows: Mnnual ring present, but faintly demarked: wood cells long, natrow, sharp-pointed, thin-walled; ducts very nunerous, occupving about one-lialf of the area, in radial rows of from 2 to 10 , pitted, the pits small, round; medullary ray's munerous, of short, thin-walled cells, rectangular or irregular in transterse section, arranged in 2 to sometimes 4 rertical rows of approximately 10 to 30 cells each.

Habitat: Specimen Ridge, near head of Crystal Creek, Yellowstone National Park; collected by F. H. Knowltou, Angust 22, 1887.

\section{Quercinium Lamarense 11 . sp.}

I'l. CXVII, fig. 5; Pl. CXX, fig. :2; Pl. CXXI, figs. 1, 2.

Transverse section.-Annual ring present, but very faint; consisting of but 1 or 2 rows of thickened cells. In the succeeding spring wood the ducts are much larger, thus making the ring visible to the naked eye.

Ducts numerous, scattered, most abundant in spring and summer wood; all single-that is, not contiguous. They are almost perfectly circular, being rery slightly elongated radially. They are large, though not remarkably so for the genns; the larger ones ranging in diameter from 0.16 to $0.23 \mathrm{~mm}$., the smaller being about $0.20 \mathrm{~mm}$. The very smallest ducts are $0.05 \mathrm{~mm}$. in diameter, and the more common of the small ones are 0.10 or $0.12 \mathrm{~mm}$. in diameter. None of the dncts are arranged in notable radial rows.

The wood cells are in distinct radial rows, and are large and thickwalled. In most the lumen is nearly obliterated. The average size of the wood cells is $0.02 \mathrm{~mm}$.

The medullary rays are neither very numerous nor conspicnous. They are mainly only 1 cell broad, with an occasional wide one of 20 or more cells, as will be described under the tangential section. Some of the singlecelled rays pass for a considerable distance among the ducts, but by far the larger number lie between two ducts (see fig. 1 of Pl. CXXI).

Radial section.-The only sections available in this direction were, unfortunately, froin poorly preserved portions of the specimen, and do not show the structure clearly. The wood cells, so far as can be made ont, are very long, and, as shown by the transverse section, have thick walls The rays 
form high plates of cells, the exact length of which can not be determined with satisfaction. If there were markings on the rays they can not be seen; neither can the markings on the ducts be observed.

Tangential section.-This section shows much better under the microscope than the radial one.

The rays are found to be of two distinct kinds: The most numerous are only 1 cell broad and from 10 to 25 cells high, the individual cells being thin-walled and oblong in shape. At seattered intervals are very broad rays composed of 10 to 20 rows of cells and extending for long distances through the section (see fig. 2 of PI. CXXI). These broad rays are often somewhat cut by wood cells passing diagonally throngh them (see fig. 2 of Pl. CXXI). This does not, however, interfere with the ray as a whole, which is clearly demarked from the small rays of a single series of superimposed cells. The individual cells of the large rays are nearly circular in cross section, or more or less 6 -sided by mutual pressure. They are also thin-walled.

Associated with the small rays is usually a layer or two of short-celled tissue or series of parenchymatous cells. Except for there being shorter cells they are not to be distinguished from the ordinary wood cells.

The ducts show clearly enongh in this section, but they are not well enough preserved to pernit the markings on the walls to be made out. It would seem that the walls were pitted, but this is largely surmised.

A considerable number of species of Quercinium, ${ }^{1}$ or oak wood, in a fossil state, have been described from various parts of the world. Wood of this kind is readily distinguished by the large isolated ducts and the two kinds of medullary rays.

The species under consideration resembles a number of described forms, but they are all from the Old World, and are readily distinguished from it.

This species is closely allied to Quercinium linoultoni Felix, and may possibly be the same, but as Felix's species is not fully illustrated it is difficult to be positive. Q. lamarense seems to differ in the shape and size of the large ducts, but it will need a careful comparison of the sections to be positive. For the present, at least, they may remain distinct.

Habitat: Specimen Ridge, Yellowstone National Park; specimen from

${ }^{1}$ Fifteen species aud varicties. 
an upright trumk, t feet in dianeter; collacted hy li. H. Knuwlton, August 2.2. 1887

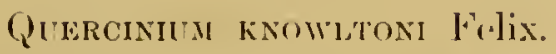

(nercinium linoultoni lelix: Uudersnehung iiber fossile Hïlzer: \%eitschr. d. Wentseh. geol. Gesell., Jahr. 18!16, 1). 250, Pl. VI, fig. "2, 1896.

As stated moler the preceding species, these 2 fomms may be irlentical, but in alsence of full drawings of ?. lnomltomi it seems best to regard them as distinct. The size and shape of the ducts certainly differ greatly.

Habitat: Anetlyst Mountain, Yellowstone National I'ark; collected by J. Felix in 1888.

\section{BIOLOGICAL CONSIDERATION OF TIIE TEIRTARY FLORA.}

The Tertiary flora of the Yellowstone National Park possesses great biological interest. It is a rich flora, and on comparing it with the living flora it hecomes apjarent that qreat elimatic changes must have taken place since the close of the Miocene period to have made these morlifications in plant life possible. 'The fossil flom embraces about 150 forms that have been distributed among 33 natural families. Following is a list of these families, with the number of species or forms referred to each:'

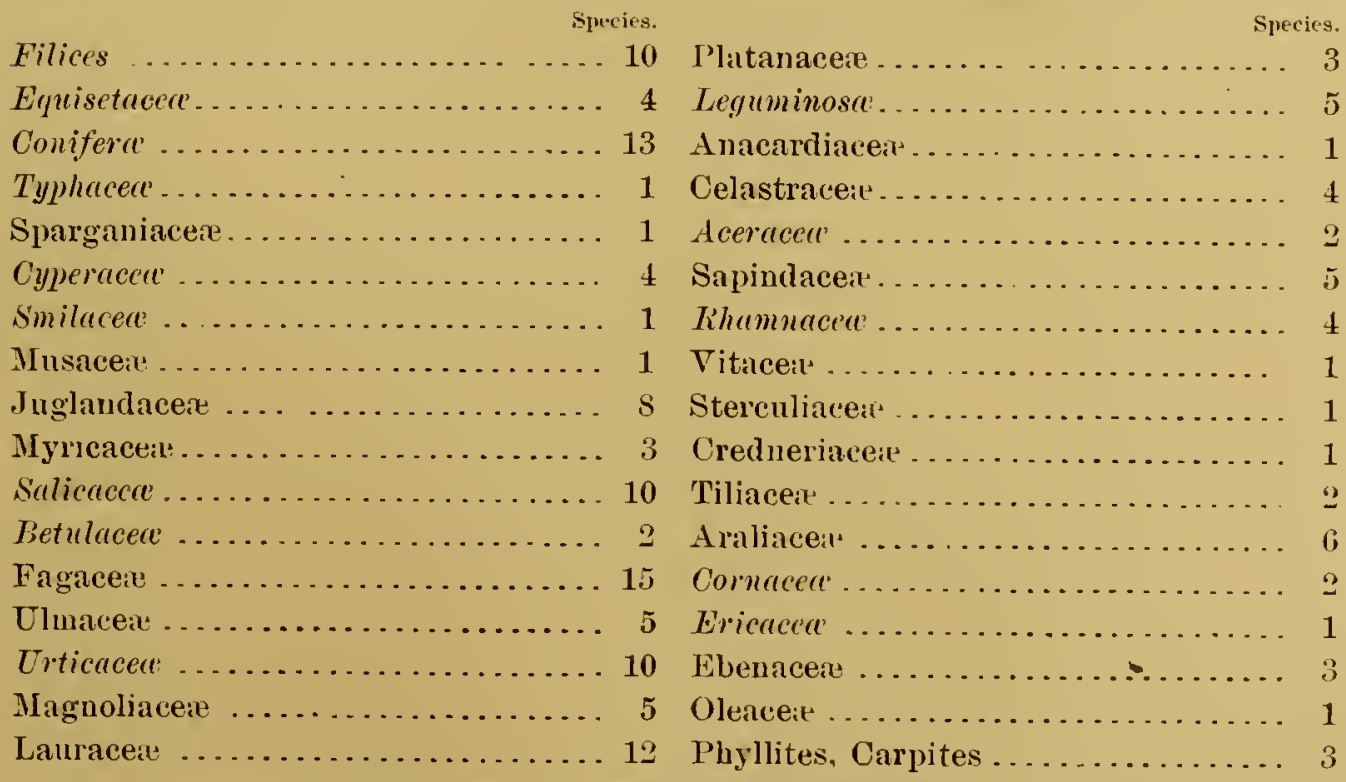

The urlers that are also found in the present flora are printed in italics. 
The excellent Flora of the Yellowstone National Park, ${ }^{1}$ by Mr. Frank Tweedr, has heen mate the basis of all comparisons between the fossil and living foras. According to Tweety, the present flora embraces 69 natural tamilies, 273 genera, and 657 species. The fossil fora embraces 33 families, 63 genera, and 148 species. The living flom las, therefore, $t$ genera to each order and 2.4 species to each genus, while the fossil flora has not quite 2 genera to each family and 2.3 species to each gentr. The relative imopition between the families, genera, and species is shown to be approximately the same in the Tertiary and the living floras. A still further comparison shows that there are a fraction more than twice as many living as forsil families, 4.3 times as many living genera, and 4.6 times as many species.

On comparing the families in the two floras, it is found that 19 of the 33 fosil families are not represented in the living flora. In the list of families above given the ones not italicized are the families not represented at the present time. It will be seen that such important families as the Juglandacer, Fagacere, Uluareer, Magnoliacere, Lauracer, Platanacere, Anacardiacere, Celastracer, Vitacere, Sterculiacer, Tiliacere, Araliacer, Ebenaces, and Oleaces are not represented in the present flora. In other worls, there are no wahnuts, beeches, oaks, chestnuts, elms, magnolias, sycamores, sumacs, grapes, lindens, aralias, persimmons, or aslies at the present day. The absence of such important trees and shrubs produces a profound modification of the flowal surromdings.

The dominant element in the living flora consists of the abmedant coniferous forests; yet only 8 species are represented, and of these only 5 are at all common, and 65 per cent of the whole coniferous growth is made up of 1 species. The fossil flora is represented by 13 species, or nearly twice as many as the living. Amoug them was a nuagnificent Sequoia that was closely allied to the living Sequoin sempervirens of the Pacitic coast. It lawl trums 10 feet in cliameter and probably of rast height. There were also 2 well-markerd species of Secpuoia, known from the leaves, and a number of supposed Sequoia cones. The pines were also abundant, no fewer than 8 species laving been detected.

The deciduons-leaved trees and shrubs of the Yellowstone National Park are conspicuously few in numbers. There are 2 species of Betula, 2 
of Alums, 7 of Salix, 2 of Populus, 1 of Aecr, 4 of Varecinimu, 5 of the

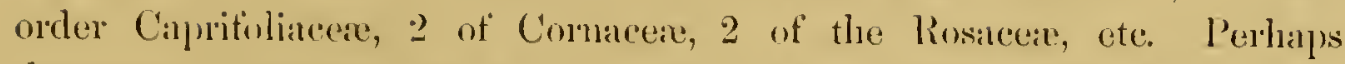
the most conspicuous tree is the quaking aspen (Populus tremuloides). The cottonrood (I'. angustifolia) is lene, heing found only alonge Cache Creek. Several of the willows are abumelant, as is also the common birel (Iirtula glumblotosu), and the . June berry (Amelunchior relnifoliu). 'l'he other shrubs are rare, or are confined to few localities.

The fossil flor:a, on the other hand, was especially rich in deciduous leaved regetation. Thus the Juglandacea was represented by 5 species of Juglans and 4 sjecies of Hicoria (Carya), a mumber of which were very abundant. The gemus Populus was especially rich, there being no fewer' than 7 species. Certain of these, as Populus speciosu, I'. duphnogenoides, and $P$.glunduliferu, were in great abundance, and the stratum in which they occur consists of a perfect mat of these leaves. Something like 100 examples of 1 species were obtained.

Another striking feature was the presence of numerous magnificent magnolias. Of these, + species have been described from the leaves and 1 from the thick petals of the flower. The species described as Magnolic spcctabilis is represented by a great number of leares in a fine state of preservation. It appears to be more closely related to the living $\boldsymbol{M}$. grandiftora (M. faticla of later authors) than any one previously described.

The sycamores were also an important element in this flora. Of the 2 species described from the leaves and 1 from the wood, the one known as I'lutams guillelme was especially abundant. It is found in nearly all the Tertiary beds in the Park and is represented in the collections by nearly 200 examples. The species described as Platanimim haydcni is based upon a trunk or branch 6 inches in diameter. It is most elosely related to the living Platamus occiclentalis.

Another important group is formed by 4 species of Aralia. Of these, Aratia notata ras evidently one of the most abundant and imposing trees of the whole flora. The collections contain over 100 examples, none of which are entire, however, as some of the leaves must have been fully 3 feet in length and more than 2 feet in width. A small leaf and one of medium size are fignued on the plates. Aratia whitneyi, a species common to the Auriferous gravels of California, lad striking 5 to 7 lobed leaves, often 1 foot in lengtl. This species was not so abundant, judging from 
the fossil remains, as the former species, but it was apparently quite widely distributed. The other species had smaller 3 or 5 lobed leaves.

The family Lauracea was strongly represented by 5 genera, 11 speeies, and a large number of examples. The gems Laurus, which is now exclusively an Old World groul, was represented by 6 well-marked speeies. The genera Malapoenna or Litsed and Cinnamommun, other Old World forms, were both represented, the former by 2 and the latter by 1 speeies. The genus Persea, an extensive Old World genus, with species also in tropical America and the southern United States, was represented by 1 species, which is elosely related to a small tree now living in the Sonth.

Another large and important gronp, now entirely unrepresented in the Park, is the Fagacer, embracing 2 species of Fagus, 1 of Castanea, 11 of Qnereus, and 1 of Dryophyllum. The Fagus here described is a beantiful, characteristic leaf and was evidently rare, as only a few examples were obtained. The Castanea, on the other hand, was very abmudant and widely distributed within the Park. The leaves are large, and as handsome and striking as are the leaves of the living species. The oaks, however, were abundant in species and nsually in individuals, and all but 3 proved to be new to science. Perlaps the most marked are Quercus yanceyi, Q. culveri, and Q. grossidentata.

The family Urticacese, which is represented in the living flora by a single rare herb (Urtica gracilis), was represented during Tertiary times by some 10 species of Ficus and a single more or less doubtfinl species of Artocarpus. Several of the figures are represented by a large number of specimens-as, for example, Ficus densifolia-but most of them were rare, at least as evidenced by the fossil remains. It is of great interest to learn, however, that they were once present in a region that has long since ceased to support them. The curious leaf referred provisionally to Artocarpus is also of much interest as indicating the possible presence of the bread-fruit trees in this portion of the Ameriean Continent. Two numistakable species of Artocarpus have already been detected, 1 from the Laranie and Denver beds of Colorado, and the other from the Auriferous gravels of California and the Miocene of Oregon. It is therefore not improbable that this type was in existence in the Yellowstone National Park during the early Tertiary.

The family Leguminose, now represented by a host of small herbaceous plauts, was then represented by 3 species of Acacia and 2 of Legu- 
minosites, but the fossil forms are not particularly satisfactory. 'The forms referred to Acacia consist of mell-defined porls and are somewlat conventionally regarded as representing the molern Acucia. No leaves were obtained that could with satisfaction be lield as representing the foliage of these pod-bearing sllubs or trees. The 2 species of Leguninosites are supposed to represent leaflets of some leguninous plant, but beyond this it is not possible to renture.

The only remaining grotu of deciduous-leaved plants of any magnitude is the Sapindacer, with 5 species of Sapindus. One of these, Sapindus affinis, is perhaps the most abundant form found among the Tertiary plants. The small characteristic leaflets are found in the greatest profusion. The other species were less abundant.

The other forms that require mention are: Ulmus, 4 species; Acer, at least 2 species; Celastrus, 3 species, and Rhammus, Paliums, Zizyphus, Cissus, Pterospermites, Tilia, and Rhus, with a single species each.

The vascular cryptogams appear to have been a more prominent feature of the flora during Tertiary times than at present. Of the 2 families present, the Filices and Equisetacex, the former is represented by 10 and the latter by 4 species, while the living flora has but 6 ferns and 4 horsetails, all rare.

The ferms were evidently abundant. They belong to 6 genera, and are represented in several cases by a large number of specimens. The largest genus is Asplenium, with 4 species. The species described as Asplenimm magnum is one of the largest and finest forms that has been detected outside of the Carboniferous. Asplenimm iddingsi is also a large, well-marked species. The genus Dryopteris, the old Aspidium, is represented by 2 species, both of which are rather rare. They are, however, both fruiting, a condition of uncommon occurrence among fossil forms. There is also a beautiful Woodwardia, quite closely allied to a species now living in the eastern United States, and fine examples of the widely distributed climbing fern (Lygodium laulfusii). The only living North American species ( $L$. palmatum) is found from Massachusetts and New York south to Kentucky and Florida, and is generally rare throughout its range. The other ferns are an Osmunda and a delicate form referred provisionally to the genus Devallia.

The genus Equisetum, althongh represented by 4 more or less satisfac- 
tory species, was not abundant or particularly important. The most abmdant form (E. haguri) is small and has much the appearance of the living $E$. limosmm. The largest form ( $E$. microrlontum) is very rare. It was about $3 \mathrm{~cm}$. in rliameter.

From what has been presented, it is obrious that the present flora of the Yellowstone National Park has comparatively little relation to the Tertiary flora, and can not be considered as the descendant of it. It is also clear that the climatic conditions must have greatly clanged. The Tertiary flora appears to have miginated to the south, while the present flora is evidently of more northern origin. The climate dming 'Tertiary time, as made out by the regetation, was a temperate or subtenperate one, not mulike that of Virginia at the present time, and the presence of the numerous species of Ficus would indicate that it even bordered on subtropical. The conditions, howerer, that permitted the growth of this seemingly subtropical regetation may have been different from the conditions now necessary for the growth of these plants. Thus, the genus Dicksonia is at present a tropical or subtropical nenus, yet at least 1 species is distributed well into the temperate region. If a series of beds should be discovered in which there were a lirge number of Dicksmias, it might be supposed to indicate tropical or subtropical conditions; yet, as a matter of fact, these species may at that time all have been so constituted as to grow in a temperate land, and the gemus as a whole may have become tropical in recent times. Following ont this general line of argment, it may be said that while the Tertiary regetation of the Yellowstone National Park would, from onr present stmdard, be regarded as indicnting a temperate or possibly warmer climate, the actual conditions then prevailing mar have been quite different. It is certain, however, that the conditions were very different from those now prevailing. 
FossIL Flolid.

Table shoring the distribution of the Tertiany plests of the Jellowstone Sational Darti.

\begin{tabular}{|c|c|c|c|c|c|c|c|c|c|c|c|c|c|c|c|c|c|}
\hline \multirow{4}{*}{ sperica. } & \multicolumn{12}{|c|}{ l bistrilsution in tlu. I'urk. } & \multicolumn{5}{|c|}{ Distribntion oulside. } \\
\hline & \multicolumn{5}{|c|}{ Fort I'nion (Eneche). } & \multicolumn{4}{|c|}{$\begin{array}{l}\text { Inte runediate } \\
\text { (Al iocenc). }\end{array}$} & \multicolumn{3}{|c|}{$\begin{array}{l}\text { Lamar Flora } \\
\text { (Al iocelic). }\end{array}$} & \multirow[b]{2}{*}{ 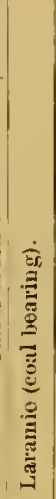 } & \multirow[b]{2}{*}{ 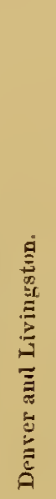 } & \multirow[b]{2}{*}{ 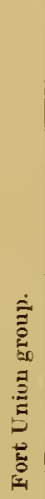 } & \multirow[b]{2}{*}{ 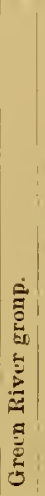 } & \\
\hline & 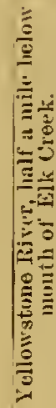 & 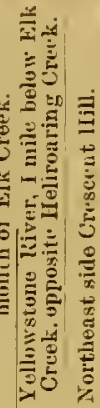 & 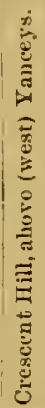 & 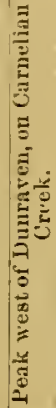 & 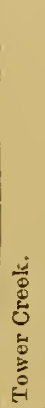 & 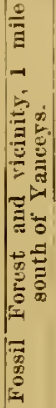 & 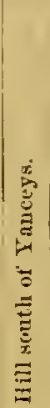 & 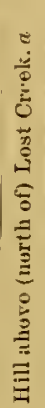 & 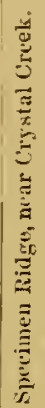 & 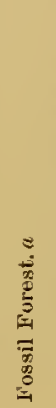 & 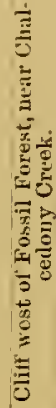 & 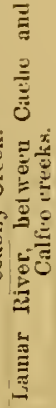 & & & & & 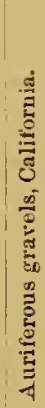 \\
\hline & 1. & 2. 3. & 4. & 5. & 6. & 7. & 8. & 9. & 10. & 11. & 12. & 13. & 14. & 15. & 16. & 17. & 18. \\
\hline
\end{tabular}

1. Wootwarlia preareulat it n. sp

2. Asplenitum iñdingsi u. sp

3. Asplenium magnur in. sp

4. Aspleninu cressum (Lx.)

5. Aspleniur remotideus $\mathrm{n}$. sp

6. Dryopteris wuedii $u$. sp

7. Drşopteris xantholitheusis n. sp

8. Derallia ? montana u. sp .

9. Lygodium kaulfusii Heer $b$

10. Usmunda affinis $\mathrm{Lx}$

11. Equisetum hagnei n. sp.

12. Equisetum lesınerenxi n. sp.

13. Equisetum canaliculatum n. sp

14. Equiset um deciduum n. sp

15. Pinus gracilistrobus $\mathrm{u} . \mathrm{sp}$

16. Pinus premurraj:ana

17. Pinus macrolepis n. s],

18. Pinus sp

19. Pinus wardii n. sp

20. Pinus iddingsi n. p

21. Taxites olriki Heer

22. Sequoia couttgix Heer

23. Seqnoia langsdorfi i (Brgt.) Heer.

24. Sequoia, rones of.

25. Ploradmites? latissima u. sp......

26. Sparganium stygium Heer

27. Cyperacites angustior $\mathrm{Al} . \mathrm{Br} . \imath$..

28. Cyperacites giganteus $\mathrm{n} . \mathrm{sp}$.

29. Cyperacites $\mathrm{sp}$

30. Crperacites sp

31. Smilax lamarensis n. sp

32. Jusophyllum complicatnm $L x$

33. Juglans califoruica $\mathbf{L x}$

34. Juglans rugosa $\mathrm{Lx}$

$a$ The numbers refer to the beds in whirh the plants were found.

$\checkmark$ Cherry Creek, Oregon.

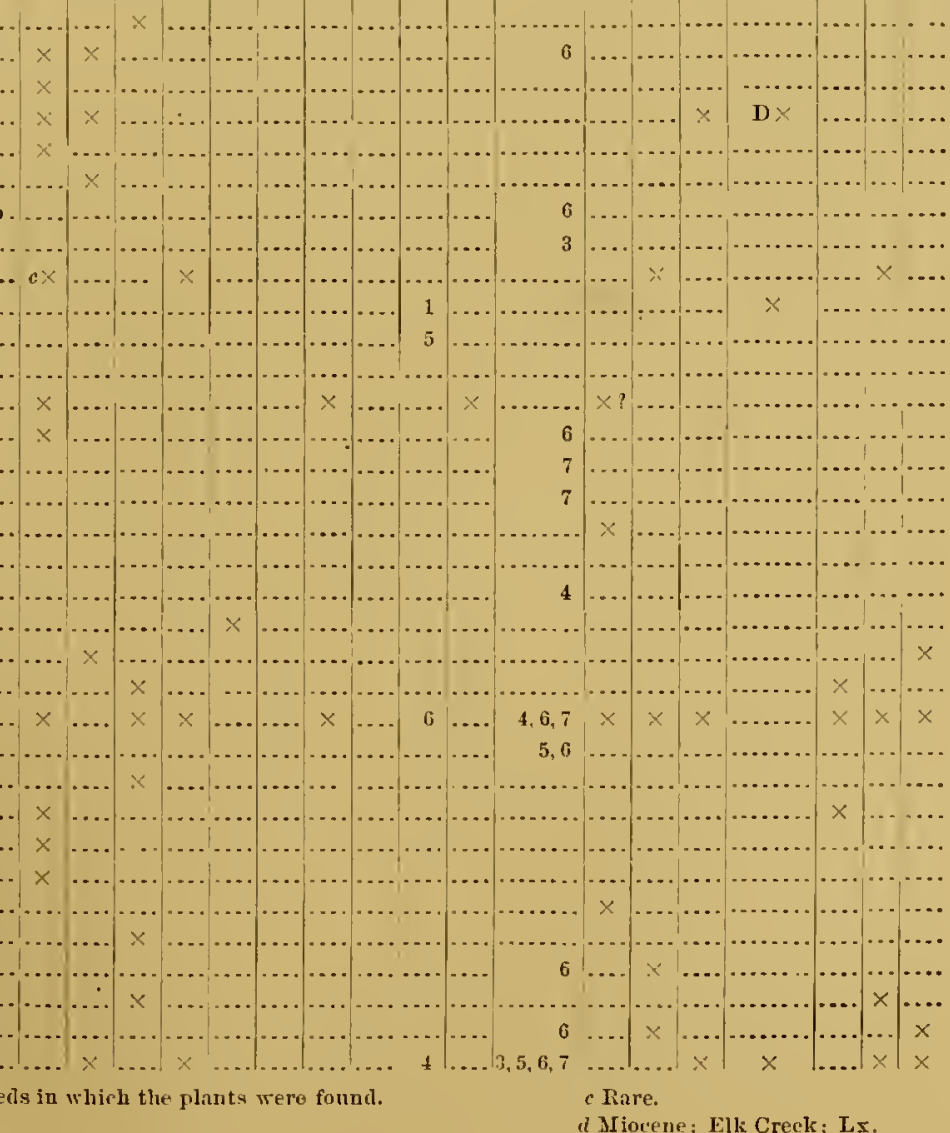


780 GEOLOGY OF THE YELLOWSTONE NATIONAL PARK.

Table showing the rlistribution of the Tertiary plants of the Fellowstone National Park-Continued.

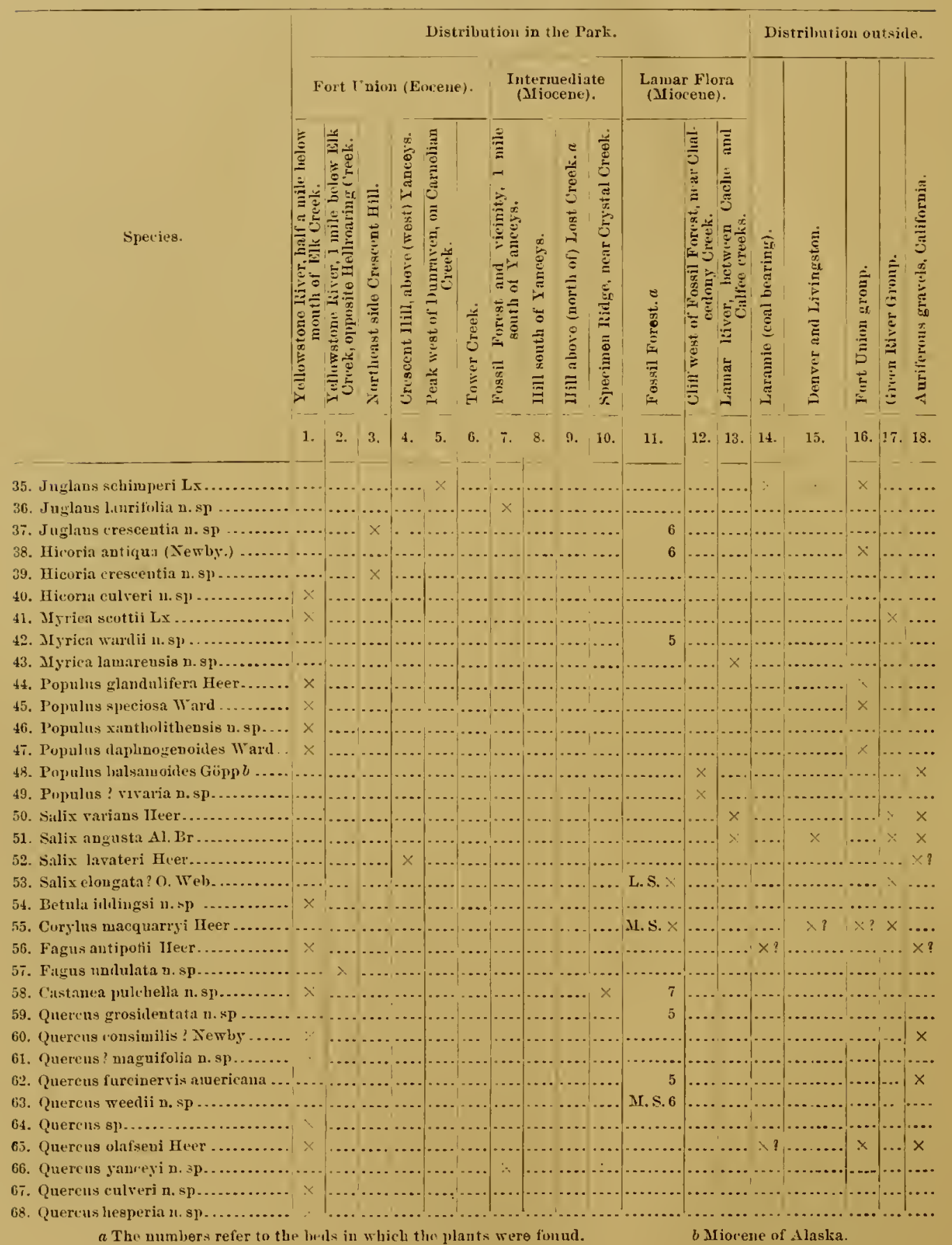


FOSSII, FLORA.

Table showing the distribution of the Terlinry plants of the Vellowstom Sutomal Park-Continnd.

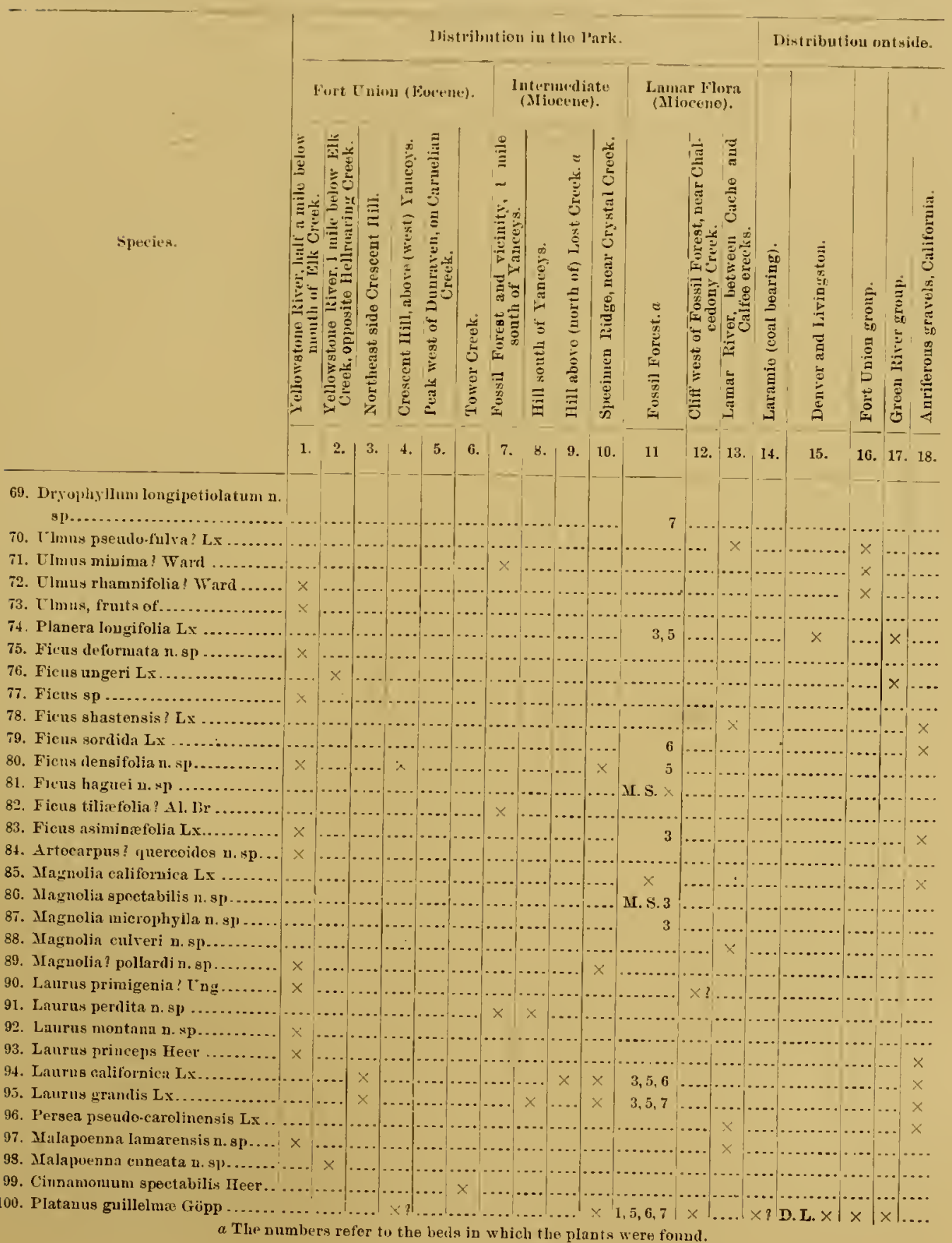


Table showing the distributim of the Tertiary plants of the Yellowstone Tational Park-Continued.

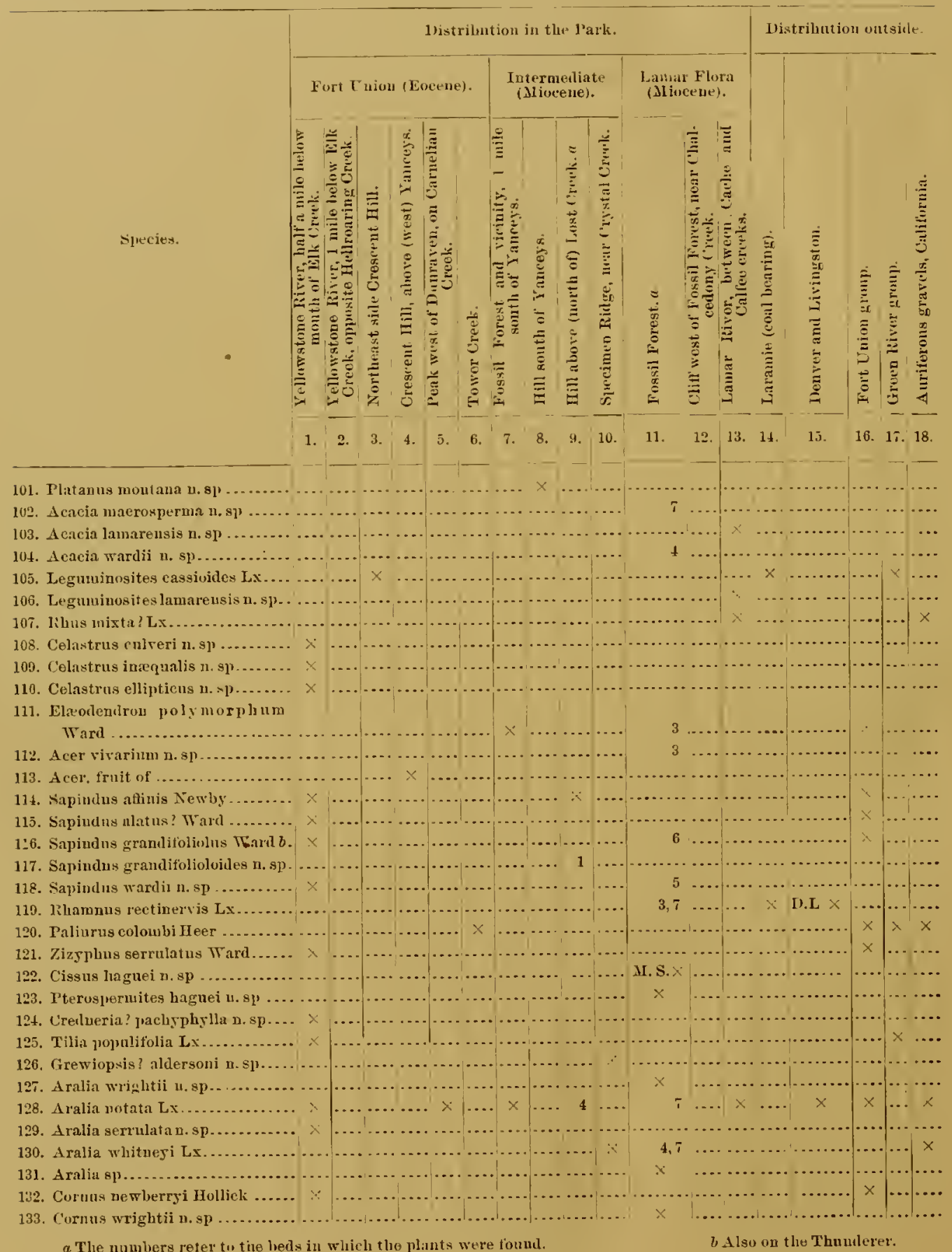


FOSSIL FLORA.

Table showing the distribution of the Tertiary plants of the Jellowstone National Parli-Continued.

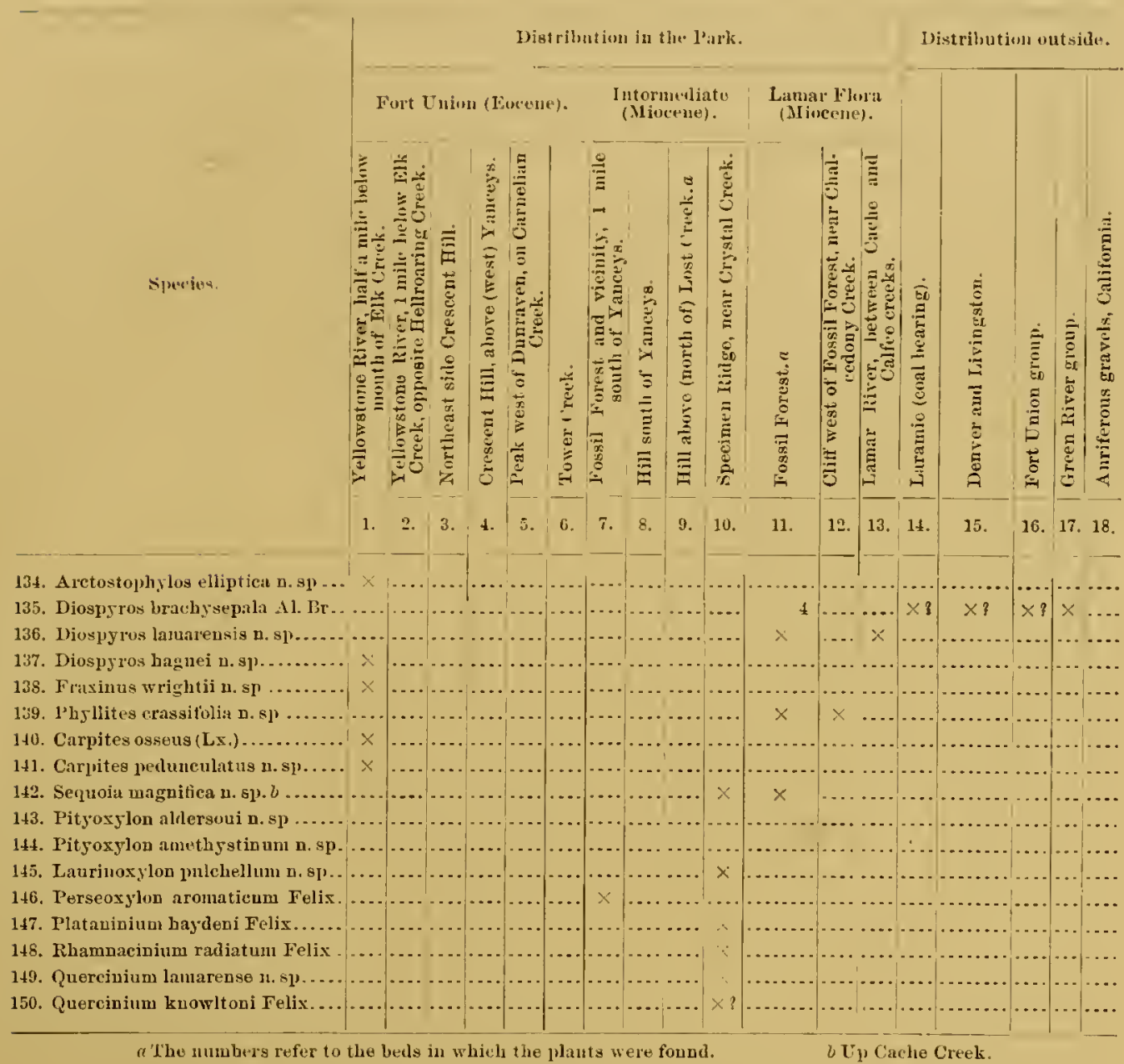

GEOLOGICAL CONSIDERATIUN OF' THE TERTLAR FLORA.

Naturally the geological aspects of this fossil flora are considered as of paramount importance, for it was to ascertain the bearing of the plants on the question of geological age that this investigation was undertaken. As I have already pointed out under the section devoted to the biological aspects of the flora (p. 775), a very large proportion of the plants were found to be new to science, and therefore could have only limited value in determining the age, but enough previonsly described forms were recognized to warrant certain deductions. It is the purpose to set these conelusions forth in this section. 
The first plants brought back from this portion of the Yellowstone National Park by the early Hayden survey parties were submitted to Prof. Leo Lesquereux, and althongh few in number the specimens and species were nevertheless sufficient to afford some indication of their age. Professor Lesquereux regarded the plints from Elk Creek and vicinity as indicating an Eocene age, and those from the well-known Fossil Forest on the west side of the Lamar Valley as closely allied to those of the Auriferous gravels of California. It is a pleasine to state that this adumbration has been abuntantly eonfirmed by the results of more searehing study of a larger amount of material, but at the time this was outlined the facts were so few that the suggestions were not regarded as conclusions, and as it was before any careful detailed geologieal work had been done, these now elearly defined horizons came to be grouped together under the somewhat noncommittal term Volcanic Tertiary.

Although the geology of the region has been fully discussed by Mr. Arnold Hagne in Part I of this monograph, it seems necessary, for the satisfactory understanding of the problems requiring solution, to set forth briefly the geological features characterizing this portion of the Park which have a direct hearing upon the remarkable flora found.

In the first place, all the material constituting the beds in which the Tertiary plants are embedded is of volcanic origin. According to the geologists, this material may be divided into two distinet periods of volcanic eruption, which may be distinguished by their mineral composition.

The older series of these lavas has been designated as the early acid breecias and flows, and the younger as the early basic breceias and flows. Both these series of rocks carry plant remains. In general the matrix in which the plants are preserved is a fine-grained ash, probably deposited as at mud flow, with all the appearance of stratification and other inclications of water-laid deposits. Oceasionally the material is much coarser and has the appearance of breccias mixed with fine sediments. The acid rocks are usually light in color-yellow, lavender, or gray-while the basic rocks, which earry more iron, are darker in color-frequently some slade of green or dark brown, passing over into black. In some instances, as might be expected with fine water-laid beds, the deposits in both series of lavas closely resemble one another, while the great mass of lava of the two bodies may be readily distinguished. The acid breceias, the oldest of the 
lava flows, rest in many places upon the upturned edges of Archean and Palenzoic rocks. In most instances the basic breccias eitlier rest directly upon the acid rocks or else the underlying rocks are not exposed. The acid hreceias are found on both banks of the Yellowstone River near the month of Elk Creek, and near the junction of the Yellowstome River iritl Hellroaring Creek, as well as on Crescent Hill and near the head of 'Tower' Creek.

In the neighborhood of Lost Creek, and on the northern end of Specimen Ridge, along the drainage of Crystal Creek, the basic breceias are known to lie directly upon the acid breccias. In these localities the flowa has a character distinctly its own, and bears evidence of being younger than the flora from the acid breccias. The basic series of rocks is typified at the Fossil Forest, and also at the cliff a short distance to the south and east of the Fossil Forest. They occur also on the east bank of Lamar River, between Cache and Calfee creeks. All of these localities are charaterized by their plant remains, and the following determinations of age are fully warranted.

The table of clistribution of 'Tertiary plants in the Yellowstone National Park has been prepared for the purpose of showing in a graphic mamer the distribution of the varions plants within the limits of the Park and the affinities of those having an outside clistribution. From this it appears that the 'lertiary flora consists of 150 more or less satisfactory species. Of this number, 81 species, or over 50 per cent, are here described for the first time. New species can not, of course, have the value in determining age that previnusly described forms have, but when their general facies as well as close affinities are taken into account, they also become of positive value. On eliminating the 81 new species, together with 8 forms not specifically named, there remain 61 species upon which we must depend in the determination of the ages of the various strata in which they are contained.

A further examination of the table brings out the fact that this flora may be naturally divided into 3 more or less distinct subfloras or stages. These three divisions are the older or acid series, the intermediate series, and the basic or younger series. The first division (acid) has a flora of 79 species; the second (intermediate) a flora of 30 species, and the third (basic) a flora of 70 species. It further appears that 23 species or forms are common to two or more of the divisions.

MON XXXII, PT $11-50$ 
The flora of the older or acid series will be first considered. Of the 79 species, 42 are either new to science or not specifically named, leaving 37 species having a distribution beyond the limits of the Park. Following is a list of these species:

Asplenium erosum (Lx.). Lygodium kanlfusii (Heer).

Tuxites olriki Heer.

Sequoia conttsi: Heer.

Sequoia langsdorfii (Brgt.) Heer.

Spargauium stygium Heer.

Cyperacites angustior $\mathrm{Nl}$. Bl.

Musophyllum complicatum $\mathrm{Lx}$.

Juglans rugosa Lx.

Juglans schimperi Lx.

Myrica scottii Lx.

Populus glaniulifera Heer.

Populus speciosa Ward.

l'opulus daphnogenoides Wiard.

Salix lavateri Heel.

Fagus autipofi Heer.

Quercus consimilis Newby.

Quercus olafseni Heer.

\author{
Ulmus rhamnifolia Ward. \\ Ficus ungeri $\mathrm{Lx}$. \\ Ficus asiminæfolia $L x$. \\ Laurus primigenia ? Ung. \\ Laurus princeps Lx. \\ Laurus californica Lx. \\ Laurus grandis Lx. \\ Ciunamonum spectabilis Heer. \\ Platauıs guillelma Göpp. \\ Legnminosites cassioides Lx. \\ Sapindus affinis Lx. \\ Sapintus alatus Ward. \\ Sapindus grandifolius Ward. \\ l'aliurns colombi Heer. \\ Zizypluns serrulatus Ward. \\ Tilia populifolia Lx. \\ Aralia notata $\mathrm{Lx}$. \\ Cornns newberryi Hollick.
}

These 37 species have the following distribution: Five are found in the coal-bearing Laramie, 5 in the Denver and Livingston, 17 , or nearly 50 per cent, in the Fort Union, 9 in the Green River group, and 11 in the Auriferous gravels of California. Of the species common to the acid rocks and the Laramie at Denver and Livingston beds, not one is found exclusively in these beds, but they are such species as Sequoia langsdorfii, Juglans rugosa, Platamus guillelme, and Juglans schimperi, which enjoy a wide geological and geographical distribution.

The Fort Union element in this flora is a very important one; in fact, it may be called the dominant element. It includes at least 12 species that have never before been found outside of the type locality. Among these are Sparganium stygium, Populus speciosa, Populus daphrogenoides, Ulmus minimu, Ulmus rhamnifolia, Sapindus affinis, Sapindus grandifoliolus, and Cormus newberryi. Some of these are represented by as many as 200 individuals, showing that they existed in great abundance, as they are also known to have existed at the mouth of the Yellowstone. This abundance 
also makes their determination certain. Several other species, having a wider distribntion, are very abmondant in these beds, such as Aralia notata, which is represented by more than 100 specimens, and Sequoic lanystorfii, which has a wide distribution, but is most abundant in this country in the Fort Union beds. Sequoia couttsice, having a somewhat wide range, is also very abundant in the beds under consideration and the Fort Union. Besides these are a number of species that can not be mistaken, as Zizyphus scrulatus, Taxites olrili, etc.

One species, Asplenium crosum, has been fonnd in both Laramie and Denver strata in Colorado. It is represented by only 2 or 3 small and more or less dubbtful examples from the Yellowstone below Elk Creek. Jugluns rugosa is a species of wide distribution and therefore of comparatively little value stratigraphically. It is found from the Laramie to the Hiocene, but is rare in the acid beds within the Park. Quercus olafseni has been found in the Laramie, but its determination in the Park depends on a single doubtful fragment from the vicinity of Elk Creek.

The species that have also been found in the Green River beds are comparatively unimportant. Lyyodium kunlfusii is, in this country, a typical Green River species. It is rare in the acid series, but abundant in the basic series along the Lamar River. Musophyllum complicatum has never before been reported outside of the Green River beds. Ficus unyeri and Tilia populifolia are typical Green River plants, but are represented here by one or two examples each.

The species found in the Auriferons gravels are the only ones remaining to be considered. Of the 11 species, Juglans ruyosa, Quercus Ireweri, Salix lavateri, and Quercus olafseni are open to doubt, as they are represented by only one or two fragments each. Ficus asiminicefolin likewise depends upon a single leaf, but it is a well-preserved one, and the determination is probably correct. Aralia notata, another of the species, is very rare, if really found at all, in the Auriferous gravels. The three remaining species are relatively abundant, and there is little question as to the correctness of their determination.

The species whose distribution lies beyond the limits of the Park having been passed in review, it will be of interest to note the obvious affinities of certain of the more important new forms. Thus, Asplenium remotidens is closely related to $A$. erosum, and Dryopteris weedii and D. xuntho- 
lithensis to Lastrea goldiamum, both of which are abundant in the Denver berls of Colorado. Juglans crescentia is related to J. nigella, as identified by Professor Ward in the Fort Union group. The beantiful new Populus xantholithensis is very elose to P. genatrix of Newberry, from the Fort Union group. Betula illdingsi is obviously related to B. prisca; Quercus yenceyi to Q. laurifolia; Platanus montana to P. raynoldsii; Celastrus culveri to C. ovatus and C.curvinervis; and Sapindus grandifolioloides to S. grandifoliolus, all of the Fort Union group.

From this evidence it appears that the flora of the early acid breccias in the Yellowstone National Park finds its closest affinity with the flora of the Fort Union group, and it is unhesitatingly referred to that age. The relation of this flora to that of the Laramie is unimportant, being confined to less than half a dozen species. Its relationship to the Denver and Green River floras is naturally closer, but it forms only a small element of these, as also with the flora of the Auriferous gravels of California. The relation, as based on total number of species, is unimportant, but in the upper beds it begins to show a transition.

It will be next in order to consider the intermediate flora. As already stated, this embraces 30 species, of which number 16 are confined to these beds and 14 are distributed outside, either in the acid or basic series or beyond the limits of the Park. A further analysis brings ont the fact that of the 16 species peculiar to these beds 13 are regarded as being new to science, and of the 14 species found beyond the limits of these beds 5 are new to science. This makes a total of 18 species that are regarded as new, leaving 12 species having a distribution without the Park. Following is a complete list of these 12 species:

Osmunda affinis Lx.

Sequoia langsdorfii (Brgt.) Heer.

Juglaus rugosa $L x$.

Ulmus minima Ward.

Ficus tilizefolia Al. Br.

Laurus califoruica $\mathrm{Lx}$.

\author{
Lanrus grandis $\mathbf{L x}$. \\ Platauus guillelmæ Göpp. \\ Elæodeulron polymorphum Ward. \\ Sapindus affinis $L x$. \\ Aralia notata $\mathbf{L x}$. \\ Aralial whitneyi Lx.
}

Four of the species above enumerated (Sequoia langslorfi, Juglans rugosa, Platanus guillelme, and Aralia notata) have a wide distribution, being found from the Laramie to the Upper Miocene, and are therefore of comparatively little value. One of the remaining (Osmunda affinis) is found in 
the Denver beds; 3 are confined to the Fort Union, and 6 species are found in the Auriferons gravels of California.

Of the 5 new species found in other beds, 2 are common to the older or acid series and 3 to the younger or basic series. It therefore becomes apparent that this flora, although reasonably distinct, finds its greatest affinity witl the younger or basic series. This is slown by the species common to the intermediate series and the Auriferous gravels and by the new species common to the basic series. This is not especially pronounced, and conld hardly be made out for the intermediate Hora as a whole, were it not for certain species that come from rocks that are directly succeeded by the basic rocks. For these reasons it was at first supposed that a part of the localities represented belonged to the lower and a part to the upper beds, but by combining several of these this intemediate flora was worked out. But, as stated above, the rocks of this series that are known to be the lowest bear a flora nearest to that of the acid rocks, and the rocks known to be higher hold plants most nearly related to those of the upper or younger beds.

It now remains to consider the flora of the basic breccias and its relationships. The typical locality for this flora is the Fossil Forest and vicinity, including the locality on the east side of the Lamar River, between Cache and Calfee creeks. This flora, as a whole, embraces 70 species or forms, distributed as follows: 38 species new to science, 3 forms not specifically named, and 29 species having a distribution beyond the limits of the Park. Following is a list of the species laving an outside distribution:

Lygodium kaulfusii Heer.

Sequoia langsdorfii (Brgt.) Heer.

Juglans culifornica $\mathrm{Lx}$.

Juglans l'ugosa Lx.

Hicoria antiqua (Newby.) Ku.

Populns balsamoides Göpp.

Salix varians Heer.

Salix augusta Al. Br.

Salix elongata Heer.

Corylus macquarryi (Forbes) Heer.

Quercus furcinervis americana Ku.

Ulmus pseudo-fulva Lx.

Planera longifolia Lx.

Ficus shastensis? Lx.
Ficus sordida Lx.

Ficus asiminafolia $\mathrm{Lx}$.

Magnolia californica Lx.

Lanrus californica Lx.

Laurus primigenia? Ung.

Laurus granclis Lx.

Persea psendo-curolinensis Lx. :

Platanns guillelma Göpp.

RLus mixta Lx.

Elreodendron polymorphum Ward.

Sapindus gramdifolius Ward.

Rhamuıs rectinervis $\mathrm{Lx}$.

Aralia notata $L x$.

Aralia whitneyi Lx. 
Of these 29 species, only 4 have been found in the true Laramie. These ąre Juglans rugosa, Hlatanus guillelma, Rhamnus rectinervis, and Diospyros brachysepala, the last open to doubt. All of these species have a wide vertical range and are consequently of little value in indicating age. The affinities of this flora with that of the Laramie may therefore be regarded as unimportant.

The relationship of this flora with the Fort Union, Denver, and Green River groups is also relatively unimportant. There are 7 species found in each of these groups, but none are confined to the Denver, and only 1 to the Green River, and 3 to the Fort Union. The rest are of wide geographical and geological distribution.

The relationship of the flora of the basic rocks is clearly with that of the Auriferons gravels of California, for no fewer than 17 of the 29 species are common to the two localities, and 12 of the species are exclusively confined to them. These are such important species as Aralia whitneyi, Persea pseudo-carolinensis, Laums californica, Laurus grandis, Magnolia californica, Ficus sordida, Juglans californich, Rhus mixta, etc. Most of these are present in numbers in the Park flora, and there can therefore be no question as to the correctness of their identification.

Besides the species above enmmerated that have actually been found common to the two localities, the numerons new species are in many cases mmistakably related to species known only from the Auriferous gravels. Thus, Mugnolia culveri is close to M. californica, and Magnolia spectabilis is so close to $M$. lanceolata that Lesquereux so identified it. Other examples might be given, but they are nunecessary. The preponderance of evidence points to the similarity of age between the flora of the basic series and that of the Auriferous gravels of California. The fixing of the exact age of the Auriferous gravels is not a difficult matter. They were at first supposed to be Lower Pliocene in age, but the latest evidence, derived from a more or less complete restudy of the abundant flora, together with a thorough investigation of the stratigraphy, makes it reasonably certain that it is really Upper Miocene. This is the view taken in the present instance, and this flora in the Yellowstone National Park is referred to the Upper Miocene:

Asplenium iddingsii $\mathrm{n}$. sp.

Lygodium kanlfusii.

Equisetum canalienlatum n. sp.
Magnolia? pollardi $\mathrm{u}$. sp.

Laurus primigenia? Ung.

Laurus californica Lx. 
Eq̨uisetum deciduum 1 . s]).

Sequoia laugsdorfii (Brgt.) Heer.

Juglans rugosa $\mathbf{L x}$.

Juglaus crescentia n. sp.

Casianea pulchella n. sp).

Ficus densifolia u. sp.

Ficus asiminafolia Lx.
Laurus grandis Lx.

Litsea lamarensis n. sp.

Platanus guillelma Göpp.

Elreodendron polymorphum Ward.

Sapindus grandifoliolus Ward.

Sapindus wardii n. sp.

A ralia notata $\mathrm{Lx}$.

Some of these species, as Lygodium kanlfusii, Castamea pulchella, Laurus grandis, Platanus guillelme, Sapindus grandifoliolus, and Aralia notata, are inportant well-1marked species that have weight in showing the close relationships between the floras of the two series; but, on the other hand, the perfect distinctness of the beds is shown by the fact that there are some 40 species that are confined to tach horizon. It will not, therefore, be difficult in future to determine the horizons of the various plant-bearing beds within the Yellowstone National Park.

In order to show low remarkably distinct these three floras are, it will be necessary only to consider the species in common between them. As already stated, only 23 forms out of the total of 147 forms are common to two or more of the series of beds. It will not be necessary to present a complete list of these species in common. The numerical results show that 8 forms only are common to the three beds, 2 to the acid and intermediate, and 3 to the intermediate and basic, and, finally, that 10 are common to the acid and basic. When these facts are presented in connection with the total flora of each series, the differences become even more marked. Thus, the lower or acid series, with a flora of 79 species, has only 20 species common to the others. Of these, 8 are common to all three beds, 2 to it and the intermediate beds, and 10 to it and the upper or basic beds. The intermediate beds, with a flora of 30 species, have 13 species in common with the others. Of these, 8 , as above stated, are common to all three, 2 to intermediate and acid, and 3 to intermediate and basic. The basic or younger beds, with a flora of 70 species, have 20 species common to the others. Of these, it is hardly necessary to repeat, 8 are common to all three, 3 to it and intermediate, and 10 to it and acid. These 3 floras are, therefore, shown to be markedly distinct, and it will not be difficult to distinguish them in future. 

PLATE LXXVII. 


\section{PLATE L X X VII.}

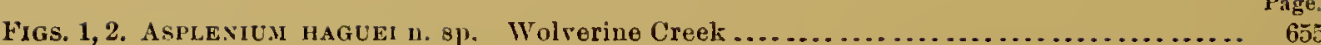

3, 4. Trapa? Micropitylla Lx. Wolverine Creek.......................... 661

5. Sfquola Laxgsnorfil? (Brgt.) Heer. Wolverine Creek ................... 657

6. Quercus vllisiana Lx. Nount Everts .............................. 659

7-9. Paliurus minimus u. sp. Wolverine Creek ............................ 659

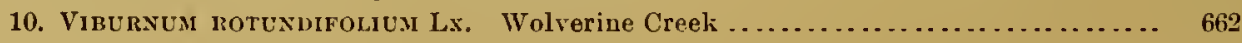

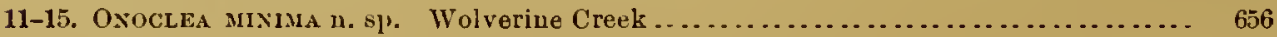

794 


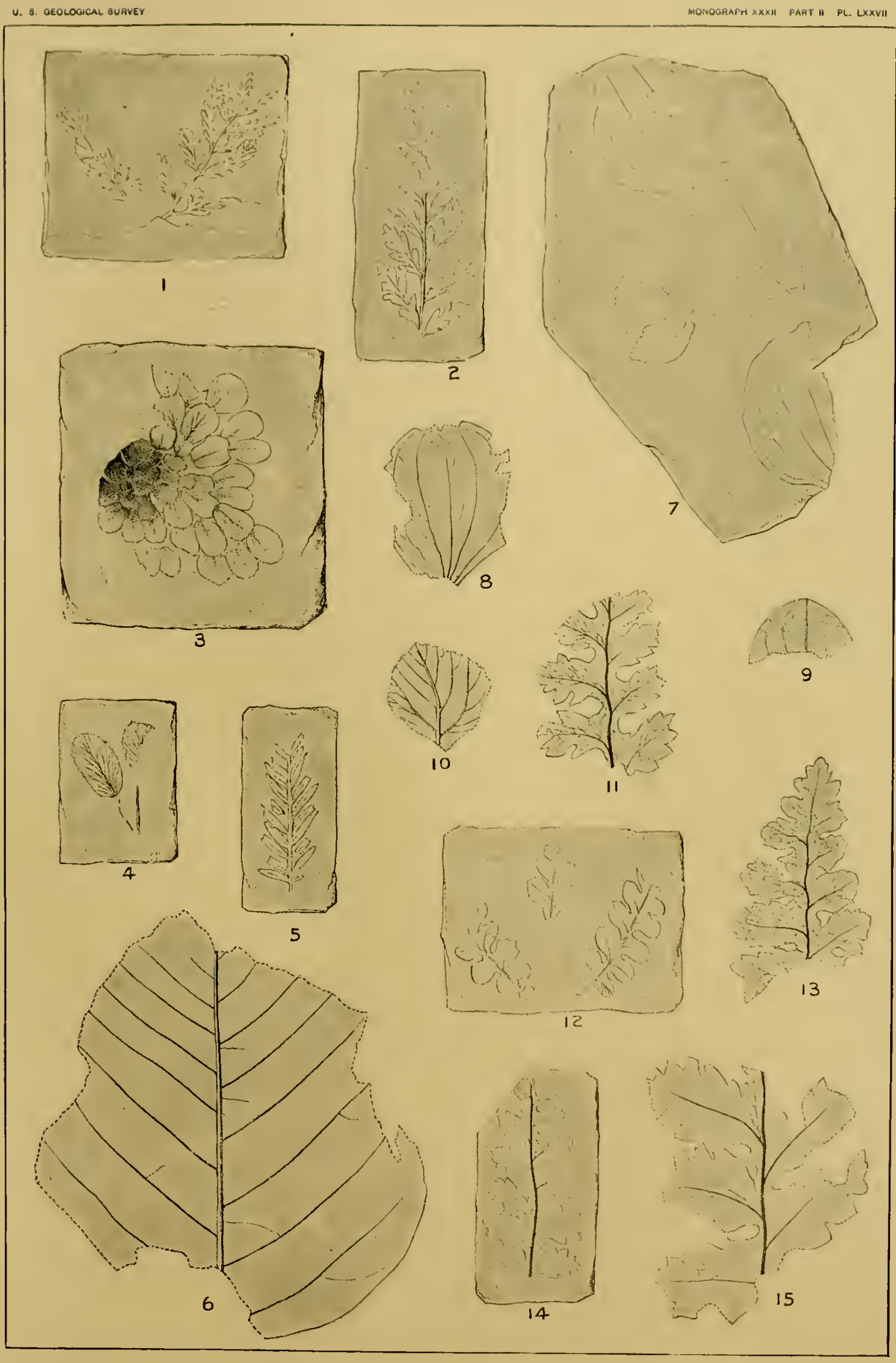

LARAMIE FORMATION. 



\section{PLATE LXXVIII.}




\section{PLA T E L X X VIII.}

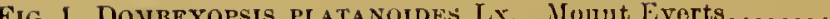

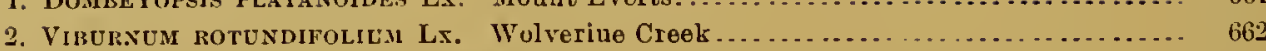

3. Paliurus zizyplionesi Lx. Wolverine Creek......................... 660

4. MYrica bolanderi? Lx. Mount Everts ................................ 658

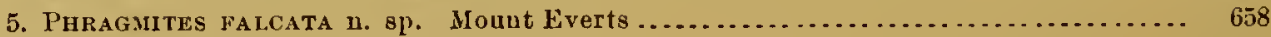

6. Fraxinus denticulata Lx. Mount Everts .............................. 662

7. Phyllites sp. Mount Everts ...................................... 662

8, 9. Viburvum kotundifolium Lx. Wolverine Creek....................... 662 


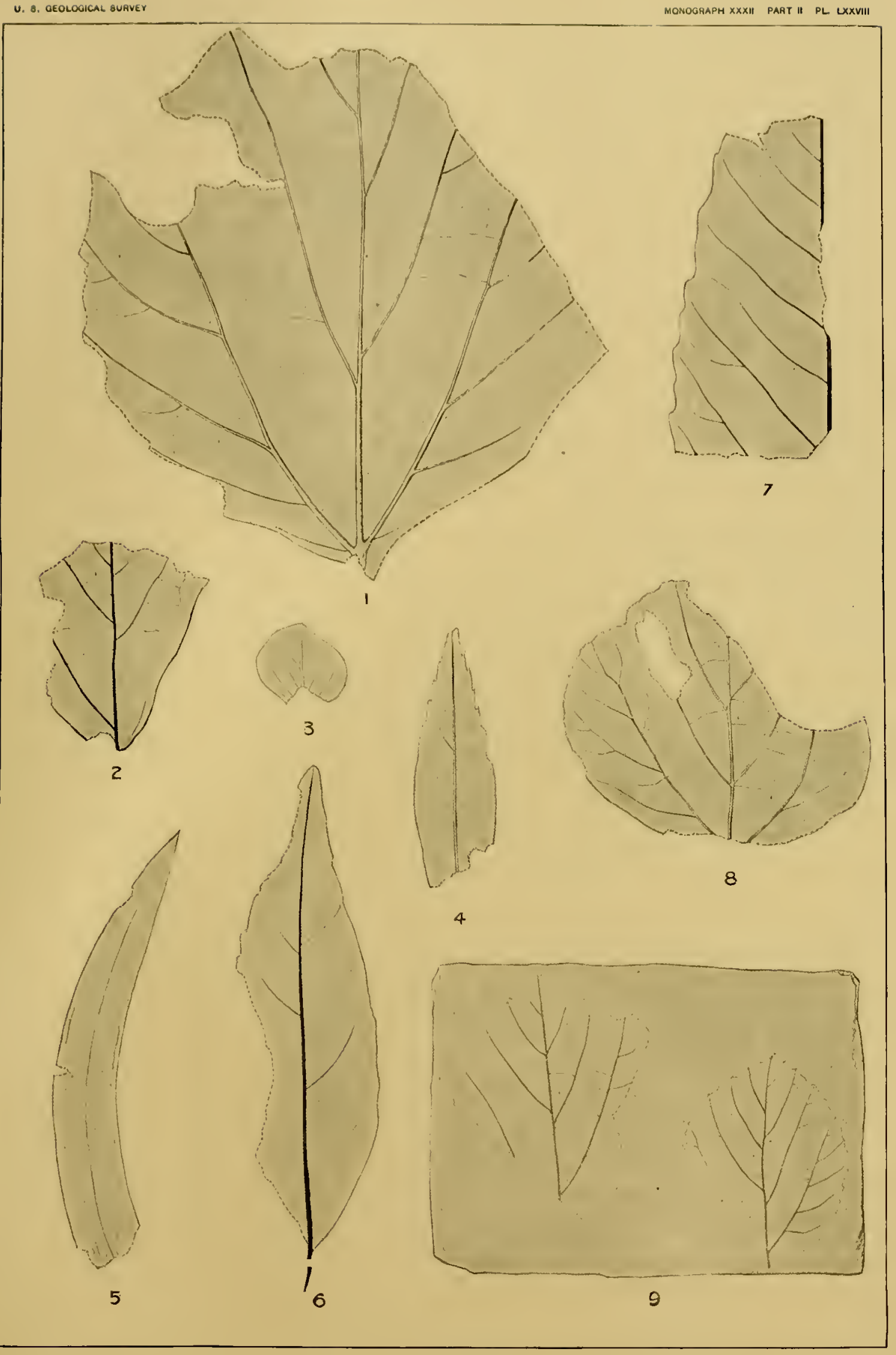

LARAMIE FORMATION. 

PLATE LXXIX. 


\section{PLATE LXXIX}

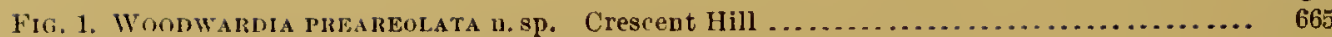

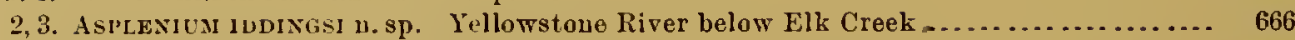

4. Devalla ? moxtana n. sp. Fossil Forest................................ 671

5-8. Asplenica magum n. sp. lellowstome River below Elk Creek ................. 667

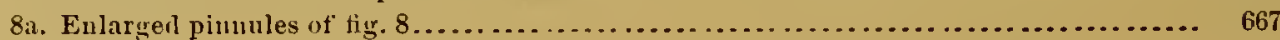

798 


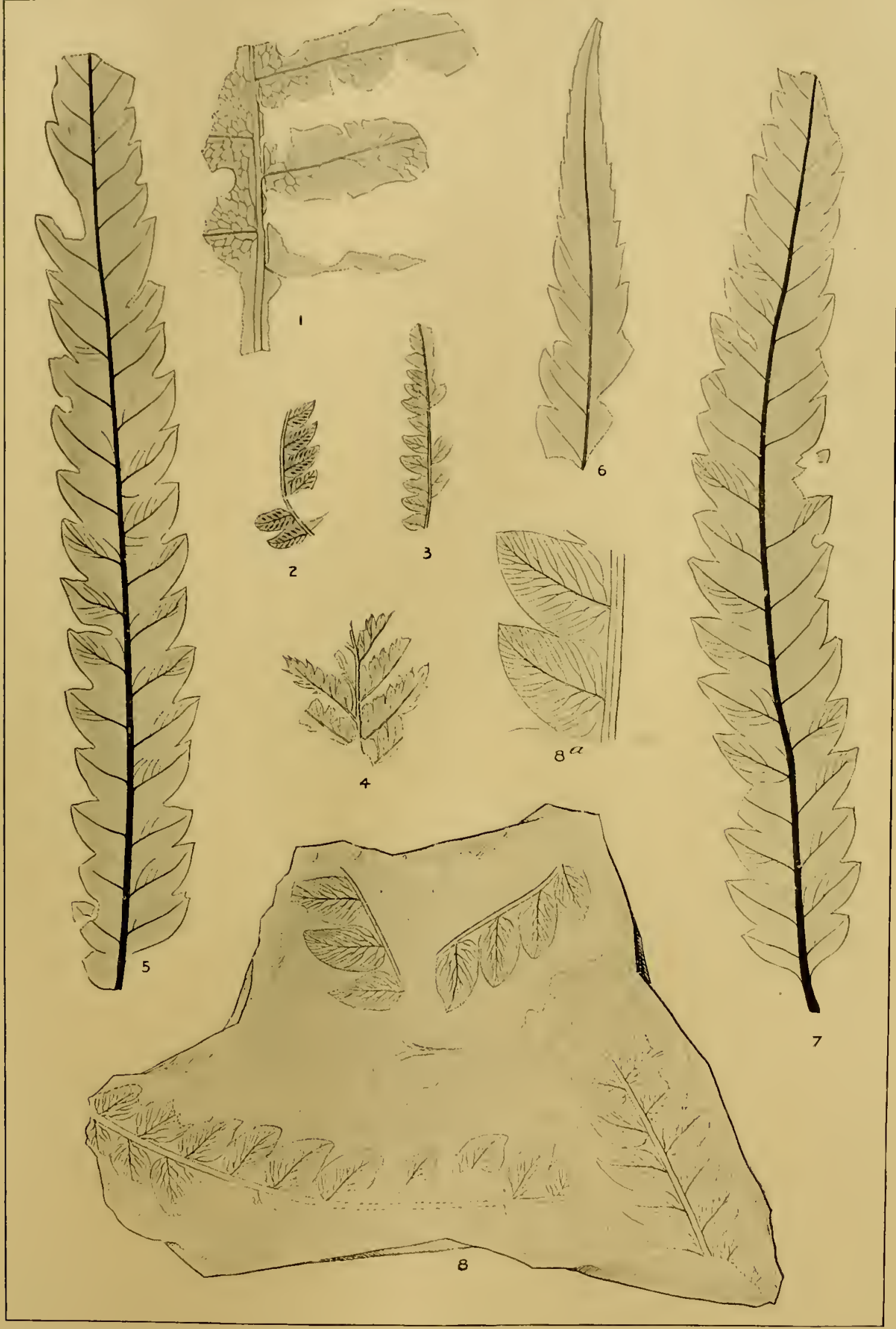

TERTIARY. 



\section{PLATE LXXX.}




\section{PLATE LXXX.}

Figs. 1, 2. Lyodich kathlisil Heer. lamal River ...... Page.

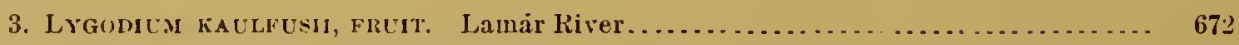

4,5. Osuunid Afrivis Lx. Hill above Lost Creek......................... 673

6. Asplenium erosum? (Lx.) Kn. Yellowstone River below Elk Creek ............ 668

7. Asplesium iemotidess n. sp. Yellowstone River helow Elk Creek ............ 669

8. Dnyoptriks weeni n, sp. Yellowstone River below Elk Creek ................ 669

9, 10. Asplexitu IDdingsi n. s]. Yellowstone River below Elk Creek............... 666

11. Pinus macroleis n. sp. Fossil Forest.............................. 679

12. Pinus gracilistrobus n. sp. Fossil Forest......................... 676 


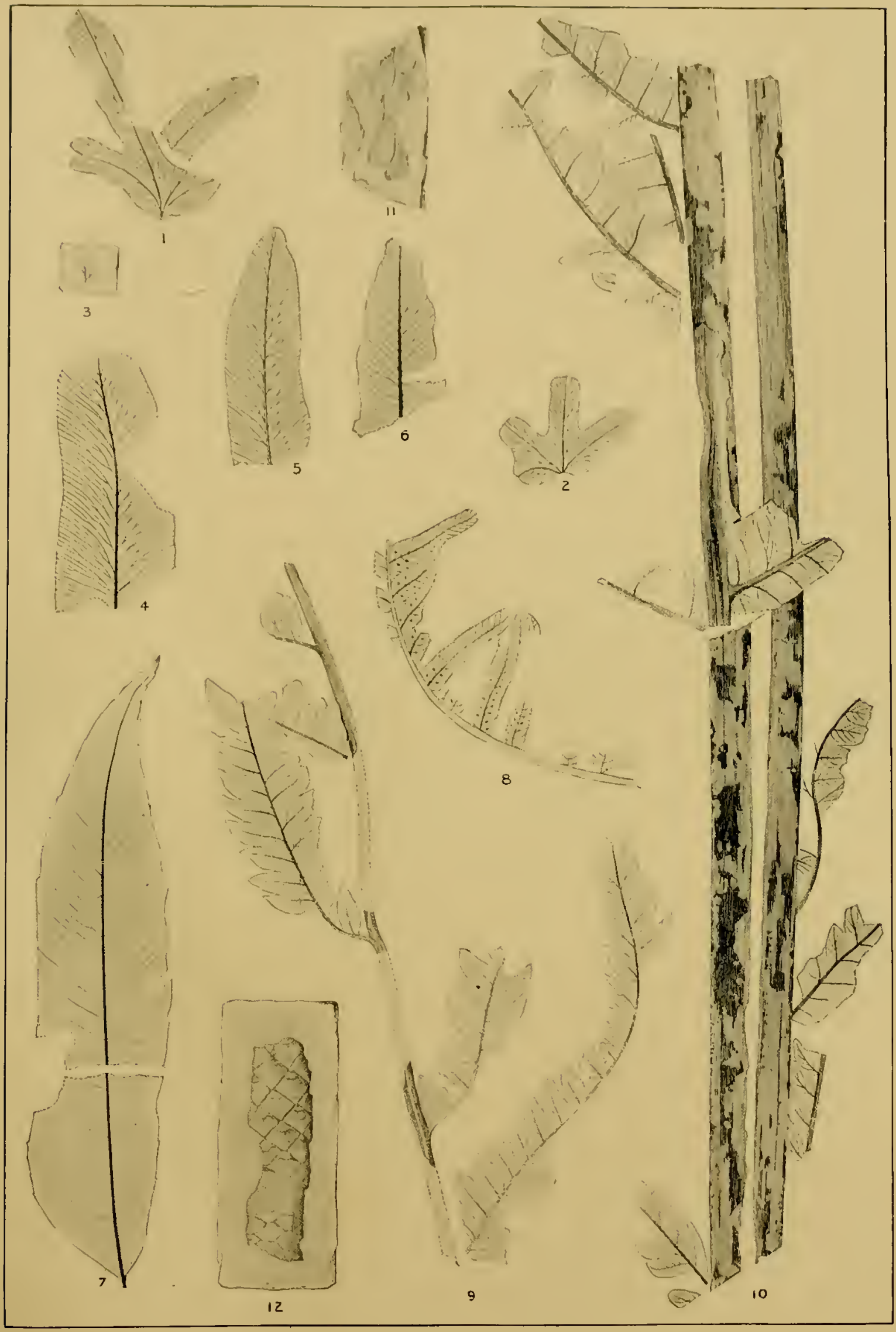





\section{PLATE LXXXI.}




\section{PLA TE LX X X I.}

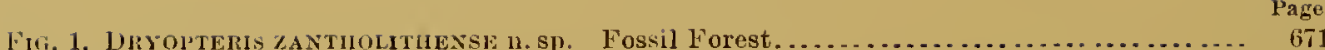

2. DRYOPTERIS WEeni n. sp. Yellowstone River helow Elk Creek................. 669

3, 4. Eqcisetum иagisi 11. sp. Ilill above Lost Creek .......................... 674

5. Equisetca deciduci n. sp. Yellewstono liver below Elk Creek............... 676

6. Equisetua caxaliculatum n. sp. Yancegs Fonsil Forest..................... 675

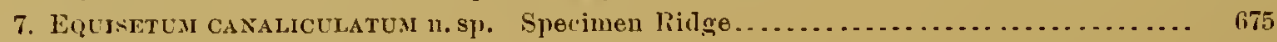

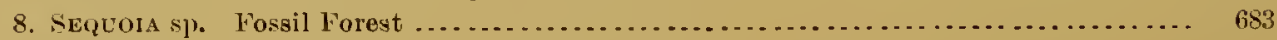

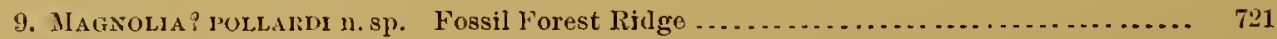

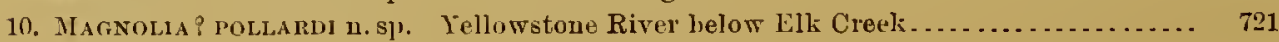




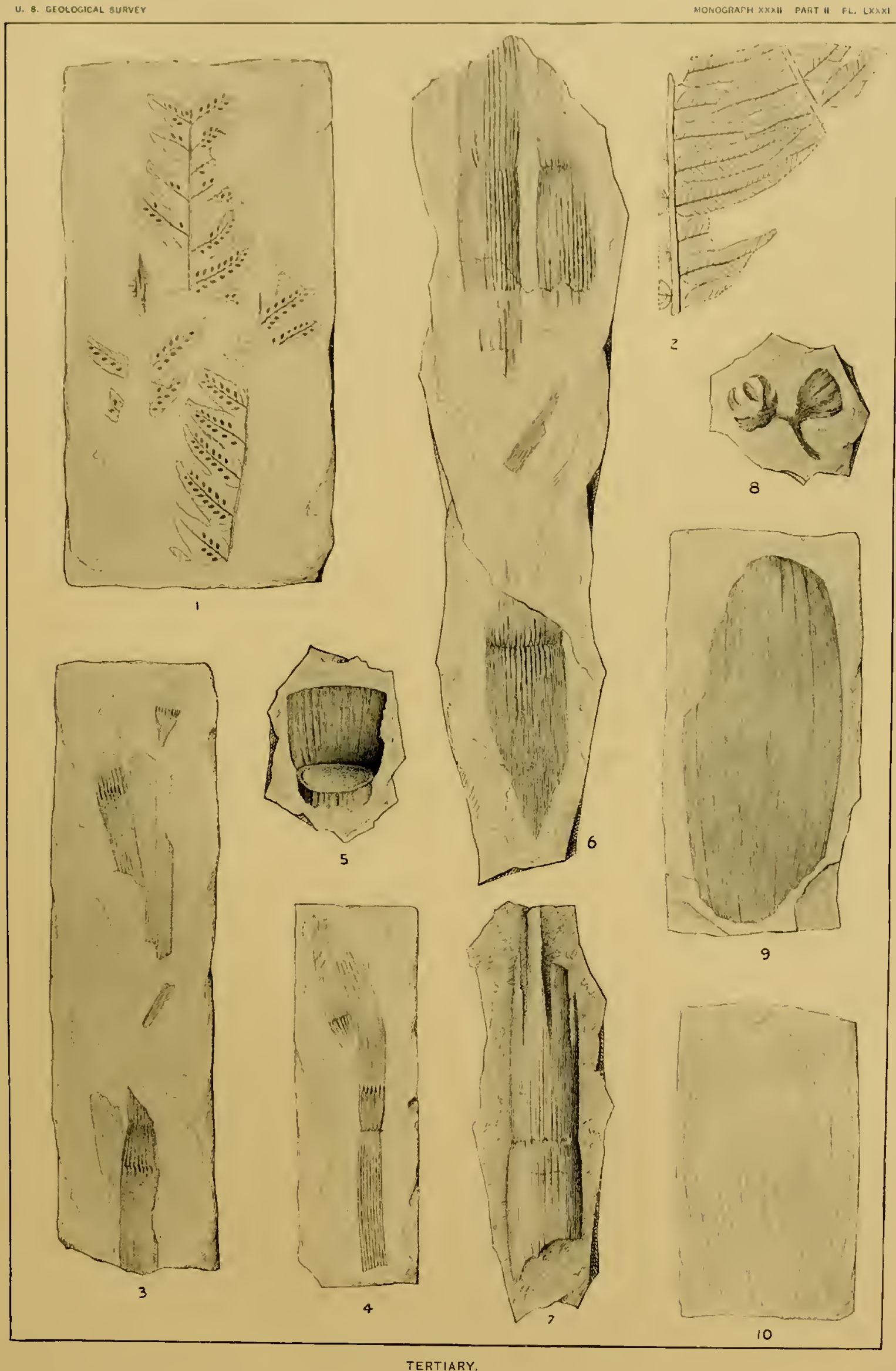





\section{PLATE LXXXII.}




\section{PLA T E L X X Y I I}

Fin. 1. Taxites olkni Heer ......

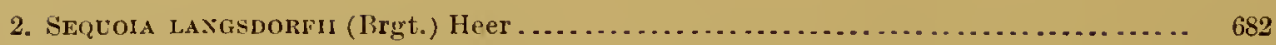

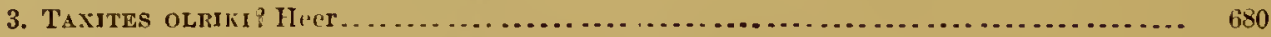

4. Taxites olriki Heer. Yellowstone liver below Elk Creck ..................... 680

5. Pinus Prenurerayara 11. sp. East of Yellowstone Lake ..................... 677

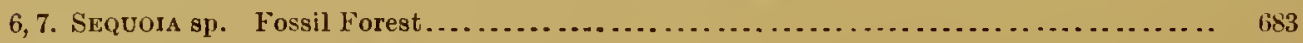

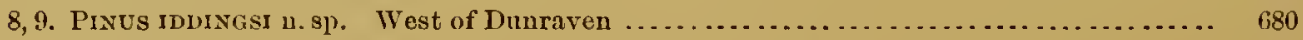

10. Cyperacites gigantius n. sp. Yellowstone River below Elk Creek.............. 684 804 


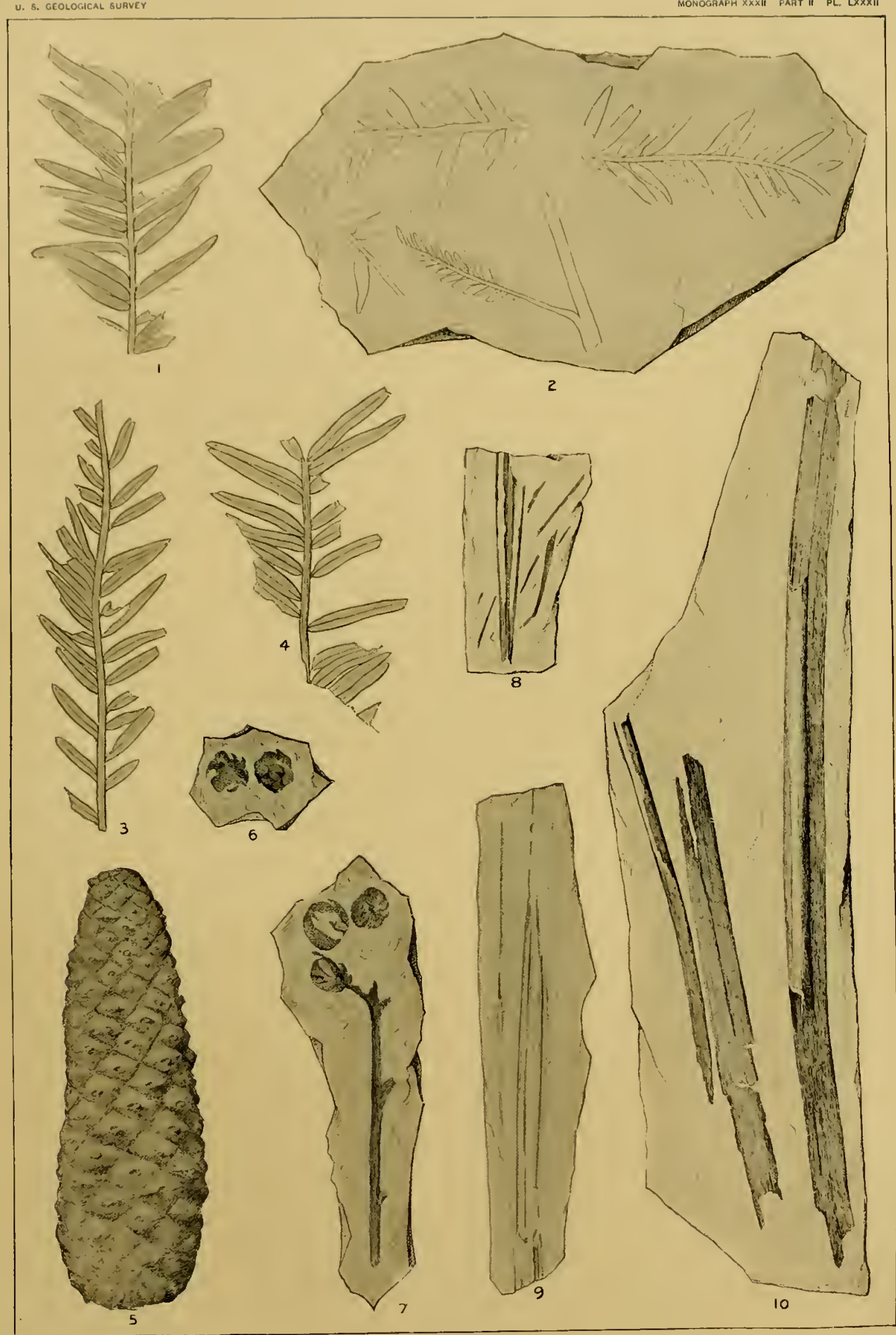

TERTIARY 

PLATE LXXXIII. 


\section{PLATE L X X X I I .}

Fig, 1, Musophyllum complicatum Lx. Crescent Hill.

.............................. 688

1. Cyperncites sp. Fussil Forest...................................... 684

5. Pirfagmites? latissima n. $\mathbf{n}$. Crescent Hill............................ 683

6. Crperacites? sp. Crescent Hill..................................... 685

7. Hicori. cllveri n. sp. Yellowstone River below Elk Creek .................... 691 


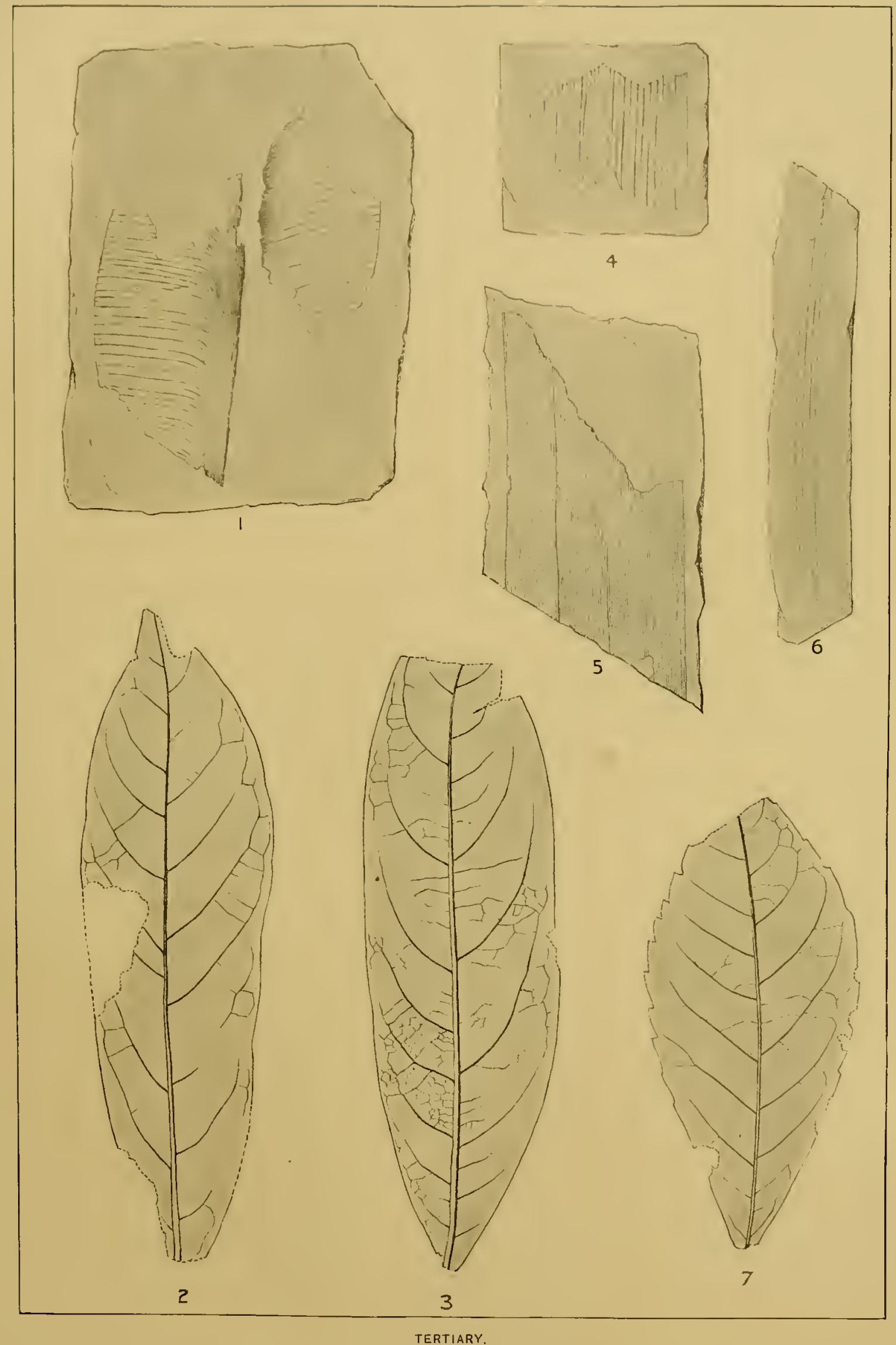





\section{PLATE LXXXIV.}




\section{P L A T E L X X X I V.}

Yemstone liver lotow Elk

2. Poptles Daphogenomes Ward. Yellowstone River below Elk Creek............ 695

3. Populus speciosa Ward. Yellowstone River below Ell Creek .................... 694

4. Mrrica warbir 11. sp. Fossil Forest .................................... 692

5. Mrrica LamaRensis n. sp. Lamar River................................ 693

6. MYrica scotrin Lx. Yellowstone River below Elk Creek ...................... 692

7. Hicoria crescentia n. sp. Crescent Hill.................................. 690

8. Juglays crescentia n. sp. Crescent Hill . . . . . . . . . . . . . . . . . . . . . . . . 689 


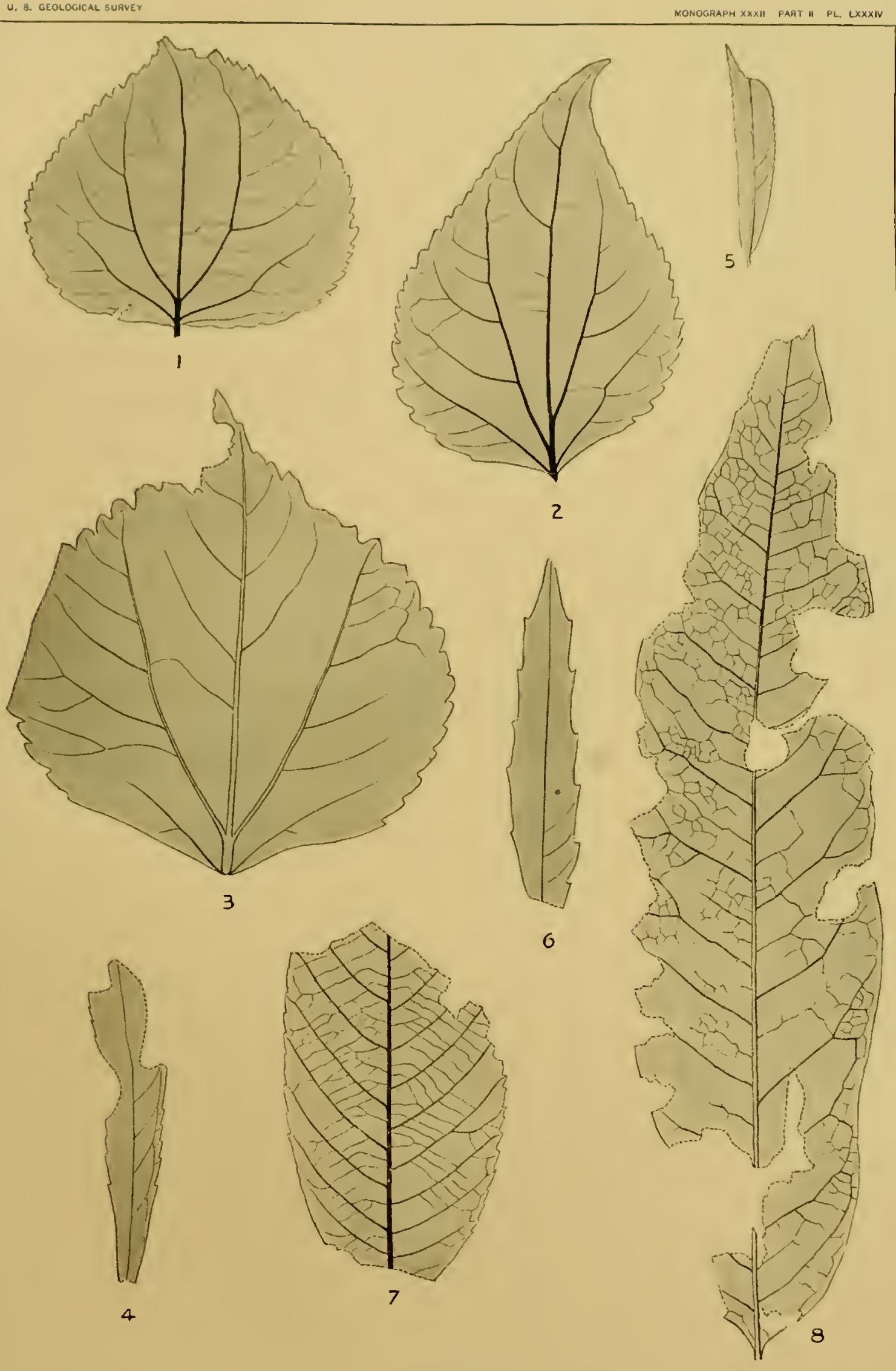



PLATE LXXXV. 
PLA TE L X X X V.

Figs. 1, 2. Popul's xantholithexsis 1. sp. Yellowstone River below Elk Creek......... 695

3. Salix varians Heer. Lamar River.................................. 697

4, 5. Fagrs cunduata n. sp. Vellowstone River below Elk Creek ................. 700

810 


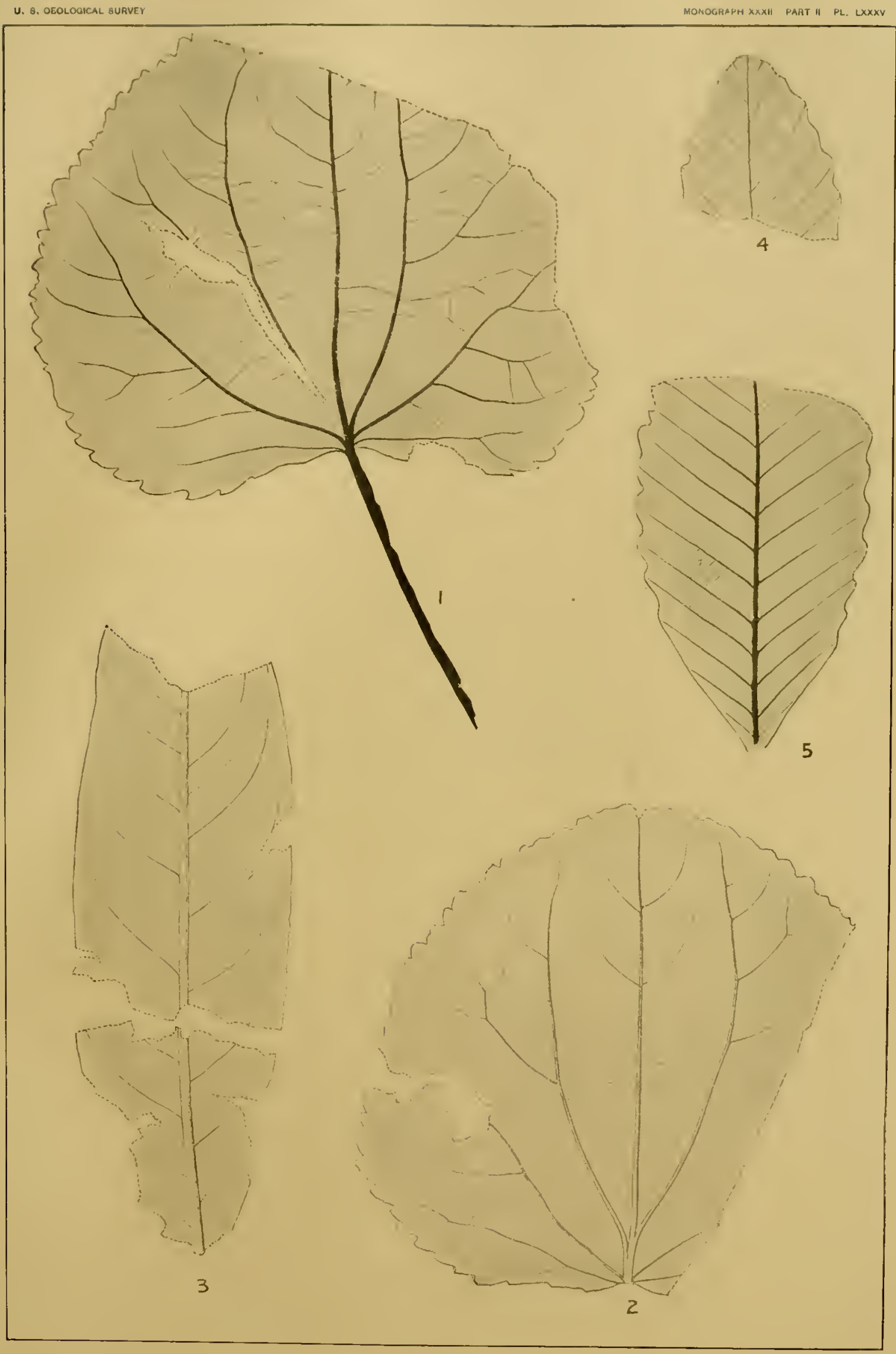





\section{PLATE LXXXVI.}




\section{PLATE L X X Y I}

Fig. 1. Populus balsamoldes: Güpp. Fossil Forest ............................. 696

2. Populus? vivaria 11. sp. Fossil Forest.................................... 696

3. Corylus macquarry Heer. Fossil Forest................................ 699

4,5. Betula IDdixgsi n. sp. Yellowstone River below Elk Creek................... 698

6-8. Castanea rulchella 11. sp. Fossil Forest............................ 702 


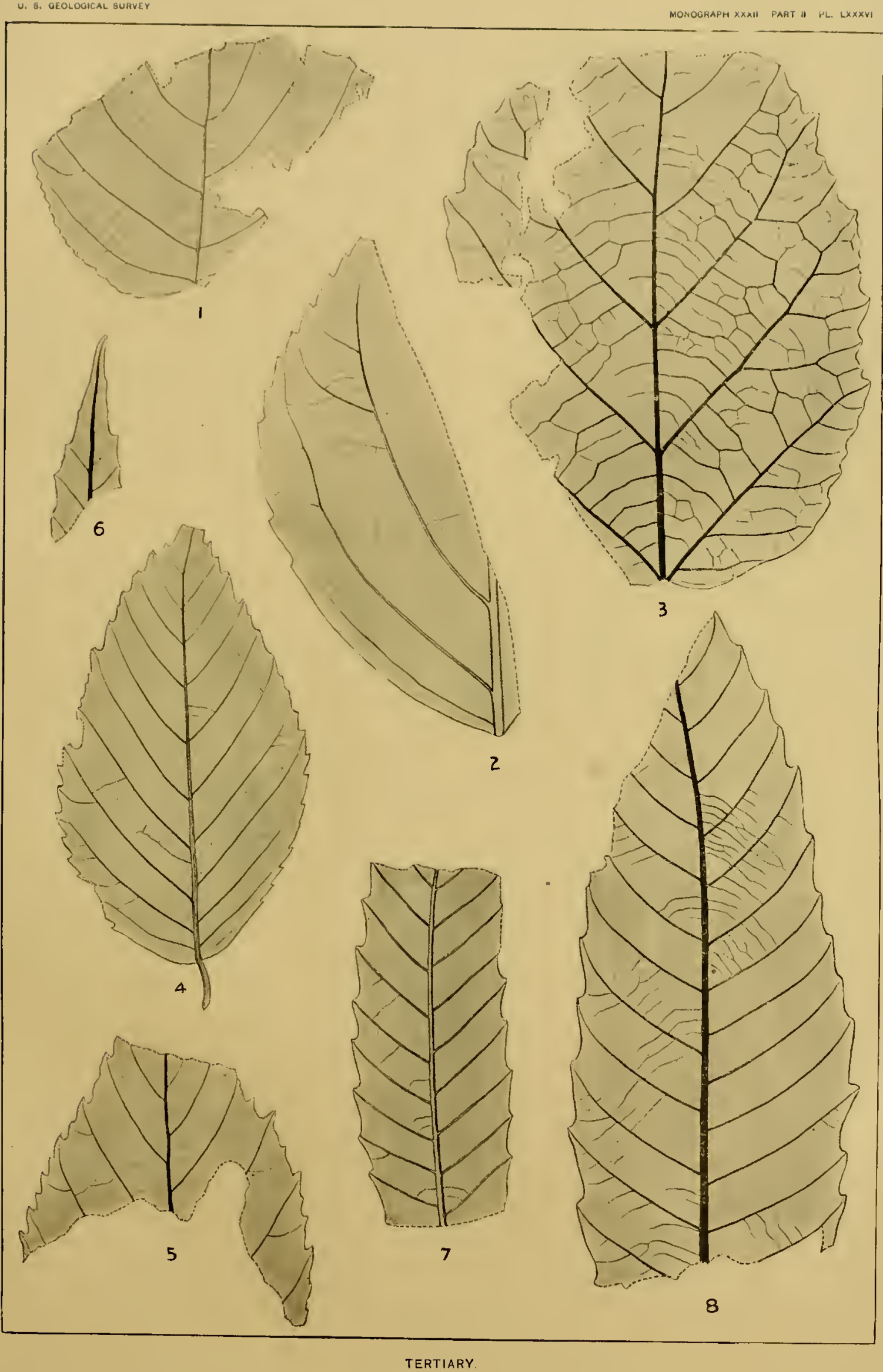





\section{PLATE LXXXVII.}




\section{P I. A TE L X X X V I I.}

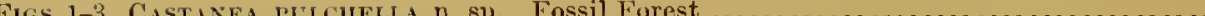

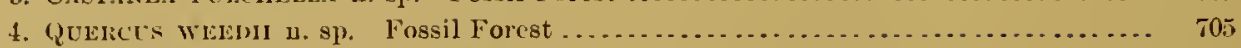

5. Quencen cutreri n. sp. Yellowstone River lolow Elk Creek............... 708

6. Quencts coxsmilis? Newby. Yellowstono River below Elk Creek... . ........ 704

7. Quencus grossidentata n. sp. Fossil Forest ................................ 704 


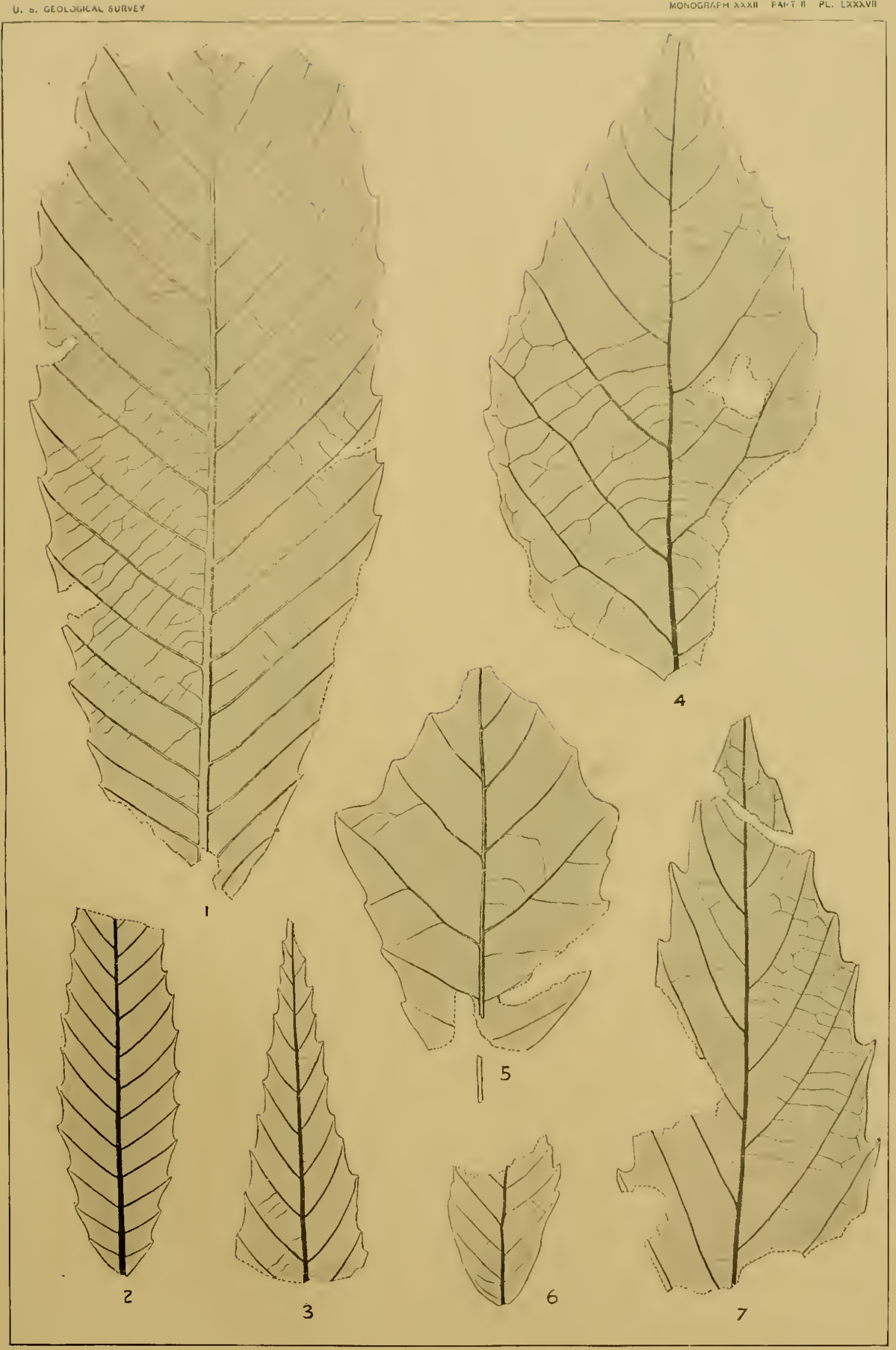

TERTIARY. 

PLATE LXXXVIII. 


\section{PLATE LXXXVIII.}

Fig. 1. Quercus? yagnifolia n. sp. Yellowstone River below Elk Creek - - t.

2. UlaUS PSEUDO-FULYA? Lx. Lamar River .............................. 711

3,4. Ulús, Ficits. Yellowstone River below Elk Creek ........................ 712

5. Quncus furcinervis ailericaxa lín. Fossil Folest ....................... 705

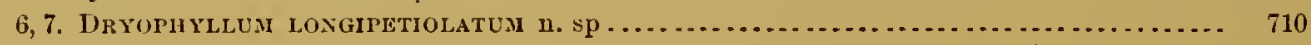




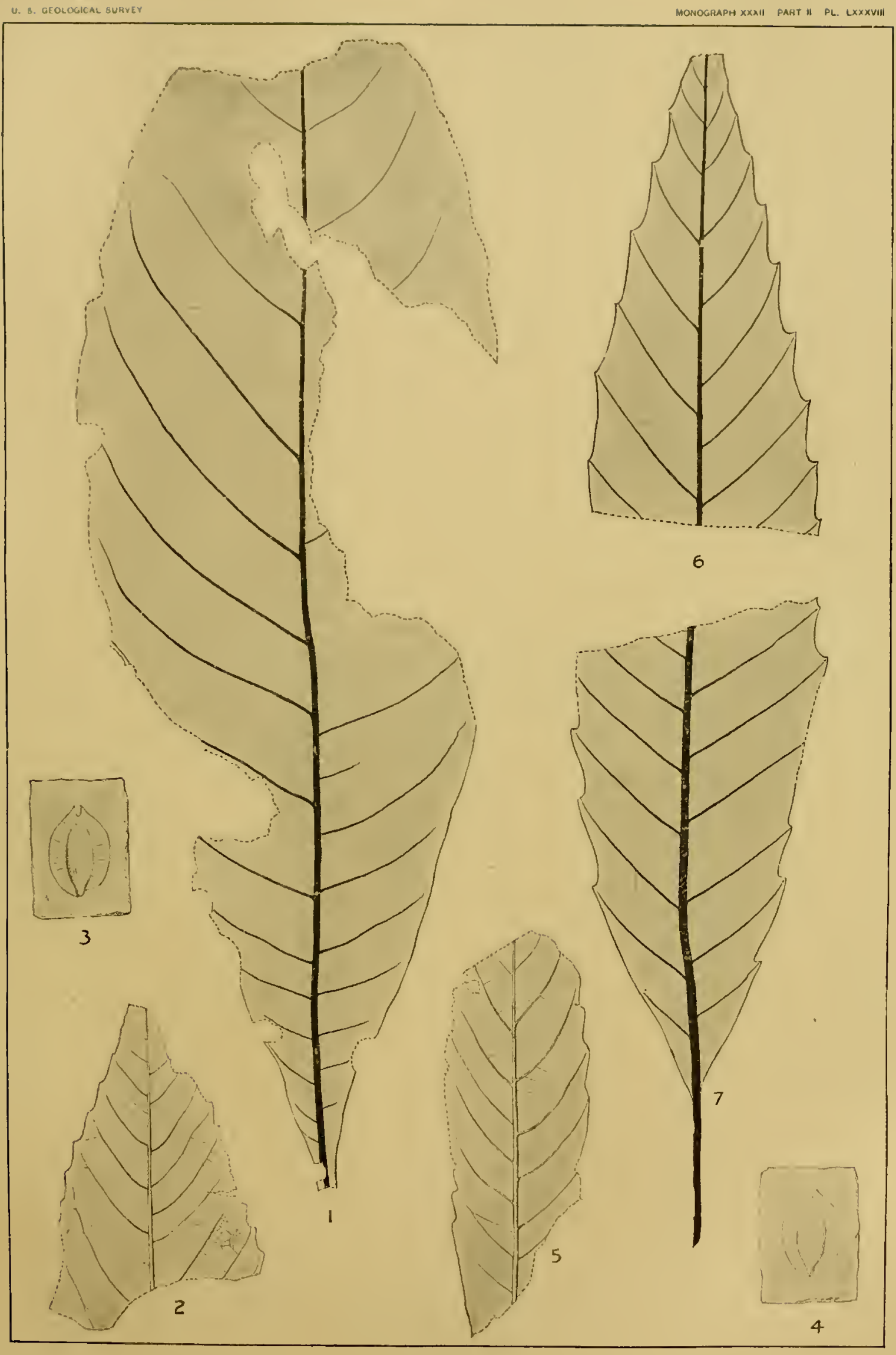

TERTIARY. 



\section{PLATE LXXXIX.}

MON XXXII, PT II-52 


\section{PLATE L X X X I X}

Fig. 1. Ficts DEXSIFOLIA Ho

2. Quercus raxceri n. sp. Yancers Fossil Forest

3. Ficus sp. Yellowstone River below Elk Creek ............................. 713

4. Legumixosites Lesquirunda.i Kn. Crescent Hill ...................... 730

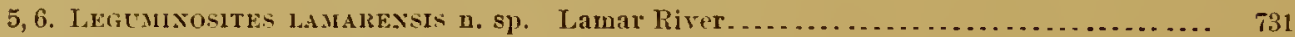

7. Qukizces sp. Yellowstone River below Elk Creek ............................ 707

818 


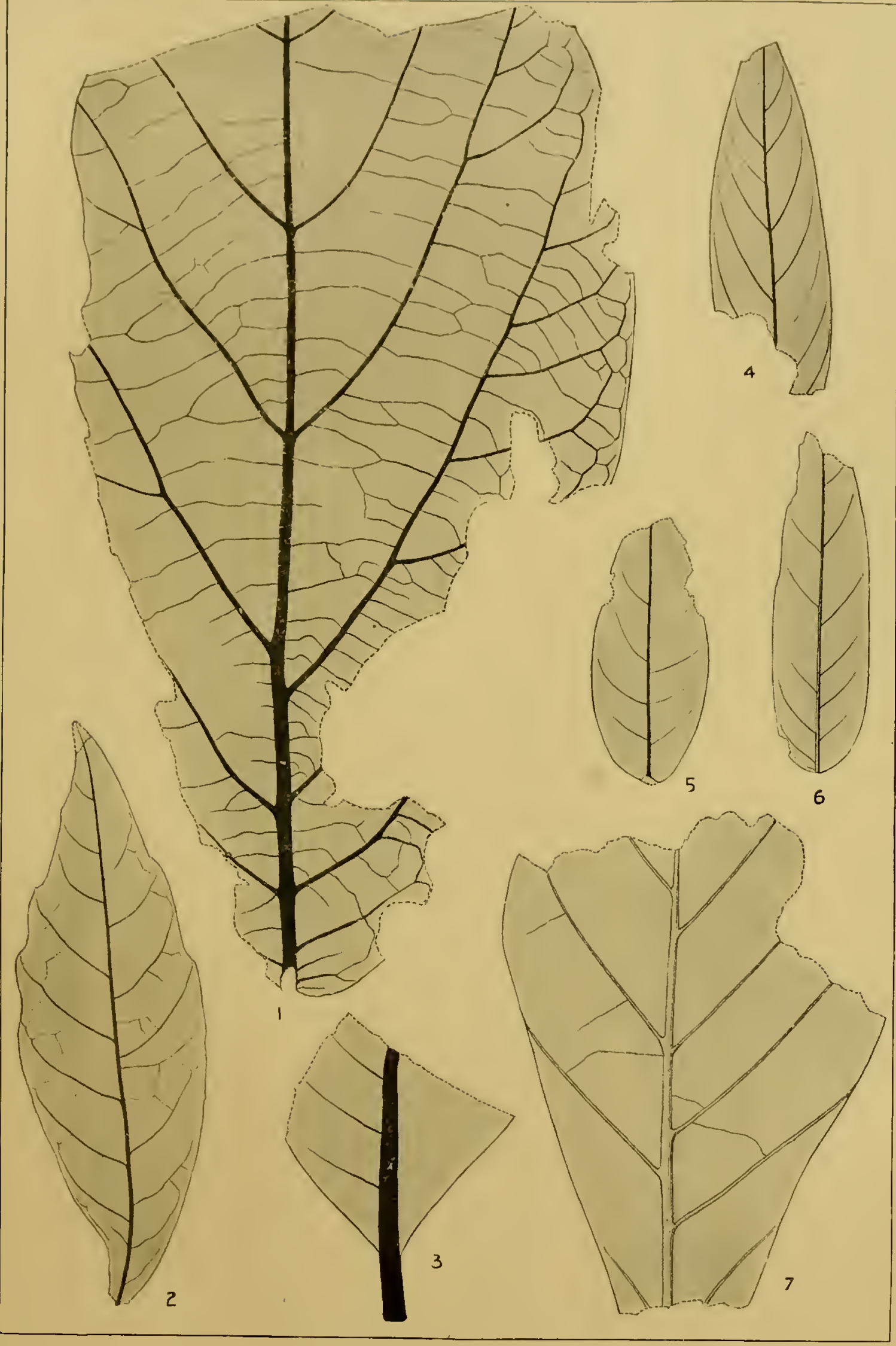

TERTIARY 



\section{PLATE XC.}




\section{PLA TE X C.}

71

3. Ficus haguei 1. sp. Fossil Forest .................................. 715

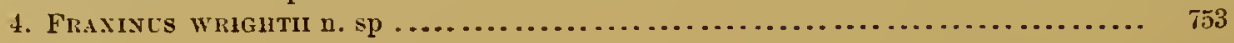

820 


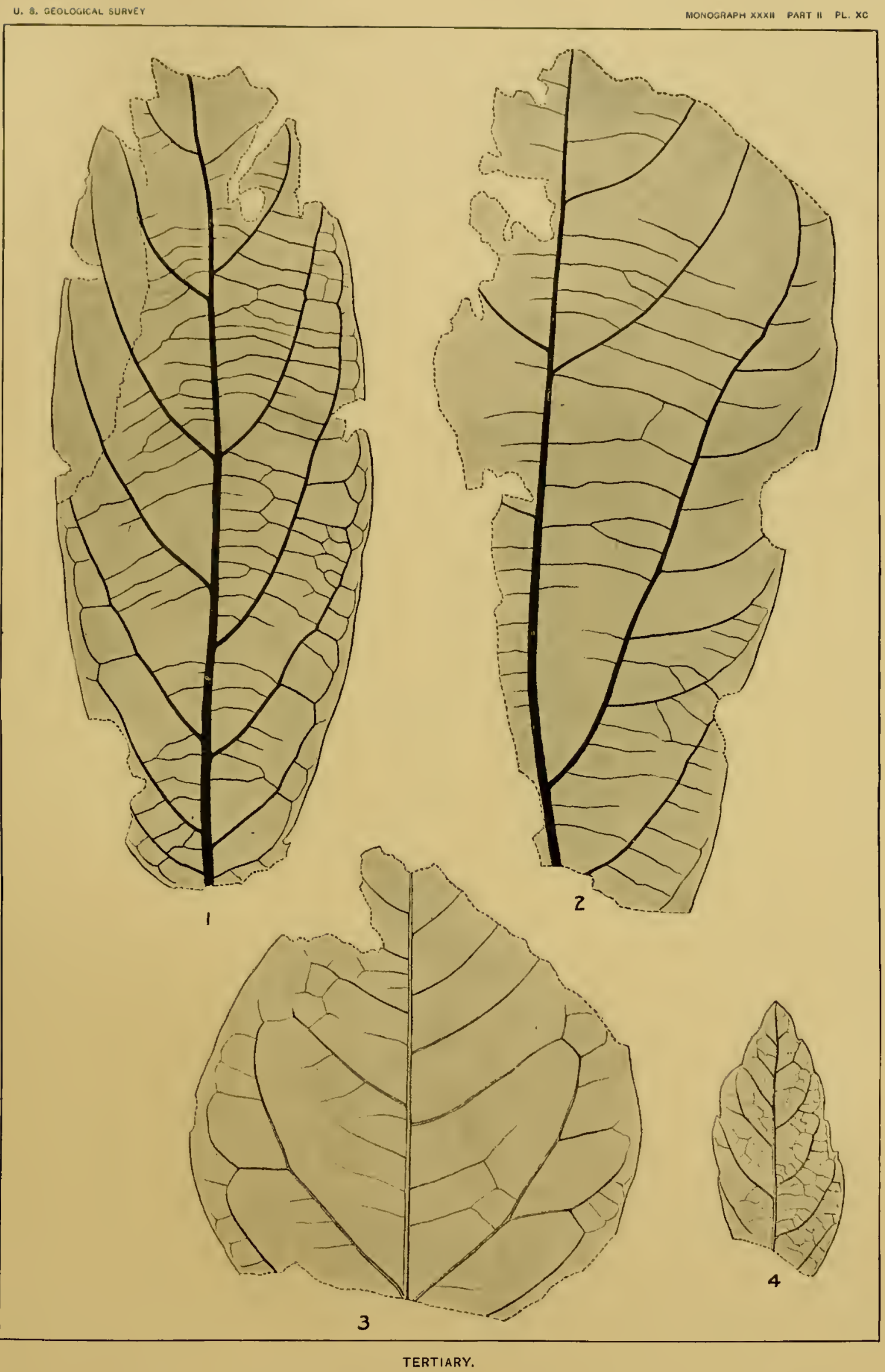





\section{PLATE XCI.}




\section{PLA T E X C I.}

Fig. 1. Ficus densifoira

2. Fices deformata n. sp. Yellowstone River below Elk Creek.................. 712

3. Ficus uxgeri Lx. Yellowstone River below Elk Creek...................... 713

4,5. LaURU Prinigenia? Ung.......................................... 722 


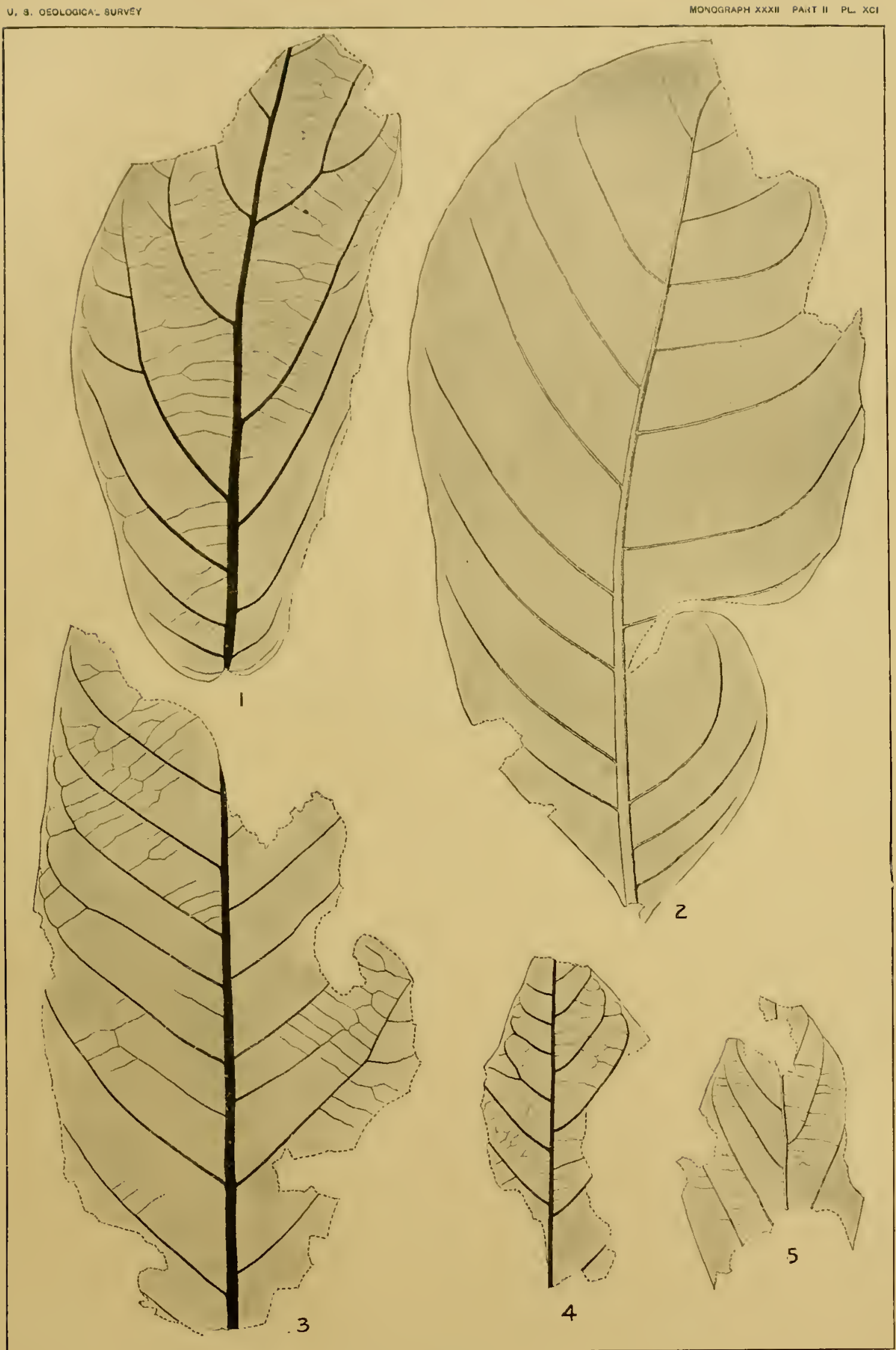





\section{PLATE XCII.}




\section{PLA'TE XCII.}

Fig. 1. ARtocarpus ? QunRCoIdes n. sp. Yellowstone River below Elk Creek ........... 716

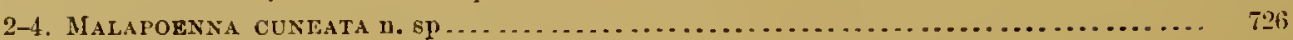

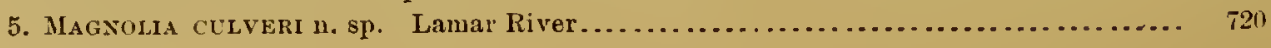




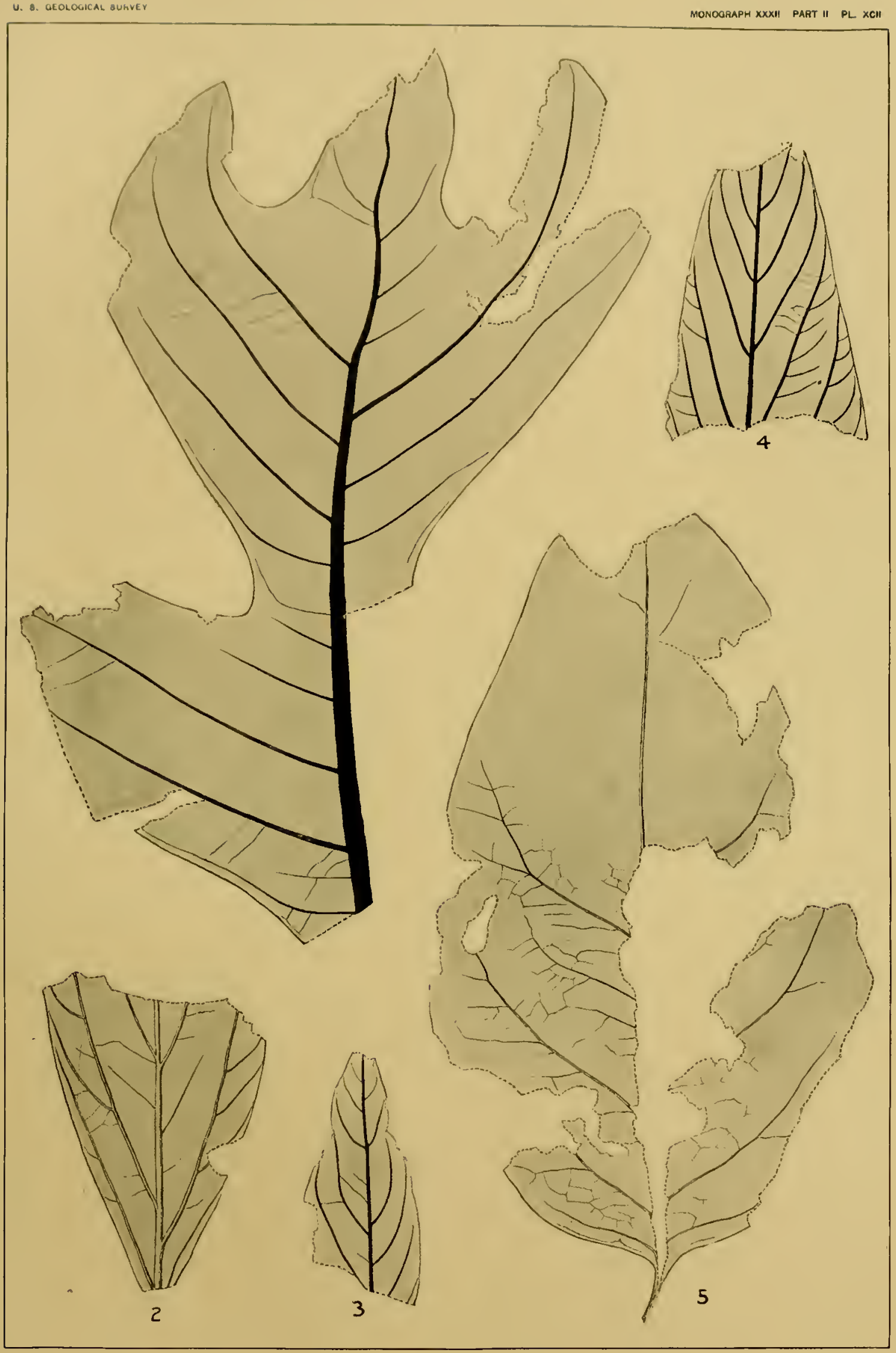

TERTIARY, 



\section{PLATE XCIII.}




\section{PLATE XCIII.}

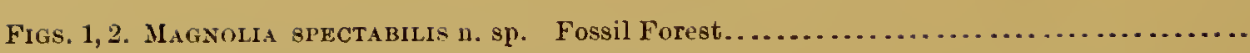

Pge.

3. Lacrus graxdis Lx. Specimen Ridge ...............................

4, 5. Malapoenva lanarexis n, sp. Lamar River .......................... 726 826 


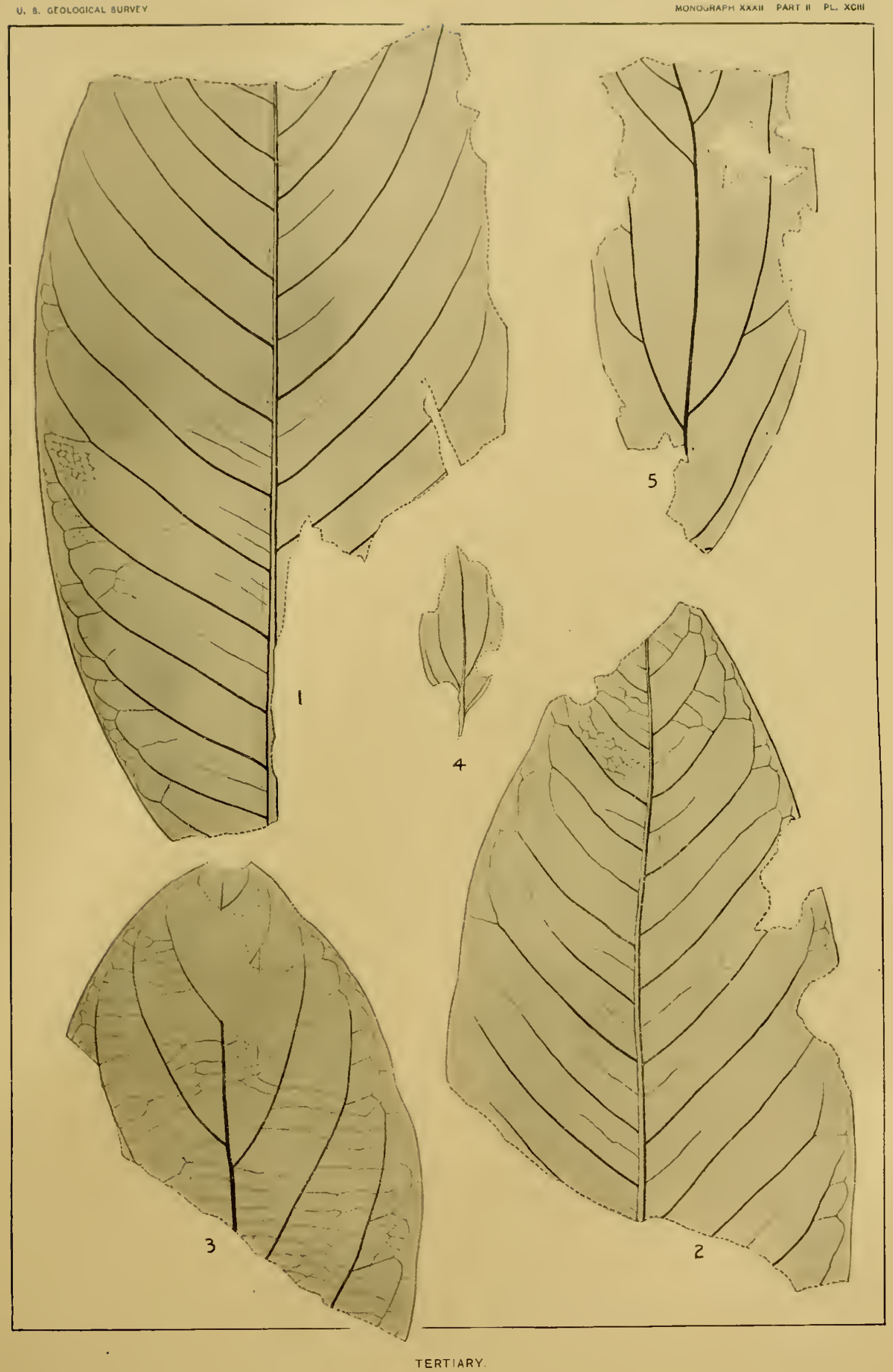





\section{PLATE XCIV.}





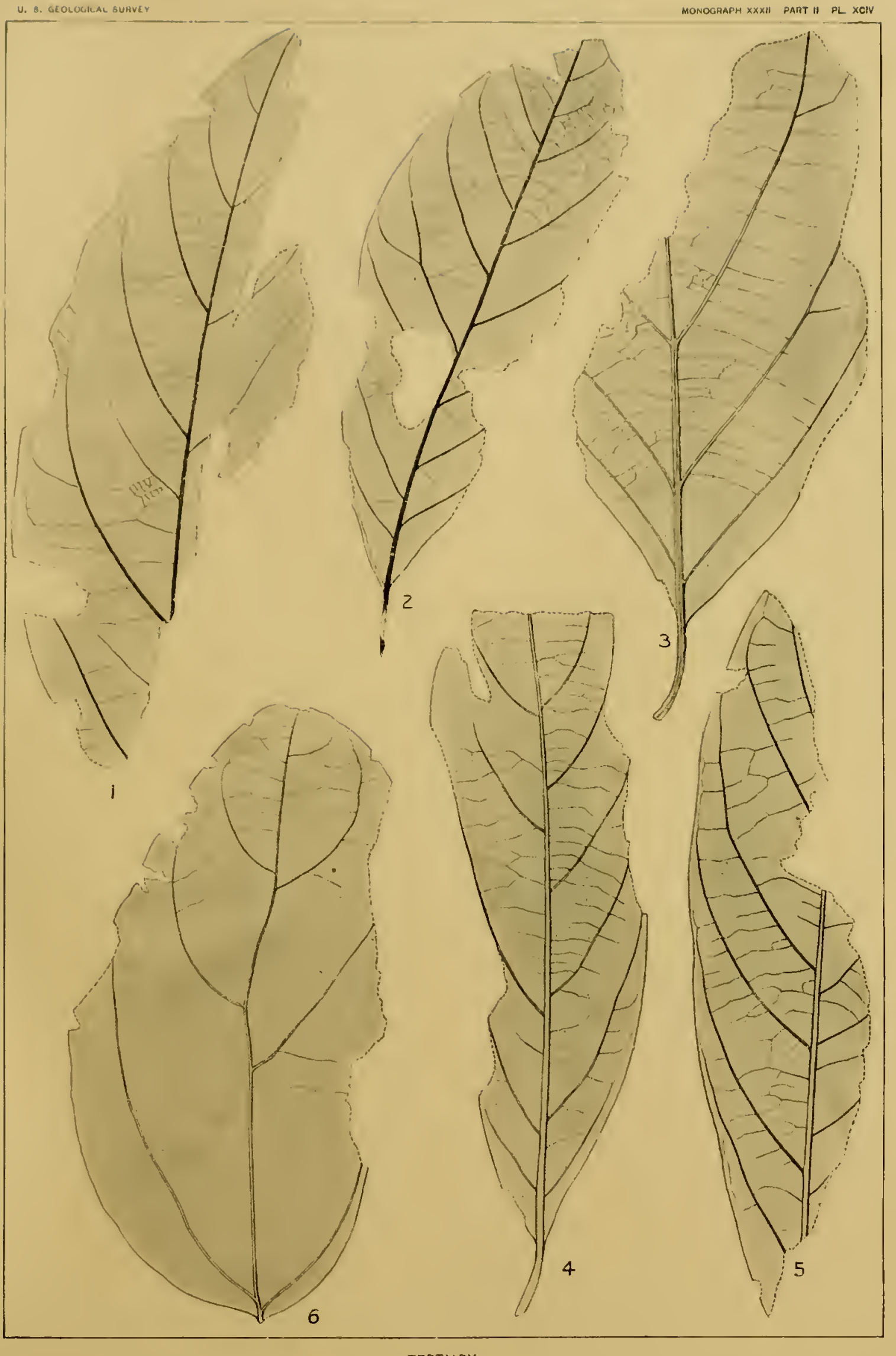





\section{PLATE XCV.}




\section{PLA T E X C V}

Page.

2. Laurus Montana n. sp. Yellowstone River below Eilk Creek..................... 724

3. Laurus princeps Heer, Yellowstone River below Elk Creek..................... 725

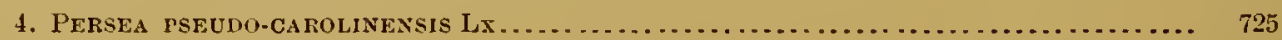

5,6. Drospyrus Lamarexsis n. sp. Specimen Ridge.......................... 751

830 


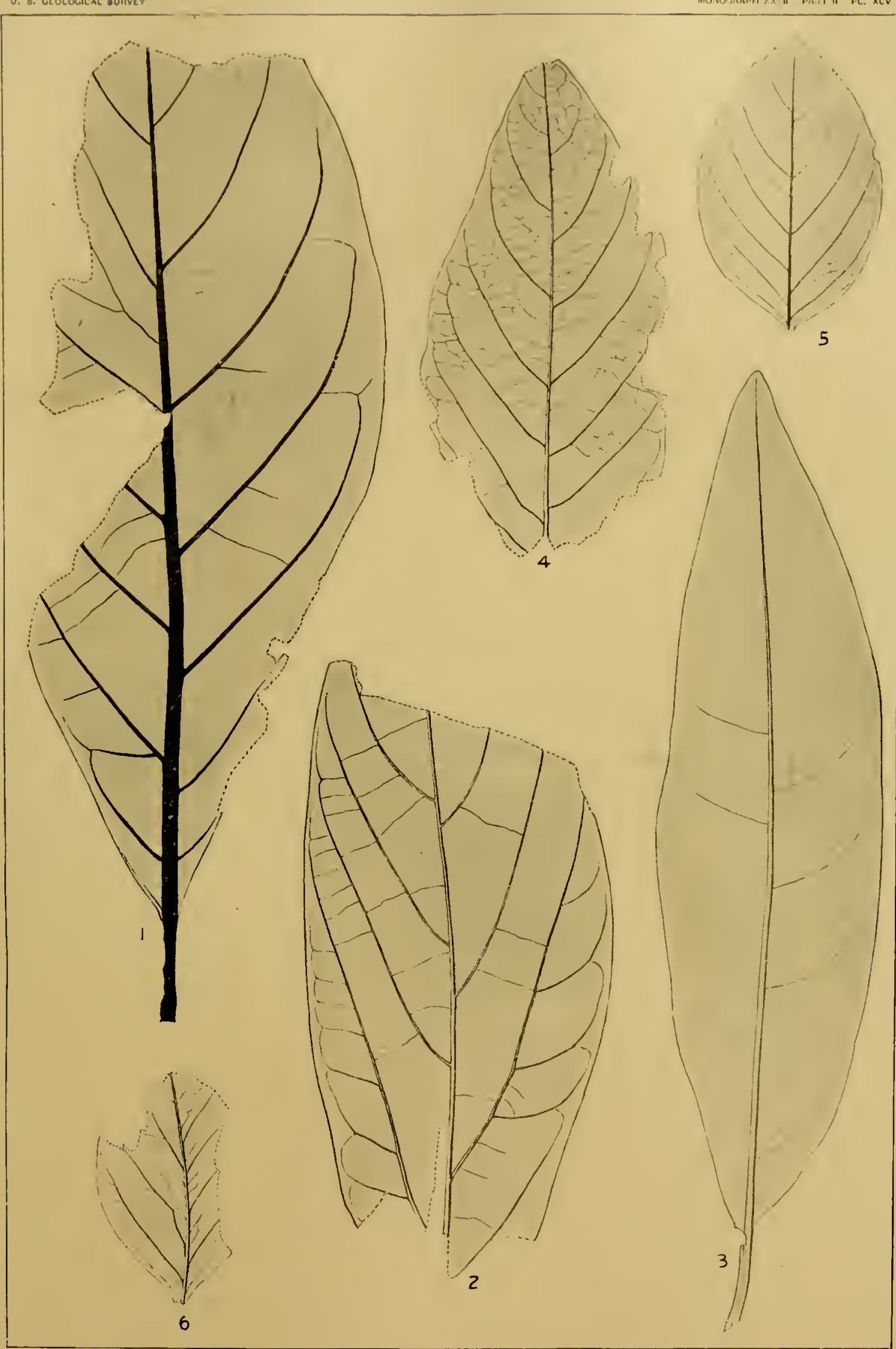

TERTIARY. 



\section{PLATE XCVI.}




\section{PLATE XCVI.}

Fig. 1. Platands gullelly Göpp. Fossil Forest.......... Page.

2, 3. Platanus noviraxa n. sp. Hill above Lost Creek ........................... 728

4. Diospyros ladarensis n. sp. Lamar River .............................. 751

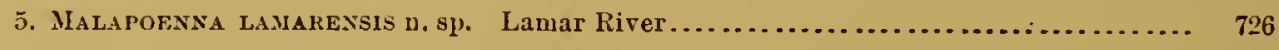




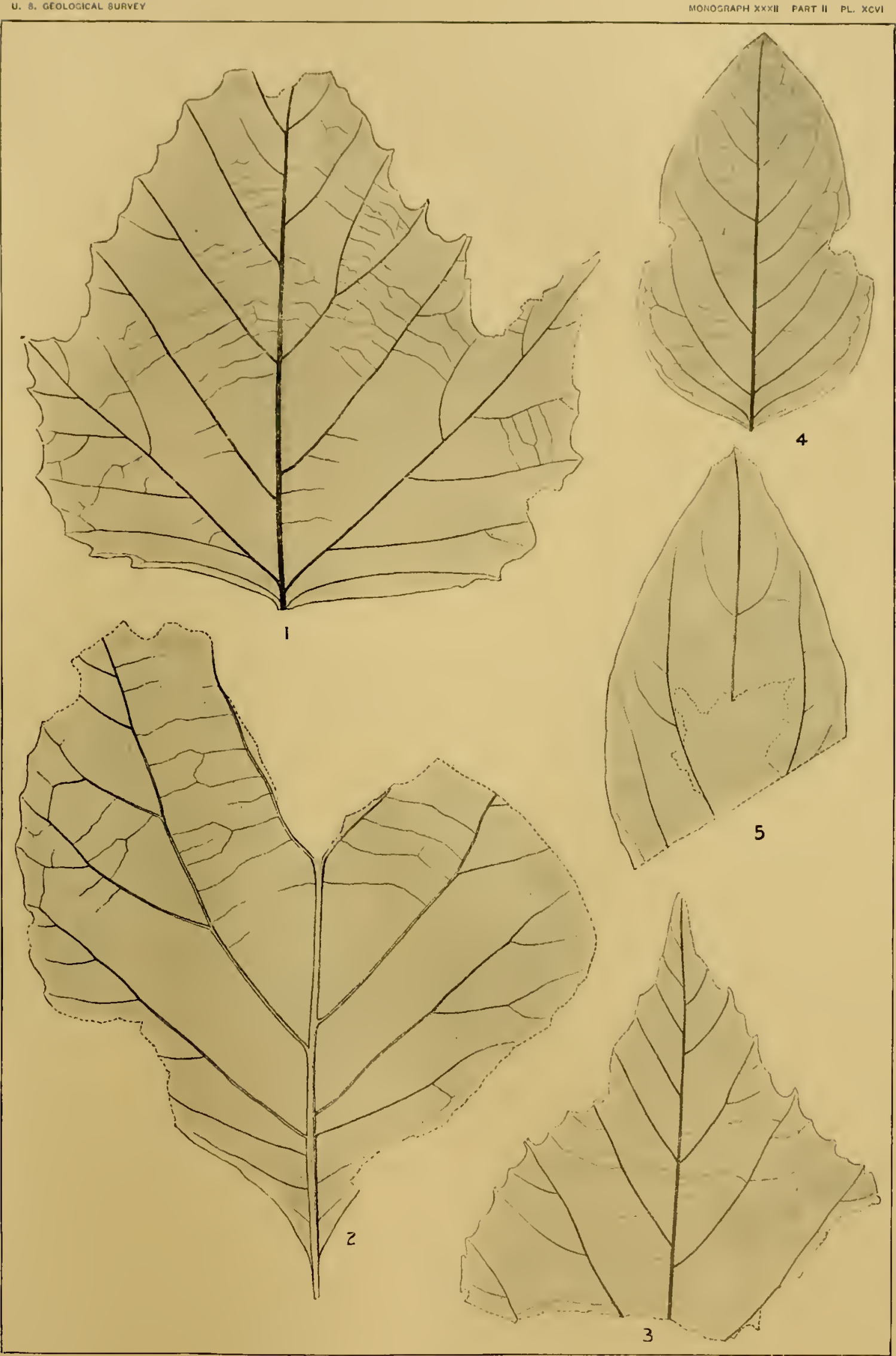





\section{PLATE XCVII.}

MON XXXI, P'T H-.j3 


\section{PLATE XCVII.}

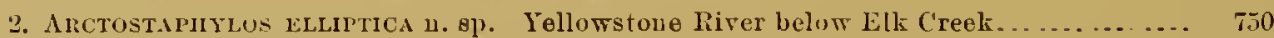

3. Celastrus Elipticus n. sp. Vellowstone River below Elk Creek............... 734

4. Celastres celvini n. op. Vellowstone River below Elk Creek ................. 732

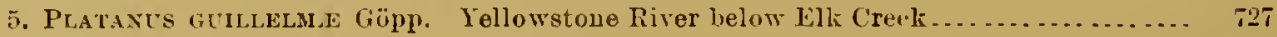




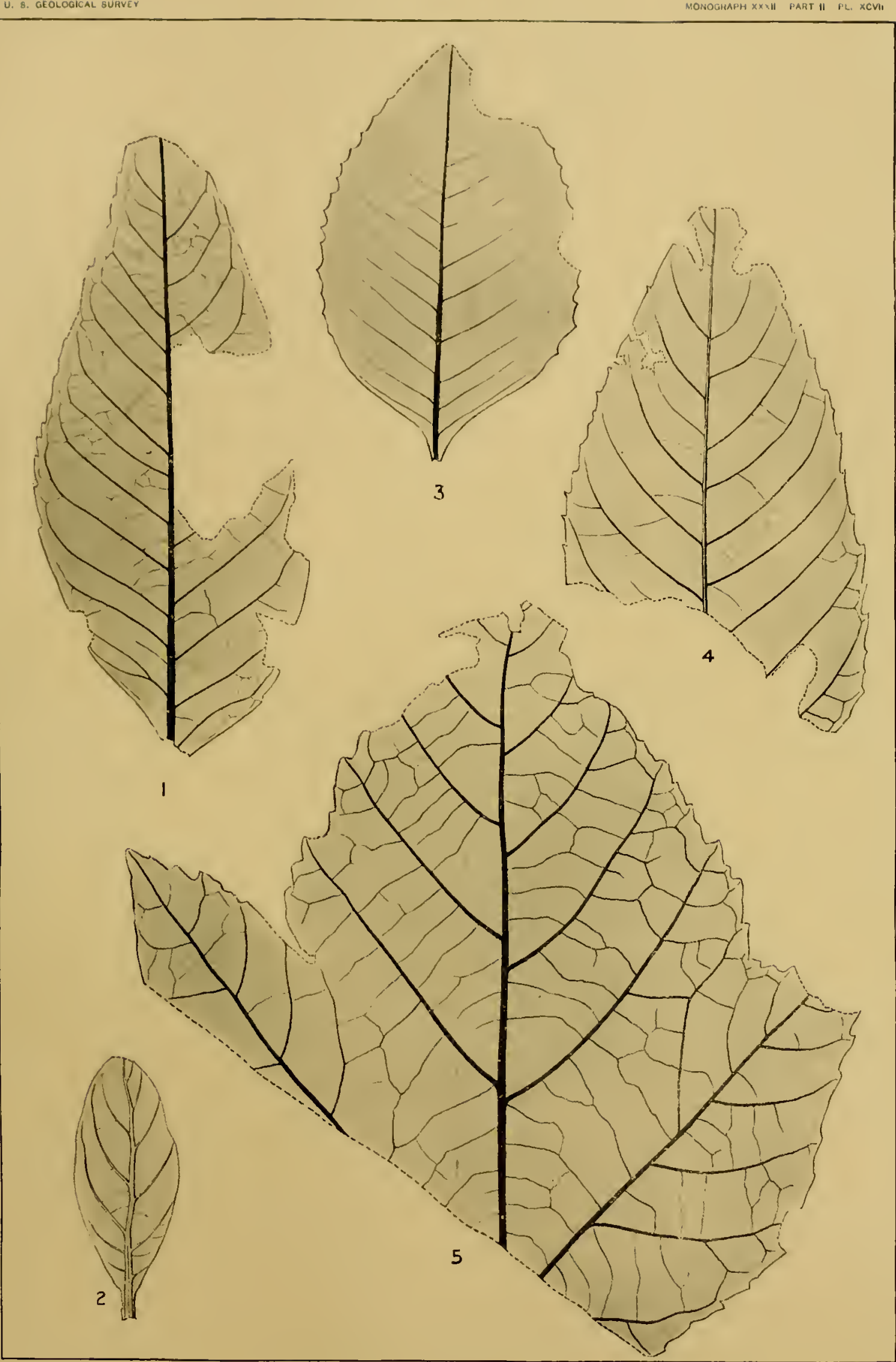

TERTIARY 


\section{PLATE XCVIII.}




\section{PLATE XCVIII.}

Page.

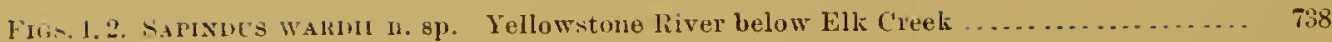

3. Celastres dx.equalis n. sp. Yellowstone River helow Elk Creek ............. 733

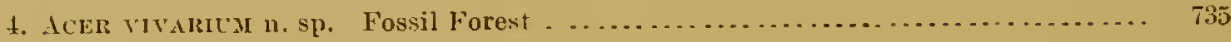

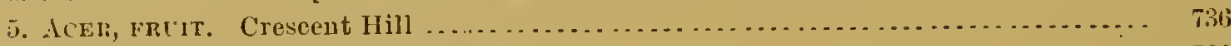

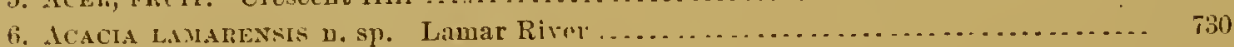

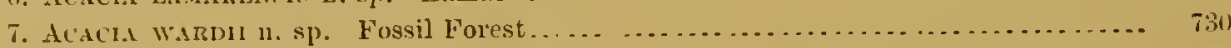

8. ACacia motrosperia n, sp. Fossil forest............................. 729

836 


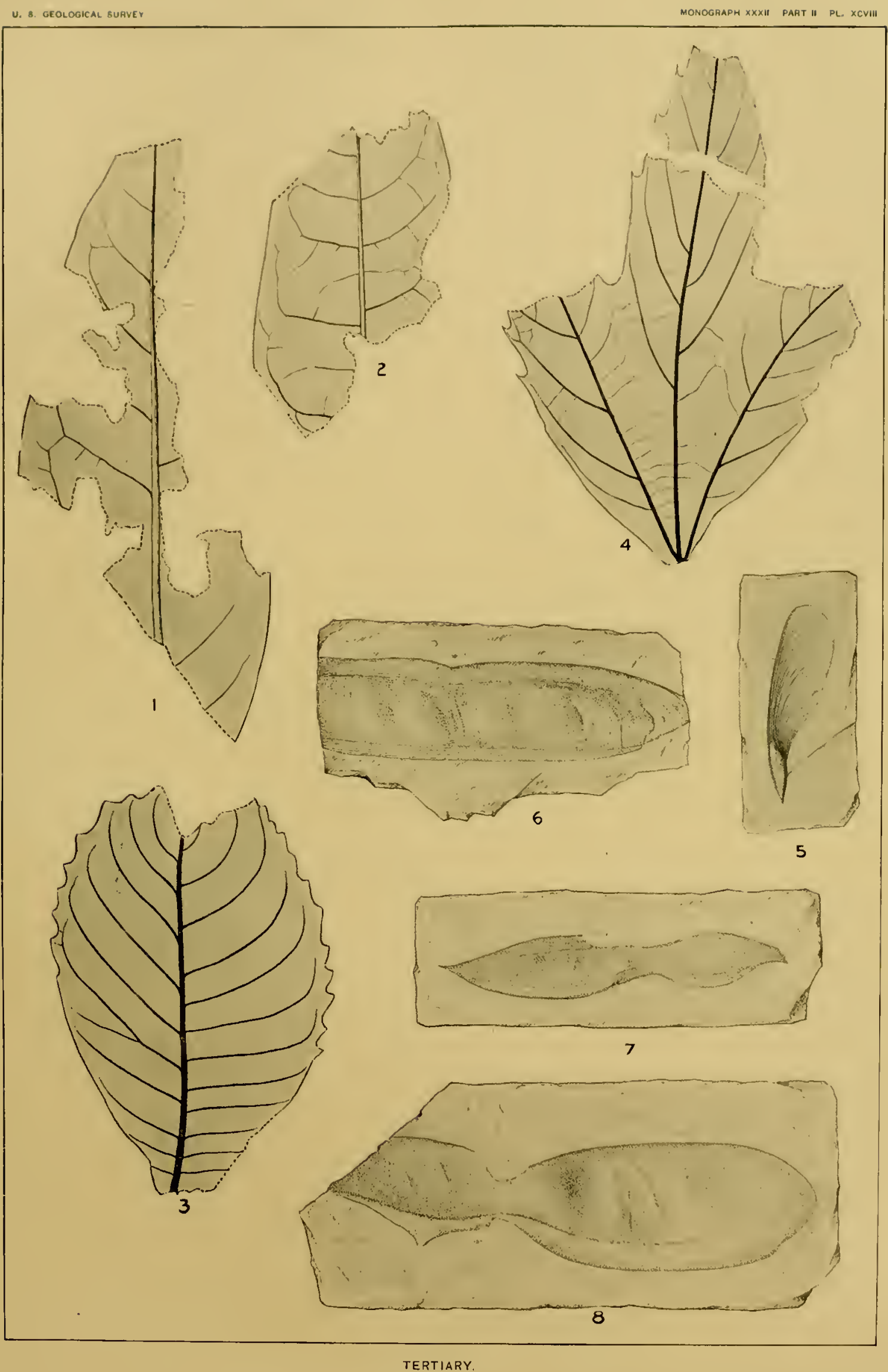





\section{PLATE XCIX.}




\section{PLATE XCIX.}

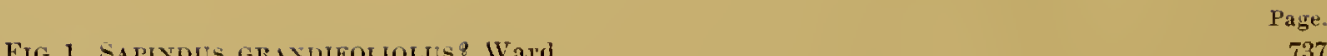

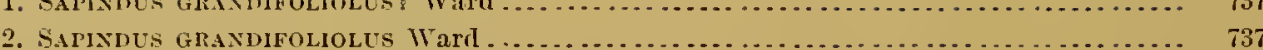

8. Aralia Whitey Lx. Fossil Forest Ridge ........................................ 748

4. Ptenosiemutes haguei u. sp. Fossil Forest Ridge ...................... 712

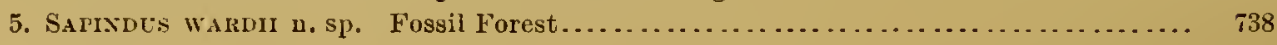

838 


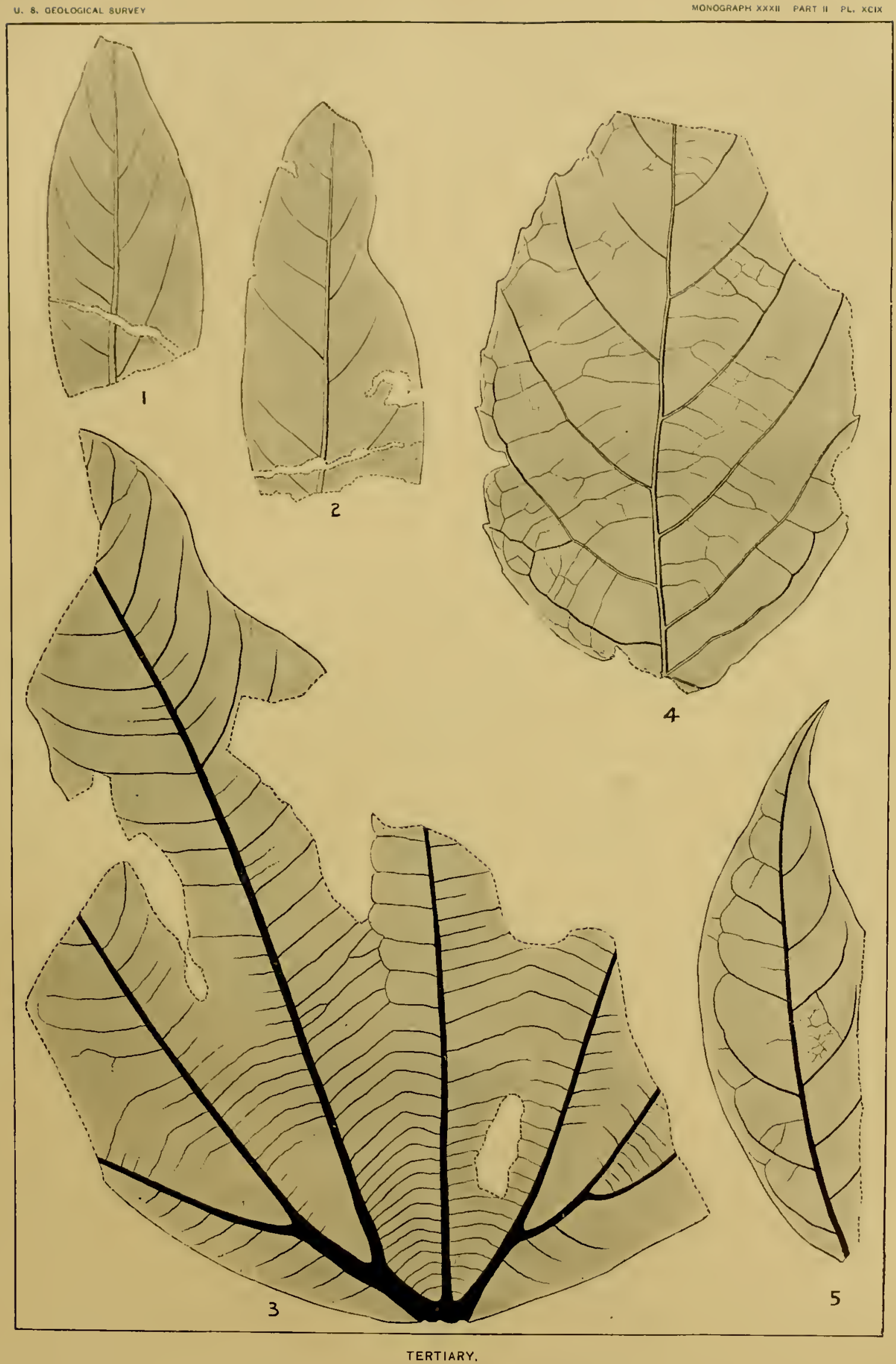





\section{PLATE C.}




\section{PLATE C.}

Fig. 1. Aralia notata Lx. Yellowstone River below Elk Creek

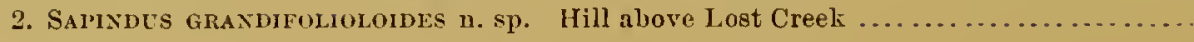

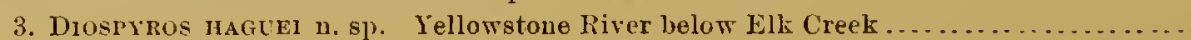




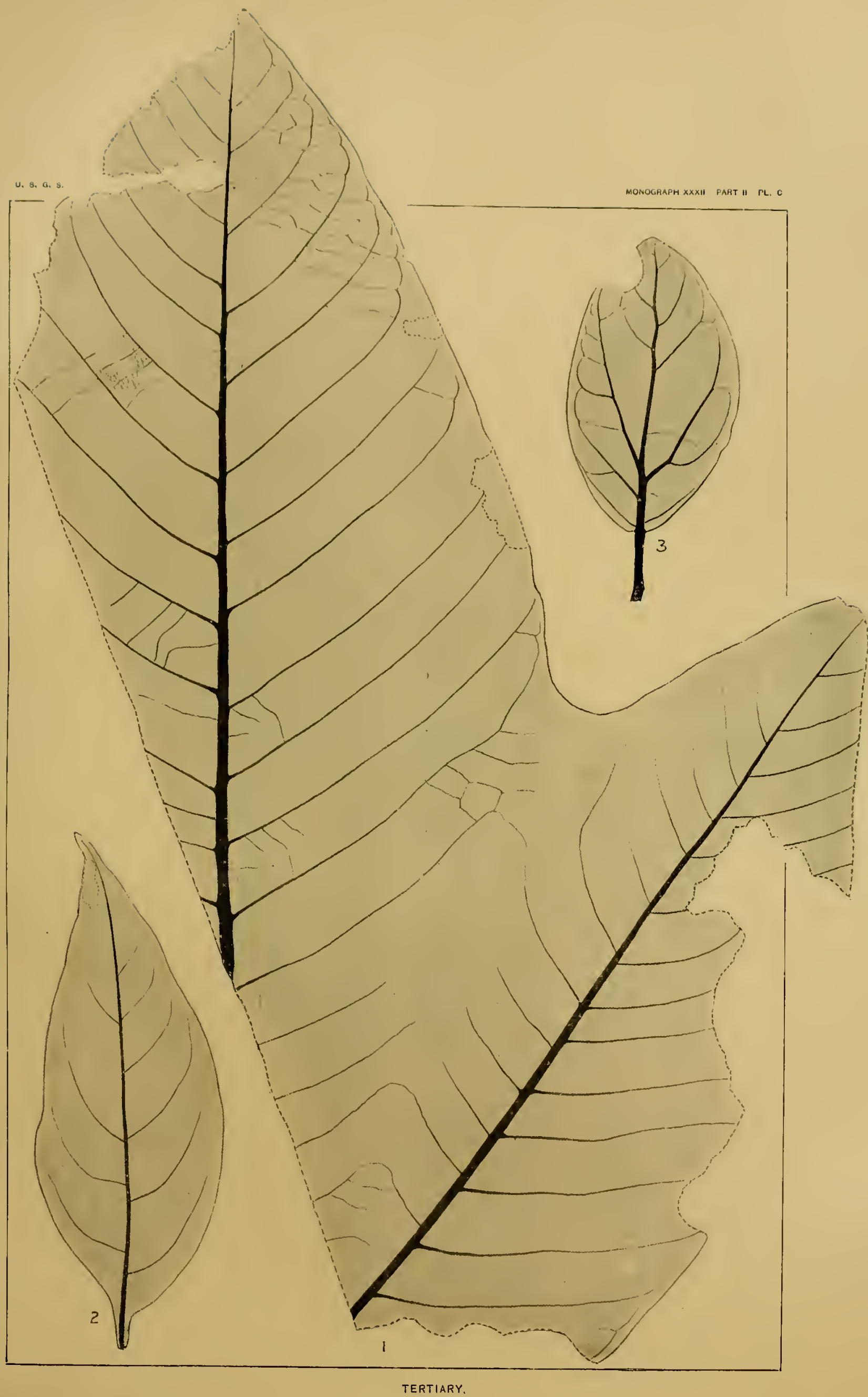





\section{PLATE CI.}





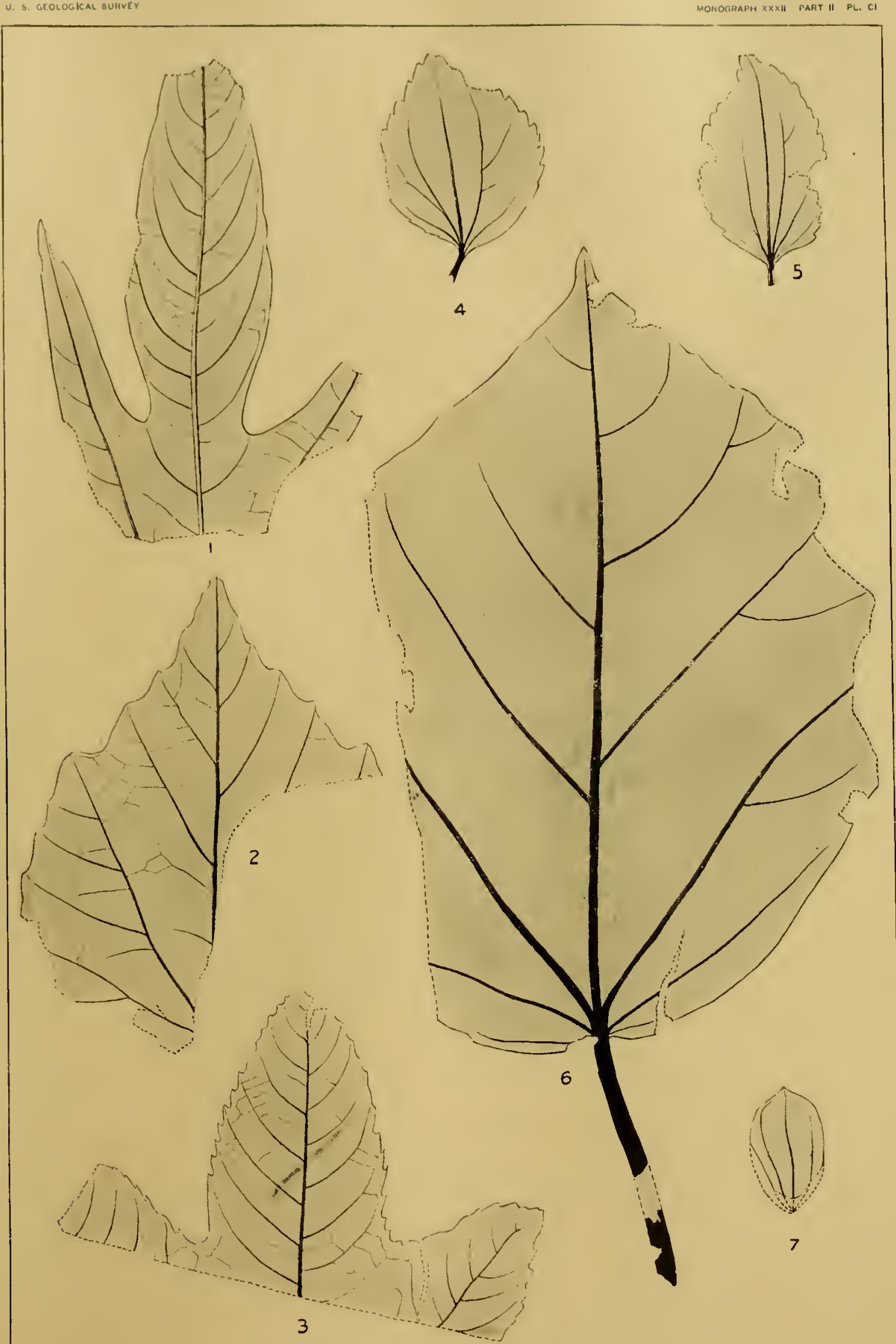

TERTIARY, 



\section{PLATE CII.}




\section{PLATE C I I.}

Figs. 1-3. Sapindes affinis Newby. Yellowston River below Elk Creek ................ 736

4. Sapindi, Graxdfoliolts? Wart. Yellowstone Rirer below Elk Creek......... 737

5. Phylutes crassifolia 1. sp. Fossil Forest........................... 753 844 

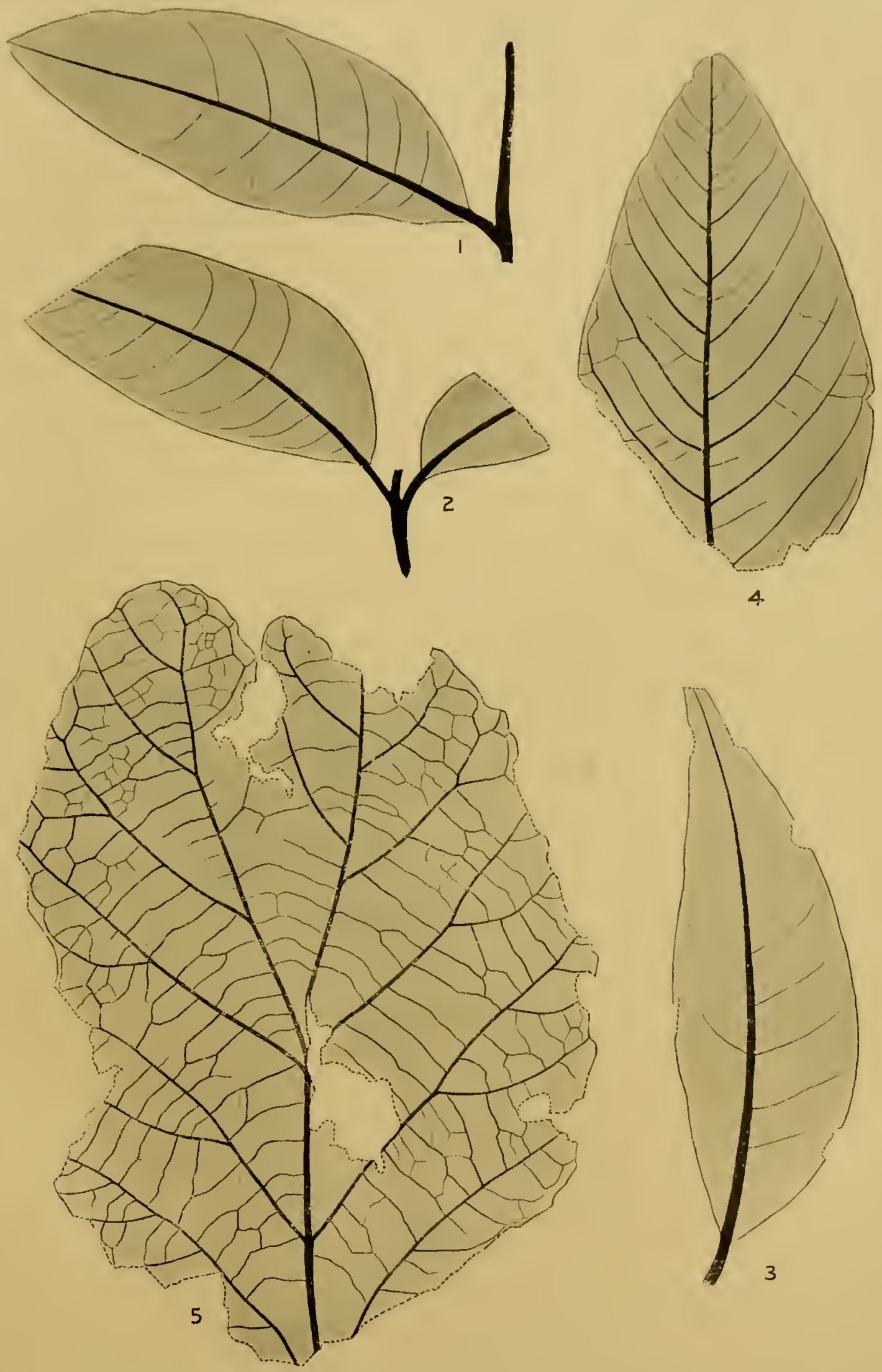

TERTIARY. 



\section{PLATE CIII.}




\section{P L A T E C I I I.}

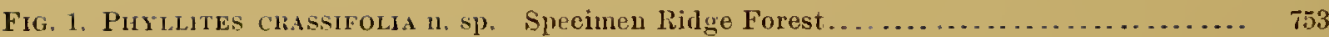

2. PHyllites sp. Tellowstone River below lik Creek...................... 753

3. Canpites pencicteatus 11. sp. lellowstone River below Elk Creek.............. 755

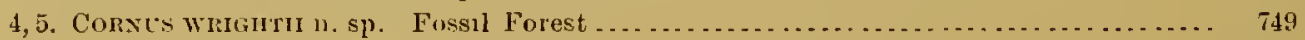

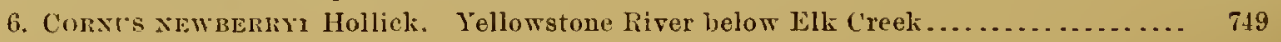




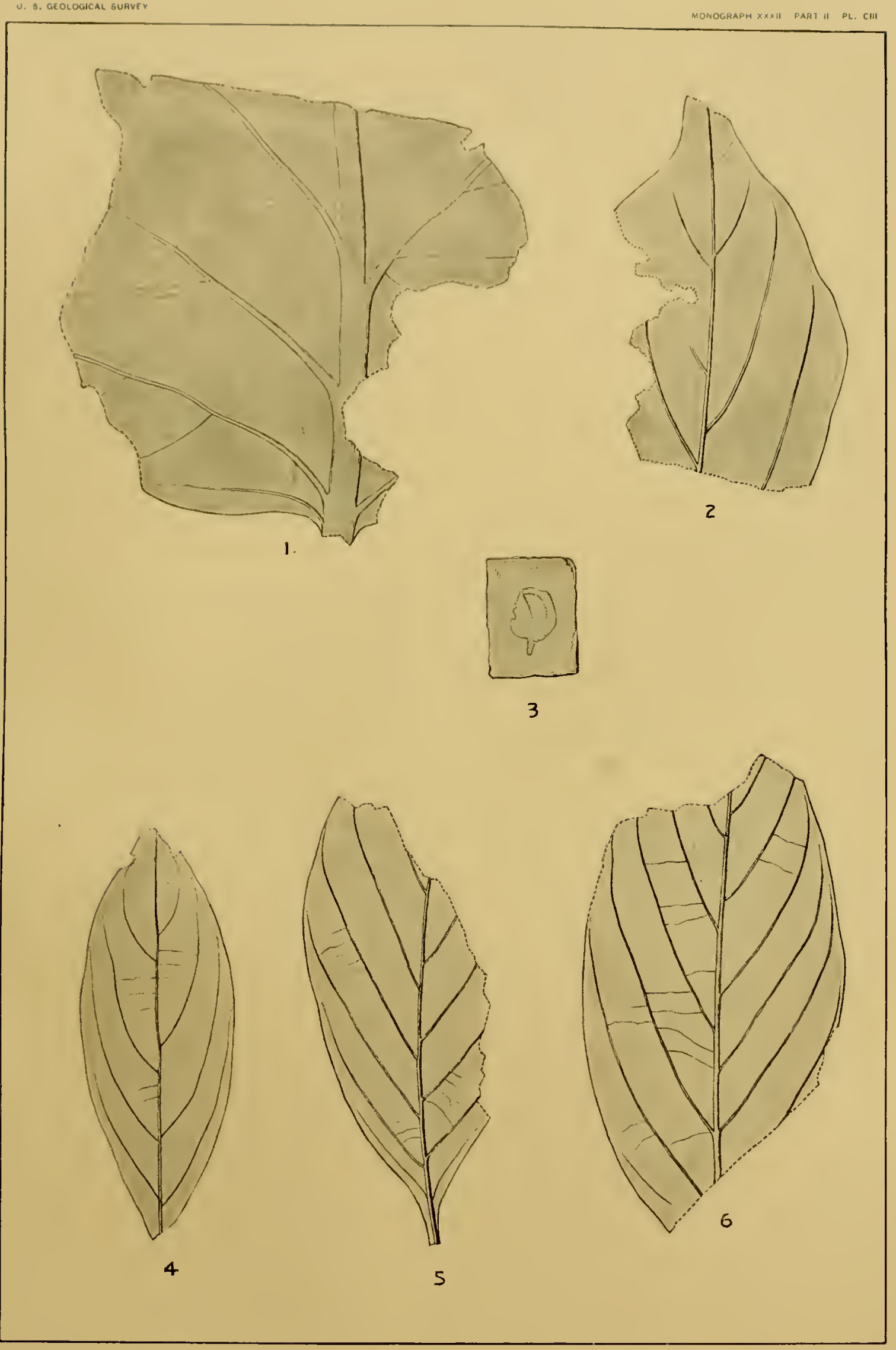

TERTIARY 



\section{PLATE CIV.}




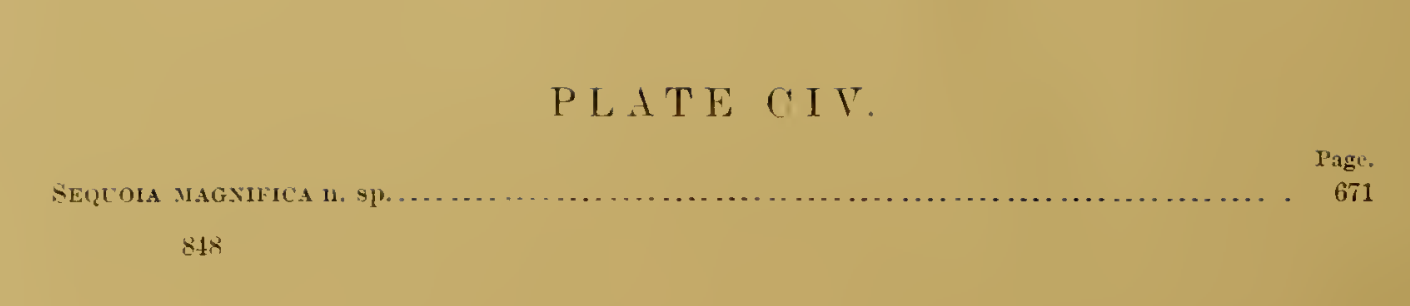




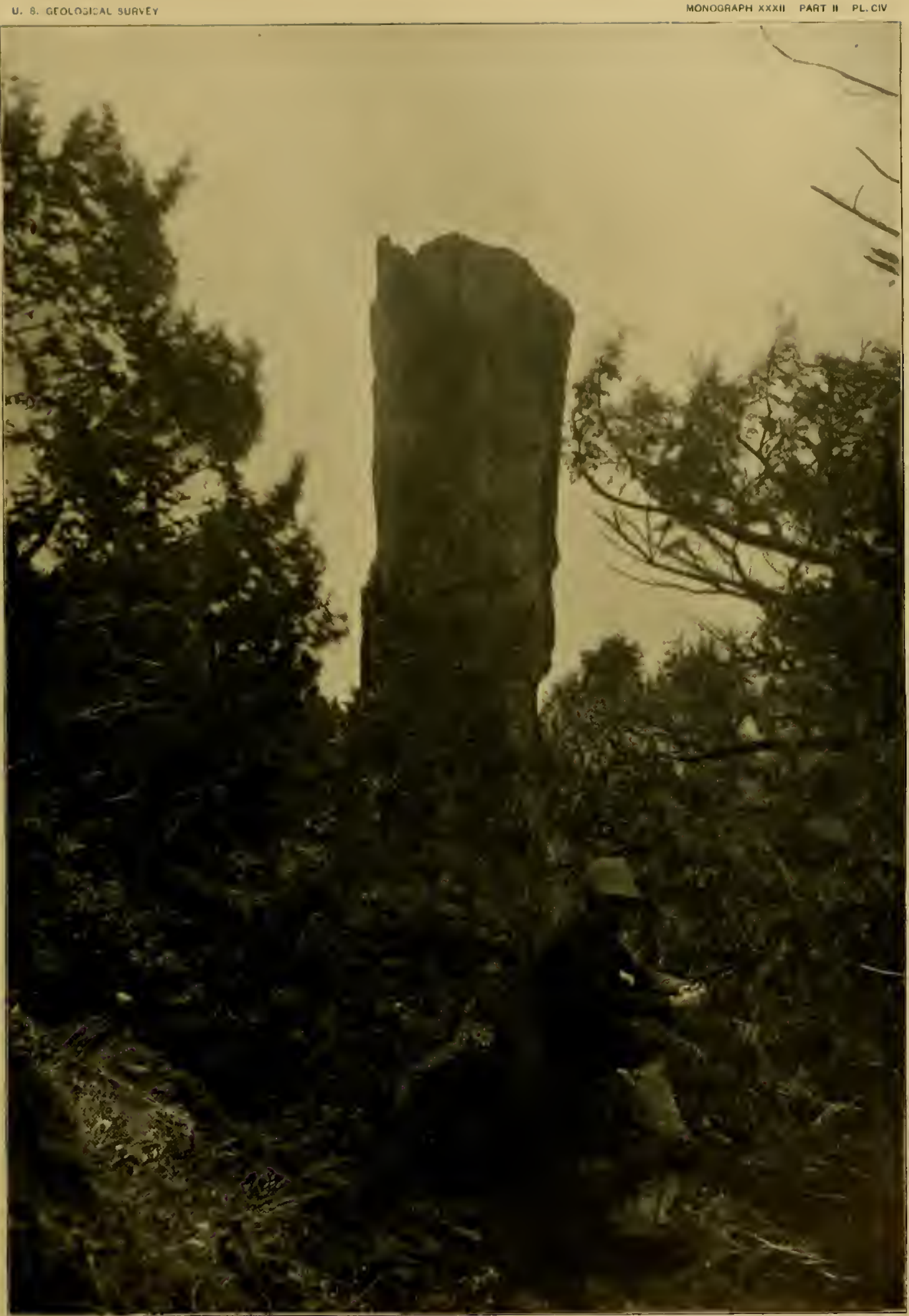

SEQUOIA MAGNIFICA. 



\section{PLATE CV.}

MON XXXII, P'T II- 54 


$$
\text { PLLA } \mathrm{TE} \text { CV. }
$$




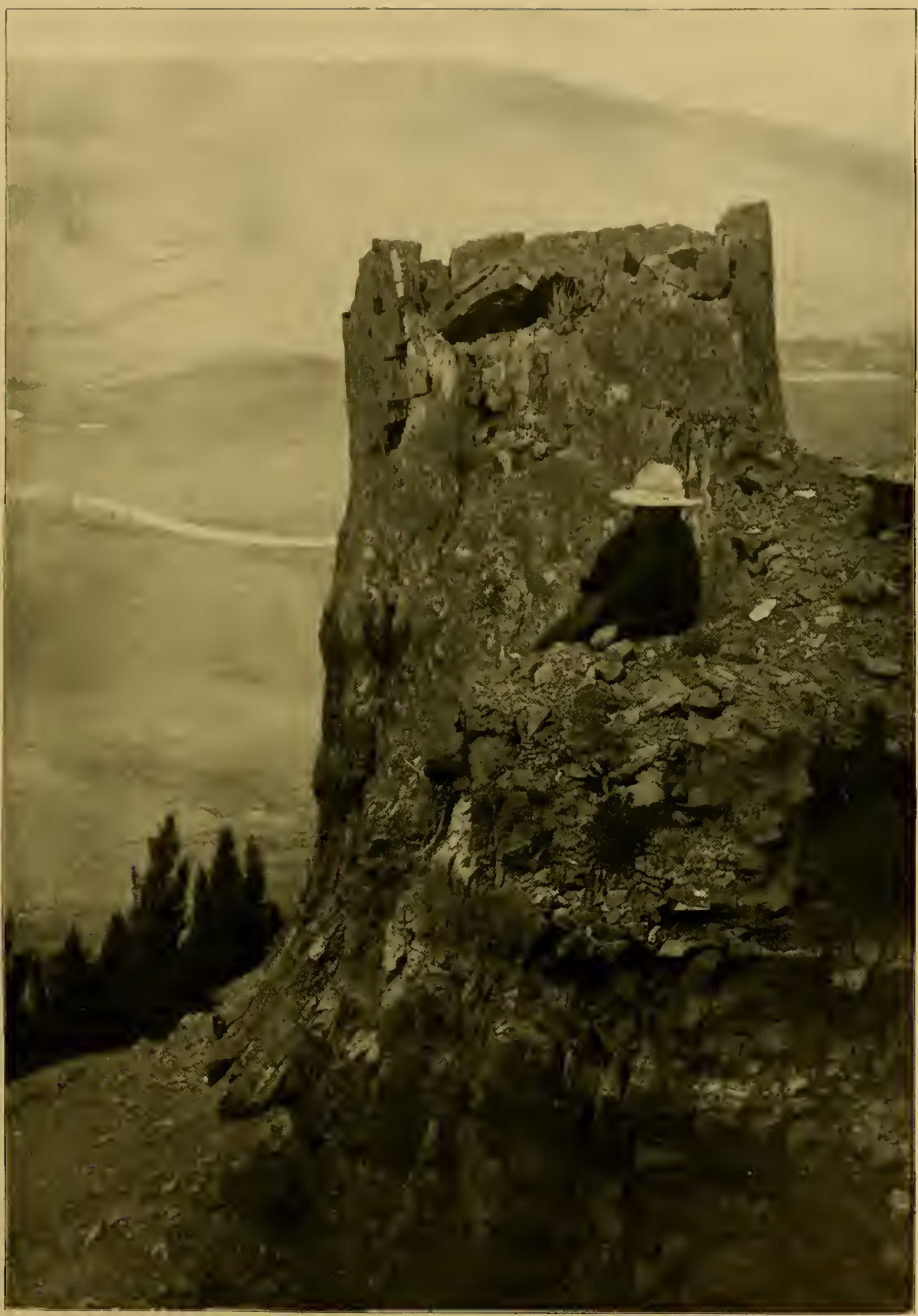

SEQUOIA MAGNIFICA. 
PLATE CVI. 


\section{PLATE CVI.}

Pityoxylon aldersoni n, sp.. 


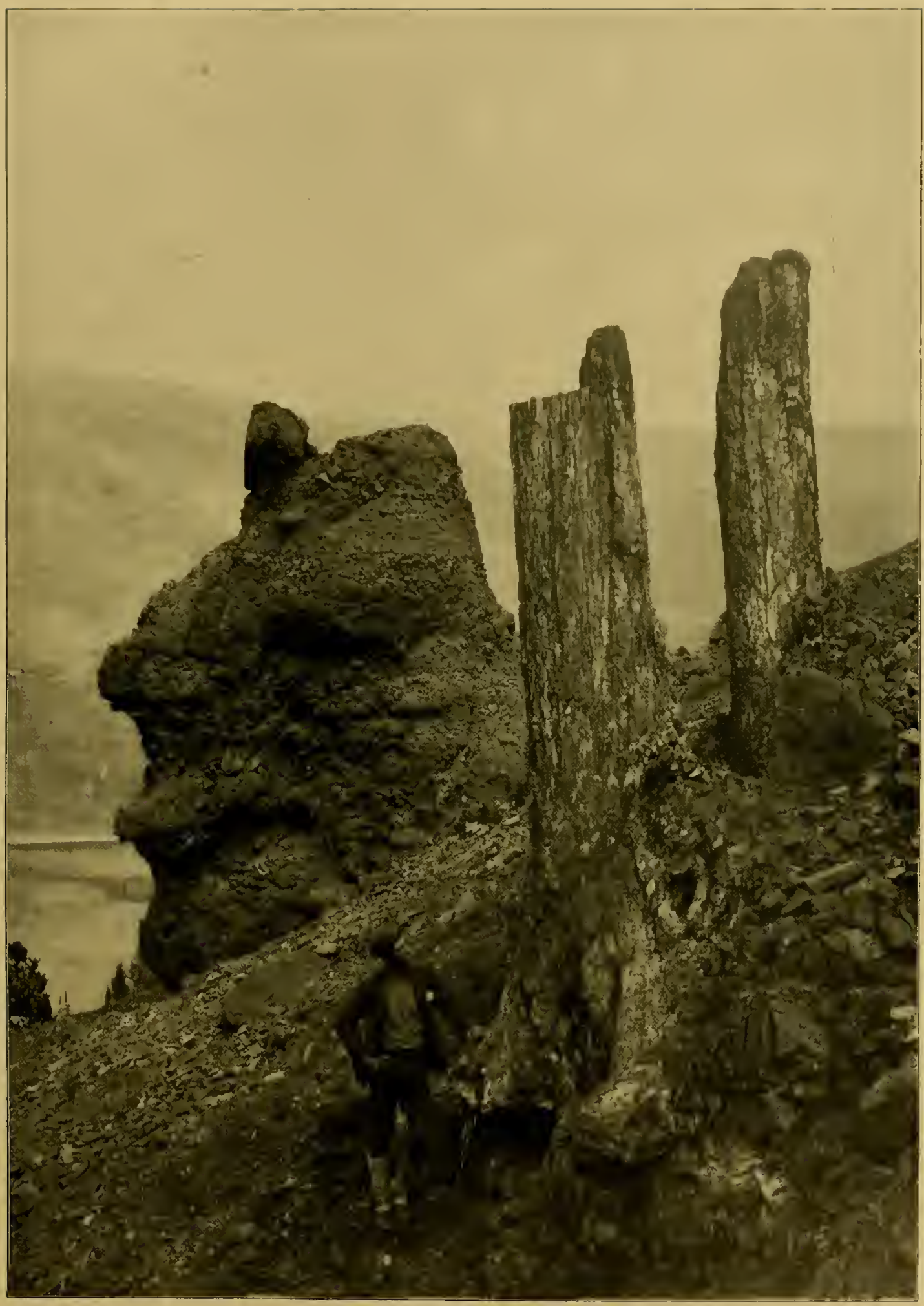

PITYOXYLON ALDERSONI. 



\section{PLATE CVII.}




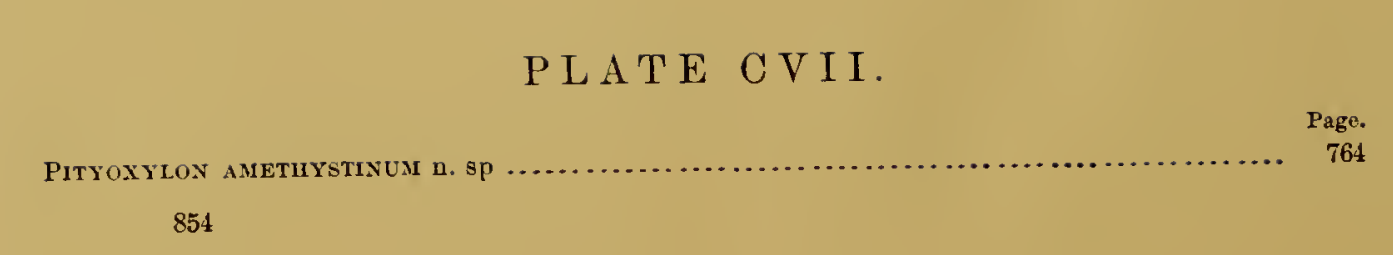




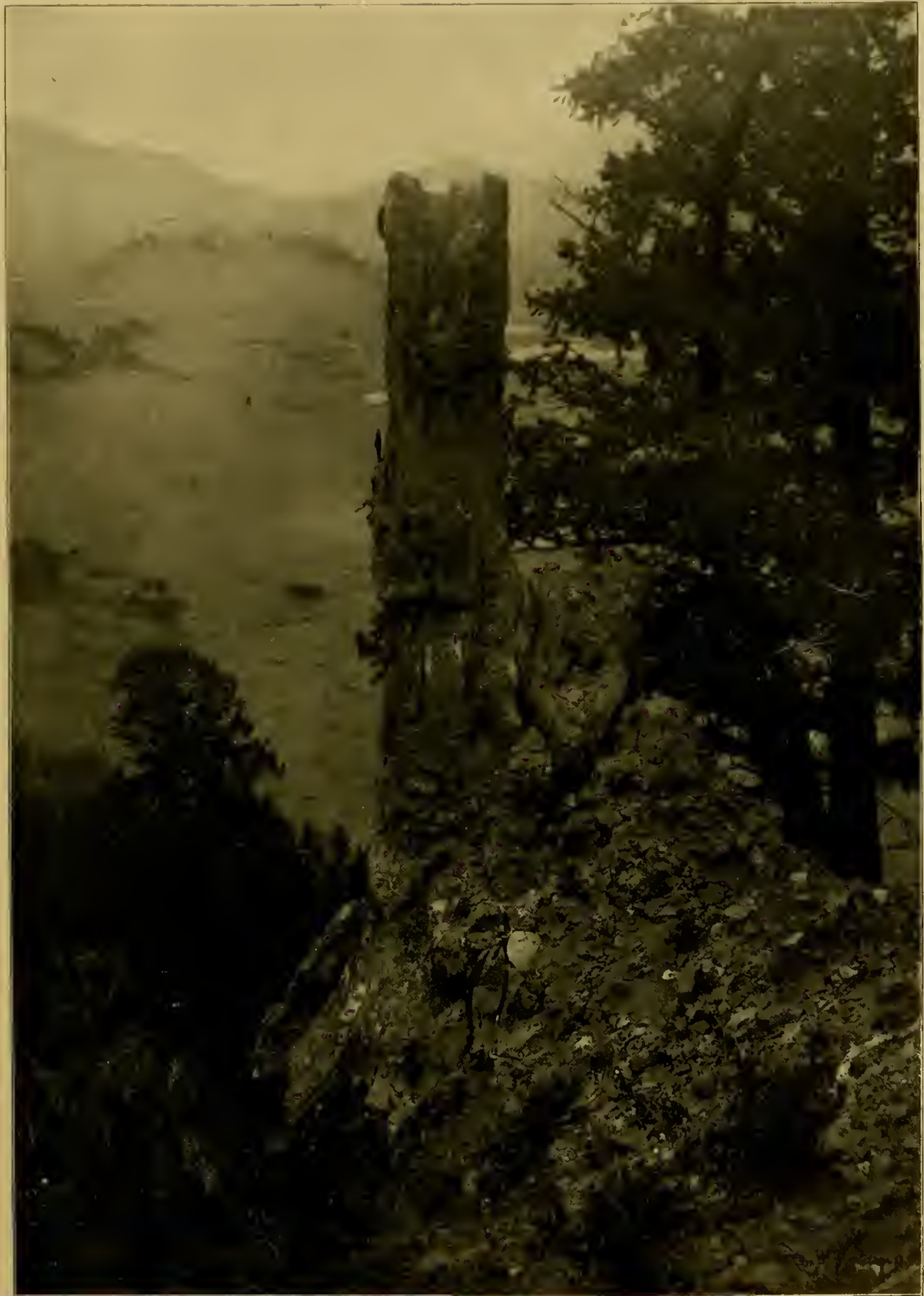

PITYOXYLON AMETHYSTINUM. 



\section{PLATE CVIII.}




\section{PLATE CVIII.}

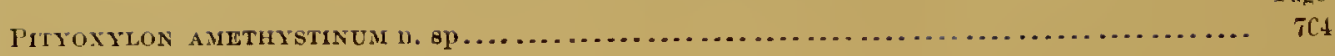




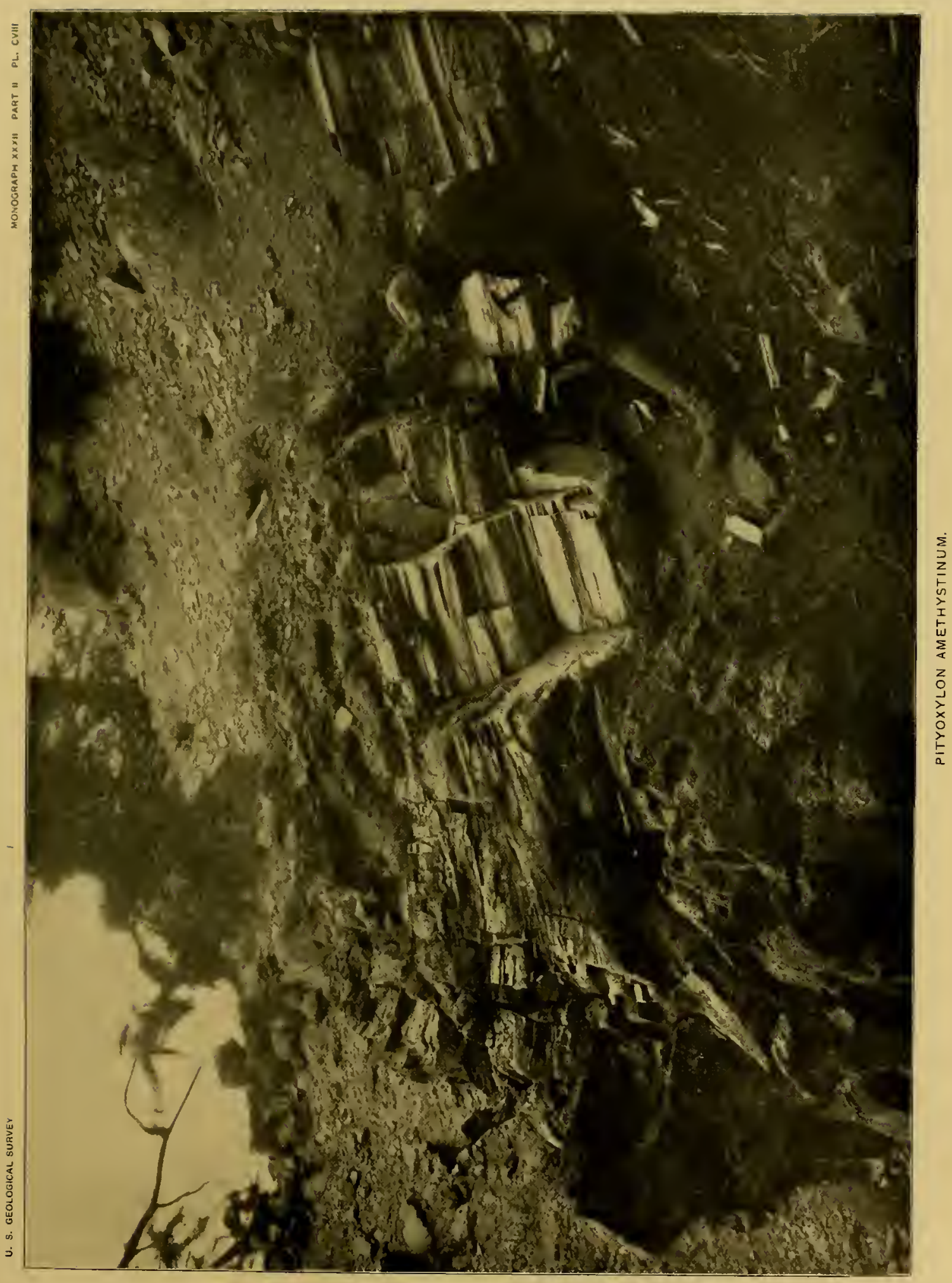





\section{PLATE CIX.}




\section{PLATE CIX.}




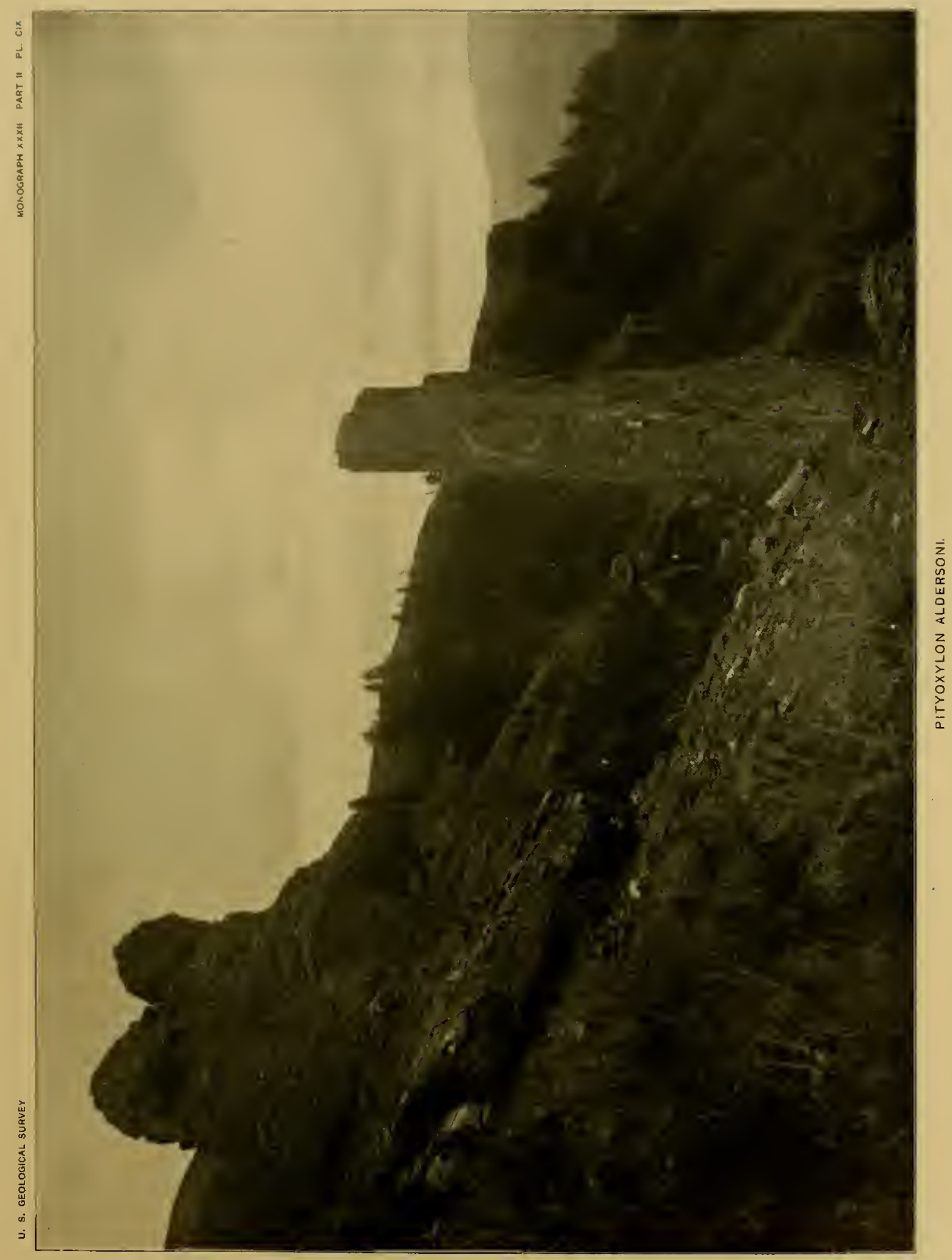




\section{PLATE CX.}




\section{PLATE CX.}




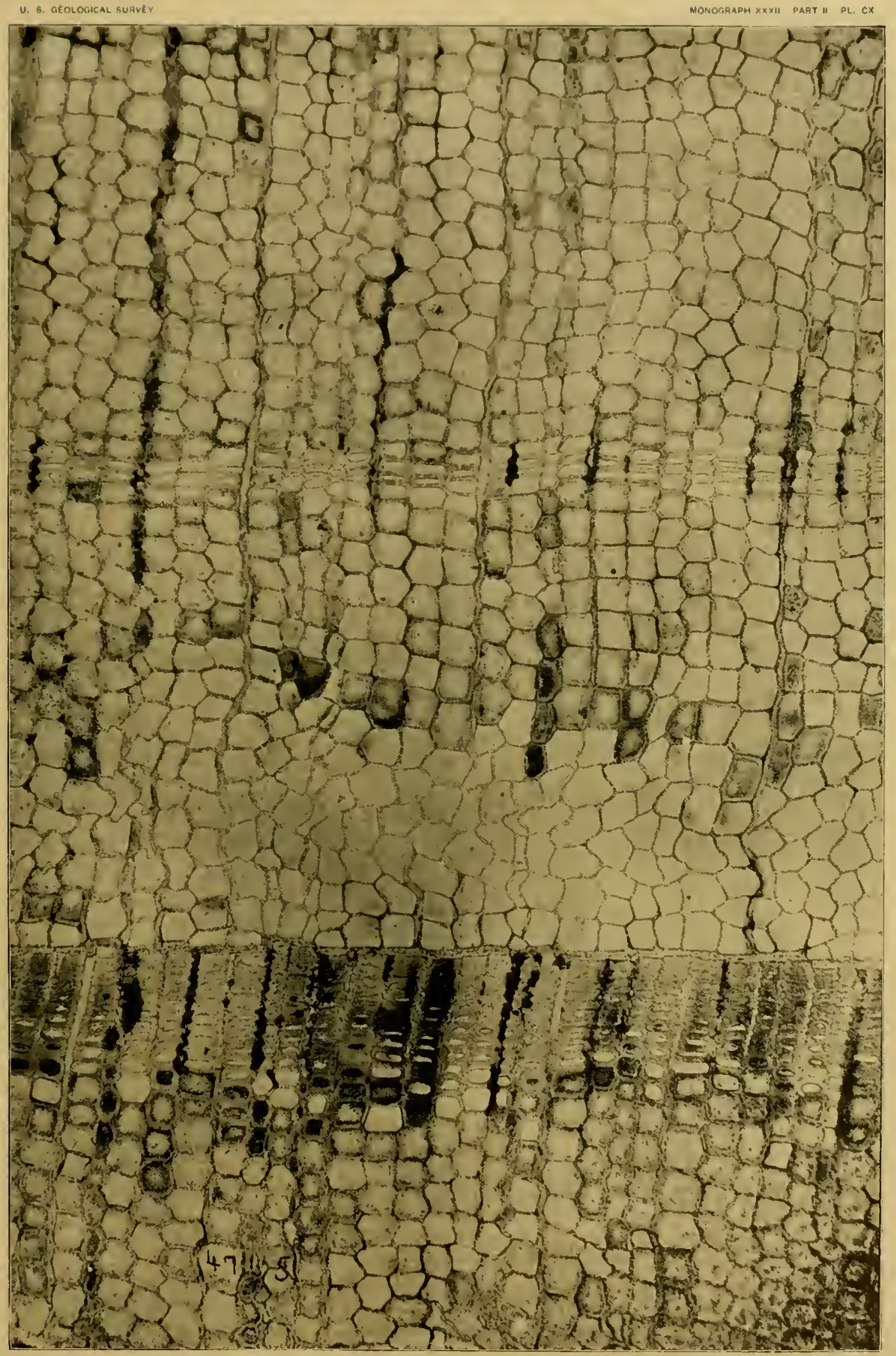





\section{PLATE CXI.}




\section{PLATE CXI.}

Transverse section through one annual and two smaller rings of growth. Magnified 100 diameters. 


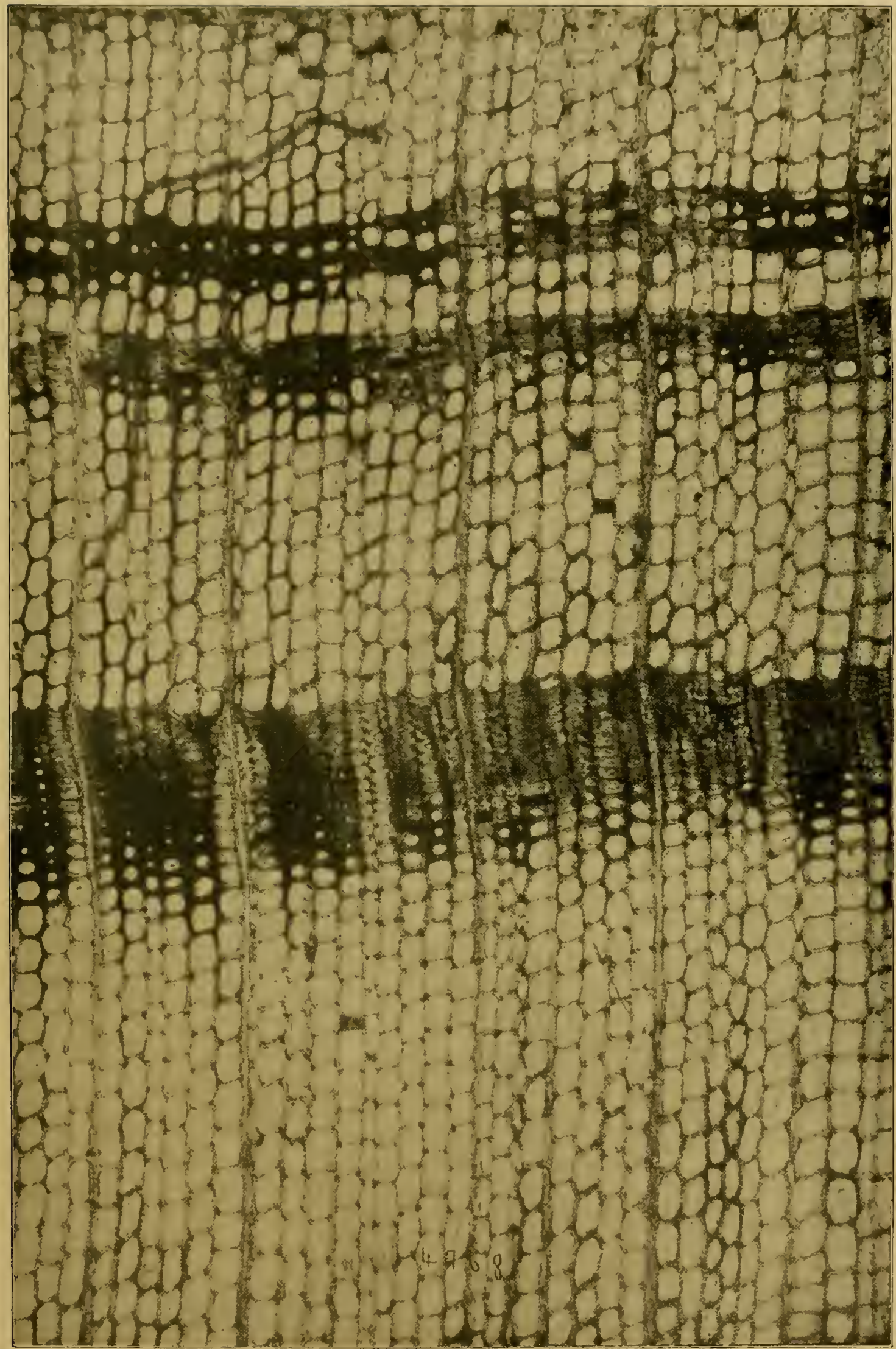




\section{PLATE CXII.}


<smiles>[CH]C#C</smiles> 


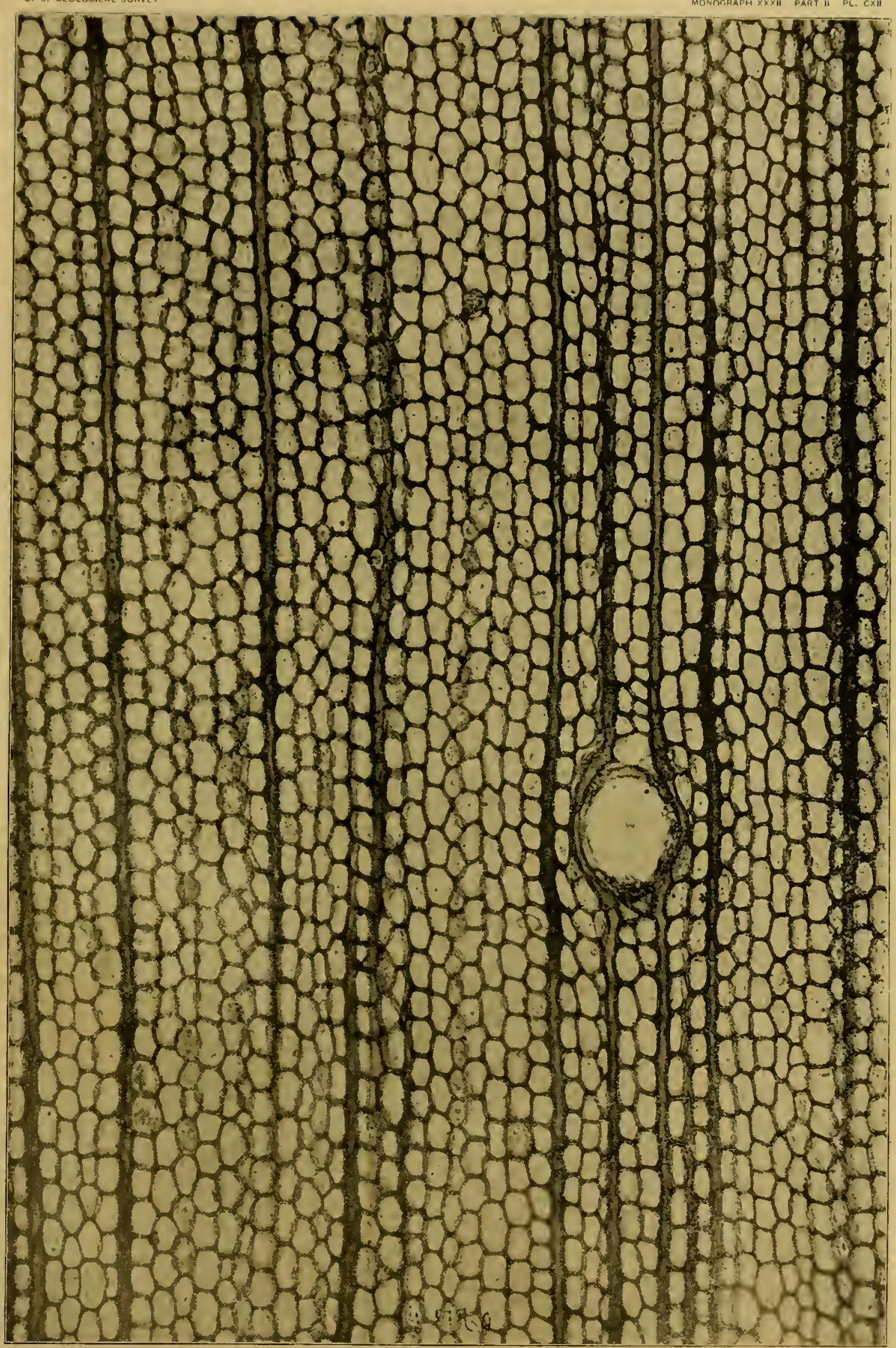





\section{PLATE CXIII.}

MON XXXII, P'I II- T, 



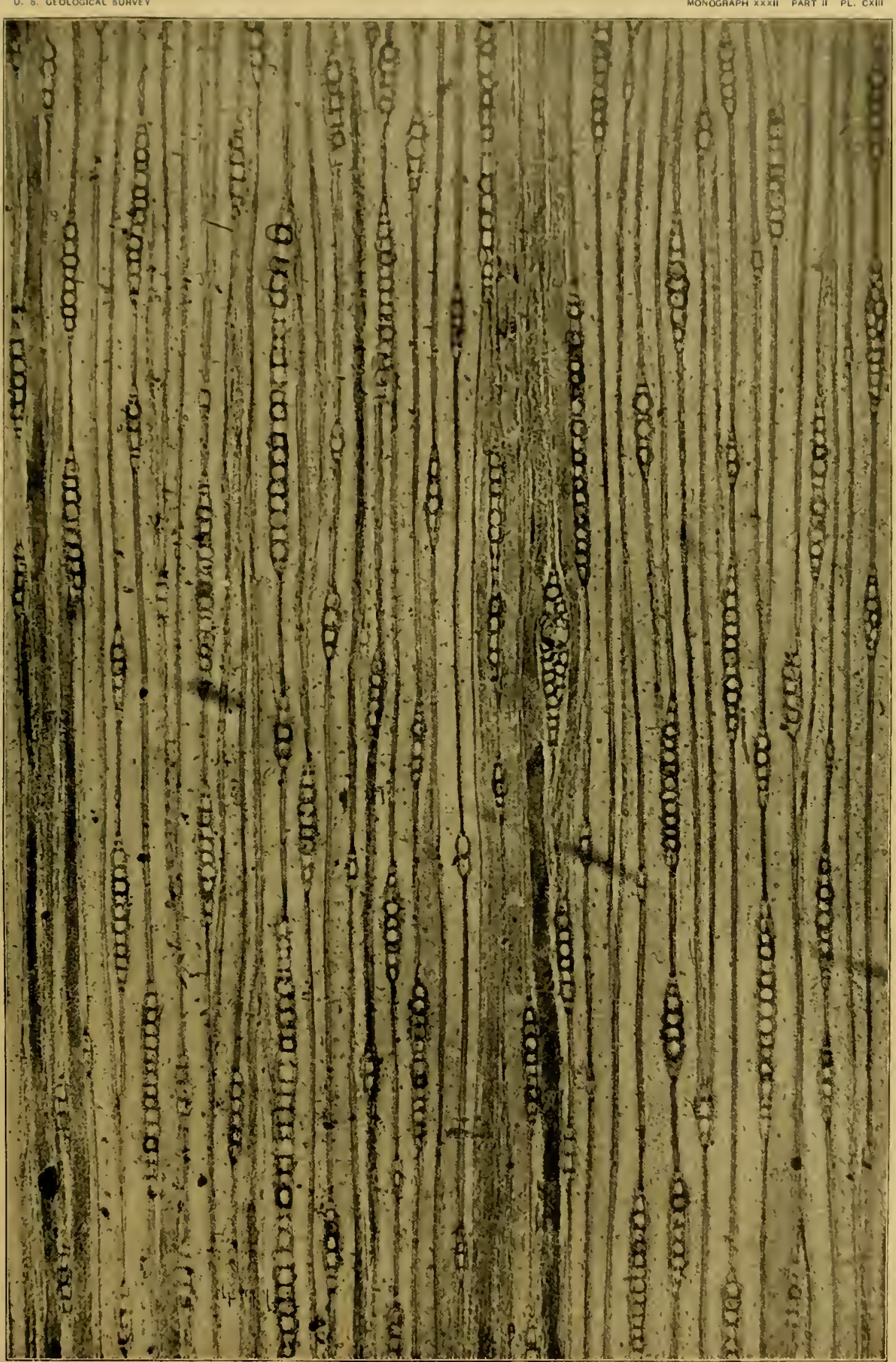

PITYOXYLON ALDERSONI. 



\section{PLATE CXIV.}




\section{P I A T E C X I V.}

PITYOXYLOX AMLTUIATIXCM n, s]

'Transrerse section prossing nearly though one aunual ring. Multiplied 100 dianeters. 


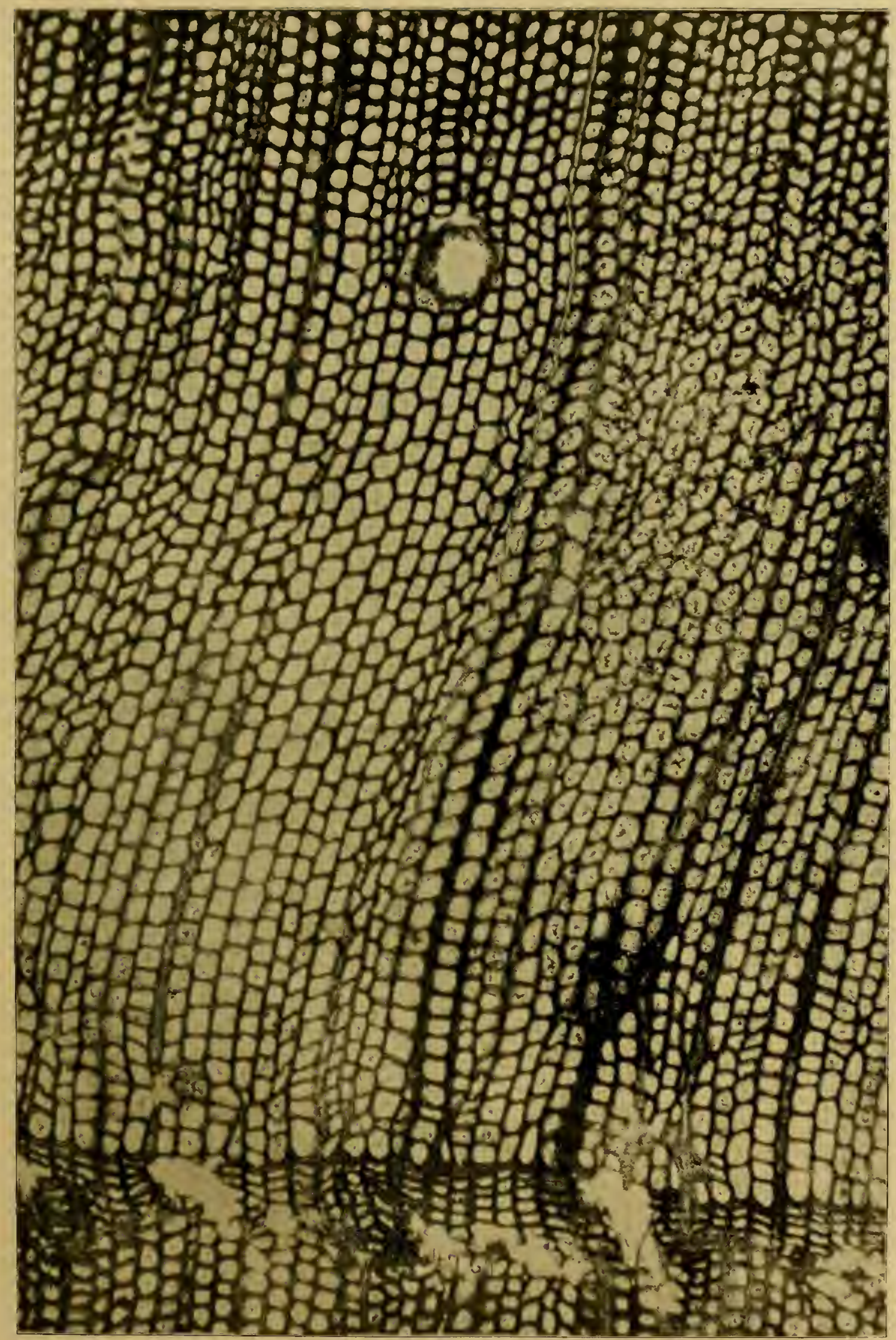




\section{PLATE CXV.}




\section{PLA T E C X V.}

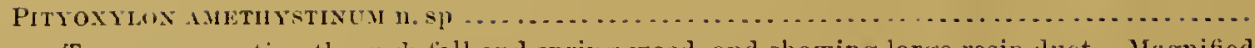

Transverse sertion through fall and spriug wood, and showing large resin duct. Magnified 100 dimueters. 


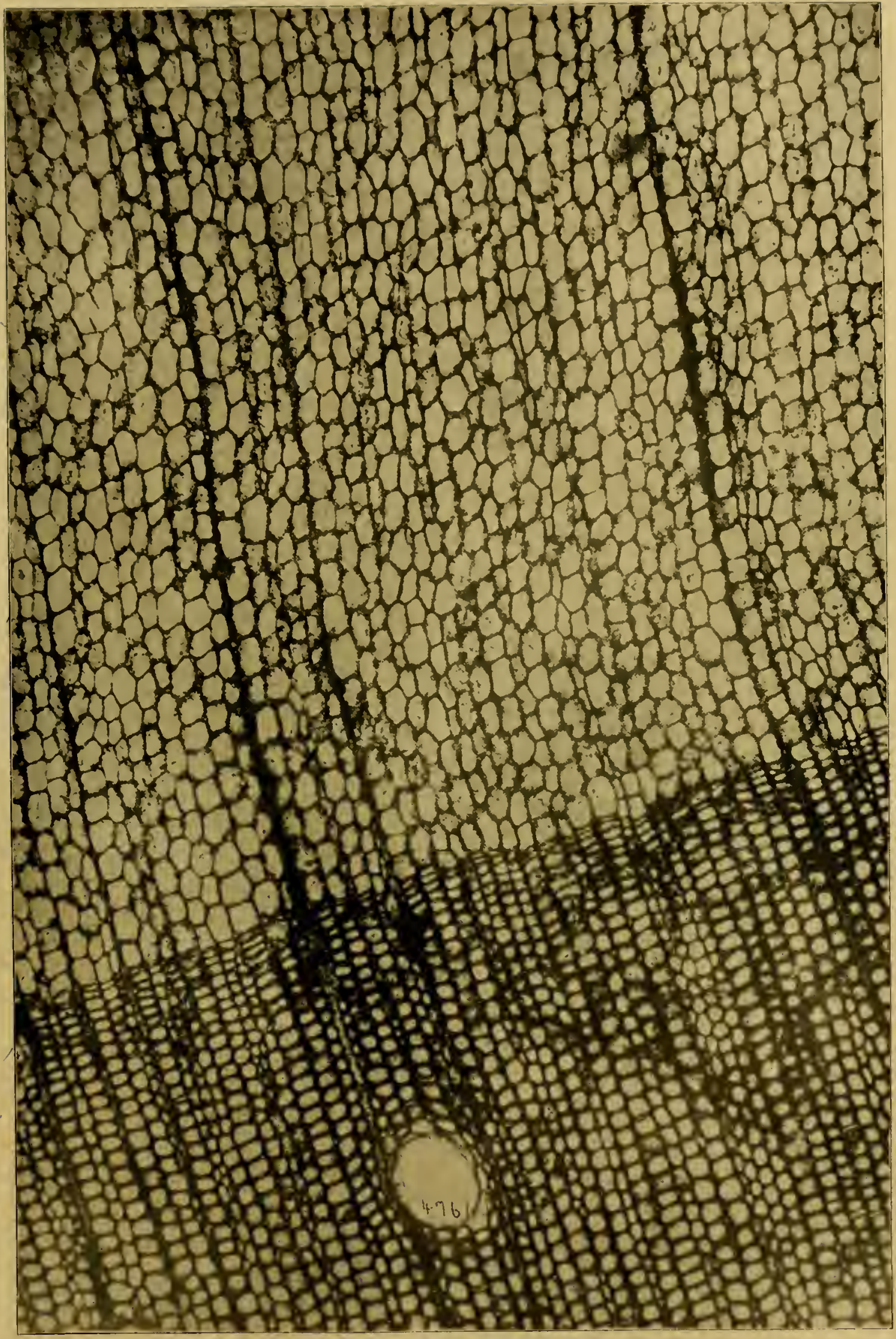




\section{PLATE CXVI.}





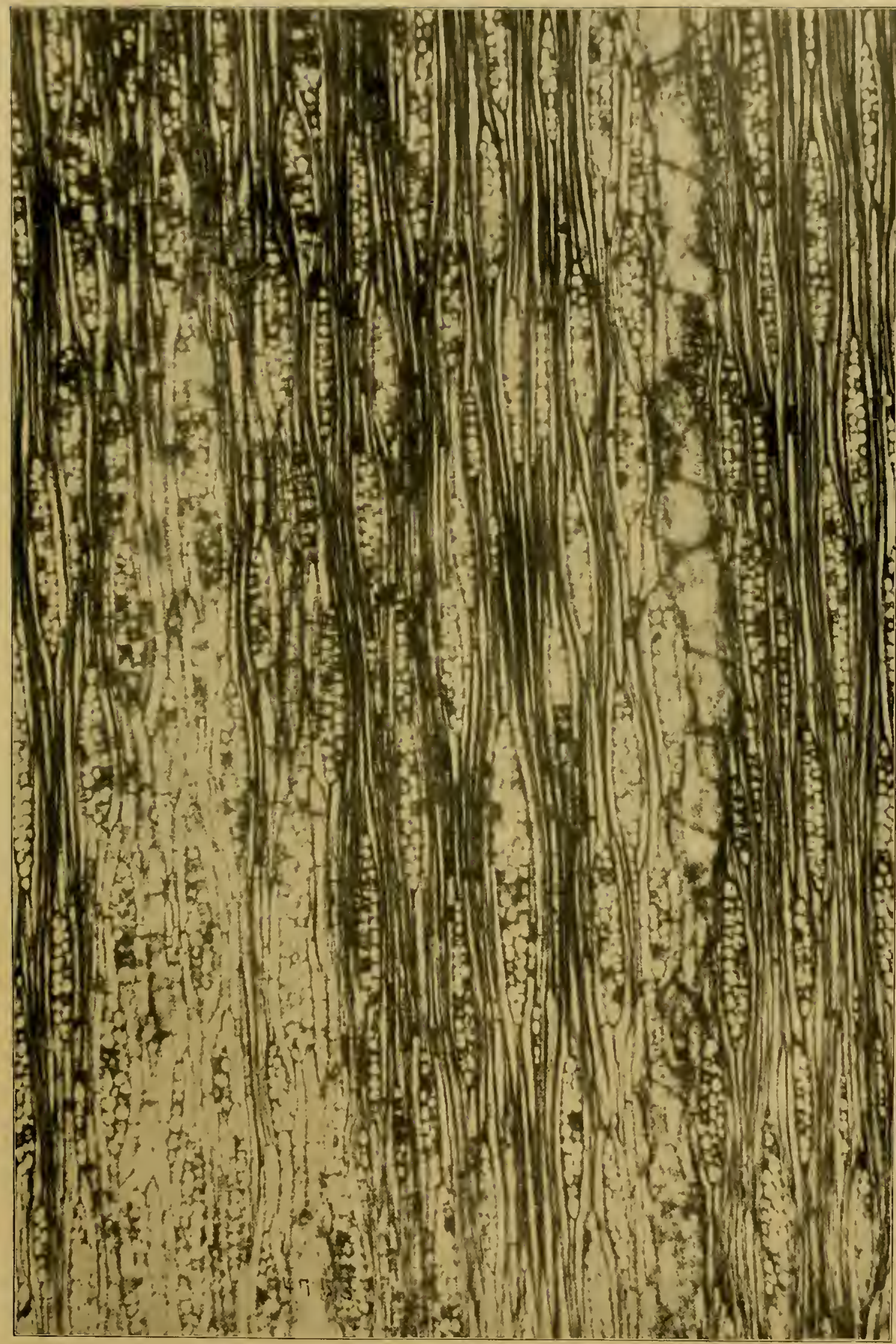





\section{PLATE CXVII.}




\section{PLATE CXVII.}

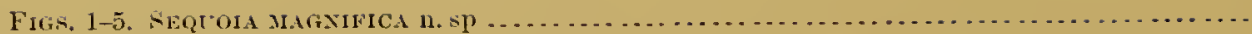

1. Tangential section $\times: 10$ diameters. Shows wod iells, unednllary rays, and resin tube of short square-wallesl cells.

2. Radial section $\times 90$ dianters. Slonws mood exlls, with a single series of pits, long medullary rays, aut resin tuhe witl dark contents.

3. Rarlial section $\times 90$ dianeters. Suows wool w1ls in vicinity of annual ring, small pits in one or two rows, and merlullary rays.

4. Radial sectiou $\times 90$ diameters. Slows annual ring, with fall anel spring cells and mednllary rays.

5. Tangential section $\times 90$ diameters. Shows wool cells, medullary rays, and resin tube with slark eontents. 

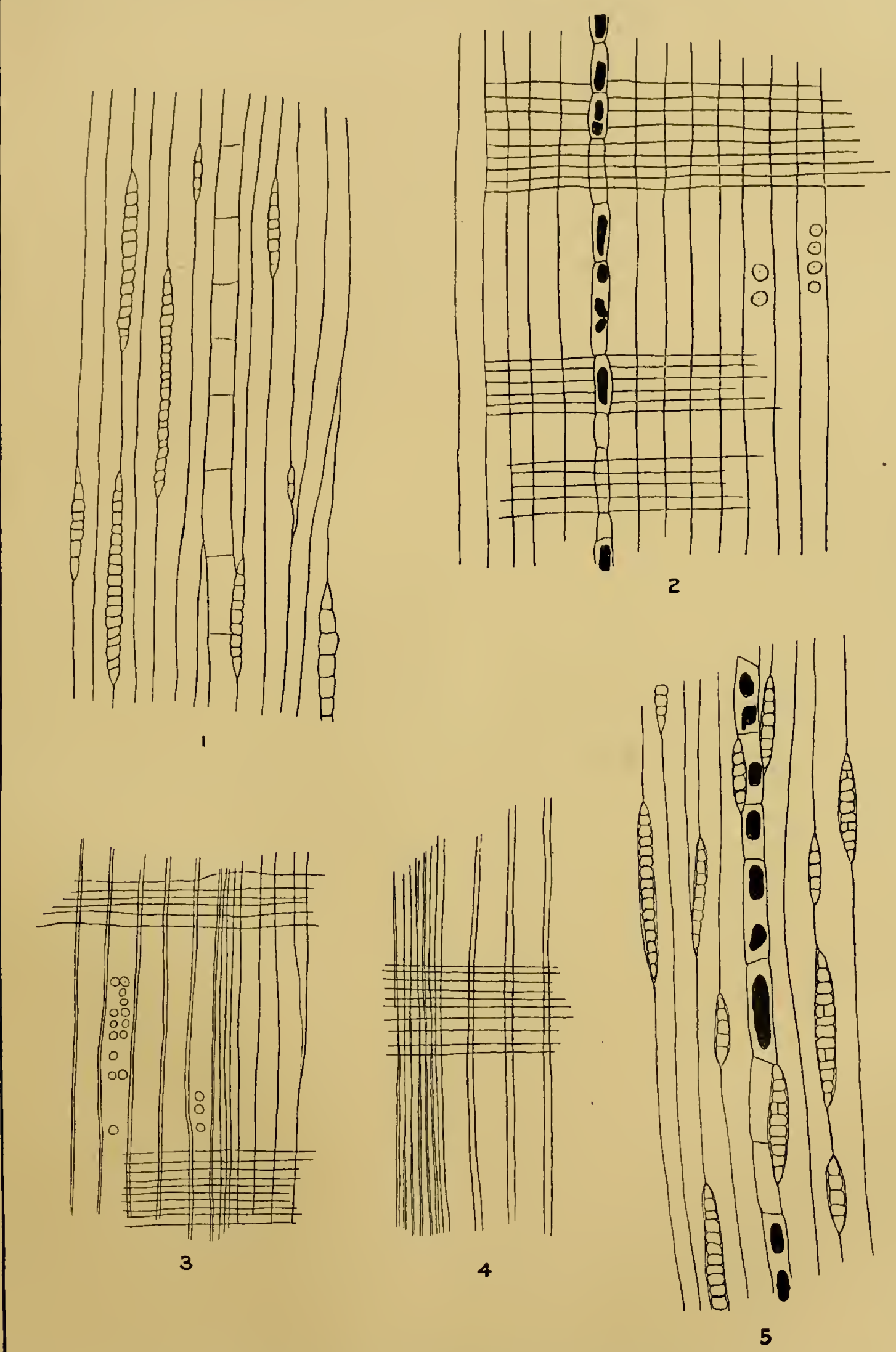



\section{PLATE CXVIII.}




\section{PI. A TE CX Y II I}

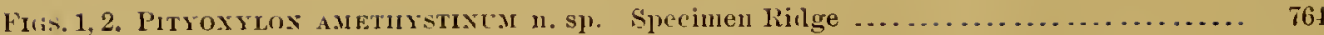

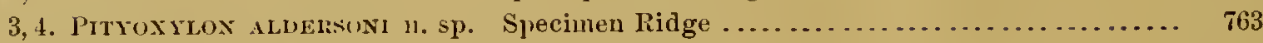

5. QUERTINIU LaMALEXSE 11. sp. Specinen Ridge........................ 771

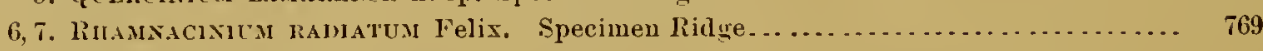

1. Raclial section $\times 90$ iliameters. Shows wood cells with single row of pits, and spring and fall wood; also meilullars rags.

2. Tangential section $\times 90$ cliameters. Slows the long wood cells ami sinut muclnllary rays.

3. Radial section $\times 90$ li:imeters. Shows wood celis with a single row uf pits.

4. Transverse section throngh annual riug, $\times 90$ cliameters.

5. Trausverse section $\times 320$ diameters. Shows the fall and spring wool.

6. Transverse section $\times 90$ diameter's. Shows mehlullary rays of short cells, thin-walled wood cells, anel series of lluets.

7. Tangential section $\times 90$ diameters. Shows wood cells, medullary rays, and dotted durts. 

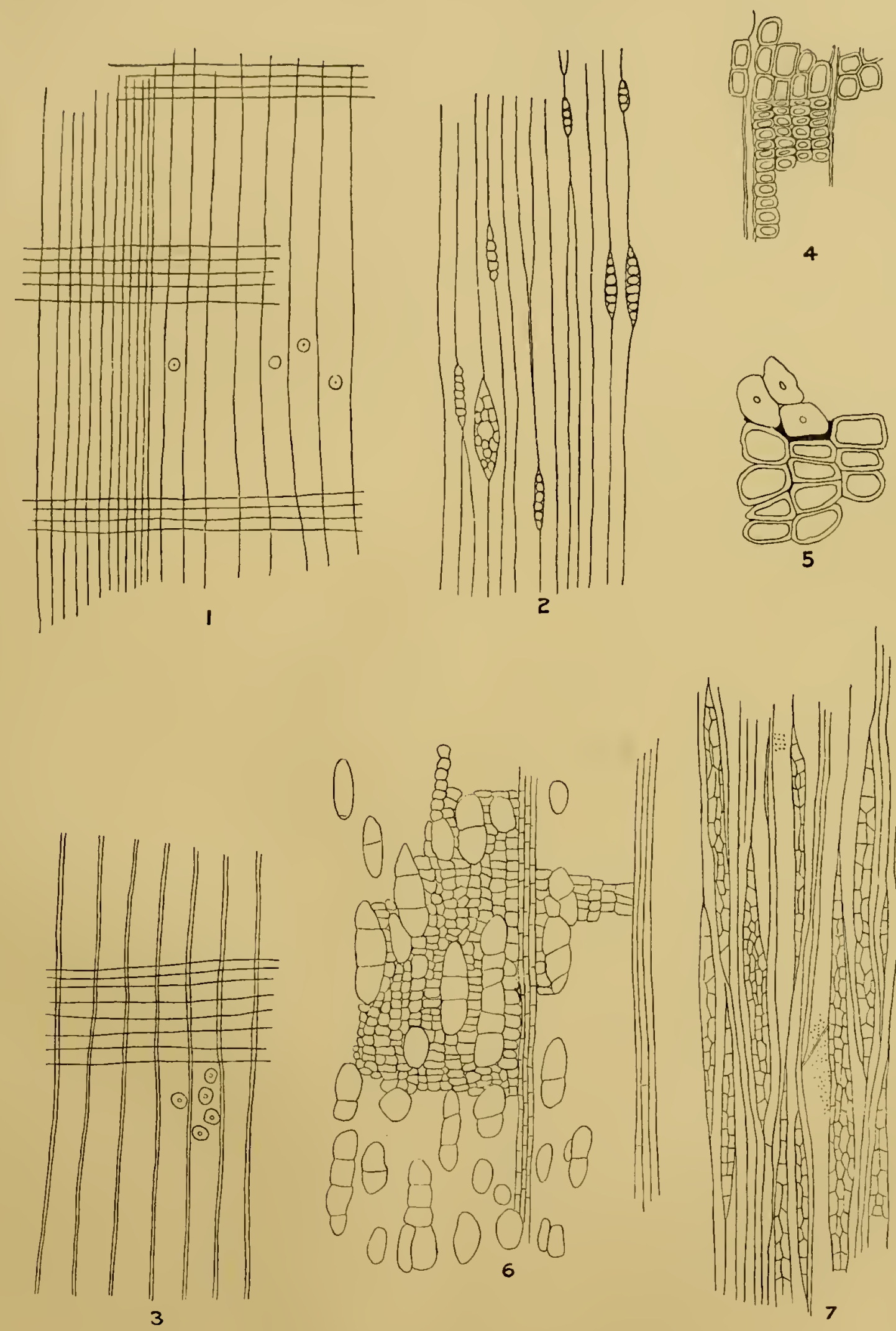

0

A

A)

N $\because$ - 4 A

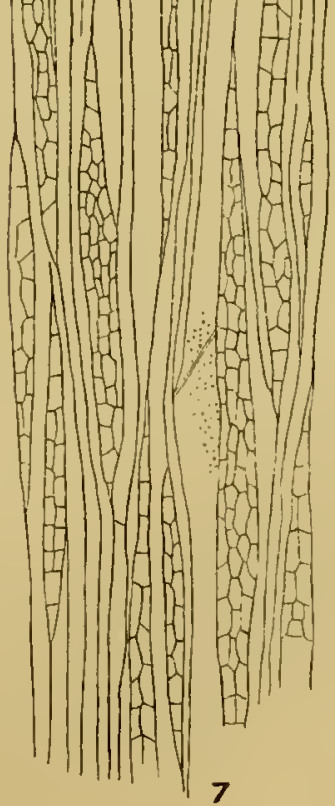





\section{PLATE CXIX}




\section{PLATE CXIX.}

Felix. Specimen Miliger.

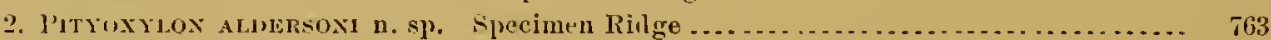

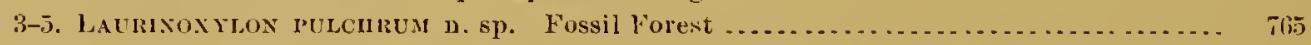

1. Radial section $\times 90$ dianeters, showing wool cells, medullary rays of short cells, and larue duets.

2. Trinsverse section $\times 320$ dianeters, pissing through an aunual ring.

3. Racial section $\times 90$ diameters, showing norrow wool cells, large plate of meduliary rays of sliort cells, and large dotted ducts.

4. Rallial section of reolatiforu luct $\times 320$ diameters.

5. Radial section of dotted luet $\times 320$ diameters.

878 

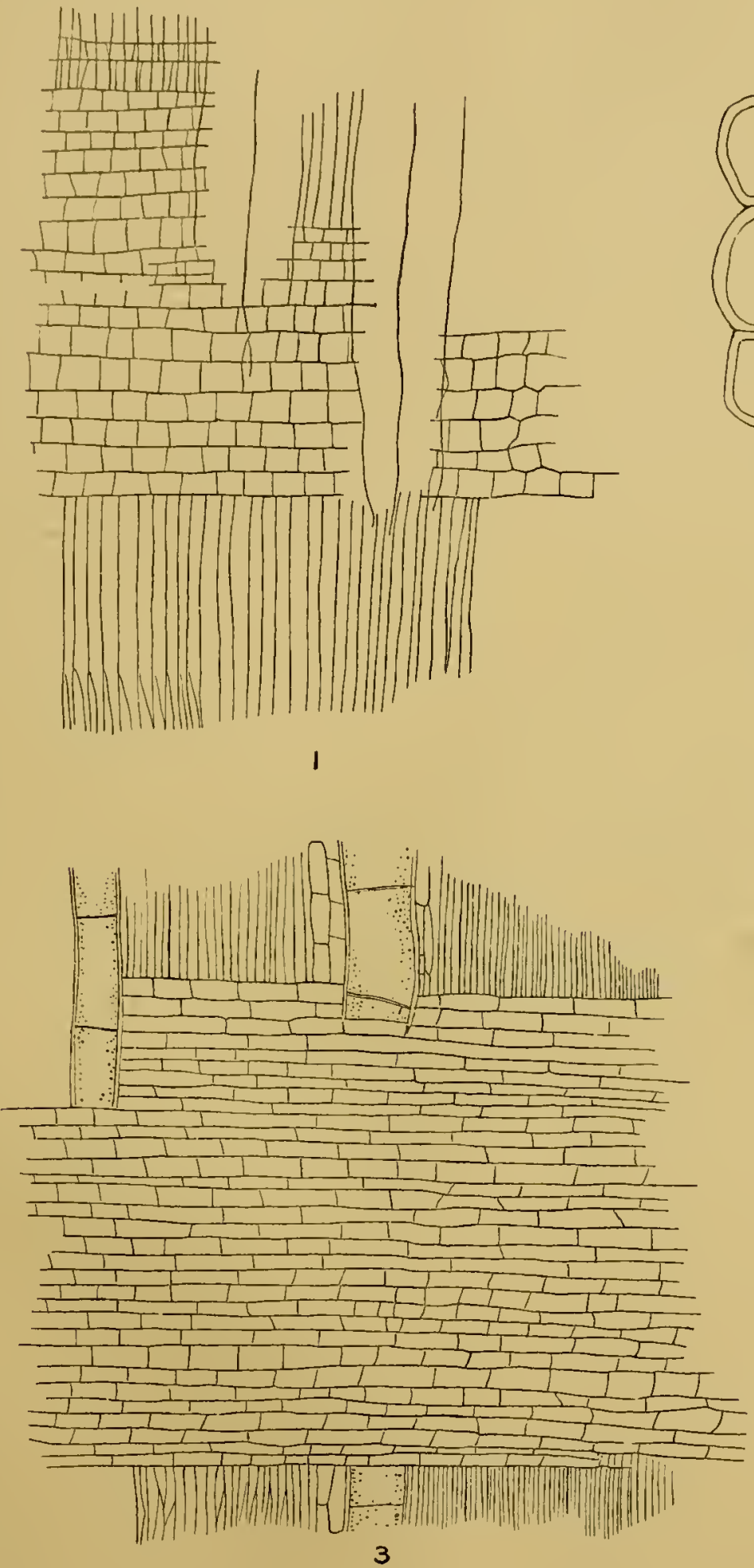
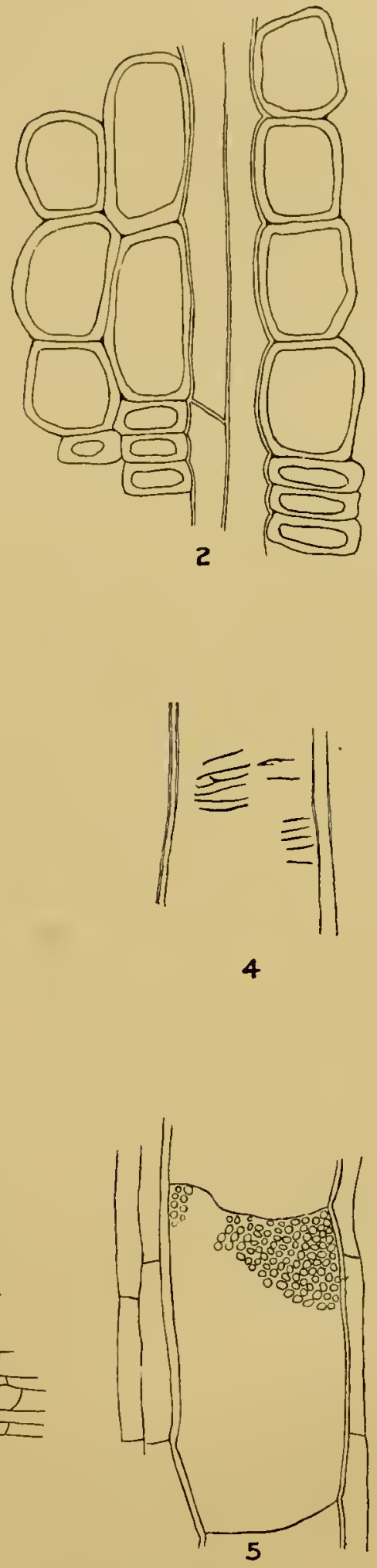



\section{PLATE CXX.}




\section{PLATE CXX.}

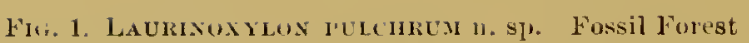

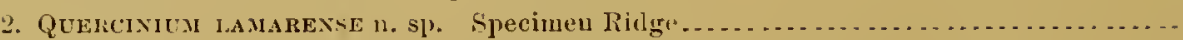

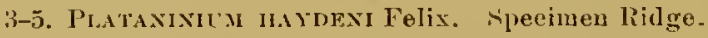

1. 'Transverso section $\times 90$ diaucters, shuming wond cel]s of two kinds, medullary ritye, and large ducts.

2. Transverse section $\times 320$ dinneter's, througl duet.

3. Tangential section $\times 90$ dianwters, showing woul cells, scalariform ducts, and very lirge medullary rays.

4. Transverse section $\times 90$ diamcters, whowing short-celled unedullary rays with black cell contests, wood cells in ricinity of ammul ring, and unmerons large ducts.

5. Radial section $\times 90$ diameturs, sbowing narrow wood cells, numerous ducts, and shortcelled mednllary rays.

$8<0$ 


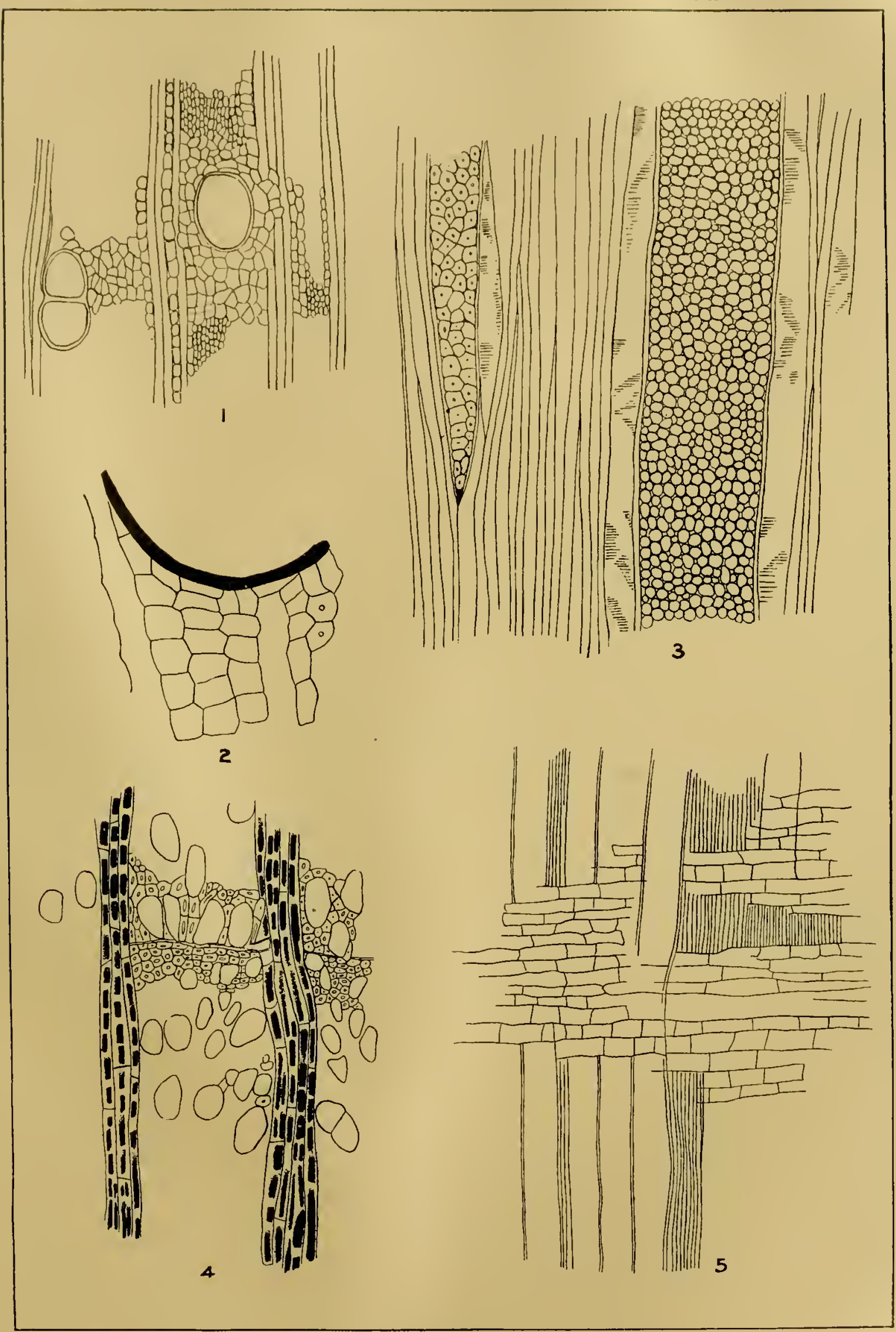

TERTIARY 



\section{PLATE CXXI.}




\section{PLA TE CXXI.}

Figis. 1, 2. QTercisium lamaresse n. sp. Specimen Rilge

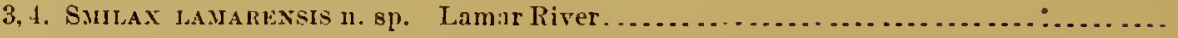

1. Trausverse section $\times 90$ diameters, showing thick-walled wood cells, immense ducts, and usullly single-cellel merlullary rass.

2. Tangential scction $\times 90$ diameters, showing wood cells, and large and swall uedullary rays. 


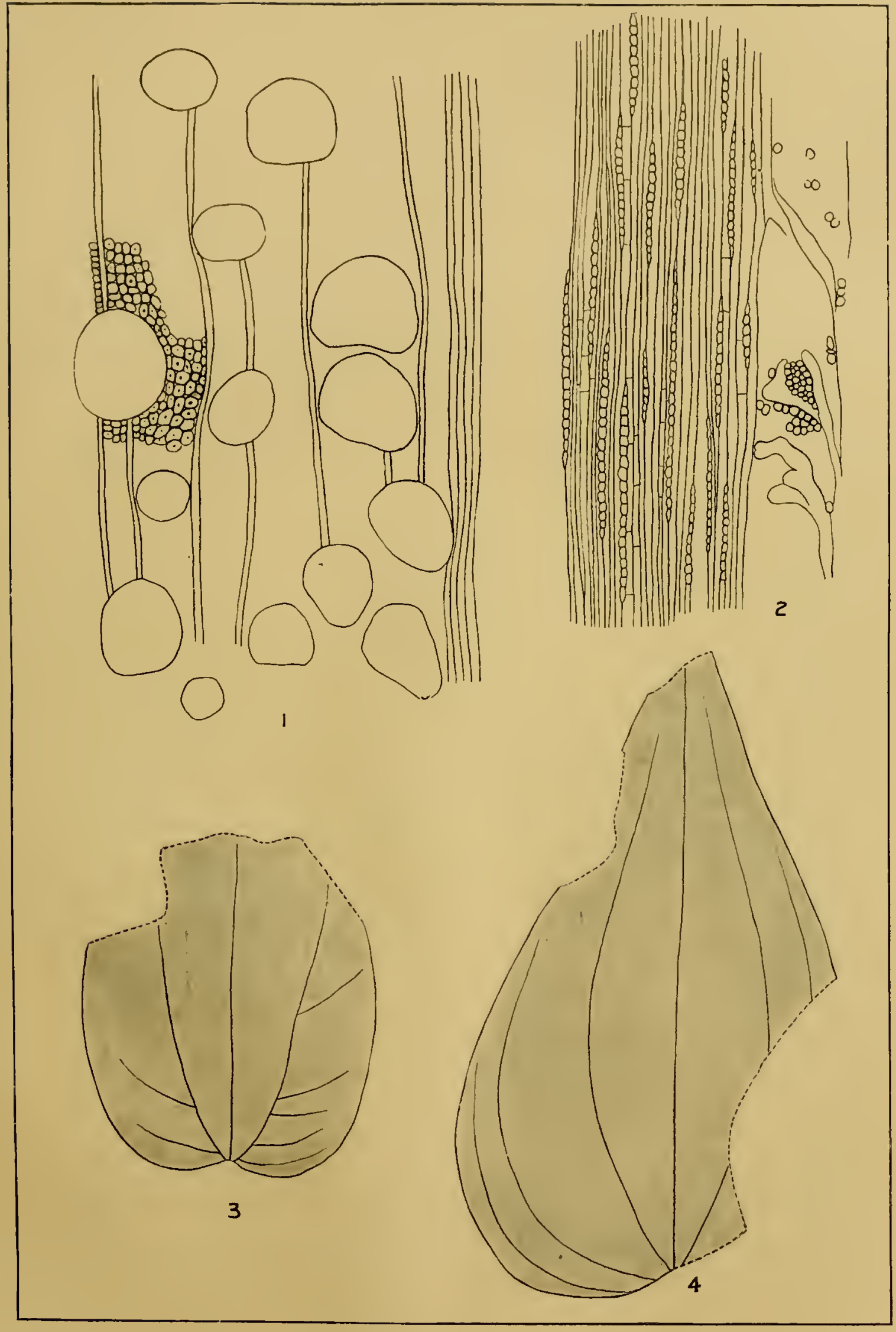

TERTIARY 



\section{NDEX.}

Nimbers in ila'ic are those of pages on which illustrations (plates or figures) appear; numbers in black-fuccl tspe are those ut pages un which fossils are described iu dutail.

\section{A.}

A bietites dubius Lx.ex.

A bsaroka liange, analyses of rocks of............

Absarokites, analyses of ...................... $83,329,352$ churacter aud uccurrence of.................. 328-339

pbotoujeregraphs of .

A bsarokite-shushonite-banakite rucks, character and occurrence of

Acacia lamarensis n, sp.

Acacia macrosperma n. sp................... $\mathbf{7 9 9}, 836$

Acacia microplyylla Heer....................... . 730

Acacia wardii u. 8 . ......................... $7 \mathbf{3 0}, 836$

Acambena ugagensis Swallow................... 560

Aceracese, descrjption of species of ........... 735-736

Acer, fruit of . ............... 736, 330

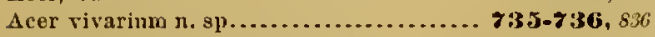

Acer trilobatum productum Heer................ 73

A cer trilobatum tricuspidatum Heer............. 736

Acrotreta attenuata $\mathbf{H e}$..................... $\$ 49$

Acrutreta gemma Billings................... 449,472

Acrotreta pyxilicula White .................... 44

dcrotreta subconica Mleek .................... 449

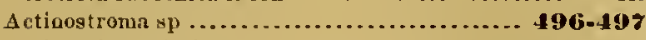

Actinocriuus viaticus ........................ 488

A gnostus bideus Meek ................... \$5. 4 fif

A guostus interstrictas White ........... 154-455, 47 4

Agnustus josuphus ................

455

Agnostus tumilesus H. \& W ............... 45, tit

Allanite, occurrence of .......................

Alnus carpiueides $\mathrm{Lx} \ldots \ldots \ldots \ldots \ldots \ldots \ldots \ldots \ldots \ldots . .6 \%$

Alum Creek, obsidian near ..................... 388

A naly res of rocks. $61,65,70,81,83,116,163,260,261,263,272.325$

Amethyst Mountain, fossil forest o11.............. $757-758$

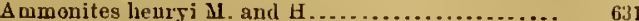

A rnmonites placenta De Kay .................... 640

Amnicola (?) cretacea..................... $\mathbf{6 3 3}, 648$

Auacardiacere, descriptions of species of........... 73

A uatina (Cercomya) punctata u. sp ........ 625-629, 640

A vatina (Cercomya) sp ...................... 629

A udesite, character of $\ldots \ldots \ldots \ldots \ldots \ldots \ldots \ldots \ldots \ldots, 4,75-82,122$

occurrence of ..................... $4,24:-246,314-321$

photomicrograph of ....................... 850

A udesite-porphyry, characters of ............... 16,94-97 occurrence of .... 10,12, 19, 211, 21, 21, 12, $43,45,16,47,52,59$ photonucrographs of ...................... 62,104 A pdesitic breccia, occurrence of ............. 4, 56, 270-27t A udromeda grayana $\mathrm{Lx}$...................... 661 Auemia subcretacea (Sap.) Gard. and Ett........ 657, 658 A visotrypa sp........................... 516.517

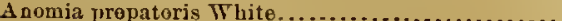

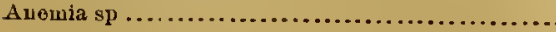

Anuuites scabriculus Nurwoud aud Pratten... .2 Page.

Inomites semireticulatus Martı ................ 535

Autler l'eak, features of ...................... 20,23

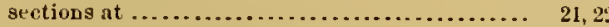

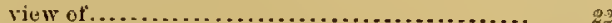

Apatite, occurrence of ........................

Araliacex .................................

A ralia nngustiloba $\mathrm{Lx}$....................... 745

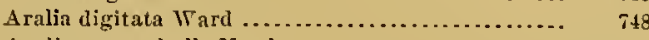

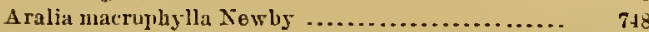

Aralia notata Ix....................... 745-747,840

Aralia serrulata n. sp .................. 747-7 18, $s 4$ ?

Aralia sp...................................

Aralia whitneyi Lx ....................... $\mathbf{\$} \$ \mathbf{8}, 838$

A ralia wrightii n. sp ..................... $744-745, s 47$

Arca sp .................................... 638

A rehimedes 8 n......................... 492, 519.520

Aretustophyles elliptica n. sp............. 750-751, 8\%4

Arctostopuylus uva-ursi (L.) spreug ............. 750

Arionellus (Bathyurus) texanus sloumard ......... 460

Arionellus levis u. sp................... \$62-463,4 2

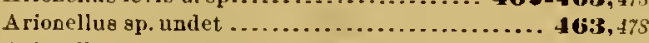

Arionellus tripunctatus Whitfield ..............460,461

Artocarpus incisa L . . . . . . . . . . . . . . . . . . . . . $\quad 717$

Artocarpus legsigiana (Lx.) Kn .................... 717

Artocarpus ? "1uercoides n. 8p ............ \% 16-7 18, s.4

Asplenium erosum ! (Lx.) Kn .................... 668-669

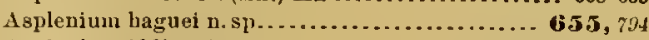

Asplenium iddingsi 0. sp ............. (i66-667, 298,800

Asplenium magu um n. sp................. 667, 668 , 79s

Aspleniun remotilens n. sp .................... (569, soo

Astarte meeki n. sp ......................... (620,64t

Astarte packarti..............................

Astarte sp .................................. $\mathbf{6}: \mathbf{2 0}$

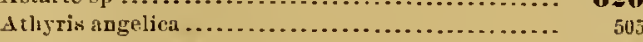

Atuyris asblandensis Herrick .................. 562

A thy ris claytoni . . . . . . . . . . . . . . . . . . . . . .

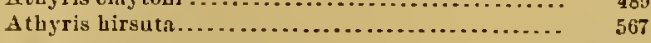

A thy ris iucrassata White.................... 488,562,563

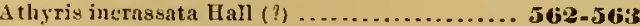

Athy ris lamellosa Muok ....................... 561

Atuyris lamellosa Léveillé............. 561-562, 698

Athyris mira.............................. 570

A tliyris occideutalis ........................... 505

Athyris occideutalis var. triplicata............... 505

A thyris planesuleata (?) Hall aud Whitfield ... 489,533,554 At lyris roissyi ............................ 566 -507

Atbyris royssi Walcott ...................... 569 Athyris vittata var. triplicata 0. var....... 504-505, 550

A trypa desiuamata Walcott...................5 502,503

Atrypo reticularis $1 \ldots \ldots \ldots \ldots \ldots \ldots \ldots \ldots .481, \mathbf{5 0 2}, 503.550$ 
Page.

Atrspa missouriensis Miller. $81,50 \div-504,580$ Aulopora geometrica n. $\mathrm{p}$. $492,508-509,584$ A valanche Pesk, dikes and rocks of............... $305-306$ Aricula custa Hall.

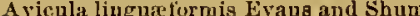
Aricula mucronata ............................ Aricula nebrascena Evansand Shumard.......... 6:5 Aricula (Oxstoma) unucroutata $\mathrm{Xl}$. and $\mathrm{H}$ Avicula (Uxytoma) wyomingeugio $\mathrm{D} . \mathrm{sp}$

B.

Baculites asper MLorton (?)..................... 636

Baldy Hountain, character of rocks at........... 310,344

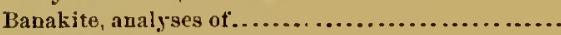
character and occurrence of $\ldots \ldots \ldots \ldots \ldots \ldots \ldots . .34-351$

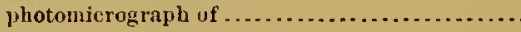

Bannock Peak, features of .

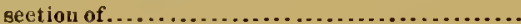

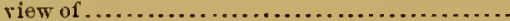

Barlow Peak, features of ........................ 192-194 fossils of ............................... 193

Baroda wromingeusis Meek .................... 638

Baronett Peak, view of......................... 204

Basalt, analysis of ............................ 438 character of ....................... 239-240, 241-242 interuingling of rhyolite and ............. $430-432$ occurrence of . ............. 241-242, 275-281,302-304, 439 photomicrographs of ......................250,430

Basalt-porphyr5, occurreuce of ................ 244

Basaltic andesite, occurrence of.............. 296, 302-394

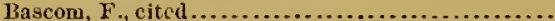

Bathyuriscus JIeek $(1) \ldots \ldots \ldots \ldots \ldots \ldots \ldots \ldots \ldots \ldots, \mathbf{4 6 6}$

Bathyuriseus ap. undet ......................... $\quad 469$

Lat by urus conicus Billings ................... 465

Bear Creek, Mantana, analysis of rocks from........ 352

Bea rerdan Creek, lavas on ..............340,342, 347,350

Bechler Canjou, rhyolite of ................. 375-377

Belemnites densus 4 . and H ................63 1-6342

Berr. Creek, sectiou of rocks ou .............. 153-154

Betuls elliptica Say ........................... 698

Betula iddingsi $n$. sp................... $695-699,81$ ?

Betula lutea Micbx . ...................... 699

Betula parcedentata Lx .......................... 698

Betula prisea Ett.......................... 699

Betula sterensoni Lx........................ 698

Betulacer, descriptions of species at .........695-699

Big Game Ridge, descriptire geology of............ 165-202 features of .............................. 188-191

Bighorn Pass, featnres of ...................... $24-27$ intrusive sheet at ......................... $69-72$ section at . . . . . . . . .

Billingsella Hall ........................... 450

Billingsella coloradooneie Slumard ....... \$50-\$51, 470

Billiugsella pepina Hall and Clarke ............... $\$ \mathbf{4 5 0}$

Birch Hills, analjeie of dacite porphyry of......... 163 features of ............................. 162-164

Isobcat hidge, rocke of ....................... 180-181

Bornemann, J. G., cited ...................... $\$ 12$

Brachiopoda, descriptions of species of. . 502-505, 609-610, 636

Breccia, acid, occurrence and character of ......... 121-127, $219-220,237,270-274,281-296$ andesitic, occurrence of ................. $4,56,91$ baeic, occurrence and character of ........... 220-223 $238-239,275-281,296-298$

Bridge Creek, rljolite on ..................... 386-387 Brügger $_{t}$ W. C., cited......................... 240
Page.

Bryozoa. descriptious of epecies of ............... $516-576$ Buffalo plateau, geology of ...................... 206-207 Bumsen Peak, intrusire rocks of ................ $86-88$ Byemalith, detiuition of...................... 17-18

\section{C.}

Cacbe Creek, fossil forest on ................... 760 Caniarophoria ringens Swallow ........ 491, 537-538, 590 Canaroto.chia Hall ........................ 538 Camarotrechia cauarsfera Wiochell (?) .......... 542 Camarotreclia herrickana $11.8 p \ldots \ldots \ldots \ldots .539,541,542,540$ Camarutrechia netallica White.... 489, 539, 540-5 41, 530 Camarotechia orhicularis..................... 543 Camarotechia sappho Fall ..............492, 5\$1-542 Comarotrechia sp ..................... 512-513,590 Cambrian fassils, descriptions of ............. $440-478$ lists of .................................. $440-\$ 41$ plates slowing......................... $468-\$ 78$ Camptonectes (Agassiz) Heek ................. 613 Camptoncetes bellistriatus Ileek .........613-61 1,64 ? Camptouectes bellistriatus var distans $n$. rar....61 $1,6 \pm 0$ Camptonectes extenuatus (M. sud H.) Hall and Whitfield ............................ $\quad 613$ Camptonect es extenuat us (MI. and H.) Whitfeld. 614, 615, 616 Camptonectes pertenuistriatue Hall aud Whitfield....................... (61\$-615, 616,6ะ2 Camptonectes plateseiformis TV hite...........615-616 Capulus paralius Wincliell.................... 576 Carbouiferous fossils, table showiug renge of ....... 484-486 Carboniferous and Devonian fossils, descriptions of. 479-559

plates showing ........................... 580-598 Cardium pauperculum $\mathbf{M}$ eek.................. \$38 Cardium shumardi Ar. and H .................. 621 Cartium sulıcurtum Meek .................... 638 Carpites pelunculatus n. sp................... 755, 846 Caryo antiquorum Newly ................... 690 Castanea ungeri Heer...................... 701, 703 Castanea pulchella n. sp.............. 70:2-704, 812,814 Celastracein, deseriptions of species of........... $732-735$ Celastrus culveri n. sp .................... $73 \mathbf{2}$, s 34 Celastrus currinervis Ward .................. 732 Celastrus ellipticus n. sp.................. 734,834 Celastrus incentualis $\mathrm{n} . \mathrm{sp} \ldots \ldots \ldots \ldots \ldots \ldots \ldots \ldots$. $\mathbf{3 3 3}, 536$ Celastrus ovatus Ward .......................699.732 Cephalopora, descriptions ot species of .... 630-632, 636, 640 Ceritbium (?) sp .............................. 6:39 Changel Mauntain, festures of .................. 196 Chatari, T. M., analyses of rocks by ............ 135, 352 Chemical analşses of rocks. Sce Aualyoes.

Chicken Ridge, toporraphic and geologic features of. 191-194 Chonete illinoisensis....................... 526 Clovetes logani Norwuod and l'ratten ............. $5: 28$ Chonetes logaoensis Hall and Whitfield ........... 489, 5.25-5.27, 580 Chonetes ornatus Shumard . .............5.5.5.28, 586 Clirustsehoft, C. von, cited...................... $\$ 18$ Cinvabar Mountain, section of ................. 53-54 Cinnamomum spectabile Heer............... 7.22, 323 Cissus haguei $\mathrm{n} . \mathrm{sp} \ldots \ldots \ldots \ldots \ldots \ldots \ldots \ldots \ldots, \boldsymbol{\gamma} \mathbb{1 1}, \mathrm{st}$ ?

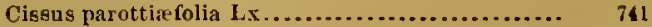
Cladopora labiosa ........................... 501 Clalopora pigguis ........................... $5 u$ Cladopora sp............................. 500-501 Cliothyris King ......................... 566.56r Cliothyris crassicardipalis iv bite ..... 562, 567-568, 598 
INDEX.

Page.

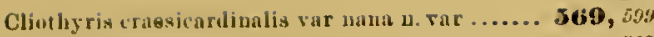
Cliothyris hirsuta.......................... 560

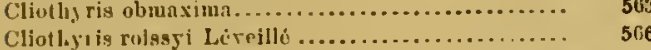

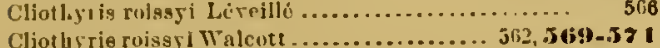

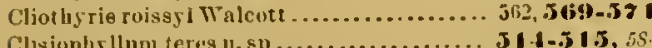

Ccelenterata, descriptions of species of............508-515

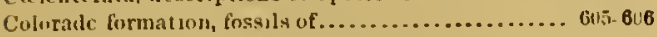
descriptions of fossils of .................... 6...

Colmmar Chll, Madison Canyon riew of. . ........ 36.

Columnar structure. plate ehowing ............... 436

Comalt Creck, character of rby-ulito on ........... 377-378

rocks of ................................ 161

Conchita rhomboidalis 1 ilckess............... 525

Coniferit descriptions of species of ............. (70-683

Conocarlium napalconense Winchell............. 57

Conocarlium pulduellum White and $W$ bitfielıl.... 571.

$572,5 s 1$

Conocarlium emiplenum.

$5 \pi 1$

Couocarilium trigutale Hall..................

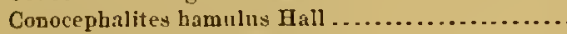

Conoceplalitos $\pi$ isconensis Hall.................

Couoceplahus antiquatus

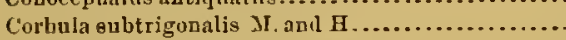

Cor bulus subtrigonalis rar. pervndata. . ...........

Corimsa glabra Agaesiz.

Corracere

Cornus acuminata Newby.

Cornus newberry Hollick........................

Corrus oralis Ix.

........................................

Cornug panjeulata L Hér

Corous wrightii n. sp.....

Corslus macquarryi (Forbes) Heer ............. 699, 81 ?

Cottouwood Creek, IIontana, analysis of rock from.

Coulter Creek rocks of ......................... 179-180

Coulter Peak, rocks of ...................... 318-319

Crags (The). features of ........................ $3-5$

Cranilall Basin, acıd ureccia of..................

basalt flows of............................ 239-240

basıc breccia of ............................. 238

dissectcd roleano of ......................... 245-268

extent of erosion iu...................... 232-233

intrusuve rocks of ......................... 240-259

lara tow $\mathrm{o}$ of .......................... 238-239

map ehowing dissected rolcano of............ 216

Craudall volcauo, analyses of rocks of ............ 250-267

Crania levis Keyes..................... 520-52 1, 556

Crauia mode 6 ta............................. $\quad 520$

Cianja liermiana.............................. 520

Crasua rowleyi............................... 520

Credneria ${ }^{1}$ pachipphylla $\mathbf{s}$. sp ................. 7.12, 84,

Credueriacero .............................. $712-743$

Crepicephalua Owen ...................... 159-460

Crepicephalns iow en 6 is.......................459,460

Crepsephalus (Logadellus) maculosts............ 405

Crepicephalus (Loganellus) montanensis............ 460

Crepicephalus oonstus......................... 4 tio

Crepicephalus texauus Shumard........ $460, \mathbf{1 6 0 - 1 6 1 , \pm 7 8}$

Crepicepbalus wisconensis..................... 459,461

Cretaceous fossils, oceurrenco of...............6 604-607

description of .......................... 632-640

Crimsos Peak, rocks of ....................... 158

Cross, Wuitman, cited.......................... 17

Crow foot Rilge, features of ............... 3, 5, 6, 27-30

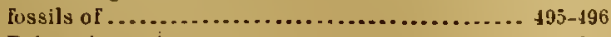
Paleozoic section at ..................... 6-8, Cruetacea, descriptions of species of............ 576-578
Pago.

'rystals in rigyolite, forms of growth of .......... $410-416$ Cuenllea haguei Meek...................... (8) $8, c 14$ Cupressianxylon entreton Fulix................. 76 Cyathophyllum caspitosum Gohl fuss (1) ........ 481, 500 Cyperacites giganteus n. ep................... ist, sot

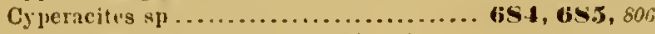
Cypleracese, descriptions of species of ........... 684-685 Cy nereardia bathonica d Orbigay ............... 623-624 Cy pricarlia (1) haguej n. sp ........... 62:3-624, 644 Cypuiba einnabarusis n. ep ............. 621-692, $c 1$ Cรnriua (?) jllluggsi n. sp ................... 622, 64

D.

Dacite, oc surrences of ................. 172-173, 288-290 photomicrographs of ...................... 104, 130

Dacite-porpbyry, analyses of ................. 65, 163 character of $\ldots \ldots \ldots \ldots \ldots \ldots \ldots \ldots \ldots .64-69,84-85,86-88$ photomicrograph of ....................... 6

Dakot a conglomerate, occurrence of............. 48,49 Dakota formation, fossils of ..................... C04-605, 632 Dakota limestune, occurrence of................ 49 Daua, J. D., cited........................... 245,49? Darwiu, Charles, eited......................... 82 Danbrée, A., citell ........................... $\$ 18$ Derbsa keokuk Hall (?) ............... 491, 492, J24.52.5 Derallia ? montana u. sp.................671-672, 998 Deronian fossils, descriptions of ................ $496-507$ table sliowing. Deronian aad Carboniferons fossils, descriptions of. 479-599 plates suowiug........................... es $80-59 s$ Dicellocephalus latifroms Slumard.............. 461-462

Dicellonus Hall...........................

Dicellomus nana ............................... $446,16 s$

Dicollonus uanus $\mathrm{M}$, and $\mathrm{H}$.................446, 14

Dicellon.us politus .........................446, 468

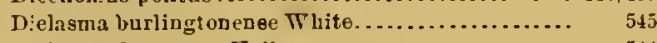

Dielaswa formosum Hall..................... 54

Dielasma rowleyi Hall and Clarke............... 545

Dielasma utah Hall anl Whitfield...... 489,5 14-5.5.590

Dike rocks, characiers of . ................ 94-97, 128-133 grales of crystallization of............ 107-108, 113-114 variation iu nineral composition of........... 105-113

Dikes, occurreuce of................... 10,21,224-231 features of . ................. 224-231, 240-259, 304-321

Diospyros brachysepala Al. Br.................

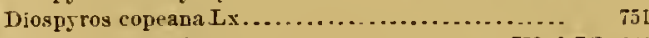

Diospyros luaguei $\mathrm{D} . \mathrm{sp} \ldots \ldots \ldots \ldots \ldots \ldots \ldots \ldots .752, \mathbf{7 5 3}, s \pm 0$

Diosprros lsmarensis n. 8 . ........... 751 -752, 830,883

Diospyros obtusa Tarkl...................... 752

Diosprros stecosepala Heer................... 662

Diosp yros virginiaua $L$...................... 75

Diorite, cluaracter of .......................... $97-103$ mineral composition of.................... 109-113 occurrence of............................. 252-256 photomicrographs of ...................... 104, 250 riews of specinens of...................... 100

Diorite.porph fry, occurrence of . ......... 242-246, 252-256 photomicrographs of ..................... 104, 314 view of specimen of ......................... 100

Domberopsis fularanoides Lx................661, 756

Dome (The), features of ......................... 12-13 zone of contact between intruded sheet and coun iry roeks near.......................... 68

Donax cumeata Stanton ...................... 6i3s

Douax (?) oblonga Stanton. . ...................... 638

Dosinia jurassica Whitfield.................... 622 


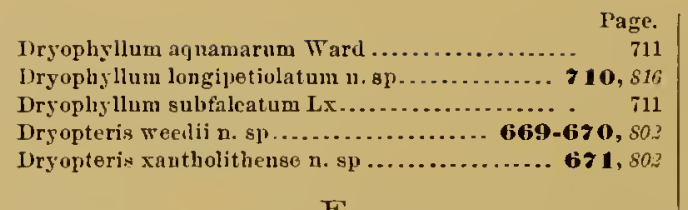

Eagle Peak, view of .......................... $\quad 296$

Ealios, L. G., clienical aoalyses of rocks mate by.. $260-261,325,329,340,347,352$

Ehenacex ..............................

Echo Peak, aoalysis of rocks of ..................

banding in rocks of ..................... 67-68

riew of...

Echinoidea descriptions of apecies of .............

Echivolermata, 609

Edwards and Haime, cited.................... 498

Electric Peak, analyses of intrusire roek of . ...... 115-121

chemical correlation of rocks of Sepulchre

Mountaio with those of . . ................ 142-148

comparison of rocks from Sepulchre Mountain

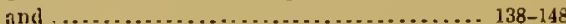

liagram slowing molecular variation of rocks at. $\quad 119$

liagram showing rariation iu silica percentages

of racks at .............................

fentures of .......................... 50-55, 89-92

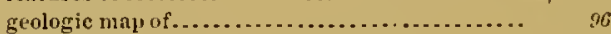

grades of crystallization of rocks of........... 107

igneous rocks of . ......................... 89-148

intrusive rocks of ......................... $92-121$

location and altitule of .

mineral and chemical composition of intrusire

rocks of .............................. 105-121

notable intrusivo shcet at .................. $82-84$

orler of eruption of rucks at................. 140

porphyries at ............................. 94-97 quartz-nica-diorite-purphyry at.............. 103-10

sections at .......................... 50-51.53-54 stock rocks aod apopliyses at.............. $97-103$ riews of.

Elicodeudron polsuorphnn TTard $734-735,83$

Ellis formation, fossils of . . .................. 174, 176

Ellis sa odst one, fossils of...................... 197

Eudothyra baileri .......................... 599

Eodothyra bailoyi var parra D. var........ 492, 507, 599

Eudothyra bowmani......................... $\quad 507$

Endothyra lobata ........................... 507

Equisitacer, descriptions of species of . ........... $674-676$

Equisetum canaliculatum n. sp ............675, 676,802

Equisetum decidum n. өp................... 67 6, $80 z$

Equisetum baguei n. sp.................... 6z $1, s 02$

Equisetun hiemale.......................... 676

Equisetum lesquereuxii $\mathrm{Kn} \ldots \ldots \ldots \ldots \ldots \ldots \ldots \ldots$ (\$75

Eqquisetum limosum $L \ldots \ldots \ldots \ldots \ldots \ldots \ldots \ldots \ldots 67,675$

Equisetum robnstum ........................ 670

Ericacex......................................

Erillopora (?) sp........................... J17

Etna (Mount), profilo of .............................

Eumetria altirostris White..................... 56

Eumetria rera ................................. 491, 493, 560-561, 587

Eumetria vemeniliana Hall ....... 491, 493, 560-561, 587
Eumetria verneuiliana Thitfield ................ 560

Eumierotjs curta (Hall) Jeek and Hajlen......... tif

Euomphalus luxus White..................... 489,573

Euomphalus (Straparollus) ophirensis ........... 489

Euomphalıs (Straparollus) utahensis $\mathrm{Hall}$ and Wbit.

field...
F.

B.

Fagacex, descriptions of species of............. Page.

Fagus a otipofii Abich ........................

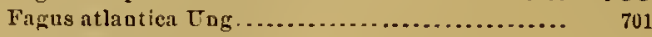

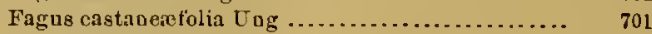

Fagus dentata Göpp ...................... 700,701

Fagus ferooin $\mathrm{Ung}$......................... 701

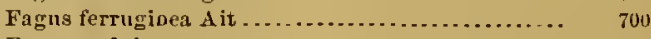

Fagns uodulata n. 81.............. ร00-702, 703,81)

Fails River Basin, liasalt ia.............. rhyolite in ................................... $377-379$

Fan Creek, rocks on and near ........ $43-41,45,40,47,48,58$ sectiuns on and near....................... 48,58

Fan Pass, rocks of . . . . . . . . section at ............................... 49

Fan $(\mathrm{Tl}$ e), features of ..................... $45-50$

Farosites sp.............................5. 501,580

Fawn Creek, rocks on ........................

Fawn Crrek Valley, features of ................ $39-40$ section in .................................. 38

Fawn Pass, formations exposetl near............. $42-43$ rocks vear................................ 43

Feldspar microlites, photomicrograph slowiog..... 423

Feldypar ucedles, photomicrograplu showiog ....... 114

Fenestella Lonsulale........................ 518.519

Filices, descriptions of spevies of............... $665-673$

Ficus asminrefolia $\mathrm{L} x \ldots \ldots \ldots \ldots \ldots \ldots \ldots \ldots \ldots . .713,7 \mathbf{7 6}$

Ficus deformata n. өp...................... 712-713, 82.0

Ficus deasifolia n. sp............. 7 1/-715, $818,820,822$

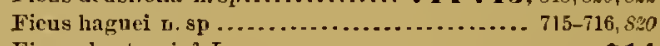

Fiens ghortensis ? Lx .......................

Ficus sordila $\mathrm{Lx} \ldots \ldots \ldots \ldots \ldots \ldots \ldots \ldots \ldots \ldots \ldots$, 11

Ficns sp ............................... $7 \mathbf{1 3}, 818$

Ficus tilizfolia ? Al. Br ..................... g16

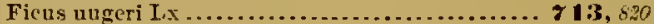

Flat Mountain, rocks and fossils of .............. 196-197

Flora, fossil, description of ................... 651-882

plateg showing ............................ $794-892$

Furellen Peak, rocks of ..................... 158-150

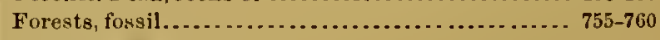

Fort Ellis, Montana, analysis of rocks from....... $\quad 352$

Fraxinus aftiois Newby.......................

Fraxinus denticulata Heer ................662, 796

Fraxinns beerii $\mathrm{Lx}$........................... 753

Fraxinus wrightii o. $\$$ p.................... ร5:3, $8 \$ 0$

Friedel aud Sarasio, cited................... $\$ 18$

\section{G.}

Gabbro, occurrence of...................... 246-252 photomicrograph of ...................... 250 Gabbro-porphyry, occurrence of............ 242, 246-252 Gallatin fault, course of ....................... 30

Gallatin Jountaius, descriptive geology of ........ 1-59 extrusive rocks west and southwest of ........ I37-138 geologic cross sections of ..................... intrusive rocks of . .......................... $00-85$

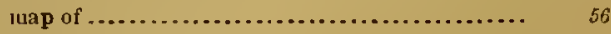
panoramic riew of ....................... 15 Gallatin River, geology of region north of ......... $41-50$ laccolithic mass $00 \ldots \ldots . \ldots \ldots \ldots \ldots \ldots \ldots . \quad 81-85$ section near............................. 58 Gallatin Talley, features of ................. 27-30 Gardiner River, rocks near.................... $\quad 45$ Gastropoda, deseriptions of species of ............505-507, $629-630,632-633,639$ Geikie, A., and Teall, J.J.H., citerl.............. 67 Geonomites schimperi Lx.................... 65 


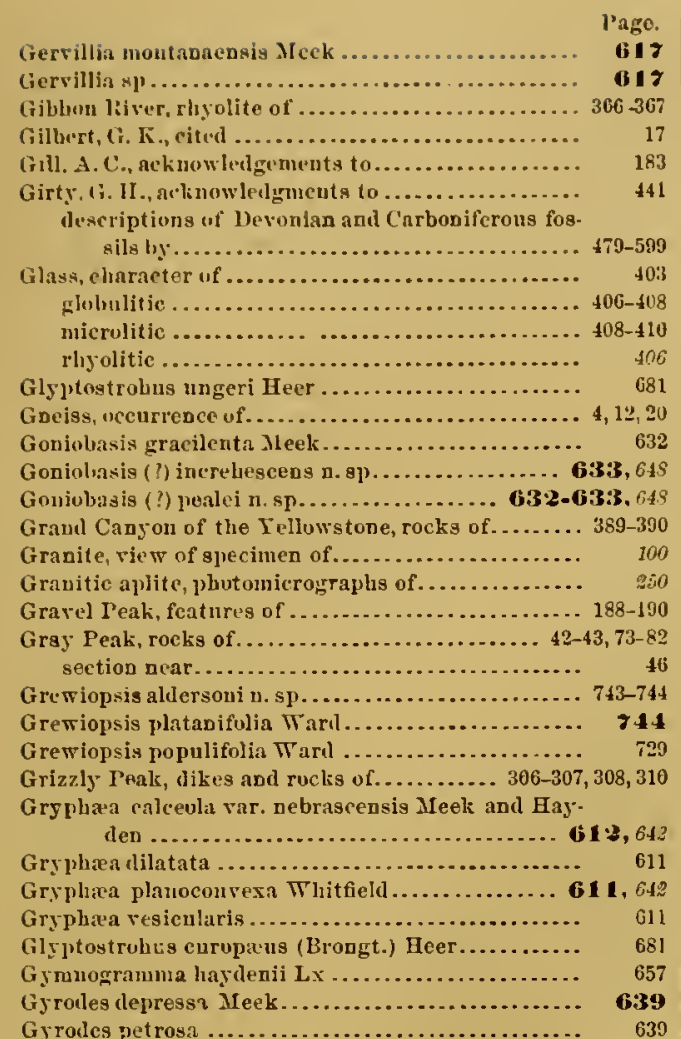

II.

Eague, Aruohl, letter of transmittal by.

Haguia, deseription of ........................ 12.2

Hagnia sphrerica, 11. sp . ............... 449-443,474

Haldat dn Lys, C. N. A.de, cited ................. $\$ 18$

Hall. James ................................ 446

Hall and Whitfield, cited.............. $487,498,499,526$

Hemipronites crenistriata..................... 540

Herrick, C. L., cited ......................... 493

Hicoria antiquurum (Newby) Kn .............. 690

Hicoria crescentia,n. sp .................. 690-691, sos

Hicoria culveri n. sp...................... 69 1-692, 806

Hicoria orata (Mill.) Britton ..................... 692

Hillebrantl, W. F., analyses by .................. 354

Hinde, G.J., cited.......................... $\$ 42$

Hornbleule-mica-andesites, occurrence of ........... 290-291

Holasterella wrighti var. amerieana $\mathrm{n}$. var....... 508, 599

Holmes, W. H., cited .......... 14,31, 221, 357, 651-652, 756

Homomya gallatinensis $\mathrm{n} . \mathrm{sp} . \ldots \ldots \ldots \ldots \ldots .6 \mathrm{625}-6 \mathrm{26}, 616$

Hoodoo Basin, feutures of ..................... 223

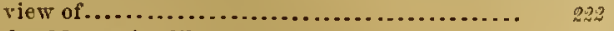

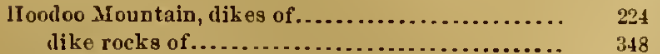

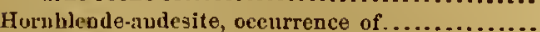

Hornblende-andesite-porpbyry, analyses of.........

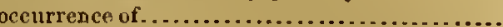

Hornblenıle-nica-andesite-porphyry, analy'ses of . cbaracter of ......................... 60-64.73-77 accurrence uf............................... 256-258
IJorublende-pyroxone-sudesite, acenrrence of...... 258.059

291-294, 300-301

llornblende pyroxene-andesite-porphyry, vecurrence of ............................... 80

Iloyt P'eak, dikes and rucks of................ 30 t-307

Huckloberry Mountain, dacito of................. 172-173 lescriptivo geulogy of................... 165-202 letailed geology of ........................ 170-173 rbyolito of .............................. 172 II urrieane деяa, dilies of. .......................... 225-229 nature of, volcauic rocks of ................ 340,340 view of ................................

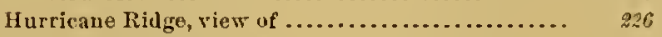
11 ustedia triangularis Miller.................... 560

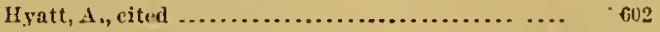
Hyolithes primurdialis . . . . . . . . . . . . . Hyolithes (Theca) primordialis Hall ............. 454

\section{I.}

Ildings, J, P., cited .............. 17,89, 261, 292, 333, 360 Idlulings and I'enfield, cited..................... 380 I goeous rocks of Absaroka Range and Two Ocean Platean ........................... 269-325

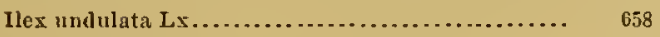

Indian L'reek, intrusive sheet north of............. 68

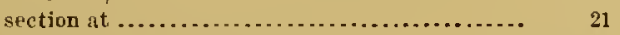
Indian Creek laccolith, features of ......... 10, 13-16,60-64 mode of oritrin of ............................ 9 Index Peak, riew of'.......................... $\quad 218$ Inoceramus acuteplicat us n, sp.... 6:34-6:3.5, 637, 648,650 Inoceramus altus ............................. $\quad 635$ Inocoramus flaceilus White.................. 6.34 Inoceramus fragilis ........................... $\quad 635$ Inoceramus umbonatus Meek and Hayden......... 634 Inoceranus undabundus Heck and Hayden....... 63. Intrusive flows, Crandall Basin .................. $240-259$ Intrusire rocks, analyses of . ................. $\quad \mathbf{4 2 6}$ Iphidea Billings............................. 4 t7

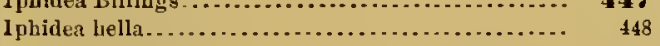
I phidea coslata ............................... $4 \mathbf{4 8}$ Iphidea labradorica ........................... 448 Iphidea ornatella................................. I phidea pannula $W$ hite.......................... 448 Iplider prospectensig.......................... 448 Iphider senlptils Meek.............. \$47-448, 449,468 lphidea sp. undet $\ldots \ldots \ldots \ldots \ldots \ldots \ldots \ldots \ldots \ldots \ldots 419,46 s$ Iris Falls, rhyolite at. . ......................... $\quad 376$ Ishawooa Canjon, analysis of rocks from.......... 329 dike rocks of ............................ $\quad 3 \$ 9$

J.

Joseph Peak, igneons wass of................ $73-82$

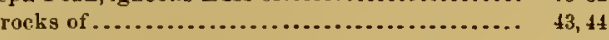
section at ............................... 47 Juratrias fossils . . . . . . . . . . . . . . . . . . Juld, J. W., cited ............................... 243, 245 Jukes-Browue, A.J., eited ..................... 40 Juglandaces, descriptions of species of....... $687-692$ Juglans californica Lx ...................... bs Juglans crescentia, n. sp ... . . . . . . . . ..... 6\$9-690, 808 Juglans denticulata Heer ..................... 689 Juglans egregia Lx............................. 688 Iuglans laurifolia n. $8 \mathrm{p} \ldots \ldots \ldots \ldots \ldots \ldots \ldots \ldots .6 . \ldots . \ldots .689,806$ Juglaus nigella Čng ......................... 691

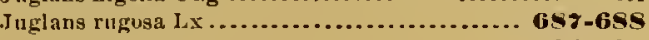

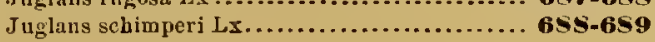


Jurassic fossils, occurrence of . ............... Page. description of . $601-604,608-632$

II.

Kersatite, analfses of ......................... characters of .............................. Kioderbook fossils, list of...

ISing, Clarence, eited.

Küch, R., cited

liuntze, Otto, citod

Kutorgio minutissima II. \& $\mathrm{T}$.

Kutorgina sculptilis Meek.....................

\section{I.}

Laccolith, definition of ....................... 17

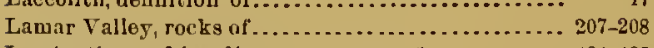

Lamiuation and hading, occurrence of ........... $424-425$

Lamprophyric rocks, occurrence of ................ 259

Lat amie tlora, discussion of.................... 663-665 tablo ehowing distribution of ................. 663

Lastrea goldisna Lx......................... 670

Lanracere, descriptions of species of ............... $722-729$

Laurinoxylon aromaticum lielix................ 767

Laurinoxylow brauberi Kn.................... $\quad 766$

Laurinoxylon lesquereuxiana $\mathrm{Ku}$.............. $\quad 767$

Lauriouxylon pulchrum $\mathrm{n.9p........} \mathbf{7 6 5}, 767, \delta 72,87 \delta, \delta 80$

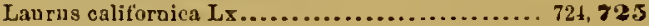

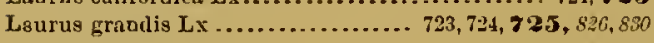

Laurus montana 1. sp ......................

Laurus perdita n. вp......................... ร23. 828

Laurns primizenia (?) $\mathrm{Dng} \ldots \ldots \ldots \ldots \ldots \ldots \ldots$ 7 22-723, $5_{23}$

Laurus princeps Heer ....................

Laurus triseriata Caep ...................... 766-767

Lava, rlıjolitic, occurrevee of ...................... 4,5

Lava flowe, Crandall Basin..................... 238-239

Leguminosæ, description of epecies of ........... 729-730

Leguminosites cnssioides Lx.................. 730

Leguminosites lamareusis n. sp.............. $7 \mathbf{7 3 1}$, s1s

Leguminoeites lesquereuxinna $\mathrm{Kn} . . . \ldots \ldots \ldots \ldots$. $3 \mathbf{3 0}$, s1s

Leguminosites proserpiate Heer ................ 731

Leptæua rhomboidalis Wilckens........4 48, 489, 492, 525

Leptæna teouibtriata Hall .................... 525

Lesquereux, L., fossil plants determiaed by........ 651

Leucite-hanakite, auslyses of .................. $\quad 347$

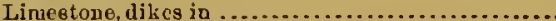

Lima cinnabarensiśs. sp...............619-613,64?

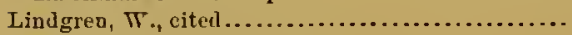

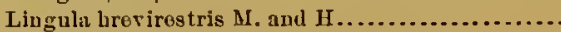

Lingela sp. undet

Lingula subspatulata Hall and IIeek ........... $\mathbf{6 3 \mathbf { 6 }}$

Liagulepis Hall ........................ 143-14

Liorhynchus greenianum Elrich ................ 503

Liorliyuchus loguei $\mathrm{n}$. sp................ 543-544, $5: 30$

Limbrnchus Kelloggi........................ 54

Liostraeus parvus n. «p............... 163-164, 478

Liorhyuchus (Puguax?) striatocostatum M. and W. 544

Lithoidal rhyolite, riews uf ................... $\$ 64$

Lithoidite, character of . ....................... 364-365

Lithophyse, characters uf ................... $416-422$

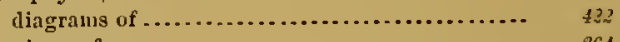

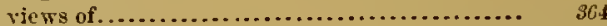

Lithostrotion $\mathrm{sp} \ldots \ldots \ldots \ldots \ldots \ldots \ldots \ldots \ldots \ldots \ldots .513-514$

Litsea cubeata n. sp.................. 726-727, 824

Litsea weediana Ír........................ 659
Page. ittle Quadrant Mountain, features of........... $\quad 36-39$ sertiuns of berls at...................... 36, 37, 38 Little Sunlight Creek, fussils from............... 481 Luwer Carbodiforeus foesils, table stowing range of. 484-486 descriptions of $\ldots \ldots \ldots \ldots \ldots .507-578$ Lower Gejser Basiu, rbyolite of .......... 369-372, 374-375

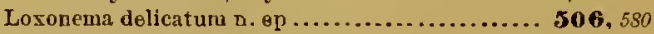
Loxonema tenuilineatum Swallow .............. 5 ; Loxonema (?) sp ............................ 572,580 Lygodium kaulfusii Heer..............6. L. ygodium neuropteroides $\mathrm{Lx} . \ldots \ldots \ldots \ldots \ldots \ldots \ldots \ldots$

Lyosoma powelli White .....................

\section{Lyosoma powelli White...........}

Mactra arenaria Meek (?).................... 639

Mactra (Cymbophora?) warrenaua (A. and H.) Meek.

Mactra (Trigonella ?) a revaria Meek .............. 619

Mactra warrevaua Meek and Hayden............. Madison limestone, fussils of.............. 487-488, 490,4.1 table ehowing zoological groups if ............ 495 Madisun Plateau, rhyolite of ................... 367-309 Madison Ragge, features of eastern Hank of ...... $57-59$ Jaclison liver, rlyolite of ....................... 366-367 Magnetite, occurrence of .................... 400-401 Magoolia acuminata L.......................... IJagnolia californica (?) $\mathrm{Lx} \ldots \ldots \ldots \ldots \ldots \ldots \ldots \ldots, 7 \mathrm{f}, 721$ Magoolia culreri $\mathbf{n} . \mathrm{sp} \ldots \ldots \ldots \ldots \ldots \ldots \ldots \ldots$ 7 20-721,824 Maguolia fœetida Sarg......................... 719

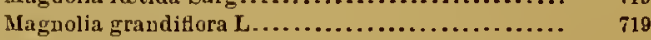
Magnolia inglefeldi Heer .................... 719, 720

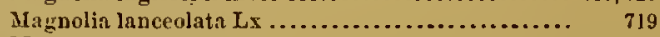

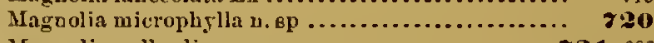
Magnolia pollardi $n .8 p \ldots \ldots \ldots \ldots \ldots \ldots \ldots \ldots \ldots, \mathbf{2 1}, 803$ Maguolin epectabilis n.sp.............. . 18-2:20, 826 Iagnoliecer, descriptions of epecies of ........... $718-722$

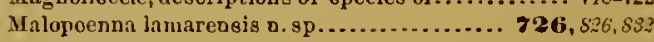
Malapoenaa weediana (?) Kn .................. (j59 Mameurh Hot Spriogs, character of rhjolites \&t.... 357-359 Martinia rostrata a. ep .............489, 553-55 $\mathbf{4}, 568,594$ Mauva Kien, profile of . . . . . . . . . . . . . . . . . $2: 2$ Meek, F. B., cited ................. 482, 487, 489, 494, 611, 619 Melville, W. H., chemical analyses b5...... 115, 261, 347,354 Mrenophyllim (?) excarat um............. 511-512, 84

Menophsllum tenuimarginatum................ 511 Merrill, G. P. cited........................... $\quad 351$

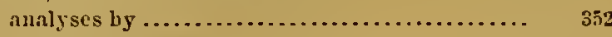

Meeoziuic fossils, descriptions of ...............6.60-640 1lites showing...........................641-6.0 Meunier, Stanislas, cjted ..................... $\quad 418$ Mica-dncite-porphyzy, Bunsen Peak, axalysis of .... 87 Miea-gueiss, occurrence of .................... 4

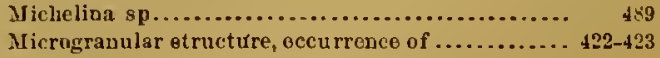
Micrographic phenocrysts, photomicrographs ohow: ing ................................ $\$$ Micromita Meek ................................ 447 Middle Creek, dikcs on and near.............224,312-314 Minette, analysis of ........................... 70 Mink Creek, rocks and fossils of ................ 199-200 Modioln subimbricata Meek ................617-618 Modiola (Vulsella) eubimhricata Meek............ 617 Montana, character of ahsarokites from.......... 351-355 Montan formation, fossils of . ................. 606-6u7 description of tessils of .................... $636-640$ 
INI) I:X.

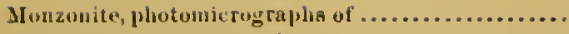

Jount Ioane, Rrulesitw of . .

Mfount Eitna protilo of .........................

Mount liverts, intrusivo rouks of ..................

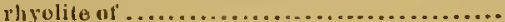

Mount Ilancock, features of .................. 1yu-191

Mount Holmes, analysis of rncks of .............. features of bymalith of ............... 16-20,6t-60 view of bysmatulith of.

view of mouotains nortl of country rowk witur.......................

Mount Langford, lliko at......................

Moont Nurris, fuesil torest on .....................

Mount Norris aud The 'Thuolerer, view of .........

Mount Scliurz, rockg of ........................ 316-318

Mount Sterenson, rocks of . .................. 315-316

Ilount Fesuvins, proble of..................... 933

Yügge, 0 . cited........................... 399

Musacer, descriptions of species of............. 686-687

M usophyllnm complieatum Lx............ 6\$6.6\$7. 800

Myacites (Plouromya) subcompressa Yeek ........ 626

Myacites subcompressus (Mfeck) White........... 626

Mrrica baksirefulia $\mathrm{Ung}$..................... 603

Myrica bolauderi (?) Lx ................65s-659, 79

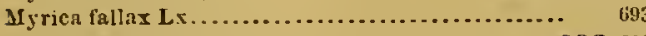

Mrrica lamatensis o sp..................693,sos

Afyrica polymory, ha Scbimp................... 692

Mfrica acottii Lx........................ 692, sos

Ml yrica torreyi Lx.

If rica wardii 1. sp....................69.693. 808

II ricaces, descriptioes of species of

$.69 \cdot 2-693$

\section{N.}

Natica (?) sp

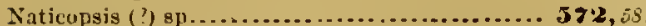

Latural lírilge, Btidgo Creek, rlyolite at ......... 386-387 views ot.

Neritina nebrascensis M. and H............. 629-630

Neritioa (?) phaseolaris White.................. 629

Neritiua pisum Hek ......................... 030

Neritula powelli White ........................ 630

Neritina w youingeasis n. 8p............ 629-630, 649

Nucula sp.

\section{O.}

Obolella Hall.

......................

Obolella chromatica............................

Obolella nada M. and H

446

Obolella polita.

Obolus Euch

Obolus (Lingulella) desideratus $W$ alcott.... $15-4 \notin 6,465$

Obolus (Lingulella) ferrugibeus.................. 445

Obolus (Lingulella) granrillensis ................ 445

Obolns (Lisgulella) manticulus .................. 445

Obolus (Lingulella) perat teanatus ...............

Obolus (Lingulella) rotundatus ................. 445

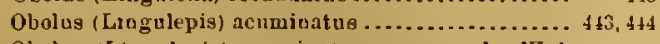

Obolus (Iingulepis) acuminatus, rar. meekı $\mathrm{F}_{\mathrm{al}}$

$$
\text { cott .............................4, } 465
$$

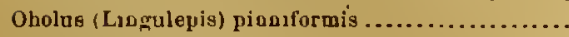

Obsidian Cliff, ribyolite of . ...................... 359-3tic

riews of................................. 860

Olencese ............................... \$ 5.8

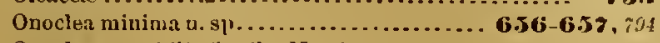

Oooclea sens:bilis tossilis Jewby ............. 650,666
Panc.

Ophits atul related basalts, occurrence of ........ $430-439$ (Oppelin (?) sp ............................6.30-6:3 1 Oppolia subjulicatella Vacek.................. Orthis coloratoensis Shumart................. 450 Orthus creniktriata ............................. 52 Ortbis Keokuk.............................. 524 Orthis miebelina ........................... 521 Orthjs p.phina IInll . . ....................... 450 Orthis (?) rerulicha................ \$1-152, $4.0,4 z^{2}$ Orthis (1) sindberui ................. 45.2-15:3, $4: 0$

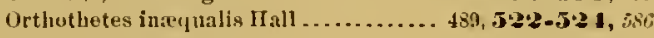
Orthot betes intatus........................ 523.5SO Orthothetes sp............................. 5.2t

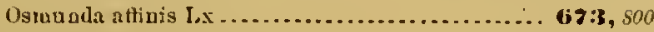
Osprey Falle, basalt at....................... 434

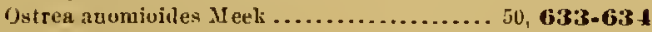
Ostrea engelmanji $\mathbf{H}$ ek ..................... G1 Ostrea patiua................................. 611 Ostrea pellucida M. and H ................... 637 Ostrea suleniscus Meek ....................... 6:37 (1)stien sp.................................... $6: 38$ Ostrua strigilecula $\Pi$ bite.................... 610 Outlet Caugon, topographis nal geolugic features of - 194-196 Oweu, D. D., cited ..............................

\section{P.}

Pacliyplyyllum bouchardi . . . . . . . Pachyply-llom devouicnse ...................... 499,500 Paclipplyllura solitarion........................ 499

Pachypbrllum sy......................... 497-500

Pacliypbyllum woolmani ................... 498,499 Pacific Creek, rocks aul fossils of ................ 198-190 Paleozoic fossils, descriptions of................ 440-599 Paliurus cololuli Heer .................660, $\mathbf{7} \mathbf{1 0}, s 43$ Paliurus mioimus n. ๓p ....................659-660 Paliurus zizyphoides Ix..................... 660, 790 Panther Creek, stracture of mountains gouth of .... 9-20 Peale, A. C., cited ............................ $\quad 489$ fossils eollected by ........................ 601, 602 Pebble Creek, rocks of ......................... 211 Pectes bellistriata $\mathbf{Y}$ eek ..................... 613 Pelecypola, descriptions of specics of ... 610,632, 633-635, 637 Pentacrinus asteriseus Meek aul Hayden ......... Gos Pestacrious whitei ............................ 60.6 Perispluinctes sp ............................ 6:3 t Perlite, riews of specitnens of .................. 970 Persea pseuda-cnrolideosis L. ............ 723, >25. 830 Perseuxylon aromaticus Felix................. Pbenocrysts, llevelopnent of.................. 206-268 Pholadomya inequplieata n. sp..............625, 64 Pholadonya kingi Meek .................. 6.24-625, 646 Pholadoryar multilineata Gabb................. 625 Plıoladomya nerndana Gabl.................... 62. Pluragmites alaskana Heer ...................... $6 . .8$ Plıramites fílcata D. sp ....................... 6.5s, , 50

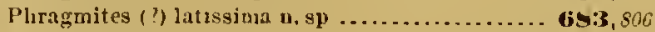
Phyllites crossitola u. sp............. 75:3-754, s4t $s 46$ Phyllites osseus Lx ....................... \$51

Phyllites sp ................................... Pinan kıngi dreek............................ Pinus contorta Dougl ......................... 680 Pinus contorta murrayana .................... Praus edulis Engelm........................... $\quad 680$ Pinus texilis..................................... $6 \sigma_{8}$ Pinus gracilistrobus a. sp ................6.611, 6 g $\mathbf{6}, 500$ 
Pibus juldingsi n. sp....................... 680, 504

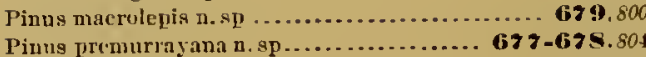

Piuus scopulorum........................... 678

Pinns 8p ..............................678-679

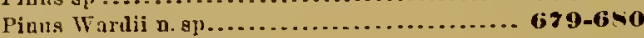

Pinyon P'eak, features of . .................... 184-188

I'irsson, L. Y., analyses by ..................... 354

rit.d .................................. 241

Pitchstone Platean, rbyolite of . . . .............. 379-381

Pityoxylon allersoni n. sp..... 763-764, $85,2,864,866,875$

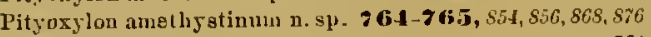
Pityoxylon fallax Felix ....................... 764

Plicenticeras plicenta (De Kay) Meek ........... 610

Plagioclase, character of phenocrysts of........... 399

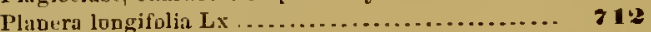

Plants fossl, descriptions of. . ............... 651-882

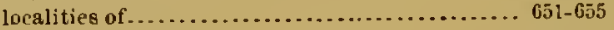

plates showing ......................... $\gamma 94-8 s ?$

Plataosere, descriptions of species of ........... $727-729$

Plataninium hayleni Felix ............. 7 67-7 69, 580

Plataninium porosum Felix.................. 769

Platant: borealis Casp........................ 76.

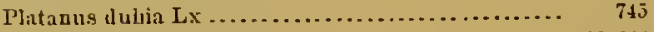

Plitanus gnilleluxe Güpp .................. 727-ז28, \$34

Platanus haydenii Nowby.................... 706

Plitanus klobsii Casp........................ 769

Platanus montana n. $8 \mathrm{p}$..................... $728-729,882$

Platanus nubilis Newby .................... 745

Platan ns nccidentalis L ...................... $\quad$ i68

Platanus raynohlsii Newby ................... 72.

Plat jceras Conrad .................... 57 \-57 6i, 581

Platsceras cornuforme Wincbell................ 574

Platfceras nebrascenso Meek................. 570

Platyceras primordialis Hall (?) .............. I5:3, di4

Platyceras vomerium Winchell ................. 515.514

Platycrinus laydeni ......................... 515-516

Platycrinus sjmmetricus Wachsmuth and Springer. $\$ 88$,
J15-516

06-50\%, 5 so

Platystuma tuinutura b. sp....

$626.627,646$

Pleuromya subcoupressa Meck.......... 626-627, 646

Pleuromya weberensis Mesk.................. 620

Pleurotomaria isaacsi Hall and Whitfield (?) - $480, \mathbf{5 0 5}, 550$

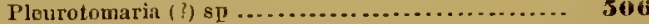

Populuxylon ..................................... 769

Populus aublyrhyocha Ward.................

Populus balsamoides Göplb....................

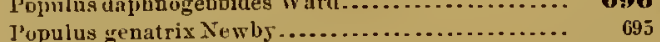

Populus glablulifera Heer .................. 69., sos

Populus greniopsis W Ward..................... 696

Populus oxjrbyncba Tard ................... 694

Populus speciosa Ward..................... 6! 4,805

Populus ?) vivaria n. sp...............696-69) 81 ?

Populus xant bolithensis n. sp.............. 695-696

Populus zadıchi Heer...................... 694

l'orifera, descriptions of species of ............... 508

Porphyry, occurrences of ............... 14, 20,94-97

l'roductelia alifera n. sp.............. 492, 5330-5:3 1, s8

Productella arcuata Hall..................... 533

Productella concentrica llall..................529,530

Productella coopere nsis Swallow ....... 492, 528-530, 537

Proilnctella pyxidea Hall ...................... 529, 530

l'roduetella slumardiana Hall ............... 529,530

I'roductus flemingi var. burlingtonensis .......... 535-530

Productus gallatinensis n, sp ...... 5333-.534, 537, 586,587 roductus levicosta $W$ hite................. 489, 534, 591

Productus l evicostus White ..................... 534

Productns vewberryi Hall.................... 531, 532

Proluctus newberryi var. nnnosus.............. 530

Productus parviformis u. sp ....... 488, 533, 536-537, 586

Productus parrus 11. and W.................. 488

Proluctus parvus White......................4 488,537

'roductus papulata........................... 532

Productus scabriculns Martin ........... $53 \mathbf{1} \mathbf{- 5 3 3}, 590$

Productus semireticulatus Martin .. 489. 533, 535-536, 591

Proetus loganensis Hall and Wh hitfield. 489, 57 7-578,599

Proetus peruccillens Hall aud W bitfield .......... $\$ 89$

ร76-577, 577, 578,599

Prospect Poak, analysis of basalt from........... $\$ 38$

Protocaulia slumardi II. nod II ............... 62

Protozot, descriptions of species of ............... 507

Psendubruokite, occnrrence of................. 401-402

I'seudononotis curta (Hall) ?.................. 617

Psendomonotis (Eumicrotis) curta Hall............ 617

Pteria mucronata, M. and H................... 616

Pteria (Oxгtoma) munsteri (Brown) M. and H..... 616

Ptiria (Oxytoma) nebrascana (E. and S.) Meek..... 637

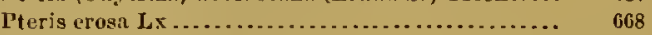

Pterospermites haguei $\mathrm{n}$. sp .................. $\mathbf{7 1 2}, s s 8$

I'tilopora sp............................ 512 1518

Ptychoparia antiquata Salter sp....... 156i-157, 458,478 I't5choparia (?) dialemata............. $460-461, \mathbf{1 6} 2,476$ l'tychoparia eryon Hall...................... 458

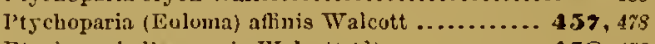
Ptychoparia llanoensis Walcott (?)............5. 476 Ptychoparia (Lonchocephalus) hamulus Owen..... 161 Ptychoparia (Lonebocephalus) wisconseusis Owen. Iti.

162

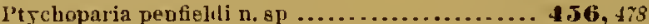

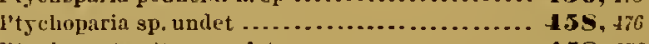
l'tychoparia (!) eq. undet ................... 158, 476

Pt 5 choparia striata........................ $\$ 60$ Ptychoparia teucer........................... 158 Ptrcboparia wisconsensis..................... $\$$ t 6 l'usiunculus primordialis Fill.................. $\$ 54$ I'umice, occurrence of ....................... 403-406 l'yruseac, cbaracter of phenocrysts of .............. 399-400 Pyroxene-andesite, occurreuce of ............ 291-295, 301-302 photomicrograpbs of ....................... 130 Psroxene-andesite-porplysy, Monnt Everts ....... 85-86 Pyrula (?) sp............................... 639

Q.

Qualrant formation, comparison of sections of...... \$1 Quadrant Mountain, rocks of.................. $33-35$ section of ............................. $34-35$ Quartz, characters of phenocrssts of . . . . . . . . . . 395-398 Quartz-bilnakite, analyses of ................... 347 photomic rographs of ..................... $\$ 950$ Quartz-mica-liorite, occurrence of ............... 252-256 Quartz-mica-lliorite-porphyry, cliaracters ot........ 103-105 Quartzite, occurrence of................. $7,8,33,34,17,48$ Quercinium knowltoni Felix................. 772, ร 73

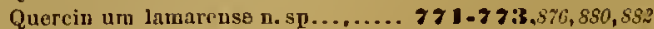
Quercus boweniana Lx....................... 710 Quercus breweri Lx......................... 704 Quercus consimilis ? Nowby ................. J01, s14 Quercus culveri n. sp...................... ร08, 709. 814 Quercus drymeja Ung........................ 703 Quercus laurifolia Newby.................... 708 Quercus ellisiana Lx..................... 65!, 794

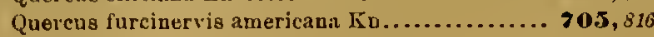


INIEY.

Page.

Quercus furciberria Rossm

Quercus grïulandiea Heer

Quercus grosaidentata n. sp.

Quering hesperia n. sp.

Quercus ? maguifolia n. sp.................. 704-705, s16

Quercus ulafseni lIeer....

Quercus prinoidl's Wilk .

Quercus viburdfolin Lx .......................... 706

Quercus weetiin. sp.

70.5-706, 81

Quercus yancegi a.sp

ว07-708, $s 18$

\section{R.}

Fid Creek, rocks on -

Fed Mountrins, rlyolite of . $. \ldots \ldots \ldots \ldots \ldots \ldots . .381-38$

Reiss and Stiilıel, cited .................... 294, 409-410 Reticularia conperensis $\mathrm{S} w$ allow... $489,5.55-556,568,59.5$ Reticularia copperensis var ............. 556-557, 59. Feticulsria (?) peculiaris Shumard ....... 488, 557, 558, 595 Reticularia setigera Hall..................... 556 Retieularia (?) subrotunulata Hall.........557-558, 595 Retzia (?) circularis Miller..................... 560 Retzia (?) plicata Miller....................... $\quad 560$ Retzia popeana Swallow ...................... $\quad 560$ Retzia radialis Walcott ....................... $\quad 560$ Retzia vera Hall ............................ 560 Retzia verueuili Hall. ........................ 560 Rhamnacer, descriptions of species of ........... $\boldsymbol{\gamma} \neq 0$ Rhanmacinium racliatum Felix ........769-7 7 $\mathbf{\text { , }}, 876,87 s$ Kbamous rectinerris Heer..................... J10 Rhipidouella miehelina Léroilló ................ 521 Rhus bentirei $\mathrm{Lx} \ldots \ldots \ldots \ldots \ldots \ldots \ldots \ldots \ldots \ldots \ldots \ldots . . . \ldots \ldots$ Rhynchonella camarifera Winchell.............. 5 . Rhynchonella guathophora Mleek......... 60!-6 1 \$, 64 Rhy nchonella metallica Thite............... 491,540 Rlyzchonella myrina $\mathbf{H a l l}$ and Whitfeld ......... Gog lihynchonella pustulosa (?) ................... 489 Rly bchonella pustulosa (?) Hall and Whitfield .. $489,5 \leq 0,590$ Rlyjnchonella ringens Swallow................. 537-538 Phynchoneila sappho Hall..................... $5 t_{1}$ Rliybchodella (Stcuoceswa) sappho Hall......... Rhynchophora pustulosa.................... 510 Rhyolites, analyses of .......................... 420 character and occurrence of . . ............... 356-4:42 characters of groundniass of ................ $402-410$ intermingling of basalt aud . ............... $430-432$ 111icroscopical characters of ................. 393- 110 occurrence of......................... 4,5, 172 variations in composition of . ............... 427- 429 views of....

Rhyolite-felsite, analyses of .....................

Rhyolitic glasses, photomicrographs of............ 406

Roth, J., cited .

Russell, I. C., cited............................ 18

\section{s.}

Sabal major (?) Ung.

Saddle ciountain, rloglite of

Salicacer, descriptions ot epecies of............... $69 \notin-698$

Salix angusta Al. Br....................... 697

Salix lavateri Hetr............................69?

Salix varians Heer ....................... 698. 810

Sanidine, character of pledocrysts of ............. 398-399 Sapinilus sttinis Newly....................... $\mathbf{9 3 3 6 , 7 3 7}$ Sxpindus alatus ? Trard ........................ $7 \mathbf{7 3 7}$ Sapinlacere, descriptions of species of............... $736-739$
Page. Sapinulus gruadifolioloiles $n$. sp.............. 7:5\$, 540 Sapindus grandifoliolus WVard............... $7: 37$, \$44 Sapindus oltusifolius $1, x \ldots \ldots \ldots \ldots \ldots \ldots \ldots \ldots$. $7: 8$ Sapindus wardii n. sp................. Serpluiucrinus sp............................ Scaphites cf, rentricosus MI. and H............. 040 Scaphites venticomb Ieek and Haylen .......... \$:34 Schists, ocenrrence of ....................... \&,11-12 Schuchert, Chatles, scknowledgments to .......... 480 Seminula humilis n. sp............. 565-566, 508,598 Seminula jumstura n. sp .................... 56(i, 519 Seminula madisonensis $\mathrm{n}$. sp .......... 492, 56.3-564, 598 Seminula madisonensis var. persilla .......56-5655, 5.9S Seruinula quadrata.......................... 402 Seminula subtilita ...................... 4 ! 2561,598 Seminula wasatchensis........................ 565 Sepulchro Mountain, analyses of rocks of .......... 26 claracter of lava at . .......................341, 34] chemical analyses of rocks of .............. 1:5-137 chemical correlation of rocks of Electric Peak

rith these of - .................. comparison of rocks frum Electric Peak and.... $13 \div-1 \cdot 18$ diagram showing molecular rariations of rocks

at ..................................... 136

like rucks of . . . . . . . . general features of...................... $83-92$ grailes of crratallization of eruptire rocks of . .. 131-133 ignewns rocks of ........................ 89-1 48 mideral abol chemical conposition of eruptive

rocks of............................ 134-137 order of eruption of rocks at.............. 140

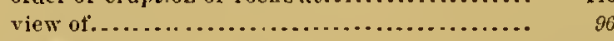
volcauic rocks ot........................ 121-137 Sequoia couttsia Heer ....................... 6\$ Sequoia cones ot ......................... (j\$i3, 802,804 Seruoia langadorfii? (Brgt.) Heer............... (65

$652-653,734,804,99$

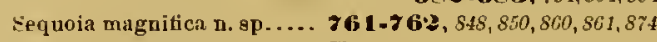
Sequoia reichenbachi (Gein.) Heer ............... \$is Sequoia sempervirens ......................... 759 Smithia woodmani ....................... 498 Smilacen, descriptions of species of . . . . . . . . . . . . 685-686 Suilax lamarensis n. 8p................. 685-686, $s s^{3}$ Snilax fretido-spina L ...................... 686

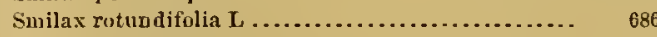
Suake River, section in hills near ................ $\quad \mathbf{1 5 6}$ Snake Rirer gorge, geology ot"................. 173-175 coals of ................................. 170 Snake River fault, featurcs of .................. 197-198 Snake River hot springs, features of............. 177-188 view of . ................................. Iis Snowy Mountain, section at................... $\quad 206$ Snowy Range, serlimentary rocks of............. 205-206 topograplyy and geulogy of soutliern end of..... 20:-244 South ead hills of Gallatin hange, features of ...... 10-11 Sulenopleura (?) weedi ................... \$64-165.478 Solla Butte Creek, rocks of................... 210-211 Sorla Butte Falley, gcolog 5 of ................... 212-214 sections in ............................ 212, $213-214$ Sparganinceid descriptions of species of . ......... 68.3-684 Sparganium stygium Hecr................... 683-68 Specimen Riclge, fossil forest at.................. 758 lara at ................................. 341

spherulites in obsiclian, character of ............. 362-364 figures showing sections of ................ 41 :

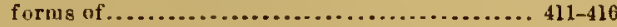
views ot $\ldots \ldots \ldots \ldots \ldots \ldots \ldots \ldots \ldots \ldots \ldots . \ldots \ldots, 410,414,42$. 
Sbales, occurrence of ..................... $\begin{array}{r}\text { Page. } \\ 8,15\end{array}$

Shoshonite, analyses of ....................... 83,340 cbaracter asd occurrence of .............. 339-347 phetomierograpls of ................

Silica percentages, rocks of Electric Peak......... 116-118 Slengh Creek, topography aut geology of valley of. 208-210 Spirifer alua pinensis..................... $489,548,59$ Spirifer argentarius.......................... 550

Spiriter ${ }^{\prime}$ I licstus ........................... 548

Spirtfe- cameratus ........................... 540

Surifer carteri Hall .......................... 55

Spirifer centronata Hall and Whitfeld .......... 489,547

Spirifer centreastus Winchell ................. $\$ 88$

$499,540,547-519,550,552,52$

Spirifer centrenatus rar. semifurcatus...... $\mathbf{5 4 9 - 5 5 0 , 5 9 4}$

Spiriter enspidatus $\mathbf{Y e e k}$....................... 559

Spirifer (Cyrtia) bannibalensis Swallow .......... $555^{\circ}$

Spirifor engelmanni Jieek ................... J04, 580

Spirifer extenuatus.......................... 488

Spirifer turbesi ............................. 55

Spirifer birtus White and $T$ hitfele.............. 555

Spirifer lamellesus Léreille .................... 561

Spirifer marionensis Shumard (?) ............... 5.5

Spirifer (Martinia) glaber $\mathbf{3}$ artin ................. $488-557$

Spirifer (Msrtinia) peculiaris White............ $488-557$

Spirifer mesicestalis ......................... $\quad 519$

Spinifer (?) peculiaris shumard ..................

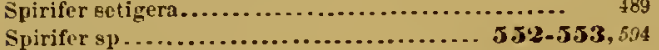

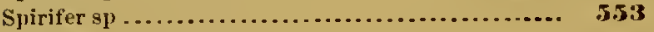

Spirifer etriatus White ..................... 488

Spirter striatus var. nadibedezsis n. var. 488, 5.51 -5.52. 504

Spirifer subattenuat ne Hall................. \$92, 550

Spirifer (Sy ringothyris) cuspidatue.............. 505

Spirifera albapidensis...................... $\quad 489$

Spirifera cooperensis Swsllow................... 553

Spirifera setigera $H$. and $W \ldots \ldots \ldots \ldots \ldots \ldots \ldots . . . \ldots \ldots$

Spirifera subrotundata Hall .................. 557,558

Spiriferina soliderestris Herrick................. 546, 590

Spiriferiua solilorestris White .......... 515-547.593

Spirigern buzona........................... 565

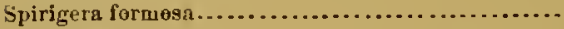

Spirigera monticula...........................

Spirigera olmaxiua ...........................

Splenopteris guyottii Lx.......................

Syusre Bntte, Jontana, analyses of igneous recks from .

Stsnton, T. W. fussils idéatified by ................

Stellaria Creek, rocks on ........................

Stelzuer, A., cited ...............................

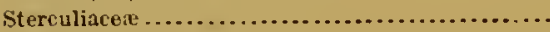

Stipking water River, like rocks of ............. 347, 350

nature of rocks at ......................... 340,345

Steck rocks, characters of .................... 97-103

Straparellus utahensis Hall and $T$ hitfell.. 489, 5733-5 7 4,

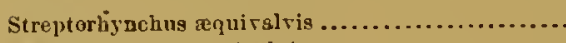

Strepterbyachus equiraltis

Streptorlarochue ingeollalis

Strepterhynchus intlatns......................

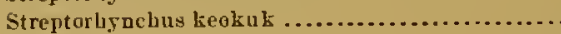

Stricteporella (3)

Strophomera rbomboilalıs Thite ............ $\$ 88,489,525$

Survey l'eak, rocks of ....................... 159-160

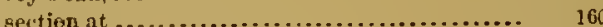

Sylran Pass, dikes and flews near.............. 304-314

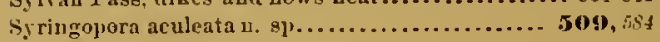

Syringopora surcularia $n$. sp ................ $5 \mathbf{1 0 , 5 8 t}$ Syringothrris carteri Hall .........4 458,492, 55\$-559. 525 Sriugothris cuspidatns Walcett .............. 559

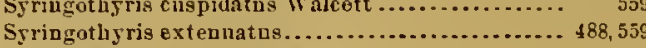
Syriagutbyris typa Wjechell.................. 558

I.

Taneredia (?) knowltoni a. sp.................621,64

Tapes myomingensis Meek .................... 638

Taxitis olriki Hess........................ 680, $s 04$

Terebratula (Dielasena) burlingtoneasis .......... 488

Terebratula gorbsi S. A. Miller .................. 545

Terebratula marcyi Shumard ................... 561

Tereluratula micheliua ........................ 521

Terehratula utah Hall and $T$ bitfield ............489,54t

Tertiary tiera, biologieal consideration of ......... $773-i \varepsilon 3$ description of plants ef.................. 665-791 geulogical consideration of ................ 783-981 table showirn distribution of ................ 749 plates showing plants of .................... 79\$-\$\$?

Teton Range, crystallivo schists of .............. 152-157 descriptive geolugy of northern end ef ......... 149-16 map of northern end ef................... 150 selimentary recks of ....................... $\quad 150$ topographic features of ................... 151-152 rolcanic rocks of ....................... 157, 161-162 Tetranthera dealbata R. Br..................... 726 Tetranthera sessiliflera $\mathrm{Lx} . . \ldots \ldots \ldots \ldots \ldots \ldots \ldots \ldots . .6 \ldots$ 'Theca gregaria............................... 454 Theca primortialis Hall...................... $\$ 5 \$$ Theca (Pngiunculus) gregaria II. and H.......... 45t Thrscia (?) montanaensis (Mfoek) ?............625, 644 Thraeis woedi $\mathrm{n}$. ep .......................6.67, 649 Three kiver Peak, features of.................. 23-24 rocke of .................................. 16 section of ................................ 23 view of................................... 24

Thunderer (The) and Monnt Norris, view of....... $29: 3$ Tilia populifolia $\mathrm{Lx} . \ldots \ldots \ldots \ldots \ldots \ldots \ldots \ldots \ldots \ldots \ldots$, $\mathbf{1 3}$ Titauifereus iron ore, eccurrence of ............... $400-401$ Tower Falls, basalt at . . . . . . . . . . . . . . . . . . $434-435$ Trachytic rbsolite, accurrence of.............. 321-328 Trapa ? micrephylla Lx....................661, 791 Triassic fessils......................... 197.600-601, 603

Trilohite Point, recks of ..................... 11-12 zone of contact bet ween intrudod sheet and conn. try rock near

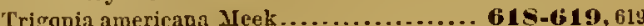
'I'rigonia costata .......................... 619 Trigonia elegantissima Meek................... (19, 644 l'rironia montanaensis Meek ............... 619-620 Tutf (andesitic), eccurrence of ................. Turf-breccia, andesitic, occurrence of ...............

Turritella sp................................ 630

Twu Ocean Pass, analyois of rocks from ........... 329 character of lava at............................... 340,343 chemical composition of rocks from .......... 329, 337

Two Ocenn Platent, rocks of .................... 20s-31101) topograplyy snel geology of................. 200-202

Trpbacen, descriptieus of species of ............ 6.63

U.

Clmacer, descriptions of epecies of .............. 711-712

Clmus, truits el.......................... ₹ 1:, s' 16

Ulmus minimit ? Ward ......................... 711

thouns psendo fulva? Lx................... 711,816 
INDEX.

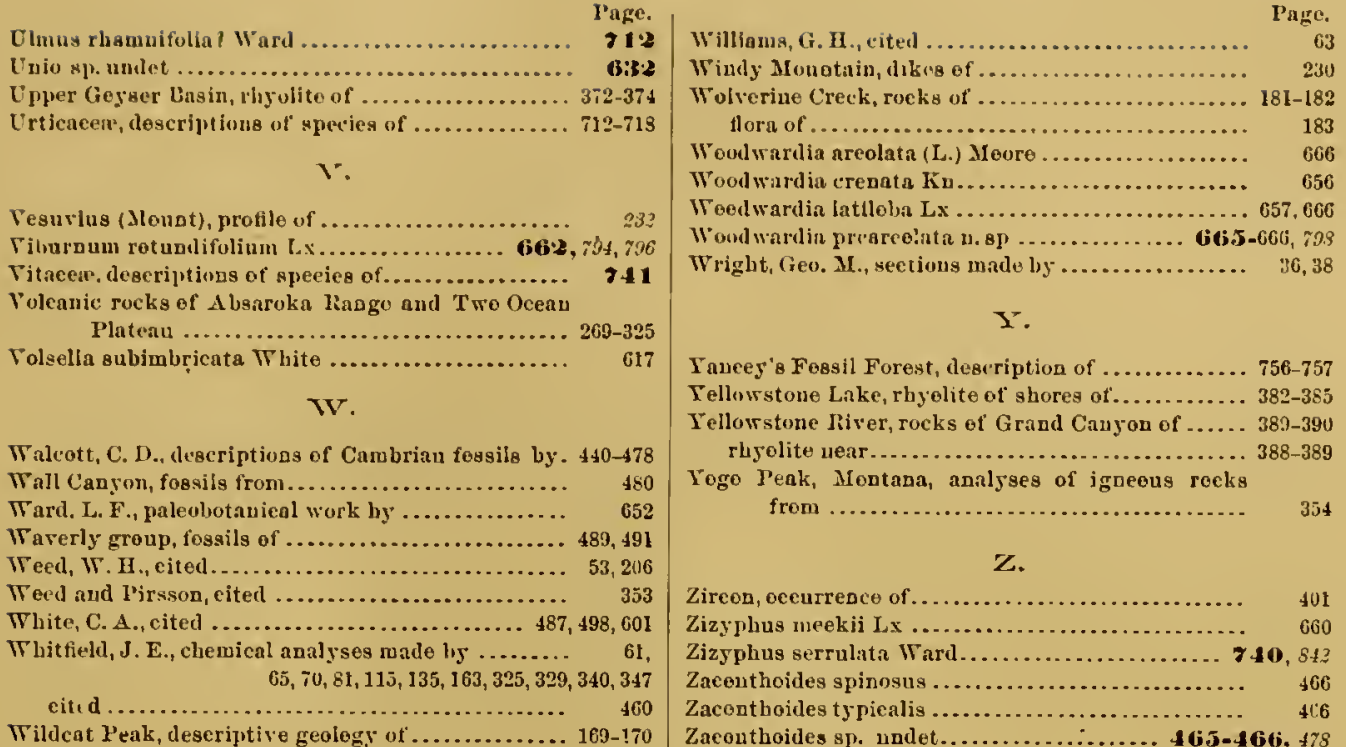





\section{ADVFRTISEMENT.}

[Monograph XXXI1.]

The statute approved Iarch 3, 1879, establishing the United States Geological survey, contains tho fullowing provisions:

"The publications of the Geolorieal Survey shall eonsist of the anmal report of operations, geolorical and economic malus ilhnstrating the resources aud classitieation of the lands, and reports upon general and economie geology and pilfeontologio. The annual report of operations of the Geologieal Survey shall accompany the anmal report of the Seeretary of the lnterior. All speeial memoirs and reports of sain Survey shill be issued in uniform quarto series if deemed necessiry by the Director, but otherw ise in ordinary oetavos. 'Three thousand copies of each shall be published for seientitic exehanges aul for sale at the price of publication; and all literary and cartographic materials received in exchange shall be the property of the United States and torm a part of the library of the organization: And the money resulting from the sale of such publications shall be eovered into the Treasury of the United States."

Except in those eases in which an extra nunber of any speejal memoir or report has been supplien to the Surver by speeial resolntion of Cungless or has been ordered by the Seeretary of the Interior, this oftiee has no copies for orratnitons distribution.

\section{ANNUAL REPORTS.}

I. First Anumal Report of the Uniter States Geological Survey, by Clarence ling. 1880. $8^{\circ}$. 78 pl. 1 map.-A preliminary report slescriling plan of organization and publieations.

II Seeond Annual keport of the United States Geological Snrvey, 1880-'81, by J. W. Powell.

1882. 80. lv, 588 11). 62 jl. 1 mill.

111. Third Annual Report of the Uniterl States Geolugical Survey, 1881-'8*, by J. W. Powell. 1883. $8^{\circ}$. xviii, $564 \mathrm{pp} .67 \mathrm{pl}$. and maps.

IV. Fourtl Annull Report of the Uniterl States Geological Snrey, 1882-'83, by J. W. l'owell.

1884. 80 . xxxii, $473 \mathrm{pp}$. 85 pl. and majs.

V. Fifth Annul lieport of the United States Geologieal survey, 1883-'84, ly J. W. l'owell.

1885. 8. xxxvi, 469 11). 58 pl. and maps.

VI. Sixth Annul Report of the United states Geolugical Survey, 1884-' 75 , by J. W. l'owell.

1885. 80 xxix, 570 lip. 65 pl. and maps.

VII. Seventh Annual Report of the United States Geologieal Survey, 1885-86, hy J. W. I'owell.

1888. $88^{\circ}$. $\mathrm{xx}, 656 \mathrm{jll}$. $71 \mathrm{pl}$. and maps.

VIil. Eighth Annual Report of the United States Geologieal Survey, 1886-'87, hy J. W. Powell.

1889. 80.2 it. xix, 474, xii plu. 53 pl. and nials; 1 prel. leat, 475-1063 ju, 54-76 pl. ind malss.

IX. Ninth Annual Report of the United States Geologieal Survey. 1887-88, by J. W. Powell.

1889. $8{ }^{\circ}$ xiii, $717 \mathrm{pl}$. $88 \mathrm{pl}$. and maps.

X. Tentli Annual Report of the United States Geologieal Sucvey, 1888-'89, by J. W. l'owell.

1890. 8 . 2 pt. $\times 1,774$ 1)., 98 jl. and maps; viii, 123 lil.

XI. Eleventh Anmul Report of the United Stites Geologieal Survey, 1889-90, 1y J. W. l'owell.

1891. $80.2 \mathrm{pt}, \mathrm{xr}, 757 \mathrm{pl}, 66 \mathrm{pl}$. and waps; ix, $351 \mathrm{pl}$., $30 \mathrm{pl}$. and maps.

XII. Twelfth Anumal Report of the United States Geological Surrey, 1890-91, ly J. W. Purell.

1891. $8^{\circ}$. 2 pt., xiii, 675 pli., 53 pl. and maps; xviii, $576 \mathrm{mp}, 116$ pl. and niaps.

XIII. Thirteenth Annual Report of the United States Geological Snrver, 1891-292, 119 J. WF.

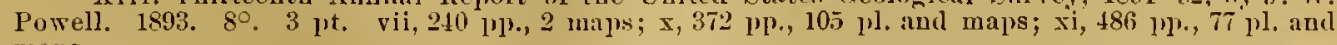
maps.

XIV. Fonrteenth Anmal Report of the United States Geologieal Survey, 1892-93, ly .I. W. Powell. 18!13. 80 . '2 pt. vi, 321 pl., 1 pl.; xx, 597 pl., 74 pl. and walls.

XY. Fifteenth Annual Report of the United States Geological Survey, 1893-94, ly J. W. Powell. 1895. $8^{\circ}$ xir, 755 plp., 48 pl. and maps.

AVr. Sixteenth Aumul Reprit of the United states Geological Snrvey, 1894-95, Charles 1 .

Waleott, Direetor. 1895. (Part I, 1896.) x. 4 pt. xxii, 910 ll., 117 pl. and maps; xix, 598 ll., 43 pl. and maps; xv, $646 \mathrm{pl}$., 23 pl.; xix, 735 plo; 6 pl.

XVII. Seventeenth Annual Repoit of the United States Feological Survey, 1895-96, Charles

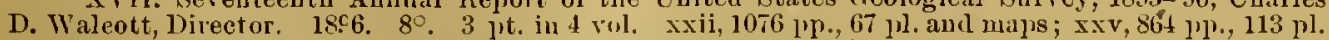
and maps; xxiii, 542 pl., 8 pl. and maps; iii, 543-1058 pp., 9-13 pl.

XVin. Eighteentli Anmal Report of the United States Geological Survey, 1896-97, Charlis D.

Walcott, Director. 1897. (l’arts $I 1$ and 111,1898 .) 80. 5 pt. in 6 vol. 1-440 pl., 4 pl. and mals; $i-r$, 
1-653 pp., 105 pl. an 1 11aps; i-v, 1-861 pir., 115 pl. and maps; $i-x, 1-756$ pp., 102 pl. and maps; i-xii, $1-612$ pp., 1 pl.; 643-1400 pl.

XIX. Ninetenth Auninal Report of the United States Geological Survey, I8:7-'98, ('larles U. Walcott, Director. 1898. 8. 6 pt. in 7 vol.

\section{MONOGRAPHS.}

I. Lake Bonmeville, hy Grove Karl filbert. 1890. 40. $\mathrm{xx}, 438 \mathrm{pl}$. $51 \mathrm{pl}$. I map. Price $\$ 1.50$. I1. Tertiary History of the Grand Cañon District, with Atlas, by Clarence E. Dutton, Capt., U. S. A 1882. 40. xiv, $26 \pm \mathrm{pp}$. $42 \mathrm{pl}$. and atlas of 24 sheets folio. Price $\$ 10.00$

111. Geology of the Comstock Lole aud the Washoe Distriet, with Atlas, lyg George F. Becker.

1882. 4. $\mathrm{xv}, 122 \mathrm{pl}$. $7 \mathrm{pl}$. and atlas of $2 \mathrm{l}$ sheets folin. Price $\$ 11.00$.

IV. Comstock Nining and Miners, by Eliot Lord. 1883. 40. xiv, 45l pp. 3 pl. Price $\$ 1.50$

$\mathrm{V}$. The Copper-Beariug Rocks of Lake Superior, hy Rolaud Duer Irving. 1883. 45. xvi, 464

p1. $15 \mathrm{j}$. $29 \mathrm{pl}$. and maps. Price $\$ 1.85$.

VI. Contributions to the Knowledge of the Older Hesozoic Flora of Virginia, loy Willian Iforris

Fontaiue 1883 . to xi, $144 \mathrm{pp} .54 \mathrm{l}$. $54 \mathrm{pl}$. Price $\$ 1.05$.

VII. Sil rer-Lead Depesits of Eureka, Nevada, by Joseph Story Curtis. 1884. 40. xiii, 200 Pl. 16 pl. Price $\$ 1.20$.

VIII. Paleontology of the Eureka I)istrict, by ('harles Donlittle Walcott. 1884. 40. xiii, 298

pl. 24l. 24 1.l. Price $\$ 1.10$.

IX. Brachiopeda and Lamellihraucbiata of the Raritau Claps and Greensand Marls uf New Jersey, by Roliert P. Whitfield. 1885. 40. xx, 338 pl. 35 pl. I map. Price $\$ 1.15$.

X. Dinoeerata. A Monomaph of an Extinet Order of Gigantic Mamnals, by Othuiel Charles Marsh. I886. 40. Xviii, 243 \%1. 56 \}. 56 pl. Prife $\$ 2.70$

I1. Geological 11 istory of Lake Lahontan, a Quaternary Lake of Northwesteru Nevada, by Israel Cook Russell. 1885. 4c. xir, $288 \mathrm{pp}$. 46 pl. incl maps. Price $\$ 1.75$.

XII. Geology and Mining Industry of Learville, Colnrado, with Atlas, by Samuel Franklin

Emmens. 1886. 40. xxix, $770 \mathrm{pm}$. 45 $\mathrm{jl}$. and at las of 35 sheets folio. Price $\$ 8.40$.

XIII. Geolngy of the Quieksilver Deposits of the Pacitic Sloje, with Atlas, by George F. Becker.

1888. 4. xix, 486 p. 7 pl. and atlas of 14 sheets tolio. Price $\$ 2.00$.

Niv. Fossil Fishes and Fnssil Plants of the Triassic Rocks of New Jersey and the Comeeticut

Valler, by John \$. Newberry. 1888. to. xir, $152 \mathrm{pp.} 26 \mathrm{pl}$. Price $\$ 1.00$.

¿ The Potomac or Younger Mesozoic Flora, by Willian Morris Fontaine. 1889. 40. xiv,

$377 \mathrm{pl}$. iso pl. Text and plates lumud separately. P'rice $\$ 2.50$.

Xv1. The Paleozoic Fishes of Nurth America, by John Streng Newberry. 1889. $4^{\circ} .340 \mathrm{pp}$. 53 w. Price $\$ 1.00$.

IVII. The Flura of the Dakota Groul, a Posthmons. Work, by Leri Lesquerenx. Edited by

F. H. Kuowlton. I891. 40. $400 \mathrm{Hp}, 66$ l1. Price $\$ 1.10$.

IVIII. Gitsteropoda and Cephalopoda of the Raritan Clays and Greens:nd Marls of New Jersey,

ly holuert P. Whitfiehl. 1891. 4\%. $402 \mathrm{pp} .50 \mathrm{pl}$. Price $\$ 1.00$.

XIX. The Penokee Iron-Bearing Series of Northern Wiseonsin and Miehigan, by Roland D. Irving and C. li. Van Hise. 1892. 4० xix, $534 \mathrm{pp}$. Price $\$ 1.70$.

XX. Geology of the Eureka District, Yevala, with an Atlas, by Arneld Hague. 1892. 40. xvii, $419 \mathrm{pp} .8 \mathrm{pl}$. Price $\$ 5.25$.

XXI. The Tertiary Rhynchophorons Culeoptera of the United States, by Samuel Hubbart Sund-

ler. 1843. 40 xi, 20671.12 pl. Price 90 cents.

Xil. A IImual of Topographic Methods, by Henry Gannott, Chief Topographer. 1893. $4^{\circ}$. xiv. 300 p. 18 pl. l'riee $\$ 1.00$.

XXil. Geolory of the Green Monntains in Massachusetts, by Raphael Punpelly, T. Nelson Dale, aml J. E. Wottit. 1894. 4. xiv, $206 \mathrm{pp}$. 23 pl. Prico $\$ 1.30$.

XXiV. Jollusea and Crustaceil of the Mlocene Formations of New Jersey, by Robert Parr Whit-

field. 1894. to. $193 \mathrm{jp}$. $24 \mathrm{wl}$. Price 40 cents.

XX. The Glacial Lake Agassiz, hy Warren Upham. 1895. $4^{\circ}$. xxiv, 658 pl. 38 pl. Price $\$ 1.70$.

XXVI. Flora of the Ambor Clays, lyy Johu Strong Newberry; a P'sthumous W' $V^{\prime}$ ork, edited by Arthu. Holliek. 1895. to. $260 \mathrm{pp}$. $58 \mathrm{pl}$. Price $\$ 1.00$.

XXV1l. Geology of the Denver Basin in Colorado, bg Samuel Franklin Eunons, Whitman Cross, and George Ilomans Eldridwe. 1896. 40.556 pp. 31 1l. Price $\$ 1.50$.

XXVIII. The Marquette Iron-Bearing District of Iichigan, with Atlas, by C. R. Van 1 lise and

W. S. Bayley, including a Chapter on the Republic Trongh, by H. L. Smyth. 1895.40 .608 p. 35 il. and atlas of 39 sheets folio. Priee $\$ 5.75$.

XXIX. Geology of Old Hampshire County, Massachusetts, ('omprisingr Frankliu, Hampshire, aud Hampden Connties, by Benjaunin Kemall Emerson. 1898. 40. xxi, $790 \mathrm{pp}$. $35 \mathrm{pl}$. Price $\$ 1.90$

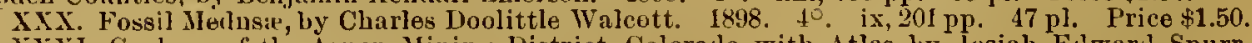

XXXI. Geology of the Aspen Mlining District, Coloraclo, with Atlas, by Josiab Edward Spurr.

1898. 40. xxxv, $260 \mathrm{pl}$. $43 \mathrm{pl}$, and atlas of 30 sheets folio. Price $\$ 3.60$.

In press:

XXxil. Geology of the Iellowstone Natienal Park, Part 1I, Meseriptive Geology, Petrograply, and Paleontologr. by Arnol, Hagne, J. P. Iddings, W. Harvey Weed, Charles D. Walcett, G. H. Girty, T. W. Stanton, aud F. H. Kuewlton. 1899. 40. xvii, $893 \mathrm{pp}, 121 \mathrm{pl}$. Price -

XXXV. The Later Extinct Floras of North America, by John Strong Newberry; edited by Arthur Hollick. 1898. 40. xviii, $295 \mathrm{pl}, 68 \mathrm{pl}$. Price $\$ 1.25$. 
In preparalion:

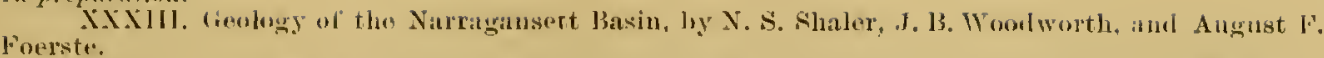

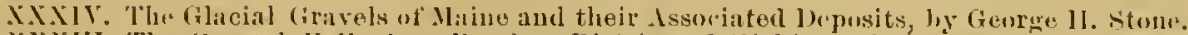

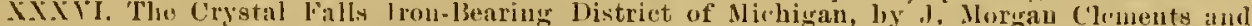

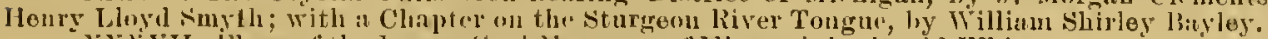

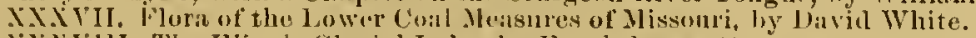

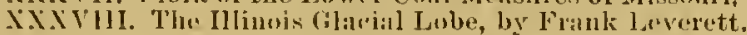

- Fora of the Laramie and Allied l'orinations, by Frank liall knowlton.

\section{IBULLF'TINS.}

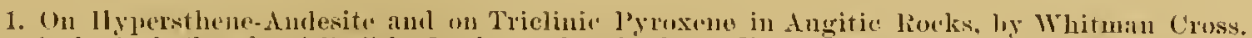

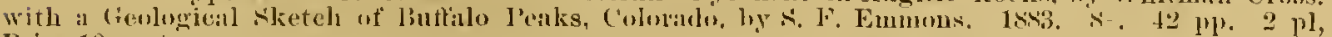
Price 10 cents.

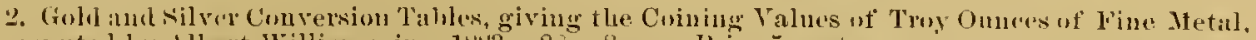

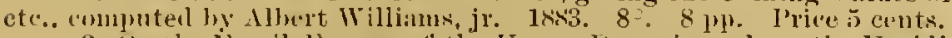

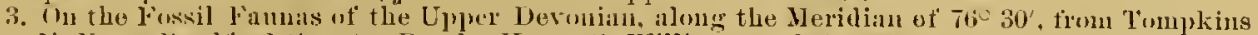

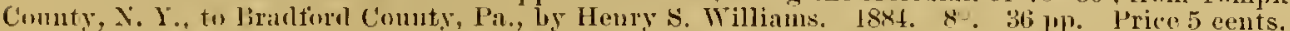

4. On yusuzuic Fossils, Jy Charles $A$. White. 1884. 8 . 36 pl\%. 4 pl. l'rice 5 ecents.

5. A Dirtionary of Altitudes in the Cnited Ntates, emmpilen hy Henry Gannett. 1884. 8-. 325 l'l. P'rice 20 cents.

6. Elevations in the Dominion of Canada, Jy .T. W. Spencer. 188t. 8-. 43 pls. Price 5 cents.

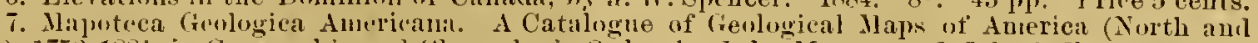

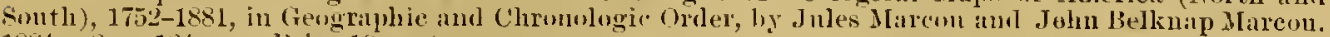
1884. 8 . 184 l'l, l'rice 10 cents.

x. On Seeondary Eularwuents of Mineral Fracments in Certain Rucks, by li. D. Irring and

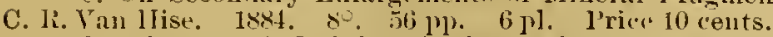

9. A Report of Workilone in the Wishington Latheratory dnring the Fiscal Year 1883-'84. r*. W.

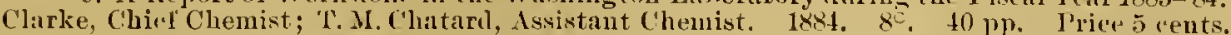

10. On the Cambrian Fannas of North Anerica. Prelininary Studies, by Charles Imolittle

Wolentt. 18.4. 8. Tt p. 10 pl. l'rice 5 cents.

11. On the Qnaternary and Recont Mnllns'il of the Great Basiu; with Description of New Forms, by li. Ellsworth Call. Intrulueed by a Sketeh of the Quateruary Lakes of the Great Basin, by" (i. K. Gilbert. 18xt. 8. 66 p), 6 pl. Price 5 ceuts.

12. A Crestallogral hie Stuly of the Thinelite of Lake Lahentan, by Edward s. Dana. 188. 80. 34 pl. 3 pl. Price of cents.

13. Boundiries of the United States and of the Several States and Territories, with a Historical Sketeh of the 'Territorial Changes, by Henry Gannett. 1885. 80. 135 Ip. Price 10 cents.

14. The Electrical and Magnetic Properties of the Iroul-(arburets, lig Carl Barns and Vincent Strmihal. 1885. 8०. $238 \mathrm{pP}$. Price 15 cents.

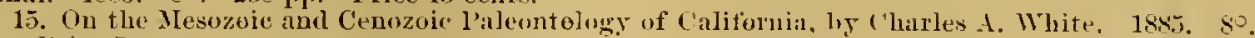
33 l'l. l'rice 5 cents.

16. On the Higher lerouian lannas of Ontario Connts, New York, by fohn M. C'larke. 1885. 80. 86 1'l. 3 pl. P'rice 5 c'ents.

17. On the Tlevelopment of Crystallization in the Inneous locks of Washor, Nevala, with Notes on the Geology of the District, by Aruold Hagne and Joseph l’. Idlings. 1885. 8-. 44 pl. P'rice 5 cents.

18. On Marine Eorene, Fresh-Water Mincene, and other Fossil Moblusen of Western Yorth America, by Charles A. White. 188.5. 80. 26 p). 3 pl. Price 5 cents.

19. Notes un the Stratipraphy of Calitornia, by (qeorqe F. Becker. 1885. $80.28 \mathrm{pp}$. I'riecōents.

20. C'ontributions to the Nlineralogy of the Rocky Mlountains, by Whituna C'rows and wV. F. Hille

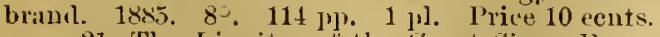

21. The Lignites of the cireat sionx lieservation; a Report ou the liegion between the frand and Morean Rivers, Dakota, Wy Bailey Willis. 1885. 8. $16 \mathrm{pp}, 5$ pl. l'rice 5 cents.

22. On Now Cretaceous Fossils from California, ly Charles $\Lambda$. White. 1885. 83. 25 yp. 5 pl. Price $\overline{5}$ cents.

23. Observations on the Jun'tion letween th. Listem Sindstone and the Kewcenaw Series on

keweenat loint, Lake superior, by R. I. Irving and T. C. C'lamberlin. 1885. 8c. 124 pl. 17 pl.

Price 15 cents.

24. List of Marine IIollusea, comprising the Quat ruary Foswils aul Recent Forms from Americau Localities hetween Cipr' Hatteras and Cape Rorne, including the Bermudas, by Williau Healey Dill. 188.5. $8^{\circ} .336 \mathrm{pp}$. l'rice 25 crints.

25. The Present Technical Conditinn of the Steel Industry of the linited States, ly Ihineas

Banes. $1885.80 .85 \mathrm{pr}$. Prive 10 cents.

26. Copper Simelting, by IIenry M. Howe. 1885. 80. 107 11p. Price 10 cents.

27. Report of Work done in the Division of Chemistry and Physics, mainly during the Fiseal Yeal

188t-85. 1886. 8. 80 pr. l'rice 10 cents.

28. The Gabbros and Associated Hornblenta lioeks ecurring in the Neighborluod of Baltinore,

Marglaurl, by (ienge Huntington Willitus. 1886. 8.o. 78 p. T pl. I'rice 10 cents.

MON XXX1I- 57 
29. On the Fesh-Water lnvertebrates of the North American Turassir, by Charles A. White. 1886. x. 41 pl. 4 pl. I'rice 5 cents.

30. Second Contribution to the studies on the Cambrian Famas of Forth America, by ('harles

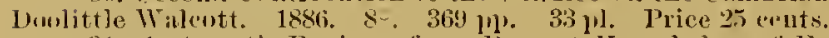

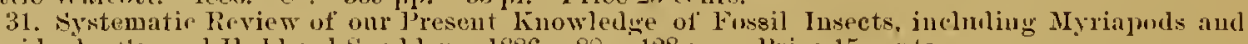

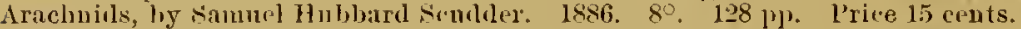

32. Lists and Analyses of the Slineral springs of the United States; a Preliminary Ntmly, by Albert C. Peale. 18:6.

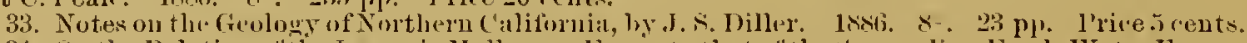
34. On the Relat ion of the Laramie Mollusian Fand that of the sueceeding Fresh-Water Eorene

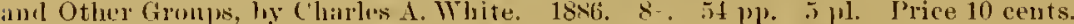

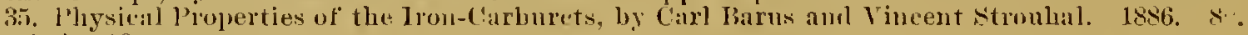
$621 \%$ i'rice 10 cents.

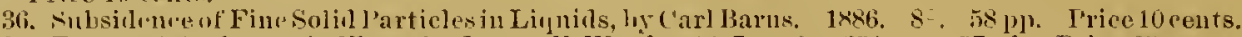

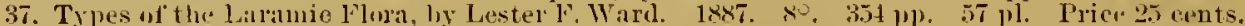

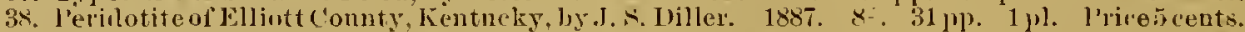
39, 'The I pper' leatches and Deltas of the Glacial Lake Agassiz, ly Warren Uphan. 1887. \&. 81 p. 1 1 ll. l'ries 10 cents.

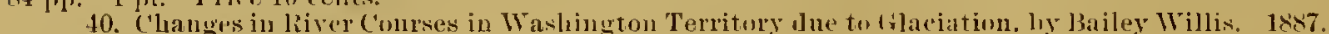
8. 10 pl. 4 pl. Prien cents.

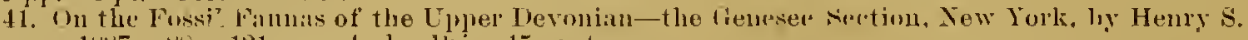

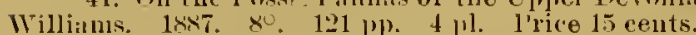

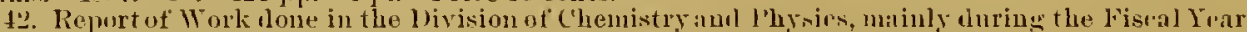

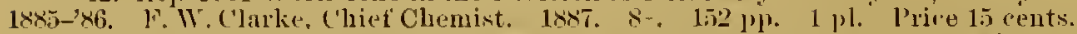

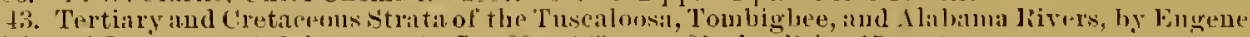

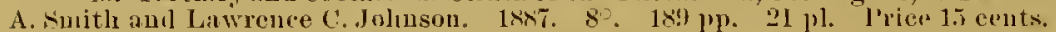

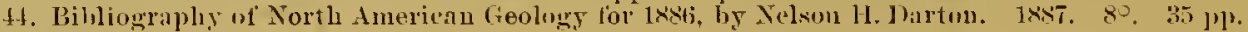
Priec 5 centits.

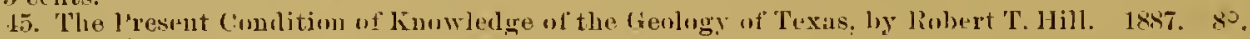
$94 \mathrm{pl}$. Price 10 ceuts.

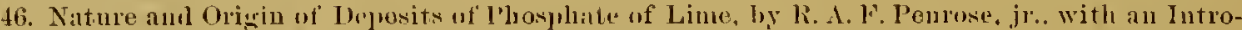

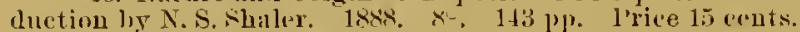

47. Inalyes of Waters of the Yellowstone Natimil Pink, with an Aerount of the Methouls of

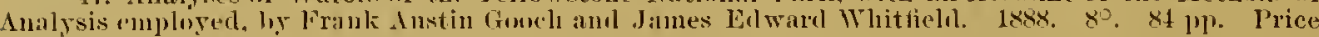
10 rents.

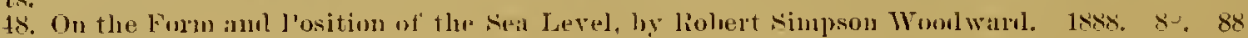
1י. l'rive 10 ients.

19. Latitudes and Longitueles of' ('ertain l'oints in Missonri, Limsis, and New Mexico, by Rohert Simpson Woodwarl. 1884. \&. $133 \mathrm{pl}$. Prire 15 rents.

50. Formulas aul Tables to Facilitate the Comstrutiun anl Iso of Japs, ly Robert Simpson

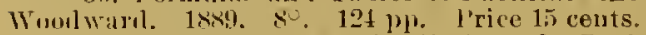

51. On Insertelorate Fosils from the Pacitic Const, lyy Charles Abiathat White, 1889. 8-. 102

p). 14 j1. l'rice 15 cents.

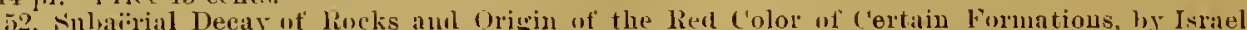

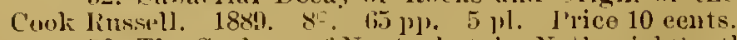
10 cents.

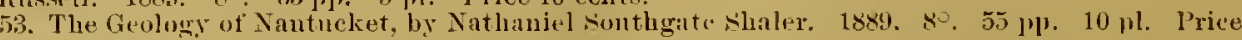
54. On the l'hermo-blectrie Mrasnrement of High Temperatures, ly Carl liarus. 1889. 80. 313 pl... incl. 1 pl. 11 pl. Price 25 cents.

55. liegert of Work done in the Divisim of C'hemistry and Physies, mainly during the Fiseal

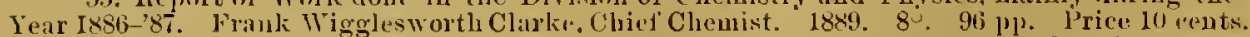

56. Fossil woml and Lignite of the l'ntomac Formation, by l'ank Hall linowlton. 1889 . 8 .

72 pl. 7 ji. J'rice 10 cents.

57. A Geological Reconnoissauce in tonthwestern liansis, by Rohert Hay. 18.90. 80. 19 p.

2 11. Prices 5 rents.

58. The Glicinl Bommlary in Western l'ennsylvania, Ohio, Rentueky, Inuliana, and Illinois, hy George Frederiek Wright, with an Introduction by Thomes Chrowler Chamberlin. 1890. 80.112 l're, incl. 1 pl. 8 pl. Prive 15 ceuts.

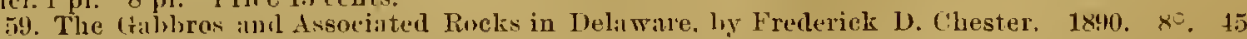

pl. 1 pl. l'rice 10 enists.

60. Report of Work rlone in the Division of chemistry and Plysies, mitinly during the Fiseal

Year 1887-'88. F. W. Clarkt, Chief ('hemist. 1890. 8, 174 pl. Priwe 15 cents.

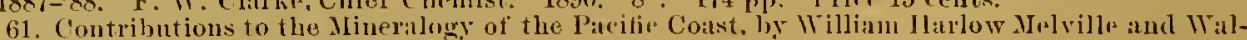

demar Limlerren, $1890.80 .40 \mathrm{~m}, 3$ pl. Price 5 cents.

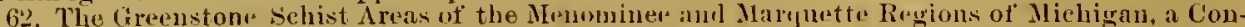
tribution to the Sulyeet of Dynamie detamurphism in Eruptive Rocks, by George I luntington Williams,

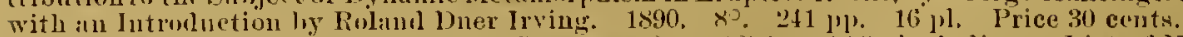

63. A Bibliography of Paleozoic ('rustarea from 16!I to 1XS, including a List of Forth Amerienu Species and a sistumatic Arraugement of (ienera, by Anthmy Wr. Togdes. 18!0. 80. $177 \mathrm{pP}$. Price 15 cents.

64. A Repont of Work don" in the Division of Chemisty aml Physins, Milnly during the Fischl

Tear 1858-89. F. W. Clarke, Chict Chemist. 1890. \&. 60 pls. Priee 10 ceuts. 


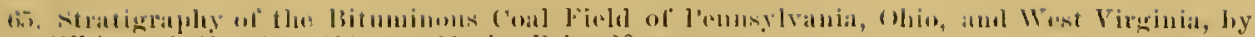

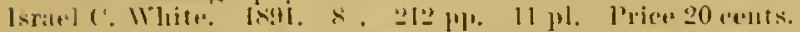

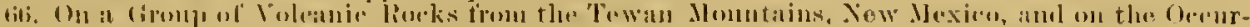

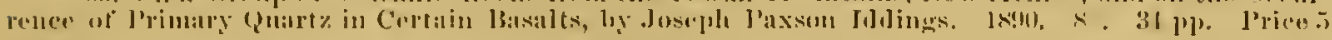
('elith.

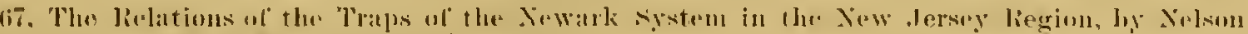

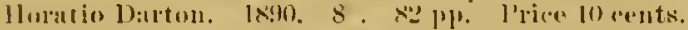
cents.

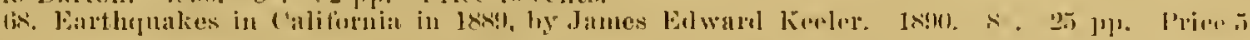

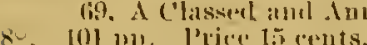

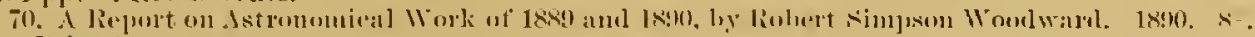
79) 1'p. I'rice 10 cents.

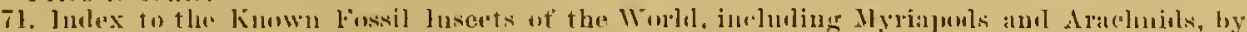

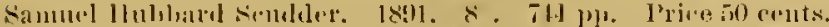

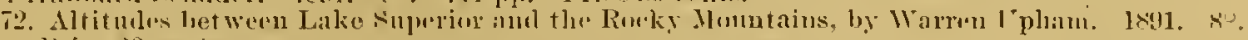

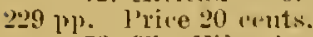

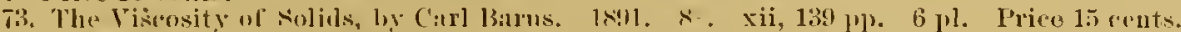

74. The Jliuerals of North C'arolinil, hy Frederiek Augustus Genth. 1891. 8?. 119 jp. l'rice lis rents.

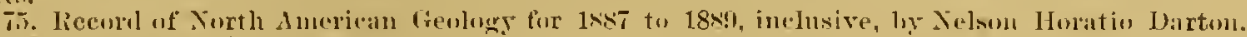

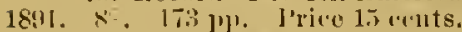

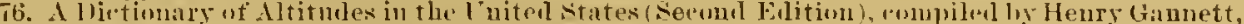

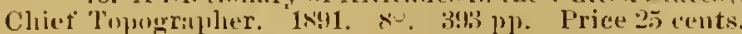

77. The Texan Fermian and its Mesuzoic Types of Fossils, ly ('harles A. White. 1891. \&. 51 1]1. 4 jul. Price 10 enents.

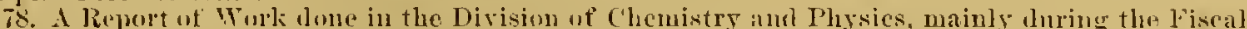

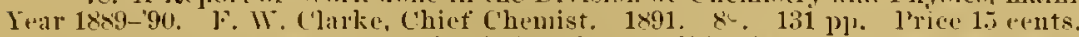

79. A Late Voleanic Eruption in Northern ('alifornia and its Peenliar Lara, ly J. s. Diller.

so. Corrolition l'apers-Devonian and ('arlwniferons, loy Hents shaler Willians. 1891. so.

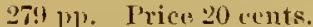

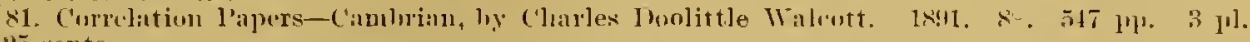
Price 25 cents. cents.

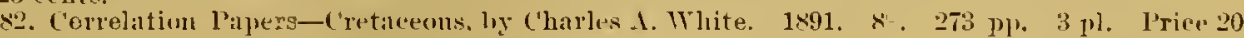

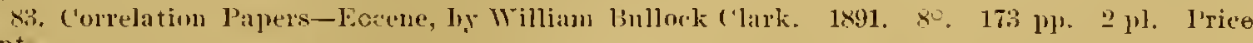
1.i ents.

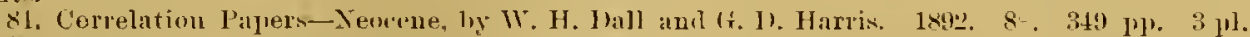

Prive :-i cellstis.

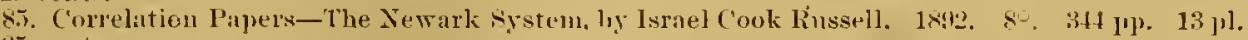
Price 25 cents.

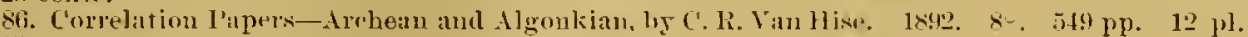

Prico 25 cents.

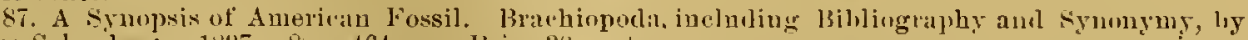
Charles Selucliert. 1897. 8. 464 pl. l'ricu 30 cents.

88. The Cretacems Foraminileril of New Jerser, ly linfins Mather liagr, Jr. 189k. 80. 897 lp.

b pl. l'rice 10 cruts.

89. Some Lava Flow's of the Wrstern Slope of the Sierni Nevarla, Calitornia. by $F$. Leslie Rausome. 18!s. N'. $74 \mathrm{pp}, 11 \mathrm{pl}$. I'rice 15 cents.

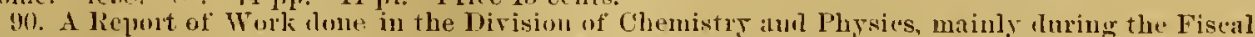

Year 1840-91. F. W. Clarke, Chief ('hemist. 1692. 80. TT pil. Price 10 cents.

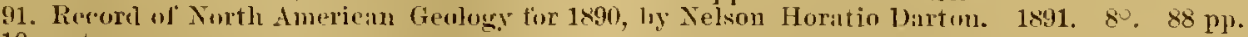
Price 10 cents.

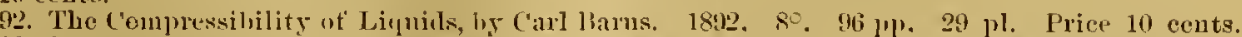

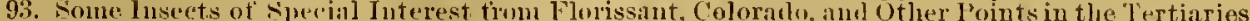

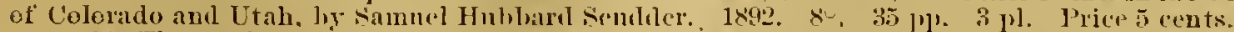

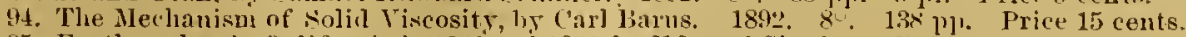

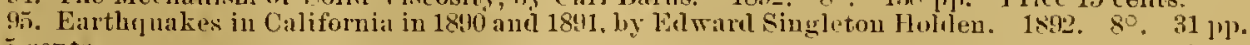
Price.ivents.

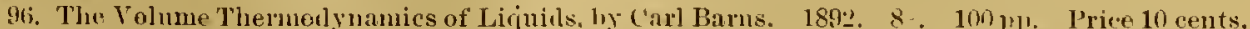
97. The Hesozoic Echinoilermata of the Tnitei States, 1y W. D. "lark. 1893. 8. 207 pl. 50 pl. Price 20 cents.

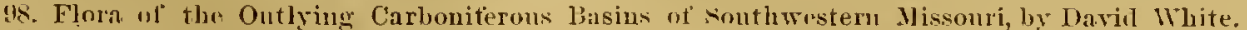

1843. 8*. $139 \mathrm{lll}$. 5 pl. Price 15 cents.

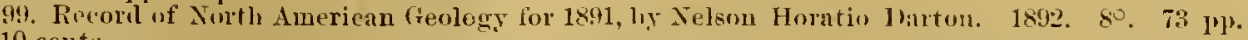
price 10 cents.

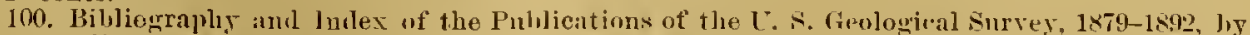

Philip Creveling Warmau, 1893. 80. $495 \mathrm{pl}$. Price 25 cents.

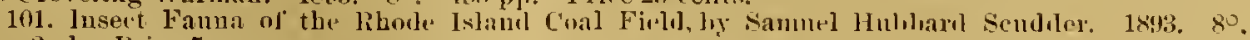
27 jl). 2 pl. I'rice 5 cents.

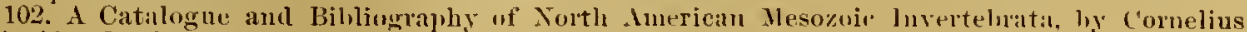

Breckinrillge Boyle. 1892. 80. 315 ]p." Price 25 cents. 
108. Higln Temperature ITork in Irneons Fuxion and lindlition, whietly in Relation to Prussnre,

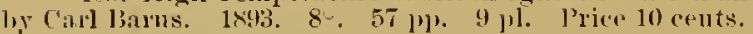

104. Glaciation of the Jellowstone Valley nortl of the Jark, by Walter Harvey Wreed. 1843. 80.

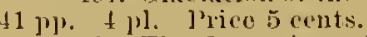

105. The Larante and the (xorlying Livingstoue Formation in Montana, ly Walter Harvey

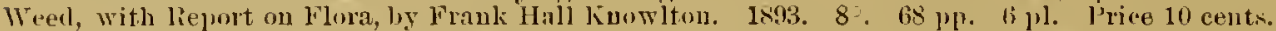

106. The coloralo Formation and $\mathrm{jts}$ luvertebrate Fama, by 'T. IT. Stanton. 1893. 8.288 111. 45 jil. l'rico 20 ('ents.

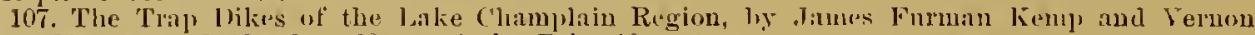
Freenau Mirsters. IN93. 8-. 62 mp. 4 pl. Price 10 cents.

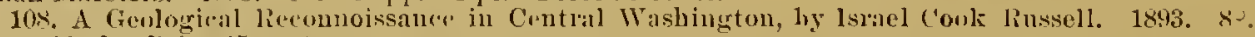
108 il). [2 jol. Plive 15 cents.

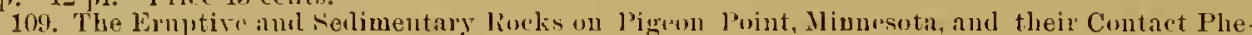

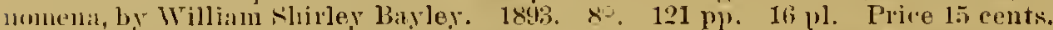

110. The Paleozuic Sinction in the Vicinty of Threr Forks, Mmitan, by Allert Charles l'eale.

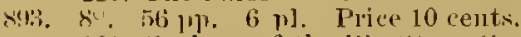

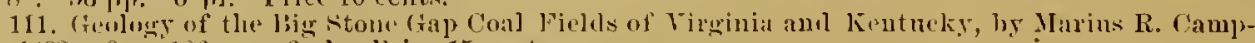

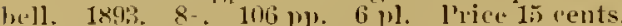

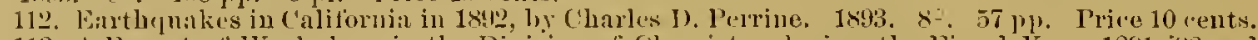

113. A lieport of Work lone in the Division of Chemistry during the Fiscal Ycars 1891-12 and

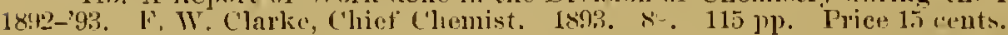

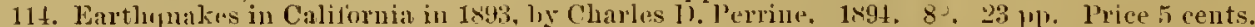

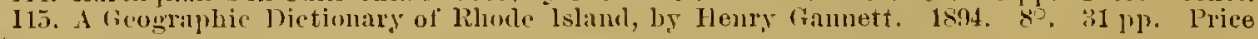
i) rents.

1 i) ceuts.

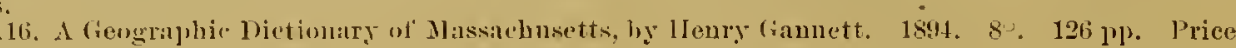

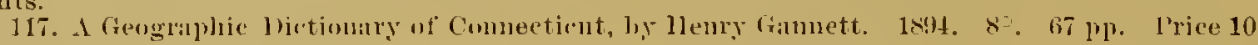
ceuts.

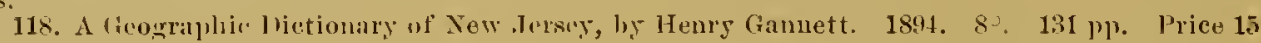
rents.

119. A fieological lieconnoissance in Jorthwest Wyoming, by George llomans lidrirge. 1894. 8 . 72 pl'. Price 10 conts.

120. 'Th" levonian fisstem of Fasteru l'enyslvan anl New Jork, hy Charles S. Prosser. 1894.

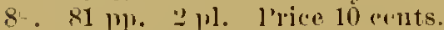

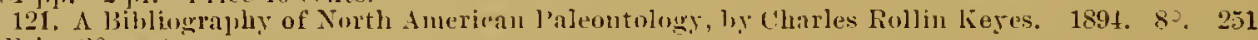

ij). J'rice 20 ceuts.

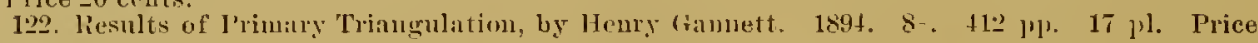
$2 \pi$ cents.

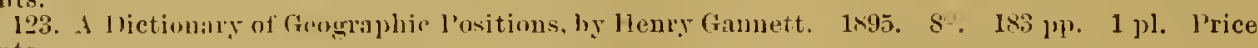
15 inents.

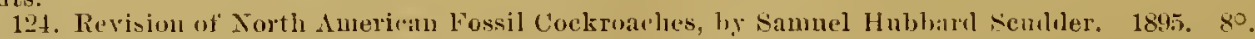

$176)$ li. 12 pl. Price 15 cents.

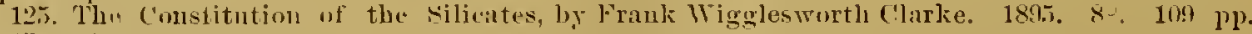
Price 15 cents.

126. A Mincmagrical L,xicon of Franklim, Hampshire, and Hamplen comties, Massichnsetts,

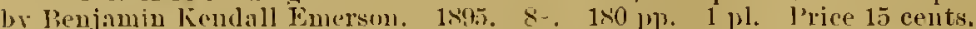

127. Catalogne and Index of Contributions to North American Geologr, 1732-1891, br Nelson Joratio Bartum. J896. 8. 1045 jp. I'rice 60 cents.

128. The licar River Formation and its Characteristic Famua, lyg Charles 1. White. 184.5 .80$.

108 נر. 11 p. Price 1.5 cents.

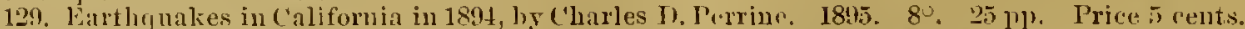
130. Bibliogriphy :m Index of Torti Americau Geology, Paleontology, Petrology, and Miner-

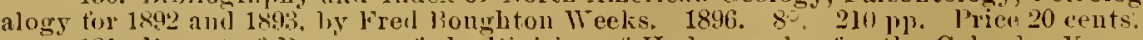

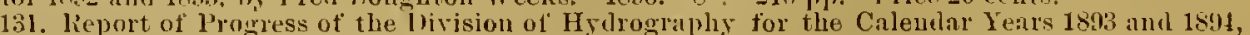

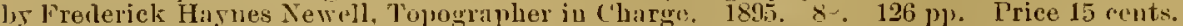

132. "Lhe lisseminated Leal Ores af' Sontheastern Missoni, by Arthm IVinslow. 1816.80. 31 1). Price 5 cruts.

133. Contrihntions to the ('retaceous l'uleontology of the Pacitic Coast: 'The l'auna of the Knoxville Beds, hy '1. W. Stanton. 1895. 8. 132 pl. 20 pl. Price 15 rents.

134. The Cambrian Rocks of l'enusplvania, by Charles Doolittle Wilcott. 1896. 80.435. 15 pl. l'rice ì cents.

135. Biblouraphy and Index of Talth Amerioan Geologs, Paleoutologr, letrologr, and Miner-

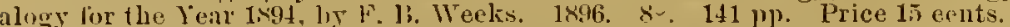

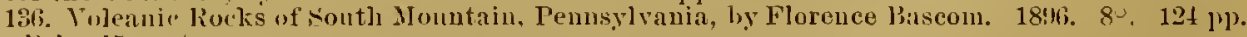
28 pl. Price 15 cents.

137. The Geology of th" Fort Riley llilitary lieservation and Vicinity, Kausas, by Robert Hay.

18416. 8. 35 j). 8 jil. Price 5 rents.

158. Artesian-1Ve]l Prospects in the Atlantic Coastal Plain leuriou, hy X. 11. Darton. 1896. 820 pp. 1! pl. J'rice 20 cents.

139. Geologr of the C'astle Monntain Miniug l)istrict, Momtana, hỵ W. H. Wreed and l. V. Pirs-

sol1. 1896. 8. 164 pl. 17 pl. Price 15 .ents.

140. Report ol Progress of the Division of Hydrouraphy for the Calemdar Iear 1s45, by lirerlerick

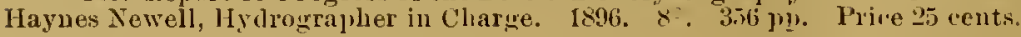


111. 'lhe bocene Deposits of the Mldulle Atlantic Slope in Jelaware, Maryland, and Virginial, by William lsullock Clank. 18!6. \& . 167 pu. 40 pl. P'rire lis cents.

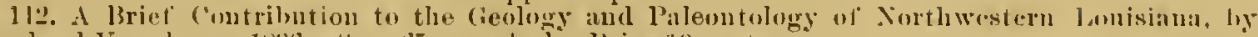

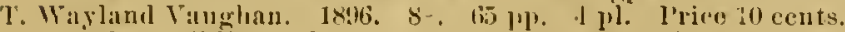

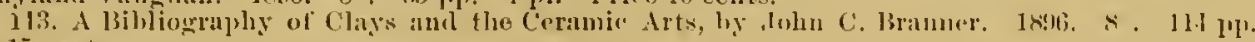
prine 15 ceuts.

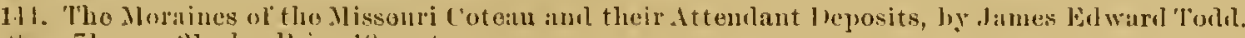

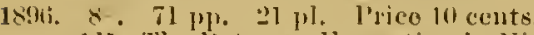
1 is cents.

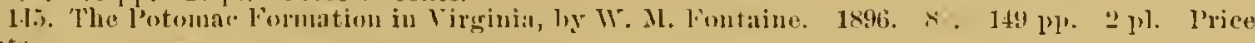

1Hi. Bibliograplyy and ludex of Forth Aundean (ieolngy, P'aleontology, Petrologr, and Mlinct-

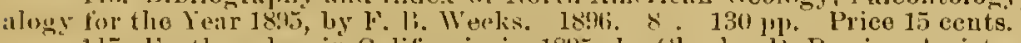

1.17. Varthunalies iu California in 1895, ing charles 1). Perrive, Assistant Astronomer in ('harge of liarthuake Observations at tho Lick (Observatory. 1896. 8. 23 pl. l'rice 5 eents.

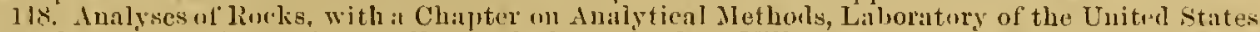

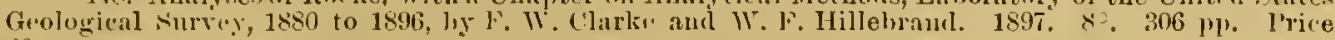
20 ('ents.

149. Bibliowaphy aml Ind ox North Anerican Geolows, Paleontologr, Petrologr, and Miner-

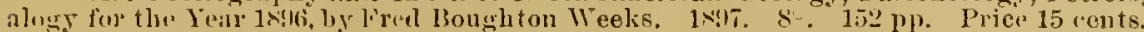

150. The lidneationil Series of liock Speriuens collecterl amel distributed by the United stitus

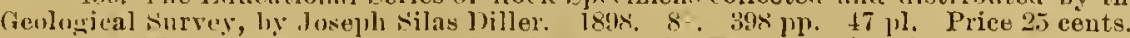

1.31. 'The Lower Crutacents Gryphiras of the Texis Region, by R. 'T. Hill and T. Wayland Villghiln. 1898. \& 139 13.

15\%. A Catalogne of the C retaceous and Textiary Plants of North America. by l. H. Kunwlom. 1Nis. 247 lip. l'rico 20 cents.

158. A Bibliographic Inlex of North American Carloniferons Invertebratw, hy sturt Weller.

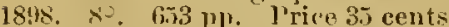

15t. A Gazetrer of kansas, by llewry (ianuett. 1898. 8-. 246 plp. 6 pl. Price 20 cents.

15.5. Earthupak's in ('alifurnia in 1896 ind 1897, be Charles 1). l'errine, Assistant Astromuer

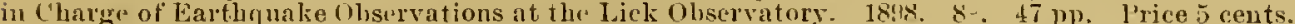

156. Bibliogralhy and lndex of Jorth American tieologa, Palloutologs, l'etrology, and Mliner-

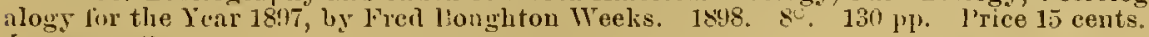
III preparation:

Hall.

157. The Gueisses, Gabliro-Schists, and Associated Rocks of Sontheastern Minnesutil, ly (.. IV.

158. The Moraines of South Makota and their Attendant Ueposits, by J. E. 'Todd.

1.59. The Geologry of kistern lierkshire ('ounty, Massachusetts, by 1. K. Emerson. Gamett.

160. A Dictionary of Altitules in the United states (Thirrl Edition), compiled by llanry

\section{WATER-SUPPLI AND IRRIGATION PAPERS.}

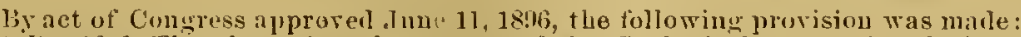

"l'voridel. That hereatter the reports of the fieolo inal survey" in relation to the gangine of streams aud to the methorls of utiliziner the water rosonces nily be prin ed in octaro form not to

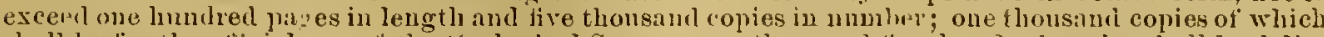

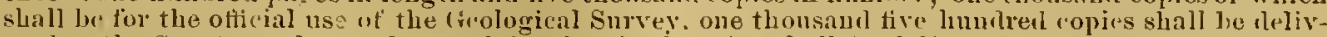
"red to tho senate, and two thonsand five hundred copres shall be delivered to the llonse of Representitives, for clisirilution.

Fuller this law the following pirners havo heen issued:

1. Pumping Water for Irrigation, by Horluert M. "ilson. 1896. 8- . 57 plp. 9 pl.

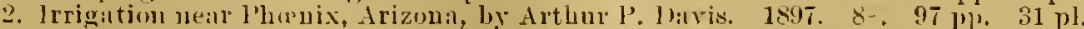

3. Seware Irrigation, hy George W. liafter. 1*97. 8-. $100 \mathrm{~lm}, \quad+1 \mathrm{l}$.

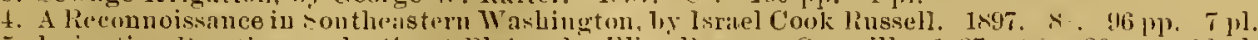

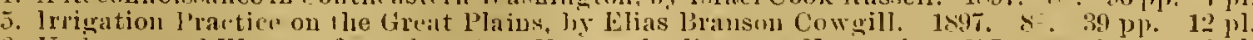

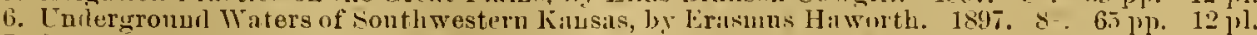

7. Seepiage Waters of Northern Utal, by Sammel Fortier. 1897.8 . 50 pp. 3 pl.

8. Winduills for Irrigation, ly Edward ('harles 11 urphy. 1897. 8. $49 \mathrm{pl}$. 8 pl.

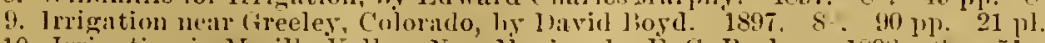

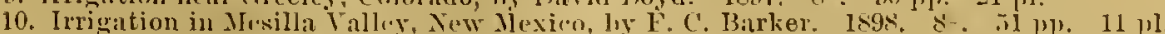

11. River Heights for 1896, by Arthur l'. Davis, 1897. $\%$. $100 \mathrm{pp}$.

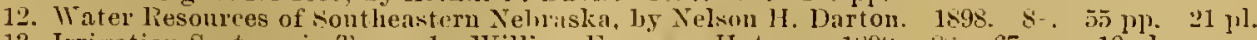

13. Irrigation Systens in 'T'exas, ly Willian Ferguson Hutson. 1898. $86.67 \mathrm{pl} .10 \mathrm{pl}$.

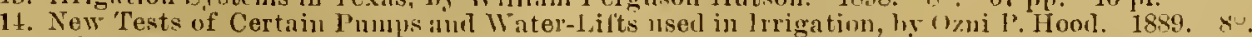

$91 \mathrm{ll} .1 \mathrm{pl}$

15. Operations at River Stations, 1897, l'art 1. 1898. \& 100 pl.

16. Operations at River Stitions, 1897. Part II. 18918. \&-. 101-200 111..

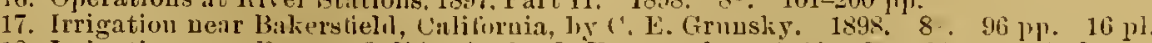

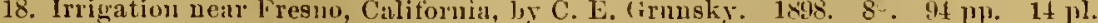

19. Irrigation near Merced, California, ly C. K. Grumbliy. 1899. $8^{\circ}$. 5! 11p. $11 \mathrm{pl}$

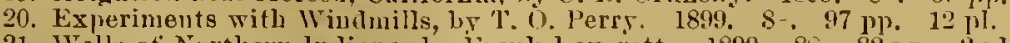

21. Wells of Nortleru Indiana, ly jank levcrett, 1809. 80. 82 jp. 2 jul.

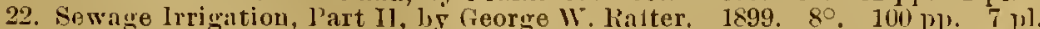

23. Water-Iight Problems of Bighoru Minutains, by Elwood Mead. 1894. 8-. 62 pp. $7 \mathrm{pl}$. 
III presx:

2.t. Water Resources of the State of New Vork, Part I, b5 George Wr. Ratter. 1899.80. $44 \mathrm{pl} .13 \mathrm{pl}$.

25. Water Resources of the State of New York, Part II, by George W. Rafter. $1899.8^{\circ}$. $101-200 \mathrm{pl}$. $12 \mathrm{pl}$.

26. Wells of Sonthurn Indiana (Continnation wt No. 21), by Frank Leverett. 1899. $8^{\circ} .61$ pp. In prepuration:

27. Op'rations at liver Stations, 1898, I'art I.

28. Operations at livier Stations, 1898,1 'art iI

29. Wells aml Windmills in Nebraska, bg Edwin H. Barlumr.

30. Water liesomces of the Lower Peninsula of Michigan, by Altiver 1s. Lane.

\section{TOPOGRAPHIC MAP OF THE UNITED STATES.}

Wher, in 1882, the Geolngical Survey was direeterl by law to make a grologic: maj of the Uniterl States there was in existence po suitalio topographie map to sorvas a base for the geologic map.

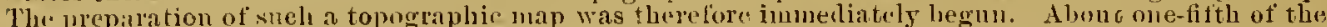
Iroa of the conntry, oxeluling Alaska, has nuw been thus mapperl. The map is published in atlas sheets, each shect represinting a small qualrangular district, as explained nbder the next heading. The s'parate sheets are sold at is conts each whin fewer than 100 copies are purchased, but when ther ale ordered in lots of 100 or moro enpies, whether of the same shiet or of liftilent shrets, the prive is "2 cents eacl. The mapped areas are willely seattred, nearly erery state being representerl.

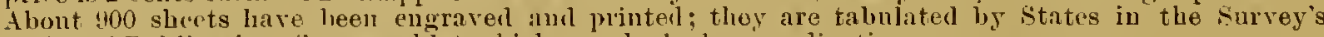
"List of Pullications," a pamplilet which may he hacl on applieation.

The map shets represent a creat variety of topmraphic features, and with the ald of clescriptive tert they cin he nserl to illustrate topographic forms. This has lest to the projection of an erheational series of toporraphie folios, for nse wherever peovraphy is taught $1 n$ high schools, tcacleuies, and colleges. Or this series the first folio has been issued, viz:

1. 'hesionalie trues, hy Henry liannett, ls9s, folio, consisting of the folluwing sheets and 4 jages of descriptire text: Fargo (X. Wak.-Mnn.), a region in yonth; Charleston (W. Va.), a region in maturity; Callwell (Kans. ), a region in oll age; Palmyra (Va.), a rejuemated region; Mount šbasta, ('al.), i Fom voleauic mountain; Eagle (Wis.), moraines; sun l'rairie (Wis.), drumlins; Donaldsunville (La.), viver Hood plains; Boothbay (He.), a fiorl eoast; Atlantic City (N.J.), a barrier-beaeh roast.

\section{GEOLORIC ATLAS OF THL ITAITED STATES.}

The Geologic Atlas of che Uniter States is the final form of pnblication of the topographic and genlogie mapss. 'The atlas is issued in parts, progressively as the surveys are extended, and is dlesigned iltinately to cover the entire conutry.

Under the plan adopterl the entire area of the "omntry is dividoul into small rectingulan clistriets (Ilesimated quadrangles), lyonnded by eertain meridians and parallels. 'The mit of survey is also the unit if pulblication, and the maps and deseriptions of each rertangnlar clistriet are issmerl as a folow of the Geologic Atlas.

Each folio contains topographic, weologic, oemomie, and structural maps, together with textual lescriptions ind explanations, and is desiguated hy the name of a prineipal town or of a prominent natural feature within the distriet.

"Two forms of issue have been adopted, a "librars edition" and : "liels edition." In both the slieets are bouml hetween heary paper "overs, lut the library copies are permanently hound, while the sheets and corers at the field copie's ale only trmporarily wired together.

I'nder the law a cops ot each folio is sent to certain public lilmraries and edneational institutims. The remainder are solu at ari cents each, except such as contain :m musnal amount of matter. which ire priced aecordingly. P'reparment is olvligatory. The folios rearly for distribution are listed helow.

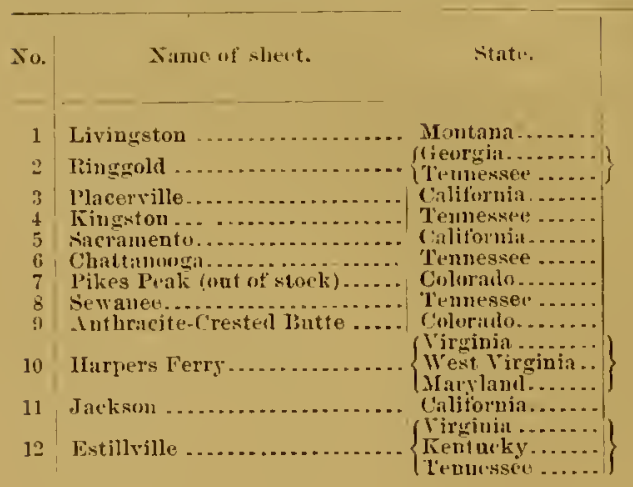

limitinu् meriuliuts.

Limiting parallels.

\begin{tabular}{rr}
\hline $\begin{array}{c}\text { Area, in } \\
\text { sluare } \\
\text { miles. }\end{array}$ & $\begin{array}{c}\text { 'rice, } \\
\text { in } \\
\text { cents. }\end{array}$ \\
& \\
3,354 & 25 \\
9811 & 25 \\
932 & 25 \\
969 & 25 \\
932 & 25 \\
975 & 25 \\
932 & 25 \\
975 & 25 \\
165 & 50 \\
925 & 25 \\
938 & 25 \\
9.7 & 25
\end{tabular}


ADVLITISEMENT.

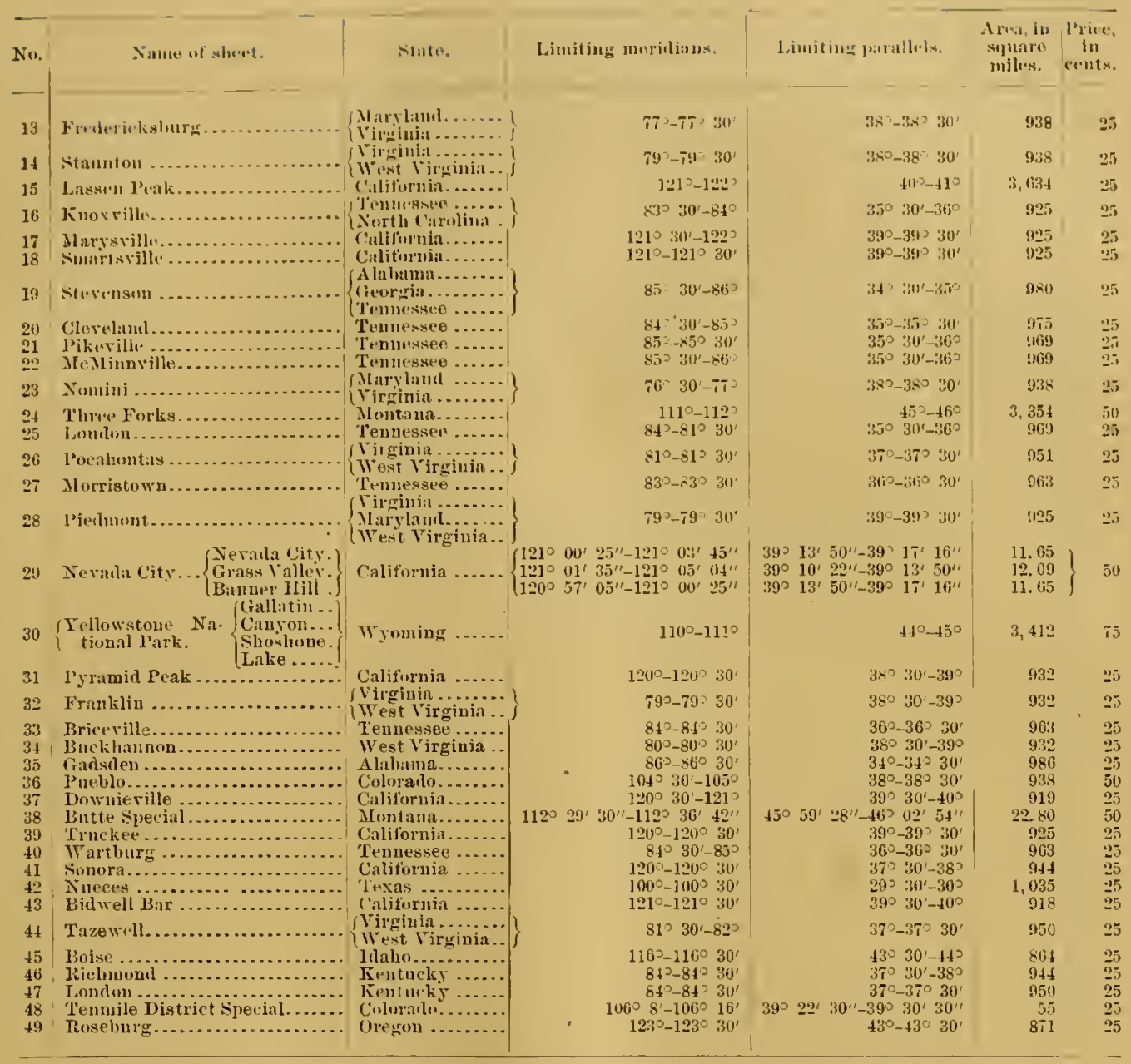

\section{STATISTICAL PAPJKS.}

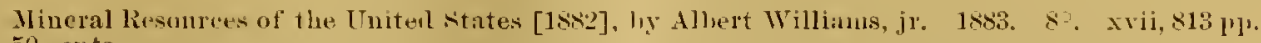
Price 50 cents.

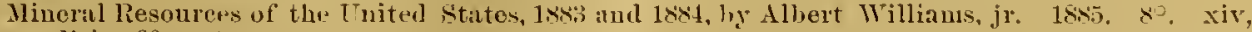
1016 1']. Price 60 cents.

Nineral Resources of the United States, 1885. Division of Nlining Statistics and Technology. 1886. 8. vii, 576 pli. Price 40 cents.

Mineral Resonces of the United States. 1886, by lavid T. Day. 1887. 8. viij, \&13 l'1. Price 60 cents.

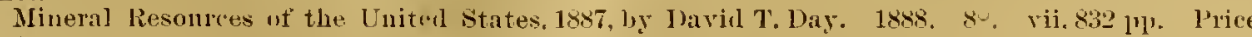
50 cellts.

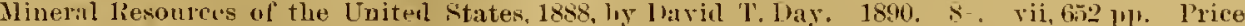
50 c'ents.

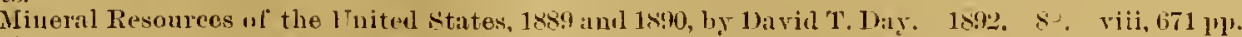
Pric" 50 a"ents.

Mineral Resource's of the United States, 1891, by Mavid T. Day. 1893. 85. vii, 6ian pr. l'rice 50 cents.

Mineral Resources of the United States, 1892, by Inavid T. Tay. 1893. 8\%. vii, 850 pp. l'rice 50 cents.

Mlineral Resururces of the United States, 1893, by llavid T. Day. 1894. 8-, riii, 810 1r. Price 50 cents. 
(1) Mareb 2, 189., the following provision was included in an act of Congress:

I'rocidcl. That hereafter' the report of the mineril resonrces of the United States shall be issued as a part of the report of the Director of the Geological snrvey."

In compliance with this legrislation the following reports bave becn publishert:

Nineral Resources of the I nited states, 1894, David T. Das, Chict of Division. 1895. 8 . Iv,

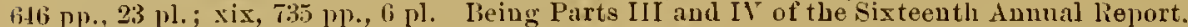

Mineral Lesources of the United States, 1895, David 'T. Day, Clief' of Division. 1896.80. xxiii, 542 p., 8 pl. and maps; iii, 543-1058 pl., 9-13 pl. Being Part III (in 2 vols.) of the Seventeentb Annual leport.

Mlineral Resources of the thuted States, 1896, David ' $T$. Daf, ('hief of Division. 1897. 84. xii. 642 pl., 1 pl.: 643-1400 pp. Being Part $Y$ (in 2 vols.) of the Nineteenth Annual Report.

Jlineril Resonrees of the Luiterl states, 1897 , David ' $T$, Dity, Chief of Division. 1898. $8^{\circ}$. viii, $651 \mathrm{pp} ., 11 \mathrm{pl}$; ; vii, $706 \mathrm{pp}$. Being Part VI (in 2 vols.) of the Nineteenth Anmal lieport.

The money receiver from the sule of the survey lublications is lepositerl in the Treasury, and the Secretary of that hepartment deelines to receive hank cherks, drafts, or postage stamps: all remittances, therifore, must he by MoNeY onmen, midfe pilyalle to the Director of the United states

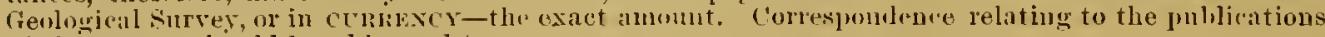

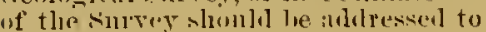

The Dikector,

WaAHNiTuN, 1). C., April, 1s9\%.

UNITEN STATHS GEOLOGICAL SUREY,

WASIINTETON, D. C. 
[Take this leaf nut and piste thon sejarated titlog "uwe three of your eata logne carle. Tho list ind serond titleg neill nos adition; over the thiral write thut subjert untor which you would place the book in your library.]

\section{IJBRALY CATALOGUE SIJISS.}

United States. Hepartment of the interior. ( $I T . S$. geologiral survey.) 1)epartment of the interior | - | Monograples / of the / Tuiterl States genlegrical survey | Volume XxxiI | Part II | [Noal uf tho department] | W:shington | government printing offien | IK99 sccond fille: Intited States goologional survey | Clarles D. Walcott, dimetor | - Goology | of the | Volluwstone national park | - | Part Il | Deseriptive grologr, petograpliy, and paleoutology | by | Arnolil Hague, J.P. Iddings, W. H. Weed | aud | C. D. Walcott, F. 11. Girty, T. W. Stanton, ane F. II. Knowltou | [Vignette] |

Washingtou | goverument printing offien | 1899

4․ xrii, $893 \mathrm{pp} .121 \mathrm{pl}$.

\section{Hague (A mold) ant olhers.}

United Status geolugieal survey | Charles D. Walcott, director |-| Geolngy | of the | Vellowstoue national park | - | l'art 11 | Descriptive geology, petrugraphy, and palentelogy | ly | Aruold Hague, J. l'. Iddings, WV. H. Weed | and | C. D. Walcott, G. H. Girty, T. W. Stanton, and F. H. Knowlton I [Vigniette] I

Vashingt on | government printing oflice | Kx99

4?. $\mathrm{xrii}, 893 \mathrm{pp} .121 \mathrm{pl}$.

[TNition STATEs. Department of the interior. (U. S. genlogical survey.) donngraph XXXI1.]

United States geologieal survey | Charles D. Walcott, director $|-|$ Geology $\mid$ of the | Vellowstone natioual park | - | Part IT | Descriptive geology, petrography, and paloontelogy | by | Arnold llagne, J. P. Ildings, W. H. Weerl | and | C. D. Walcott, G. Il. Girty, T. W. Stanton, and F. Il. Knowlton | [Vignotte] ।

Washington | govermunt printimg office | 1899

4․ xvii, $893 \mathrm{nl} .121 \mathrm{ml}$.

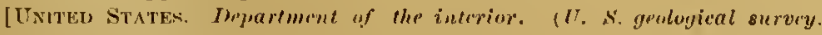
Monugraph XXXII. 







$$
\text { • }
$$


